UNIVERSIDADE DE SÃO PAULO

FACULDADE DE FILOSOFIA, LETRAS E CIÊNCIAS HUMANAS

DEPARTAMENTO DE LETRAS CLÁSSICAS E VERNÁCULAS

PROGRAMA DE PÓS-GRADUAÇÃO EM FILOLOGIA E LÍNGUA PORTUGUESA

JOSENILCE RODRIGUES DE OLIVEIRA BARRETO

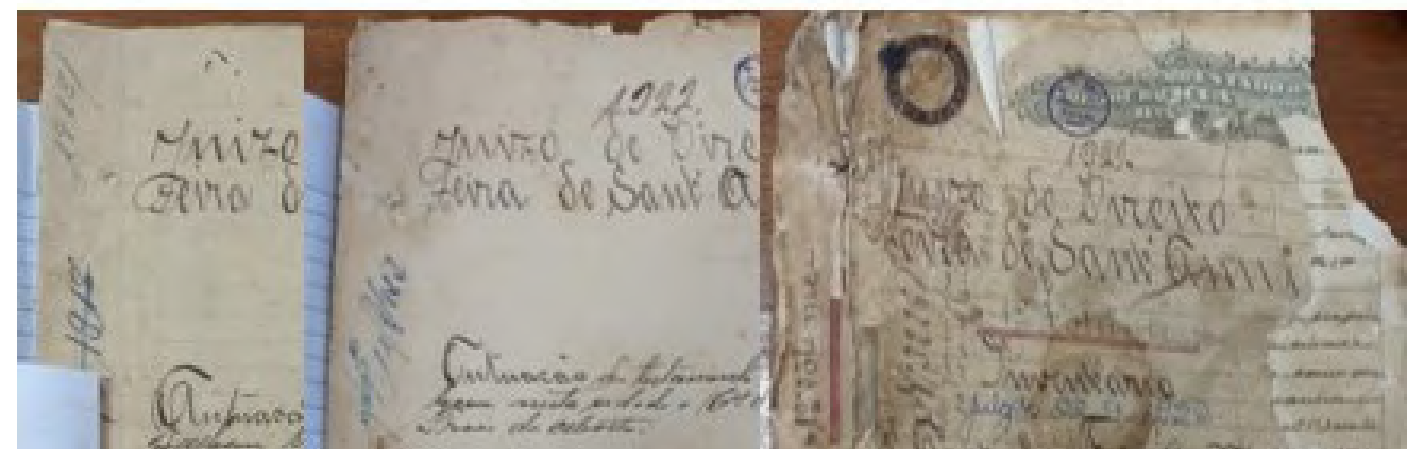

EDIÇÃO E ESTUDO LEXICAL DE DOCUMENTOS NOVECENTISTAS DO SERTÃO BAIANO

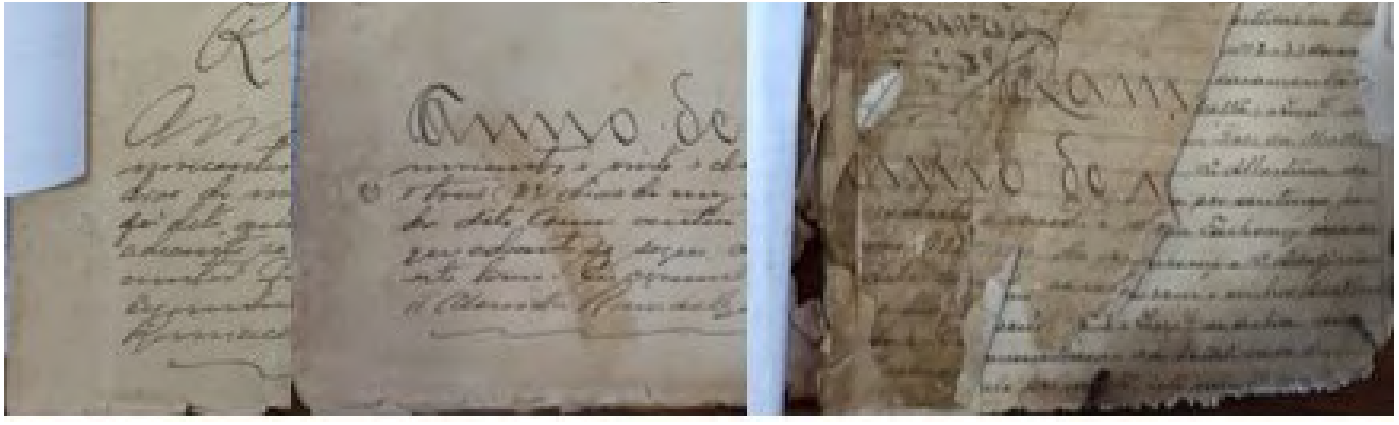

Versão Corrigida

Volume I 
JOSENILCE RODRIGUES DE OLIVEIRA BARRETO

\title{
EDIÇÃO E ESTUDO LEXICAL DE DOCUMENTOS NOVECENTISTAS DO SERTÃO BAIANO
}

\author{
Versão Corrigida
}

Volume I

Tese de doutoramento apresentada ao Programa de Pós-Graduação em Filologia e Língua Portuguesa da Faculdade de Filosofia, Letras e Ciências Humanas da Universidade de São Paulo, como requisito para obtenção do título de Doutora em Letras.

Orientador: Prof. Dr. Manoel Mourivaldo Santiago Almeida 
Autorizo a reprodução e divulgação total ou parcial deste trabalho, por qualquer meio convencional ou eletrônico, para fins de estudo e pesquisa, desde que citada a fonte.

Catalogação na Publicação

Serviço de Biblioteca e Documentação

Faculdade de Filosofia, Letras e Ciências Humanas da Universidade de São Paulo

BARRETO, Josenilce Rodrigues de Oliveira

Edição e estudo lexical de documentos

novecentistas do Sertão baiano / Josenilce Rodrigues

de Oliveira BARRETO; orientador Manoel Mourivaldo

Santiago Almeida. - São Paulo, 2020.

$1560 \mathrm{f}$.

Tese (Doutorado)- Faculdade de Filosofia, Letras e Ciências Humanas da Universidade de São Paulo. Departamento de Letras Clássicas e Vernáculas. Área de concentração: Filologia e Língua Portuguesa.

1. Edições fac-similar e semidiplomática. 2. Lexicologia. 3. Campos Lexicais. 4. Perfil sócio filológico-lexical dos escreventes. 5. Documentos feirenses novecentistas. I. Almeida, Manoel Mourivaldo Santiago, orient. II. Título. 


\section{ENTREGA DO EXEMPLAR CORRIGIDO DA TESE}

\section{Termo de Ciência e Concordância do orientador}

Nome do (a) aluno (a): Josenilce Rodrigues de Oliveira Barreto

Data da defesa: $25 / 06 / 2020$

Nome do Prof. (a) orientador (a): Manoel Mourivaldo Santiago Almeida

Nos termos da legislação vigente, declaro ESTAR CIENTE do conteúdo deste EXEMPLAR CORRIGIDO elaborado em atenção às sugestões dos membros da comissão Julgadora na sessão de defesa do trabalho, manifestando-me plenamente favorável ao seu encaminhamento e publicação no Portal Digital de Teses da USP.

São Paulo, 21/08/2020

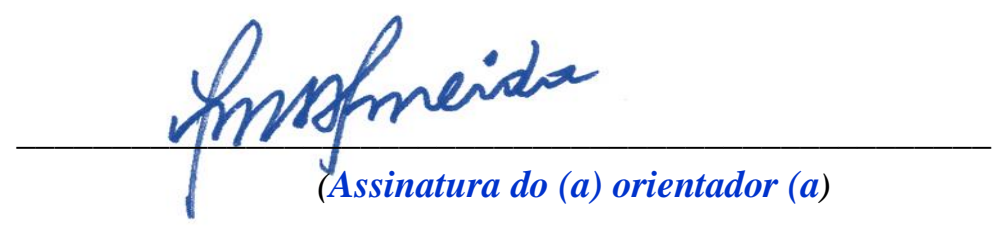


BARRETO, Josenilce Rodrigues de Oliveira. Edição e estudo lexical de documentos novecentistas do Sertão baiano. Tese apresentada à Faculdade de Filosofia, Letras e Ciências Humanas da Universidade de São Paulo para obtenção do título de Doutora em Letras.

Aprovada em: 25/06/2020.

\section{Banca Examinadora:}

Prof. Dr. Manoel Mourivaldo Santiago Almeida (Universidade de São Paulo - Orientador) Julgamento Assinatura

Prof. Dr. Sílvio de Almeida Toledo Neto (Universidade de São Paulo - Membro Interno) Julgamento Assinatura

Profa. Dra. Rita de Cássia Ribeiro de Queiroz (Universidade Estadual de Feira de Santana Membro Externo)

Julgamento Assinatura

Prof. Dr. Expedito Eloísio Ximenes (Universidade Estadual do Ceará - Membro Externo) Julgamento Assinatura

\section{Suplentes:}

Prof. Dr. Phablo Roberto Marchis Fachin (Universidade de São Paulo - Membro Interno) Julgamento Assinatura

Prof. Dr. Fábio César Montanheiro (Universidade Federal de Ouro Preto - Membro Externo) Julgamento Assinatura

Profa. Dra. Eliana Correia Brandão Gonçalves (Universidade Federal da Bahia - Membro Externo)

Julgamento Assinatura 
Ao meu amado painho, José Alves Barreto (in memoriam), e à minha amada mainha, Alaide Rodrigues de Oliveira Barreto, pelo amor, pela vida, pelos ensinamentos, pela paciência, e sem os quais nada disso teria sentido. Muito obrigada por acreditarem e por me ensinarem a acreditar no quão poderosa é a educação! Graças a vocês aqui estou e por vocês sou somente amor! 


\section{AGRADECIMENTOS}

Àqueles que contribuíram, com o seu afeto, ações e/ou palavras de incentivo, para o início e também durante o andamento e após a conclusão desta tese, dedico este espaço no qual externo os meus sinceros e profundos agradecimentos.

Sempre, e em primeiro lugar, a Deus, pelo dom da vida, pelo amor, pelo cuidado e por ter me conduzido até aqui;

Aos meus amados pais, José Alves Barreto (in memoriam) e Alaide Rodrigues de Oliveira Barreto, pelo amor, dedicação, incentivo e sem os quais absolutamente nada teria sentido;

Ao meu irmão querido, Josenilton de Oliveira Barreto, pelo carinho e cuidado;

Ao querido Jorge Flávio Florêncio Soares, pelo amor, companheirismo, apoio integral e incentivo durante toda esta jornada, o meu amor e a minha sincera gratidão. Sem você, com certeza, tudo teria sido muito mais difícil;

Ao meu orientador, Prof. Dr. Manoel Mourivaldo Santiago Almeida, pelo acolhimento desde a seleção para ingresso no Curso de Doutorado, por aceitar me orientar, por ser genuinamente humano e por ter abraçado tudo o que propus durante esta trajetória. $\mathrm{O}$ meu muito obrigada;

À querida Profa. Dra. Rita de Cássia Ribeiro de Queiroz, pelas orientações acadêmicas desde a minha graduação, pelo carinho, cuidado, amor, amizade e respeito ao longo e para além desta trajetória. És um presente de Deus em minha vida e a quem agradeço por boa parte do que sou e do aprendi até aqui;

Ao Prof. Dr. Sílvio de Almeida Toledo Neto, pelas valiosas sugestões durante o exame de qualificação e durante a defesa, e por me privilegiar com os seus conhecimentos e de quem sou fã assumida (risos);

Ao querido Prof. Dr. Expedito Eloísio Ximenes por ter aceitado o convite para participar da banca examinadora, pelas valiosas contribuições e sugestões bibliográficas, pela gentileza de sempre e por acreditar no meu trabalho. Muitíssimo obrigada!;

Aos queridos Prof. Dr. Phablo Roberto Marchis Fachin, Prof. Dr. Fábio César Montanheiro e Profa. Dra. Eliana Correia Brandão Gonçalves, por, generosa e rapidamente, terem aceitado compor a banca examinadora, enquanto membros suplentes;

À Profa. Dra. Ieda Maria Alves, a quem tive o prazer de conhecer pessoalmente e ser sua aluna durante o curso de doutorado, e a quem admiro pelo exemplo de profissionalismo e de ser humano;

À minha amiga e companheira de doutorado, Bárbara Bezerra de Santana Pereira, por compartilharmos as nossas angústias e sonhos, e por ser uma amiga maravilhosa;

À minha amiga paulista que o doutorado e a USP me deram, Ana Carolina Estremadoiro Prudente do Amaral, pelo encontro de almas, pela amizade, pelos risos, sonhos e conversas partilhadas durante e para além do doutorado; 
À minha amiga-irmã Valéria Rios Oliveira Alves, pelas palavras de incentivo, por sempre acreditar em mim, desde os tempos do mestrado, e por ser uma amiga tão maravilhosa e tão incrível que nem consigo descrever;

À minha segunda amiga-irmã Daianna Quelle da Silva Santos da Silva, pelas palavras de carinho, incentivo, apoio e amizade antes, durante e para além do doutorado;

À querida amiga Liviane Gomes Ataíde Santana, pela amizade desde a minha graduação, pelo carinho, respeito, disponibilidade e pelo résumé;

À antes professora e hoje amiga Valéria Marta Ribeiro Soares, pela amizade, pelos olhares e abraços sempre tão afetuosos e cheios de verdade;

Ao amigo Danilo Cerqueira Almeida, pela amizade, pelo companheirismo nas atividades da Revista Graduando e pelo exemplo de profissionalismo;

À Profa. Dra. Josane Moreira de Oliveira, por ser a minha professora malvada favorita durante o mestrado e por ser um poço de amor, embora se esforce bastante para transparecer não sê-lo (risos);

À querida Profa. Dra. Maria da Conceição Reis Teixeira, pelo carinho e acolhimento de sempre;

Às amigas Gleide Conceição de Jesus Silveira, Rosana Maria Rios Carneiro, Lidiane Ferreira da Silva e Viviane Macedo, pela amizade, respeito e carinho desde os tempos de graduação;

Às queridas Mariana Barbosa Batista e Ana Claudia de Ataide Almeida Mota, pelo apoio, carinho e amizade constantes;

À querida Suzana Souza, uma ex-aluna que se tornou amiga, pelo afeto, pela torcida e pelo abstract;

Às minhas amigas e colegas de trabalho na Universidade Federal do Oeste da Bahia, Carla Cristina Braga dos Santos e Aline Ribeiro Pessoa, pelas partilhas, carinho e amizade;

À Revista Graduando, por fazer parte da minha trajetória acadêmica e por ter me oportunizado tantos aprendizados;

Ao Núcleo de Estudos do Manuscrito da Universidade Estadual de Feira de Santana-BA, muito especialmente à sua coordenadora Profa. Dra. Rita de Cássia Ribeiro de Queiroz, por me acolher há 10 anos e por ter me oportunizado ingressar na pesquisa científica;

Ao Centro de Documentação e Pesquisa da Universidade Estadual de Feira de Santana-BA, especialmente ao seu administrador Luiz Cleber Moraes Freire e aos bolsistas, pela recepção, atenção e disponibilização dos manuscritos para a realização deste e de outros trabalhos;

Ao Arquivo Público Municipal de Feira de Santana-BA, especialmente aos seus funcionários, pela recepção e disponibilização dos documentos da Intendência Municipal de Feira de Santana-BA para a realização desta pesquisa; 
Ao Arquivo da Faculdade de Direito de Recife-PE, especialmente ao arquivista, Dreyson Ribeiro Rodrigues, e à Técnica em Arquivo, Elivanda Souza, pelo rápido retorno e pela disponibilização dos documentos solicitados para a realização desta pesquisa;

Ao Arquivo da Faculdade de Direito da Bahia, pela disponibilização das informações solicitadas;

À Universidade Federal do Oeste da Bahia, especialmente ao Centro das Humanidades, pela concessão do meu afastamento parcial para a conclusão desta tese;

Aos meus colegas do Centro das Humanidades da Universidade Federal do Oeste da Bahia, pelo afeto sempre partilhado;

Aos meus alunos e ex-alunos, pela torcida e palavras de carinho;

Enfim, a todos, o meu muito obrigada! 
Num manuscrito autógrafo o texto nunca vem só. [...] [nele] encontramos uma grande variedade de outras coisas que podem ser, no fundo, testemunhos (ainda que fragmentários) da tecitura de que o autor se socorreu para urdir o texto, ou que de alguma maneira a acompanharam. Falaremos de suportes stricto sensu (papéis, tintas, grafitos, colagens), de instrumentos (canetas, lápis, recortes de textos anteriores), de marcas de circunstância (manchas de comida ou bebida, dedadas), de notas deíticas (referências extratextuais do autor a si próprio, ao tempo e ao espaço em que se encontra), de traços caligráficos (que falam da velocidade da escrita, por exemplo, ou da escola, ou da época da alfabetização), de marcas de correção e de reescrita, de marcações para tipografia, mas também de textos preexistentes

(nos casos de reaproveitamento de recortes de textos anteriores, agora reavaliados e recontextualizados), mesmo que alheios (que passam assim a ser glosados) - enfim, de todo o conjunto de informações, mais ou menos explícitas, mais ou menos objetivas, documentadas no manuscrito e que explicam, a quem isso possa interessar, as circunstâncias em que aquele texto, na forma que vem testemunhada naquele manuscrito concreto, foi efetivamente 


\section{RESUMO}

BARRETO, Josenilce Rodrigues de Oliveira. Edição e estudo lexical de documentos novecentistas do Sertão baiano. Tese (Doutorado em Filologia e Língua Portuguesa), Faculdade de Filosofia, Letras e Ciências Humanas, Universidade de São Paulo, 2020.

Os manuscritos atestam a língua e os aspectos da história e da cultura de uma determinada sociedade. Logo, quando o filólogo tem acesso a documentos armazenados em acervos públicos e/ou privados, ele é conduzido a investigar tais aspectos e a preservar as informações constantes naqueles, através da edição. Partindo-se disso, a Filologia, ciência milenar, que tem como objetivo central a preservação de fontes documentais, oferece, junto às suas ciências afins (a Paleografia, a Codicologia, a Diplomática e a Ecdótica), o aparato teóricometodológico necessário à realização de edições e ao estudo de textos diversos. À vista disso, apresentamos, nesta tese, as edições fac-similar e semidiplomática de três documentos feirenses do início do século XX, que estão sob a guarda do Centro de Documentação e Pesquisa (CEDOC), órgão pertencente à Universidade Estadual de Feira de Santana-BA. Tratam-se de dois testamentos e do primeiro volume de um inventário, lavrados entre 1918 e 1922 na cidade de Feira de Santana-BA, e cujo total de fólios chega a 187, os quais encontram-se escritos no recto e verso, em letra cursiva, em papel almaço e em formulários, nos quais constam carimbos, selos, manchas, borrões, rasgões, furos etc., dos quais estes últimos dificultaram, em parte, a leitura de alguns trechos dos documentos sem, no entanto, impedi-la. Além das edições, realizamos a descrição codicológica de 27 documentos armazenados no CEDOC/UEFS, dentre os quais estão inclusos os 3 que foram editados, e paleográfica e diplomaticamente descritos, a fim de realizarmos a contextualização sóciohistórica do corpus e dos seus escreventes. Ademais, depois de editados, os dois testamentos e o primeiro volume do inventário tiveram o seu vocabulário estudado, a partir do método dos Campos Lexicais, estabelecido por Coseriu ([1977] 1991), o qual nos possibilitou inventariar, alocar e analisar 369 lexias em 10 Campos Lexicais, subdivididos em macrocampos, microcampos, subcampos (e suas subdivisões) lexicais, com o objetivo de trazer à tona as lexias consideradas as mais representativas do corpus e, portanto, do vocabulário dos escreventes. Ao final desta tese, apresentamos o perfil sócio filológico-lexical dos escreventes, que redigiram a maior quantidade de fólios do corpus, tarefa realizada a partir das discussões empreendidas ao longo do trabalho. Para a realização dos nossos objetivos de pesquisa, contudo, utilizamos como aporte teórico os trabalhos de Andrade (2010), Bueno (1967), Dubois (1993), Cambraia (2005), Fachin (2008), Megale e Toledo Neto (2005), Melo (1971), Spaggiari e Perugi (2004), Queiroz $(2006,2007)$ etc., que tratam do labor filológico, paleográfico e/ou codicológico, e Abbade (2003, 2006, 2009, 2011), Biderman (1981, 1996, 1998, 2001), Coseriu ([1977] 1991), Geckeler (1976), Oliveira e Isquerdo (2001), Paula (2007), Queiroz (2012), Xavier (2012) etc., que tratam do léxico, da sua teorização e da aplicação do método dos Campos Lexicais a textos diversos, no nosso caso a documentos notariais.

Palavras-chave: Edições fac-similar e semidiplomática. Lexicologia. Campos Lexicais. Perfil sócio filológico-lexical dos escreventes. Documentos feirenses novecentistas. 


\begin{abstract}
BARRETO, Josenilce Rodrigues de Oliveira. Lexical study and edition of 20th century documents from bahian outback. Tese (Doutorado em Filologia e Língua Portuguesa), Faculdade de Filosofia, Letras e Ciências Humanas, Universidade de São Paulo, 2020.
\end{abstract}

As manuscripts evidence the language and many aspects of the history and culture of a given society, when the philologist has access to documents stored in public and/or private collections, he/she is led to investigate such aspects and to preserve the information contained in each of them through edition. Thus, Philology - an ancient science that aims to preserve documentary sources - along with its related areas (Paleography, Codicology, Diplomatics and Ecdotics) offers necessary theoretical-methodological contribution to text editing and study of several texts. Considering this, we present in this thesis the facsimile and semidiplomatic editions of three documents from the beginning of the 20th century, these being under the custody of the Documentation and Research Center (CEDOC), an organ situated in the State University of Feira de Santana-BA (UEFS). For this work we chose two testaments and the first volume of an inventory drawn up between 1918 and 1922 in the city of Feira de Santana-BA, which total number of folios reaches 187, written double-sided in cursive on foolscap paper and forms, containing stamps, seals, stains, blots, tears, holes, etc. - the latter made it difficult to read some parts of the documents, yet without restraint. Also, we carried out a codicological description of 27 documents stored at CEDOC/UEFS, 3 among them edited, then paleographically and diplomatically described to contextualize socio-historically both the corpus and its writers. Furthermore, after being edited, the two wills and the first volume of the inventory had their vocabulary analyzed based on the Lexical Fields method established by Coseriu ([1977] 1991), which helped us catalogue, allocate and analyze 369 lexias in 10 Lexical Fields, subdivided into lexical macrofields, microfields and subfields with the purpose of bringing up the most representative lexias of the corpus and, therefore, the vocabulary of the writers. To conclude, we present the writers' social-philological-lexical profiles, who wrote most of folios of the corpus - done after discussions throughout our work. In order to achieve our research goals we took as theoretical support the works of Andrade (2010), Bueno (1967), Dubois (1993), Cambraia (2005), Fachin (2008), Megale e Toledo Neto (2005), Melo (1971), Spaggiari e Perugi (2004), Queiroz (2006, 2007) etc., who deal with the philological, paleographic and/or codicological work, and of Abbade (2003, 2006, 2009, 2011), Biderman (1981, 1996, 1998, 2001), Coseriu ([1977] 1991), Geckeler (1976), Oliveira e Isquerdo (2001), Paula (2007), Queiroz (2012), Xavier (2012) etc., who deal with the lexicon, its theorization and the application of Lexical Fields to different texts - in our case, to notarized documents.

Keywords: Facsimile and semi-diplomatic editions. Lexicology. Lexical Fields. Writers' social-philological-lexical profiles. Feirense documents from the nineties. 


\section{RÉSUMÉ}

BARRETO, Josenilce Rodrigues de Oliveira. Édition et étude lexicale de documents du XXe siècle du "Sertão" de Bahia. Tese (Doutorado em Filologia e Língua Portuguesa), Faculdade de Filosofia, Letras e Ciências Humanas, Universidade de São Paulo, 2020.

Les manuscrits attestent la langue et les aspects de l'histoire et de la culture d'une certaine société. Donc, quand le philologue a accès aux documents stockés dans des bâtiments publics et/ou privés, il est amené à rechercher tels aspects et à conserver les informations qui y apparaissent à travers l'édition. A partir de cela, la Philologie, une science millénaire, a le but central de préserver des sources documentaires, d'offrir avec ses sciences connexes (la Paléographie, la Codicologie, la Diplomatique et l'Ecdotique), l'appareil théoricométhodologique nécessaire à la réalisation d'éditions et à l'étude de divers textes. De cette façon, nous présentons dans cette thèse, les éditions fac-similé et semi-diplomatique de trois documents de Feira de Santana du début du XXe siècle qui sont sous la responsabilité du Centre de Documentation et Recherche, un organe qui appartient à l'Université d'État de Feira de Santana (UEFS) - Bahia. Il s'agit de deux testaments et du premier volume d'un inventaire rédigés entre 1918 et 1922 dans la ville de Feira de Santana - Bahia, dont la quantité de folios est 187, lesquels se trouvent écrits sur le recto et le verso, en cursive sur des papiers lignés et des formulaires sur lesquels il y a des cachets, taches, déchirures, trous, etc. dont ces derniers sont devenus difficile, en partie, la lecture de certains extraits des documents sans, cependant, l'empêcher. Au-delà des éditions, nous avons réalisé la description codicologique de 27 documents stockés dans le Centre de Documentation et Recherche / UEFS, parmi lesquels les trois qui ont été édités, et paléographiques et diplomatiquement décrits, a fin de réaliser la contextualisation socio-historique du corpus et de ses auteurs. En outre, les deux testements et le premier volume de l'inventaire ont été édités et ensuite leur vocabulaire a été étudié selon la méthode des Champs Lexicaux établie par Coseriu ([1977] 1991), ce qui nous a permis d'inventorier, distribuer et analyser 369 lexies dans dix Champs Lexicaux, subdivisés en macro-champs, micro-champs et sous-champs (et leurs subdivisions) lexicaux, avec l'objectif de présenter les lexies les plus représentatives du corpus et, donc du vocabulaire des scriptores. À la fin de cette thèse, nous présentons le profil sociophilologique-lexical des scriptores qui ont écrit la plus grande quantité de folios du corpus, une tâche accomplie a partir des discussions engagées tout au long du travail. Pour la réalisation de nos objectifs de recherche, cependant, nous utilisons les travaux d'Andrade (2010), Bueno (1967), Dubois (1993), Cambraia (2005), Fachin (2008), Megale et Toledo Neto (2005), Melo (1971), Spaggiari et Perugi (2004) Queiroz (2006, 2007) etc., qui traitent du travail philologique, paléographique et/ou codicologique, et Abbade (2003, 2006, 2009, 2011), Biderman (1981, 1996, 1998, 2001), Coseriu (1991), Geckeler (1976), Oliveira et Isquerdo (2001), Paula (2007), Queiroz (2012), Xavier (2012) etc., qui traitent du lexique, de sa théorisation et de l'application de la méthode des Champs Lexicaux à textes divers, et dans notre cas, à des documents notaires.

Mots-clés: Éditions fac-similé et semi-diplomatique. Lexicologie. Champs Lexicaux. Profil socio-philologique-lexical des scriptores. Documents de Feira de Santana du XXe siècle. 


\title{
LISTA DE ABREVIATURAS E SIGLAS
}

\author{
ABRALIN: Associação Brasileira de Linguística \\ Adapt. Adaptado \\ adj.: $\quad$ Adjetivo \\ adv.: $\quad$ Advérbio
}

ANPOLL: Associação Nacional de Pós-Graduação e Pesquisa em Letras e Linguística

APMFS Arquivo Público Municipal de Feira de Santana

BA: $\quad$ Bahia

C.f.: $\quad$ Conferir

CEDOC: Centro de Documentação e Pesquisa

CEDOHS: Corpus Eletrônico de Documentos Históricos do Sertão

D.: Dom

D.: Dona

Dr.: $\quad$ Doutor

Dra.: $\quad$ Doutora

EDHILP: Edições Digitais para a História da Língua Portuguesa

f.: $\quad$ Fólio

GELNE: Grupo de Estudos Linguísticos e Literários do Nordeste

GT: $\quad$ Grupo de Trabalho

IAFM: Inventário de Agostinho Fróes da Motta

Km: Quilômetro

loc.: $\quad$ Locução

num.: $\quad$ Numeral

p. Página

Prof.: $\quad$ Professor

Profa:: Professora

PUC/SP: Pontíficia Universidade Católica de São Paulo

PUCRS: $\quad$ Pontíficia Universidade Católica do Rio Grande do Sul

r: $\quad$ Recto

s.f.: $\quad$ Substantivo feminino

s.m.: $\quad$ Substantivo masculino

TAFM: $\quad$ Testamento de Agostinho Fróes da Motta

TGT: $\quad$ Teoria Geral da Terminologia

TMAM: $\quad$ Testamento de Maximiana de Almeida Motta

UEFS: $\quad$ Universidade Estadual de Feira de Santana

UEL: Universidade Estadual de Londrina

UFBA: Universidade Federal da Bahia

UFPB: $\quad$ Universidade Federal da Paraíba

USP: $\quad$ Universidade de São Paulo

V. Verbo

v.: $\quad$ Verso

Var. Variação 


\section{LISTA DE FIGURAS}

FIGURA 1 FIGURA 2 FIGURA 3 FIGURA 4 FIGURA 5 FIGURA 6 FIGURA 7 FIGURA 8 FIGURA 9 -

FIGURA 10 FIGURA 11 FIGURA 12 FIGURA 13 -

FIGURA 14 FIGURA 15 -

FIGURA 16 FIGURA 17 FIGURA 18 -

FIGURA 19 -

FIGURA 20 FIGURA 21 -

FIGURA 22 FIGURA 23 FIGURA 24 FIGURA 25 -

FIGURA 26 FIGURA 27 FIGURA 28 -

FIGURA 29 FIGURA 30 FIGURA 31 -

FIGURA 32 -

FIGURA 33 FIGURA 34 -

FIGURA 35 -
Acervo do Arquivo Público Municipal de Feira de Santana-BA. 45

Campo do gado de Feira de Santana-BA no século XIX......................... 48

Praça do Comércio de Feira de Santana-BA (19--).................................. 48

Igreja da Matriz de Feira de Santana-BA (19--).................................... 49

Rua Direita em Feira de Santana (19--)................................................. 50

Rua do Meio em Feira de Santana-BA (19--)...................................... 50

Avenida Senhor dos Passos em Feira de Santana-BA, em 19--............. 51

Sede da Filarmônica 25 de Março em Feira de Santana-BA (19--)........ 51

À direita, sede da Sociedade Montepio dos Artistas Feirenses, 52 localizada ao lado da Sede da Filarmônica 25 de Março, no Centro de Feira de Santana-BA (19--)....

Escola Normal de Feira de Santana-BA (19--)...................................... 52

Cine Teatro Santana de Feira de Santana-BA (19--).............................. 53

Feira livre semanal de Feira de Santana-BA (196-)............................... 53

Primeiro prédio da Santa Casa de Misericórdia em Feira de Santana- 62 BA

Quadro do Intendente Agostinho Fróes da Motta.

66

Grupo Escolar Dr. J.J. Seabra, atual Centro Universitário de Cultura e 69 Arte - CUCA.

Coreto da Praça Fróes da Motta em Feira de Santana-BA (19--)............ 71

Praça Fróes da Motta em dia de festa (19--)............................................. 72

Escola Municipal Maria Quitéria, segundo prédio escolar de Feira de 73

Santana-BA (19--).

Escola Municipal João Florêncio, atual prédio do Arquivo Público 73

Municipal de Feira de Santana-BA (19--)....

Prédio da Vila Fróes da Motta, antes e depois da reforma...................... 75

Escola Estadual Agostinho Fróes da Mota, localizada em Feira de 76 Santana-BA (19--).

Avenida Eduardo Fróes da Motta em Feira de Santana-BA (19--)......... 77

Prédio-sede da Intendência Municipal de Feira de Santana-BA (19--)... 79

Primeira Agência do Banco do Brasil de Feira de Santana (19--).......... 84

Pórtico da Universidade Estadual de Feira de Santana, instituição onde 107

o CEDOC está localizado.

Emblema do CEDOC/ UEFS

108

Caixas-arquivo do acervo do CEDOC/ UEFS....................................... 108

Processo de limpeza e de catalogação dos documentos, feito pelos 108 estagiários do CEDOC/UEFS.

Sala de Pesquisa do CEDOC/UEFS....................................................... 109

Separação dos fólios 1v e 10r pela dobra................................................. 238

Ficha de identificação inserida no fólio 1r pelos estagiários do 238 CEDOC/UEFS.

Detalhes para o carimbo, os furos, as inscrições v e o rasgão no fólio $1 \mathrm{r} .$.

Marca d'água e pontusais no fólio $1 \mathrm{v}$

Detalhe para o barbante que costura os fólios $2 \mathrm{r}, 2 \mathrm{v}, 3 \mathrm{r}, 3 \mathrm{v}, 4 \mathrm{r}$ e $4 \mathrm{v}$ e para os furos próximos à marca de dobra do papel.

Perda de suporte material no centro da extremidade direita do fólio

(1)

(5)

1

2

3

2

69

1

3

3

75

6

77

9

8

2

07

8

08

09

238


2r.

FIGURA 36 - $\quad$ Perda de suporte material no centro da extremidade direita do fólio 3r......

FIGURA 37 - $\quad$ Perda de suporte material no centro da extremidade direita do fólio $4 \mathrm{r}$.

FIGURA 38 -

Escudo entre os $3^{\circ}, 4^{\circ}$ e $5^{\circ}$ pontusais dos fólios $2 \mathrm{v}, 3 \mathrm{v}, 4 \mathrm{v}$ e $5 \mathrm{v}$...

Marca d'água com a inscrição “A. BINDA \& C", entre os $2^{\circ}, 3^{\circ}, 4,5^{\circ}$, $6^{\circ}$ e $7^{\circ}$ pontusais no fólio $10 \mathrm{v}$

FIGURA 40 - Fólio 5v, à esquerda, com detalhes para o conteúdo do sobrescrito, primeira figura à direita, e manchas ocasionadas pela aplicação de lacre, segunda figura à direita.

FIGURA 41 - Formulários preenchidos manualmente: fólios 7r, à esquerda, e 8r, à direita......

FIGURA 42 Reclamo “de" nos fólios 3v/4r e numeração progressiva no fólio 4r.......

FIGURA 43 Selos de impostos no fólio 10r.

242

FIGURA 44 -

Empaginação dos fólios 1r e 2r, escritos por Manuel Francisco de Almeida Ramalho e João Carneiro Vital, respectivamente.

FIGURA 45 - $\quad$ Empaginação dos fólios 2v e 4v, escritos por João Carneiro Vital e Manuel Francisco de Almeida Ramalho, respectivamente.

FIGURA 46 Rubricas do Tabelião de Notas João Carneiro Vital.

FIGURA 47 -

FIGURA 48 -

Sinal público, no fólio 4r, do Tabelião de Notas João Carneiro Vital......

Ganchos nas assinaturas pessoais das testemunhas, no fólio $4 \mathrm{r}$

244

FIGURA 49 -

Ganchos e laçada nas assinaturas pessoais das testemunhas e do Juiz de Direito, respectivamente, no fólio $5 \mathrm{r}$.

FIGURA 50 -

Gancho na assinatura pessoal do Tabelião de Notas, no fólio $5 \mathrm{v}$.

245

245

247

247

248

249

250

251

FIGURA 51 -

Gancho e laçadas nas assinaturas pessoais dos escrivães e do coletor estadual, no fólio 6r.

FIGURA 52 - $\quad$ Ficha de identificação inserida em acima do fólio 1r do testamento de Agostinho Fróes da Motta.

FIGURA 53 - Carimbo molhado com a inscrição "E. V. REIS | Fls. | Escrivão Civel" no fólio $1 \mathrm{r}$ do testamento do Coronel Agostinho Fróes da Motta

FIGURA 54 - Características codicológicas do fólio 1r do testamento de Agostinho Fróes da Motta.

FIGURA 55 Dois selos de impostos no centro da margem inferior do fólio $5 \mathrm{v}$.....

253

Formulário de imposto preenchido manualmente, com detalhe para um carimbo molhado e uma perfuração na lateral da margem esquerda.......

FIGURA 57 Ondulação, rasgões e furos nas margens do fólio $11 \mathrm{r}$......

Retângulo de papel almaço colado na vertical da margem direita do fólio $11 \mathrm{v}$.

FIGURA 59 -

Pedaço de linha de tricô vermelho no fólio $5 \mathrm{v}$. UNIDOS DO BRAZIL $\square 15$ DE NOVEMBRO $\square$ DE 1989", no fólio 9v.

FIGURA 61 -

Detalhe para as marcas de dobras e mancha de tinta no fólio $9 \mathrm{v}$.

Reclamo "Notas" nos fólios 7v/8r e numeração progressiva na margem superior direita do fólio 8r.

FIGURA 63 Empaginação do fólio 2r, escrito por João Carneiro Vital. 
FIGURA 65 - Empaginação do fólio 9r, escrito por Manuel Francisco de Almeida

FIGURA 66 -

FIGURA 67 FIGURA 68 FIGURA 69 FIGURA 70 FIGURA 71 -

FIGURA 72 FIGURA 73 FIGURA 74 FIGURA 75 FIGURA 76 FIGURA 77 FIGURA 78 -

FIGURA 79 FIGURA 80 FIGURA 81 -

FIGURA 82 -

FIGURA 83 -

FIGURA 84 -

FIGURA 85 FIGURA 86 FIGURA 87 FIGURA 88 -

FIGURA 89 -

FIGURA 90 -

FIGURA 91 -

FIGURA 92 -

FIGURA 93 -

FIGURA 94 -
Ramalho e José Telles Barreto.

Assinatura pessoal do escrevente João Carneiro Vital, na margem 260 superior direita, dos fólios 2r, 3r, 4r, 6r, 7r e 8r.

Sinal público do Tabelião João Carneiro Vital, nos fólios 5v e 8r.......... 260

Laçada e sinal público na assinatura pessoal do testador, no fólio 5v..... 261

Ganchos nas assinaturas das testemunhas do processo, no fólio 6r......... 261

Inventário do Coronel Agostinho Fróes da Motta.................................. 262

Fólio 1r do inventário de Agostinho Fróes da Motta, com detalhe para 263 a ficha de identificação.

Aspectos codicológicos do fólio 1r........................................................ 264

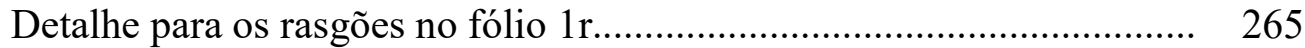

Recortes de papel colados no verso do primeiro fólio............................. 266

Aspectos codicológicos do fólio 2r...................................................... 266

Aspectos codicológicos do fólio 3r, com detalhe para o carimbo seco.... 267

Exemplo de perfurações na vertical esquerda dos fólios rectos............... 268

Selo de imposto, com detalhe para a parte central em alto relevo, e 268 timbre estadual, ambos na maioria dos fólios rectos.

Numeração progressiva na maioria dos fólios rectos.............................. 269

Reclamos "Cotegi-/Cotegipe" nos fólios 16v e 17r................................ 269

Escudo do Estado da Bahia com a inscrição "ESTADO DA BAHIA | 269

PER ARDUA SURGO | BRAZIL" e contramarca "IMPOSTO DO SELLO" no recto do fólio $33 \mathrm{r}$.

Escudo das Armas Nacionais do Brasil com a inscrição "ESTADOS UNIDOS DO BRAZIL | 15 DE NOVEMBRO DE 1889" no verso do fólio 31 .

270

Marca d'água com a inscrição "HAMMERMILL | BOND" na vertical do fólio 109 r...

Exemplos de marcas de selos de impostos nos fólios $15 \mathrm{r}$ e 91r, respectivamente.

Exemplo de marcas de tinta azul no fólio $29 \mathrm{v}$

Exemplos de marcas de cola e de dobras verticais......................................

Exemplos de recortes e de colagem....................

Exemplos de recortes e de colagem.

Carimbo seco, com a inscrição "Dr. José Maria Neves | Advogado", no centro da margem superior do fólio $47 \mathrm{r}$.

Carimbo seco, de $50 \mathrm{~mm}$ de diâmetro, com a inscrição "INTENDENCIA MUNICIPAL DE FEIRA DE SANT'ANNA | ESTADO DA BAHIA | BRAZIL", no centro da margem superior do fólio $149 \mathrm{v}$.

Cartão postal colunado, no fólio 58r, com detalhe para os carimbos molhados, para o selo de imposto e para a inscrição tipográfica na vertical da margem central.

Cartão postal colunado, no fólio 59r, com detalhe para os carimbos molhados, para o selo de imposto e para a inscrição tipográfica na vertical da margem esquerda.

Detalhes para os furos, a marca de dobra e a inexistência de numeração nos fólios 102 recto e verso sem pauta.

Exemplo de in-fólio do livro de caixa da firma comercial Agostinho

Fróes da Motta e Filho, com perda de suporte material.

Exemplo de in-fólio com tendência quebradiça nas linhas marginais 
FIGURA 95 - $\quad$ Exemplos de

FIGURA 96 -

FIGURA 97 -

FIGURA 98 -

FIGURA 99 -

FIGURA 100 -

FIGURA 101 -

FIGURA 102 -

FIGURA 103 -

FIGURA 104 -

FIGURA 105 -

FIGURA 106 -

FIGURA 107 -

FIGURA 108 -

FIGURA 109 -

FIGURA 110 -

FIGURA 111 -

FIGURA 112 -

FIGURA 113 -

FIGURA 114 -

FIGURA 115 -

FIGURA 116 FIGURA 117 -

FIGURA 118 FIGURA 119 FIGURA 120 FIGURA 121 -

FIGURA 122 -

FIGURA 123 FIGURA 124 FIGURA 125 Macêdo. Cerqueira. Santos.
Exemplos de correção da numeração dos fólios..

287

Exemplo de trecho sublinhado, com detalhe para a anotação "Vide"......

Exemplos de trechos sublinhados, com detalhes para as inserções de pontuações e de "x".

Exemplo de trecho datiloscrito com detalhes para as marcações que indicam o sentido de leitura.

Exemplos de inserções manuscritas feitas durante a revisão do texto.....

Anulação e correção de informação nos fólios 149r/v.

Traço longo sinuoso na vertical do centro do fólio $27 \mathrm{r}$......

Fac-símile do registro da carta de bacharel de Agnello Ribeiro de

Exemplos de aspectos paleográficos na scripta de Cesar Ribeiro de

Exemplos de aspectos paleográficos na scripta de Manoel Gomes dos

Ficha de identificação do inventário de Antonio Alves Barretto, com detalhe para a sua ficha de identificação.

Procuração feita por Antonio Alves Barretto para o seu advogado, com detalhe para a sua assinatura com gancho.

Trecho do depoimento e assinatura pessoal do Major Estanislau Alves Barretto nos fólios $67 \mathrm{v}$ e $69 \mathrm{v}$ do primeiro volume do inventário do Coronel Agostinho Fróes da Motta (1922).

Procuração e assinatura, com laçada, de João Constantino Faskomy, no fólio $514 \mathrm{r} / \mathrm{v}$ da petição solicitada por Adalberto Alves de Farias e Arthur Fróes da Motta (1927-1930).

Procuração de Adalberto Alves de Farias, no fólio 64r, da ação ordinária de filiação e petição de herança (1922-1927)...

Assinatura do Coronel Tertuliano José de Almeida no termo de apresentação para ser avaliador dos bens de Dona Maximiana de Almeida Motta em seu inventário (1918-1919).

Chácara de Tertuliano Almeida, construída em 1919..

Testemunhas do testamento do Coronel Agostinho Fróes da Motta........

Casarão Villa Áurea de Epiphanio José de Souza.....

Tela inicial do Site de Laurence Anthony.....

Instruções sobre as ferramentas do AntConc apresentadas no ícone Ajuda do Site de Laurence Anthony.

Tela inicial do AntConc versão 3.5.8.

Opções do ícone File do aplicativo de Software AntConc, com detalhe para o Open File(s).

Configurações do AntConc aplicadas ao corpus de análise..

Resultado da primeira leitura do AntConc em relação ao corpus.............

Resultados da busca do item lexical <casa > na ferramenta Word List....

Resultados da busca do item lexical <casa> na ferramenta Concordance.

Resultados da busca por $<$ casa de $>$ na ferramenta Clusters $/ N$-Grams.... 
FIGURA 126 - Distribuição das lexias por escrevente. 


\section{LISTA DE QUADROS}

QUADRO 1 QUADRO 2 -

QUADRO 3 -

QUADRO 4 QUADRO 5 QUADRO 6 QUADRO 7 QUADRO 8 QUADRO 9 QUADRO 10 QUADRO 11 QUADRO 12 QUADRO 13 QUADRO 14 QUADRO 15 QUADRO 16 QUADRO 17 QUADRO 18 QUADRO 19 QUADRO 20 QUADRO 21 QUADRO 22 QUADRO 23 QUADRO 24 QUADRO 25 QUADRO 26 QUADRO 27 QUADRO 28 QUADRO 29 QUADRO 30 QUADRO 31 QUADRO 32 QUADRO 33 -

QUADRO 34 QUADRO 35 -

QUADRO 36 QUADRO 37 QUADRO 38 -

QUADRO 39 QUADRO 40 -
Políticos de Feira de Santana nos fins do século XIX e início do XX... Índices populacional e de analfabetismo nos Estados do Nordeste brasileiro em 1900.

Lista dos documentos cíveis da família Fróes da Motta, disponíveis 110 no CEDOC/UEFS

Modelo de Guia Básico de Descrição Codicológica............................. 116

Ficha codicológica do primeiro documento......................................... 117

Ficha codicológica do segundo documento........................................ 119

Ficha codicológica do terceiro documento........................................... 121

Ficha codicológica do quarto documento............................................. 124

Ficha codicológica do quinto documento.......................................... 127

Ficha codicológica do sexto documento.............................................. 130

Ficha codicológica do sétimo documento......................................... 132

Ficha codicológica do oitavo documento........................................... 134

Ficha codicológica do nono documento.............................................. 137

Ficha codicológica do décimo documento........................................... 141

Ficha codicológica do décimo primeiro documento............................. 145

Ficha codicológica do décimo segundo documento............................. 152

Ficha codicológica do décimo terceiro documento.............................. 157

Ficha codicológica do décimo quarto documento.................................. 160

Ficha codicológica do décimo quinto documento.................................. 164

Ficha codicológica do décimo sexto documento................................... 165

Ficha codicológica do décimo sétimo documento................................ 168

Ficha codicológica do décimo oitavo documento................................ 172

Ficha codicológica do décimo nono documento................................... 176

Ficha codicológica do vigésimo documento........................................ 180

Ficha codicológica do vigésimo primeiro documento.......................... 181

Ficha codicológica do vigésimo segundo documento........................... 185

Ficha codicológica do vigésimo terceiro documento............................ 186

Ficha codicológica do vigésimo quarto documento.............................. 189

Ficha codicológica do vigésimo quinto documento............................. 191

Ficha codicológica do vigésimo sexto documento............................... 193

Ficha codicológica do vigésimo sétimo documento............................. 197

Caracterização diplomática dos documentos estudados........................ 206

Punhos que escreveram o testamento de Dona Maximiana de Almeida 246 Motta.....

Punho de José Telles Barreto.............................................................. 258

Relação dos selos de impostos constantes no primeiro volume do 274 inventário do Coronel Agostinho Fróes da Motta.

Carimbos molhados dos escreventes..................................................... 275

Exemplos de manchas no documento................................................. 276

Escreventes do primeiro volume do inventário de Agostinho Fróes da 279 Motta..

Exemplos da scripta dos "sujeitos" da lei que redigiram o primeiro volume do inventário.

Exemplos da scripta dos membros e do funcionário da firma comercial da família Fróes da Motta..... 
QUADRO 41 - Assinaturas pessoais dos escreventes do primeiro volume do 285 inventário.

QUADRO 42 - Exemplos de ausência de cursus do escrevente Manuel Francisco de 293 Almeida Ramalho

QUADRO 43 - Amostra de aspectos gráficos e de escrita fonética do escrevente Manuel Francisco de Almeida Ramalho.

QUADRO 44 - Amostra de aspectos gráficos e de escrita fonética do escrevente Jacintho Ferreira da Silva.

QUADRO 45 - Amostra de aspectos gráficos e de escrita fonética do escrevente José Maria Neves.

QUADRO 46 - Amostra de aspectos gráficos e de escrita fonética do escrevente João Carneiro Vital

QUADRO 47 - Amostra de aspectos gráficos e de escrita fonética do escrevente Agnello Ribeiro de Macêdo

QUADRO 48 - Amostra de aspectos gráficos e de escrita fonética do escrevente Altino Teixeira.

QUADRO 49 - Aspectos da escrita fonética de Cesar Ribeiro de Cerqueira.

Exemplos de aspectos da escrita fonética de Manoel Gomes dos Santos.

QUADRO 51 - "Sujeitos" processuais do testamento de Dona Maximiana de Almeida Motta....

QUADRO 52 - "Sujeitos" processuais do testamento do Coronel Agostinho Fróes da Motta.

QUADRO 53 - "Sujeitos" processuais do primeiro volume do inventário do Coronel Agostinho Fróes da Motta.

QUADRO 54 - Sumarização do conteúdo constante no primeiro volume do inventário do Coronel Agostinho Fróes da Motta.

QUADRO 55 Macrocampos e microcampos do Campo Lexical Documentos

QUADRO 57 - Macrocampos, microcampos, subcampos, sub-subcampos e sub-subsubcampos do Campo Lexical Imóveis.

QUADRO 58 - Macrocampos, microcampos, subcampos e sub-subcampo do Campo Lexical Instituições e locais sociais e públicos.

QUADRO 59 - Macrocampos do Campo Lexical procedimentos jurídicos... moedas e transações econômicas.

QUADRO 63 - Macrocampos, microcampos, subcampos, sub-subcampos, sub-subsubcampos, sub-sub-sub-subcampos e sub-sub-sub-sub-subcampos do Campo Lexical Topônimos.

QUADRO 64 - Macrocampos do Campo Lexical Tributação. 


\section{LISTA DE TABELAS}

TABELA 1 - Escolas criadas nos distritos da cidade de Feira de Santana-BA, em 96 1896.

TABELA 2 - Perfil socioeducacional dos escreventes do corpus...... 


\section{LISTA DE ORGANOGRAMAS}

ORGANOGRAMA 1 - Árvore genealógica de Manuel Francisco de Almeida 308 Ramalho

ORGANOGRAMA 2 Árvore genealógica de Jacintho Ferreira da Silva. seus cônjuges.

ORGANOGRAMA 11 Árvore genealógica de Tertuliano José de Almeida Árvore genealógica de Amadeu Saback de Oliveira. 
SUMÁRIO SOBRE A "PRINCESA DO SERTÃO" E OS SEUS GOVERNANTES NO INÍCIO DO SÉCULO XX.. NOTAS SOBRE A FUNDAÇÃO DA CIDADE E AS PRIMEIRAS MUDANÇAS NA FEIRA DE SANTANA DO INÍCIO DO SÉCULO XX.

SOBRE A ESCOLHA DOS "DIRIGENTES POLÍTICOS” E 54 OS “ARES DE PROGRESSO” DE FEIRA DE SANTANA NAS PRIMEIRAS DÉCADAS DO SÉCULO XX..

2.3 SOBRE A PREOCUPAÇÃO DOS GOVERNANTES DE FEIRA DE SANTANA COM A DEMOCRATIZAÇÃO DO ACESSO À EDUCAÇÃO PÚBLICA NO INÍCIO DO SÉCULO XX.

2.4 SÍNTESE DA SEÇÃO

CARACTERIZAÇÃO DO CORPUS PARA OS ESTUDOS 105 FILOLÓGICO-LINGUÍSTICOS.

3.1 DELINEANDO O CORPUS: DESCRIÇÃO CODICOLÓGICA 106 DE DOCUMENTOS NOVECENTISTAS DO SERTÃO BAIANO. DOCUMENTOS

3.3 SÍNTESE DA SEÇÃO DE TRÊS DOCUMENTOS NOVECENTISTAS DO SERTÃO BAIANO. 
DA ECDÓTICA

T.2 TIPOS DE EDIÇÃO DE TEXTOS......................................... 227

4.3 DA DESCRIÇÃO À EDIÇÃO DE TEXTOS: 233 ESQUADRINHAMENTO DO CORPUS.

4.3.1 Descrição dos aspectos codicológicos e paleográficos do 235 corpus.

4.3.2 Descrição das mãos que escrevem: uma proposta de 302 categorização do perfil socioeducacional dos escreventes do corpus.

4.3.3 Descrição do conteúdo do corpus........................................... 324

4.3.3.1 Sobre os laços familiares da Família Fróes da Motta: 339 construindo árvores genealógicas.

4.3.4 Descrição do perfil socioprofissional dos indivíduos 348 envolvidos no processo de produção do corpus.

4.3.5 Apresentação das edições fac-similar e semidiplomática do 383 corpus.

4.3.5.1 Descrição dos critérios adotados 384

4.3.5.2 Edições fac-similar e semidiplomática do testamento de Dona 388 Maximiana de Almeida Motta.

4.3.5.3 Edições fac-similar e semidiplomática do testamento do 422 Coronel Agostinho Fróes da Motta

4.3.5.4 Edições fac-similar e semidiplomática do primeiro volume do 456 inventário do Coronel Agostinho Fróes da Motta.

4.4 SÍNTESE DA SEÇÃO. 1037

DAS CIÊNCIAS DO LÉXICO AO ESTUDO DO 1040 VOCABULÁRIO DE TRÊS DOCUMENTOS NOVECENTISTAS DO SERTÃO BAIANO.

5.1 CONSIDERAÇÕES SOBRE AS CIÊNCIAS E OS ESTUDOS 1040 DO LÉXICO.

5.2 O ESTABELECIMENTO DO MÉTODO DOS CAMPOS 1054 LEXICAIS. 
ANÁLISE DO LÉXICO DO CORPUS

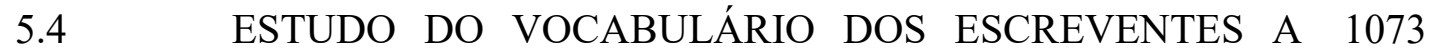

PARTIR DE CAMPOS LEXICAIS

\subsection{1}

Campo Lexical Documentos.

1074

5.4.1.1 Macrocampo documentos jurídicos.......................................... 1075

5.4.1.1.1 Microcampo documentos prescritivos...................................... 1075

5.4.1.1.2 Microcampo documentos deliberativos.................................... 1077

5.4.1.1.3 Microcampo documentos peticionados..................................... 1078

5.4.1.1.4 Microcampo documentos remetidos.......................................... 1078

5.4.1.1.5 Microcampo documentos comprobatórios................................... 1079

5.4.1.1.6 Microcampo documentos contratuais..................................... 1080

5.4.1.1.7 Microcampo documentos juntivos........................................... 1081

5.4.1.1.8 Microcampo documentos de recurso........................................... 1082

5.4.1.1.9 Microcampo documentos de partilha......................................... 1082

5.4.1.1.10 Microcampo documentos fiscais e contábeis.............................. 1083

5.4.1.1.11 Microcampo documentos cartoriais............................................ 1083

5.4.1.1.12 Microcampo documentos mantidos em Juízo............................. 1084

5.4.1.2 Macrocampo documentos pessoais........................................... 1084

5.4.1.2.1 Microcampo Generalidades...................................................... 1084

5.4.1.2.2 Microcampo correspondências pessoais....................................... 1085

5.4.1.2.3 Microcampo documentos imagéticos......................................... 1086

5.4.2 Campo Lexical Fazenda........................................................ 1086

5.4.2.1 Macrocampo arredores da fazenda............................................. 1086

5.4.2.1.1 Microcampo árvores da fazenda.............................................. 1087

5.4.2.1.1.1 Subcampo frutos de árvores da fazenda................................... 1088

5.4.2.1.1.2 Subcampo mudas de árvores da fazenda................................... 1088

5.4.2.1.2 Microcampo animais da fazenda................................................ 1088

5.4.2.1.2.1 Subcampo fêmeas de animais da fazenda..................................... 1090

5.4.2.1.2.2 Subcampo filhotes de animais da fazenda................................. 1090

5.4.2.1.3 Microcampo transportes usados na fazenda............................... 1091

5.4.3 Campo Lexical Imóveis............................................................ 1091

5.4.3.1 Macrocampo generalidades.................................................... 1093

5.4.3.1.1 Microcampo peças utilizadas na construção do imóvel.............. 1093 
5.4.3.1.2 Microcampo área externa do imóvel.......................................... 1094

5.4.3.1.2.1 Subcampo cômodos da área externa do imóvel........................... 1094

5.4.3.1.2.2 Subcampo objetos da área externa do imóvel............................. 1094

5.4.3.1.3 Microcampo móveis do imóvel.................................................... 1094

5.4.3.1.3.1 Subcampo móveis de gabinete............................................... 1095

5.4.3.1.3.1.1 Sub-subcampo generalidades................................................... 1095

5.4.3.1.3.1.2 Sub-subcampo móveis de assento............................................. 1095

5.4.3.1.3.1.3 Sub-subcampo móveis sobre os quais são realizados trabalhos 1095 de escritórios

5.4.3.1.3.1.4 Sub-subcampo móveis nos quais são guardados objetos de 1095 valor

5.4.3.1.3.1.4.1 Sub-sub-subcampo objetos guardados no interior do cofre de 1096 gabinete.

5.4.3.1.3.2 Subcampo árvores utilizadas na fabricação de mobílias do 1098 imóvel

5.4.3.2 Macrocampo imóveis de residência

1098

5.4.3.2.1 Microcampo cômodos do imóvel de residência............................ 1099

5.4.3.2.1.1 Subcampo mobílias, instrumentos musicais e objetos de 1101 ornamentação da sala de visitas

5.4.3.2.1.1.1 Sub-subcampo mobílias de assento da sala de visitas.................. 1101

5.4.3.2.1.1.2 Sub-subcampo instrumentos musicais da sala de visitas............. 1102

5.4.3.2.1.1.3 Sub-subcampo objetos de ornamentação da sala de visitas.......... 1102

5.4.3.2.1.2 Subcampo mobílias da sala de jantar............................................ 1103

5.4.3.2.1.2.1 Sub-subcampo objetos guardados no guarda-louça ou no porta- 1104 cristal da sala de jantar.

5.4.3.2.1.3 Subcampo mobílias e cômodos do quarto..................................... 1106

5.4.3.2.1.3.1 Sub-subcampo mobílias do quarto............................................... 1106

5.4.3.2.1.3.2 Sub-subcampo cômodos do quarto............................................. 1107

5.4.3.3 Macrocampo imóveis comerciais................................................ 1107

5.4.2.3.1 Microcampo Generalidades........................................................ 1107

5.4.2.3.1.1 Subcampo Casas Comerciais................................................... 1107

5.4.2.3.2 Microcampo imóveis comerciais de armazenamento de 1107 mercadorias 
5.4.4.2 Macrocampo Instituições, locais e territórios públicos ou administrativos.

5.4.4.2.1.1 Subcampo locais públicos onde se realizam atividades jurídicas.

5.4.4.2.1.1.1 Sub-subcampo dispositivos da sala das audiências.........

5.4.4.2.2 Microcampo Instituições administrativas..

Microcampo instituições públicas que cobram e recebem impostos.

5.4.4.2.4.1 Subcampo instituições educacionais de ensino superior.. pelo poder judiciário.

5.4.4.2.6.1 Subcampo territórios divididos pelo poder judiciário. 
5.4.6.6 Macrocampo cargos municipais.............................................. 1122

5.4.6.7 Macrocampo cargos processuais............................................ 1122

5.4.6.7.1 Microcampo ocupações processuais........................................ 1126

5.4.6.8 Macrocampo cargos eclesiásticos............................................ 1129

5.4.6.9 Macrocampo cargos e patentes militares................................. 1130

5.4.6.9.1 Microcampo cargos militares................................................. 1130

5.4.6.9.2 Microcampo patentes militares................................................ 1130

5.4.6.10 Macrocampo profissionais da Saúde.......................................... 1131

5.4.6.10.1 Microcampo profissionais da Medicina................................... 1131

5.4.6.10.2 Microcampo profissionais da Farmácia..................................... 1131

5.4.6.11 Macrocampo profissionais da Educação.................................... 1131

5.4.6.12 Macrocampo profissionais da Engenharia................................. 1131

5.4.6.13 Macrocampo profissionais do Jornalismo.................................. 1131

5.4.6.14 Macrocampo profissionais do Comércio e da Indústria............... 1131

5.4.6.14.1 Microcampo profissionais do Comércio....................................... 1131

5.4.6.14.2 Microcampo profissionais da Indústria.................................... 1132

5.4.6.15 Macrocampo profissionais de Banco.......................................... 1132

5.4.6.16 Macrocampo profissionais de Leilão........................................... 1132

5.4.6.17 Macrocampo profissionais do campo......................................... 1133

5.4.6.18 Macrocampo profissionais do artesanato................................... 1133

5.4.6.19 Macrocampo profissionais do lar............................................. 1133

5.4.7 Campo Lexical da Sexualidade................................................... 1133

5.4.7.1 Macrocampo Generalidades..................................................... 1134

5.4.7.2 Macrocampo das ações......................................................... 1134

5.4.7.3 Macrocampo dos qualificadores da mulher.............................. 1134

5.4.8 Campo Lexical títulos econômicos, moedas e transações 1135

5.4.8.1 Macrocampo títulos econômicos.................................................. 1135

5.4.8.2 Macrocampo moedas econômicas................................................. 1136

5.4.8.3 Macrocampo transações econômicas............................................ 1138

5.4.8.3.1 Microcampo ações.............................................................. 1138

5.4.8.4 Macrocampo pagamentos...................................................... 1139

5.4.9 Campo Lexical Topônimos............................................................. 1139 
5.4.9.1 Macrocampo Países.................................................................... 1141

5.4.9.1.1 Microcampo Estados brasileiros................................................ 1141

5.4.9.1.1.1 Subcampo cidades da Bahia..................................................... 1141

5.4.9.1.1.1.1 Sub-subcampo generalidades................................................... 1141

5.4.9.1.1.1.1.1 Sub-sub-subcampo bairros da Capital do Estado........................ 1141

5.4.9.1.1.1.1.2 Sub-sub-sub-subcampo ruas urbanas dos bairros da Capital do 1142 Estado

5.4.9.1.1.1.2 Sub-subcampo cidades do interior baiano.................................. 1142

5.4.9.1.1.1.2.1 Sub-sub-subcampo fazendas das cidades do interior baiano........ 1143

5.4.9.1.1.1.2.2 Sub-sub-subcampo ruas urbanas das cidades do interior baiano.. 1145

5.4.9.1.1.1.2.2.1 Sub-sub-sub-subcampo ruas urbanas de Feira de Santana-BA.... 1145

5.4.9.1.1.1.2.2.2 Sub-sub-sub-sub-subcampo praças urbanas de Feira de 1147 Santana-BA

5.4.9.1.1.1.2.3 Sub-sub-subcampo estradas das cidades do interior baiano......... 1148

5.4.9.1.1.1.2.3.1 Sub-sub-sub-subcampo estradas de Feira de Santana-BA........... 1148

5.4.9.1.1.1.2.3.1.1 Sub-sub-sub-sub-subcampo estradas dos bairros suburbanos de 1148 Feira de Santana-BA

\section{4 .10}

Campo Lexical Tributação

1148

5.4.10.1 Macrocampo Generalidades..................................................... 1148

5.4.10.2 Macrocampo impostos de serviços públicos................................ 1149

5.4.10.2.1 Microcampo selos pagos na execução de serviços públicos........ 1149

\section{6}

6.1

6.2

6.3

6.4
PERFIL SÓCIO FILOLÓGICO-LEXICAL DE SEIS 1157 ESCREVENTES DO CORPUS.

PERFIL SÓCIO FILOLÓGICO-LEXICAL DO 1157 ESCREVENTE 1

$\begin{array}{lllll}\text { PERFIL SÓCIO FILOLÓGICO-LEXICAL DO } & 1160\end{array}$ ESCREVENTE 2

$\begin{array}{lllll}\text { PERFIL SÓCIO } & \text { FILOLÓGICO-LEXICAL } & \text { DO } & 1161\end{array}$ ESCREVENTE 3

PERFIL SÓCIO FILOLÓGICO-LEXICAL DO 1162 
6.5 PERFIL SÓCIO FILOLÓGICO-LEXICAL DO 1163 ESCREVENTE 5 .

$\begin{array}{lllll}6.6 & \text { PERFIL SÓCIO } & \text { FILOLÓGICO-LEXICAL DO } & 1164\end{array}$ ESCREVENTE 6 ...

6.7 SÍNTESE DA SEÇÃO.. 1165

ANEXOS.

1184

ANEXO A - FAC-SÍMILES DO CORPUS.............................. 1185

ANEXO B - FAC-SÍMILE DO FÓLIO 374r DA AÇÃO 1559 ORDINÁRIA DE SONEGADOS (1929).

ANEXO C - FAC-SÍMILE DO FÓLIO 374v DA AÇÃO 1560 ORDINÁRIA DE SONEGADOS (1929) 


\section{INTRODUÇÃO}

A tarefa mais laboriosa para o pesquisador que lida, em sua prática diária, com documentos históricos é selecionar, dentre vários, um único documento ou um conjunto documental para ser preparado para edição e publicação. A essa dificuldade, soma-se a escolha que o pesquisador precisa fazer de um único, dentre tantos, elemento linguístico para ser estudado com maior profundidade, já que o tempo e os recursos de pesquisa lhe exigem tais escolhas. Disso, constata-se que os documentos históricos, que constituem fonte de prazer e de árduo trabalho para o pesquisador, precisam ter o seu conteúdo e, quando possível, a sua materialidade preservadas, e a sua língua, atestada no texto, estudada, a partir de um elemento linguístico, que se julga representativo do corpus, definido a partir da leitura inicial do texto e da sua contribuição para o estudo da língua vernácula constante no(s) documento(s) escolhido(s).

Contudo, para tomar a decisão considerada a mais acertada acerca do corpus e dos objetivos de pesquisa a serem traçados, o pesquisador deve pesar, em primeiro lugar, sobre qual(is) a(s) espécie(s) e/ou tipologia(s) documental(is) e o acervo/arquivo a ser estudado e a sua relevância para a sociedade representada nos documentos, a qual, na maioria das vezes, desconhece a sua existência. Em segundo lugar, o mesmo pesquisador deve refletir, antes de realizar as suas escolhas, sobre os seus objetivos em paralelo com a contribuição do seu trabalho para a preservação a) das informações circunscritas nos documentos selecionados, b) dos aspectos sócio-históricos (externos ao corpus) que conduzem o pesquisador ao conhecimento mais amplo dos membros da sociedade, que produziram os documentos, e dos próprios textos, e c) do estudo de um elemento linguístico que possibilite ao pesquisador não apenas conhecer, mas descrever um ou mais aspectos da língua utilizada pelos membros da comunidade, que redigiram e/ou contribuíram para o processo de produção dos textos, lavrados em uma determinada época e que se encontram sob a análise do pesquisador.

Partindo disso, o investigador começa a traçar os caminhos que o conduzirão às respostas das questões que, provavelmente, serão levantadas a partir das suas escolhas de pesquisa. À vista disso, ao selecionarmos os documentos que compõem o corpus desta tese, levamos em consideração os itens apontados e os harmonizamos com as escolhas de pesquisa que temos feito há alguns anos. Sobre estas, contudo, julgamos necessário contextualizar como e porque tivemos acesso aos documentos que apresentamos nesta tese, a fim de possibilitarmos a compreensão dos objetivos traçados durante a nossa pesquisa, os quais culminaram nos resultados apresentados ao longo desta tese de doutoramento. 
Assim sendo, voltamos a 2010, ano em que a referida autora desta tese teve o seu primeiro contato, enquanto bolsista voluntária, a nível de Iniciação Científica, com os documentos disponíveis no Centro de Documentação e Pesquisa, doravante CEDOC, localizado na Universidade Estadual de Feira de Santana-BA, onde buscou, junto com a sua orientadora, à época da sua Graduação em Licenciatura em Letras Vernáculas na referida universidade, selecionar um auto de partilha da primeira metade do século XX para realizar a edição filológica do referido documento.

Àquela época, a sua orientadora, Professora Doutora Rita de Cássia Ribeiro de Queiroz, já coordenava o Núcleo de Estudos do Manuscrito, ao qual estava vinculado o Projeto de Pesquisa intitulado Estudo histórico-filológico e artístico de documentos manuscritos baianos dos séculos XVIII ao XX, criado em 2004 e no qual os pesquisadores se dedicavam (e ainda se dedicam, já que o projeto está em andamento) à realização de edições semidiplomáticas e do estudo histórico e artístico de documentos manuscritos baianos, vinculados às esferas eclesiástica, cível, crime e comercial, produzidos entre os séculos XVIII e XX, pertencentes aos municípios baianos de Água Fria, Cachoeira, Conceição da Feira, Feira de Santana, Riachão do Jacuípe, Santo Amaro, São Gonçalo dos Campos, Serrinha e Tanquinho.

No referido projeto, o objetivo geral pleiteado pela coordenadora foi o de realizar a edição de variados documentos baianos que abrangessem aqueles municípios e aquele período. Ainda em 2010, a Professora Doutora Rita de Cássia Ribeiro de Queiroz criou e coordenou, até 2017, um outro Projeto de Pesquisa, no qual o objetivo foi o de "estudar o léxico da língua portuguesa presente em textos representativos da cultura, sejam estes literários ou não literários, da atualidade ou de épocas pretéritas, manuscritos ou impressos, através de teorias que priorizassem a onomasiologia, isto é, que partissem do conceito para chegar ao signo".

Ao projeto Língua e cultura: estudos sobre o léxico boa parte dos pesquisadores que tinha editado os documentos vinculados ao projeto de pesquisa anterior passou a integrar esse, com o intuito de analisar o léxico dos textos preparados filologicamente. Nesse contexto, a autora desta tese acabou inserida em ambos os projetos, já que primeiro realizou a edição semidiplomática do auto de partilha selecionado no CEDOC/UEFS e, em seguida, o estudou lexicalmente, a partir da proposta de análise estruturada por Eugenio Coseriu ([1977] 1991), a partir da qual foi estudado o Campo Lexical da Fazenda, que era o mais representativo do corpus. 
A partir desses trabalhos foi sendo então delineado, pela iniciante à pesquisa científica, um caminho que começaria a se consolidar dois anos mais tarde, em 2012, quando ambas, a orientadora e a orientanda, voltaram ao CEDOC/UEFS para selecionar, a priori, outros autos de partilha para serem editados e estudados, agora, durante o Curso de Mestrado em Estudos Linguísticos na mesma instituição. Contudo, ao folhearem os catálogos disponíveis no CEDOC/UEFS, nos quais há uma grande quantidade de documentos cíveis e crimes catalogados e pertencentes a inúmeras cidades baianas dos fins dos séculos XIX e XX (até 1975), a tipologia documental que nos interessou, seja por estruturas diplomáticas, seja por seu conteúdo, seja pelos indivíduos mencionados, seja pela sua contribuição para a história e memória de Feira de Santana-BA, foi uma ação de desquite que foi editada e estudada lexicalmente durante a pesquisa de Mestrado, que culminou na produção da dissertação intitulada Pelos caminhos da separação: edição semidiplomática e estudo do vocabulário de uma "acção ordinária de desquite” do início do século XX e defendida em 2014.

A escolha por uma ação de desquite, datada de 1919 a 1922, cuja autora do processo fora a senhora Albertina da Motta Barretto, deu-se, principalmente, após conhecermos o seu sobrenome, o qual nos suscitou bastante curiosidade, haja vista se tratar da filha do então Intendente da cidade de Feira de Santana-BA, no início do século XX, o Coronel Agostinho Fróes da Motta, cuja visibilidade política, histórica e social é bastante notória e estudada por vários memorialistas e historiadores, principalmente os de Feira de Santana-BA, até os dias atuais.

A partir da descoberta da identidade da autora e do réu do processo, das informações acerca das partes interessadas, da disposição geográfica da cidade de Feira de Santana-BA naquele período, do léxico evidenciado no texto, das relações sociais que pululavam do corpus, dos nomes de figuras públicas mencionadas no texto, dentre outros aspectos, entendemos que se tratava de um documento que acrescentaria muito ao conhecimento da história da cidade e da identidade das pessoas que, não apenas viveram, mas foram determinantes para a afirmação de Feira de Santana-BA enquanto uma "cidade progressista", que tinha personalidades políticas, cujo poder econômico e posição social foram cruciais para a consolidação das relações sociais descritas na referida ação de desquite.

Portanto, à medida que a pesquisa foi sendo desenvolvida e a dissertação de mestrado escrita, fomos identificando muitas lacunas advindas das informações do documento, principalmente, porque a menção de variados nomes de pessoas, até então, desconhecidas e a remissão a outros documentos constantes no CEDOC/UEFS e relacionados à ação de desquite se fazia de forma constante, o que nos levou a compreender que aquele trabalho não poderia 
se encerrar naquele momento, mas deveria ser aprofundado com vistas à uma descrição ampla não apenas das informações que contribuíriam para a composição do cenário político, histórico, econômico e social no qual aquelas pessoas estavam inseridas, mas também para o levantamento e análise do léxico utilizado pelos escreventes que, rotativamente, produziam e lavravam os documentos.

Logo, o preenchimento das lacunas suscitadas durante a pesquisa de mestrado se fazia imprescindível para fecharmos "um quadro" que nos permitisse "perfilar" os escreventes, as partes mencionadas, incluindo-se nestas as figuras políticas, e uma parte do léxico da língua portuguesa, expressa nas escolhas lexicais dos escreventes, sobre os quais não sabíamos praticamente nada, já que, até então, nem sequer havíamos pensado na possibilidade de tal perfilamento sócio-histórico, linguístico e cultural.

Somente após a defesa da dissertação de mestrado é que a autora desta tese continuou, com o intuito de começar a elaborar o seu projeto de doutorado, consultando os catálogos do CEDOC/UEFS com o objetivo de encontrar os documentos mencionados na ação de desquite supramencionada e a investigar a existência de outros documentos que, de forma direta ou indireta, tiveram quaisquer relações com algum(ns) do(s) membro(s) da família Fróes da Motta e/ou com os escreventes ou partes citadas naquele processo judicial.

Felizmente, já nas primeiras buscas foram encontrados não apenas um, mas vários documentos, cujos interessados e/ou partes envolvidas foram os membros da referida família e cujos escreventes foram os mesmos que escreveram e lavraram a ação de desquite estudada. Assim, desde o início da nossa investigação até o presente momento, conseguimos identificar vários processos jurídicos, cíveis e crimes, envolvendo um, dois, três ou até mais membros daquela família, em cada documento, dentre os quais foi selecionado como corpus para esta tese de doutoramento apenas três, a saber: o testamento do Coronel Agostinho Fróes da Motta e o da sua primeira esposa, Dona Maximiana de Almeida Motta, e também o primeiro volume do inventário do referido coronel e patriarca da família Fróes da Motta, haja vista que foi a partir do referido casal que o clã adquiriu visibilidade política, financeira e social, como apontamos na próxima seção, e a partir dos quais inúmeros outros processos judiciais foram instaurados na então Comarca de Feira de Santana-BA.

Logo, como se tratava de uma família, cujo sobrenome era bastante influente na cidade de Feira de Santana-BA naquele período, optamos por editar filológica e estudar lexicalmente aqueles três documentos, por se tratarem de textos importantes para o conhecimento da história local - que também inclui a própria história de vida e ascensão social e política do Coronel Agostinho Fróes da Motta e da sua família, da estrutura 
geográfica da cidade e das relações sociais existentes entre os membros familiares e amigos, dentre os quais estavam personalidades políticas e ocupantes de cargos públicos importantes no cenário feirense, como apontado na próxima seção, e cuja descrição tem nos ajudado a compreender as relações que os indivíduos estabeleceram entre si e com os documentos produzidos.

Assim, com o intuito de preencher as lacunas que surgiram, a nossa pesquisa que se iniciou com a leitura de uma boa parte dos documentos que se relacionavam com a família Fróes da Motta, a partir da qual buscamos associar os indivíduos e as relações sociais e familiares, inicialmente descritas no documento editado na dissertação de mestrado, para, a partir da combinação das informações anteriores com as novas, delinearmos a nossa proposta e estratégia de trabalho pensadas para esta tese, que consiste, basicamente, de três grandes objetivos, a saber: primeiro, preparar uma edição confiável para estudos linguísticos e historiográficos, já que os mesmos documentos editados foram lexicalmente estudados e contribuem para a descrição de parte da história da cidade e dos indivíduos, que se fizeram presentes no processo de produção e lavração dos dois testamentos e do primeiro volume do inventário dos patriarcas da família Fróes da Motta, e em torno dos quais boa parte desta tese está alicerçada, já que tanto o léxico quanto os aspectos sócio-históricos são imprescindíveis para o fazer filológico.

Segundo, descrever, a partir de fichas codicológicas, e caracterizar diplomaticamente os vinte e sete documentos cíveis selecionados do CEDOC/UEFS, com o fito de que as informações advindas da descrição codicológica nos ajude na exposição e junção 1) dos aspectos sócio-históricos, portanto, externos ao corpus, que surgiram durante a leitura e edição dos três documentos selecionados como corpus desta tese; e 2) dos sujeitos e de suas relações descritas nos processos. Ademais, com a descrição apresentada buscamos oferecer ao arquivo do CEDOC/UEFS uma contribuição para complementação das informações referentes à catalogação daqueles documentos, que possuem equívocos dessa natureza.

Terceiro, levantar, inventariar e analisar as lexias que constituem o vocabulário dos escreventes que redigiram os dois testamentos e o primeiro volume do inventário, lavrados entre 1918 e 1922 na cidade de Feira de Santana-BA, por entendermos que esse tipo de estudo pode nos permitir definir quais as lexias utilizadas pelos escreventes e os seus contextos de uso, bem como os Campos Lexicais mais profícuos e, portanto, representativos do corpus. Com isso, acreditamos que esse tipo de análise contribuirá não somente para os estudos lexicais, que vêm crescendo expressivamente no Brasil, mas também para a sócio-história do 
português brasileiro utilizado pelos "homens da lei", que compunham as camadas sociais privilegiadas de Feira de Santana-BA no início do século XX.

Ao traçar esses três objetivos, entendemos que somente a edição filológica e as informações advindas dos documentos editados não seriam suficientes para compreendermos a presença e as relações sociais estabelecidas pelas partes envolvidas e pelos escreventes do corpus. Também compreendemos que apenas o estudo do vocabulário não "daria conta" de responder às questões que começavam a aparecer durante o andamento da pesquisa e que, provavelmente, conduziria a nossa análise a caminhos mais amplos para, quem sabe, conseguirmos "fechar" um perfil socioeducacional dos escreventes e um socioprofissional dos indivíduos, que foram mencionados como partes interessadas ou testemunhas nos processos editados.

Mais do que isso, compreendemos que se quiséssemos apresentar uma análise mais completa do corpus, precisaríamos percorrer um longo caminho: pesquisas que nos ajudassem a compreender os aspectos sócio-históricos do corpus e junto a estes a produção de organogramas, nos quais as genealogias de vários indivíduos estivessem descritas, com o objetivo de nos permitir relacioná-las com os círculos sociais, dentro dos quais vários casamentos foram realizados para fortalecer os laços políticos e de amizade, nos quais aqueles sujeitos encontravam-se inseridos. Além disso, ao "acessarmos" parte do vocabulário dos escreventes a partir do corpus, partimos da hipótese de que as escolhas lexicais advinham de homens que, por ofício ou formação educacional, não apenas conheciam, mas sabiam como e onde empregar as estruturas inerentes à composição diplomática de testamentos e de inventários, o que nos levou a inferir que, provavelmente, um perfil socioeducacional poderia nos oferecer dados que nos permitissem traçar um "retrato" daqueles indivíduos, a partir do que a materialidade dos documentos, da língua e do que os contextos histórico, político, econômico e social nos ofereceriam. Nesse percurso, levantamos, portanto, a hipótese de que somente a combinação de todos esses fatores nos permitiria traçar um perfil que desse conta da complexidade do corpus e dos seus escreventes.

Para chegar à confirmação ou não da nossa hipótese, portanto, começamos a nossa busca por informações advindas de vários documentos do CEDOC/UEFS, de obras bibliográficas sobre Feira de Santana-BA e os seus administradores, de arquivos públicos, de periódicos locais e de dissertações de mestrado que versassem os anos de 1900 a 1930, período que antecede e sucede o momento de produção do corpus e que, portanto, nos permitiriam obter as informações de que necessitávamos para a composição da história externa do corpus. A partir do que nos foi apresentado nos materiais consultados, produzimos 
as seções que se seguem, partindo primordialmente das seguintes questões, que nortearam este trabalho: Quais e que tipo de informações podem ser extraídas de documentos notariais como, por exemplo, testamentos e inventários do início do século XX, produzidos em uma cidade do interior baiano que, até então, estava em fase de crescimento econômico? Quem foram, do ponto de vista político, econômico e social, os indivíduos, incluindo-se nestes os escreventes, que produziram ou contribuíram para o processo de produção do corpus? O vocabulário que consta nos documentos editados pode ser alocado no Método dos Campos Lexicais, proposto por Eugenio Coseriu ([1977] 1991)? E, em caso positivo, quais os Campos Lexicais são os mais representativos do corpus e, portanto, podem nos possibilitar a associação das escolhas lexicais com os seus escreventes? É possível, a partir da combinação do léxico com os aspectos sociais, históricos, políticos, econômicos e educacionais, traçar um perfil dos escreventes do corpus?

Para tentar responder a essas questões, retornamos ao momento em que, para definirmos o corpus desta tese, partimos da assertiva de que o que buscávamos era, sobretudo, um trabalho que desse continuidade ao que iniciamos durante a pesquisa que coadunou na dissertação de mestrado, defendida em 2014, justamente porque os documentos jurídicos têm se apresentado como um "fundo documental" (BELLOTTO, 2006) bastante profícuo para variados estudos e, principalmente, porque, além de estarem salvaguardados em uma importante instituição que abriga, cuida e disponibiliza milhares de documentos produzidos, durante várias décadas, nas cidades do interior baiano, os processos jurídicos que estão no CEDOC/UEFS constituem-se partes da história do sertão baiano e da sua sociedade que, se estudados, relacionados e combinados, possibilitarão a descrição sócio-histórica-cultural, política, econômica e até educacional das cidades e dos indivíduos que as povoaram durante o final do século XIX até 1975, o que já nos indica a relevância do arquivo para a preservação da história e da memória, quase sempre, desconhecida pelos habitantes das cidades que compõem o sertão baiano.

Partindo disso, este trabalho, que está inserido no Projeto de Pesquisa Edição e estudo de textos literários e não literários em língua portuguesa, coordenado pelo Prof. Dr. Manoel Mourivaldo Santiago Almeida, vinculado à linha de pesquisa Filologia do Português do Programa de Pós-Graduação em Filologia e Língua Portuguesa do Departamento de Letras Clássicas e Vernáculas da Faculdade de Filosofia, Letras e Ciências Humanas da Universidade de São Paulo, representa uma tentativa de contribuir para a constituição de corpora não literários escritos em língua portuguesa no Sertão baiano, e para os estudos do 
léxico do português culto, utilizado pela classe dominante de Feira de Santana-BA nas primeiras décadas do século XX.

Assim, ao relacionarmos os objetivos de nossa pesquisa com as questões levantadas, acreditamos que, consequentemente, a relação entre língua e cultura se evidenciará, já que estas estão entrelaçadas, principalmente, porque através do léxico é possível conhecer como uma dada sociedade pensa(va) e se relaciona(va) em um determinado período, neste caso no início do século XX na referida cidade.

Assim, para o desenvolvimento desta tese, utilizamo-nos, em um primeiro momento, da Filologia, que é consagrada como a ciência do texto e que, etimologicamente, advém do

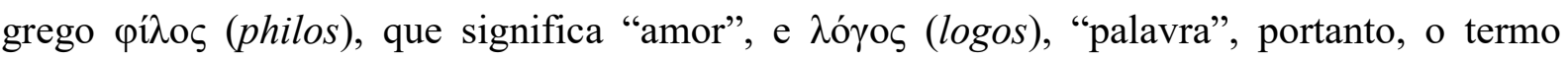
Filologia pode ser entendido como "amor à palavra" e, como amantes da palavra, os filólogos podem se debruçar sobre textos produzidos em épocas pretéritas, modernas e/ou contemporâneas, sejam aqueles manuscritos, datiloscritos ou digitoscritos, produzidos por pessoas com escolaridade variada e em comunidades e épocas distintas. Partindo dessa assertiva, o trabalho do filólogo acaba sendo amplo, pois abrange a produção intelectual e cultural de povos distintos em momentos históricos variados, o que permite que a Filologia interaja com outras ciências, a fim de melhor estudar os textos e as sociedades que os produziram.

Destarte, embora seja considerada uma ciência antiga, já que a sua origem remonta à Antiguidade Clássica, a Filologia tem se adaptado às demandas emergentes de novos gêneros textuais produzidos em ambientes virtuais, o que tem lhe exigido a criação de modelos de edições digitais para atender às variadas demandas. Contudo, embora esses modelos tenham ganhado bastante visibilidade dentro dos estudos filológicos contemporâneos, não os abordaremos pois não são o foco desta tese.

Partindo do princípio de que a Filologia trabalha com o texto de modo a preservar as suas informações, incluindo-se nisso os aspectos relacionados às sociedades e às culturas que o produziram, trazemos à tona, como dissemos anteriormente, alguns documentos feirenses, armazenados no CEDOC/UEFS, os quais são estudados filológica e lexicalmente nas seções seguintes.

Contudo, além da Filologia, também utilizamos a Paleografia, a Codicologia, a Diplomática e a Ecdótica, com o objetivo de aprofundarmos o nível de análise do corpus que, em um segundo momento, tem o seu léxico estudado, a partir da Lexicologia, classificada como uma das ciências do léxico, e cujo objeto de estudo é o próprio léxico que, no caso deste trabalho, centra-se no vocabulário dos escreventes que produziram os documentos editados, a 
partir do qual apresentamos as lexias mais recorrentes no corpus, as quais estão dispostas em Campos Lexicais, que julgamos evidenciar as escolhas lexicais e, portanto, o modo de pensar daqueles indivíduos, membros da sociedade feirense do início do século XX, haja vista tratarem-se de testamentos e de inventário nos quais muitas lexias sobre os meios urbano, rural e jurídico estão presentes, o que nos tem permitido identificar a variedade de lexias conhecidas e utilizadas pelos escreventes, o que igualmente evidencia a diversidade de itens lexicais que compunham o vocabulário daqueles indivíduos e, portanto, a assertiva de que cultura e sociedade estão, indubitavelmente, imbricadas na análise lexical se torna inconteste.

Assim, esta tese encontra-se dividida em sete seções, a saber: além deste texto introdutório, uma segunda seção, História externa do corpus: considerações sobre a “Princesa do Sertão" e os seus governantes no início do século XX, na qual apresentamos informações sobre a história externa do corpus, constituída de um levantamento sobre a origem da cidade e a atuação dos seus administradores nas primeiras décadas do século XX. Trata-se, portanto, de uma seção idealizada e produzida para contextualizar o locus e os indivíduos mencionados no corpus.

Na terceira seção, Caracterização do corpus para os estudos filológico-linguísticos, listamos e fichamos codicologicamente os vinte e sete documentos selecionados do CEDOC/UEFS, com o fito de alinharmos as informações descritas na seção anterior com as emergidas da leitura dos documentos expostos nesta seção, a partir da qual conseguimos estabelecer as relações entre os indivíduos que produziram e/ou contribuíram para o processo de produção do corpus, efetivamente analisado na quarta seção. Ao final da terceira seção, apresentamos a caracterização diplomaticamente dos documentos descritos nas respectivas fichas codicológicas e damos especial atenção às espécies documentais selecionadas como corpus.

Na quarta seção, Da Filologia e suas ciências afins à edição de três documentos novecentistas do sertão baiano, apresentamos um panorama da Crítica Textual, da Filologia moderna, da Paleografia, da Codicologia e da Ecdótica, com o intuito de ampararmos teoricamente o estudo a ser realizado: a descrição dos aspectos codicológicos, paleográficos, dos punhos que escreveram os documentos, do conteúdo do corpus, do perfil socioprofissional dos sujeitos que participaram da produção dos textos e, por fim, apresentamos as edições fac-similar e semidiplomática do corpus.

$\mathrm{Na}$ quinta seção, Das ciências do léxico ao estudo do vocabulário de três documentos novecentistas do sertão baiano, fazemos considerações sobre as ciências e os estudos do léxico, seguidas de discussões sobre o estabelecimento do método dos campos 
lexicais, proposto por Eugenio Coseriu (1977), bem como dos procedimentos adotados para a divisão e análise do léxico, do estudo do vocabulário propriamente dito e, por fim, de uma síntese da seção e dos resultados encontrados na análise lexical.

Na sexta seção, Perfil sócio filológico-lexical de seis escreventes do corpus, construímos um perfil, amparado nos aspectos sociais, filológicos e lexicais, dos escreventes que escreveram a maior quantidade de fólios do corpus, a partir das informações e das análises apresentadas nas seções anteriores.

Na sétima seção, Considerações Finais, realizamos um balanço do que discutimos ao longo desta tese, bem como apresentamos perspectivas de pesquisas futuras acerca dos documentos listados na terceira seção. Por fim, elencamos as referências utilizadas para a realização deste trabalho, seguidas dos anexos. 


\section{HISTÓRIA EXTERNA DO CORPUS: CONSIDERAÇÕES SOBRE A "PRINCESA DO SERTÃO” E OS SEUS GOVERNANTES NO INÍCIO DO SÉCULO XX}

Como pontuado na introdução desta tese, nesta seção o nosso objetivo é compreender o cenário em que os documentos editados e as relações estabelecidas entre os seus indivíduos são apresentados nas fontes pesquisadas. Para isso, dispomos de dados sobre Feira de Santana-BA entre os anos de 1900 a 1930, período que antecede e sucede o momento de produção dos documentos ${ }^{1}$ que compõem o corpus desta tese, a fim de os relacionarmos com as informações emergidas da leitura do corpus e, a partir disso, compreendermos os elos entre os seus "dirigentes" políticos, bem como os contextos social, histórico, econômico e político, vivenciados por aqueles, principalmente por se tratarem de figuras públicas, cujas influências contribuíram para o "progresso" da cidade de Feira de Santana-BA nos primeiros anos do século XX, o que justifica a necessidade da produção desta seção por entendermos que todos os eventos sociais, políticos e econômicos da cidade refletiram, direta ou indiretamente, no processo de produção dos documentos, sobre os quais nos debruçamos.

A partir da necessidade de compreendermos quem foram, do ponto de vista econômico, político e social, os indivíduos mencionados no corpus, decidimos ampliar o nosso campo de investigação sobre a cidade, os seus administradores e os "sujeitos" (CUNHA, 2013) da lei, inseridos no referido período e nos documentos pesquisados e, para isso, amparamo-nos em textos de ampla circulação, tais como reportagens e notas que veicularam, entre 1909 e 1930, no Folha do Norte, periódico feirense criado em 17 de setembro de 1909 e veiculado em muitas cidades ${ }^{2}$ brasileiras e em Portugal. Atualmente, o

\footnotetext{
${ }^{1}$ Como dito anteriormente, os três documentos que compõem o corpus desta tese são dois testamentos e o primeiro volume de um inventário, lavrados entre 1918 e 1922 e se encontram listados no quadro 3, alocado na subseção 3.1 Delineando o corpus: descrição codicológica de documentos novecentistas do Sertão baiano, na qual são descritos, além daqueles, outros vinte e quatro documentos armazenados no CEDOC/UEFS, os quais contribuíram para a produção desta seção, e sem os quais muitas informações advindas do corpus estariam incompletas.

${ }^{2}$ Conforme nota inserida em todos os exemplares do Folha do Norte daquele período, o periódico circulava nas cidades e distritos de Feira de Santana, Tanquinho, Bom Despacho, Almas, Bomfim, Chapada, Gameleira, Santa Luzia, Humildes, Limoeiro, São Roque, Fortaleza, São Vicente, São José, Santa Bárbara, Candeal, Riachão do Jacuípe, Pé de Serra, Coité, Valente, Gavião, Serra Preta, Berimbau, Picado, Mercês, Oliveira, Lapa, Coração de Maria, Irará, São Simão, Pedrão, Ouriçangas, Bento Simões, Mucambo, Sant’Anna do Lustosa, São Gonçalo dos Campos, Umburanas, Conceição da Feira, Cachoeira, São Félix, Muritiba, Capivari, Camisão, Santo Estevão, Castro Alves, Conceição do Almeida, Cruz das Almas, Baixa Grande, São João do Paraguassú, Caetité, Itaberaba, Orobó Grande, Monte Alegre, Mundo Novo, Baixa do Palmeira, Maracás, Campestre, Minas do Rio de Contas, Conquista, Macaúbas, Santa Inês, Brejões, Bahia (para se referir à capital do Estado, Salvador), Esplanada, Mata de São João, Alagoinhas, Cidade do Bomfim, Juazeiro, Cidade da Barra, Nazareth, Amargosa, Santo Antônio de Jesus, Conde, Abadia, Pojuca, Itaparica, Monte Santo, Uauá, Acari, Queimadas, Santa Luzia, Itiúba, Remanso, Cumbe, Pombal, Barreiras, Maragogipe, Ilhéus, Belmonte, Itabuna, Bom Conselho, Santo Amaro, Bom Jardim, Sant'Anna dos Brejões, Morro do Chapéu, Ventura, Andaraí, Jacobina, Jeremoabo, São Bento das Lajes, Vila de São Francisco, Jequié, Serrinha, Machado Portela, Barra do Rio de Contas, Itapicurú,
} 
Folha do Norte continua circulando em Feira de Santana-BA e os seus exemplares do início do século XX foram digitalizados e estão disponíveis para pesquisa local no Museu Casa do Sertão, localizado na Universidade Estadual de Feira de Santana-BA, exemplares dos quais extraímos informações para compor o quadro de relações existentes entre os indivíduos que aparecem no corpus.

Sobre os "ares de longevidade" do Folha do Norte, em 17 de setembro de 1927, foi publicada uma nota no referido jornal para parabenizar o seu décimo oitavo aniversário:

A Folha do Norte foi $\mid$ criada sem alardes, modesta, | mas resoluta, decidida a | propugnar sempre pelo engrandecimento, | pela prosperidade, e pelos créditos $\mid$ da terra bem amada. || Alentavam-na a experiência de | seu fundador e dirigente $\mid \mathrm{o}$ saudoso Tito Ruy Bacellar, | a inteligência robustecida pelo | estudo do jovem Arnold Silva | e a clarividência de João | Carneiro Vital. || Essa tríade intelectual feirense, | já afeita a testilha das | letras e conhecedora das dificuldades | com que arca o jornalismo $\mid$ no interior para viver e | triunfar não vacilou, no entanto, | em meter ombros a empresa | para defesa eficiente dos augustos | ideais do torrão pátrio ${ }^{3}$ (A FOLHA..., FOLHA DO NORTE, 17 set. 1927, p. 1).

Como se pode notar, a criação do Folha do Norte ocorreu através da iniciativa de três senhores reconhecidos social e politicamente em Feira de Santana-BA: o Coronel Tito Ruy Bacelar, que era redator-chefe do periódico; o então jovem Arnold Ferreira da Silva, secretário do periódico no ano de sua criação; e o Tabelião de Notas João Carneiro Vital, redator do referido jornal, o que evidencia o empenho de um seleto trio para criar e manter vivo o periódico. Entretanto, a iniciativa daquela "tríade intelectual" não ocorreu despropositadamente, mas para fazer oposição política ao Jornal O Município, criado em 1892

Curuçá, Jaguaribe, Porto Seguro, Tucano, Caravelas, Cidade de Areia, Rio de Janeiro, Rio Grande do Sul (nas cidades de Porto Alegre, São Gabriel e Livramento), Pernambuco (nas cidades de Recife, Pesqueira, Taracatú), Espírito Santo (nas cidades de Vitória e Guarapari), Minas Gerais (nas cidades de Belo Horizonte, São João Nepomuceno, Januária, Ubá, Teófilo Otoni, São Sebastião do Herval, São João Del Rei, Fortaleza, Itapecerica e Barbacena), Alagoas (na cidade de Penedo), Paraíba, Sergipe (na cidade de Buquim), São Paulo (na Capital, Itapira, Ribeirão Preto, Cajuru, Monte Azul, Matão, Mogi Mirim, Rio Claro, Pirassununga, Jaú e Descalvado), Acre Federal (nas cidades de Rio Laco, Sena Madureira e Porto Acre), Ceará (Canindé), Mato Grosso (Curumbá) e Portugal (nas cidades de Alvações do Corgo, Guimarães e Foz do Douro).

${ }^{3}$ A transcrição de todas as notas extraídas do Jornal Folha do Norte e dos Livros da Intendência Municipal de Feira de Santana-BA foi realizada com base nas normas de transcrição de documentos, propostas por Megale e Toledo Neto (2005) e, por nós, adaptadas às necessidades dos textos editados. Assim, os excertos foram transcritos, nesta seção, obedecendo-se aos seguintes critérios: 1. A transcrição foi conservadora; 2. As abreviaturas, alfabéticas ou não, foram desenvolvidas, marcando-se, em itálico, as letras omitidas na abreviatura, respeitando a grafia do manuscrito; 3. Não foi estabelecida fronteira de palavras que vieram escritas juntas, nem se introduziu hífen ou apóstrofo onde não houvesse; 4. A pontuação e a acentuação originais foram rigorosamente mantidas; 5. Foi respeitado o emprego de maiúsculas e minúsculas como se apresentavam no original; 7. As palavras com algum desvio da norma padrão vigente foram transcritas exatamente como constam nos textos; 8. Foi inserida barra vertical ( | ) para indicar mudança de linha; 9. Foram inseridas duas barras verticais ( II ) para indicar mudança de parágrafo; 10. Foram inseridos colchetes [ ] nos casos das interpolações. Exemplo: "[ad]miradores, que o acom- | panharam." (CORONEL..., FOLHA DO NORTE, 22 out. 1909, p. 1). 
e administrado pelo Coronel Abdon Alves de Abreu, que assumiu a Intendência Municipal entre 1908 e 1912, e que se manteve junto com os seus aliados à frente das publicações d'O Município até o último ano de sua circulação, em 1911.

Quando O Município parou de circular não houve mais oposição ao Folha do Norte, que se tornou o único periódico veiculado semanalmente na cidade de Feira de Santana-BA. Nas páginas de ambos os periódicos encontravam-se publicações que serviram como instrumentos para atacar e/ou parabenizar as gestões municipais da época, atitudes políticas semelhantes às dos jornais criados antes ou no mesmo período que aqueles, a saber: $O$ Feirense (1866), Gazeta do Povo (1892-1899), O Propulsor (1895), O Progresso (1900-1909) e $A$ República (1905), que, em seus devidos contextos e fins, alavancaram positivamente ou propagaram mentiras acerca dos intendentes que atuaram em seus respectivos momentos político e histórico de Feira de Santana-BA (CUNHA, 2013).

Além do Folha do Norte, também consultamos os Livros de registros de oficios expedidos pela Intendência Municipal de Feira de Santana (1893-1908 e 1915-1923), o de registro de títulos dos empregados municipais de Feira de Santana (1912-1920) e os de Lançamentos de impostos de indústrias e profissões de Feira de Santana (1916 e 1917), armazenados e disponíveis para pesquisa local no Arquivo Público Municipal de Feira de Santana $^{4}$, doravante APMFS, cujo acervo, composto por variados livros, fotografias e correspondências da administração pública, está organizado em caixas-arquivo amarelas do tipo polionda ou alocado em estantes de ferro, nas quais estão dispostos os referidos livros, revestidos por uma folha de papel pardo, no qual foi anexada uma ficha de identificação.

\footnotetext{
${ }^{4}$ Este arquivo está localizado na Avenida Senhor dos Passos, n. 1101, Centro da Cidade de Feira de Santana BA, CEP: 44002-375.
} 
Figura 1 - Acervo do Arquivo Público Municipal de Feira de Santana-BA
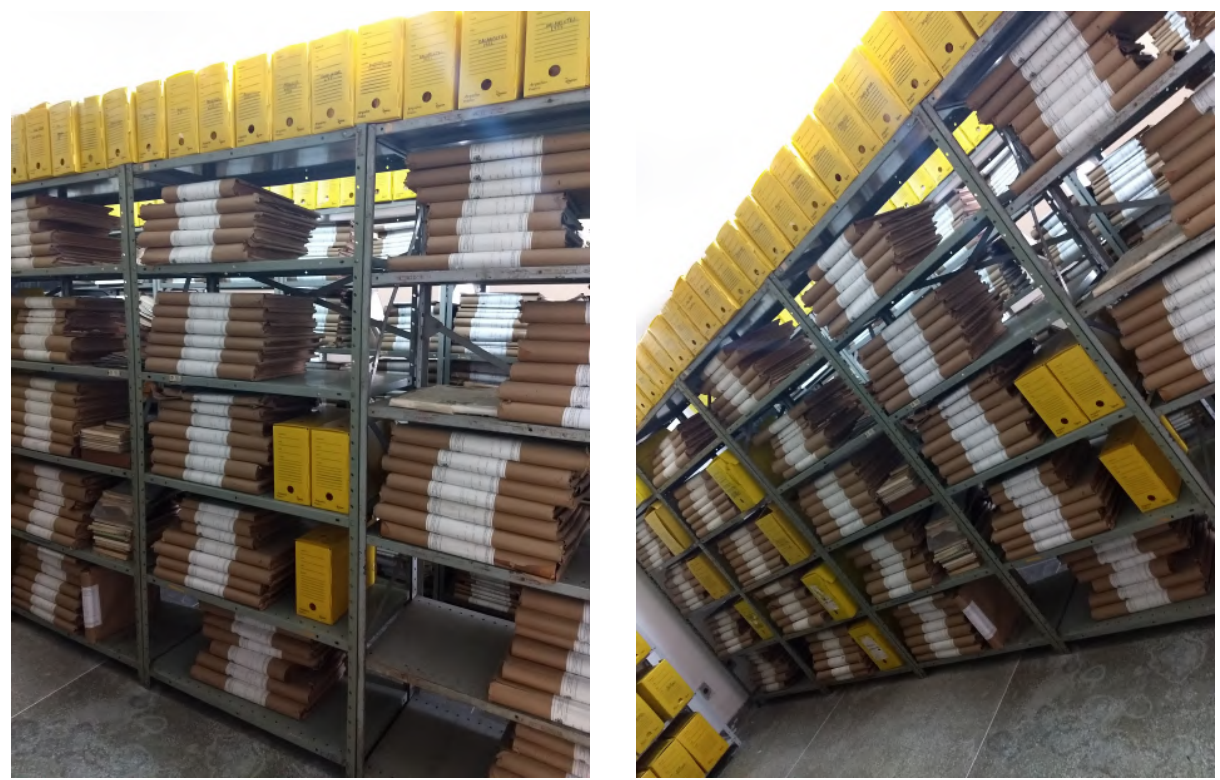

Fonte: Arquivo Público Municipal de Feira de Santana-BA ${ }^{5}$

Essas fontes, somadas a livros e dissertações de mestrado, defendidas no âmbito de alguns programas brasileiros de Pós-Graduação em História, tais como Boaventura (2006), Cerqueira e Souza (2009), Costa (2013), Cunha (2013), Freire (2007), Oliveira (2016), Reis (2012), Rodrigues (2016), Silva (2012), Simões (2007) etc. nos permitiram compreender as relações existentes entre os indivíduos mencionados nos documentos a que consultamos, sobre as quais passamos a abordar nas próximas seções.

\subsection{NOTAS SOBRE A FUNDAÇÃO DA CIDADE E AS PRIMEIRAS MUDANÇAS NA FEIRA DE SANTANA DO INÍCIO DO SÉCULO XX}

De acordo com Freire (2007), Feira de Santana, cidade localizada a 116 quilômetros de Salvador, Capital do Estado da Bahia, começou o seu povoamento quando um casal de moradores doou algumas tarefas de terras para a construção de uma capela, cuja invocação advinha de Santa Ana e de São Domingos. A partir da sua construção, começou a ser formada uma feira de gado semanal, que favoreceu os crescimentos populacional e econômico da cidade, que confluíram para a sua emancipação política, separando-a de Cachoeira-BA, em 12

\footnotetext{
${ }^{5}$ Esta fotografia, assim como a grande maioria disposta nesta tese, foi tirada pela autora desta tese. Assim, vale destacar que só serão mencionados os nomes dos(as) autores(as), cujas fotografia(s) não foram tiradas pela referida autora.
} 
de junho de 1855, e elevando Feira de Santana à condição de "cabeça da Comarca”, passando a exercer, portanto, jurisdição sobre o Termo de mesmo nome e sobre o recém-criado Termo de Camisão ${ }^{6}$ e da paróquia de Conceição do Coité.

Em 1859, houve a incorporação das paróquias de Humildes e de Remédios da Gameleira, desmembradas de São Gonçalo dos Campos, que permaneceram assim até o fim do Império, em 1889 (FREIRE, 2007). Nesse contexto, o local deixou de ser chamado Fazenda Santana dos Olhos d'Água e passou a ser denominado Arraial de Santana da Feira e, em seguida, de Comercial Cidade de Feira de Santana (BOAVENTURA, 2006; SIMÕES, 2007). Ainda nos fins do século XIX, o número de mão-de-obra nas fazendas cresceu não somente por conta da criação de gado, mas também por causa do cultivo de lavouras de tabaco, mandioca, algodão, milho, feijão e, em menor número, cana-de-açúcar, além de couros secos, solas e peles (FOLHA DO NORTE, 1916), o que evidenciava o interesse dos fazendeiros e comerciantes da época em manter a alta produtividade da pecuária e da agricultura no sertão baiano, esta última alicerçada, principalmente, pelo trabalho escravo.

Sobre os altos índices de produtividade da pecuária e da agricultura desenvolvidas em Feira de Santana, o Intendente Coronel Bernardino da Silva Bahia enalteceu, em ofício de número 55 emitido, em 19 de março de 1920, pela Intendência Municipal de Feira de Santana, a cidade e a sua forte produção pastoril e agrícola quando solicitou a ajuda do Deputado Federal Arlindo Baptista Leone para a construção de uma barragem no Rio Jacuípe, que possibilitaria maior acesso à água para cultivo da lavoura e criação de gado.

[...] Nossos mui sinceros e respeitosos cumprimentos. II Motivo da mais alta transcendencia, e que diz respeito | ao progresso deste florescente municipio, induznos a diri- | girmos o presente fazendo um justo apello a Vossa Excellencia, como | dignissimo representante desta Circunscripção no Congresso | Federal. Como sabe Vossa Excellencia, o municipio da Feira de | Sant'Anna é um dos mais prosperos do nosso vasto Esta- $\mid$ do, e, os seus administradores o tem collocado ultimamente $\mid \mathrm{em}$ nivel condigno e relativo as suas riquezas naturaes. $\|$ É nelle que se concentram todos os productos da indus- | tria pastoril de nossos sertões, apar de sua muito des- | envolvida agricultura, da qual, com as propriedades | feraces de seu solo, obtuir-se os apreciaveis ceriaes, o | fumo, o algodão, tuberculos e luxuriantes pomares, cons- | tituindo assim um dos principaes celeiros do Paiz e | proporcionando largas rendas ao erario publico. [...] (LIVRO DE REGISTROS DE OFÍCIOS..., 1920, f. 102r102v).

Como se pode notar, o Intendente não somente enalteceu, mas deixou claro o seu interesse em levar o "progresso" para o município, a partir da construção da referida

\footnotetext{
6 Este Termo aparece no primeiro volume do inventário que compõe o corpus desta tese como uma das localidades em que o inventariado possuía bens a serem avaliados e partilhados entre os seus herdeiros. Logo, trata-se de um Termo relevante no contexto de produção do corpus.
} 
barragem, para a qual a argumentação se baseava na existência das riquezas naturais e de toda a produção advinda da criação de gado e da agricultura, que tornavam Feira de Santana “[...] um dos principaes celeiros do Paiz [que proporcionaria] largas rendas ao erario publico [...]" (LIVRO DE REGISTROS DE OFÍCIOS..., 1920, f. 120v), ou seja, a contribuição do Deputado Federal poderia ser tranquilamente feita, pois, segundo o Intendente, já havia garantias de que o município apresentava "ares" de prosperidade e de mudanças tanto do ponto de vista geográfico quanto econômico.

Assim, devido à sua localização estratégica, inserida em uma área de transição entre o litoral e o sertão baianos, bem como pela fertilidade do seu solo e por ser ponto de descanso das boiadas, que matavam a sua sede nas águas dos rios Jacuípe e Pojuca, próximos à Feira de Santana, que se tornou um lugar de passagem daqueles que faziam o transporte do gado, que era levado à feira semanal da cidade, cuja frequência favoreceu a formação e a consolidação de uma elite econômica de fazendeiros, que enriqueceu, sobretudo, por conta dessa atividade (CUNHA, 2013; FREIRE, 2007), Feira de Santana foi sendo povoada e apontada recorrentemente nas notas do Jornal Folha do Norte (1916-1927) como uma cidade de destaque com vistas ao progresso, o que lhe rendeu a alcunha de "Princesa do Sertão", até hoje utilizada.

Conforme o histórico de Feira de Santana, disponibilizado pelo IBGE, em 1911 a referida cidade contava com 9 distritos $^{7}$, a saber: Feira de Santana, Almas, Bom Despacho, Nossa Senhora dos Humildes ${ }^{8}$, Remédios da Gameleira ${ }^{9}$, Bonfim de Feira, Santa Bárbara, São José das Itapororocas e Tanquinho, dos quais os fazendeiros escolheram se instalar em Feira de Santana, onde fizeram fortunas e conquistaram posição social graças à pecuária e à agricultura, principalmente por causa da primeira e da feira de gado semanal.

Nas segundas-feiras, muitas pessoas saíam das cidades circunvizinhas para comercializar ora na venda de gado ora na feira livre, ambas na feira semanal. Assim, foram instituídos como locais importantes de Feira de Santana o Campo do Gado e a feira livre, nos quais eram realizadas inúmeras atividades comerciais desde a compra, venda ou troca de excedentes dos roceiros e lavradores até o fluxo de pessoas que gastavam o seu dinheiro em bares, restaurantes e hoteis da cidade durante a feira ou durante a sua passagem entre o litoral e o sertão baianos. Devido a isso, a Intendência Municipal de Feira de Santana reconheceu a importância da feira semanal e decretou a existência de uma exposição de gado anual com o

\footnotetext{
${ }^{7}$ Informações extraídas da seção Histórico do IBGE, disponível em: https://biblioteca.ibge.gov.br/visualizacao/dtbs/bahia/feiradesantana.pdf. Acesso em: 29 jul. 2019.

${ }^{8}$ Termo também constante no primeiro volume do inventário que compõe o corpus desta pesquisa.

${ }^{9}$ Este Termo é citado em alguns documentos listados no quadro 3 desta tese.
} 
objetivo de incentivar a pecuária na cidade (CUNHA, 2013; LIVRO DE REGISTROS DE OFÍCIOS..., 1915-1923).

Figura 2 - Campo do gado de Feira de Santana-BA no século XIX

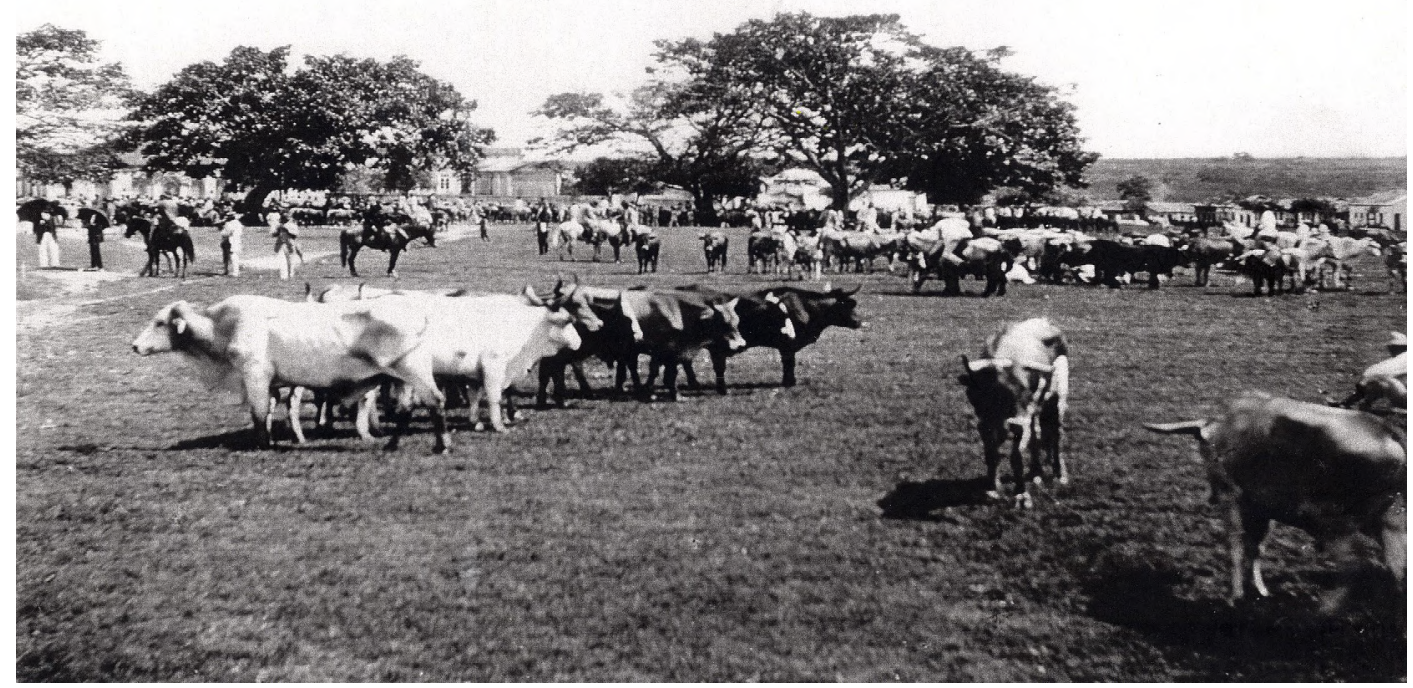

Disponível em: http://www.memorialdafeira.ba.gov.br/conteudo.asp?catimg=1. Acesso em: 29 mar. 2019.

Figura 3 - Praça do Comércio de Feira de Santana-BA (19--)

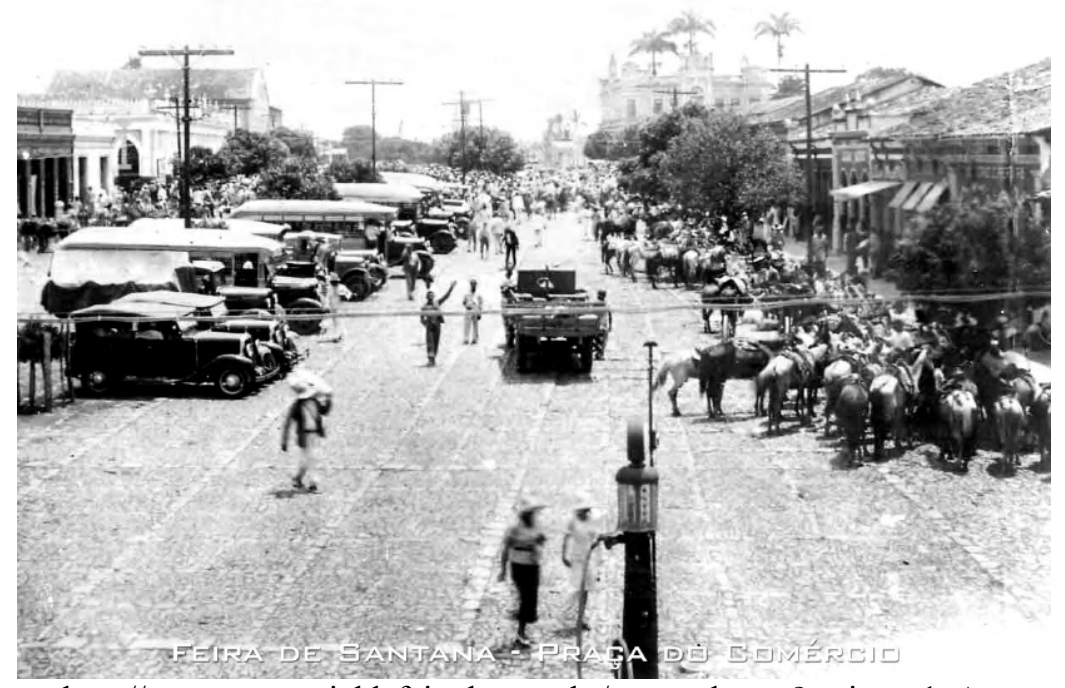

Disponível em: http://www.memorialdafeira.ba.gov.br/conteudo.asp?catimg=1. Acesso em: 29 mar. 2019.

Com isso, a feira semanal junto com o culto à Senhora Santana (padroeira da cidade) foram a base para que o município recebesse o nome atual, cuja área urbana foi dividida, naquela época, em dois pontos principais, a saber: a feira do gado, localizada ao norte da cidade, e a Igreja da Matriz, ao sul. A sede da cidade era dividida entre becos, pequenas ruas e 
as ruas principais, das quais se destacavam a Rua Direita (atual Conselheiro Franco ${ }^{10}$ ), que começava no Largo da Praça de Sant'Anna e terminava na Praça dos Remédios; a Rua Senhor dos $\operatorname{Passos}^{11}$ (atualmente Avenida Senhor dos Passos), que abrangia as ruas Barão de Cotegipe e Conselheiro Cunha e terminava no Campo General Camara, antigamente denominado Campo do Gado, onde se faziam as transações de animais; e a Rua do Meio (atual Sales Barbosa), que ficava entre as duas anteriores, conforme o Livro de Nomenclatura de Ruas de Feira de Santana (1886-1902).

$\mathrm{Na}$ Rua Direita existiam as principais casas comerciais da cidade, as sedes das filarmônicas, a Escola Normal, a Companhia Melhoramentos de Feira de Santana e o Cine Teatro Santana. Na Rua do Meio, assim denominada porque se encontrava entre a Rua Direita e a Rua Senhor dos Passos, era onde moravam os principais comerciantes, proprietários e pecuaristas, e na Rua Senhor dos Passos havia grande movimento por conta da feira semanal que funcionou até 1977 (C.f. CUNHA, 2013). Sobre essas ruas e sobre a sua visibilidade para a economia e a sociedade feirenses, seguem algumas imagens, a fim de as relacionarmos com as informações seguintes.

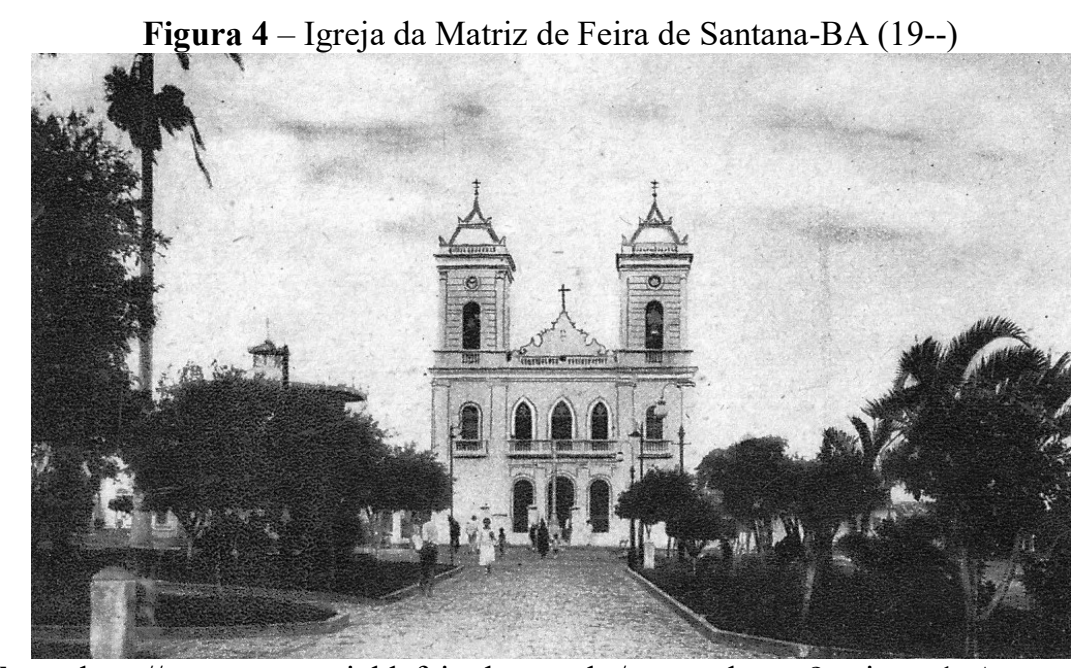

Disponível em: http://www.memorialdafeira.ba.gov.br/conteudo.asp?catimg=1. Acesso em: 29 mar. 2019.

\footnotetext{
${ }^{10}$ Avenida que aparece bastante em quase todos os documentos pesquisados.

11 Avenida na qual muitos comerciantes possuíam casas de comércio, de aluguel ou de residência, nas três primeiras décadas do século XX e atualmente.
} 
Figura 5 - Rua Direita em Feira de Santana (19--)

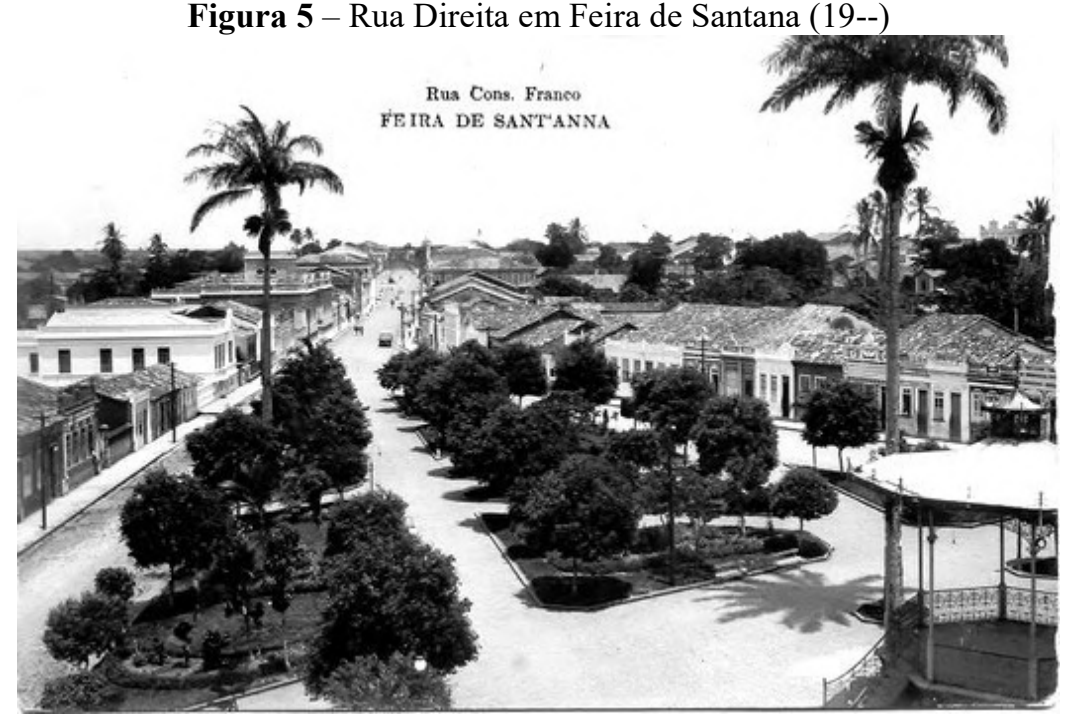

Disponível em: http://www.memorialdafeira.ba.gov.br/conteudo.asp?catimg=1. Acesso em: 29 mar. 2019.

Figura 6 - Rua do Meio em Feira de Santana-BA (19--)

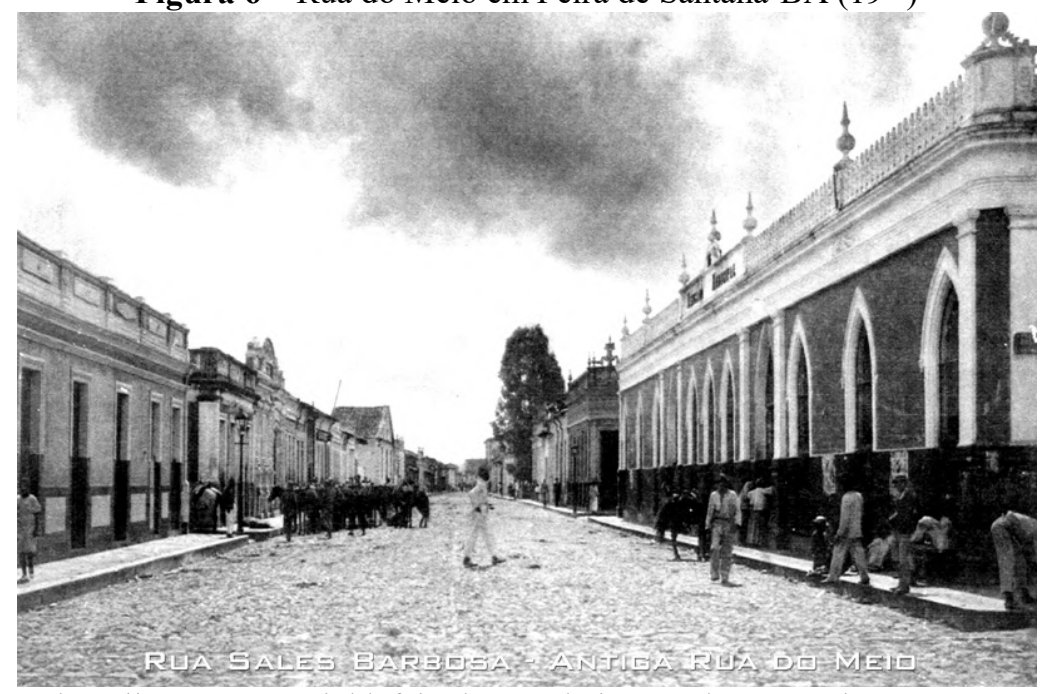

Disponível em: http://www.memorialdafeira.ba.gov.br/conteudo.asp?catimg=1. Acesso em: 29 mar. 2019. 
Figura 7 - Avenida Senhor dos Passos em Feira de Santana-BA, em 19--

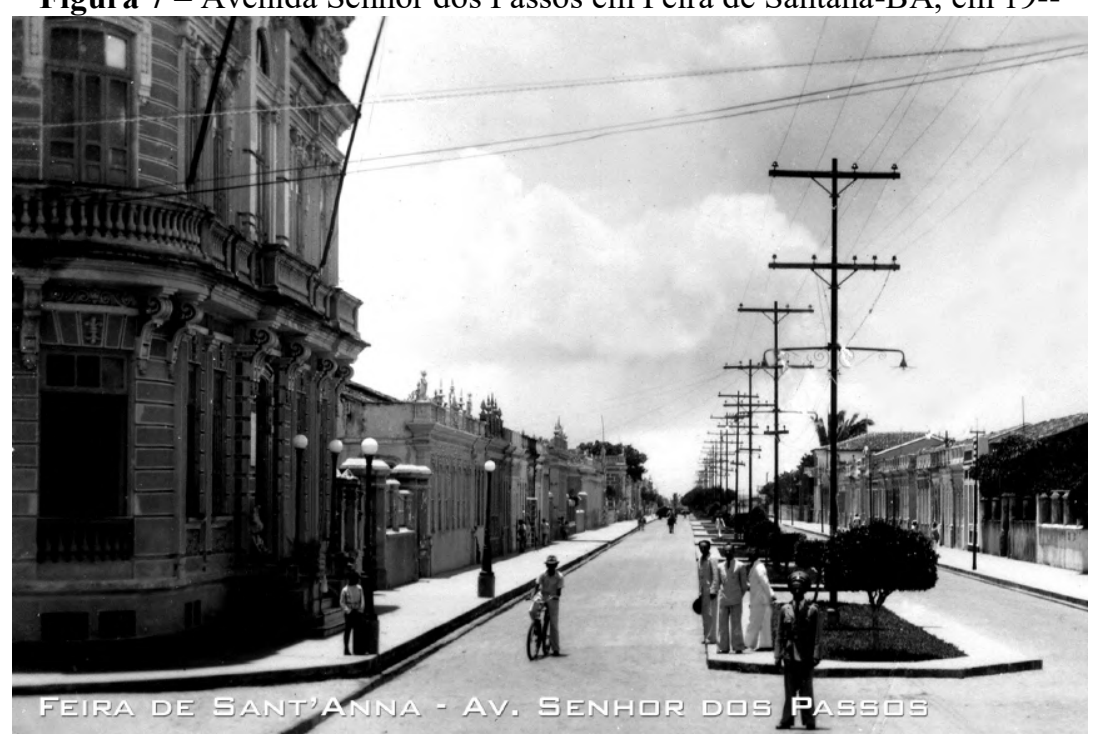

Disponível em: http:/www.memorialdafeira.ba.gov.br/conteudo.asp?catimg=1. Acesso em: 29 mar. 2019.

Figura 8 - Sede da Filarmônica 25 de Março em Feira de Santana-BA (19--)

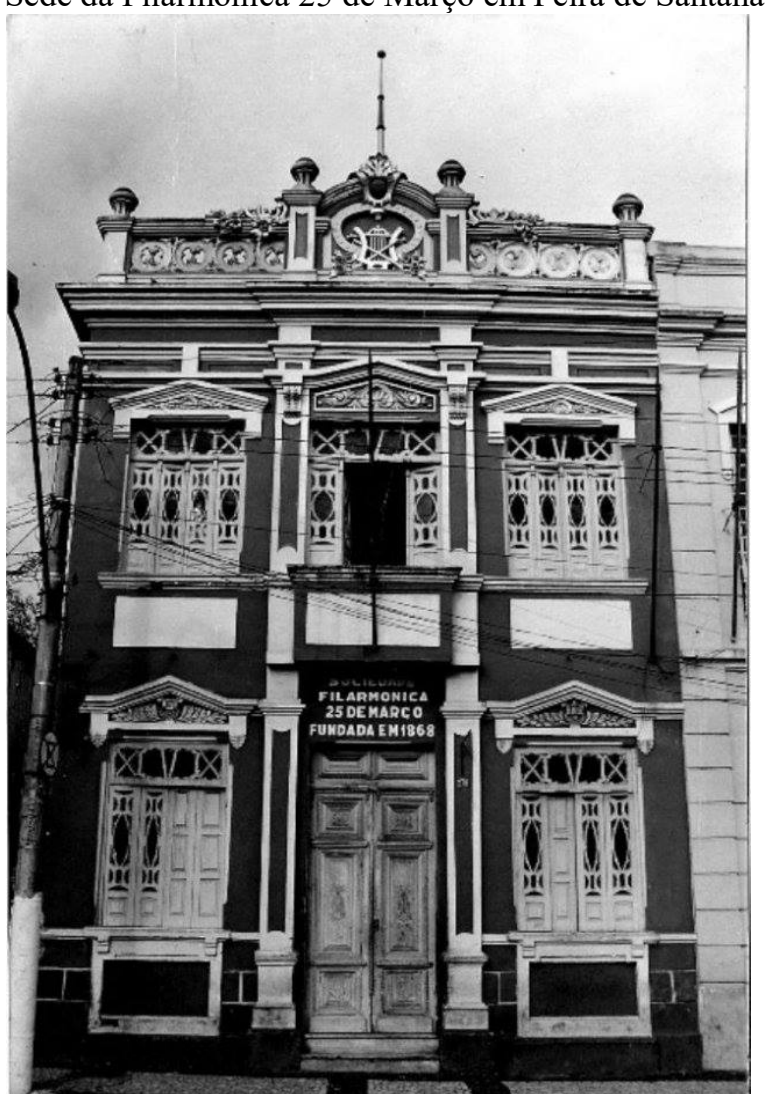

Disponível em: http://www.tribunafeirense.com.br/noticias/7246/lembrancas-das-nossasfilarmonicas.html. Acesso em: 29 mar. 2019. 
Figura 9 - À direita, sede da Sociedade Montepio dos Artistas Feirenses, localizada ao lado da Sede da Filarmônica 25 de Março, no Centro de Feira de Santana-BA (19--)

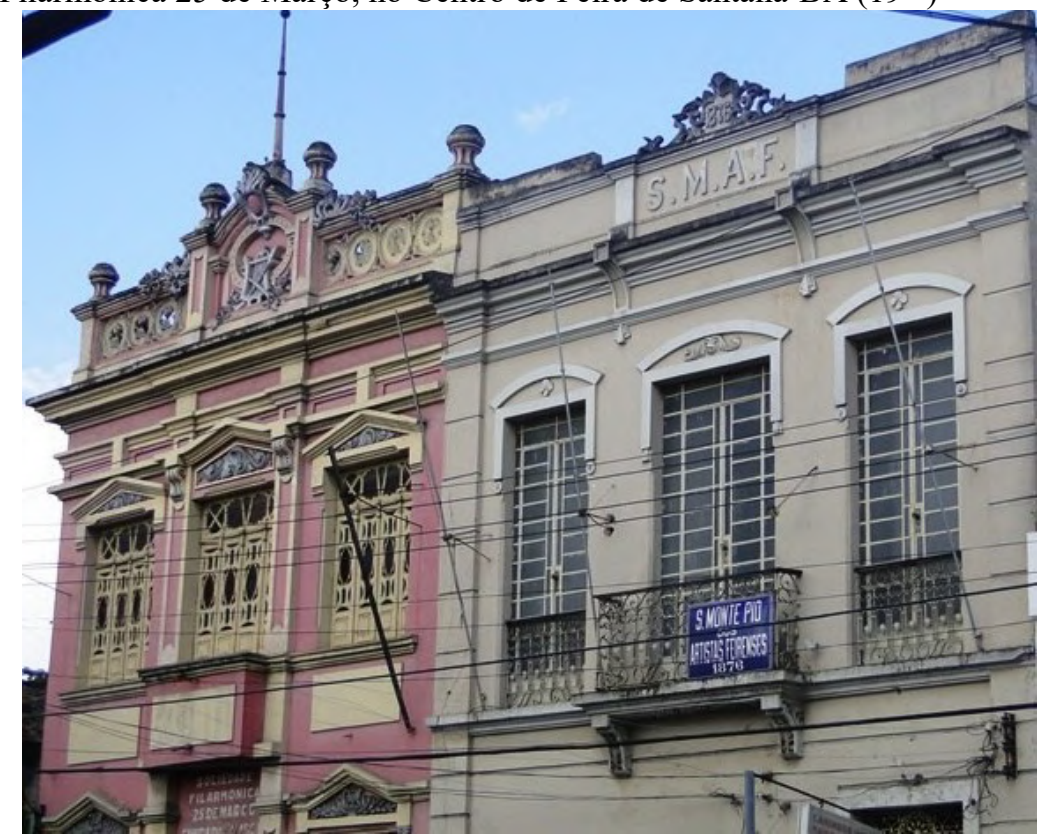

Disponível em: http://blogdafeira.com.br/home/2013/08/28/filarmonica-25-de-marco-emontepioexemplos-do-descaso-com-a-historia-de-feira/. Acesso em: 29 mar. 2019.

Figura 10 - Escola Normal de Feira de Santana-BA (19--)

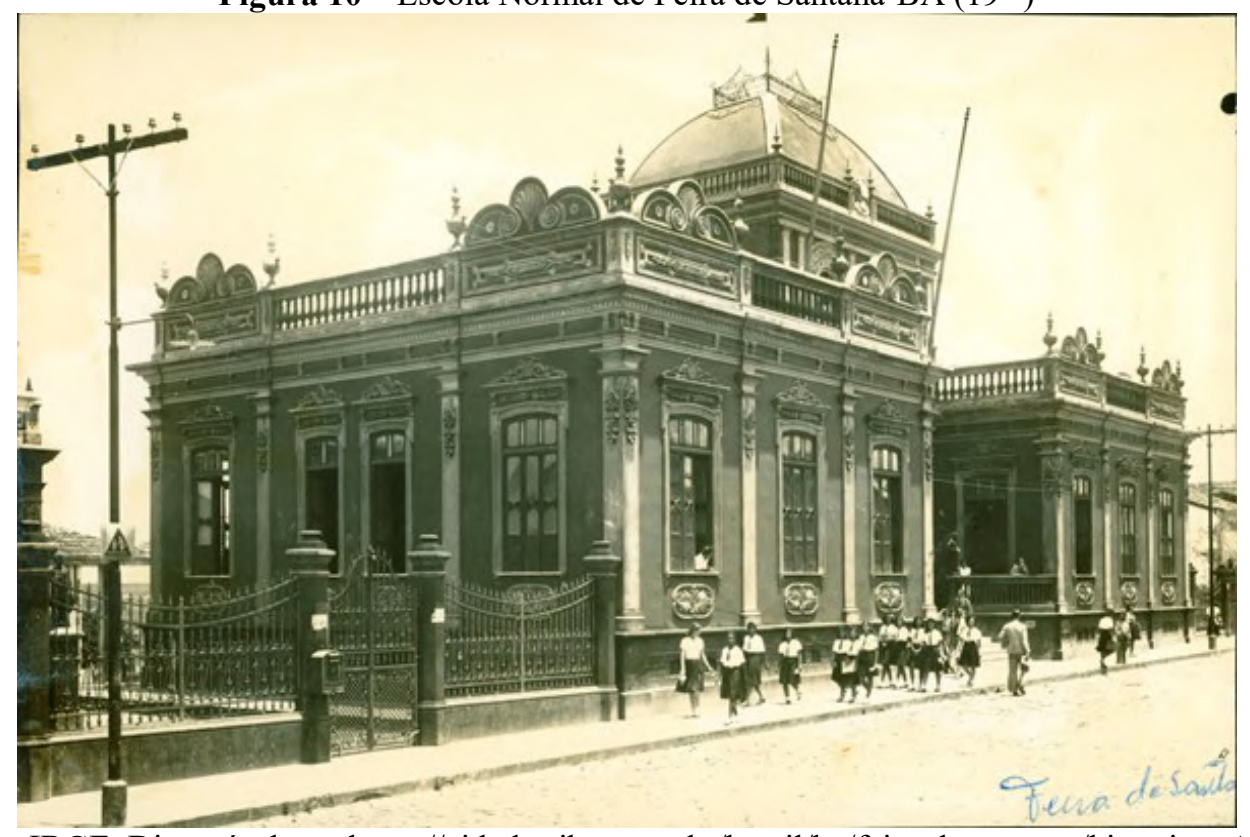

Fonte: Cidades IBGE. Disponível em: https:/cidades.ibge.gov.br/brasil/ba/feira-de-santana/historico. Acesso em: 29 mar. 2019. 
Figura 11 - Cine Teatro Santana de Feira de Santana-BA (19--)

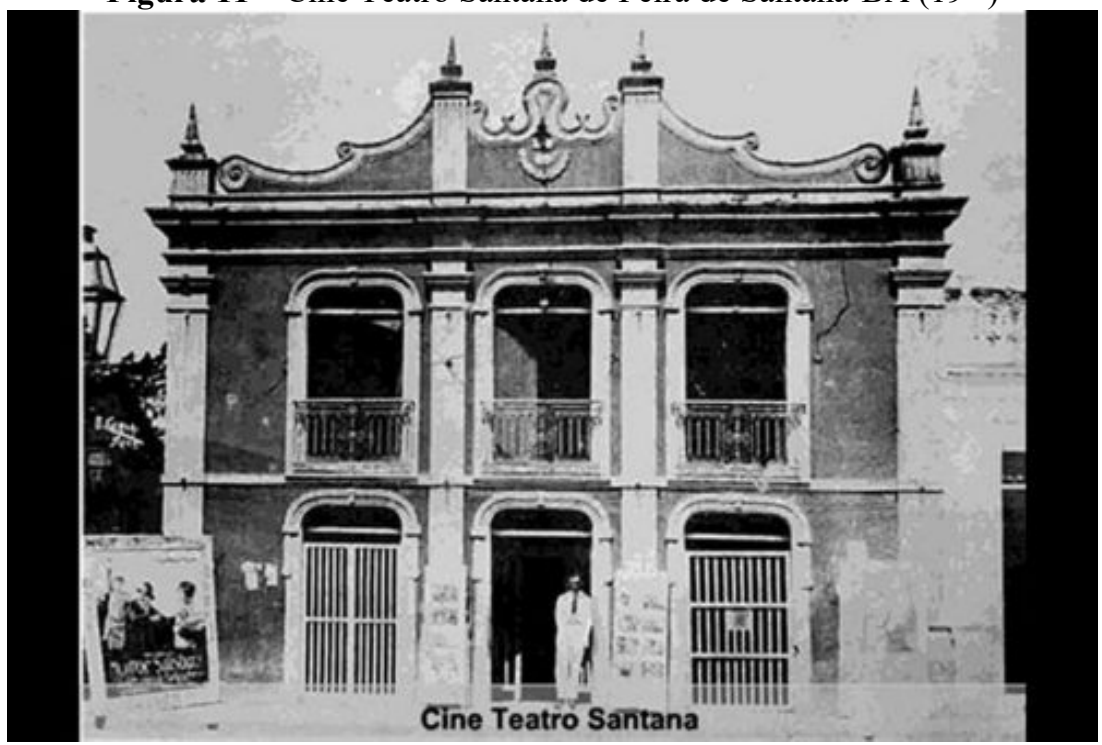

Disponível em: http://www.jornalgrandebahia.com.br/2017/08/feira-de-santana-o-cine-teatro-santanapor-adilson-simas/. Acesso em: 29 mar. 2019.

Figura 12 - Feira livre semanal de Feira de Santana-BA (196-)

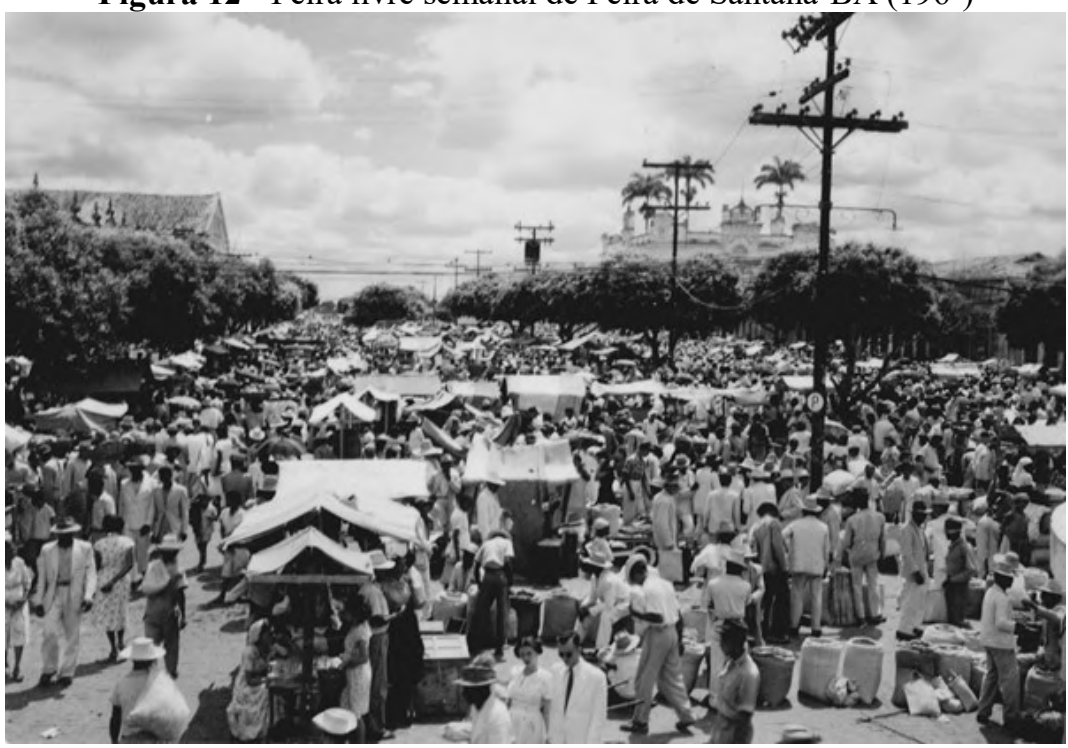

Fonte: Cidades IBGE. Disponível em: https://cidades.ibge.gov.br/brasil/ba/feira-de-santana/historico. Acesso em: 29 mar. 2019.

Todos esses locais estavam relacionados, porque ainda nas primeiras décadas do século XX a classe dominante de Feira de Santana, composta por comerciantes, joalheiros, taberneiros, donos de casas de pasto, de salgadeiras, de bilhar, de agência de bilhetes, sapateiros, açougueiros, hoteleiros, funileiros, tanueiros, ferreiros, fogueteiros, cabeleireiros, fazendeiros, médicos, advogados, juízes, dentistas, servidores municipais, caixeiros, farmacêuticos, lavradores, artistas (marceneiros, escultores, oleiros, carpinteiros, pintores e decoradores), telegrafistas, alfaiates e agrimensores, buscou disseminar um discurso de 
civilidade, cujo maior artífice era o desejo de mudança, identificado nas obras realizadas na cidade e inspiradas nos modelos europeus, e para as quais os dirigentes se empenharam reiteradamente.

Dentre as "melhorias" realizadas na cidade estavam a construção de mercados de cereais e fressuras, de travessas adjacentes e calçamentos, a criação de um campo de esporte no prolongamento das ruas Senhor dos Passos e Doutor Manoel Victorino, compras de mudas de plantas para arborização de ruas e praças, melhorias nos talhos do açougue do Mercado Municipal, criação de serviços de abastecimento de água, instalação de esgoto e luz elétrica (esta última seria implementada pela Companhia Geral Commercial de São Salvador), criação de ferrovias de entroncamento, troca do calçamento de algumas ruas, que passariam a ser calçadas com paralelepípedos ou pedras comuns, construção de estradas de ferro que ligariam Feira de Santana a Monte Alegre, a Salvador, ao distrito de Almas e a outros distritos, reparos na fonte do matadouro, pois "espíritos perversos e malfazejos" estavam destruindo na "calada da noite os reparos provisórios feitos", edificação do Paço Municipal, reforma da Igreja Senhor dos Passos, inauguração da Ponte Rio Branco sobre o Rio Jacuípe e construção de prédios escolares (LIVRO DE REGISTROS DE OFÍCIOS..., 1915-1923).

Todas essas obras foram realizadas por Intendentes que administraram a cidade em períodos diferentes e que foram escolhidos através do voto popular, advindo, principalmente, da elite feirense. Sobre esses administradores e as respectivas obras que implementaram em Feira de Santana-BA no período que estudamos, levantamos informações, que estão descritas a seguir, que nos permitem "mapear" a sua atuação no "progresso" da cidade.

\subsection{SOBRE A ESCOLHA DOS "DIRIGENTES POLÍTICOS” E OS “ARES DE PROGRESSO” DE FEIRA DE SANTANA NAS PRIMEIRAS DÉCADAS DO SÉCULO $\mathrm{XX}$}

Antes da instauração do período Republicano no Brasil, Feira de Santana-BA foi gerida pelo Presidente da Câmara Municipal, que também exercia as funções executivas, como foi o caso, por exemplo, da gestão do Doutor Joaquim Remédios Monteiro, que fícou no cargo por três anos, de 1887 a 1890 (GOVERNANTES..., 2016).

Com a República, a administração da cidade passou a ser feita por Intendentes, dos quais o primeiro foi o Coronel Joaquim de Melo Sampaio que, por motivos de saúde, abdicou do cargo pouco tempo depois de tê-lo assumido: foi nomeado em janeiro de 1890 e 
substituído pelo Coronel José Freire de Lima, em julho do mesmo ano, o qual permaneceu no cargo até 1903, quando faleceu e foi substituído pelo Coronel José Antunes Guimarães.

De janeiro de 1904 a abril de 1907, Tito Ruy Bacelar foi eleito Intendente Municipal, mas também não terminou o mandato, pois se candidatou a deputado estadual e ganhou a eleição, deixando, portanto, o cargo de Intendente vago, que imediatamente foi ocupado pelo seu antecessor: o Coronel José Antunes Guimarães, que voltou à administração da cidade de abril a dezembro de 1907.

Nos livros de alistamento eleitoral da Intendência Municipal de Feira de Santana-BA verifica-se que, em 1905, fazendeiros, escrivães, farmacêuticos, comerciantes e servidores municipais compunham a lista de eleitores aptos ao direito de voto, dentre os quais estavam os senhores Antonio Onofre Carneiro, Arthur Fróes da Motta, Antero Alves Boaventura, Antonio Alves Barretto, Agostinho Fróes da Motta, Aurelio Vasconcellos, Bernardino da Silva Bahia, David de Mello Lima, Estanislau Alves Barretto, Estanislau Alves Barretto Filho, Deoclecio da Silva Daltro, Godofredo Rebello de Figueiredo, Gonçalo Alves Boaventura, Juvencio Erudilho da Silva Lima, João Carneiro Vital, José Alves Boaventura, José Alves Barretto Neto, Leolindo dos Santos Ramos, Manoel Francisco de Almeida Ramalho, Manoel Eustaquio Rebello de Figueiredo, Macario Gomes de Cerqueira, Manoel Portugal dos Santos, Petronillo Guaviro de Meirelles, Quintiliano Martins da Silva, Valentim José de Souza Junior e Agerico Moreira de Almeida.

Já nas eleições realizadas em finais do ano de 1907 e disputadas entre o Coronel e militar Abdon Alves de Abreu e o Coronel Bernardino da Silva Bahia houve a descoberta de fraudes eleitorais que deram um novo rumo à administração pública nos anos de 1908 a 1915 e, como solução para os conflitos eleitorais descobertos naquele ano, o Governador do Estado decretou que o primeiro candidato governaria a cidade entre 1908 e 1912, e o segundo entre 1912 e 1915, como reiteraremos mais adiante. No ano de 1911, contudo, alguns dos eleitores alistados, e somados aos de 1905, foram Amadeu Saback de Oliveira, Augusto Joaquim Fructuoso, Davino Moreira de Almeida, Joaquim Honorio de Oliveira, Clodoaldo Almeida, Oscar do Espirito Santo e Salvador Simões Portugal.

Nas mesmas eleições de 1911, a chapa vencedora foi a composta pelo Coronel Agostinho Fróes da Motta e os Conselheiros Municipais Coronel Abdon Alves de Abreu, Coronel Tito Ruy Bacellar, Coronel José Antunes Guimarães, Coronel Antonio dos Santos Rubem, Doutor Joaquim Raul dos Reis Gordilho, Doutor Symphronio Olympio da Costa, Major Silvino dos Santos Ramos, Capitão José Ribeiro Falcão, Capitão João Ferreira de 
Almeida e Coronel Epiphanio José de Souza, conforme nota do periódico Folha do Norte (29 out. 1911, p. 1).

Ainda naquelas eleições também foram eleitos os seguintes Juízes de Paz: Juvêncio Erudilho, com 137 votos; Francisco Garrido, com 135 votos; Manoel Ribeiro Falcão, com 72 votos; Estanislau Alves Barretto, com 64 votos; Antonio Victorino, com 27 votos; Francolino Mattos, com 26 votos; Joviniano Caribé, com 16 votos; e Henrique Dantas, com 12 votos, resultados também publicados no Folha do Norte (18 nov. 1911, p. 1), o que revela que a escolha dos administradores da cidade advinha dos interesses estabelecidos pelos eleitores, dentre os quais uma boa parcela fazia parte da eleição e da própria administração pública.

Em 17 de dezembro de 1911 também foram eleitos os provedores da Santa Casa de Misericórdia de Feira de Santana-BA, que atuariam no ano de 1912, a saber: Provedor: Coronel Bernardino da Silva Bahia, Tesoureiro: Coronel Epiphanio José de Souza, Procurador Geral: Major Antonio Onofre Carneiro e Visitadores: Doutor Raul Gordilho, Major Valentim de Souza Junior, Capitão Amadeu Saback de Oliveira, Coronel Agostinho Fróes da Motta, Major Juvêncio Erudilho e Major Manoel Portugal dos Santos, os quais também faziam parte da administração da cidade.

De 1916 a 1919 o Intendente Municipal foi o Coronel Agostinho Fróes da Motta, cuja administração é descrita mais adiante, e cujo sucessor foi o Coronel Bernardino da Silva Bahia, que assumiu o cargo de 1920 a 1923. Em sequência, Arnold Ferreira da Silva se tornou Intendente, no período de 1924 a 1927, e foi sucedido pelo advogado e promotor público Elpidio Raymundo da Nova, que governou de 1928 a 1931, década em que o grupo de eleitores era formado por negociantes, funcionários públicos, médicos, lavradores e donos de grandes propriedades, escrivães, artistas, farmacêuticos, jornalistas, tipógrafos, jardineiros, guarda-livros e capelão de asilo.

Entre os eleitores de 1930 figuravam Antonio Onofre Carneiro, Agerico Moreira de Almeida, Augusto Fróes da Motta, Aurelio de Vasconcellos, Arnold Ferreira da Silva, Amadeu Saback de Oliveira, Arlindo Pereira Ramos, Arthur Fróes da Motta, Clodoaldo Almeida, David de Mello Lima, Eduardo Fróes da Motta, Elpidio Raymundo da Nova, Godofredo Rebello de Figueiredo, Gastão Clovis de Souza Guimarães, Gonçalo Alves Boaventura, Manoel Portugal dos Santos, Manoel Eustaquio Rebello de Figueiredo, Mario Saback de Oliveira, Manuel Francisco de Almeida Ramalho, Pedro Dias de Carvalho, Petronillo Guaviro de Meirelles, Auto Esmeraldo dos Reis, Arthur de Assis e Durval Capirunga do Lago que, de forma direta ou indireta, também aparecem como indivíduos 
constantes no corpus desta tese, e cuja maioria já fazia parte do grupo de eleitores nos anos anteriores.

Sobre os Intendentes anteriores ao Coronel José Freire de Lima, pouquíssima informação existe nos Livros da Intendência Municipal, que foram preservados e que estão disponíveis no APMFS-BA. Assim sendo, sobre a administração de Tito Ruy Bacellar encontramos algumas solicitações sobre questões escolares, as quais são apontadas mais adiante.

Sobre as administrações dos coronéis Abdon Alves de Abreu, Bernardino da Silva Bahia, Agostinho Fróes da Motta e do jornalista Arnold Ferreira da Silva, identificamos que todos apresentavam em suas posturas políticas um ideal progressista que via nas obras públicas a serem realizadas um meio de transformar Feira de Santana em uma cidade com "ares europeus". Assim sendo, os anos de 1908 a 1927 correspondem a um período de "explosão" de obras públicas, para as quais os gestores tiveram que estabelecer relações sociais, econômicas e até familiares entre os seus correligionários.

Devido a isso e levando em consideração aquele período, apresentamos as principais obras realizadas pelos referidos intendentes, a fim de compreendermos as suas relações e como isso se direciona para a composição do corpus que estudamos. Assim, sobre a instalação de luz elétrica na cidade, por exemplo, o Jornal Folha do Norte veiculou a seguinte notícia:

\begin{abstract}
Luz electrica $\|$ Os $^{12}$ senhor coronel Ignacio Bastos e $\mid$ José Alves de Souza Ferreira $\mid$ estiveram nesta cidade e nos | fizerem agradavel visita, de- | clarando-nos que traziam como | principal objectivo o desejo | de introduziem nesta cidade a | illuminação publica por ener- $\mid$ gia electrica, depedendo so- $\mid$ mente que o governo munici- | pal abra concurrencia para | então apresentarem propos- | tas. || Agradecemos a proveitosa | visita e concebemos ser via- | vel o almejado fim, desde quan- $\mid$ do, aberta a concurrencia pu- | blica, depois de votada a com | petente lei, muitas vantajens | advirão de modo reflectido e | seguro para garantias futuras. || Ao conselho, pois, cumpre $\mid$ quanto antes, estudar o assum $\mid$ pto. (LUZ..., Folha do Norte, 11 jan. 1913, p. 3).
\end{abstract}

Essa notícia trouxe esperança aos dirigentes da cidade, já que, a partir de então, as reuniões do Conselho Municipal reiteradamente trariam aquele assunto como ponto de discussão e de interesse público. Contudo, para a implementação das várias obras

\footnotetext{
${ }^{12}$ Como mencionado nos critérios de transcrição adotados para os textos publicados no Folha do Norte, e expostos na nota de rodapé de número 3 , todas as reportagens publicadas nas colunas do referido periódico e transcritas ao longo desta tese foram rigorosamente revisadas e transcritas exatamente como constam nas edições impressas. Logo, fez-se dispensável o uso de expressões como, por exemplo sic para indicar que houve erros tipográficos nos textos citados nesta seção. Esta nota vale para todas as citações em que constam problemas tipográficos no texto aqui transcrito.
} 
progressistas, os Intendentes junto com o Conselho Municipal determinaram a desapropriação e destruição de casebres e casas que "enfeiavam" a cidade, como afirmaram os redatores do Folha do Norte em 11 de abril de 1915: “[...] fazemos votos que leve | de vencida a demolição | dos outros casebres e | dos situados a praça General | Argolo $^{13}$, também incluídos na | mesma lei, todos os quaes | tanto afeiam a nossa | bela cidade" (FOLHA DO NORTE, 1915, p. 1), e também os Intendentes Bernardino da Silva Bahia, em ofício registrado pela Intendência Municipal, em 17 de novembro de 1915, e Agostinho Fróes da Motta, em ofício datado de 16 de maio de 1916:

Intendencia Municipal da Feira de Sant'Anna | em 17 de Novembro de 1915. || Senhores Membros do Concelho Municipal || Tendo sido a Intendencia, autorisada pela lei numero | 124 de 16 de Abril de 1913, a desapropriar varios | casebres a rua Consilheiro Franco, o que effectuou, | e em cujo terreno, por benemerencia do Governo | do Estado, está sendo construido um predio es- | colar, pelo, digo, que pelo seu estylo moderno tor- | na-se um dos mais magnificentes fora da Capi- | tal, é justo que volvamos nossas vistas para $\mid$ o embellezamento desta rua, que sendo uma | das principaes da cidade, sob todos os aspectos. I ainda contém tortuosidades e pardieiros, in- | dignos de ainda permaneceram ali, maximi $\mid$ os de numeros 10 , digo 2, 4 e 6 á Praça de Sant' | Anna e os de numeros 10, 22, 24, 26, 28 e 30 á | referida rua Conselheiro Franco, cujas desapro- | priações se fasem indispensaveis E por isso | solicito-vos que decreteis a necessaria auto- | risação para esse fim. Reitero-vos os meus | protestos da maior consideração e estima. | Saudações. (assignado) Bernardino da Silva Bahia (LIVRO DE REGISTROS DE OFÍCIOS..., 1915, f. 8r$8 v)$;

[...] submette a vossa a- | preciação a inclusa planta para edificação de um | predio para escolas municipaes. Sem embargo do con- | teúdo de minha mensagem de 6 do corrente, á Praça | General Argollo, onde proximamente será iniciada a | construção do predio para o Asylo de Lourdes, contigua | existe uma area de terreno, onde poderá ser levantado $\mid$ o primeiro edificio do ensino poderá ser dado com | brevidade, visto ali achar-se demolidos e expropriados | varios casebres, o que no momento é da maior van- | tagem. [...] Saudações. (Assignado) Agostinho Fróes da Motta. (LIVRO DE REGISTROS DE OFÍCIOS..., 1916, f. 19v).

Nesses textos fica clara a forma como a cidade era vista quando o assunto eram as residências de pessoas pobres e, na maioria dos casos, negras, situadas em ruas e praças centrais da cidade, que estavam "enfeiadas" por conta da existência de tais casebres, que deveriam ser removidos para que o "progresso" finalmente chegasse à Feira de Santana-BA. Por conta das desapropriações, restou aos moradores migrar para bairros afastados do centro da cidade, dentre os quais se destacavam o Alto do Cruzeiro, Calumbi, Sobradinho, Mochila, Mangabeira, Baraúnas, Queimadinhas, Tanque da Nação, Pedra do Descanso, Canto Escuro, Beco da Esteira, Salto do Bode, Beco do Mocó, Baixa da Égua, Fiado Rua do Tranca e Rua

${ }^{13}$ Praça mencionada em alguns dos documentos consultados no CEDOC/UEFS e na qual se encontram o Casarão Fróes da Motta e muitos dos imóveis citados nos processos jurídicos pesquisados. 
do Bom e Barato, que se tornaram bairros ocupados por pessoas de pouco ou quase nenhum poder aquisitivo (C.f. BOAVENTURA, 2006; SILVA, 2012).

Assim, com o desejo de otimizar as atividades do município, os dirigentes também criaram novos cargos direcionados aos serviços públicos, a saber: os de professores primários, o de engenheiro municipal, os de fiscais geral, auxiliar e da iluminação e asseio públicos, os de carcereiros, os de oficiais de Justiça, os de secretário, tesoureiro, contador, lançador, amanuense, médico, porteiro, bibliotecário e guarda municipais, e o de administrador do matadouro municipal, para os quais foram nomeados indivíduos diplomados ou não, conforme descrição feita nas nomeações registradas nos dois Livros de registros de ofícios expedidos pela Intendência Municipal de Feira de Santana (1893-1908; 1915-1923) e no Livro de registros de títulos dos empregados municipais (1912-1920).

Além da criação dos referidos cargos, a Intendência Municipal de Feira de SantanaBA também implantou a Guarda Noturna Comercial, que vigorou de 1913 a 1930, e foi patrocinada pelos comerciantes da cidade que se sentiram lesados com o alto índice de roubos nas suas casas comerciais. A iniciativa de criar a referida Guarda surgiu após o delegado de polícia da cidade afirmar que o grupo policial existente era composto apenas por quatro praças, um sargento e um cabo, e que, por isso, o corpo policial não estava conseguindo prender todos os ladrões da cidade (CUNHA, 2013).

À vista disso, vários comerciantes uniram-se - dentre os quais estavam como cabeças da Comissão da Guarda Noturna Comercial o Coronel Agostinho Fróes da Motta e Manoel Portugal dos Santos, os quais reuniram outros comerciantes da cidade - e instituíram que cada um contribuiria monetariamente com a referida Guarda de acordo com o número de estabelecimentos que possuíam, o que quer dizer que quem tivesse mais casas comerciais pagaria mais caro pelo serviço da Guarda Noturna Comercial, como foi o caso do próprio Coronel Agostinho Fróes da Motta, que tinha mais de quatro casas comerciais e por isso pagaria 100 réis, enquanto que os que tinham dois ou três estabelecimentos pagariam 50 réis e quem tivesse apenas um contribuiria com 20 réis (CUNHA, 2013; FOLHA DO NORTE, 1915).

Ainda de acordo com Cunha (2013), outra maneira de "melhorar a cidade" foi a criação de espaços de diversão e lazer para as classes mais abastadas, dentre os quais estavam incluídos o Cine Teatro Santana - fundado em 1919 e fruto da junção do cinema Victória com o teatro Santana, que se tornou um dos espaços mais valorizados e frequentados pela "elite feirense" - as filarmônicas, as festas religiosas e os clubes e grupos literários. 
Sobre o Cine Teatro Santana, rotineiramente as suas atividades foram veiculadas no Folha do Norte, com o intuito de divulgar e de atrair a sociedade feirense para os seus espetáculos, como pode ser observado, por exemplo, no seguinte anúncio:

Theatro || Continúa a nos proporcionar | boas noites de diversões o "Ci- | nema Victoria". || Em o domingo ultimo, foram | exhibidas entre outros, os films | "Drama no circo" e "À beira do | abysmo". || Para amanhan está annunciado | variadissimo programma (THEATRO, FOLHA DO NORTE, 19 jan. 1913, p. 2).

Para além disso, o mesmo periódico publicou uma nota, em agosto daquele mesmo ano, afirmando que o Cine Teatro Santana era o único teatro existente na cidade e que, por conta disso, um número excessivo de pessoas frequentava os seus espetáculos, para os quais eram vendidos mais ingressos do que a capacidade de lotação do espaço comportaria, o que gerava bastante tumulto e confluía para a necessidade de intervenção policial para acalmar os ânimos daqueles que estariam causando confusão. Mais do que isso, a nota deixava clara a necessidade de se buscar a "moralização" do teatro, para a qual, se preciso fosse, seriam anunciados publicamente os nomes daqueles que estariam causando problemas durante os espetáculos para que fossem devidamente afastados ou punidos pela lei, conforme exposto no texto a seguir:

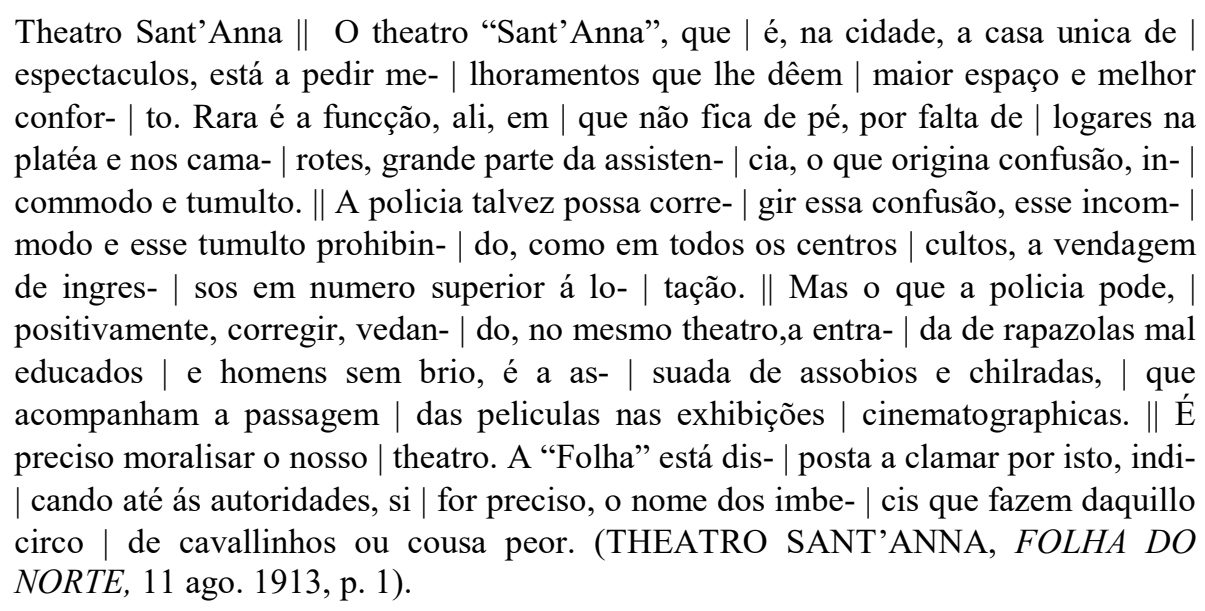

Outra instituição que contava com a participação de vários dirigentes políticos da cidade eram as filarmônicas, que se tornaram frequentes nos eventos municipais. As Sociedades Filarmônicas Victória e 25 de Março foram fundadas ainda no século XIX, enquanto a Filarmônica Euterpe Feirense foi fundada em 13 de dezembro de 1921, dirigida por Leolindo Ramos Junior, e cujo vice-presidente foi Augusto Fróes da Motta, a qual vigora até os dias atuais. Como exemplo de sua visibilidade social, as duas primeiras filarmônicas sempre eram convidadas a participar dos festejos, desfiles, inaugurações de obras públicas 
municipais e recepção de políticos, intelectuais e familiares dos dirigentes que moravam em outras cidades, o que demonstra o papel daquelas na vida pública feirense.

Sobre, por exemplo, as participações daquelas instituições nos festejos municipais que ocorreram ao longo dos anos, o Intendente Coronel José Freire de Lima, em 14 de dezembro de 1903, emitiu um ofício convidando as Sociedades Filarmônica Victória, 25 de Março e Monte Pio dos Artistas Feirenses, e os representantes da Santa Casa de Misericórdia, do Conselho Diretor do Centro Operário, da Associação dos empregados do Comércio, o Promotor Público da cidade, a Redação do Propulsor e do Progresso, os subcomissários de polícia dos distritos de Santa Bárbara, Tanquinho, Bom Despacho, Almas, Bomfim, Gamelleira, São José, Humildes e os professores Lucindo dos Santos Silva, Alipio de Miranda, Geminiano Alves da Costa, Leolinda Bacellar de Mello Lima, Maria Carolina de Castro Fiuza e Odilia Vieira Mendes para assistirem à cerimônia de posse do novo Intendente, Tito Ruy Bacellar, e do Conselho Municipal eleitos, que cumpririam o mandato do período de 1904 a 1907.

Analogamente, o Intendente Bernardino da Silva Bahia também convocou, em ofício de número 77, emitido em 29 de agosto de 1922, a Filarmônica Victória e os professores municipais para a comemoração do Centenário da Independência do Brasil, o primeiro festejado pela Intendência Municipal, em 07 de setembro de 1922 (LIVRO DE REGISTROS DE OFÍCIOS..., 1922). Para a comemoração do centenário, contudo, foi instalado um concurso público para escolher a mulher "mais bela" da cidade. Na ocasião, o "Concurso do Centenário" contou com a participação de dezenas de mulheres, casadas ou solteiras, dentre as quais figuravam Hilda Saback, Thereza Silva, Laura Saback, Esther Saback de Oliveira, Luiza Bahia, Iaiá Bahia, Zenita Saback, Ersilia Franco de Almeida, Maria Lambert Motta, dentre muitas outras, das quais a vencedora do concurso "Qual a mais bella das feirenses?" foi Hilda Saback, que obteve 1115 votos, apurados em 6 de maio de 1922 e cujo resultado foi divulgado no Folha do Norte na referida data.

Além das filarmônicas, havia a sociedade de caridade dirigida pela Irmandade da Misericórdia, fundada em 1859, e que era responsável pelo Cemitério Piedade e pela Santa Casa de Misericórdia. 
Figura 13 - Primeiro prédio da Santa Casa de Misericórdia em Feira de Santana-BA

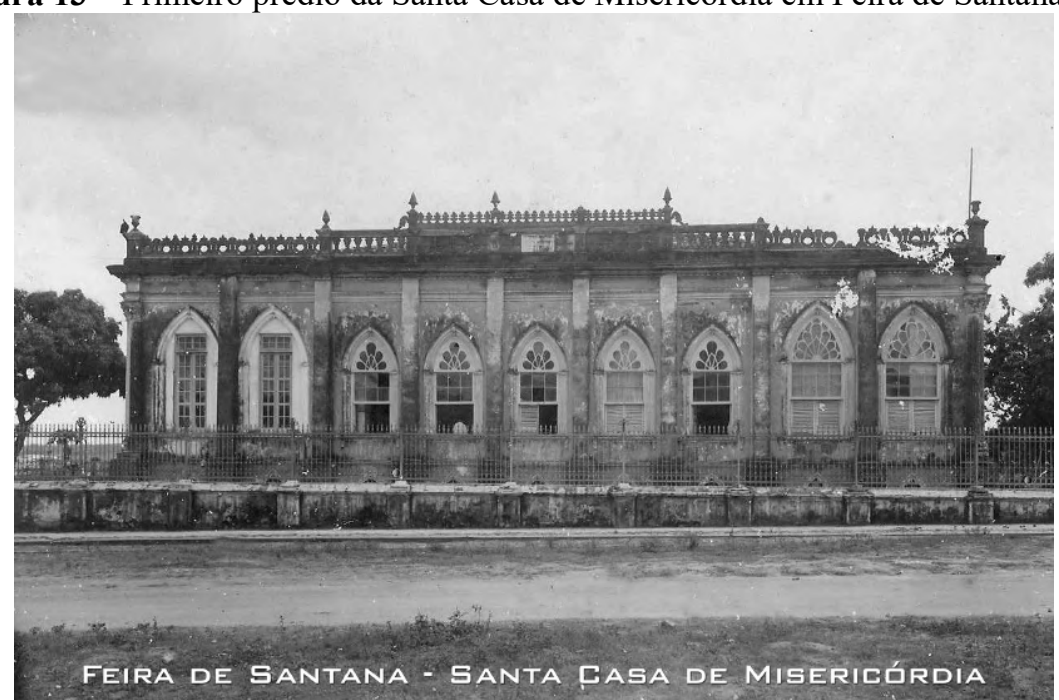

Disponível em: http://www.memorialdafeira.ba.gov.br/conteudo.asp?catimg=7. Acesso em: 07 set. 2019.

Essa instituição de caridade foi beneficiada pela maioria dos gestores de Feira de Santana do início do século XX, dentre os quais estava o Coronel Agostinho Fróes da Motta, que se tornou o seu provedor em 6 de outubro de 1909, conforme a seguinte nota:

\footnotetext{
Provedoria da Santa Casa || De volta da Europa, re- | assumiu, no dia 6 do fluente, | o cargo de Provedor da San- $\mid$ ta Casa de Misericordia, o | nosso distincto amigo e cor| religionario coronel Agosti- $\mid$ nho Froes da Motta, que de | maneira tão zelosa e brilhan- | temente vai dirigindo aquella $\mid$ pia e utilissima instituição (PROVEDORIA..., FOLHA DO NORTE, 6 out. 1909, p. 2).
}

Não se conformando em ser apenas provedor, o referido coronel e a sua primeira esposa, Dona Maximiana de Almeida Motta, beneficiaram a Santa Casa de Misericórdia, em seus respectivos testamentos, nos quais foram deixadas quantias em dinheiro não somente para essa como para outras sociedades de caridade, a saber: o Asilo Nossa Senhora de Lourdes e a Sociedade Monte Pio dos Artistas Feirenses, principalmente porque, no contexto da época, fazer parte da administração, ser sócio ou benfeitor de uma sociedade de caridade conferia ao indivíduo "caridoso" prestígio social e oportunidade de estabelecer relações de poder com outros indivíduos também abastados. Logo, tratava-se, como afirma Cunha (2013), de "estratégias políticas" para convencer os outros de sua importância social e para se manter como "dirigente" e/ou influenciador da elite local.

Outra atividade de diversão e de lazer em Feira de Santana-BA era a participação da elite feirense nas celebrações religiosas católicas, compostas pelas festas de Nossa Senhora Santana, de São João, de São Pedro etc., sendo a primeira destas a mais movimentada e da qual participavam e organizavam muitos comerciantes, políticos e fazendeiros, inclusive o 
Coronel Agostinho Fróes da Motta, que foi o organizador de uma das festas de Nossa Senhora Santana mais elogiada do seu tempo (C.f. BOAVENTURA, 2006).

Sobre os homens mais ricos das primeiras décadas do século XX na cidade de Feira de Santana-BA, Eurico Alves Boaventura, em seu livro A paisagem urbana e o homem: memórias de Feira de Santana (2006), afirmou que nesse quadro estavam os coronéis Agostinho Fróes da Motta, Bernardino da Silva Bahia, Epiphanio José de Souza, o Major Quintiliano Martins da Silva Júnior, entre outros. Além disso, existia em Feira de Santana-BA uma concentração de renda nas mãos de quatro famílias ${ }^{14}$ (Fróes da Motta, Bahia, Falcão e Boaventura) que eram proprietárias de terras, casas comerciais e indústria, além de participarem tanto do executivo quanto dos conselhos municipais de Feira de Santana-BA (LIVRO DE REGISTROS DE OFÍCIOS..., 1915-1923; SIMÕES, 2007).

Sobre as famílias Fróes da Motta, Bahia, Falcão e Boaventura, algumas informações se fazem pertinentes, haja vista as relações estabelecidas entre elas esclarecerem a presença de seus membros familiares nos documentos consultados. Sobre a primeira família, as fontes pesquisadas nos permitem afirmar que Agostinho Fróes da Motta possuía a patente de tenente coronel antes do Intendente Tito Ruy Bacelar, coronel, político, fazendeiro, jornalista e redator chefe do jornal O Progresso (1900-1909) e dono do Folha do Norte, conceder-lhe, em 1903, a patente de coronel, que foi utilizada até os seus últimos dias de vida e após aqueles (FOLHA DO NORTE, 1909-1930).

Ainda sobre a titulação de Agostinho Fróes da Motta, em ofício de 10 de agosto de 1918, a Intendência Municipal de Feira de Santana-BA o descreveu como Comandante da $42^{\mathrm{a}}$ Brigada, o que nos permite entender que ele também fazia parte do serviço militar. Contudo, também é sabido que ele começou a sua vida como um homem de poucos recursos, que, ao longo dos anos, conseguiu acumular um patrimônio significativo, composto de terrenos, fazendas, animais de fazenda, automóveis, notas promissórias de empréstimos a receber, dinheiro, apólices bancárias, prata, ouro, armazém e comércio de fumo, criação e comércio de gado, farmácia e comércio de transporte de água, além de ter assumido cargos políticos e administrativos na Intendência Municipal de Feira de Santana-BA, o que demonstra a sua ascensão e visibilidade no cenário feirense, contundentemente asseveradas por Eurico Alves Boaventura (2006, p. 109) em suas memórias de infância:

\footnotetext{
${ }^{14}$ Além dessas famílias, o próprio Boaventura (2006, p. 141) destaca a existência das famílias “[...] Carneiro, a mais densa em número de componentes, derramados em três séculos por todo o sertão. A Vital, atualmente reduzida em número [...] A família Sampaio, chefiada pelo Coronel Tibúrcio Sampaio, de quem descende pelo lado paterno o poeta Godofredo Filho [...] o grande clã dos Macedos [...] os Silva Lima, Cerqueira Lima [...]", dentre várias outras, que também possuíam riquezas na cidade de Feira de Santana-BA, mas não tão vultuosas quanto as das quatro famílias mencionadas.
} 
[...] Onde está a velha mobília de jacarandá, confeccionada por um modesto tabaréu, marceneiro autônomo, que, depois, chegou a coronel, chefe político de real expressão, intendente, e que quando exigiu do Estado um grupo escolar para a sua terra, por não ter recursos o Estado, fez ele do seu bolso o grande palácio da Rua Direita, esperando que lhe pagasse a despesa o governador posteriormente? Este operário passou a enfardador de fumo poderoso. [...].

A partir dessas informações, compreende-se que o Coronel Agostinho Fróes da Motta se configurava como um forte político, comerciante e, consequentemente, como o centro de sua família, não apenas por ser o seu patriarca, mas porque foi a partir dos seus bens e do seu nome que todos os seus filhos e demais herdeiros prosperaram econômica e socialmente. Essa prosperidade e reconhecimento público, contudo, só foram alcançados pelo Coronel Agostinho Fróes da Motta, após longos e produtivos 40 anos de trabalho, que se iniciaram ainda na puberdade quando o coronel foi enviado por seus pais, em 1870, para Feira de Santana-BA para iniciar as suas atividades laborais, cidade onde adquiriu prestígio político, social e econômico, tornando-se comerciante, intendente, conselheiro municipal e coronel (REIS, 2012).

Do ponto de vista biográfico, Agostinho Fróes da Motta nasceu em 04 de maio de 1856 e faleceu, aos 66 anos de idade, em 22 de março de 1922 de arteriosclerose, depois de 3 meses acamado ${ }^{15}$. Após um ano do seu falecimento, foram celebradas missas em que a Filarmônica Victória tocou "dolentes marchas", que "abrilhantaram" as celebrações do primeiro aniversário de sepultamento do coronel, conforme agradecimento amplamente divulgado no Folha do Norte (CORONEL..., 26 mar. 1923, p. 4):

Coronel Agostinho Fróes | da Motta || AGRADECIMENTO || Arthur Fróes da Motta | e família, João Constantino | Faskomy e família, penho- | rados agradecem a todas | as pessoas que se dignaram | assistir ás missas que man- | daram rezar na igreja ma- | triz desta cidade, no dia $\mid 24$ do corrente, anniversa- | rio do sepultamento de seu | saudoso pai e sogro Co- | ronel AGOSTINHO FRO- | ES DA MOTTA. Agra- | decem mui desvanecidos o | comparecimento da distinc- | ta banda musical da "So- | ciedade Philarmonica Vic- | toria", que, com suas do- | lentes marchas, veio dar | brilhantismo aos mesmos | actos. || Feira, 26 de Março de | 1923.

Contudo, antes do falecimento do Coronel Agostinho Fróes da Motta, a sociedade feirense já o estimava e, por isso, em 07 de julho de 1909, o Folha do Norte noticiou o seu retorno à Princesa do Sertão, após o coronel ter passado um período na Europa, de onde

\footnotetext{
${ }^{15}$ De acordo com Oliveira (1991), o Coronel Agostinho Fróes da Motta ficou acamado em 13 de dezembro de 1921 e, mesmo tendo assistência médica, familiar e de amigos durante 100 dias, acabou não resistindo e faleceu às 14 horas do dia 22 de março de 1922, o que foi lamentado por toda a cidade, segundo o Folha do Norte (1922).
} 
trouxe várias ideias para implementar o progresso em Feira de Santana-BA. As duas notas publicadas no periódico tinham como teor notificar a sociedade feirense sobre o bom estado de saúde do coronel, das cidades que ele visitou na Europa e da sua chegada à Feira de Santana, recepcionado, inclusive, por um grande número de admiradores.

Coronel Agostinho Motta || De Paris, onde chegára traz- | ante-hontem, telegraphou o nosso | presado e distincto amigo coro- | nel Agostinho Froes da Motta | para sua casa commercial desta | cidade, dizendo achar-se em pleno goso de saúde. || É possível, portanto, já achar- | se aquelle amigo em viagem de | retorno á nosso paiz, com o que | muito nos congratulamos. (CORONEL..., FOLHA DO NORTE, 07 jul. 1909 , p. 2);

Coronel Agostinho Froes || Em a noite de 16 do andante | chegou a esta cidade, em trem | especial, de volta da Europa, o | nosso prestigioso amigo e dis- $\mid$ tincto correligionario coronel | Agostinho Froes da Motta, ne- | gociante nesta praça. || O illustre recem chegado per- $\mid$ correo, em viagem de recreio, | as capitaes mais importantes | do velho mundo, trazendo as | melhores impressões da Suissa, | Allemanha, Italia, França e | Inglaterra, em cujas localidades demorou-se em agradabilissima | visita. || Não obstante a falta de previa | communicação, que em tempo | trouxesse ao conhecimento dos | amigos do nosso presado con- | terraneo a noticia de sua che- $\mid$ gada, no dia acima menciona- $\mid$ do, todavia foi elle recebido na $\mid$ gare crescido numero de $\mid$ [ad]miradores, que o acom- $\mid$ panharam até a sua residencia. || Ao nosso bondoso amigo e | dedicado correligionario apre- | sentamos affectuosamente as | nossas boas vindas. (CORONEL..., FOLHA DO NORTE, 22 out. 1909 , p. 1).

Em circunstância diferente, o Folha do Norte também divulgou uma nota, em 10 de agosto de 1911, na qual demonstrava consternação e desejo de restabelecimento da saúde do bemfeitor da cidade:

Coronel Agostinho Fróes | Já vae em caminho de com- | pleto restabelecimento, da mo- | lestia que ultimamente o pren- | deu ao leito, o nosso mui preza- $\mid$ do correligionario e distincto | amigo coronel Agostinho Fróes | da Motta, abastado negociante | e capitalista e poderosa influ- | encia politica neste municipio. || Em visita a sua senhoria esteve nesta | cidade, na passada semana, o seu $\mid$ digno filho e talentoso acade- | mico de medicina Eduardo Motta. || Visitanto ao mui digno ami- | go, trazemos os melhores votos pela | volta completa de sua vigorosa | saúde. (CORONEL..., FOLHA DO NORTE, 10 ago. 1911, p. 2).

Durante a sua vida, Agostinho Fróes da Motta foi considerado nos relatos biográficos como um "homem de cor", ou seja, um homem negro, como atesta a fotografia emoldurada em um quadro com a inscrição: "Agostinho Fróes da Mota - Nascido em Feira de Santana no ano de 1856 e falecido em 1922. Foi Intendente de Feira, de 1916 a 1919, tendo realizado uma boa administração, foi Provedor da Santa Casa de Misericórdia. Iniciou a construção do majestoso prédio da antiga Escola Normal de Feira, atual Centro Universitário de Cultura e Arte (CUCA). No seu governo construiu o prédio da $1^{\text {a }}$ Escola Municipal João Florêncio, em 
1917, atual prédio do Arquivo Público Municipal e em 1918 a Escola Maria Quitéria”, exposto na sala de pesquisa do APMFS-BA.

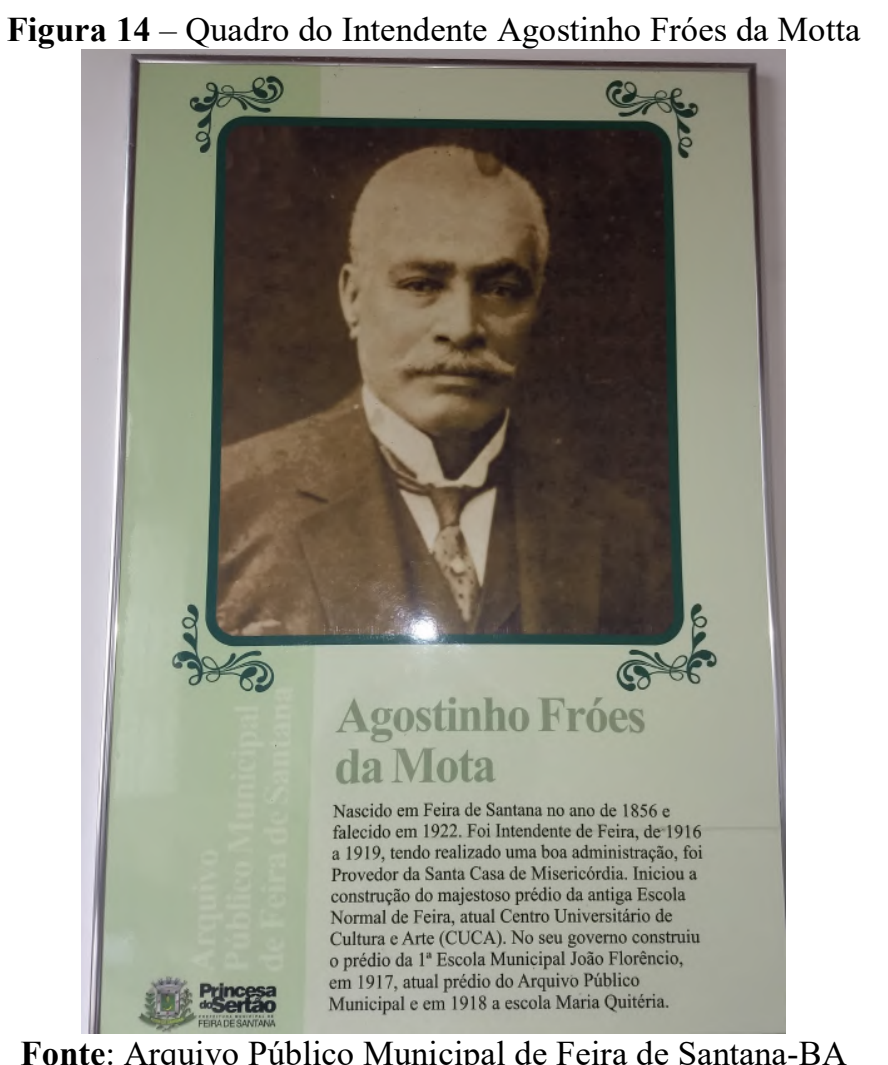

Além disso, o referido coronel era filho legítimo de José Borges da Motta e Maria Valéria de Jesus, sobre os quais não se sabe, ao certo, se teriam sido escravos ou se já eram libertos quando o mandaram para morar em Feira de Santana-BA. Contudo, acredita-se que o coronel Agostinho Fróes da Motta tenha nascido em São Gonçalo dos Campos, uma pequena cidade do interior da Bahia, localizada a 115 quilômetros de Salvador-BA (REIS, 2012), informação contestada no testamento do próprio Agostinho Fróes da Motta, no qual este afirmou ser natural de Feira de Santana-BA, o que nos leva a refletir sobre duas questões.

Primeiro, após a sua ascensão social, talvez o coronel tenha preferido se declarar oriundo de Feira de Santana-BA com o intuito de valorizar a cidade que o acolheu e lhe permitiu alcançar riqueza. Segundo, talvez ele tenha optado por não fazer remissão e nem deixar registrada a sua origem, advinda de São Gonçalo dos Campos-BA, para não se recordar e nem os seus afetos das dificuldades enfrentadas em sua juventude. Contudo, não passam de meras hipóteses, já que não conseguimos encontrar a sua certidão de nascimento ou livro de batismo, que poderiam sanar essa questão. 
Aos dezenove anos de idade, o Coronel Agostinho Fróes da Motta se casou, no dia 11 de maio de 1875, com D. Maximiana de Almeida Motta, nascida em 21 de fevereiro de 1855 na Fazenda Mocó, em Feira de Santana-BA, cuja personalidade foi descrita pelos conterrâneos e por Oliveira (1991) como calma, forte, resignada e bastante religiosa, e cujas primeiras letras aprendeu com a mãe.

Após aprender a ler e a escrever, a senhora Fróes da Motta prosseguiu os seus estudos na escola da mesma fazenda onde nasceu e da qual saiu somente quando se casou com o coronel, com quem teve seis filhos, a saber: Albertina, que se desquitou duas vezes, uma em 1922 e outra em 1940, e quem recebeu o apoio financeiro, moral e paternal do seu pai durante todo o seu primeiro processo judicial de desquite; Arthur, que se tornou um reconhecido farmacêutico na cidade e Tesoureiro Municipal, nomeado em 19 de agosto de 1935 pelo Prefeito Heráclito Dias de Carvalho; Augusto, que foi um reconhecido Capitão da Brigada Nacional e sobre o qual aparecem, no CEDOC/UEFS, alguns documentos jurídicos acerca de suas relações conjugal, familiar e comercial.

Amália, que foi deserdada pelos pais e quem contestou a sua deserdação na Justiça junto com o seu segundo marido, João Constantino Faskomy; Eduardo, que foi médico e a quem foi dado o direito legal, por parte dos seus pais, de administrar os bens e o zelo do nome da família; e Adalgisa, filha caçula, casada com o senhor Adalberto Alves de Farias, que era sócio do seu pai e residente na cidade de Ilhéus no período em que o inventário do Coronel Agostinho Fróes da Motta começou a ser feito. Ainda sobre essa filha, em 02 de dezembro de 1924, Adalgisa de Almeida Motta Farias se encontrava desquitada do seu então marido e sem filhos, como mencionado no quarto volume do inventário do referido coronel e, devido a isso, na ação ordinária de filiação e petição de herança requerida por Alberto de Almeida Motta, ela passou a ser a sua própria representante legal no decorrer do processo, já que o seu exmarido havia deixado de sê-lo.

Além dos seis filhos tidos com D. Maximiana de Almeida Motta, o coronel Agostinho Fróes da Motta teve com a senhora Guilhermina de Almeida, com quem viveu, por vários anos, um relacionamento extraconjugal, o filho Alberto de Almeida Motta, que só foi reconhecido como tal após um longo processo de filiação e petição de herança, instaurado a pedido dele, após o falecimento do seu pai, que participou de toda a sua vida e financiou os seus estudos na Capital do Estado. Biograficamente, Alberto de Almeida Motta foi engenheiro, residiu em Feira de Santana-BA, após a conclusão do seu Curso de Engenharia em Salvador-BA, casou-se, teve filhos e faleceu muito jovem, deixando, inclusive, alguns processos judiciais que envolviam a disputa pela sua herança em aberto. 
Do ponto de vista comercial, pelo fato de Feira de Santana-BA possuir terras férteis à plantação de fumo e uma significativa presença de negros escravizados ou libertos e um território geográfico propício à comercialização, o Coronel Agostinho Fróes da Motta se tornou, então, um grande exportador de fumo, além de alguém que emprestava dinheiro a juros, alugava casas, possuía criação e comércio de gado e atuava como representante da primeira Agência do Banco do Brasil na cidade de Feira de Santana-BA, atividades que favoreceram o crescimento substancial de sua fortuna.

Enquanto político, o Coronel Agostinho Fróes da Motta foi membro da comissão de obras públicas e higiene, em 1901; Conselheiro Municipal, a partir de 1902; e Intendente da cidade de Feira de Santana, entre 1916 e 1919, cuja nomeação ocorreu em 01 de janeiro de 1916, como atesta o título de nomeação de Intendente, constante no Livro de registros de títulos dos empregados municipais (1912-1920).

[...] Timbre do Estado || Registro de titulo de nomeação de Intendente. || O Doutor Governador do Estado da Bahia, usando | da attribuição que lhe é conferida pelo paragra- | pho primeiro do artigo 14 da Lei numero 1102 de 11 de Agosto | do corrente anno, resolve nomear o cidadão Co- $\mid$ ronel Agostinho Froes da Motta, para o cargo de | Intendente do Municipio da Feira de Sant'Anna, | devendo assumir o exercicio do mesmo, de primeiro de Ja- $\mid$ neiro proximo vindouro em diante. Palacio do Go- | verno do Estado da Bahia, 3 de Dezembro de 1915. | (Assignados) José Joaquim Seabra. Arlindo Fragoso. Cumpra- $\mid$ se e registre-se. Directoria do Interior, Justica e Ins- | trucção Publica da Bahia, 4 de Dezembro de 1915 | Antonio Dantas. Registrado ás folhas. 12verso do livro - | competente. Directoria do Interior, Justica e Ins- | trucção Publica do Estado da Bahia, 6 de Dezem- | bro de 1915. O amanuense Octaviano Pessoa da | Silva. Pagou a quantia de dois mil reis, de emo- | lumentos do registro do presente titulo. Collectoria | Estadual da Feira de Sant'Anna, 16 de Dezembro | de 1915. O Collector. José Alves Franco. O Escrivão | Deoclecio da Silva Daltro. Reconhecido e proclamado em sessão | de verificação de poderes em 17 de Dezembro de 1915. | (Assignados) Bernardino da Silva Bahia. Presentes Juven- | cio Erudilho da Silva Lima Primeiro Secretario Leolindo dos Santos Ra- | mos Segundo Secretario Prestou o compromisso legal e assumiu | o exercicio do cargo em sessão solemne de posse do | Concelho Municipal, effectuada hoje, primeiro de Janeiro de 1916. O Presidente (Assignado) Bernardino Bahia. Registrado | por mim, José Moreira de Araujo, amanuense. (LIVRO DE REGISTROS DE TÍTULOS..., 1916, f. 11r-11v).

No mesmo ano em que assumiu a Intendência Municipal, Agostinho Fróes da Motta continuou as obras iniciadas pelo seu antecessor, Coronel Bernardino da Silva Bahia, e conseguiu finalizar a construção do prédio escolar, que havia sido aprovado pelo Conselho Municipal, em 1913, e cuja edificação foi iniciada em 1914, quando foi noticiada no Folha do Norte (PREDIO..., 26 jul. 1914, p. 1) a chegada do engenheiro Luiz Affonso de Sá Adami, nomeado pelo Governo do Estado. 
Predio escolar || Chegou a esta cidade no re- | gular de 22 do corrente o engenheiro fiscal nomeado pelo | governo do Estado para acom- | panhar a construcção do pre- | dio escolar desta cidade. || Sua Senhoria no dia immediato fez a | locação do terreno, que é á rua | Conselheiro Franco, demarcando a | área onde tem de ser edificado | o predio, cujos trabalhos de | nivelamento e galpão para ma- | teriaes estão sendo feitos.

Com a chegada do engenheiro responsável pela obra e com a demarcação do terreno onde seria levantado o primeiro prédio escolar da cidade, Agostinho Fróes da Motta destinou recursos públicos e próprios para a finalização do referido prédio, que recebeu o nome de Grupo Escolar Dr. J.J. Seabra, atual Centro Universitário de Cultura e Arte - CUCA, localizado no Centro de Feira de Santana-BA.

Figura 15 - Grupo Escolar Dr. J.J. Seabra, atual Centro Universitário de Cultura e Arte - CUCA

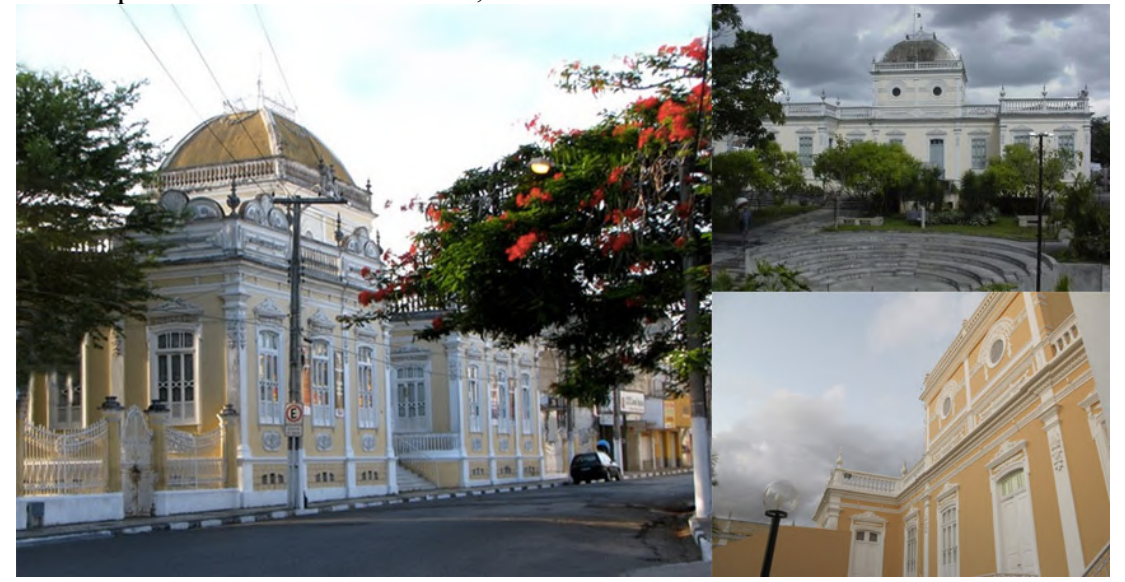

Fonte: http://feirenses.com/patrimonios-materiais-feirenses-tombados/. Acesso em: 27 out. 2017.

Mesmo com a construção do primeiro prédio escolar da cidade, as preocupações do Intendente com a instrução pública não cessaram, pelo contrário, apesar de ter "instrução incompleta", pois desconhecemos a existência de qualquer registro documental que ateste o nível de escolaridade de Agostinho Fróes da Motta, em ofício de número 119, de 16 de novembro de 1916, o Intendente propôs ao Conselho Municipal o seguinte:

[...] Apesar do avultado numero de escolas publicas estado | aes e municipaes nesta cidade, todas com frequencia | regulamentar, ultrapassada mesmo em algumas, observa-se | nos suburbios grande quantidade de creanças em idade | escolar que não as frequentam, ordinariamente pela escassez $\mid$ de recursos reunida a negligencia de paes menos favoreci- $\mid$ dos e ignorantes. Cogita esta Intendencia de obriar taes $\mid$ inconvenientes, prestando assistencia espiritual mais pron- $\mid$ ta e mais efficaz a esses nossos concidadãos, secundando $\mid$ os patrioticos esforsos de benemeritos patricios, dando fran- $\mid$ co combate ao analfabetismo. O Municipio, na medi- $\mid$ da de seus recursos, no cumprimento de um de seus $\mid$ deveres primordios, pode promover a effectividade de medi- $\mid$ das attinentes a esse nobilissimo fim. Para alcançar esse | nobre e patriotico intento, julga esta Intendencia que a $\mid$ creação nesta cidade ou seus suburbios, em logares con- | siderados os mais convenientes, de escolas para adultos $\mid$ e creanças, estas mixtas e diurnas, podem ser custeadas $\mid$ pela verba 
destinada a Instrucção e economias verifica- | das em outras verbas. As cadeiras deverão ser preenchidas | livremente por pessoas idoneas, diplomadas ou não, medi| ante contracto e os serventuarios considerados funccionarios | em commissão, sujeitos ao regulamento da Instrucção | no que diz respeito ás funcções e a fiscalização especial | da Intendencia e do Concelho. Acredito que os resultados | sejam os mais lisongeiros possivel. Confiado nas luzes | e patriotismo do honrado Concelho espero que sejam decre $\mid$ tadas as medidas necessarias e que julgar opportunas ao | fim visado. Reitero os meus protestos da mais distincta | consideração e apreço. Saudações. (Assignados) Agostinho | Froes da Motta. Registrado por mim, José Moreira de Ara- | ujo, amanuense. (LIVRO DE REGISTROS DE OFÍCIOS..., 1916, f. 39r-39v, grifos nossos).

Apesar de existirem escolas primárias isoladas ${ }^{16}$ funcionando na cidade com um bom número de matrículas, o Grupo J. J. Seabra surgiu “[...] como a instituição responsável pela difusão do ensino primário, em contraposição às escolas isoladas [...]” (OLIVEIRA, 2019, p. 101). Logo, o prédio escolar J. J. Seabra, que foi criado com o intuito de unificar as aulas e uniformizar as práticas e os métodos de ensino, foi desocupado e extinto, em 1927, e passou a funcionar como a Escola Normal de Feira de Santana, na qual foram formados(as) os(as) novos(as) professores(as) para atenderem a demanda do alunado feirense (OLIVEIRA, 2019).

Ainda em 1918 e com a inauguração do Grupo Escolar J. J. Seabra, o Intendente Agostinho Fróes da Motta ainda manifestava uma preocupação com as crianças, moradoras de zonas periféricas, que não estavam inseridas no espaço escolar por "negligência dos pais" e sobre esse assunto, em 27 de maio de 1918, foi emitido um ofício pela Intendência Municipal sobre a necessidade de registro civil de crianças em idade escolar, as quais, somente depois disso, poderiam frequentar as escolas existentes e mais duas que seriam construídas nos bairros Olhos d'Água e Sobradinho, as quais contribuiriam para o alcance do objetivo do Intendente: o fim do analfabetismo que atrapalhava o "progresso" da cidade.

Além das crianças, o governo municipal também queria inserir adultos analfabetos na educação primária e, para isso, foram criadas escolas mistas diurnas para as quais foram nomeados professores "idôneos" com ou sem diplomas para atuarem no ensino público primário, no qual pequenos "patrícios” e famílias carentes seriam beneficiadas.

Cinco dias depois do registro daquele ofício, Agostinho Fróes da Motta comunicou ao Conselho Municipal, via documento registrado em 20 de novembro de 1916, que se afastaria das suas funções por um período de 30 dias ou mais para uma viagem ao Rio de Janeiro, onde fez visitas a políticos e ampliou as suas relações como Intendente. Durante a sua ausência, o

${ }^{16}$ Essas escolas isoladas foram inseridas no Projeto denominado Escolas Reunidas de Feira de Santana, inaugurado em 1928, e cujo funcionamento ocorreu na Escola Maria Quitéria, na Praça General Argolo, e tinha como objetivo unificar as aulas isoladas. Assim, um grupo "[...] de até três aulas em um só prédio escolar era chamada de Escolas Reunidas; a partir de quatro aulas reunidas em um só prédio, denominava-se Prédio Escolar. Em Feira de Santana, o Grupo Escolar chega primeiro que o projeto de Escolas Reunidas". (OLIVEIRA, 2019, p. 104). 
Coronel Bernardino da Silva Bahia assumiu a Intendência Municipal, já que era o então Presidente do Conselho Municipal, e devolveu a direção da Intendência em 23 de dezembro do mesmo ano, quando Agostinho Fróes da Motta finalmente retornara do Rio de Janeiro.

No ano seguinte, em 01 de fevereiro de 1917, o Intendente Agostinho Fróes da Motta mandou publicar, no Folha do Norte, um edital de abertura de concorrência para a implementação do calçamento da rua Dr. Manoel Victorino, para o qual o licitante se comprometeria a preparar o terreno e fornecer o material necessário para a obra, sendo que o pagamento do serviço só seria realizado após a conferência do calçamento, que deveria estar "completamente pronto, batido, embrechado e coberto de areia" e, depois disso, seria pago em parcelas pela Intendência Municipal.

Ainda naquele ano, o Intendente Agostinho Fróes da Motta ordenou que fosse edificado, com o seu próprio dinheiro, um coreto em frente ao palacete em que morava, o que se justificava não simplesmente por querer "embelezar a cidade", mas porque isso valorizaria tanto a sua residência quanto os imóveis que existiam na mesma rua, pertencentes ao próprio Intendente ou aos seus companheiros de política (CUNHA, 2013).

Figura 16 - Coreto da Praça Fróes da Motta em Feira de Santana-BA (19--)

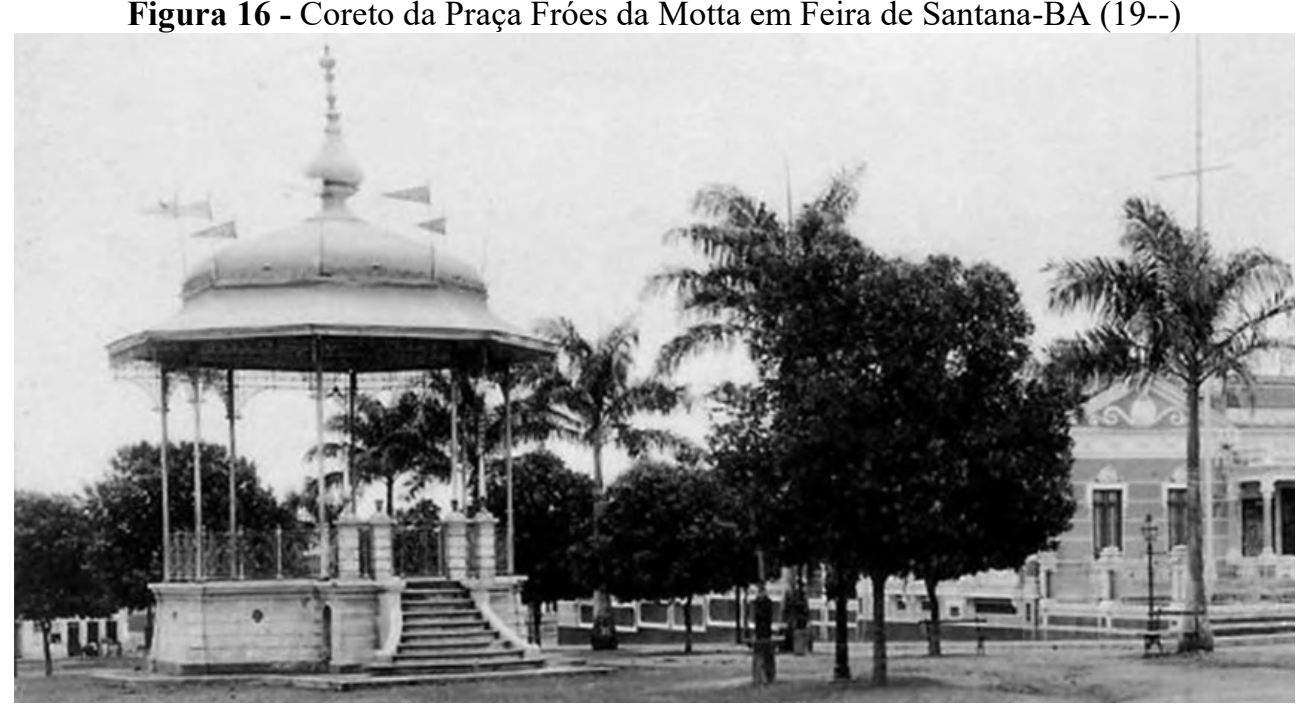

Disponível em: https://feirenses.com/coreto-da-froes-da-motta/. Acesso em: 27 out. 2017. 


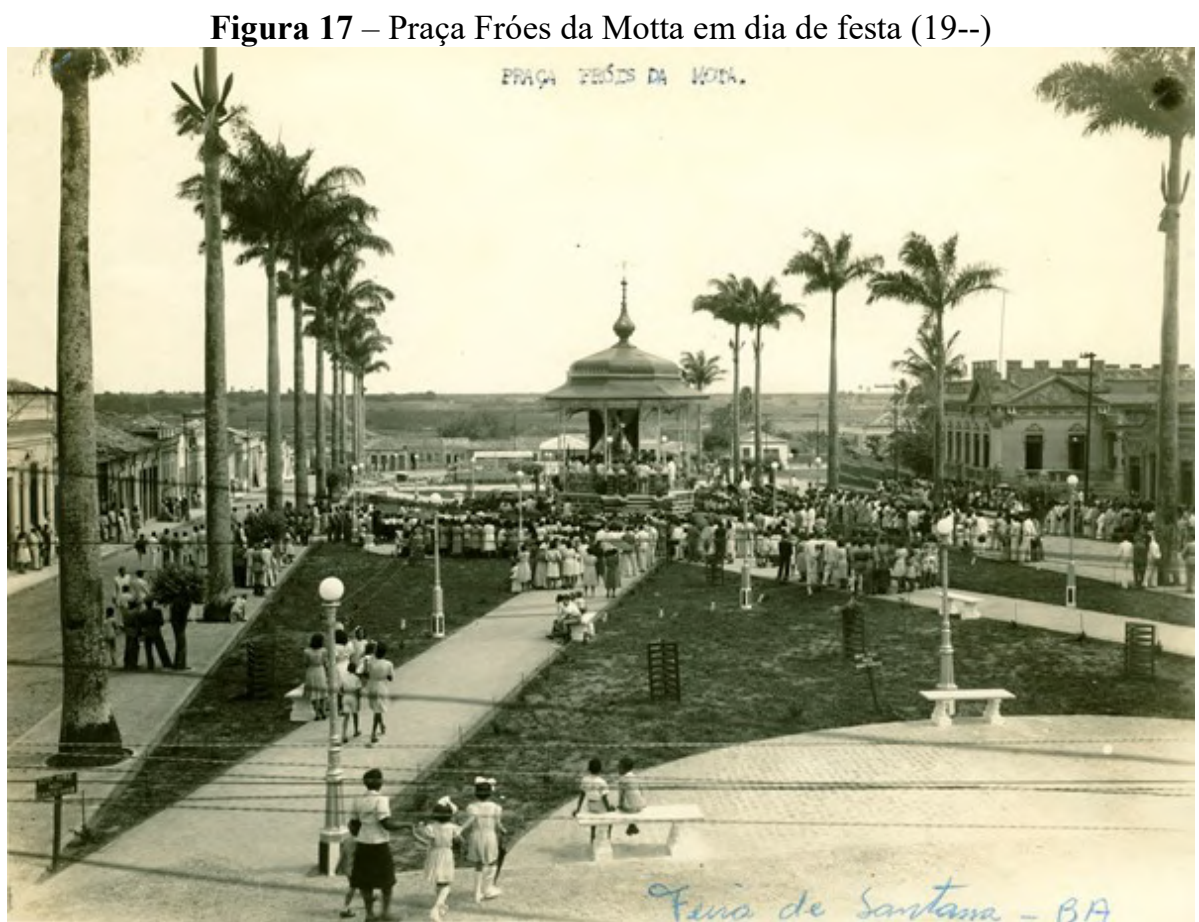

Fonte: Cidades IBGE. Disponível em: https://cidades.ibge.gov.br/brasil/ba/feira-de-santana/historico. Acesso em: 29 mar. 2019.

Em agosto do mesmo ano, o Intendente continuou e ampliou as obras do seu antecessor e amigo, Coronel Bernardino da Silva Bahia, demonstrando, inclusive, o desejo de promover melhorias não apenas na cidade, mas também nos distritos, realizando, para isso, uma "excursão" junto com o Secretário Municipal, José Telles Barreto, para conhecer as necessidades de Santa Bárbara e Tanquinho, como atesta a seguinte notícia veiculada no Folha do Norte (O SENHOR..., 25 ago. 1917, p. 2):

\begin{abstract}
O Senhor Intendente | inicia uma excursão | aos districtos || O senhor coronel Agostinho Fróes | da Motta, digno e operoso in- | tendente municipal, seguiu, na | quinta-feira ultima, em excur- | são pelos districtos de Santa | Bárbara e Tanquinho, afim de | conhecer de visa as suas ne- | cessidades e determinar os me- | lhoramentos precisos. || Em companhia de sua senhoria se- | guiu o seu secretario, o senhor José | Barreto. || Sabemos que o honrado ti- | tular pretende tambem fazer | igual digressão aos demais dis- | trictos do municipio, com os $\mid$ mesmos intuitos. || Muito louvavel e digno dos $\mid$ maiores applausos é esse modo $\mid$ de proceder, que merece fran- $\mid$ co apoio. || Acompanham aos excursio- | nistas os nossos votos de fe- | liz viagem.
\end{abstract}

Enquanto o Intendente estava em excursão pelos distritos, prosseguia na cidade as obras de construção de mais duas escolas, em 1917: Escola Municipal, que atualmente se chama Escola Municipal Maria Quitéria; e Escola Municipal João Florêncio, atual Arquivo Público Municipal de Feira de Santana, ambas localizadas no Centro da cidade. 
Figura 18 - Escola Municipal Maria Quitéria, segundo prédio escolar de Feira de Santana-BA (19--)

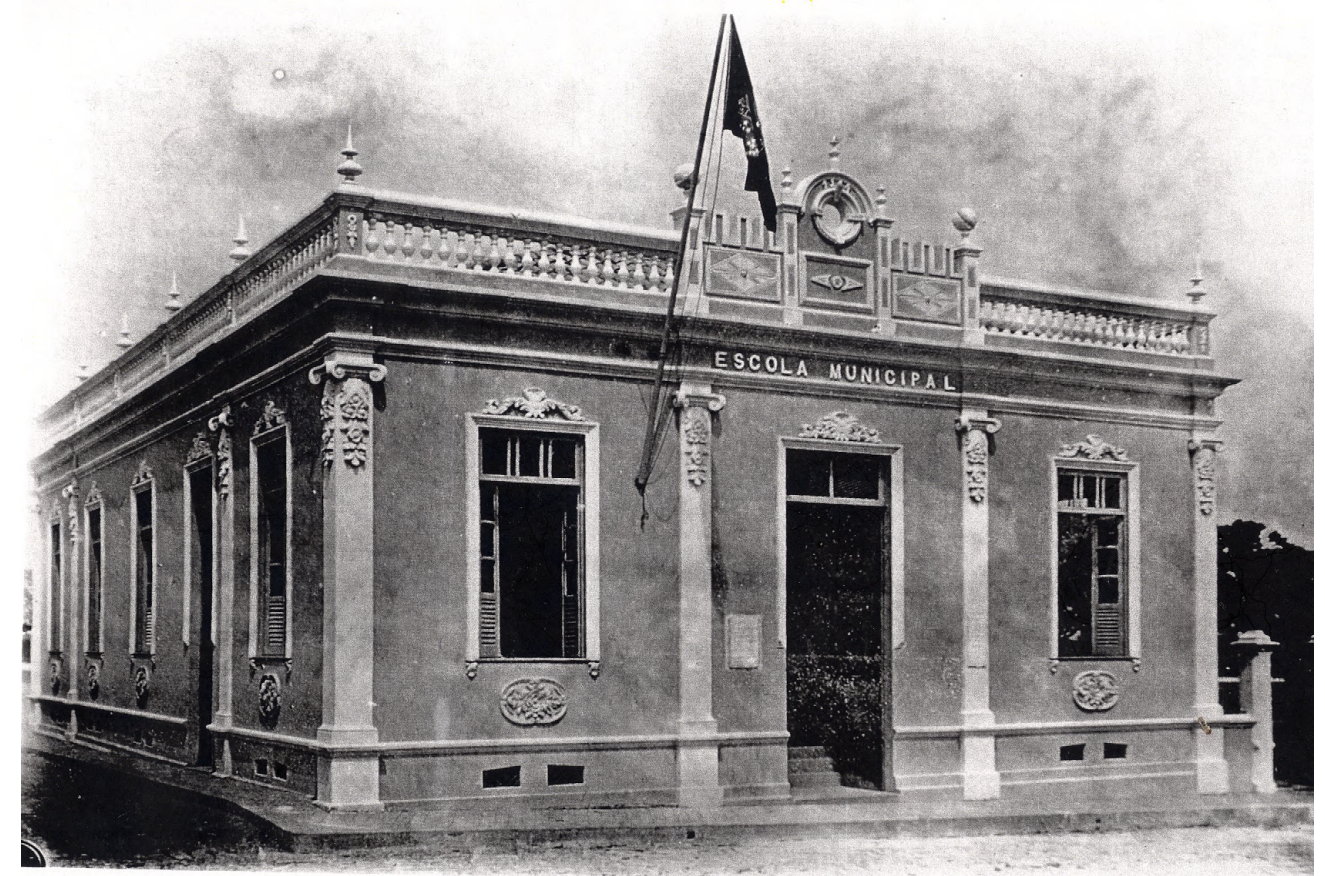

Fonte: http://www.memorialdafeira.ba.gov.br/conteudo.asp?catimg=1. Acesso em: 27 out. 2017.

Figura 19 - Escola Municipal João Florêncio, atual prédio do Arquivo Público Municipal de Feira de Santana-BA (19--)

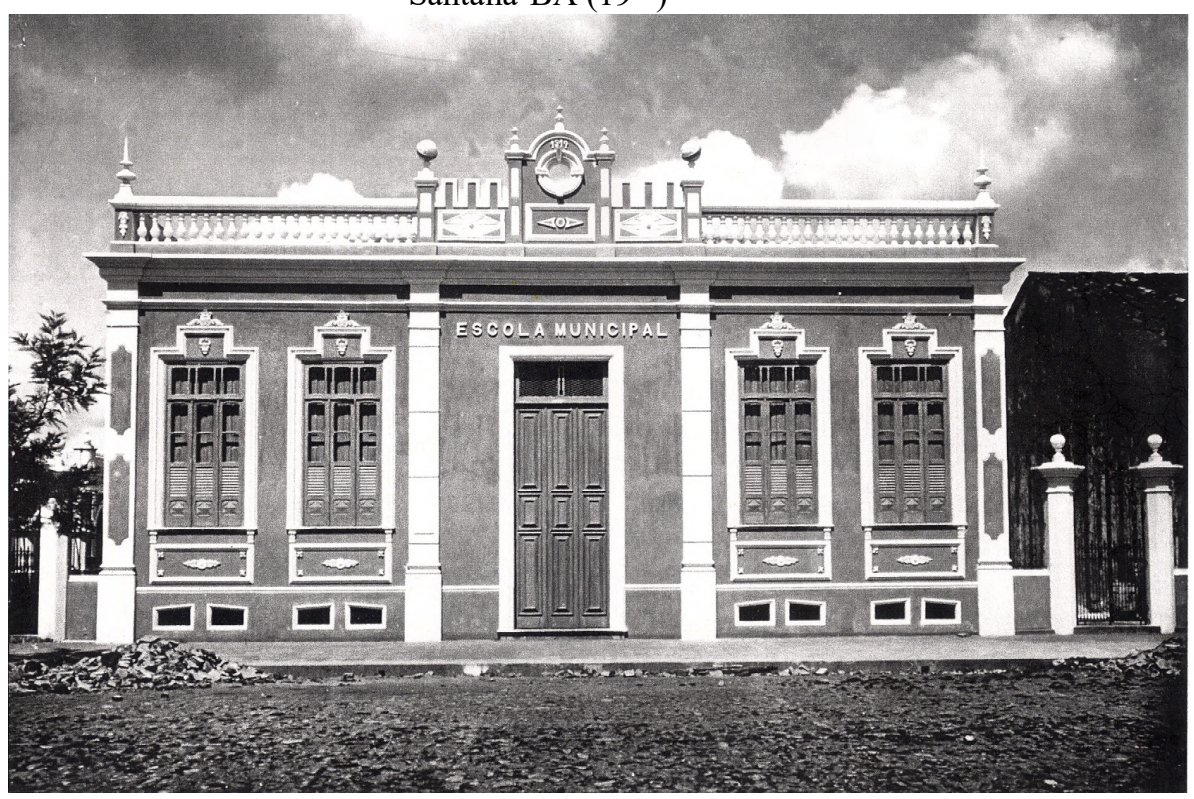

Fonte: http://www.memorialdafeira.ba.gov.br/conteudo.asp?catimg=1\#gallery1-50. Acesso em: 27 out. 2017.

Para festejar a conclusão e entrega desses dois prédios, o Intendente emitiu ofício, em 15 de dezembro de 1917, convidando as Filarmônicas 25 de Março e Victória para participarem da sua inauguração.

[...] Illustrissimos Senhores Presidente e mais membros da Directoria | da Sociedade Philarmonica 25 de Março. || Tenho a maior satisfação em communicar-vos | que no 
dia primeiro de Janeiro proximo, pretende esta | Intendencia inaugurar os dois predios escola- | res ultimamente construidos nesta cidade, pelo | Municipio. Embora nunca tivesse cojitado em fes- | tas ruidosas, comtudo suppõe esta Intendencia | que não deveria deixar passar em completo silen- | cio essa occurencia, que é muito significativa | e do mais interesse para o bom nome que felis- | mente gosa a nossa terra e a sua laboriosa e | progressista população. Assim pensando, cumpre | esta Intendencia o grato dever de convidar es- $\mid$ ta distincta e sympathisada Sociedade, parte inte- $\mid$ grante do povo e elemento preponderante e da ma- $\mid$ ior valia na vida social da Feira, a tomar | parte e com o seu valiosissimo concurso abri | lhantar o acto da inauguração do predio, que | é do povo e para o povo, situado na praça General | Argollo, as 5 horas da tarde precisas, do mencio- | nado dia. Dedicada, como sempre tem sido essa | distincta Sociedade a todas as nobres causas | do nosso querido torrão, decerto não se excu- | sará de acceder a este convite, o que anteci- | padamente agradeço. Identico convite tenho | dirigido á Sociedade Philarmonica Victoria, para assistir | a inauguração do outro predio, na rua Barão | de Cotegipe, ás 3 horas. Queirão acceitar os $\mid$ meus protestos da maior consideração e apreço. | Saudações. (Assignado) Agostinho Fróes da Motta. | Registrado por mim, José Moreira de Araujo, ama- | nuense da Secretaria. (LIVRO DE REGISTROS DE OFÍCIOS..., 1917, f. 63r).

Após a inauguração, o Intendente emitiu agradecimentos aos presentes e, no ano seguinte, em 17 de março de 1918, uma epidemia no distrito de Bom Despacho atraiu a preocupação do gestor, que pediu ajuda ao Governador do Estado para que enviasse pelo menos dois médicos para ajudarem a população daquele distrito, que já havia perdido 34 habitantes e mais 116 encontravam-se doentes.

Telegramma ao Doutor Governador em 17 de Março 1918. || Levo conhecimento Vossa Excellencia assustadora epedemia | febres patustre districto Bom Despacho zonas visi | nhas neste Municipio. Intendencia attendendo recla- $\mid$ mos povo mandou medico verificar carater mo- | lestia medicando 116 enfermos acamados no arraial | e haverem fallecido dentro 15 dias 34 pessoas. Exgo- | ttado esforços municipio e se propagando molestia | peço Vossa Excellencia providencias immediatas mandando | pelo menos dois medicos tratamento, crescente e avul- $\mid$ tado numero doentes. Saudações. (Assignado) Agosti- $\mid$ nho Froes. Registrado por mim, José Moreira de $\mid$ Araujo, amanuense da Secretaria. (LIVRO DE REGISTROS DE OFÍCIOS..., 1918, f. 69r).

Além das preocupações municipais, o Intendente também teve que lidar com a perda de sua primeira esposa, que muito o abalou e, por isso, decidiu se afastar de suas atividades administrativas para que não prejudicasse a Intendência Municipal, segundo as suas palavras registradas no seguinte ofício:

Intendencia Municipal da Feira de | Sant'Anna em 14 de Maio de 1918. || Illustrissimo Senhor Coronel Presidente do Concelho Municipal || Em virtude do profundo abalo moral e phy- | sico em mim produsido com o fallecimento | de minha esposa, e para que o serviço pu- | blico não seja de qualquer forma perturbado, | transmitto-vos, nesta data, na forma da Lei, | o exercicio do cargo de Intendente Munici- | pal. Apresento-vos os meus protestos da | maior consideração e estima. 
Affectuosas | saudações. (Assignado) Agostinho Fróes da | Motta. Registrado por mim, José Moreira de | Araujo, amanuense da Secretaria. (LIVRO DE REGISTROS DE OFÍCIOS..., 1918, f. 71v).

Mesmo consternado, o Intendente continuou demonstrando extrema preocupação e zelo com a administração pública e, após o período de luto, retornou às suas atividades. Com o passar dos anos e com o acúmulo de riqueza, o Coronel Agostinho Fróes da Motta e a sua família se tornaram os mais afortunados de Feira de Santana nas três primeiras décadas do século XX e, como símbolo de riqueza e de luxo, acabaram construindo o Casarão Fróes da Motta - A vila, um palacete em estilo neo-clássico, que foi residência do Coronel Agostinho Fróes da Motta, onde, após a sua morte, o seu filho, Eduardo Fróes da Motta, também morou.

O Casarão foi construído no final do século XIX e a sua primeira reforma data de 1923/1924, localizado na atual Rua General Câmara, esquina com a Praça Fróes da Motta em Feira de Santana-BA. Recentemente, a vila foi restaurada e funciona como um local que abriga eventos culturais e comerciais, cujos alugueis são recebidos pela Fundação Senhor dos Passos, atual administradora do Casarão Fróes da Motta.

Figura 20 - Prédio da Vila Fróes da Motta, antes e depois da reforma

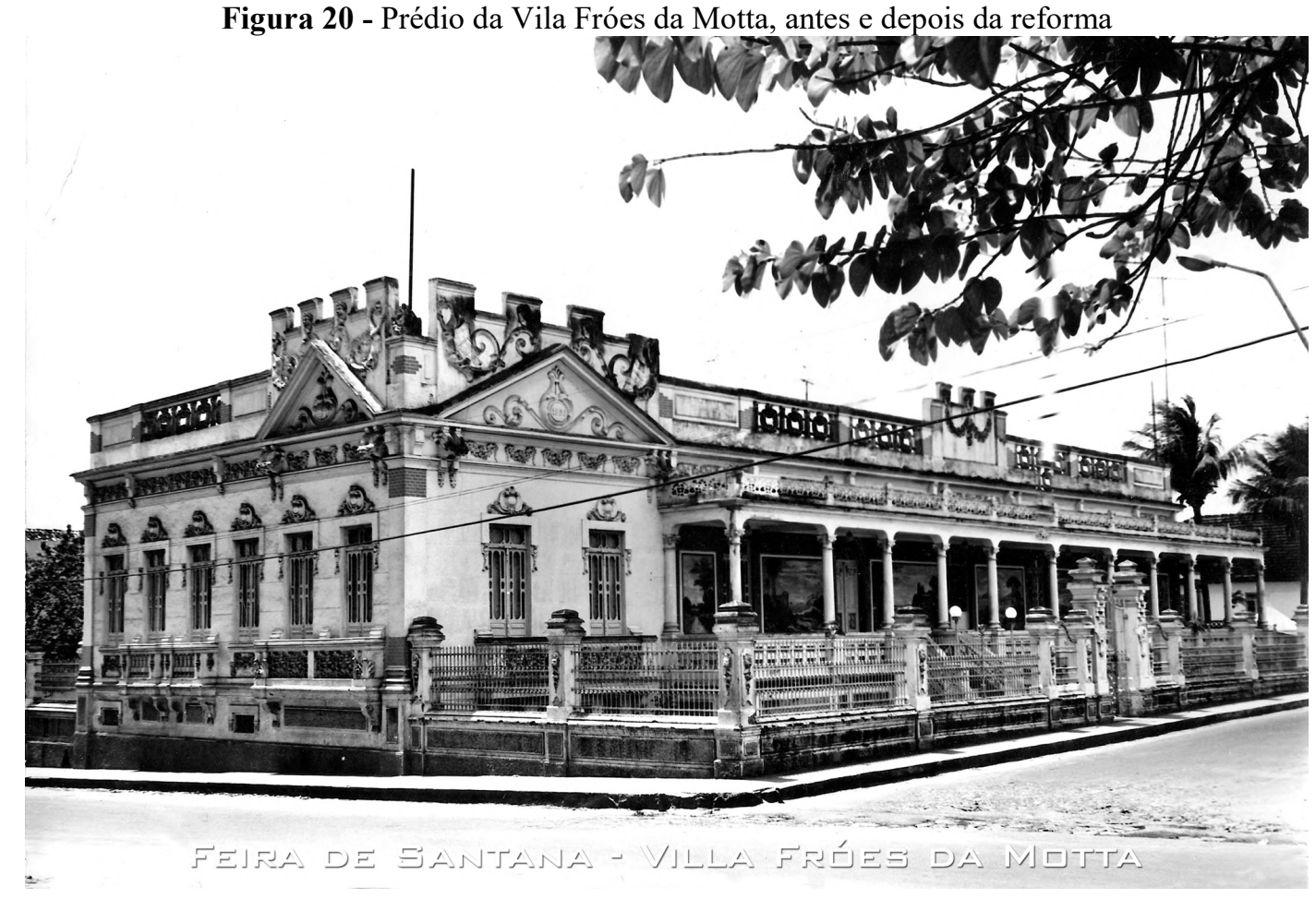




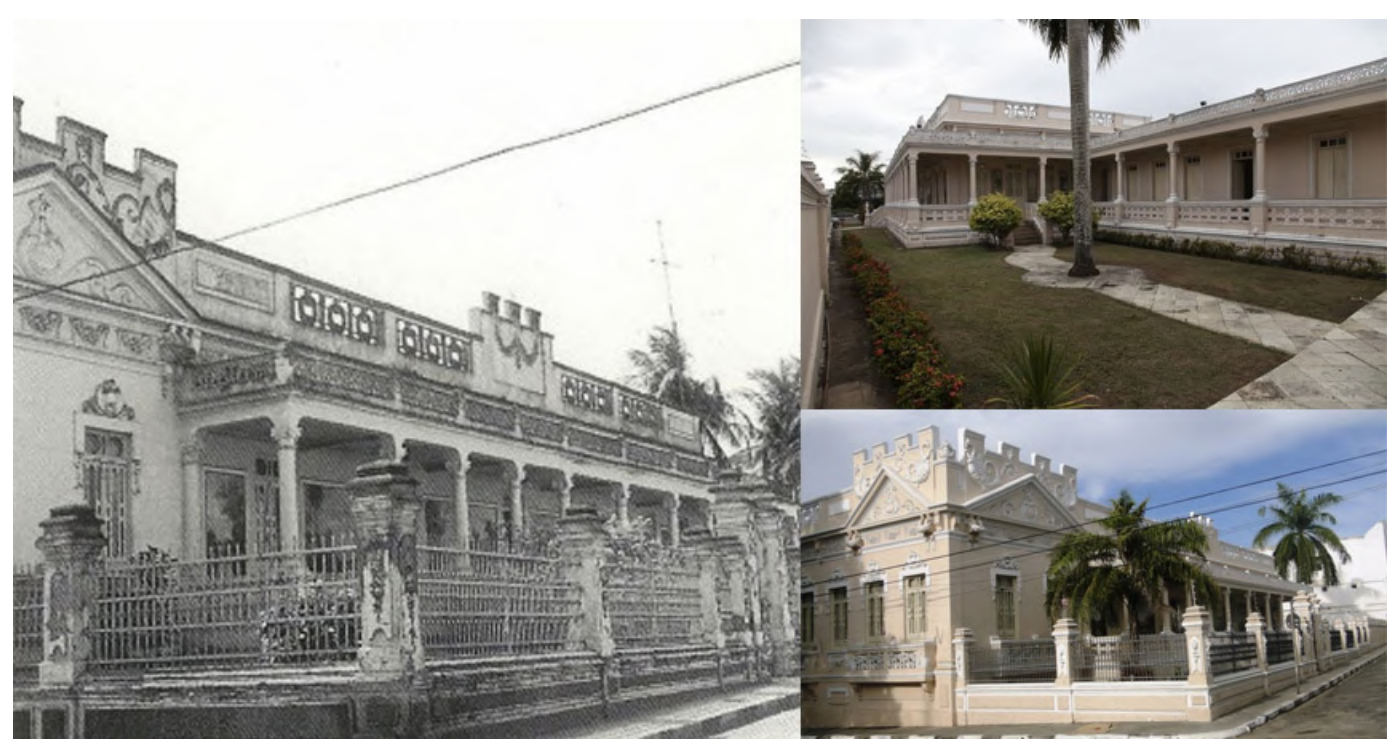

Fontes: http://www.memorialdafeira.ba.gov.br/conteudo.asp?catimg=7\#gallery7-22 e http://feirenses.com/patrimonios-materiais-feirenses-tombados/. Acesso em: 27 out. 2017.

Como reconhecimento de sua contribuição política, econômica e visibilidade social, na atual Feira de Santana-BA há colégios, ruas e avenidas que receberam os nomes do Coronel Agostinho Fróes da Motta e o de seu filho caçula, Eduardo Fróes da Motta, o que evidencia a relevância dos Fróes da Motta para toda a cidade. Como prova disso, os seus sucessores políticos construíram e nomearam, na Rua Coronel Álvaro Simões, no Centro da cidade, uma escola, cuja fachada aparece a seguir, com o nome do Intendente Agostinho Fróes da Motta, como forma de homenageá-lo e as suas benfeitorias na Feira de Santana do seu tempo.

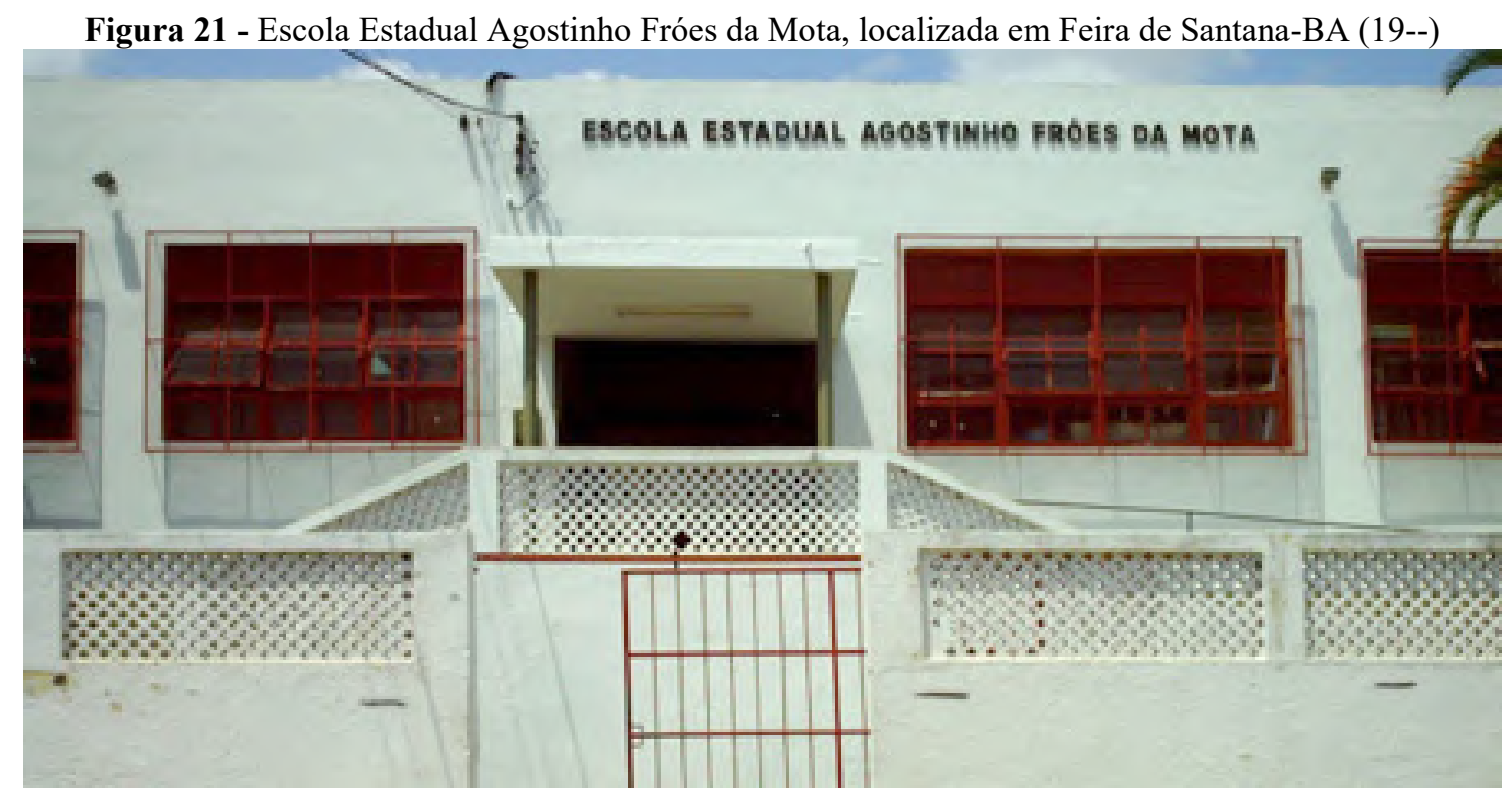

Fonte: http://escolas.educacao.ba.gov.br/node/12177. Acesso em: 17 nov. 2019. 
$\mathrm{Na}$ Feira de Santana atual, não somente o pai, mas o filho Eduardo Fróes da Motta também foi homenageado ao ter o seu nome estampado em uma das principais avenidas da cidade, localizada no Anel de Contorno, sobre o qual se apoia toda a cidade.

Figura 22 - Avenida Eduardo Fróes da Motta em Feira de Santana-BA (19--)

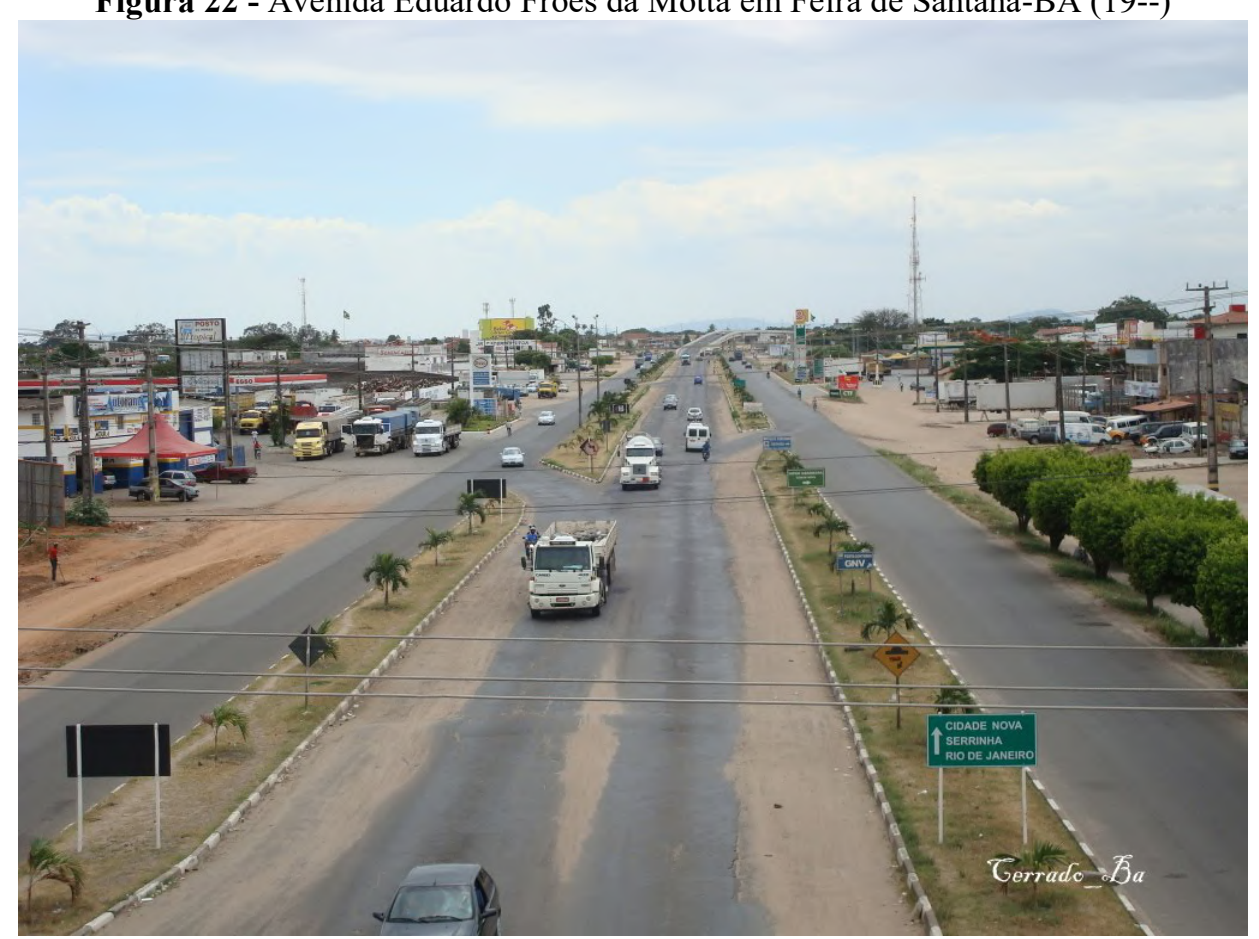

Fonte: Google maps. Acesso em: 27 out. 2017.

Como se pode notar, portanto, a história dos Fróes da Motta é rica em aspectos que nos levam a conhecer e a compreender a atual conjuntura geográfica e social de Feira de Santana-BA, bem como os papéis importantes, enquanto político, comerciante, homem que fazia caridade às instituições públicas etc., exercidos pelo Coronel Agostinho Fróes da Motta.

Sobre a família Bahia, esta era conduzida pelo Coronel Bernardino da Silva Bahia, Conselheiro Municipal e Intendente de Feira de Santana, por duas vezes, de cujos mandatos foram frutos vários dos melhoramentos já mencionados. Sobre a sua relevância para o cenário feirense, o Folha do Norte, em 20 de junho de 1914, publicou em sua primeira página uma nota em homenagem ao aniversário do então Intendente:

Coronel Bernardino Bahia || PASSOU hontem a data natalicia do digno e ope- | roso coronel Bernardino da Silva Bahia, honrado intendente des- | te município. || Cavalheiro dotado das mais bellas qualidades e insignes | predicados moraes, tornase por isso credor da estima de | quantos se aproximam de sua sympathica individualidade. || Administrador correcto e criterioso, chefe acatado e | prestigioso nesta grande unidade do Estado, sua excellencia, verda- | deiro abnegado, em pouco tempo de sua fecunda gestão, tem | conseguido elevar este futuroso municipio a par dos mais | progressistas do Estado. || Ahi então, á vista de to- | dos, os emprehendimentos | que vem executando no cur- | to periodo de 20 mezes, para | 
attestarem sua solicitude e | seu patriotismo, que por si | só constituem um padrão de | benemerencia para um fe- | cundo periodo governamental. || Tolerante por indole, mas | de uma tolerancia sadia e $\mid$ bem entendida, é o digno ci- $\mid$ dadão, pelo affecto e res- | peito que inspira, pela ina- | tacavel honestidade, pelo | desprendimento de interes- | se individual, um beneme- $\mid$ rito a quem o municipio da $\mid$ Feira de Sant'Anna vai de | vendo os melhores serviços, | a sua paz e harmonia fecun- | das, que se tem desdobrado em seu proveito, reflectindo satis- | factoriamente em todas as classes sociaes. || Ausente embora, na capital, com sua extremecida fa- | milia, não passa em olvido a data anomastica do illustre e | digno concidadão, a quem nós, os da "Folha do Norte", | apresentamos os mais effusivos e cordiaes cumprimentos e | votamos sinceramente pela continuação das felicidades que | frue e que ellas se reflictam sobre nosso municipio accen- | tuando-se mais e mais até o ponto de constituil-o em ver- | dadeiro seio de Abrahão.

Essa homenagem é uma amostra de como os feitos do Intendente eram vistos pela sociedade, os quais serviram, inclusive, como alicerce para que ele fosse reeleito em 1919 e cuja nomeação foi realizada em 31 de Dezembro daquele ano, como podemos observar a seguir.

Timbre do Estado || O Governador do Estado da Bahia, usando da | attribuição que lhe é conferida pelo §primeiro do artigo | 14 da Lei numero 1102 de 11 de Agosto de 1915, resolve | nomear o cidadão Bernardino da Silva Bahia | para o cargo de Intendente do Municipio da Feira | de Sant'Anna durante o biennio de 1920 a $1921 . \mid$ Palacio do Governo do Estado da Bahia, 31 de De- | zembro de 1919. (Assignados) Antonio Ferrão | Muniz de Aragão. Doutor Gonçalo Muniz Sodré | de Aragão. Numero 60 Reis $5 \$ 000$ Pagou cinco mil | reis de taxas de registro. Directoria das Rendas do Es- | tado da Bahia, 3 de Janeiro de 1920. O Escriptura- | rio Gaudencio de Carvalho Camara. O Frel S. Gama. | Reconhecido e proclamado em sessão de 10 de Ja- | neiro de 1920. (Assignado) Leolindo Santos Ramos | Pharmaceutico José Alves Boaventura Primeiro Secretario Celso Valverde | Martins Segundo Secretario. Prestou o compromisso legal e | assumiu o exercicio do cargo em sessão solemne de posse do | Concelho Municipal, effectuada hoje, primeiro de Ja- | neiro de 1920. O Presidente Leolindo Santos Ramos | Registrado por mim, Joaquim Baptista Pedreira. | amanuense interino da Secretaria. [...] (LIVRO DE REGISTROS DE TÍTULOS..., 1919, f. 19r).

Apesar da nomeação atestar que ele ficaria no cargo por dois anos, Bernardino da Silva Bahia se manteve como Intendente Municipal até 1923, sendo sucedido pelo seu genro, Arnold Ferreira da Silva, que foi eleito com o apoio do sogro. Sob a administração de Bernardino da Silva Bahia, em 1922, foram iniciadas as obras de ampliação de rodagens, que possibilitariam o acesso tanto da capital quanto do interior a partir de Feira de Santana-BA, o que traria mais rapidez na locomoção e diminuição do tempo de viagem entre as cidades que circunvizinhavam a Princesa do Sertão.

Em 30 de abril de 1923, o Intendente emitiu ofício para a edificação do Paço Municipal, para a qual foi angariada uma substancial quantia dos cofres públicos e, por conta disso, a Intendência ficou impossibilitada de financiar quaisquer outras obras de semelhante 
magnitude. Contudo, apesar das dificuldades financeiras, o município conseguiu finalizar e inaugurar a nova sede da Intendência Municipal, que se tornou um símbolo de progresso e poder político.

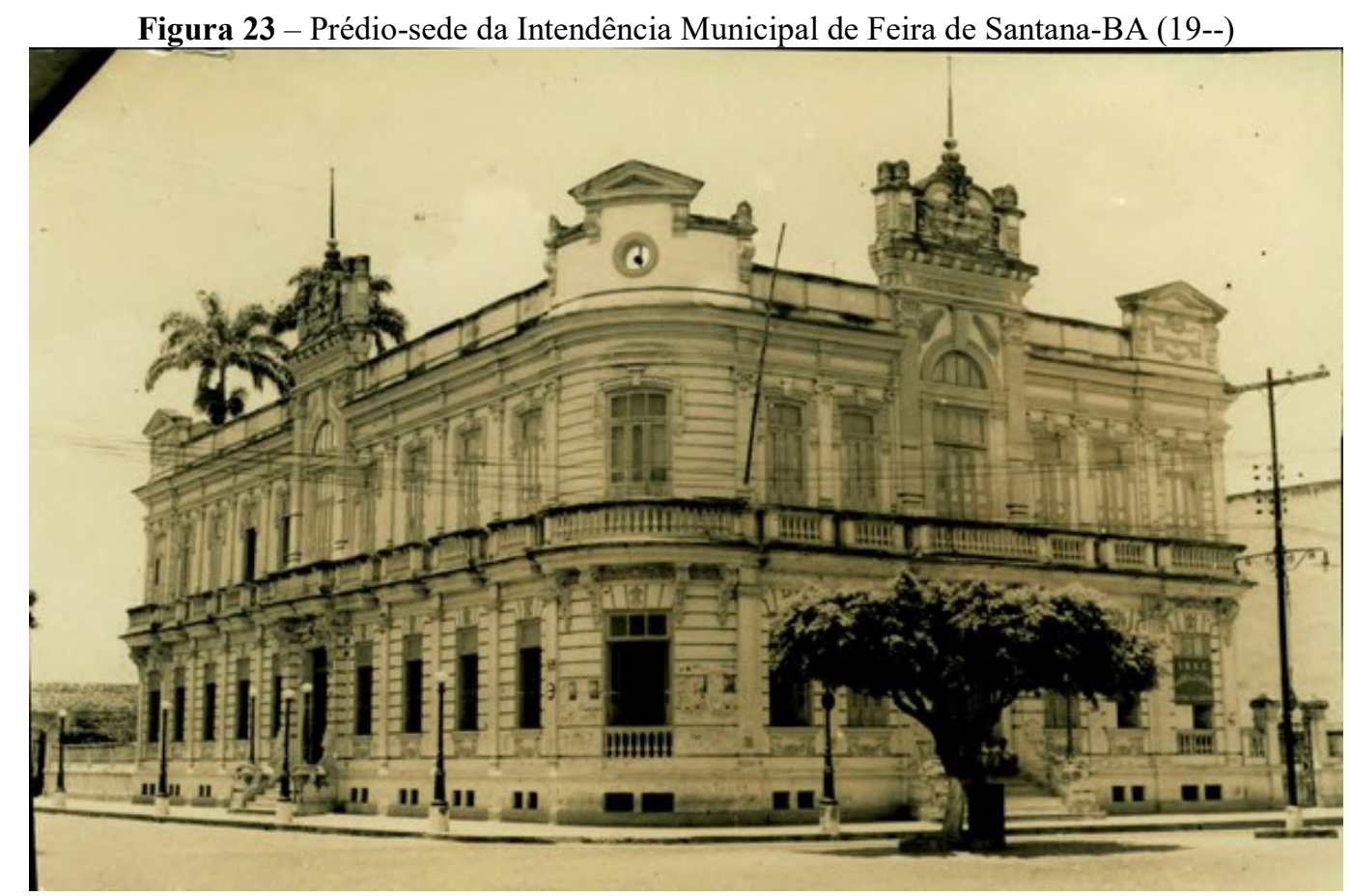

Fonte: Cidades IBGE (2019). Disponível em: https://cidades.ibge.gov.br/brasil/ba/feira-desantana/historico. Acesso em: 07 set. 2019.

Tratavam-se de melhorias em pontos específicos da cidade, principalmente naqueles em que a classe abastada de Feira de Santana-BA vivia e/ou frequentava, o que, inevitavelmente, contribuiu para a valorização das casas de residência, pontos comerciais e terrenos em que o "progresso" chegara. Do ponto de vista biográfico, econômico e social falamos mais desse Intendente na subseção Descrição do perfil socioprofissional dos indivíduos envolvidos no processo de produção do corpus, posto que o Coronel Bernardino da Silva Bahia foi uma das figuras que participou, enquanto testemunha, do testamento da matriarca dos Fróes da Motta, além de ter mantido uma relação de amizade com toda a família.

Sobre a família Falcão, esta possuía inúmeros membros (BOAVENTURA, 2006) e atividades econômicas voltadas para "[...] casas comerciais, sapataria, açougues, alfaiataria e casas de aluguel" (OLIVEIRA, 2016, p. 30), e foi liderada por Manoel Ribeiro Falcão, que era dono do Jornal A República, que circulou em Feira de Santana-BA, e d'O Trabalho, veiculado na cidade de São Gonçalo dos Campos-BA. O patriarca dessa família foi dono de 
um palacete na cidade e exportador de fumo, cujos descendentes ${ }^{17}$ se mantiveram na política feirense junto com outras personalidades como, por exemplo, Arnold Ferreira da Silva (jornalista, conselheiro municipal e Intendente), João Durval Carneiro (que foi vereador e depois prefeito da cidade na década 1950) e Almachio Alves Boaventura, que também foi Tabelião de $\operatorname{Notas}^{18}$, professor e depois se tornou prefeito da cidade em 1950 com o apoio de Eduardo Fróes da Motta, filho caçula do Coronel Agostinho Fróes da Motta.

Sobre a última, a Boaventura era uma família tradicional formada por fazendeiros, entre os quais estavam:

[...] José Alves Boaventura, importante fazendeiro e dono de farmácia, que exerceu por diversas vezes o cargo de Conselheiro Municipal e a direção de entidades filantrópicas como a Santa Casa de Misericórdia. O primo deste, Gonçalo Alves Boaventura, pai de Eurico Alves, era comerciante de couro, proprietário de terras e foi Conselheiro Municipal (1924-1926) e Francisco Alves Boaventura, importante fazendeiro que apareceu entre os quinze maiores contribuintes do imposto rural da cidade em 190538. Também dessa família se destacou o Padre Ovídio Boaventura, que no século XIX foi uma figura de destaque, sendo o fundador da Santa Casa de Misericórdia, do Asilo Nossa Senhora de Lourdes e do Monte Pio dos Artistas Feirenses (CUNHA, 2013, p. 27).

Sobre José Alves Boaventura, falamos mais de sua atuação municipal na subseção

\section{Descrição do perfil socioprofissional dos indivíduos envolvidos no processo de produção}

do corpus. Sobre os demais Boaventura, observamos que se tratavam de pessoas ricas e influentes na cidade, que trabalhavam com o "[...] comércio de gado, a torrefação de café, farmácia, olaria, casas de aluguel e outros investimentos" (OLIVEIRA, 2016, p. 30) e, por isso, a sua relação com os demais políticos era profícua.

Com a implantação da Primeira República e com a aliança entre aquelas quatro famílias, o progresso em Feira de Santana começou a chegar através da urbanização, da autonomia dos Estados e do federalismo, que, entre outras coisas, oportunizou a criação do cargo de Intendente Municipal, escolhido através de eleições municipais, nas quais a grande maioria da população não participava, haja vista que boa parte era semianalfabeta ou analfabeta, restando então um seleto grupo de eleitores, cujos perfis eram de pessoas não somente escolarizadas, mas também detentoras de riqueza e de algum prestígio social.

\footnotetext{
${ }^{17}$ Dentre esses descendentes, destacou-se o seu sobrinho João Marinho Falcão que era comerciante e pecuarista, provedor da Santa Casa de Misericórdia nos anos de 1932 e 1933, prefeito de Feira de Santana (1954 a 1959), empregado, quando jovem, do seu tio na firma Ribeiro \& Cia, que mais tarde se tornou sua junto com a Casa Ramos, que pertencia a Leolindo dos Santos Ramos.

${ }^{18}$ Por conta desse cargo, Almachio Alves Boaventura aparece em alguns processos da década de 1920, listados no quadro 3 desta tese e descritos nas respectivas fichas codicológicas.
} 
Assim, os profissionais que se candidatavam aos cargos administrativos eram os mesmos que votavam, prática que se perpetuou entre os descendentes dos eleitores, já que, a partir de 1920, os filhos, genros, sobrinhos e irmãos, que eram formados em Direito, Medicina, Jornalismo etc., também se candidataram a cargos políticos, indicados ou influenciados por seus patriarcas, como foram os casos, por exemplo, de Agostinho Fróes da Motta que inseriu o seu filho Eduardo Fróes da Motta, médico, em cargos políticos e administrativos de Feira de Santana (inclusive este já havia atuado como Primeiro Juiz de Paz e de Casamentos em Mogi Mirim - $\mathrm{SP}^{19}$ na época em que morou naquela cidade); prática que também foi realizada pelo seu amigo, o coronel Bernardino da Silva Bahia - fazendeiro, comerciante e político - que conduziu o seu genro Arnold Ferreira da Silva, jornalista e depois coronel, a ocupar cargos políticos na mesma cidade, assim como também fez com que o seu filho Carlos Arthur Rubinos Bahia ${ }^{20}$, pecuarista, se tornasse político, sendo, posteriormente, líder da União Democrática Nacional (UDN) e candidato à prefeitura de Feira de Santana por duas vezes: 1947 e 1950, nas quais foi derrotado.

Longe das relações familiares, a política feirense nem sempre se fez amistosa. Exemplo claro disso se iniciou em 1908, quando os coronéis Abdon Alves de Abreu e Bernardino da Silva Bahia tomaram posse, ao mesmo tempo, como Intendentes eleitos de Feira de Santana-BA. Ambas as posses contaram com a presença de figuras importantes como, por exemplo, coronéis, capitães, farmacêuticos e médicos. Entretanto, foram constatadas fraudes eleitorais, realizadas a partir de duplicatas e de formação de duas mesas eleitorais, portanto resultados diferentes e fraudulentos (C.f. CUNHA, 2013).

Em vista das fraudes constatadas, coube ao então governador do Estado da Bahia, José Marcelino de Souza, decidir o pleito, determinando o seguinte: Abdon Alves de Abreu governaria o munícipio de janeiro de 1908 a dezembro 1911, e Bernardino da Silva Bahia, de janeiro de 1912 a dezembro de 1915, decisão aceita por ambos. Entretanto, o coronel Bernardino da Silva Bahia se aliou ao seu compadre ${ }^{21}$ e amigo Agostinho Fróes da Motta e juntos criaram uma aliança para se manterem no poder político e se tornarem junto com Tertuliano José de Almeida, Quintiliano Martins da Silva, Heráclito Dias de Carvalho ${ }^{22}$ etc. oposição política ao Intendente Abdon Alves de Abreu, passando a não pagar mais impostos de gado e a não participar das reuniões do Conselho Municipal, o que as tornava sem quorum

\footnotetext{
${ }^{19}$ Informação extraída do primeiro volume da ação ordinária de sonegados (1929), listada no quadro 3.

20 Vulgarmente conhecido como Carlito Bahia, morador no casarão da Fazenda Paus Altos, que foi completamente modernizado (BOAVENTURA, 2006).

${ }^{21}$ O Coronel Bernardino da Silva Bahia foi padrinho de batismo de Eduardo Fróes da Motta, filho do Coronel Agostinho Fróes da Motta.

${ }^{22}$ Todos estes indivíduos aparecem como testemunhas no corpus desta tese, como veremos nas próximas seções.
} 
e, devido a isso, a ilegitimidade da administração de Abdon Alves de Abreu acabou sendo afirmada entre os seus correligionários (C.f. CUNHA, 2013).

Apesar disso, Abdon Alves de Abreu terminou o seu mandato e, como combinado, em 1912, Bernardino da Silva Bahia assumiu como Intendente de Feira de Santana-BA junto com os seus conselheiros e Juízes de Paz municipais também eleitos. Nesse ínterim, pode-se observar que não havia imparcialidade quando o assunto eram as relações políticas, comerciais, familiares e de compadrio entre as classes abastadas de Feira de Santana-BA, o que nos permite entender o contexto político e social em que aquelas personalidades estavam imersas, principalmente porque aqueles mesmos indivíduos estavam presentes em situações diversas, que confluíram para a participação de cada um deles, seja como os principais interessados seja como testemunhas, parceiros políticos ou amigos íntimos nos processos lidos e analisados durante a nossa pesquisa. Assim, a afirmativa de Cunha (2013, p. 115) se torna inconteste, quando ela nos assegura que:

[...] O segundo casamento do coronel Agostinho Froés da Motta com a filha do coronel Tertuliano de Almeida, a entrada de seu filho Eduardo Froés da Motta na vida política, bem como o ingresso de Arnold Ferreira da Silva nesse cenário político por meio de dois casamentos com as filhas do coronel Bernardino Bahia, assumindo a chefia do executivo, logo após o seu último mandato de intendente sugerindo uma herança de mandato, exemplificam como as relações familiares e de compadrio estavam entrelaçadas nos emaranhados da vida política feirense.

Logo, a relação entre eleitores e candidatos políticos se dava por meio de laços familiares e de compadrio, estabelecidos dentro do clã feirense que ditava as ordens e decidia o futuro não somente da cidade como também dos seus próprios familiares. Exemplo disso ocorreu em 1927, quando foi criado o primeiro Banco de Crédito Popular de Feira de Santana-BA, noticiado pelo Jornal Folha do Norte (BANCO..., 7 maio 1927, p. 1, grifos nossos) da seguinte maneira:

Fundou-se no ultimo domingo, | nesta cidade, o banco $\mid$ de crédito popular da | Feira de Sant'Anna, sociedade | cooperativa de credito, de | responsabilidade limitada, e forma | anonyma, systema Luzzati... | Foi subscrito o capital | mínimo de $1.0 \$ 000 \$ 000$. || Elegeram-se de acordo com $\mid$ o estatuto, três conselhos $\mid$ de administração, tendo sido | escolhidos diretores o srs. | Eduardo Motta (presidente), Arnold | Silva (gerente) e Carlos Bahia (secretário). || A comissão fiscal é composta | dos srs. Coronéis Bernardino Bahia, | Mario Saback de Oliveira e | Leolindo dos Santos Ramos. O | Banco de Credito Popular fará, | por estes dias, o depósito | legal no cartório do Registro | das Hypothecas, devendo iniciar | suas operações em primeiro | de julho próximo à Rua | Bernardino Bahia, numero 2 | onde vai ser instalado. || A sessão de fundação | efectou-se no edifício do | governo municipal, tendo sido | o facto oficialmente comunicado | aos senhores Doutores Governador do | Estado e presidente do Banco | do Distrito Federal. 
Na notícia, Eduardo Fróes da Motta ocupava o cargo de Presidente, Arnold Ferreira da Silva o de gerente e Carlos Arthur Rubinos Bahia o de secretário do Banco de Crédito Popular de Feira de Santana, seguidos da comissão fiscal composta pelos coronéis Bernardino da Silva Bahia, Mario Saback de Oliveira e Leolindo dos Santos Ramos, todos unidos por relações de parentesco, de amizade ou de compadrio, já que Bernardino da Silva Bahia era pai de Carlos Arthur Rubinos Bahia e sogro de Arnold Ferreira da Silva, enquanto que Eduardo Fróes da Motta era filho do Coronel Agostinho Fróes da Motta e os coronéis Mario Saback de Oliveira $^{23}$, irmão de Amadeu Saback de Oliveira - testemunha no testamento do Coronel Agostinho Fróes da Motta - e Leolindo dos Santos Ramos - testemunha no testamento de Dona Maximiana de Almeida Motta - eram figuras recorrentes quando os assuntos se relacionavam à administração pública, o que, de fato, reforça o nosso argumento de que se tratavam de pessoas unidas por relações que lhes permitiram entrar e permanecer no clã que detinha os poderes político e econômico da cidade, bem como uma posição social privilegiada, que favoreceu a perpetuação dos seus nomes e familiares dentre os abastados de Feira de Santana do início do século XX.

Exemplo da importância do Banco de Crédito Popular de Feira de Santana é a sua notoriedade em um dos processos que analisamos: o quinto volume de uma petição corrida junto ao Superior Tribunal de Apelação, iniciada em 07 de maio de 1927, na qual foram apelantes Adalberto Alves de Farias - genro do Coronel Agostinho Fróes da Motta - e Arthur Fróes da Motta contra Eduardo Fróes da Motta, ambos filhos do referido coronel. No fólio 608 recto, foi inserido um comprovante de depósito, datado de 4 de dezembro de 1928, escrito em papel timbrado com a inscrição: "BANCO DE CREDITO POPULAR DA FEIRA DE SANT'ANNA - Sociedade Cooperativa de Responsabilidade Limitada e Forma Anonyma”, no qual havia a certificação de que naquele banco existiam oito contos quinhentos e dez mil, novecentos e setenta e oito réis $(\$ 8: 510.978)$, depositados, via ordem judicial, pelo inventariante do Coronel Agostinho Fróes da Motta e Presidente do Banco de Crédito Popular de Feira de Santana-BA, Eduardo Fróes da Motta, para serem sacados por João Constantino Faskomy, referentes ao quinhão de sua esposa, irmã do inventariante e filha do inventariado, Amália da Motta Faskomy, recibo que foi assinado pelo gerente do Banco, Arnold Ferreira da

\footnotetext{
${ }^{23}$ De acordo com a Ação de Embargo, datada de 1933 a 1937, armazenada no CEDOC/UEFS sob a localização: Estante 10, Caixa 255 e Documento 5367, em 1929, este coronel pagou 120:085\$000 (cento e vinte contos e oitenta e cinco mil réis) pela Fazenda Genipapo, que pertencia ao falecido Coronel Agostinho Fróes da Motta.
} 
Silva, e pelo Secretário, Carlos Arthur Rubinos Bahia, o que evidencia a relevância do referido banco para a economia da cidade.

Figura 24 - Primeira Agência do Banco do Brasil de Feira de Santana (19--)

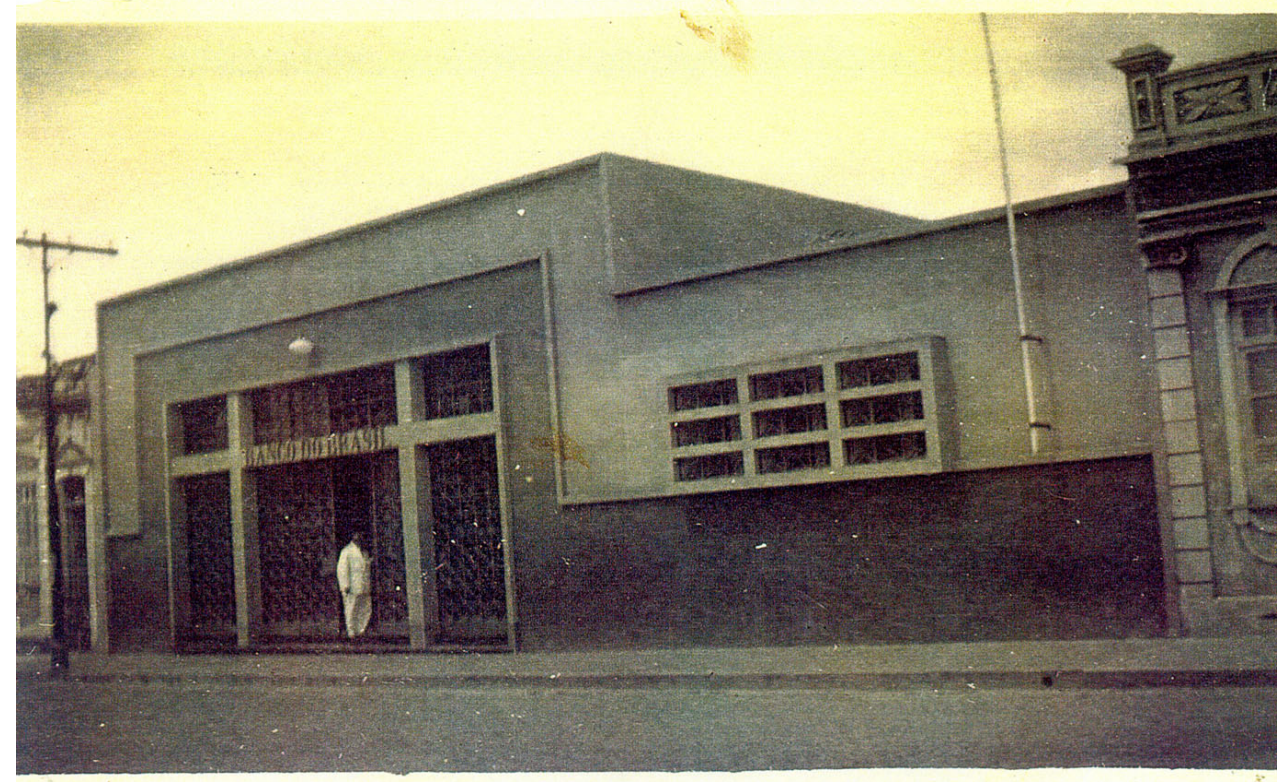

Fonte: http://www.memorialdafeira.ba.gov.br/conteudo.asp?catimg=1\#gallery1-50. Acesso em: 27 out. 2017.

Ainda sobre os dirigentes políticos que compuseram o cenário econômico, político e social de Feira de Santana nos fins do século XIX e início do XX, expomos as suas fotopinturas ou fotografias, a fim de relacionarmos o que foi exposto até aqui com as relações que tecemos entre os sujeitos que participaram da produção do corpus desta tese.

Quadro 1 - Políticos de Feira de Santana nos fins do século XIX e início do XX

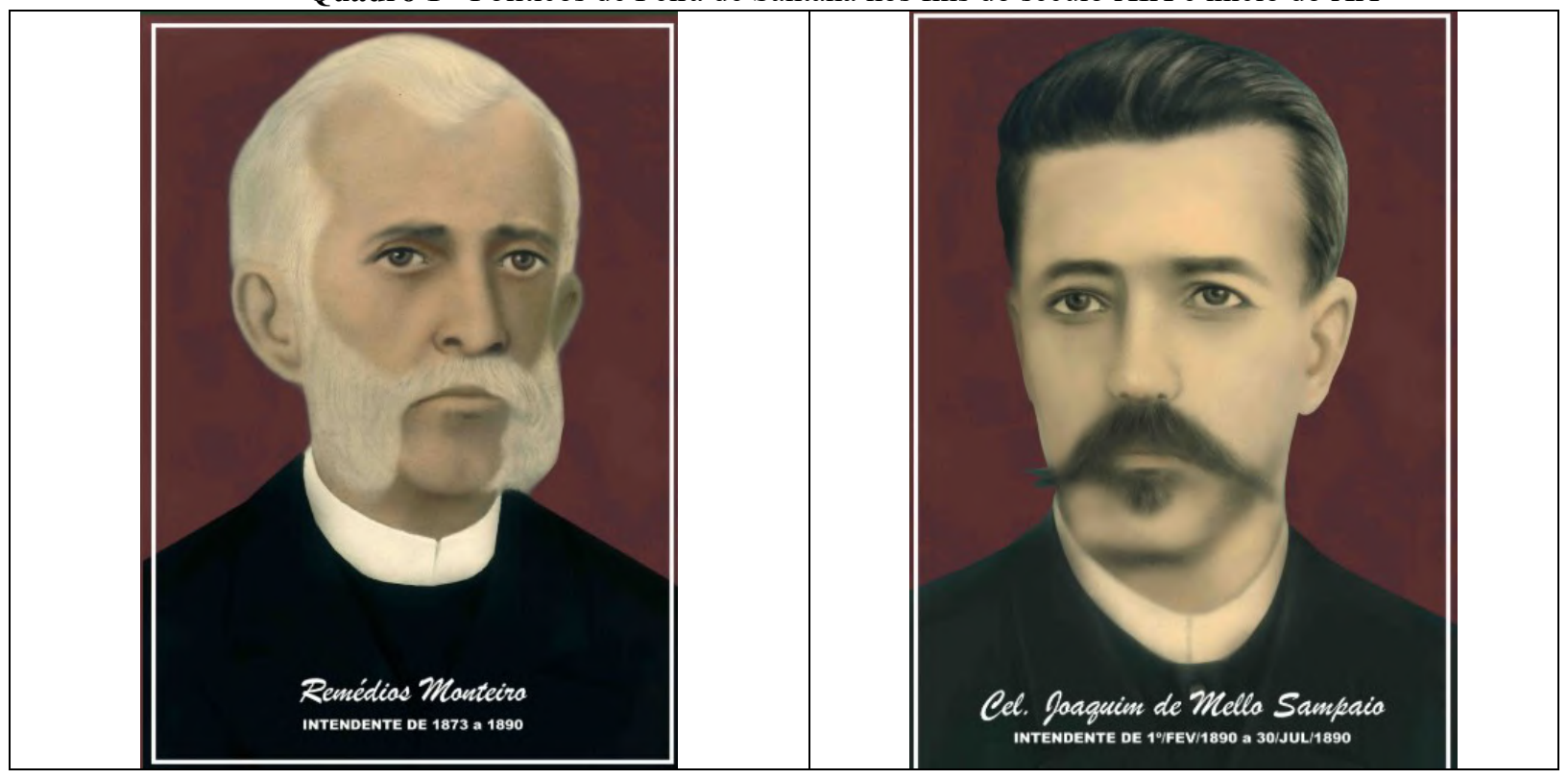




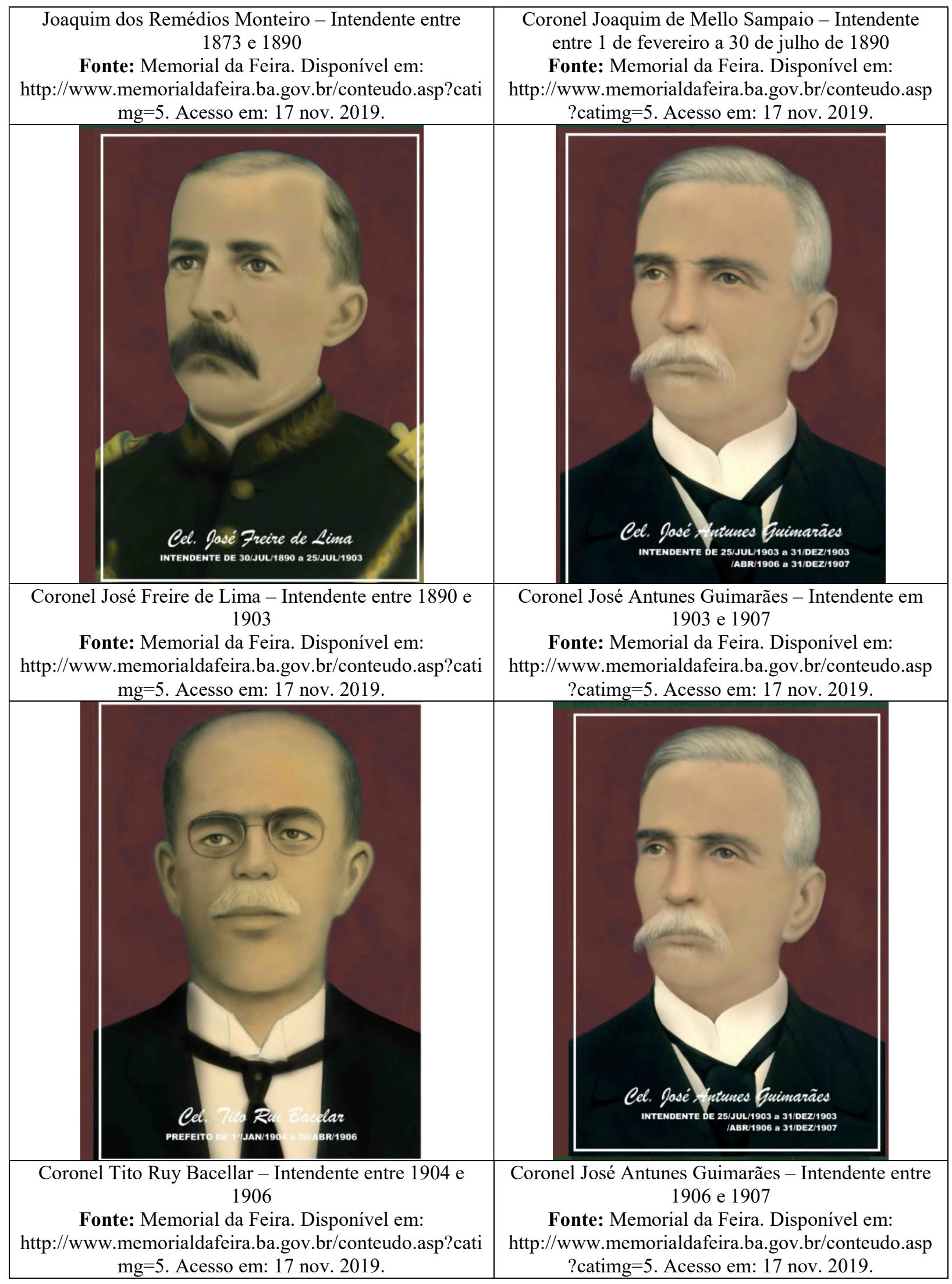




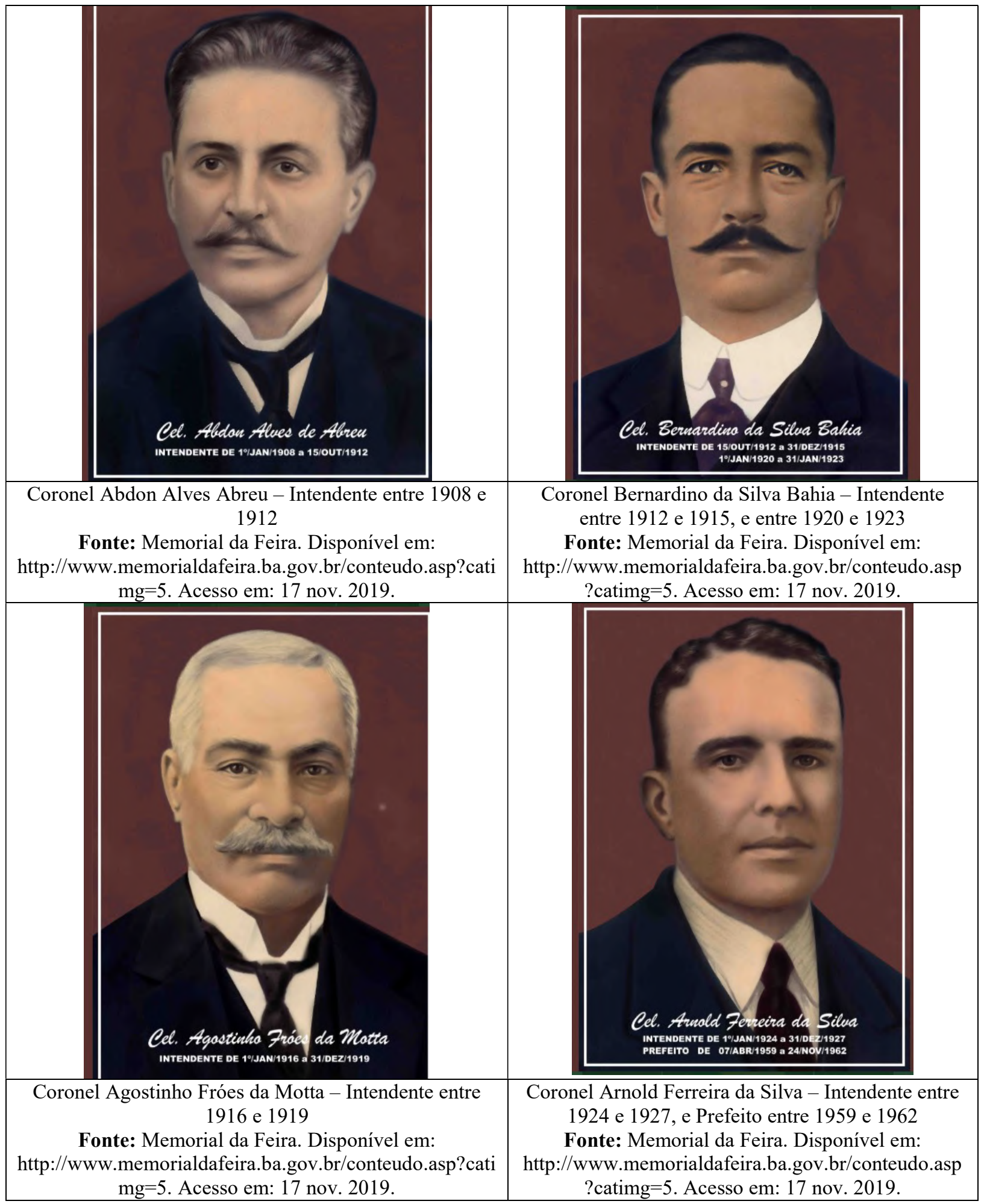




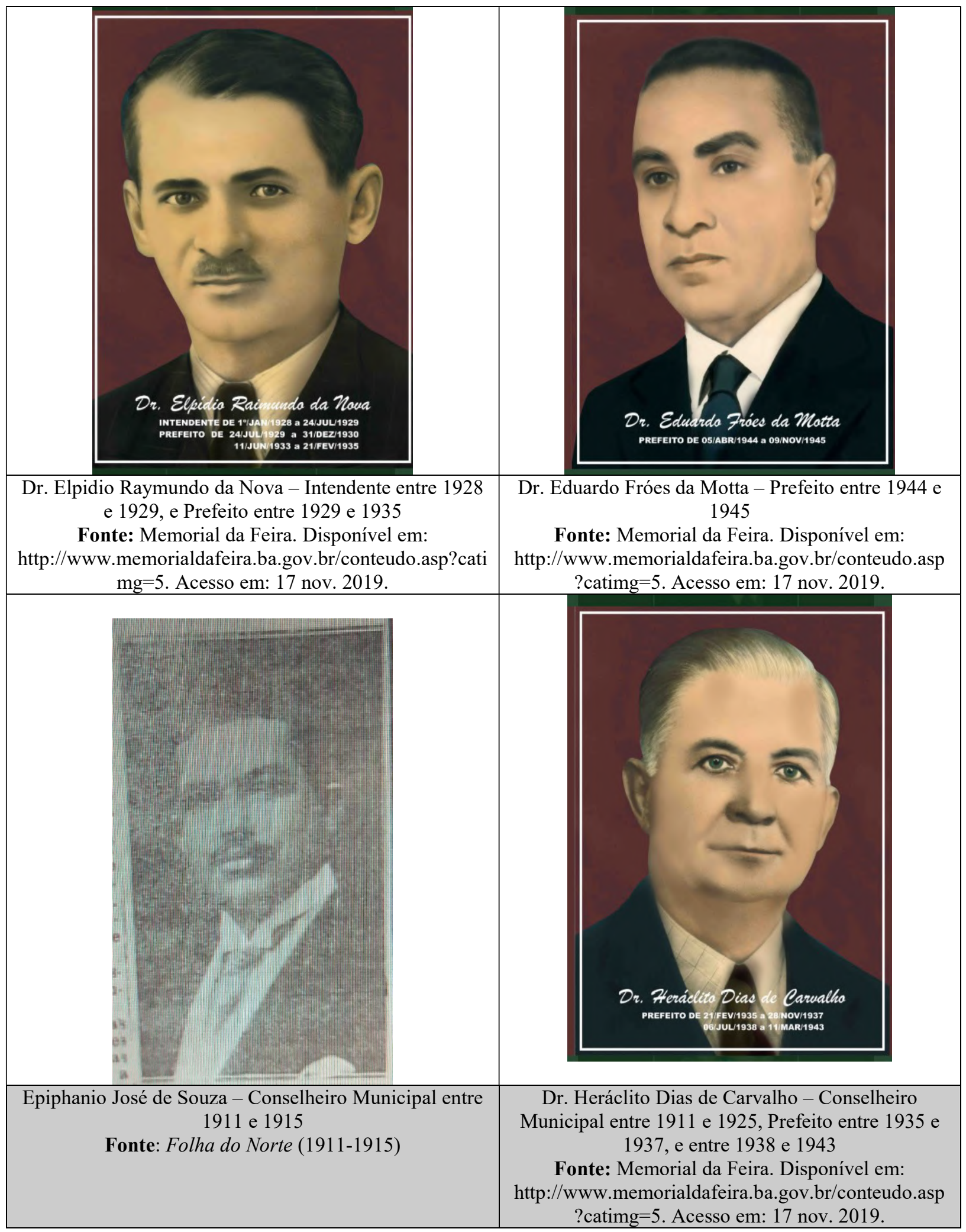




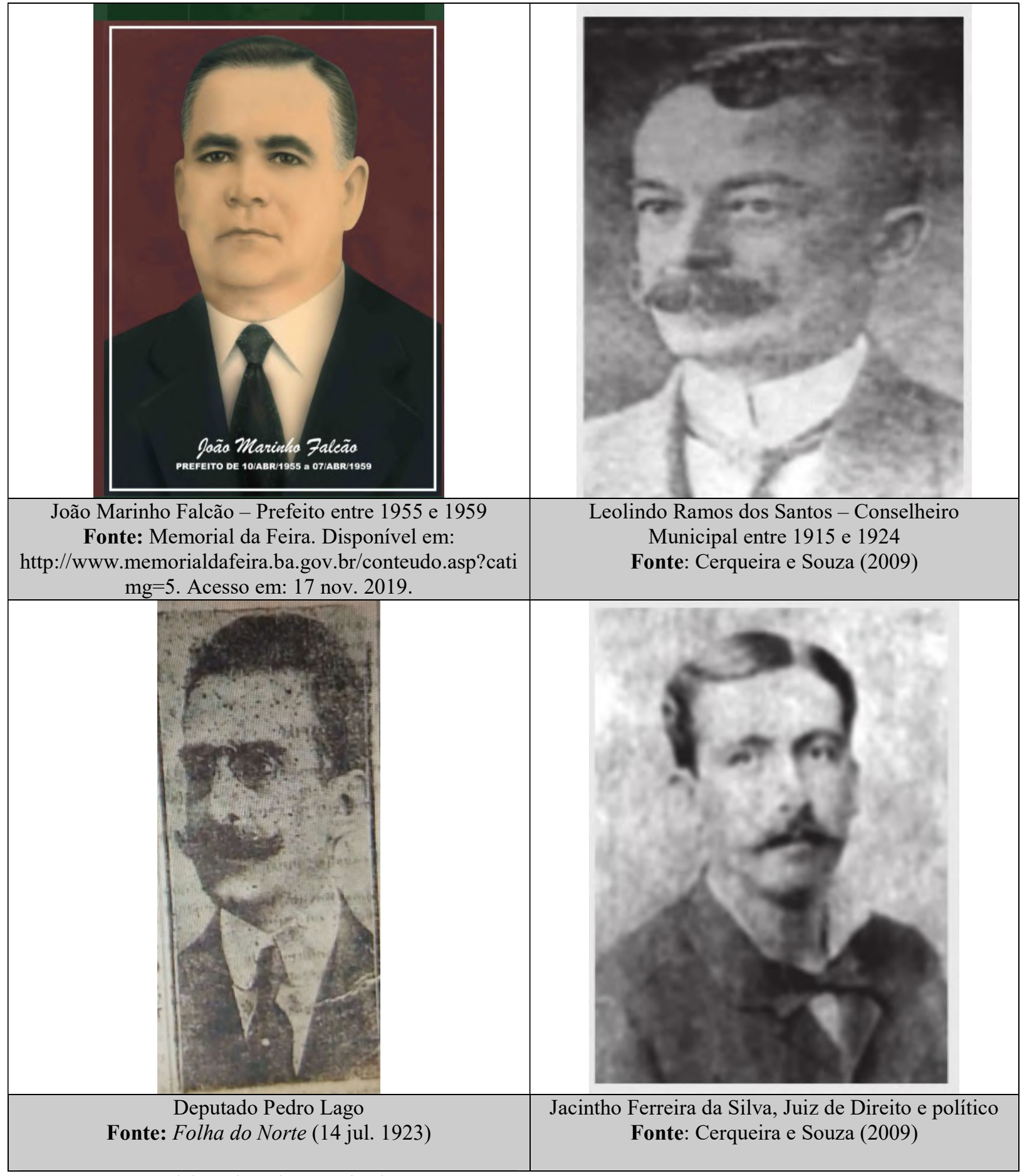

Fonte: Elaborado pela pesquisadora

Além das figuras políticas apresentadas anteriormente, havia Elpidio Raymundo da Nova e Jacintho Ferreira da Silva que também se destacaram, junto com os demais, enquanto políticos de Feira de Santana-BA. Além da política, os dois se dedicaram às leis, sendo o primeiro advogado, promotor e Prefeito da cidade de Feira de Santana entre 1928 e $1931^{24}$, e

${ }^{24}$ Informação confirmada na Ação de Embargo, datada de 1933 a 1937, armazenada no CEDOC/UEFS sob a localização: Estante 10, Caixa 255 e Documento 5367. 
o segundo, Juiz de Direito da Comarca de Feira de Santana e figura participante das atividades sociais e políticas da cidade, ambos profissionais recorrentes nos processos jurídicos encontrados no CEDOC/UEFS, o que evidencia a ocupação de mais de uma função/ofício por cada uma daquelas personalidades, que desempenharam papéis importantes tanto dentro quanto fora do cenário político feirense.

Essa constatação tem nos permitido compreender a influência e as relações de todos aqueles "sujeitos" quando ocuparam os seus respectivos cargos, os quais nos possibilitam reafirmar que os laços existentes entre aqueles iam muito além da política, constituindo-se esta apenas como meio para estreitar as relações de amizade e de compadrio entre a maioria dos indivíduos que constam nos processos listados na próxima seção.

Das informações elencadas, podemos concluir que Feira de Santana no início do século XX era formada por pessoas de classes abastadas ou que fizeram fortunas, através do comércio, da pecuária, da agricultura e da política, e que se mantiveram na administração pública, através de laços familiares (quando casavam os filhos para unir as famílias ou quando lançavam os seus descendentes na política), de amizade (quando se tornavam frequentadores assíduos de suas residências ou de instituições sociais ou quando se tornavam padrinhos de batismo ou de casamento dos filhos dos seus companheiros políticos) e de compadrio (quando apadrinhavam/apoiavam publicamente a inserção dos seus familiares na vida pública), o que nos permite afirmar que tanto a vida pública quanto a particular daqueles indivíduos se misturavam e até se confundiam.

Evidência disso é a existência de várias reportagens do Folha do Norte (1909-1930), em que informações da vida privada dos Intendentes, especialmente da do Coronel Agostinho Fróes da Motta e da de Bernardino da Silva Bahia, eram amplamente veiculadas pelo referido periódico que, como apresentamos anteriormente, circulava em muitas cidades brasileiras e algumas de Portugal, o que tornava aquelas informações de amplo conhecimento público. A título de exemplo, uma das reportagens tratava da chegada do filho caçula do Coronel Agostinho Fróes da Motta e da festa que o recepcionou, inclusive com a participação de figuras ilustres da cidade e da Filarmônica 25 de Março.

Doutor Eduardo Motta || SUA CHEGADA || Conforme noticiamos e era | esperado, chegou no regular | de sabbado ultimo, o nosso il- | lustre conterraneo doutor Eduar| do Motta, recem-diplomado | pela Faculdade de Medicina | deste Estado. || Cavalheiros, familias e ami- | gos em farta concurrencia | aguardavam na gare da Central | a chegada do comboio, que nes- | se dia, ao acaso, chegou no ho- | rario. || A banda da sociedade "25 | de Março", para maior realce | da solemnidade, compareceu | com a sua direcção. || Desembarcado o doutor Eduardo, | com pessoas de sua familia, que | foram assistir a solemnidade da | sua formatura, compoz-se um | 
numeroso prestito que o acom- | panhou ao palacete da residen- | cia dos seus dignos genitores. || Ahi chegados, o doutor Auto Reis, orador da 25 de "Março", | num brilhante improviso, inter- $\mid$ pretando o sentir daquella so- $\mid$ ciedade e das pessoas presentes $\mid$ felicitou o seu jovem collega $\mid$ enaltecendo os esforços dis- $\mid$ pendidos para a conquista dos | louros daquella victoria. Em | bello e substancioso discurso o | doutor Eduardo agradeceu, e prose- $\mid$ guindo com phrases buriladas $\mid$ e alevantados conceitos, em-| polgou os ouvintes com uma | bellissima oração, que, pero- | rando, deixou o auditorio en- | cantado e commovido pela | belleza da phrase com que | manifestou sua gratidão e re- $\mid$ conhecimento aos seus geni- $\mid$ tores em um abraço cheio de $\mid$ ternura filial, retribuindo com $\mid$ a effusão que transborda dos $\mid$ corações de paes e que mal | se avalia. (DOUTOR..., FOLHA DO NORTE, 11 jan. 1913, p. 2).

Além de registrar a alegria com que a cidade recebia Eduardo Fróes da Motta, essa reportagem também registra a data do seu retorno à Princesa do Sertão, informação utilizada em alguns dos processos que listados na próxima seção, e cuja reportagem serviu como prova legal anexada aos autos dos processos para atestar o seu envolvimento, à distância, na edificação de uma casa que seria sua, mas que foi construída e inspecionada pelo seu pai Agostinho Fróes da Motta, ainda em vida, e, nos respectivos processos, fruto de brigas judiciais entre os irmãos Fróes da Motta.

Ainda do ponto de vista jurídico, outras reportagens do Folha do Norte serviram não somente como provas nos tribunais, mas também como um meio para responder às críticas recebidas pelos advogados e juízes envolvidos nos processos, cujas partes eram membros da família do referido coronel. Sobre isso, em 23 de maio de 1922, dois meses após o falecimento do Coronel Agostinho Fróes da Motta, foi publicada a seguinte reportagem, redigida por Agnello Ribeiro de Macêdo em resposta à confusão ocorrida em uma das audiências públicas, nas quais era advogado de uma das partes.

JUSTIÇA Á MATROCA E EM POLVOROSA \|| Não é o juiz quem manda no "forum" || Mas o escrivão topou advogado pela prôa || De dia para dia as leis da Republica e as leis deste Es- | tado se vão tornando menos valiosas nesta comarca! As ga- | rantias promettidas pelas constituições federal e estadual | vão sendo desrespeitadas pelo proprio poder judiciario,aqui, | incumbido de effectival-as. Não commentamos o facto que | vamos tornar conhecido do publico. Eil-o: || Na quartafeira ultima, 24 do corrente, seriam dez e $\mid$ meia horas, quando na sala das audiencias do juizo de di- $\mid$ reito, no edificio da Intendencia Municipal, se reuniram o $\mid$ sr. dr. Jacintho Ferreira da Silva, juiz de direito effectivo | desta comarca; o senhor coronel escrivão do civel, Francisco Ra- | malho; o senhor doutor José Maria Neves, como advogado do senhor | engenheiro Alberto de Almeida, n'uma justificação, | por testemunhas, para prova de sua paternidade, e o senhor doutor | Agnello Ribeiro de Macêdo, advogado do senhor doutor Eduardo | Fróes da Motta, que fôra citado para assistir á dita justifica- | ção, como inventariante e herdeiro que é do fallecido coro- | nel Agostinho Fróes da Motta. O dito juiz-presidente do | acto judicial, sentado no topo da mesa, e os demais occu- | pando os seus logares, deu começo aos trabalhos da $\mid$ diligencia. A assistencia dos curiosos era regular. Compa- $\mid$ receu a primeira testemunha, senhor major Estanislau Alves Bar- | retto e foi qualificada, compromissada e inquerida pelo ad- | vogado do justificante, tudo muito direitinho, 
sem o mais | leve incidente. Concluida a inquirição por parte do justifi- | cante foram os respectivos autos passados ao advogado do $\mid$ justificado para reperguntar a mesma testemunha, na forma | permittida por lei. Começou o barulho. Logo que o advo- | gado do justificado, com venia do juiz, principiou a redigir | a sua primeira pergunta á testemunha, o senhor escrivão explo- | diu em attitude aggressiva ao advogado do justificado: le- | vantou-se bruscamente, empallideceu e gritou á vontade pro- | vocando a justa e opportuna reacção do advogado do jus- | tificado, que, inteiramente conscio dos seus direitos e deve- | res, por sua vez, com voz vibrante, clara e firme, declarou | que aquelle procedimento do senhor escrivão era illegal e cri- | minoso: illegal porque os escrivães são machinas que se de- | vem conservar silenciosas nos actos juridicos, só para faze- | rem o que lhes for mandado por juizes; criminoso | porque importava num desrespeito á autoridade do | juiz que presidia aquelle acto; mas, que o mesmo escrivão | assim procedia porque o juiz que presidia áquelle acto não | sabia, não queria ou não podia cumprir com os seus deve- | res de officio: mantendo a ordem e a moralidade no forum, | como a lei lhe recommenda, mandando autuar a quem quer | que o desobedecesse ou desrespeitasse. Continuando, disse | ainda o advogado do justificado que como juiz que | fora e como advogado que é, conhece, por escala, todos | os seus direitos e deveres; que se não arreceia de ameaças; | e que ninguem lhe demoverá do proposito de continuar, | desassombradamente, no exercicio da sua nobre profissão | de advogado, neste forum, para defender o direito das par- | tes que para isso the procurarem. || O juizpresidente do dito acto manteve-se, a tudo, cégo | e surdo! Ficou impassivel! Os animos dos contendores se | acalmaram e o advogado do justificado continuou a reper- | guntar a testemunha, escrevendo o senhor escrivão tudo quanto | lhe fôra ditado até o fim. || Depois foram inqueridas e reperguntadas mais duas tes- | temunhas sem mais nenhum incidente. \| Pela exposição, fiel, deste acto, bem se vê como anda $\mid$ a justiça daqui. Á matroca (JUSTIÇA..., FOLHA DO NORTE, 23 maio 1922, p. 1-2).

Nessa reportagem, identifica-se que durante uma das audiências públicas - na qual a testemunha Estanislau Alves Barretto ${ }^{25}$ depôs sobre a paternidade de Alberto de Almeida Motta, filho do Coronel Agostinho Fróes da Motta, já falecido na data em que a reportagem foi publicada - houve exaltações por parte do escrivão Manuel Francisco de Almeida Ramalho, o que se tornou motivo suficiente para que o advogado Agnello Ribeiro de Macêdo fosse a público esclarecer o ocorrido. Nota-se, portanto, que as questões de foro privado passaram a ser públicas, principalmente pelo fato de o coronel falecido ter sido figura pública e influente dentro e fora da cidade, bem como pelas proporções que as questões jurídicas e familiares tomaram.

Sobre os documentos de foro íntimo que se tornam de interesse público, Oliveira, Macêdo e Sobral (2017, p. 2) nos garantem que esse tipo de documentação “[...] são produtos socioculturais que constituem referenciais para a memória coletiva e para a pesquisa histórica". Mais do que isso, essas documentações revelam não somente traços da personalidade, mas dos eventos, das funções sociais e das "diferentes personas" que fizeram parte da vida do indivíduo em sociedade (OLIVEIRA; MACÊDO; SOBRAL, 2017).

\footnotetext{
${ }^{25}$ Apresentamos mais informações sobre essa testemunha na seção Descrição do perfil socioprofissional dos indivíduos envolvidos no processo de produção do corpus.
} 
Logo, quando os documentos de foro íntimo se tornam de conhecimento público como é o caso, por exemplo, de processos jurídicos produzidos para circularem nos tribunais e, em um segundo momento, como objetos de reportagens veiculadas em periódicos de grande circulação ou como objetos de pesquisa, após a sua doação para arquivos de instituições públicas, os eventos da vida particular se misturam com os da vida pública e isso nos permite conhecer os sujeitos processuais como um todo, ou seja, o conhecimento de todos os papéis desempenhados por figuras públicas possibilita que "vejamos" o indivíduo de forma completa, atuando em vários contextos e sob várias perspectivas.

Assim, essa forma de olhar as pessoas públicas nos leva, enquanto pesquisadores, a entender, por exemplo, por quais motivos os políticos feirenses direcionaram tanta atenção à democratização do acesso à educação pública às classes mais pobres de Feira de Santana-BA, criando inclusive escolas e mais escolas para sanar tal problemática, quando o contexto vigente favorecia a manutenção da administração pública nas mãos de um seleto grupo economicamente favorecido, que enviava os seus descendentes em idade escolar para estudar fora da Princesa do Sertão, os quais mais tarde ocupariam os seus lugares na política, na economia e na sociedade feirenses. Para compreender as motivações dos dirigentes políticos em relação à educação popular de Feira de Santana-BA, tecemos algumas considerações a seguir.

\subsection{SOBRE A PREOCUPAÇÃO DOS GOVERNANTES DE FEIRA DE SANTANA COM A DEMOCRATIZAÇÃO DO ACESSO À EDUCAÇÃO PÚBLICA NO INÍCIO DO SÉCULO XX}

Uma das grandes obras realizadas pelos dirigentes políticos de Feira de Santana-BA foi a construção de prédios escolares que, teoricamente, democratizariam o acesso à educação pública nas primeiras décadas do século XX. A justificativa para a existência dessa preocupação pessoal e política dos intendentes e conselheiros municipais com a educação pública e, mais especificamente, com uma educação popular voltada para as classes mais pobres da cidade era o contexto socioeducacional que Feira de Santana-BA vivia antes das administrações de Bernardino da Silva Bahia, Agostinho Fróes da Motta e Arnold Ferreira da Silva, o que prejudicava a implementação do "progresso" vislumbrado por aqueles políticos.

Assim, para compreendermos o porquê de a educação popular ter se tornado uma questão de ordem pública tão latente em Feira de Santana-BA no início do século XX, 
partimos do conhecimento do processo de escolarização no Brasil naquele período, mais especificamente na região Nordeste, na Bahia e em Feira de Santana, a fim de entendermos como ocorria a formação escolar e quem eram as pessoas que tinham acesso à escolarização naquele período e as motivações dos intendentes que se dedicaram à referida questão.

No Período Imperial, momento em que a efetiva instrução popular não saiu do texto de lei que a instituía, pois os interesses públicos ainda eram o de manter a educação escolar básica restrita às classes mais abastadas, o Ensino Superior, especialmente dos cursos jurídicos, representava o interesse do governo brasileiro que buscava independência da Metrópole, de onde vinham aqueles que ocupariam relevantes cargos no governo. Logo, formar profissionais com capacidade técnica para ocupar cargos políticos, técnicos e administrativos seria uma maneira de "libertar" os Estados da Metrópole, iniciativa que foi tomada por D. Pedro I, que implementou os cursos jurídicos no Brasil, em 1825 (XAVIER; RIBEIRO; NORONHA, 1994).

A partir da criação do Curso Jurídico da Corte, as instituições de ensino superior cresceram em todo o Período Imperial e, após a Independência, já se tinha um perfil do ensino público brasileiro: um ensino voltado àqueles que buscavam ascensão social, o que aumentou a demanda de ensino superior e junto à esta a existência de variados fatores, dentre os quais estava uma grande carência de pessoal qualificado para ocupar cargos administrativos, o que se estendeu até à República, bem como os movimentos pela emancipação, sobre os quais se encontrava a pressão da elite intelectual que buscava a difusão da instrução e da ciência, e os fatores econômicos e sociais que prejudicavam aqueles que almejavam uma boa posição social (XAVIER; RIBEIRO; NORONHA, 1994).

Naquele contexto, a sociedade brasileira tinha os seus pilares em uma economia agroexportadora e latifundiária que, após a abolição da escravidão, passou a se valer, majoritariamente, do trabalho semi-servil. Assim, as camadas médias da população se constituíam de pessoas desligadas das atividades agropecuárias, da exportação e dos latifúndios, o que as levavam a buscar na escolaridade, principalmente na de nível superior, uma possibilidade de melhorar a sua posição social. Logo, a classe média brasileira daquele período era composta de pessoas ligadas "[...] ao funcionalismo estatal, militar e civil, profissionais liberais, os chamados literatos (professores, artistas, jornalistas, publicistas e padres) e os comerciantes." (XAVIER; RIBEIRO; NORONHA, 1994, p. 67).

A partir da implementação da República Federativa do Brasil (1889), os cargos públicos se multiplicaram e junto a estes aumentou, significativamente, a demanda de letrados, dentre os quais se destacavam, em primeiro lugar, os cursos de Direito - que 
formavam juristas e pessoas que acabavam ocupando cargos da administração, os quais eram os ansiados pela política e economia locais; em segundo lugar, os de Engenharia - que se destacavam por conta do desenvolvimento de empreendimentos estatais ou privados, voltados para os transportes, mineração e urbanização, esta última principalmente no sudeste do Brasil e, em terceiro lugar, os de Medicina - que ocupavam maior prestígio social quando o assunto era escolaridade, e dentro dos quais estavam, além daqueles que queriam apenas exercer a medicina, os profissionais que se tornavam funcionários públicos, civis ou militares (XAVIER; RIBEIRO; NORONHA, 1994).

O prestígio social e os altos salários advindos da formação profissional daqueles cursos confluíram para a ampliação de um cenário social de exclusão daqueles que não obtinham tais formações. Contudo, a Constituição Imperial restringia o direito de voto aos analfabetos, combinado com o critério de renda, que excluía grande parte da população da vida política, que acabava ficando reservada às elites como um privilégio de classe. Logo,

Numa época em que o Brasil contava com, aproximadamente, $85 \%$ de analfabetos, excluí-los do processo eleitoral, como também as mulheres, conforme interpretação da época, era diminuir intencionalmente o número de eleitores (e sua qualidade também) e, assim, perpetuar a sociedade de direitos e privilégios de muito poucos (FREIRE, 1993, p. 175).

Com a "Lei Saraiva", implementada em 1881, o alistamento eleitoral ficou mais restrito, haja vista a necessidade de não apenas ser minimamente alfabetizado, mas de ter domínio de leitura e de escrita para que a população conseguisse votar, o que, segundo a Constituição Imperial, dava um caráter democrático às eleições diretas, argumento ratificado por alguns homens públicos e intelectuais que admitiam a alfabetização como uma condição, sine qua non, para o alistamento eleitoral (XAVIER; RIBEIRO; NORONHA, 1994).

Esse argumento se perpetuou na Constituição Republicana, que retirou o critério eleitoral de renda, mas manteve a restrição de voto ao analfabeto. Assim, a República Velha (1889-1930) se sustentou a partir de manobras políticas que "[...] iam desde a composição de um colégio eleitoral restrito e comprometido até a mais aberta fraude eleitoral." (XAVIER; RIBEIRO; NORONHA, 1994, p. 104). Sobre a instrução pública naquele período, na região Sudeste houve forte pressão popular que criou "[...] condições materiais favoráveis para a ampliação do sistema de instrução pública” (XAVIER; RIBEIRO; NORONHA, 1994, p. 105), o que foi influenciado pelo "progresso econômico" da região.

Em contrapartida, nas regiões Norte e Nordeste, a instrução popular não era vista nem como necessidade nem como prioridade, já que não havia pressão para isso, ao contrário, o 
fato de a sua população ser constituída por camponeses (submissos aos coronéis), senhores de terra e do poder local era fator decisivo para a manutenção dos altos índices de analfabetismo nas referidas regiões (XAVIER; RIBEIRO; NORONHA, 1994). No caso do Nordeste brasileiro, a desigualdade educacional amplificou consideravelmente as desigualdades sociais, conforme afirmam Komatsu et al. (2017), explicadas pelos altos índices de analfabetismo na região.

Sobre esses índices de analfabetismo, o Censo de 1900 nos esclarece que, de uma população estimada em, por exemplo, 490.784 habitantes, 408.463 se encontravam em situação de analfabetismo no Estado da Paraíba, enquanto que, de um total de 499.308 habitantes, 372.284 não sabiam ler no Estado do Maranhão, o que revela, infelizmente, o grande descaso do Governo daquele período com a instrução popular, principalmente, nos Estados localizados no Nordeste do país, sobre os quais dispomos um quadro com o número populacional de cada Estado brasileiro daquela região e a respectiva taxa de indivíduos não alfabetizados.

Quadro 2 - Índices populacional e de analfabetismo nos Estados do Nordeste brasileiro em 1900

\begin{tabular}{|l|c|c|c|}
\hline \multicolumn{1}{|c|}{ ESTADO } & $\begin{array}{c}\text { POPULAÇÃO } \\
\text { TOTAL }\end{array}$ & $\begin{array}{c}\text { POPULAÇÃO } \\
\text { ANALFABETA }\end{array}$ & $\begin{array}{c}\text { PERCENTUAL } \\
\text { POPULACIONAL } \\
\text { ANALFABETO }\end{array}$ \\
\hline BAHIA & 2.117 .956 & 1.634 .832 & $77.18 \%$ \\
\hline PERNAMBUCO & 1.178 .150 & 950.556 & $80.68 \%$ \\
\hline ALAGOAS & 649.273 & 519.710 & $80.04 \%$ \\
\hline CEARÁ & 849.127 & 664.224 & $78.22 \%$ \\
\hline MARANHÃO & 499.308 & 372.284 & $74.55 \%$ \\
\hline PARAÍBA & 490.784 & 408.463 & $83.22 \%$ \\
\hline SERGIPE & 356.264 & 268.235 & $75.29 \%$ \\
\hline PIAUÍ & 334.328 & 276.617 & $82.73 \%$ \\
\hline RIO GRANDE DO NORTE & 274.317 & 218.393 & $79.61 \%$ \\
\hline
\end{tabular}

Fonte: Adaptado de Brazil - Directoria Geral de Estatística (1916).

Identifica-se a existência de uma alarmante taxa de analfabetismo em todos os Estados do Nordeste brasileiro, o que coaduna a assertiva de que na "República Velha" (1889-1930) momento histórico brasileiro em que a educação se mantinha, apesar de alguns avanços ocorridos na transição do Império para a República, atrelada a um modelo escolar no qual uma pequeníssima parcela da população tinha acesso ao ensino primário, que priorizava o bom comportamento do aluno e a memorização, testada em provas escritas e orais (BRAGA, 2014) - perpetuavam-se os privilégios da elite, principalmente quando se tratava do acesso à educação formal, para a qual uma média de $75 \%$ da população nordestina se encontrava 
completamente analfabeta, portanto, excluída da participação política e da possibilidade de ascensão social, advinda da escolarização.

Nesse contexto, insere-se Feira de Santana-BA, na qual havia, entre 1890 e 1925, altos índices de analfabetismo, combatidos pelo poder público, que tinha como intuito construir "[...] uma nova sociedade para dar conta das demandas sociais surgidas, dentre aquelas as que combatessem o considerado perigoso ócio das camadas populares que ocupavam e movimentavam as ruas das cidades: os novos trabalhadores livres." (OLIVEIRA, 2016, p. $48)$.

Para combater o analfabetismo e o "ócio das camadas populares", o governo municipal adotou algumas estratégias, dentre as quais estava a criação de escolas e a nomeação de um grupo de professores, que teria como "missão" instruir a população da cidade e dos distritos. Assim, em 1896, foram abertas 5 escolas na cidade de Feira de SantanaBA, a saber: a Primeira Escola do Sexo Masculino, dirigida pelo professor Lucindo dos Santos Silva e Mello; a Segunda Escola do Sexo Masculino, dirigida pelo professor Saturnino Alves da Silva Pereira; a Primeira Escola do Sexo Feminino, dirigida pela professora Leolinda Bacellar de Mello Silva; a Segunda Escola do Sexo Feminino, dirigida pela professora Maria Carolina de Castro Fiuza; e a Terceira Escola do Sexo Feminino, dirigida pela professora Jovina Adelaide Leite ${ }^{26}$, os quais foram nomeados em 30 de dezembro de 1895 (LIVRO DE ASSENTAMENTO..., 1896-1925). Além dessas escolas, a Intendência Municipal também criou, no mesmo período, outras nos distritos da cidade, como podemos identificar na tabela seguinte:

Tabela 1 - Escolas criadas nos distritos da cidade de Feira de Santana-BA, em 1896

\begin{tabular}{l|l|l}
\multicolumn{1}{c}{ DISTRITO } & \multicolumn{1}{c}{ ESCOLA(S) } & \multicolumn{1}{c}{ DIRIGENTE } \\
\hline Humildes & Escola do Sexo Masculino & $\begin{array}{l}\text { Professor Manoel Alves de São } \\
\text { Boaventura }\end{array}$ \\
\hline Almas & Escola do Sexo Feminino & $\begin{array}{l}\text { Professora Candida Emilia de Souza e } \\
\text { Oliveira }\end{array}$ \\
& Escola Mista & $\begin{array}{l}\text { Professora Rosa Ignacia Lopes da } \\
\text { Cunha }\end{array}$ \\
\hline Remédios da Gameleira & Escola Mista & \begin{tabular}{l} 
Professora Eufrosina Adelaide da Silva \\
\hline Bomfim da Feira
\end{tabular} \\
& $\begin{array}{l}\text { Escola do Sexo Masculino } \\
\text { Professor Paulino Joaquim de Oliveira } \\
\text { Dantas }\end{array}$ \\
& Escola do Sexo Feminino & $\begin{array}{l}\text { Professora Odilia Vieira Mendes } \\
\text { Professora Maria Philadelphia da }\end{array}$ \\
\hline
\end{tabular}

\footnotetext{
${ }^{26}$ Poucos meses depois de assumir o cargo, esta professora foi exonerada e substituída pela professora Anna Fausta Carneiro, nomeada em 30 de junho de 1896.

${ }^{27}$ Pai do Padre Ovídio Alves de São Boaventura, sobre quem brevemente falamos na quarta seção.
} 


\begin{tabular}{|c|c|c|}
\hline & Feminino & Rocha \\
\hline \multirow[t]{2}{*}{ Tanquinho } & Escola do Sexo Masculino & Professor José Ferreira da Costa \\
\hline & Escola do Sexo Feminino & Professora Rosalina Emiliana Barata \\
\hline \multirow[t]{2}{*}{ Santa Bárbara } & Escola do Sexo Masculino & Professor João Muniz Fiuza \\
\hline & Escola do Sexo Feminino & Professora Maria Elisa da Silva Ávila \\
\hline Bom Despacho & Escola do Sexo Masculino & Professor Geminiano Alves da Costa \\
\hline $\begin{array}{l}\text { São José das } \\
\text { Itapororocas }\end{array}$ & Escola Mista & Professora Januaria Perpetua Gomes \\
\hline Arraial do Limoeiro & Escola Mista & $\begin{array}{l}\text { Professora Maria Ybaldina de Assis } \\
\text { Regis }\end{array}$ \\
\hline Arraial de São Vicente & Escola Mista & Professora Hortência Gomes da Costa \\
\hline
\end{tabular}

Com a criação dessas 20 escolas (5 na cidade e 15 nos distritos),

Cada professor(a) ocupava uma "cadeira" que correspondia a uma sala de aula; assim, uma sala de aula era considerada uma escola: escolas isoladas, quando localizadas nos arraiais ou distritos ou subúrbios da cidade, ou escolas urbanas, quando localizadas dentro da sede do município, ou, ainda, podiam ser chamadas de aulas públicas ou aulas particulares, já que cada aula equivalia a uma sala de aula e, portanto, uma escola. (OLIVEIRA, 2019, p. 99).

Com isso, a instrução pública começou a ser disseminada na Princesa do Sertão, apesar de não terem sido criados, até então, prédios escolares apropriados para o seu funcionamento, ao contrário, as aulas isoladas ocorriam em casas alugadas, cujos locatários eram os próprios professores ou pessoas que tinham imóveis disponíveis para locação, conforme comprova um documento avulso da Intendência Municipal, datado de 9 de Agosto de 1900, no qual há a declaração de que “[...] foi approvado, por | esta Inspectoria, e pelo espaço de dous $\mid$ annos, o contracto que firmastes com o | proprietario Doutor Jacintho Ferreira da Silva ${ }^{28}$, | para o aluguel da casa em que funccio- | na a escola do sexo femminino dessa cidade" (DOCUMENTO AVULSO - LIVRO DE REGISTROS DE OFÍCIOS..., 1900). Anos mais tarde, em 7 de janeiro de 1904, alguns professores e outros locatários alugaram as suas casas ou prédios de sua propriedade para a instalação das escolas primárias municipais.

Além do problema do espaço escolar improvisado, os professores tinham que lidar com a falta ou o mau estado do material didático e dos móveis escolares. Sobre esse assunto, uma das professoras da Escola do Sexo Masculino do distrito de Humildes, Maria Christina de Bittencourt, redigiu um documento, em 30 de novembro de 1904, direcionado ao então

\footnotetext{
${ }^{28}$ Este locatário também exercia o cargo de Juiz de Direito da Comarca de Feira de Santana e político, como sinalizado anteriormente.
} 
Intendente Tito Ruy Bacellar, em busca de soluções junto à Intendência Municipal para os problemas estruturais da escola em que trabalhava.

\begin{abstract}
Freguezia dos Humildes 30 de Novembro de 1904 || Excellentissimo Senhor || Tenho a communicar a Vossa Excellencia para os de- | vidos fins, a falta de livros para os | trabalhos escolares, e o estado em que se $\mid$ acha o material da mesma, os bancos $\mid$ precisos de concertos, as carteiras ligeiros $\mid$ reparos, a cadeira dous pés novos, os $\mid$ livros são; Registro mensal, Visitas, o livro | de Actas e o Inventario, pois só exis- | te o de Matriculas. Confiada na justa | administração de Vossa Excellencia espero promptas | providencias. || Cordiaes Saudações. || Ao Excellentissimo Senhor Coronel Tito Ruy Bacellar. | Dignissimo Intendente no Municipio da Feira e Sant' | Anna. || Maria Christina de Bittencourt. || Professora Publica do sexo Mascolino. (DOCUMENTO AVULSO - LIVRO DE REGISTROS DE OFÍCIOS...,1904).
\end{abstract}

Apesar da existência desse documento, não se sabe se o Intendente providenciou as respectivas soluções para os problemas elencados, pois não há no Livro de registros de ofícios da Intendência Municipal de Feira de Santana (1893-1913) nenhum documento que comprove a tomada de qualquer decisão do poder público sobre as questões apresentadas pela professora. Logo, depreende-se que as atividades escolares continuaram e apenas em $01 \mathrm{de}$ fevereiro de 1913 o então Intendente Bernardino da Silva Bahia reportou uma reclamação ao Delegado Escolar, que também era Juiz de Direito, sobre a reprovação de todos os alunos matriculados nas escolas da cidade no ano de 1912, o que era, segundo o Intendente, culpa dos professores inassíduos e, portanto, competia ao Delegado Escolar solucionar o problema no ano letivo que ora se iniciava.

Officio || Excellentissimo Senhor Doutor Juiz do | Direito, Delegado Escolar | Desejando ardentemente que $\mid$ o ensino primario do muni- $\mid$ cipio, a que tenho a honra de $\mid$ superintender, tenha o maior $\mid$ desenvolvimento possivel, ve- $\mid$ nho por meio do presente pe- $\mid$ dir o valioso concurso de Vossa | Excellencia como digno delegado es- | colar. | Sem fallar nas 13 cadeiras | elementares estaduaes, 7 são | custeadas pelo municipio e $\mid$ dentre ellas nenhuma houve $\mid$ que desse sequer um alumno | approvado no anno letivo que | findou. | Não conhece bem esta In- | tendencia todas as causas que $\mid$ a isso concorrem. | Uma porém, que ao seu al- | cance chega, attentas as syn- $\mid$ dicancias procedidas é que as $\mid$ faltas de assiduidade no exer| cicio do magisterio têm sido | muito accentuadas. | Assim é que já no começo | do curso, neste anno, as ca- $\mid$ deiras do sexo femenino ainda $\mid$ não abriram as aulas respecti- | vas, assim tambem as mixtas | dos arraiaes de São Roque e Li- | moeiro. | Espera essa Intendencia que $\mid$ os patrioticos esforços de Vossa $\mid$ Excellencia conjugados a boa vonta- $\mid$ de do Governo Municipal, le- $\mid$ ve a bom caminho o auhelo $\mid$ de levantamento intellectual | do municipio, cuja nova gera- | ção caminha para um futuro | não remoto, dirigir os seus | destinos. | Reitero a Vossa Excellencia os meus | protestos de muita estima e con- | sideração. | Saudações | BERNARDINO DA SILVA BAHIA. | Intendente (LIVRO DE REGISTROS DE OFÍCIOS..., 1913). 
A preocupação do poder público com a inserção e aprovação do alunado primário ficou mais nítida quando foi noticiada no Folha do Norte (PREDIO..., 03 maio 1914, p. 1) a aprovação para edificação do primeiro prédio escolar da cidade, conforme reportamos anteriormente e reiteramos com a seguinte notícia:

Predio escolar || O governo approva a | planta e constitue | commissão para | edificalo \| O governo do Estado, por | acto de 25 de Abril ultimo, | approvou a planta para o pre- $\mid$ dio escolar nesta cidade, em | tempo enviada pela intenden- | cia e autorisou a construcção | do mesmo, nomeando os senhores | coronel Bernardino da Silva Ba- | hia, Intendente, coronel Agosti- | nho Fróes da Motta, presi- | dente do concelho e José | Alves Franco, collector esta- | doal, para della se encarre- | garem, e o engenheiro Luiz | Affonso de Sá Adami para fis- | calisar as obras. || Merece os mais legitimos e | justos applausos este acto de | justiça do governo, coroando os | esforços dos honrados cidadãos $\mid$ que, por fortuna desta terra $\mid$ se acham actualmente á frente $\mid$ dos seus destinos. || A população da cidade e $\mid$ mesmo do municipio deve | está possuida da mais plena | satisfação diante desse acto do | governo, que constitue uma | reivindicação. || Nunca mais, temos fé, a | Providencia que castiga e pre- | mia, consentirá em que este | torrão amado passe por tão ru- $\mid$ des e longas provações, como | foram os 5 annos do nefasto | desgoverno do infeliz senhor Ab- | don de Abreu. || Ainda que por misericordia | e caridade christã se queira | sepultar no olvido esse periodo | triste dos nossos destinos, a | indignação nos assoberba, não | por nós individualmente, seja | dito de passagem ao relembrar | que esse então governante pro- | telou, por inconfessaveis e su- | balternos interesses, a edifica- | ção de um predio escolar, por | conta do governo, na terra do | seu berço!!!... || Mas o DESTINO é implacavel | e após um dia surge outro | dia. || A Feira não é mais gover- | nada pelos abdons e terá um | PREDIO DUPLO, como se fosse o | pagamento dos juros de móra | de um direito postergado e | sonegado por um seu filho, | posteriormente reconhecido | por aquella JUSTIÇA que, | attenta, sempre vela. || Governar é cousa que ser- | ve para dignificar e realçar aos que são investidos des- | sas funcções, ainda mesmo | quando formidaveis ou syste- | maticas opposições lhes em- | bargem os éstos; e, palmilhan- | do o ostracismo, merecem os | respeitos de seus concidadãos. | Mas, para esse ex-intendente | teve e continúa ter effeito | contrario, isto é: - ter gover- | nado sua terra apenas servio | para annullal-o, achatal-o e | perder o resto do pouco con- | ceito em que era tido. || Si por uma irrisão cruel, | dessas que se não explicam, | esse predio não chegar a | ser edificado, restanos a ple- $\mid$ na, absoluta que tal successo | nunca terá sido originado | por mesquinhos interesses.

A aprovação da planta para a construção do prédio escolar, mais do que uma preocupação com a população, serviu como prova da eficiência do governo de Bernardino da Silva Bahia e do "fracasso" da gestão de Abdon Alves Abreu, que foi bastante criticada na reportagem, o que evidencia, mais uma vez, a rivalidade política entre ambos. A postura política de Bernardino da Silva Bahia em relação à educação escolar e ao discurso de civilidade e patriotismo também se fez presente no seu segundo mandato como Intendente, quando ele fez questão de emitir um ofício, em 12 de setembro de 1922, repreendendo a professora da Escola do Sexo Feminino da cidade pela "sua falta de cortesia e cumprimento 
do dever" por não ter ido e nem ter levado as crianças da sua escola para o ato cívico do dia 7 de setembro daquele ano (LIVRO DE REGISTROS DE OFÍCIOS..., 1922, f. 140r).

$\mathrm{O}$ "pulso firme" quando o assunto era o respeito aos atos de patriotismo somado à vontade de promover um ensino primário que chegasse a todos os feirenses fizeram com que Bernardino da Silva Bahia propusesse ao Conselho Municipal a criação de mais uma escola de terceira classe (mista), destinada às crianças do distrito de Fortaleza, localizado no interior da cidade, conforme ofício de 9 de abril de 1923:

Intendencia Municipal da Feira de Sant'Anna, em | 9 de Abril de 1923. || Senhores Membros do Concelho Municipal. || Venho mais uma vez solicitar o vosso concurso para $\mid$ a realisação de um serviço que se me afigura de evi- $\mid$ dente utilidade para o bem geral. Bem sabeis que | uma das principaes preocupações de quem administra, se | não a maior de todas, deve ser a diffusão da instrucção | ao povo, salvando-o assim, da ignorancia que é a origem $\mid$ de todos os seus males. E o Municipio da Feira de Sant' | Anna, tem-se revelado neste particular um esforçado, | o que attestam os incalculaveis beneficios prestados pelas $\mid$ diversas Escolas publicas a seu cargo, que nesta cidade, | quer nos seus Districtos do interior, todos bem dirigidos | e de frequencia bem animadora. Ora, cerca de 2 le- $\mid$ guas desta cidade, fica o arraial de Fortaleza, de popu- | lação infantil não pequena, e já se resente profun- | damente da falta de uma escola, onde vão os seus ha- | bitantes beber a luz bemfazeja da instruç̧ão. É, pois | de inteira justiça e manifesta necessidade, a crea- | ção n'aquelle arraial de uma escola de terceira classe. | E como conheço perfeitamente, vosso desvelo pela cau- $\mid$ sa do ensino publico, espero, como já disse, o vosso $\mid$ concurso, para o effectivar desse desideratum, ma- $\mid$ is uma vez envio-vos os meus protestos protestos | de respeitoso consideração. Affectuosas saudações | (Assignado) Bernardino da Silva Bahia. Registra- $\mid$ do por mim, amanuense da secretaria, Joaquim | Baptista Pedreira. (LIVRO DE REGISTROS DE OFÍCIOS..., 1923, f. 146r).

Nesse período, portanto, a criação de mais uma escola demandaria a ocupação dos cargos escolares, dentre os quais estavam os de professores primários e secundários, e o de Delegado Escolar, ocupado pelo Promotor Público ou Juiz de Direito da Comarca, que seriam posteriormente ocupados (LIVROS DE REGISTROS DE OFÍCIOS..., 1915-1923; LIVRO DE ASSENTAMENTO..., 1896-1925). Apesar dessa iniciativa, as reformas educacionais em Feira de Santana-BA não surtiram o efeito esperado, ao contrário, serviram como justificativa para “[...] um acréscimo de gastos não prescritos para os municípios, o que levou a piora das condições de manutenção das aulas [...]" (OLIVEIRA, 2016, p. 54).

Com isso, identifica-se, mais uma vez, que o interesse dos dirigentes políticos era a manutenção de um discurso de progresso urbano, agora pautado em uma "[...] lógica de pedagogização dos espaços urbanos [...]” (OLIVEIRA, 2016, p. 54), demagogicamente destinados às classes menos abastadas, conforme ofício do próprio Intendente, o Coronel 
Agostinho Fróes da Motta, transcrito do Livro de Registros de Ofícios da Intendência Municipal de Feira de Santana (1916, f. 18v):

\begin{abstract}
Intendencia Municipal da Feira de Sant'Anna, em 6 | de Maio de 1916. || Senhores Membros do Concelho Municipal \| É intento da minha administração, attender, quanto pos- | sível a locação do ensino Municipal em edifícios apro- | priados, esparsos, em pontos convenientes, onde a população | escolar, principalmente a menos abastada, possa sem ne- $\mid$ cessidade de faser grande percurso, attingir a escola. Essas | construcções, encaradas sob dois pontos digo principaes aspe- $\mid$ ctos embellezamento da cidade, e construcção relativamen- $\mid$ te pouco dispendiosas, attendendo o nosso systema de edifi $\mid$ cação, que satisfaz perfeitamente as nossas necessidades. | Pelo lado economico, o municipio enriquece o seu pa- $\mid$ trimonio em edificios adequados as suas necessidades $\mid$ e deveres, poupando-se ao pagamento de aluguéis de $\mid$ casas, sem as condicções mais rudimentares de conforto $\mid$ para o fim em que são empregados. Na rua dos Remedi- $\mid$ os existem os casebres de numeros 17 , $19,21,23$ e 25 que | podem ser desapropriados com pequeno dispendio para $\mid$ o Municipio, visto as condições decadentes em que se | acham, e deixariam uma area espaçosa e convenien- | te para edificação do primeiro predio escolar do $\mathrm{Mu}-$ | nicipio. [...].
\end{abstract}

O desejo do Intendente se concretizou naquele mesmo ano $^{29}$, apesar do problema recorrente de pagamento dos vencimentos atrasados dos professores municipais, os quais incluíam as aulas ministradas, o aluguel e o asseio das suas casas que funcionavam como espaços escolares e a respectiva mobília, e eram divididos

[...] em duas partes: a primeira parte deveria corresponder ao pagamento dos proventos dos professores, no qual se incluiria o aluguel da casa onde funcionavam as aulas, mais o pagamento correspondente ao asseio da escola; a segunda parte corresponderia a compra de mobília escolar, sob a responsabilidade da Intendência Municipal. (OLIVEIRA, 2016, p. 59-60).

Apesar dos problemas administrativos, a Intendência Municipal conseguiu construir e entregar os prédios escolares, cujos maiores interessados, seja por questões pessoais e/ou políticas, foram os Intendentes Bernardino da Silva Bahia e Agostinho Fróes da Motta. Contudo, apesar da iniciativa destes, nem todo o corpo discente da cidade tinha interesse em frequentar as escolas públicas existentes e nem as que viriam a existir, principalmente por conta dos problemas que persistiram no cenário educacional da cidade.

Devido a isso, uma parte do alunado, oriunda de classes sociais mais abastadas, tinha aulas particulares, ministradas por variados professores, dentre os quais alguns que ministravam aulas tanto na rede pública municipal quanto nas residências dos alunos

\footnotetext{
${ }^{29} 1916$ foi o ano em que, de fato, houve a conclusão da construção do prédio escolar Dr. J.J. Seabra, atual Centro Universitário de Cultura e Arte - CUCA, iniciado em 1913, na gestão do Intendente Coronel Bernardino Bahia, e entregue em 1916, durante o mandato do Coronel Agostinho Fróes da Motta.
} 
abastados, informação constatada nos registros dos livros oficiais de instrução pública da Intendência Municipal, que continham a quantidade de aulas efetivamente ministradas por cada professor municipal que também atuava como instrutor particular. Essa estratégia foi adotada pela administração municipal com a finalidade de contabilizar as aulas que, de fato, foram ministradas e de controlar o pagamento exato de cada professor, que, muitas das vezes, esperava uma média de 10 meses para receber o seu salário (LIVRO DE ASSENTAMENTO..., 1896-1925; OLIVEIRA, 2016).

Em um cenário que buscava incentivar o acesso à escolarização das classes populares, dentro das quais se encontravam trabalhadores do comércio, de serviços e da agricultura, classificados como negociantes de alimentos, de animais, de fumo, joalheiros, sapateiros, atendentes de farmácia, fotógrafos, açougueiros, oleiros, ourives, cabeleireiros, torneiros, funileiros, alfaiates, ferreiros, marceneiros, fogueteiros etc. (LIVRO DE INDÚSTRIA..., 1916), poucos eram os que conseguiam ter acesso à educação formal, haja vista que, mesmo depois da construção de prédios escolares na cidade e da implementação da Escola dos Pobres ou Escola Popular ${ }^{30}$, “[...] continuaram existindo, principalmente nos subúrbios, distritos e povoados feirenses [...]" (OLIVEIRA, 2016, p. 71) alunos fora das escolas, principalmente porque boa parte das crianças não tinha nem sequer as suas certidões de nascimento, problema que o governo municipal tentou resolver reiteradamente através da criação de mutirões anunciados no Folha do Norte, que objetivavam registrar o máximo de crianças em idade escolar para que elas fossem, enfim, matriculadas.

É possível compreender, contudo, que as “[...] estratégias de escolarização das aulas e instrução do povo explicitou os anseios e as preocupações de uma elite política e econômica, no sentido de atender às exigências do mercado de trabalho. [...]” (OLIVEIRA, 2019, p. 105, grifo da autora). Logo, os gestores municipais de Feira de Santana-BA das primeiras décadas do século XX viam na democratização do acesso à educação popular uma forma de tornar a cidade um símbolo de progresso para as cidades vizinhas, que compunham o Sertão baiano novecentista, e para capacitar tecnicamente os nativos que atuariam no comércio, na pecuária e na agricultura como mãos de obra qualificadas e mais baratas do que aquelas que viriam de outras cidades para trabalhar na Princesa do Sertão, o que quer dizer que a preocupação dos dirigentes políticos feirenses era semelhante à dos políticos de outras cidades brasileiras daquele período: capacitar mão de obra para combater o "ócio das camadas populares" e junto

\footnotetext{
${ }^{30}$ Essa Escola funcionava no turno noturno no prédio da Sociedade Monte Pio dos Artistas Feirenses e era destinada à educação de feirenses pobres. As notícias sobre essa escola começaram a circular no Folha do Norte a partir de 1921 e tinha como administrador João Alves da Costa (OLIVEIRA, 2019).
} 
a isso tornar a cidade independente das grandes metrópoles no que dizia respeito à dependência de mão de obra devidamente qualificada, que viria dos grandes centros urbanos.

\subsection{SÍNTESE DA SEÇÃO}

Como vimos, a doação de terras para a construção de uma pequena capela feita em devoção à Santa Ana e a São Domingos fez surgir uma pequena cidade no interior da Bahia, localizada entre o litoral e o sertão, e cuja criação de uma feira de gado semanal somada à feira livre fizeram com que Feira de Santana-BA crescesse e adquirisse o status de cidade em franco desenvolvimento, o que serviu para que os dirigentes políticos, mais tarde, angariassem fundos para levar o "progresso", inspirado em modelos europeus, à Princesa do Sertão, alcunha que até os dias atuais é utilizada para demarcar o espaço geográfico-social que a cidade ocupa frente à sua circuvizinhança.

O inchaço populacional somado ao crescimento econômico fez com que a cidade logo se emancipasse, tornando-se a "cabeça da Comarca", o que conduziu vários outros Termos a serem politicamente dependentes de Feira de Santana-BA e a torná-la um lugar de referência para as demais cidades do interior baiano. Nisso, a implementação do progresso, nos mais variados setores, aliado à escolha dos dirigentes políticos da cidade alavancaram o nome, o comércio, a agricultura e a pecuária da Princesa do Sertão, já que os seus governantes, principalmente os eleitos a partir de 1912, formaram alianças com deputados e governadores, que injetaram bastante capital nas obras e na economia da cidade.

Nesse contexto, vários foram os dirigentes políticos (conselheiros municipais e intendentes) que entraram e se mantiveram na administração pública da cidade por vários anos consecutivos. Dentre esses, vimos os nomes de Bernardino da Silva Bahia e Agostinho Fróes da Motta serem citados, reiteradamente, à frente das obras e atividades administrativas de Feira de Santana-BA, justamente porque começaram como conselheiros municipais e se tornaram intendentes de Feira de Santana-BA, ao longo dos anos.

Mais do que isso, observamos que os laços políticos daqueles se estenderam à esfera familiar: seja como amigos, compadres, genros ou sogros, seja como padrinhos políticos dos seus familiares, que se lançaram e se mantiveram, mesmo após a morte dos seus benfeitores, na política feirense. Exemplo disso, foram os casos de Arnold Ferreira da Silva e de Carlos Arthur Rubinos Bahia, que eram genro e filho, respectivamente, do Intendente Bernardino da Silva Bahia; e de Eduardo Fróes da Motta, afilhado desse, e Arthur Fróes da Motta, ambos 
filhos do coronel Agostinho Fróes da Motta, o que comprova a assertiva de que, embora tivessem feito, enquanto políticos, muitas obras progressistas na cidade, um dos legados que ficou e que foi levado adiante pelos seus familiares foi o interesse pela carreira política e a manutenção dos respectivos nomes de família na administração pública feirense por longos e profícuos anos.

A perpetuação dos Bahia e dos Fróes da Motta na vida pública de Feira de SantanaBA só foi possível, contudo, por conta do legado deixado pelos patriarcas, a partir das grandes obras públicas que deram visibilidade política e social à gestão dos referidos governantes. Exemplo disso foi a construção de prédios escolares, calçamentos de vias públicas, proteção contra roubos dos estabelecimentos comerciais, construção do matadouro municipal e das estradas de rodagem, fornecimento de energia elétrica etc., que trouxeram "ares de progresso" para a Princesa do Sertão e demarcaram o quão preocupados os dirigentes políticos estavam tanto com a instrução pública escolar quanto com o embelezamento das ruas, praças e avenidas, e com a rapidez no deslocamento de pessoas e mercadorias que entravam e saíam de Feira de Santana-BA.

Nesse cenário e a partir dos interesses pessoais dos dirigentes políticos, insere-se o corpus da nossa pesquisa: documentos históricos, lavrados na cidade de Feira de Santana no período de 1918 a 1922, armazenados em um arquivo público da referida cidade e cujas partes interessadas e/ou envolvidas foram Agostinho Fróes da Motta, suas primeira e segunda esposas e filhos, e Bernardino da Silva Bahia que aparece como amigo e testemunha em um dos documentos.

Portanto, ao reunirmos as informações elencadas ao longo desta seção, começamos, de fato, a compor o "quebra-cabeças" acerca da vida e da atuação política e econômica dos indivíduos que aparecem no corpus desta tese, sobre o qual começamos a falar na próxima seção, que versa sobre os documentos selecionados do CEDOC/UEFS e as suas descrições codicológica e diplomática. 


\section{CARACTERIZAÇÃO DO CORPUS PARA OS ESTUdOS FILOLÓGICO- LINGUÍSTICOS}

Como o nosso objetivo é preparar uma edição filológica do corpus adequada a fins linguísticos, optamos por, em primeiro lugar, apresentar, nesta seção, os documentos selecionados do CEDOC/UEFS e a sua descrição, a fim de que as informações emergidas de cada um deles nos possibilitem, em uma ampla perspectiva, conhecer 1) a atuação socioprofissional dos indivíduos que constam e que produziram os documentos que editamos, e 2) as informações que se relacionam às mencionadas no corpus, no qual os membros da família Fróes da Motta e os demais envolvidos, que surgem como homens e mulheres que, por sua posição social, política e/ou econômica no cenário feirense, participaram diversas vezes de processos, cujo teor principal eram as relações familiares, que nos ajudaram a produzir as árvores genealógicas dos indivíduos citados e, consequentemente, a estabelecer as relações sociais entre as famílias, as quais nos permitiram, em segundo lugar, combinar as informações da seção anterior com as dos documentos expostos nesta para, então, podermos apresentar um perfil mais detalhado dos escreventes e das partes envolvidas no corpus.

Assim, a construção desta seção se fez imprescindível porque a descrição codicológica dos vinte e sete documentos listados, dentre os quais estão inclusos os selecionados como corpus, "dialoga" e converge para a compreensão dos dados constantes no corpus, os quais, sem o "amparo" das informações advindas dos demais documentos, não nos permitiriam compreender, de forma panorâmica, a atuação e os cargos ocupados por aqueles indivíduos que, como mencionado na seção anterior, influenciaram, de forma decisiva, a administração de Feira de Santana-BA na primeira metade do século XX.

A partir disso, acreditamos que (além da descrição codicológica, da caracterização diplomática dos documentos e das suas informações contribuírem para a "reconstrução" da história externa do corpus e dos caminhos que nos conduziram à escolha dos processos que, na seção seguinte, são retomados, descritos e editados filologicamente), posteriormente, alguns dos elementos expostos na descrição codicológica também podem ser, caso os membros da administração do CEDOC/UEFS julguem pertinentes, incorporados às fichas de identificação dos documentos, especialmente, as informações que dizem respeito à correção de dados relacionados à catalogação.

Feitas essas considerações, apresentamos na subseção 3.1 Delineando o corpus: descrição codicológica de documentos novecentistas do sertão baiano os documentos listados cronológica e descritos codicologicamente, seguidos de sua caracterização 
diplomática para, em sequência, alinharmos as suas informações com as emergidas da leitura dos testamentos e do inventário arrolados na próxima seção, e a partir das quais elaboramos as árvores genealógicas de vários indivíduos, os seus perfis socioprofissionais e, quando possível, socioeducacionais em paralelo com a análise filológica do corpus, do seu conteúdo e do seu vocabulário.

\subsection{DELINEANDO O CORPUS: DESCRIÇÃO CODICOLÓGICA DE DOCUMENTOS NOVECENTISTAS DO SERTÃO BAIANO}

De modo geral, todo documento é entendido como “[...] um registro de comportamento de escrita [...]" (DUARTE, 2019, p. 28), lançado sobre um suporte, no qual se assenta alguma informação. Assim, um documento que se caracteriza, por exemplo, por ser escrito em papel e à mão e por possuir características que lhe atribuem um valor material, cultural, social, linguístico, memorialístico, identitário e/ou estético acaba adquirindo um status de patrimônio documental histórico.

Dessa assertiva, adentramos, especificamente, no âmbito dos documentos diplomáticos jurídicos (BELLOTTO, 2002), que se encontram à disposição de pesquisadores no Centro de Documentação e Pesquisa (CEDOC), acervo criado em 1999, a partir da doação de documentos do Fórum Desembargador Filinto Bastos ${ }^{31}$, que abriga documentos dos séculos XIX e XX, das esferas crime e cível, tais como autos de defloramento, processos crime de estupro, de homicídio, de aborto, de corrupção de menores, queixas de curandeirismo, de porte ilegal de armas, autos de partilhas, alvarás, notificações, instrumentos de agravo, ações de deserdação, ações ordinárias, ações executivas, ações de embargos, de liquidações de sociedade, de arrolamento de terras, de desquite, de pós-desquite, de lesão corporal, testamentos, inventários, enfim.

O CEDOC é um órgão pertencente à Universidade Estadual de Feira de Santana-BA e possui um grupo de funcionários e de estagiários que são responsáveis pela limpeza, catalogação, acondicionamento e armazenamento dos referidos documentos, que se

\footnotetext{
${ }^{31}$ Filinto Justiniano Ferreira Bastos foi um importante jurista, formado em Ciências Jurídicas e Sociais pela Faculdade de Direito de Recife, em 1882, e foi aprovado em concurso público, em 1896, através da defesa da tese intitulada Theses apresentada ao concurso para preenchimento de uma vaga aberta no Tribunal de appellação e Revista deste estado em 9 de novembro de 1896. (MARTINS, 1931; OBRAS..., 2011).
} 
encontram à disposição ${ }^{32}$ de diversos pesquisadores e estudantes da área de Letras, História, Direito, enfim, haja vista que os documentos possuem informações importantes sobre épocas, lugares, sociedades, culturas e grupos sociais ou familiares distintos, que viveram em muitas das cidades que compõem o Sertão baiano dos séculos XIX e XX.

Sobre essas cidades, o acervo possui uma documentação ampla da Comarca de Feira de Santana-BA e dos seus antigos termos e distritos, bem como de Riachão do Jacuípe-BA, de acervos de história oral, da Filarmônica 25 de Março e de documentos particulares, que estão disponíveis para pesquisa local. Sobre os documentos da Comarca de Feira de Santana-BA, estima-se um total de 2.756 processos crime, escritos entre 1883 e 1975 , e 14.000 processos cíveis, além de Livros de Notas lavrados entre 1835 e $1930^{33}$.

Partindo disso, apresentamos, a seguir, algumas imagens do pórtico da Universidade Estadual de Feira de Santana-BA, do emblema do CEDOC/UEFS, do armazenamento da documentação nas estantes do arquivo, dos processos de limpeza e de catalogação dos documentos, feitos pelos estagiários, e da sala de pesquisa do CEDOC/UEFS, local onde o pesquisador consulta a documentação desejada.

Figura 25 - Pórtico da Universidade Estadual de Feira de Santana, instituição onde o CEDOC está

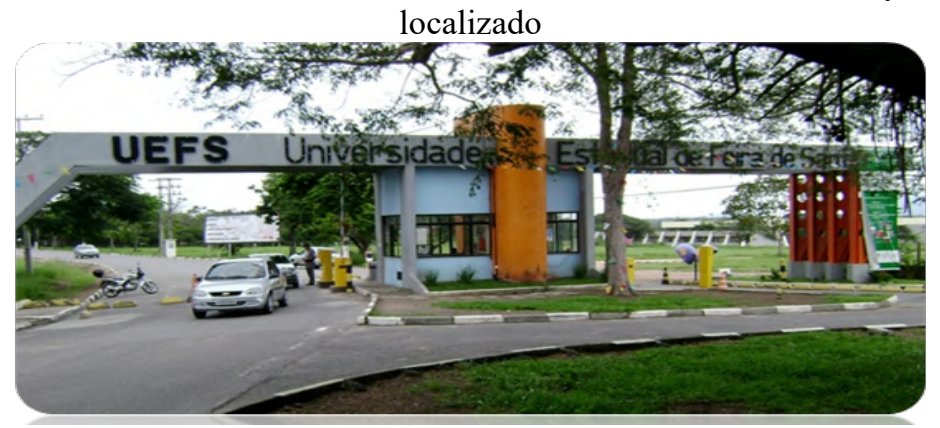

Fonte: www.uefs.br. Acesso em: 10 dez. 2017.

\footnotetext{
32 Os documentos armazenados no CEDOC estão disponíveis para consulta local e, atualmente, é possível verificar os dados da sua localização, através do endereço eletrônico: http://www.cedoc.uefs.br/, que tem permitido que pesquisadores cadastrados no sistema acessem variadas informações sobre o acervo, tais como: notícias e avisos, histórico sobre a constituição do acervo, informações sobre quais os tipos de documentos que se encontram disponíveis naquele, projetos em andamento, pesquisadores associados, equipe administrativa e contato. Além desses tópicos, há um ícone denominado "pesquisar", que permite que o pesquisador cadastrado consulte a localização da documentação desejada.

33 Mais informações sobre o acervo do CEDOC/UEFS podem ser consultadas no site http://www.cedoc.uefs.br/acervo.
} 
Figura 26 - Emblema do CEDOC/ UEFS

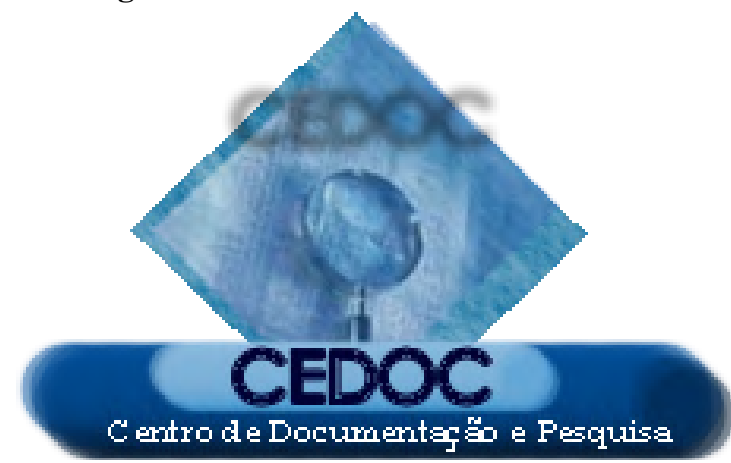

Fonte: http://www.uefs.br/portal/departamentos/dchf/menus/cedoc-1. Acesso em: 10 dez. 2017.

Figura 27 - Caixas-arquivo do acervo do CEDOC/ UEFS

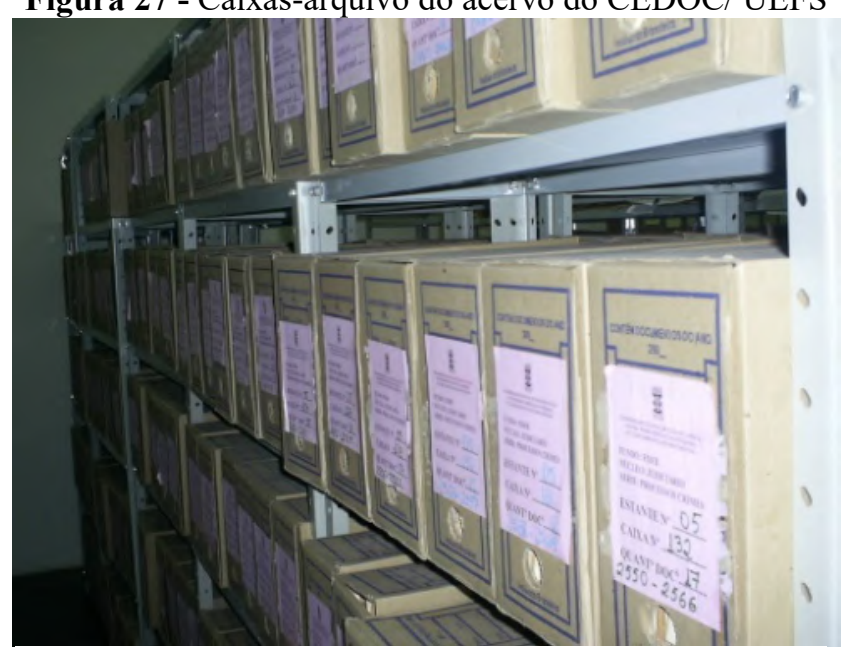

Fonte: http://www2.uefs.br/cedoc/Historico.html. Acesso em: 10 dez. 2017.

Figura 28 - Processo de limpeza e de catalogação dos documentos, feito pelos estagiários do CEDOC/UEFS

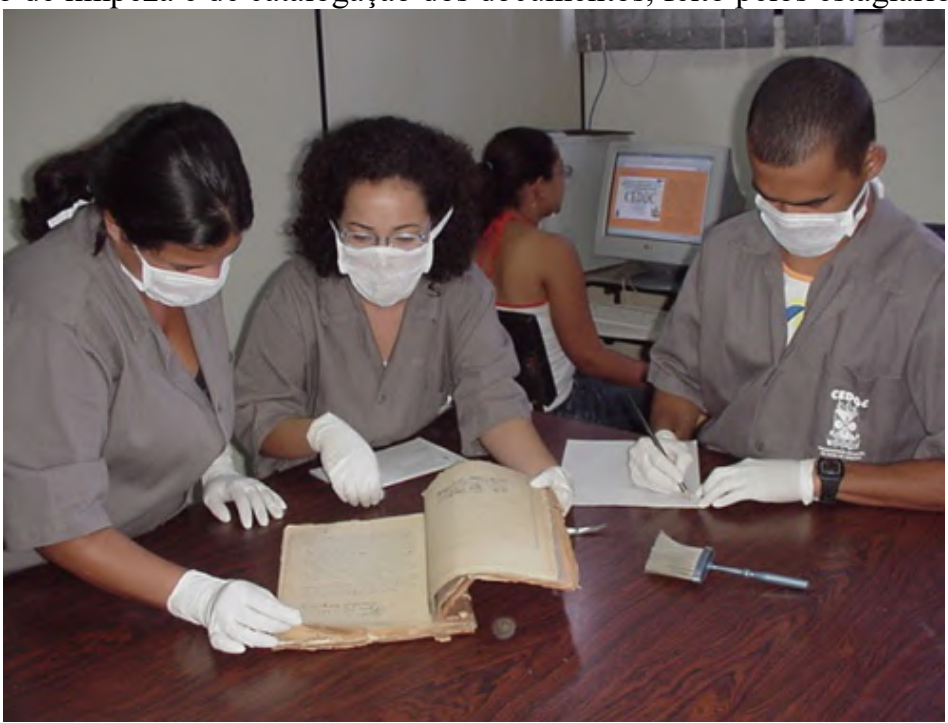

Fonte: http://www2.uefs.br/cedoc/Historico.html. Acesso em: 10 dez. 2017 


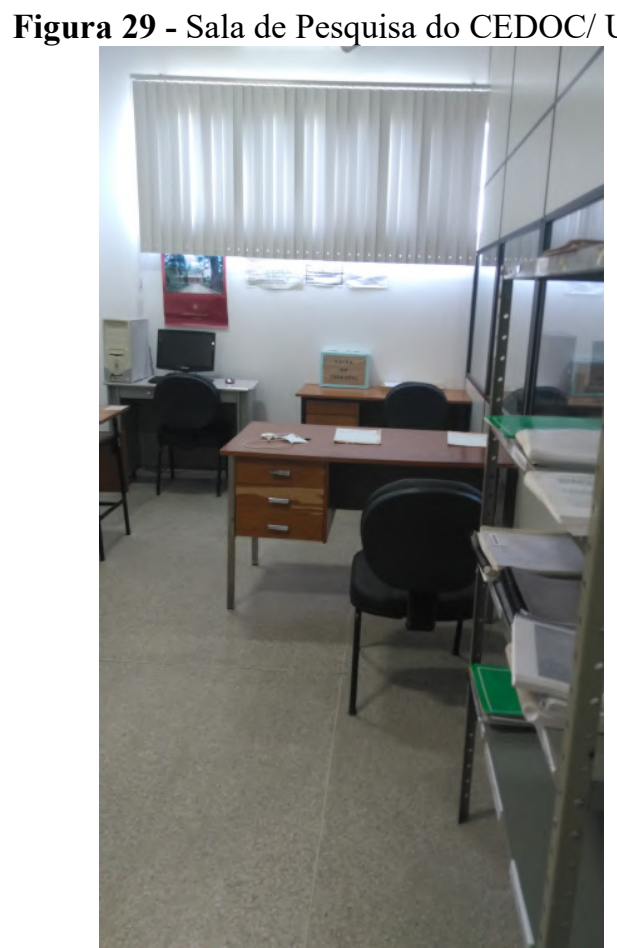

Fonte: CEDOC/UEFS

Ao visitarmos o CEDOC/UEFS, consultamos variados documentos, dentre os quais constam alguns processos jurídicos, cujas partes interessadas são membros de uma família influente, política, econômica e socialmente, no início do século XX, na cidade de Feira de Santana-BA, a família Fróes da Motta, cujo patriarca foi o Intendente Agostinho Fróes da Motta. Assim, ao consultarmos os catálogos que inventariam toda a gama documental disponível no acervo, identificamos vinte e sete ${ }^{34}$ processos cíveis pertencentes aos membros $^{35}$ da referida família, os quais estão apresentados no quadro a seguir, organizado por

\footnotetext{
${ }^{34}$ É importante salientar que esse número de documentos se refere apenas aos processos cíveis, cujas partes interessadas ou citadas são membros da Família Fróes da Motta, haja vista que ainda não consultamos, por conta da quantidade de documentos, do tempo, do recurso e dos objetivos de pesquisa, todos os catálogos dos processos cíveis e crimes, relacionados ou que fazem menção aos membros da referida família, o que nos indica que, provavelmente, ainda existam muitos outros processos a serem somados ao quadro 3. Logo, o levantamento que apresentamos nesta tese é parcial, principalmente porque o nosso foco são os testamentos e inventários dos patriarcas da família, o que não nos impede, por exemplo, de fazer um levantamento completo de toda documentação acerca dessa família em oportunidades futuras.

${ }^{35}$ É necessário frisar que só elencamos os documentos cíveis, cujos membros foram o Coronel Agostinho Fróes da Motta, as suas esposas e os seus filhos. Os documentos que possuem como partes interessadas os netos, sobrinhos, irmãos, genros etc. do Coronel Agostinho Fróes da Motta não entraram no levantamento que fizemos, haja vista que o nosso foco, nesta tese, está direcionado ao patriarca e à matriarca da família Fróes da Motta, enquanto acumuladores de riqueza, de visibilidade social e cujo corpus deste trabalho, os testamentos e inventário daqueles, possui aspectos linguísticos, sociais e culturais interessantes para um trabalho de teor filológico e linguístico, como é o caso deste. Assim, almejamos, em um futuro próximo, ampliar esse levantamento com vistas a inserir todos os documentos que possuem como membros os Fróes da Motta, sejam estes de quaisquer gerações, principalmente porque, em trabalhos futuros, o nosso foco é editar todos os documentos descritos nesta tese e que se referem à referida família.
} 
ordem de datação dos documentos, com o objetivo de proporcionar uma melhor visualização das respectivas informações.

Cabe ressaltar que o quadro 3 foi elaborado levando-se em consideração uma primeira coluna com a ordem de apresentação do documento, definida a partir da sua cronologia; uma segunda coluna com a sua classificação no acervo, organizada a partir de sua "seção, série, subsérie e tipologia", identificadas a partir da ficha, inserida no documento, pelos estagiários do CEDOC/UEFS, e pela leitura inicial de cada um dos processos; uma terceira coluna com o número de fólios de cada documento; uma quarta coluna com a datação em que o documento fora lavrado; uma quinta coluna com os nomes das partes envolvidas e/ou interessadas em cada processo, já que o nosso interesse é compreender as relações entre os membros familiares e, quando possível, "mapear" a atuação profissional dos escreventes mencionados em cada processo; uma sexta coluna com o nome da localidade em que cada processo ocorreu e onde fora lavrado; e uma sétima e última coluna com a catalogação de cada processo disponível no acervo do CEDOC/UEFS, o que facilita a sua consulta e/ou busca no acervo.

Quadro 3 - Lista dos documentos cíveis da família Fróes da Motta, disponíveis no CEDOC/UEFS

\begin{tabular}{|c|c|c|c|c|c|c|}
\hline & DOCUMENTO & $\begin{array}{l}\text { NÚMERO } \\
\text { DE } \\
\text { FÓLIOS } \\
\end{array}$ & PERÍODO & $\begin{array}{c}\text { PARTES } \\
\text { INTERESSADAS }\end{array}$ & LOCALIDADE & $\begin{array}{c}\text { LOCALIZAÇÃO } \\
\text { NO CEDOC }\end{array}$ \\
\hline 1 & $\begin{array}{c}\text { Seção } \\
\text { Judiciário; Série } \\
\text { Cíveis; Subsérie } \\
\text { Ações; } \\
\text { Tipologia } \\
\text { Deserdação }\end{array}$ & $34^{36}$ & $1906-1907$ & $\begin{array}{l}\text { Parte I: Agostinho Fróes } \\
\text { da Motta e Maximiana de } \\
\text { Almeida Motta; Parte II: } \\
\text { Amália Fróes da Motta e } \\
\text { Adelardo Galdino de } \\
\text { Carvalho }\end{array}$ & $\begin{array}{l}\text { Feira de Santana } \\
\text { - lavrado em } \\
\text { Feira de Santana }\end{array}$ & $\begin{array}{c}\text { Estante 09, Caixa } \\
\text { 236, Documento } \\
5022\end{array}$ \\
\hline 2 & $\begin{array}{l}\text { Seção } \\
\text { Judiciário; Série } \\
\text { Cível; Subsérie: } \\
\text { Inventário; } \\
\text { Tipologia } \\
\text { Testamento }\end{array}$ & $10^{37}$ & 1918 & $\begin{array}{l}\text { Maximiana de Almeida } \\
\text { Motta }\end{array}$ & $\begin{array}{l}\text { Feira de Santana } \\
\text { - lavrado em } \\
\text { Feira de Santana }\end{array}$ & $\begin{array}{l}\text { Estante 06, Caixa } \\
166, \text { Documento } \\
2569\end{array}$ \\
\hline 3 & $\begin{array}{l}\text { Seção } \\
\text { Judiciário; Série } \\
\text { Cível; Subsérie: }\end{array}$ & $70^{38}$ & $1918-1919$ & $\begin{array}{l}\text { Parte I: João Constantino } \\
\text { Faskomy e Amalia Motta } \\
\text { Faskomy; Parte II: }\end{array}$ & $\begin{array}{l}\text { Feira de Santana } \\
\text { - lavrado em } \\
\text { Feira de Santana }\end{array}$ & $\begin{array}{l}\text { Estante 13, Caixa } \\
348, \quad \text { Documento } \\
7974\end{array}$ \\
\hline
\end{tabular}

\footnotetext{
${ }^{36} \mathrm{Na}$ ficha de identificação inserida pelos estagiários do CEDOC consta que o documento possui 30 fólios, mas possui 34, dos quais os três últimos estão em branco, portanto não foram contabilizados.

${ }^{37} \mathrm{Na}$ ficha de identificação inserida pelos estagiários do CEDOC consta que o documento possui 9 fólios, mas possui 10, como pode ser verificado na edição fac-similar que realizamos nesta tese.

${ }^{38} \mathrm{Na}$ ficha de identificação inserida pelos estagiários do CEDOC consta que o documento possui 69 fólios, mas possui 70, pois o último fólio não foi contabilizado.
} 


\begin{tabular}{|c|c|c|c|c|c|c|}
\hline & $\begin{array}{l}\text { Ações; } \\
\text { Tipologia } \\
\text { Instrumento de } \\
\text { Agravo }\end{array}$ & & & $\begin{array}{l}\text { Maximiana de Almeida } \\
\text { Motta }\end{array}$ & & \\
\hline 4 & $\begin{array}{l}\text { Seção } \\
\text { Judiciário; Série } \\
\text { Cível; Subsérie } \\
\text { Inventário; } \\
\text { Tipologia } \\
\text { Inventário }\end{array}$ & $219^{39}$ & 1918-1919 & $\begin{array}{l}\text { Maximiana de Almeida } \\
\text { Motta }\end{array}$ & $\begin{array}{l}\text { Feira de Santana } \\
\text { - lavrado em } \\
\text { Feira de Santana }\end{array}$ & $\begin{array}{l}\text { Estante 09, Caixa } \\
240, \text { Documento } \\
5094\end{array}$ \\
\hline 5 & $\begin{array}{l}\text { Seção } \\
\text { Judiciário; Série } \\
\text { Cível; Subsérie } \\
\text { Ação Ordinária } \\
\text { de Desquite }\end{array}$ & $97^{40}$ & $1919-1922$ & $\begin{array}{l}\text { Parte I: Albertina da } \\
\text { Motta Barretto; Parte II: } \\
\text { Antonio Alves Barretto }\end{array}$ & $\begin{array}{l}\text { Feira de Santana } \\
\text { - lavrado em } \\
\text { Feira de Santana }\end{array}$ & $\begin{array}{l}\text { Estante } 03 \text {, Caixa } \\
65, \quad \text { Documento } \\
753\end{array}$ \\
\hline 6 & $\begin{array}{l}\text { Seção } \\
\text { Judiciário; Série } \\
\text { Cível; Subsérie } \\
\text { Inventário Pós- } \\
\text { desquite }\end{array}$ & $39^{41}$ & 1922 & $\begin{array}{lrr}\text { Parte I: Antonio Alves } \\
\text { Barretto Parte } \\
\text { Albertina da } \\
\text { Barretto } & & \\
\end{array}$ & $\begin{array}{l}\text { Feira de Santana } \\
\text { - lavrado em } \\
\text { Feira de Santana }\end{array}$ & $\begin{array}{l}\text { Estante } 01 \text {, Caixa } \\
23, \quad \text { Documento } \\
241\end{array}$ \\
\hline 7 & $\begin{array}{l}\text { Seção } \\
\text { Judiciário; Série } \\
\text { Cível; Subsérie } \\
\text { Inventário; } \\
\text { Tipologia } \\
\text { Testamento }\end{array}$ & $11^{42}$ & 1922 & Agostinho Fróes da Motta & $\begin{array}{l}\text { Feira de Santana } \\
\text { - lavrado em } \\
\text { Feira de Santana }\end{array}$ & $\begin{array}{l}\text { Estante 06, Caixa } \\
166, \quad \text { Documento } \\
2573\end{array}$ \\
\hline 8 & $\begin{array}{l}\text { Seção } \\
\text { Judiciário; Série } \\
\text { Cível; Subsérie: } \\
\text { Ações; } \\
\text { Tipologia } \\
\text { Instrumento de }\end{array}$ & $95^{43}$ & 1922 & $\begin{array}{l}\text { Parte I: Eduardo Fróes da } \\
\text { Motta; Parte II: Alberto } \\
\text { de Almeida Motta }\end{array}$ & $\begin{array}{l}\text { Feira de Santana } \\
\text { - lavrado em } \\
\text { Feira de Santana }\end{array}$ & $\begin{array}{l}\text { Estante } 10, \text { Caixa } \\
256, \quad \text { Documento } \\
5370\end{array}$ \\
\hline
\end{tabular}

\footnotetext{
${ }^{39} \mathrm{Na}$ ficha de identificação inserida pelos estagiários do CEDOC consta que o documento possui 220 fólios, mas possui 219.

${ }^{40} \mathrm{Na}$ ficha de identificação inserida pelos estagiários do CEDOC consta que o documento possui 96 fólios, mas possui 97.

${ }^{41} \mathrm{Na}$ ficha de identificação inserida pelos estagiários do CEDOC consta que o documento possui 40 fólios, mas possui 39, sendo que um fólio em branco não foi contabilizado.

${ }^{42} \mathrm{Na}$ ficha de identificação inserida pelos estagiários do CEDOC consta que o documento possui 9 fólios, mas possui 11 .

${ }^{43} \mathrm{Na}$ ficha de identificação inserida pelos estagiários do CEDOC consta que o documento possui 93 fólios, mas possui 95 , pois o primeiro e o último fólios não foram contabilizados.
} 


\begin{tabular}{|c|c|c|c|c|c|c|}
\hline & Agravo & & & & & \\
\hline 9 & $\begin{array}{l}\text { Seção } \\
\text { Judiciário; Série } \\
\text { Cível; Subsérie: } \\
\text { Ações; } \\
\text { Tipologia Ação } \\
\text { executiva }\end{array}$ & $179^{44}$ & 1922-1924 & $\begin{array}{l}\text { Parte I: Arthur Fróes da } \\
\text { Motta; Parte II: Augusto } \\
\text { Fróes da Motta }\end{array}$ & $\begin{array}{l}\text { Feira de Santana } \\
\text { - lavrado em } \\
\text { Feira de Santana }\end{array}$ & $\begin{array}{lr}\text { Estante } 10, \text { Caixa } \\
255, \text { Documento } \\
5366\end{array}$ \\
\hline 10 & $\begin{array}{l}\text { Seção } \\
\text { Judiciário; Série } \\
\text { Cível; Subsérie: } \\
\text { Inventário; } \\
\text { Tipologia - } \\
\text { Volumes I, II, } \\
\text { III e IV do } \\
\text { Inventário de } \\
\text { Agostinho Fróes } \\
\text { da Motta }\end{array}$ & $\begin{array}{c}\text { Volume I: } \\
166^{45} \\
\text { Volume II: } \\
216 \\
\text { Volume } \\
\text { III: } 183^{46} \\
\text { Volume } \\
\text { IV: } 234^{47} \\
\text { TOTAL: } \\
799\end{array}$ & $1922-1925$ & Agostinho Fróes da Motta & $\begin{array}{l}\text { Feira de Santana } \\
\text { - lavrado em } \\
\text { Feira de Santana }\end{array}$ & $\begin{array}{l}\text { Estante 06, Caixa } \\
175, \text { Documento } \\
2887\end{array}$ \\
\hline 11 & $\begin{array}{l}\text { Seção } \\
\text { Judiciário; Série } \\
\text { Cível; Subsérie } \\
\text { Ações; } \\
\text { Tipologia } \\
\text { Ordinária de } \\
\text { filiação } \\
\text { petição } \\
\text { herança }\end{array}$ & $366^{48}$ & 1922-1927 & $\begin{array}{l}\text { Parte I: Alberto de } \\
\text { Almeida Motta; Parte II: } \\
\text { Eduardo Fróes da Motta }\end{array}$ & $\begin{array}{l}\text { Feira de Santana } \\
\text { - lavrado em } \\
\text { Feira de Santana }\end{array}$ & $\begin{array}{l}\text { Estante 13, Caixa } \\
339, \quad \text { Documento } \\
7766\end{array}$ \\
\hline 12 & $\begin{array}{l}\text { Seção } \\
\text { Judiciário; Série }\end{array}$ & $248^{49}$ & $1923-1928$ & $\begin{array}{l}\text { Parte I: Adalberto Alves } \\
\text { de Farias e Adalgisa de }\end{array}$ & $\begin{array}{l}\text { Feira de Santana } \\
\text { - lavrado em }\end{array}$ & $\begin{array}{l}\text { Estante } 13 \text {, Caixa } \\
345, \text { Documento }\end{array}$ \\
\hline
\end{tabular}

\footnotetext{
${ }^{44} \mathrm{Na}$ ficha de identificação inserida pelos estagiários do CEDOC consta que o documento possui 177 fólios, mas possui 179, pois os fólios 91r e o último não foram devidamente contabilizados. Também cabe ressaltar que este documento está sendo editado semidiplomaticamente, desde 01 de agosto de 2019, por um bolsista de Iniciação Científica, vinculado ao Projeto de Pesquisa Estudo filológico-linguístico de documentos jurídicos da Bahia novecentista, executado junto à Universidade Federal do Oeste da Bahia, instituição na qual a autora desta tese é docente e coordenadora do referido projeto.

${ }^{45} \mathrm{Na}$ ficha de identificação inserida pelos estagiários do CEDOC consta que o documento possui 164 fólios, mas possui 166, pois os fólios 102 recto e verso não foram contabilizados.

${ }^{46} \mathrm{Na}$ ficha de identificação inserida pelos estagiários do CEDOC consta que o documento possui 172 fólios, mas possui 183 , pois alguns fólios não foram contabilizados.

${ }^{47} \mathrm{Na}$ ficha de identificação inserida pelos estagiários do CEDOC consta que o documento possui 219 fólios, mas possui 234.

${ }^{48} \mathrm{Na}$ ficha de identificação inserida pelos estagiários do CEDOC consta que o documento possui 357 fólios, mas possui 366.

${ }^{49} \mathrm{Na}$ ficha de identificação inserida pelos estagiários do CEDOC consta que o documento possui 247 fólios, mas possui 248.
} 


\begin{tabular}{|c|c|c|c|c|c|c|}
\hline & $\begin{array}{l}\text { Cível; Subsérie } \\
\text { Ações; } \\
\text { Tipologia } \\
\text { Petição de } \\
\text { encerramento de } \\
\text { firma comercial }\end{array}$ & & & $\begin{array}{llr}\text { Almeida } & \text { Motta Farias; } \\
\text { Parte II: Eduardo Fróes } \\
\text { da Motta } & & \\
& & \end{array}$ & Feira de Santana & 7899 \\
\hline 13 & $\begin{array}{l}\text { Seção } \\
\text { Judiciário; Série } \\
\text { Cível; Subsérie } \\
\text { Ações; } \\
\text { Tipologia } \\
\text { Instrumento de } \\
\text { Agravo }\end{array}$ & $117^{50}$ & 1927-1929 & $\begin{array}{l}\text { Parte I: Alberto de } \\
\text { Almeida Motta e Arthur } \\
\text { Fróes da Motta; Parte II: } \\
\text { Eduardo Fróes da Motta e } \\
\text { Augusto Fróes da Motta }\end{array}$ & $\begin{array}{l}\text { Feira de Santana } \\
\text { - lavrado em } \\
\text { Feira de Santana }\end{array}$ & $\begin{array}{l}\text { Estante } 13 \text {, Caixa } \\
361, \text { Documento } \\
8410\end{array}$ \\
\hline 14 & $\begin{array}{l}\text { Seção } \\
\text { Judiciário; Série } \\
\text { Cível; Subsérie } \\
\text { Ações; } \\
\text { Tipologia } \\
\text { Petição }\end{array}$ & $353^{51}$ & $1927-1930$ & $\begin{array}{l}\text { Parte I: Adalberto Alves } \\
\text { de Farias e Arthur Fróes } \\
\text { da Motta; Parte II: } \\
\text { Eduardo Fróes da Motta }\end{array}$ & $\begin{array}{l}\text { Feira de Santana } \\
\text { - lavrado em } \\
\text { Feira de Santana }\end{array}$ & $\begin{array}{l}\text { Estante 13, Caixa } \\
347, \quad \text { Documento } \\
7970\end{array}$ \\
\hline 15 & $\begin{array}{l}\text { Seção } \\
\text { Judiciário; Série } \\
\text { Cível; Subsérie } \\
\text { Ações; } \\
\text { Tipologia } \\
\text { Liquidação de } \\
\text { sociedade }\end{array}$ & $06^{52}$ & 1928-1928 & $\begin{array}{l}\text { Parte I: Adalberto Alves } \\
\text { de Farias; Parte II: } \\
\text { Eduardo Fróes da Motta }\end{array}$ & $\begin{array}{l}\text { Feira de Santana } \\
\text { - lavrado em } \\
\text { Feira de Santana }\end{array}$ & $\begin{array}{l}\text { Estante 13, Caixa } \\
360, \text { Documento } \\
8377\end{array}$ \\
\hline 16 & $\begin{array}{l}\text { Seção } \\
\text { Judiciário; Série } \\
\text { Cível; Subsérie } \\
\text { Ações; } \\
\text { Tipologia } \\
\text { Petição de } \\
\text { intimação de } \\
\text { herdeiros }\end{array}$ & $15^{53}$ & $1928-1929$ & $\begin{array}{l}\text { Parte I: João Constantino } \\
\text { Kaskomy; Parte II: } \\
\text { Eduardo Fróes da Motta }\end{array}$ & $\begin{array}{l}\text { Feira de Santana } \\
\text { - lavrado em } \\
\text { Feira de Santana }\end{array}$ & $\begin{array}{l}\text { Estante 13, Caixa } \\
348, \text { Documento } \\
7977\end{array}$ \\
\hline
\end{tabular}

${ }^{50} \mathrm{Na}$ ficha de identificação inserida pelos estagiários do CEDOC consta que o documento possui 116 fólios, mas possui 117, pois o último fólio em branco não foi contabilizado.

${ }^{51} \mathrm{Na}$ ficha de identificação inserida pelos estagiários do CEDOC consta que o documento possui 668 fólios, mas possui 353, equivalente ao quarto volume dessa petição.

${ }_{52} \mathrm{Na}$ ficha de identificação inserida pelos estagiários do CEDOC consta que o documento possui 02 fólios, mas possui 06.

${ }^{53} \mathrm{Na}$ ficha de identificação inserida pelos estagiários do CEDOC consta que o documento possui 13 fólios, mas possui 15 . 


\begin{tabular}{|c|c|c|c|c|c|c|}
\hline 17 & $\begin{array}{l}\text { Seção } \\
\text { Judiciário; Série } \\
\text { Cível; Subsérie } \\
\text { Ações; } \\
\text { Tipologia } \\
\text { Ordinária de } \\
\text { sonegados }\end{array}$ & $\begin{array}{c}203^{54} \\
\text { (Primeiro } \\
\text { volume) }\end{array}$ & 1929-1929 & 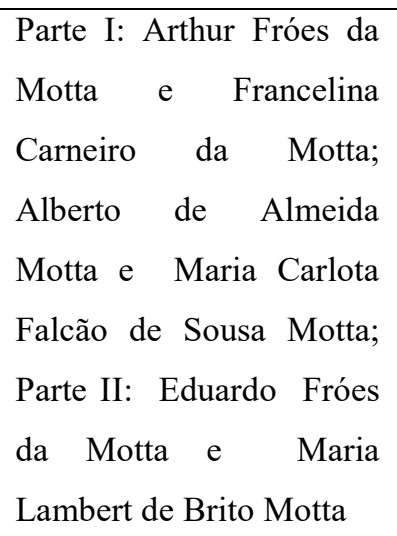 & $\begin{array}{l}\text { Feira de Santana } \\
\text { - lavrado em } \\
\text { Feira de Santana }\end{array}$ & $\begin{array}{lr}\text { Estante } 10, \text { Caixa } \\
255, \text { Documento } \\
5365\end{array}$ \\
\hline 18 & $\begin{array}{l}\text { Seção } \\
\text { Judiciário; Série } \\
\text { Cível; Subsérie } \\
\text { Ações; } \\
\text { Tipologia } \\
\text { Ordinária de } \\
\text { sonegados }\end{array}$ & $\begin{array}{c}414^{55} \\
\text { (Segundo e } \\
\text { terceiro } \\
\text { volumes) }\end{array}$ & $1929-1930$ & 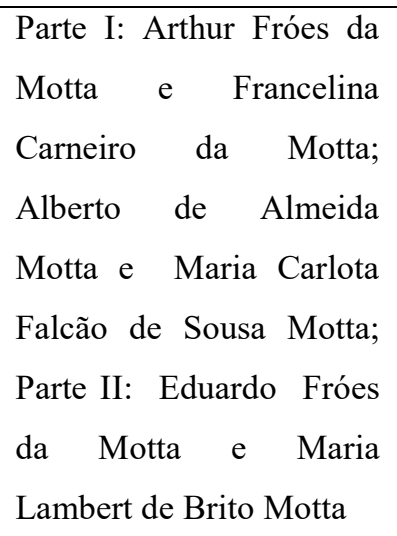 & $\begin{array}{l}\text { Feira de Santana } \\
\text { - lavrado em } \\
\text { Feira de Santana }\end{array}$ & $\begin{array}{l}\text { Estante 13, Caixa } \\
340, \quad \text { Documento } \\
7767\end{array}$ \\
\hline 19 & $\begin{array}{l}\text { Seção } \\
\text { Judiciário; Série } \\
\text { Cível; Subsérie } \\
\text { Inventário; } \\
\text { Tipologia } \\
\text { Traslado de } \\
\text { Inventário }\end{array}$ & $228^{56}$ & 1929-1929 & $\begin{array}{l}\text { Parte I: Agostinho Fróes } \\
\text { da Motta; Parte II: } \\
\text { Eduardo Fróes da Motta }\end{array}$ & $\begin{array}{l}\text { Feira de Santana } \\
\text { - lavrado em } \\
\text { Feira de Santana }\end{array}$ & $\begin{array}{l}\text { Estante 13, Caixa } \\
348, \quad \text { Documento } \\
7975\end{array}$ \\
\hline 20 & $\begin{array}{l}\text { Seção } \\
\text { Judiciário; Série } \\
\text { Cíveis; Subsérie } \\
\text { Ações; } \\
\text { Tipologia } \\
\text { Alvará }\end{array}$ & $5^{57}$ & 1932-1932 & Augusto Fróes da Motta & $\begin{array}{l}\text { Feira de Santana } \\
\text { - lavrado em } \\
\text { Feira de Santana }\end{array}$ & $\begin{array}{l}\text { Estante } 08 \text {, Caixa } \\
212, \text { Documento } \\
4405\end{array}$ \\
\hline 21 & $\begin{array}{l}\text { Seção } \\
\text { Judiciário; Série } \\
\text { Cíveis; Subsérie }\end{array}$ & $\begin{array}{c}173^{58} \\
\text { (Quinto } \\
\text { volume) }\end{array}$ & $1933-1937$ & $\begin{array}{l}\text { Parte I: Eduardo Fróes da } \\
\text { Motta e Maria Lambert } \\
\text { de Brito Motta; Parte II: }\end{array}$ & $\begin{array}{l}\text { Feira de Santana } \\
\text { - lavrado em } \\
\text { Feira de Santana }\end{array}$ & $\begin{array}{l}\text { Estante } 10, \text { Caixa } \\
255, \text { Documento } \\
5367\end{array}$ \\
\hline
\end{tabular}

${ }^{54} \mathrm{Na}$ ficha de identificação inserida pelos estagiários do CEDOC consta que o documento possui 201 fólios, mas possui 203.

${ }^{55} \mathrm{Na}$ ficha de identificação inserida pelos estagiários do CEDOC consta que o documento possui 233 fólios, mas possui 414 , pois existem erros na numeração desse documento.

${ }^{56} \mathrm{Na}$ ficha de identificação inserida pelos estagiários do CEDOC consta que o documento possui 227 fólios, mas possui 228, pois o último fólio em branco não foi contabilizado.

${ }^{57} \mathrm{Na}$ ficha de identificação inserida pelos estagiários do CEDOC consta que o documento possui 3 fólios, mas possui 5, pois o primeiro e último fólios não foram contabilizados. 


\begin{tabular}{|c|c|c|c|c|c|c|}
\hline & $\begin{array}{l}\text { Ações; } \\
\text { Tipologia } \\
\text { Embargo }\end{array}$ & & & $\begin{array}{l}\text { Arthur Fróes da Motta e } \\
\text { Alberto de Almeida } \\
\text { Motta }\end{array}$ & & \\
\hline 22 & $\begin{array}{l}\text { Seção } \\
\text { Judiciário; Série } \\
\text { Cível; Subsérie } \\
\text { Ação; Tipologia } \\
\text { Alvará }\end{array}$ & $4^{59}$ & $1937-1937$ & Eduardo Fróes da Motta & $\begin{array}{l}\text { Feira de Santana } \\
-\quad \text { lavrado em } \\
\text { Feira de Santana }\end{array}$ & $\begin{array}{l}\text { Estante } 08 \text {, Caixa } \\
212, \text { Documento } \\
4414\end{array}$ \\
\hline 23 & $\begin{array}{l}\text { Seção } \\
\text { Judiciário; Série } \\
\text { Cível; Subsérie } \\
\text { Inventário; } \\
\text { Tipologia: } \\
\text { Testamento }\end{array}$ & $14^{60}$ & $1940-1943$ & $\begin{array}{l}\text { Albertina de Almeida } \\
\text { Motta }\end{array}$ & $\begin{array}{l}\text { Feira de Santana } \\
\text { - lavrado em } \\
\text { Feira de Santana }\end{array}$ & $\begin{array}{l}\text { Estante 06, Caixa } \\
171, \text { Documento } \\
2716\end{array}$ \\
\hline 24 & $\begin{array}{l}\text { Seção } \\
\text { Judiciário; Série } \\
\text { Cível; Subsérie } \\
\text { Ação; Tipologia } \\
\text { Notificação }\end{array}$ & $12^{61}$ & $1945-1946$ & $\begin{array}{l}\text { Parte I: Augusto Marcos } \\
\text { Carneiro; Parte II: } \\
\text { Eduardo Fróes da Motta }\end{array}$ & $\begin{array}{l}\text { Feira de Santana } \\
\text { - lavrado em } \\
\text { Feira de Santana }\end{array}$ & $\begin{array}{lr}\text { Estante } 13, \text { Caixa } \\
362, \text { Documento } \\
8416\end{array}$ \\
\hline 25 & $\begin{array}{l}\text { Seção } \\
\text { Judiciário; Série } \\
\text { Cível; Subsérie } \\
\text { Inventário; } \\
\text { Tipologia } \\
\text { Testamento }\end{array}$ & $6^{62}$ & 1951 & Arthur Fróes da Motta & $\begin{array}{l}\text { Feira de Santana } \\
\text { - lavrado em } \\
\text { Feira de Santana }\end{array}$ & $\begin{array}{l}\text { Estante } 06, \text { Caixa } \\
166, \text { Documento } \\
2571\end{array}$ \\
\hline 26 & $\begin{array}{l}\text { Seção } \\
\text { Judiciário; Série } \\
\text { Cível; Subsérie } \\
\text { Inventário }\end{array}$ & $250^{63}$ & $1951-1959$ & Arthur Fróes da Motta & $\begin{array}{l}\text { Feira de Santana } \\
\text { - lavrado em } \\
\text { Feira de Santana }\end{array}$ & $\begin{array}{l}\text { Estante } 03 \text {, Caixa } \\
78, \quad \text { Documento } \\
945\end{array}$ \\
\hline 27 & Seção & $64^{64}$ & 1969 & $\begin{array}{llll}\text { Parte } & \text { I: } & \text { Maria } & \text { Luiza }\end{array}$ & Feira de Santana & Estante 14, Caixa \\
\hline
\end{tabular}

${ }^{58} \mathrm{Na}$ ficha de identificação inserida pelos estagiários do CEDOC consta que o documento possui 169 fólios, mas possui 173, já que alguns fólios não foram contabilizados.

${ }_{59} \mathrm{Na}$ ficha de identificação inserida pelos estagiários do CEDOC consta que o documento possui 2 fólios, mas possui 4.

${ }^{60} \mathrm{Na}$ ficha de identificação inserida pelos estagiários do CEDOC consta que o documento possui 12 fólios, mas possui 14.

${ }^{61} \mathrm{Na}$ ficha de identificação inserida pelos estagiários do CEDOC consta que o documento possui 10 fólios, mas possui 12 .

${ }^{62} \mathrm{Na}$ ficha de identificação inserida pelos estagiários do CEDOC consta que o documento possui 6 fólios, mas possui 11.

${ }^{63} \mathrm{Na}$ ficha de identificação inserida pelos estagiários do CEDOC consta que o documento possui 230 fólios e na folha de papel almaço, também inserida pelo arquivo, consta a informação de que o documento possui 236 fólios, o que já demonstra um conflito de informações. Contudo, segundo a nossa contagem, esse processo possui 250 fólios. 


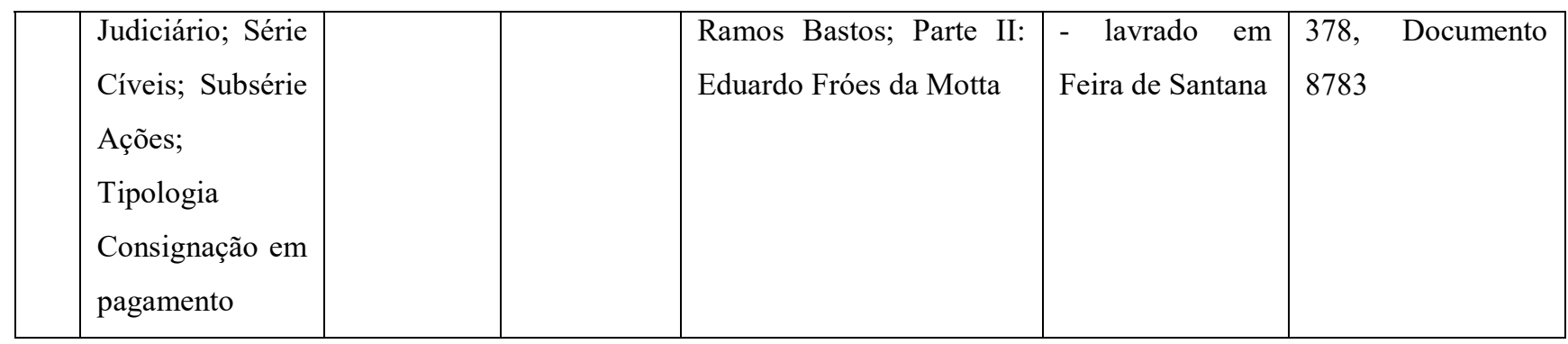

Fonte: Elaborado pela pesquisadora

Após essa apresentação dos documentos identificados como pertencentes ou que fazem menção a um ou mais membros da família Fróes da Motta, optamos por produzir uma ficha codicológica para cada um deles, organizada a partir do Guia Básico de Descrição Codicológica, proposto por Cambraia (2005) e adaptado às necessidades da documentação exposta nesta tese, a fim de disponibilizar aos pesquisadores uma descrição codicológica pormenorizada dos documentos listados, a qual facilitará os trabalhos a serem realizados posteriormente com aqueles documentos. Assim sendo, as fichas codicológicas seguem a mesma ordem crescente de datação disposta no quadro 3, obedecendo à seguinte disposição:

Quadro 4 - Modelo de Guia Básico de Descrição Codicológica

\section{ESPÉCIE/ TIPOLOGIA DOCUMENTAL E AUTORES}

1. Cota: cidade em que se encontra o documento; nome da instituição; coleção de que faz parte; e número ou sigla de identificação;

2. Datação: explícita (transcrever, informando fólio e linha em que consta);

3. Lugar de origem: explícito (transcrever, informando fólio e linha em que consta);

4. Fólio de abertura: transcrição, seguida da fotografia digital do primeiro fólio;

5. Suporte material: papiro (papiráceo), pergaminho (membra-náceo); papel (cartáceo, pautado etc.).

6. Composição: número de fólios; formato (in-plano, in-fólio, bifólio, in-quarto etc.); e dimensão dos fólios (altura x largura, em milímetros);

7. Organização da página: dimensão da mancha escrita; número de colunas e de linhas; pautado; numeração (foliação [número só no recto do fólio] ou paginação [número no recto e no verso]); reclamos (ausência ou presença e localização na página); assinaturas (presença ou ausência, sistema);

8. Particularidades: marcas especiais (carimbos, ex-libris, assinaturas pessoais, etc.);

9. Conteúdo: identificação do conteúdo do códice, informando o(s) seu(s) autor(es);

10. Escrevente(s): nome(s), por ordem de aparecimento nos textos, do(s) escrevente(s) que redigiu(ram) o documento, com destaque para o(s) nome(s) daquele(s) que também consta $(\mathrm{m})$ no corpus analisado na quarta seção.

Fonte: Cambraia (2005)

\footnotetext{
${ }^{64} \mathrm{Na}$ ficha de identificação inserida pelos estagiários do CEDOC consta que o documento possui 39 fólios, mas
} possui 64 , pois os recibos de pagamentos, anexados ao processo, não foram contabilizados. 
Seguindo o modelo proposto, apresentamos vinte e sete quadros com a descrição codicológica de cada documento.

Quadro 5 - Ficha codicológica do primeiro documento

\section{AÇÃO DE DESERDAÇÃO REQUERIDA POR MAXIMIANA DE ALMEIDA MOTTA E AGOSTINHO FRÓES DA MOTTA}

1. Cota: Feira de Santana - Bahia; Centro de Documentação e Pesquisa/ UEFS; Seção Judiciária, Série Cíveis, Subsérie Ações, Tipologia Deserdação; Localização: Estante 09, Caixa 236 e Documento 5022.

2. Datação: 1906 - 1907 “[...] $1906 \mid 1907$ [...]” (f. 1r, 1. 1; 3).

3. Lugar de origem: Feira de Santana - “[...] Feira de Sant'anna [...]” (f. 1r, 1. 2).

4. Fólio de abertura65: "1906 | A 17 | 1907 | Juizo Preparador | Feira de Sant'anna | Acção Ordinaria $\mid$ de $\mid$ Desherdação | Agostinho Fróes da Motta e sua | senhora Dona Maximiana de Almei- | da Motta Autor Autora | Dona Amalia Fróes da Motta | e Adelardo Galdino de Carvalho Ré Réu | Escrivão | DanielMeireles | Anno de mil | nove centos e seis, aos dose dias $\mid$ do mez de Julho, do dito ano, fa- | ço autuação da petição, procu- | rão e certidão que adiante se seguem; | do que faço este termo. Eu [Daniel]" (f. 1r, 1. 1-30).

\begin{tabular}{l} 
5. Suporte material: papel almaço, com pauta na maioria dos fólios e de baixa gramatura. \\
\hline 6. Composição: 34 fólios (dos quais os fólios $3 \mathrm{r} / \mathrm{v}, 8 \mathrm{r}, 26 \mathrm{r}, 27 \mathrm{r}$ são formulários preenchidos \\
manualmente, os fólios $12 \mathrm{v}, 16 \mathrm{v}, 18 \mathrm{v}, 25 \mathrm{v}, 32 \mathrm{r} / \mathrm{v}, 33 \mathrm{r} / \mathrm{v}$ e $34 \mathrm{r} / \mathrm{v}$ estão em branco, e os \\
demais são manuscritos); formatos (in-plano e in-fólio); e dimensão dos fólios: f. 8r, 26r e \\
$27 \mathrm{r}$ - $215 \mathrm{~mm} \times 175 \mathrm{~mm}$, e todos os demais fólios - 330mm x 210mm.
\end{tabular}

\footnotetext{
${ }^{65}$ A transcrição dos fólios de abertura também foi realizada com base nas normas de transcrição de documentos, propostas por Megale e Toledo Neto (2005) e, por nós, adaptadas às necessidades dos textos editados. Assim, os fólios foram transcritos, nesta seção, obedecendo-se aos seguintes critérios: 1. A transcrição foi conservadora; 2. As abreviaturas, alfabéticas ou não, foram desenvolvidas, marcando-se, em itálico, as letras omitidas na abreviatura, respeitando a grafia do manuscrito; 3 . Não foi estabelecida fronteira de palavras que vieram escritas juntas, nem se introduziu hífen ou apóstrofo onde não houvesse; 4. A pontuação e a acentuação originais foram rigorosamente mantidas; 5. Foi respeitado o emprego de maiúsculas e minúsculas como se apresentavam no original; 7. As palavras com algum desvio da norma padrão vigente foram transcritas exatamente como constam nos textos; 8. Foi inserida barra vertical ( | ) para indicar mudança de linha; 9. Foram inseridos colchetes [ ] nos casos das interpolações.
} 
7. Organização da página: dimensão ${ }^{66}$ da mancha escrita: $\mathrm{f}$. $1 \mathrm{r}, 2 \mathrm{r}, 3 \mathrm{r}, 4 \mathrm{r}-287 \mathrm{~mm} \mathrm{x}$ $225 \mathrm{~mm}$, f. 8 r, 26r e $27 \mathrm{r}-215 \mathrm{~mm}$ x $175 \mathrm{~mm}$; 1 coluna e número de linhas da mancha escrita variável: fólio $1 \mathrm{r}-20$ linhas, f. $1 \mathrm{v}-1$ linha, f. $2 \mathrm{r}-31$ linhas, f. $2 \mathrm{v}-8$ linhas, f. $5 \mathrm{v}-3$ linhas, f. 6v - 7 linhas etc.; pautado; numeração por foliação (sistema 1r, 2r, 3r, 4r etc.); e reclamos ("residen-/ residencia" nos fólios 4r/4v, "raptadada/ raptada" nos fólios 13v/14r e "do/do" nos fólios 13r/13v).

8. Particularidades: $O$ documento não possui capa, mas há uma folha de papel almaço, que funciona como uma espécie de invólucro, que foi inserido pelos estagiários do CEDOC/UEFS, para proteger o documento da umidade e garantir a conservação do suporte material, o que evita o contato direto das mãos do pesquisador com o manuscrito. Além disso, na folha há as seguintes informações sobre o documento: "Subsérie: Ação, Tipologia: Ação Ordinária de deserdação, Parte I - Agostinho Fróes da Motta e Maximiana de Almeida Motta/ Parte II: Amália Fróes da Mota, Localidade: FSA, Período: 1906-1907, № de folhas: 30", as quais foram escritas a lápis pelos estagiários do arquivo; há uma ficha de identificação inserida pelos estagiários do CEDOC/UEFS, anexa ao primeiro fólio do documento, com as seguintes informações: no cabeçalho - "UNIVERSIDADE ESTADUAL DE FEIRA DE SANTANA, DEPARTAMENTO DE CIÊNCIAS HUMANAS E FILOSOFIA, CENTRO DE DOCUMENTAÇÃO E PESQUISA, LEVANTAMENTO GERAL DOS NÚCLEOS DOCUMENTAIS", ao lado do cabeçalho "CLASSIFICAÇÃO: E (estante), Cx (caixa) e Doc (documento)", na linha seguinte: "NÚCLEO: FÓRUM DESEMBARGADOR FILINTO BASTOS, SEÇÃO: JUDICIÁRIO, SÉRIE (com espaço para preenchimento manual), SUBSÉRIE (com espaço para preenchimento manual), TIPOLOGIA (com espaço para preenchimento manual), COMARCA: FSA, $\mathrm{N}^{\circ}$ DE FOLHAS (com espaço para preenchimento manual), LOCALIDADE (com espaço para preenchimento manual), PERÍODO (com espaço para preenchimento manual), PARTES E/OU INTERESSADOS (com espaço para preenchimento manual) e OBS. (com espaço para preenchimento manual)"; no fólio 1r na margem centro-superior há a inscrição "1907" que supomos ter sido feita a posteriori por terceiros, pois foi escrita com uma caneta na cor azul e fora dos padrões de datação existentes no respectivo documento; no fólio $3 \mathrm{v}$ há um sinal público, produzido com uma reta com uma bifurcação de três hastes, nas quais há as iniciais $\mathrm{D}, \mathrm{B}, \mathrm{M}$ que fazem referência ao nome do escrivão Daniel Borges de Meireles; dos fólios 10 ao 25 e dos 28 ao 31 rectos há o timbre "THEZOURO DO ESTADO DA BAHIA" na parte centro-superior do fólio, acompanhado de dois selos; no fólio $2 \mathrm{v}$, há dois selos no valor de 200 e 100 réis $^{67}$, respectivamente; nos fólios $5 \mathrm{v}$ e $6 \mathrm{r}$, há seis selos, dos quais três no valor de 200 réis cada estão no fólio $5 \mathrm{v}$ e outros três no valor de 100 réis cada, no fólio 6r; e variadas assinaturas pessoais ao longo do documento.

9. Conteúdo: Trata-se de uma ação de deserdação, cujas partes interessadas foram o Coronel Agostinho Fróes da Motta e a sua esposa, Dona Maximiana de Almeida Motta; e a sua filha Amalia Fróes da Motta e o seu genro Adelardo Galdino de Carvalho, estes que se casaram "sem o consentimento e sem o suprimento do mesmo consentimento pelo Juiz competente", o que se configurava como ilegal já que foi alegado pela primeira parte que a jovem era menor de 21 anos de idade e que, por conta do não consentimento dos seus genitores, aquela seria incursa em um processo de deserdação.

Além disso, no documento há a confirmação de que Amália Fróes da Motta se casou

\footnotetext{
${ }^{66}$ Apresentamos apenas as dimensões da mancha escrita, a presença de selos, carimbos e reclamos de alguns fólios do manuscrito, haja vista a quantidade excessiva de fólios e de repetições daqueles. Vale ressaltar que esta nota é válida para os demais documentos.

${ }^{67}$ A moeda vigente no período em que todos esses documentos foram produzidos era o réis, cuja leitura é feita, a título de exemplo, do seguinte modo: $\$ 1$ (um réis), $\$ 100$ (cem réis), $1 \$ 000$ (hum mil réis), $10 \$ 000$ (dez mil réis), $100 \$ 000$ (cem mil réis), 1:000\$000 (hum conto de réis).
} 
aos 20 anos de idade com Adelardo Galdino de Carvalho, 21 anos de idade, no dia 10 de abril de 1906, às 4 horas da tarde, em Feira de Santana-BA, na residência de Emilio Gomes Paim, situada na rua Dr. Manoel Victorino, pelo regime de comunhão de bens.

Ao longo do processo, é declarado que os réus não compareceram a quatro audiências públicas, e que o Coronel Agostinho Fróes da Motta e a sua esposa solicitaram que lhes fosse dada ciência do teor constante dos autos de justificação de casamento, emitidos a pedido dos réus. Nos referidos autos constam as seguintes informações: nome, filiação, idade e residência de Adelardo Galdino de Carvalho, bem como a declaração de que foi esse quem "raptou" Amalia Fróes da Motta da casa dos seus pais e que, por isso, desejava reparar a falta que lhe causou, casando-se com urgência com aquela, dispensando, portanto, os proclamas exigidos por lei e as formalidades cabíveis.

Com base nisso, o advogado dos autores, Miguel Ribeiro de Oliveira, embasou a sua acusação em dois fatos principais: primeiro, na menoridade da ré e, segundo, no não consentimento dos seus pais ou de um Juiz de Direito para a realização do casamento, como a lei preconizava, e não de um Juiz Preparador, como aconteceu no caso relatado. Por fim, as custas do processo foram avaliadas em dez contos de réis por parte de dois peritos nomeados pelo Juiz de Direito em serviço: João Virgilio de Castro e Godofredo Rebello de Figueiredo ${ }^{68}$. A última audiência pública estava marcada para ocorrer no dia 27 de outubro de 1906, mas os réus não foram intimados porque a Justiça não sabia onde eles se encontravam para entregar a intimação. Como resultado disso, todo o processo ocorreu à revelia dos réus e foi encerrado no dia 12 de fevereiro de 1907, sendo, portanto, declarada deserdada a referida filha do Coronel Agostinho Fróes da Motta.

10. Escreventes: Daniel Borges de Meirelles, Miguel Ribeiro de Oliveira, Manuel Araujo, Augusto Alves d'Abreu, Francisco de Souza Dias, João Virgílio de Castro e Godofredo Rebello de Figueiredo.

Fonte: Elaborado pela pesquisadora

Quadro 6 - Ficha codicológica do segundo documento

\section{TESTAMENTO DE MAXIMIANA DE ALMEIDA MOTTA}

1. Cota: Feira de Santana - Bahia; Centro de Documentação e Pesquisa/ UEFS; Seção Judiciária, Série Cíveis, Subsérie Inventário, Tipologia Testamento; Localização: Estante 06, Caixa 166 e Documento 2569.

2. Datação: 1918 - "1918 [...]" (f. 1r, 1. 1).

3. Lugar de origem: Feira de Santana - “[...] Feira de Sant'anna [...]” (f. 1r, 1. 3).

4. Fólio de abertura: "1918 | Juizo de Direito | Feira de Sant'anna | Autuação du testamento com que | falleceu Dona Maximiana de Al- | meida Motta, nesta cidade | da Feira de Sant'Anna em doze | de Maio de mil e novecentos e dezoito. | Escrivão | Ramalho | Anno de mil | novecentos e dezoito, aos treze | dias do mez de Maio do anno | já dito, autuo em testamento que | adeante se segue; do que para | constar faço este termo. Eu | Manuel

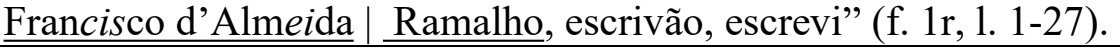

\footnotetext{
${ }^{68}$ Indivíduo que também exercia, na década de 1920, a função de Escrivão dos casamentos da Comarca de Feira de Santana-BA.
} 


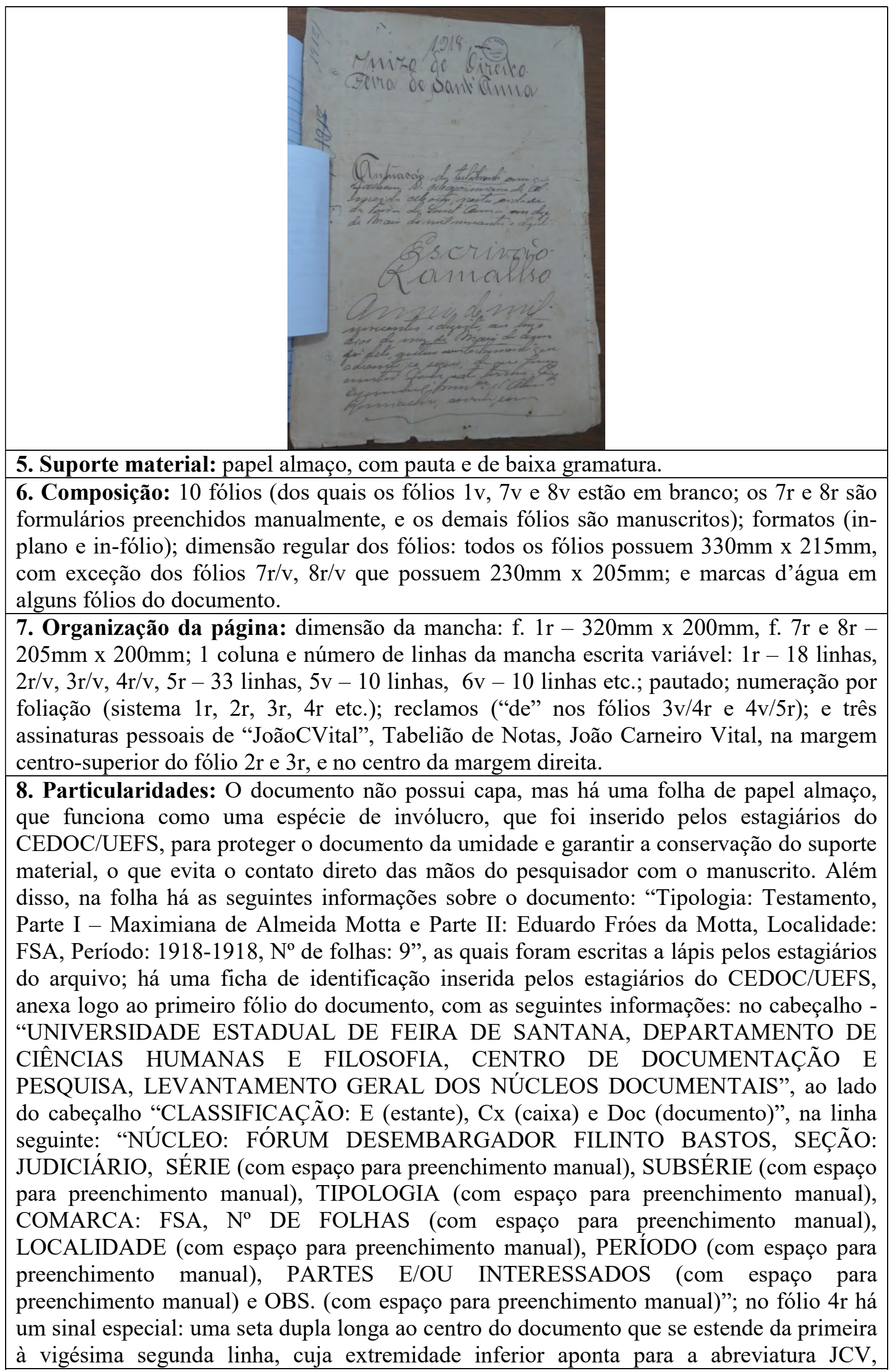


equivalente à abreviatura do nome do Tabelião de Notas, João Carneiro Vital; há um carimbo molhado com a inscrição: "EV Reis - Escrivão Civil" no fólio 1r, e 10 selos de impostos no fólio 10r, dos quais 7 são no valor de 300 réis e 3 no de 200 réis; há 8 marcas de cera vermelha feitas com sinetes para lacrar correspondências (3 na margem direita, 3 na margem esquerda e 2 ao centro) no fólio $5 \mathrm{v}$. Ainda neste fólio, há um trecho de 6 linhas, a saber: "Testamento solemne de Dona | Maximiana de Almeida Motta, ap- | provado em dez de Março de mil | novecentos e quinze, por mim | Tabellião. | João Carneiro Vital" (f. $5 \mathrm{v}, 1$. 269-275) escrito de cabeça para baixo em um fólio que apresenta 3 dobras, justamente porque o documento estava dobrado, lacrado e selado e, devido a isso, a ocorrência das manchas pelo lacre de cera vermelha e do trecho escrito em sentido oposto aos demais; e perfurações na margem lateral esquerda, nos fólios $2 \mathrm{r}$ ao $5 \mathrm{v}$, dentre os quais os fólios 2r, 2v, 3r, 3v, 4r e 4v se encontram amarrados por um barbante.

9. Conteúdo: Trata-se do testamento de Dona Maximiana de Almeida Motta, feito sob a sua supervisão e aprovação, e cujos três testamenteiros eleitos foram o seu filho caçula, o Doutor Eduardo Fróes da Motta, o seu primo e compadre, o Coronel Tertuliano José de Almeida, e o seu amigo Epiphanio José de Souza, respectivamente.

Dos três, o primeiro foi quem aceitou o cargo de testamenteiro ${ }^{69}$ e se tornou o representante legal dos bens da testadora, ficando incumbido de pagar os impostos das custas judiciárias e dos emolumentos, por conta da abertura e registro do testamento de sua genitora.

Além disso, no documento há uma descrição dos bens deixados pela testadora e a quem cada um deles se dirigiria após a sua morte, bem como vestígios das relações familiares, sociais, políticas e religiosas da testadora para com a sua família e a sociedade feirense.

Escrito em 10 fólios, o testamento em si compreende apenas os 5 primeiros fólios, ficando nos outros 5 fólios o registro da abertura do testamento, os formulários que atestavam o pagamento das custas da abertura do testamento por parte do testamenteiro, o termo de aceitação da testamentaria e o pagamento dos selos estaduais para selar o testamento $^{70}$.

10. Escreventes: Manuel Francisco de Almeida Ramalho, João Carneiro Vital, Jacintho Ferreira da Silva e Agerico Moreira de Almeida.

Fonte: Elaborado pela pesquisadora

Quadro 7 - Ficha codicológica do terceiro documento

\section{AÇÃO DE INSTRUMENTO DE AGRAVO REQUERIDA POR JOÃO CONSTANTINO FASKOMY E AMÁLIA DA MOTTA FASKOMY}

1. Cota: Feira de Santana - Bahia; Centro de Documentação e Pesquisa/ UEFS; Seção Judiciária, Série Cíveis, Subsérie Ações, Tipologia Instrumento de Agravo; Localização: Estante 13, Caixa 348 e Documento 7974.

2. Datação: 1919 - "1919 [...]" (f. 1r, 1. 1).

3. Lugar de origem: Feira de Santana - “[...] Feira de Sant'Anna [...]” (f. 1r, 1. 4).

4. Fólio de abertura: "29-3919|22-3-1919 | 1919 | Juizo de Direito | Cidade da | Feira de

\footnotetext{
${ }^{69}$ Apesar de Eduardo Fróes da Motta ter sido eleito pela própria testadora, Dona Maximiana de Almeida Motta, como o seu primeiro testamenteiro, este foi, por um certo tempo, destituído pelo seu pai, o Coronel Agostinho Fróes da Motta, do cargo de inventariante dos bens deixados por Dona Maximiana de Almeida Motta. Contudo, durante o inventário da genitora, o Juiz determinou que o filho Eduardo Fróes da Motta fosse recolocado no cargo de inventariante, em respeito à última vontade da testadora.

${ }^{70}$ Mais detalhes do conteúdo desse documento são retomados na seção 4.3.3 Descrição do conteúdo do corpus.
} 
Sant Anna | Instrumento de $\mid$ aggravo passado a $\mid$ favor do Coronel João | Constantino Faskomy | e sua mulher Dona | Amalia Motta Fas=| komy, extrahido dos $\mid$ autos de inventario $\mid$ dos bens deixados por $\mid$ fallecimento de Dona $\mid$ Maximiana de $\mathrm{Al}=\mid$ meida Motta, na for= | ma abaixo: | Saibam | quantos este publico $\mid$ instrumento virem, que | no anno de mil no= | vecentos e dezenove $\mid$ aos dezoito dias do mez $\mid$ de Março, do dito an- $\mid$ no, nesta cidade da $\mid$ Feira de Sant'Anna $\mid$ do Estado Federado da" (f. 1r, 1. 1-30).

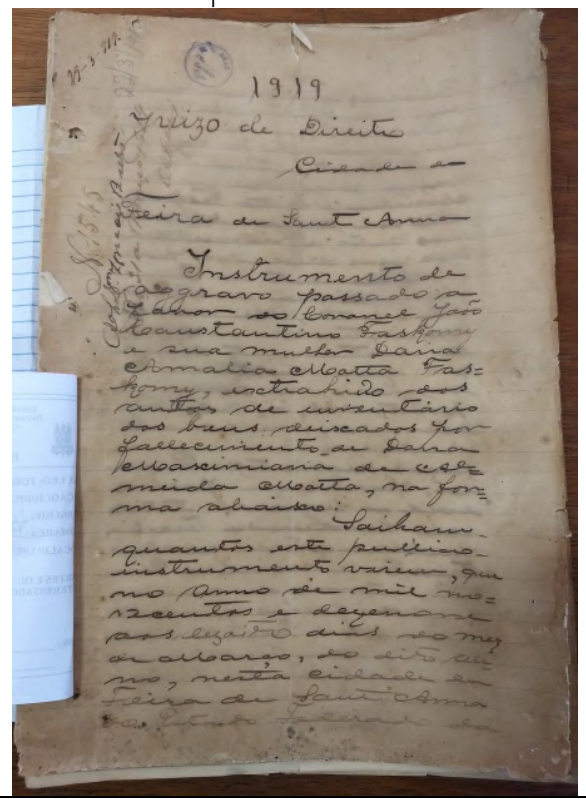

5. Suporte material: papel almaço, com pauta e de baixa gramatura.

6. Composição: 70 fólios (todos manuscritos e nenhum fólio em branco); formatos (inplano e in-fólio); dimensão regular dos fólios: $330 \mathrm{~mm}$ x $220 \mathrm{~mm}$.

7. Organização da página: dimensão da mancha escrita: $320 \mathrm{~mm} \times 200 \mathrm{~mm}$ em todos os fólios, com exceção do fólio 10r que possui $320 \mathrm{~mm}$ x $190 \mathrm{~mm}$ de mancha escrita; 1 coluna em todos os fólios; número de linhas da mancha escrita regular: 33 linhas manuscritas; pautado; numeração por foliação (sistema 1r, 2r, 3r, 4r etc.); e reclamos ("fun/funcionava" nos fólios $2 \mathrm{v} / 3 \mathrm{r}$, "está/está" nos fólios $6 \mathrm{v} / 7 \mathrm{r}$, "juramentos/juramentos" nos fólios $10 \mathrm{v} / 11 \mathrm{r}$, "em/em" nos fólios 13v/14r).

8. Particularidades: $\mathrm{O}$ documento não possui capa, mas há uma folha de papel almaço, que funciona como uma espécie de invólucro, que foi inserido pelos estagiários do $\mathrm{CEDOC/UEFS,} \mathrm{para} \mathrm{proteger} \mathrm{o} \mathrm{documento} \mathrm{da} \mathrm{umidade} \mathrm{e} \mathrm{garantir} \mathrm{a} \mathrm{conservação} \mathrm{do} \mathrm{suporte}$ material, o que evita o contato direto das mãos do pesquisador com o manuscrito. Além disso, na folha há as seguintes informações sobre o documento: "Subsérie: Ações, Tipologia: Instrumento de Agravo, Parte I - Maximiana de Almeida Motta, Parte II: João Constantino Faskomy e sua mulher "Amélia" ${ }^{71 " ~(s i c) ~ F r o ́ e s ~ d a ~ M o t t a, ~ L o c a l i d a d e: ~ F S A, ~}$ Período: 1918-1919, № de folhas: 69", as quais foram escritas a lápis pelos estagiários do arquivo; há uma ficha de identificação inserida pelos estagiários do CEDOC/UEFS, anexa ao primeiro fólio do documento, com as seguintes informações: no cabeçalho "UNIVERSIDADE ESTADUAL DE FEIRA DE SANTANA, DEPARTAMENTO DE CIÊNCIAS HUMANAS E FILOSOFIA, CENTRO DE DOCUMENTAÇÃO E PESQUISA, LEVANTAMENTO GERAL DOS NÚCLEOS DOCUMENTAIS", ao lado do cabeçalho "CLASSIFICAÇÃO: E (estante), Cx (caixa) e Doc (documento)", na linha seguinte: "NÚCLEO: FÓRUM DESEMBARGADOR FILINTO BASTOS, SEÇÃO: JUDICIÁRIO, SÉRIE (com espaço para preenchimento manual), SUBSÉRIE (com espaço

${ }^{71}$ Equivocadamente, os estagiários escreveram Amélia ao invés de Amália, na folha de papel almaço usada como invólucro. 
para preenchimento manual), TIPOLOGIA (com espaço para preenchimento manual), COMARCA: FSA, $\mathrm{N}^{\circ}$ DE FOLHAS (com espaço para preenchimento manual), LOCALIDADE (com espaço para preenchimento manual), PERÍODO (com espaço para preenchimento manual), PARTES E/OU INTERESSADOS (com espaço para preenchimento manual) e OBS. (com espaço para preenchimento manual)"; quase todo o documento (até o fólio 68 verso) se constitui uma trasladação de outro; há 5 perfurações, na margem esquerda (dos fólios rectos) e na margem direita (dos fólios versos), que indicam que o documento recebeu costura com barbante; um carimbo molhado no fólio 1r; e 8 selos de impostos no valor de cinco réis cada e 1 de dois réis, no fólio 69r; notas marginálias nos fólios: $2 \mathrm{v}, 4 \mathrm{r}, 9 \mathrm{r}, 12 \mathrm{r} / \mathrm{v}, 13 \mathrm{v}, 14 \mathrm{r} / \mathrm{v}, 15 \mathrm{r} / \mathrm{v}, 16 \mathrm{r} / \mathrm{v}, 18 \mathrm{v}, 19 \mathrm{v}, 21 \mathrm{v}, 23 \mathrm{v}, 24 \mathrm{r}, 31 \mathrm{v}, 35 \mathrm{r} / \mathrm{v}, 36 \mathrm{r} / \mathrm{v}$, $39 \mathrm{v}, 44 \mathrm{v}, 50 \mathrm{r}, 52 \mathrm{r}, 55 \mathrm{r}, 67 \mathrm{r}$ e $70 \mathrm{r}$; marcas de umidade em alguns fólios; e assinaturas pessoais ao longo do documento.

9. Conteúdo: Trata-se de uma ação de instrumento de agravo, lavrada entre 1918 e 1919 e requerida pelo Coronel João Constantino Faskomy e sua esposa, Amalia Motta Faskomy, em oposição ao testamento de Dona Maximiana de Almeida Motta, no qual a autora deste processo não entrou no título de herdeiros da testadora por ter sido deserdada, em processo anterior.

Para contestar isso, o Coronel João Constantino Faskomy e a sua esposa elegeram como seus representantes o advogado Arthur de Almeida Boaventura ${ }^{72}$, que deu entrada na referida ação, a fim de reaver os direitos legais de Dona Amalia Motta Faskomy, como filha legítima de Dona Maximiana de Almeida Motta, já que naquele momento estava ocorrendo a feitura do inventário da matriarca dos Fróes da Motta.

Nesse contexto, é-nos informado no documento que o marido de Amalia Motta Faskomy era brasileiro naturalizado, nascido na Síria, funcionário público, residente na cidade de Ilhéus-BA e que a sua esposa era bínuba, ou seja, viúva e casada em segundas núpcias com o autor desta ação, que, por intermédio do seu advogado, justificou a deserdação da sua esposa como uma "ação tirânica, injustificável e feita por ímpeto paterno", baseada nas leis Afonsinas e Manoelinas, consideradas aberrantes na argumentação do advogado, justamente porque no momento da produção deste documento já vigorava o novo Código Civil, o de 1916.

Mais adiante, há a transcrição do testamento de Dona Maximiana de Almeida Motta, seguida da certidão de casamento de Amalia Motta Faskomy, antes chamada Amalia da Motta Carvalho, ambos casados às 10 horas da manhã do dia 24 de setembro de 1918 na residência de Augusto Fróes da Motta, irmão da então nubente que era brasileira, de profissão doméstica e residente em Feira de Santana-BA, ambos nubentes com 31 anos de idade.

Além disso, há no processo a anexação de uma procuração feita por Adalgisa Fróes da Motta, solteira na época e irmã de Amalia Motta Faskomy, constituindo o seu irmão, Eduardo Fróes da Motta, como o seu procurador legal. Em 11 de março de 1919 ocorreu uma audiência em que estiveram presentes o advogado Agnello Ribeiro de Macêdo, representante do Coronel Agostinho Fróes da Mota, inventariante de Maximiana de Almeida Motta, e os legatários da inventariada (Albertina da Motta Barretto e o seu então marido Antonio Alves Barretto, representados por seu advogado José Maria Neves; Eduardo Fróes da Motta, Arthur Fróes da Motta e Adalgisa de Almeida Motta, todos representados pelo próprio Eduardo Fróes da Motta, acompanhado de Augusto Fróes da Motta e de Arthur de Almeida Boaventura, advogado de Amalia da Motta Faskomy e de João Constantino Faskomy) para procederem à audiência em que seria discutido o direito ou não de herança de Amalia Motta Faskomy como herdeira de sua mãe, já que existia uma

\footnotetext{
${ }^{72}$ Formado em Ciências Jurídicas e Sociais pela Faculdade de Direito de Recife, em 1885 (MARTINS, 1931).
} 
ação de deserdação julgada.

Logo, esse documento tem relação direta com o primeiro, a ação de deserdação, já que a fuga da casa dos pais foi o estopim para a abertura do processo de deserdação contra Amália Fróes da Motta. Naquela audiência, o Doutor José Maria Neves, novo representante dos autores da ação, declarou que ficaria satisfeito com qualquer decisão tomada pelo Juiz, enquanto que Eduardo Fróes da Motta (em seu nome e no de sua irmã Adalgisa de Almeida Motta), Arthur e Augusto Fróes da Motta declararam que eram contra a inclusão do nome de sua irmã Amalia de Almeida Motta (nome de solteira que deveria ser incluído no título de herdeiros) no inventário de Dona Maximiana de Almeida Motta. Em seguida, houve a transcrição de alguns fólios constantes da ação de deserdação deferida em processo anterior a este e, como conclusão, em 22 de abril de 1919, o processo foi recebido pelo Desembargador Botelho Benjamin na Secretaria do Tribunal Superior de Justiça para, enfim, ser julgado o recurso interposto pelos autores deste processo.

10. Escreventes: Jacintho Ferreira da Silva, Manuel Francisco de Almeida Ramalho, João Carneiro Vital, Antonio Monis Ornellas, Ignacio Paschoal Bastos, Domingos Adami $^{73}$ e J. Botelho Benjamim.

Fonte: Elaborado pela pesquisadora

Quadro 8 - Ficha codicológica do quarto documento

\section{INVENTÁRIO DE MAXIMIANA DE ALMEIDA MOTTA}

1. Cota: Feira de Santana - Bahia; Centro de Documentação e Pesquisa/ UEFS; Seção Judiciária, Série Cíveis, Subsérie Inventário; Localização: Estante 09, Caixa 240 e Documento 5094.

2. Datação: 1918 - "1918 [...]" (f. 1r, 1. 1).

3. Lugar de origem: Feira de Santana - "[...] Feira de Sant'anna [...]” (f. 1r, 1. 3).

4. Fólio de abertura: "1918 | Juizo de Direito | Feira de Sant'anna | Inventario | Dona Maximiana d'Almeida Motta | fallecida c testamento | Coronel Agostinho Fróes da Motta | inventariante | Escrivão | Ramalho $\mid$ Anno de mil | novecentos e dezoito aos treis dias do $\mid$ mez de Julho do dito anno a[rasgado] | tuo a petição que se segue; $\mathrm{d}[\mathrm{o}]$ | [rasgado] faço este termo.

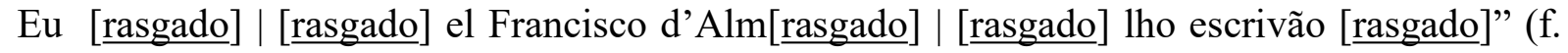
1r, 1. 1-30).

\footnotetext{
${ }^{73}$ Formado em Ciências Jurídicas em 1894 pela Faculdade Livre de Direito da Bahia.
} 


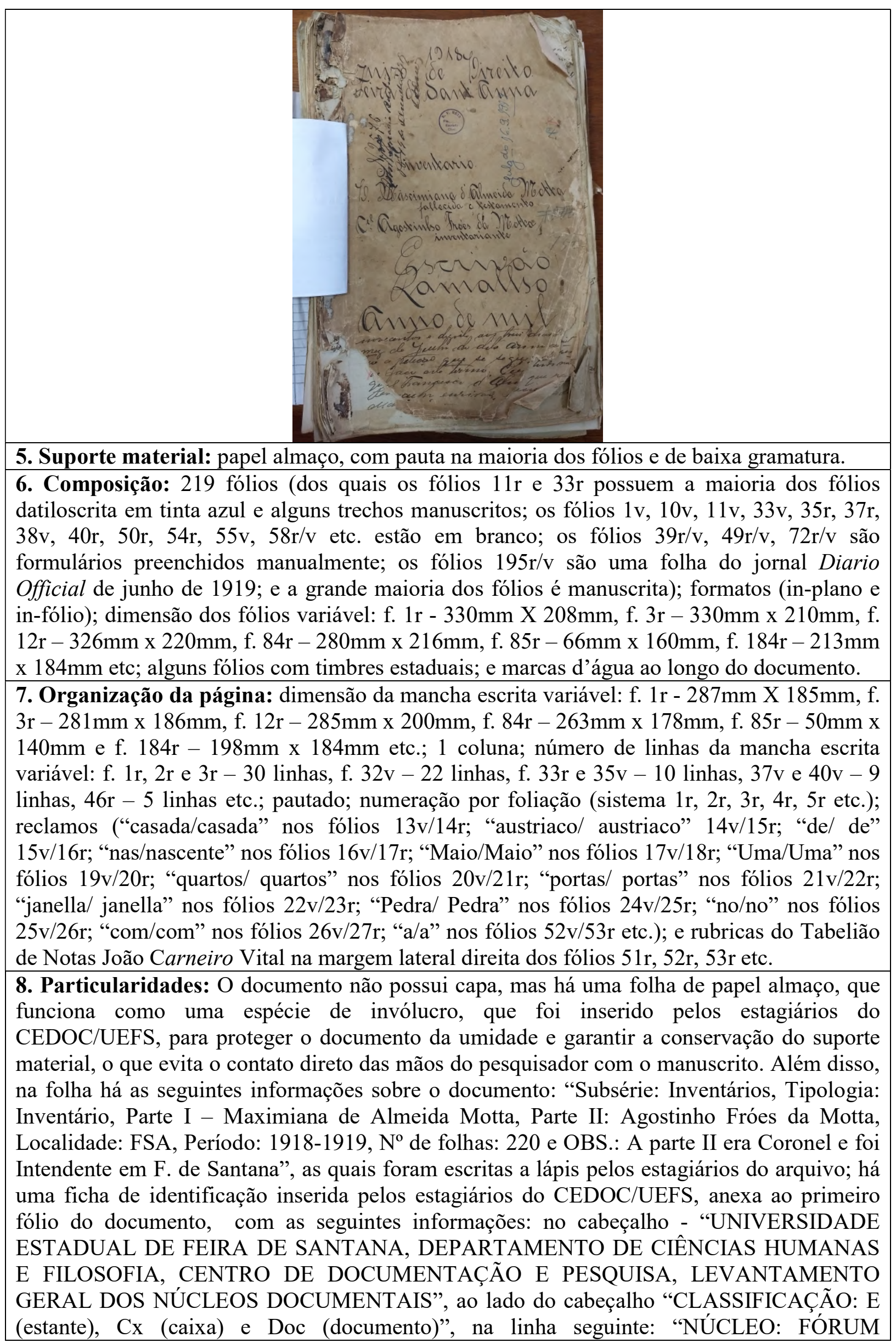


DESEMBARGADOR FILINTO BASTOS, SEÇÃO: JUDICIÁRIO, SÉRIE (com espaço para preenchimento manual), SUBSÉRIE (com espaço para preenchimento manual), TIPOLOGIA (com espaço para preenchimento manual), COMARCA: FSA, $\mathrm{N}^{\circ}$ DE FOLHAS (com espaço para preenchimento manual), LOCALIDADE (com espaço para preenchimento manual), PERÍODO (com espaço para preenchimento manual), PARTES E/OU INTERESSADOS (com espaço para preenchimento manual) e OBS. (com espaço para preenchimento manual)"; há um barbante amarrado em forma de X, com a finalidade de "embrulhar" todo o documento, a fim de mantê-lo junto e organizado; notas marginálias em vários fólios, por exemplo, nos fólios $4 \mathrm{r}$ ao $5 \mathrm{v}, 13 \mathrm{v}, 14 \mathrm{r}, 29 \mathrm{v}, 30 \mathrm{r} / \mathrm{v}, 31 \mathrm{r} / \mathrm{v}, 32 \mathrm{r}$ etc.; alguns fólios com carimbos secos e riscos longos; os fólios $1 \mathrm{r}$ ao $2 \mathrm{v}$, e $3 \mathrm{r}$ ao $7 \mathrm{v}$ estão colados; os três primeiros fólios possuem margens rasgadas, o que ocasionou perda de conteúdo nos fólios 1 e 2 rectos; marcas de dobras nos primeiros fólios; marcas, em alguns fólios, de exposição ao sol; carimbo molhado com a inscrição "E. V. REIS | folhas | Escrivão | Civel", na margem central superior do fólio 1r; selo de imposto no valor de 300 réis no fólio $2 \mathrm{v}$; palavras ou trechos grifados com giz de cera vermelho, ao longo do documento; sinal público: seta que aponta para a abreviatura JCV, referente ao nome do Tabelião João Carneiro Vital, nos fólios $12 \mathrm{v}, 34 \mathrm{v}, 39 \mathrm{v}, 49 \mathrm{v}$ e $53 \mathrm{v}$, por exemplo; alguns fólios escritos com tinta ferrogálica apresentam um grau maior de dificuldade de leitura por conta da oxidação da tinta; inúmeros selos de impostos de variados valores, assinaturas pessoais, alguns carimbos secos ao longo do documento; e riscadura no fólio 219r.

9. Conteúdo: Trata-se do inventário de Dona Maximiana de Almeida Motta, falecida em 12 de maio de 1918, aos 62 anos de idade. No processo, há a transcrição do testamento deixado pela falecida, o qual foi levado em consideração na feitura do seu inventário, iniciado em 3 de julho de 1918, com exceção da escolha do primeiro testamenteiro que, ao invés de ter sido o seu filho Eduardo Fróes da Motta, como declarado em seu testamento, foi o seu esposo, o Coronel Agostinho Fróes da Motta, o qual prontamente aceitou o cargo e assinou o termo da testamentaria.

Para dar prosseguimento ao inventário, o inventariante elegeu como o seu advogado e representante legal o advogado Agnello Ribeiro de Macêdo, que escreveu uma declaração na qual anunciava os nomes, a data de nascimento e o estado civil dos filhos da inventariada, deixando claro que entre aqueles havia Amália da Motta Faskomy, filha que naquele momento já havia sido deserdada por seus genitores.

Depois da inventariação dos bens, foi apresentada uma procuração por parte do Capitão Antonio Alves Barretto, esposo de Dona Albertina da Motta Barretto, passada ao advogado José Maria Neves para representá-lo no inventário de sua falecida sogra, revogando, para isso, a procuração passada anteriormente ao seu cunhado Doutor Eduardo Fróes da Motta.

Mais adiante, o Coronel Agostinho Fróes da Motta solicitou, por meio de seu advogado, que fosse marcada uma audiência pública com os herdeiros de sua falecida esposa para que fossem feitas as devidas declarações e a avaliação dos bens deixados pela inventariada. Para isso, foi requerida a inserção de um avaliador do Juizo, incluindo-se, agora, a adição do nome do seu filho Eduardo Fróes da Motta como inventariante de Dona Maximiana de Almeida Motta, já que ele havia sido o testamenteiro escolhido pela própria testadora, agora inventariada. Logo, foram designados quatro avaliadores, dentre os quais estavam Joaquim Honorio de Oliveira ${ }^{74}$ e Tertuliano José de Almeida, que avaliaram as casas, terrenos, chácaras, fazendas, animais, móveis das casas e das fazendas, dívidas ativas e passivas, dinheiro e apólices deixados pela inventariada.

O processo foi encerrado em 16 de setembro de 1919, após a partilha cabível ao

\footnotetext{
${ }^{74}$ Indivíduo que também foi avaliador dos bens do inventário do Coronel Agostinho Fróes da Motta.
} 
inventariante e aos seis filhos da inventariada, dentre os quais estava a filha Amália da Motta Faskomy, que conseguiu receber o seu quinhão, mesmo contra a vontade do seu pai e irmãos. 10. Escreventes: Manuel Francisco de Almeida Ramalho, Jacintho Ferreira da Silva, Agostinho Fróes da Motta, Agnello Ribeiro de Macêdo, João Carneiro Vital, José Maria Neves, Antonio Alves Barretto, Eduardo Fróes da Motta, Augusto de Lima Soares, Arthur Almeida Boaventura, Jeronymo José Albernaz, Daniel Borges de Meirelles, Godofredo Rebello de Figueiredo, Joaquim Honorio d'Oliveira, Joaquim Hervton dos Reis, Agerico Moreira de Almeida, Antonio Lopes de Souza, Manoel Satyro da Silva Ribeiro ${ }^{75}$, Miguel Cruz, Hugolino Carneiro de Oliveira, José Silvino de Oliveira, Manoel Estevão Carneiro, Cosme Pereira, Liberino Ferreira de Oliveira, Manoel Ferreira Côelho ${ }^{76}$, Ezequiel Pondé, Adnil de Souza Pedreira, G. Claudiano Santos, Renato Villas Bôas, João J. Araujo, José Fernandes da Costa, José Alfrêdo Guimarães, Antonio José de Cerqueira, Juvencio Pereira Lima, João Balduino de Oliveira Andrade, Alfredo Pereira Borges, José Cavalcante de Barros Alencar, Manoel Eustachio, Elpidio Raymundo da Nova, Arthur Fróes da Motta, Augusto Fróes da Motta e Manuel Araujo.

Fonte: Elaborado pela pesquisadora

Quadro 9 - Ficha codicológica do quinto documento

AÇÃO ORDINÁRIA DE DESQUITE ${ }^{77}$ SOLICITADA POR ALBERTINA DA MOTTA BARRETTO

1. Cota: Feira de Santana - Bahia; Centro de Documentação e Pesquisa/ UEFS; Seção Judiciária, Série Processo Cível, Subsérie Ação ordinária de desquite; Localização: Estante 03, Caixa 65 e Documento 753.

2. Datação: 1919 - "1919 [...]" (f. 1r, 1. 1).

3. Lugar de origem: Feira de Santana - "[...] Feira de Sant'anna [...]” (f. 1r, 1. 3).

4. Fólio de abertura: "1919 | Juizo de Direito | Feira de Sant’anna | Acção Ordinaria de Desquite | Dona Albertina da Motta Barretto | -Autora- | Antonio Alves Barretto | -Rèo- | Escrivão | Ramalho | Anno de mil | novecentos e dizenove, aos dizoito | dias do mez de Dizembro do dito | anno autuo a petição que se se-| gue; do que faço este termo. | Eu Manuel

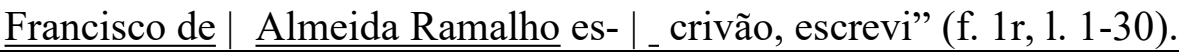

\footnotetext{
${ }^{75}$ Formado em Ciências Jurídicas em 1913 pela Faculdade Livre de Direito da Bahia.

${ }^{76}$ Formado em Ciências Jurídicas em 1894 pela Faculdade Livre de Direito da Bahia.

77 A edição filológica e a descrição pormenorizada desse documento já foi realizada pela autora desta tese e se encontra disponível na dissertação de mestrado intitulada Pelos caminhos da separação: edição semidiplomática e estudo do vocabulário de uma "acção ordinaria de desquite" do início do século XX, defendida em 14 de março de 2014, junto ao Programa de Pós-Graduação em Estudos Linguísticos, da Universidade Estadual de Feira de Santana - UEFS, e disponível em: https://drive.google.com/file/d/0B2fjUZN8T38endTVXhrUkVnVGM/view. Acesso em: 31 maio 2019.
} 


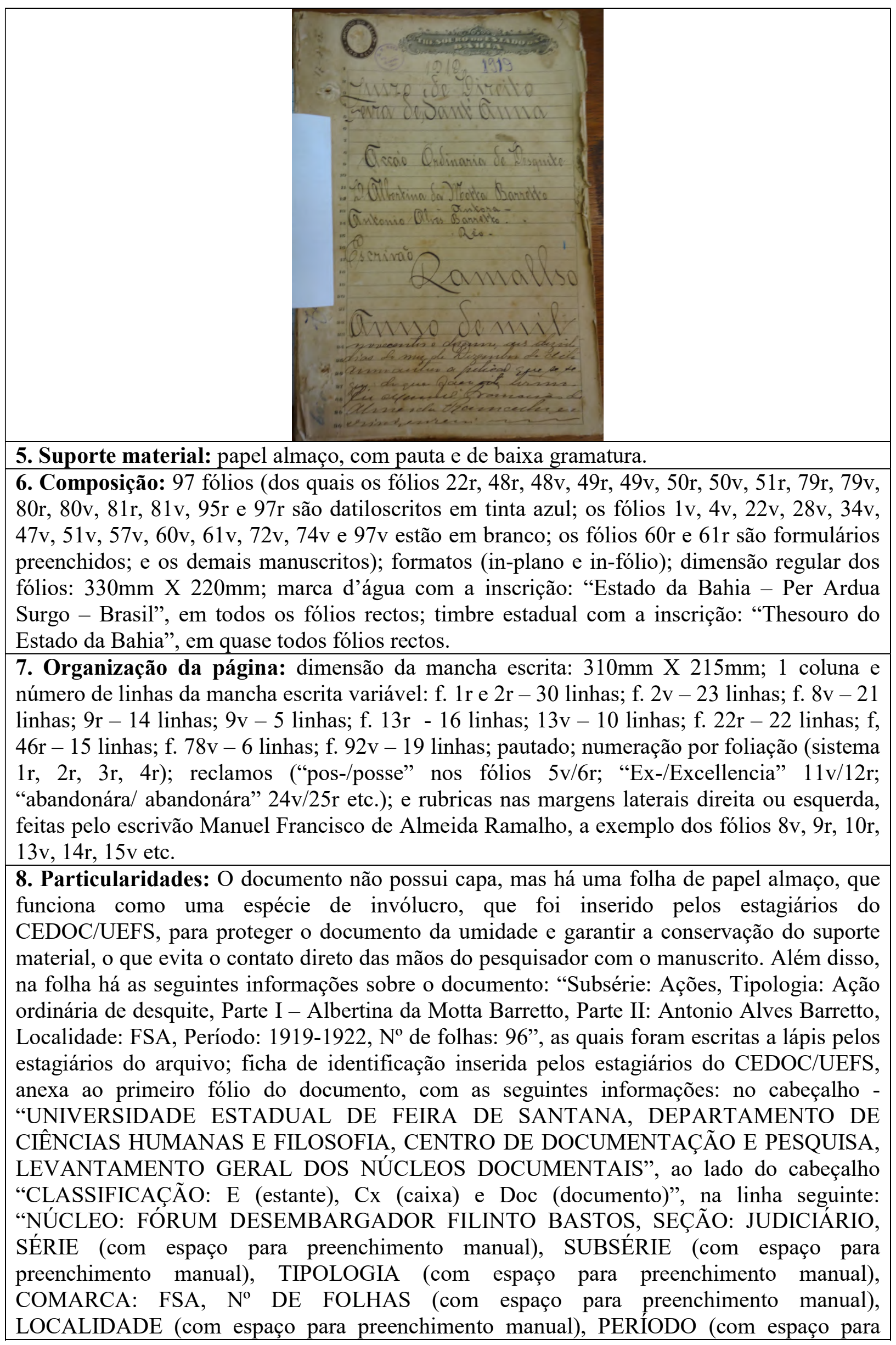


preenchimento manual), PARTES E/OU INTERESSADOS (com espaço para preenchimento manual) e OBS. (com espaço para preenchimento manual)"; carimbo seco na margem superior direita dos fólios datiloscritos, cuja inscrição é o nome do advogado do réu, o Bacharel em Direito José Maria Neves; outros carimbos secos ao longo do documento; algumas expressões em latim ao longo do documento, a saber: "in fine, Versus, Vis sui conscia, sui potens, sui motrix, a quo e sine qua non", identificadas nos fólios $3 \mathrm{v}, 22 \mathrm{r}, 40 \mathrm{v}$, 50v, 75v, 76r, 76v e 80v; há 3 tipos de selos de impostos ao longo do documento; dobras, manchas, rasgaduras e marcas de costura nas margens dos fólios soltos; alguns fólios ainda estão presos por costura, feita com barbante vermelho; trechos destacados com caneta de cor vermelha ou sublinhados em azul; riscaduras em alguns fólios.

9. Conteúdo: Trata-se de uma ação de desquite requerida por Dona Albertina da Motta Barretto contra o seu então marido, o Capitão Antonio Alves Barretto, que já havia "abandonado o lar conjugal", mas ambos ainda continuavam casados oficialmente. Após a morte da genitora da autora deste processo, Dona Albertina da Motta Barretto solicitou a abertura da ação, a fim de desquitar-se do seu esposo antes que a sua herança fosse recebida e o seu marido recebesse a sua meação na dita herança. Naquele cenário, foram levadas testemunhas e depoimentos de ambas as partes sobre o relacionamento do casal e o motivo da dissolução do casamento. Como resolução do processo, em 12 de maio de 1922, a autora conseguiu se desquitar.

10. Escreventes: Manuel Francisco de Almeida Ramalho, Jacintho Ferreira da Silva, Agnello Ribeiro de Macêdo, João Carneiro Vital, Augusto de Lima Soares, Cezar Ribeiro de Cerqueira, José Maria Neves, Antonio Alves Barretto, Manuel Araujo, José Telles Barreto, Antonio Monis Ornellas, Nuno da Silva Rocha, Ignacio Paschoal Bastos, Domingos Adami, Francisco Alexandre de Sousa ${ }^{78}$, J. Botelho Benjamim, Candido Leão, Leovigildo de Carvalho, Manoel Gomes dos Santos e Arnold Ferreira da Silva.

Fonte: Elaborado pela pesquisadora

Quadro 10 - Ficha codicológica do sexto documento

\section{INVENTÁRIO PÓS-DESQUITE SOLICITADO POR ANTONIO ALVES BARRETTO}

1. Cota: Feira de Santana - Bahia; Centro de Documentação e Pesquisa/ UEFS; Seção Judiciária, Série Processo Cível, Subsérie Inventário; Localização: Estante 01, Caixa 23 e Documento 241.

2. Datação: 1922 - "1922 [...]" (f. 1r, 1. 1).

3. Lugar de origem: Feira de Santana - “[...] Feira de Sant'anna [...]” (f. 1r, 1. 3).

4. Fólio de abertura: "1922 | Juizo de Direito | Feira de Sant'anna | Inventario Após o Desquite. | Antonio Alves Barretto | inventariante | Dona Albertina da Motta Barretto sua | mulher | Escrivão | Ramalho | Anno de mil | novecentos e vinte e dois aos doze (12) dias | do mez de Maio do Anno já dito autuo | a petição que se segue; do que faço | este termo. Eu

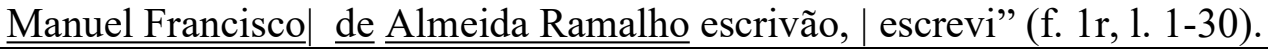

\footnotetext{
${ }^{78}$ Formado em Ciências Jurídicas em 1903 pela Faculdade Livre de Direito da Bahia.
} 


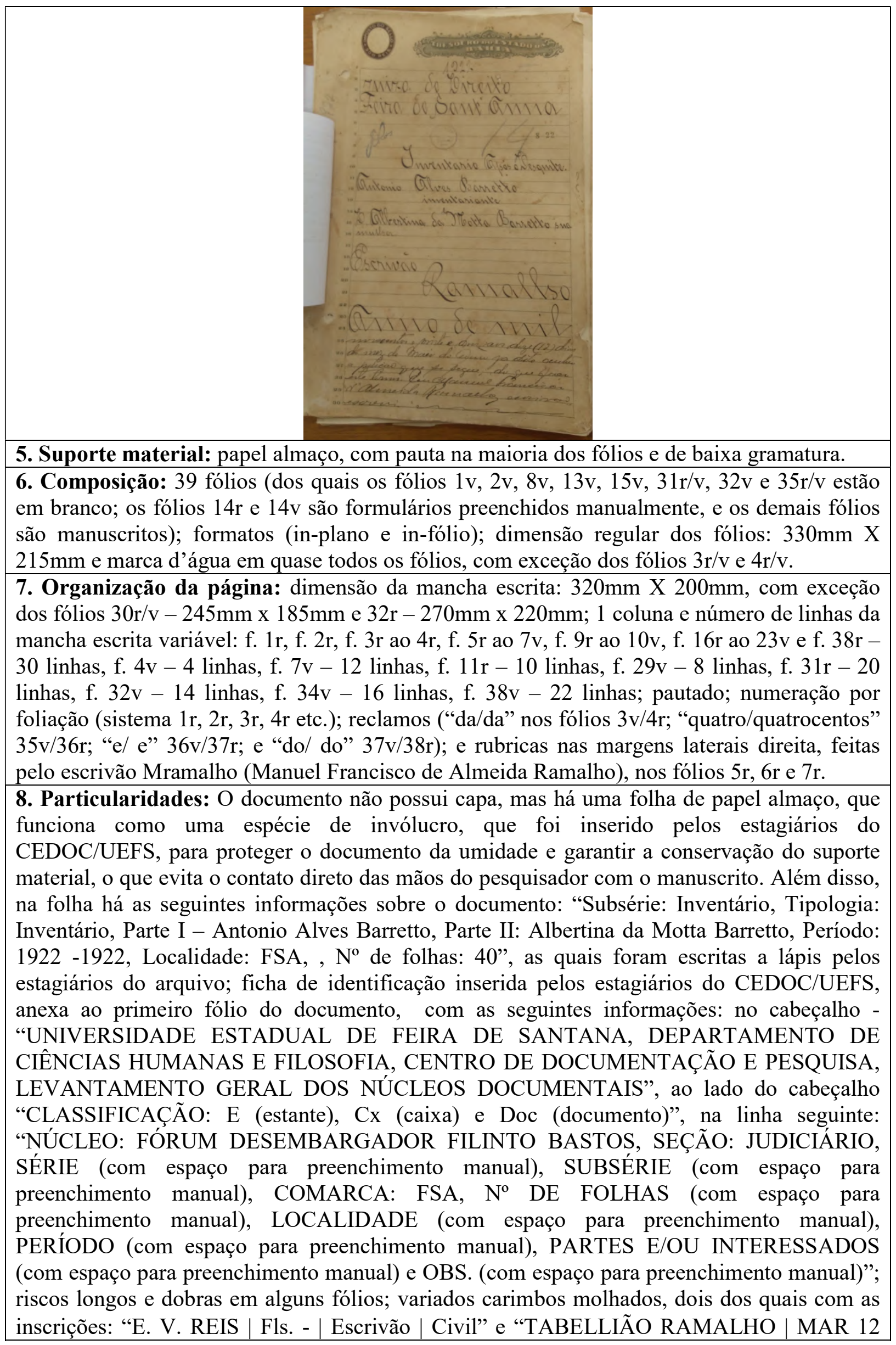


1922 | FEIRA DE SANT'ANNA, na margem centro-superior dos fólios 1r, 3r e 4v; carimbos secos nas margens superiores esquerda da maioria dos fólios rectos; os fólios $5 \mathrm{r}$ ao $7 \mathrm{v}$ estão presos por uma colagem; perfurações na margem esquerda, indicando que havia uma costura feita, provavelmente, com barbante; selos de impostos diferentes ao longo do documento; sinal público: seta dupla, no fólio $14 \mathrm{v}$, cuja extremidade inferior possui as iniciais $\mathrm{JCV}$, correspondentes às iniciais do nome do Tabelião de Notas, João Carneiro Vital; documento escrito em tinta preta e azul; trechos sublinhados em tinta azul; assinaturas pessoais ao longo do documento.

9. Conteúdo: O processo foi iniciado em 12 de maio de 1922, mesma data em que a ação de desquite proposta por Dona Albertina da Motta Barretto foi concluída e a autora declarada como parte vencedora do processo. Neste inventário, há o relato da não embargação do senhor Antonio Alves Barretto em relação à decisão do Egrégio Tribunal Superior de Justiça quanto à referida ação de desquite movida por sua esposa.

Para tanto, neste documento foi solicitado que a esposa fosse intimada para acompanhar a inventariação e divisão dos bens do casal, após o desquite. Para isso, o autor e inventariante deste processo elegeu Estanislau Alves Barretto, o seu pai, e o Doutor José Maria Neves, o seu advogado, para receberem os aluguéis das casas alugadas pelo casal ou alugar as desocupadas ou fazer reparos nas que precisassem, ou alugassem as que viessem a lhes pertencer após a partilha dos bens da mãe de Dona Albertina da Motta Barretto, Dona Maximiana de Almeida Motta, os quais deveriam prestar sempre contas de tudo o que fizessem ou deixassem de fazer ao inventariante.

Ainda neste processo, houve a retomada das justificativas apontadas na ação de desquite para a separação judicial, sendo que, mais uma vez, o autor, através do seu advogado, defendeu-se da argumentação apresentada pelo advogado de sua ex-esposa, alegando que foi levado a abandonar o lar conjugal por conta dos maus tratos sofridos por aquela e pelas constantes discussões entre o casal.

A partir do fólio 8r, foi feito o termo de juramento do inventariante no qual foi iniciado o inventário dos bens do casal, após o desquite, sendo o próprio Antonio Alves Barretto o inventariante. Foram descritas nos respectivos fólios que correspondem ao inventário dos bens do casal quantias em dinheiro, apólices federais, 10 móveis e 16 imóveis.

Do fólio $12 \mathrm{r}$ em diante, é-nos informado que Dona Albertina da Motta Barretto foi intimada pelo Oficial de Justiça, Manoel Gomes dos Santos, para comparecer na primeira audiência do inventário dos bens, que contaria com a presença de um avaliador dos respectivos bens do casal. Como representante legal, a ré elegeu o advogado Agnello Ribeiro de Macêdo, o mesmo que a defendeu na ação de desquite, para acompanhar todo o processo em seu nome.

Assim, do fólio $17 \mathrm{r}$ ao $23 \mathrm{v}$, há a resposta da ré, por meio do seu advogado, sobre as declarações do inventariante no que dizia respeito à constituição do próprio inventário, pois, segundo a sua defesa, não havia argumentos nem sequer para a produção de tal processo, pois este foi movido por quem foi réu e perdeu a ação de desquite, e por quem era o inventariante de um inventário que não tinha a parte inventariada falecida.

Logo, para o advogado, este inventário se contituía como ilegal. Contudo, o advogado de Antonio Alves Barretto pediu vistas do processo e afirmou que o inventariante se conformou com o desquite e que, como estava na posse dos bens do casal, queria a sua devida divisão, já que o desquite havia se consolidado. Deferidas as vistas do advogado do autor, foi marcada uma nova audiência para a feitura do inventário dos bens do casal, para a qual Dona Albertina Fróes Motta, sobrenome adotado após o desquite, passou uma procuração, em 12 de junho de 1922, na cidade de Mundo Novo-BA, para que o advogado e o solicitador a representassem na presente causa, Manoel Pimentel e Isaac Jorge Franco, já que Agnello Ribeiro de Macêdo deixou claro que, após o falecimento do Coronel Agostinho Fróes da 
Motta, pai da ré, ele precisaria acertar com o irmão da ré se continuaria ou não prestando serviços jurídicos àquela.

Assim sendo, no fólio 35r há um termo de partilha amigável dos bens do casal no qual o advogado Altino Teixeira foi o representante de Dona Albertina Fróes da Motta, pois o advogado Manoel Pimentel lhe passou uma procuração para representá-la, pelo fato de se encontrar doente e não puder comparecer à audiência pública instaurada para o inventário.

Naquela audiência, ficou decidido de comum acordo que todos os bens somados em 41:772\$400 (quarenta e um contos, setecentos e setenta e dois mil e quatrocentos réis) deveriam ser divididos em duas partes iguais e que o autor abriria mão dos seus direitos nas apólices federais, divididas entre a sua ex-esposa e os irmãos desta como herança recebida da sexta verba do testamento de sua mãe, Dona Maximiana de Almeida Motta. Em troca dos seus direitos nas apólices, o réu receberia da ex-esposa quatro contos de réis. O processo foi concluído em 15 de agosto de 1922, após a descrição e homologação dos pagamentos que seriam feitos às autoridades que participaram do referido processo.

10. Escreventes: Manuel Francisco de Almeida Ramalho, Arnold Ferreira da Silva, José Maria Neves, Manoel Gomes dos Santos, Jacintho Ferreira da Silva, Agnello Ribeiro de Macêdo, João Carneiro Vital, Elpidio Raymundo da Nova, Manoel Pimentel, Albertina Fróes da Motta, Altino Teixeira, José Carlos Normando e Manuel Araujo.

Fonte: Elaborado pela pesquisadora

Quadro 11 - Ficha codicológica do sétimo documento

\section{TESTAMENTO DE AGOSTINHO FRÓES DA MOTTA}

1. Cota: Feira de Santana - Bahia; Centro de Documentação e Pesquisa/ UEFS; Seção Judiciária, Série Cíveis, Subsérie Inventário, Tipologia Testamento; Localização: Estante 06, Caixa 166 e Documento 2573.

2. Datação: 1922 - "1922 [...]" (f. 1r, 1. 1).

3. Lugar de origem: Feira de Santana - “[...] Feira de Sant'anna [...]” (f. 1r, 1. 3).

4. Fólio de abertura: "1922 | Juizo de Direito | Feira de Sant'anna | Autuação do testamento com que fal.| leceu nesta cidade o Coronel Agostinho | Fróes da Motta. | Escrivão | Ramalho | Anno de mil | novecentos e vinte e dois aos vinte | e treis (23) dias do mez de Março | do dito Anno autuo o testamento | que adeante se segue: do que faço | este termo. Eu Manuel

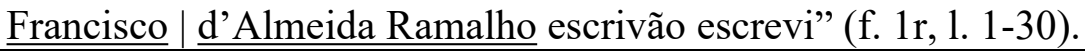




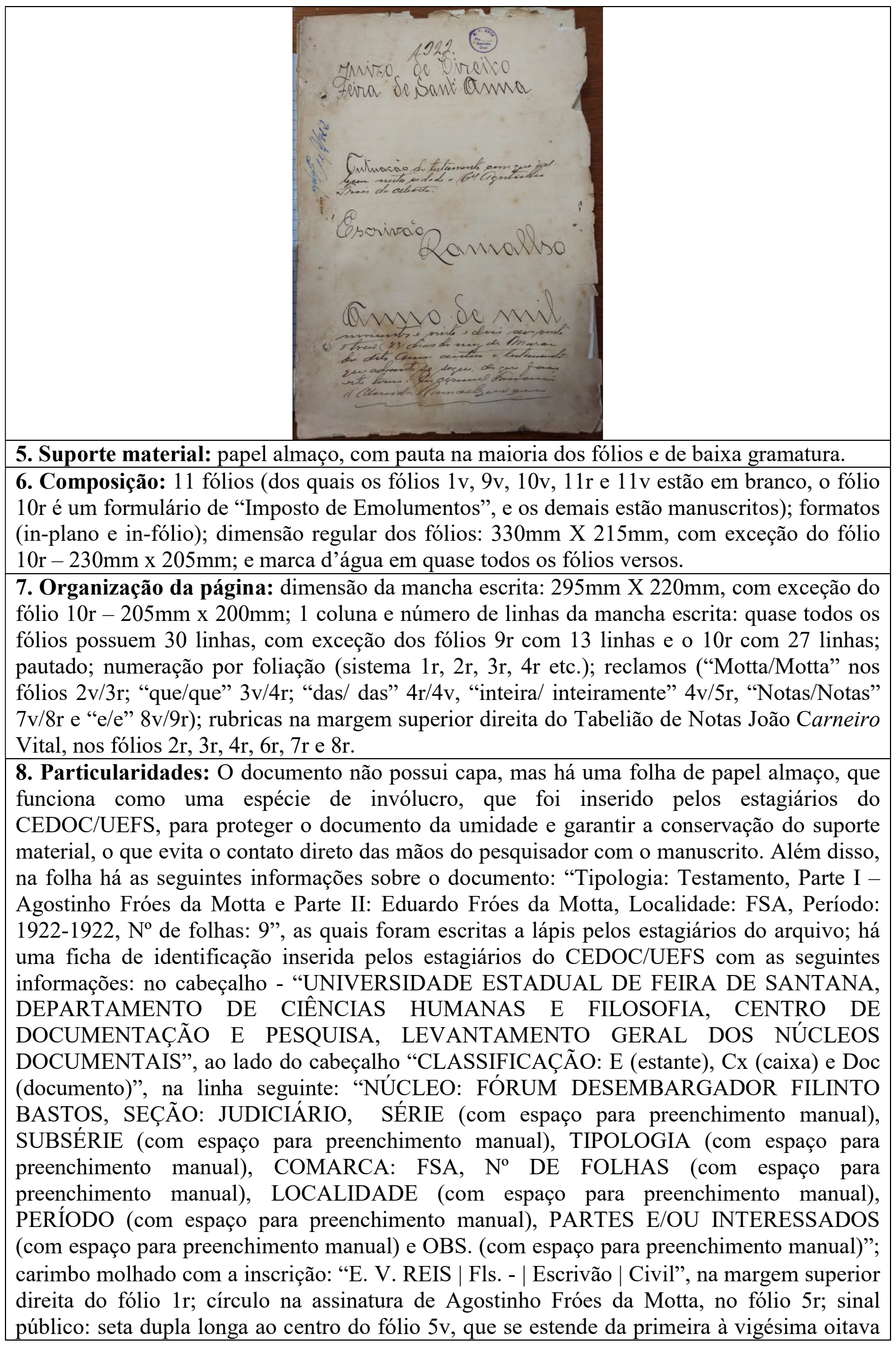


linha, cuja extremidade inferior aponta para a abreviatura JCV, equivalente à abreviatura do nome do Tabelião de Notas, João Carneiro Vital; dobras e rasgos nas margens do primeiro fólio.

9. Conteúdo: Trata-se do testamento do Coronel Agostinho Fróes da Motta, no qual há a descrição dos bens do referido coronel, bem como a sua vontade quanto à destinação de cada um deles, após a sua morte. Além disso, no documento é possível identificar as relações sociais, políticas, religiosas e familiares do testador para com os seus entes queridos e a comunidade feirense $^{79}$.

10. Escreventes: Manuel Francisco de Almeida Ramalho, João Carneiro Vital, Jacintho Ferreira da Silva e José Telles Barreto.

Fonte: Elaborado pela pesquisadora

Quadro 12 - Ficha codicológica do oitavo documento

\section{AÇÃO DE INSTRUMENTO DE AGRAVO REQUERIDA POR EDUARDO FRÓES DA MOTTA}

1. Cota: Feira de Santana - Bahia; Centro de Documentação e Pesquisa/ UEFS; Seção Judiciária, Série Cível; Subsérie: Ações; Tipologia Instrumento de Agravo; Localização: Estante 10, Caixa 256 e Documento 5370.

2. Datação: 1922 - "1922 [...]” (f. 1r, 1. 1).

3. Lugar de origem: Feira de Santana - "[...] Feira de Sant'anna [...]” (f. 1r, 1. 6).

4. Fólio de abertura: "1922 | Tribunal Superior d Justiça | Numero 1818 | Instrumento de ag-| gravado. | Feira de Sant'Anna. | Doutor Eduardo Fróes da Motta Aggravante | Engenheiro Alberto de Almeida Motta Aggravado | Juizo ao Excellentissimo Senhor Desembargador | Paulo Teixeira Relator | Ezequiel Pondé | Duarte Guimarães | O Escrivão | Igna[cio] Paschoal [rasgado]" (f. 1r, 1. 1-30).

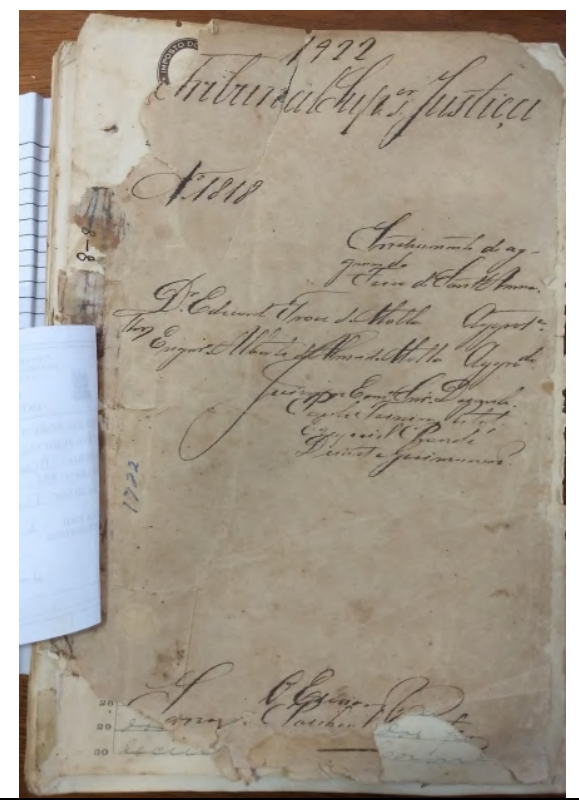

5. Suporte material: papel almaço, com pauta na maioria dos fólios e de baixa gramatura.

6. Composição: 95 fólios (dos quais os fólios $1 \mathrm{v}, 84 \mathrm{v}$ e $94 \mathrm{v}$ estão em branco, e todos os demais manuscritos, incluindo-se nestes o fólio 83r, que foi escrito a lápis); formatos (inplano e in-fólio); dimensão dos fólios variável: f. 1r - 330mm X 215mm, f. 2 r $-330 \mathrm{~mm}$ x

79 Mais detalhes do conteúdo deste documento serão retomados na seção 4.3.3 Descrição do conteúdo do corpus. 
220mm, f. 92r e 93r - 280mm x 210mm etc.; marca d'água em quase todos os fólios versos, com exceção dos fólios 1r, 86r, 88r, 89r, 90r, 91r, 92r, 93r e 94r.

7. Organização da página: dimensão da mancha escrita variável: f. 1r - 330mm X 195mm, f. $2 \mathrm{r}-328 \mathrm{~mm} \times 205 \mathrm{~mm}$, f. $92 \mathrm{r}$ e $93 \mathrm{r}-245 \mathrm{~mm} \times 195 \mathrm{~mm}$ etc.; 1 coluna e número de linhas da mancha escrita variável: f. 1r e $2 \mathrm{r}-30$ linhas, f. $70 \mathrm{v}-27$ linhas, f. $71 \mathrm{v}-23$ linhas, f. $79 \mathrm{v}-13$ linhas, f. 82v- 24 linhas, f. $84 r-9$ linhas, f. 85r - 25 linhas, f. 86r - 26 linhas, f. 92r - 15 linhas e f. 92v - 16 linhas etc.; pautado; numeração por foliação (sistema $1 \mathrm{r}^{80}, 2 \mathrm{r}, 3 \mathrm{r}, 4 \mathrm{r}$ etc.); reclamos em quase todo o documento, por exemplo: "seguem/ seguem" nos fólios $2 \mathrm{v} / 3 \mathrm{r}$; "Fran=/Francisco" 3v/4r; "com o/ com o" 4v/5r, "natu-/ natural" 5v/6r, "a von-/a vontade" 6v/7r, "e/e" 7v/8r; "a nem/nem" 9v/10r, "re-/referencia" 10v/11r, "da/da" 11v/12r, "mil/mil" $12 \mathrm{v} / 13 \mathrm{r}$, "Regis= /Registro" 13v/14r, "Phar- /Pharmaceutico" 14v/15r, "de/de" 16v/17r, "Março/Março" 17v/18r, "sob/ sob" 18v/19r, "tes/ testamento" 19v/20r, "publi=/ publico" $22 \mathrm{v} / 23 \mathrm{r}$, "dito/ dito" 23v/24r, "Os=/ Oscar" 24v/25r, "publico/ publico" 25v/26r, "acha= / achara" 28v/29r, "Entre- / Entretanto" 29v/30r, "domici=/ domiciliado" 30v/31r, "da/ da" 31v/32r, "trata $=$ / tratarem" 32v/33r, "seu/ seu" 33v/34r, "Clovis/ Clovis" 34v/35r; rubricas do Tabelião MRamalho - Manuel Ramalho, na margem superior direita dos fólios 72 ao 82 rectos.

8. Particularidades: O documento não possui capa, mas há uma folha de papel almaço, que funciona como uma espécie de invólucro, que foi inserido pelos estagiários do CEDOC/UEFS, para proteger o documento da umidade e garantir a conservação do suporte material, o que evita o contato direto das mãos do pesquisador com o manuscrito. Além disso, na folha há as seguintes informações sobre o documento: "Subsérie: Ações, Tipologia: Instrumento de Agravo, Parte I - Alberto de Almeida Motta e Parte II: Eduardo Fróes da Motta, Localidade: FSA, Período: 1922-1922, No de folhas: 93", as quais foram escritas a lápis pelos estagiários do arquivo; há uma ficha de identificação anexa ao primeiro fólio do documento, inserida pelos estagiários do CEDOC/UEFS com as seguintes informações: no cabeçalho - "UNIVERSIDADE ESTADUAL DE FEIRA DE SANTANA, DEPARTAMENTO DE CIÊNCIAS HUMANAS E FILOSOFIA, CENTRO DE DOCUMENTAÇÃO E PESQUISA, LEVANTAMENTO GERAL DOS NÚCLEOS DOCUMENTAIS", ao lado do cabeçalho "CLASSIFICAÇÃO: E (estante), Cx (caixa) e Doc (documento)", na linha seguinte: "NÚCLEO: FÓRUM DESEMBARGADOR FILINTO BASTOS, SEÇÃO: JUDICIÁRIO, SÉRIE (com espaço para preenchimento manual), SUBSÉRIE (com espaço para preenchimento manual), TIPOLOGIA (com espaço para preenchimento manual), COMARCA: FSA, $\mathrm{N}^{\mathrm{o}}$ DE FOLHAS (com espaço para preenchimento manual), LOCALIDADE (com espaço para preenchimento manual), PERÍODO (com espaço para preenchimento manual), PARTES E/OU INTERESSADOS (com espaço para preenchimento manual) e OBS. (com espaço para preenchimento manual)"; rasgaduras nas margens do fólio 1r; timbres estaduais, carimbos secos e riscos longos por toda extensão do documento; dois carimbos molhados com a inscrição: "TABELIÃO RAMALHO AGO 291922 | FEIRA DE SANT’ANNA", no fólio 86v; vários selos de impostos de variados valores ao longo do documento; palavras e/ou trechos grifados e/ou sinalizados com giz de cera azul ou caneta preta nos fólios $2 \mathrm{v}, 3 \mathrm{r}, 4 \mathrm{r} / \mathrm{v}, 5 \mathrm{r}, 11 \mathrm{v}, 13 \mathrm{v}, 26 \mathrm{v}, 28 \mathrm{r}, 38 \mathrm{v}, 47 \mathrm{r}, 48 \mathrm{r} / \mathrm{v}$, $49 \mathrm{r} / \mathrm{v}, 50 \mathrm{v}, 51 \mathrm{r} / \mathrm{v}, 52 \mathrm{r}, 53 \mathrm{r} / \mathrm{v}, 54 \mathrm{v}, 57 \mathrm{r}, 63 \mathrm{r}, 66 \mathrm{r} / \mathrm{v}, 68 \mathrm{r} / \mathrm{v}, 77 \mathrm{v}, 78 \mathrm{r}, 82 \mathrm{r} / \mathrm{v}, 88 \mathrm{v}$ e $90 \mathrm{r} ;$ rasgos nas margens superiores direita e esquerda, e inferiores direita e esquerda do fólio 1r; fólios 1r ao $2 \mathrm{v}, 71 \mathrm{r}$ ao $83 \mathrm{v}$ e o $90 \mathrm{r}$ ao $94 \mathrm{v}$ estão presos por uma colagem; e, em alguns trechos do

\footnotetext{
${ }^{80}$ Cabe ressaltar que esta numeração foi iniciada pelo escrevente a partir do fólio $2 \mathrm{r}$, o qual foi sinalizado como sendo o $1 \mathrm{r}$, haja vista que o primeiro não foi numerado, portanto, ficou fora da contagem geral dos fólios. Inferimos, a partir disto, que essa contagem foi feita levando-se em consideração que o fólio 1r pode ter sido visto pelo escrevente como não apenas um termo de abertura do processo, mas como uma espécie de capa do processo e que, devido a isso, pode não ter sido numerado e nem contabilizado por aquele.
} 
documento, riscaduras feitas pelos escreventes, e manchas ocasionadas por um papel em cima do outro.

9. Conteúdo: Trata-se de uma ação de instrumento de agravo, lavrada em 1922, e requerida por Eduardo Fróes da Motta contra o seu irmão Alberto de Almeida Motta. Neste processo há referência ao pedido de reconhecimento de paternidade pleiteado pelo agravado no inventário do seu pai, Agostinho Fróes da Motta, cujas provas apresentadas por aquele acabaram sendo refutadas por Eduardo Fróes da Motta, no que dizia respeito à inserção do nome de Alberto de Almeida Motta no título de herdeiros do inventariado.

Para contestar isso, o advogado de defesa de Eduardo Fróes da Motta solicitou a trasladação do contrato ante-nupcial dos pais de Alberto e do testamento de Agostinho Fróes da Motta, nos quais este afirmou ter apenas 6 filhos, frutos do primeiro casamento com Dona Maximiana de Almeida Motta, e Dona Guilhermina de Almeida Motta apenas um: o referido Alberto de Almeida Motta. Os referidos documentos foram utilizados como provas de que os nubentes, à época do contrato ante-nupcial, tinham filhos, mas que Alberto de Almeida Motta era filho apenas e exclusivamente de sua mãe, já que o coronel não havia declarado ser o seu pai.

Entretanto, mesmo com as provas apresentadas por Alberto - cartões postais, cartas, fotografias e o proclama do seu casamento publicado no jornal Folha do Norte, o advogado de Eduardo Fróes da Motta fez menção de que as palavras de carinho constantes nos documentos apresentados eram provas de que tanto o pai quanto o próprio Eduardo tinham afeto por Alberto, assim como sentiriam por qualquer outra pessoa que sentissem carinho, por isso poderiam tê-lo chamado de filho e de irmão nas correspondências.

Entretanto, a partir do fólio 13r há a transcrição das duas vias do testamento do Coronel Agostinho Fróes da Motta: uma que havia ficado cerrada em cofre particular e outra registrada no Livro de Notas do Tabelião João Carneiro Vital. Essas transcrições foram solicitadas por Eduardo Fróes da Motta, a fim de comprovar a não menção do nome de Alberto entre os herdeiros citados pelo seu pai, incluindo-se também como justificativa do não reconhecimento legal da paternidade o sobrenome patronímico "Fróes da Motta" que os filhos legítimos possuíam e Alberto de Almeida Motta não.

Em contrapartida, o advogado de Alberto de Almeida Motta contestou as afirmações do advogado de Eduardo Fróes da Motta, afirmando que os documentos apresentados somados às testemunhas ouvidas eram as provas de que não somente o coronel o reconhecia como filho, como também o próprio matrimônio do inventariado com a genitora de Alberto de Almeida Motta se configuravam motivo legal para o reconhecimento de sua paternidade, além da afirmação de que a não adoção do sobrenome patronímico "Fróes da Motta" não se configurava prova da não paternidade, pois o sobrenome herdado dos seus ascendentes seria o "Motta" e não o "Fróes da Motta" e que isso era tão verdadeiro que as suas irmãs, enquanto solteiras, possuíam apenas o sobrenome Motta, como eram os casos de Albertina de Almeida Motta, Amália de Almeida Motta e Adalgisa de Almeida Motta e não Fróes da Motta, como utilizado pelos seus irmãos, Eduardo Fróes da Motta, Augusto Fróes da Motta e Arthur Fróes da Motta, provas que culminaram no deferimento de sua reclamação para que o seu nome fosse, enfim, lançado no título de herdeiros do inventariado, já que o inventário dos bens deixados pelo seu pai estava em andamento. Assim, mesmo com a contestação do seu irmão Eduardo Fróes da Motta, em 23 de novembro de 1922, a ação foi encerrada com o ganho de causa por parte de Alberto de Almeida Motta, e feita a publicação da decisão judicial nas notas oficiais.

10. Escreventes: Ignacio Paschoal Bastos, Manuel Francisco de Almeida Ramalho, João Carneiro Vital, Antonio Monis Ornellas, Domingos Adami, Francisco Xavier Ferreira da 
Silva, Paulo Teixeira, Manoel Pimentel, João Marques dos Reis, Archimedes Pessôa da Silva ${ }^{81}$, José Maria Neves, José Carlos Normando, Ezequiel Pondé e Leovigildo de Carvalho. Fonte: Elaborado pela pesquisadora

Quadro 13 - Ficha codicológica do nono documento

\section{AÇÃO EXECUTIVA ${ }^{82}$ REQUERIDA POR ARTHUR FRÓES DA MOTTA}

1. Cota: Feira de Santana - Bahia; Centro de Documentação e Pesquisa/ UEFS; Seção Judiciária, Série Cíveis; Subsérie: Ações; Tipologia Ação Executiva; Localização: Estante 10, Caixa 255 e Documento 5366.

2. Datação: 1922 a 1924 - "1922 28-7-24 [...]" (f. 1r, 1. 1).

3. Lugar de origem: Feira de Santana - “[...] Feira de Sant'anna [...]” (f. 1r, 1. 3).

4. Fólio de abertura: "1922 28-7-24 | Juizo de Direito | Feira de Sant'anna | Acção Executiva | Pharmaceutico Arthur Froes da Motta | exequente | Augusto Froes da Motta. | executado. | Escrivão | Ra [rasgado + 10 linhas]" (f. 1r, 1. 1-19).

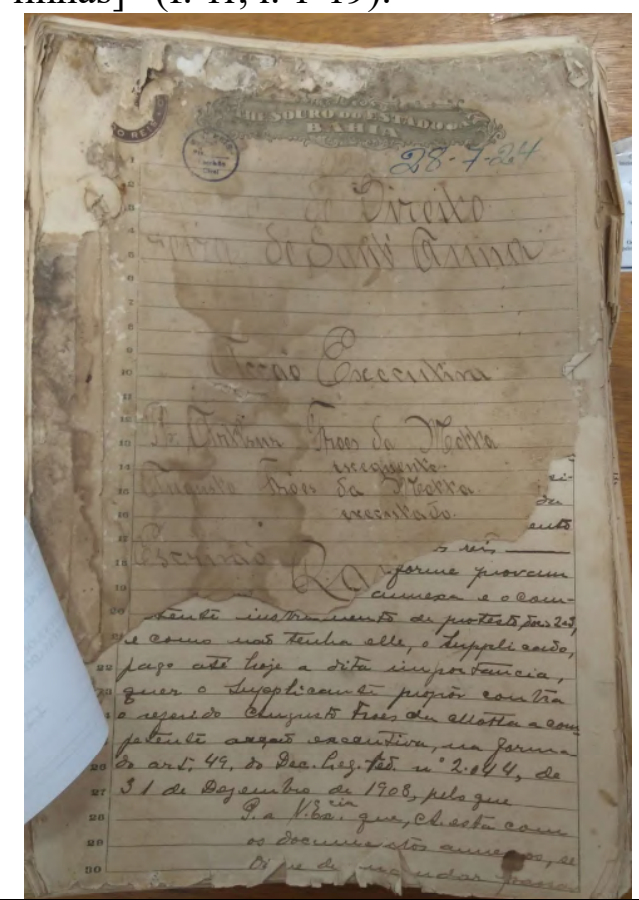

5. Suporte material: papel almaço, com pauta na maioria dos fólios e de baixa gramatura.

6. Composição: 179 fólios (dos quais os fólios 1v, 5v, 16v, 18v, 22r, 37r, 45r, 46v, 61v, 64v, $66 \mathrm{v}, 80 \mathrm{v}, 93 \mathrm{v}, 94 \mathrm{v}, 96 \mathrm{v}, 97 \mathrm{v}, 98 \mathrm{v}, 156 \mathrm{v}, 157 \mathrm{v}, 161 \mathrm{v}, 165 \mathrm{v}, 166 \mathrm{v}$ e $173 \mathrm{v}$ estão branco; os fólios 46r, 51v e 62r são híbridos ${ }^{83}$; os fólios $49 \mathrm{r} / \mathrm{v}$, 50r/v e $51 \mathrm{r}$ são datiloscritos; o fólio $6 \mathrm{r}$ é um formulário de Letra de Câmbio, o 16r é um formulário de Imposto de Taxa Judiciária, os $17 \mathrm{r}$ e $18 \mathrm{r}$ são formulários de Impostos de Custas Judiciárias, o $67 \mathrm{r}$ é um formulário de Imposto de Selo por Verba, o 72r e 74r são formulários de Impostos de Emolumentos, o 91r é

\footnotetext{
${ }^{81}$ Formado em Ciências Jurídicas em 1911 pela Faculdade Livre de Direito da Bahia.

${ }^{82}$ Este documento encontra-se, atualmente, em fase de edição semidiplomática, atividade vinculada ao plano de trabalho intitulado Edições fac-similar e semidiplomática de uma ação executiva novecentista do sertão baiano $\mathrm{e}$ desenvolvido por um bolsista de Iniciação Científica, vinculado ao Projeto de Pesquisa intitulado Estudo filológico-linguístico de documentos jurídicos da Bahia novecentista, aprovado, em vigência desde julho de 2019 e coordenado pela autora desta tese junto à Universidade Federal do Oeste da Bahia, instituição em que a referida autora é docente.

${ }^{83} \mathrm{Na}$ descrição codicológica, utilizamos o termo "híbrido" para indicar fólios que possuem trechos datiloscritos e/ou timbrados (próprios de formulários) e manuscritos.
} 
um formulário de Certificado de Registro e o 95r é um formulário de Imposto de transmissão e transcripção de certidão; o fólio 33r é uma página do Jornal Folha do Norte com o título "Mulheres levianas", na qual há decisões do referido processo publicadas no referido periódico; os fólios 38r e 42r são duas páginas do Jornal Folha do Norte com a publicação dos editais de $2^{\mathrm{a}}$ e $3^{\mathrm{a}}$ Praças, constantes neste processo; e os demais fólios são manuscritos); formatos (in-plano e in-fólio); dimensão dos fólios variável: f. $1 \mathrm{r}-240 \mathrm{~mm}$ x 205mm, f. 4r $335 \mathrm{~mm}$ X 220mm, f. $6 \mathrm{r}-290 \mathrm{~mm}$ x $110 \mathrm{~mm}$, f. $95 \mathrm{r}$ e $96 \mathrm{r}-330 \mathrm{~mm}$ x $200 \mathrm{~mm}$ etc.; documento incompleto.

7. Organização da página: dimensão da mancha escrita variável: f. $1 \mathrm{r}-205 \mathrm{~mm} \times 160 \mathrm{~mm}$, f. $4 \mathrm{r}-313 \mathrm{~mm} \times 180 \mathrm{~mm}$, f. $6 \mathrm{r}-290 \mathrm{~mm} \times 110 \mathrm{~mm}$, f. $95 \mathrm{r}$ e $96 \mathrm{r}-205 \mathrm{~mm} \times 165 \mathrm{~mm}$ etc.; 1 coluna e número de linhas da mancha escrita variável: f.1r - 20 linhas, f. $2 \mathrm{r}, 3 \mathrm{r}, 4 \mathrm{r} / \mathrm{v}, 5 \mathrm{r}-30$ linhas, f. $2 \mathrm{v}-25$ linhas, f. $3 \mathrm{v}, 12 \mathrm{v}$ e $20 \mathrm{v}-8$ linhas, f. $6 \mathrm{v}-10$ linhas, f. $7 \mathrm{r}-13$ linhas, f. $7 \mathrm{v}-$ 7 linhas, f. 10v - 21 linhas, f. $12 \mathrm{r}-5$ linhas, f. 15r e 20r - 18 linhas, f. $23 \mathrm{v}-13$ linhas, f. $44 \mathrm{v}$ - 6 linhas, f. 56v, 77v, 80v, 81r/v, 82r/v, 83r/v, 84r/v, 85r/v, 86r - 23 linhas, f. 86v - 2 linhas etc.; pautado; numeração por foliação (sistema 1r, 2r, 3r, 4r etc.); reclamos ("afim/afim" nos fólios 11v/12r; "para/para" 9v/10r; "merca/mercador" 4v/5r, "com/com" 27v/28r, "a/a" 40v/41r, "um/um" 52v/53r, "por/por" 84v/85r; "Do=/Documento" 128v/129r, "con=/contos" 129v/130r, "Augusto/Augusto" 130v/131r etc.); rubricas na margem superior direita do Tabelião de Notas JoãoCVital, nos fólios 4r, 5r, 52r, 65r e 66r; e rubricas do escrivão MRamalho na margem superior direita dos fólios 57r, 58r, 59r, 60r, 61r, 62r, 63r e 64r.

8. Particularidades: O documento não possui capa, mas há uma folha de papel almaço, que funciona como uma espécie de invólucro, que foi inserido pelos estagiários do CEDOC/UEFS, para proteger o documento da umidade e garantir a conservação do suporte material, o que evita o contato direto das mãos do pesquisador com o manuscrito. Além disso, na folha há as seguintes informações sobre o documento: "Subsérie: Ações, Tipologia: Ação Executiva, Parte I - Augusto Fróes da Motta e Parte II: Arthur Fróes da Motta, Localidade: FSA, Período: 1922-1924, Nº dolhas: 177”, as quais foram escritas a lápis pelos estagiários do arquivo; há uma ficha de identificação anexa ao primeiro fólio do documento, inserida pelos estagiários do CEDOC/UEFS com as seguintes informações: no cabeçalho "UNIVERSIDADE ESTADUAL DE FEIRA DE SANTANA, DEPARTAMENTO DE CIÊNCIAS HUMANAS E FILOSOFIA, CENTRO DE DOCUMENTAÇÃO E PESQUISA, LEVANTAMENTO GERAL DOS NÚCLEOS DOCUMENTAIS", ao lado do cabeçalho "CLASSIFICAÇÃO: E (estante), Cx (caixa) e Doc (documento)", na linha seguinte: "NÚCLEO: FÓRUM DESEMBARGADOR FILINTO BASTOS, SEÇÃO: JUDICIÁRIO, SÉRIE (com espaço para preenchimento manual), SUBSÉRIE (com espaço para preenchimento manual), TIPOLOGIA (com espaço para preenchimento manual), COMARCA: FSA, $\mathrm{N}^{\circ}$ DE FOLHAS (com espaço para preenchimento manual), LOCALIDADE (com espaço para preenchimento manual), PERÍODO (com espaço para preenchimento manual), PARTES E/OU INTERESSADOS (com espaço para preenchimento manual) e OBS. (com espaço para preenchimento manual)"; riscos longos em alguns fólios do documento; trechos destacados em cor vermelha; sinal público: seta dupla longa ao centro dos fólios $5 \mathrm{r}, 54 \mathrm{r}$ e $66 \mathrm{r}$, cuja extremidade inferior aponta para a abreviatura JCV, equivalente à abreviatura do nome do Tabelião de Notas, João Carneiro Vital; rasgos nas margens dos fólios 1r/v; muitas marcas de umidade, nos fólios $2 \mathrm{r}, 3 \mathrm{r} / \mathrm{v}, 7 \mathrm{r}$ e $11 \mathrm{r} / \mathrm{v}$; vários carimbos molhados, dentre os quais podemos mencionar: um com a inscrição "E. V. REIS | Fls. - | Escrivão Civil", na margem superior esquerda do fólio 1r; outro com a inscrição "TABELLIÃO RAMALHO | NOV 16 923| FEIRA DE SANT'ANNA”, na margem centro-direita do fólio 3v; um carimbo molhado com a inscrição "FIEL FONTES | Unapetinga de Souza Guimarães ADVOGADOS | CONSELHEIRO DANTAS | (RUA DO CAFÉ PIRANGY) | Tel. 280 BAHIA", na margem superior esquerda do fólio 47r; outro carimbo molhado com a inscrição 
“COLLECTORIA FEDERAL | FEIRA DE SANT'ANNA", na margem inferior direita do fólio 70r; um carimbo seco da Intendência Municipal de Feira de Santana, no fólio 55r; diversos selos de impostos ao longo do documento, dentre os quais podemos mencionar, por exemplo: 1 selo no valor de 300 réis no fólio $2 \mathrm{v} ; 1$ selo no valor de 2 réis no fólio $3 \mathrm{r} ; 2$ selos no valor de 300 réis no fólio 5r; 2 selos no valor de 300 réis no fólio $8 \mathrm{v} ; 7$ selos no valor de hum mil réis e 2 no valor de 300 réis no fólio 19r; 1 selo no valor de 300 réis nos fólios $23 \mathrm{r}$ e 25 r, respectivamente; 7 selos no valor de 300 réis no fólio 47r; 2 selos no valor de 300 réis nos fólios $51 \mathrm{v}$ e $53 \mathrm{v}$, respectivamente; 1 selo no valor de 300 réis no fólio $54 \mathrm{v}$; 2 selos no valor de hum mil réis e outro no valor de 300 réis nos fólios $55 \mathrm{r}$ e $56 \mathrm{r}$, respectivamente; 2 selos no valor hum mil réis no fólio $61 \mathrm{r}$ etc.; fólios que se encontram presos por uma colagem: f. $1 \mathrm{r}$ ao $3 \mathrm{v}, 27 \mathrm{r}$ ao $28 \mathrm{r}, 46 \mathrm{r}$ ao $47 \mathrm{v}, 57 \mathrm{r}$ ao $61 \mathrm{v}, 62 \mathrm{r}$ ao $64 \mathrm{v}, 65 \mathrm{r}$ ao $67 \mathrm{v}, 71 \mathrm{r}$ ao $72 \mathrm{v}$ e $73 \mathrm{r}$ ao $74 \mathrm{v}$; o fólio $1 \mathrm{r}$ apresenta $130 \mathrm{~mm}$ de suporte material rasgado, ou seja, informações perdidas; riscaduras em alguns trechos do documento.

9. Conteúdo: Trata-se de uma ação executiva solicitada por Arthur Fróes da Motta e lavrada entre 1922 a 1924. A ação se refere a uma dívida no valor de 50:117, 900 (cinquenta contos, cento e dezessete mil e novecentos réis) devidos, através de uma nota promissória, por Augusto Fróes da Motta ao autor desta ação, o qual foi à Justiça Pública cobrar o devido pagamento.

Entretanto, como Augusto Fróes da Motta informou que não teria condições financeiras de pagar ao seu irmão, os seus bens e os de sua esposa, Almerinda de Almeida da Motta, acabaram sendo penhorados. Assim, 13 casas, situadas no centro da cidade de Feira de Santana-BA, e 3 fazendas (Boqueirão, distrito de Tanquinho; São Luiz, Distrito de Humildes; e Boa Vista, distrito de Feira de Santana-BA) foram descritas e avaliadas por avaliadores designados pelo Juiz para que fossem leiloadas, e o pagamento realizado a Arthur Fróes da Motta.

Contudo, após o lançamento do Edital de Primeira Praça Pública no Juízo de Direito da Comarca de Feira de Santana, feito a pedido de Arthur Fróes da Motta, e para o qual não apareceu comprador para os bens, o Juiz lançou um Segundo Edital com abatimento de dez por cento em cima de cada bem, mas como não houve comprador interessado, o mesmo Juiz, Jacintho Ferreira da Silva, lançou um Terceiro Edital com o abatimento de vinte por cento no valor dos bens.

Todos os editais foram publicados no Jornal Folha do Norte, a fim de tornar pública e dentro da lei a venda dos referidos bens, para os quais, no dia do leilão do último edital, apareceu Arthur Assis, único licitante do leilão e empregado de Eduardo Fróes da Motta, irmão dos exequente e executado, ofertando o valor de quinze contos de réis, quando o valor pedido foi o de 44:040,000 (quarenta e quatro contos e quarenta mil réis) sobre todos os bens leiloados.

Entretanto, após a publicação dos autos de arrematação, em 13 de março de 1923, Dona Almerinda de Almeida Motta, esposa de Augusto Fróes da Motta, pediu vistas dos autos de arrematação por se sentir prejudicada naqueles, alegando, inclusive, que a penhora dos bens do casal se deu por um suposto débito do seu marido, o qual foi reconhecido por este, mas que tudo, segundo aquela, não passava de uma "farsa" do seu próprio marido, do seu cunhado e de terceiros contra aquela.

Essa afirmação se dava porque, segundo a embargante, o seu marido queria retirar-lhe os referidos bens por conta de um problema conjugal ocorrido no dia 22 de março de 1922, quando o cônjuge deu-lhe um tiro com arma de fogo por conta de "insinuações e calúnias de infidelidade" contra aquela e que, portanto, depois dessa data, ela solicitou o desquite, mas o marido teria inventado a referida dívida para the prejudicar financeiramente, haja vista que, segundo ela, antes daquele acontecimento, ele nunca havia contraído esse tipo de dívida e que, até então, viviam bem financeiramente. 
Para comprovar as suas afirmações, a embargante apresentou doze documentos, dentre os quais figuravam certidões que comprovavam 1) o pagamento de impostos do seu marido e do arrematante, 2) a menção ao nome do arrematante como testemunha tanto no processo criminal $^{84}$ que o seu marido respondeu por tentativa de homicídio quanto na ação de desquite $^{85}$ que ela moveu contra aquele e 3) traslado da meação recebida por seu marido no inventário de sua sogra, que comprovariam a veracidade de suas acusações sobre o seu marido.

Contudo, o advogado de Augusto Fróes da Motta, Vicente dos Reis, contestou o instrumento de agravo proposto pela embargante e o que se seguiu foi o depósito feito ao escrivão, Manuel Francisco de Almeida Ramalho, da quantia referente ao auto de arrematação feito pelo arrematante, Arthur de Assis. A partir do fólio 92r, o exequente da ação, Arthur Fróes da Motta, solicitou em 14 de maio de 1923, através de um termo de levantamento da quantia de 44:040,000, o recebimento do depósito feito no cartório, ou seja, mesmo oferecendo quinze contos de réis, o arrematante acabou depositando o valor de 44:040,000 de réis, sem, no entanto, explicar o por quê dessa divergência de valores.

Para recebê-los, o executante apresentou como seu fiador Eduardo Fróes da Motta, o qual garantira à Justiça que, caso a esposa de Augusto Fróes da Motta ganhasse a ação movida contra o marido, o valor retirado da guarda cartorial poderia ser devolvido. Depois dos argumentos apresentados pelos advogados de Arthur Fróes da Motta e pelo de sua cunhada, no dia 14 de junho de 1924 começou a ser declarada a decisão do Juiz de Direito da Comarca de Feira de Santana, com base na decisão do Egrégio Superior Tribunal (o qual foi favorável à apelação de Dona Almerinda de Almeida Motta), que levou em consideração as alegações e as provas apresentadas pelo advogado da embargante, mas não se sabe, contudo, a decisão final do Juiz de Direito, pois está faltando o último fólio, haja vista o fólio $178 \mathrm{v}$ conter informações inconclusivas, constatadas a partir de um texto de conclusão processual iniciado, mas não finalizado. Portanto, não se sabe o que o Juiz de Direito da Comarca de Feira de Santana deferiu neste processo, mesmo após ser divulgado o veredicto do Egrégio Superior Tribunal de Justiça.

\footnotetext{
${ }^{84}$ Ao termos acesso a esse documento, identificamos que o Capitão da Brigada Nacional Augusto Fróes da Motta se tornou réu em um processo crime de lesão corporal por ter disparado um tiro de arma de fogo, à queima-roupa, contra a sua esposa, Dona Almerinda de Almeida Motta, exatamente no dia 22 de março de 1922, horas antes do óbito do Coronel Agostinho Fróes da Motta, pai e genro do réu e da autora, respectivamente. Nesse processo, o réu acusou a sua esposa de ter cometido adultério com Auto Esmeraldo dos Reis, médico assistente do seu pai, este acamado na época. Contudo, apesar da confissão do réu de tentativa de homicídio e da legitimação do ato por parte do depoimento de algumas testemunhas, dentre as quais estava Arthur Assis, o arrematante dos bens de Augusto Fróes da Motta na referida Ação Executiva, o réu foi absolvido por dois fatores: primeiro, pelo crime ter sido considerado um "crime de honra" e, segundo, por causa da sua influência econômica e social na sociedade feirense vigente. Logo, trata-se de um documento que explica várias relações familiares e o motivo da existência de alguns processos mencionados no quadro 3 desta tese como, por exemplo, a referida ação executiva e o documento de número 20, o Alvará solicitado por Augusto Fróes da Motta. Cabe destacar que esse processo crime de lesão corporal não figura entre os vinte e sete documentos descritos codicologicamente nesta seção, porque priorizamos apenas os processos cíveis. Contudo, o referido processo, cuja autora foi Almerinda de Almeida Motta e o réu, Augusto Fróes da Motta, lavrado em 1922, com 54 fólios, escritos no recto e verso e também armazendo no CEDOC/UEFS sob a localização: Estante 05, Caixa 121 e Documento 2431, encontra-se, atualmente, em fase de edição semidiplomática, levantamento de abreviaturas e estudo do léxico jurídico, realizados no plano de trabalho intitulado Edição semidiplomática e estudo do vocabulário jurídico de uma ação de lesão corporal novecentista do Sertão baiano, desenvolvido por uma bolsista de Iniciação Científica, vinculada ao Projeto de Pesquisa intitulado Estudo filológico-linguístico de documentos jurídicos da Bahia novecentista, aprovado, em vigência desde julho de 2019 e coordenado pela autora desta tese junto à Universidade Federal do Oeste da Bahia, instituição em que a referida autora é docente.

${ }^{85}$ Documento não catalogado no CEDOC/UEFS.
} 
10. Escreventes: Manuel Francisco de Almeida Ramalho, Jacintho Ferreira da Silva, Vicente dos Reis ${ }^{86}$, Arthur Fróes da Motta, João Carneiro Vital, Cesar Ribeiro de Cerqueira, Estanislau Alves Barretto, Manuel Araujo, José Telles Barreto, Manoel Satyro da Silva Ribeiro, Pedro Paulo da Silva, Arnold Ferreira da Silva, Joaquim Honorio d'Oliveira, Wenceslau Unapetinga de Souza Guimarães, Almerinda de Almeida Motta, Bernardino Bahia, Albertino Pedreira Dantas, Deoclecio da Silva Daltro, Oscar Erudilho, Leoncio Evangelista dos Santos, Manoel Costa Ferreira, José Moreira de Araujo, Joaquim Dultra Santos, Agnello Ribeiro de Macêdo, Ignacio Paschoal Bastos, Antonio Monis Ornellas, Domingos Adami, Arthur de Lemos, Francisco de Souza Dias, Manoel José de Magalhães Aguiar, Maximiano Cecilio Soledade, Lyderico Santos Cruz e Fiel Fontes.

Fonte: Elaborado pela pesquisadora

Quadro 14 - Ficha codicológica do décimo documento

INVENTÁRIO DO CORONEL AGOSTINHO FRÓES DA MOTTA

1. Cota: Feira de Santana - Bahia; Centro de Documentação e Pesquisa/ UEFS; Seção Judiciária, Série Cíveis; Subsérie: Inventário; Tipologia Inventário; Localização: Estante 06, Caixa 175 e Documento 2887.

2. Datação: 1922 - "1922 [...]" (f. 1r, 1. 1).

3. Lugar de origem: Feira de Santana - “[...] Feira de Sant'anna [...]” (f. 1r, 1. 3).

4. Fólio de abertura: "1922 | Juizo de Direito | Feira de Sant'anna $\mid \leq<$ Primeiro Volume $>>\mid$ Inventario | Julgado 22_9_1922 | Coronel Agostinho Fróes da Mott[rasgado] | fallecido c// testamento | Doutor Eduardo Fróes da Motta | inventariante e test[rasgado] | Escrivão Ram[rasgado] | Anno de [rasgado] | novecentos e vinte e do[rasgado] | nove (19) dias do $\mathrm{m}[$ rasgado] | do dito anno autu[rasgado] | [manchado] se segue; d[rasgado] | mo. Eu $\mathrm{M}[\underline{\mathrm{rasgado}}]$ | [escrevi]" (f. 1r, 1. 1-26).

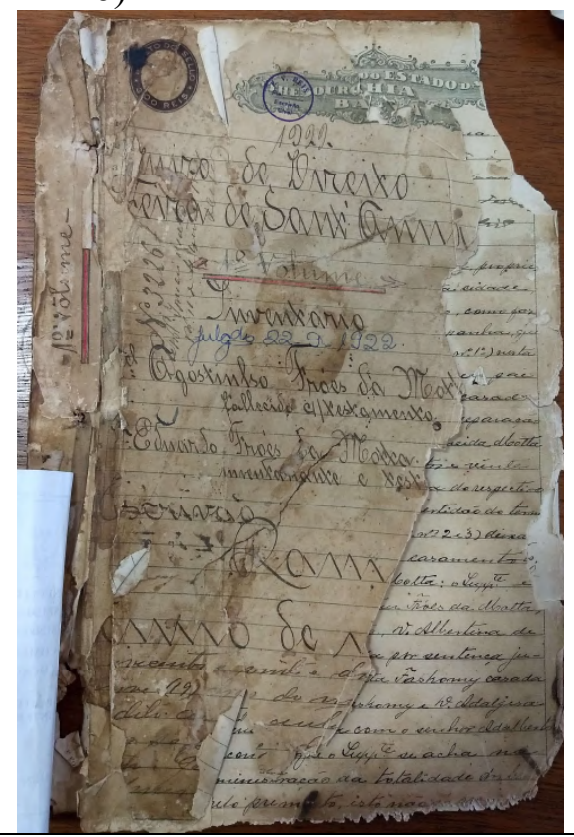

5. Suporte material: papel almaço, com pauta na maioria dos fólios e de baixa gramatura.

6. Composição: 799 fólios, subdivididos em 4 volumes, a saber: Volume I - 166 fólios,

\footnotetext{
${ }^{86}$ Autodeclarado como advogado e escrivão, formado pela Faculdade de Direito da Bahia, como consta na Ação ordinária de sonegados (1929) proposta por Arthur Fróes da Motta e Francelina Carneiro da Motta; Alberto de Almeida Motta e Maria Carlota Falcão de Sousa Motta.
} 
Volume II - 216 fólios, Volume III - 183 fólios e Volume IV: 234 fólios (dos quais, por exemplo, os fólios 27r, 30v, 36v, 43r, 44v, 45v, 46r, 51v, 57v, 58v, 59v, 62v, 63v, 66v, 76v, $78 \mathrm{r}, 83 \mathrm{v}, 84 \mathrm{v}, 87 \mathrm{v}, 93 \mathrm{v}, 94 \mathrm{v}, 98 \mathrm{v}, 101 \mathrm{v}, 102 \mathrm{r}, 102 \mathrm{v}, 107 \mathrm{v}, 109 \mathrm{v}, 114 \mathrm{v}, 116 \mathrm{v}, 125 \mathrm{v}, 126 \mathrm{v}$, $133 \mathrm{r}, 135 \mathrm{v}, 137 \mathrm{r}, 143 \mathrm{r}, 144 \mathrm{v}, 147 \mathrm{v}, 148 \mathrm{v}, 150 \mathrm{r}$ e $154 \mathrm{v}$ estão em branco; os 30r, 35r, 47r, 50r, $51 \mathrm{r}, 64 \mathrm{r}, 64 \mathrm{v}, 79 \mathrm{r}, 87 \mathrm{r}, 97 \mathrm{v}, 114 \mathrm{r}, 118 \mathrm{r}, 122 \mathrm{r}, 122 \mathrm{v}, 123 \mathrm{r}, 124 \mathrm{r}$ e 124v são híbridos; os 47v, 49v, 95r, 97r, 111r e 113v são datiloscritos; os 3r, 3v, 40r, 40v, 77r, 77v, 83r, 84r, 98r, 148r e 149r são formulários preenchidos manualmente; os fólios $150 \mathrm{v}$ ao $154 \mathrm{r}$ são folhas do livro de caixa da Firma Agostinho Fróes da Motta e Filho, que foram anexadas como fólios; e os demais fólios são manuscritos); formatos (in-plano e in-fólio); dimensão dos fólios variável: primeiro volume - fólio $1 \mathrm{r}-330 \mathrm{~mm}$ x $220 \mathrm{~mm}$, fólio $65 \mathrm{r}-315 \mathrm{~mm}$ X $215 \mathrm{~mm}$, f. $142 \mathrm{r}$ e $143 \mathrm{r}-$ $330 \mathrm{~mm} \times 220 \mathrm{~mm}$, f. $147 \mathrm{r}-215 \mathrm{~mm} \times 190 \mathrm{~mm}$, f. $148 \mathrm{r}-320 \mathrm{~mm} \times 430 \mathrm{~mm}$ etc; segundo volume: fólios $1 \mathrm{r}$ ao $215 \mathrm{r}-333 \mathrm{~mm}$ x $220 \mathrm{~mm}, 216 \mathrm{r}$ e $216 \mathrm{v}-328 \mathrm{~mm} \times 217 \mathrm{~mm}$; terceiro volume: $1 \mathrm{r}-330 \mathrm{~mm}$ x $215 \mathrm{~mm}, 2 \mathrm{r}-335 \mathrm{~mm}$ x $220 \mathrm{~mm}, 92 \mathrm{r}-261 \mathrm{~mm} \times 207 \mathrm{~mm}, 95 \mathrm{r}-275 \mathrm{~mm}$ x $210 \mathrm{~mm}, 105 \mathrm{r}-332 \mathrm{~mm}$ x 220mm, $129 \mathrm{r}-162 \mathrm{~mm}$ x $225 \mathrm{~mm}, 130 \mathrm{r}-273 \mathrm{~mm}$ x $212 \mathrm{~mm}$ etc.; quarto volume: $1 \mathrm{r}-330 \mathrm{~mm}$ x $220 \mathrm{~mm}, 61 \mathrm{r}-330 \mathrm{~mm} \times 218 \mathrm{~mm}, 71 \mathrm{r}-330 \mathrm{~mm} \times 215 \mathrm{~mm}, 163 \mathrm{r}$ $-268 \mathrm{~mm} \times 215 \mathrm{~mm}, 182 \mathrm{r}-257 \mathrm{~mm} \times 210 \mathrm{~mm}, 202 \mathrm{r}-333 \mathrm{~mm} \times 245 \mathrm{~mm}$ etc.

7. Organização da página: dimensão da mancha escrita variável: fólio $1 \mathrm{r}-325 \mathrm{~mm} \mathrm{x}$ $180 \mathrm{~mm}$, fólio $65 \mathrm{r}-295 \mathrm{~mm} \times 170 \mathrm{~mm}$, f. $142 \mathrm{r}-265 \mathrm{~mm} \times 180 \mathrm{~mm}$, f. $143 \mathrm{r}-320 \mathrm{~mm} \times$ $180 \mathrm{~mm}$, f. $147 \mathrm{r}-125 \mathrm{~mm} \times 170 \mathrm{~mm}$, f. $148 \mathrm{r}-280 \mathrm{~mm}$ x $430 \mathrm{~mm}$ etc.; segundo volume: fólios $1 \mathrm{r}$ ao $215 \mathrm{r}-320 \mathrm{~mm} \times 206 \mathrm{~mm}, 216 \mathrm{r}-315 \mathrm{~mm} \times 180 \mathrm{~mm}, 216 \mathrm{v}-66 \mathrm{~mm} \times 171 \mathrm{~mm}$; terceiro volume: $1 \mathrm{r}-315 \mathrm{~mm}$ x $200 \mathrm{~mm}, 2 \mathrm{r}-325 \mathrm{~mm} \times 200 \mathrm{~mm}, 2 \mathrm{v}-275 \mathrm{~mm} \times 175 \mathrm{~mm}, 92 \mathrm{r}-200 \mathrm{~mm}$ x $180 \mathrm{~mm}, 95 \mathrm{r}-260 \mathrm{~mm} \times 182 \mathrm{~mm}, 105 \mathrm{r}-322 \mathrm{~mm} \times 180 \mathrm{~mm}, 129 \mathrm{r}-148 \mathrm{~mm} \times 220 \mathrm{~mm}, 130 \mathrm{r}-$ $270 \mathrm{~mm}$ x $205 \mathrm{~mm}$ etc.; quarto volume: $1 \mathrm{r}-315 \mathrm{~mm} \times 175 \mathrm{~mm}, 61 \mathrm{r}-310 \mathrm{~mm} \times 182 \mathrm{~mm}, 71 \mathrm{r}-$ $315 \mathrm{~mm} \times 202 \mathrm{~mm}, 163 \mathrm{r}-255 \mathrm{~mm} \times 183 \mathrm{~mm}, 182 \mathrm{r}-195 \mathrm{~mm} \times 185 \mathrm{~mm}, 202 \mathrm{r}-292 \mathrm{~mm} \times$ $212 \mathrm{~mm}$ etc.; 1 coluna na maioria dos fólios, com exceção dos fólios $129 \mathrm{v}$ ao $133 \mathrm{v}$, e número de linhas da mancha escrita variável: f. 1r e $2 \mathrm{r}-30$ linhas, f. 26v - 27 linhas, f. 27v, 29v, 97v, $110 \mathrm{v}$ e $118 \mathrm{v}-8$ linhas, f. $28 \mathrm{v}, 121 \mathrm{r}$ e $138 \mathrm{r}$ ao $142 \mathrm{r}-23$ linhas, f. 29r, 34r e 100v - 14 linhas, f. $33 \mathrm{r}-10$ linhas, f. $33 \mathrm{v}, 123 \mathrm{v}$ e $134 \mathrm{v}-7$ linhas, f. $34 \mathrm{v}$ e $137 \mathrm{v}-6$ linhas, f. $40 \mathrm{v}-2$ linhas, f. $42 \mathrm{v}$ e $92 \mathrm{v}-15$ linhas, f. 50r - 21 linhas, f. 79v - 16 linhas, f. 82r - 24 linhas, f. 86v e 116r - 5 linhas, f. 117v - 18 linhas; f. 121v - 22 linhas, f. 125r - 17 linhas, f. 126r - 28 linhas, f. 142v - 4 linhas, f. $147 \mathrm{r}$ - 9 linhas etc.; pautado; numeração por foliação em quase todos os fólios rectos (sistema 1r, 2r, 3r, 4r etc.); reclamos ao longo de todo o documento, por exemplo: "Cotegi/ Cotegipe" nos fólios 16v/17r, "inclusive/ inclusive" 19v/20r, "opportuna-/ opportunamente" 21v/22r, "um/ um" 23v/24r, "uma/ uma" 24v/25r e 130v/131r, "Na/ Na" 25v/26r, "sendo-lhe/ sendo-lhe" 38v/39r, "dese-/ desesseis" 52v/53r, "vinte/ vinte" 53v/54r, "colla/ colladas" 55v/56r, "no-/ novecentos" 56v/57r, "Per-/ Perguntado" 67v/68r, "Agostinho/ Agostinho" 70v/71r, "Perguntado/ Perguntado" 71v/72r, "nascera/ nascera" 72v/73r, "do/ do" 80v/81r, "digo/ digo" 92r/92v, "nubente/ nubente" 99v/100r, "fi-/ filho" $103 \mathrm{v} / 104 \mathrm{r}$, “este/ este" 106v/107r, "ja/ Jacintho" 117r/117v, "Cento/ Cento" 127v/128r, "quantia/ quantia" 130r/130v, "de/ de" 131r/131v, "janel=/ janellas" 131v/132r, "quan-/ quantia" 133r/133v, "cadeiras/ cadeiras" 155v/156r, "sa-/ sallas" 158r/158v, "vin-/ vinte" 158v/159r, "tanque de/ tanque de" 159v/160r, "voltada/ voltada" 160v/161r, "Sul./ Sul." 161v/162r, "Henrique/ Henrique" 164v/165r, e "Noticias/ Noticias" 165v/166r; rubricas do escrivão "Mramalho", Manuel Francisco de Almeida Ramalho, na margem superior direita dos fólios $4 \mathrm{r}$ ao $15 \mathrm{r}$, do $18 \mathrm{r}$, ao $20 \mathrm{r}$, do $103 \mathrm{r}$ ao $105 \mathrm{r}$, e do tabelião "JoãoCVital", João Carneiro Vital, na margem superior direita dos fólios $16 \mathrm{r}$, $17 \mathrm{r}$ e do $99 \mathrm{r}$ ao $101 \mathrm{r}$ etc.

8. Particularidades: O documento não possui capa, mas há uma folha de papel almaço, que funciona como uma espécie de invólucro, que foi inserido pelos estagiários do CEDOC/UEFS, para proteger o documento da umidade e garantir a conservação do suporte material, o que evita o contato direto das mãos do pesquisador com o manuscrito. Além disso, 
na folha há as seguintes informações sobre o documento: Volume 1: "Subsérie: Inventário, Parte I - Agostinho Fróes da Motta e Parte II: Eduardo Fróes da Motta, Localidade: FSA, Período: 1922-1922, № de folhas: 164, VOLUME I"; Volume 2: "Subsérie: Inventário, Parte I - Agostinho Fróes da Motta e Parte II: Eduardo Fróes da Motta, Localidade: FSA, Período: 1922-1924, No de folhas: 216, VOLUME II", Volume 3: "Subsérie: Inventário, Parte I Agostinho Fróes da Motta e Parte II: Eduardo Fróes da Motta, Localidade: FSA, Período: 1924-1925, No de folhas: 172, Obs: há uma folha sem numeração entre as folhas 130 e 131 . A página 89 é repetida uma vez, VOLUME III" e Volume 4: "Subsérie: Inventário, Parte I Agostinho Fróes da Motta e Parte II: Eduardo Fróes da Motta, Localidade: FSA, Período: 1924-1925, Nº dolhas: 219, VOLUME IV”, as quais foram escritas a lápis pelos estagiários do arquivo; ficha de identificação inserida nos volumes 1 e 3 com as seguintes informações: no cabeçalho - "UNIVERSIDADE ESTADUAL DE FEIRA DE SANTANA, DEPARTAMENTO DE CIÊNCIAS HUMANAS E FILOSOFIA, CENTRO DE DOCUMENTAÇÃO E PESQUISA, LEVANTAMENTO GERAL DOS NÚCLEOS DOCUMENTAIS", ao lado do cabeçalho "CLASSIFICAÇÃO: E (estante), Cx (caixa) e Doc (documento)", na linha seguinte: "NÚCLEO: FÓRUM DESEMBARGADOR FILINTO BASTOS, SEÇÃO: JUDICIÁRIO, SÉRIE (com espaço para preenchimento manual), SUBSÉRIE (com espaço para preenchimento manual), TIPOLOGIA (com espaço para preenchimento manual), COMARCA: FSA, $\mathrm{N}^{\mathrm{o}}$ DE FOLHAS (com espaço para preenchimento manual), LOCALIDADE (com espaço para preenchimento manual), PERÍODO (com espaço para preenchimento manual), PARTES E/OU INTERESSADOS (com espaço para preenchimento manual) e OBS. (com espaço para preenchimento manual)"; riscos longos, ganchos e laçadas ao longo do documento; vários carimbos molhados, dentre os quais consta um com a inscrição: "E. V. REIS | Fls. _ | Escrivão | Civel”, na margem superior esquerda do fólio 1r; e outro com a inscrição: "TABELLIÃO RAMALHO | JUL 7 1922 | FEIRA DE SANT'ANNA", na margem inferior direita dos fólios 58r, 59r, 65v, 107r e $135 \mathrm{v}$; sinal público: uma seta dupla, cuja extremidade inferior aponta para a abreviatura JCV, equivalente à abreviatura do nome do Tabelião de Notas, João Carneiro Vital, no fólio 31r, 35r, 93r, 100r e 101r; marcas d'água em vários fólios rectos ou versos, dentre os quais podemos mencionar uma filigrana com a inscrição: "ESTADOS UNIDOS DO BRAZIL | 15 DE NOVEMBRO DE 1889"; um cartão postal colado em cada um dos fólios 58r e 59r; sucessivas riscaduras na numeração progressiva de vários fólios rectos; marcas de umidade e rasgos em alguns fólios; trechos grifados com giz de cera de cor azul, nos fólios $25 \mathrm{v}, 26 \mathrm{r}$, $133 \mathrm{r}, 133 \mathrm{v}$ e $153 \mathrm{r}$, e com giz de cera de cor vermelha, nos fólios 119r, 119v, 133r, 133v, $146 \mathrm{v}, 152 \mathrm{r}, 153 \mathrm{r}$ e $154 \mathrm{r}$; erros de numeração de alguns fólios do primeiro volume: os de número $102 \mathrm{r}, 102 \mathrm{v}, 106 \mathrm{r}$ e $106 \mathrm{v}$ não foram devidamente contabilizados; variados selos de impostos ao longo de todo o documento, por exemplo: 1 selo no valor de 300 réis, nos fólios $2 \mathrm{v}, 40 \mathrm{v}, 44 \mathrm{r}, 64 \mathrm{v}, 79 \mathrm{r}, 124 \mathrm{v}, 135 \mathrm{r}$ e $144 \mathrm{r}$; 6 selos no valor de 300 réis, nos fólios $14 \mathrm{v}$ e $15 \mathrm{v} ; 2$ de 1 mil réis, no fólio 31 r; 1 de 2 mil réis, 1 de 100 réis, 2 de 300 réis e 1 de 200 réis, no fólio $45 \mathrm{r}$; 4 de 100 réis, no fólio $135 \mathrm{v}$ etc.; trechos rasgados nas margens dos fólios $1 \mathrm{r}$ ao $4 \mathrm{v}$; texto escrito na vertical do fólio $1 \mathrm{v}$; alguns fólios se encontram presos por uma colagem, por exemplo: f. $1 \mathrm{r}$ ao $3 \mathrm{v}, 18 \mathrm{r}$ ao $20 \mathrm{v}, 37 \mathrm{r}$ ao $40 \mathrm{v}, 95 \mathrm{r}$ ao $97 \mathrm{v}, 102 \mathrm{r}$ ao $114 \mathrm{v}, 125 \mathrm{r}$ ao $127 \mathrm{v}$, e do $153 \mathrm{r}$ ao $164 \mathrm{v}$; rasgos nas margens laterais de alguns fólios, o que indica perda de informações; recortes retangulares de páginas de jornal, inseridos no interior do segundo e terceiro volumes; dobras nas margens de alguns fólios do documento.

9. Conteúdo: Trata-se do inventário do Coronel Agostinho Fróes da Motta, cujo inventariante foi o seu filho caçula, o Dr. Eduardo Fróes da Motta. Este documento foi lavrado entre 1922 a 1925 e possui um total de 799 fólios escritos no recto e verso, subdividido em 4 volumes com quantidades de fólios distintas. Nestes volumes há a descrição da última vontade do inventariado, deixada em seu testamento, bem como indícios de como se configuravam as 
relações entre os seus familiares, e entre o inventariado e as instituições sociais citadas em seu testamento, haja vista que, além de benfeitor, o coronel também possuía bastante poder aquisitivo e prestígio social, além da descrição dos bens imóveis deixados, já que vários deles estavam situados no centro da cidade de Feira de Santana-BA, onde existiam/existem muitas ruas importantes para a cidade.

O segundo volume é constituído, basicamente, da trasladação das informações constantes no primeiro volume e no testamento do inventariado, bem como de uma solicitação de João Constantino Faskomy e de sua esposa, Dona Amalia da Motta Faskomy, na qual afirmam que o inventariante apresentou avaliações indevidas dos bens do inventariado, bem como postergou o inventário, o que, segundo eles, seria motivo suficiente para retirar o Doutor Eduardo Fróes da Motta do cargo de testamenteiro e inventariante do falecido Coronel Agostinho Fróes da Motta, o que foi contestado pelo advogado daquele, através da recapitulação de todos os acontecimentos registrados no volume anterior.

O terceiro volume, por sua vez, traz informações novas como, por exemplo, várias multas, impostos e adicionais sobre o quinhão de cada herdeiro, haja vista o atraso no cumprimento do testamento que, por lei, deveria ocorrer em, no máximo, em dois anos. Logo, tratavam-se de multas referentes ao atraso no andamento e conclusão das divisões hereditárias, constantes no testamento do inventariado. Entretanto, os herdeiros Arthur Fróes da Motta, Amália da Motta Faskomy e o seu cônjuge, João Constantino Faskomy, contestaram a partilha e solicitaram a sua revisão, visto que um dos avaliadores, Valentim José de Souza Junior, era devedor do espólio, ou seja, possuía uma dívida junto à firma Agostinho Fróes da Motta e Filho, o que evidenciava um conflito de interesses.

Além desses, Adalgisa de Almeida Motta Farias e o seu cônjuge, Adalberto Alves de Farias, não concordaram nem com a partilha e a avaliação do bens nem com a inclusão, por parte do inventariante, do nome de Amália da Motta Faskomy no rol de herdeiros do falecido, já que essa foi deserdada pelo Coronel Agostinho Fróes da Motta, em seu testamento. Ainda nesse volume, o inventariante se comprometeu a pagar uma dívida do seu irmão, Augusto Fróes da Motta, e herdeiro do inventariado, feita a Alberto Moraes Martins Catharino, a qual seria descontada da herança a ser recebida pelo referido irmão, e também solicitou que o herdeiro João Constantino Faskomy recebesse as cabeças de gado complementares ao quinhão de sua esposa, Dona Amália da Motta Faskomy, e que a Justiça nomeasse um depositário para o recebimento do quinhão, em separado dos demais herdeiros, de Alberto de Almeida Motta, o que foi atendido pela Justiça, que nomeou o Coronel Tertuliano José de Almeida para esse fim. Em seguida, foi realizada uma nova avaliação dos bens, os quais foram repartidos entre os herdeiros do inventariado.

No quarto e último volume, há informações que dizem respeito à uma petição do inventariante para executar reparos em vários imóveis, pertencentes ao espólio, os quais haviam sido bastante danificados por conta dos "fortes aguaceiros" caídos na cidade durante aqueles dias. Além disso, o inventariante solicitou a junção das somas referentes ao dinheiro constante da moeda alemã desvalorizada - marcos, mas que fazia parte do espólio e de algumas apólices dos jornais A Feira e Jornal de Notícias, pertencentes aos herdeiros.

O Juiz neste volume, Lyderico Santos Cruz, argumentou que em sua vida de magistrado nunca havia se deparado com "um feito de marcha tão irregular e complicada, como o presente inventário". Além disso, existe, nesse último volume, a trasladação da partilha dos bens e os seus respectivos impostos, sobre a qual alguns herdeiros recorreram, através de um Termo de Apelação, no qual foi trasladado o instrumento de agravo proposto por João Constantino Faskomy contra Eduardo Fróes da Motta.

Além do esposo de Amália da Motta Faskomy, Arthur Fróes da Motta e Adalberto Alves de Farias também contestaram a decisão judicial e apelaram desta, o que foi indeferido pelo Superior Tribunal de Justiça. Por fim, o inventariante solicitou que fossem trasladadas as 
certidões de compra e venda dos bens do espólio que os herdeiros Arthur Fróes da Motta, Adalgisa da Motta Farias, Albertina de Almeida Motta e Augusto Fróes da Motta venderam ou penhoaram como garantia de pagamento de dívidas, o que foi atendido, e as certidões trasladadas no inventário.

Adicionalmente, Adalgisa da Motta Farias apresentou uma procuração em que nomeava um novo advogado, diferente do que o seu ex-marido, Adalberto Alves de Farias, havia constituído, haja vista que a requerente informou, através da trasladação do processo de seu desquite amigável e da partilha dos bens do casal, que se encontrava desquitada judicialmente, o que the dava plenos direitos de nomear um advogado que a representasse no inventário, bem como deixou claro que desistia da ação de apelação interposta pelo seu exmarido contra o seu irmão, Eduardo Fróes da Motta.

10. Escreventes: Manuel Francisco de Almeida Ramalho, Lyderico Santos Cruz, Jacintho Ferreira da Silva, Agnello Ribeiro de Macêdo, João Carneiro Vital, Manoel Pimentel, Eduardo Fróes da Motta, Cesar Ribeiro de Cerqueira, Bernardino Senna Santos, Diogenes de Sousa Lima, José Telles Barreto, Albertina Fróes da Motta, José Maria Neves, Alberto de Almeida Motta, Elpidio Raymundo da Nova, Manuel Araujo, Altino Teixeira, Agostinho Fróes da Motta, Aurelio Vasconcellos, João Marques dos Reis, Manoel Gomes dos Santos, Joaquim Honorio d'Oliveira, Adalberto Alves de Farias, Afonso Pedreira de Cerqueira, Albertino Dantas, Petronillo Guaviro de Meireles, José de Sá Roriz, Maximiano Cecilio Soledade, Vicente dos Reis, João Constantino Faskomy, João Eduardo de Macedo, Arnaldo Dantas, Hygino Pereira da Silva, Oscar Erudilho, Edgard Saback Fernandes, Germano de Lima Pedreira, José do Patrocinio e Silva, David de Melo Lima, Adalgisa de Almeida Motta, Alfredo Manoel da Costa, José Portugal, Manoel José de Magalhães Aguiar, Deoclecio da Silva Daltro, Ignacio Paschoal Bastos, Antonio Monis Ornellas, Domingos Adami, Pedro Ribeiro, Paulo Teixeira, Candido Leão, Antonio Bulcão, Durval Pereira Fraga, José Carlos e Fernandes, Francisco Alexandre de Sousa, Nelson P. Ribeiro e José Dantas Martins Fontes.

Fonte: Elaborado pela pesquisadora

Quadro 15 - Ficha codicológica do décimo primeiro documento

AÇÃO ORDINÁRIA DE FILIAÇÃO E PETIÇÃO DE HERANÇA SOLICITADA POR ALBERTO DE ALMEIDA MOTTA

1. Cota: Feira de Santana - Bahia; Centro de Documentação e Pesquisa/ UEFS; Seção Judiciária, Série Cíveis; Subsérie Ações; Tipologia Ordinária; Localização: Estante 13, Caixa 339 e Documento 7766.

2. Datação: 1922 - 1927 - “1922 9-9-27 [...]” (f. 1r, 1. 1).

3. Lugar de origem: Feira de Santana - “[...] [Feira] de Sant'anna [...]” (f. 1r, 1. 3).

4. Fólio de abertura: "1922 9-9-27* | [Juizo] de Direito | [Feira] de Sant'anna | Acção Ordinaria | Engenheiro Alberto de Almeida Motta |-Autôr- | Doutor Eduardo Fróes da Motta e Outros | -Réos- | Escrivão | Ramalho | Anno de mil | novecentos e vinte e dois, aos cinco | dias do mez de Dezembro do dito | anno autuo a petição que se se- | gue; do que faço este termo. Eu, $\mid$ Manuel Francisco d'Almeida Ra $\mid$ malho, [escrivão escrevi]" (f. 1r, 1. 1-30). 


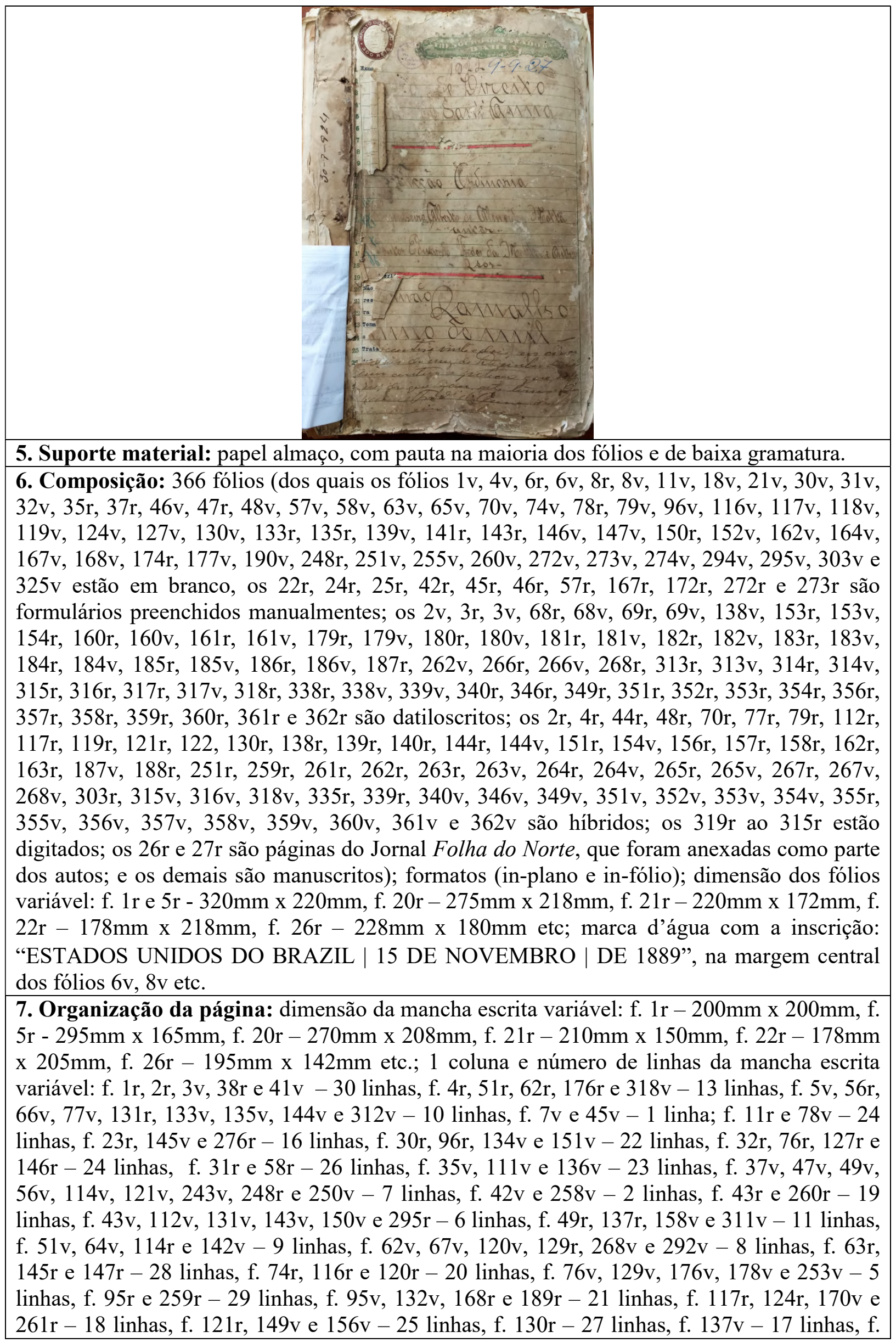


141v e $243 \mathrm{r}-14$ linhas, f. $159 \mathrm{v}$ e $291 \mathrm{r}-4$ linhas, f. $172 \mathrm{v}-3$ linhas, f. $175 \mathrm{v}, 189 \mathrm{v}$ e $292 \mathrm{v}-$ 15 linhas e f. 177r - 12 linhas; pautado; numeração por foliação (sistema 1r, 2r, 3r, 4r etc.); reclamos ("Ferreira/ Ferreira" nos fólios 9v/10r e 50v/51r, "com/ com" 10v/11r e 305/306r, "a/ a" 13v/14r, "Juizo- / Juizo-" 14v/15r, "legalisado/ legalisado" 15v/16r, "pedido/ pedido" 16v/17r, "(assignado)/ (assignado)" 17v/18r, "nasci-/ nascimento" 19v/20r, "Mais/ Mais" 20v/21r, "Fro-/ Fróes" 38v/39r, "ela/ ela" 39v/40r, "Al-/ Almeida" 40v/41r, "acompa/ acompanhar" 52v/53r, "trataram/ trataram" 53v/54r, "firmada/ firmada" 54v/55v, "fei-/ feiras" 55v/56r, "pro-/ propor" 59v/60r, "um/ um" 60v/61r, "Es-/ Estrada" 72v/73r, "trans-/ transcripto" 75v/76r, "Respondeu/ Respondeu" 80v/81r e 90v/91r, "Coronel/ Coronel" 81v/82r e 108v/109r, "porque/ porque" 82v/83r, "Perguntado/ Perguntado" 83v/84r, 84v/85r, 93r/93v e 97v/98r, "setenta/setenta" 85v/86r, "Gui/ Guilhermina" 86v/87r e 105v/106r, "disseram/ disseram" 87v/88r, "amigo/ amigo" 88v/89r, "Agostinho/ Agostinho" 89v/90r e 102v/103r, "pa/ palavra" 93v/94r; "Dona/ Dona" 98v/99r, "demais/ demais" 99v/100r, "este/ este" 101v/102r, "ignora/ ignora" 103v/104r, "que/ que" 104r/104v, "é/ é" 104v/105r, "lhe/ lhe" 106v/107r, "compan/ companhia" 107v/108r, "Guilhermina/ Guilhermina" 3v/4r, "Agostinho?/ Agostinho?" 110v/111r, “julgada/ julgada" 115v/116r, “item?/ item?" 125v/126r, "exem-/ exemplar" 126v/127r, "deferimen-/ deferimento" 134r/134v, "preca-/ precatoria" 165v/166r, "Garcia/ Garcia" 169r/169v, "Abril/ Abril" 169v/170r e 195v/196r, "cons/ consta" 170r/170v, "quator=/ quatorze" 191v/192r, "A=/ Alberto" 192v/193r, "e/ e" 193v/194r e 198v/199r, "amplitude/ amplitude" 194v/195r, "con=/ contido" 196v/197r, “(1920)/ (1920)" 197v/198r, "do/ do" 199v/200r e 212v/213r, "des=/ dessas" 200v/201r, "com/ com" 201v/202r, "tivesse/ tivesse" 202v/203r, "Do=/ Documento" 203v/204r e $219 \mathrm{r} / 219 \mathrm{v}$, "tudo/ tudo" 205v/206r, "nem/ nem" 206v/207r, "Disse/ disse" 207v/208r, "=Attestado=/ =Attestato=" 208v/209r, "deixar/ deixar" 209v/210r, "intimado=/ intimado" $210 \mathrm{v} / 211 \mathrm{r}$, "acer=/ acervo" $213 \mathrm{v} / 214 \mathrm{r}$, "aos/ aos" $214 \mathrm{v} / 215 \mathrm{r}$, "re=/ requerimento" $216 \mathrm{r} / 216 \mathrm{v}$, "Sen=/ Senhor" 216v/217r, "res=/ resposta" 219v/220r, "de/ de" 220v/221r, "a pedido/ a pedido" $222 \mathrm{v} / 223 \mathrm{r}$, "vinte/ vinte" $223 \mathrm{v} / 224 \mathrm{r}$ e $309 \mathrm{v} / 310 \mathrm{r}$, "inves=/ investigação" 224v/225r, "agravante/ agravante" 225v/226r, "a=/ além” 226v/227r, "illi=/ illidiu” 227v/228r, "pelo/ pelo" 228v/229r, "at=/ attribuindo-se" 229v/230r, "vista/ vista" 230v/231r, "estivessem/ estivessem" 231v/232r, "deccorren=/ deccorrentes" 232v/233r, "in=/ indicação" 233v/234r, "revelados-/ revelados" 234v/235r, "ao/ ao" 235v/236r, "pedi=/ pedidos" 236v/237r, "dita/ dita" 237v/238r, "Fei=/ Feira" 238v/239r, "re/ reporto" 239v/240r, "Es-/ Escrivão" 242r/242v, "Conclusões/ Conclusões" 242v/243r, "da/ da" 245v/246r, "Esta/ Estado" 246v/247r, "Junt-/ Juntada" 250r/250v, "Adalber/ Adalberto" 252v/253r, "co-/ como" 256v/257r, "que/ que" 257v/258r, "Ri-/ Ribeiro" 257v/258r, "verso/ verso" 290v/291r, "Cer-/ Certidão" 291v/292r, "Fa-/ Farias" 305r/305v, "ca-/ casas" 306r/306v, "Bra-/ Brazil" 306v/307r, "Mo-/ Motta" 307r/307v, "Ha-/ Haverá" 307v/308r, "fi-/ ficando" 308r/308v, "pe-/ pelo" 309r/309v, "interposta/ interposta" 310r/310v, "dou/ dou" 310v/311r e "ficaram/ ficaram" 311r/311v); rubrica do Tabelião "JoãoCVital", na margem superior direita do fólio $72 \mathrm{r}$, e rubrica do escrivão "Mramalho", Manuel Francisco de Almeida Ramalho, na margem superior direita dos fólios 9r, 10r, 11r, 12r, 14r, 16r, 17r, 19r e 21r.

8. Particularidades: O documento não possui capa, mas há uma folha de papel almaço, que funciona como uma espécie de invólucro, que foi inserido pelos estagiários do CEDOC/UEFS, para proteger o documento da umidade e garantir a conservação do suporte material, o que evita o contato direto das mãos do pesquisador com o manuscrito. Além disso, na folha há as seguintes informações sobre o documento: "Subsérie: Ações, Tipologia: Ação Ordinária, Parte I - Eduardo Fróes da Motta e Parte II: Alberto de Almeida Motta, Período: 1922-1927, Localidade: FSA, $\mathrm{N}^{0}$ de folhas: 357, Obs.: Contestação do inventário contém 3 exemplares do Folha do Norte", as quais foram escritas a lápis pelos estagiários do arquivo; ficha de identificação inserida pelos estagiários do CEDOC/UEFS com as seguintes 
informações: no cabeçalho - "UNIVERSIDADE ESTADUAL DE FEIRA DE SANTANA, DEPARTAMENTO DE CIÊNCIAS HUMANAS E FILOSOFIA, CENTRO DE DOCUMENTAÇÃO E PESQUISA, LEVANTAMENTO GERAL DOS NÚCLEOS DOCUMENTAIS", ao lado do cabeçalho "CLASSIFICAÇÃO: E (estante), Cx (caixa) e Doc (documento)", na linha seguinte: "NÚCLEO: FÓRUM DESEMBARGADOR FILINTO BASTOS, SEÇÃO: JUDICIÁRIO, SÉRIE (com espaço para preenchimento manual), SUBSÉRIE (com espaço para preenchimento manual), TIPOLOGIA (com espaço para preenchimento manual), COMARCA: FSA, $\mathrm{N}^{\circ}$ DE FOLHAS (com espaço para preenchimento manual), LOCALIDADE (com espaço para preenchimento manual), PERÍODO (com espaço para preenchimento manual), PARTES E/OU INTERESSADOS (com espaço para preenchimento manual) e OBS. (com espaço para preenchimento manual)"; riscos longos, ganchos, laçadas, timbres estaduais, carimbos secos e riscaduras ao longo do documento; marcas de ataques de cupim e de fungos; variados selos de impostos: 3 selos no valor de 300 réis, nos fólios 4r, 28v, 70r, 11r, 21r e 22v, 156r, 157r, 158r, 162r, 169v e 170r; 2 selos no valor de 2 mil réis, no fólio $5 \mathrm{r}$; 2 no valor de 300 réis, nos fólios $5 \mathrm{v}, 7 \mathrm{v}, 24 \mathrm{r}, 28 \mathrm{r}$, $33 \mathrm{v}, 42 \mathrm{v}, 66 \mathrm{v}, 71 \mathrm{r}, 71 \mathrm{v}, 73 \mathrm{v}, 139 \mathrm{r}, 154 \mathrm{v}$ e 163r; 1 de 1 mil réis, no fólio 7r; 3 de 100 réis, nos fólios $21 \mathrm{r}, 122 \mathrm{r}, 134 \mathrm{v}, 140 \mathrm{r}, 142 \mathrm{v}$ e 146r; 7 de 300 réis, no fólio $18 \mathrm{r} ; 5$ de 300 réis, no fólio $22 \mathrm{r} ; 8$ de 300 réis, nos fólios $23 \mathrm{v}$ e $25 \mathrm{v}$; 1 de 300 réis, nos fólios $29 \mathrm{v}, 30 \mathrm{r}, 34 \mathrm{v}, 44 \mathrm{r}, 48 \mathrm{r}, 63 \mathrm{r}$, 65r, 77r, 79r, 95r, 112r, 117r, 119r, 130r, 144v e 151v; 4 de 300 réis, nos fólios 31r, 32r, 41v, $188 \mathrm{v}$ e $335 \mathrm{v} ; 1$ de 200 réis, no fólio $45 \mathrm{r} ; 2$ de 300 réis e 1 de 1 mil réis, no fólio $64 \mathrm{r} ; 1$ de 2 mil réis, nos fólios 66r, 304r e 318v; 2 de 300 réis e 6 de 100 réis, nos fólios 118r, 120r e $163 \mathrm{v} ; 6$ de 100 réis, nos fólios 140v, 166v e 242v; 2 de 300 réis e 1 de 1 mil réis, no fólio $147 \mathrm{r} ; 12$ de 300 réis, no fólio 155v; 6 de 300 réis, nos fólios 156v, 157v e 158v; 2 de 1 mil réis, 2 de 300 réis e 1 de 100 réis, no fólio $187 \mathrm{v} ; 5$ de 1 mil réis e 1 de 10 réis, no fólio 240r; 3 de 100 réis e 1 de 30 réis, nos fólios $244 \mathrm{v}$ e 246r; 2 de 300 réis e 2 de 30 réis cada, no fólio 245r; 1 de 300 réis e 1 de 30 réis, nos fólios 251r, 259r, 261r, 296r, 303r, 326v e 334v; 2 de réis e 1 de 300 réis, no fólio 268v; 18 de 2 mil réis, 3 de 300 réis, 1 de 30 réis e 2 de 5 mil réis, no fólio 274r; 1 de 5 mil réis e 1 de 1 mil réis, no fólio 298r; 2 de 30 réis, 1 de 600 réis e 2 de 300 réis, no fólio $304 \mathrm{v} ; 2$ de 1 mil réis, 1 de 300 réis e 1 de 30 réis, no fólio $325 \mathrm{r}$; 2 de 1 mil réis, no fólio 333v; 2 de 100 réis e 1 de 1 mil réis, no fólio $340 \mathrm{v} ; 4$ de 100 réis, nos fólios $345 \mathrm{r}, 346 \mathrm{v}, 351 \mathrm{v}, 352 \mathrm{v}, 353 \mathrm{v}, 354 \mathrm{v}, 355 \mathrm{v}, 356 \mathrm{v}, 357 \mathrm{v}, 358 \mathrm{v}, 359 \mathrm{v}, 360 \mathrm{v}, 361 \mathrm{v}$ e $362 \mathrm{v}$; e 1 de 300 réis e outro de 100 réis, no fólio $349 \mathrm{v}$; carimbo molhado com a inscrição: "E. V. REIS | Fls. _ Escrivão | Civel" na margem superior esquerda do fólio 1r; carimbo molhado com a inscrição: "TABELLIÃO RAMALHO | OUT 241922 | FEIRA DE SANT'ANNA" na margem centro-direita do fólio $5 \mathrm{v}$ e na margem centro-superior do fólio 7v; carimbo seco, em alto relevo, com a inscrição: "MANUEL FRANCISCO DE ALMEIDA RAMALHO ESCRIVÃO | DOS | FEITOS CIVEIS | E | CRIMINAES | FEIRA DE SANTANA" na margem superior esquerda do fólio 19r; carimbo molhado com a inscrição: "TABELLIÃO RAMALHO | MAR 291922 | FEIRA DE SANT'ANNA" na margem inferior esquerda do fólio 22r; carimbo molhado com a inscrição: "TABELLIÃO RAMALHO | MAI 271922 | FEIRA DE SANT'ANNA" na margem centro-superior direita do fólio 23v, outro na margem superior direita do fólio $24 \mathrm{v}$, outro na margem centro-superior do fólio $25 \mathrm{v}$ e um outro na margem superior direita do fólio 28v; três carimbos com a inscrição: "TABELLIÃO RAMALHO | DEZ 51922 | FEIRA DE SANT'ANNA" na margem centro-inferior dos fólios 31r e 32r; carimbo molhado com a inscrição: "ILHEOS | 5 | DEZ | 1922| BAHIA" nas margens superior direita e esquerda, e inferior do fólio 45r, e um desse carimbo na margem inferior direita do fólio 46r; três carimbos com a inscrição: "TABELLIÃO RAMALHO ABR 181922 | FEIRA DE SANT'ANNA" na margem centro-inferior e direita do fólio 147r; dois carimbos molhados com a inscrição: "TABELLIÃO RAMALHO | ABR 261923 
FEIRA DE SANT'ANNA" na margem centro-inferior dos fólios 156v e 157v, e três deles no 158v; um carimbo seco com a inscrição: "Dr. José Maria Neves | Advogado" na margem superior direita dos fólios 160r, 161r, 162r, 179r, 180r, 181r, 182r, 183r, 184r, 185r, 186r, 187r, 328r, 329r, 330r, 331r, 332r e 333r; um carimbo molhado com a inscrição: “TABELLIÃO RAMALHO | JAN 271923 | FEIRA DE SANT’ANNA" na margem inferior direita do fólio 188v; dois carimbos molhados com a inscrição: "JOSÉ CARLOS E FERNANDES | ESCRIVÃO INTERINO | BAHIA" na margem inferior direita do fólio 304v; dois timbres com a inscrição: "IMPOSTO DO SELLO" e "THESOURO DO ESTADO DA BAHIA", em quase todos os fólios rectos; sinal público: seta dupla, cuja extremidade inferior aponta para a abreviatura "JCV", equivalente à do tabelião João Carneiro Vital, nos fólios $22 \mathrm{v}, 23 \mathrm{v}, 24 \mathrm{v}, 64 \mathrm{r}, 66 \mathrm{v}, 118 \mathrm{r}, 120 \mathrm{r}, 155 \mathrm{v}$ e 335v; negligência na numeração dos fólios 6r, 6v, $8 \mathrm{r}$ e $8 \mathrm{v}$, que não foram contabilizados; sinal especial feito a próprio punho pelo Coronel Agostinho Fróes da Motta em sua assinatura, nos fólios 22r, 23r e 25r; cartão postal colado na margem centro-superior de cada um dos fólios 31r e 32r; fita adesiva na cor parda, que foi utilizada para colar, na margem central, os fólios $22 \mathrm{v}$ e $25 \mathrm{v}$; fita preta de papel, colada nas 4 margens do fólio 28r; colagem que une os fólios $1 \mathrm{r}$ ao $4 \mathrm{v}$, o $7 \mathrm{r}$ ao $9 \mathrm{v}$, o $10 \mathrm{r}$ ao $16 \mathrm{v}$ e o $17 \mathrm{r}$ ao $19 \mathrm{v}$; dobras, feitas em 4 partes, que ocasionaram rasgaduras no local das próprias dobras, no fólio $28 \mathrm{v}$; riscaduras feitas pelos escreventes, sinalizadas com a expressão: "Sem effeito", nos fólios $122 \mathrm{v}$ e $247 \mathrm{v}$; trechos escritos com caneta de tinta azul, no fólio $191 \mathrm{r}$; trechos escritos com caneta de tinta vermelha, nos fólios 193r, 199r, 200r, 200v, 203v, 204r, 204v, 205r, 206r, $208 \mathrm{v}, 209 \mathrm{r}, 209 \mathrm{v}, 210 \mathrm{r}, 211 \mathrm{r}, 211 \mathrm{v}, 212 \mathrm{r}, 212 \mathrm{v}, 213 \mathrm{v}, 214 \mathrm{v}, 215 \mathrm{v}, 217 \mathrm{v}, 219 \mathrm{r}, 219 \mathrm{v}, 220 \mathrm{v}$, $221 \mathrm{v}, 222 \mathrm{r}, 228 \mathrm{v}, 229 \mathrm{v}, 235 \mathrm{v}, 237 \mathrm{r}$ e $238 \mathrm{v}$; trechos grifados com giz de cera de cor azul, nos fólios 10v, 19r, 19v, 26r, 27r, 86r, 91v, 107v, 125v, 182r, 182v, 183v, 185v, 186r, 186v, 193r e 334r; trechos grifados com giz de cera de cor preta, nos fólios $15 \mathrm{r}, 73 \mathrm{r}, 239 \mathrm{r}, 359 \mathrm{v}, 360 \mathrm{v}$ e $362 \mathrm{v}$; trechos grifados com giz de cera de cor vermelha, nos fólios 29r, $81 \mathrm{r}$ e $221 \mathrm{v}$; manchas na margem centro-inferior do fólio $241 \mathrm{v}$, na margem central direita do $242 \mathrm{r}$, e nas margens inferior esquerda e na centro-direita do fólio 345v; rasgos nas margens superior, inferior, direita e esquerda de um ou outro fólio do documento.

9. Conteúdo: Trata-se de uma ação ordinária de filiação e petição de herança, requerida por Alberto de Almeida Motta e sua esposa, Maria Carlota Falcão de Sousa Motta, contra Eduardo Fróes da Motta, seus irmãos e os seus respectivos cônjuges, lavrada entre 1922 a 1927, cujo primeiro volume possui 361 fólios, de um total de três volumes, cujo conteúdo principal é o pedido do autor para que o seu irmão Eduardo Fróes da Motta, inventariante dos bens deixados pelo seu pai, acatasse a decisão do Egrégio Tribunal Superior de Justiça de incluir o seu nome no rol de herdeiros do falecido, o que não foi feito até aquele momento pelo inventariante e pelos demais herdeiros do Coronel Agostinho Fróes da Motta.

Em vista disso, o autor buscou provar neste processo que: 1) era filho do coronel falecido e de Dona Guilhermina de Almeida Motta, 2) que ele foi educado pelo pai, 3) que os seus irmãos, frutos do primeiro matrimônio do seu pai, sempre o trataram como irmão, em particular o inventariante que sempre o tratou com carinho e amor fraternal, 4) que a sua mãe sempre foi amante única e exclusivamente do seu pai até que se tornou esposa daquele, 5) que a sua mãe sempre foi leal e sempre teve bom comportamento social, 6) que a posse do estado de filho só poderia ser contestada se aquele que a contestasse apresentasse provas melhores de que o autor não era filho do coronel falecido, 7) que se ele não fosse filho do coronel Fróes da Motta, este teria declarado no ato do seu casamento com a sua genitora e que o autor sempre usou o nome de família de seu pai, 8) que os filhos naturais, mesmo que adulterinos, poderiam ser legitimados por consequente matrimônio dos seus pais, 9) que a legitimação dos filhos adulterinos ocorreria independente da vontade dos pais ou dos irmãos, haja vista ser um direito reconhecido pela Justiça, 10) que a lei vigente garantia os seus direitos enquanto filho do coronel Agostinho Fróes da Motta, 11) que os filhos legitimados teriam os mesmos 
direitos que os legítimos, e 12) que provada a sua paternidade, o seu nome deveria ser incluído no rol de herdeiros e deveria receber a sua devida herança.

Ao final desses quesitos, o autor solicitou que os réus fossem convocados para uma audiência e pagou o valor de 10 contos de réis pelas custas da abertura do processso. Assim, para provar os doze quesitos, o autor apresentou, ao longo do processo, documentos como, por exemplo, cartões postais, dedicatórias no verso de duas fotografias: uma de Eduardo Fróes da Motta para Alberto de Almeida Motta e outra do Coronel Agostinho Fróes da Motta para Dona Guilhermina de Almeida, cartas, telegramas, recortes do Jornal Folha do Norte, dedicatória feita na quarta página de uma tese inaugural escrita por Eduardo Fróes da Motta, e destinada ao seu irmão "sincero e amigo Alberto", transcrições do termo de inventariante do testamento do seu pai, da declaração de título de herdeiros e do termo de aresto no qual foi determinado pela Justiça o lançamento do nome do suplicante no título de herdeiros do coronel falecido.

Diante disso, foram citados o Doutor Eduardo Fróes da Motta e a sua mulher, Dona Maria Lambert da Motta, Dona Albertina de Almeida Motta, ora desquitada, o Capitão Augusto Fróes da Motta e a sua mulher, Dona Almerinda de Almeida Motta, o Farmacêutico Athur Fróes da Motta e a sua mulher, Dona Francelina Carneiro da Motta, Dona Amália de Almeida Motta Faskomy e o seu marido por cabeça do casal e representante legal desta, o Coronel João Constantino Faskomy, e Dona Adalgisa de Almeida Motta Farias e o seu marido por cabeça do casal e representante legal desta, Adalberto Alves de Farias para comparecerem às audiências públicas marcadas.

Nesse contexto, o Doutor Eduardo Fróes da Motta apresentou uma defesa em que contestou as alegações do irmão, apresentando como contra provas o pedido de trasladação da certidão de nascimento de Alberto de Almeida Motta e a escritura do contrato antenupcial do seu pai com a genitora daquele. Em contrapartida, para provar os seus argumentos, Alberto de Almeida Motta ofereceu à Justiça o depoimento de 5 testemunhas, a saber: Major Estanislau Alves Barretto, Major Leôncio Evangelista dos Santos, Alfredo Antunes Guimarães, Justino de Figueirêdo Mascarenhas e Francisco da Silva Meneses para falarem sobre o relacionamento do coronel com ele, enquanto filho, e com a genitora deste. Em contrapartida, Eduardo Fróes da Motta também fez o mesmo, trazendo as seguintes testemunhas para falarem em Juízo: Francisco Alves Ferreira Duara, David Sebastião Franco, Hilarião Abade Pinto, Rozendo de Oliveira Lopes e Lucio José de Cerqueira.

Ouvidas as 5 testemunhas apresentadas por Alberto de Almeida Motta, por aquelas foi afirmado o seguinte: que o autor desta ação era filho do Coronel Agostinho Fróes da Motta e de Dona Guilhermina de Almeida Motta, que pelo seu pai foi educado e que este havia lhe dado a "carta de engenheiro", e que sabiam disso por terem ouvido do próprio Agostinho Fróes da Motta ou de outras pessoas, já que o relacionamento dos pais do autor era fato público e notório na cidade, como afirmaram as testemunhas.

Além disso, as testemunhas afirmaram que Dona Guilhermina de Almeida, mesmo noiva de "Tito de Tal", foi raptada e deflorada por alguém a mando do coronel, enquanto aquela era jovem e que o referido coronel alugou e mobiliou uma casa para que ela morasse, tornando-se, portanto, sua "amante, teúda e manteúda" até a data do seu casamento, em 05 de janeiro de 1920, período em que ela passou a residir no Casarão Fróes da Motta, mas onde ela e o seu filho Alberto não estavam no dia do falecimento do coronel, 22 de março de 1922, porque, segundo as testemunhas, à essa altura, ela estava residindo em uma de suas chácaras na cidade de Feira de Santana-BA, o que se justificava porque os filhos do primeiro casamento do coronel não a aceitavam na residência onde o seu pai, o coronel Fróes da Motta, passou mais de 100 dias acamado, apesar de tratarem Alberto de Almeida Motta como irmão.

Logo, foi afirmado por uma das testemunhas que, por medo das possíveis atitudes dos seus enteados, Dona Guilhermina de Almeida Motta não estava presente nos últimos 
momentos da morte do seu marido. Entretanto, as testemunhas também afirmaram que aquela foi a única ocasião em que a genitora de Alberto de Almeida Motta estava ausente da companhia do seu marido, já que "viviam em harmonia" e que ela sempre viveu de maneira honrada e apresentava bom comportamento.

Em contrapartida, foi confirmado pelas testemunhas apresentadas por Eduardo Fróes da Motta que Alberto de Almeida Motta era filho do Coronel Agostinho Fróes da Motta e de Dona Guilhermina de Almeida Motta, que esta não foi raptada pela pessoa do coronel, mas ouviram dizer que pelo Major Estanislau Alves Barretto, padrinho de Alberto e amigo do coronel, e que mais de uma vez Dona Guilhermina e seu filho se ausentaram da residência do coronel, inclusive durante os últimos momentos de vida daquele, e que, segundo uma das testemunhas, Dona Guilhermina era filha do coronel Tertuliano de Almeida e que à época do seu rapto sua mãe já era falecida. Além disso, foi dito por uma das testemunhas que à época do rapto de Dona Guilhermina, esta "tinha namoros" com o filho do Major Estanislau Alves Barretto, e que o coronel Agostinho Fróes da Motta vivia em harmonia com a sua primeira mulher, dando-lhe todo conforto para o seu bem estar, inclusive a sua companhia.

Diante de tais afirmações, Alberto de Almeida Motta, por meio do seu advogado, suplicou que a Justiça expedisse intimações para que os seus irmãos comparecessem à próxima audiência para prestarem esclarecimentos sobre as 4 primeiras questões do processo, o que foi prontamente deferido pelo Juiz. Nisto, Eduardo Fróes da Motta solicitou nova data para depor, pois apresentou um atestado médico no qual ficou esclarecido que ele se encontrava sob cuidados médicos e que, portanto, estaria em repouso. Já as irmãs Albertina e Adalgisa pediram dispensa do depoimento alegando desconhecer as questões para as quais foram chamadas e que, inclusive, o seu irmão Eduardo já tinha sido intimado e, como representante legal dos bens do seu pai, poderia responder às devidas questões.

No dia do depoimento de Eduardo Fróes da Motta, este afirmou o seguinte: que não sabia se Alberto de Almeida Motta era filho do seu pai, pois a certidão de nascimento do requerente e o contrato antenupcial dos genitores daquele, bem como o testamento do seu pai não faziam menção à existência daquele como filho do coronel. Também afirmou que o seu pai foi quem pagou os estudos de Alberto, mas que ele fez isso não somente com aquele, mas com diversos parentes; que realmente o tratava como irmão por conta do afeto que existia entre ambos e que isso era comum em suas relações de amizade, e que o seu pai conviveu com Dona Guilhermina, sem faltar com as suas obrigações conjugais com a sua mãe e que não tinha conhecimento de que aquela tivesse fama com outro homem, que mesmo tendo um relacionamento fraternal com Alberto aquele nunca lhe perguntou sobre a sua paternidade, mas sabia que ele era filho natural, ou seja, que possuía em seus documentos apenas o nome de sua mãe.

Além disso, Eduardo Fróes da Motta disse que se Dona Guilhermina de Almeida não tivesse comportamento exemplar o seu pai não teria contraído núpcias com ela, mas que sobre a paternidade do filho daquela não tinha nada a afirmar. Em sequência, Eduardo também suplicou que a Justiça intimasse Alberto para dar o seu depoimento, mas esse não foi encontrado por duas vezes, pois estava em Salvador-BA cuidando de sua saúde, a qual, segundo o seu médico, Dr. Gastão Clóvis de Souza Guimarães, estava fragilizada, pois Alberto de Almeida Motta tinha uma cardiopatia renal grave e por isso necessitava de repouso mental e físico, recomendando, portanto, que o seu depoimento fosse tomado quando estivesse bem.

Entretanto, Eduardo Fróes da Motta contestou a opinião médica apresentada, dispondo, em Juízo, dois documentos nos quais dois outros médicos renomados declararam que o tipo de doença atestada pelo médico do autor não o tornava incapaz de prestar depoimento. Com isso, Alberto de Almeida Motta foi intimado novamente e, por fim, cedeu o seu depoimento em sua residência, já que alegou que não poderia se locomover. Dado o seu 
depoimento, o seu advogado e o do réo apresentaram as suas razões finais acerca do processo e, a partir disso, foi dada a sentença final pelo Juiz Lyderico Santos Cruz que citou como parte vencedora do processo o autor Alberto de Almeida Motta e condenou os réus ao pagamento das custas do processo, decisão que foi publicada logo na audiência seguinte.

Cientes da decisão judicial e insatisfeitos com esta, os réus entraram com um recurso de apelação para o qual todos os envolvidos foram novamente intimados e, desta vez, ao invés de ser o senhor Adalberto Alves de Farias o representante legal de Dona Adalgisa de Almeida Motta Farias, quem a representou foi o seu novo advogado Eduardo Teixeira de Araújo, agora nomeado, afirmando que este seria o seu representante no processo, já que ela estava desquitada e que, portanto, todos os feitos do advogado anterior, sob a autorização do seu exmarido, seriam revogados, inclusive a apelação interposta por seu ex-marido junto com o seu irmão, Eduardo.

Ouvidas as partes e feita a análise do processo, o Tribunal Superior de Justiça indeferiu o recurso de apelação, exigindo que os apelantes pagassem as custas do processo. Não se conformando, mais uma vez, com a decisão judicial proferida, o inventariante e testamenteiro dos bens deixados pelo Coronel Agostinho Fróes da Motta, Eduardo Fróes da Motta, pediu vistas do processo e o embargou. Nos embargos do aresto, o embargante voltou a alegar que as provas apresentadas não seriam suficientes para o "reconhecimento do estado de posse de filho" de Alberto de Almeida Motta, sendo, portanto, a certidão de nascimento deste, o testamento do seu pai e o contrato antenupcial dos genitores daquele suficientes para provar que o seu falecido pai não o mencionou e nem o registrou como filho e, por isso, pedia que os julgadores dessem uma nova sentença que anularia as duas anteriores. Assim, o processo foi, por ora, "finalizado" em 11 de outubro de 1927, após o recebimento das folhas de embargação por parte dos julgadores para devida apreciação.

10. Escreventes: Manuel Francisco de Almeida Ramalho, Arnold Ferreira da Silva, José Maria Neves, Alberto de Almeida Motta, Maria Carlota Falcão de Sousa Motta, José Telles Barreto, Cesar Ribeiro de Cerqueira, Manoel Pimentel, Eduardo Fróes da Motta, João Carneiro Vital, Agnello Ribeiro de Macêdo, Adalberto Alves Farias, Aurelio Vasconcellos, Altino Teixeira, Pedro Americo de Britto, Manoel Gomes dos Santos, Jacintho Ferreira da Silva, Gastão Clovis de Souza Guimarães, Adalgisa de Almeida Motta Farias, Hildebrando Cordeiro de Almeida, Aurino Cavalcante da Cruz, José Anisio Teixeira de Araujo, Francisco Martins da Silva, Oscar de Garcia, José Heraclides Ferreira, Aureliano Augusto A. do Nascimento, Laura Almeida, Maximiano Cecilio Soledade, Ignacio Paschoal Bastos, Antonio Monis Ornellas, Domingos Adami, Paulo Ribeiro, Antonio Bulcão, Arthur de Lemos, Lyderico Santos Cruz, Manuel Araujo, Vicente dos Reis, Germano de Lima Pedreira, Hygino Pereira da Silva, Arthur Fróes da Motta, Eduardo Teixeira de Araujo, Lucatino Doria, José Dantas Martins Fontes, José Carlos e Fernandes, João Constantino Faskomy, Pedro Ribeiro, Francisco Moreira Simas, Montenegro Junior, Duarte Guimarães e Salles Moniz.

Fonte: Elaborado pela pesquisadora

Quadro 16 - Ficha codicológica do décimo segundo documento

\section{PETIÇÃO DE ENCERRAMENTO DE FIRMA COMERCIAL}

1. Cota: Feira de Santana - Bahia; Centro de Documentação e Pesquisa/ UEFS; Seção Judiciária, Série Cíveis; Tipologia Petição; Localização: Estante 13, Caixa 345 e Documento 7899. 


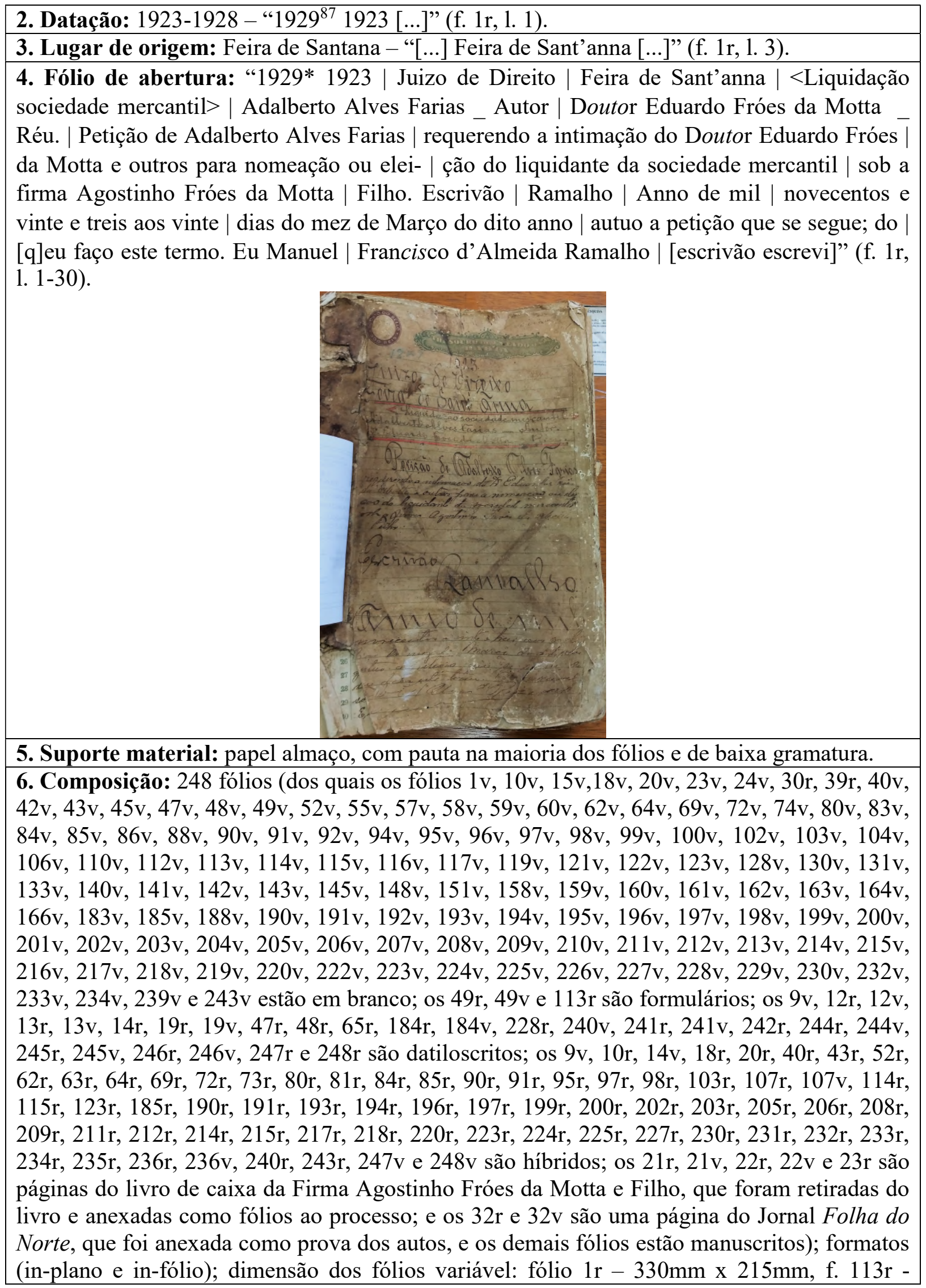

${ }^{87}$ É importante ressaltar que, embora exista uma menção de que o processo se encerrou em 1929, as informações do texto nos permitem afirmar, inclusive por conta da última datação presente nos últimos fólios, que o processo foi "encerrado" em 1928, como consta na edição fac-similar do primeiro fólio recto. 
$60 \mathrm{~mm}$ X $175 \mathrm{~mm}$, f. $121 \mathrm{r}-265 \mathrm{~mm}$ x $210 \mathrm{~mm}$, f. $142 \mathrm{r}-278 \mathrm{~mm}$ x $278 \mathrm{~mm}$, f. $143 \mathrm{r}-330 \mathrm{~mm}$ x $238 \mathrm{~mm}$, f. $149 \mathrm{r}-332 \mathrm{~mm}$ x $220 \mathrm{~mm}$, f. $183 \mathrm{r}-330 \mathrm{~mm}$ x $222 \mathrm{~mm}$, f. $186 \mathrm{r}$ a $188 \mathrm{r}-325 \mathrm{~mm}$ x $210 \mathrm{~mm}$ e f. $244 \mathrm{r}$ a $248 \mathrm{r}-290 \mathrm{~mm} \times 220 \mathrm{~mm}$ etc.

7. Organização da página: dimensão da mancha escrita variável: fólio $1 \mathrm{r}-320 \mathrm{~mm} \mathrm{x}$ $175 \mathrm{~mm}$, f. $113 \mathrm{r}-60 \mathrm{~mm}$ X $175 \mathrm{~mm}$, f. $121 \mathrm{r}-232 \mathrm{~mm}$ x $185 \mathrm{~mm}$, f. $142 \mathrm{r}-216 \mathrm{~mm}$ x $255 \mathrm{~mm}$, f. $143 \mathrm{r}-2900 \mathrm{~mm} \times 200 \mathrm{~mm}$, f. $149 \mathrm{r}-320 \mathrm{~mm} \times 175 \mathrm{~mm}$, f. $183 \mathrm{r}-300 \mathrm{~mm} \times 190 \mathrm{~mm}$, f. $186 \mathrm{r}$ a $188 \mathrm{r}-310 \mathrm{~mm} \times 170 \mathrm{~mm}$, f. $244 \mathrm{r}$ a $248 \mathrm{r}-265 \mathrm{~mm} \times 210 \mathrm{~mm}$ etc.; 1 coluna e número de linhas da mancha escrita variável: f. $1 \mathrm{r}, 2 \mathrm{r}$ e $2 \mathrm{v}-30$ linhas, f. $3 \mathrm{r}, 3 \mathrm{v}, 4 \mathrm{r}, 4 \mathrm{v}, 5 \mathrm{r}, 5 \mathrm{v}, 6 \mathrm{r}, 6 \mathrm{v}$ e $17 \mathrm{r}-23$ linhas, f. $8 \mathrm{r}, 17 \mathrm{v}$ e $71 \mathrm{r}-10$ linhas, f. $8 \mathrm{v}, 39 \mathrm{v}, 104 \mathrm{r}$ e $130 \mathrm{v}-8$ linhas, f. $11 \mathrm{v}$ e $65 \mathrm{v}-2$ linhas, f. $16 \mathrm{r}$ e $145 \mathrm{r}-18$ linhas, $16 \mathrm{v}, 102 \mathrm{r}$ e $122 \mathrm{r}-7$ linhas, f. 81r, 139v e 221v - 9 linhas, f. 105v e 106r - 6 linhas, f. 110r - 19 linhas, f. 199r - 17 linhas e f. $237 \mathrm{v}-15$ linhas etc.; pautado; numeração por foliação (sistema 1r, 2r, 3r, 4r etc.); reclamos ("demonstra-/ demonstractivo" nos fólios 26v/27r; "da/ da" 75v/76r; "verda/ verdade" 76v/77r, "Con/ Conclusão" 77v/78r, "Au-/Augusto" 78v/79r; "Cecilio/ Cecilio" 93v/94r; "hon- /hontem" 111v/112r, "Em/ Em" 125v/126r; e "Feira/ Feira" 144v/145r); rubrica "SantosCruz", referente ao Juiz Lyderico Santos Cruz, constante na vertical da margem centro-direita do fólio 98r, na margem centrosuperior dos fólios 144r, 145r, 149r, 150r, 151, 184r e 203r e na margem superior direita dos fólios 206r, 209r, 212r e 215r; rubrica "JoãoCVital", referente ao tabelião João Carneiro Vital, na margem superior direita dos fólios 131r, 139r, 140r, 141r, 142r, 143r, 145r, 147r, 148r, 152 r, 153r, 154r, 155r, 157r e 158r; rubrica "M. Eust.", referente ao tabelião Manoel Eustachio Rebello de Figueiredo, na margem superior direita dos fólios 134r, 135r, 136r, 137r, 138r, 139r, 140r, 143r, 146r, 147r, 148r, 152r, 153r, 154r, 155r, 157r e 158r; duas rubricas, uma ao lado da outra, dos tabeliães "M. Eust." e "JoãoCVital" na margem superior direita dos fólios 160r ,161v, 162r, 163r, 164r, 165r, 166r, 167r, 168r, 169r, 170r, 171r, 172r, $173 \mathrm{r}, 174 \mathrm{r}, 175 \mathrm{r}, 176 \mathrm{r}, 177 \mathrm{r}, 178 \mathrm{r}, 179 \mathrm{r}, 180 \mathrm{r}, 181 \mathrm{r}, 181 \mathrm{v}, 182 \mathrm{r}, 183 \mathrm{r}, 186 \mathrm{r}, 187 \mathrm{r}$ e $188 \mathrm{r}$; rubrica "H.Cordeiro", referente ao advogado Hildebrando Cordeiro, na margem superior direita dos fólios 244r, 245r, 246r, 247r e 248r.

8. Particularidades: $O$ documento não possui capa, mas há uma folha de papel almaço, que funciona como uma espécie de invólucro, que foi inserido pelos estagiários do CEDOC/UEFS, para proteger o documento da umidade e garantir a conservação do suporte material, o que evita o contato direto das mãos do pesquisador com o manuscrito. Além disso, na folha há as seguintes informações sobre o documento: "Subsérie: Ações, Tipologia Petição, Parte I - Eduardo Fróes da Motta e Parte II: Adalberto Alves Farias, Localidade: FSA, Período: 1923-1928, No de folhas: 247”, as quais foram escritas a lápis pelos estagiários do arquivo; há uma ficha de identificação inserida pelos estagiários do CEDOC/UEFS com as seguintes informações: no cabeçalho - "UNIVERSIDADE ESTADUAL DE FEIRA DE SANTANA, DEPARTAMENTO DE CIÊNCIAS HUMANAS E FILOSOFIA, CENTRO DE DOCUMENTAÇÃO E PESQUISA, LEVANTAMENTO GERAL DOS NÚCLEOS DOCUMENTAIS", ao lado do cabeçalho "CLASSIFICAÇÃO: E (estante), Cx (caixa) e Doc (documento)", na linha seguinte: "NÚCLEO: FÓRUM DESEMBARGADOR FILINTO BASTOS, SEÇÃO: JUDICIÁRIO, SÉRIE (com espaço para preenchimento manual), SUBSÉRIE (com espaço para preenchimento manual), TIPOLOGIA (com espaço para preenchimento manual), COMARCA: FSA, $\mathrm{N}^{\mathrm{o}}$ DE FOLHAS (com espaço para preenchimento manual), LOCALIDADE (com espaço para preenchimento manual), PERÍODO (com espaço para preenchimento manual), PARTES E/OU INTERESSADOS (com espaço para preenchimento manual) e OBS. (com espaço para preenchimento manual)"; escurecimento do fólio 1r; marcas de costura em todos os fólios do documento; ganchos, laçadas e riscos longos; um carimbo molhado com a inscrição: "Affonso Pedreira Cerqueira" e outro com a inscrição: "Reconheço a firma _ $\mid$ Em testemunho _ da verdade $\mid$ Bahia, _ de de 19 ", ambos no fólio 7v; carimbo molhado com a inscrição: "Junta Comercial | 
Bahia", nos fólios 25r, 26r, 27r e 28r; carimbo molhado com a inscrição: "Pagou Secretario $\mid$ da Junta Commercial de São Salvador $\mid \_$de _ de 19 _ O Thesoureiro _ ", no fólio 29v; carimbo molhado com a inscrição: "TABELLIÃO RAMALHO | ABR 18 1928 | FEIRA DE SANT'ANNA", no fólio 41v; carimbo molhado com a inscrição: "REPARTIÇÃO GERAL DOS TELEGRAMAS | MAI 121923 | ESTAÇÃO | FEIRA DE SANT'ANNA”, no fólio $41 \mathrm{v}$; colagem que prende os fólios $1 \mathrm{r}$ ao $5 \mathrm{v}$, 20r ao $23 \mathrm{v}$ e $75 \mathrm{r}$ ao $77 \mathrm{v}$; variados selos ao longo do documento, a saber: 5 selos no valor de 100 réis e 1 no de 1 mil réis, no fólio $6 \mathrm{v} ; 4$ no valor de 300 réis e 1 no de 2 mil réis, no fólio $7 \mathrm{v} ; 6$ no valor de 100 réis, nos fólios $10 \mathrm{r}$, $11 \mathrm{v}$ e $41 \mathrm{v} ; 1$ no valor de 2 mil réis, no fólio $11 \mathrm{r}$; 1 no valor de 300 réis, no fólio $18 \mathrm{r}$; 1 no valor de 300 réis e 3 no valor de 100 réis, no fólio 20r; 3 no valor de 1 mil réis, no fólio $24 \mathrm{r}$; 3 no valor de 300 réis, 3 no valor de 100 réis e 1 no valor de 1 mil réis, no fólio $25 \mathrm{r}$; 1 no valor de 300 réis, nos fólios 26r, 27r, 28r e 29r; 3 no valor de 100 réis, nos fólios 31v, 40r, 45r, 46v, $52 \mathrm{r}$ e $53 \mathrm{v} ; 2$ no valor de 1 mil réis, no fólio $38 \mathrm{v}$; 1 no valor de 2 mil réis, nos fólios $41 \mathrm{r}$ e 237r; 3 no valor de 100 réis e 1 no valor de 30 réis, nos fólios 55r, 62r, 63r, 64r, 65v, 69r, 72r, $73 \mathrm{v}, 74 \mathrm{r}, 80 \mathrm{r}, 81 \mathrm{r}, 84 \mathrm{r}, 85 \mathrm{r}, 89 \mathrm{v}, 95 \mathrm{r}$ e 108v; 1 no valor de 300 réis e 1 no valor de 30 réis, nos fólios 90r, 91r, 96r, 97r, 98r, 100r, 103r, 107v, 109r, 114r, 115r, 123r, 127r, 190r, 191r, 193r, 194r, 196r, 197r, 199r, 200r, 202r, 203r, 205r, 206r, 208r, 209r, 211r, 212r, 214r, 215r, 217r, 218r, 220r, 223r, 224r, 225r, 227r e 230r; 7 no valor de 100 réis, no fólio 117r; 2 no valor de 300 réis e 2 no valor de 30 réis, nos fólios 145r e 185r; 4 no valor de 300 réis, no fólio $151 \mathrm{r}$; 1 no valor de 300 réis e 1 no valor de 100 réis, nos fólios 232r, 233r, 234r e 235r; 4 no valor de 300 réis, no fólio $237 \mathrm{v}$; 4 no valor de 50 réis, 1 no valor de 600 réis, no fólio $247 \mathrm{v}$; 2 no valor de 50 réis, no fólio $248 \mathrm{v}$; inscrição em tinta azul feita, provavelmente, por terceiros, no fólio 1r; um selo de imposto com a inscrição: "Imposto do sello", na margem superior esquerda, e um timbre estadual com a inscrição "Thesouro do Estado da Bahia", na margem centrosuperior da maioria dos fólios rectos; rasgo significativo do suporte material na margem inferior direita do fólio 1r; sinal especial feito, a próprio punho, pelo Coronel Agostinho Fróes da Motta na sua assinatura pessoal e trecho escrito na vertical da margem direita, ambos no fólio $14 \mathrm{v}$; trechos escritos com caneta de tinta vermelha nos fólios $37 \mathrm{r}, 37 \mathrm{v}, 38 \mathrm{r}, 140 \mathrm{r}, 142 \mathrm{r}$, $143 \mathrm{r}, 236 \mathrm{v}, 240 \mathrm{r}, 240 \mathrm{v}, 242 \mathrm{r}, 242 \mathrm{v}$ e $243 \mathrm{r}$; trechos sublinhados com caneta de tinta vermelha, nos fólios $137 \mathrm{v}$ e $139 \mathrm{r}$; trechos sublinhados com caneta de tinta preta, nos fólios $148 \mathrm{r}, 152 \mathrm{r}$, $153 \mathrm{r}, 153 \mathrm{v}, 154 \mathrm{r}, 154 \mathrm{v}, 155 \mathrm{r}, 155 \mathrm{v}, 156 \mathrm{r}, 156 \mathrm{v}, 157 \mathrm{r}, 157 \mathrm{v}, 159 \mathrm{r}, 160 \mathrm{r}, 161 \mathrm{v}, 162 \mathrm{r}, 163 \mathrm{r}$, $164 \mathrm{r}, 165 \mathrm{r}, 165 \mathrm{v}, 166 \mathrm{r}, 167 \mathrm{r}, 167 \mathrm{v}, 168 \mathrm{r}, 168 \mathrm{v}, 169 \mathrm{r}, 169 \mathrm{v}, 170 \mathrm{r}, 170 \mathrm{v}, 171 \mathrm{r}, 171 \mathrm{v}, 172 \mathrm{r}$, $172 \mathrm{v}, 173 \mathrm{r}, 173 \mathrm{v}, 174 \mathrm{r}, 174 \mathrm{v}, 175 \mathrm{r}, 175 \mathrm{v}, 176 \mathrm{r}, 176 \mathrm{v}, 177 \mathrm{r}, 177 \mathrm{v}, 178 \mathrm{r}, 178 \mathrm{v}, 179 \mathrm{r}, 179 \mathrm{v}$, $180 \mathrm{r}, 180 \mathrm{v}, 181 \mathrm{r}, 181 \mathrm{v}, 182 \mathrm{r}, 182 \mathrm{v}, 183 \mathrm{r}, 186 \mathrm{r}, 186 \mathrm{v}, 187 \mathrm{r}, 187 \mathrm{v}$ e $188 \mathrm{r}$; riscaduras, sinalizadas com a expressão: "Sem effeito", nos fólios $81 \mathrm{v}$ e 238v; correções inseridas com caneta de tinta preta, nos fólios datiloscritos $241 \mathrm{r}$ e $241 \mathrm{v}$; rasgos na margem esquerda (para os fólios rectos) e na margem direita (para os fólios versos) dos 4 últimos fólios do documento.

9. Conteúdo: Trata-se de uma petição, na qual Adalberto Alves de Farias, esposo de Dona Adalgisa de Almeida Motta Farias e genro do falecido Agostinho Fróes da Motta, solicitou que fosse devidamente encerrada a firma comercial no nome de Agostinho Fróes da Motta e Filho, alegando, para isso, que o filho, ora sócio da firma, Dr. Eduardo Fróes da Motta, não havia encerrado a firma, mesmo depois de um ano decorrido após a morte do seu pai e sócio da referida firma.

Neste meandro, foi trasladado o contrato comercial estabelecido entre o falecido e Eduardo Fróes da Motta, o qual alegou que o encerramento se deu durante o inventário do seu pai e que as contas concernentes à firma estavam expostas nas folhas do livro-caixa da empresa, anexadas nos fólios 145 a 149 do inventário do seu pai. Destarte, no contrato comercial apresentado constava que a firma teria duração de 3 anos contados a partir de $1^{\circ}$ de julho de 1919 a 30 de junho de 1922, o que quer dizer que na data da morte do seu sócio e pai, 
em 22 de março de 1922, a firma ainda estava em vigor.

Entretanto, as alegações do Dr. Eduardo Fróes da Motta diziam que a partir do momento em que o seu pai faleceu, automaticamente a sociedade mercantil teria sido dissolvida, o que foi sumariamente contestado por Adalberto Alves de Farias, haja vista que este afirmou que a prestação de contas apresentada pelo seu cunhado seria fradulenta, pois os números apresentados seriam incompatíveis entre as contas, datadas desde a morte do coronel Agostinho Fróes da Motta. Diante disso, Adalberto Alves de Farias solicitou que o liquidante da firma prestasse os devidos esclarecimentos acerca do balanço comercial apresentado, pedido que se justificava porque tanto ele quanto os demais herdeiros do falecido estariam sendo lesados por aquele.

Logo, além de Adalberto e a sua esposa, também não concordaram com o balanço apresentado João Constantino Faskomy e a sua esposa, Amalia da Motta Faskomy, e Arthur Fróes da Motta, todos herdeiros interessados na devida prestação de contas, o que levou o Dr. Eduardo Fróes da Motta a apresentar novos balanços referentes ao período de 23 de março de 1922 a 31 de dezembro de 1926, bem como a cópia traduzida dos telegramas trocados entre a firma Agostinho Fróes da Motta e Filho e a W. B. Michaelicus e Co., empresa alemã, com a qual estavam negociando a venda de 690 fardos de fumo, que seriam exportados.

Também foi apresentada uma petição por parte do Dr. Eduardo Fróes da Motta solicitando a autorização do Juiz de Direito para que o seu advogado, em seu nome, fizesse a cobrança das dívidas da firma, ora em liquidação, na Comarca de Feira de Santana e em outras nas quais a firma tinha dívidas a receber, o que foi deferido pelo Juiz. Contudo, mesmo apresentando os balanços e balancetes referentes ao período entre o falecimento do seu pai e a data de abertura e fechamento deste processo, o Juiz ordenou que fosse feito um exame pericial nos livros da firma em liquidação, uma vez que os demais herdeiros haviam levantado a hipótese de existência de fraudes nos dividendos da empresa.

Devido a isso, foram intimados todos os interessados para uma audiência em que seriam designados os peritos para a execução da decisão judicial. Assim sendo, na primeira audiência a designação dos peritos não foi feita, pois uma das herdeiras, D. Albertina de Almeida Motta, não foi encontrada para intimação e nem o seu representante legal, o que fez com que uma nova audiência fosse marcada e, caso aquela não fosse novamente encontrada, a designação ocorreria à sua revelia.

No fólio 93r foi registrada a segunda audiência na qual foram designados 3 peritos, a saber: Paulo de Lemos Bastos, gerente do Banco do Brasil naquela cidade, o qual acabara pedindo dispensa do cargo de perito por se dizer de função incompatível com aquela requerida pelo Juiz; Leolindo dos Santos Ramos, que não foi encontrado para intimação, pois estava no Município de Mundo Novo-BA, mas solicitou, por meio de carta, dispensa do cargo porque passaria 30 dias na Capital organizando o casamento de uma de suas filhas; e Camillo de Mello Lima, proprietário de uma pensão na cidade e quem também pediu dispensa do cargo de perito por se achar com a "saúde alterada" e "com muitos afazeres que lhe tomavam muito tempo", ficando assim inabilitado para "estudos e exames [daquela] natureza".

Diante das recusas, 3 novos peritos foram intimados: Adalardo Bacellar, Cicero Lima e João Carneiro Vital, dos quais o primeiro aceitou o cargo, mas justificou que seria necessário o pagamento de 4 contos de réis, haja vista que no período de análise dos livros da firma ele perderia alguns trabalhos, bem como teria despesas com viagem e hospedagem, o que foi prontamente aceito por Adalberto Alves de Farias, Arthur Fróes da Motta, Eduardo Fróes da Motta, Albertina Fróes da Motta, Dr. José Maria Neves, Augusto Fróes da Motta e Elpidio Raymundo da Nova. Sobre o segundo perito intimado, Cicero Lima, este se recusou a aceitar o cargo justificando que era sobrinho de Arthur de Assis, escriturário da referida firma, portanto haveria, segundo ele, conflitos de interesse. Sobre o terceiro, o Tabelião João Carneiro Vital, este foi eleito perito desempatador e aceitou prontamente a incumbência lhe 
dada.

Com a recusa de Cicero Lima, o Juiz mandou intimar o senhor Manoel Eustaquio Rebello de Figueiredo como perito, o qual também aceitou o cargo. Nomeados os peritos e aceitos os cargos por aqueles, foi realizado o exame pericial nos livros da firma Agostinho Fróes da Motta e Filho e respondidos, ao todo, 61 quesitos pelos peritos, dos quais 10 foram apresentados pelo Juiz, 12 por João Constantino Faskomy e sua esposa, Dona Amália de Almeida Motta Faskomy, através do seu advogado José Maria Neves, 20 por Adalberto Alves de Farias, por meio do seu advogado Agnello Ribeiro de Macêdo e 19 por Eduardo Fróes da Motta.

Em seguida, nos fólios 236 recto e verso, Arthur Fróes da Motta solicitou, por meio do seu advogado nomeado Hildebrando Cordeiro de Almeida ${ }^{88}$, que a Justiça intimasse o seu irmão, Eduardo Fróes da Motta, para que este liquidasse a firma que até aquela data, 26 de abril de 1928, ainda não havia sido findada. A partir do fólio 240 recto, os irmãos Arthur Fróes da Motta e Alberto de Almeida Motta suplicaram que a Justiça obrigasse Eduardo Fróes da Motta a liquidar definitivamente a sociedade comercial Agostinho Fróes da Motta e Filho e a apresentar o orçamento final daquela ou então o destituir do cargo de sócio liquidante, já que, segundo aqueles, Eduardo Fróes da Motta havia cometido "omissões, negligências culpáveis, abusos e fraudes", haja vista que o prazo de dois meses para o fechamento da firma já havia finalizado e a firma continuava aberta, o que dava a entender, segundo os suplicantes, que isso era intencional por parte do sócio liquidante. Assim, em 17 de novembro de 1928 este processo foi "encerrado", após a solicitação feita pelos irmãos pedindo esclarecimentos dos empréstimos feitos e não recebidos pela firma, dentre os quais estavam os concedidos à Dona Albertina de Almeida Motta, enquanto o seu pai ainda estava vivo. Por fim, aos fólios 244 a 248 rectos e versos, foram anexadas as folhas dos livros de caixa da firma referentes aos empréstimos feitos àquela.

10. Escreventes: Manuel Francisco de Almeida Ramalho, Jacintho Ferreira da Silva, Agnello Ribeiro de Macêdo, Adalberto Alves Farias, Altino Teixeira, Eduardo Fróes da Motta, João Carneiro Vital, Agostinho Fróes da Motta, Oscar Falcão, Cesar Ribeiro de Cerqueira, Eduardo Cesar Rios, Maximiano Cecilio Soledade, José Maria Neves, João Constantino Faskomy, Arthur Fróes da Motta, Arnold Ferreira da Silva, Arnaldo Cohim Pacheco, Lyderico Santos Cruz, Elpidio Raymundo da Nova, Pedro Americo de Britto, Camillo de Mello Lima, Leolindo dos Santos Ramos, Cicero Lima, Adalardo Bacellar, Albertina Fróes da Motta, Augusto Fróes da Motta, José Percelino Victoria, Manoel Eustachio Rebello de Figueiredo, Vicente dos Reis, Alfredo Manoel da Costa, Abdon Alves Affonso e Hildebrando Cordeiro de Almeida.

Fonte: Elaborado pela pesquisadora

Quadro 17 - Ficha codicológica do décimo terceiro documento

AÇÃO DE INSTRUMENTO DE AGRAVO PROPOSTA POR ALBERTO DE ALMEIDA MOTTA E ARTHUR FRÓES DA MOTTA

1. Cota: Feira de Santana - Bahia; Centro de Documentação e Pesquisa/ UEFS; Seção Judiciária, Série Cíveis; Subsérie: Ações; Tipologia Instrumento de Agravo; Localização: Estante 13, Caixa 361 e Documento 8410.

2. Datação: 15 de agosto de 1927 - "[...] quinze de Agosto | de mil novecentos e vinte e sete [...]" (f. 1r, 1. 4-5).

3. Lugar de origem: Feira de Santana - "[...] Feira, quinze de Agosto | de mil novecentos e

\footnotetext{
${ }^{88}$ Formado em Ciências Jurídicas em 1913 pela Faculdade Livre de Direito da Bahia.
} 
vinte e sete [...]" (f. 1r, 1. 4-5).

4. Fólio de abertura: "inclusive o poder de arguir de suspeito | a quem o for._Collada uma estampilha | da União no valor de dois mil reis as- | sim inutilisada: Feira, quinze de Agosto | de mil novecentos e vinte e sete (assignado) | Pharmaceutico Arthur Fróes da Motta. | Em seguida estava o reconhecimento da | firma supra, na forma seguinte: Reco- | nheço a letra e firma supra do Phar- | maceutico Arthur Fróes da Motta. | Feira de Sant'Anna, quinze de Agosto | de mil novecentos e vinte e sete. Em | testemunho (signal publico) João Carneiro Vital da $\mid$ verdade. _ João Carneiro Vital _ Á mar- $\mid$ gem estavam collados quatro sellos $\mid$ do Estado todos no valor total de mil | e duzentos reis, assim inutilisados: | Feira, quinze de Agosto de mil nove- $\mid$ centos e vinte e sete. (Assignado) João $\mid$ Carneiro Vital. = Minuta $=1$ (Folhas 453 a folhas 459, do quarto Volume) Pelos | aggravantes, Engenheiro Alberto de | Almeida Motta e Pharmaceutico | Arthur Fróes da Motta . xxx O acata- | mento que nos habituamos a tribu- | tar á rectidão moral do Juiz a quó, | a quem as auras da bôa fama já sa- | graram o nome de bom Juiz, impôe-nos $\mid$ o dever de lhe pedirmos venia para | aggravar do seu despacho de deliberação." (f. 1r, 1. 1-30).

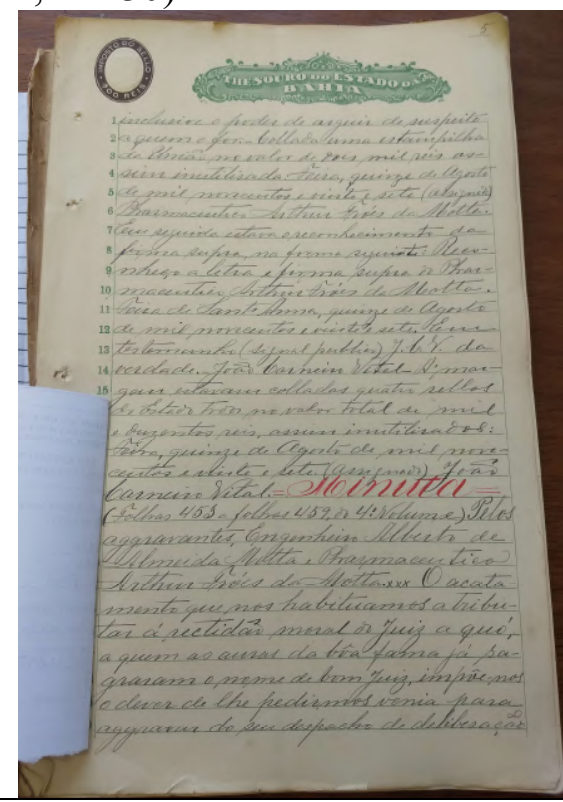

5. Suporte material: papel almaço, com pauta e de baixa gramatura.

6. Composição: $117^{89}$ fólios (dos quais todos são manuscritos, com exceção dos fólios $116 \mathrm{v}$ e $117 \mathrm{r}$, que estão em branco); formatos (in-plano e in-fólio); dimensão dos fólios variável: f. 1r $-340 \mathrm{~mm} \times 218 \mathrm{~mm}, 2 \mathrm{r}-330 \mathrm{~mm} \times 210 \mathrm{~mm}, 118 \mathrm{r}$ e $119 \mathrm{r}-330 \mathrm{~mm}$ x $217 \mathrm{~mm}, 120 \mathrm{r}-331 \mathrm{~mm}$ x $220 \mathrm{~mm}$ e $121 \mathrm{r}-338 \mathrm{~mm} \times 222 \mathrm{~m}$ etc.

7. Organização da página: dimensão da mancha escrita variável: f. $1 \mathrm{r}-318 \mathrm{~mm} \times 182 \mathrm{~mm}$, $2 \mathrm{r}-280 \mathrm{~mm} \times 180 \mathrm{~mm}, 118 \mathrm{r}$ e $119 \mathrm{r}-315 \mathrm{~mm} \times 178 \mathrm{~mm}, 120 \mathrm{r}-113 \mathrm{~mm} \times 117 \mathrm{~mm}$ etc.; 1 coluna e número de linhas da mancha escrita variável: f. $1 \mathrm{r}$ ao $109 \mathrm{v}, 110 \mathrm{v}$ ao $114 \mathrm{r}, 115 \mathrm{r}$ e $115 \mathrm{v}$ - 30 linhas, f. 110r e 114v - 27 linhas, f. 116r - 13 linhas e f. 117v - 2 linhas; pautado; numeração por foliação (sistema $5 \mathrm{r}, 6 \mathrm{r}, 7 \mathrm{r}$ etc.); reclamos ("e/e" nos fólios $1 \mathrm{v} / 2 \mathrm{r}$, "que/que" nos fólios $2 \mathrm{v} / 3 \mathrm{r}$, "podemos/podemos" nos 3v/4r, "suscitadas/suscitadas" nos $4 \mathrm{v} / 5 \mathrm{r}$, "Codigo/

89 Esse documento começa no fólio $5 \mathrm{r}$, logo os quatro primeiros fólios ou estão desaparecidos ou foram destruídos. O documento tem, ao todo, 117 fólios, mas foi iniciado, pelo scriptor, a partir do fólio 5r e finalizado no $121 \mathrm{v}$. Entretanto, optamos por corrigir a numeração desse manuscrito, assim como o fizemos nos demais que apresentaram erros dessa natureza, e iniciamos a sua contagem a partir do fólio 1r, por isso para cada descrição existente no texto decrescemos 4 fólios, por exemplo, no manuscrito o reclamo "inventariante/ inventariante" aparece nos fólios 13v e 14r, mas, após a correção da numeração, entendemos que ele se encontra, de fato, nos fólios $9 \mathrm{v}$ e10r. 
Codigo" nos 5v/6r, "aggravado/ aggravado" nos 6v/7r, "do/ do" nos 7v/8r, "folhas/ folhas" nos $8 \mathrm{r} / 8 \mathrm{v}$, "inventariante/ inventariante" nos $9 \mathrm{v} / 10 \mathrm{r}$, "venda/ venda" nos $10 \mathrm{v} / 11 \mathrm{r}$, "do/ do" nos $12 \mathrm{v} / 13 \mathrm{r}$, "firma/ firma" nos $15 \mathrm{v} / 16 \mathrm{r}$, "ao/ ao" nos $16 \mathrm{v} / 17 \mathrm{r}$, "peti-/ petição" nos $17 \mathrm{v} / 18 \mathrm{r}$, "cartorio/ cartorio" nos 18v/19r, "tes-/ testamenteiro" nos 19v/20r, "her-/ herdeiro" nos 20v/21r, "Conde/ Conde" nos 21v/22r, "Ares-/ Aresto" nos 22v/23r, "fazen-/ fazendas" nos $24 \mathrm{v} / 25$, "man-/ mandato" nos 26v/27r, "reis/ reis" nos $27 \mathrm{v} / 28 \mathrm{r}$, "que/ que" nos 29v/30r, "dividas/ dividas" nos 30v/31r, "acom-/ acompanhar" nos 31v/32r, "fumo/ fumo" nos $33 \mathrm{v} / 34 \mathrm{r}$, "por/ por" nos 34v/35r, "para/ para" nos 35v/36r, "car-/ cartões" nos 36v/37r, "contos/ contos" nos 37v/38r, "ao/ ao" nos 38v/39r, "pois/ pois" nos 39v/40r, "que/ que" nos $40 \mathrm{v} / 41 \mathrm{r}$, "no/ no" nos 42v/43r, "a/ a" nos 43v/44r, "inventario/ inventario" nos 44v/45r, "visto/ visto" nos 45v/46r, "escrevi/ escrevi" nos 46v/47r, "para/ para" nos 47v/48r, "em/ em" nos 48v/49r, "man-/ mandado" nos 49v/50r, "tenham/ tenham" nos 50v/51r, "bem/ bem como" nos 51v/52r, "to-/ todos" nos 52r/52v, "pre-/ prejuizos" nos 52v/53r, "advo-/ advogado" nos 53v/54r, "e/ e" nos 54v/55r, "Em/ Embaixo" nos 55v/56r, "sen-/ sentimentalismo" nos 56v/57r, "occasionaes/ occasionaes" nos 57v/58r, "algum/ algum" nos 58v/59r, "a/ a" nos 59v/60r, "seu/ seu" nos 60v/61r, "o/ o" nos 61v/62r, "me-/ melhor" nos $62 \mathrm{v} / 63 \mathrm{r}$, "os/ os" nos 63v/64r, "importan-/ importancia" nos 64v/65r, "Novo./ Novo." nos 65v/66r, "no-/ novecentos" nos 66v/67r, "mes-/ mesmas" nos 67v/68r, "nes-/ neste" nos 68v/69r, "combinou/ combinou" nos 69v/70r, "umifica-/ umificação" nos 70v/71r, "que/ que" nos 71v/72r, "tes-/ testemunhas" nos 73v/74r, "le-/ legal" nos 74v/75r, "Eduardo/ Eduardo" nos 75v/76r, "e/ e" nos 76v/77r, "res-/ respostas" nos 77v/78r, "zona/ zona" nos 78v/79r, "ou/ outros" nos 79v/80r, "jura-/ juramento" nos 80v/81r, "nun-/ nunca" nos $81 \mathrm{v} / 82 \mathrm{r}$, "não/ não" nos $82 \mathrm{v} / 83 \mathrm{r}$, "Con-/ Conclusão" nos $83 \mathrm{v} / 84 \mathrm{r}$, "de/ de" nos $84 \mathrm{v} / 85 \mathrm{r}$, "quinhão/ quinhão" nos $85 \mathrm{v} / 86 \mathrm{r}$, "casa/ casa" nos $87 \mathrm{v} / 88 \mathrm{r}$, "desva-/ desvalorisada" nos $88 \mathrm{v} / 89 \mathrm{r}$, "marcos_/ marcos" nos 89v/90r, "a-/ advogado" nos 90r/90v, "seguintes/ seguintes" nos 90v/91r, "pelo/ pelo" nos 91v/92r, "avalia-/ avaliações" nos 92v/93r, "nudez/ nudez" nos 93v/94r, "di/ direito" nos 94v/95r, "afas-/ afastando-se" nos 95v/96r, "pos-/ posses" nos 96v/97r, "rela-/ relação" nos 97v/98r, "o/ o" nos 98v/99r, "liquidar/ liquidar" nos 99v/100r, "es-/ escandaloso" nos 102v/103r, "Se-/ Senhor" nos 103v/104r, "Jacin-/ Jacintho" nos 104v/105r, "Man-/ Manga" nos 105v/106r, "uma/ uma" nos 106v/107r, "escriptu-/ escriptura" nos 107v/108r e "mil/ mil" nos 108v/109r); rubrica do Juiz Lyderico dos Santos Cruz (SantosCruz), na margem central do fólio 118v; rubrica do Juiz Manoel Côelho, na margem centro-direita do fólio 119v.

8. Particularidades: O documento não possui capa, mas há uma folha de papel almaço, que funciona como uma espécie de invólucro, que foi inserido pelos estagiários do CEDOC/UEFS, para proteger o documento da umidade e garantir a conservação do suporte material, o que evita o contato direto das mãos do pesquisador com o manuscrito. Além disso, na folha há as seguintes informações sobre o documento: "Subsérie: Ações, Tipologia: Instrumento de Agravo, Parte I - Eduardo Fróes da Motta e Parte II: Alberto d'Almeida Motta e Arthur Fróes da Motta, Localidade: FSA, Período: 1928-1929, № de folhas: 116", as quais foram escritas a lápis pelos estagiários do arquivo; ficha de identificação inserida pelos estagiários do CEDOC/UEFS com as seguintes informações: no cabeçalho "UNIVERSIDADE ESTADUAL DE FEIRA DE SANTANA, DEPARTAMENTO DE CIÊNCIAS HUMANAS E FILOSOFIA, CENTRO DE DOCUMENTAÇÃO E PESQUISA, LEVANTAMENTO GERAL DOS NÚCLEOS DOCUMENTAIS", ao lado do cabeçalho "CLASSIFICAÇÃO: E (estante), Cx (caixa) e Doc (documento)", na linha seguinte: "NÚCLEO: FÓRUM DESEMBARGADOR FILINTO BASTOS, SEÇÃO: JUDICIÁRIO, SÉRIE (com espaço para preenchimento manual), SUBSÉRIE (com espaço para preenchimento manual), TIPOLOGIA (com espaço para preenchimento manual), COMARCA: FSA, $\mathrm{N}^{\circ}$ DE FOLHAS (com espaço para preenchimento manual), LOCALIDADE (com espaço para preenchimento manual), PERÍODO (com espaço para 
preenchimento manual), PARTES E/OU INTERESSADOS (com espaço para preenchimento manual) e OBS. (com espaço para preenchimento manual)"; dois timbres estaduais com as inscrições: "Thesouro do Estado da Bahia" e "IMPOSTO DO SELLO", em quase todos fólios rectos; dois selos de impostos no valor de 600 e 100 réis, respectivamente, na margem centrosuperior dos fólios 118r e 119r; palavras e/ou trechos sublinhados ou escritos com canetas de tinta vermelha ou preta nos fólios $5 \mathrm{v}, 13 \mathrm{r} / \mathrm{v}, 14 \mathrm{r}, 19 \mathrm{r} / \mathrm{v}, 20 \mathrm{r} / \mathrm{v}, 21 \mathrm{r} / \mathrm{v}, 22 \mathrm{r}, 23 \mathrm{r}, 24 \mathrm{r}, 26 \mathrm{r} / \mathrm{v}$, $27 \mathrm{r} / \mathrm{v}, 28 \mathrm{r} / \mathrm{v}, 29 \mathrm{r}, 30 \mathrm{r}, 31 \mathrm{r} / \mathrm{v}, 32 \mathrm{r} / \mathrm{v}, 33 \mathrm{r} / \mathrm{v}, 34 \mathrm{r} / \mathrm{v}, 35 \mathrm{r} / \mathrm{v}, 41 \mathrm{v}, 43 \mathrm{r}, 44 \mathrm{r}, 45 \mathrm{r}, 46 \mathrm{r} / \mathrm{v}, 47 \mathrm{v}, 48 \mathrm{r} / \mathrm{v}$, $50 \mathrm{r}, 51 \mathrm{r}, 52 \mathrm{r}, 53 \mathrm{r}, 55 \mathrm{r} / \mathrm{v}, 56 \mathrm{r}, 57 \mathrm{r} / \mathrm{v}, 58 \mathrm{r} / \mathrm{v}, 59 \mathrm{r}, 60 \mathrm{r} / \mathrm{v}, 65 \mathrm{r}, 67 \mathrm{r} / \mathrm{v}, 68 \mathrm{v}, 69 \mathrm{r}, 70 \mathrm{r}, 71 \mathrm{r}, 74 \mathrm{v}, 75 \mathrm{r} / \mathrm{v}$, $76 \mathrm{r} / \mathrm{v}, 77 \mathrm{r} / \mathrm{v}, 78 \mathrm{r} / \mathrm{v}, 82 \mathrm{r}, 84 \mathrm{v}, 86 \mathrm{v}, 87 \mathrm{r} / \mathrm{v}, 88 \mathrm{r} / \mathrm{v}, 89 \mathrm{v}, 90 \mathrm{v}, 91 \mathrm{v}, 92 \mathrm{v}, 93 \mathrm{r}, 94 \mathrm{r}, 95 \mathrm{r} / \mathrm{v}, 96 \mathrm{v}, 97 \mathrm{r}$, $98 \mathrm{r} / \mathrm{v}, 99 \mathrm{r} / \mathrm{v}, 100 \mathrm{v}, 101 \mathrm{r} / \mathrm{v}, 102 \mathrm{r} / \mathrm{v}, 104 \mathrm{v}, 105 \mathrm{r}, 106 \mathrm{v}, 107 \mathrm{v}, 108 \mathrm{v}, 109 \mathrm{r} / \mathrm{v}, 110 \mathrm{r}, 111 \mathrm{v}, 112 \mathrm{r} / \mathrm{v}$.

9. Conteúdo: Trata-se da trasladação de parte do quarto volume da petição ${ }^{90}$ proposta por Adalberto Alves de Farias e Arthur Fróes da Motta contra Eduardo Fróes da Motta, na qual havia uma procuração passada pelo farmacêutico Arthur Fróes da Motta ao seu advogado, Hildebrando Cordeiro de Almeida, em 15 de agosto de 1927, para lhe representar legalmente no inventário do seu falecido pai, Agostinho Fróes da Motta.

Neste documento também há a trasladação do quinhão de Alberto de Almeida Motta e dos demais herdeiros na partilha dos bens do inventariado, além da argumentação de que o inventariante, Eduardo Fróes da Motta, "sonegou" bens no inventário. Em outros termos, este processo se constitui, em grande parte, da trasladação de várias partes de outros processos, inclusive do processo de instrumento de agravo proposto por Alberto de Almeida Motta e Arthur Fróes da Motta contra o inventariante e contra Augusto Fróes da Motta.

Finalizado em 10 de abril de 1929, esse processo foi deferido com a sentença judicial de que o inventariante estava destituído do referido cargo, porque, segundo o Juiz Lyderico Santos Cruz, Eduardo Fróes da Motta havia ultrapassado o prazo para o encerramento do inventário que, àquela altura, já estava no seu sexto ano sem finalização, bem como porque o inventariante havia se aproveitado do prestígio social e político que tinha na cidade para protelar o inventário e agir de modo a se beneficiar na partilha, prejudicando os demais herdeiros.

O Juiz também alegou, em seu parecer, que a avaliação das fazendas São Luiz, Genipapo e Queimadinhas deveria ser refeita, já que o valor das respectivas avaliações, apresentadas pelo inventariante, era "fraudulento". Em seguida, o Juiz mandou publicar a sentença, que foi assinada por ele e pelo Desembargador do Superior Tribunal de Justiça, Antônio Bulcão. Em seguida o escrivão Vicente dos Reis notificou, através de uma certidão, que os advogados dos apelantes e apelados haviam sido intimados acerca do conteúdo deste documento.

10. Escreventes: Vicente dos Reis, Silio Soledade, Villebaldo Garcez Paranhos Montenegro, Nuno da Silva Rocha, Ignacio Paschoal Bastos, Pedro Ribeiro, Lyderico Santos Cruz, Antonio Bulcão e Manoel Coêlho.

Fonte: Elaborado pela pesquisadora

Quadro 18 - Ficha codicológica do décimo quarto documento

\section{PETIÇÃO SOLICITADA POR ADALBERTO ALVES DE FARIAS E ARTHUR FRÓES DA MOTTA}

1. Cota: Feira de Santana - Bahia; Centro de Documentação e Pesquisa/ UEFS; Seção Judiciária, Série Cíveis; Tipologia Petição; Localização: Estante 13, Caixa 347 e Documento 7970.

\footnotetext{
${ }^{90}$ Esta petição é o décimo quarto documento listado nesta seção, cuja localização no CEDOC/UEFS é: Estante
} 13, Caixa 347 e Documento 7970. 
2. Datação: 1927 "Bahia, 7 de Maio de 1927 [...]" (f. 1r, 1. 1).

3. Lugar de origem: Bahia ${ }^{91}$ - "Bahia, 7 de Maio de 1927 [...]" (f. 1r, 1. 1).

4. Fólio de abertura: "Bahia, 7 de Maio de 1927 | Illustrissimo Senhor Doutor Manoel Pimentel | Notifico Vossa Senhoria que, pelo aresto de 22 de Abril | de 1927, decidio o Tribunal a appellação | civil da Feira d Sant'Anna, sob o numero 3226 | em que são appellantes Adalberto Alves Farias | e Arthur Froes da Motta e appellado Doutor E- | duardo Froes da Motta constituinte de Vossa Senhoria | dando provimento ao recurso | Custas por quem de direito | Sciente. Vem Ignacio Pascoal Bastos | 10-5 (Maio) 1927 Escrivão ManoelPimentel | Bahia, 5 de Maio $27 \mid$ Ignacio Pascoal" (f. 1r, 1. 1-30).

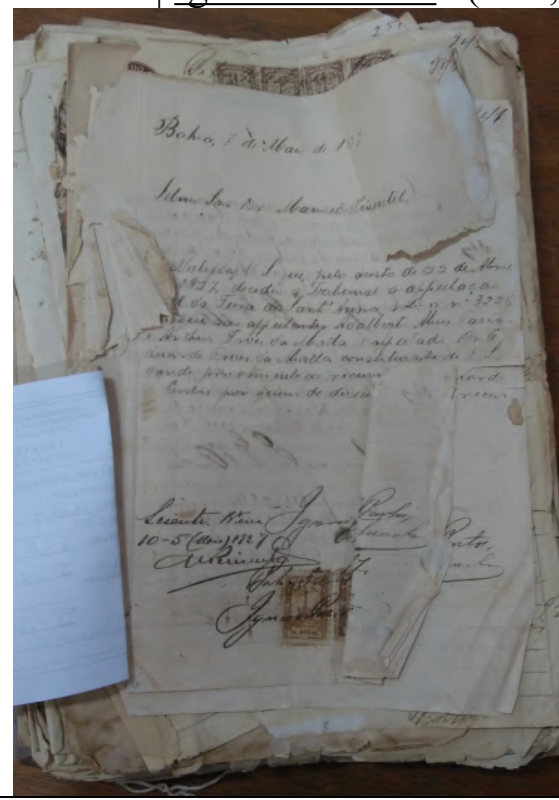

5. Suporte material: papel almaço, com pauta e de baixa gramatura.

6. Composição: 353 fólios (dos quais os fólios $7 \mathrm{v}, 8 \mathrm{v}, 9 \mathrm{v}, 10 \mathrm{v}, 11 \mathrm{v}, 12 \mathrm{v}, 13 \mathrm{v}, 14 \mathrm{r}, 15 \mathrm{v}, 17 \mathrm{v}$, $18 \mathrm{v}, 26 \mathrm{v}, 27 \mathrm{v}, 31 \mathrm{v}, 33 \mathrm{v}, 34 \mathrm{v}, 47 \mathrm{v}, 49 \mathrm{r}, 52 \mathrm{r}, 53 \mathrm{v}, 56 \mathrm{r}$ etc. estão em branco, os fólios $5 \mathrm{r}, 24 \mathrm{r} / \mathrm{v}$, $36 \mathrm{r} / \mathrm{v}, 57 \mathrm{r} / \mathrm{v}, 58 \mathrm{r} / \mathrm{v}, 66 \mathrm{r}, 69 \mathrm{r}, 80 \mathrm{r}, 145 \mathrm{r} / \mathrm{v}, 190 \mathrm{r}$ etc. são híbridos, os fólios 113r, 129r, 143r etc. são formulários de pagamento de impostos e os demais fólios são manuscritos); formatos (inplano e in-fólio); dimensão dos fólios variável: f. $1 \mathrm{r}-283 \mathrm{~mm}$ x $212 \mathrm{~mm}, 2 \mathrm{r}-284 \mathrm{~mm}$ x $213 \mathrm{~mm}, 3 \mathrm{r}-330 \mathrm{~mm} \times 220 \mathrm{~mm}, 4 \mathrm{r}-335 \mathrm{~mm} \times 220 \mathrm{~mm}, 7 \mathrm{r}-269 \mathrm{~mm} \times 204 \mathrm{~mm}, 255 \mathrm{r}-332 \mathrm{~mm}$ x $218 \mathrm{~mm}, 371 \mathrm{r}-330 \mathrm{~mm}$ x $221 \mathrm{~mm}, 388 \mathrm{r}-330 \mathrm{~mm}$ x $220 \mathrm{~mm}, 411 \mathrm{r}-277 \mathrm{~mm}$ x $200 \mathrm{~mm}$ e $433 \mathrm{r}-260 \mathrm{~mm} \times 204 \mathrm{~mm}$ etc.

7. Organização da página: dimensão da mancha escrita variável: f. $1 \mathrm{r}-266 \mathrm{~mm} \times 180 \mathrm{~mm}$, $2 \mathrm{r}-255 \mathrm{~mm} \times 210 \mathrm{~mm}, 3 \mathrm{r}-330 \mathrm{~mm} \times 192 \mathrm{~mm}, 4 \mathrm{r}-235 \mathrm{~mm} \times 177 \mathrm{~mm}, 7 \mathrm{r}-250 \mathrm{~mm} \times 168 \mathrm{~mm}$, $255 \mathrm{r}-305 \mathrm{~mm} \times 189 \mathrm{~mm}, 371 \mathrm{r}-305 \mathrm{~mm} \times 202 \mathrm{~mm}, 388 \mathrm{r}-315 \mathrm{~mm} \times 187 \mathrm{~mm}, 411 \mathrm{r}-220 \mathrm{~mm}$ x $189 \mathrm{~mm}$ e $433 \mathrm{r}-242 \mathrm{~mm}$ x $187 \mathrm{~mm}$ etc.; 1 coluna e número de linhas da mancha escrita variável: f. $1 \mathrm{r}, 2 \mathrm{r}-30$ linhas, f. $2 \mathrm{v}$ e $5 \mathrm{r}-20$ linhas, f. $4 \mathrm{r}-15$ linhas, f. $4 \mathrm{v}-8$ linhas, f. $6 \mathrm{r}-11$ linhas, f. $14 \mathrm{v}-9$ linhas, f. $17 \mathrm{r}-13$ linhas, f. $18 \mathrm{r}-14$ linhas etc.; pautado; numeração ${ }^{92}$ por foliação em todos os fólios rectos (sistema 1r, 2r, 3r, 4r etc.); reclamos ("dos/ dos" nos fólios 16v/17r; "San-/ Sant'Anna" 19r/19v; "Engenheiro/ Engenheiro" 37r/37v, "dos/ dos" 38r/38v, "especial/ especial" 38v/39r, "o/ o" 39v/40r, "nada/ nada" 72v/73r etc.).

8. Particularidades: $O$ documento não possui capa, mas há uma ficha de identificação inserida pelos estagiários do CEDOC/UEFS com as seguintes informações: no cabeçalho "UNIVERSIDADE ESTADUAL DE FEIRA DE SANTANA, DEPARTAMENTO DE

\footnotetext{
${ }^{91}$ No documento, a referência à Bahia como cidade onde o documento fora produzido dizia respeito à capital do Estado, Salvador.

${ }_{92}$ A numeração do documento começa em 240.
} 
CIÊNCIAS HUMANAS E FILOSOFIA, CENTRO DE DOCUMENTAÇÃO E PESQUISA, LEVANTAMENTO GERAL DOS NÚCLEOS DOCUMENTAIS", ao lado do cabeçalho "CLASSIFICAÇÃO: E (estante), Cx (caixa) e Doc (documento)", na linha seguinte: "NÚCLEO: FÓRUM DESEMBARGADOR FILINTO BASTOS, SEÇÃO: JUDICIÁRIO, SÉRIE (com espaço para preenchimento manual), SUBSÉRIE (com espaço para preenchimento manual), TIPOLOGIA (com espaço para preenchimento manual), COMARCA: FSA, $\mathrm{N}^{\circ}$ DE FOLHAS (com espaço para preenchimento manual), LOCALIDADE (com espaço para preenchimento manual), PERÍODO (com espaço para preenchimento manual), PARTES E/OU INTERESSADOS (com espaço para preenchimento manual) e OBS. (com espaço para preenchimento manual)"; rasgos nas margens de vários fólios; dois timbres estaduais com as inscrições: "Thesouro do Estado da Bahia" e "IMPOSTO DO SELLO", em quase todos fólios rectos; dobras na parte interna do papel e nas margens de alguns fólios; marcas de costura na margem esquerda dos fólios soltos; riscos longos, ganchos e laçadas; escurecimento do papel em alguns fólios; carimbo molhado com a inscrição: "TABELLIÃO Soledade | FEV 181928 | FEIRA DE SANT'ANNA", na margem centro-inferior dos fólios 57r, 120r, 136r etc.; variados selos de impostos ao longo do documento: 2 selos no valor de 600 e 100 réis, respectivamente, na margem inferior centroesquerda dos fólios 1r e 2r; 4 selos no valor de 100 réis cada na margem centro-superior do fólio 3r; 4 selos no valor de 100 réis cada na margem centro-inferior do fólio 5r; 6 selos, dos quais 4 são no valor de 300 réis e 2 no valor de 100 réis, na margem centro-superior do fólio $17 \mathrm{r} ; 3$ selos, dos quais 1 no valor de 600 réis e 2 no valor de 50 réis, na margem central do fólio 20v etc; sinal público: seta dupla, cuja extremidade inferior aponta para a abreviatura $\mathrm{JCV}$, equivalente à abreviatura do nome do Tabelião de Notas, João Carneiro Vital, nos fólios $27 \mathrm{v}, 70 \mathrm{v}, 83 \mathrm{r}$ etc.; trechos sublinhados com caneta de cores variadas nos fólios 42r, 50r, 51r, $57 \mathrm{r} / \mathrm{v}, 58 \mathrm{r}, 74 \mathrm{v}, 87 \mathrm{r}, 92 \mathrm{r}, 140 \mathrm{v}, 141 \mathrm{r}, 148 \mathrm{r}$ etc.

9. Conteúdo: Trata-se do quarto volume de uma petição que correria no Superior Tribunal de Apelação, datada de 07 de maio de 1927, na qual foram apelantes Adalberto Alves de Farias e Arthur Fróes da Motta contra Eduardo Fróes da Motta. É-nos informado, neste documento, que o inventário, feito anteriormente, foi revogado, com a justificativa de que havia "irregularidades, vícios e falhas nas avaliações dos bens", bem como divergências entre os herdeiros, dentre os quais estava Arthur Fróes da Motta que não aceitava as decisões que o seu irmão, Dr. Eduardo Fróes da Motta, queria tomar para levar adiante todo o processo.

Assim, ao solicitar que os demais herdeiros também dividissem os honorários do advogado, Eduardo Fróes da Motta acabou criando uma situação desconfortável com os irmãos, haja vista que, em resposta à sua solicitação, Arthur Fróes da Motta acabou recomendando a Eduardo Fróes da Motta que renunciasse ao cargo de inventariante dos bens do pai deles, já que havia tantos "incômodos", declarados pelo próprio Eduardo Fróes da Motta. Em prosseguimento, alguns interessados acabaram concordando em dividir as despesas do processo com o inventariante e outros discordaram tanto sobre a divisão das custas quanto sobre a revogação do inventário, sendo que esta decisão havia sido tomada pelo Egrégio Superior Tribunal de Justiça.

Nesse ínterim, Alberto de Almeida Motta solicitou judicialmente o recebimento de sua parte na herança deixada pelo seu pai, haja vista que, no terceiro volume do inventário, há a notificação de que ocorreu a anulação do referido inventário, sendo que os demais interessados já estavam de posse de seus quinhões ou já os tinham vendido, enquanto que Alberto de Almeida Motta ainda não o tinha recebido com a justificativa de que o inventário havia sido anulado. Assim, Arthur Fróes da Motta respondeu solicitando que a parte desse irmão fosse deferida e, para isso, defendeu-o contra o que ele chamou de "injustiça".

Ainda foi salientado que a devolução das partes de cada herdeiro seria impossível, porque alguns deles já havia alienado a herança paterna recebida. Em vista disso, os herdeiros 
Eduardo Fróes da Motta, Augusto Fróes da Motta e João Constantino Faskomy concordaram com a sugestão de Arthur Fróes da Motta, feita pelo seu então advogado, Hildebrando Cordeiro de Almeida, de ceder a parte de Alberto de Almeida Motta. É interessante mencionar que foi Arthur Fróes da Motta quem solicitou à Justiça, duas vezes, que o andamento do inventário fosse realizado, alegando, inclusive, que a demora do seu encerramento se dava por "propósito protelatório" do inventariante, já que já havia transcorrido 8 meses desde a decisão do Egrégio Superior Tribunal e o inventariante não havia acatado as sugestões dadas pelo Tribunal para que o inventário fosse retomado.

Em vista disso, o inventariante, Eduardo Fróes da Motta, obedeceu à ordem judicial e, em audiência pública, apresentou as suas declarações acerca dos bens não mencionados no inventário do seu pai, incluindo, inclusive, as idades e raças dos gados, que já haviam sido herdados e até vendidos pelos herdeiros. Assim, seguiram as descrições complementares às primeiras inclusas no inventário, já anulado, de todos os bens móveis, semoventes e imóveis do inventariado, para os quais foi expedida solicitação de avaliação, a qual foi realizada por Valentim José de Souza Junior e Joaquim Honorio de Oliveira, na cidade de Feira de SantanaBA; por Guilhermino de Oliveira Cintra e Adnil de Sousa Pedreira, que avaliaram as Fazendas e os animais destas no Termo do Camisão; por José Moreira de Almeida e João Borges para procederem as avaliações dos bens existentes na cidade de Mundo Novo-BA; e por Manoel Mascarenhas e Hugolino Carneiro de Oliveira como avaliadores dos bens na cidade de Riachão do Jacuípe-BA.

Nesse meandro, o Engenheiro Alberto de Almeida Motta solicitou, em Juízo, que lhe fossem concedidas 853 tarefas de terras localizadas na Fazenda São Luiz, avaliadas em 12 contos e quinhentos mil réis, pedido que foi negado por parte do inventariante, já que este alegou que na primeira partilha essas terras faziam parte do seu próprio quinhão e, por isso, já havia feito melhorias na dita fazenda, o que, segundo ele, infringiria os seus direitos e o levaria à constestação.

Prestes a findar o prazo para que o inventariante dos bens do Coronel Agostinho Fróes da Motta desse prosseguimento ao inventário, o Farmacêutico Arthur Fróes da Motta e o seu irmão, Engenheiro Alberto de Almeida Motta, solicitaram, através do mesmo advogado constituído, que o inventariante cumprisse o prazo, naquele momento, prorrogado, sob pena de ser destituído do cargo caso não o cumprisse, já que se passaram 6 anos desde o início do primeiro inventário. Diante das acusações recebidas, o inventariante decidiu refutá-las, entretanto o Juiz deferiu alguns pedidos de Arthur Fróes da Motta e o de Alberto de Almeida Motta, acrescentando ao quinhão deste, além da Fazenda São Luiz, duas casas e uma parte em dinheiro, mantendo-se a partilha feita no primeiro inventário no que referia aos demais herdeiros, mas manteve o inventariante no seu cargo.

Em vista dessa decisão, Arthur Fróes da Motta e Alberto de Almeida Motta entraram com uma ação de instrumento de agravo contra as decisões que beneficiaram o Eduardo Fróes da Motta e este também recorreu da decisão por não aceitar o quinhão destinado a Alberto de Almeida Motta. Ao longo deste processo, foi mencionado que o total da soma de todos os bens do acervo do coronel Agostinho Fróes da Motta era de dois mil cento e trinta e um contos setecentes e quarenta e cinco mil trezentos e noventa e cinco réis $(2: 131.745 \$ 395)$, dentre os quais estavam inseridos bens imóveis, semoventes, móveis, dinheiro, dívidas ativas e passivas, ouro e títulos, os quais foram divididos entre os herdeiros, obedecendo, inclusive, a vontade do inventariado, atestada em seu testamento.

10. Escreventes: Manoel Pimentel, Ignacio Paschoal Bastos, Cesar Cabral, Francisco Moreira Simas, Vicente dos Reis, Alfredo Manoel da Costa, Eduardo Fróes da Motta, José Maria Neves, Augusto Fróes da Motta, Arthur Fróes da Motta, Adalgisa de Almeida Motta, Almerinda de Almeida Motta, Igmédio Evangelista de Almeida, Albertina Motta de Almeida, Alcides Oliveira, Cleolinto Cardoso Gomes, Euclides de Souza Pinto, Antonio 
Gonçalves Sobreira, Hildebrando Cordeiro de Almeida, João Carneiro Vital, José Barbosa de Souza Junior, João Constantino Faskomy, Abdon Alves Affonso, Hygino Pereira da Silva, Elpidio Raymundo da Nova, Maximiano Cecilio Soledade, Alberto de Almeida Motta, Joaquim Honorio d'Oliveira, Silvestre Carneiro da Silva, Oscar Erudilho, Adnil de Souza Pedreira, Pedro Ferreira, Gaudencio Santos, João Borges, Sebastião Alfredo Ramos, Webster Marques de Oliveira Lima, O. A. Barreto, Colanico Nunes Rios, Maurillo Eugenio Cesar Junior, Pedro Paulo da Silva, Manoel Mascarenhas, A. Silva, Octavio Joaquim Fructuoso, Candido Carvalho Vieira, Domicio de Barros, Manoel Araujo, Agnello Ribeiro de Macêdo e José Portugal.

Fonte: Elaborado pela pesquisadora

Quadro 19 - Ficha codicológica do décimo quinto documento

AÇÃO DE LIQUIDAÇÃO DE SOCIEDADE MERCANTIL SOLICITADA POR ADALBERTO ALVES DE FARIAS

1. Cota: Feira de Santana - Bahia; Centro de Documentação e Pesquisa/ UEFS; Seção Judiciária, Série Cíveis; Subsérie: Ações; Tipologia Liquidação de sociedade; Localização: Estante 13, Caixa 360 e Documento 8377.

2. Datação: 1928 - “1928 [...]” (f. 1r, 1. 1).

3. Lugar de origem: Feira de Santana - “[...] Feira de Sant'anna [...]” (f. 1r, 1. 3).

4. Fólio de abertura: "1928 | Juizo de Direito | da Feira de Sant'anna | ESTADO DA BAHIA

| Continuação da Sociedade | Mercantil digo Liquidação | de Sociedade Mercantil. | Adalberto Alves de Farias | Autor. | Doutor Eduardo Fróes da Motta | Réo. | Escrivão Reis AUTUAÇÃO | Anno de mil novecentos e vinte e oito aos | 28 dias do mez de Abril do dito anno, autuo a $\mid$ que se segue do que faço este termo. $\mid \mathrm{Eu}$, Vicente dos Reis escrivão que subscrevo." (f. 1r, 1. 1-24).

5. Suporte material: papel cartolina ${ }^{93}$ e papel almaço, com pauta em quase todos os fólios e de baixa gramatura.

6. Composição: 06 fólios (dos quais os fólios 1v, 2r, 2v, 3v, 4v, 5r, 5v, 6r e $6 \mathrm{v}$ estão em branco, o fólio $1 \mathrm{r}$ é um formulário e apenas os fólios $1 \mathrm{r}$, $3 \mathrm{r}$ e $4 \mathrm{r}$ possuem mancha escrita); formatos (in-plano e in-fólio); dimensão regular dos fólios: $320 \mathrm{~mm}$ x $225 \mathrm{~mm}$.

\footnotetext{
93 Também chamado papel cartão.
} 
7. Organização da página: dimensão da mancha escrita: f. 1r - 290mm X 200mm; 1 coluna e número de linhas da mancha escrita variável: f. $1 \mathrm{r}-26$ linhas, f. $3 r-25$ linhas e f. $4 \mathrm{r}-32$ linhas etc.; pautado; sem numeração; sem reclamos; assinatura do Tabelião João Carneiro Vital, na vertical da margem inferior esquerda do fólio $4 \mathrm{r}$.

8. Particularidades: O documento não possui capa, mas há uma folha de papel almaço, que funciona como uma espécie de invólucro, que foi inserido pelos estagiários do CEDOC/UEFS, para proteger o documento da umidade e garantir a conservação do suporte material, o que evita o contato direto das mãos do pesquisador com o manuscrito. Além disso, na folha há as seguintes informações sobre o documento: "Subsérie: Ações, Tipologia: Liquidação de sociedade, Parte I - Agostinho Fróes da Motta e Parte II: Adalberto de Almeida Motta ${ }^{94}$, Localidade: FSA, Período: 1928-1928, $\mathrm{N}^{\mathrm{o}}$ de folhas: 02", as quais foram escritas a lápis pelos estagiários do arquivo; há uma ficha de identificação inserida pelos estagiários do CEDOC/UEFS com as seguintes informações: no cabeçalho "UNIVERSIDADE ESTADUAL DE FEIRA DE SANTANA, DEPARTAMENTO DE CIÊNCIAS HUMANAS E FILOSOFIA, CENTRO DE DOCUMENTAÇÃO E PESQUISA, LEVANTAMENTO GERAL DOS NÚCLEOS DOCUMENTAIS", ao lado do cabeçalho "CLASSIFICAÇÃO: E (estante), Cx (caixa) e Doc (documento)", na linha seguinte: "NÚCLEO: FÓRUM DESEMBARGADOR FILINTO BASTOS, SEÇÃO: JUDICIÁRIO, SÉRIE (com espaço para preenchimento manual), SUBSÉRIE (com espaço para preenchimento manual), TIPOLOGIA (com espaço para preenchimento manual), COMARCA: FSA, $\mathrm{N}^{\circ}$ DE FOLHAS (com espaço para preenchimento manual), LOCALIDADE (com espaço para preenchimento manual), PERÍODO (com espaço para preenchimento manual), PARTES E/OU INTERESSADOS (com espaço para preenchimento manual) e OBS. (com espaço para preenchimento manual)"; rasgos e dobras nas margens laterais de alguns fólios; manchas de tinta e de umidade; dois timbres estaduais com as inscrições: "Thesouro do Estado da Bahia" e "IMPOSTO DO SELLO", no fólio 3r; dois selos de impostos no valor de 600 réis, na margem vertical inferior esquerda fólio $4 \mathrm{r}$, e outro selo de imposto entre as linhas 23 a 26 na margem centro-esquerda do mesmo fólio; sinal público: seta que aponta para a abreviatura JCV, referente ao nome do Tabelião João Carneiro Vital, na margem inferior do fólio 4r.

9. Conteúdo: Trata-se da abertura de uma ação de liquidação de sociedade, lavrada em 28 de abril de 1928, e cuja parte interessada foi o engenheiro Alberto de Almeida Motta que passa uma procuração ao advogado Hildebrando Cordeiro de Almeida para representar os seus direitos neste processo, cujo interesse principal era a liquidação da sociedade existente entre Adalberto Alves de Farias e a firma Agostinho Fróes da Motta e Filho.

10. Escreventes: Vicente dos Reis, Abdon Alves Affonso, Hildebrando Cordeiro de Almeida, Alberto de Almeida Motta e João Carneiro Vital.

Fonte: Elaborado pela pesquisadora

Quadro 20 - Ficha codicológica do décimo sexto documento

\section{PETIÇÃO DE INTIMAÇÃO DE HERDEIROS SOLICITADA POR JOÃO CONSTANTINO FASKOMY}

1. Cota: Feira de Santana - Bahia; Centro de Documentação e Pesquisa/ UEFS; Seção Judiciária, Série Cíveis; Subsérie: Ações; Tipologia Petição; Localização: Estante 13, Caixa 348 e Documento 7977.

\footnotetext{
${ }^{94}$ Há um equívoco na folha de papel almaço e na ficha de identificação deste documento no que concerne ao nome deste senhor, pois no processo o seu nome é Adalberto Alves de Farias e não Adalberto de Almeida Motta, como os estagiários escreveram.
} 


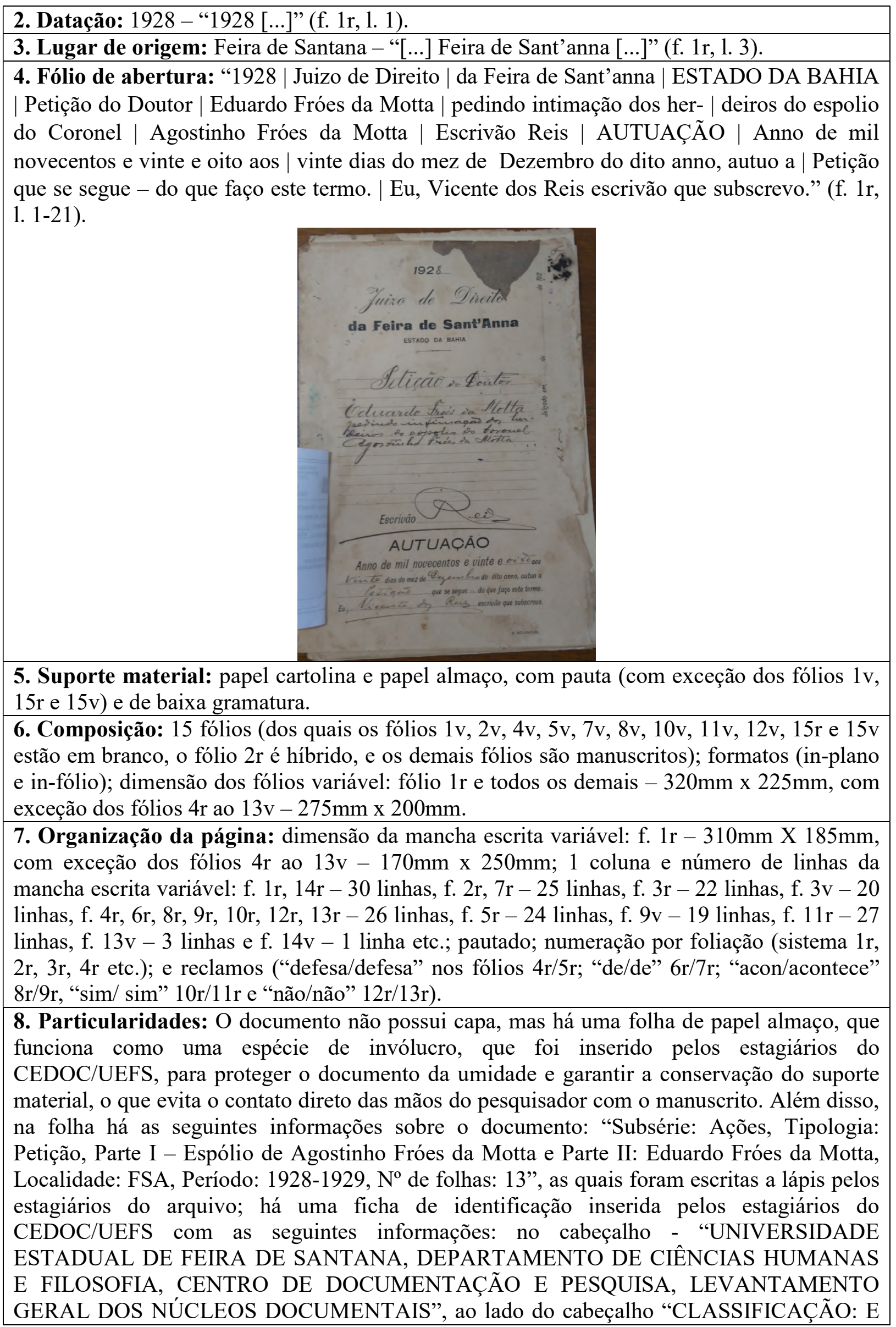


(estante), Cx (caixa) e Doc (documento)", na linha seguinte: "NÚCLEO: FÓRUM DESEMBARGADOR FILINTO BASTOS, SEÇÃO: JUDICIÁRIO, SÉRIE (com espaço para preenchimento manual), SUBSÉRIE (com espaço para preenchimento manual), TIPOLOGIA (com espaço para preenchimento manual), COMARCA: FSA, No DE FOLHAS (com espaço para preenchimento manual), LOCALIDADE (com espaço para preenchimento manual), PERÍODO (com espaço para preenchimento manual), PARTES E/OU INTERESSADOS (com espaço para preenchimento manual) e OBS. (com espaço para preenchimento manual)"; dois timbres com a inscrição: "IMPOSTO DO SELLO", este em alto relevo, e "THESOURO DO ESTADO DA BAHIA", em alguns fólios; laçadas; manchas de tinta nas margens superiores dos fólios 1r, 2r, 3r e 3v; marcas de umidade no recto e verso do último fólio; marcas de costura nas margens esquerdas dos fólios soltos; escurecimento do primeiro e último fólios.

9. Conteúdo: Trata-se de um processo movido por João Constantino Faskomy contra Eduardo Fróes da Motta, inventariante dos bens do seu pai, sob a alegação de que o falecido Coronel Agostinho Fróes da Motta vendeu uma casa na cidade de Santa Bárbara-BA, herdada após a partilha dos bens deixados por Dona Maximiana de Almeida Motta.

Eduardo Fróes da Motta, entretanto, respondeu que este processo não poderia correr sem a presença dos demais herdeiros dos seus pais: seus irmãos. Com isso, o escrivão Vicente dos Reis expediu cartas de intimação para serem entregues aos herdeiros do coronel Agostinho Fróes da Motta: Augusto Fróes da Motta, Igmedio Evangelista de Almeida (por cabeça de sua mulher, Albertina Fróes da Motta), Arthur Fróes da Motta, Alberto de Almeida Motta $^{95}$ e Adalgisa de Almeida Motta. Destes, esta última não recebeu a intimação, pois o Oficial de Justiça não conseguiu entregá-la, enquanto que Arthur Fróes da Motta a recebeu pelas mãos do Oficial de Justiça, mas deu ciência de que não concordava que o irmão, Eduardo Fróes da Motta, contratasse advogado para se defender na ação movida por seu cunhado, por dois motivos: primeiro, porque Eduardo Fróes da Motta não era mais o inventariante dos bens do seu pai por decisão do Tribunal Superior de Justiça, que o removeu das referidas funções por ter sido comprovada a sua "falta de idoneidade moral", e segundo porque, de fato, houve a venda irregular da referida casa que pertencia ao senhor João Constantino Faskomy e à sua esposa, Amalia da Motta Faskomy.

Igualmente, Dona Albertina Motta de Almeida deu ciência do recebimento da intimação e indicou que concordava com as razões apresentadas pelo seu irmão Arthur Fróes da Motta e, portanto, discordava da petição do seu irmão Eduardo Fróes da Motta. Augusto Fróes da Motta e Alberto de Almeida Motta, por sua vez, apenas deram ciência do recebimento das respectivas intimações. O processo foi encerrado em 27 de novembro de 1929 com a notificação de que o Oficial de Justiça Augusto Antonio Pereira fez a devida entrega das intimações, com exceção da de Dona Adalgisa de Almeida Motta, que não foi encontrada.

10. Escreventes: Vicente dos Reis, Abdon Alves Affonso, Eduardo Fróes da Motta, Augusto Antonio Teixeira, Alberto de Almeida Motta, Arthur Fróes da Motta, Albertina Motta de Almeida, Augusto Fróes da Motta e Manoel Ferreira Côelho.

Fonte: Elaborado pela pesquisadora

\footnotetext{
95 Neste documento, o engenheiro Alberto de Almeida Motta já havia sido integrado como um dos herdeiros legais do seu pai, o Coronel Agostinho Fróes da Motta.
} 
Quadro 21 - Ficha codicológica do décimo sétimo documento

\section{PRIMEIRO VOLUME DA AÇÃO ORDINÁRIA DE SONEGADOS (1929) PROPOSTA POR ARTHUR FRÓES DA MOTTA E FRANCELINA CARNEIRO DA MOTTA; ALBERTO DE ALMEIDA MOTTA E MARIA CARLOTA FALCÃO DE SOUSA MOTTA}

1. Cota: Feira de Santana - Bahia; Centro de Documentação e Pesquisa/ UEFS; Seção Judiciária, Série Cíveis; Subsérie: Ações; Ação Ordinária; Localização: Estante 10, Caixa 255 e Documento 5365.

2. Datação: 1929 - “[...] Feira, 21 de Outubro 1929 [...]" (f. 1r, 1. 3).

3. Lugar de origem: Feira de Santana - "[...] Feira, 21 de Outubro 1929 [...]” (f. 1r, 1. 3).

4. Fólio de abertura: "Excellentissimo senhor doutor Juiz de Direito | Do Autor Como requer | Feira, 21 de Outubro 1929| Manoel Coelho $\mid$ O pharmaceutico Arthur Fróes da Motta e sua mulher e o engenheiro Al- | berto de Almeida Motta e sua mulher,proprietarios e residentes nes- | ta cidade,vêm,na qualidade de filhos e noras do coronel Agostinho Fróes | da Motta,falecido nesta cidade a 23 de março de 1922,propôr a pre- | sente ação ordinaria contra o doutor Eduardo Fróes da Motta e sua mu- | lher, proprietarios e residentes nesta cidade,na qualidade,o primeiro, | de Inventariante do espolio e Liquidante da firma Agostinho Fróes | da Motta \& Filho,por sonegação de bens pertencentes ao acervo do mes- $\mid$ mo Coronel Agostinho Fróes da Motta; pelo que se propõem provar: | Primeiro | Que o doutor Eduardo Fróes da Motta se achava na posse dos bens do es- | polio do coronel Agostinho Fróes da Motta até a conclusão do respectivo | inventario e partilha,na qualidade de Inventariante de seu acervo e | de Liquidante da firma Agostinho Fróes da Motta \& Filho,onde se en- | contravam os maiores haveres do socio fallecido e chefe desta firma, | o Pae dos autores e do reu,coronel Agostinho Fróes da Motta; | Segundo | Que o doutor Eduardo Fróes da Motta,como Inventariante,se recusou a res- | tituir aos herdeiros bens do acervo,cuja existencia negou,apezar de $\mid$ se acharem estes sob a sua posse e de terem sido apontados e reclama- $\mid$ dos pelos herdeiros por occasião do inventario; " (f. 1r, 1. 1-30).

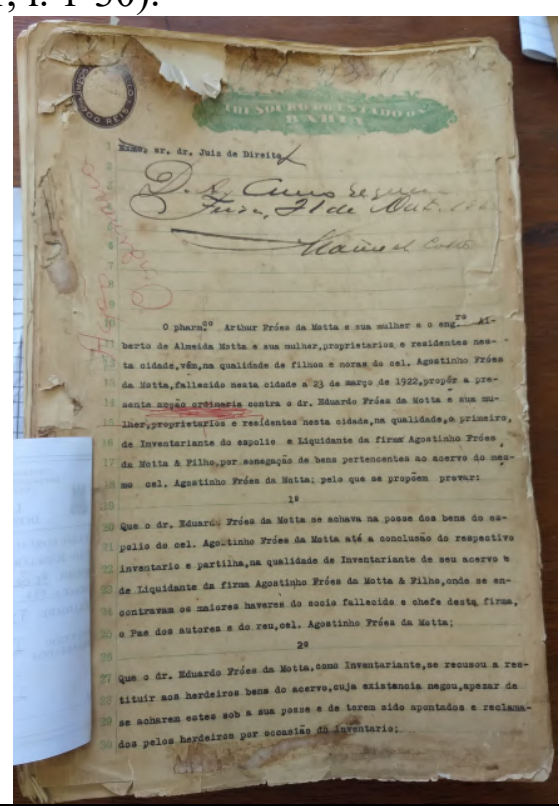

5. Suporte material: papel almaço e papel cartolina, com pauta na maioria dos fólios e de baixa gramatura.

6. Composição: 203 fólios (dos quais os fólios 60v, 61v, 70v, 77v, 81v, 86v, 107v, 159v, $167 \mathrm{v}, 175 \mathrm{v}, 183 \mathrm{v}, 202 \mathrm{v}$ e $203 \mathrm{v}$ estão em branco; o fólio $192 \mathrm{r}$ é um formulário preenchido manualmente; os fólios 1v, 2r/v, 63r/v, 64r/v, 173r/v, 174r e 178r são datiloscritos; os 1r, 3r/v, 
4r, 65r, 68r/v, 70r, 174v, 176r e 178v são híbridos; e os demais são manuscritos); formatos (in-plano e in-fólio); dimensão regular dos fólios: $320 \mathrm{~mm}$ x $225 \mathrm{~mm}$.

7. Organização da página: dimensão da mancha escrita, na maioria dos fólios: f. $1 \mathrm{r}-290 \mathrm{~mm}$ X 200mm; 1 coluna e número de linhas da mancha escrita variável: f. 1r ao 4r- 30 linhas, f. $4 \mathrm{v}-4$ linhas, f. $5 \mathrm{r}$ e $77 \mathrm{r}-5$ linhas, $6 \mathrm{v}$ e $81 \mathrm{r}-9$ linhas, f. $55 \mathrm{r}-10$ linhas, f. 55v - 7 linhas, f. $57 \mathrm{r}-24$ linhas, f. $57 \mathrm{v}-8$ linhas, f. 60r, 175r e 177r -23 linhas, f. 62v, 69v, 87v, 113v e 197v - 19 linhas, f. $65 \mathrm{r}-18$ linhas, f. 65v - 17 linhas, f. 78r - 12 linhas, f. 112v - 2 linhas e f. 196r - 13 linhas etc.; pautado; numeração por foliação (sistema 1r, 2r, 3r etc.); reclamos ("assim/ assim" nos fólios 7v/8r, "Mo-/ Motta" nos 8r/8v, "Faskomy/ Faskomy" nos 8v/9r, com/ com" nos 9v/10r, "dos/ dos" nos 10v/11r, "des-/ descriptas" nos 11v/12r, "de-/ depois" nos 12v/13r, "necessario/ necessario" nos 13v/14r, "ares-/ aresto" nos 14v/15r, "Outrosim/ Outrosim" nos $15 \mathrm{v} / 16 \mathrm{r}$, "no-/ novecentos" nos 16r/16v, "ao/ ao" nos 16v/17r, "sendo/ sendo" nos $17 \mathrm{v} / 18 \mathrm{r}$, "Dez/ Dez" nos 18v/19r, "dois/ dois" nos 19v/20r, "com-/ compareceu" nos 20v/21r, "da/ da" nos $21 \mathrm{v} / 22 \mathrm{r}$, "de/ de" nos 22v/23r, "mil/ mil" nos 23v/24r, "mil/ mil" nos 24v/25r, "dezeseis/ dezeseis" nos 25v/26r, "duzentos/ duzentos" nos 26v/27r, "fazenda/ fazenda" nos 27v/28r, "reis/ reis" nos 28v/29r, "cada/ cada" nos 29v/30r, "que/ que" nos 30v/31r, "José/ José" nos 31v/32r, "Tribunal,/ Tribunal," nos 32v/33r, "Geni-/ Genipapo" nos 33v/34r, "cha-/ chamamos" nos 34v/35r, "bemfeitoria/ bemfeitorias" nos 35v/36r, "immediata,/ immediata" nos 36v/37r, "pagamento/ pagamento" nos 37v/38r, "mon-/ monte" nos 38v/39r, "figurar, figurar" nos 39v/40r, "pres-/ prestou" nos 40v/41r, "qualquer/ qualquer" nos 41v/42r, "in-/ inventariante" nos 42v/43r, "com/ com" nos 43v/44r, "juros/ juros" nos 44v/45r, "inventariado/ inventariado" nos 45v/46r, "não/ não" nos 46v/47r, "definitivo/ definitivo" nos 47v/48r, "se-/ seguros" nos 48v/49r, "resol-/ resolvido" nos 49v/50r, "herdeiro/ herdeiro" nos 50v/51r, "Conde \& / Conde \&" nos 54v/55r, "nomeado/ nomeado" nos 55v/56r, "na/ na" nos 73v/74r, "oito./ oito." nos 74v/75r, "Juiz/ Juiz" nos 75v/76r, "ruinas/ ruinas" nos 76v/77r, "Motta/ Motta" nos 77v/78r, "igual/ igual" nos 78v/79r, "comprador/ comprador" nos 81v/82r, "Sant'/ Sant'Anna" nos 82v/83r, "que/ que" nos 87v/88r, "vontade/ vontade" nos 90v/91r, "o/ o" nos 91v/92r, "dois/ dois" nos 92v/93r, "por/ por" nos 93v/94r, "se-/ segunda" nos 94v/95r, "cida-/ cidadão" nos 95v/96r, "Carneiro,/ Carneiro," nos 96v/97r, "mez/ mez" nos 97v/98r, "demais/ demais" nos 98v/99r, "e/ e" nos 99v/100r, "ho-/ horas" nos 100v/101r, "de-/ declarados" nos 101v/102r, "se-/ seguinte" nos 102v/103r, "Feira/ Feira de Sant'Anna" nos 103v/104r, "her-/ herdeiros" nos 104v/105r, "exis-/ existente" nos 105v/106r, "documentos,/ documentos," nos 108v/109r, "18/2/ 18/2" nos 110v/111r, "Macêdo/ Macêdo" nos 112v/113r, "de-/ devedor" nos 113v/114r, "apresenta/ apresenta" nos 116v/117r, "pri-/ primeira" nos 117v/118r, "treis/ tres" nos 119v/120r, "prejuizos./ prejuizos." nos 120v/121r, "encerramento/ encerramento" nos 122v/123r, "liquidante/ liquidante" nos 123v/124r, "para/ para" nos 124v/125r, "so-/ social" nos 125v/126r, "em/ em" nos 126v/127r, "Demons-/ Demonstrativo" nos 127v/128r, "Arthur/ Arthur" nos 128v/129r, "Banco/ Banco" nos 129v/130r, "Agos-/ Agostinho" nos 131v/132r, "De-/ Devedores" nos 132v/133r, "Fe-/ Fevereiro" nos 133v/134r, "liqui-/ liquidação" nos 134v/135r, "400:000\$/ 400:000\$000" nos 135v/136r, "Motta./ Motta." nos 136v/137r, "liqui-/ liquidação" nos 137v/138r, "Fróes/ Fróes" nos 138v/139r, "ju-/ judicial" nos 139v/140r, "juros/ juros" nos 140v/141r, "fi-/ fixara" nos 141v/142r, "conse-/ conseguintemente" nos 142v/143r, "do/ do" nos 143v/144r, "1924/ 1924" nos 144v/145r, "sob/ sob" nos 145v/146r, "fallecido/ fallecido" nos 146v/147r, "Edu-/ Eduardo" nos 147v/148r, "sete/ sete" nos 148v/149r, "Certi-/ Certifico" nos 149v/150r, "do/ do" nos 150v/151r, "interessa-/ interessados" nos 151v/152r, "li-/ liquidante" nos 152v/153r, "na/ na" nos 153v/154r, "gastou/ gastou" nos 154v/155r, "reis/ réis" nos $155 \mathrm{v} / 156 \mathrm{r}$, "gasto/ gasto" nos 156v/157r, "que/ que" nos 157v/158r, "e/ e" nos 159v/160r, "e/ $\mathrm{e}$ " nos 161v/162r, "do/ do" nos 162v/163r, "lhe/ lhe" nos 163v/164r, "mez/ mez" nos 164v/165r, "desempe-/ desempenhar" nos 165v/166r, "de/ de" nos 166v/167r, "e/ e" nos 
167v/168r, "Monte/ Montenegro" nos 169v/170r, "de-/ decujus" nos 170v/171r, "termo./ termo" nos 177v/178r, "pe-/ penas" nos 183v/184r, "porque/ porque" nos 185v/186r, "lá/ lá" nos $186 \mathrm{v} / 187 \mathrm{r}$, "perguntado/ perguntado" nos $187 \mathrm{v} / 188 \mathrm{r}$, "sabe/ sabe" nos $188 \mathrm{v} / 189 \mathrm{r}$, "o/ o" nos 196v/197r, "passado/ passado" nos 198r/198v, "medi-/ medico" nos 199r/199v, "quando/ quando" nos 199v/200r, "perguntado./ perguntado." nos 200r/200v, e "Eduardo/ Eduardo" nos 200v/201r).

8. Particularidades: O documento não possui capa, mas há uma folha de papel almaço, que funciona como uma espécie de invólucro, que foi inserido pelos estagiários do CEDOC/UEFS, para proteger o documento da umidade e garantir a conservação do suporte material, o que evita o contato direto das mãos do pesquisador com o manuscrito. Além disso, na folha há as seguintes informações sobre o documento: "Subsérie: Ações, Tipologia: Ação Ordinária, Parte I - Eduardo Fróes da Motta e Parte II: Arthur Fróes da Motta e sua mulher e Alberto de Almeida Motta e sua mulher, Período: 1929-1929, $\mathrm{N}^{\mathrm{o}}$ de folhas: 201, Localidade: FSA, Obs.: Contém um exemplar Folha do Norte de 02 de Dezembro de 1917", as quais foram escritas a lápis pelos estagiários do arquivo; há uma ficha de identificação inserida pelos estagiários do CEDOC/UEFS com as seguintes informações: no cabeçalho "UNIVERSIDADE ESTADUAL DE FEIRA DE SANTANA, DEPARTAMENTO DE CIÊNCIAS HUMANAS E FILOSOFIA, CENTRO DE DOCUMENTAÇÃO E PESQUISA, LEVANTAMENTO GERAL DOS NÚCLEOS DOCUMENTAIS", ao lado do cabeçalho "CLASSIFICAÇÃO: E (estante), Cx (caixa) e Doc (documento)", na linha seguinte: "NÚCLEO: FÓRUM DESEMBARGADOR FILINTO BASTOS, SEÇÃO: JUDICIÁRIO, SÉRIE (com espaço para preenchimento manual), SUBSÉRIE (com espaço para preenchimento manual), TIPOLOGIA (com espaço para preenchimento manual), COMARCA: FSA, $\mathrm{N}^{\circ}$ DE FOLHAS (com espaço para preenchimento manual), LOCALIDADE (com espaço para preenchimento manual), PERÍODO (com espaço para preenchimento manual), PARTES E/OU INTERESSADOS (com espaço para preenchimento manual) e OBS. (com espaço para preenchimento manual)"; o documento começa no fólio $2 \mathrm{r}$, o que indica que o primeiro esteja perdido ou desaparecido; o documento possui bastante erro de numeração, apesar da tentativa de correção por parte dos escreventes; dois timbres com a inscrição: "IMPOSTO DO SELLO", este em alto relevo, e "THESOURO DO ESTADO DA BAHIA", em quase todos os fólios rectos; marcas de costura nos fólios soltos; ataques de broca em alguns fólios; marcas de umidade; rasgos nas margens do último fólio; dobras nas margens de alguns fólios; manchas de tintas passadas de um fólio para outro; palavras ou trechos sublinhados ou escritos com caneta de tinta preta ou vermelha nos fólios $1 \mathrm{r}, 2 \mathrm{r} / \mathrm{v}, 3 \mathrm{r} / \mathrm{v}$, $4 \mathrm{r}, 7 \mathrm{v}, 8 \mathrm{r} / \mathrm{v}, 9 \mathrm{r} / \mathrm{v}, 10 \mathrm{r} / \mathrm{v}, 11 \mathrm{v}, 12 \mathrm{r}, 13 \mathrm{r} / \mathrm{v}, 14 \mathrm{r}, 15 \mathrm{r} / \mathrm{v}, 16 \mathrm{v}, 17 \mathrm{r} / \mathrm{v}, 18 \mathrm{r}, 20 \mathrm{v}, 22 \mathrm{r} / \mathrm{v}, 23 \mathrm{r}, 30 \mathrm{r} / \mathrm{v}$, $31 \mathrm{r} / \mathrm{v}, 32 \mathrm{r} / \mathrm{v}, 33 \mathrm{v}, 41 \mathrm{v}, 42 \mathrm{r} / \mathrm{v}, 43 \mathrm{r} / \mathrm{v}, 44 \mathrm{r} / \mathrm{v}, 45 \mathrm{r} / \mathrm{v}, 46 \mathrm{r}, 49 \mathrm{v}, 50 \mathrm{r}, 51 \mathrm{v}, 52 \mathrm{r} / \mathrm{v}, 53 \mathrm{r} / \mathrm{v}, 70 \mathrm{r}, 71 \mathrm{r} / \mathrm{v}$, $72 \mathrm{r}, 73 \mathrm{r} / \mathrm{v}, 74 \mathrm{r} / \mathrm{v}, 75 \mathrm{r} / \mathrm{v}, 76 \mathrm{r} / \mathrm{v}, 79 \mathrm{r} / \mathrm{v}, 82 \mathrm{r} / \mathrm{v}, 83 \mathrm{r} / \mathrm{v}, 85 \mathrm{v}, 86 \mathrm{r}, 87 \mathrm{r} / \mathrm{v}, 88 \mathrm{r} / \mathrm{v}, 95 \mathrm{v}, 98 \mathrm{v}, 99 \mathrm{r} / \mathrm{v}$, $100 \mathrm{r} / \mathrm{v}, 101 \mathrm{r} / \mathrm{v}, 102 \mathrm{r} / \mathrm{v}, 103 \mathrm{r} / \mathrm{v}, 106 \mathrm{r} / \mathrm{v}, 107 \mathrm{r}, 108 \mathrm{r} / \mathrm{v}, 109 \mathrm{v}, 110 \mathrm{r} / \mathrm{v}, 111 \mathrm{r} / \mathrm{v}, 112 \mathrm{r}, 113 \mathrm{r} / \mathrm{v}, 116 \mathrm{r}$, $117 \mathrm{r}, 119 \mathrm{r} / \mathrm{v}, 121 \mathrm{r} / \mathrm{v}, 122 \mathrm{r}, 123 \mathrm{r}, 124 \mathrm{r} / \mathrm{v}, 125 \mathrm{v}, 126 \mathrm{r} / \mathrm{v}, 127 \mathrm{r} / \mathrm{v}, 128 \mathrm{r} / \mathrm{v}, 129 \mathrm{r} / \mathrm{v}, 130 \mathrm{r} / \mathrm{v}, 132 \mathrm{r} / \mathrm{v}$, $133 \mathrm{r} / \mathrm{v}, 134 \mathrm{r} / \mathrm{v}, 135 \mathrm{r} / \mathrm{v}, 136 \mathrm{r} / \mathrm{v}, 137 \mathrm{r} / \mathrm{v}, 138 \mathrm{r} / \mathrm{v}, 139 \mathrm{r} / \mathrm{v}, 140 \mathrm{r} / \mathrm{v}, 141 \mathrm{r} / \mathrm{v}, 142 \mathrm{r} / \mathrm{v}, 143 \mathrm{r} / \mathrm{v}, 144 \mathrm{r} / \mathrm{v}$, $145 \mathrm{r} / \mathrm{v}, 146 \mathrm{r} / \mathrm{v}, 147 \mathrm{r} / \mathrm{v}, 148 \mathrm{r} / \mathrm{v}, 149 \mathrm{r} / \mathrm{v}, 150 \mathrm{r} / \mathrm{v}, 151 \mathrm{r} / \mathrm{v}, 152 \mathrm{r} / \mathrm{v}, 153 \mathrm{r} / \mathrm{v}, 155 \mathrm{r}, 156 \mathrm{r} / \mathrm{v}, 157 \mathrm{v}$, $158 \mathrm{r} / \mathrm{v}, 160 \mathrm{v}, 161 \mathrm{r} / \mathrm{v}, 162 \mathrm{r}, 163 \mathrm{r} / \mathrm{v}, 164 \mathrm{v}, 165 \mathrm{r} / \mathrm{v}, 166 \mathrm{r} / \mathrm{v}, 168 \mathrm{v}$ e $169 \mathrm{v}$; carimbo seco com a inscrição: "INTENDÊNCIA MUNICIPAL DE FEIRA DE SANT'ANNA | ESTADO DA BAHIA | BRAZIL", na margem superior esquerda do fólio 83r; vários selos de impostos ao longo do documento: 1 de 5000 réis no fólio 4r; 1 de 2000 réis no fólio 5r; 2 de 600 réis no fólio 5v; 2 de 1000 no fólio 6r; 2 de 600 réis no fólio 6v; 3 (um no valor de 2000 e 2 de 600 réis) no fólio 61r; 2 de 1000 réis no fólio 78r; 2 de 600 réis no fólio 81 r; 4 de 100 réis no fólio $82 \mathrm{v}$ e 4 ( 1 de 2000, 1 de 600, 1 de 100 e 1 de 30 réis) no fólio 83r etc.; uma página do Jornal Folha do Norte, de 22 de dezembro de 1917, no fólio 84r, na qual há uma nota sobre a chegada do Doutor Eduardo Fróes da Motta e sua esposa, filhos e sogra à cidade de Feira de 
Santana; sinal público: seta dupla ao centro do documento que se estende da primeira à oitava linha, cuja extremidade inferior aponta para a abreviatura JCV, equivalente à abreviatura do nome do Tabelião de Notas, João Carneiro Vital nos fólios $5 \mathrm{v}, 61 \mathrm{r}$ e $78 \mathrm{v}$; fólios $52 \mathrm{r}$ ao $54 \mathrm{v}$ costurados com um barbante vermelho; fólios $180 \mathrm{r}$ ao $181 \mathrm{v}, 182 \mathrm{r}$ ao $183 \mathrm{v}$ e $193 \mathrm{r}$ ao $195 \mathrm{v}$ presos por uma colagem nas margens esquerdas; fólio $85 \mathrm{r}$ bastante escurecido por conta do seu contato com a página do Jornal Folha do Norte, anexada ao processo; duas manchas (uma marrom e outra preta) nas margens superior e central, respectivamente, no fólio $85 \mathrm{v}$.

9. Conteúdo: Trata-se do primeiro volume de uma ação ordinária de sonegados, em que os herdeiros Arthur Fróes da Motta e Francelina Carneiro da Motta, Alberto de Almeida Motta e Maria Carlota Falcão de Sousa Motta reclamaram à Justiça a sonegação de bens por parte do então inventariante dos bens do Coronel Agostinho Fróes da Motta, Eduardo Fróes da Motta e sua esposa Dona Maria Lambert de Brito Motta.

Dentre os bens alegados como sonegados estavam uma casa situada à Rua dos Remédios, número $32^{96}$ (e antes número 29), que foi comprada em ruínas e reformada pelo inventariado e na qual residia a sua filha, Adalgisa de Almeida Motta Farias, sendo que a referida casa e outra à Rua General Osório ${ }^{97}$, número 98 , bem como o recebimento de dívidas da firma Agostinho Fróes da Motta e Filho faziam parte do espólio dos bens dos falecidos coronel Agostinho Fróes da Motta e de sua primeira esposa, Dona Maximiana de Almeida Motta, o qual se encontrava na posse de Eduardo Fróes da Motta.

Para dar prosseguimento à ação, os autores instituíram como advogado Hildebrando Cordeiro de Almeida, que pediu a trasladação de vários trechos de outros documentos, a fim de retomar as decisões e arguições realizadas. Nesse contexto, Eduardo Fróes da Motta rebateu as acusações, afirmando que não passava de "chicana" dos herdeiros impugnantes, mesmo porque, segundo o inventariante, a casa à rua General Osório nunca existiu, mas sim o prédio em que funcionava a firma Agostinho Fróes da Motta e Filho, que possuía a parte da frente situada à Rua dos Remédios e a parte dos fundos à General Osório. Contudo, após herdar o referido prédio, Eduardo Fróes da Motta separou ambas as partes, transformando a que dava para os fundos em um depósito, ora reclamado pelos autores desta ação.

A fim de provar as suas afirmações, o farmacêutico Arthur Fróes da Motta e o engenheiro Alberto de Almeida Motta solicitaram a trasladação da escritura de compra e venda da casa situada à Rua dos Remédios, número 32, e na qual residia a sua irmã, Adalgisa de Almeida Motta Farias, e foi constatado que ela foi comprada em 13 de setembro de 1913 pelo Coronel Agostinho Fróes da Motta, que pagou o valor de $720 \$ 000$ (setecentos e vinte mil réis) a Zeferino José Pereira de Souza e sua mulher, Dona Edeltrudes Florentina de Souza, vendedores da casa.

Além da trasladação da escritura, também foram trasladados o testamento do inventariado, a partilha dos bens no inventário de Dona Maximiana de Almeida Motta, os editais de praça em que Eduardo Fróes da Motta cobrou publicamente as dívidas ativas dos devedores da firma Agostinho Fróes da Motta e Filho, seguidos de uma nova publicação em que aquele desistiu da cobrança de dívidas, a qual foi autorizada pelo Juiz de Direito Lyderico Santos Cruz, Desembargador no mesmo período. Além disso, também foi passada uma certidão a pedido de Hildebrando Cordeiro de Almeida acerca das dívidas ativas, da avaliação dos bens da firma e do saldo existente no cofre da firma Agostinho Fróes da Motta e Filho, referentes aos anos de 1922 a 1926.

Diante das arguições e da trasladação de vários documentos (dentre os quais estava um despacho de 29 de agosto de 1929 em que o Juiz proferiu uma sentença destituindo Eduardo

\footnotetext{
${ }^{96}$ A fotografia dessa casa se encontra no fac-símile do fólio $374 \mathrm{r}$ desta ação ordinária de sonegados, disposto no anexo B desta tese.

${ }^{97}$ A fotografia dessa casa se encontra no fac-símile do fólio $374 \mathrm{v}$ desta ação ordinária de sonegados, disposto no anexo $\mathrm{C}$ desta tese.
} 
Fróes da Motta do cargo de inventariante dos bens do seu pai, substituindo-o pelo Coronel Tertuliano José de Almeida, que aceitou a deliberação judicial, o que foi contestado por Arthur Fróes da Motta e Alberto de Almeida Motta, os quais afirmaram que, de acordo com o artigo 1325, número 45, do Código do Processo do Estado, isso era contra a lei, já que o referido inventariado tinha outros filhos, além de Eduardo Fróes da Motta, que poderiam assumir o cargo de inventariante, o que foi deferido pelo Superior Tribunal de Justiça, que determinou que fosse escolhido o co-herdeiro que "tivesse mais conhecimento dos bens e probidade") foram apresentadas as testemunhas (Candido Elpidio Vaccarezza, médico, e Gregorio de Souza Reis, artista decorador) dos autores da ação para comprovar a compra e reconstrução da casa, situada à Rua dos Remédios, número 32, as quais confirmaram que foi o Coronel Agostinho Fróes da Motta quem comprou, reconstruiu e pagou as despesas de toda a obra da casa. Após essas alegações, o escrivão e contador Segismundo de Cerqueira Bastos expediu as contas a serem pagas pela conclusão do processo em 23 de novembro de 1929.

10. Escreventes: Manoel Ferreira Côelho, Hildebrando Cordeiro de Almeida, Manoel Araujo, Arthur Fróes da Motta, João Carneiro Vital, Alberto de Almeida Motta, Silio Soledade, Vicente dos Reis, Augusto Antonio Pereira, Elpidio Raymundo da Nova, Arnold Ferreira da Silva, Altino Moraes Mattos, Ignacio Paschoal Bastos, Hygino Pereira da Silva, Julio Borba, Segismundo de Cerqueira Bastos e Aristoteles José da Silva.

Fonte: Elaborado pela pesquisadora

Quadro 22 - Ficha codicológica do décimo oitavo documento

\section{SEGUNDO E TERCEIRO VOLUMES DA AÇÃO ORDINÁRIA ${ }^{98}$ DE SONEGADOS PROPOSTA POR ARTHUR FRÓES DA MOTTA E FRANCELINA CARNEIRO DA MOTTA; ALBERTO DE ALMEIDA MOTTA E MARIA CARLOTA FALCÃO DE SOUSA MOTTA}

1. Cota: Feira de Santana - Bahia; Centro de Documentação e Pesquisa/ UEFS; Seção Judiciária, Série Cíveis; Subsérie: Ações; Tipologia Ordinária; Localização: Estante 13, Caixa 340 e Documento 7767.

2. Datação: 1929-1930 - “1929 [...] 1930” (v. 2, f. 1r, 1. 1; v. 3, f. 1r, 1. 1).

3. Lugar de origem: Feira de Santana - "[...] FEIRA DE SANT'ANNA [...]” (f. 1r, 1. 3).

4. Fólios de abertura do segundo e terceiro volumes: " 1929 | JUIZO DE DIREITO FEIRA DE SANT'ANNA | ESTADO DA BAHIA | Segundo Volume | Segundo Volume [rasgado] Ordinaria $\mid$ de $\mid$ [rasgado] gados $\mid$ [rasgado] Alberto de Almeida Motta | Autores [rasgado] Doutor Eduardo Fróes da Motta | [rasgado] a mulher | Réos | [rasgado] Escrivão Reis | AUTUAÇÃO | [rasgado] vctos e | [rasgado] do dito anno, | [rasgado] e se segue | [rasgado] o que subscrevo. A GRAPHICA DA FEIRA" (AÇÃO ORDINÁRIA, v. 2, f. 1r, 1 . $1-30)$.

“1930 | JUIZO DE DIREITO | DA FEIRA DE SANT’ANNA | ESTADO DA BAHIA Terceiro Volume | Numero 4684 | Feira de Sant'Anna | Terceiro Volume | dos | Autos da Acção Ordinaria de | Sonegados | Engenheiro Alberto de Almeida Motta | e outros | Autores |

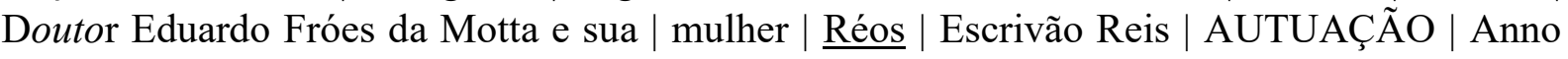
de mil novecentos e $\mid$ aos_dias do mez de _ do dito anno, $\mid$ autuo o_ que se segue _ do

\footnotetext{
${ }^{98}$ É importante mencionar que embora se tratem de dois volumes que fazem parte do primeiro volume da ação ordinária, apresentada anteriormente, e também solicitada por Arthur Fróes da Motta, Alberto de Almeida Motta e as respectivas esposas destes, tratam-se de documentos classificados, pelo CEDOC/UEFS, como distintos, pois possuem fichas de identificação e datações diferentes.
} 
que | faço este termo. | Eu, _ escrivão que subscrevo. | A GRAPHICA DA FEIRA" (AÇÃO ORDINÁRIA, v. 3, f. 1r, 1. 1-30)
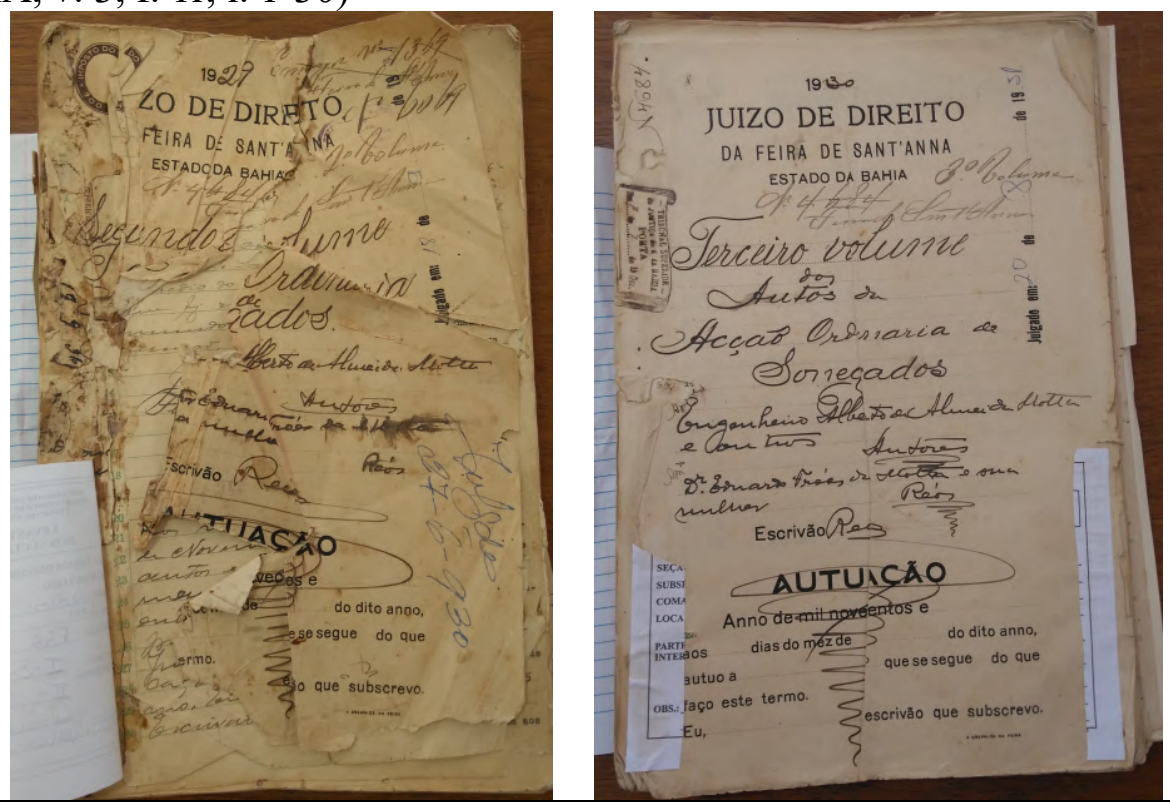

5. Suporte material: papel almaço, cartolina e papel bíblia, com pauta na maioria dos fólios e de baixa gramatura.

6. Composição: 414 fólios (dos quais os fólios 1v, 38v, 39v, 40v, 41v, 95r, 97v etc. estão em branco, os fólios 97r, 124r, 140r, 141r, 157r etc. são formulários preenchidos manualmente, os fólios 172r/v, 173r/v, 174r, 175r etc. são datiloscritos, os fólios 3r/v, 39r, 161r, 162r/v, 170r são híbridos e os demais fólios são manuscritos); formatos (in-plano e in-fólio); dimensão dos fólios variável: primeiro volume: $1 \mathrm{r}-300 \mathrm{~mm} \times 200 \mathrm{~mm}, 2 \mathrm{r}-330 \mathrm{~mm} \times$ $210 \mathrm{~mm}, 3 \mathrm{r}-335 \mathrm{~mm} \times 180 \mathrm{~mm}, 5 \mathrm{r}-340 \mathrm{~mm} \times 220 \mathrm{~mm}, 49 \mathrm{r}-275 \mathrm{~mm} \times 214 \mathrm{~mm}, 50 \mathrm{r}-279 \mathrm{~mm}$ x $211 \mathrm{~mm}, 106 \mathrm{r}-230 \mathrm{~mm}$ x $179 \mathrm{~mm}, 121 \mathrm{r}-342 \mathrm{~mm}$ x $221 \mathrm{~mm}$; segundo volume: $1 \mathrm{r}-333 \mathrm{~mm}$ x 222mm, $37 \mathrm{r}-335 \mathrm{~mm} \times 212 \mathrm{~mm}, 60 \mathrm{r}-270 \mathrm{~mm} \times 298 \mathrm{~mm}, 63 \mathrm{r}-178 \mathrm{~mm} \times 210 \mathrm{~mm}$ e $64 \mathrm{r}-$ $72 \mathrm{~mm} \times 170 \mathrm{~mm}$ etc.

7. Organização da página: dimensão da mancha escrita variável: primeiro volume: f. 1r $275 \mathrm{~mm} \times 195 \mathrm{~mm}, 2 \mathrm{r}-280 \mathrm{~mm} \times 180 \mathrm{~mm}, 3 \mathrm{r}-270 \mathrm{~mm} \times 175 \mathrm{~mm}, 5 \mathrm{r}-325 \mathrm{~mm} \times 180 \mathrm{~mm}, 49 \mathrm{r}$ $-214 \mathrm{~mm} \times 177 \mathrm{~mm}, 50 \mathrm{r}-246 \mathrm{~mm} \times 175 \mathrm{~mm}, 106 \mathrm{r}-205 \mathrm{~mm} \times 173 \mathrm{~mm}, 121 \mathrm{r}-236 \mathrm{~mm} \times$ $190 \mathrm{~mm}$; segundo volume: $1 \mathrm{r}-318 \mathrm{~mm} \times 210 \mathrm{~mm}, 37 \mathrm{r}-312 \mathrm{~mm} \times 190 \mathrm{~mm}$, $60 \mathrm{r}-255 \mathrm{~mm} \times$ $159 \mathrm{~mm}, 63 \mathrm{r}-173 \mathrm{~mm} \times 173 \mathrm{~mm}$ e $64 \mathrm{r}-50 \mathrm{~mm} \times 145 \mathrm{~mm}$ etc.; 1 coluna na maioria dos fólios e 2 colunas no fólio $229 \mathrm{r} / \mathrm{v}$; número de linhas da mancha escrita variável: f. $3 \mathrm{r}, 4 \mathrm{r} / \mathrm{v}$ ao $12 \mathrm{v}-$ 30 linhas, f. $3 v-3$ linhas, f. $13 r-19$ linhas, f. 13v- 21 linhas, f. $15 v-4$ linhas, f. 20r - 26 linhas, f. 20v - 11 linhas etc.; pautado; numeração ${ }^{99}$ por foliação (sistema 1r, 2r, 3r, 4r etc.); e reclamos ("respondeu/ respondeu" nos fólios 4v/5r, "da/ da" nos fólios 5v/6r, "Dou-/ Doutor" $6 \mathrm{v} / 7 \mathrm{r}$, "con-/ contradicções" 8v/9r, "depen-/ dependencia" 9v/10r, era/ era" 10v/11r, "General/ General" 11v/12r, "em/ em" 12v/13r etc.).

8. Particularidades: O documento não possui capa, mas há uma folha de papel almaço, que funciona como uma espécie de invólucro, que foi inserido pelos estagiários do CEDOC/UEFS, para proteger o documento da umidade e garantir a conservação do suporte material, o que evita o contato direto das mãos do pesquisador com o manuscrito. Além disso, na folha há as seguintes informações sobre o documento: "Subsérie: Ações, Tipologia: Ordinária, Parte I - Eduardo Fróes da Motta e Parte II: Arthur Fróes da Motta e Alberto de Almeida Fróes da Motta, Localidade: FSA, Período: 1929-1930, $\mathrm{N}^{\mathrm{o}}$ de folhas: 233, Obs.: Volume 2 da Ação Ordinária", as quais foram escritas a lápis pelos estagiários do arquivo; há

\footnotetext{
${ }^{99}$ A numeração deste documento começa em 212 e possui erro de numeração.
} 
uma ficha de identificação inserida pelos estagiários do CEDOC/UEFS com as seguintes informações: no cabeçalho - "UNIVERSIDADE ESTADUAL DE FEIRA DE SANTANA, DEPARTAMENTO DE CIÊNCIAS HUMANAS E FILOSOFIA, CENTRO DE DOCUMENTAÇÃO E PESQUISA, LEVANTAMENTO GERAL DOS NÚCLEOS DOCUMENTAIS", ao lado do cabeçalho "CLASSIFICAÇÃO: E (estante), Cx (caixa) e Doc (documento)", na linha seguinte: "NÚCLEO: FÓRUM DESEMBARGADOR FILINTO BASTOS, SEÇÃO: JUDICIÁRIO, SÉRIE (com espaço para preenchimento manual), SUBSÉRIE (com espaço para preenchimento manual), TIPOLOGIA (com espaço para preenchimento manual), COMARCA: FSA, $\mathrm{N}^{\circ}$ DE FOLHAS (com espaço para preenchimento manual), LOCALIDADE (com espaço para preenchimento manual), PERÍODO (com espaço para preenchimento manual), PARTES E/OU INTERESSADOS (com espaço para preenchimento manual) e OBS. (com espaço para preenchimento manual)"; 4 selos de impostos ( 2 de 1 mil réis, 1 de 800 réis e 1 de 30 réis) na margem centro-inferior do fólio $95 \mathrm{r}$ etc.; danos significativos ao suporte material nos três primeiros fólios do segundo volume, o que ocasionou perda de informações; trechos sublinhados com canetas de cores diferentes ao longo dos fólios $4 \mathrm{v}, 5 \mathrm{r} / \mathrm{v}$ ao $12 \mathrm{v}, 42 \mathrm{r}, 67 \mathrm{v}, 73 \mathrm{r}, 75 \mathrm{v}, 76 \mathrm{r}, 78 \mathrm{r}, 95 \mathrm{v}, 150 \mathrm{v}$ etc.; dois timbres estaduais com as inscrições: "Thesouro do Estado da Bahia" e "IMPOSTO DO SELLO", em quase todos fólios rectos; riscaduras, rasgos e/ou furos nas margens de vários fólios, ganchos e laçadas em muitos fólios e marcas de costura nos fólios soltos; marcas de dobras em alguns fólios e na página de jornal anexada ao documento; escurecimento de vários fólios; recortes de papel colados em alguns fólios; carimbo molhado com a inscrição: “TABELLIÃO Soledade | MAI 221928 | FEIRA DE SANT'ANNA", na margem centroinferior do fólio 41r; carimbo molhado com a inscrição: "PREFEITURA MUNICIPAL | DA | Feira de Sant'anna", na margem superior esquerda do fólio 95r; outros carimbos molhados, manchas de tinta, sinais públicos e papéis timbrados ao longo do documento.

9. Conteúdo: Trata-se da continuidade da ação ordinária de sonegados em que Arthur Fróes da Motta e Francelina Carneiro da Motta, Alberto de Almeida Motta e Maria Carlota Falcão de Sousa Motta processaram Eduardo Fróes da Motta e Maria Lambert de Brito Motta por conta da sonegação de bens do espólio do falecido Coronel Agostinho Fróes da Motta.

Em 26 de novembro de 1929 este processo teve prosseguimento a partir da convocação de Eduardo Fróes da Motta para prestar o seu depoimento acerca dos itens da petição inicial desta ação, sujeito à pena de confesso caso não comparecesse. Em seguida, foram arguidas as testemunhas (Demétrio da Silva Pimentel, Domingos Paschoal Dias, Manoel Lacerda, João Lacerda, todos artistas ${ }^{100}$, e Joaquim Honório de Oliveira, funcionário público) apresentadas pelo réo, Eduardo Fróes da Motta, as quais afirmaram que a casa foi, de fato, comprada pelo Coronel Agostinho Fróes da Motta, que a comprou para construir, no mesmo terreno, uma nova casa, cuja obra o próprio coronel fiscalizara, para o seu filho, Eduardo Fróes da Motta, enquanto este residia em Mogi Mirim - São Paulo e que o encarregado de pagar aos operários da obra realizada entre 1916 e 1917 foi David de Mello Lima, empregado do falecido coronel, que, depois de sua morte, passou a trabalhar como funcionário do réu.

Sobre a casa, que era dependência do prédio da firma Agostinho Fróes da Motta e

\footnotetext{
${ }^{100}$ Uma curiosidade acerca dessa profissão é que todas as testemunhas que assim se autodeclararam, ao longo dos três volumes desta ação, eram pessoas que executavam trabalhos braçais, tais como: Mauricio Linhares de Azevedo, Demétrio da Silva Pimentel, Pedro Rodrigues de Oliveira e José Vicente de Andrade que se autodeclararam artistas de carpina (carpinteiros), Julio de Castro e Euclides de Souza artistas de pintura (pintor), Gregorio de Souza Reis artista decorador, Domingos Paschoal Dias artista pedreiro e mestre carpinteiro, Augusto José de Souza artista pedreiro, José Joaquim Rodrigues artista serralheiro e Manoel Lacerda e João Lacerda que se autodeclararam como artistas sem, no entanto, especificarem qual o tipo de serviço que realizaram na construção da casa, número 32, na Rua dos Remédios. Como se pode notar, o ofício de artista era atribuído a pessoas que se ocupavam de realizar trabalhos que demandavam bastante esforço físico.
} 
Filho, foi afirmado pela segunda testemunha que foi o próprio Eduardo Fróes da Motta quem ordenou a divisão da parte dos fundos do estabelecimento, que funcionaria uma como escritório e a outra para aluguel, mas que até aquela data os fundos funcionavam como depósito pertencente a Eduardo Fróes da Motta e que era o coronel quem, em vida, administrava, fiscalizava e pagava os funcionários de toda a obra.

Além das testemunhas, Eduardo Fróes da Motta também prestou o seu depoimento confirmando e contestando as arguições dos advogados, o qual foi finalizado e seguido do pedido de uma certidão, cujo teor foi extraído dos autos do inventário do seu pai acerca dos bens do espólio e de suas avaliações, inclusive o quinhão que coube ao herdeiro Eduardo Fróes da Motta, que escreveu à sua irmã, Adalgisa de Almeida Motta, para que ela comprovasse que a casa onde morava pertencia ao réu e que este fazia reparos regularmente na casa, o que, de fato, ela o fez, mas ressaltou que o referido imóvel não constou entre os bens do inventário de sua mãe, Maximiana de Almeida Motta, como o réu alegou.

Diante disso, Eduardo Fróes da Motta solicitou a trasladação dos fólios do inventário de sua mãe e do seu pai, nos quais havia a confirmação de que existia a referida casa, que foi descrita da seguinte maneira: "Uma casa com duas portas e treis janellas de frente para o poente, treis portas de fundo para a rua General Osorio, a dividir em quatro compartimentos, escriptorio, sob numero 29, á rua dos Remedios que avaliamos por treis contos de reis" (INVENTÁRIO DE AGOSTINHO..., f. 279v-280r; f. 315r).

$\mathrm{O}$ advogado dos autores acrescentou os depoimentos das testemunhas Pedro Alcântara Carvalho e José Joaquim Rodrigues, ambos artistas, além daqueles já prestados a esta ação pelo médico Candido Elpidio Vaccarezza e Gregorio de Souza Reis, que afirmaram que foi o Coronel Agostinho Fróes da Motta quem os contratou para trabalhar na obra e que o mesmo afirmou que a casa reconstruída seria para o seu filho Eduardo Fróes da Motta que, na época da obra, residia em São Paulo. A fim de fortalecer a sua defesa, o réu solicitou a emissão de cartas precatórias da Comarca de Feira de Santana a Ilhéus, Cachoeira, Cruz das Almas, Irará, Santo Amaro, Santo Antônio de Jesus, Salvador, Santa Rita do Rio Preto e Vila de São Francisco, todas cidades do Estado da Bahia, com o objetivo de serem ouvidas as demais testemunhas, que trabalharam na construção da referida casa, o que foi acatado pelo Juiz.

Em seguida, foram apresentadas as arguições dos autores e dos réus, a partir das quais o Juiz Manoel Ferreira Côelho sentenciou a ação ordinária como improcedente e condenou os autores a pagarem as custas do processo. Nos fólios seguintes, foi anexada uma reclamação individual de Alberto de Almeida Motta para que o seu irmão, Eduardo Fróes da Motta, fosse punido judicialmente por ter excluído o seu nome do rol de herdeiros do inventariado, mesmo depois da decisão favorável do Superior Tribunal de Justiça acerca da comprovação da sua paternidade.

Em 27 de maio de 1930 foi iniciado o terceiro volume desta ação, no qual os autores apelaram da decisão do Juiz sobre a improcedência dessa ação. Para isso, recorreram ao Superior Tribunal de Justiça e solicitaram, a priori, a trasladação do processo de encerramento da firma comercial Agostinho Fróes da Motta e Filho, e, em seguida, apelantes e apelados reapresentaram as respectivas defesas, das quais o Juiz Manoel Ferreira Côelho definiu como ofensiva, inclusive à sua pessoa, a defesa do advogado dos apelantes, afirmando que o advogado Hildebrando Cordeiro de Almeida foi descortês e usou uma linguagem ofensiva, o que foi veementemente rebatido pelo advogado, que anexou ao processo pareceres de outros advogados, dentre os quais figuraram o advogado Agnello Ribeiro de Macêdo, o Promotor Público da Comarca José Barbosa de Souza Junior, o advogado e "delegado de carreira" Amarilio Cavalcanti e o advogado Elpidio Raymundo da Nova, cujos pareceres comprovaram que o advogado Hildebrando Cordeiro de Almeida sempre agiu com delicadeza em todas as circunstâncias em que trabalharam juntos.

Em seguida, foram intimadas novas testemunhas, a saber: de São Gonçalo dos 
Campos, Conrado Milano do Nascimento, artista; de São Félix, Comarca de Cachoeira, Gregório de Souza Reis, artista decorador, ambos trabalharam na obra da casa, número 32, à Rua dos Remédios. Por fim, em 20 de fevereiro de 1933 foi expedido um mandato de intimação para os réus, o Doutor Eduardo Fróes da Motta e a sua esposa, Maria Lambert de Brito Motta, acerca da decisão do Juiz Manoel Ferreira Côelho de condená-los na ação de sonegados proposta, obrigando-os a comparecerem para responder as questões levantadas pelo advogado dos autores desta ação.

10. Escreventes ${ }^{101}$ : Vicente dos Reis, Manoel Ferreira Côelho, Hildebrando Cordeiro de Almeida, Augusto Antonio Pereira, Elpidio Raymundo da Nova, Eduardo Fróes da Motta, Adalgisa de Almeida Motta, Silio Soledade, Arnold Ferreira da Silva, José Salvador, Altino Moraes de Mattos, Paulino Chaves da Costa, Zacharias Germano Gomes, R. Sampaio S., Arnaldo da Silva Vidal, Honorato J. Pereira Maltez, Clodomiro Torres, Amadocimo Pereira, José Baptista da Fonsêca, Manoel Pedro da Silveira, A. P. Cerqueira, Juvenal Eugenio de Queiros, Gilberto Soares, José Antonio Susart, Otto Brandão de Moura, Cesar Ribeiro de Cerqueira, Almiro Gomes, Manoel Portugal dos Santos, Arthur Fróes da Motta, Albertina Motta de Almeida, João Carneiro Vital, José Joaquim Rodrigues, Eduardo de Lacerda, João Simões Ferreira, Alfredo Julião Britto, David de Mello Lima, Manoel Araujo, José Portugal, Euclides de Souza Pinto, José Maria Neves, Odilon Santos, Eduardo Espinola, Altino Teixeira, Villebaldo Garcez Paranhos Montenegro, Ignacio Paschoal Bastos, Domingos Adami, Filinto Bastos, Oscar Erudilho, Agnello Ribeiro de Macêdo, José Barbosa de Souza Junior, Amarilio Cavalcante, Salles Moniz, Perpetua da Silva Machado, Gregorio Moreira de Jesus, Joaquim Alves Pedreira, Arlindo Portugal, Joaquim O. Bastos, Oscar Moreira Sodré de Aragão, Cesario de Azevêdo C., Duarte Guimarães, Pedro Oliveira Porto, Pedro Ribeira, Constantino Vicente dos Reis, Paulo Teixeira, Lyderico Santos Cruz, Cyrillo de S. Leal, Oswaldo Hugo Sacramento, Benjamim Martins Ferreira, Álvaro de Faria, Antonio de Oliveira Motta e Miguel Barretto da Silva.

Fonte: Elaborado pela pesquisadora

Quadro 23 - Ficha codicológica do décimo nono documento

\section{TRASLADO DO INVENTÁRIO DE AGOSTINHO FRÓES DA MOTTA}

1. Cota: Feira de Santana - Bahia; Centro de Documentação e Pesquisa/ UEFS; Seção Judiciária, Série Cíveis; Subsérie: Inventário; Tipologia Traslado de inventário; Localização: Estante 13, Caixa 348 e Documento 7975.

2. Datação: 1929 - "1929 [...]" (f. 1r, 1. 1).

3. Lugar de origem: Feira de Santana - “[...] DA FEIRA DE SANT'ANNA [...]” (f. 1r, 1. 3).

4. Fólio de abertura: "1929 | JUIZO DE DIREITO | DA FEIRA DE SANT'ANNA ESTADO DA BAHIA | Primeiro Volume | Traslado | Inventario dos bens | deixados pelo fallecido | Coronel Agostinho Froes | da Motta | Escrivão Reis | AUTUAÇÃO | Anno de mil novecentos e vinte nove $\mid$ aos _ dias do mez de _ do dito anno, | autuo o traslado que se segue; do que | faço este termo. | Eu, Vicente dos Reis escrivão que subscrevo | A GRAPHICA DA FEIRA" (f. 1r, 1. 1-30).

101 Mais três rubricas estão ilegíveis no documento, o que impossibilitou identificar os nomes dos respectivos escreventes. 


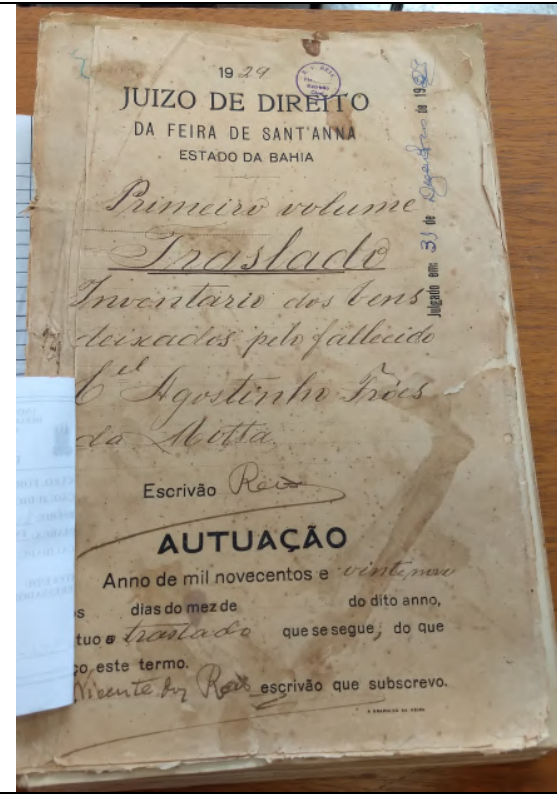

5. Suporte material: papel almaço e de cartolina, com pauta na maioria dos fólios e de baixa gramatura.

6. Composição: 228 fólios (dos quais os fólios 1v, 228r e 228v estão em branco, sendo que o fólio 1r é um formulário preenchido manualmente); formatos (in-plano e in-fólio); dimensão regular dos fólios: $320 \mathrm{~mm}$ x $225 \mathrm{~mm}$.

7. Organização da página: dimensão da mancha escrita regular: f. 1r - 290mm X 200mm; 1 coluna e número de linhas da mancha escrita regular: 30 linhas em todos os fólios; pautado; numeração ${ }^{102}$ por foliação (sistema $1 \mathrm{r}, 2 \mathrm{r}, 3 \mathrm{r}, 4 \mathrm{r}$ etc.); reclamos ("escrivão/ escrivão" nos fólios $2 \mathrm{v} / 3 \mathrm{r}$, "se/ se" nos 3v/4r, "Silva/ Silva" nos 4v/5r, "for/ for" nos 5v/6r, "sob/ sob" nos 6v/7r, "Alves/ Alves" nos 7v/8r, "e/ e" nos 8v/9r, "de/ de" nos 9v/10r, "de/ de" nos 10v/11r, "Mi-/ Ministerio" nos 11v/12r, "Ri/ Ribeiro" nos 12v/13r, "este/ este" nos 13v/14r, "effei-/ effeitos" nos 14v/15r, "que/ que" nos 15v/16r, "cinco/ cinco" nos 16v/17r, "prescrip-/ prescripções" nos 17v/18r, "nada/ nada" nos 18v/19r, "improcedente/ improcedentes" nos 19v/20r, "aliás/ aliás" nos 20v/21r, "disco/ discolos" nos 21v/22r, "de-/ demonstrativo" nos $22 \mathrm{v} / 23 \mathrm{r}$, "carto-/ cartorio" nos $23 \mathrm{v} / 24 \mathrm{r}$, "paga/ pagamento" nos $24 \mathrm{v} / 25 \mathrm{r}$, "contos/ contos" nos $25 \mathrm{v} / 26 \mathrm{r}$, "deixa/ deixado" nos 26v/27r, "e/ e" nos 27v/28r, "final-/ finalisando" nos 28v/29r, "do/ do" nos 29v/30r, "discriminação/ discriminação" nos 30v/31r, "entraram/ entraram" nos $31 \mathrm{v} / 32 \mathrm{r}$, "referi/ referida" nos 32v/33r, "confirma/ confirmado" nos 33v/34r, "quatrocento/ quatrocentos" nos 34v/35r, "manifestado/ manifestado" nos 35v/36r, "da/ daquelle" nos $36 \mathrm{v} / 37 \mathrm{r}$, "reallizados/ reallezados" nos 37v/38r, "mas/ mas" nos 38v/39r, "adj-/ adjudicação" nos 39v/40r, "li-/ limitados" nos 40v/41r, "do/ do" nos 41v/42r, "nove/ novecentos" nos $42 \mathrm{v} / 43 \mathrm{r}$, "commerciaes/ commerciaes" nos 43v/44r, "a quar/ a quarta" nos 44v/45r, "colla/ colladas" nos 45v/46r, "qua-/ quatrocentos" nos 46v/47r, "sentença/ sentença" nos 47v/48r, "teor/ teor" nos 48v/49r, "novecentos/ novecentos" nos 49v/50r, "actu-/ actual" nos 50v/51r, "pre/ precisa" nos 51v/52r, "folha/ folha" nos 52v/53r, "Carnei/ Carneiro" nos 53v/54r, "Christo,/ Chisto," nos 54v/55r, "Carva/ Carvalho" nos 55v/56r, "por/ por" nos 56v/57r, "vinte/ vinte" nos 57v/48r, "vin/ vinte" nos 58v/59r, "Alberti/ Albertina" nos 59v/60r, "do-/ dominio" nos 60v/61r, "qua/ quatrocentos" nos 61v/62r, "vinte/ vinte" nos 62v/63r, "e/ e" nos

102 Cabe destacar que existe erro de numeração neste documento, pois um dos scriptores inseriu duas numerações neste documento: a primeira, no centro da margem esquerda, e a segunda na margem inferior direita, a qual se apresenta incompleta e confusa. Além disso, o primeiro fólio não foi enumerado e contabilizado, e o segundo fólio aparece como o primeiro. Ademais, a partir do fólio 197r, a numeração se apresenta de forma bastante equivocada, pois recomeça em 101r e vai até $131 \mathrm{v}$, penúltimo fólio do documento. 
64v/65r, "pela/ pela" nos 65v/66r, "vinte/ vinte" nos 66v/67r, "Municipal/ Municipal" nos $67 \mathrm{v} / 68 \mathrm{r}$, "Escripta/ escripta" nos 68v/69r, "teor/ teor" nos 69v/70r, "fazenda/ fazenda" nos 70v/71r, "Sant'Anna/ na" nos 71v/72r, "provimento/ provimento" nos 72v/73r, "disposto/ disposto" nos 73v/74r, "sete/ sete" nos 74v/75r, "este/ este" nos 75v/76r, "dita/ dita" nos 76v/77r, "Paschoal/ Paschoal" nos 77v/78r, "tendo/ tendo" nos 78v/79r, "irmã/ irmã" nos 79v/80r, "profe/ proferida" nos 80v/81r, "com/ com" nos 81v/82r, "seguin-/ seguinte" nos $82 \mathrm{v} / 83 \mathrm{r}$, "novecen-/ novecentos" nos 83v/84r, "que/ que" nos $84 \mathrm{v} / 85 \mathrm{r}$, "Eu,/ eu," nos 86v/87r, "Juizo/ Juizo" nos 86v/87r, "novecentos/ novecentos" nos 87v/88r, "folhas/ folhas" nos $88 \mathrm{v} / 89 \mathrm{r}$, "Novo/ Novo" nos 89v/90r, "refe-/ referido" nos 90v/91r, "quatrocen/ quatrocentos" nos 91v/92r, "Mo-/ Motta" nos 92r/92v, "Motta/ Motta" nos 92v/93r, "in-/ inclusive" nos 93v/94r, "no/ novecentos" nos 94r/94v, "ne-/ nenhuma" nos 94v/95r, "Illustrissimo/ Illustrissimo" nos 95v/96r, "Fróes/ Fróes" nos 96v/97r, "final/ final" nos 97v/98r, "sua/ sua" nos 98v/99r, "rito/ rito" nos 99v/100r, "mil/ mil" nos 100v/101r, "nosso/ nosso" nos 101v/102r, "Figuei-/ Figueira" nos 102v/103r, "ti-/ titulo" nos 103r/103v, "Co-/ Coronel" nos 103v/104r, "Moniz/ Moniz" nos 104v/105r, "quinhão/ quinhão" nos 105v/106r, "sua/ sua" nos 106v/107r, "qua-/ quatorze" nos 107v/108r, "consti-/ constituinte" nos 108v/109r, "Doutor/ Doutor" nos 109v/110r, "e/ e" nos 110v/111r, "Hildebran-/ Hildebrando" nos $111 \mathrm{v} / 112 \mathrm{r}$, "es-/ estadoal" nos 112r/112v, "Hil-/ Hildebrando" nos 112v/113r, "direito./ direito." nos 113v/114r, "termo./ termo." nos 114v/115r, "que/ que" nos 115v/116r, "bens/ bens" nos 116v/117r, "ser/ ser" nos 117v/118r, "meio/ meio" nos 118v/119r, "Terceiro/ Terceiro" nos 119v/120r, "Fei-/ Feira" nos 120v/121r, "autos/ autos" nos 121v/122r, "Maxi-/ Maximiano" nos 122v/123r, "dos/ dos" nos 123v/124r, "da/ da" nos 124v/125r, "que/ que" nos 125v/126r, "calices/ calices" nos 126v/127r, "Semo-/ Semoventes" nos 127r/127v, "anno/ anno" nos 127v/128r, "fazen-/ fazenda" nos 128v/129r, "termo./ termo." nos 129v/130r, "conso-/ consoante" nos 130r/130v, "ver-/ verdade" nos 130v/131r, "que/ que" nos 131v/132r, "outorgante/ outorgante" nos 132v/133r, "Vicen-/ Vicente" nos 133v/134r, "guarda-/ guarda-roupa" nos 134v/135r, "sacco/ sacco" nos 135v/136r, "nu-/ numero" nos 136v/137r, "a/ a" nos 137v/138r, "para/ para" nos 138v/139r, "avaliamos/ avaliamos" nos 139v/140r, "vinte/ vinte" nos 140v/141r, "Uma/ Uma" nos 141v/142r, "avaliamos/ avaliamos" nos 142v/143r, "que/ que" nos 143v/144r, "que/ que" nos 144v/145r, "Senhor/ Senhor" nos 145v/146r, "nesta/ nesta" nos 146v/147r, "menos/ menos" nos 147v/148r, "feito/ feito" nos 148v/149r, "setecentos/ setecentos" nos 149v/150r, "de/ de" nos 150v/151r, "me/ me" nos 151v/152r, "Agostinho/ Agostinho" nos 152v/153r, "Es-/ Escrivão" nos 153v/154r, "reis/ reis" nos 154v/155r, "12:000\$000/ 12:000\$000" nos 155v/156r, "oito/ oito" nos 156v/157r, "de/ de" nos 157v/158r, "Silva/ Silva" nos 158v/159r, "falleci-/ fallecimento" nos 159v/160r, "re-/ recurso" nos 160v/161r, "soli-/ solicitou" nos 161r/161v, "Pri-/ Primeira" nos 161v/162r, "seu/ seu" nos 162v/163r, "o/ o" nos 163v/164r, "Estado/ Estado" nos 164v/165r, "no-/ nomeado" nos 165v/166r, "mandado/ mandado" nos 166v/167r, "e/ e" nos 167v/168r, "por/ por" nos 168v/169r, "Quei-/ Queimadinhas" nos 169v/170r, "de/ de" nos 170v/171r, "novecentos/ novecentos" nos 171v/172r, "Re=/ Remettidos" nos 172v/173r, "que/ que" nos 173v/174r, "predios,/ predios" nos 174v/175r, "vinte/ vinte" nos 175v/176r, "Silva/ Silva" nos 176v/177r, "pro-/ procurador" nos 177v/178r, "a-/ avaliador" nos 178v/179r, "sendo-me/ sendo-me" nos 179v/180r, "Anna/ na" nos 180r/180v, "ava-/ avaliações" nos 180v/181r, "por/ por" nos 181v/182r, "Maio/ Maio" nos 182v/183r, "e do-/ e documento" nos 183v/184r, "um/ um" nos 184v/185r, "Vi-/ Vicente" nos 185r/185v, "Estado/ Estado" nos 185v/186r, "fazendas/ fazendas" nos 186v/187r, "por/ por" nos $187 \mathrm{v} / 188 \mathrm{r}$, "positivamente/ positivamente" nos 188v/189r, "de/ de" nos 189v/190r, "da/ da" nos 190v/191r, "a/ a" nos 191v/192r, "mil/ mil" nos 192v/193r, "dos/ dos" nos 193v/194r, "quantias/ quantias" nos 195v/196r, "1:046\$740/ 1:046\$740" nos 196v/197r, "Mundo/ Mundo" nos 197v/198r, "trans-/ transporte" nos 198v/199r, "oito/ oito" nos 199v/200r, "Deustc-/ Deustchland" nos 200v/201r, 
"reis/ reis" nos 201v/202r, "Fróes/ Fróes" nos 202v/203r, "empres-/ emprestimo" nos 203v/204r, "a/ a" nos 204v/205r, "e/ e" nos 205v/206r, "ordenados/ ordenados" nos 206v/207r, "por-/ porquanto" nos 207v/208r, "Motta/ Motta" nos 208v/209r, "em/ em" nos 209v/210r, "termo/ termo" nos 210v/211r, "livro/ livro" nos 211v/212r, "inven-/ inventario" nos 212v/213r, “expe-/ expede" nos 213v/214r, "38677/ 38677" nos 214v/215r, "indevidamente/ indevidamente" nos 215v/216r, "quantia/ quantia" nos 216v/217r, "com/ com" nos 217v/218r, "fei-/ feita" nos 218r/218v, "avaliada/ avaliada" nos 218v/219r, "escandalosa-/ escandalosamente" nos 219v/220r, "ditas/ ditas" nos 220v/221r, "do/ do" nos $221 \mathrm{v} / 222 \mathrm{r}$, "additamento/ additamento" nos 222v/223r, "caso/ caso" nos 223v/224r, "collo-/ collocional-os" nos 224v/225r, "Doutor/ Doutor" nos 225v/226r e "que/ que" nos 226v/227r); sem assinaturas pessoais ou rubricas.

8. Particularidades: O documento não possui capa, mas há uma folha de papel almaço, que funciona como uma espécie de invólucro, que foi inserido pelos estagiários do CEDOC/UEFS, para proteger o documento da umidade e garantir a conservação do suporte material, o que evita o contato direto das mãos do pesquisador com o manuscrito. Além disso, na folha há as seguintes informações sobre o documento: "Subsérie: Inventário, Tipologia: Traslado de inventário, Parte I - Agostinho Fróes da Motta e Parte II: Eduardo Fróes da Motta, Localidade: FSA, Período: 1929, $\mathrm{N}^{\circ}$ de folhas: 227”, as quais foram escritas a lápis pelos estagiários do arquivo; há uma ficha de identificação inserida pelos estagiários do CEDOC/UEFS com as seguintes informações: no cabeçalho - "UNIVERSIDADE ESTADUAL DE FEIRA DE SANTANA, DEPARTAMENTO DE CIÊNCIAS HUMANAS E FILOSOFIA, CENTRO DE DOCUMENTAÇÃO E PESQUISA, LEVANTAMENTO GERAL DOS NÚCLEOS DOCUMENTAIS", ao lado do cabeçalho "CLASSIFICAÇÃO: E (estante), Cx (caixa) e Doc (documento)", na linha seguinte: "NÚCLEO: FÓRUM DESEMBARGADOR FILINTO BASTOS, SEÇÃO: JUDICIÁRIO, SÉRIE (com espaço para preenchimento manual), SUBSÉRIE (com espaço para preenchimento manual), TIPOLOGIA (com espaço para preenchimento manual), COMARCA: FSA, No DE FOLHAS (com espaço para preenchimento manual), LOCALIDADE (com espaço para preenchimento manual), PERÍODO (com espaço para preenchimento manual), PARTES E/OU INTERESSADOS (com espaço para preenchimento manual) e OBS. (com espaço para preenchimento manual)"; carimbo molhado, na margem centro-direita superior do fólio 1r, com a inscrição: "E. V. REIS | Folhas _ Escrivão Civil"; palavras ou trechos escritos com caneta de tinha vermelha, nos fólios $2 \mathrm{r} / \mathrm{v}, 3 \mathrm{r} / \mathrm{v}, 4 \mathrm{r}, 5 \mathrm{r} / \mathrm{v}, 6 \mathrm{v}, 7 \mathrm{v}, 8 \mathrm{v}, 9 \mathrm{v}, 10 \mathrm{v}, 12 \mathrm{r} / \mathrm{v}, 13 \mathrm{r} / \mathrm{v}$, $14 \mathrm{r} / \mathrm{v}, 15 \mathrm{r} / \mathrm{v}, 16 \mathrm{r} / \mathrm{v}, 17 \mathrm{r}, 20 \mathrm{r}, 22 \mathrm{r}, 24 \mathrm{v}, 26 \mathrm{v}, 30 \mathrm{r}, 32 \mathrm{r}, 34 \mathrm{v}, 36 \mathrm{v}, 39 \mathrm{r}, 41 \mathrm{r}, 42 \mathrm{r} / \mathrm{v}, 43 \mathrm{r}, 44 \mathrm{r}, 45 \mathrm{v}$, $46 \mathrm{r} / \mathrm{v}, 47 \mathrm{r} / \mathrm{v}, 48 \mathrm{v}, 49 \mathrm{r}, 50 \mathrm{v}, 52 \mathrm{v}, 53 \mathrm{v}, 54 \mathrm{r}, 56 \mathrm{v}, 58 \mathrm{r}, 59 \mathrm{r}, 60 \mathrm{r}, 61 \mathrm{r}, 62 \mathrm{v}, 6 \mathrm{r}, 67 \mathrm{r}, 68 \mathrm{v}, 69 \mathrm{v}, 70 \mathrm{r}$, $71 \mathrm{r} / \mathrm{v}, 72 \mathrm{v}, 74 \mathrm{r} / \mathrm{v}, 75 \mathrm{v}, 76 \mathrm{r} / \mathrm{v}, 77 \mathrm{r} / \mathrm{v}, 78 \mathrm{r} / \mathrm{v}, 79 \mathrm{r} / \mathrm{v}, 80 \mathrm{r} / \mathrm{v}, 81 \mathrm{r} / \mathrm{v}, 82 \mathrm{r} / \mathrm{v}, 83 \mathrm{r} / \mathrm{v}, 84 \mathrm{r}, 85 \mathrm{r} / \mathrm{v}, 86 \mathrm{r}$, $87 \mathrm{r}, 88 \mathrm{r} / \mathrm{v}, 89 \mathrm{r} / \mathrm{v}, 90 \mathrm{r} / \mathrm{v}, 92 \mathrm{r} / \mathrm{v}, 93 \mathrm{r} / \mathrm{v}, 94 \mathrm{v}, 95 \mathrm{v}, 96 \mathrm{r} / \mathrm{v}, 97 \mathrm{r} / \mathrm{v}, 98 \mathrm{r} / \mathrm{v}, 99 \mathrm{r} / \mathrm{v}, 101 \mathrm{r}, 105 \mathrm{v}, 106 \mathrm{r}$, $107 \mathrm{r} / \mathrm{v}, 108 \mathrm{r} / \mathrm{v}, 109 \mathrm{v}, 110 \mathrm{r} / \mathrm{v}, 111 \mathrm{r} / \mathrm{v}, 113 \mathrm{r} / \mathrm{v}, 114 \mathrm{r} / \mathrm{v}, 115 \mathrm{r}, 118 \mathrm{v}, 119 \mathrm{v}, 120 \mathrm{r} / \mathrm{v}, 121 \mathrm{r} / \mathrm{v}, 122 \mathrm{r}$, $123 \mathrm{r} / \mathrm{v}, 124 \mathrm{v}, 126 \mathrm{r}, 129 \mathrm{r} / \mathrm{v}, 130 \mathrm{r}, 131 \mathrm{v}, 132 \mathrm{r} / \mathrm{v}, 133 \mathrm{v}, 134 \mathrm{r}, 137 \mathrm{v}, 145 \mathrm{v}, 146 \mathrm{v}, 150 \mathrm{r} / \mathrm{v}, 151 \mathrm{r} / \mathrm{v}$, $152 \mathrm{r} / \mathrm{v}, 154 \mathrm{r}, 156 \mathrm{r} / \mathrm{v}, 157 \mathrm{r} / \mathrm{v}, 158 \mathrm{r} / \mathrm{v}, 159 \mathrm{r}, 162 \mathrm{r}, 164 \mathrm{r}, 165 \mathrm{r} / \mathrm{v}, 166 \mathrm{r} / \mathrm{v}, 167 \mathrm{r}, 168 \mathrm{r}, 169 \mathrm{v}$, $170 \mathrm{r} / \mathrm{v}, 171 \mathrm{r} / \mathrm{v}, 172 \mathrm{r} / \mathrm{v}, 173 \mathrm{r}, 176 \mathrm{r} / \mathrm{v}, 177 \mathrm{r} / \mathrm{v}, 178 \mathrm{v}, 179 \mathrm{r} / \mathrm{v}, 180 \mathrm{r}, 181 \mathrm{r}, 182 \mathrm{r} / \mathrm{v}, 183 \mathrm{r} / \mathrm{v}, 184 \mathrm{r}$, $185 \mathrm{r} / \mathrm{v}, 186 \mathrm{v}, 189 \mathrm{v}, 190 \mathrm{v}, 192 \mathrm{r} / \mathrm{v}, 193 \mathrm{r} / \mathrm{v}, 194 \mathrm{r}, 200 \mathrm{v}, 208 \mathrm{v}, 209 \mathrm{r}, 210 \mathrm{v}, 211 \mathrm{r}, 212 \mathrm{r}, 213 \mathrm{v}$, $214 \mathrm{r} / \mathrm{v}$ e $215 \mathrm{r}$; dobras nas margens dos dois últimos fólios; escurecimento do verso do último fólio; marcas de costura na margem esquerda de todos os fólios.

9. Conteúdo: Trata-se da trasladação do inventário do Coronel Agostinho Fróes da Motta. $\mathrm{O}$ escrivão, Vicente dos Reis, anuncia, no segundo fólio, que será trasladado o terceiro volume do inventário, mas há também trechos do quarto volume como, por exemplo, a trasladação da ação de desquite e da partilha dos bens de Adalgisa da Motta Farias e do seu ex-marido, bem como o termo de desistência de apelação proposto por Adalberto Alves de Farias contra o excunhado, Eduardo Fróes da Motta. Em suma, foram transcritas informações do terceiro e do 
quarto volumes do referido inventário, as quais já foram descritas anteriormente, na ficha codicológica do inventário do coronel supracitado, o que dispensa a sua repetição.

10. Scriptor: Vicente dos Reis.

Fonte: Elaborado pela pesquisadora

Quadro 24 - Ficha codicológica do vigésimo documento

\section{ALVARÁ SOLICITADO POR AUGUSTO FRÓES DA MOTTA}

1. Cota: Feira de Santana - Bahia; Centro de Documentação e Pesquisa/ UEFS; Seção Judiciária, Série Cíveis; Subsérie: Ações; Tipologia Alvará; Localização: Estante 08, Caixa 212 e Documento 4405.

2. Datação: 1932 - "1932 [...]" (f. 1r, 1. 1).

3. Lugar de origem: Feira de Santana - “[...] DA FEIRA DE SANT'ANNA [...]” (f. 1r, 1. 3).

4. Fólio de abertura: "1932 | JUIZO DE DIREITO | DA FEIRA DE SANT'ANNA ESTADO DA BAHIA | Alvará de licença | requerido por Augus- | to Fróes da Motta $<$ Julgado 19-12-32> Escrivão Interino Constantino Reis | AUTUAÇÃO | Anno de mil novecentos e 32 | aos 18 dias do mez de Janeiro do dito anno | autuo a petição que se segue do que | faço este termo. | Eu, Constantino Reis escrivão que subscrevo. | A GRAPHICA DA FEIRA" (f. 1r, 1. 1-30).

5. Suporte material: papel cartolina e almaço, com pauta na maioria dos fólios e de baixa gramatura.

6. Composição: 5 fólios (dos quais os fólios 1v, 5r e 5v estão em branco, o fólio 1r é um formulário preenchido manualmente e os demais são manuscritos); formatos (in-plano e infólio); dimensão regular dos fólios: $330 \mathrm{~mm}$ x $228 \mathrm{~mm}$.

7. Organização da página: dimensão da mancha escrita variável: f. 1r - 300mm X 200mm, $2 \mathrm{r}-280 \mathrm{~mm} \times 175 \mathrm{~mm}, 2 \mathrm{v}$ e $4 \mathrm{r}-280 \mathrm{~mm} \times 185 \mathrm{~mm}, 3 \mathrm{r}-275 \mathrm{~mm} \times 185 \mathrm{~mm}, 3 \mathrm{v}-278 \mathrm{~mm} \times$ $185 \mathrm{~mm}, 4 \mathrm{v}-207 \mathrm{~mm} \times 182 \mathrm{~mm}$ etc.; 1 coluna e número de linhas da mancha escrita: $\mathrm{f}$. $1 \mathrm{r}, 2 \mathrm{r}$, $2 \mathrm{v}, 3 \mathrm{r}, 3 \mathrm{v}$ e $4 \mathrm{r}-30$ linhas e $4 \mathrm{v}-23$ linhas; pautado; sem numeração; e um único reclamo ("foram/ foram" nos fólios 3v/4r).

8. Particularidades: O documento não possui capa, mas há uma folha de papel almaço, que funciona como uma espécie de invólucro, que foi inserido pelos estagiários do CEDOC/UEFS, para proteger o documento da umidade e garantir a conservação do suporte material, o que evita o contato direto das mãos do pesquisador com o manuscrito. Além disso, 
na folha há as seguintes informações sobre o documento: "Subsérie: Ações, Tipologia: Alvará, Parte I - Augusto Fróes da Motta, Localidade: Feira de Santana, Período: 1932|1932, $\mathrm{N}^{\mathrm{o}}$ de folhas: 3 , as quais foram escritas a lápis pelos estagiários do arquivo; há uma ficha de identificação inserida pelos estagiários do CEDOC/UEFS com as seguintes informações: no cabeçalho - "UNIVERSIDADE ESTADUAL DE FEIRA DE SANTANA, DEPARTAMENTO DE CIÊNCIAS HUMANAS E FILOSOFIA, CENTRO DE DOCUMENTAÇÃO E PESQUISA, LEVANTAMENTO GERAL DOS NÚCLEOS DOCUMENTAIS", ao lado do cabeçalho "CLASSIFICAÇÃO: E (estante), Cx (caixa) e Doc (documento)", na linha seguinte: "NÚCLEO: FÓRUM DESEMBARGADOR FILINTO BASTOS, SEÇÃO: JUDICIÁRIO, SÉRIE (com espaço para preenchimento manual), SUBSÉRIE (com espaço para preenchimento manual), TIPOLOGIA (com espaço para preenchimento manual), COMARCA: FSA, $\mathrm{N}^{\mathrm{o}}$ DE FOLHAS (com espaço para preenchimento manual), LOCALIDADE (com espaço para preenchimento manual), PERÍODO (com espaço para preenchimento manual), PARTES E/OU INTERESSADOS (com espaço para preenchimento manual) e OBS. (com espaço para preenchimento manual)"; ganchos e laçadas; dobras nas margens; marcas de costura na margem esquerda dos fólios; dois timbres estaduais com as inscrições: "Thesouro do Estado da Bahia" e "IMPOSTO DO SELLO", nos fólios 2r, 3r e 4r; três selos de impostos no valor de 5.000, 600 e 200 réis cada, na margem centro-inferior do fólio $3 \mathrm{v}$.

9. Conteúdo: Trata-se de um alvará solicitado por Augusto Fróes da Motta, que pleiteia o aval da Justiça para levantar o valor constante na conta de caderneta n. 62838 do seu filho Luiz Fróes da Motta, menor de idade, na Caixa Econômica Federal, localizada na Capital do Estado. A justificativa do requerente é a de que precisava levantar o valor da caderneta para pagar as despesas em benefício do próprio filho, pedido que foi deferido pelo Juiz.

10. Escreventes: Constantino Vicente dos Reis, Augusto Fróes da Motta, Luis Fróes da Motta, Manoel Ferreira Côelho e Joaquim Alves Pedreira S.

Fonte: Elaborado pela pesquisadora

Quadro 25 - Ficha codicológica do vigésimo primeiro documento

\section{QUINTO VOLUME DA AÇÃO DE EMBARGO PROPOSTA POR EDUARDO FRÓES DA MOTTA E MARIA LAMBERT DE BRITO MOTTA}

1. Cota: Feira de Santana - Bahia; Centro de Documentação e Pesquisa/ UEFS; Seção Judiciária, Série Cíveis; Subsérie: Ações; Tipologia Embargo; Localização: Estante 10, Caixa 255 e Documento 5367.

2. Datação: 1936 - "1936 [...]” (f. 1r, 1. 1).

3. Lugar de origem: Feira de Santana - “[...] Feira de Sant'An | na [...]” (f. 1r, 1. 7-8).

4. Fólio de abertura: "1936 Quinto Volume | Corte de Appellação | Numero 6069 Embargos de $\mid$ dade de senten $\mid$ de $\mid$ Feira de Sant'An | Doutor Eduardo Fróes da | Motta e sua mulher $=\mid$ Pharmaceutico Arthur Fróes d $\mid$ Motta, inventariante do | bens deixados por Agosti $\mid$ Fróes da Motta | Juizes | Paulo Teixeira - Relator | Salvio Martins Primeiro Adjunto | Santos Cruz Segundo | O sub Escrivão da Côrte de Appellação | [Oswaldo Hugo Sacramento]" (f. 1r, 1. 1-30). 


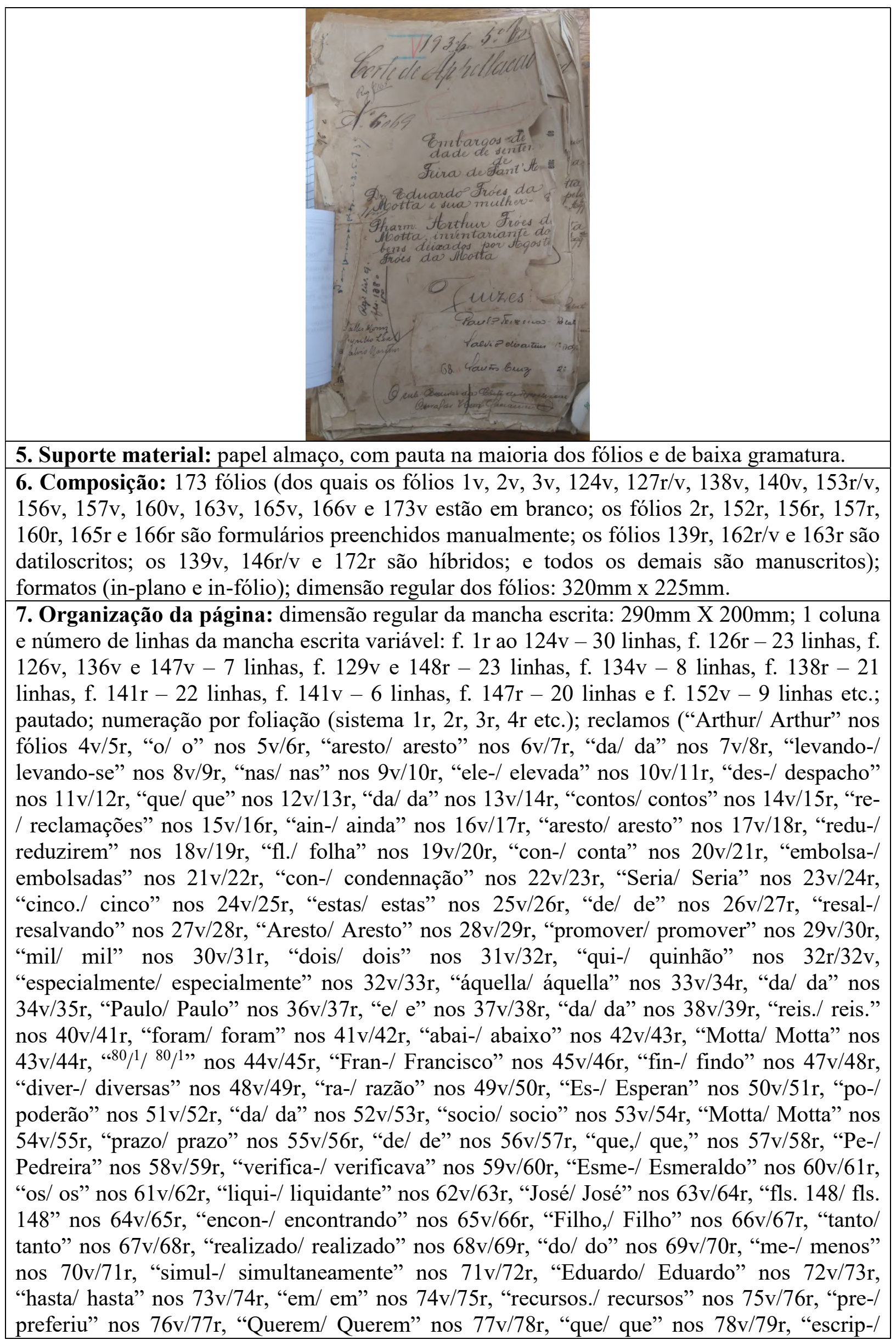


escripta" nos 79v/80r, "obrigação/ obrigação" nos 80v/81r, "por/ por" nos 81v/82r, "di-/ divida" nos 82v/83r, "existen-/ existente" nos 83v/84r, "sem/ sem" nos $84 \mathrm{v} / 85 \mathrm{r}$, "na/ na" nos 85v/86r, "declarações/ declarações" nos 86v/87r, "pago/ pago" nos 87v/88r, "da/ da" nos 88v/89r, "vulgarmen-/ vulgarmente" nos 89v/90r, "desta/ desta" nos 90v/91r, "volume,/ volume," nos 91v/92r, "dispendido/ dispendido" nos 92v/93r, "prejuizo/ prejuizo" nos 93v/94r, "consequen-/ consequencias" nos 94v/95r, "Caixa/ Caixa" nos 95v/96r, "virtude/ virtude" nos 96v/97r, "despesas/ despesas" nos 97v/98r, "\&/ \&" nos 98v/99r, "pas-/ passivas" nos 99v/100r, "volume)/ volume)" nos 100v/101r, "Agos-/ Agostinho" nos 101v/102r, "co-/ como" nos 102v/103r, "na/ na" nos 103v/104r, "fôra/ fôra" nos 104v/105r, "interessados./ interessados." nos 105v/106r, "vai/ vai" nos 106v/107r, "in-/ inventariante" nos 107v/108r, "tam-/ tambem" nos 108v/109r, "interessa-/ interessados" nos 109v/110r, "anterior/ anterior" nos 110v/111r, "equi-/ equivalente" nos 111r/111v, "as-/ assignado" nos $111 \mathrm{v} / 112 \mathrm{r}$, "testamen-/ testamentario" nos 112v/113r, "extra-/ extrahido" nos 113v/114r, "con-/ contos" nos 114v/115r, "cin-/ cincoenta" nos 115v/116r, "Bank/ Bank" nos 116v/117r, "conserva-/ conservação" nos 117v/118r, "data,/ data," nos 118v/119r, "na/ na" nos 119v/120r, "con-/ contos" nos 120v/121r, "intime-/ intime-se" nos 131v/132r, "janella/ janellas" nos 134v/135r e "reclama-/ reclamações" nos $138 \mathrm{r} / 138 \mathrm{v}$ ); sem assinaturas pessoais nas margens do documento.

8. Particularidades: $O$ documento não possui capa, mas há uma folha de papel almaço, que funciona como uma espécie de invólucro, que foi inserido pelos estagiários do CEDOC/UEFS, para proteger o documento da umidade e garantir a conservação do suporte material, o que evita o contato direto das mãos do pesquisador com o manuscrito. Além disso, na folha há as seguintes informações sobre o documento: "Subsérie: Ações, Tipologia: Embargo, Parte I - Arthur Fróes da Motta e Parte II: Eduardo Fróes da Motta, Localidade: FSA, Período: 1933-1937, No de folhas: 169”, as quais foram escritas a lápis pelos estagiários do arquivo; há uma ficha de identificação inserida pelos estagiários do CEDOC/UEFS com as seguintes informações: no cabeçalho - "UNIVERSIDADE ESTADUAL DE FEIRA DE SANTANA, DEPARTAMENTO DE CIÊNCIAS HUMANAS E FILOSOFIA, CENTRO DE DOCUMENTAÇÃO E PESQUISA, LEVANTAMENTO GERAL DOS NÚCLEOS DOCUMENTAIS", ao lado do cabeçalho "CLASSIFICAÇÃO: E (estante), Cx (caixa) e Doc (documento)", na linha seguinte: "NÚCLEO: FÓRUM DESEMBARGADOR FILINTO BASTOS, SEÇÃO: JUDICIÁRIO, SÉRIE (com espaço para preenchimento manual), SUBSÉRIE (com espaço para preenchimento manual), TIPOLOGIA (com espaço para preenchimento manual), COMARCA: FSA, $\mathrm{N}^{\mathrm{o}}$ DE FOLHAS (com espaço para preenchimento manual), LOCALIDADE (com espaço para preenchimento manual), PERÍODO (com espaço para preenchimento manual), PARTES E/OU INTERESSADOS (com espaço para preenchimento manual) e OBS. (com espaço para preenchimento manual)"; a maioria do documento é escrita a lápis e uma pequena parte à caneta preta ou azul; o fólio 1r possui um recorte de papel, em forma de retângulo, colado à margem inferior direita do fólio; o documento possui erro de numeração; rasgos e dobras nas margens de alguns fólios; marcas de costura nos fólios soltos; escurecimento do papel e manchas em alguns fólios; dois timbres com a inscrição: "IMPOSTO DO SELLO | 700 REIS" e "THESOURO DO ESTADO DA BAHIA", em quase todos os fólios rectos; manchas de umidade na margem inferior direita de vários fólios; ganchos, laçadas e riscaduras em alguns fólios; algumas palavras ou trechos sublinhados ou escritos com caneta de tinta preta, azul ou vermelha nos fólios $4 \mathrm{r} / \mathrm{v}, 5 \mathrm{r} / \mathrm{v}, 6 \mathrm{v}$, $7 \mathrm{r}, 8 \mathrm{r}, 9 \mathrm{r} / \mathrm{v}, 11 \mathrm{r}, 12 \mathrm{r} / \mathrm{v} 13 \mathrm{r} / \mathrm{v}, 14 \mathrm{r} / \mathrm{v}, 15 \mathrm{v}, 16 \mathrm{v}, 17 \mathrm{r} / \mathrm{v}, 18 \mathrm{r} / \mathrm{v}, 19 \mathrm{r}, 20 \mathrm{v}, 21 \mathrm{r} / \mathrm{v}, 22 \mathrm{r} / \mathrm{v}, 23 \mathrm{r}, 24 \mathrm{v}$, $25 \mathrm{r} / \mathrm{v}, 26 \mathrm{r} / \mathrm{v}, 27 \mathrm{r} / \mathrm{v}, 28 \mathrm{v}, 29 \mathrm{r} / \mathrm{v}, 30 \mathrm{r}, 33 \mathrm{r}, 34 \mathrm{v}, 35 \mathrm{r}, 38 \mathrm{v}, 40 \mathrm{r}, 41 \mathrm{r}, 42 \mathrm{v}, 43 \mathrm{r}, 47 \mathrm{v}, 51 \mathrm{r} / \mathrm{v}, 52 \mathrm{v}$, $53 \mathrm{v}, 54 \mathrm{r} / \mathrm{v}, 62 \mathrm{v}, 63 \mathrm{r}, 64 \mathrm{r} / \mathrm{v}, 65 \mathrm{r}, 66 \mathrm{r}, 67 \mathrm{v}, 68 \mathrm{r}, 70 \mathrm{r} / \mathrm{v}, 71 \mathrm{v}, 75 \mathrm{v}, 81 \mathrm{r}, 84 \mathrm{v}, 85 \mathrm{r}, 86 \mathrm{r} / \mathrm{v}, 90 \mathrm{r} / \mathrm{v}, 99 \mathrm{r}$, $100 \mathrm{r}, 103 \mathrm{v}, 104 \mathrm{r} / \mathrm{v}, 107 \mathrm{r} / \mathrm{v}, 108 \mathrm{r}, 109 \mathrm{r}, 110 \mathrm{v}, 112 \mathrm{r}, 113 \mathrm{r} / \mathrm{v}, 114 \mathrm{r}, 119 \mathrm{v}, 121 \mathrm{r}, 128 \mathrm{r}, 136 \mathrm{r}$, 139r/v e 163r; vários carimbos molhados, dentre os quais há um com a inscrição: "Prefeitura 
Municipal | Feira", na margem superior esquerda do fólio 146r; selos de impostos ao longo do documento: 2 (um no valor de 1000 e outro no de 400 réis) no fólio 125 r; 3 ( 1 de 200 e 2 de 400 réis cada) no fólio $139 \mathrm{v} ; 4$ ( 1 de 200, 1 de 1000, 1 de 2000 e 1 de 400 réis) no fólio 140r; 6 ( 2 de 200, 3 de 800 e 1 de 100 réis) no fólio 146r; 1 de 20 réis no fólio 150 r; 4 ( 1 de 200, 1 de 5000, 1 de 1000 e 1 de 400) no fólio 151r; 4 ( 1 de 200, 1 de 1000, 1 de 400 e 1 de 200) no fólio 152v; 3 ( 1 de 5000, 1 de 2000 e 1 de 1000) no fólio 160v; 2 ( 1 de 200 e 1 de 400 réis) no fólio 163r; 2 ( 1 de 800 e 1 de 100 réis) no fólio 172r; 6 de 400 réis cada no fólio 166r; 1 de 100 réis nos fólios 168r e 170r; e 2 ( 1 de 800 e 1 de 100 réis) no fólio 171v; página do Jornal Folha do Norte, de Junho de 1936, no fólio 150r, na qual há a publicação da Receita e das despesas da Prefeitura Municipal de Feira de Santana.

9. Conteúdo: Trata-se do quinto volume de uma ação de embargo proposta por Eduardo Fróes da Motta e Dona Maria Lambert de Brito Motta contra Arthur Fróes da Motta e Alberto de Almeida Motta. Neste processo, Arthur Fróes da Motta é apresentado como o embargado e inventariante dos bens deixados por seu pai, o que levou o seu irmão, Eduardo Fróes da Motta, a solicitar a abertura desta ação de embargo, iniciada com a trasladação de uma ação de instrumento de agravo, datada de 8 de maio de 1933, extraída de uma ação de sonegados contra aquele e anexada a este processo, cujo interesse do embargado era provar que o embargante havia sonegado alguns bens do inventário do seu pai, Coronel Agostinho Fróes da Motta, a fim de se beneficiar na partilha, sobre a qual havia recebido 105:550\$448 (cento e cinco contos, quinhentos e cinquenta mil e quatrocentos e quarenta e oito réis), enquanto que os demais herdeiros apenas 13:193\$811 (treze contos, cento e noventa e três mil e oitocentos e onze réis), o que foi ratificado pelo novo inventariante, o farmacêutico Arthur Fróes da Motta, que alegou que aquele havia agido "com requintes de perversidade monstruosa" para com os seus irmãos, dos quais o engenheiro Alberto de Almeida Motta, já se achava falecido antes mesmo da finalização deste processo, apesar de ser mencionado como aliado de Arthur Fróes da Motta nesta ação.

Para reaver a quantia "sonegada" pelo antigo inventariante, foram pedidas pelos interessados algumas certidões e a trasladação de processos anteriores em que Eduardo Fróes da Motta fora condenado, apesar deste negar veemente as acusações que lhe foram feitas, dentre as quais a notificação de que devia ao espólio do inventário a quantia de 57:498\$628, referentes aos juros transcorridos da firma Agostinho Fróes da Motta e Filho, já encerrada naquele período. Apesar da arguição do advogado do novo inventariante, Eduardo Fróes da Motta acusou o seu irmão de querer lhe prejudicar quanto ao recebimento do seu quinhão na herança paternal, já que Arthur Fróes da Motta solicitou a penhora de 5 casas de Eduardo Fróes da Motta, situadas à Praça Fróes da Motta, avaliadas em 12:000\$000 (doze contos de réis) cada uma, o que totalizariam 60:000\$000 (sessenta contos de réis), que pagariam a dívida que o seu irmão havia contraído junto ao espólio.

Apesar dessas afirmações, Eduardo Fróes da Motta, após solicitar e lhe ser concedida a isenção do pagamento de impostos daquelas casas junto ao Prefeito da época, Elpidio Raymundo da Nova, conseguiu a nulidade da sentença, ou seja, a decisão da Corte de Apelação foi a de que o embargante não poderia pagar juros que eram da firma, haja vista esta já ter sido encerrada e, por isso, não cabia ao embargado pagar uma dívida que não era sua. Em 13 de agosto de 1937, foi publicada a sentença a favor do embargante, cabendo a Arthur Fróes da Motta o pagamento das custas deste processo.

10. Escreventes ${ }^{103}$ : Oswaldo Hugo Sacramento, Ignacio Paschoal Bastos, Constantino Vicente dos Reis, Silio Soledade, Villebaldo Garcez Paranhos Montenegro, Domingos Adami, Cyrillo Leal, Elpidio Raymundo da Nova, Manoel Ferreira Côelho, Hildebrando

103 Duas rubricas estão ilegíveis no documento, o que impossibilitou identificar os nomes dos respectivos scriptores. 
Cordeiro de Almeida, Antonio Mattos, João Pedro de Oliveira, Miguel Barretto da Silva, Péricles Ribeiro de Macêdo, Eduardo Fróes da Motta, Juvencio Pedreira, João Carneiro Vital, Altino Moraes Mattos, José Portugal, Pedro Ribeiro, Antonio Bulcão, Salvio Martins, Salles Moniz, Lyderico Santos Cruz e Paulo Teixeira.

Fonte: Elaborado pela pesquisadora

Quadro 26 - Ficha codicológica do vigésimo segundo documento

\section{ALVARÁ SOLICITADO POR EDUARDO FRÓES DA MOTTA}

1. Cota: Feira de Santana - Bahia; Centro de Documentação e Pesquisa/ UEFS; Seção Judiciária, Série Cíveis; Subsérie Ação; Tipologia Alvará; Localização: Estante 08, Caixa 212 e Documento 4414.

2. Datação: 1937 - “1937 [...]” (f. 1r, 1. 1).

3. Lugar de origem: Feira de Santana - “[...] FEIRA DE SANT'ANNA [...]” (f. 1r, 1. 3).

4. Fólio de abertura: "1937 | JUIZO DE DIREITO | DA FEIRA DE SANT'ANNA ESTADO DA BAHIA | Alvará requerido | pelo Doutor Eduardo Fróes | da Motta | Escrivão -Constantino Reis | AUTUAÇÃO | Anno de mil novecentos e $37 \mid$ aos 14 dias do mez de Fevereiro do dito anno, | autuo a petição que se segue do que $\mid$ faço este termo. $\mid$ Eu, Constantino Reis escrivão que subscrevo. | Folha da Feira" (f. 1r, 1. 1-21).

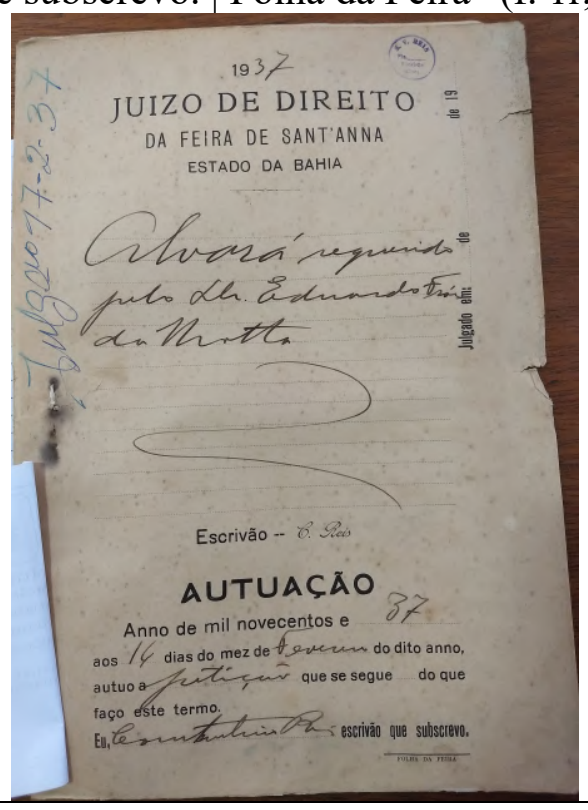

5. Suporte material: papel cartolina e almaço, com pauta na maioria dos fólios e de baixa gramatura.

6. Composição: 04 fólios (dos quais os fólios 1v, 3v, 4r e 4v estão em branco, o fólio 1r é um formulário preenchido manualmente, o fólio $2 \mathrm{r}$ é híbrido, e os demais fólios são manuscritos); formatos (in-plano e in-fólio); dimensão dos fólios variável: fólios $1 \mathrm{r}, 4 \mathrm{r}$ e $4 \mathrm{v}-325 \mathrm{~mm} \mathrm{x}$ $235 \mathrm{~mm}$ e os demais fólios $-330 \mathrm{~mm}$ x $215 \mathrm{~mm}$; marca d'água nos fólios $2 \mathrm{r}$, 3r e 3v.

7. Organização da página: dimensão da mancha escrita variável: fólios 1r, 4r e 4v - 315mm X $200 \mathrm{~mm}$ e os demais fólios $-315 \mathrm{~mm}$ x $180 \mathrm{~mm}$; 1 coluna e número de linhas da mancha escrita variável: f. 1 r - 26 linhas e f. 2 r, 2v e 3r-30 linhas etc.; pautado; sem numeração; e sem reclamos.

8. Particularidades: O documento não possui capa, mas há uma folha de papel almaço, que funciona como uma espécie de invólucro, que foi inserido pelos estagiários do CEDOC/UEFS, para proteger o documento da umidade e garantir a conservação do suporte material, o que evita o contato direto das mãos do pesquisador com o manuscrito. Além disso, 
na folha há as seguintes informações sobre o documento: "Subsérie: Ações, Tipologia: Alvará, Parte II: Eduardo Fróes da Motta, Localidade: Feira de Santana, Período: 1937-1937, $\mathrm{N}^{\mathrm{o}}$ de folhas: 02 ", as quais foram escritas a lápis pelos estagiários do arquivo; há uma ficha de identificação inserida pelos estagiários do CEDOC/UEFS com as seguintes informações: no cabeçalho - "UNIVERSIDADE ESTADUAL DE FEIRA DE SANTANA, DEPARTAMENTO DE CIÊNCIAS HUMANAS E FILOSOFIA, CENTRO DE DOCUMENTAÇÃO E PESQUISA, LEVANTAMENTO GERAL DOS NÚCLEOS DOCUMENTAIS", ao lado do cabeçalho "CLASSIFICAÇÃO: E (estante), Cx (caixa) e Doc (documento)", na linha seguinte: "NÚCLEO: FÓRUM DESEMBARGADOR FILINTO BASTOS, SEÇÃO: JUDICIÁRIO, SÉRIE (com espaço para preenchimento manual), SUBSÉRIE (com espaço para preenchimento manual), TIPOLOGIA (com espaço para preenchimento manual), COMARCA: FSA, $\mathrm{N}^{\mathrm{o}}$ DE FOLHAS (com espaço para preenchimento manual), LOCALIDADE (com espaço para preenchimento manual), PERÍODO (com espaço para preenchimento manual), PARTES E/OU INTERESSADOS (com espaço para preenchimento manual) e OBS. (com espaço para preenchimento manual)"; rasgos nas margens do primeiro e último fólios; marca de grampo no centro da margem esquerda de todos os fólios; carimbo molhado com a inscrição "E. V. REIS | Folhas Escrivão Civil", no fólio 1r; selo de imposto no valor de 100 réis, no fólio 2 r; e selo de imposto no valor de 5 réis, no fólio $2 \mathrm{v}$.

9. Conteúdo: Trata-se de um alvará solicitado por Eduardo Fróes da Motta, que requereu da Justiça autorização para vender um sítio denominado Ponto Central que, na época, valia 5 contos de réis e pertencente ao seu filho menor de idade. Vale salientar que a solicitação do alvará se deu por conta de uma oferta de compra do referido sítio no valor 8 contos de réis, o qual seria investido em outro imóvel já de interesse do suplicante e em benefício do seu filho. Em 18 de fevereiro de 1937 foi expedido o alvará solicitado.

10. Escreventes: Constantino Vicente dos Reis, Manoel Ferreira Côelho, Eduardo Fróes da Motta, R. Pedreira e Antonio Mattos.

Fonte: Elaborado pela pesquisadora

Quadro 27 - Ficha codicológica do vigésimo terceiro documento

\section{TESTAMENTO DE ALBERTINA MOTTA DE ALMEIDA ${ }^{104}$}

1. Cota: Feira de Santana - Bahia; Centro de Documentação e Pesquisa/ UEFS; Seção Judiciária, Série Cíveis; Subsérie Inventário; Tipologia Testamento; Localização: Estante 06, Caixa 171 e Documento 2716.

2. Datação: 1943 - "1943 [...]” (f. 1r, 1. 1).

3. Lugar de origem: Feira de Santana - “[...] JUIZO DE DIREITO DA FEIRA DE SANT'ANNA [...]" (f. 1r, 1. 3).

4. Fólio de abertura: "1943 | REPUBLICA DOS ESTADOS UNIDOS DO BRASIL | Juizo de Direito da Feira de Sant'ana | ESTADO DA BAHIA | Testamento da | falecida Albertina | de Almeida Mota | Escrivão - Constantino REIS | AUTUAÇÃO | Ano de mil novecentos e 43 aos 31 dias | do mês de maio do dito ano, | autuo a petição que se segue do que | faço este termo. $\mid \mathrm{Eu}$, Constantino Reis escrivão que $\mid$ subscrevo. | Folha da Feira - Feira | Autuação e apresentação \# 3,000" (f. 1r, 1. 1-21).

\footnotetext{
104 Neste documento, a autora, Albertina Motta de Almeida, utiliza o sobrenome do seu segundo marido,
} Igmedio Evangelista de Almeida. 


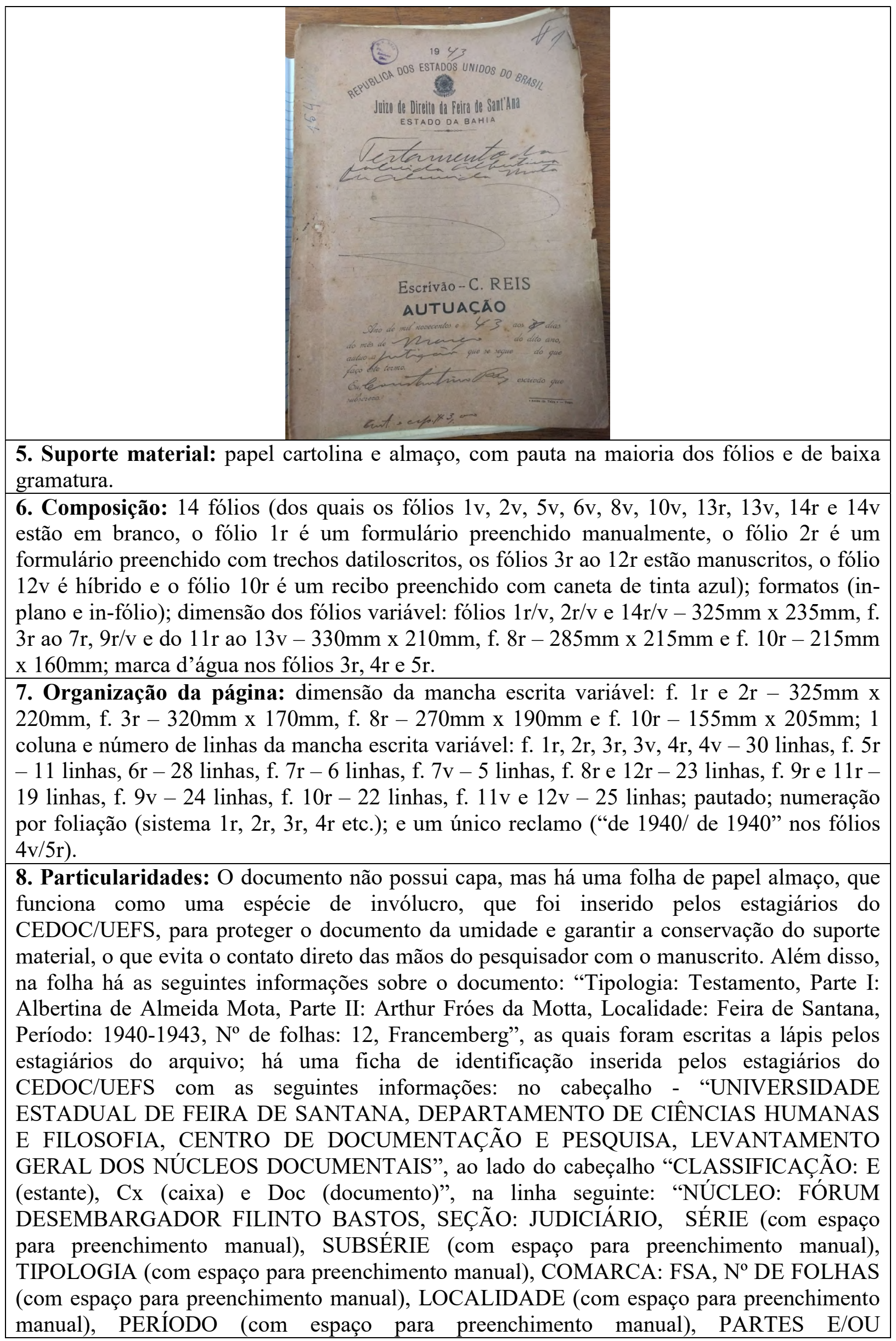


INTERESSADOS (com espaço para preenchimento manual) e OBS. (com espaço para preenchimento manual)"; riscos longos, rasgos e dobras em alguns fólios; escurecimento de alguns fólios; três marcas de grampo na margem esquerda de quase todos os fólios; vários fólios timbrados; um carimbo molhado com a inscrição "E. V. REIS | Fls.

Escrivão | Civel", na margem superior esquerda do fólio 1r; quatro carimbos molhados com a inscrição "Almachio Alves Boaventura | Tabelião de Notas | 22 Nov. 1940 | do $1^{\circ}$ Oficio | Feira de Sant'Ana", no fólio 5r; 2 selos de impostos no valor de 200 e 100 réis, respectivamente, no fólio 5r; 11 selos de impostos, dos quais 4 são no valor de 1 mil réis, 2 no valor de 200 réis e 5 no valor de 300 réis, todos no fólio 5r; 7 carimbos molhados com a inscrição “TABELIONATO BOAVENTURA | 30 | MAR. | 43 | FEIRA - BAHIA”, inseridos em cada um dos 7 selos - de um total de 11, no fólio 5r.

9. Conteúdo: Trata-se do testamento de Albertina Motta de Almeida, o qual estava guardado em cofre à prova de fogo e no qual há a informação de que este revogava os outros três, feitos anteriormente pela autora. Assim, em 21 de novembro de 1940, a autora declarou ao Tabelião de Notas que era filha legítima do coronel Agostinho Fróes da Motta e de Dona Maximiana de Almeida Motta, ambos já falecidos, que era casada em segunda núpcias com Igmedio Evangelista de Almeida e de quem se achava desquitada, e não possuía nenhum filho de nenhum dos dois casamentos ${ }^{105}$, também declarou que era Católica Apostólica Romana, que deixava 41 apólices federais, no valor de um conto de réis cada uma, e mais 4 que possuía em comum com os seus irmãos, herança de sua mãe, todas ficariam para o seu irmão Arthur Fróes da Motta e para os herdeiros deste, caso ele faltasse, incluindo-se nisso os juros das ditas apólices, após a sua morte.

Também deixou uma casa na rua Monsenhor Tertuliano para a sua cunhada, Francelina Carneiro da Motta, esposa do seu irmão Arthur Fróes da Motta, outra casa na rua Doutor Filinto Bastos para o seu irmão Arthur Fróes da Motta, e mais outra na mesma rua para o seu sobrinho e afilhado José Filho, filho do mesmo irmão Arthur Fróes da Motta. Para a sua sobrinha e afilhada Antonieta Carvalho da Silva, casada com Antonio Deraldo da Silva, deixou a sua casa de residência situada na rua Monsenhor Tertuliano e para a sua companheira Isaura Teixeira da Silva ${ }^{106}$ deixou uma casa na rua Doutor Filinto Bastos e, na falta daquela, a casa deveria ficar para a Seráfica Ordem Terceira da Penitenciária de São Francisco de Assis, dentre outros bens para outros beneficiários.

A testadora também deixou como seus testamenteiros, em primeiro lugar, o seu irmão Arthur Fróes da Motta, em segundo lugar, Raul Ferreira da Silva e, em terceiro lugar, Alvaro dos Santos Rubens, sendo que o primeiro aceitou o cargo da testamentaria e o processo foi encerrado, com as devidas custas, em 17 de abril de 1943.

10. Escreventes ${ }^{107}$ : Constantino Vicente dos Reis, Almachio Alves Boaventura, Arthur Fróes da Motta, Demócrito de Lima Soares, Fernando Alves e José Simões.

Fonte: Elaborado pela pesquisadora

\footnotetext{
${ }^{105}$ Reiteramos que Albertina de Almeida Motta foi casada, em primeiras núpcias, com Antônio Alves Barretto e, em segundas núpcias, com Igmedio Evangelista de Almeida.

106 Albertina de Almeida Motta declarou em seu testamento, na Verba Nona, o seguinte bem para a sua companheira: “[...] Deixa em usofruto | à sua companheira Isaura Teixeira da Silva uma | casa nesta Cidade à rua 'Doutor Filinto Bastos', nume- | ro sessenta e seis (66). Por falecimento de Isaura Teixei- | ra da Silva esta mesma casa ficará pertencendo à | Serafica Ordem Terceira da Penitencia de São Fran- | cisco de Assis, nesta Cidade, sob a guarda do Vigario | Local; isenta esta verba de selo de herança e quaisquer | onus [...]" (TESTAMENTO DE ALBERTINA DE ALMEIDA MOTTA, 1940, f. 4r, 1. 3-11).

107 Três rubricas estão ilegíveis no documento, o que impossibilitou identificar os nomes dos respectivos scriptores.
} 
Quadro 28 - Ficha codicológica do vigésimo quarto documento

NOTIFICAÇÃO SOLICITADA POR AUGUSTO MARCOS CARNEIRO

1. Cota: Feira de Santana - Bahia; Centro de Documentação e Pesquisa/ UEFS; Seção Judiciária, Série Cíveis; Subsérie Ações; Tipologia Notificação; Localização: Estante 13, Caixa 362 e Documento 8416.

2. Datação: 1945 - "1945 [...]" (f. 1r, 1. 1).

3. Lugar de origem: Feira de Santana - “[...] FEIRA DE SANT'ANNA [...]" (f. 1r, 1. 3).

4. Fólio de abertura: " 1945 Folhas Numero $1 \mid$ JUIZO DE DIREITO $\mid$ DA | COMARCA DE FEIRA DE SANT'ANNA | DO ESTADO DA BAHIA | Notificação | Augusto Marcos Carneiro | Requerente $\mid$ Doutor Eduardo Fróes da Motta $\mid$ Requerido $\mid$ Gerolina Nunes Falcão $\mid$ ESCRIVÃ | ANO | Aos dez (10) dias do mês de agosto | do Ano de mil novecentos e quarenta e cinco n'esta cidade de Feira $\mid$ de Sant'Ana em meu cartorio, autuo a petição | que adiante se segue, do que fiz este termo. Eu, Gerolina Nu- | nes Falcão, Escrivã que subscrevi.” (f. 1r, 1 . $1-18)$.

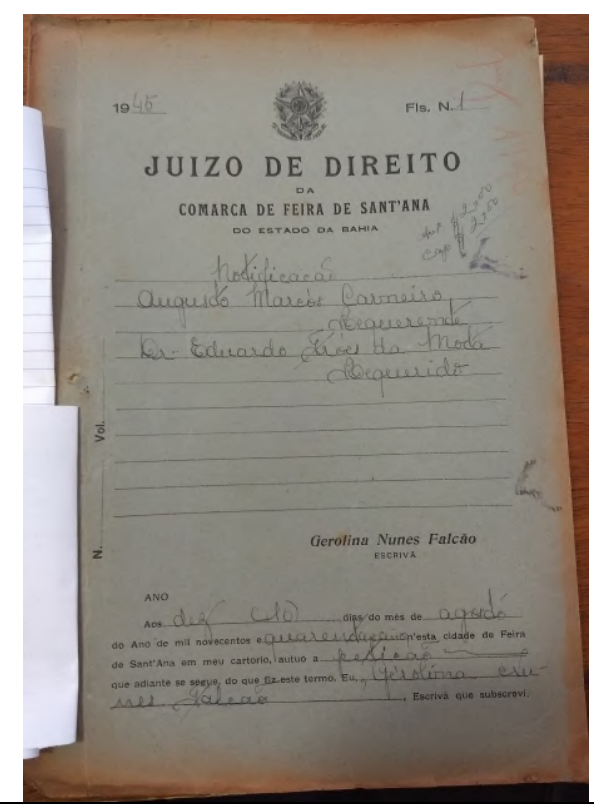

5. Suporte material: papel cartolina e almaço, com pauta (com exceção do último fólio) e de baixa gramatura.

6. Composição: 12 fólios (dos quais os fólios $1 \mathrm{v}, 2 \mathrm{v}, 3 \mathrm{v}, 6 \mathrm{v}, 8 \mathrm{v}, 9 \mathrm{v}, 10 \mathrm{v}, 13 \mathrm{r}$ e $13 \mathrm{v}$ estão em branco, o fólio 1r é um formulário preenchido manualmente, os fólios $2 \mathrm{r}, 3 \mathrm{r}, 8 \mathrm{r}, 11 \mathrm{r}$ e $11 \mathrm{v}$ são híbridos, o fólio $5 \mathrm{r}$ é datiloscrito, os fólios 9r e 10r são recibos de pagamento, e os demais fólios são manuscritos); formatos (in-plano e in-fólio); dimensão variável dos fólios: fólio 1r e $13 \mathrm{r}-350 \mathrm{~mm} \times 240 \mathrm{~mm}$, com exceção dos fólios $9 \mathrm{r}$ e $10 \mathrm{r}-110 \mathrm{~mm} \times 185 \mathrm{~mm}$ e dos demais fólios que medem $335 \mathrm{~mm} \times 225 \mathrm{~mm}$.

7. Organização da página: dimensão da mancha escrita variável: f. $1 \mathrm{r}-300 \mathrm{~mm} X 210 \mathrm{~mm}$, f. $2 \mathrm{r}-300 \mathrm{~mm} \times 210 \mathrm{~mm}$, f. $9 \mathrm{r}$ e $10 \mathrm{r}-110 \mathrm{~mm}$ x $185 \mathrm{~mm} ; 1$ coluna e número de linhas da mancha escrita variável: f. $1 \mathrm{r}-23$ linhas, f. $2 \mathrm{r}$ e $3 \mathrm{r}-36$ linhas, f. $4 \mathrm{r}-20$ linhas, f. $4 \mathrm{v}-06$ linhas, f. 5r, 6r, 7r, 8r, 11r e 12r -30 linhas, f. 5v -27 linhas, f. $7 \mathrm{v}-8$ linhas, f. 9r e 10r -14 linhas, f. 11v - 24 linhas, e f. 12v - 13 linhas; pautado; numeração por foliação (sistema 1r, $2 r, 3 r, 4 r$ etc.); sem reclamos; rubrica da escrivã Gerolina Nunes Falcão, na margem superior direita dos fólios 2r, 3r, 4r, 5r, 6r, 7r, 8r, 9r, 10r, 11r e 12r.

8. Particularidades: $\mathrm{O}$ documento não possui capa, mas há uma folha de papel almaço, que funciona como uma espécie de invólucro, que foi inserido pelos estagiários do CEDOC/UEFS, para proteger o documento da umidade e garantir a conservação do suporte 
material, o que evita o contato direto das mãos do pesquisador com o manuscrito. Além disso, na folha há as seguintes informações sobre o documento: "Subsérie: Ações, Tipologia: Notificação, Parte I - Eduardo Fróes da Motta e Parte II: Augusto Marcos Carneiro, Localidade: FSA, Período: 1945-1946, № de folhas: 10", as quais foram escritas a lápis pelos estagiários do arquivo; há uma ficha de identificação inserida pelos estagiários do CEDOC/UEFS com as seguintes informações: no cabeçalho - "UNIVERSIDADE ESTADUAL DE FEIRA DE SANTANA, DEPARTAMENTO DE CIÊNCIAS HUMANAS E FILOSOFIA, CENTRO DE DOCUMENTAÇÃO E PESQUISA, LEVANTAMENTO GERAL DOS NÚCLEOS DOCUMENTAIS", ao lado do cabeçalho "CLASSIFICAÇÃO: E (estante), Cx (caixa) e Doc (documento)", na linha seguinte: "NÚCLEO: FÓRUM DESEMBARGADOR FILINTO BASTOS, SEÇÃO: JUDICIÁRIO, SÉRIE (com espaço para preenchimento manual), SUBSÉRIE (com espaço para preenchimento manual), TIPOLOGIA (com espaço para preenchimento manual), COMARCA: FSA, N DE FOLHAS (com espaço para preenchimento manual), LOCALIDADE (com espaço para preenchimento manual), PERÍODO (com espaço para preenchimento manual), PARTES E/OU INTERESSADOS (com espaço para preenchimento manual) e OBS. (com espaço para preenchimento manual)"; a maioria dos fólios é timbrada; marcas, no primeiro e último fólios, de exposição ao sol; manchas em locais variados dos fólios; marca de grampo no centro da margem esquerda de todos os fólios; 3 selos de impostos, dos quais um é no valor de hum mil réis e os outros dois no valor de cem réis cada, no fólio 2r; 13 selos de impostos, dos quais um no valor de 3 cruzeiros, dois no valor de 0,40 cruzeiros cada, três no valor de 0,30 cruzeiros cada, cinco no valor de 300 réis cada, um no valor de 0,10 cruzeiros e outro no valor de 100 réis; 6 selos de impostos, dos quais 3 são no valor de 0,50 cruzeiros cada e 3 no valor de 100 réis cada, no fólio $5 \mathrm{v}$; 4 selos de impostos, dos quais 2 são no valor de 0,50 cruzeiros cada e 2 no valor de 100 réis cada, no fólio 6r; 4 selos de impostos, dos quais 1 no valor de 0,40 cruzeiros, 2 no valor 0,50 cruzeiros e 1 no valor de 100 réis, no fólio 7r; 3 selos de impostos, dos quais 2 no valor de 100 réis e 1 no valor de 1 mil réis, no fólio $8 \mathrm{r} ; 2$ selos de impostos no valor de 100 réis e de 0,40 cruzeiros cada, nos fólios 9r e 10r; 13 selos de impostos, dos quais 5 no valor de 0,50 cruzeiros cada, 2 no valor de 0,20 cruzeiros, 1 no valor de 5 cruzeiros, 1 no valor de 800 réis, 1 no valor de 300 réis, 1 no valor de 100 réis, 1 no valor de 0,40 cruzeiros e 1 no valor de 1,00 cruzeiros, no fólio $11 \mathrm{v}$; dois carimbos molhados com a inscrição: "Tabelionato Boaventura $\mid 1^{\circ}$ Sello $\mid$ Almachio Alves Boaventura | TABELIÃO | FEIRA BAHIA" e "Tabelionato Boaventura | Feira Bahia", no fólio 3r.

9. Conteúdo: Trata-se de uma ação de notificação, instaurada em 10 de agosto de 1945, acerca do não recebimento dos alugueis de duas casas, cada uma alugada no valor de 160 cruzeiros e situadas à Praça Fróes da Motta, pertencentes ao Doutor Eduardo Fróes da Motta e alugadas ao locatário, Augusto Marcos Carneiro, que alegou que o referido dono se negou a receber os dois aluguéis e, por isso, requeria que a Justiça o notificasse para recebê-los ou que fosse depositada a devida quantia na conta daquele, a fim de evitar que o locatário caísse em mora.

Para isso, o autor constituiu seu procurador e advogado, o Bacharel em Direito Péricles Ribeiro de Macêdo para requerer à Justiça o recebimento de 640 cruzeiros, referentes aos meses de julho e agosto das duas casas, para serem entregues ao locatário, já que este se recusava a recebê-los. Após isso, a escrivã Gerolina Nunes Falcão foi quem expediu carta de intimação para que o Oficial de Justiça Benjamin Martins Ferreira a entregasse ao Doutor Eduardo Fróes da Motta, como de fato o fez. Em seguida, o locatário solicitou que o valor deixado no cartório da escrivã lhe fosse devolvido, pois o próprio Eduardo Fróes da Motta o recebeu diretamente das suas mãos, estando, portanto, a dívida paga, como comprovavam os recibos anexados ao processo. Logo, foi devolvida ao senhor Augusto Marcos Carneiro a quantia depositada por ele no cartório da escrivã e o processo foi dado por encerrado, haja 
vista a desistência do autor do processo, no dia 22 de maio de 1946.

10. Escreventes: Gerolina Nunes Falcão, Aliber do Amaral Baptista, Antonio Mattos, Péricles Ribeiro de Macêdo, Augusto Marcos Carneiro, Almachio Alves Boaventura, Benjamim Martins Ferreira, Raimundo Dultra Pomponet e Alice de Oliveira Matos.

Fonte: Elaborado pela pesquisadora

Quadro 29 - Ficha codicológica do vigésimo quinto documento

\section{TESTAMENTO DE ARTHUR FRÓES DA MOTTA}

1. Cota: Feira de Santana - Bahia; Centro de Documentação e Pesquisa/ UEFS; Seção Judiciário, Série Cíveis; Subsérie Inventário; Tipologia Testamento; Localização: Estante 06, Caixa 166 e Documento 2571.

2. Datação: 1951 - “=1951= [...]" (f. 2r, 1. 1).

3. Lugar de origem: Feira de Santana - "[...] FEIRA DE SANTANA [...]” (f. 2r, 1. 5).

4. Fólio de abertura: " $=1951=\mid$ Juizo de Direito $\mid$ da Vara Civel $\mid$ da Comarca da $\mid$ Feira de Santana | Bahia | Testamento | do falecido Artur Fróes | da Mota | Escrivão | Reis | Autuação | ano de mil novecentos e cincoenta $\mid$ e um, aos dezesseis dias do mês $\mid$ de Outubro do dito ano, em meu | Cartorio, autuo o testamento que $\mid$ se segue. Do que faço este termo. | O Escrivão Constan- | tino Vicente dos Reis." (f. $\left.2 r^{108}, 1.1-30\right)$.

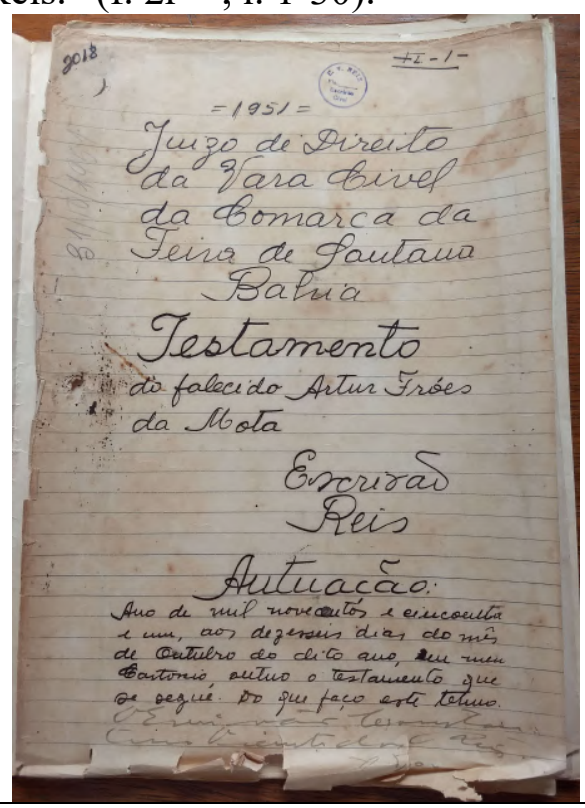

5. Suporte material: papel cartolina e almaço, com pauta (com exceção do primeiro e do último fólios) e de baixa gramatura.

\footnotetext{
108 Nesta ficha, decidimos editar semidiplomaticamente este fólio, pois encontramos mais informações neste do que no 1r, cujo teor é o seguinte: "REPUBLICA DOS ESTADOS UNIDOS DO BRAZIL| TABELIONATO BOAVENTURA $\mid 1^{\circ}$ OFICIO | ALMACHIO ALVES BOAVENTURA | TABELIÃO | AVENIDA SENHOR DOS PASSOS NUMERO 71 - FONE 45 | Feira de Santana - Estado da Bahia | Livro Numero 1 (um) Folhas 19 verso a 20 | Escritura de testamento | Outorgante Artur Fróes da Mota | Outorgado | VALOR: CRUZEIRO \$ | Grafica da Feira - Feira - Bahia". Logo, como se pode notar, a edição semidiplomática do fólio 2r contribuiu para preencher o item 2 desta ficha.
} 
6. Composição: 11 fólios (dos quais os fólios $1 \mathrm{v}, 2 \mathrm{v}, 6 \mathrm{v}, 7 \mathrm{v}, 10 \mathrm{v}$ e $11 \mathrm{v}$ estão em branco; os fólios $1 \mathrm{r} / \mathrm{v}$ e $11 \mathrm{r} / \mathrm{v}$ são uma espécie de capa e quarta capa que envolvem o processo, das quais a capa é um formulário com lacunas que foram preenchidas datiloscritamente, e a quarta capa está em branco; os fólios 3r, 3v e 10r são híbridos; os fólios 6r e 7r são formulários de custas judiciárias e taxas diversas, preenchidos manualmente, e os demais fólios são manuscritos); formatos (in-plano e in-fólio); dimensão dos fólios variável: fólio $1 \mathrm{r}-330 \mathrm{~mm}$ x $235 \mathrm{~mm}, 2 \mathrm{r}-$ $325 \mathrm{~mm} \times 215 \mathrm{~mm}, 3 \mathrm{r}-310 \mathrm{~mm} \times 219 \mathrm{~mm}$ e $6 \mathrm{r}$ e $7 \mathrm{r}-225 \mathrm{~mm} \times 190 \mathrm{~mm}$.

7. Organização da página: dimensão da mancha escrita variável: $\mathrm{f}$. $1 \mathrm{r}-285 \mathrm{~mm} \mathrm{X} 185 \mathrm{~mm}$, f. $2 \mathrm{r}-320 \mathrm{~mm}$ x $200 \mathrm{~mm}$, f. $3 \mathrm{r}-290 \mathrm{~mm}$ x $175 \mathrm{~mm}$, e f. $6 \mathrm{r}$ e $7 \mathrm{r}-225 \mathrm{~mm}$ x $190 \mathrm{~mm}$; 1 coluna e número de linhas da mancha escrita variável: f. 1r - 13 linhas, f. 2 r, 3r, 4r e 9r - 30 linhas, f. $3 v-22$ linhas, f. 4v-28 linhas, f. 5r - 19 linhas, 5v - 18 linhas, 6r e 7r -23 linhas, 8v-6 linhas, $9 \mathrm{v}-21$ linhas e $11 \mathrm{r}-2$ linhas; pautado; numeração por foliação até o fólio $7 \mathrm{r}$ (sistema 1r, 2r, 3r, 4r, 5r, 6r e 7r); falta de numeração dos fólios $8 \mathrm{r}$ ao $11 \mathrm{r}$; e um único reclamo ("quem/ quem" nos fólios $3 \mathrm{r} / 3 \mathrm{v}$ ).

8. Particularidades: O documento não possui capa, mas há uma folha de papel almaço, que funciona como uma espécie de invólucro, que foi inserido pelos estagiários do CEDOC/UEFS, para proteger o documento da umidade e garantir a conservação do suporte material, o que evita o contato direto das mãos do pesquisador com o manuscrito. Além disso, na folha há as seguintes informações sobre o documento: "Tipologia: Testamento, Parte I Arthur Fróes da Motta e Parte II: Francelina Carneiro da Motta, Localidade: FSA, Período: 1951/51, No de folhas: 06, Francemberg", as quais foram escritas a lápis pelos estagiários do arquivo; há uma ficha de identificação inserida pelos estagiários do CEDOC/UEFS com as seguintes informações: no cabeçalho - "UNIVERSIDADE ESTADUAL DE FEIRA DE SANTANA, DEPARTAMENTO DE CIÊNCIAS HUMANAS E FILOSOFIA, CENTRO DE DOCUMENTAÇÃO E PESQUISA, LEVANTAMENTO GERAL DOS NÚCLEOS DOCUMENTAIS", ao lado do cabeçalho "CLASSIFICAÇÃO: E (estante), Cx (caixa) e Doc (documento)", na linha seguinte: "NÚCLEO: FÓRUM DESEMBARGADOR FILINTO BASTOS, SEÇÃO: JUDICIÁRIO, SÉRIE (com espaço para preenchimento manual), SUBSÉRIE (com espaço para preenchimento manual), TIPOLOGIA (com espaço para preenchimento manual), COMARCA: FSA, $\mathrm{N}^{\mathrm{o}}$ DE FOLHAS (com espaço para preenchimento manual), LOCALIDADE (com espaço para preenchimento manual), PERÍODO (com espaço para preenchimento manual), PARTES E/OU INTERESSADOS (com espaço para preenchimento manual) e OBS. (com espaço para preenchimento manual)"; fólios com timbres personalizados nos fólios 3r, 3v e 10r; manchas em locais variados de alguns fólios; dobra vertical no centro do último fólio; presença de dois grampos e uma perfuração na margem esquerda do primeiro fólio; perfuração única na margem esquerda de alguns fólios; 5 selos de impostos, dos quais 3 são no valor de 1 cruzeiro e 2 no de 0,10 cruzeiros, no fólio 3v; 2 selos de impostos no valor de 20 réis cada e 1 no de 10 réis, no fólio 8r; carimbo seco com a inscrição: "ALMACHIO ALVES BOAVENTURA | TABELIÃO | FEIRA-BAHIA", na margem superior centro-direita e direita, respectivamente, nos fólios 1r e 3r; carimbo molhado com a inscrição: "E. V. REIS | Fls. __ | Escrivão | Civel”, na margem centro-direita superior do fólio 2r; carimbo molhado com a inscrição: "Tabelionato Boaventura $\mid 1^{\circ}$ OFICIO | Almachio Alves Boaventura | TABELIÃO | FEIRA-BAHIA", na margem centro-inferior do fólio $3 \mathrm{v}$; carimbo molhado com a inscrição: "CONSTANTINO VICENTE DOS REIS | ESCRIVÃO DOS | FEITOS CIVEIS E CRIMINAES | $1^{\circ}$ OFICIO |

/19 _ FEIRA DE SANTANA - BAHIA", na margem centro-superior dos fólios 4r, 5r, 8r e 10r; carimbo molhado com a inscrição: "VISTO | Feira, $/ 19$

Chefe de Seção", na margem inferior direita do fólio 8r; brasão da República Federativa do Brasil, na margem superior esquerda do fólio $2 \mathrm{r}$. 
9. Conteúdo: Trata-se do testamento de Arthur Fróes da Móta ${ }^{109}$, redigido em 15 de abril de 1950, em sua própria residência, pelo Tabelião de Notas Almachio Alves Boaventura. O testador declarou que era filho legítimo do Coronel Agostinho Fróes da Móta e de Dona Maximiana de Almeida Móta, que era casado pelo regime de comunhão de bens com Dona Francelina Carneiro da Móta, de cujo casamento deixou o filho José Fróes da Móta, e que este testamento revogaria os dois anteriores, o primeiro em 27 de junho 1925 junto ao Tabelião de Notas João Carneiro Vital e o segundo em 21 de novembro de 1940 junto ao tabelião Almachio Alves Boaventura.

Além disso, Arthur Fróes da Móta instituiu a sua esposa como sua legítima herdeira e a parte da herança que caberia ao seu filho ficaria "gravada com inalienabilidade e impenhorabilidade vitalícias". O testador também declarou como seus testamenteiros a sua esposa e o Cônego Mário Pessôa da Silva e, por fim, declarou ser Católico Apostólico Romano e que cria em Deus sobre todas as coisas. Em seguida, foi feito o termo de apresentação do testamento e sua conclusão. Entretanto, nos fólios $6 \mathrm{r}$ e $7 \mathrm{r}$, há um formulário de pagamento das taxas judiciárias, pagas por Arthur Cezar da Silva Lago referente ao testamento, datado de 25 de agosto de 1917, de Pedro Rodrigo do Lago.

Em outras palavras, tratam-se de dois formulários de pagamento de taxas judiciárias, cujos teores foram o seguinte: "Exercicio de 1917 | Numero 878 | 128 | Imposto de Custas judiciarias $\mid$ Multa $1 \%$ ao mez $\mid$ Reis $2 \$ 000 \mid \ldots \$$ _ _ Reis $2 \$ 000 \mid$ A folhas 42 do livro da receita fica lançada a debito | do Collector, que pagou Arthur Cezar | da Silva Lago, | a quantia de dois mil reis | proveniente de custas pela | assignatura do Senhor Doutor Juiz de Direito | da Comarca Jacintho Ferreira da | Silva na abertura do testamento | com que falleceu Pedro Rodrigo do | Lago. | Collectoria da Feira de Sant'Anna do Estado | da Bahia, em 25 de Agosto de 1917 | O Collector, | O Escrivão, | José Alves Franco | D.S Daltro" (f. 6r, 1.1-23) e "Exercicio de 1917 | Numero 879 | 129 | Imposto de Taxas diversas | Multa 1\% ao mez | Reis $10 \$ 000 \mid$ __ $\quad$ Reis $10 \$ 000 \mid$ A folhas 43 do livro da receita fica lançada a debito | do Collector, que pagou Arthur Cezar $\mid$ da Silva Lago, | a quantia de dez mil reis | proveniente do imposto do | Registro de testamento com que fal- | leceu Pedro Rodrigo do | Lago. Collectoria da Feira de Sant'Anna do Estado | da Bahia, em 25 de Agosto de 1917 | O Collector, | O Escrivão, | José Alves Franco | D.S Daltro" (f. 7r, 1. 1-23), os quais se referem, portanto, a outro testamento e não ao de Arthur Fróes da Móta, o que indica um erro grave de quem os anexou aos autos. Após isso, há um termo de registro do testamento de Arthur Fróes da Móta, seguido do termo de compromisso da testamenteira, datado de 25 de outubro de 1951 e assinado por Dona Francelina Carneiro da Móta, seguidos do recebimento dos autos e suas respectivas conclusões.

10. Escreventes ${ }^{110}$ : Almachio Alves Boaventura, Constantino Vicente dos Reis, Antonio Mattos, Candido Colombo Cerqueira, Deoclecio da Silva Daltro, Samuel Santos, Aristophanes de Almeida Gomes, Alberto Alves Boaventura e Alice de Oliveira Mattos.

Fonte: Elaborado pela pesquisadora

Quadro 30 - Ficha codicológica do vigésimo sexto documento INVENTÁRIO DE ARTHUR FRÓES DA MOTTA

1. Cota: Feira de Santana - Bahia; Centro de Documentação e Pesquisa/ UEFS; Seção

\footnotetext{
109 Neste documento já se encontra a variante <Móta $>$ em oposição a $<$ Motta $>$, esta constante em outros documentos.

110 Duas rubricas estão ilegíveis no documento, o que impossibilitou identificar os nomes dos respectivos scriptores.
} 


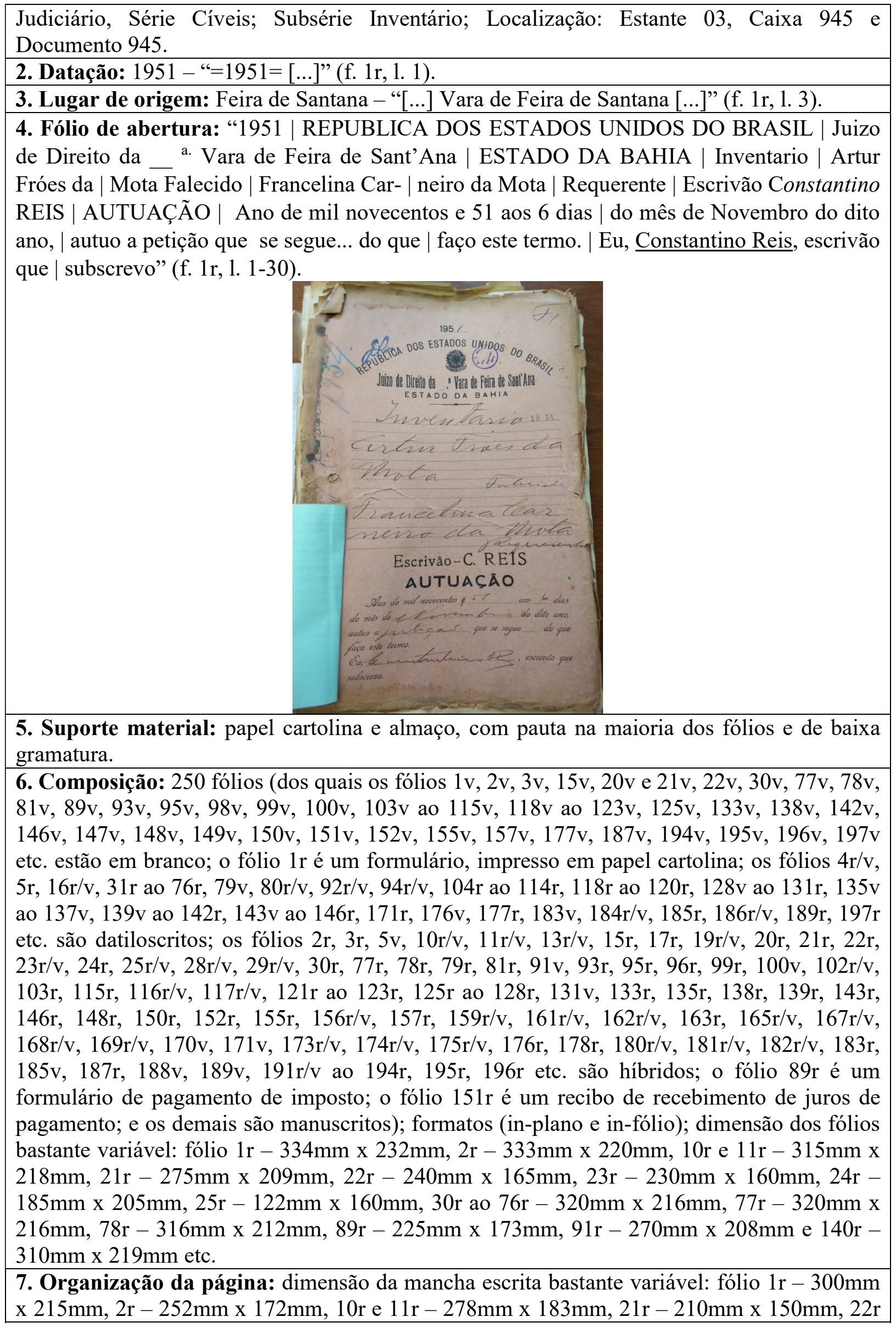


$-170 \mathrm{~mm} \times 140 \mathrm{~mm}, 23 \mathrm{r}-195 \mathrm{~mm} \times 142 \mathrm{~mm}, 24 \mathrm{r}-148 \mathrm{~mm} \times 185 \mathrm{~mm}, 25 \mathrm{r}-100 \mathrm{~mm} \times$ $145 \mathrm{~mm}, 30 \mathrm{r}$ ao $76 \mathrm{r}-285 \mathrm{~mm} \times 173 \mathrm{~mm}, 77 \mathrm{r}-80 \mathrm{~mm} \times 158 \mathrm{~mm}, 78 \mathrm{r}-300 \mathrm{~mm} \times 188 \mathrm{~mm}, 89 \mathrm{r}-$ $212 \mathrm{~mm} \times 170 \mathrm{~mm}, 91 \mathrm{r}-248 \mathrm{~mm} \times 186 \mathrm{~mm}$ e $140 \mathrm{r}-290 \mathrm{~mm} \times 175 \mathrm{~mm}$ etc.; 1 coluna e número de linhas da mancha escrita variável: f. 4r, $5 \mathrm{r}, 6 \mathrm{r}$ ao $8 \mathrm{v}-30$ linhas, f. $5 \mathrm{v}-9$ linhas, f. $9 \mathrm{r}-24$ linhas, f. 9v-21 linhas, f. 12r - 25 linhas, 14r - 8 linhas; f. 26v - 20 linhas etc., pautado em sua grande maioria; numeração por foliação (sistema 1r, 2r, 3r, 4r etc.); e reclamos ("do-/ dona" nos fólios 4r/4v, "n $8 / n^{\circ} 8$ " nos 4v/5r, "Mota/ Mota" nos 6v/7r, "cartorio/ cartorio" nos 7v/8r, "quinze/ quinze" nos 16r/16v, "ladrilhos/ ladrilhos" nos $16 \mathrm{v} / 17 \mathrm{r}$ etc.).

8. Particularidades: $\mathrm{O}$ documento não possui capa, mas há uma folha de papel almaço, que funciona como uma espécie de invólucro, que foi inserido pelos estagiários do CEDOC/UEFS, para proteger o documento da umidade e garantir a conservação do suporte material, o que evita o contato direto das mãos do pesquisador com o manuscrito. Além disso, na folha há as seguintes informações sobre o documento: "SÉRIE: PROCESSO CÍVEL, SUBSÉRIE: INVENTÁRIO, INVENTARIADO: ARTHUR FRÓES DA MOTTA, INVENTARIANTE: FRANCELINA CARNEIRO DA MOTTA, PERÍODO: 1951-1959, LOCALIDADE: FEIRA DE SANTANA, PÁGINAS: 236, OBSERVAÇÃO: INVENTÁRIO DA FAMÍLIA FRÓES DA MOTTA", as quais foram escritas a lápis pelos estagiários do arquivo; ficha de identificação inserida pelos estagiários do CEDOC/UEFS com as seguintes informações: no cabeçalho - "UNIVERSIDADE ESTADUAL DE FEIRA DE SANTANA, DEPARTAMENTO DE CIÊNCIAS HUMANAS E FILOSOFIA, CENTRO DE DOCUMENTAÇÃO E PESQUISA, LEVANTAMENTO GERAL DOS NÚCLEOS DOCUMENTAIS", ao lado do cabeçalho "CLASSIFICAÇÃO: E (estante), Cx (caixa) e Doc (documento)", na linha seguinte: "NÚCLEO: FÓRUM DESEMBARGADOR FILINTO BASTOS, SEÇÃO: JUDICIÁRIO, SÉRIE (com espaço para preenchimento manual), SUBSÉRIE (com espaço para preenchimento manual), TIPOLOGIA (com espaço para preenchimento manual), COMARCA: FSA, $\mathrm{N}^{\mathrm{o}}$ DE FOLHAS (com espaço para preenchimento manual), LOCALIDADE (com espaço para preenchimento manual), PERÍODO (com espaço para preenchimento manual), PARTES E/OU INTERESSADOS (com espaço para preenchimento manual) e OBS. (com espaço para preenchimento manual)"; perfuração única na margem lateral esquerda de todos os fólios; vários fólios com timbres personalizados; manchas em vários lugares do documento; riscos longos em vários fólios; não constam os fólios $204 \mathrm{r}$ ao $213 \mathrm{v}$, o que indica que, provavelmente, estão desaparecidos; datação inserida com caneta de tinta azul, na margem lateral esquerda do fólio 1r; marcas de umidade nas margens laterais dos fólios $1 \mathrm{r}$ ao $5 \mathrm{r}$, indicando que houve o derramamento de algum líquido sobre o documento; presença de muitos carimbos, a saber: carimbo molhado com a inscrição: "E. V. REIS | Fls. __ | Escrivão | Civel”, na margem centro-direita superior do fólio 1r; carimbo molhado com a inscrição: "Tabelionato Boaventura $\mid 1^{\circ}$ OFICIO | Almachio Alves Boaventura | TABELIÃO | FEIRA-BAHIA" em margens variadas nos fólios $3 \mathrm{r}, 4 \mathrm{r}$ ao $9 \mathrm{r}, 5 \mathrm{v}, 12 \mathrm{r}, 14 \mathrm{r}$ ao $18 \mathrm{r}, 26 \mathrm{r}, 27 \mathrm{r}, 99 \mathrm{v}, 100 \mathrm{r}$ etc.; carimbo molhado com a inscrição: "Tabelionato Boaventura $\mid 1^{\circ}$ OFICIO | Almachio Alves Boaventura | TABELIÃO | Walter Livramento Silva | TABELIÃO SUBSTITUTO | FEIRA-BAHIA" nos fólios 21r, 22r, 23v, 24r, 25v; carimbo molhado com a inscrição: "-RECO- TABELIONATO BOAVENTURA" na margem inferior direita do fólio 25r; carimbo molhado com a inscrição: "CARTORIO DO CIVEL E CRIME | JOSÉ FERNANDES LUZ | (ESCRIVÃO) | ITACARÉ | BAHIA" na margem central do fólio 88v; carimbo molhado com a inscrição: "CONSTANTINO VICENTE DOS REIS | ESCRIVÃO DOS | FEITOS CIVEIS E CRIMINAES | $1^{\circ}$ OFICIO |

/19 _ FEIRA DE SANTANA - BAHIA", na margem centro-superior dos fólios 101 r, 124r, 128r ao 132r, 134r, 149r, 153r, 154r, 158r, 160r, 164r, 165r, 166r, 170r, 172r etc.; vários selos de impostos ao longo do documento: 2 ( 1 de 1,00 e outro de 0,20 cruzeiros) no fólio 2r; 8 ( 2 de 1,50, 5 de 1,00 e 1 de 2,00 cuzeiros) no fólio $3 r ; 5$ ( 1 de $0,10,1$ de 0,50, 1 de 
$5,00,1$ de 4,00 e 1 de 52,00 cruzeiros) no fólio 5v; 2 ( 1 de 1,00 e 1 de 0,20 cruzeiros) no fólio 20r; 6 ( 3 de 0,50, 2 de 1,50 e 1 de 5,00) no fólio 21 r; 7 ( 2 de 1,00, 2 de 1,50, 2 de 0,50 e 1 de 5,00 cruzeiros) no fólio 22r, 2 ( 1 de 1,50 e 1 de 2,00 cruzeiros) no fólio $23 \mathrm{r} ; 5$ ( 1 de 1,50, 2 de 0,50 e 2 de 1,00 cruzeiros) no fólio 23v; 7 ( 2 de 1,50, 3 de 0,50 e 2 de 1,00 cruzeiros) no fólio 24r; 2 ( 1 de 1,50 e 1 de 0,50 cruzeiros) no fólio $25 \mathrm{r} ; 5$ ( 1 de 1,50, 2 de 0,50 e 2 de 1,00 cruzeiros) no fólio $25 \mathrm{v}$ etc.; grifos com caneta de cor vermelha no fólio $4 \mathrm{v}$; rubrica do advogado Fausto Penalva nos versos dos fólios $31 \mathrm{v}$ ao $76 \mathrm{v}$; erro de numeração a partir do fólio 151r; suporte material bastante danificado, nos fólios $140 \mathrm{r}$ ao $145 \mathrm{v}$, o que impossibilitou a leitura de vários trechos do documento, que desapareceram junto com os pedaços de papel que se soltaram e desapareceram.

9. Conteúdo: Trata-se do inventário de Arthur Fróes da Mota, cuja testamenteira e inventariante foi Dona Francelina Carneiro da Mota, viúva do inventariado e de cujo casamento nasceu José Fróes da Mota. Neste documento, é-nos relatado que antes da partilha dos bens avaliados em trezentos e quarenta e quatro mil e quatrocentos cruzeiros, o filho do casal entrou na Justiça solicitando a anulação do testamento do pai, redigido pelo Tabelião de Notas Almachio Alves Boaventura.

Para a anulação, José Fróes da Mota alegou que a feitura do testamento não seguiu as formalidades legais no que concernia à leitura pública do documento para o testador e para as cinco testemunhas, o que, segundo a argumentação do advogado, configurava-se motivo suficiente para a sua nulidade. Contudo, a inventariante contrariou os argumentos do filho dizendo que tudo não passava do interesse daquele em dispor da sua "[...] legítima para cobrir os riscos de negocios esconsos e premeditadamente realisados com êsse proposito malsão" (f. 104r, 1. 1-3), ou seja, segundo a inventariante, o seu filho agia de forma descautelosa, o que já era sabido pelo inventariado e por isso este deixou claro que a legítima do filho ficaria "[...] gravada com as clausulas de inalienabilidade vitalicia e impenhorabilidade tambem vitalicia, extensiva esta aos rendimentos [...]" (f. 4v, 1. 9-11).

Após as argumentações empreendidas pelos respectivos advogados do filho e da viúva do inventariado, o Juiz expediu uma sentença dando ganho de causa à inventariante e autorizou, em 31 de dezembro de 1953, o prosseguimento do inventário, no qual os bens foram avaliados por Paulino Chaves da Costa e, em seguida, divididos para os dois herdeiros e para Francisco Nunes Amorim, que foi credor do inventariado. Entretanto, vale a entrelinha de que dos fólios 239r até o final do documento foram inseridos fólios que tratavam da cobrança de uma dívida da Empresa Afonso Cavalcante junto à Prefeitura Municipal de Feira de Santana-BA, a qual não tinha relação com o inventário descrito, o que nos leva a afirmar que, provavelmente, tratam-se de fólios referentes a outro processo, os quais foram indevidamente anexados.

10. Escreventes: Constantino Vicente dos Reis, Candido Colombo Cerqueira, Edelvito Campêllo d'Araujo, Francelina Carneiro da Motta, Walter Livramento Silva, Almachio Alves Boaventura, Osvaldo Requião, Heraldo Silva, Paulino Chaves da Costa, Adherbal Saback Miranda, Waldomiro Cerqueira da Silva, Manoel Oliveira Teixeira, Floriano Mota, José Fróes da Motta, Silio Soledade, Augusto T. Carneiro de Albuquerque, David Santos Souza, José Fernandes Luz, Alympo Carvalho, Fausto Penalva, Cesar Dias Veiga, Antonio Costa Bitencourt, Mario Martins Moreira, Antonio Manuel de Araujo, Alice de Oliveira Matos, Oscar Ribeiro, S. Dantas Carneiro, Manoel Costa Ferreira, Afonso Cavalcante, Aristophanes de Almeida Gomes, Manoel Barros Reis, João de Gomes, José Gonçalves, Cynobelires Meira da Silveira, Arnold Ferreira da Silva, Helena de Lima Teixeira, Bernadeth Oliveira Lopes, Edmilson Lopes dos Reis, Israel Almeida Santos e Antonio de Oliveira Mattos.

Fonte: Elaborado pela pesquisadora 
Quadro 31 - Ficha codicológica do vigésimo sétimo documento

\section{AÇÃO DE CONSIGNAÇÃO EM PAGAMENTO SOLICITADA POR MARIA LUZIA RAMOS BASTOS}

1. Cota: Feira de Santana - Bahia; Centro de Documentação e Pesquisa/ UEFS; Seção Judiciário, Série Cíveis; Subsérie Ações; Tipologia Consignação em Pagamento; Localização: Estante 14, Caixa 378 e Documento 8783.

2. Datação: 1969 - 1970 “[...]1969 [...] Julgado 1970 [...]” (f. 1r, 1. 1).

3. Lugar de origem: Feira de Santana - "[...] FEIRA DE SANTANA [...]” (f. 1r, 1. 7).

4. Fólio de abertura: "1969 | Folha $1 \mid$ Julgado 1970| REPUBLICA FEDERATIVA DO BRASIL | PODER JUDICIÁRIO | Forum Desembargador Filinto Bastos | Cartório do $2^{\circ}$ Oficio dos Feitos Cíveis | FEIRA DE SANTANA - BAHIA | A/ Consignação em Pagamento 02/69 | Natureza do Feito Número de Registro | 10/04/1969 | Autora Maria Luzia Ramos Bastos | Réu Eduardo Fróes da Mota | Renato Sá [...] | AUTUAÇÃO | Ao(s) dez dia(s) do mês de Abril de 1969 | em êste Cartório, autuo a inicial de folhas 2 e documento(s) de folhas 3 a folhas 5 e, | para constar, lavro êste têrmo. Eu, Elia Souza Bacellar | Sub-Escrivã(o), Subscrevo. [...]" (f. 1r, 1. 1-30).

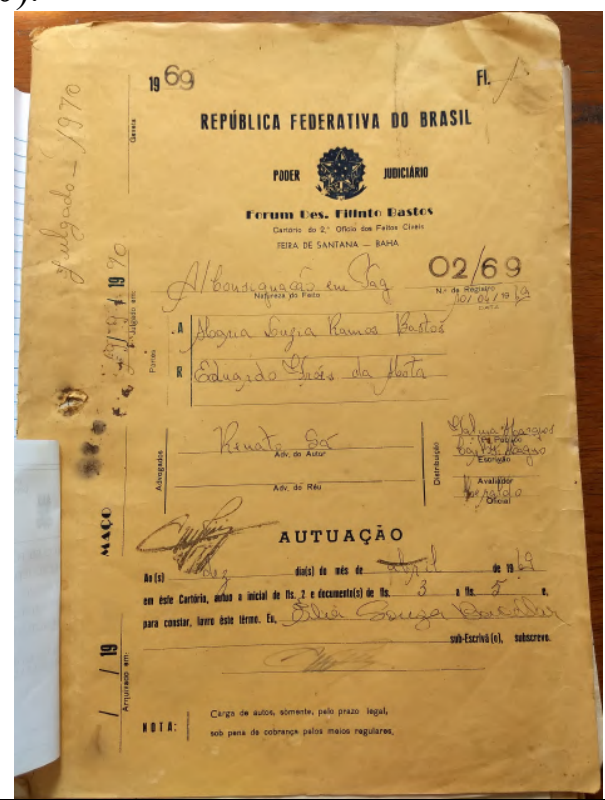

5. Suporte material: papel cartolina e almaço, com pauta na maioria dos fólios e de baixa gramatura.

6. Composição: 64 fólios (dos quais os fólios 1v, 3v, 4v, 5v, 6v, 7r, 7v, 8v, 9v, 10v, 11v, 12r, $12 \mathrm{v}, 15 \mathrm{v}, 17 \mathrm{v}, 19 \mathrm{v}, 21 \mathrm{v}, 23 \mathrm{v}, 30 \mathrm{v}, 32 \mathrm{v}, 34 \mathrm{v}, 36 \mathrm{v}, 37 \mathrm{v}, 38 \mathrm{v}, 40 \mathrm{v}, 42 \mathrm{v}, 44 \mathrm{v}, 46 \mathrm{v}, 48 \mathrm{v}, 51 \mathrm{v}, 53 \mathrm{v}$, $54 \mathrm{v}, 56 \mathrm{v}, 57 \mathrm{v}, 59 \mathrm{v}, 64 \mathrm{r}$ e $64 \mathrm{v}$ estão em branco; os fólios $1 \mathrm{r}, 1 \mathrm{v}, 64 \mathrm{r}$ e $64 \mathrm{v}$ compõem uma "pasta modelo 17", inserida como "capa, segunda capa, terceira capa e quarta capa" do processo; os fólios 14v, 27r e 61r são datiloscritos; os fólios 2r, 2v, 3r, 13r, 15r, 16r, 19r, 25r, 33r e 49r são híbridos; os 26r e 61r são manuscritos; e os 4r, 5r, 6r, 8r, 9r, 10r, 11r, 14r, 17r, 18r, 21r, 22r, 23r, 24r, 25r, 18r, 29r, 30r, 31r, 32r, 35r, 36r, 37r, 38r, 39r, 40r, 41r, 42r, 43r, 44r, 45r, 47r, 48r, 50r, 51r, 52r, 53r, 54r, 56r, 59r, 60r e 63r são formulários preenchidos, em sua grande maioria, datiloscritamente); formatos (in-plano e in-fólio); dimensão dos fólios variável: fólio $1 \mathrm{r}-330 \mathrm{~mm} \times 239 \mathrm{~mm}, 2 \mathrm{r}-322 \mathrm{~mm} \times 219 \mathrm{~mm}, 4 \mathrm{r}-115 \mathrm{~mm} \times 180 \mathrm{~mm}, 5 \mathrm{r}-$ $315 \mathrm{~mm} \times 210 \mathrm{~mm}, 6 \mathrm{r}-101 \mathrm{~mm} \times 139 \mathrm{~mm}, 7 \mathrm{r}-310 \mathrm{~mm} \times 218 \mathrm{~mm}, 8 \mathrm{r}-100 \mathrm{~mm} \times 180 \mathrm{~mm}, 10 \mathrm{r}$ $-335 \mathrm{~mm} \times 222 \mathrm{~mm}$ etc.

7. Organização da página: dimensão da mancha escrita variável: f. $1 \mathrm{r}-287 \mathrm{~mm} \times 225 \mathrm{~mm}$, $2 \mathrm{r}-288 \mathrm{~mm} \times 210 \mathrm{~mm}, 4 \mathrm{r}-98 \mathrm{~mm} \times 175 \mathrm{~mm}, 6 \mathrm{r}-90 \mathrm{~mm} \times 127 \mathrm{~mm}, 7 \mathrm{r}-268 \mathrm{~mm} \times 170 \mathrm{~mm}, 8 \mathrm{r}$ 
$-85 \mathrm{~mm} \times 170 \mathrm{~mm}, 10 \mathrm{r}-180 \mathrm{~mm} \times 180 \mathrm{~mm}$ etc.; 1 coluna e número de linhas da mancha escrita variável: f. $1 \mathrm{r}, 2 \mathrm{r}, 2 \mathrm{v}$ e $3 \mathrm{r}-30$ linhas, f. $14 \mathrm{v}-43$ linhas, f. $15 \mathrm{r}-17$ linhas, f. $16 \mathrm{r}-13$ linhas etc.; numeração por foliação na maioria dos fólios (sistema 1r, 2r, 3r, 4r etc.); um único reclamo ("efetu-/ efetuou" nos fólios $2 \mathrm{r} / 2 \mathrm{v}$ ).

8. Particularidades: O documento não possui capa, mas há uma folha de papel almaço, que funciona como uma espécie de invólucro, que foi inserido pelos estagiários do CEDOC/UEFS, para proteger o documento da umidade e garantir a conservação do suporte material, o que evita o contato direto das mãos do pesquisador com o manuscrito. Além disso, na folha há as seguintes informações sobre o documento: "Subsérie: Ações, Tipologia: Consignação em Pagamento, Parte I - Eduardo Fróes da Motta e Parte II: Maria Luzia Ramos Bastos, Localidade: FSA, Período: $1969-1969$, $\mathrm{N}^{\circ}$ de folhas: $29^{111}$ ", as quais foram escritas a lápis pelos estagiários do arquivo; há uma ficha de identificação inserida pelos estagiários do CEDOC/UEFS com as seguintes informações: no cabeçalho - "UNIVERSIDADE ESTADUAL DE FEIRA DE SANTANA, DEPARTAMENTO DE CIÊNCIAS HUMANAS E FILOSOFIA, CENTRO DE DOCUMENTAÇÃO E PESQUISA, LEVANTAMENTO GERAL DOS NÚCLEOS DOCUMENTAIS", ao lado do cabeçalho "CLASSIFICAÇÃO: E (estante), Cx (caixa) e Doc (documento)", na linha seguinte: "NÚCLEO: FÓRUM DESEMBARGADOR FILINTO BASTOS, SEÇÃO: JUDICIÁRIO, SÉRIE (com espaço para preenchimento manual), SUBSÉRIE (com espaço para preenchimento manual), TIPOLOGIA (com espaço para preenchimento manual), COMARCA: FSA, N ${ }^{\circ}$ DE FOLHAS (com espaço para preenchimento manual), LOCALIDADE (com espaço para preenchimento manual), PERÍODO (com espaço para preenchimento manual), PARTES E/OU INTERESSADOS (com espaço para preenchimento manual) e OBS. (com espaço para preenchimento manual)"; perfuração única na margem esquerda de alguns fólios; marcas de grampo na margem esquerda de vários fólios; fólios com timbres personalizados; riscaduras em alguns fólios; marcas, em alguns fólios, de exposição ao sol; marcas de oxidação, em alguns fólios, causadas pelos grampos presos ao documento; marcas de tinta, em alguns fólios; ataques de cupim no último fólio; selos de impostos no documento, a saber: 4 selos de impostos de 1 cruzeiro novo e 5 de 500 cruzeiros novos, no fólio $2 \mathrm{v} ; 1$ de 1 cruzeiro novo e 2 de 0,50 centavos, no fólio $4 \mathrm{r} ; 1$ de 10 cruzeiros novos e 1 de 2 cruzeiros novos, no fólio $5 \mathrm{r}$; 1 de 3 cruzeiros novos, no fólio 6r; 4 de 1 cruzeiro novo, 4 de 10 centavos, 1 de 5 mil, 1 de 500 e 2 de 200 cruzeiros novos, no fólio 26v etc.; palavras escritas na cor vermelha, nos fólios $2 \mathrm{r}$ e $2 \mathrm{v}$; riscadura, indicada em vermelho, no fólio $3 \mathrm{r}$; vários carimbos molhados ao longo do documento, a saber: "DISTRIBUIÇÃO $\mid$ Ao Juiz da _ Vara _ $\mid \mathrm{O} \_$Promotor Público o Oficial _ Página _ | Número _ Livro _. Em _ _ _ _ _ _ | Distribuidor/a", na vertical da margem centro-direita do fólio 2r; "ANTONIO MANOEL DE ARAÚJO | TABELIÃO | CARTÓRIO DO $1^{\circ}$ OFÍCIO | Av. Senhor dos Passos, [1565] | Feira de Santana - Bahia" e "Reconheço a firma _ I _ | Feira _ _ _ 19_ $\mid$ Em testemunho __ da verdade $\mid \ldots$ _ I TABELIÃO", ambos na margem centro-inferior do fólio 3r; carimbo molhado com a inscrição: "BANEB | 30 jun 69 | CAIXA", na margem centro-inferior do fólio 21r, na margem superior direita do fólio 60r, na margem centro-inferior dos fólios $25 \mathrm{r}, 27 \mathrm{r}$ e $54 \mathrm{r}$, na margem inferior direita dos fólios 43r, 45r, 49r, 51r, 53r, 56r, 58r e 59r e 2 desses carimbos na margem inferior direita e esquerda, respectivamente, do fólio 40r; carimbo molhado com a inscrição: "RECEBIDO | Em __ _ _ _,", na vertical da margem superior esquerda dos fólios 22r, 28v, 46r; 5 carimbos molhados com a inscrição: "CARTÓRIO DO $2^{\circ}$ OFÍCIO DOS FEITOS

${ }^{111}$ É importante ressaltar que há uma divergência neste item, pois nesta folha os estagiários do CEDOC/UEFS informaram que o documento possuía 29 fólios, mas na ficha de identificação, inserida logo depois desta, consta que há 39 fólios. Entretanto, nenhuma das duas informações está correta, pois, ao todo, o documento possui 64 fólios rectos e versos, se contabilizados todos os recibos de pagamentos anexados. 
CÍVEIS | CARLOS MAGNO CARNEIRO DE OLIVEIRA | Feira - Bahia", na margem central e inferior do fólio 28v; carimbos molhados com lacunas para preenchimento manual, tais como "certidões, termo de juntada, termo de conclusão, data, remessa para conta, termo de recebimento e termo de publicação", nos fólios 13r, 16v, 21v, 23r, 23v, 25v, 27v, 28r, 29r, $29 \mathrm{v}, 30 \mathrm{r}, 30 \mathrm{v}, 40 \mathrm{v}, 41 \mathrm{v}, 43 \mathrm{v}, 45 \mathrm{v}, 47 \mathrm{r}, 47 \mathrm{v}, 51 \mathrm{v}, 53 \mathrm{v}, 54 \mathrm{v}, 56 \mathrm{v}, 57 \mathrm{r}, 57 \mathrm{v}, 59 \mathrm{v}, 61 \mathrm{v}, 62 \mathrm{r}, 62 \mathrm{v}$ e $63 \mathrm{v}$.

9. Conteúdo: Trata-se de uma ação de consignação em pagamento, solicitada por Dona Maria Luzia Ramos Bastos, viúva de José Monteiro Bastos, contra o Dr. Eduardo Fróes da Motta, que se recusou a receber os pagamentos dos aluguéis dos meses de janeiro, fevereiro e março de 1969 do prédio em que a autora era locatária desde 1953. Em vista disso, a autora recorreu à Justiça para que o depósito do valor fosse feito após uma audiência entre as partes ou então, caso o réu não comparecesse, via depósito em conta bancária do Dr. Eduardo Fróes da Motta.

Após a abertura do processo, em 10 de abril de 1969, a autora solicitou que os meses subsequentes aos não recebidos fossem depositados no "Banco do Estado da Bahia", onde o réu tinha conta aberta. Ciente disso, Dona Maria Luzia Ramos Bastos efetuou o depósito dos aluguéis referentes aos meses de janeiro a dezembro de 1969 e de janeiro a junho do ano seguinte, feitos de acordo com os reajustes previstos em lei.

Encerrada em 8 de outubro de 1970, a ação teve como solução o saque dos referidos depósitos por parte do Dr. Eduardo Fróes da Motta, através do seu advogado, que deixou claro que havia uma ação de despejo por falta de pagamento contra a família de José Monteiro Bastos, mas, em vista dos pagamentos feitos naquele momento, davam-se por encerrados o processo e a referida ação.

10. Escreventes ${ }^{112}$ : Elia Souza Bacellar, Renato Ribeiro de Sá Bitencourt Câmara, Antonieta Borges de Oliveira, A. A. Lopes, Carlos Magno Carneiro de Oliveira, Heraldo Silva, Alice de Oliveira Mattos e Edmilson Jatahy Fonseca.

Fonte: Elaborado pela pesquisadora

Em geral, os vinte e sete documentos descritos estão em razoável estado de conservação, haja vista a maioria possuir o suporte físico muito bem preservado enquanto alguns poucos estão bastante deteriorados. Do ponto de vista da sua composição, as seguintes características materiais se sobressaem: o tipo de papel da maioria dos documentos é almaço e, em alguns casos, de cartolina ou papel bíblia; com gramatura baixa, presença de inúmeros selos, carimbos, timbres e marcas d'água que indicam a proveniência dos papéis que compõem o documento; marcas de costura em muitos documentos, dentre os quais alguns fólios ainda se apresentam presos à costura com barbante de cor vermelha ou branco; muitos formulários de pagamento de impostos, preenchidos manual ou datiloscritamente e que também constituem os documentos, já que foram contabilizados como peças processuais; além de fólios totalmente manuscritos, datiloscritos ou híbridos, bem como cartões postais e recortes de jornais ou páginas inteiras anexadas à maioria dos processos.

Sobre o estado de conservação do suporte material, há documentos que apresentam alguns danos, tais como marcas de umidade, ataques de broca e de cupim, dobras, rasgaduras

112 Quatro rubricas estão ilegíveis no documento, o que impossibilitou identificar os nomes dos respectivos scriptores. 
e borrões, os quais foram mencionados nas fichas codicológicas, a partir das quais também foi possível elencar várias assinaturas pessoais, os nomes dos escreventes e os reclamos, dos quais estes últimos poderão, por exemplo, ser minuciosamente classificados em trabalhos futuros, já que, como observado nas fichas codicológicas, a sua quantidade é bastante expressiva nos documentos, o que tornaria, neste momento, a sua classificação exaustiva.

Outro aspecto relevante a ser mencionado é a necessidade de correção, em alguns processos, do número de fólios e dos nomes das partes envolvidas, citadas nas suas respectivas fichas de identificação inseridas pelos estagiários do CEDOC/UEFS, as quais são um guia para o pesquisador e, portanto, não devem apresentar quaisquer erros. Assim, após devida notificação à administração do CEDOC/UEFS, esperamos que as fichas de identificação sejam devidamente corrigidas, o que contribuirá para que o arquivo disponibilize informações atualizadas, o que garantirá que outros pesquisadores tenham acesso a dados fidedignos de cada processo.

Por fim, é possível ratificar o que falamos na segunda seção acerca das relações dos sujeitos que aparecem nos documentos, já que a sua maioria consta no corpus selecionado para esta tese, definido como os testamentos e o primeiro volume do inventário dos patriarcas da família Fróes da Motta. A escolha por esses três documentos, dentre os vinte e sete que compõem a documentação descrita, deu-se pelo fato de buscarmos não somente preservar as informações dos referidos documentos para a posteridade, através do trabalho filológico, mas também por nos permitirem traçar as relações entre os envolvidos, realizar a leitura dos textos enquanto o estado de conservação dos suportes materiais o permite e por conta do seu valor cultural, social, histórico e linguístico para a cidade de Feira de Santana-BA e para o estudo da língua, especificamente o léxico de língua portuguesa atestado nos documentos.

Em outras palavras, na segunda seção desta tese vimos informações sobre a vida política, social e econômica do ex-Intendente Agostinho Fróes da Motta, as quais foram, em grande parte, confirmadas na descrição dos conteúdos dos documentos expostos nesta seção. Mais do que isso, o levantamento das informações dos documentos nos permitiu conhecer os processos que advieram da lavração do inventário do patriarca dos Fróes da Motta, e isso possibilita que vejamos aquele indivíduo como um todo: como político, esposo, pai, amigo, compadre, filantropo, comerciante etc.

Assim, após a produção do inventário de Agostinho Fróes da Motta, pudemos visualizar, a partir dos documentos listados nesta seção, quais foram os sujeitos que compuseram o círculo familiar, de amizades e de negócios da família Fróes da Motta, ou seja, as esposas, os filhos, os genros, noras, amigos, compadres, políticos e "sujeitos" da lei (juízes, 
advogados, tabeliães, escrivães, oficiais de Justiça, desembargadores etc.) que participaram de forma direta ou indireta não somente da produção dos documentos que elegemos como corpus, mas daqueles que os "circunvizinharam": os produzidos antes e depois dos dois testamentos e do inventário dos patriarcas.

Assim, sobre os indivíduos que contribuíram para a produção do corpus, recolhemos informações dos documentos descritos nesta seção e em outros como, por exemplo, dissertações, periódicos locais e documentos disponíveis no APMFS-BA, a fim de traçarmos os seus relacionamentos, os quais são descritos na quarta seção. Sobre os "sujeitos" da lei, que foram, de fato, quem escreveram o corpus sobre o qual nos debruçamos, realizamos uma análise do seu vocabulário, exposta na quinta seção, para a qual foi necessário, primeiro, identificar as suas relações familiares, econômicas e sociais, bem como, quando possível, a formação educacional daqueles, a fim de compreendermos os aspectos socioculturais que influenciaram as suas escolhas lexicais e, para isso, recorremos, mais uma vez, a documentos disponíveis em arquivos públicos, que nos ajudaram nessa empreitada.

Para finalizar esta seção, reafirmamos que as relações estabelecidas entre aquelas pessoas ultrapassavam as esferas dos negócios e da política e alcançavam os seios familiares e afetivos das partes envolvidas no corpus, como apresentamos na quarta seção.

\subsection{CARACTERIZAÇÃO DIPLOMÁTICA DOS DOCUMENTOS}

Dos vinte e sete documentos listados, os que possuem, se somados, a maior quantidade de fólios são os testamentos e os inventários dos patriarcas da Família Fróes da Motta, o que se justifica pela quantidade de informações descritas nos textos, as quais nos deram evidências do quão rica, influente, conflituosa e importante foi a família por eles constituída.

Entretanto, pelo fato de testamentos, inventários e demais processos, citados no terceiro quadro, tratarem-se de "espécies e tipologias documentais" (BELLOTTO, 2008), decidimos apresentar, nesta subseção, a descrição diplomática dos documentos analisados, haja vista a mescla no uso dos termos testamento e inventário ao longo desta tese.

De modo geral, os documentos diplomáticos são caracterizados, sobretudo, por relatarem um acontecimento social, escrito em material mole como, por exemplo, papiro, pergaminho, papel, cera etc. (ANDRADE, 2010) e por serem de “[...] natureza jurídica que refletem no ato escrito as relações políticas, legais, sociais e administrativas entre o Estado e os cidadãos [...]" (BELLOTTO, 2008, p. 12), definição que se adequa aos manuscritos aqui 
trabalhados, haja vista se tratarem de documentos jurídicos, que se inserem no campo da Diplomática, a qual engloba o estudo de documentos que comprovam um fato ou acontecimento (CAMBRAIA, 2005; SPINA, 1977).

Para além dessa acepção, a Diplomática tem as suas raízes no passado quando a necessidade de "[...] orientar a avaliação da autenticidade de documentos legais, tanto através de sua escrita quanto de sua forma e de seu conteúdo [...]" (CAMBRAIA, 2005, p. 25) se fez pertinente ainda nos séculos XVI e XVII, período em que a falsificação e as dúvidas acerca da autenticidade de documentos medievais surgiu consideravelmente, o que fez com que os documentos passassem a ser submetidos a determinado tipo de crítica quanto à sua veracidade ou não, o que indica que já naquele momento existiam documentos falsos, os chamados "diplomas medievais", que eram forjados para que os senhores de terras ou o clero conseguissem desapropriar pequenos agricultores e tomar as suas terras (BELLOTTO, 2006; 2008).

Dessa problemática nasceu a Diplomática, que passou a ser concebida como uma das "ciências documentárias" que estuda a estrutura formal dos documentos escritos, que são de ordem administrativa ou jurídica. Logo, trata-se de uma ciência indispensável para a formação de pesquisadores da Arquivística, da Filologia, da Paleografia e da Codicologia, justamente porque todas essas áreas precisam dos conhecimentos disponibilizados por aquela para a realização de análises do documento (BELLOTTO, 2006; 2008).

No âmbito da Diplomática, que se serviu dos conhecimentos dos filólogos, historiadores e teólogos para a realização de uma avaliação crítica dos diplomas, a técnica de avaliação dos documentos foi sendo aperfeiçoada e, devido a isso, a Diplomática ganhou espaço no direito eclesiástico, passando a figurar como a ciência técnica que atesta(va) a veracidade dos documentos de origem governamental ou notarial (BELLOTTO, 2006).

Ao definir a estrutura formal do documento como o seu objeto de estudo (BELLOTTO, 2002), a Diplomática também teve que estabelecer quais elementos fariam parte da composição dos documentos diplomáticos e, para isso, caracterizou as denominadas estruturas pré-estabelecidas, assim configuradas:

[...] protocolo inicial ou protocolo, na sequência dos dados, é constituído por: 1) invocação (invocatio) que, em geral, só ocorre nos atos dispositivos mais antigos. (A expressão 'em nome de Deus' é um exemplo de invocação); 2) titulação (intitulatio), formada pelo nome próprio da autoridade (soberana ou a delegada) que emana do ato e por seus títulos; 3 ) direção ou endereço (inscriptio), parte que nomeia a quem o ato se dirige, seja um destinatário individual ou coletivo e 4) saudação (salutatio), parte final do protocolo. 
[...] texto [...] constitui-se de: 1) preâmbulo (prologus ou exordium), no qual se justifica (por razões de ordem moral, ordem jurídica ou ordem material) a criação do ato; 2) notificação (notificatio ou promulgatio), que pode ser entendida na expressão 'tenho a honra de comunicar a vós'; 3 ) exposição (narratio), na qual são explicitadas as causas do ato, o que o originou, quais as necessidades administrativas, políticas, jurídicas, econômicas, sociais ou culturais que o tornaram necessário; 4) dispositivo (dispositio), que é a própria substância do ato, 'assunto' propriamente dito, em que se determina o que se quer (iniciado por um verbo na primeira pessoa, como 'ordeno', 'mando', 'estabeleço', 'sou servido' etc.); 5) sanção (sanctio ou minatio), na qual se assinalam as penalidades, no caso do não cumprimento do dispositivo, e 6) corroboração ou cláusulas finais (valoratio ou corroboratio), em que se dispõe sobre os meios morais ou materiais que asseguram a execução do dispositivo (alguns autores classificam a parte final do texto segundo suas variantes: cominatórias, que podem ser penais ou espirituais, de garantia; de renúncia ou de corroboração).

[...] protocolo final ou escatocolo inicia-se, após a corroboração ou cláusulas finais, com: 1) subscrição/ assinatura (subscriptio), isto é, a assinatura do emissor/autor do documento ou quem o faça por sua ordem; 2) datação (datatio). Nesta, é preciso distinguir a data tópica da data cronológica ou o elemento topográfico do elemento cronológico. A primeira é referente à forma como está designado no documento o local onde ele foi assinado [...] 3) precação (apprecatio), onde, por meio de dois elementos (assinatura de testemunhas e sinais de validação, como carimbos e selos), reitera-se a legalidade do documento [...] (BELLOTTO, 2008, p. 26-28, grifos nossos).

Esses elementos, passíveis de identificação, são caracterizados como estruturas fixas constantes em documentos diplomáticos, logo se tratam de itens imprescindíveis à composição das espécies ou tipologias documentais, listadas na seção anterior. A título de exemplo, apresentamos excertos do testamento da matriarca da família Fróes da Motta, com o intuito de evidenciarmos o protocolo inicial, o texto e o protocolo final do documento, assim analisado:

Protocolo inicial: Em nome de Deus, Amem. | Eu, Maximiana de Almeida Motta, achando- $\mid$ me em perfeito estado de saude e em juizo $\mid$ seguro, mas, temendo a morte, cujo dia é incer- $\mid$ to, determinei, sem constrangimento algum e de $\mid$ minha livre e expontanea vontade, fazer o $\mid$ meu testamento como abaixo se segue:

Texto: _ $1^{\mathrm{a}}$ Verba _ Declaro que professo | a religião Catholica Apostolica Romana, em $\mid$ a qual nasci e espero morrer. $\mid 2^{a}$ Verba _ Declaro que sou $\mid$ natural da Feira de Sant'Anna deste Estado | Federado da Bahia. [...] 16 ${ }^{\text {a }}$ Verba _ Declaro que todo | estes legados que faço são livres de imposto | ou sêllo de herança; e que para o cumprimen- $\mid$ to deste meu testamento, de todos os seus lega- $\mid$ dos e disposições, marco o praso de dois annos.

Protocolo final: E por tal modo e fórma tenho concluido es- $\mid$ te meu testamento, que, muito de minha livre | vontade, e sem constrangimento ou induzi- | mento de pessôa alguma, vai escripto pelo | senhor João Carneiro Vital, Tabellião de Notas | desta cidade, ao qual mandei chamar á mi- $\mid$ nha residencia, á Praça General Argollo, e $\mid$ pedi-lhe que o escrevesse, o que feito, passei $\mid$ a lel-o e achando-o em tudo conforme o ha- $\mid$ via ditado, o datei e assignei afim de man- $\mid$ dal-o approvar pelo mesmo Tabellião João | Carneiro Vital E eu, | João Carneiro Vital, Tabellião, o escrevi e o assi- | gnei em publico e raso. | Em testemunho João Carneiro da verdade. | Vital | João Carneiro Vital Tabellião | Maximiana de Almeida Motta |

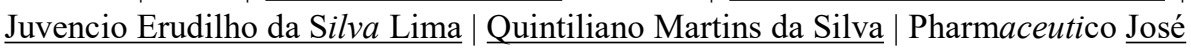
Alves Boaventura | Leolindo dos Santos Ramos | Pedro Rodrigo do Lago. (TESTAMENTO DE MAXIMIANA..., 1918, f. 2r; 4r). 
Como se pode identificar, os testamentos, de modo geral, possuem estruturas padrão, que podem ser verificadas em qualquer documento dessa natureza, mesmo nos casos em que o conteúdo não siga, rigorosamente, a mesma ordem (BELLOTTO, 2006; LIMA; SILVA, 2010). Assim sendo, todo testamento apresenta uma estrutura que contempla todos (ou quase todos) os elementos a seguir:

1. Aspectos formais: Introdução (invocação da Santíssima Trindade ou de Deus); localização e datação do documento, assinatura do testador ou de terceiro a seu rogo, assinaturas das testemunhas e do tabelião, rubricas do tabelião nas folhas do documento, instrumento de aprovação e abertura do testamento;

2. Identificação do testador - nome, condição - no caso de libertos -, naturalidade, nacionalidade, religião, nome dos pais [...], local de moradia, ocupação, filiação em irmandades e confrarias, estado conjugal, nome e ocupação do cônjuge, informações sobre casamentos anteriores, nomes, cônjuges e ocupação dos filhos (dos vivos e dos mortos);

3. Disposições e legados espirituais - local e forma detalhada do sepultamento, número de missas por intenção da própria alma e pelas das outras pessoas, bem como o local ou locais das missas, doações a Irmandades, esmolas aos pobres, legados para Igrejas e instituições de caridade [...];

4. Declarações quanto aos bens materiais - listagem dos herdeiros necessários e instituição de herdeiros e legatários, citação de alguns dos bens móveis e imóveis, bem como destino, qual o destino que lhes deveria ser dado: venda, doação, hipoteca $[\ldots]$

5. Disposições gerais, indicação de três ou quatro testamenteiros;

6. Codicilos [carta pequena ou bilhete que equivalia a um pequeno testamento sem a instituição de herdeiros] e cartas de consciência (em alguns testamentos) (LIMA; SILVA, 2010, p. 208-209).

Comparando esses elementos com os dois testamentos que compõem o nosso corpus, observamos que os elementos diplomáticos mencionados são passíveis de identificação nos textos, o que reitera a assertiva de Lima e Silva (2010) quanto à estrutura organizacional de um testamento. Em outros termos, embora possua “[...] uma organicidade jurídica e notarial, a qual pouco se alterou [...]" (LIMA; SILVA, 2010, p. 201) ao longo dos anos, o testamento faz parte de um grupo de documentos seriais, que foram instaurados pelo direito lusitano e que existem no Brasil desde a época da colonização, fato que reveste a tipologia documental testamento de uma importância para os estudos que buscam a "reconstituição e compreensão do passado" (LIMA; SILVA, 2010).

Ademais, na mesma tipologia documental estão presentes atos solenes que evidenciam não somente a preocupação do testador com o seu "futuro" após a morte (já que o indivíduo, geralmente, "barganha" o favor de "Deus", o que fica nítido a partir, por exemplo, da necessidade de deixar clara a sua orientação religiosa e o seu temor a "Deus", e os atos filantrópicos, evidentes em seu testamento a partir da doação de quantias vultosas para as 
"viúvas pobres" e para as sociedades de caridade com o intuito de mostrar-se bondoso, portanto, merecedor da complacência de Deus), mas com os seus entes queridos, que devem ficar amparados financeiramente, após a sua morte.

Semelhantemente, há nos inventários “[...] elementos importantes para a vida social e material da vila. Benfeitorias, artefatos materiais, produtos alimentícios, animais, relações de crédito e débito [...]" (LIMA; SILVA, 2010, p. 187), que são perceptíveis, por exemplo, no primeiro volume do inventário, também corpus desta tese, e no qual os últimos desejos do testador são retomados.

Para a Diplomática, portanto, existem as categorias documentais, entendidas como as “[...] gradações da representatividade jurídica dos conteúdos dos documentos que nelas se enquadram." (BELLOTTO, 2006, p. 48), e das quais destacamos os documentos de comunicação (carta, relatório, jornal interno e folheto publicitário), os documentos contábeis e financeiros (letra de câmbio, extrato bancário, balanço, balancete e declaração físcal) e os documentos jurídicos (notificação, contrato de empresa, contrato de aluguéis, contrato de compra e venda, contrato de empréstimo de dinheiro e procuração), por se tratarem de categorias que constam, como documentos anexados ou partes integrantes/peças processuais, dos documentos descritos nas fichas codicológicas apresentadas na seção anterior.

Dentro das referidas categorias, há as espécies documentais, definidas por Bellotto (2006, p. 56) como aquelas que “[...] obedece[m] a fórmulas convencionadas, em geral estabelecidas pelo direito administrativo ou notarial”. As espécies documentais, portanto, dizem respeito ao veículo de redação adequado, de modo a tornar válido e credível o conteúdo do documento. A tipologia documental, por sua vez, investiga a "configuração" que a espécie documental assume, de acordo com a atividade nela representada (BELLOTTO, 2006).

Em outras palavras, "A Tipologia Documental é a ampliação da Diplomática em direção à gênese documental, perseguindo a contextualização nas atribuições, competências, funções e atividades da entidade geradora/acumuladora [...]” (BELLOTTO, 2002, p. 19). Assim, o estudo da tipologia documental parte da "configuração/fórmula" do documento espécie documental - e se estende à investigação da(s) atividade(s) que o gerou. Logo, na análise diplomática, “[...] o elemento inicial é a decodificação do próprio documento, sendo suas etapas: da anatomia do texto ao discurso, do discurso à espécie, da espécie ao tipo, do tipo à atividade, da atividade ao produtor." (BELLOTTO, 2006, p. 61).

Amparando-nos nessas definições, portanto, decidimos elaborar o quadro 32, organizado em ordem alfabética, com o intuito de apresentarmos a definição e os elementos diplomáticos dos documentos descritos na seção anterior. Para isso, apoiamo-nos em Bellotto 
(2002, 2006 e 2008), Magalhães (19--) e Náufel (1959), por acreditarmos que as definições propostas por esses autores nos permitem compreender os elementos que constituem cada documento e, mais especificamente, as estruturas do testamento e do inventário, documentos selecionados como corpus desta tese, e a partir dos quais relacionamos o contexto de produção e os produtores dos textos.

Quadro 32 - Caracterização diplomática dos documentos estudados

\begin{tabular}{|c|c|c|}
\hline DOCUMENTO & DEFINIÇÃO DIPLOMÁTICA & ELEMENTOS DIPLOMÁTICOS \\
\hline $\begin{array}{lr}\text { Ação } & \text { de } \\
\text { consignação } & \text { em } \\
\text { pagamento } & \\
\end{array}$ & $\begin{array}{l}\text { "[ação] em que o autor pede a citação } \\
\text { do interessado [...] para virem ou } \\
\text { mandarem receber, em lugar, dia e hora } \\
\text { prefixados, o pagamento [...] sob pena } \\
\text { de ser feito o respectivo depósito, que } \\
\text { terá força de pagamento, extinguindo a } \\
\text { obrigação" (NÁUFEL, 1959, p. 38). }\end{array}$ & $\begin{array}{l}\text { Protocolo inicial: datas tópica e } \\
\text { cronológica em texto corrente. } \\
\text { Autoridades judiciais e notariais que } \\
\text { realizam o ato. Texto: dados sobre a } \\
\text { citação do interessado. Definição de } \\
\text { lugar, dia e hora para receber o } \\
\text { pagamento devido. } \\
\text { Protocolo final: Ciência aos } \\
\text { envolvidos no processo e datas } \\
\text { tópica, cronológica e assinaturas. } \\
\text { (Adapt. BELLOTTO, 2006; 2008). }\end{array}$ \\
\hline Ação de deserdação & $\begin{array}{l}\text { "[ação] que compete ao herdeiro } \\
\text { instituído ou àquele a quem aproveite a } \\
\text { deserdação ordenada em testamento, a } \\
\text { fim de provar a veracidade da causa da } \\
\text { mesma alegada pelo testador e tornar } \\
\text { efetiva a deserdação" (NÁUFEL, 1959, } \\
\text { p. 41). }\end{array}$ & $\begin{array}{l}\text { Protocolo inicial: datas tópica e } \\
\text { cronológica em texto corrente. } \\
\text { Autoridades judiciais e notariais que } \\
\text { realizam o ato. Texto: dados sobre a } \\
\text { citação dos interessados. Definição } \\
\text { de lugar, dia e hora para a audiência } \\
\text { pública e exposição de justificativas } \\
\text { para a deserdação. } \\
\text { Protocolo final: Datas tópica, } \\
\text { cronológica e assinaturas. (Adapt. } \\
\text { BELLOTTO, 2006; 2008). }\end{array}$ \\
\hline $\begin{array}{l}\text { Ação ordinária de } \\
\text { desquite }\end{array}$ & $\begin{array}{l}\text { "[ação] que um cônjuge propõe contra o } \\
\text { outro, fundado em motivo } \\
\text { expressamente previsto em lei, com o } \\
\text { fim de dissolver a sociedade conjugal e } \\
\text { pôr têrmo ao regime matrimonial dos } \\
\text { bens" (NÁUFEL, 1959, p. 43). }\end{array}$ & $\begin{array}{l}\text { Protocolo inicial: datas tópica e } \\
\text { cronológica em texto corrente. } \\
\text { Autoridades judiciais e notariais que } \\
\text { realizam o ato. Texto: dados sobre a } \\
\text { citação dos interessados. Definição } \\
\text { de lugar, dia e hora para a audiência } \\
\text { pública e exposição de justificativas } \\
\text { para a petição de desquite. Ciência às } \\
\text { partes envolvidas no processo. } \\
\text { Protocolo final: Datas tópica, } \\
\text { cronológica e assinaturas. (Adapt. } \\
\text { BELLOTTO, 2006; 2008). }\end{array}$ \\
\hline Ação de embargo & $\begin{array}{l}\text { "[ação] de apelação [...] Recurso } \\
\text { utilizado por uma pessoa para se opor } \\
\text { aos efeitos de despacho ou da sentença } \\
\text { proferida em uma demanda, mesmo na } \\
\text { fase anterior à fase executória" } \\
\text { (BELLOTTO, 2008, p. 51). }\end{array}$ & $\begin{array}{l}\text { Protocolo inicial: datas tópica e } \\
\text { cronológica em texto corrente. } \\
\text { Autoridades judiciais e notariais que } \\
\text { realizam o ato. Texto: dados sobre a } \\
\text { citação dos interessados. Definição } \\
\text { de lugar, dia e hora para a audiência } \\
\text { pública e exposição de justificativas } \\
\text { para o embargo. Ciência aos } \\
\text { embargante e embargado. } \\
\text { Protocolo final: Datas tópica, } \\
\text { cronológica e assinaturas. (Adapt. } \\
\text { BELLOTTO, 2006; 2008) }\end{array}$ \\
\hline Ação de liquidação & "[ação] em virtude do qual se põe termo & Protocolo inicial: datas tópica $\mathrm{e}$ \\
\hline
\end{tabular}




\begin{tabular}{|c|c|c|}
\hline $\begin{array}{l}\text { de sociedade } \\
\text { mercantil }\end{array}$ & $\begin{array}{l}\text { à existência da sociedade, liquidando-se } \\
\text { os seus bens e haveres para convertê-los } \\
\text { em dinheiro até onde necessário para } \\
\text { dissolução dos débitos e distribuição do } \\
\text { saldo remanescente entre os sócios, } \\
\text { proporcionalmente às suas quotas ou } \\
\text { quinhões no capital social" } \\
\text { (MAGALHÃES, 19--, p. 192). } \\
\text { "[ação] proposta por qualquer } \\
\text { interessado com o fim de ser } \\
\text { judicialmente declarada a dissolução de } \\
\text { sociedade comercial e sua conseqüente } \\
\text { liquidação, nos casos previstos em lei ou } \\
\text { no contrato social" (NÁUFEL, 1959, p. } \\
\text { 43). }\end{array}$ & $\begin{array}{l}\text { cronológica em texto corrente. } \\
\text { Autoridades judiciais e notariais que } \\
\text { realizam o ato. Texto: dados sobre a } \\
\text { citação dos interessados. Definição } \\
\text { de lugar, dia e hora para a audiência } \\
\text { pública e exposição de justificativas } \\
\text { para a liquidação da sociedade } \\
\text { mercantil. Ciência às partes } \\
\text { envolvidas no processo. } \\
\text { Protocolo final: Datas tópica, } \\
\text { cronológica e assinaturas. (Adapt. } \\
\text { BELLOTTO, 2006; 2008). }\end{array}$ \\
\hline Ação de Sonegados & $\begin{array}{l}\text { "[ação que] Compete ao herdeiro ou } \\
\text { credor da herança para haver a } \\
\text { restituição de bens subtraídos à partilha } \\
\text { por quem os tenha em seu poder, ou no } \\
\text { de outrem, com o seu conhecimento" } \\
\text { (MAGALHÃES, 19--, p. 19). }\end{array}$ & $\begin{array}{l}\text { Protocolo inicial: datas tópica e } \\
\text { cronológica em texto corrente. } \\
\text { Autoridades judiciais e notariais que } \\
\text { realizam o ato. Texto: dados sobre a } \\
\text { citação dos interessados. Definição } \\
\text { de lugar, dia e hora para a audiência } \\
\text { pública e exposição de justificativas } \\
\text { para a abertura da ação de sonegados. } \\
\text { Exposição dos bens sonegados. } \\
\text { Ciência às partes envolvidas no } \\
\text { processo. } \\
\text { Protocolo final: Datas tópica, } \\
\text { cronológica e assinaturas. (Adapt. } \\
\text { BELLOTTO, 2006; 2008). }\end{array}$ \\
\hline Ação Executiva & $\begin{array}{l}\text { "Ação de caráter especial, iniciada por } \\
\text { meio de citação do réu para que pague a } \\
\text { dívida reclamada em vinte e quatro } \\
\text { horas, ou ofereça bens à penhora, } \\
\text { contestanto a lide no prazo de dez dias, } \\
\text { após o que a ação toma o rito ordinário" } \\
\text { (NÁUFEL, 1959, p. 65). }\end{array}$ & $\begin{array}{l}\text { Protocolo inicial: datas tópica e } \\
\text { cronológica em texto corrente. } \\
\text { Autoridades judiciais e notariais que } \\
\text { realizam o ato. Texto: dados sobre a } \\
\text { citação dos interessados. Definição } \\
\text { de lugar, dia e hora para a audiência } \\
\text { pública e exposição de justificativas } \\
\text { sobre a cobrança da dívida e penhora } \\
\text { dos bens. Ciência às partes } \\
\text { envolvidas no processo. } \\
\text { Protocolo final: Datas tópica, } \\
\text { cronológica e assinaturas. (Adapt. } \\
\text { BELLOTTO, 2006; 2008). }\end{array}$ \\
\hline Ação Ordinária & $\begin{array}{l}\text { "[ação] em que se observa a série } \\
\text { inteira das formalidades estabelecidas } \\
\text { para o processo das causas em geral" } \\
\text { (MAGALHÃES, 19--, p. } 20 \text {, grifo do } \\
\text { autor). }\end{array}$ & $\begin{array}{l}\text { Protocolo inicial: datas tópica e } \\
\text { cronológica em texto corrente. } \\
\text { Autoridades judiciais e notariais que } \\
\text { realizam o ato. Texto: dados sobre a } \\
\text { citação dos interessados. Definição } \\
\text { de lugar, dia e hora para a audiência } \\
\text { pública e exposição de justificativas } \\
\text { para a abertura da ação ordinária. } \\
\text { Ciência às partes envolvidas no } \\
\text { processo. } \\
\text { Protocolo final: Datas tópica, } \\
\text { cronológica e assinaturas. (Adapt. } \\
\text { BELLOTTO, 2006; 2008). }\end{array}$ \\
\hline Alvará & $\begin{array}{l}\text { "[...] licença ou autorização dada por } \\
\text { autoridade competente de direitos ou } \\
\text { para realização de atos ou eventos, com } \\
\text { validade de um ano ou provisão especial }\end{array}$ & $\begin{array}{l}\text { "Protocolo inicial: titulação: Nome e } \\
\text { qualificação. } \\
\text { Texto: o objeto da declaração, } \\
\text { modificação ou concessão [...] do }\end{array}$ \\
\hline
\end{tabular}




\begin{tabular}{|c|c|c|}
\hline & $\begin{array}{l}\text { pela qual o juiz autoriza, aprova ou } \\
\text { confirma certo ato, estado ou direito" } \\
\text { (BELLOTTO, 2008, p. 35). }\end{array}$ & $\begin{array}{l}\text { direito e nome e qualificação do } \\
\text { beneficiado [...]. } \\
\text { Protocolo final: datas tópica e } \\
\text { cronológica. Não há assinatura e sim } \\
\text { apenas a subscrição, de próprio } \\
\text { punho". (BELLOTTO, 2008, p. 35). }\end{array}$ \\
\hline $\begin{array}{l}\text { Instrumento de } \\
\text { agravo }\end{array}$ & $\begin{array}{l}\text { "[...] documento apresentado em juízo } \\
\text { para fins de prova e considerado sob o } \\
\text { aspecto de sua forma exterior [...]" } \\
\text { (MAGALHÃES, 19--, p. 326). } \\
\text { "Recurso que se interpõe, para a } \\
\text { instância imediatamente superior, de } \\
\text { decisão de juiz singular, que não seja } \\
\text { definitiva, nos casos expressamente } \\
\text { determinados em lei" (NÁUFEL, 1959, } \\
\text { p. 126). }\end{array}$ & $\begin{array}{l}\text { Protocolo inicial: datas tópica e } \\
\text { cronológica em texto corrente. } \\
\text { Autoridades judiciais e advogados } \\
\text { que realizam o ato. Texto: dados } \\
\text { sobre o motivo do agravo. } \\
\text { Justificação da abertura do processo. } \\
\text { Protocolo final: Declarações finais e } \\
\text { setença judicial. } \\
\text { BELLOTTO, 2006; 2008). }\end{array}$ \\
\hline Inventário & $\begin{array}{l}\text { "[...] documento diplomático } \\
\text { testemunhal de assentamento [...] [ou] } \\
\text { Lista contendo a descrição individual e } \\
\text { pormenorizada de todos os bens da } \\
\text { herança, sejam eles móveis, imóveis, } \\
\text { semoventes e dívidas [...]" } \\
\text { (BELLOTTO, 2008, p. } 55 \text { ). }\end{array}$ & $\begin{array}{l}\text { "Protocolo inicial: datas tópica e } \\
\text { cronológica em texto corrente. } \\
\text { Autoridades judiciais e notariais que } \\
\text { realizam o ato. Texto: dados sobre os } \\
\text { filhos. Arrolamento dos bens } \\
\text { detalhadamente e seus valores. } \\
\text { Protocolo final: termos e registros } \\
\text { anexos." (BELLOTTO, 2008, p. 55). }\end{array}$ \\
\hline Notificação & $\begin{array}{l}\text { "documento diplomático informativo, } \\
\text { descendente. Documento que dá ciência } \\
\text { a pessoa física ou jurídica sobre um } \\
\text { processo ou um ato no qual ela é } \\
\text { interessada [...]" (BELLOTTO, 2008, p. } \\
59 \text { ). } \\
\text { "[...] ordem judicial [...] para que o } \\
\text { credor de obrigação ponha o devedor } \\
\text { em mora, quando ela não é paga no } \\
\text { vencimento" (MAGALHÃES, 19--, p. } \\
\text { 399). }\end{array}$ & $\begin{array}{l}\text { "Protocolo inicial: título: notificação. } \\
\text { Texto: prazo para o comparecimento } \\
\text { e a designação do local. } \\
\text { Protocolo final: datas tópica e } \\
\text { cronológica". (BELLOTTO, 2008, p. } \\
\text { 59). }\end{array}$ \\
\hline Petição & $\begin{array}{l}\text { "documento diplomático informativo } \\
\text { peticionário, ascendente. Instrumento } \\
\text { pelo qual se solicita à autoridade pública } \\
\text { sem ter certeza ou a segurança quanto } \\
\text { ao amparo legal do pedido [...]" } \\
\text { (BELLOTTO, 2008, p. 61-62). }\end{array}$ & $\begin{array}{l}\text { "Protocolo inicial: Nome } \mathrm{e} \\
\text { qualificação do peticionário. } \\
\text { Texto: o peticionário justifica o } \\
\text { pedido e relata suas qualificações. } \\
\text { Protocolo final: datas tópica e } \\
\text { cronológica." (BELLOTTO, 2008, p. } \\
\text { 62). }\end{array}$ \\
\hline Petição de herança & $\begin{array}{l}\text { "compete ao herdeiro legítimo ou } \\
\text { testamentário, para haver de quem } \\
\text { também se diz herdeiro a posse da } \\
\text { herança com todos os seus frutos e } \\
\text { acessórios" (MAGALHÃES, 19--, p. } \\
\text { 15). }\end{array}$ & $\begin{array}{l}\text { "Protocolo inicial: Nome e } \\
\text { qualificação do peticionário. } \\
\text { Texto: o peticionário justifica o } \\
\text { pedido e relata suas qualificações. } \\
\text { Protocolo final: datas tópica e } \\
\text { cronológica." (BELLOTTO, 2008, p. } \\
\text { 62). }\end{array}$ \\
\hline Testamento & $\begin{array}{l}\text { "[...] Disposição ou declaração solene } \\
\text { da vontade do testador sobre aquilo que } \\
\text { deseja que se faça depois da sua morte, } \\
\text { com seus bens e fortuna" (BELLOTTO, } \\
2008, \text { p. } 70 \text { ). }\end{array}$ & $\begin{array}{l}\text { Protocolo inicial: datas tópica e } \\
\text { cronológica em texto corrente. } \\
\text { Autoridades judiciais e notariais que } \\
\text { realizam o ato. Texto: dados sobre os } \\
\text { filhos. Arrolamento dos bens e dos } \\
\text { herdeiros. } \\
\text { Protocolo final: Anuência e } \\
\text { assinatura do testador, testemunhas e } \\
\text { tabelião de notas, e selagem do }\end{array}$ \\
\hline
\end{tabular}




\begin{tabular}{|c|c|c|}
\hline & & $\begin{array}{l}\text { testamento. (Adapt. BELLOTTO, } \\
\text { 2006; 2008). }\end{array}$ \\
\hline $\begin{array}{ll}\text { Traslado } & \text { de } \\
\text { inventário } & \end{array}$ & $\begin{array}{l}\text { "[documento que contém] as } \\
\text { transcrições ou reproduções de } \\
\text { contratos feitas imediatamente após sua } \\
\text { celebração por oficial público, e } \\
\text { destinadas às partes contraentes" } \\
\text { (MAGALHÃES, 19--, p. 577, grifo do } \\
\text { autor). } \\
\text { "[...] cópia ou reprodução integral de } \\
\text { documentos autênticos originais, } \\
\text { assentados em livros próprios, na área } \\
\text { notarial". (BELLOTTO, 2008, p. 71). }\end{array}$ & $\begin{array}{l}\text { Protocolo inicial: datas tópica e } \\
\text { cronológica em texto corrente. } \\
\text { Autoridades judiciais e notariais que } \\
\text { realizam o ato. Texto: trasladação } \\
\text { dos dados sobre os filhos. } \\
\text { Arrolamento dos bens e dos } \\
\text { herdeiros. } \\
\text { Protocolo final: datas tópica e } \\
\text { cronológica. (Adapt. BELLOTTO, } \\
\text { 2006; 2008). }\end{array}$ \\
\hline
\end{tabular}

Fonte: Elaborado pela pesquisadora

Ao relacionarmos essas definições com os conteúdos dos processos descritos nas fichas codicológicas anteriormente apresentadas, identificamos que ambos se harmonizam, o que nos possibilita uma compreensão ampla do processo de produção e da finalidade de cada um deles. Contudo, embora tenhamos feito um levantamento e apresentado as definições de todas as espécies e tipologias documentais, relacionadas no quadro anterior, optamos por nos deter à discussão dos termos testamento e inventário, pelo fato destes se configurarem objeto de análise filológico-linguística da nossa tese. Logo, tratam-se de espécies documentais relacionadas aos seus respectivos contextos de produção, o que nos conduz ao esmiuçamento das informações advindas dos referidos textos.

Assim sendo, identificamos, a partir da leitura das obras de Bellotto (2002, 2006 e 2008), Magalhães (19--) e Náufel (1959), que o testamento é um documento elaborado ainda em vida do autor, no qual são listados os bens do testador, que garante que a sua vontade seja feita após a sua morte, enquanto que o inventário é um documento produzido após a morte do testador e no qual também consta a arrolação dos bens obtidos durante a vida do inventariado, e que serão divididos entre os seus herdeiros, após a abertura e em conformidade com o testamento deixado, ou seja, o testamento de 11 fólios, por exemplo, do Coronel Agostinho Fróes da Motta foi feito ainda durante a sua vida, enquanto que o seu inventário, de 799 fólios, foi produzido após a sua morte, sem deixar, contudo, de levar em consideração a divisão dos bens pretendida, em seu testamento, para cada um dos seus herdeiros.

Essa afirmação se faz tão verdadeira que dos fólios $4 \mathrm{v}$ ao $15 \mathrm{r}$ do primeiro volume do inventário do referido coronel há uma cópia quase exata do seu testamento, o que comprova que a vontade do testador foi, não apenas trasladada do testamento para o inventário, mas respeitada pela maioria dos seus herdeiros, com exceção de Dona Amália da Motta Faskomy que contestou a sua deserdação, na Justiça, e do engenheiro Alberto de Almeida Motta, que 
apresentou, no próprio inventário, os motivos e provas legais para o seu reconhecimento enquanto filho e, portanto, herdeiro legal do coronel, o qual não o citou em seu testamento.

Para além disso, é cabível mencionar que ao tratarmos de testamentos, em especial o de Dona Maximiana de Almeida Motta, que foi escrito e lavrado em 1915, ano em que ainda vigorava, no Brasil, o Código Philipino que, em seu Quarto Livro no Título LXXX, preconizava que o testamento fosse definido como "[...] o acto revogavel e solemne, pelo qual uma pessôa dispõe de todos, ou parte de seus bens para depois da sua morte." (QUARTO..., online, p. 900) e que, em caso de alguma pessoa desejar fazê-lo, deveria estar presente um tabelião público e acompanhado por testemunhas “[...] varões livres, ou tidos por livres, e que sejam maiores de quatorze annos, de maneira que com o Tabellião, que fizer o testamento, sejam seis testemunhas [...]" (QUARTO..., online, p. 900), o que se harmoniza claramente com o modo como o testamento da genitora da família Fróes da Motta fora feito.

Em outros termos, o testamento de Dona Maximiana de Almeida Motta foi produzido seguindo as instruções do Quarto Livro do Código Philipino: com um tabelião de notas que registrou, entregou o testamento à sua testadora que, ao achá-lo conforme à sua vontade, o datou, o assinou e deliberou a sua aprovação por parte do tabelião, que escreveu o auto de aprovação, o qual foi assinado pela testadora e por seis testemunhas, dentre as quais estava incluído o tabelião de notas. Após as assinaturas, o testamento foi devidamente lacrado, como vontade de sua testadora, e, enfim, concluído ${ }^{113}$.

Como se pode notar, a feitura do testamento de Dona Maximiana de Almeida Motta respeitou as instruções estabelecidas pelo Código Philipino, que vigorava naquele período. Entretanto, apesar do testamento do Coronel Agostinho Fróes da Motta ter sido produzido em 1920 e aberto em 1922, momento em que o Código Philipino já havia sido substituído pelo Código Civil de 1916, aquele não apresentou uma estruturação diferente da do de Dona Maximiana de Almeida Motta e isso se justifica porque o Código Civil de 1916 estabelecia, no Título III - Da sucessão testamentária, Capítulo I - Do testamento em geral, no artigo 1.626, que "[...] Considera-se testamento o ato revogável pelo qual alguém, de conformidade com a lei, dispõe, no todo ou em parte, do seu patrimônio, para depois da sua morte [...]" (BRASIL, 1916). Ainda no Título III, mas no Capítulo III e Seção II - Do testamento cerrado, no artigo 1.638, havia a seguinte preconização:

I - Que seja escrito pelo testador, ou por outra pessoa, a seu rogo.

II - Que seja assinado pelo testador. [...]

${ }^{113}$ Para verificar tais informações, pode-se conferir os fólios 3r, 3v e 4r da edição semidiplomática do testamento de Dona Maximiana de Almeida Motta, disponível na subseção 4.3.5.1.1 desta tese. 
IV - Que o testador o entregue ao oficial em presença, quando menos, de cinco testemunhas.

V - Que o oficial, perante as testemunhas, pergunte ao testador se aquele é o seu testamento, e quer que seja aprovado, quando o testador não se tenha antecipado em declara-lo.

VI - Que para logo, em presença das testemunhas, o oficial exare o auto de aprovação, declarando nele que o testador lhe entregou o testamento e o tinha por seu, bom, firme e valioso. [...]

IX - Que o instrumento ou auto de aprovação seja lido pelo oficial, assinando ele, as testemunhas e o testador, se souber e puder. [...]

XI. Que o tabellião o cerre e cosa, depois de concluido o instrumento da approvação $^{114}$ (BRASIL, 1916).

Nestes termos, podemos depreender que o testamento do Coronel Agostinho Fróes da Motta foi feito exatamente como o Código Civil vigente ordenava, o que nos leva a compreender a estrutura do texto e as formalidades adotadas para a produção, leitura, aprovação e assinaturas subsequentes dos presentes no referido testamento. Assim, não diferente do testamento anterior, este foi feito em foro íntimo, em residência do testador, escrito pelas mãos do tabelião designado, lido, aprovado, datado e assinado pelo testador, o qual ordenou que o tabelião fizesse o respectivo auto de aprovação, sendo este, por fim, datado e assinado pelo tabelião, pelo próprio testador e por cinco testemunhas presentes. Portanto, tratam-se de formalidades que não deixam dúvidas de que o testamento fora feito dentro da lei e, portanto, passível de confiabilidade e obediente à estrutura pré-estabelecida para a respectiva espécie documental.

Ainda em 1922 foi iniciado o inventário do coronel Agostinho Fróes da Motta, ano em que o Código Civil Brasileiro de 1916 deliberava, no Título III, Capítulo XVII - Do testamenteiro, que:

Art. 1.753. O testador pode nomear um ou mais testamenteiros, conjuntos ou separados, para lhe darem cumprimento às disposições de última vontade. Art. 1.754. O testador pode também conceder ao testamenteiro a posse e administração da herança, ou de parte dela, não havendo cônjuge ou herdeiros necessários.

Art. 1.755. Tendo o testamenteiro a posse e administração dos bens, incumbe-lhe requerer inventário e cumprir o testamento.

Art. 1.757. O testamenteiro é obrigado a cumprir as disposições testamentárias, no prazo marcado pelo testador, e a dar contas do que recebeu e despendeu, subsistindo sua responsabilidade enquanto durar a execução do testamento. (BRASIL, 1916).

Mais adiante, no Título IV, Capítulo I e artigos 1770 e 1771, encontramos as seguintes disposições: "Proceder-se-á ao inventário e partilha judiciais na forma das leis em vigor no domicílio do falecido [...] No inventário, serão descritos com individuação e clareza todos os bens da herança, assim como os alheios nela encontrados" (BRASIL, 1916). Logo, em todos

\footnotetext{
${ }^{114}$ Dispomos nesta citação apenas as cláusulas do Código Civil Brasileiro, Título III, Capítulo III e Seção II e artigo 1638, que se relacionam diretamente ao modus operandi do tabelião, do testador e das testemunhas quando da feitura do testamento do Coronel Agostinho Fróes da Motta.
} 
os artigos elencados observamos que há uma clara relação entre eles e entre o que foi disposto no testamento e no inventário do Coronel Agostinho Fróes da Motta no que diz respeito à: 1) escolha de um ou mais testamenteiros, 2) delegação da administração dos seus bens ao testamenteiro escolhido pelo próprio testador, 3) obrigação do testamenteiro, enquanto administrador dos bens do testador, de requerer, no prazo estabelecido pelo testador, o inventário e cumprir as exigências do testador, constantes em seu testamento e 4) apresentação das despesas que adquiriu durante o processo, bem como o acompanhamento de toda a descrição e partilha dos bens do testador em seu inventário, o que nos leva a afirmar, mais uma vez, que todos esses itens são identificáveis a partir da leitura das duas espécies documentais em questão e ainda deixam claro que os envolvidos no processo de produção dos manuscritos relativos ao coronel Agostinho Fróes da Motta seguiram, integralmente, as disposições legais prescritas no Código Civil de 1916.

Dessas considerações, depreende-se que a caracterização diplomática dos documentos nos permite conhecer as definições e estruturas formais, estabelecidas pela Diplomática, para, enfim, compreender os contextos de produção de cada documento. Mais do que isso, a verticalização dessa discussão para o testamento e o inventário analisados nos conduz, não apenas, ao conhecimento de suas definições, estruturas e Códigos vigentes durante a produção de cada documento, mas à descrição filológica do corpus, apresentada na próxima seção, o que coadunará com o que apresentamos ao longo desta seção.

\subsection{SÍNTESE DA SEÇÃO}

Como vimos, no CEDOC/UEFS estão acondicionados centenas de documentos pertencentes às esferas cível e crime, bem como Livros de Notas e acervos de história oral, da Filarmônica 25 de Março de Feira de Santana-BA e de documentos pessoais advindos das cidades, que compõem o Sertão baiano. Dos documentos disponíveis no CEDOC/UEFS, selecionamos para a reconstituição da história externa do corpus apenas vinte e sete que se relacionam, de forma direta ou indireta, com a família Fróes da Motta e, consequentemente, com os escreventes que redigiram e/ou lavraram os documentos definidos como corpus desta tese: os dois testamentos e o primeiro volume do inventário dos patriarcas dos Fróes da Motta.

Os três documentos constituíram-se, juntos com os demais constantes no CEDOC/UEFS e descritos nesta seção, e com as fontes documentais consultadas no APMFS, referências imprescindíveis para compreendermos e esquematizarmos as relações entre os 
indivíduos que constam no corpus. Assim, quando fizemos a leitura preliminar daqueles três documentos, as informações que pulularam nos fizeram depreender, como dissemos na introdução desta tese, que precisaríamos ampliar o nosso campo de investigação para que os dados emergidos da leitura adquirissem sustentação baseada na historiografia local, já que a remissão a vários outros processos, à cidade e aos indivíduos que se encontravam fora do seio familiar dos Fróes da Motta deixara lacunas na compreensão dos fatos narrados nos documentos.

Por conta disso, decidimos combinar as informações dos documentos listados nesta seção com as da seção anterior, no intuito de preenchermos as lacunas que surgiram, o que, de fato, só foi possível a partir das descrições dos vinte e sete documentos, que nos fornecem, neste momento, amparo para podermos afirmar que os mesmos escreventes que redigiram e/ou lavraram os dois testamentos e o inventário foram os mesmos que participaram do processo de produção de quase todos os demais documentos relacionados ao clã Fróes da Motta e/ou à vida pública de Feira de Santana-BA no início do século XX, o que quer dizer que a sua participação, seja como escrivães, tabeliães, advogados, procuradores, promotores, juízes ou desembargadores seja como avaliadores de bens ou peritos, foi imprescindível para a aplicação dos procedimentos legais inerentes à instauração dos processos judiciais, cujos interessados foram os Fróes da Motta, que se firmaram como pessoas influentes em todos os círculos sociais e com as quais boa parte dos escreventes tinha uma relação íntima.

Ademais, as descrições codicológica e diplomática nos permitiram identificar a existência de um cuidado e atenção dos escreventes com a materialidade dos documentos e uma obediência ao rigor diplomático imposto às estruturas composicionais de cada espécie ou tipologia documental durante o seu processo de produção e lavração, o que nos leva a inferir que, provavelmente, todos eles tiveram uma educação formal que lhes permitiram conhecer os procedimentos técnicos jurídicos e notariais exigidos para ocupar e exercer os respectivos cargos.

Outro aspecto que também ficou bastante nítido durante a descrição codicológica dos documentos foi a fragilidade material de vários dos processos listados, o que indica a necessidade urgente, e futura, de um trabalho de edição filológica direcionado aos documentos que estão mais fragilizados. Além disso, os documentos também apresentaram, em sua materialidade, muitos carimbos, selos, marcas d'água, manchas, borrões, documentos híbridos etc., que evidenciam o quão interessantes eles são para estudos filológico-linguísticos diversos. 
Portanto, ao encerrar esta seção, fica clara a sua contribuição não somente para o entrelaçamento das informações advindas do corpus e da segunda seção, mas também para o arquivo do CEDOC/UEFS, que poderá utilizar-se das informações inseridas nas fichas codicológicas para melhorar e/ou corrigir os dados dispostos nas suas fichas de identificação, bem como para as pesquisas futuras, que serão desenvolvidas a partir da descrição codicológica realizada nesta seção. 


\section{DA FILOLOGIA E SUAS CIÊNCIAS AFINS À EDIÇÃO DE TRÊS DOCUMENTOS NOVECENTISTAS DO SERTÃO BAIANO}

Na terceira seção desta tese vimos que os documentos codicologicamente descritos tanto representam uma pequena amostra das tipologias e espécies documentais constantes no acervo do CEDOC/UEFS quanto estão relacionados aos membros da família Fróes da Motta, que são mencionados no corpus desta tese, o que justifica a necessidade de realizarmos, nesta seção, a inserção da Filologia e suas "ciências afins" 115 como os fios condutores das análises dos documentos, objetos de estudo, bem como dos tipos de edição realizados dentro da Filologia Textual, os quais nos permitirão verticalizar a análise para a descrição extrínseca e intrínseca ${ }^{116}$ do corpus.

Com esse objetivo, desenvolvemos, inicialmente, a subseção 4.1, na qual abordamos a consolidação da Crítica Textual, da Filologia Moderna, da Paleografia, da Codicologia e da Ecdótica enquanto disciplinas que tendem a se complementar quando o assunto é analisar um texto produzido em qualquer período histórico. Na subseção 4.2, sistematizamos os tipos de edição definidos por alguns filólogos, em suas respectivas obras, e, em seguida, especificamos quais daqueles tipos foram adotados para os documentos, que compõem o corpus desta tese.

A partir da subseção 4.3 Da descrição à edição de textos: esquadrinhamento do corpus, realizamos a descrição dos aspectos codicológicos e paleográficos do corpus, seguida da caracterização do perfil socioeducacional dos escreventes, para a qual buscamos compreender quem foram (do ponto de vista histórico, social, profissional e, quando possível, educacional) os "sujeitos da lei" que, de fato, produziram o corpus. Na subseção 4.3.3 sumarizamos o conteúdo e na 4.3.4 caracterizamos os sujeitos e, quando possível, listamos as respectivas árvores genealógicas, com o intuito de compreendermos quem foram e quais os seus papéis no processo de produção do corpus e dos documentos listados na seção anterior, bem como na administração pública de Feira de Santana-BA no período em que os referidos documentos foram lavrados. Na subseção 4.3.5, apresentamos os critérios de edição adotados, seguidos das edições fac-similar e semidiplomática, propriamente ditas.

\footnotetext{
115 Termo adotado de Carrasco Lazareno, Canorea Huete, López Gómez (2016).

${ }^{116} \mathrm{Na}$ subseção 4.3 apresentamos as definições adotadas, neste trabalho, para os termos descrição extrínseca e intrínseca.
} 


\subsection{PANORAMA DA CRÍTICA TEXTUAL, DA FILOLOGIA MODERNA, DA PALEOGRAFIA, DA CODICOLOGIA E DA ECDÓTICA}

A existência da Filologia, enquanto Crítica Textual, data de mais de dois mil anos, momento em que havia a necessidade de se fazer a edição de variados textos, dentre os quais figuravam, por exemplo, a Ilíada e a Odisséia, obras cuja autoria é atribuída a Homero. Com vistas à elaboração de edições daqueles manuscritos, no século III a.C, na antiga Biblioteca de Alexandria, no Egito, reuniram-se os primeiros filólogos para estudar e realizar atividades voltadas para o texto e para a língua, como aferem as palavras de Cambraia (2005, p. 38):

Dentre os diretores dessa biblioteca, destacam-se, no campo da crítica textual,
Zenódoto de Éfeso (c. $325-234$ a.C.), Aristófanes de Bizâncio (c. 258-180 a.C.) e
Aristarco de Samotrácia (c. 216-144 a.C.). Uma das contribuições desses
alexandrinos, que se dedicaram em especial à obra de Homero, mas não apenas, está
na constituição de um sistema de crítica (gr. ätüñèuéóè, isto é, "correção") baseado
na utilização de sinais com a finalidade de explicitar seu julgamento quanto à
genuinidade do texto.

Foi a partir desses primeiros filólogos que se começou a pensar em um sistema de crítica que permitisse inferir se um texto era original ou se correspondia à uma cópia, o que possibilitava, por exemplo, que se chegasse à conclusão de que um determinado texto fora produzido por um ou outro autor, permitindo-lhe, portanto, correções no que concernia tanto à leitura quanto à interpretação de obras, cuja autoria poderia ser desconhecida até aquele momento, já que aqueles filólogos estudavam os textos com vistas à sua restauração, fixação, interpretação e instauração de comentários pertinentes a cada obra.

A partir disso, o labor filológico foi se consolidando à medida que as cópias de textos diversos, tais como aqueles cuja autoria foi atribuída a Homero, foram ficando cada vez mais recorrentes, bem como os seus leitores, pertencentes à uma elite prestigiada. Assim, não é de se admirar que, ainda naquele período, Filologia fosse sinônimo de erudição, haja vista os conhecimentos necessários à realização da prática de edição de texto, como assinala Bueno (1967, p. 6):

[...] o conceito de filologia era idêntico, na antigüidade clássica, ao de erudição, não existindo diferença entre eruditus, gramaticus e philologus. A estas denominações podemos acrescentar ainda outra: a de criticus. Mas, para a cabal execução de tal ofício se requeria erudição, pleno conhecimento da língua e da literatura, da história e da mitologia, vindo, portanto, mais uma vez, confirmar que todas essas denominações, por mais variadas que fossem, se reduziam todas ao conceito único de erudição. 
Diante disso, concluímos que o filólogo é um erudito. Assim, pelo fato de cada texto possuir peculiaridades, que exigem do editor conhecimentos de várias áreas do saber, chegamos à constatação de que as ciências são cruciais para o filólogo que, em sua prática, tem uma abordagem interdisciplinar, principalmente porque a função principal desse profissional é disponibilizar edições passíveis de confiabilidade e, para isso, ele precisa conhecer o texto em toda sua amplitude. Portanto, costuma-se afirmar que:

[...] A filologia é crítica dos textos; ela procura "estabelecer o texto" por meio de critérios internos e externos que lhe são fornecidos, por um lado, pelas técnicas que lhe são próprias (comparação dos textos, das variantes, história dos manuscritos) e, por outro, pelos dados externos que lhe fornecem outras técnicas: a estatística lingüística para a datação dos documentos ou a história literária, econômica, social, etc. É na medida em que o estabelecimento do texto reclama uma massa de dados fragmentários que se fala de erudição. O trabalho principal dos filólogos é, portanto, a edição dos textos [...] (DUBOIS, 1993, p. 278).

Logo, inferimos que, ao estabelecer um texto, o filólogo parte dos aspectos que constituem a história externa e interna do texto para chegar à uma edição crítica fidedigna. Entretanto, não podemos deixar de lado o fato de que, em seu processo de transmissão, o texto acaba passando por algumas modificações, as quais podem ter ocorrido por causa de fatores exógenos ou endógenos.

Os primeiros estão diretamente relacionados com o tipo de suporte material, tais como o papiro, o pergaminho, o papel, a tinta, o grafite etc. Neste caso, as corrupções do texto podem ter sido ocasionadas por conta do manuseio indevido do suporte material, das ações de insetos (os quais podem causar furos, manchas ou estragos maiores que ocasionam a perda de informações), das ações do tempo (tais como a oxidação da tinta, a umidade, o calor, etc.), das calamidades naturais (tais como enchentes, terremotos, incêndios sem intervenção humana etc.) e do mal acondicionamento do documento. Os fatores endógenos, por sua vez, ocorrem por causa da ação de reprodução do texto em si, que podem ser autógrafas (feitas e autorizadas pelo próprio autor), apógrafas (feitas por editores ou copistas, mas com a autorização do autor) ou apócrifas (feitas por terceiros e cuja autoria é passível de dúvida).

Assim, resolver essas problemáticas é tarefa do editor crítico, já que a Crítica Textual trata exatamente da "[...] restituição da forma genuína dos textos, i. é, de sua fixação ou estabelecimento [...] (CAMBRAIA, 2005, p. 13, grifos do autor). Contudo, é durante a Antiguidade que a Filologia, enquanto prática de edição de textos, surge e, já neste período, os filólogos alexandrinos criaram, por exemplo, um sistema de análise, conhecido através dos símbolos: óbelo (-): verso apócrifo; asterisco (*): verso incorreto repetido em outro lugar, com 
vistas à identificação dos tipos de alterações sofridas pelo texto. Com isso, foi permitido que as gerações futuras àqueles filólogos pudessem conhecer tais documentos, já que os alexandrinos apenas marcavam as irregularidades, sem, no entanto, interferir diretamente no texto (C.f. CAMBRAIA, 2005).

Ainda de acordo com Cambraia (2005), é-nos informado que, durante o período da Itália renascentista (séculos XIV ao XVI), existiram gerações de filólogos que deram prosseguimento ao método aplicado pelos alexandrinos. Através dos trabalhos dos filólogos renascentistas foi possível a recolha de muitos manuscritos, comparando-os com outros mais antigos e corrigindo as falhas de cópias realizadas pelos copistas. Nesse ínterim, tem-se notícia do primeiro manual de Crítica Textual, cuja autoria é atribuída ao italiano Francesco Robortello (1516-1567).

Nos séculos seguintes, o trabalho continuou. Na França no século XVI, na Holanda nos séculos XVI e XVII e na Inglaterra e Alemanha no século XVIII, houve vários estudiosos que contribuíram para a consolidação da Crítica Textual (C.f. CAMBRAIA, 2005). Contudo, foi somente no século XIX que essa disciplina adquiriu o status de ciência, haja vista as contribuições dos estudos de Karl Lachmann (1793-1851), nos quais nos é apresentado um método para o estabelecimento de um arquétipo, aplicado a textos antigos ou perdidos, a partir do estudo da tradição dos testemunhos. Em outras palavras, foi a partir de Lachmann que a Crítica Textual adotou critérios muito mais rigorosos, tomando como ponto de partida os estudos anteriores àquele.

O método de Lachmann, também chamado de método lachamanniano, consiste, basicamente, de sete etapas, a saber: 1) a recensio na qual é feito o levantamento e recolha de todo material que transmitiu o texto. 2) A examinatio em que o editor examina cada testemunho da tradição, a fim de avaliar a sua autenticidade e a eventualidade dele constituir um possível original. Nesta etapa, o editor avalia se há apenas um testemunho daquela tradição (codex unicus) ou se existem vários testemunhos de um mesmo texto (tradição múltipla). 3) A collatio, em que o editor elimina o codex unicus e faz um exame comparativo da tradição múltipla, em busca de afinidades ou relações de parentesco entre os textos. Havendo relações de parentesco entre os testemunhos, o editor elabora a árvore genealógica dos manuscritos, etapa conhecida como 4) stemma codicum, seguida da 5) eliminatio codicum descripitorum que busca eliminar o códice que for derivado de um que ainda exista, a fim de reconstituir o original perdido. A etapa denominada 6) constitutio textus é aquela em que se apresentam quais são os testemunhos mais próximos do original e, por fim, estabelecido o texto, o editor apronta o 7) aparato crítico, que permite o confronto imediato entre a escolha 
feita pelo editor e as lições rejeitadas por ele, as quais estão devidamente recolhidas e registradas (SPAGGIARI; PERUGI, 2004).

Embora este método tenha sido criado para ser aplicado a textos muito antigos ou cujo original tenha se perdido no processo de transmissão, não podemos esquecer de que foi graças a Karl Lachmann, com a publicação das edições críticas do Novo Testamento em grego (18421850) e do poema De Rerum Natura de Lucrécio (C.f. SPINA, 1994), que a Crítica Textual passou a ser vista como ciência, no século XIX, e dessa iniciativa derivam os modelos de edições críticas de textos, realizadas pela Filologia Moderna. Assim, é notável o avanço nos campos de atuação da Crítica Textual, haja vista a sua preocupação com a genuinidade dos textos publicados.

Apesar da visibilidade do trabalho de Lachmann, Joseph Bédier (1864-1938), após utilizar, em um dos seus trabalhos, o método de seu antecessor, o criticou duramente por entender que aquele conduzia à uma “[...] distribuição do conjunto de manuscritos a uma tradição de ramos bífidos, o que praticamente inviabilizava a escolha mecânica de variantes (baseada na prevalência numérica) [...]” (CAMBRAIA, 2005, p. 52), o que levou o próprio Bédier a apresentar um método segundo o qual a edição do texto se dava com base em “[...] um 'bom testemunho', publicado quase sem retoques e acompanhado de notas que marca[va]m [...] um retorno na direção da técnica dos antigos humanistas” (CAMBRAIA, 2005, p. 52).

Nesse sentido, o professor Ivo Castro, em seu texto O retorno à filologia (1995, p. 520), assevera que os métodos " [...] lachmanniano e [...] bédierista têm em comum uma característica fundamental, que subjaz a todas as suas distinções: são filólogos do manuscrito ausente. [...]", o que quer dizer que ambos se dedicaram a estudar textos, “[...] cujo original se perdeu e de que não esperam senão captar reflexos na sua edição, que situam a montante da cadeia da transmissão apógrafa, que ambos recenseiam e colacionam de igual modo [...]" (CASTRO, 1995, p. 520).

Em contrapartida, segundo o mesmo autor (1995), temos uma Filologia que também trabalha com o "manuscrito presente", cujo objeto de estudo é o manuscrito autógrafo, que

[...] não carece de ser reconstruído ou intuído, e que é plenamente autorizado, no sentido de todas as suas marcas merecerem ser reproduzidas na edição (o que apenas levanta problemas práticos, quando as marcas não são apresentáveis em sequência linear). No caso de haver vários autógrafos, o método consiste em os ordenar cronologicamente, de acordo com o processo de génese do texto, de modo que a edição se situa a juzante dos testemunhos (CASTRO, 1995, p. 520). 
Tratam-se, portanto, de dois tipos de Filologia nos quais o filólogo lida de formas distintas. Nesse sentido, o segundo tipo de filologia, com o manuscrito presente, é o que coaduna com a nossa proposta nesta tese, já que trabalhamos com documentos autógrafos, portanto, produzidos pelos seus autores/escreventes.

Com a Filologia Moderna muito se aprimorou no que diz respeito às edições de textos, produzidos em épocas diversas. Assim, tem-se notado claramente um avanço nas pesquisas filológicas no que concerne à edição de textos literários ou não literários, principalmente porque o campo da Filologia tem se expandido cada vez mais, com grupos de pesquisa que têm se voltado para a prática de edição e disponibilização dessas edições em meios variados, o que permite que muitos outros pesquisadores tenham não somente acesso a esses documentos, mas também que os utilizem como objeto de pesquisa com focos variados, o que, inevitavelmente, torna o trabalho do filólogo cada dia mais indispensável, mesmo na era digital para a qual muitos trabalhos filológicos tem sido realizados em diversas universidades brasileiras e estrangeiras.

A título de exemplo, podemos mencionar alguns projetos de pesquisa voltados para as humanidades digitais, a saber: Corpus Anotado do Português Histórico TychoBrahe, da Universidade Estadual de Campinas; Corpus Eletrônico de Documentos Históricos do Sertão (CEDOHS), da Universidade Estadual de Feira de Santana; Edições Digitais para a História da Língua Portuguesa (EDHILP), da Universidade de Évora; Edição dos Panfletos de Eulálio Motta, da Universidade Estadual de Feira de Santana; eDictor: ferramenta para edição filológica eletrônica, da Universidade de São Paulo e da Universidade Estadual de Campinas; Post Scriptum, Arquivo Digital de Escrita Quotidiana em Portugal e Espanha na Época Moderna, P.S., da Universidade de Lisboa; e o Grupo de Pesquisa em Humanidades Digitais, da Universidade de São Paulo.

Como pode-se notar, essa Filologia Moderna inserida, por exemplo, no campo das Humanidades Digitais, continua destacando-se, principalmente, pelo fato de ocupar três funções essenciais ligadas ao tratamento do texto escrito, as quais são: função substantiva, na qual a preocupação do filólogo é a explicação, restituição da forma genuína e preparação técnica da publicação do texto; função adjetiva, na qual o filólogo extrai informações que não estão no texto como, por exemplo, “[...] a determinação de autoria, a biografia do autor, a datação do texto, a sua posição na produção literária do autor e da época, bem como a sua avaliação estética [...]" (SPINA, 1977, p. 77); e a função transcendente, na qual “[...] o texto deixa de ser um fim em si mesmo da tarefa filológica, para se transformar num instrumento 
que permite ao filólogo reconstituir a vida espiritual de um povo ou de uma comunidade em determinada época [...]" (SPINA, 1977, p. 77).

Ao ocupar essas três funções, a Filologia abre caminhos para a investigação de documentos escritos e estudados em múltiplas perspectivas. Sobre isso, recentemente os filólogos Expedito Eloísio Ximenes, da Universidade Estadual do Ceará, Alícia Duhá Lose e Arivaldo Sacramento de Souza, ambos da Universidade Federal da Bahia, fizeram um levantamento exaustivo e "de maneira incompleta" dos trabalhos realizados nos âmbitos da Linguística Histórica e da Filologia no Nordeste brasileiro nos últimos anos. Para isso, eles elencaram apenas as dissertações de mestrado e as teses de doutorado, em andamento e/ou defendidas e alocadas nos bancos de dados dos Programas de Pós-Graduação a que se detiveram, a fim de nos apresentar um panorama do que tem sido feito naquelas áreas.

Assim, ao escrever o texto Panorama das pesquisas em Filologia e Linguística Histórica no Nordeste brasileiro (2019), os autores contribuíram para a composição de uma "cartografia" dos 20 anos de pesquisas em Linguística, desenvolvidas pelo Grupo de Estudos Linguísticos e Literários do Nordeste (GELNE) brasileiro, o que coaduna com a assertiva de que, em quase todos os Estados do Nordeste brasileiro, tem sido desenvolvidas inúmeras pesquisas filológicas, dentre as quais se destacam, pelo grande número de pesquisas realizadas, em primeiro lugar, o Estado da Bahia, seguido dos Estados do Ceará, Paraíba, Pernambuco, Piauí, Rio Grande do Norte e Sergipe, ou seja, apesar de terem sido contabilizados apenas os trabalhos realizados a nível de pós-graduação, não restam dúvidas quanto à efetividade das pesquisas em Linguística Histórica e Filologia em quase todos os Estados do Nordeste brasileiro, somente para exemplificar o quão profícuo tem sido esse campo de investigação nos últimos 20 anos e, consequentemente, como a Filologia Moderna tem despontado em relação a outras áreas dos Cursos de Letras brasileiros.

Contudo, cabe mencionar que essa Filologia não atua sozinha no estudo do texto, mas conta com o auxílio de outras ciências como, por exemplo, a Paleografia, a Codicologia e a Ecdótica que, dentro de suas particularidades, contribuem para um melhor tratamento do texto, seja este manuscrito ou não. Partindo dessa assertiva, optamos por abordar, nesta seção, cada uma das ciências mencionadas pelo fato de serem pertinentes ao trabalho filológico, ora desenvolvido.

De um lado, a etimologia nos diz que a palavra Paleografia é formada pelos termos gregos paleos (antiga) e graphein (escrita), sendo, portanto, compreendida como a ciência que estuda a(s) escrita(s) antiga(s) (BERWANGER; LEAL, 2008). De outro, distintas são as 
definições apresentadas por variados autores para esta ciência, dentre as quais podemos destacar as seguintes:

Jesus Munoz y Rivero: Paleografia é a ciência da decifração dos manuscritos tendo em consideração as vicissitudes sofridas pela escrita em todos os séculos e nações, seja qual for a matéria em que ela apareça;

Maurice Prou: É a ciência das antigas escritas e tem por objeto a decifração dos escritos Antigüidade e Idade Média;

Ricardo Román Blanco: É a ciência que nos ensina a ler e interpretar corretamente documentos manuscritos antigos, ocupando-se essencialmente com a origem e evolução da escrita;

Salomon Reinach: Paleografia é a ciência da decifração dos manuscritos;

Agustin Millares Carlo: Paleografia é a ciência que trata do conhecimento e interpretação das escritas antigas e que estuda as suas origens e evolução;

Ubirajara Dolácio Mendes: Paleografia é a arte de ler documentos antigos;

José Van Den Besselaar: E o estudo metódico de textos antigos quanto à sua forma exterior. Abrange não só a história da escrita e a evolução das letras, mas também o conhecimento dos materiais e instrumentos para escrever;

João Pedro Ribeiro: Paleografia é a parte da Diplomática que, pelo caráter da letra em que se acham os documentos antigos, nos ensina a julgar sua idade, veracidade e ainda a determinar o território ou a nação a que pertencem;

Roberto Piragibe da Fonseca: É o estudo da genética dos velhos manuscritos;

Mário Curtis Giordani: A Paleografia estuda os textos antigos investigando seus caracteres externos, desde o material e instrumentos empregados para escrever até a origem e evolução da própria escrita;

João Eurípedes Franklin Leal: E o estudo técnico de textos antigos, na sua forma exterior, que compreende o conhecimento dos materiais e instrumentos para escrever, a história da escrita e a evolução das letras, objetivando sua leitura e transcrição. (BERWANGER; LEAL, 2008, p. 15-16).

Apesar da polissemia do termo, encontramos alguns pontos em comum entre esses autores, os quais confluem para uma definição de Paleografia, que seria a de que esta é uma ciência que possui técnicas para a decifração e descrição de escritas antigas constantes em manuscritos produzidos em épocas passadas, cujo conhecimento da escrita e das letras, dos materiais, dos instrumentos utilizados para escrever e da Diplomática a moldam como uma ciência, cujo aparato nos permite afirmar a datação, o local e a veracidade do manuscrito.

Em outras palavras, a Paleografia pode ser compreendida como o estudo das escritas antigas, baseado na constituição sócio-histórica dos sistemas de escrita e na capacitação de leitores modernos ao se depararem com a avaliação da autenticidade de um documento, no que concerne à interpretação adequada de sua escrita (C.f. CAMBRAIA, 2005), o que nos sugere que haja uma relação de identificação da Paleografia com a História da Escrita, principalmente pelo fato de ambas tratarem da história do desenvolvimento das escritas, ditas antigas, e representadas nos mais variados suportes materiais.

Ainda nesse contexto, mais recentemente, Carrasco Lazareno, Canorea Huete e López Gómez (2016) discutiram o status da Paleografia, cunhada inicialmente como "ciência 
auxiliar" e, depois de bastante tempo, como "ciência independente", quando conseguiu fixar um método, um objeto e fins próprios. Antes disso, porém, os autores a descrevem como uma ciência que, no início, teve o seu campo de atuação diversamente discutido, em maior ou menor grau, por um grupo de especialistas na área, que a consideraram, em um primeiro momento, como um "mero instrumento de leitura das escritas antigas", logo com um "valor prático" voltado para a elaboração de normas que auxiliassem na "correta identificação das grafias e dos signos auxiliares que acompanhavam a escrita".

Mais adiante, a divisão entre os campos de atuação da Paleografia - que estuda as escritas antigas traçadas sobre suportes brandos (papiro, pergaminho e papel) - e da Epigrafia, voltada para o estudo das escritas antigas constantes em suportes duros (metal, bronze, mármore, pedras etc.), fez com que uma dicotomia, considerada pelos autores (2016) como "artificial", estivesse estabelecida: duas ciências que abordavam o estudo das escritas antigas, mas "separadas pelos suportes materiais" sobre os quais os testemunhos encontravam-se escritos.

Essa dicotomia, contudo, fez surgir uma "inexatidão ou limitação restritiva" do conceito adotado para a Paleografia até meados do século XX, período em que Jean Mallon, membro da Nova Escola Francesa de Paleografia, publicou a Paléographie Romaine (1952), na qual levantou dúvidas sobre a definição tradicional de Paleografia, apontando que a referida ciência não apenas tinha/tem como objeto de estudo as escritas antigas, mas também um conjunto de caracteres externos de todos os monumentos que contém textos. Mallon, portanto, apontou um tipo de Paleografia voltado para o estudo de todos os monumentos gráficos, que contém elementos gráficos a serem estudos pela Paleografia (CARRASCO LAZARENO, CANOREA HUETE, LÓPEZ GÓMEZ, 2016).

A partir dessa perspectiva, a Paleografia voltou a ser vista como a ciência necessária para o estudo das escritas circunscritas tanto em suportes brandos quanto duros. Logo, com a "emancipação" da Paleografia, os seus objetivos se destacaram: estudar os desenvolvimentos das escritas em todas as suas manifestações, independentes do suporte material utilizado para a fixação dos elementos gráficos, bem como os procedimentos técnicos para fixar os signos, a datação, a localização e o estudo da "evolução" das escritas dos testemunhos ao longo da História. Partindo dessa definição, advinda, principalmente, do trabalho de Mallon, em 1972, León Gilissen estabeleceu uma Paleografia dividida em três conceitos, a saber: uma "Paleografia de leitura", uma "Paleografia de análise" e uma "Paleografia de história da escrita", os quais coincidiram com os conceitos formulados, em 1974, na Espanha, pelo Dr. 
Luis Núñez Contreras (CARRASCO LAZARENO, CANOREA HUETE, LÓPEZ GÓMEZ, 2016).

O primeiro conceito de Paleografia tem um caráter técnico-prático e o objetivo de identificar cada signo alfabético, abreviativo e auxiliar das escritas, o que conduz à uma transcrição conservadora dos textos para torná-los inteligíveis, logo trata-se de uma Paleografia, cujo sentido é utilitário, pragmático e baseado em normas de transcrição, o que a converte em uma ciência instrumental, "auxiliar" de qualquer disciplina ou investigação que tenha como base as fontes primárias (CARRASCO LAZARENO, CANOREA HUETE, LÓPEZ GÓMEZ, 2016; ÁVILA SEOANE, 2016).

O segundo conceito, iniciado por Mallon (1952), constitui-se de um estado superior à mera leitura. O objetivo da Paleografia crítica é estudar todos os caracteres que compõem a escrita, tanto estruturais (morfologia, peso, ductus, módulo e ângulo) como "modificativos" (suporte, postura, instrumento escriptórico, destinatário, nível cultural do autor e fatores psicológicos). A análise destes elementos foi completada, em 1973, por León Gilissen, que buscou estabelecer um "alfabeto típico" de cada escrita.

Logo, esclarecer questões voltadas para a identificação, autenticação, transmissão e agrupação dos testemunhos escritos, submetidos à uma rigorosa análise, a fim de datá-los e localizá-los geograficamente, e de compreender o seu processo de produção e contexto, ou seja, responder às questões que envolvem o "quando", o "onde" e o "como" sobre o testemunho escrito foi o que converteu a Paleografia crítica em "auxiliar imprescindível" da História, da Filologia e da Crítica Textual (CARRASCO LAZARENO, CANOREA HUETE, LÓPEZ GÓMEZ, 2016; ÁVILA SEOANE, 2016).

O terceiro e último conceito, a Paleografia como história da escrita, caracteriza-se como uma "ciência independente", vinculada ao estudo histórico da escrita e do seu desenvolvimento como manifestação cultural. Em outros termos, nesta Paleografia a "História da cultura escrita", dentro da qual estão os estudos voltados para a "história do alfabetismo" compreendida como a "luta do homem" por ascensão à cultura, por meio do acesso à leitura e à escrita como conquista social, logo a história social dos escreventes e dos leitores são estudadas como meio de compreender a história da escrita vinculada ao "número relativo de pessoas que sabem escrever" e ao "grau de destreza" dos escreventes -, enquadra-se, e nesse tipo de análise paleográfica o objetivo é estudar a história da escrita em suas diferentes fases, bem como as técnicas empregadas para escrever em épocas distintas, o processo de produção dos testemunhos e os produtos escritos, particularmente em seu aspecto gráfico. 
Mais do que isso, trata-se de uma Paleografia que estuda a história social das práticas e usos da cultura escrita, buscando compreender quem escreveu o texto e por quê, ou seja, os modos de produção e difusão do texto escrito, o acesso e os níveis de alfabetização e a inserção da leitura na sociedade são os focos de análise. Em síntese, na Paleografia como história da escrita, a escrita é um produto da sociedade e por isso não se podem desvincular as implicações sociais, políticas ou culturais da sua relação com as capacidades de ler e escrever, bem como dos discursos sobre a função e o destino da escrita, vistos em uma perspectiva histórica da escrita e dos seus sucessivos ciclos, das técnicas para materializá-la, da gênese dos testemunhos e das suas manifestações gráficas (CARRASCO LAZARENO, CANOREA HUETE, LÓPEZ GÓMEZ, 2016; ÁVILA SEOANE, 2016).

À vista desses três conceitos, a análise paleográfica que apresentamos nas subseções seguintes se insere, em vários aspectos, tanto na Paleografia crítica (no que concerne à compreensão do "quando", do "onde" e do "como" do processo de produção e do contexto dos documentos estudados) quanto na Paleografia como história da escrita (no que diz respeito ao estudo da história social dos escreventes, incluindo-se o acesso e os níveis de alfabetização deles; dos aspectos gráficos dos textos, dos modos de produção e difusão do escrito e, em menor medida, da inserção da leitura na sociedade), o que justifica as suas definições nesta seção.

Por muito tempo, à Paleografia e à Diplomática se atrelou a Codicologia, cujo foco é o “[...] conhecimento do material empregado na produção do manuscrito e das condições materiais em que esse trabalho se verificou [...]" (SPINA, 1977, p. 22). Na definição de Elena Rodríguez Díaz (2016), a Codicologia se encarrega do estudo dos códices ou livros copiados à mão, compreendendo-os como objetos materiais fabricados segundo diferentes técnicas, que sofrem uma "evolução funcional", e, como produtos históricos, surgem em um ambiente econômico, social e cultural determinado.

Logo, essa ciência diz respeito ao estudo da técnica do livro manuscrito ou do códice (anterior ao livro impresso) e nisto incluem-se todas as suas especificidades, tais quais: “[...] a história do manuscrito, a história das coleções de manuscritos, investigações sobre a localização atual dos manuscritos, problemas de catalogação, repertórios de catálogos, o comércio dos manuscritos, sua utilização, etc. [...]” (CAMBRAIA, 2005, p. 26).

Esses tipos de informações permitem que o crítico textual compreenda alguns dos motivos que levaram o texto a ser modificado no processo de sua transmissão e, para além disso, possibilitam que o pesquisador as use na própria descrição do códice ou do manuscrito 
em que esteja trabalhando filologicamente (CAMBRAIA, 2005). Partindo disso, reitera-se que a Codicologia:

[...] busca priorizar o estabelecimento de uma metodologia, a partir do estudo de Códices, para o estudo total dos manuscritos, entendidos cada um como realidade única. Une-se, especificamente, com a Paleografia no exame da cronologia de documentos e de outras datações, das palavras escritas erroneamente, da origem e da confecção de documentos e da procedência dos mesmos imediatamente anterior ao lugar onde se conservam [...] (ANDRADE, 2010, p. 10, grifo da autora).

Logo, somos levados a entender que é necessária a organização de uma metodologia que dê conta de todas as particularidades concernentes à produção, transmissão e ao suporte material do manuscrito, o qual possui características extrínsecas e intrínsecas, compreendidas como os aspectos inerentes tanto ao suporte material quanto à própria constituição do texto. Assim, a Codicologia e a Paleografia se unem no sentido de trazer à tona informações acerca de um determinado manuscrito, que até então estavam obscuras, o que facilita o trabalho do crítico textual no sentido de elucidar equívocos, procedentes da falta de informações imprescindíveis ao texto manuscrito.

Além disso, o aparato codicológico permite que o texto trabalhado seja descrito minuciosamente, já que uma das etapas da edição de um texto é a sua descrição, o que permite que o pesquisador conheça informações importantes sobre o manuscrito estudado. Pensando assim, podemos nos apropriar da afirmativa de que a Codicologia trabalha de "mãos dadas" não somente com a Paleografia, mas também com a Filologia e com a História, haja vista as suas contribuições para o trabalho do filólogo/crítico textual e do historiador.

Já a Ecdótica se configura como o campo de investigação que diz respeito ao estabelecimento do texto e à sua apresentação, sobretudo do texto literário. Mais do que isso, as normas gerais dessa disciplina são aplicáveis à publicação não apenas de textos literários, mas também de documentos históricos, filosóficos e religiosos. Logo, a Ecdótica pode ser definida como o "ponto de chegada" do trabalho do filólogo, o que quer dizer que se trata de uma disciplina parceira da Filologia, já que se originou desta, mais especificamente da "Filologia como comentário de textos". Embora a origem da Ecdótica se confunda com a da Crítica Textual, sendo, muitas vezes, ambas utilizadas como sinônimas, já que buscam a restituição de sua genuinidade, somente na década de 1940 é que o termo "Ecdótica" foi, de fato, adotado pelos pesquisadores da área (SPINA, 1977).

Em outras palavras, essa disciplina engloba as fases técnicas de edição e de apresentação de um texto ao público (CAMBRAIA, 2005) e, partindo disso, utilizamos o 
aparato da Ecdótica, a fim de apresentarmos os documentos editados e preparados para uma publicação, que servirá de apoio e/ou consulta para outros pesquisadores que tenham interesse em tal documentação.

Assim, além de disponibilizar, nesta tese, a edição filológica dos documentos, almejamos ampliar essa disponibilização através da criação, em um futuro próximo, de um website ou blog (por conta dos baixos custos financeiros), no qual será oferecido acesso a todos os documentos tratados filologicamente (incluindo-se o corpus desta tese e aqueles que ainda serão editados e que constam no terceiro quadro desta tese) para que outros pesquisadores, que queiram ter acesso àqueles materiais que contém a história, a cultura e a memória de Feira de Santana-BA do início do século XX, bem como de suas personalidades políticas, elencadas nos referidos textos, possam acessá-los em ambiente virtual.

Para atingir esse objetivo, pretendemos realizar a edição de todos os documentos listados, bem como levantar as suas abreviaturas e estudar o seu léxico para, a posteriori, disponibilizar virtualmente todo o material, incluindo-se as respectivas descrições codicológicas dos textos, que estarão editados, portanto, passíveis de serem acessados por outros pesquisadores, o que ampliará substancialmente a disponibilização desse material para um público composto por pesquisadores da Linguística, da Filologia, do Direito, da História etc., que se interesse por tal documentação.

Portanto, a Crítica Textual, a Filologia moderna, a Paleografia, a Codicologia e a Ecdótica possuem definições e objetivos distintos, embora caminhem na mesma direção quando o assunto é o tratamento de documentos escritos, sejam estes literários ou não. Especificamente, ao se tratar de um texto sob os cuidados da Filologia, esta concentra-se na explicação, restituição da sua genuinidade e na preparação de sua publicação, para as quais a Filologia se ampara naquelas e em outras ciências afins como, por exemplo, a História, com o intuito de esclarecer aspectos "obscuros" do texto que se tem em mãos (SPINA, 1977). Partindo-se disso, o filólogo "compila" tais conhecimentos e os utiliza em seu labor, principalmente quando vai decidir o tipo de edição a ser empregado.

\subsection{TIPOS DE EDIÇÃO DE TEXTOS}

Incontestavelmente, o trabalho do filólogo é de suma importância para conhecermos a história, a cultura e a língua das sociedades de outrora. Logo, o filólogo, ao lidar com textos, tem autonomia para decidir qual o procedimento técnico apropriado para cada documento. 
Dentre os procedimentos possíveis, podemos citar a edição de textos, entendida como o conjunto de procedimentos necessários para a seleção, descrição e preparação do texto para torná-lo publicável, logo acessível ao público a que se destina. Nesse sentido, a edição permite que as informações textuais sejam perpetuadas para que outras gerações também tenham acesso aos fatos da língua, bem como aos fatos da cultura, da história, da organização social e geográfica, atestados em documentos produzidos em épocas pretéritas.

Partindo-se disso, adentramos no âmbito da classificação tipológica das edições, a qual julgamos importante constar nesta seção por entendermos que as respectivas classificações alicerçadas em algumas obras de autores consagrados, portanto mencionadas em vários trabalhos de Filologia Textual - dialogam com o nosso interesse em discriminar as acepções adotadas para os tipos de edição, mais especificamente aqueles que serão definidos para o corpus desta tese.

Assim, dentre os tipos de edição considerados monotestemunhais e politestemunhais, decidimos trazer três autores que subdividem e explicam o que deve ser levado em consideração pelo filólogo ao decidir qual o tipo de edição apropriado para cada documento. Sobre isso, Melo (1971, p. 37) diz que o filólogo “[...] deve ser capaz de discriminar as edições e valer-se sempre dos bons textos". Nesta seara, ele ainda enfatiza que o filólogo pode realizar quatro tipos de edições: edição princeps ou príncipe, edição diplomática, edição crítica e edição fac-similar. A primeira se refere à primeira edição de uma obra antiga. A segunda consiste na reprodução fiel e meticulosa de uma outra edição, mantendo-se as abreviaturas, os erros manuscritos ou tipográficos, a pontuação, a ortografia etc. A terceira é a que "[...] procura estabelecer o texto perfeito, confrontando manuscritos ou edições de vida do autor e anotando variantes; além disso, desfaz as abreviaturas [...] corrige os erros tipográficos, interpreta os passos obscuros [...]" (MELO, 1971, p. 38), e o quarto e último tipo de edição trata da reprodução fotográfica do texto.

Spina (1977), por sua vez, esclarece-nos que, dentro da reconstituição textual, há formas de reprodução de um texto, que se subdividem em quatro tipos, a saber: a reprodução mecânica, a reprodução diplomática, a transcrição diplomático-interpretativa e o texto crítico. O primeiro tipo é aquele em que se faz a reprodução do texto por meios mecânicos, através de fotografia, fototipia ou xerografia. Neste caso, o fac-símile do texto é a sua fotografia/xerografia que "[...] reproduz com muita fidelidade as características do original [...]” (SPINA, 1977, p. 78). O segundo tipo, por sua vez, é aquele em que a reprodução consiste em uma "completa e perfeita cópia" do texto, respeitando-se a grafia, as abreviaturas, as ligaduras, a pontuação etc. 
O terceiro tipo, também denominado de "transcrição semidiplomática", é aquele em que há uma tentativa de melhoramento do texto, no sentido de realizar a divisão das palavras, o desdobramento de abreviaturas e, em alguns casos, a interferência na pontuação. Dentro desse tipo, ainda há a transcrição paleográfica que consiste em uma descrição minuciosa de todas as características caligráficas do texto, a saber: “[...] redação primitiva, correções e minúsculos sinais introduzidos pelos revisores subseqüentes do manuscrito, o recorte diferente de letras e as tintas utilizadas, a sobreposição de duas escritas, retoques feitos em épocas diferentes, um sem-número de peculiaridades do texto [...]" (SPINA, 1977, p. 79), que indicam, necessariamente, uma interferência mais profunda do editor nesses modelos de transcrição do que na reprodução diplomática.

O quarto e último tipo é aquele em que se estabelece um texto crítico, amparado nas leis e normas da Crítica Textual e no qual há

[...] a reprodução mais correta possível de um original, numa tentativa de alcançar com a maior fidelidade imaginável a última forma desejada pelo seu autor [...] A edição crítica tem por finalidade restituir ao texto a sua genuinidade, facilitar a sua leitura, torná-lo inteligível, valorizá-lo e permitir à crítica literária o exercício tranqüilo de sua tarefa [...] (SPINA, 1977, p. 79-80).

Logo, trata-se de um tipo de edição que exige do editor bastante habilidade, estudo e intuição crítica (SPINA, 1977). Cambraia, à seu modo e em seu livro intitulado Introdução à Crítica Textual (2005), utiliza-se dos tipos de edição existentes e os subdividem em dois grandes grupos: edições monotestemunhais e politestemunhais. As primeiras são aquelas que se destinam a textos, que possuem um único testemunho ou original, e dentro deste grupo estão os tipos de edição conhecidos como fac-similar, diplomática, semidiplomática, interpretativa e modernizada.

A edição fac-similar consiste na reprodução, através de meios mecânicos como fotografia, escanerização etc., da imagem do documento. Neste tipo de edição a preocupação central do editor é permitir que o acesso direto ao testemunho seja feito sem, necessariamente, o leitor e/ou o próprio editor precisarem manusear o documento. Além disso, a fotografia digital ou a escanerização do texto também auxilia o editor, através dos meios digitais, no processo de edição do documento, o qual pode ser feito a partir da ampliação, por meio da ferramenta digital zoom, dos fac-símiles no computador, tablet, notebook etc., o que corrobora 
a assertiva de que o ambiente digital pode e deve ser usado em parceria com o labor filológico $^{117}$.

A edição diplomática é aquela em que o grau de intervenção do editor é baixo, já que se faz uma transcrição conservadora de todos os elementos do texto, o que contribui para a existência de dois pontos de vista acerca deste tipo de edição. O primeiro diz que este tipo de edição facilita a leitura do texto, já que o leitor não precisará desvendar as formas gráficas da escrita original, o que demandaria mais tempo e conhecimento da história da escrita. $\mathrm{O}$ segundo ponto de vista preconiza que este tipo de edição se restringe a pesquisadores, posto que o uso das abreviaturas, da separação silábica e da união ou separação de palavras se mantêm na transcrição do texto, o que pode dificultar o entendimento das informações por parte de leitores sem formação especializada. Devido a isso, afirma-se, costumeiramente, que a edição diplomática é destinada apenas a pesquisadores que possuem conhecimento da história e desenvolvimento das línguas.

A edição semidiplomática, também denominada paleográfica, paradiplomática ou diplomático-interpretativa (CAMBRAIA, 2005), é assim classificada por possuir um grau médio de intervenção do editor, o que quer dizer que este pode, desde que avisado previamente, interferir no texto no sentido de torná-lo mais compreensível para o leitor. Neste tipo de edição, opta-se, por exemplo, por desdobrar abreviaturas, inserir ou suprimir elementos por meio de conjecturas, unir palavras separadas e/ ou separar palavras unidas. Assim, o que vai definir quais as intervenções a serem feitas são os critérios de edição adotados neste tipo de edição filológica. Logo, é de se esperar que quando se trata da edição semidiplomática, uma ou outra interferência por parte do editor pode ser feita, o que dependerá dos objetivos, dentre os quais podemos citar a facilitação da leitura do texto por parte de um público menos especializado e a tentativa de resolução de falhas existentes no processo de produção ou cópia do texto.

Já a edição interpretativa é aquela em que há o grau máximo de intervenção feita pelo editor, ou seja, este tem autonomia para, por exemplo, além de desdobrar abreviaturas, fazer conjecturas que vão além das chamadas falhas óbvias, uniformizar graficamente o texto, sem interferir nas variantes fonológicas, morfológicas, sintáticas e lexicais, mas pode uniformizar pontuação, paragrafação etc., que permitem que haja possíveis leituras do texto (C.f. CAMBRAIA, 2005).

\footnotetext{
${ }^{117}$ Sobre as edições em ambientes digitais, há variados trabalhos que abordam esse assunto e que apresentam resultados de pesquisas nessa área. A título de exemplo, podemos mencionar os trabalhos de Chartier (1994), Andrade e Lose (2012), Magalhães e Lose (2016), Monte e Paixão de Sousa (2017) etc.
} 
Por fim e não menos importante, a edição modernizada é aquela em que, para além da interpretativa, há uma uniformização linguística no sentido de corrigir variantes fonológicas, morfológicas, sintáticas e lexicais, com o objetivo de disponibilizar uma versão do texto mais próxima possível da norma gramatical vigente. Geralmente, este tipo de edição é realizado quando o pesquisador tem em mente ofertar ao público geral ou leigo um texto que não dê margem à dificuldade de leitura.

Para além dos tipos de edição monotestemunhais, há também as politestemunhais, subdivididas por Cambraia (2005) como crítica e genética. A primeira é baseada no confronto de dois ou mais testemunhos de um único texto, cujo objetivo geral é reconstituir a última forma dada ao texto pelo seu autor. Isso quer dizer que o crítico textual reúne e depois realiza o cotejo dos testemunhos encontrados, a fim de estabelecer aqueles que seriam ou não genuínos. Em outras palavras, este tipo de edição é caracterizado, por alguns autores, como sendo a base do fazer Crítica Textual, principalmente porque este tipo de edição teve o seu início voltado para o estabelecimento do original perdido, na Antiguidade, mas, não apenas isso, à garantia de genuinidade do texto estabelecido criticamente.

A edição genética, por outro lado, é aquela em que o que interessa ao pesquisador é o processo de produção do texto, desde os seus rascunhos até a sua versão publicada. Logo, não é o produto final que interessa ao crítico genético, mas todos os processos envolvidos na criação do texto, levando-se em consideração as rasuras e emendas feitas pelo autor. Sendo assim, neste tipo de edição, assim como na edição crítica, a comparação de dois ou mais testemunhos autógrafos e/ou idiógrafos é imprescindível para o trabalho do filólogo, haja vista que tanto os primeiros rascunhos quanto a versão final publicada pelo autor possuem papéis dependentes para o trabalho do crítico genético.

Contudo, apesar de Cambraia (2005) não ter mencionado à época da publicação do seu livro, há, na atualidade, a partir da existência desses dois tipos de edição politestemunhais, muitos pesquisadores de diversas universidades brasileiras e internacionais que têm se dedicado a aliar o método de edição crítica com a genética, surgindo, assim, o termo edição crítico-genética, para a qual o objetivo central tem sido fundir e difundir os dois tipos de edição. Em outros termos, neste tipo de edição, o pesquisador/crítico-genético busca apresentar ao público todos os processos envolvidos na transmissão de um determinado texto, desde os primeiros rabiscos feitos pelo autor até o confronto de todos os testemunhos existentes, incluindo-se nisso todas as edições já publicadas e acessíveis ao crítico-genético.

Como exemplos de projetos de pesquisa que trabalham com esse tipo de edição no Brasil, podemos mencionar, por exemplo, na Bahia, o Projeto de Pesquisa Edição e estudo de 
textos teatrais censurados no periodo da ditadura na Bahia (parte V): por uma relação entre filologia, crítica genética e sociologia dos textos, coordenado pela Profa. Dra. Rosa Borges dos Santos e subsidiado na Universidade Federal da Bahia (UFBA); em São Paulo, o Projeto de Pesquisa Processos de criação nas artes e na literatura, coordenado pelo Prof. Dr. Philippe Leon Marie Ghislain Willemart, na Universidade de São Paulo (USP); no Paraná, o Projeto de Pesquisa Arquivos de criação: diálogos entre linguagens, coordenado pela Profa. Dra. Edina Regina Pugas Panichi, na Universidade Estadual de Londrina (UEL) ${ }^{118}$; entre muitos outros.

Como se pode notar, Melo (1971) e Spina (1977) sinalizam a existência de apenas 4 tipos de edição, enquanto que Cambraia (2005) aponta a existência de dois grupos com 5 e 2 tipos de edição, respectivamente. Em comum, esses três autores descrevem cada tipo de edição, embora com nomenclaturas divergentes, como aqueles que possuem uma equivalência entre as definições de edição fac-similar, diplomática, semidiplomática e crítica, e entre as respectivas técnicas de reprodução do texto.

Assim, partindo dos tipos de edição apontados, muitos pesquisadores têm se apropriado de tais modelos para a realização de suas pesquisas, cujo corpus são textos literários e não literários. Consequentemente, vários grupos de pesquisa têm se debruçado na atividade de editar textos de variadas épocas e de variadas tipologias documentais, o que contribui, sobremaneira, para a preservação da memória sócio-histórica-cultural de um determinado povo e lugar.

No nosso caso, decidimos utilizar, dentre os tipos de edição apontados, dois para serem aplicados ao corpus do nosso trabalho: a edição fac-similar e a semidiplomática, porque ambos estão centrados na reconstituição textual, inserida na função substantiva da filologia (SPINA, 1977). À guisa de explicação, optamos por adotar o termo edição facsimilar por entendermos que ele é considerado, pelos autores mencionados, como o registro que se faz através, por exemplo, da fotografia digital de todo o documento, que necessita de alguma intervenção do editor, haja vista que, durante a captura das imagens dos documentos, há um "[...] processo de transposição de documentos manuscritos para o meio digital [...]" (BRITO, 2015, p. 68), o que nos faz entender que o ângulo, a luz, a focalização, o enquadramento, a profundidade, a distância etc. interferem na qualidade do material transposto para o meio digital (BRITO, 2015), logo são elementos que influenciam na qualidade da fotografia digital do manuscrito.

\footnotetext{
${ }^{118}$ É importante frisar que todas essas informações, referentes aos Projetos de Pesquisa acerca das edições crítico-genéticas realizadas no Brasil, foram retiradas da Plataforma Lattes, acessada em maio de 2020.
} 
Outra justificativa para a escolha da edição fac-similar é o fato de as fotografias digitais nos auxiliarem no processo de edição dos processos jurídicos trabalhados, já que o uso daquelas no computador e/ou no tablet facilita na visualização de todos os aspectos do texto, incluindo-se nisso os codicológicos, que permitem uma descrição minuciosa de todo o original, o que se constitui como uma ferramenta importante para o filólogo, posto que, em seu labor, este registra todo o estado de conservação do documento durante o processo de edição textual sem, contudo, precisar manusear inúmeras vezes o original, o que acabaria desgastando ainda mais o suporte material do manuscrito. Logo, a edição fac-similar restringe o manuseio do documento original, o que consequentemente contribui para a sua preservação.

Outra vantagem que nos levou a escolher este tipo de edição é o fato de a fotografia digital permitir a preservação de todas as informações dos documentos, as quais podem ser claramente observadas a partir das fotografias, principalmente porque pretendemos, em breve, disponibilizar o material editado em ambiente virtual, no qual os fac-símiles poderão ser consultados por outros pesquisadores, o que ampliará o acesso àquela documentação.

Sobre a edição semidiplomática, optamos por esta por entendermos que os documentos descritos necessitam urgentemente de uma edição, antes que os suportes materiais estejam completamente deteriorados, portanto, impossibilitados de fazermos a sua leitura, e pelo fato deste tipo de edição permitir uma intervenção mediana por parte do editor, o que quer dizer que as características do texto, tais como pontuação, acentuação, paragrafação, ortografia, assinaturas, separação vocabular etc. são mantidas, interferindo-se apenas no que concerne aos desdobramentos de abreviaturas, os quais são devidamente sinalizados na edição, o que permite que os textos sejam, posteriormente, utilizados ou consultados por outros pesquisadores que tenham interesse em um texto, que seja representativo da língua e do período em que foi escrito/lavrado.

\subsection{DA DESCRIÇÃO À EDIÇÃO DE TEXTOS: ESQUADRINHAMENTO DO CORPUS}

Nesta subseção e nas subsequentes, apresentamos a descrição e a edição dos documentos que compõem o corpus desta tese. Antes disso, porém, trazemos as definições que adotamos para os termos descrições extrínseca e intrínseca, pelo fato de serem reiterados, inúmeras vezes, ao longo do nosso trabalho e por compreendermos a necessidade de deixá-los claramente caracterizados, a fim de evitar quaisquer dúvidas quanto à acepção que tomamos para aqueles termos. 
Assim, para chegar à uma definição do que seria caracterizado, neste trabalho, como aspectos extrínsecos e intrínsecos, consultamos três obras, escritas por autores que têm variados trabalhos publicados na área: Bellotto (2002), Berwanger e Leal (2008) e Lose et al. (2009). Destes, a primeira autora define aspectos extrínsecos como aqueles que dizem respeito à estrutura física e à forma de apresentação do texto, ou seja, relaciona-se com "[...] a configuração que assume um documento de acordo com o sistema de signos de que seus executores se serviram para registrar a mensagem [...]" (BELLOTTO, 2002, p. 24), e os aspectos intrínsecos como aqueles que se relacionam com o conteúdo do documento e "com a natureza da sua proveniência e função".

Berwanger e Leal, por outro lado, em seu livro Noções de Paleografia e de Diplomática (2008), mais especificamente no capítulo intitulado Noções de Diplomática, afirmam que quando se trata da Crítica Diplomática, esta considera a forma dos diplomas, ou seja, os seus caracteres, que compreendem dois aspectos: os extrínsecos ou externos, que se referem à "[...] matéria empregada (papel, pergaminho, papiro, tintas, cores, iluminuras, encadernação", à escrita (tipo de letra, assinaturas) e ao selo [...]” (BERWANGER; LEAL, 2008, p. 28); e os intrínsecos ou internos, que dizem respeito “[...] à língua, ao teor e ao texto" (BERWANGER; LEAL, 2008, p. 28).

Semelhantemente, Lose et al., no livro Dietário (1582-1815) do Mosteiro de São Bento da Bahia: edição diplomática (2009), definem a descrição extrínseca como:

[...] a apresentação minuciosa das características físicas da obra: tamanho do suporte e da mancha escrita, quantidade de fólios, tipo de letra, indicação de presença de letras ornadas e descrição das suas cacterísticas, tinta utilizada, quantidade de linhas escritas por fólio, estado de conservação do documento, indicação da presença de ornamentos e descrição das susas (sic) características, em suma, uma descrição detalhada das características externas da obra, deixando-se de fora, neste momento, o seu conteúdo e a sua língua (LOSE et al., 2009, p. 34).

Por outro lado, esclarecem-nos ainda que a descrição intrínseca se caracteriza

[...] como aquelas características ainda não ligadas à "língua", mas sim às peculiaridades "ortográficas" de cada scriptor. É importante fazer uma ressalva para o fato de que "ortografia" [...] não deve ser pensada como a escrita correta, mas sim como a forma de escrever e de dispor e combinar os grafemas, criando, desta forma, fatos linguísticos a serem analisados (LOSE et al., 2009, p. 49).

Logo, os autores comungam, nessas três obras, da ideia de que os aspectos extrínsecos dizem respeito às características inerentes ao suporte material, ao tipo de letra, às assinaturas, à forma de apresentação do texto e aos elementos presentes no suporte material, tais como: 
selos, carimbos, filigranas etc. Na mesma direção, Bellotto (2002), Berwanger e Leal (2008) e Lose et al. (2009) compartilham da acepção de que os aspectos intrínsecos estão relacionados ao conteúdo do texto, à sua proveniência e função e às particularidades linguísticas ou ortográficas de cada scriptor.

No nosso caso, não somente assumimos as mesmas acepções defendidas pelos referidos autores, mas nos apropriamos daquelas para realizarmos as descrições extrínseca e intrínseca do corpus, bem como para, a partir disso, apresentarmos os critérios de edição adotados e a edição semidiplomática, propriamente dita, dos dois testamentos e do primeiro volume de um dos inventários listados no quadro 3 desta tese, por entendermos que, como o nosso objetivo futuro é editar todos os documentos descritos, deveríamos começar pela edição dos processos que nos "contam" os desejos, os anseios e as relações dos patriarcas para, em seguida, partirmos para os documentos em que os seus descendentes aparecem como partes interessadas e cujos interesses se relacionam, direta ou indiretamente, com o corpus definido para esta tese.

Na subseção seguinte tratamos das descrições extrínseca e intrínseca do corpus, cujo objetivo é apresentar os detalhes sobre como se encontra, atualmente, cada documento selecionado, já que acreditamos que essas informações, além de fazerem parte do labor filológico, servirão como base para que pesquisadores, em períodos futuros, saibam como se encontra/encontrava cada documento no momento em que ele foi filologicamente editado.

\subsubsection{Descrição dos aspectos codicológicos e paleográficos do corpus}

Nesta subseção, realizamos as descrições extrínseca e intrínseca do corpus, alicerçadas na Codicologia e na Paleografia, para as quais são adotados variados termos e procedimentos, que são descritos por distintos autores, dentre os quais podemos destacar Cambraia (2005), que nos fornece definições tanto da Codicologia quanto da Paleografia, bem como dois "guias básicos de descrição codicológica e bibliográfica”, que podem ser aplicados a textos manuscritos e a obras bibliográficas, e aspectos que devem ser observados na descrição paleográfica, a saber: a classificação da escrita, localização e datação; a descrição sucinta das características da escrita e do sistema de sinais abreviativos, a descrição dos elementos nãoalfabéticos e os pontos de dificuldade na leitura, e as soluções adotadas.

Em uma perspectiva mais ampla, Elena Rodríguez Díaz (2016) apresenta a Codicologia e o sistema de organização dos códices, dentro do qual estão relacionados o 
formato do livro, os suportes empregados, a composição, a tipologia e os sistemas de ordenação dos cadernos, a preparação das páginas, a cópia dos textos, as iluminuras, as miniaturas, as capitulares, as margens e as ornamentações de ambas, e "outros elementos decorativos", bem como as práticas adotadas nas correções e nas encadernações dos códices. Em direção semelhante, Dias (2018) utiliza a mesma descrição ao falar do sistema de organização dos cadernos, mais especificamente dos usos das assinaturas, dos reclamos, da paginação e da foliação dos códices.

Em contrapartida, Ávila Seoane (2016) nos oferece, além de uma divisão conceitual entre o que é caracterizado como uma "Paleografia de leitura", uma "Paleografia críticoanalítica" e uma "Paleografia e história da escrita", um conjunto de terminologias a serem adotadas durante uma análise paleográfica. Sobre as terminologias propostas, apresentamos a seguir a sua síntese:

- formato ou morfologia, que diz respeito ao aspecto arquetípico de cada signo, sem levar em conta os traços individuais da escrita de cada escrevente;

- estilo, que se refere às particularidades de cada escrevente;

- ritmo, que é determinado pela rapidez na execução dos signos, ou seja, quanto mais ágil o escrevente mais cursividade a sua escrita apresenta;

- peso, que é a proporção entre traços "grossos e finos";

- ductus, que é o número de traços que contém cada grafia, assim como sua ordem e sentido, ou seja, à medida que aumenta a cursividade, o traçado se simplifica, o que resulta de grande utilidade para entender a "evolução" morfológica de cada caractere;

- módulo, que alude ao tamanho das grafias, ou seja, à largura e à altura dos signos, proporcionadas pelas suas dimensões tanto na linha superior quanto na inferior;

- ângulo de escrita, que está relacionado com a superfície de trabalho, a posição do suporte e a forma de traçar a letra com a ponta do instrumento de escrita e a postura do escrevente;

- ângulo de inclinação, que é observado a partir das hastes superiores e inferiores em relação à caixa das linhas superior e inferior, o quer dizer que, para medi-los, deve-se levar em consideração as letras que deveriam ser retas em função do ângulo do "d" uncial que se fazia à esquerda. Em função desse ângulo, distinguem-se as escritas retas, as escritas de destros (inclinadas à direita) e as escritas de canhotos (inclinadas à esquerda);

- caixa de escrita, que é a área onde se escreve, limitada pelas margens, dentro da qual se perfilam as linhas; 
- caixa de linha ${ }^{119}$, que é o espaço delimitado por duas linhas imaginárias, horizontais e paralelas, que demarcam o espaço superior e inferior para o corpo das letras;

- linha de escrita, que é a linha inferior da caixa da linha;

- espaço interlinear, que é o espaço situado entre duas caixas de linhas. Neste espaço, encontram-se as hastes superiores e inferiores das letras e, em alguns casos, letras sobrepostas, signos abreviativos, correções e anotações;

- nexos, que se definem tradicionalmente como o conjunto gráfico de duas ou mais letras, que compartilham ao menos um dos traços, realizados de maneira premeditada, que é próprio das escritas sentadas;

- ligaduras, que são compostas por traços que unem duas palavras consecutivas, que deveriam ter sido traçadas separadamente.

Partindo do conjunto de terminologias codicológicas e paleográficas apresentadas nas obras dos autores mencionados e de alguns termos extraídos da Bibliografia Material, relacionamos as descrições extrínseca e intrínseca do corpus, iniciada pelo testamento de Dona Maximiana de Almeida Motta, armazenado sob a cota ${ }^{120}$ : Estante 06, Caixa 166 e Documento 2569 no CEDOC/UEFS, redigido e lacrado em 1915 e aberto e lido em 1918, na cidade de Feira de Santana-BA. O documento - além de ter sido escrito em papel almaço, em tinta preta, em 10 fólios rectos e versos, dos quais os fólios $1 \mathrm{v}, 7 \mathrm{v}$ e $8 \mathrm{v}$ estão em branco, os fólios $7 \mathrm{r}$ e o $8 \mathrm{r}$ são formulários manualmente preenchidos, e os demais manuscritos - é composto por 4 in-planos ${ }^{121}$ (f. $1 \mathrm{r} / 1 \mathrm{v}, 7 \mathrm{r} / 7 \mathrm{v}, 8 \mathrm{r} / 8 \mathrm{v}$ e $\left.10 \mathrm{r} / \mathrm{v}\right)$ e 4 in-fólios $(2 \mathrm{r} / 2 \mathrm{v}$ e $5 \mathrm{r} / 5 \mathrm{v}, 3 \mathrm{r} / 3 \mathrm{v}$ e $4 \mathrm{r} / 4 \mathrm{v}, 6 \mathrm{r} / 6 \mathrm{v}$ e $9 \mathrm{r} / 9 \mathrm{v})$. Sobre estes, é oportuno destacar que os fólios $1 \mathrm{v}$ e $10 \mathrm{r}$ eram um in-fólio, contudo foram, por algum motivo, separados em sua dobra, tornando-se, portanto, in-planos, como verificado a seguir.

\footnotetext{
${ }^{119}$ A definição deste termo é semelhante à de "regramento ideal", constante em Marquilhas (2000).

${ }^{120}$ Termo adotado por Cambraia (2005) no seu "guia básico de descrição codicológica".

121 Adotamos os termos utilizados por Cambraia (2005), Dias (2018) e Elena Rodríguez Díaz (2016) para a descrição dos manuscritos que trabalhamos.
} 
Figura 30 - Separação dos fólios 1v e 10r pela dobra
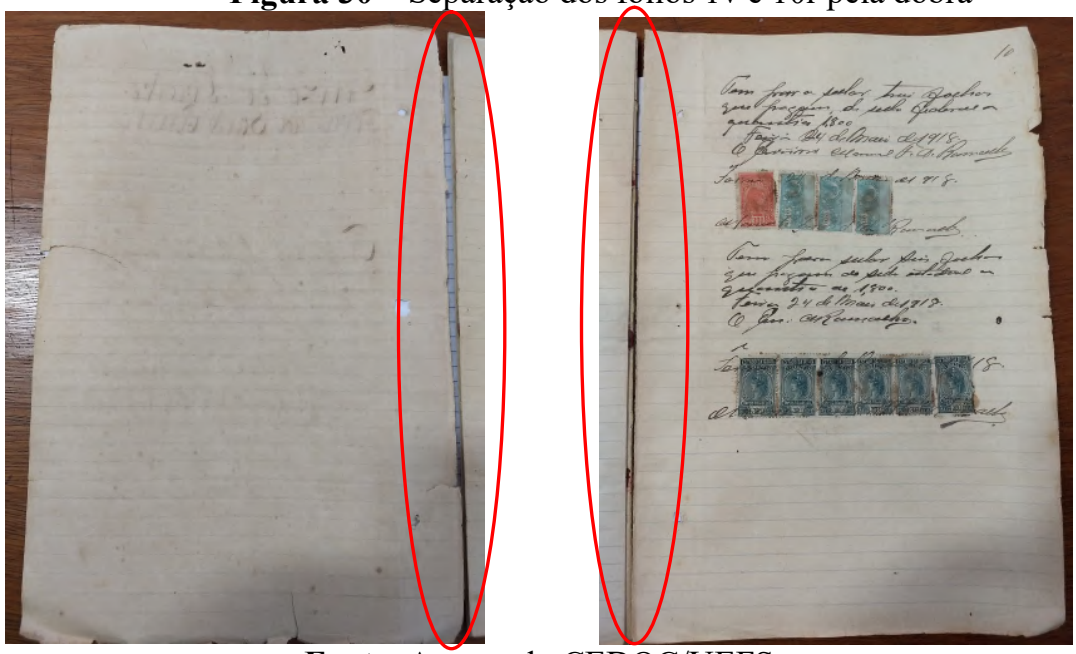

Fonte: Acervo do CEDOC/UEFS

Ainda no in-plano 1r há uma ficha de identificação - com informações sobre o fórum em que o documento foi lavrado, a sua classificação no acervo, a seção, a série, a subsérie, a tipologia, a comarca, o número de fólios, a localidade, o período e as partes envolvidas no processo - inserida, através de uma colagem, no primeiro fólio do documento pelos estagiários do CEDOC/UEFS, a fim de facilitar a sua catalogação e localização em uma das caixasarquivo do acervo, como pode ser observada na figura a seguir.

Figura 31 - Ficha de identificação inserida no fólio 1r pelos estagiários do CEDOC/UEFS
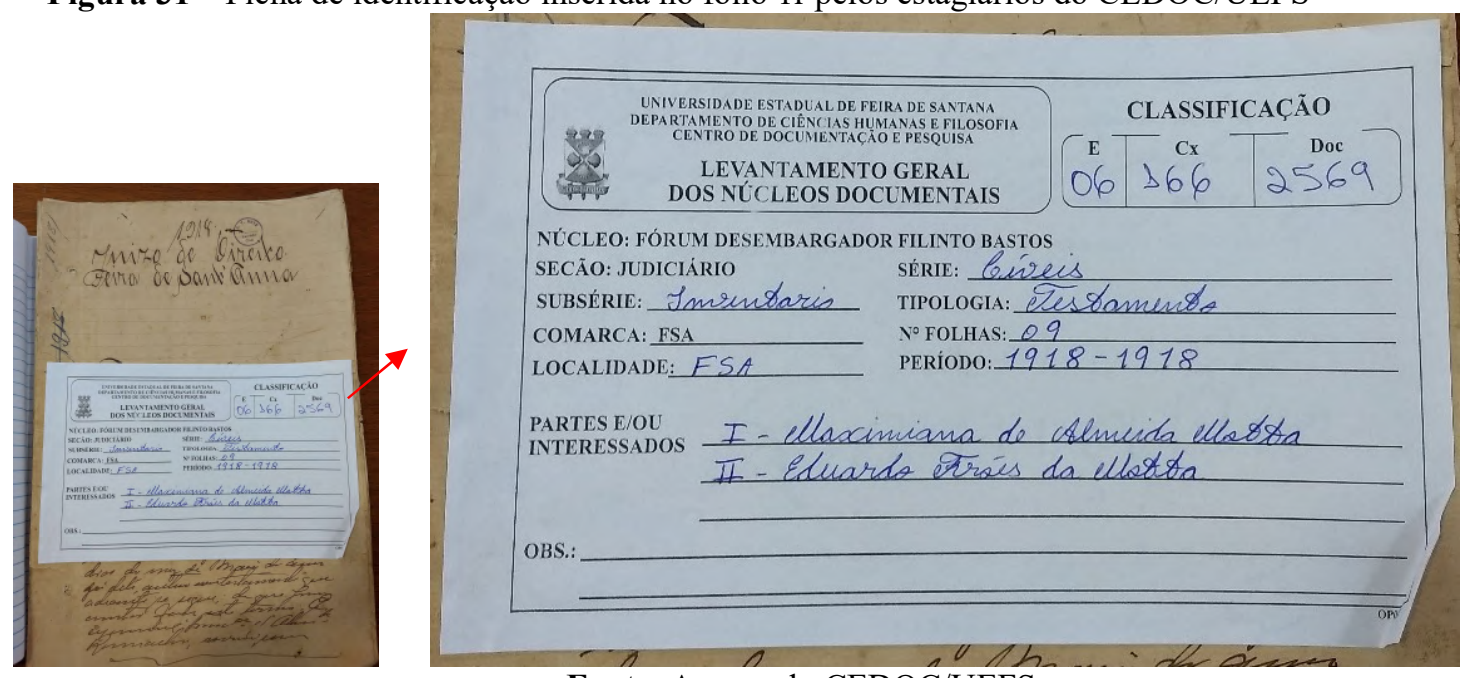

Fonte: Acervo do CEDOC/UEFS

No in-plano 1r há um carimbo molhado que, segundo García Aguilar (2011), é aquele que foi estampado em tinta e é um dos mais vistos nas obras bibliográficas consideradas antigas. Além desse tipo de carimbo, também se verifica, nos documentos estudados, a aplicação de carimbos secos, feitos por pressão, que deixam uma marca em alto relevo no papel. Contudo, apesar da autora tratar da inserção desses dois tipos de carimbos como 
elementos que ajudam na identificação da proveniência bibliográfica, constatamos que o mesmo método é observado, e foi mantido ao longo dos anos, especificamente nos manuscritos lavrados na primeira metade do século XX nas cidades que compõem o Sertão baiano e cujos documentos estão disponíveis para pesquisa no acervo do CEDOC/UEFS.

Logo, assim como a Codicologia, a Bibliografia Material, entendida como o campo de "[...] estudo da técnica do livro impresso" (CAMBRAIA, 2005, p. 29, grifo do autor) e como uma prática da área da Biblioteconomia, constitui-se ciência primordial para a descrição das materialidades dos textos, principalmente os bibliográficos, que oferecem subsídios para o conhecimento da "História do Livro" (GARCÍA AGUILAR, 2011), mas também dos manuscritos, quando apresentam problemas relacionados à transmissão dos textos (CAMBRAIA, 2005). Exemplo de semelhança entre a descrição de obras bibliográficas e manuscritas são, por exemplo, os termos adotados por Cambraia (2005) nos seus "guias básicos de descrição codicológica e bibliográfica", nos quais os termos "folha de rosto, colofão, suporte material, composição, particularidades, encadernação, conteúdo e descrições prévias" são utilizados para descrever ambas as materialidades.

Partindo disso e da terminologia usada por García Aguilar (2011), compreendemos que os carimbos constantes nos documentos estudados se classificam como molhados ou secos, conforme observamos a seguir. Além dessa classificação, também transcrevemos as inscrições dos carimbos e apresentamos as suas localizações nos manuscritos, bem como a existência de datações, a cor da tinta usada, as danificações causadas ao suporte material e os demais elementos que julgamos pertinentes à descrição codicológica.

Assim, o carimbo molhado do fólio 1r tem a inscrição "E. V. REIS | Fls. | Escrivão Civel" e apresenta $21 \mathrm{~mm}$ de diâmetro e está localizado na margem centro-direita superior. No mesmo fólio, há 3 furos na vertical da margem esquerda, dos quais o superior e o inferior têm $50 \mathrm{~mm}$ de diâmetro e o central $80 \mathrm{~mm}$, sendo a distância entre cada um de $180 \mathrm{~mm}$. Além disso, há duas datações nesse fólio: a primeira, "24/3/1918”, feita com tinta azul e anulada pelo respectivo escrevente, a qual se encontra na vertical da margem centro-esquerda superior e embaixo da ficha de identificação; e a segunda, "1918", em tinta preta e na vertical da margem superior esquerda. Por fim, no mesmo fólio também tem um rasgão de $50 \mathrm{~mm}$ de comprimento na margem centro-direita superior, conforme detalhado na figura seguinte. 
Figura 32 - Detalhes para o carimbo, os furos, as inscrições e o rasgão no fólio $1 \mathrm{r}$
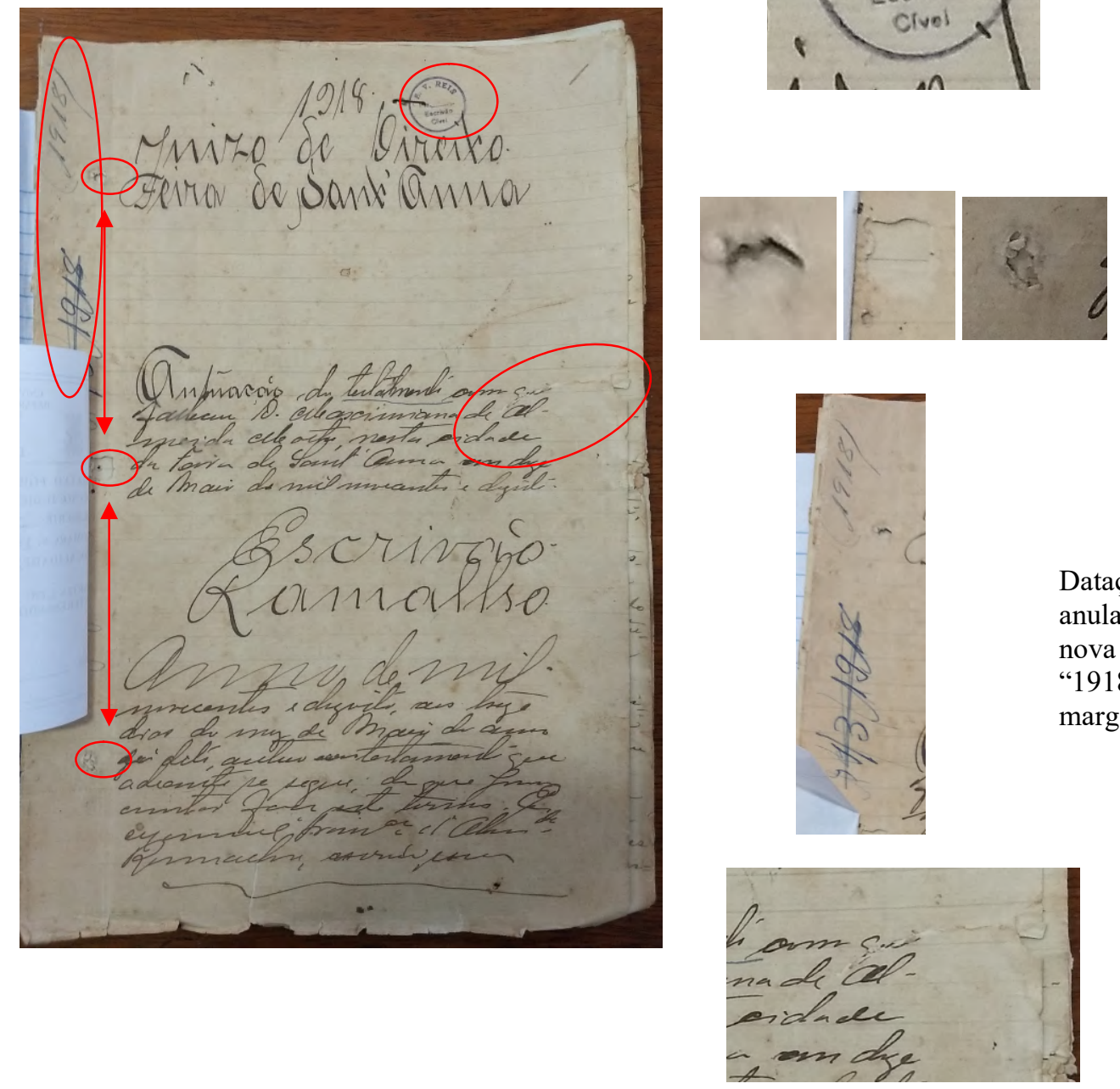

Fonte: Acervo do CEDOC/UEFS

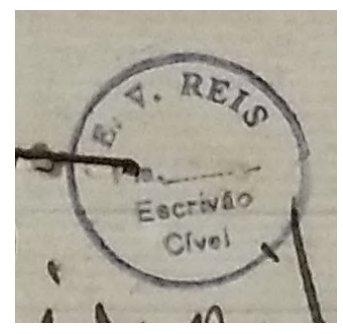

Carimbo molhado com $21 \mathrm{~mm}$ de diâmetro na margem centrodireita superior com a inscrição "E. V. REIS | Fls. | Escrivão Civel"

Furos na vertical da margem esquerda com $50 \mathrm{~mm}, 80 \mathrm{~mm} \mathrm{e}$ $50 \mathrm{~mm} \quad \mathrm{de}$ diâmetro, respectivamente

Datação "24/3/1918” anulada pelo escrevente e nova datação inserida: "1918" na vertical da margem esquerda
Rasgão de $50 \mathrm{~mm}$ de comprimento na margem centro-direita superior

No in-plano 1v há uma marca d'água que foi produzida, segundo Cabezas Fontanilla (2016), durante o processo de produção do papel, no qual a acomodação da pasta sobre os fios produz marcas singulares, geralmente, no centro do papel, as quais servem como "marca ou distintivo" dos "papeleiros", ou seja, indicam a proveniência do papel. Com a mesma técnica, foram criadas linhas translúcidas, denominadas pontusais (verticais e separadas entre si) e vergaturas (perpendiculares e mais juntas), visíveis no papel, depois de seco. A observação desses elementos é mais nítida quando o papel é colocado em um negatoscópio, equipamento que emite luz ultravioleta mas, nos casos em que os arquivos públicos não possuam tais equipamentos (realidade, por exemplo, do CEDOC/UEFS), o procedimento adotado para visualizar as marcas d'água, os pontusais e as vergaturas, quando existem, é a colocação do 
papel contra a luz e, com esse método, faz-se a medição das distâncias entre os pontusais e entre as vergaturas, a qual, geralmente, é aproximada por conta da falta do equipamento apropriado.

Sobre as marcas d'água, Ataíde e Melo (1926) apresenta uma extensa lista de classificação das marcas d'água, que se apresentam nas obras manuscritas e bibliográficas. Faria e Pericão (2008), por sua vez, oferecem-nos uma caracterização das marcas d'água enquanto elementos que "[...] apresentam desenhos muito variados: escudos ${ }^{122}$, emblemas heráldicos, castelos, figuras mitológicas [...]" etc. Por fim, Monte (2015) também faz uma descrição pormenorizada das marcas d'água presentes em correspondências paulistas, que circularam entre 1765 a 1775 . As obras desses autores tem nos auxiliado na compreensão das estruturas e dos desenhos das marcas d'água, que encontramos nos documentos que estudamos, e por isso a sua menção neste texto.

Partindo-se disso, realizamos a medição das distâncias entre os pontusais e também identificamos que no in-plano 1v há uma marca d'água, sem filigrana, composta apenas pela inscrição "FINE", que se encontra entre as linhas dos $2^{\circ}, 3^{\circ}$ e $4^{\circ}$ pontusais, os quais possuem uma distância aproximada de $30 \mathrm{~mm}$.

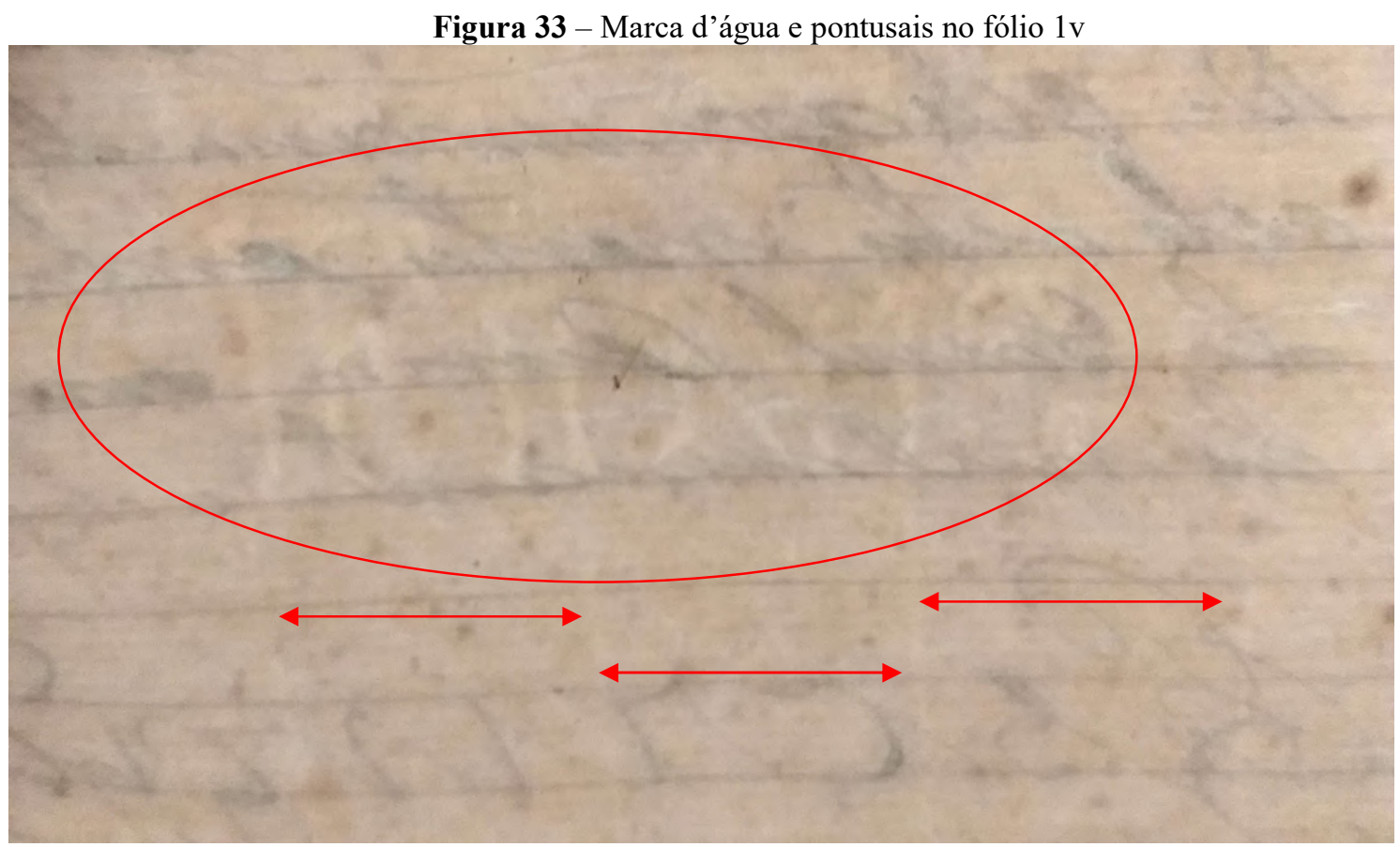

Fonte: Acervo do CEDOC/UEFS

${ }^{122}$ Vale ressaltar que tanto Ataíde e Melo (1926) quanto Faria e Pericão (2008) utilizam o termo escudo, ao invés de brasão, para descrever um dos tipos de filigranas e, seguindo as suas obras, adotamos o mesmo termo neste trabalho. 
Os in-fólios 2r, 2v, 3r, 3v, 4r e 4v, por sua vez, permanecem presos por um barbante branco que os costura, e nos mesmos fólios há pequenos furos, em grupos de 2, que se assemelham a perfurações ocasionadas por grampeações feitas com grampeador, que estão próximas à marca de dobra do papel.

Figura 34 - Detalhe para o barbante que costura os fólios $2 r, 2 v, 3 r, 3 v$, 4r e $4 v$ e para os furos próximos à marca de dobra do papel

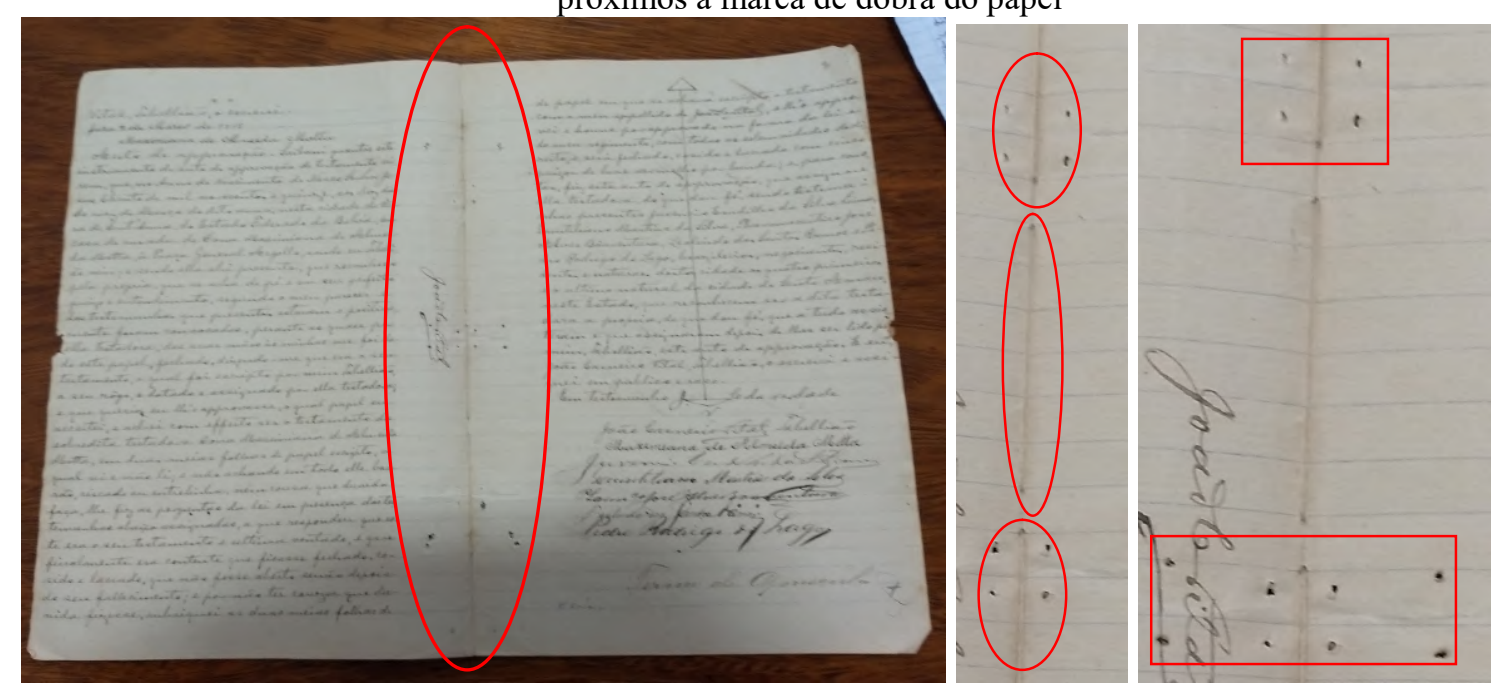

Fonte: Acervo do CEDOC/UEFS

Ainda nos mesmos fólios há perda de suporte material, de $15 \mathrm{~mm}$ de comprimento, no centro da extremidade direita dos fólios $2 \mathrm{r}, 3 \mathrm{r}$ e $4 \mathrm{r}$, conforme as figuras seguintes.

Figura 35 - Perda de suporte material no centro da extremidade direita do fólio $2 \mathrm{r}$

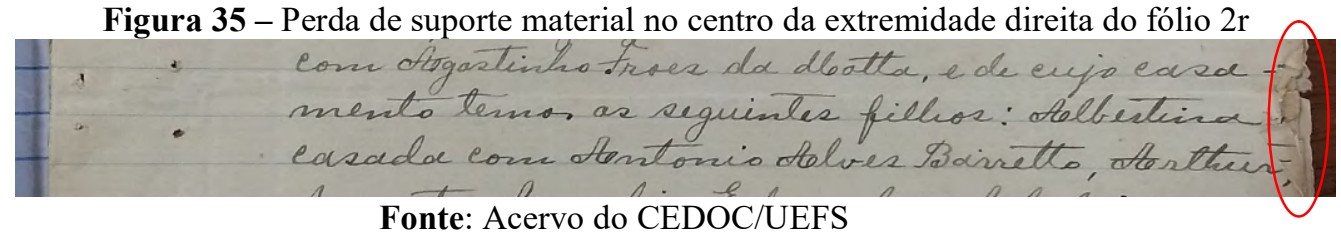

Figura 36 - Perda de suporte material no centro da extremidade direita do fólio $3 \mathrm{r}$

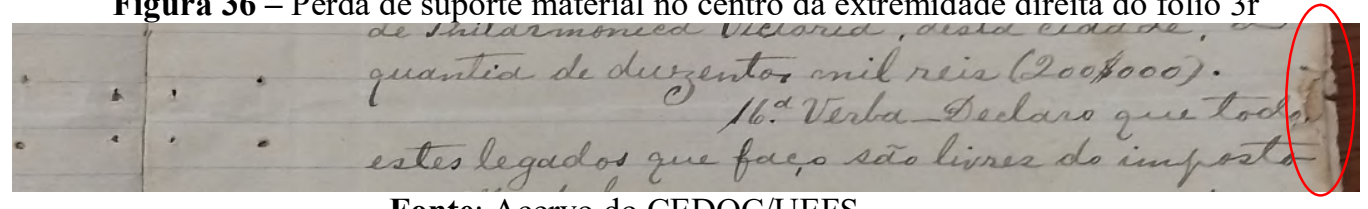

Fonte: Acervo do CEDOC/UEFS

Figura 37 - Perda de suporte material no centro da extremidade direita do fólio $4 \mathrm{r}$

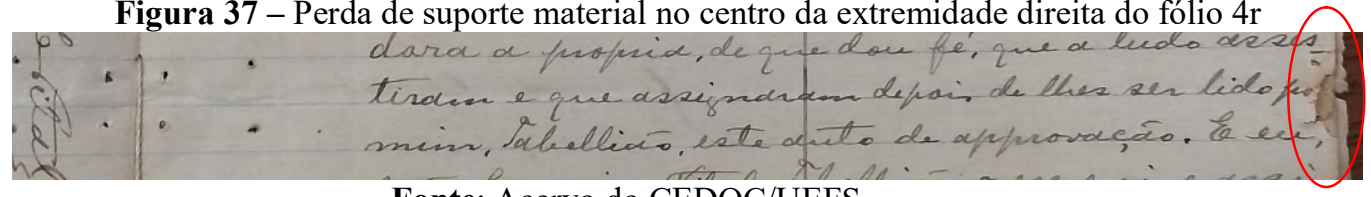

Fonte: Acervo do CEDOC/UEFS

Enquanto os fólios 2v, 3v, 4v e 5v têm um escudo com coroa no cimo, uma âncora na parte inferior, sem inscrições e com localização entre os $3^{\circ}, 4^{\circ}$ e $5^{\circ}$ pontusais, o fólio $10 \mathrm{v}$ tem 
uma marca d'água apenas com a inscrição “A. BINDA \& C”, entre os $2^{\circ}, 3^{\circ}, 4^{\circ}, 5^{\circ}, 6^{\circ}$ e $7^{\circ}$ pontusais e uma distância de $30 \mathrm{~mm}$ entre cada um deles em cada um dos fólios.

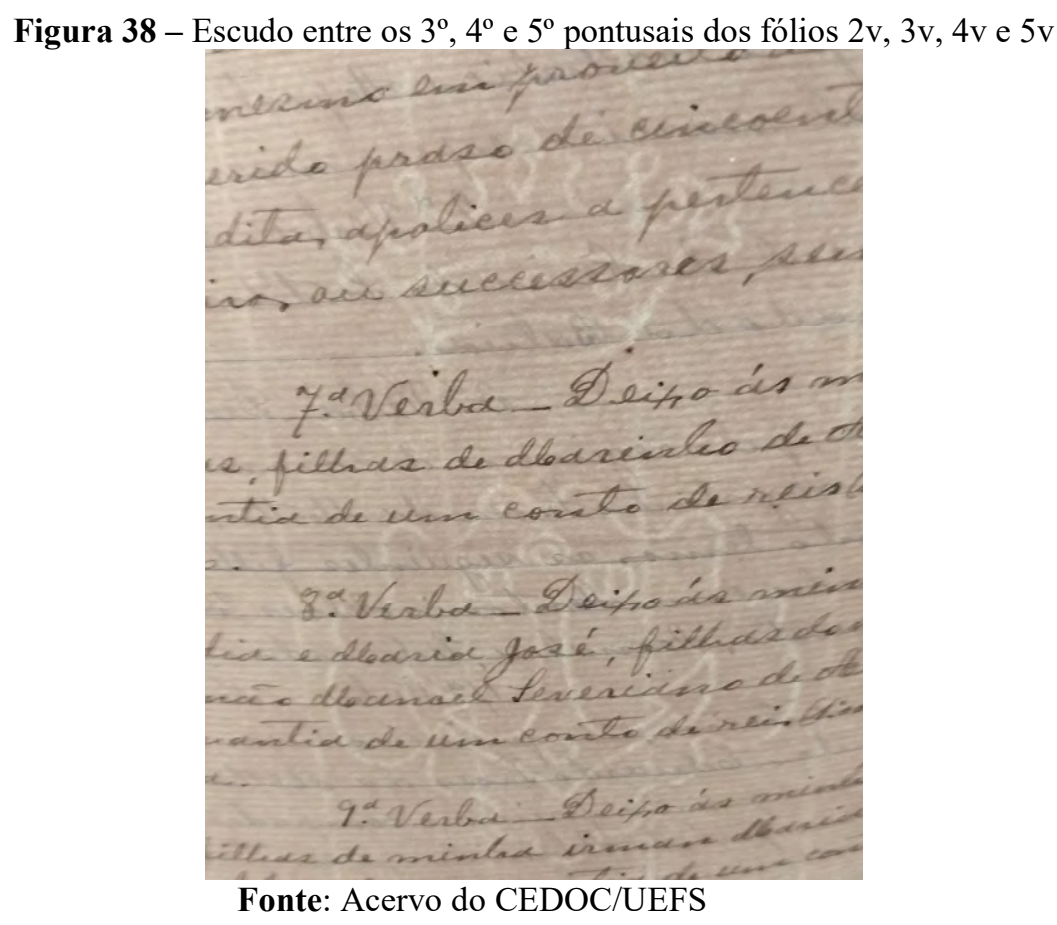

Figura 39 - Marca d'água com a inscrição “A. BINDA \& C", entre os $2^{\circ}, 3^{\circ}, 4^{\circ}, 5^{\circ}, 6^{\circ}$ e $7^{\circ}$ pontusais no fólio $10 \mathrm{v}$

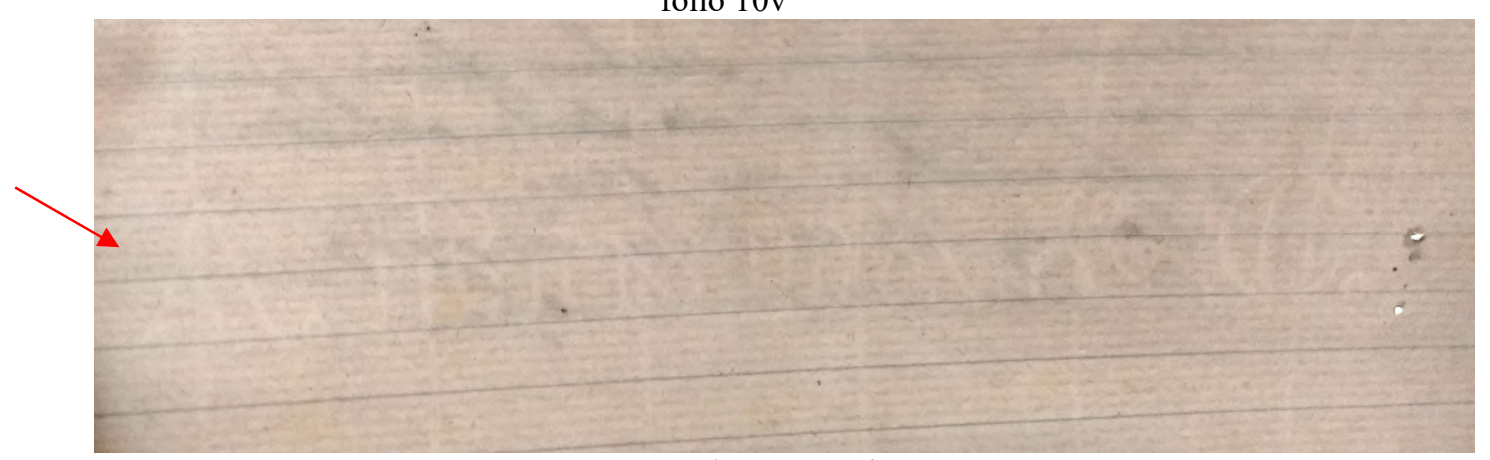

Fonte: Acervo do CEDOC/UEFS

Sobre o texto do documento, no fólio $5 \mathrm{v}$, há um trecho de 5 linhas escrito de cabeça para baixo (um sobrescrito) e 8 marcas de lacre ( 3 na margem direita, 3 na margem esquerda e 2 ao centro), feitas com sinetes para lacrar correspondências, o que se explica pelo fato de o documento, após ter sido escrito, lido e aprovado pela testadora, ter sido dobrado e selado com cera vermelha. Por fim, há dois formulários impressos pela Tipografia S. Joaquim, conforme nota inserida na vertical da margem esquerda dos referidos formulários, e manuscritos com tinta preta, os quais foram anexados ao processo e correspondem, portanto, aos fólios 7r e 8r do documento, e cujos versos estão em branco. 
Figura 40 - Fólio $5 \mathrm{v}$, à esquerda, com detalhes para o conteúdo do sobrescrito, primeira figura à direita, $\mathrm{e}$ manchas ocasionadas pela aplicação de lacre, segunda figura à direita
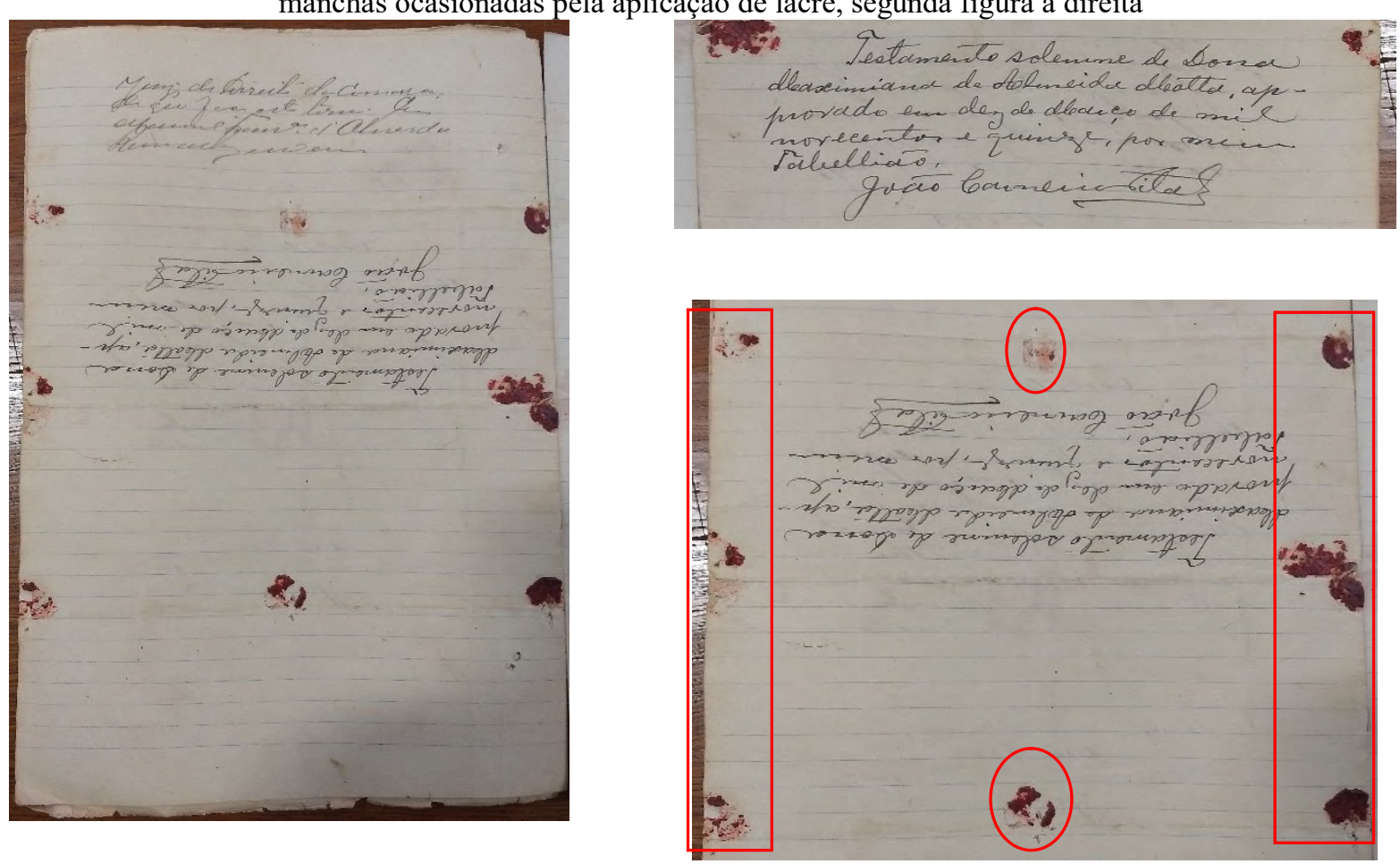

Fonte: Acervo do CEDOC/UEFS

Figura 41 - Formulários preenchidos manualmente: fólios $7 r$, à esquerda, e 8r, à direita
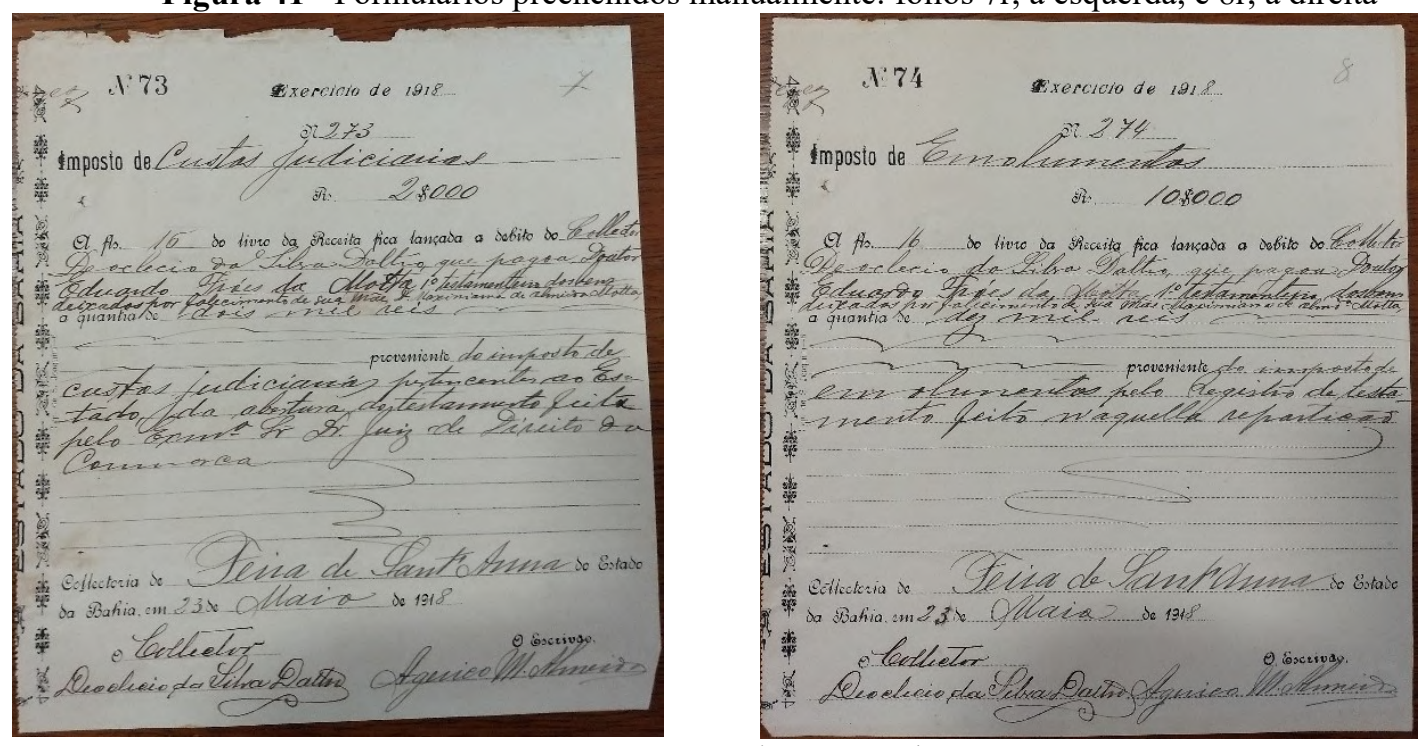

Fonte: Acervo do CEDOC/UEFS

Por fim, outros aspectos codicológicos presentes no corpus são a presença do reclamo ${ }^{123}$ "de", que se repete nos fólios $3 \mathrm{v} / 4 \mathrm{r}$ e $4 \mathrm{v} / 5 \mathrm{r}$, e a numeração progressiva dos fólios

${ }^{123}$ Termo utilizado por Cambraia (2005) e por Elena Rodríguez Díaz (2016). 
rectos no ângulo superior direito, que, assim como a tradição dos manuscritos e impressos pressupõe ${ }^{124}$, têm como utilidade a organização dos fólios do manuscrito.

Figura 42 - Reclamo “de" nos fólios 3v/4r e numeração progressiva no fólio 4r

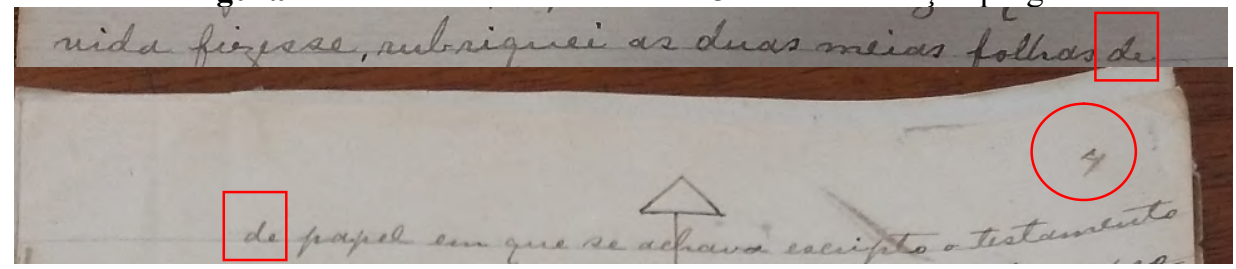

Fonte: Acervo do CEDOC/UEFS

Ademais, no recto do décimo fólio, há 10 selos de impostos, de 200 e 300 réis, distribuídos em duas partes do fólio, conforme figura seguinte.

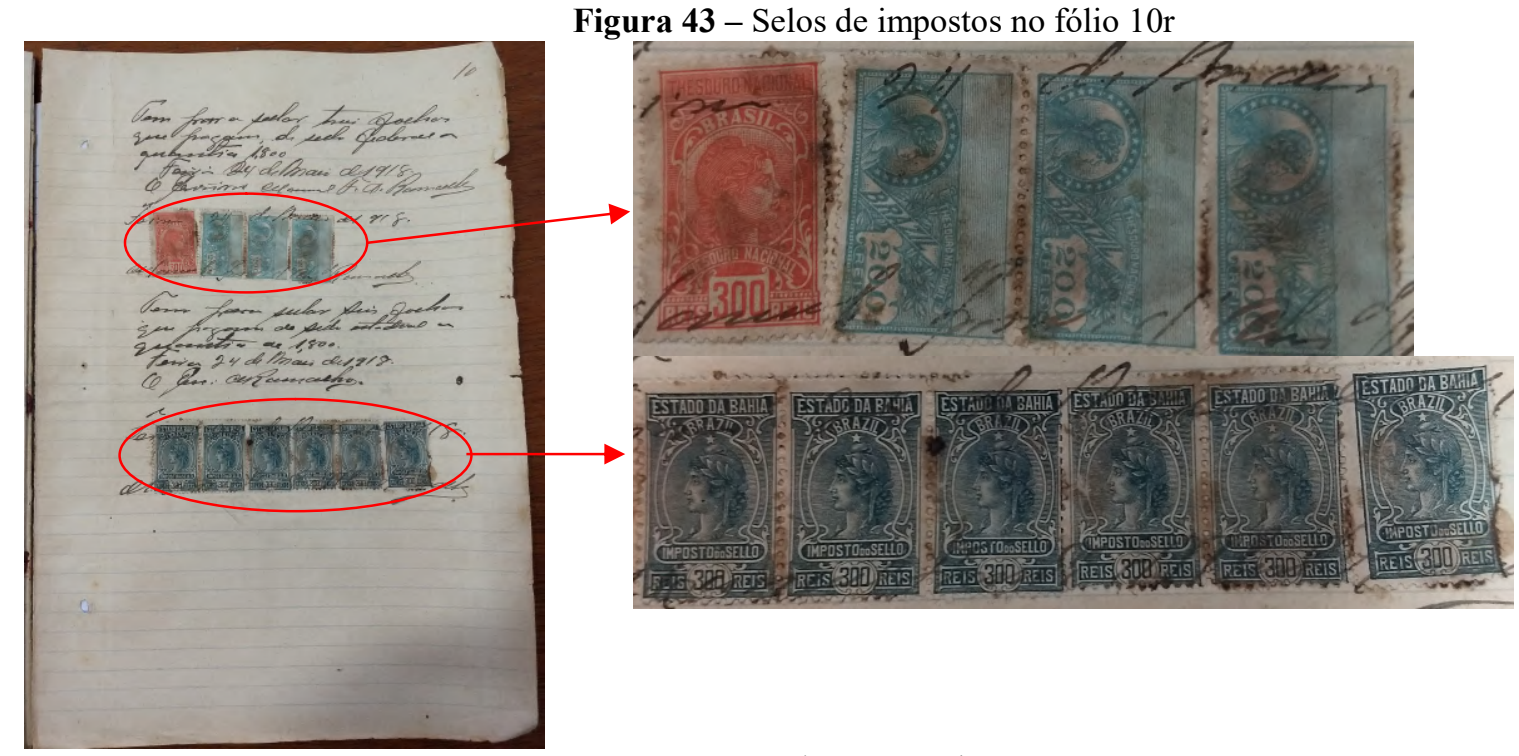

Fonte: Acervo do CEDOC/UEFS

Sobre os aspectos paleográficos encontrados no testamento de Dona Maximiana de Almeida Motta, podemos destacar que o documento foi todo escrito em letra cursiva e redigido por alguns punhos. Sobre estes, identificamos, à medida que a leitura do documento avançava, os punhos do Escrivão Manuel Francisco de Almeida Ramalho (fólios 1r, 4v, 5r, 5v, 6r, 6v, 9r, 9v, 10r e 10v), do Tabelião de Notas João Carneiro Vital (fólios 2r, 2v, 3r, 3v, 4r e 5v), do Juiz de Direito Jacintho Ferreira da Silva (fólio 5r) e do Escrivão Agerico Moreira de Almeida (fólio 6r, 7r e 8r), cujas escritas se apresentam inclinadas para a direita, o que indica que esses escreventes eram destros, como pode-se verificar nos exemplos inseridos no quadro a seguir.

\footnotetext{
${ }^{124}$ Dias (2018) faz uma descrição pormenorizada dos reclamos, do seu uso e de sua classificação, e Elena Rodríguez Díaz (2016) do sistema de ordenação dos códices, no qual inclui-se o sistema de paginação, de foliação e de prepação das folhas.
} 
Quadro 33 - Punhos que escreveram o testamento de Dona Maximiana de Almeida Motta

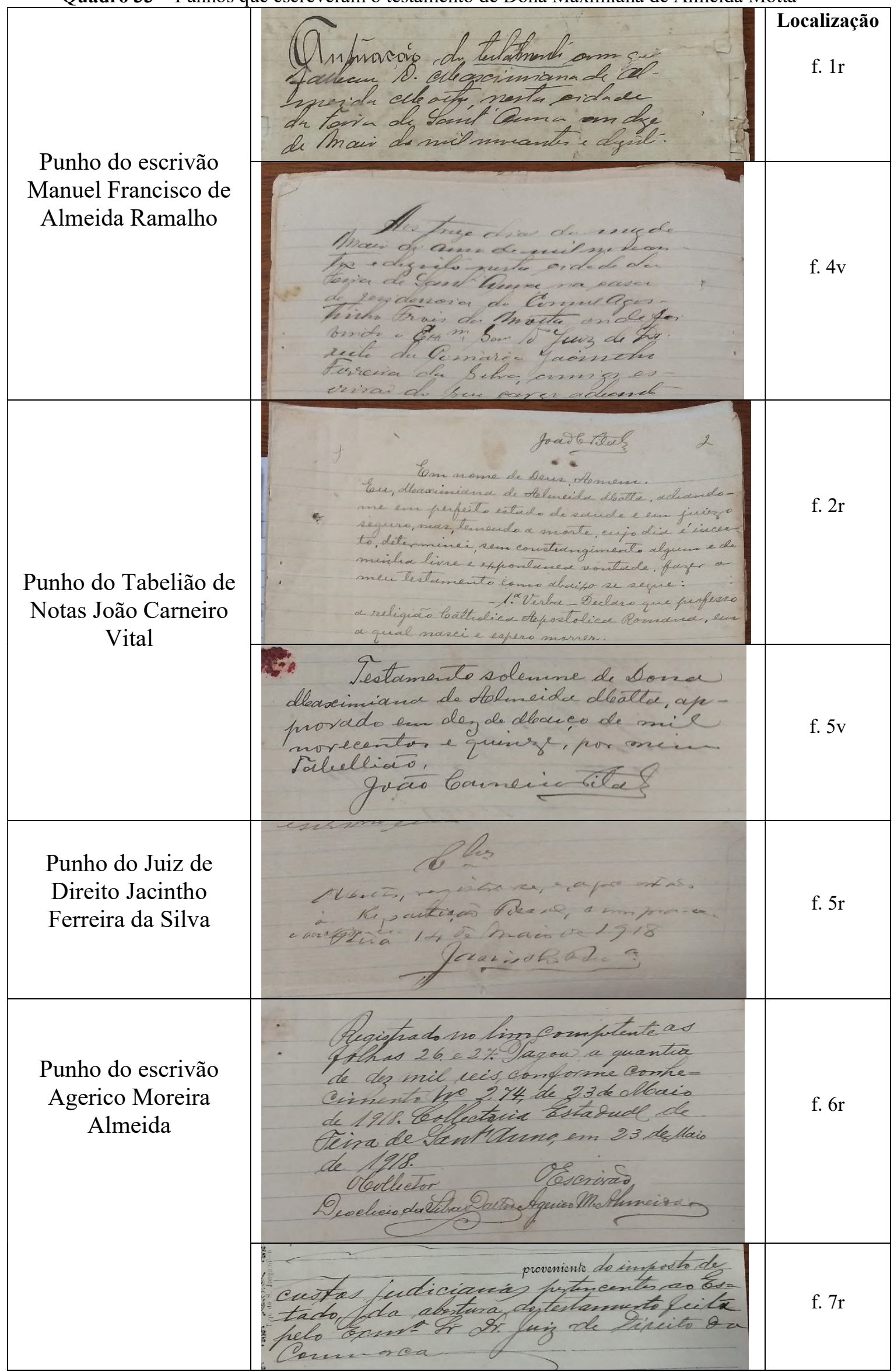

Fonte: Elaborado pela pesquisadora 
Dos fólios que têm mancha escrita, identificamos uma variável regularidade de “empaginação" (MARQUILHAS, 2000) nas "caixas de escrita” (ÁVILA SEOANE, 2016), se considerarmos o punho que escreveu cada um deles, como pode ser observado nos exemplos a seguir.

Figura 44 - Empaginação dos fólios 1r e 2r, escritos por Manuel Francisco de Almeida Ramalho e João Carneiro Vital, respectivamente

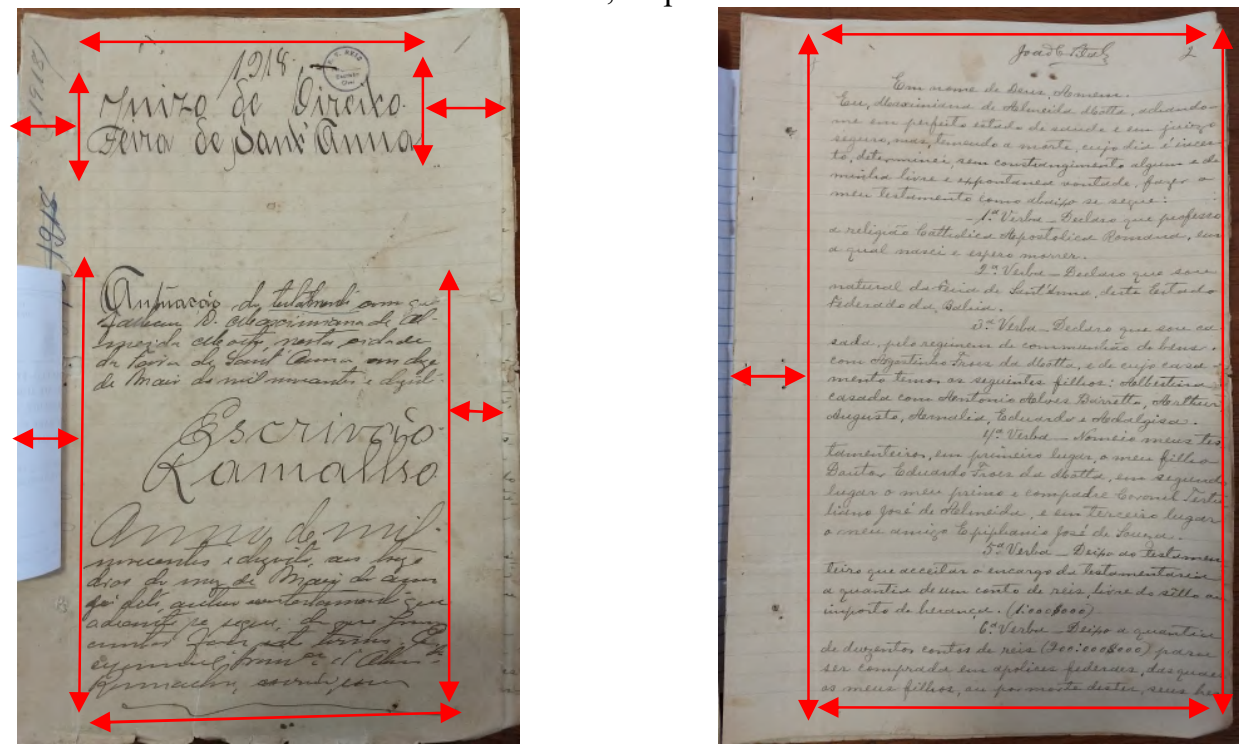

Fonte: Acervo do CEDOC/UEFS

Figura 45 - Empaginação dos fólios 2v e 4v, escritos por João Carneiro Vital e Manuel Francisco de Almeida Ramalho, respectivamente
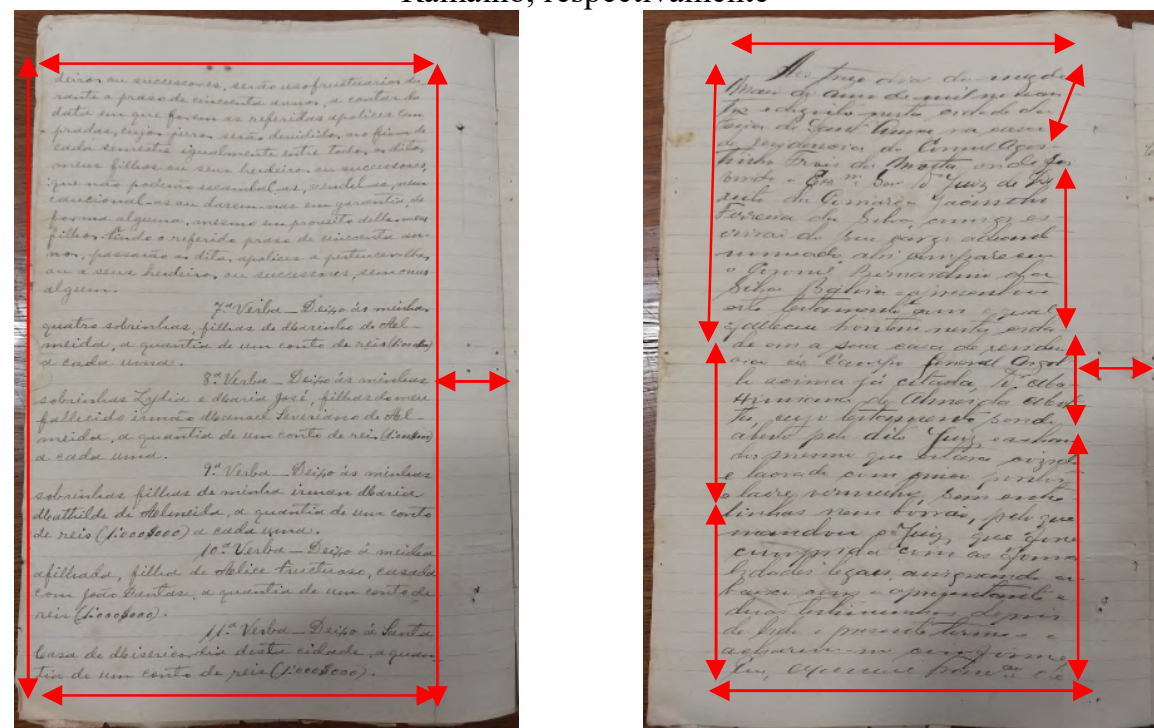

Fonte: Acervo do CEDOC/UEFS

Dessas regularidades de empaginação, depreendemos que nos fólios escritos por Manuel Francisco de Almeida Ramalho há quase a mesma proporção entre as margens superior, direita, inferior e esquerda tanto dos fólios rectos quando dos versos. Já nos fólios 
escritos por João Carneiro Vital não há espaço na margem direita dos fólios rectos e na margem esquerda dos fólios versos, apesar de sempre apresentarem a mesma distância entre as margens de todos os fólios por ele escritos.

Essa regularidade de empaginação também indica que, por conta dos espaços deixados antes e depois das quatro margens (superior, esquerda, inferior e direita) de cada fólio, do número de fólios em branco e da quantidade de linhas deixadas em branco nos fólios que apresentam mancha escrita, existia em Feira de Santana-BA uma substancial quantidade de papel circulando no período de produção do referido documento, o que implica dizer que o acesso ao papel não se constituía um problema para aqueles escreventes.

Outro aspecto paleográfico que marca os fólios escritos por João Carneiro Vital são as suas assinaturas pessoais e o seu sinal público. Sobre estes, identificamos na margem centrodireita superior dos fólios $2 \mathrm{r}$ e $3 \mathrm{r}$, e na vertical da margem centro-superior do fólio $3 \mathrm{v}$, as rubricas e o sinal público, seta dupla vertical de $188 \mathrm{~mm}$ de altura com as iniciais JCV na extremidade inferior, do referido Tabelião de Notas da Comarca de Feira de Santana-BA, como pode ser verificado nas figuras a seguir.

Figura 46 - Rubricas do Tabelião de Notas João Carneiro Vital
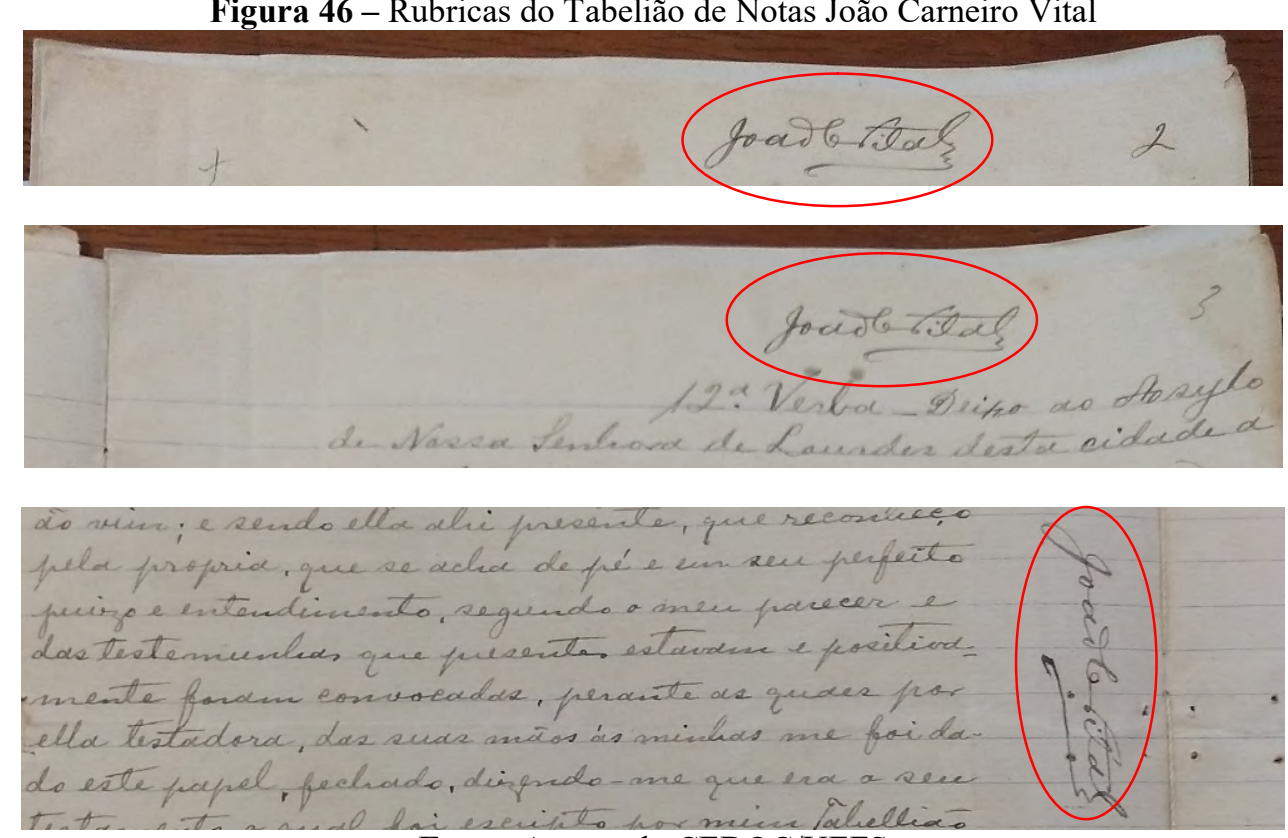

Fonte: Acervo do CEDOC/UEFS 
Figura 47 - Sinal público, no fólio 4r, do Tabelião de Notas João Carneiro Vital

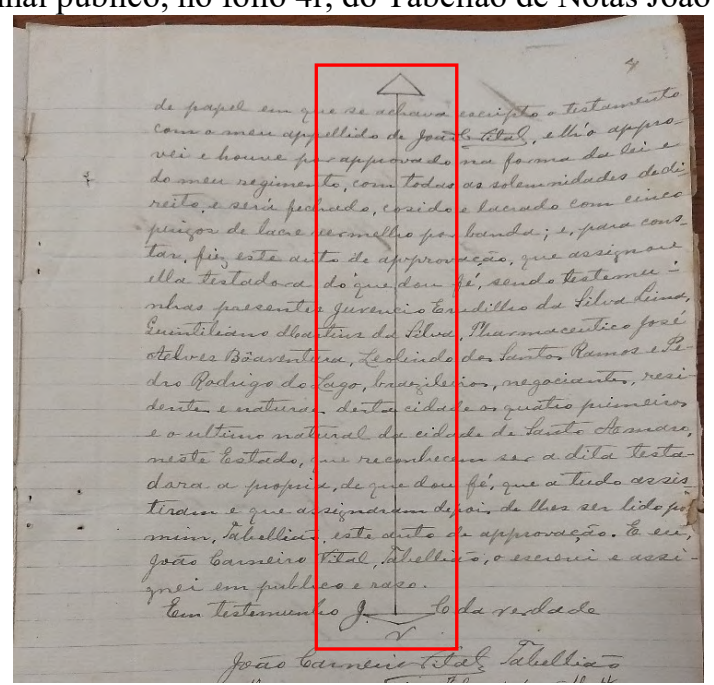

Fonte: Acervo do CEDOC/UEFS

Outro aspecto que merece ser mencionado são as assinaturas ${ }^{125}$ pessoais tanto dos escreventes quanto das testemunhas do testamento. Sobre isso, destacamos alguns elementos das assinaturas pessoais de Juvencio Erudilho da Silva Lima, Quintiliano Martins da Silva, José Alves Boaventura, Leolindo dos Santos Ramos e Pedro Rodrigo do Lago, no fólio 4r; das de Bernardino da Silva Bahia, José Telles Barreto e Jacintho Ferreira da Silva, no fólio 5r; da de João Carneiro Vital, no fólio 5v; e das de Manuel Francisco de Almeida Ramalho, Deoclecio da Silva Daltro e Agerico Moreira da Silva, no fólio 6r, a fim de evidenciar esse aspecto paleográfico, em conformidade com o modelo de análise de assinaturas proposto por Santos (2004).

Nas assinaturas analisadas, verificamos que todas possuem um "alto calibre", ou seja, o tamanho dos traços gráficos ocupa quase todo o espaço da caixa de linha; um ângulo de inclinação para a direita e uso de "mínimos gráficos", que dizem respeito à utilização de acentuação e de pontuação na assinatura; um ritmo lento, já que facilmente se identificam uma escrita angular, cortes dos " $\mathrm{t}$ " em posição correta, letras iniciais cuidadosamente traçadas, cursus na maioria das assinaturas e o uso do mesmo módulo médio de escrita, ou seja, “[...] as letras e as partes constitutivas da mesma apresentam pequenas desigualdades rítmicas [...]" (SANTOS, 2004, p. 60).

Além disso, tratam-se de assinaturas feitas com um "formato caligráfico", ou seja, um tipo de assinatura semelhante ao modelo aprendido na escola, "em função de sua regularidade e fidelidade a um modelo" (ÁVILA SEOANE, 2016) e, por fim, apenas as assinaturas de José

\footnotetext{
${ }^{125}$ Vale ressaltar que nos pautamos nos trabalhos de Ávila Seoane (2016), Marquilhas (2000) e Santos (2004) para a análise das assinaturas.
} 
Alves Boaventura, Leolindo dos Santos Ramos, Jacintho Ferreira da Silva e João Carneiro Vital possuem ligaduras; e quase todas apresentam variadas letras "individuais/monolíticas" (MARQUILHAS, 2000) e legíveis, à exceção da assinatura do Juiz de Direito Jacintho Ferreira da Silva, que apresenta variação no módulo e na legibilidade do traçado de algumas letras.

Não menos importante, Santos (2004) também aponta que as assinaturas pessoais podem apresentar ganchos, ou seja, um movimento abrupto e curto de regressão no final ou no corte do "t" da assinatura pessoal (no caso das assinaturas de Juvencio Erudilho da Silva Lima, Quintiliano Martins da Silva, José Alves Boaventura, Leolindo dos Santos Ramos, Pedro Rodrigo do Lago, Bernardino da Silva Bahia, José Telles Barreto, João Carneiro Vital e Manuel Francisco de Almeida Ramalho) e laçadas, caracterizadas como o movimento de retorno ao ponto de partida, geralmente o início ou meio da assinatura, com ou sem traço sinuoso e no mesmo cursus, ou não, da última letra da assinatura (no caso das assinaturas de Jacintho Ferreira da Silva, Deoclecio da Silva Daltro e Agerico Moreira da Silva ${ }^{126}$ ), o que dão indícios do estilo de escrita de cada escrevente.

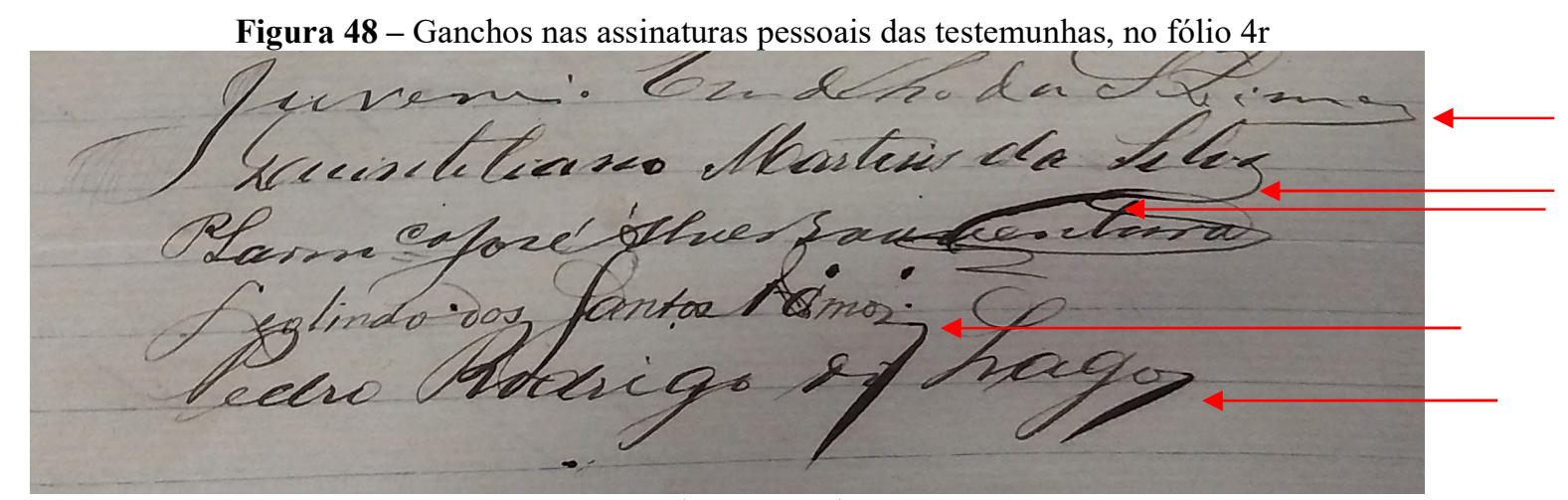

Fonte: Acervo do CEDOC/UEFS

\footnotetext{
${ }^{126}$ Ao final da assinatura, este escrivão interrompe o cursus e, em seguida, começa um novo traçado, que se inicia na linha de escrita, onde curva-se levemente à esquerda e inclina-se, junto à perna do "a" final da assinatura, para a direita, avançando com um traçado levemente sinuoso no espaço interlinear inferior, curvandose à esquerda e mantendo o tracejamento até o "l" do sobrenome "Almeida", onde finaliza o traçado (antes mesmo de alcançar a linha de escrita inferior) com uma leve curva à direita. Dentre as assinaturas analisadas, a deste escrivão é a única, nesse documento, que apresenta essa interrupção da cursividade ao final da assinatura para começar um novo traçado com a finalidade de "finalizá-la".
} 
Figura 49 - Ganchos e laçada nas assinaturas pessoais das testemunhas e do Juiz de Direito, respectivamente, no fólio $5 \mathrm{r}$

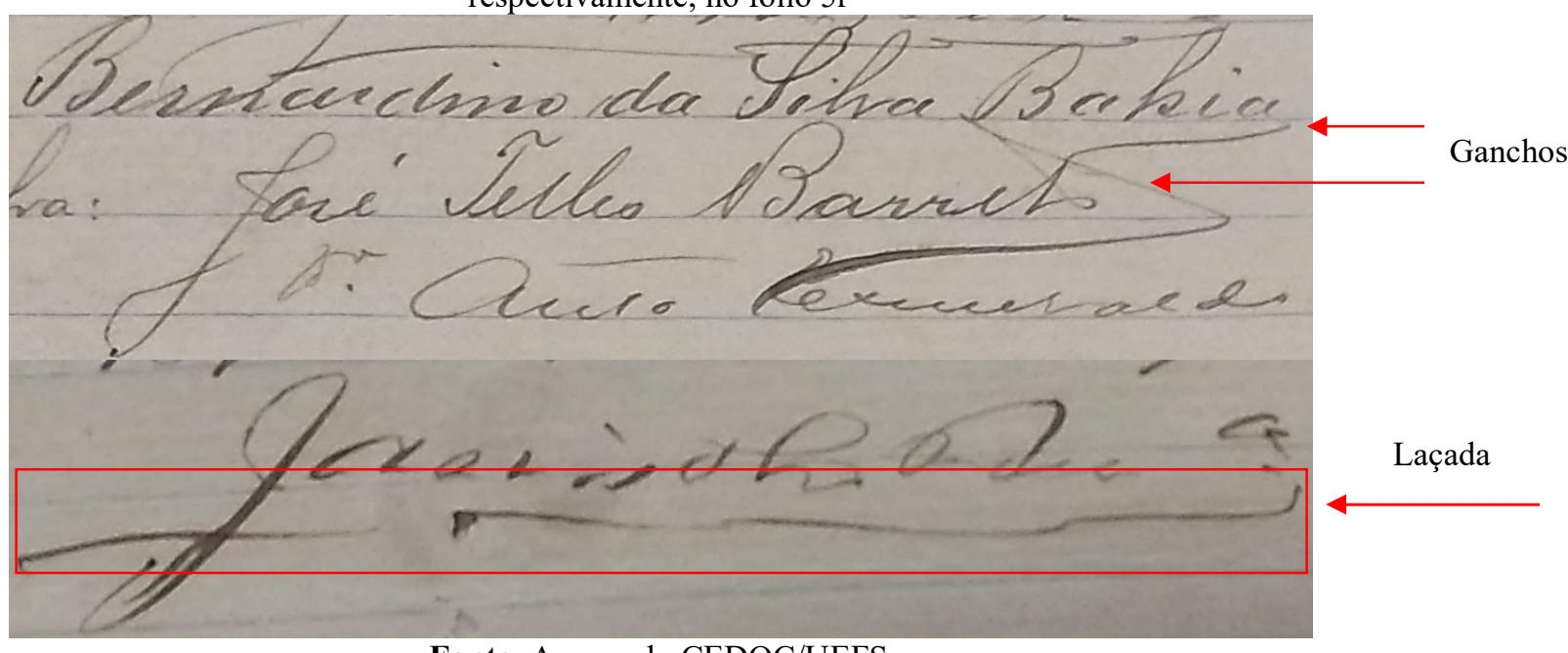

Fonte: Acervo do CEDOC/UEFS

Figura 50 - Gancho na assinatura pessoal do Tabelião de Notas, no fólio $5 \mathrm{v}$

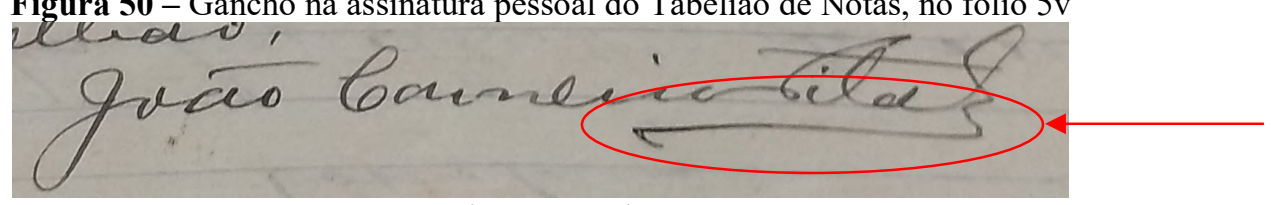

Fonte: Acervo do CEDOC/UEFS

Figura 51 - Gancho e laçadas nas assinaturas pessoais do escrivães e do coletor estadual, no fólio 6r

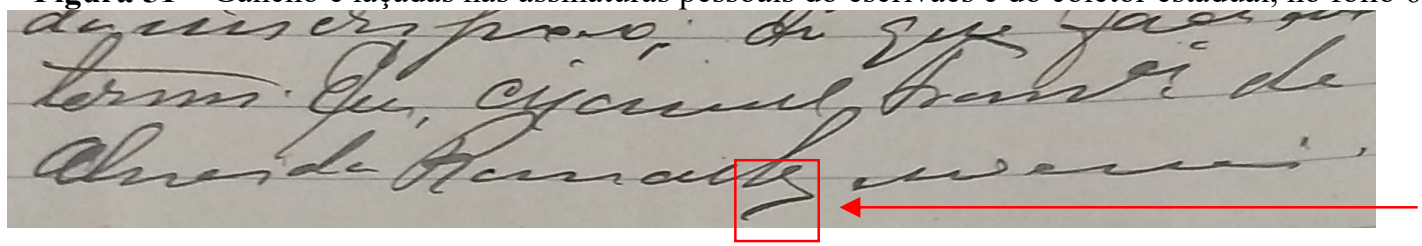

Laçadas

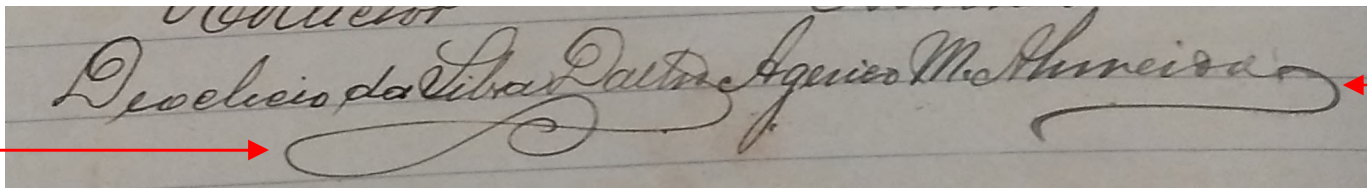

\section{Fonte: Acervo do CEDOC/UEFS}

O segundo documento é o testamento do Coronel Agostinho Fróes da Motta, armazendo no CEDOC/UEFS sob a cota: Estante 06, Caixa 166 e Documento 2573, redigido e fechado em 1920 e aberto e lido em 1922, na cidade de Feira de Santana-BA, e escrito em papel almaço, em tinta preta, em letra cursiva e em 11 fólios, rectos e versos, dos quais os fólios $1 \mathrm{v}, 9 \mathrm{v}, 10 \mathrm{v}, 11 \mathrm{r}$ e $11 \mathrm{v}$ estão em branco, o fólio 10r é um formulário de Imposto de Emolumentos, preenchido manualmente, e os demais são manuscritos.

Os 11 fólios são compostos por 5 in-planos $(2 r / 2 v, 3 r / 3 v, 6 r / 6 v, 9 r / 9 v$ e $10 r / 10 v)$ e 3 in-fólios ( $1 \mathrm{r} / 1 \mathrm{v}$ e $11 \mathrm{r} / 11 \mathrm{v}, 4 \mathrm{r} / 4 \mathrm{v}$ e $5 \mathrm{r} / 5 \mathrm{v}, 7 \mathrm{r} / 7 \mathrm{v}$ e $8 \mathrm{r} / 8 \mathrm{v})$, nos quais existem perfurações na 
vertical da margem esquerda, que indicam que, em algum momento, o documento foi costurado com barbante. Especificamente sobre o fólio 1r, há uma ficha de identificação solta, inserida pelos estagiários do CEDOC/UEFS, com informações pertinentes à catalogação e ao armazenamento do documento no acervo, a saber: o nome do fórum em que o documento foi lavrado, a classificação do processo no acervo, a seção, a série, a subsérie, a tipologia, a comarca, o número de fólios, a localidade, o período e as partes envolvidas nesse processo.

Figura 52 - Ficha de identificação inserida em cima do fólio 1r do testamento de Agostinho Fróes da

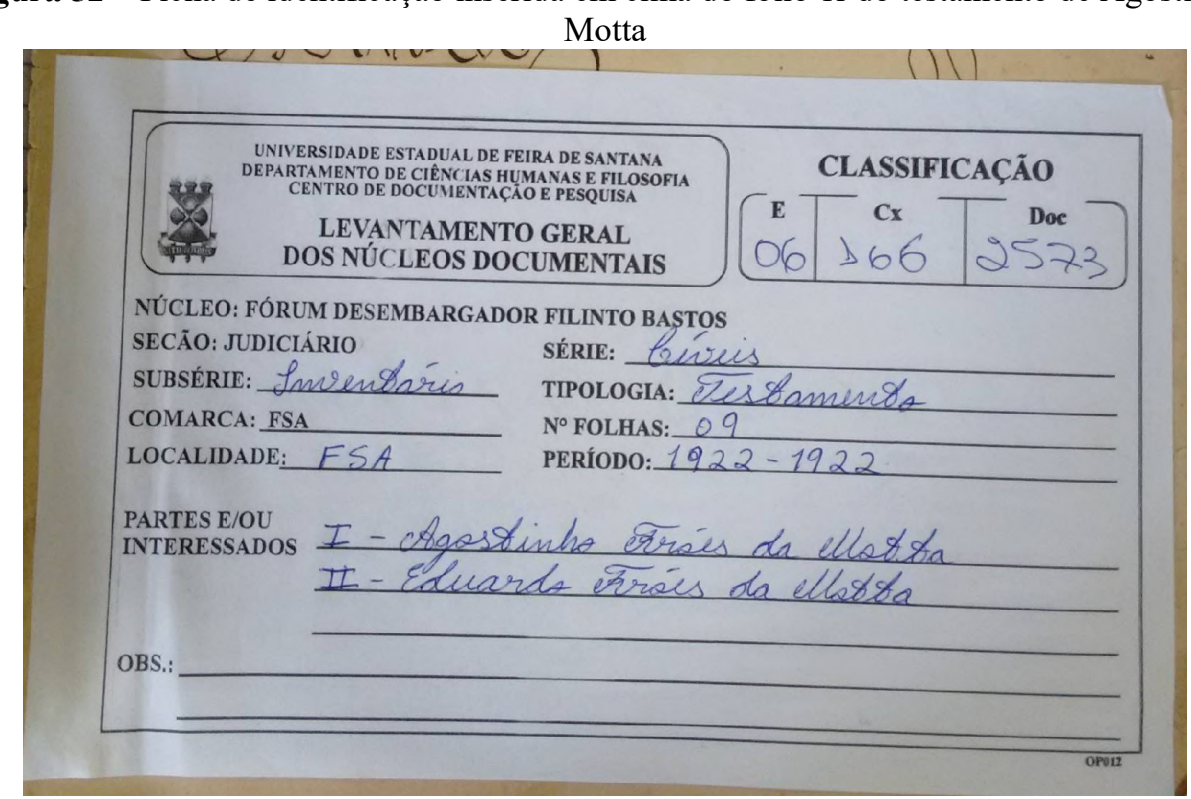

Fonte: Acervo do CEDOC/UEFS

Outra característica idêntica à encontrada no testamento anterior é a existência do mesmo carimbo molhado, de $21 \mathrm{~mm}$ de diâmetro, com a inscrição "E. V. REIS | Fls. | Escrivão Civel", na mesma localização que o carimbo do testamento anterior.

Figura 53 - Carimbo molhado com a inscrição "E. V. REIS | Fls. | Escrivão Civel” no fólio 1r do testamento do Coronel Agostinho Fróes da Motta

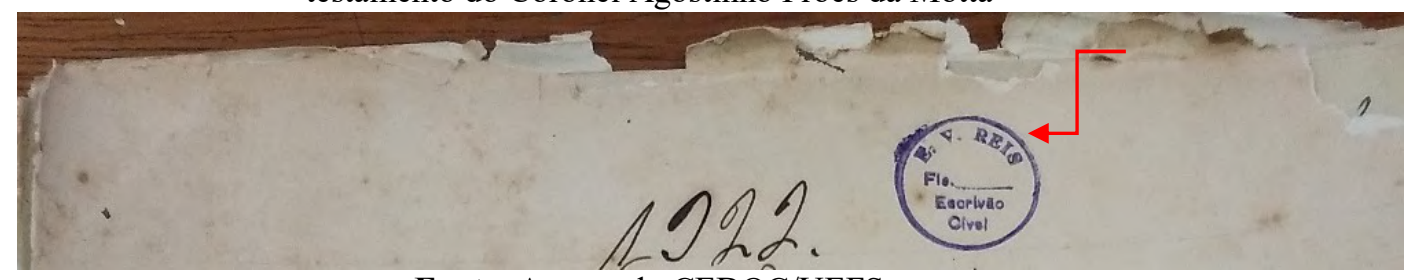

Fonte: Acervo do CEDOC/UEFS

No mesmo fólio, também há rasgões nas margens superior e lateral direitas, uma anotação com a inscrição: "julgdo . 11/4/922”, em tinta azul, constante na vertical da margem centro-superior esquerda, provavelmente feita por um punho desconhecido, já que é diferente da grafia dos escreventes identificados do documento; perfurações feitas, provavelmente, para 
costurar o documento com barbante; manchas ocasionadas pela oxidação do grampo usado para prender o documento, e pela ação de insetos; e uma marca de contato no documento, provavelmente, ocasionada por algum objeto ou pelo dorso ou lateral da mão do escrevente, como exposto na figura a seguir.

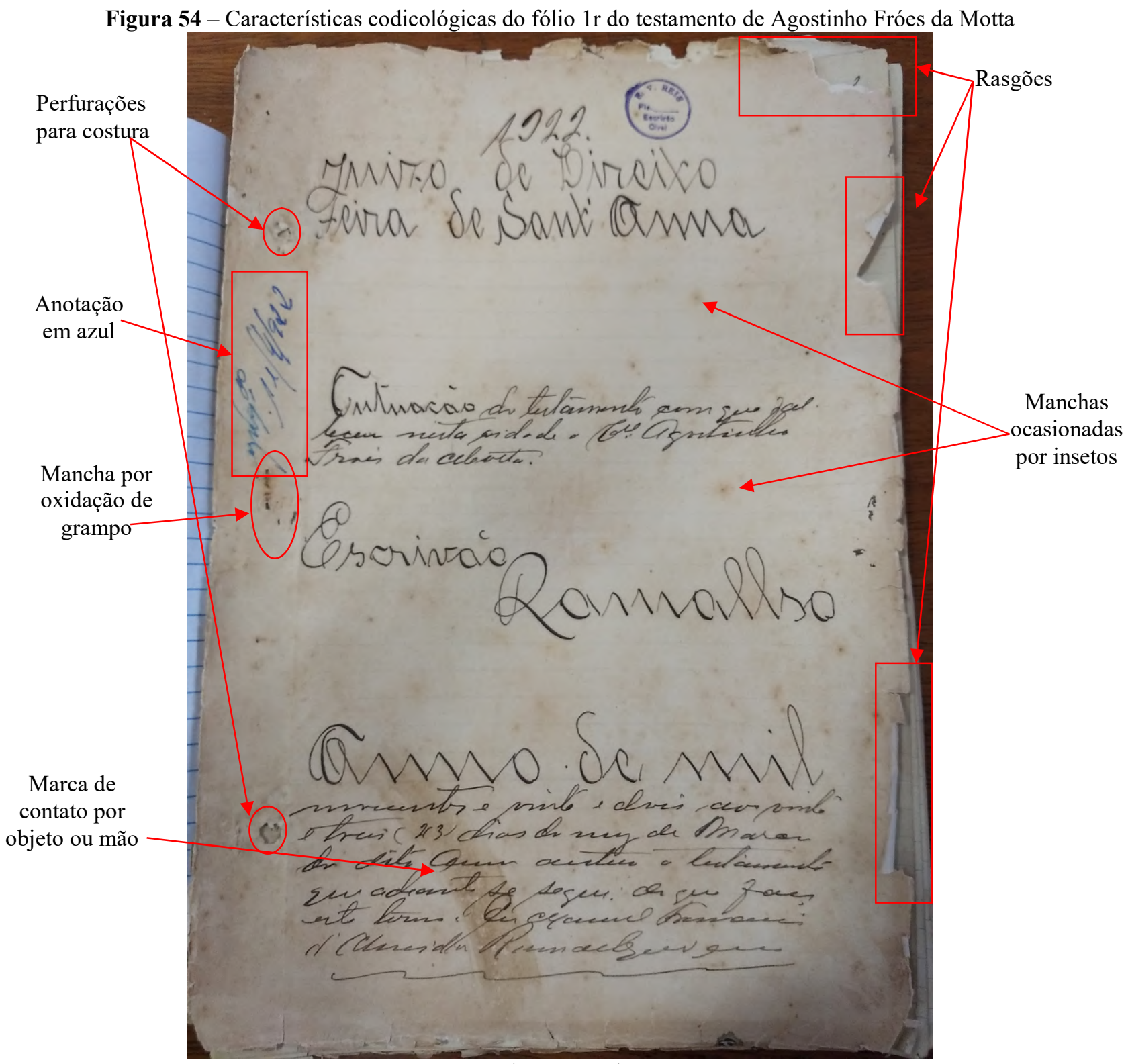

Fonte: Acervo do CEDOC/UEFS

Nos fólios subsequentes, há dois selos de impostos, no valor de 300 réis cada um, no centro da margem inferior do fólio $5 \mathrm{v}$; um formulário de imposto, manualmente preenchido, de $235 \mathrm{~mm}$ de altura $\times 210 \mathrm{~mm}$ de largura, no fólio $10 \mathrm{r}$, no qual há um carimbo molhado, com $53 \mathrm{~mm}$ de diâmetro e sem inscrição, na margem superior esquerda, e uma perfuração de $4 \mathrm{~mm}$ de diâmetro na lateral da margem esquerda; uma ondulação na vertical da margem esquerda e 
rasgões nas margens superior e direita no fólio 11r; e um retângulo de papel almaço, de $230 \mathrm{~mm}$ de altura x $60 \mathrm{~mm}$ de largura, colado na vertical da margem direita do fólio $11 \mathrm{v}$.

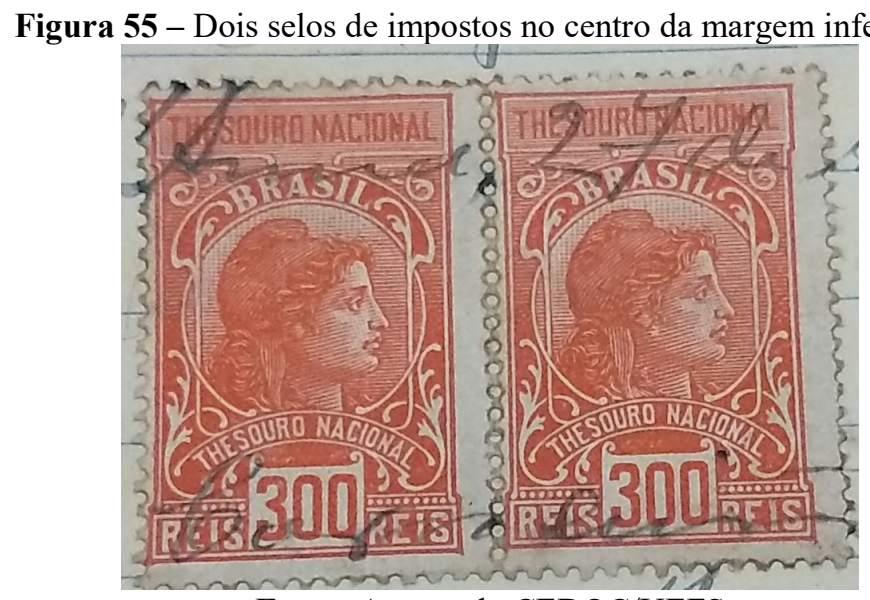

Fonte: Acervo do CEDOC/UEFS

Figura 56 - Formulário de imposto preenchido manualmente, com detalhe para um carimbo molhado e uma perfuração na lateral da margem esquerda

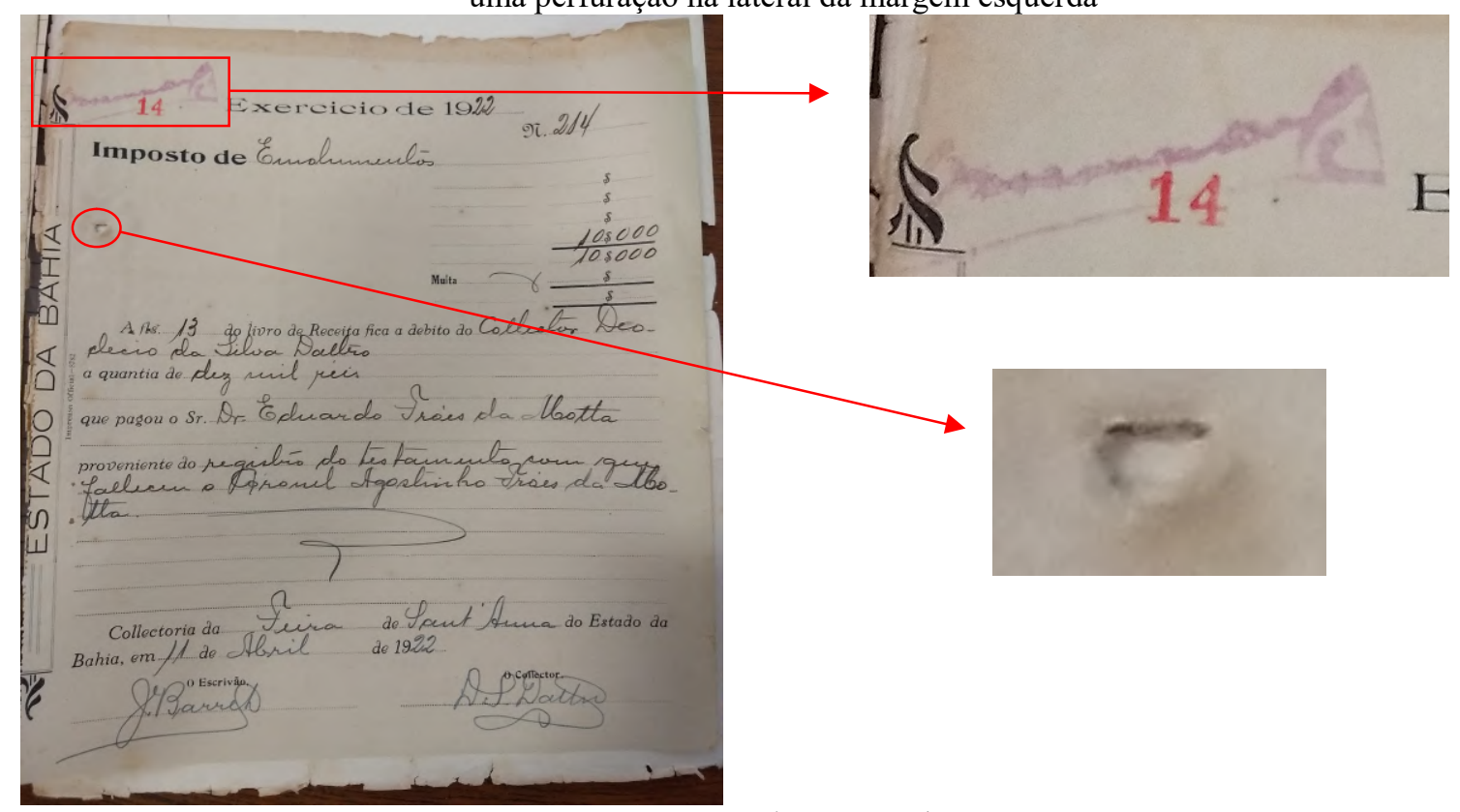

Fonte: Acervo do CEDOC/UEFS 
Figura 57 - Ondulação, rasgões e furos nas margens do fólio 11r

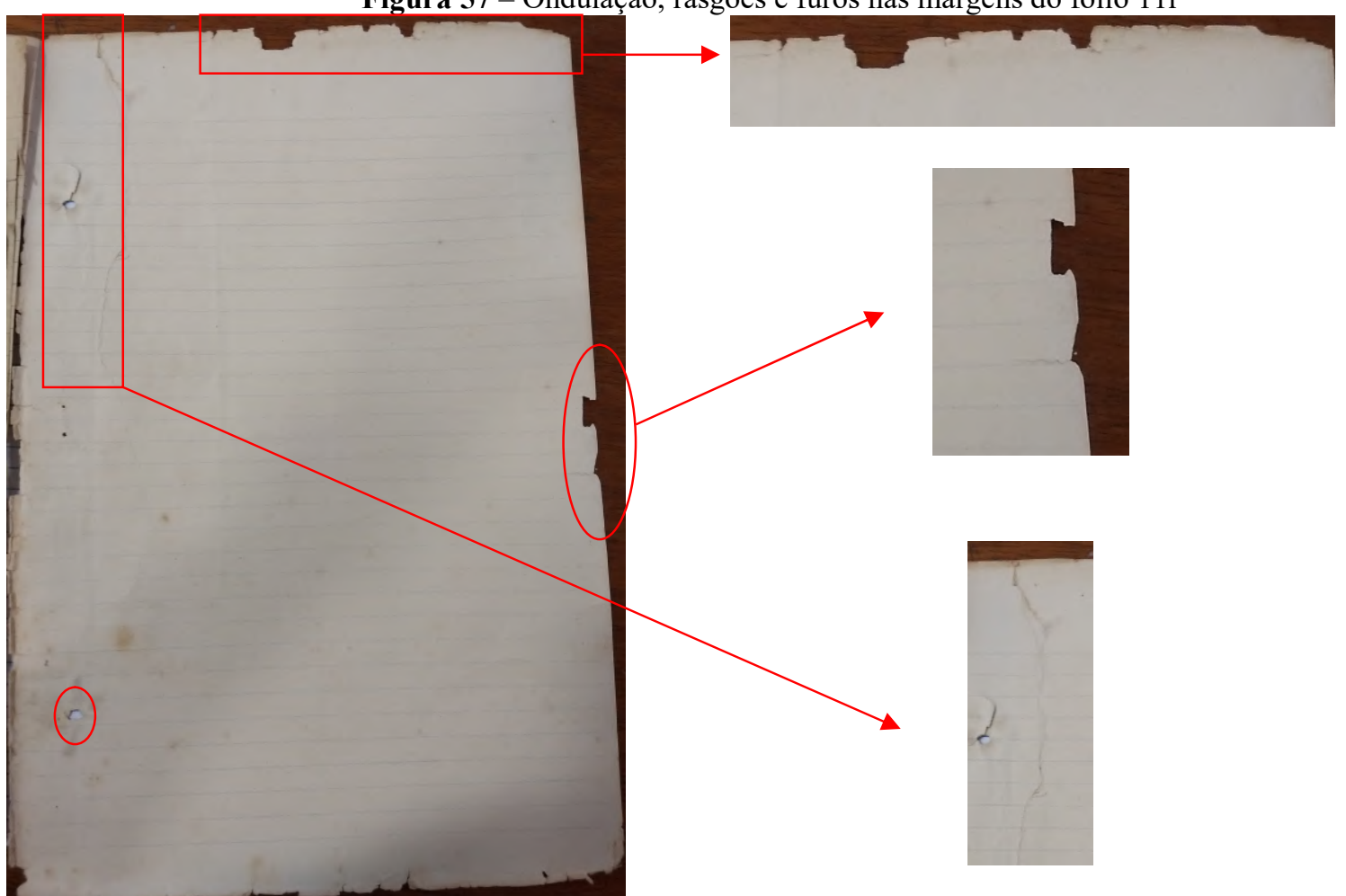

Fonte: Acervo do CEDOC/UEFS

Figura 58 - Retângulo de papel almaço colado na vertical da margem direita do fólio $11 \mathrm{v}$

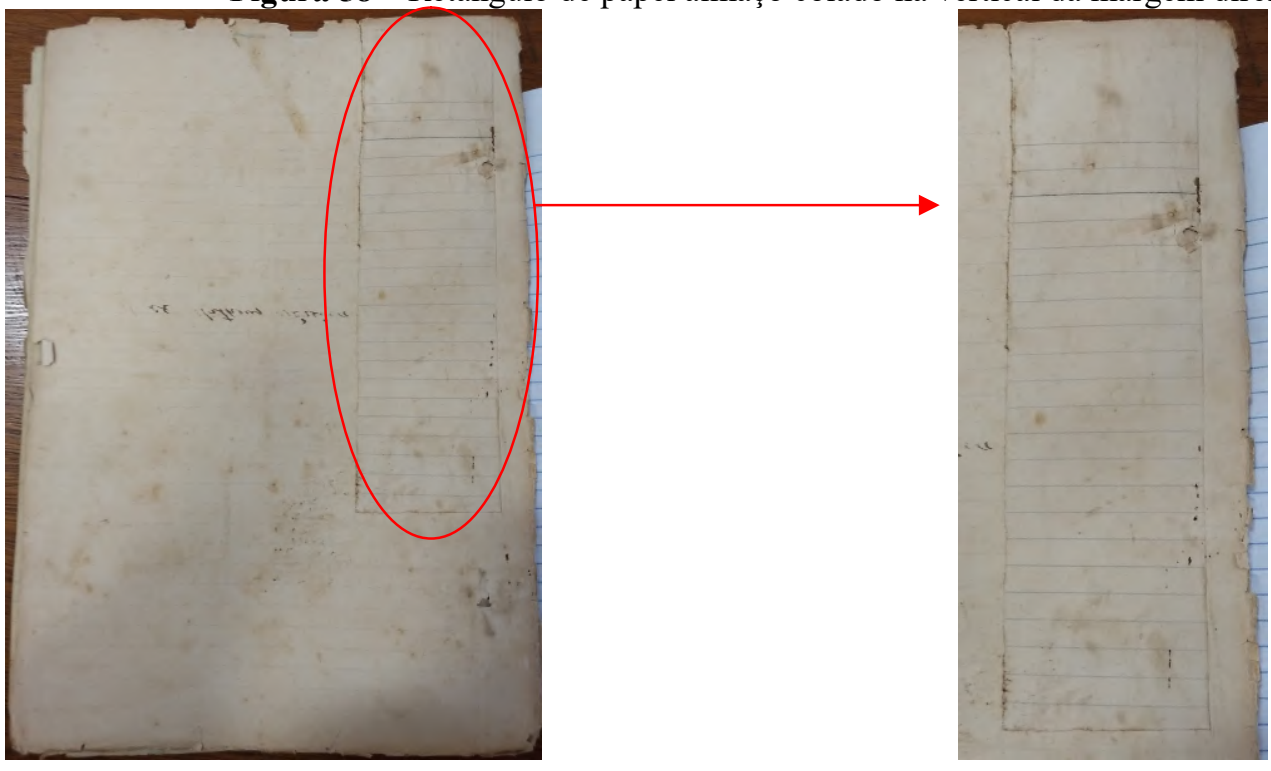

Fonte: Acervo do CEDOC/UEFS

Além desses aspectos, há um pedaço de linha de tricô vermelho, que se encontra em forma de nó com 43mm de extensão, no fólio 5v; uma marca d'água (um escudo da República Federativa do Brasil), entre os $2^{\circ}, 3^{\circ}, 4^{\circ}, 5^{\circ}$ e $6^{\circ}$ pontusais, com a inscrição "ESTADOS UNIDOS DO BRAZIL | 15 DE NOVEMBRO | DE 1989” e pontusais com distância aproximada de $28 \mathrm{~mm}$ entre cada um, nos fólios 2r, 3r, 4r, 5r, 6r e 9v; e 3 marcas de dobras na 
horizontal das margens superior, central e inferior, e uma mancha de tinta preta, de $23 \mathrm{~mm}$ de comprimento, na vertical da margem inferior esquerda do fólio $9 \mathrm{v}$.

Figura 59 - Pedaço de linha de tricô vermelho no fólio $5 \mathrm{v}$

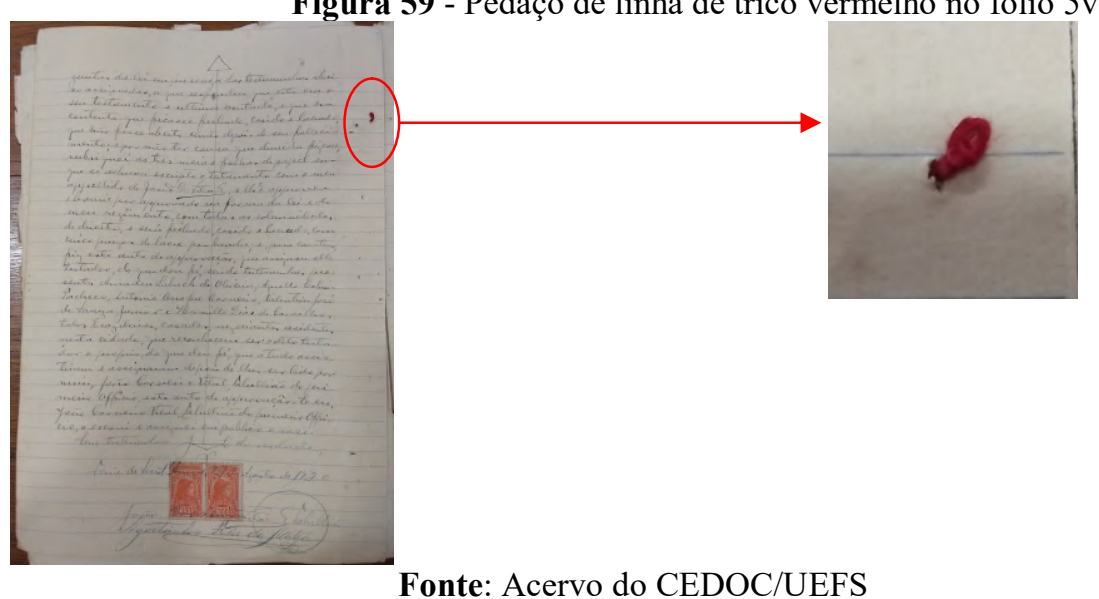

Figura 60 - Escudo da República Federativa do Brasil com a inscrição "ESTADOS UNIDOS DO BRAZIL | 15 DE NOVEMBRO | DE 1989”, no fólio 9v

Fonte: Acervo do CEDOC/UEFS 


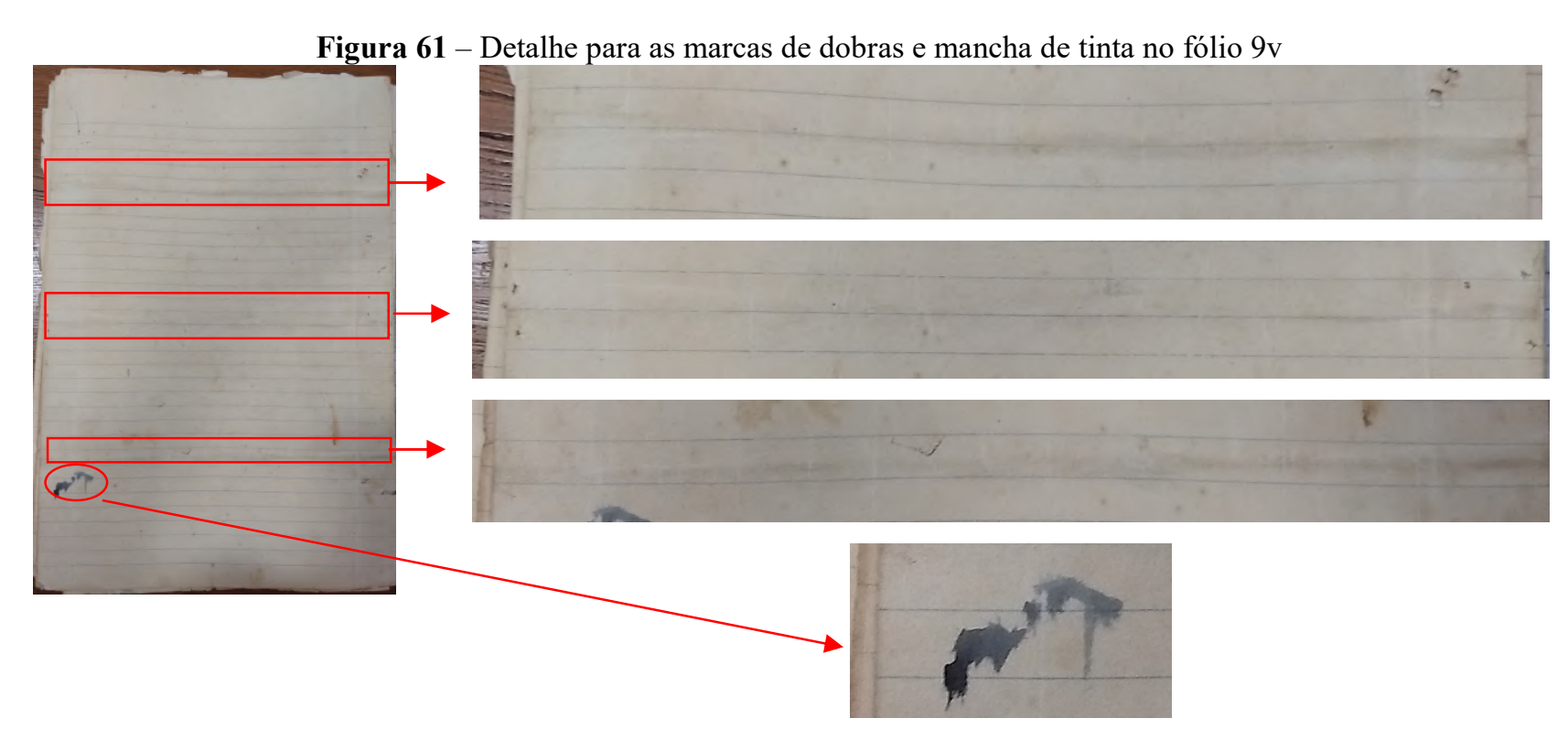

Fonte: Acervo do CEDOC/UEFS

Outro aspecto codicológico que precisa ser mencionado é a existência de numeração progressiva no ângulo superior direito de quase todos os fólios rectos, com exceção dos fólios 1r, 10r e 11r, e de reclamos, ambos utilizados para sinalizar a ordem em que o documento deveria ser organizado. Contudo, apesar de termos, nesse processo, a presença de apenas 6 reclamos: "Motta/Motta" nos fólios 2v/3r; "que/que" nos fólios 3v/4r; "das/ das" nos 4r/4v, "inteira/ inteiramente" nos 4v/5r, "Notas/Notas" nos 7v/8r e "e/e" nos 8v/9r, não se pode deixar de lado o fato de que isso significa que os escreventes Manuel Francisco de Almeida Ramalho e João Carneiro Vital tanto tinham conhecimento da existência desses recursos quanto sabiam como e onde usá-los.

Figura 62 - Reclamo "Notas" nos fólios 7v/8r e numeração progressiva na margem superior direita do fólio $8 \mathrm{r}$

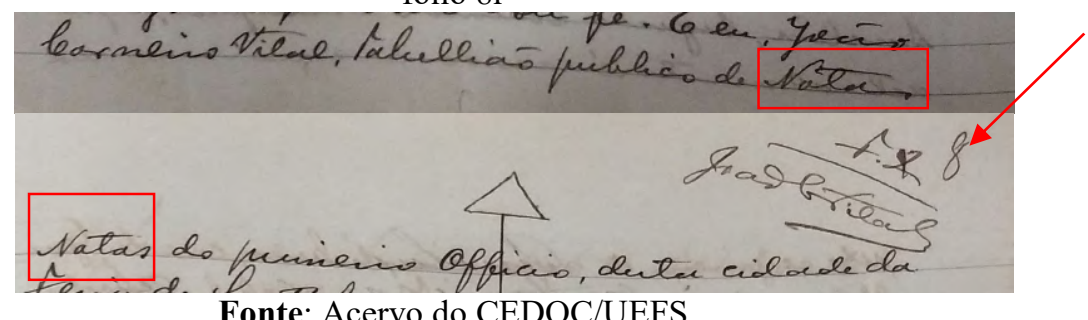

Fonte: Acervo do CEDOC/UEFS

Paleograficamente, o documento foi escrito pelo Escrivão Manuel Francisco de Almeida Ramalho (fólios 1r, 6r/6v, 8v e 9r), pelo Tabelião de Notas João Carneiro Vital (fólios $2 \mathrm{r} / 2 \mathrm{v}, 3 \mathrm{r} / 3 \mathrm{v}, 4 \mathrm{r} / 4 \mathrm{v}, 5 \mathrm{r} / 5 \mathrm{v}, 7 \mathrm{r} / 7 \mathrm{v}$ e $8 \mathrm{r}$ ), pelo Juiz de Direito Jacintho Ferreira da Silva (fólio 8v) e pelo Escrivão José Telles Barreto (fólios 9r e 10r). Destes, apenas o punho do último - que se caracteriza como destro, já que a sua escrita tem um ângulo de inclinação para 
a direita - é apresentado no quadro a seguir, já que os dos demais foram expostos anteriormente.

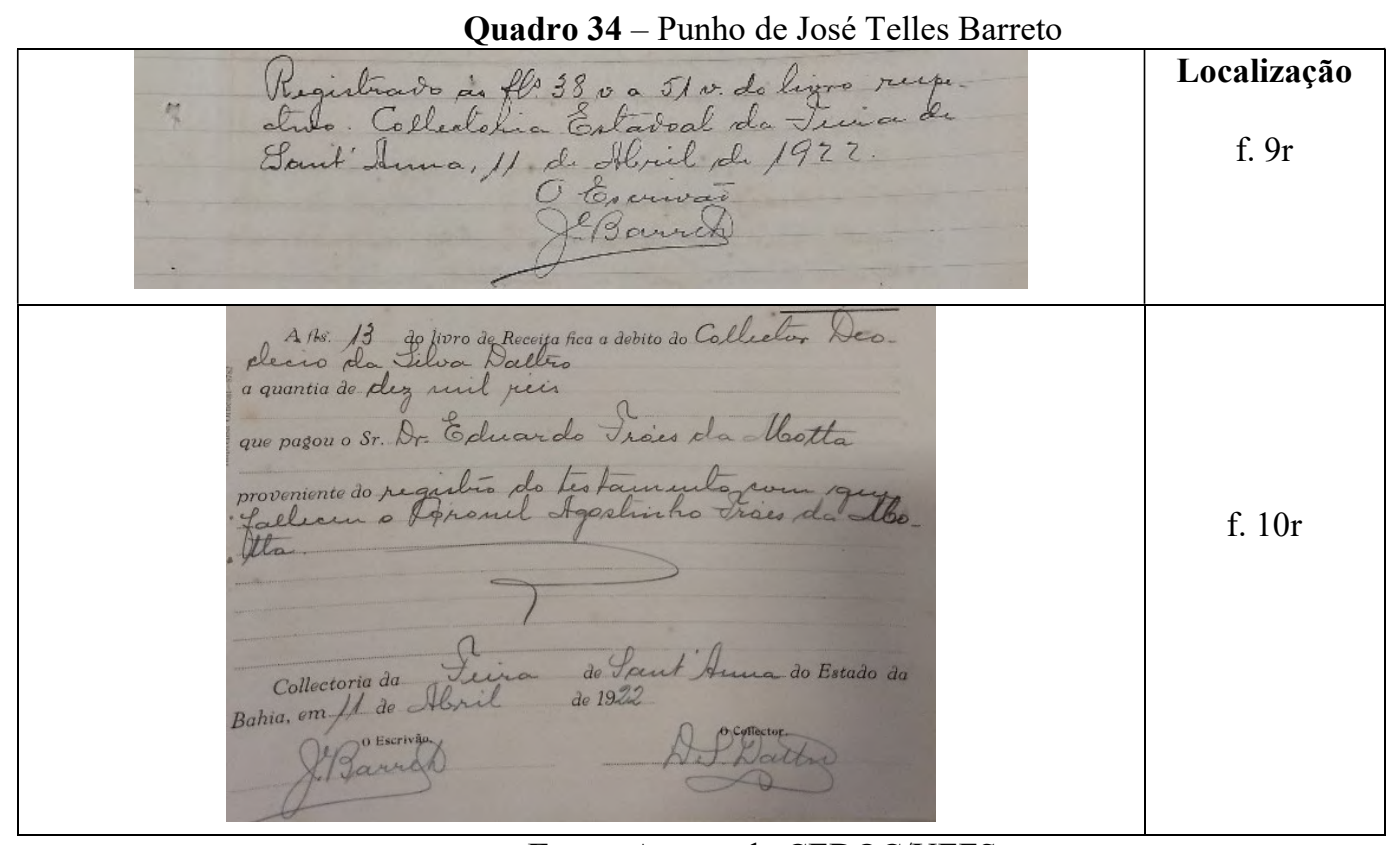

Fonte: Acervo do CEDOC/UEFS

Sobre os escreventes desse documento, é possível identificar que eles mantiveram, nos fólios escritos, regularidade de empaginação nas caixas de escrita, haja vista a visível preocupação de cada um em respeitar a paragrafação inicial e final do texto, bem como as margens superior, direita, inferior e esquerda dos fólios, conforme exemplificado nas figuras seguintes.

Figura 63 - Empaginação do fólio 2r, escrito por João Carneiro Vital

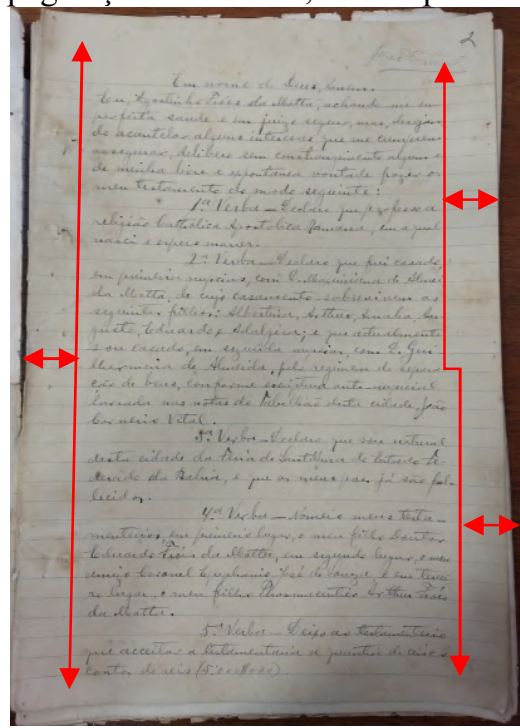

Fonte: Acervo do CEDOC/UEFS 
Figura 64 - Empaginação do fólio 8v, escrito por Manuel Francisco de Almeida Ramalho e Jacintho Ferreira da Silva

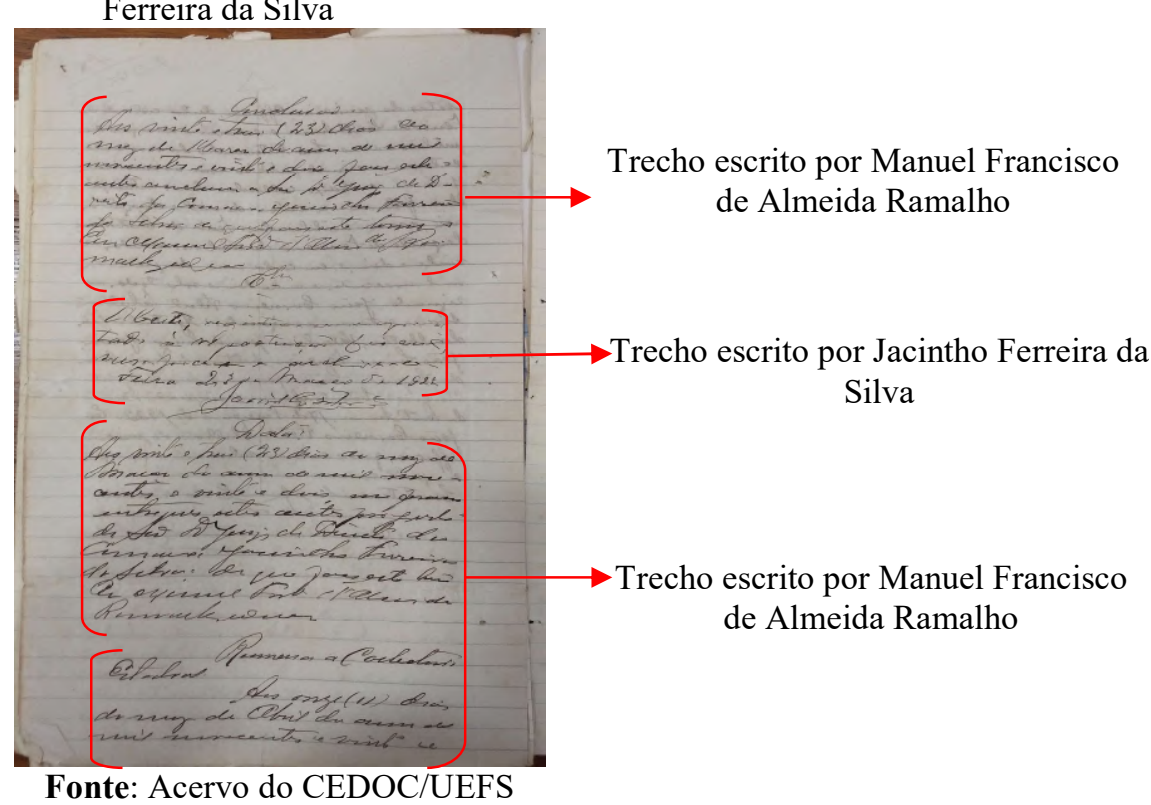

Figura 65 - Empaginação do fólio 9r, escrito por Manuel Francisco de Almeida Ramalho e José Telles

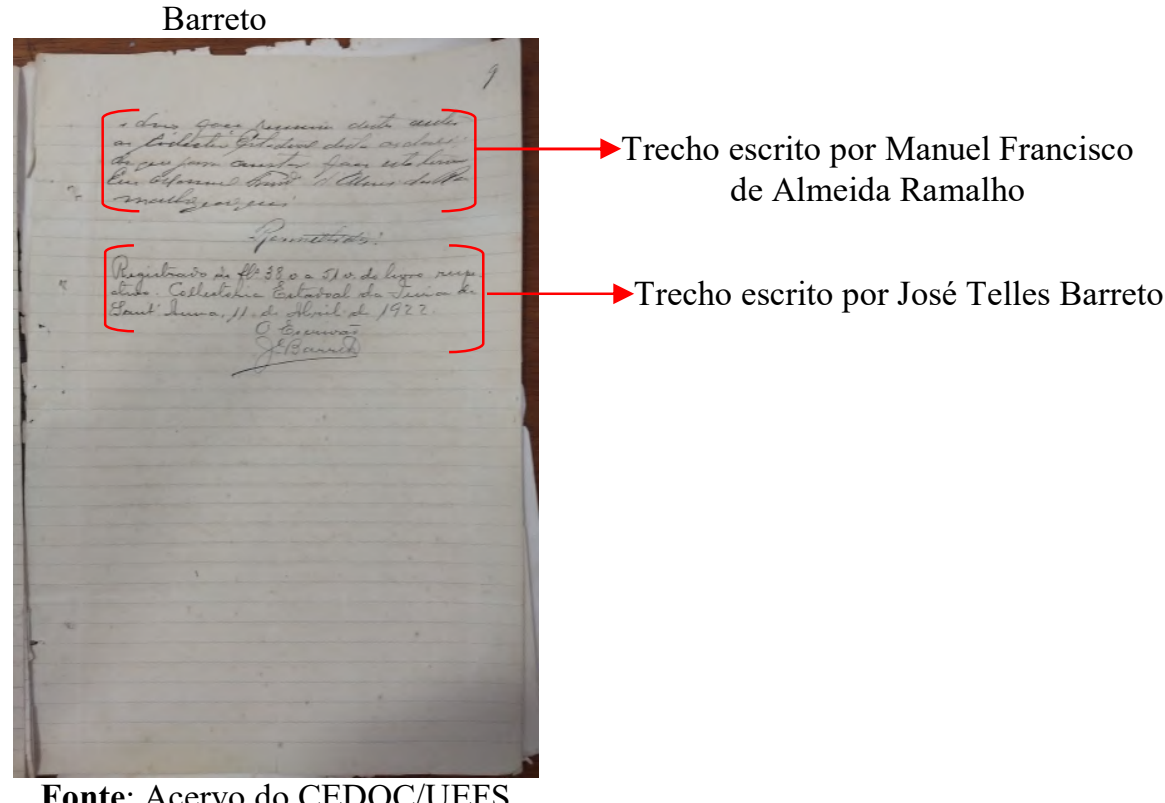

Outro aspecto paleográfico interessante são as assinaturas pessoais e os sinais públicos constantes no documento. Sobre isso, é possível obervar na margem superior direita dos fólios 2r, 3r, 4r, 6r, 7r e 8r a rubrica do Tabelião de Notas João Carneiro Vital, e um sinal público de $242 \mathrm{~mm}$ e $195 \mathrm{~mm}$ de comprimento nos fólios $5 \mathrm{v}$ e $8 \mathrm{r}$, respectivamente. 
Figura 66 - Assinatura pessoal do escrevente João Carneiro Vital, na margem superior direita, dos fólios 2r, 3r, 4r, 6r, 7r e 8r

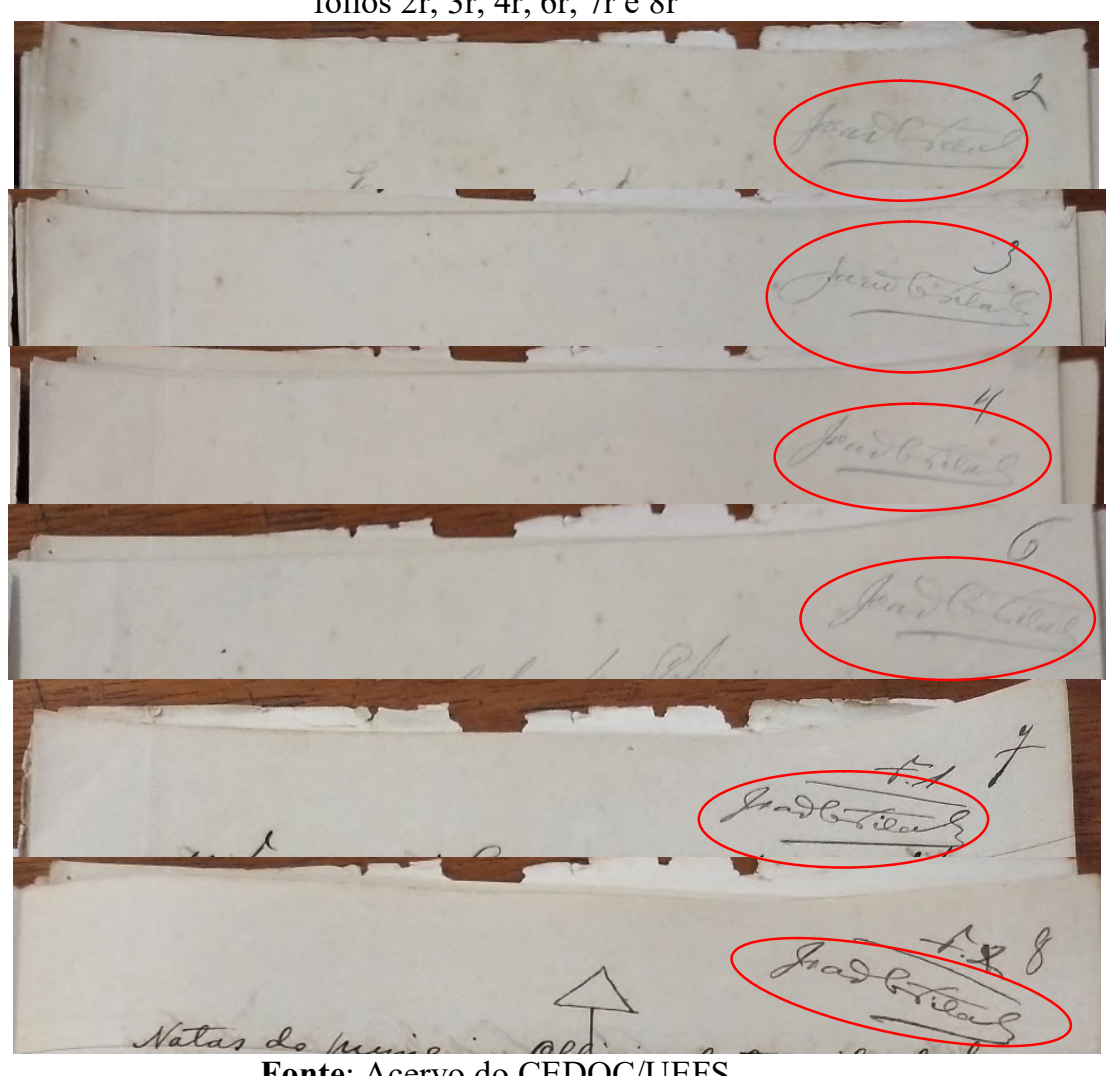

Fonte: Acervo do CEDOC/UEFS

Figura 67 - Sinal público do Tabelião João Carneiro Vital, nos fólios 5v e 8r

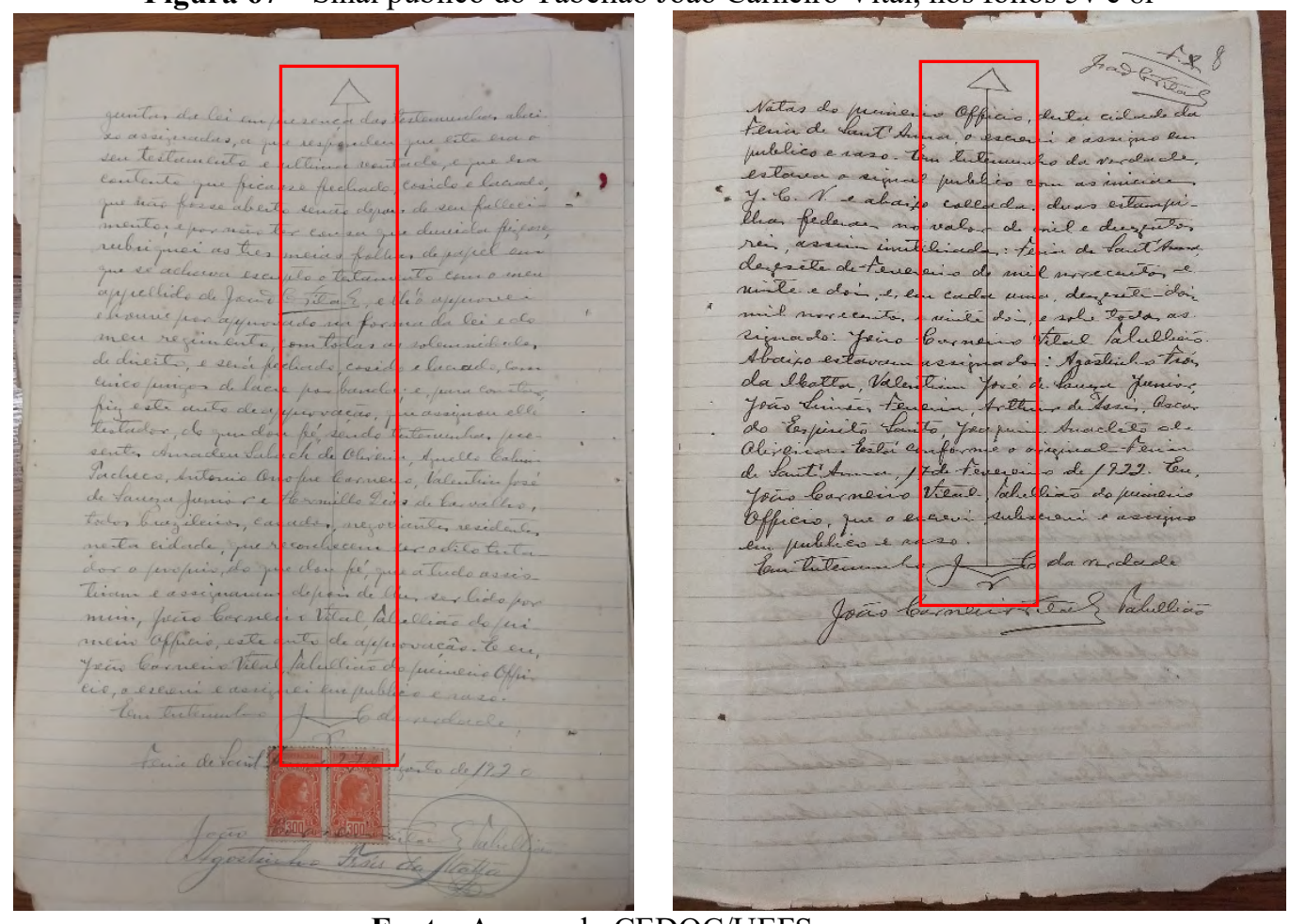

Fonte: Acervo do CEDOC/UEFS 
Por fim, um último aspecto paleográfico a ser mencionado são as laçadas das assinaturas pessoais. Sobre estas, destacamos, a seguir, apenas as das assinaturas pessoais dos indivíduos que participaram da produção do documento e que ainda não foram anteriormente mencionados. Assim, a primeira laçada a ser apresentada é a da assinatura pessoal do testador, Agostinho Fróes da Motta, haja vista a existência de um sinal público, um círculo de $38 \mathrm{~mm}$ de diâmetro, ao final da assinatura, que dá fé pública ao documento, conforme exemplificado na figura seguinte.

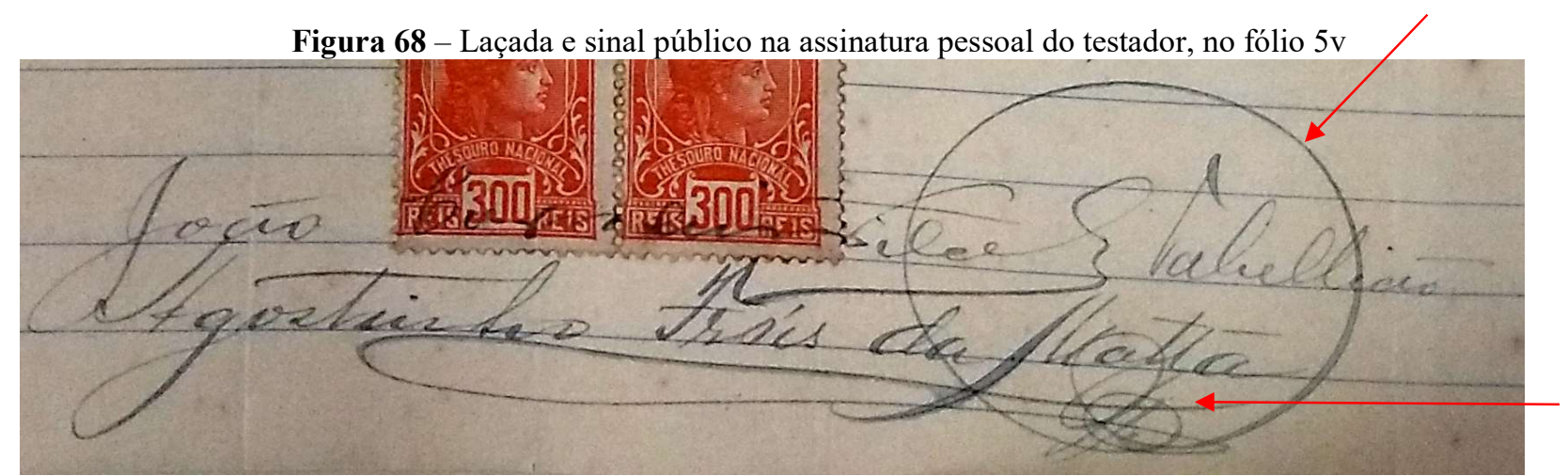

Fonte: Acervo do CEDOC/UEFS

Nas assinaturas das testemunhas (Amadeu Saback de Oliveira, Antonio Onofre Carneiro e Valentim José de Souza Junior) há ganchos, caracterizados como traços horizontais, geralmente curtos, feitos no mesmo cursus e embaixo da última letra da respectiva assinatura, conforme observado na figura 69.

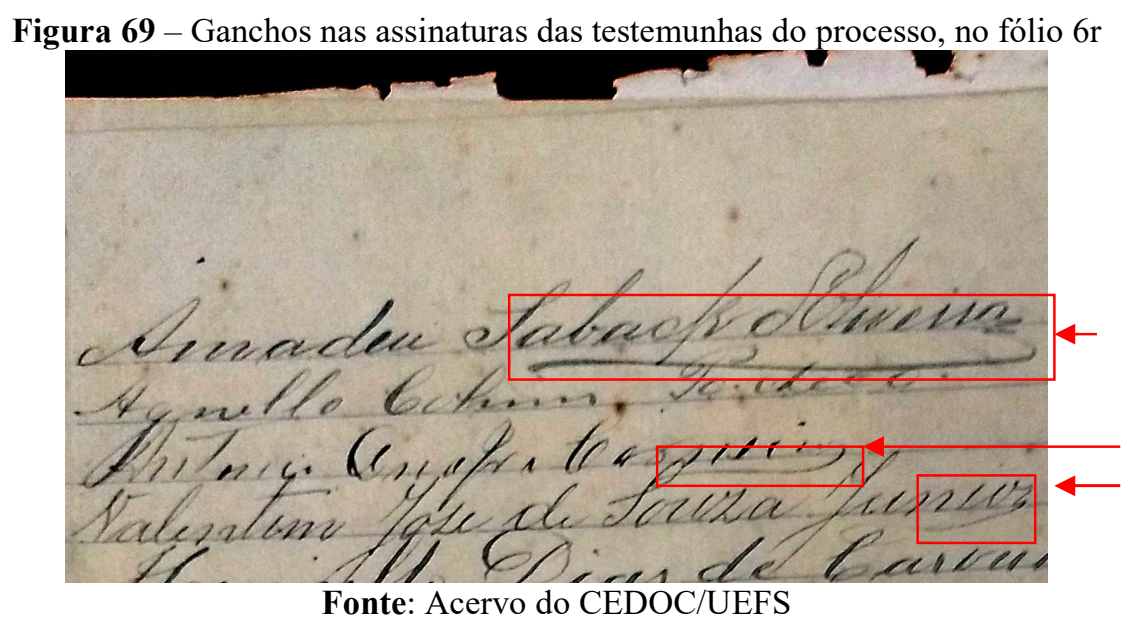

Semelhante às assinaturas do documento anterior, essas também possuem um "alto calibre", um ângulo de inclinação para a direita, uso de acentuação (com exceção da assinatura de Valentim José de Souza Junior) e de pontuação, ritmo lento, letras iniciais cuidadosamente traçadas, cursividade, alguns traçados mais grossos em algumas letras das 
assinaturas de Amadeu Saback de Oliveira, Agnello Cohim Pacheco e Antonio Onofre Carneiro (o que indica um esforço maior dessas testemunhas no tracejamento, por exemplo, do "b", “d", “s", “c", “g”, “a", “e" e "o") e uso de um mesmo módulo de escrita, com distinções entre as maiúsculas e as minúsculas. Ademais, as assinaturas são caligráficas, do tipo escolar, legíveis, sem ligaduras e com algumas "letras monolíticas" (como observado nas assinaturas de Agnello Cohim Pacheco e Antonio Onofre Carneiro).

O terceiro e último documento é o inventário de Agostinho Fróes da Motta que se encontra em razoável estado de conservação, com 799 fólios, escritos no recto e verso, em letra cursiva, em sua grande maioria em tinta preta e/ou azul, em papel almaço e/ou timbrado, iniciado em 1922 e encerrado em 1925, na cidade de Feira de Santana-BA, e armazenado no CEDOC/UEFS, sob a cota: Estante 6, Caixa 175 e Documento 2887.

O documento é dividido em 4 volumes, que apresentam quantidade de fólios distinta, a saber: volume I - 166 fólios, volume II - 216 fólios, volume III - 183 fólios e volume IV: 234 fólios, sendo que nenhum deles possui capa, mas uma folha de papel almaço, com pautas, que envolve cada um deles, a qual foi inserida pelos estagiários do CEDOC/UEFS, a fim de evitar o contato direto das mãos do pesquisador com o documento, como pode ser verificado na figura seguinte.
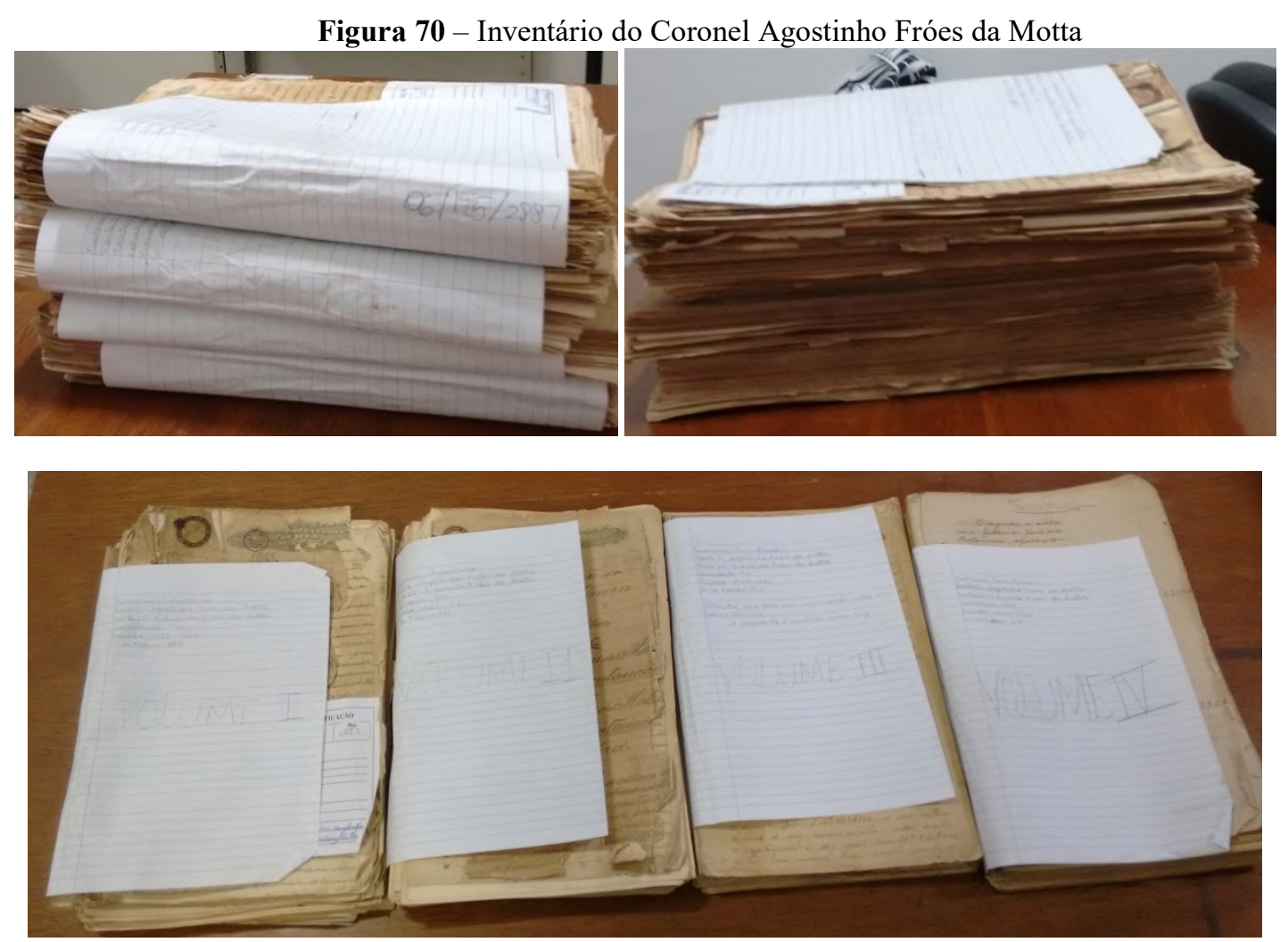

Fonte: Acervo do CEDOC/UEFS 
Dos 4 volumes, selecionamos como parte do corpus desta tese apenas o primeiro, por conta da extensão do documento e do tempo de execução da pesquisa, compreendido entre a realização das edições filológicas e o estudo lexical dos três documentos, além da leitura e descrição codicológica de todos os processos listados no quadro 3. A partir desses esclarecimentos, apresentamos a descrição codicológica e paleográfica do primeiro volume do referido inventário.

Semelhantemente aos dois documentos anteriores, na folha de rosto do primeiro volume do inventário há uma ficha de identificação com informações sobre o fórum, a classificação do documento, a seção, a série e a subsérie do processo, bem como a tipologia, a comarca, a localidade, o número de fólios, o período, as partes envolvidas e a seguinte observação: “A parte I era Coronel. Trata-se de um inventário composto por 4 (quatro) Volumes. O volume IV está incompleto", conforme figura 71.

Figura 71 - Fólio 1r do inventário de Agostinho Fróes da Motta, com detalhe para a ficha de identificação
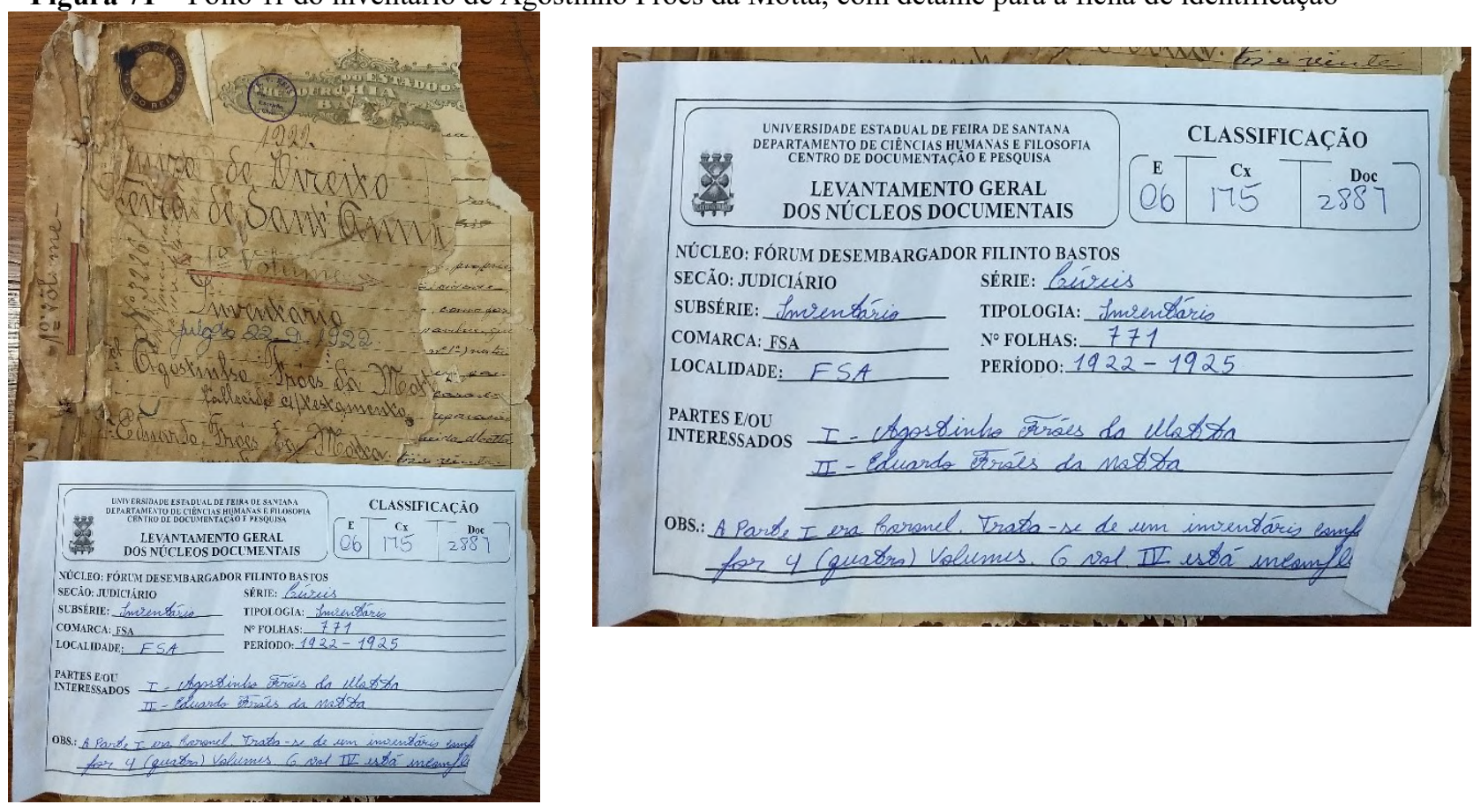

Fonte: Acervo do CEDOC/UEFS

O primeiro volume é escrito no recto e verso, dentre os quais há variados fólios em branco, datiloscritos, híbridos (com trechos manuscritos e datiloscritos), formulários, folhas do livro do caixa da Firma Agostinho Fróes da Motta e Filho, anexadas como fólios, e fólios manuscritos, como descrito no quadro 14. Além disso, o documento é composto por vários inplanos e in-fólios, os quais, se descritos individualmente, alongariam substancialmente esta 
subseção e comprometeriam o espaço para a apresentação dos demais aspectos codicológicos, considerados representativos do corpus e, portanto, imprescindíveis de serem descritos.

No primeiro fólio, portanto, é possível identificar, assim como nos outros dois documentos, o carimbo molhado, de $21 \mathrm{~mm}$ de diâmetro, do escrivão Vicente dos Reis com a inscrição "E. V. REIS | Fls. | Escrivão Civel”, localizado no centro da margem superior. Ademais, no mesmo fólio há perda significativa de suporte material, nas laterais das quatro margens, além de mancha de tinta preta, na margem superior esquerda; de manchas ocasionadas pela aplicação de cola de papel; de rasgão perpendicular da margem central à margem esquerda do fólio e rasgão, em semicírculo, no centro da margem superior; de mancha de líquido na margem superior esquerda; de escurecimento de algumas partes do fólio; de mancha marrom ocasionada pelo contato de algum objeto circular com o documento; e de um selo de imposto timbrado na margem superior esquerda, e parte de um timbre estadual na margem centro-superior do fólio, conforme sinalizado nas figuras seguintes.

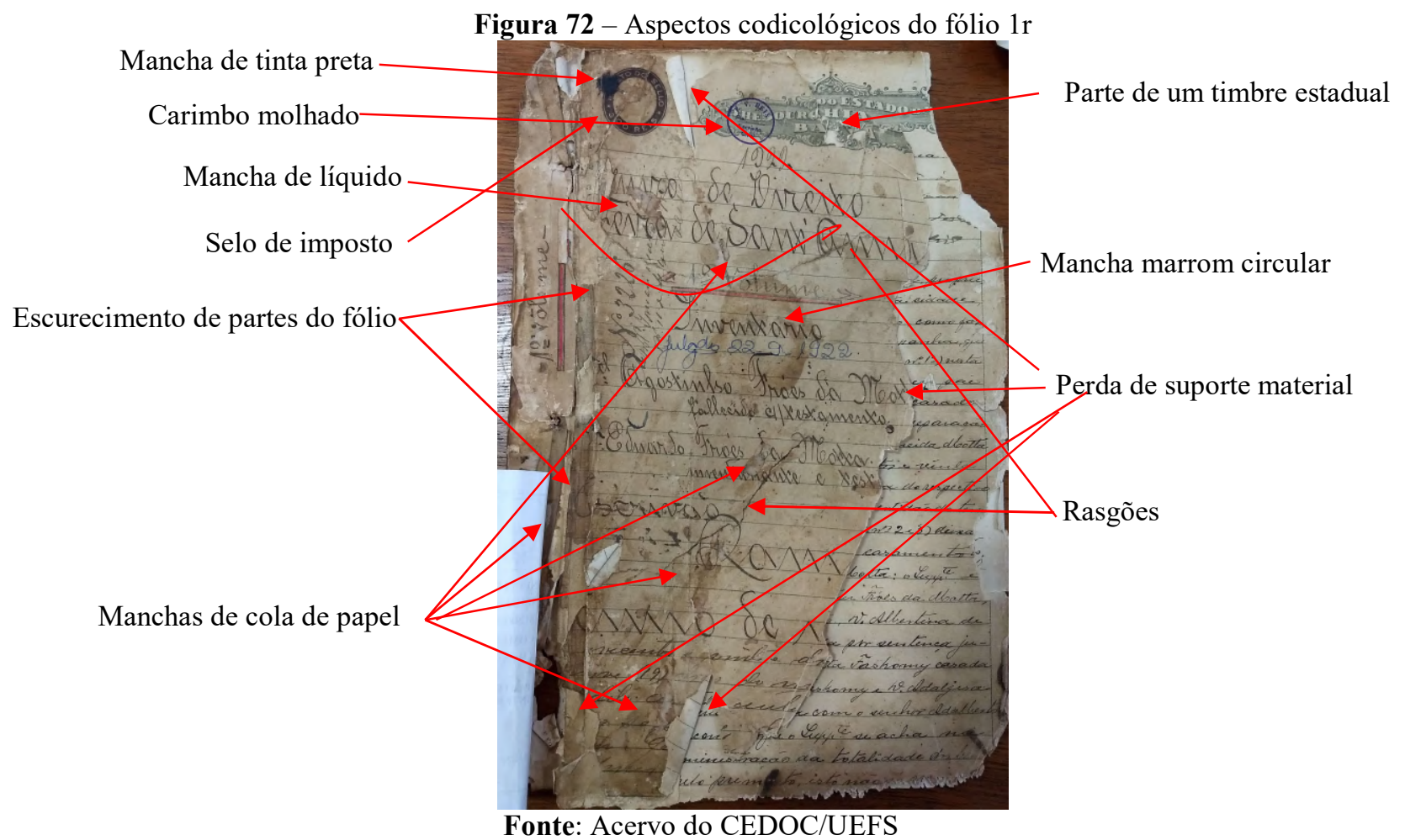


Figura 73 - Detalhe para os rasgões no fólio $1 \mathrm{r}$

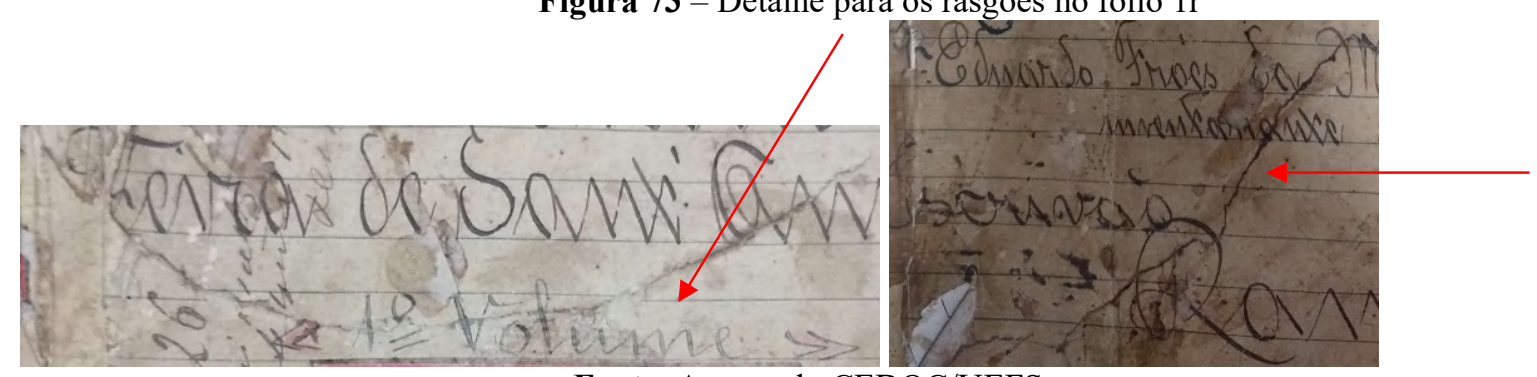

Fonte: Acervo do CEDOC/UEFS

A explicação para a origem das manchas de cola de papel é a aplicação de cola em três recortes retangulares de papel almaço, com pauta, fixados no verso do primeiro fólio, dos quais um deles foi utilizado como suporte para escrita, como poderá ser observado a seguir. Essa iniciativa do(s) escrevente(s) Manuel Francisco de Almeida Ramalho e/ou de Lyderico dos Santos Cruz, provavelmente, representa uma tentativa de manter o recto do primeiro fólio preservado, haja vista que boa parte do suporte material já se encontra perdida, o que explica a colagem de recortes de papel nos locais em que há rasgões significativos.

Contudo, essa atitude, apesar de parecer sensata naquele momento, haja vista ser a única forma de conservação do suporte material, provavelmente, conhecida por aquele(s) escrevente(s), foi insuficiente para conservar a "folha de rosto" do documento, a qual ficou suscetível a outras interferências, tais como a exposição do suporte material ao calor e à umidade, o que pode explicar as manchas de líquido e o escurecimento agressivo de algumas partes do fólio, bem como o contato do suporte com tinta ou objetos, que deixaram sobre aquele manchas danosas ao documento.

O recto do segundo fólio também tem rasgões nas laterais das margens superior, direita e inferior; uma colagem na vertical de toda a margem esquerda, a qual teve por finalidade prender o fólio anterior ao segundo e ao próximo; e marcas de exposição ao calor, como pode ser verificado a seguir. 
Figura 74 - Recortes de papel colados no verso do primeiro fólio

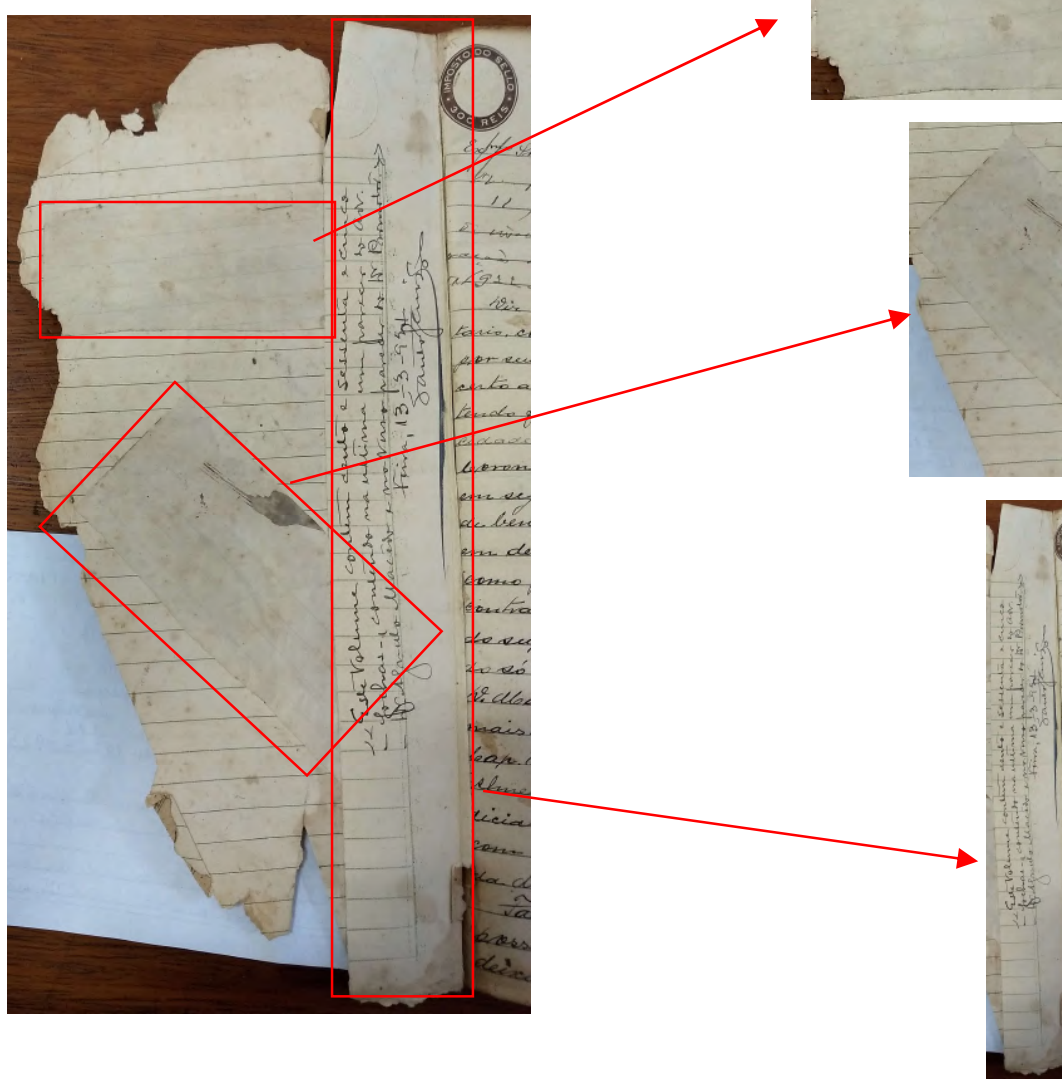

Fonte: Acervo do CEDOC/UEFS

Figura 75 - Aspectos codicológicos do fólio $2 \mathrm{r}$

Marcas de exposição ao calor

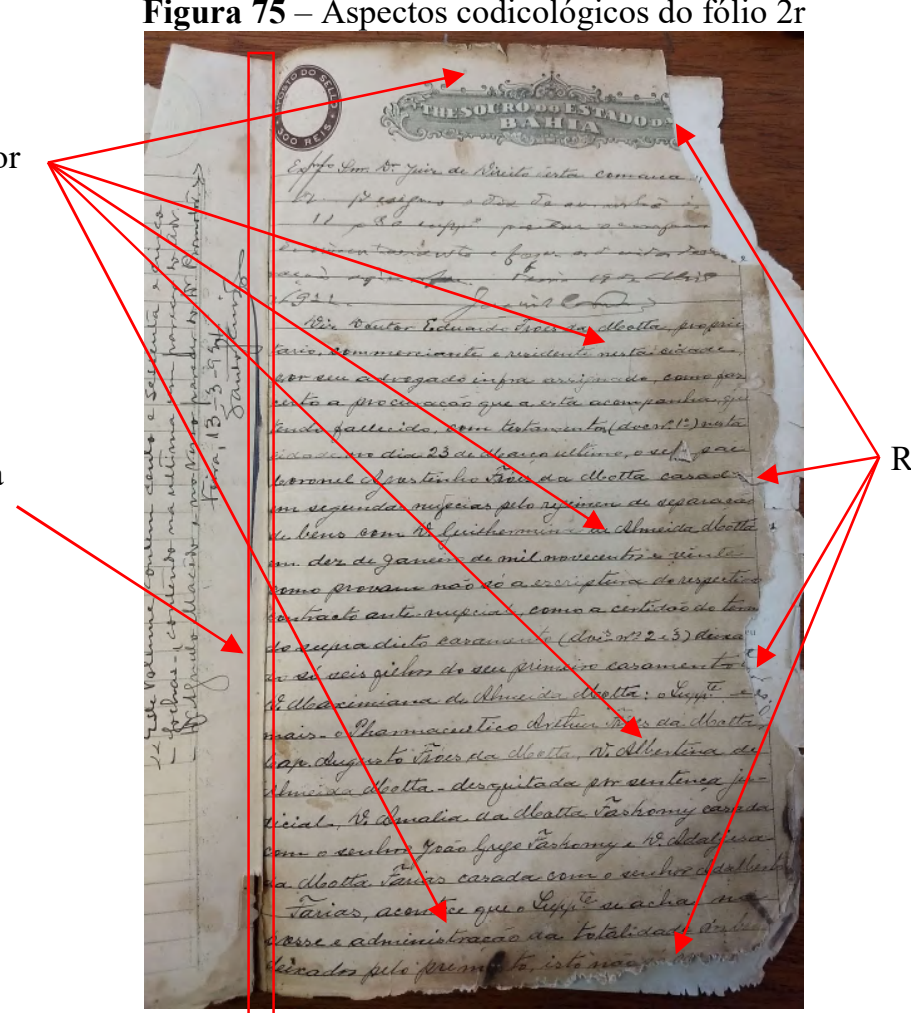

Colagem na vertical da margem esquerda 
O terceiro fólio, por sua vez, além de ser um formulário manualmente preenchido, também tem rasgões na lateral da margem direita e perfurações nas margens superior, central e inferior da lateral esquerda que, por algum motivo, expandiram-se e comprometeram a leitura do texto existente na margem inferior esquerda; além de um carimbo seco com a inscrição: “João Carneiro Vital | NOTARIO PUBLICO | Feira-de Sant'Anna | BAHIA”, na margem superior esquerda.

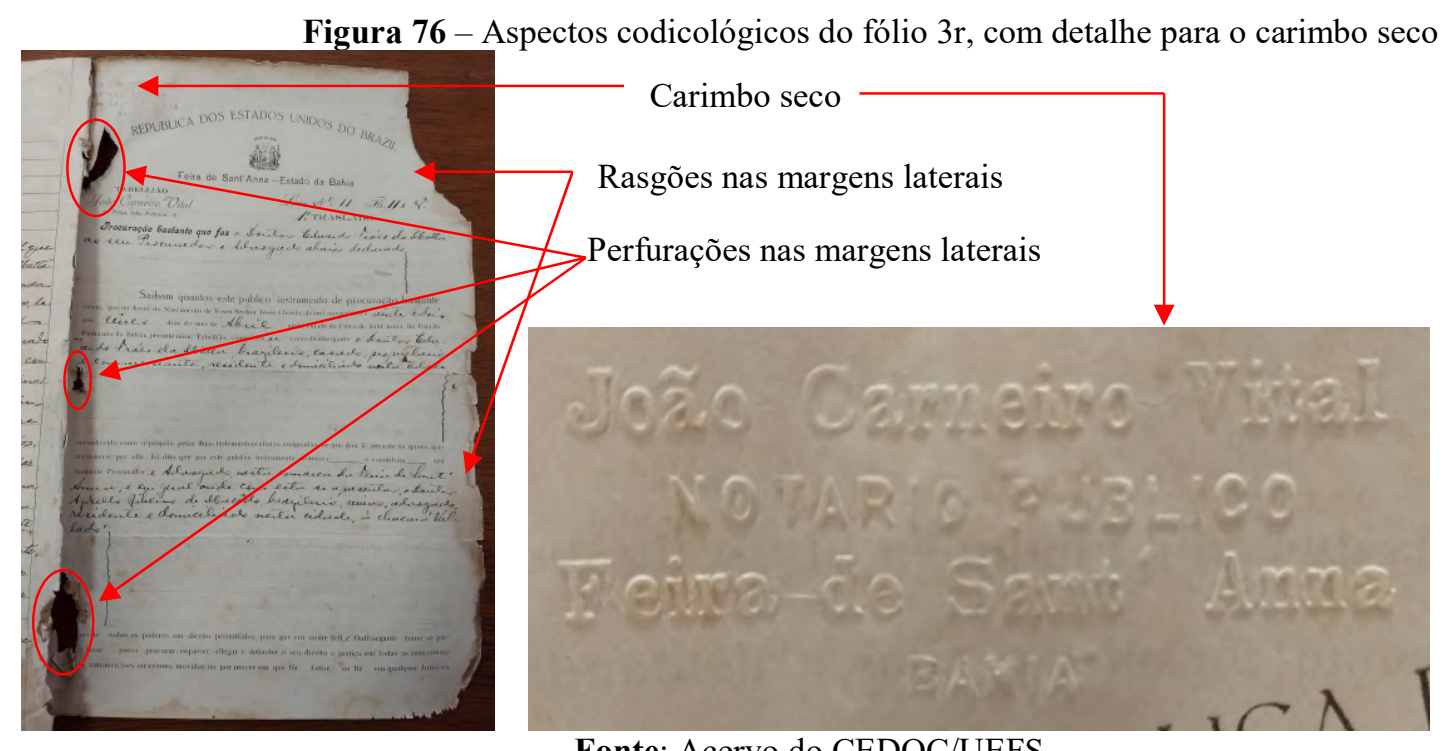

Fonte: Acervo do CEDOC/UEFS

A deterioração do suporte material desses três fólios impossibilitou o conhecimento de toda a informação neles registrada. Contudo, nos fólios subsequentes isso não acontece, porque o documento apresenta aspectos que, embora mereçam ser destacados, não comprometem a apreensão do conteúdo. Assim, o primeiro aspecto a ser mencionado são as três perfurações (superior, central e inferior) na vertical da margem esquerda de todos os fólios rectos, inclusive nos três primeiros já apresentados, que indicam que o documento foi, em algum momento, costurado com barbante.

O segundo aspecto a ser destacado é a presença de um selo de imposto, com a parte central em alto relevo (o que indica que o centro do selo foi feito através de um instrumento, que fez pressão sobre o papel), com a inscrição: "IMPOSTO DO SELLO | 300 REIS | ESTADO DA BAHIA | BRAZIL" e com 28mm de diâmetro; e um timbre estadual com a inscrição "THESOURO DO ESTADO DA BAHIA", ambos em quase todos os fólios rectos do documento. O terceiro aspecto, por sua vez, diz respeito ao recurso utilizado pelos escreventes para organizar o documento: a numeração progressiva na margem superior direita 
do recto dos fólios e o uso substancial de reclamos, na maioria dos rectos e versos, ou viceversa, dos fólios.

O quarto aspecto é a presença de marcas d'água no recto de alguns fólios timbrados. Sobre esse aspecto, a primeira filigrana encontrada é a que consta no recto de alguns fólios timbrados, a qual é composta pelo escudo do Estado da Bahia, pela inscrição: "ESTADO DA BAHIA | PER ARDUA SURGO | BRAZIL" e pela contramarca "IMPOSTO DO SELLO", as quais estão entre os $1^{\mathrm{o}}$ e $6^{\circ}$ pontusais, que estão separados um do outro por $27 \mathrm{~mm}$ de distância, conforme figura 81. A segunda filigrana é a que consta, por exemplo, no verso do fólio 31, composta pelo escudo das Armas Nacionais do Brasil e pela inscrição "ESTADOS UNIDOS DO BRAZIL | 15 DE NOVEMBRO DE 1889”, que se encontram entre os $2^{\circ}$ e $6^{\circ}$ pontusais, também separados por, aproximadamente, $27 \mathrm{~mm}$ de distância. A terceira e última marca d'água, sem desenhos e sem pontusais, encontra-se na vertical dos fólios 108r e 109r e é composta apenas pela inscrição: "HAMMERMILL | BOND”.

Figura 77 - Exemplo de perfurações na vertical esquerda dos fólios rectos

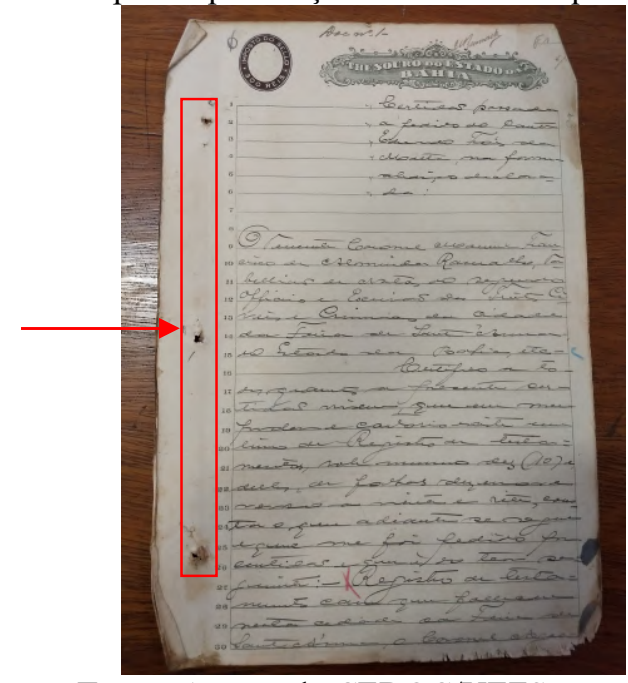

Fonte: Acervo do CEDOC/UEFS

Figura 78 - Selo de imposto, com detalhe para a parte central em alto relevo, e timbre estadual, ambos na maioria dos fólios rectos
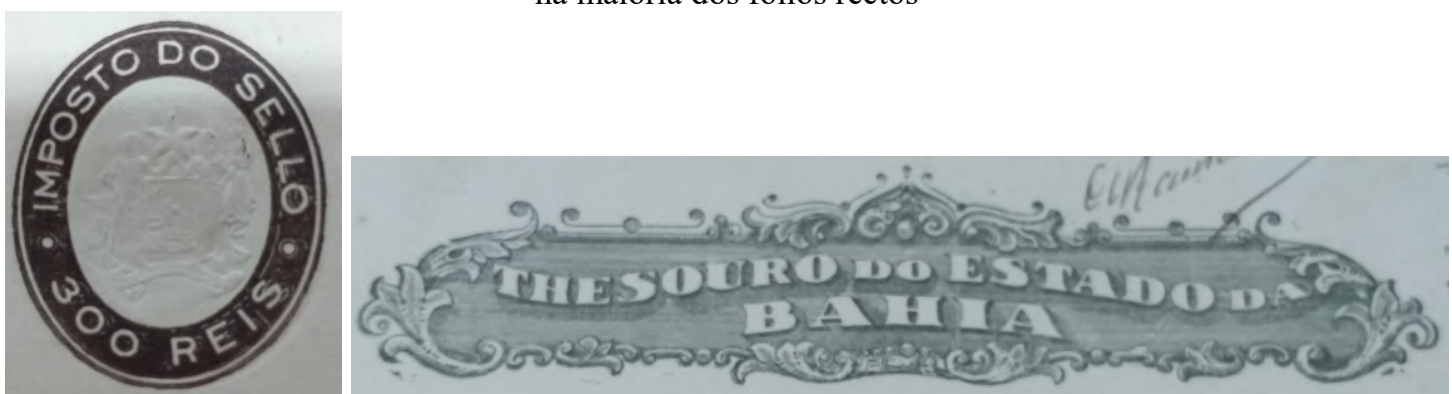

Fonte: Acervo do CEDOC/UEFS 
Figura 79 - Numeração progressiva na maioria dos fólios rectos

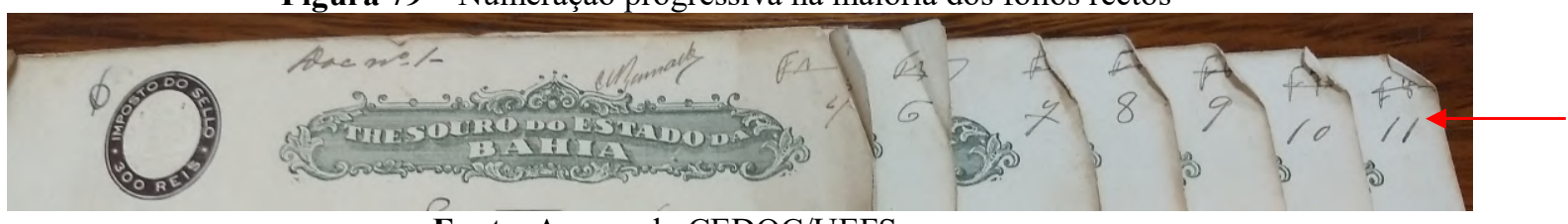

Fonte: Acervo do CEDOC/UEFS

Figura 80 - Reclamos "Cotegi-/Cotegipe" nos fólios 16v e 17r

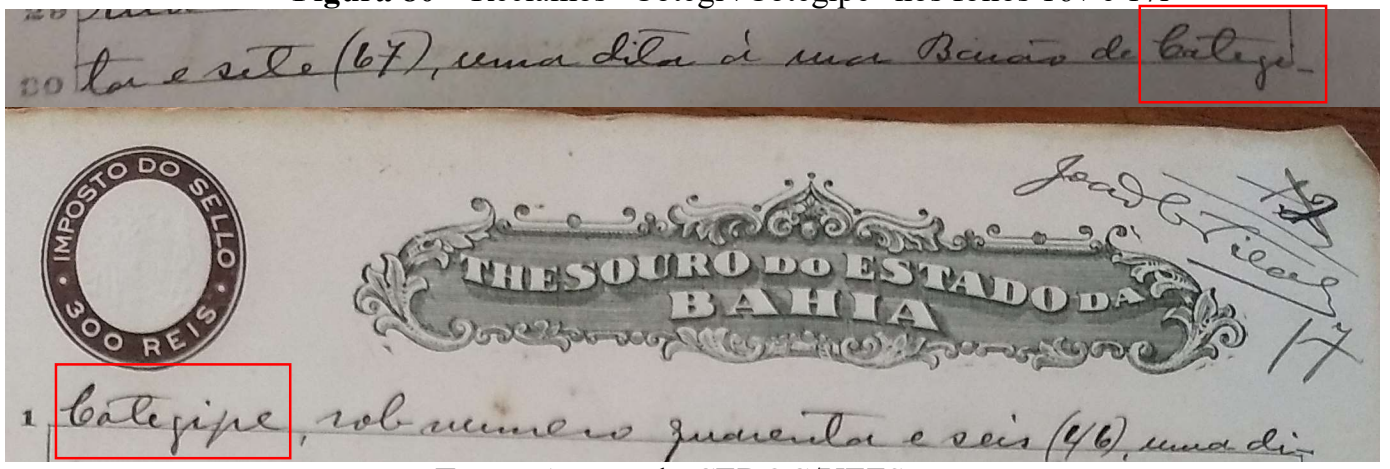

Fonte: Acervo do CEDOC/UEFS

Figura 81 -Escudo do Estado da Bahia com a inscrição "ESTADO DA BAHIA | PER ARDUA SURGO | BRAZIL" e contramarca "IMPOSTO DO SELLO" no recto do fólio 33r

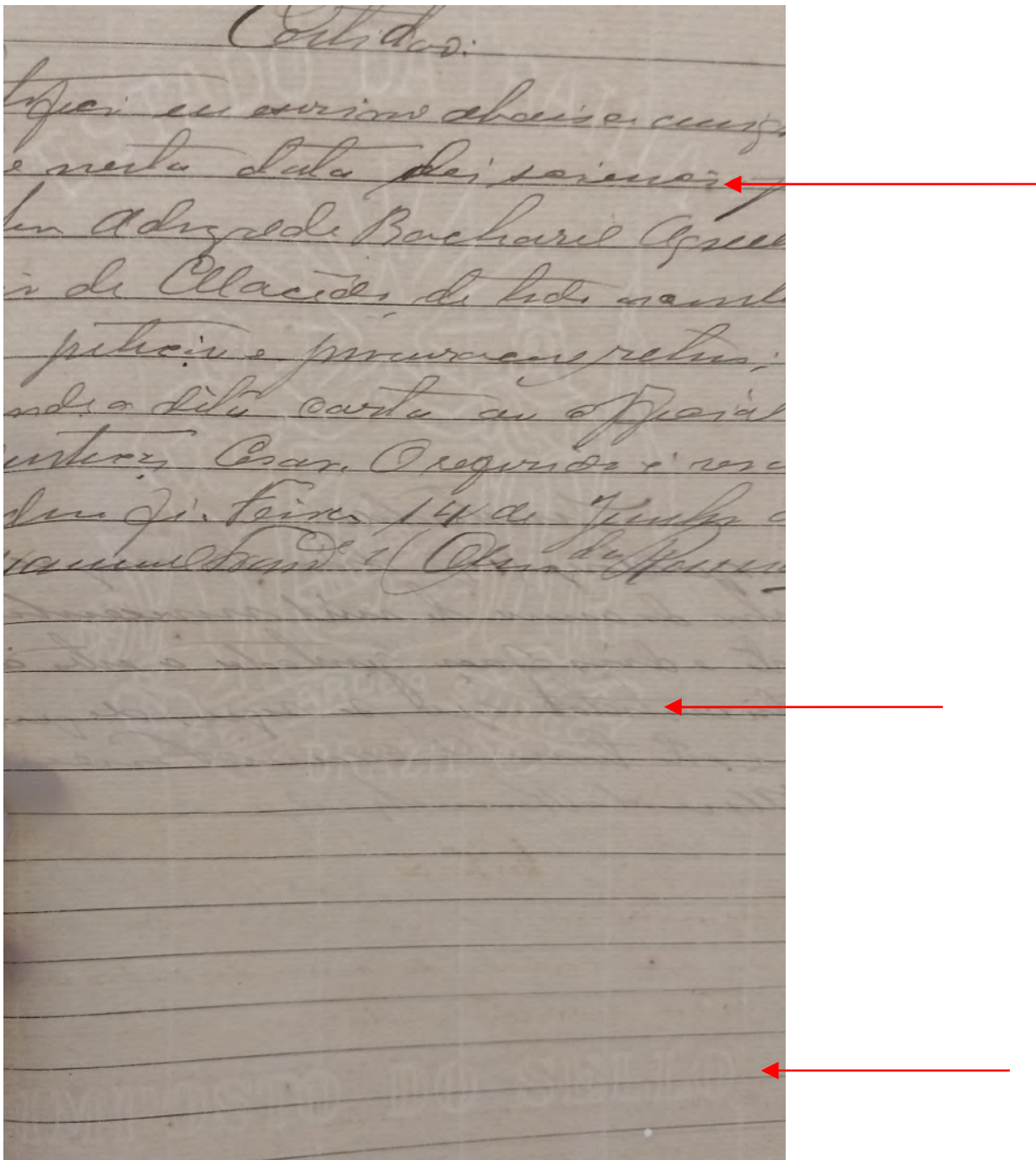

Fonte: Acervo do CEDOC/UEFS 
Figura 82 - Escudo das Armas Nacionais do Brasil com a inscrição "ESTADOS UNIDOS DO BRAZIL | 15 DE NOVEMBRO DE 1889" no verso do fólio 31

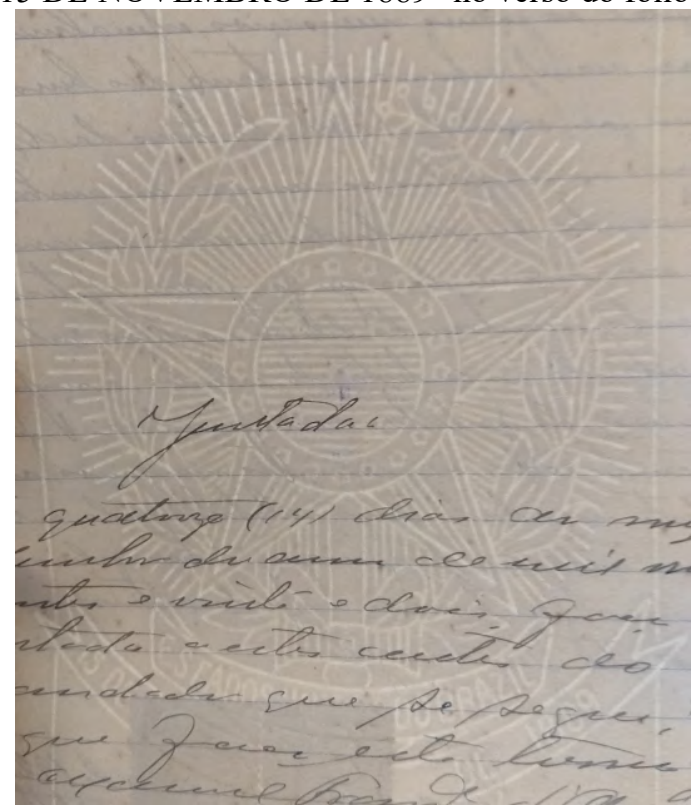

Fonte: Acervo do CEDOC/UEFS

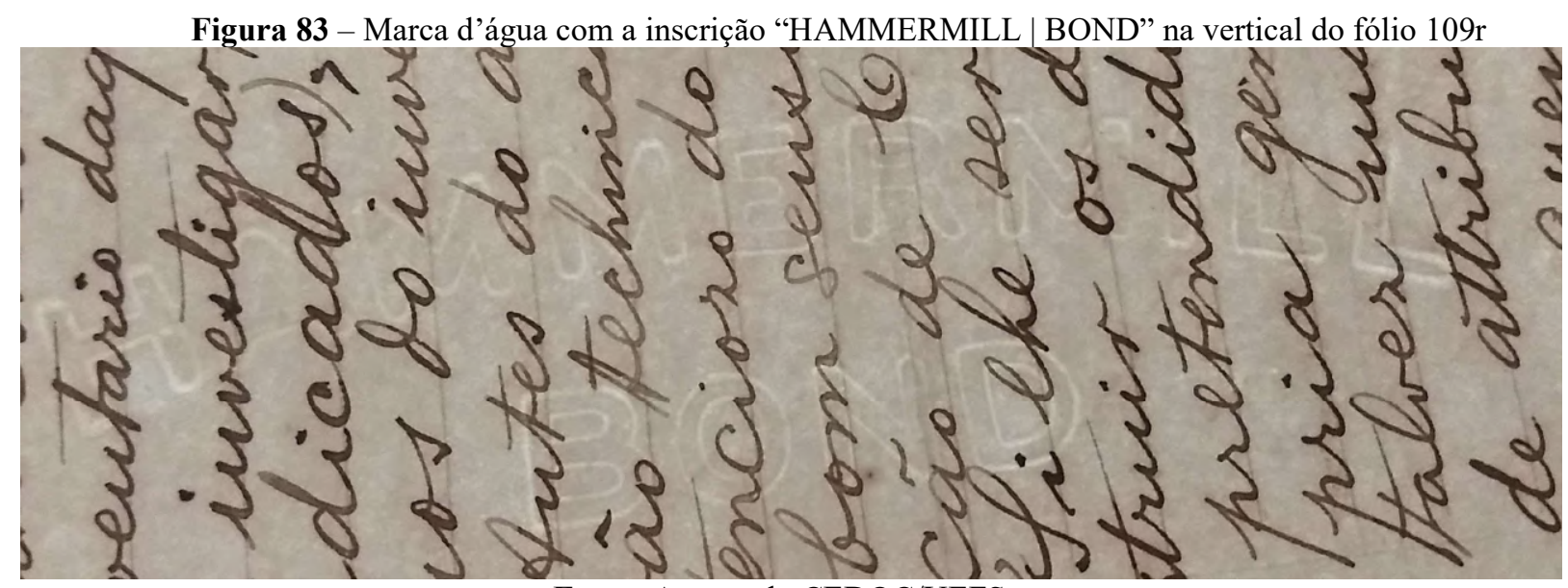

Fonte: Acervo do CEDOC/UEFS

Destacam-se, também, no documento, marcas de selos de impostos, provocadas pelo contato de fólios que os têm com os que não os têm; marcas de tinta azul, ocasionadas pela proximidade de um fólio manuscrito com um datiloscrito, marcas de cola e de dobras verticais, bem como a existência de suporte material removido, de pedaços de papel colados e de carimbos secos em alguns fólios. Sobre estes últimos, há um, com a inscrição "Dr. José Maria Neves | Advogado", no centro da margem superior dos fólios 47r, 48r, 49r e 50r, e outro com a inscrição: “INTENDENCIA MUNICIPAL DE FEIRA DE SANT'ANNA | ESTADO DA BAHIA | BRAZIL”, com 50mm de diâmetro, no centro da margem superior do fólio $149 \mathrm{v}$, como exemplificado nas figuras seguintes. 
Figura 84 - Exemplos de marcas de selos de impostos nos fólios 15r e 91r, respectivamente
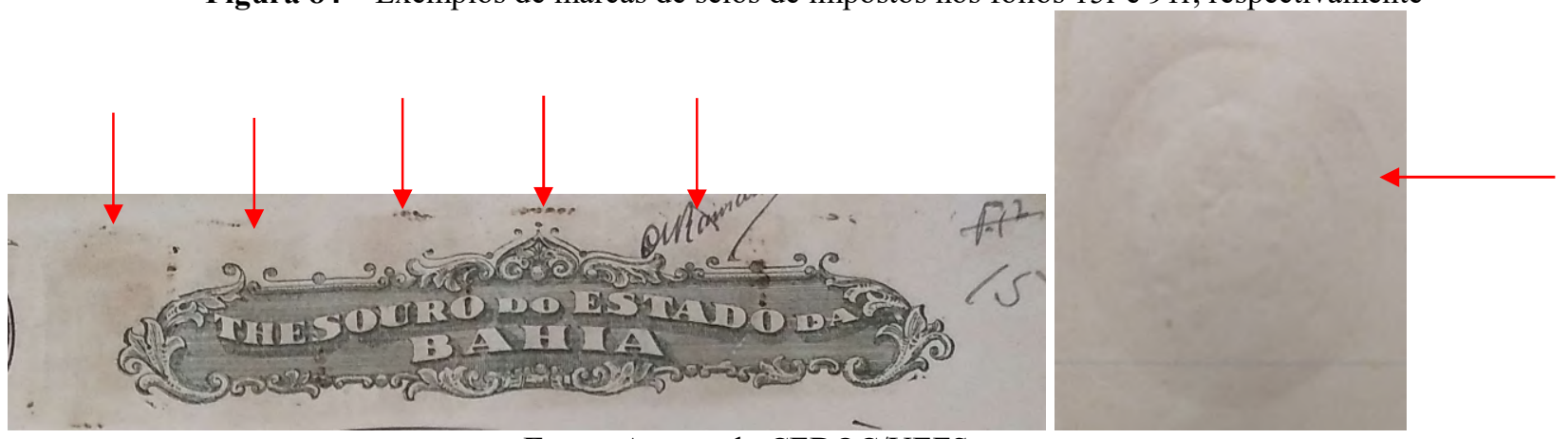

Fonte: Acervo do CEDOC/UEFS -

Figura 85 - Exemplo de marcas de tinta azul no fólio $29 \mathrm{v}$

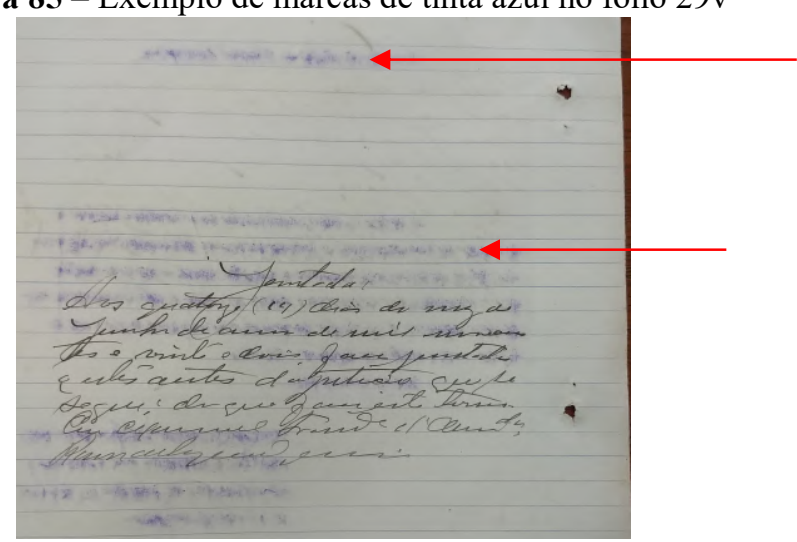

Fonte: Acervo do CEDOC/UEFS -

Figura 86 - Exemplos de marcas de cola e de dobras verticais

Marca de cola no fólio $45 \mathrm{r}$

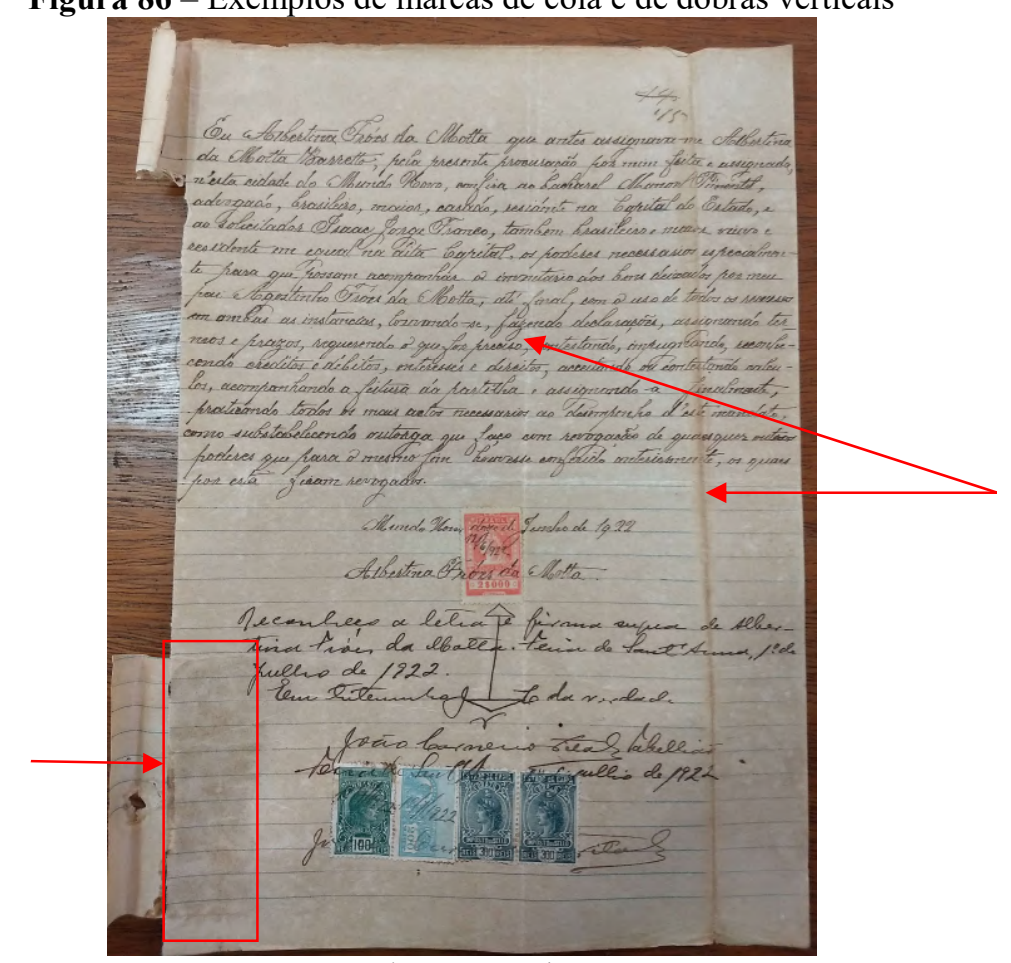

Marcas de dobras verticais no fólio $45 \mathrm{r}$

Fonte: Acervo do CEDOC/UEFS 


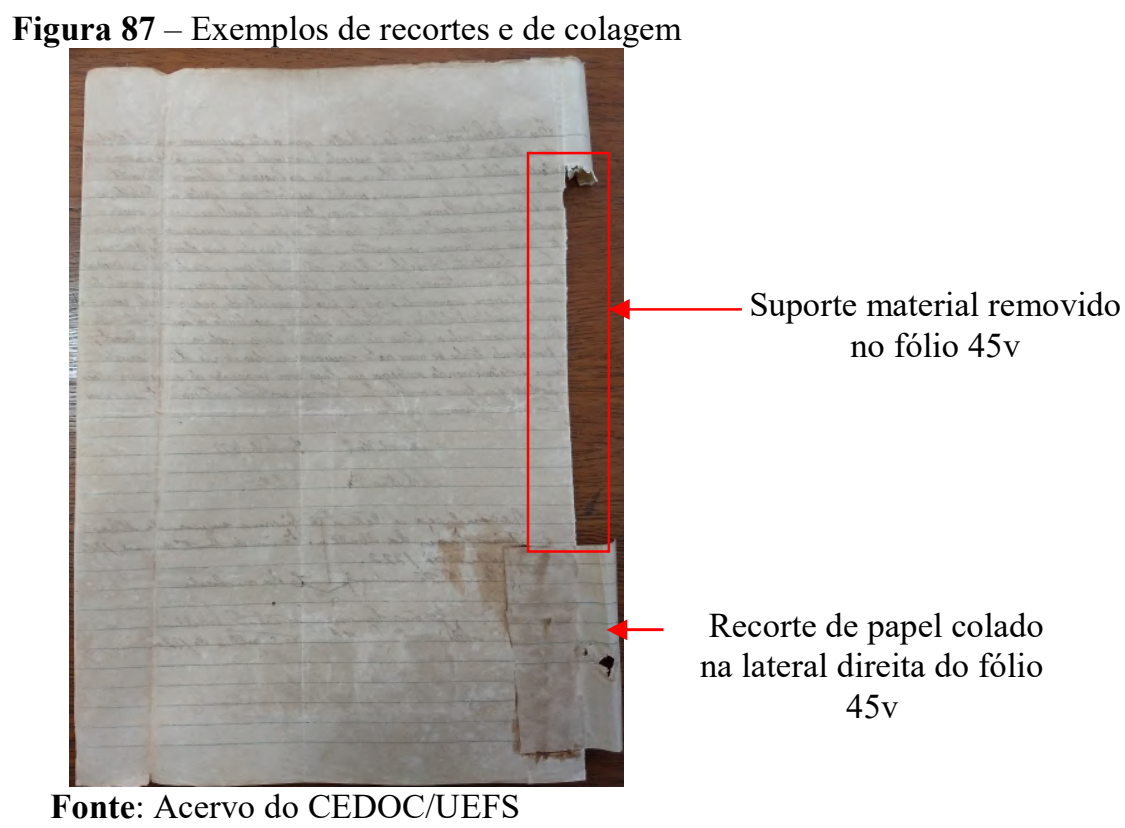

Figura 88 - Carimbo seco, com a inscrição “Dr. José Maria Neves | Advogado”, no centro da margem superior do fólio $47 \mathrm{r}$

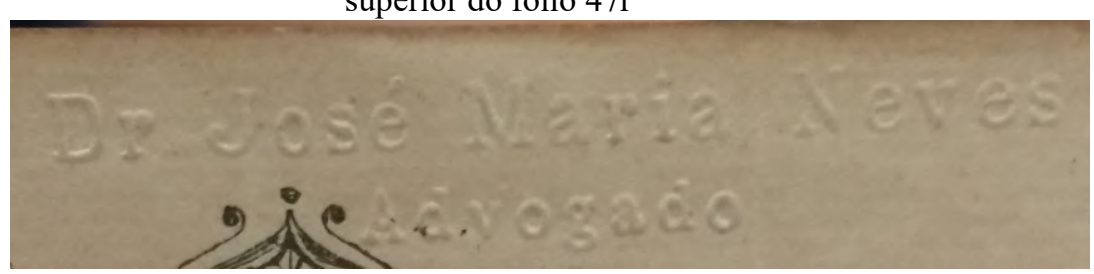

Fonte: Acervo do CEDOC/UEFS

Figura 89 - Carimbo seco, de 50mm de diâmetro, com a inscrição "INTENDENCIA MUNICIPAL DE FEIRA DE SANT’ANNA | ESTADO DA BAHIA | BRAZIL”, no centro da margem superior do fólio 149v

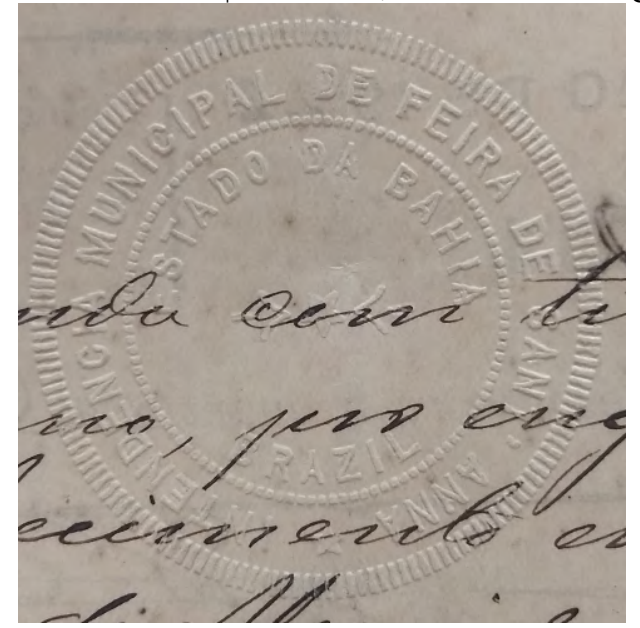

Fonte: Acervo do CEDOC/UEFS

Colados nos fólios 58r e 59r há um cartão postal colunado, com $88 \mathrm{~mm}$ de altura por $138 \mathrm{~mm}$ de largura, com dois carimbos molhados, cada um com $27 \mathrm{~mm}$ de diâmetro e um selo de imposto no valor de 50 réis, conforme as figuras seguintes. 
Figura 90 - Cartão postal colunado, no fólio 58r, com detalhe para os carimbos molhados, para o selo de imposto e para a inscrição tipográfica na vertical da margem central
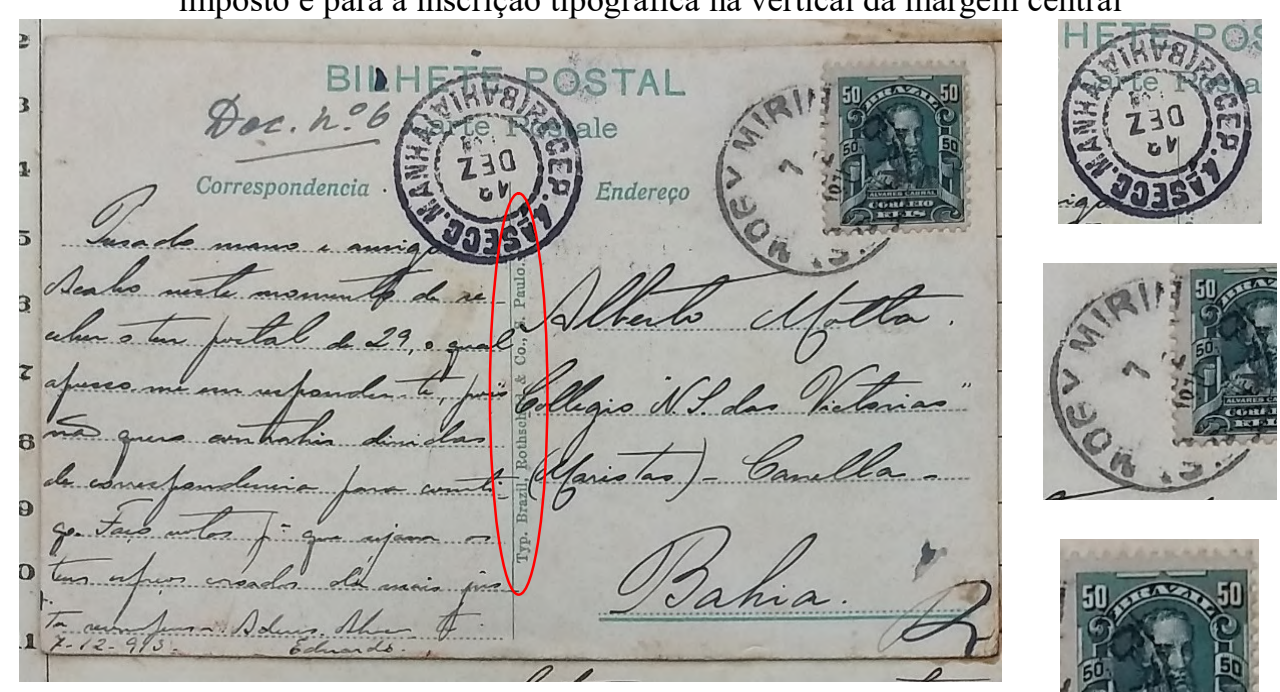

Fonte: Acervo do CEDOC/UEFS

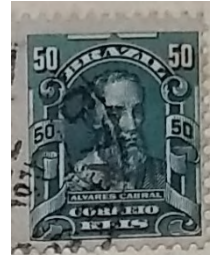

Figura 91 - Cartão postal colunado, no fólio 59r, com detalhe para os carimbos molhados, para o selo de imposto e para a inscrição tipográfica na vertical da margem esquerda
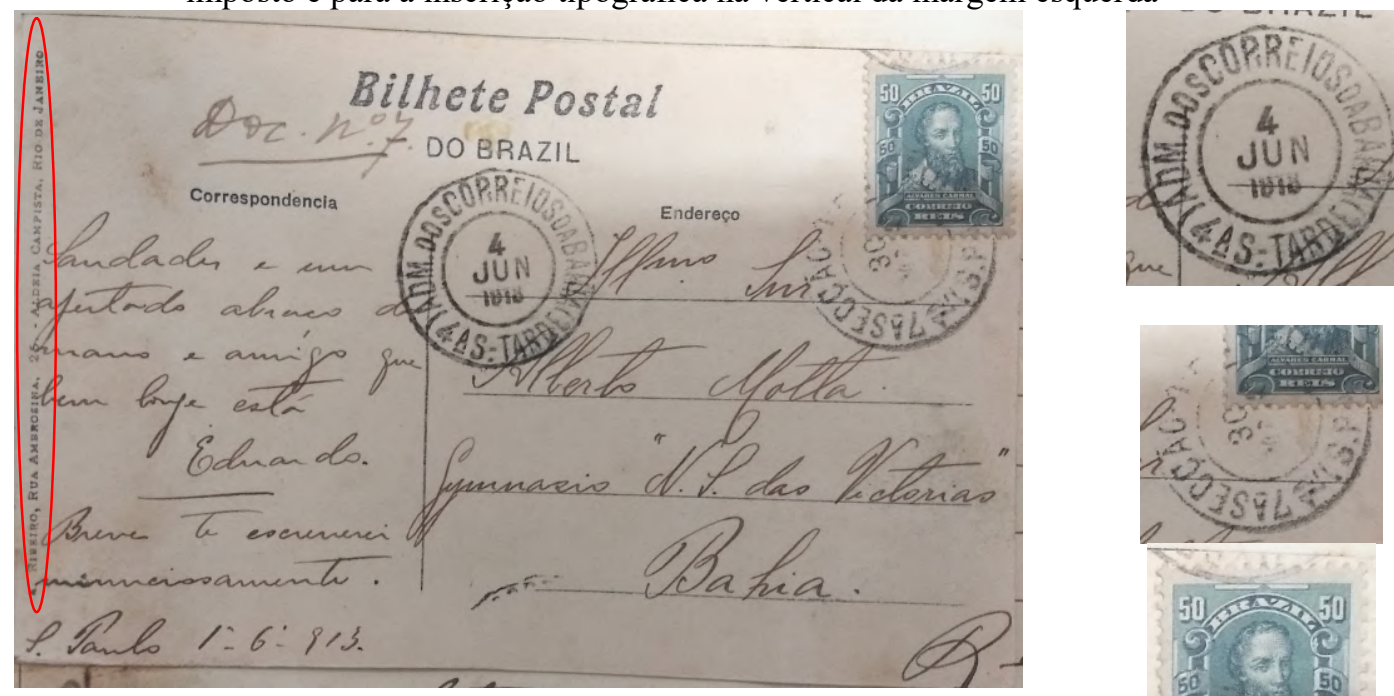

Fonte: Acervo do CEDOC/UEFS

Um aspecto interessante sobre ambos os cartões é a sua inscrição tipográfica, que indica a respectiva proveniência. O primeiro deles foi impresso na Tipografia Brazil, Rithschild \& C., em São Paulo, e o segundo na Tipografia Ribeiro, na Rua Ambrosina, 25 Aldeia Campista, no Rio de Janeiro, informações alocadas na vertical das margens central, do fólio 58r, e esquerda, do fólio 59r, respectivamente, as quais podem ser relevantes, por exemplo, para pesquisadores que investigam a produção e circulação de postais no Brasil, especialmente na Bahia e em Feira de Santana no referido período, bem como as tipografias 
brasileiras, os selos de impostos e/ou carimbos de empresas brasileiras (neste caso os Correios), que se dedica(va)m à distribuição, a nível local, regional ou nacional, de documentos da administração pública, privada ou de foro íntimo.

Sobre os selos de impostos e os carimbos pessoais de três "sujeitos" da lei que atuaram em cartórios baianos no período em que o documento fora lavrado e que são, portanto, alguns dos escreventes do referido processo, optamos por listá-los nos quadros seguintes, com o objetivo de apresentar um levantamento de todos aqueles que foram encontrados, à medida que a leitura do texto avançava. Contudo, nos casos em que um mesmo selo de imposto possuía valor igual a outro, mas apresentava elementos tipográficos distintos, decidimos inseri-los em locais separados, a fim de suscitar a sua diferenciação visual, que permite compreender que há diferenças tipológicas e tipográficas, embora o nosso intuito não seja o de apresentar uma análise dessa natureza.

Quadro 35 - Relação dos selos de impostos constantes no primeiro volume do inventário do Coronel Agostinho Fróes da Motta

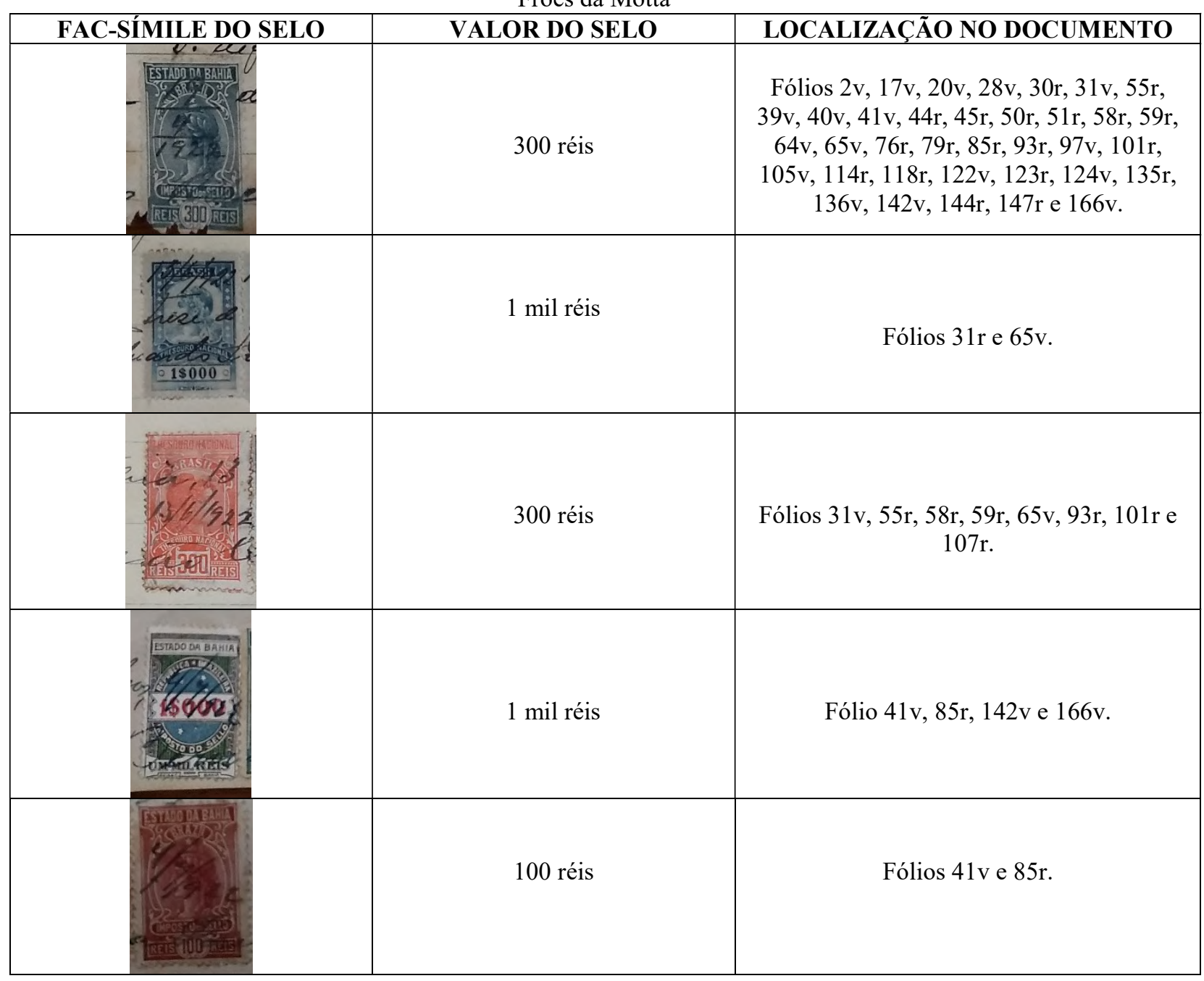




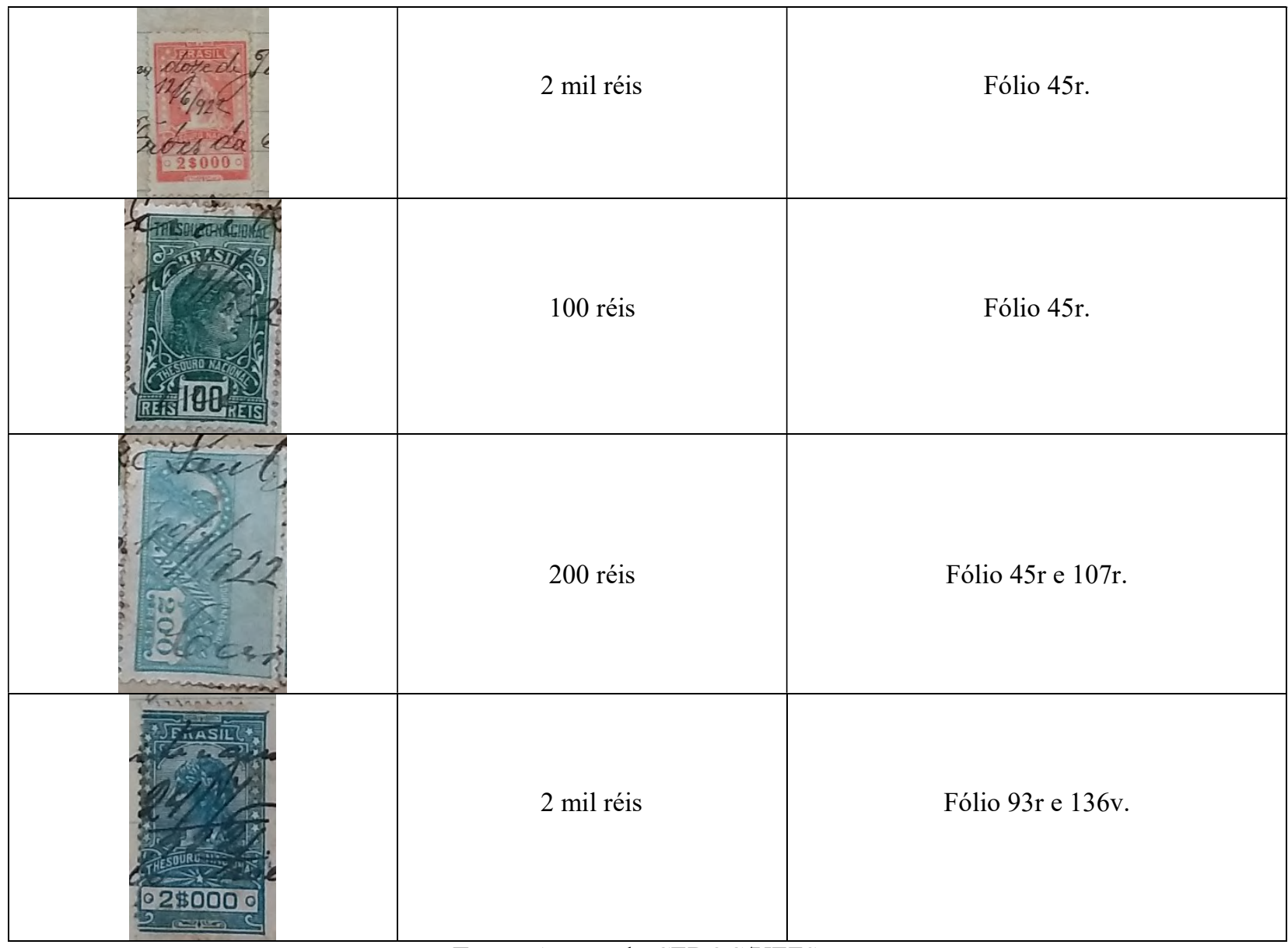

Fonte: Acervo do CEDOC/UEFS

Quadro 36 - Carimbos molhados dos escreventes

\begin{tabular}{|c|c|c|c|c|}
\hline $\begin{array}{l}\text { FAC-SÍMILE DO } \\
\text { CARIMBO }\end{array}$ & $\begin{array}{c}\text { DIMENSÃO DO } \\
\text { CARIMBO }\end{array}$ & $\begin{array}{c}\text { INSCRIÇÃO DO } \\
\text { CARIMBO }\end{array}$ & $\begin{array}{c}\text { LOCALIZAÇÃO } \\
\text { NO } \\
\text { DOCUMENTO }\end{array}$ & $\begin{array}{l}\text { COMARCA DO } \\
\text { ESCREVENTE }\end{array}$ \\
\hline 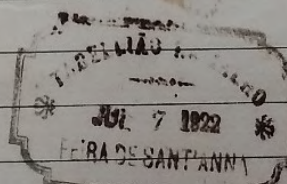 & $\begin{array}{l}30 \mathrm{~mm} \text { de altura } \mathrm{x} \\
52 \mathrm{~mm} \text { de largura }\end{array}$ & $\begin{array}{c}\text { TABELLIÃO } \\
\text { RAMALHO | JUL } 7 \\
1922 \mid \text { FEIRA DE } \\
\text { SANT'ANNA }\end{array}$ & $\begin{array}{c}\text { Fólios } 58 \mathrm{r}, 59 \mathrm{r} \mathrm{e} \\
65 \mathrm{v} .\end{array}$ & Feira de Santana \\
\hline & $\begin{array}{l}30 \mathrm{~mm} \text { de altura } \mathrm{x} \\
50 \mathrm{~mm} \text { de largura }\end{array}$ & $\begin{array}{c}\text { AURELIO } \\
\text { VASCONCELLOS | } \\
\text { Escrivão de Paz | } \\
\text { Feira de Sant'Anna }\end{array}$ & Fólio $107 \mathrm{r}$. & Feira de Santana \\
\hline 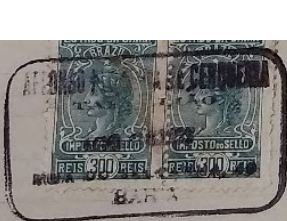 & $\begin{array}{l}32 \mathrm{~mm} \text { de altura } \mathrm{x} \\
55 \mathrm{~mm} \text { de largura }\end{array}$ & $\begin{array}{c}\text { AFFONSO } \\
\text { PEDREIRA DE } \\
\text { CERQUEIRA | } \\
\text { TABELLIÃO | RUA } \\
\text { DO }[\ldots] \mid \text { BAHIA }\end{array}$ & Fólio 136v. & Bahia (Salvador) \\
\hline
\end{tabular}

Fonte: Acervo do CEDOC/UEFS 
Apesar de existirem algumas manchas, seja de tinta ou de outras naturezas, em partes aleatórias dos fólios ou junto às perfurações, feitas para costura, na margem esquerda dos fólios rectos, elas não comprometem a leitura do texto, portanto não interferem na decodificação dos elementos gráficos, como exemplificado no quadro a seguir.

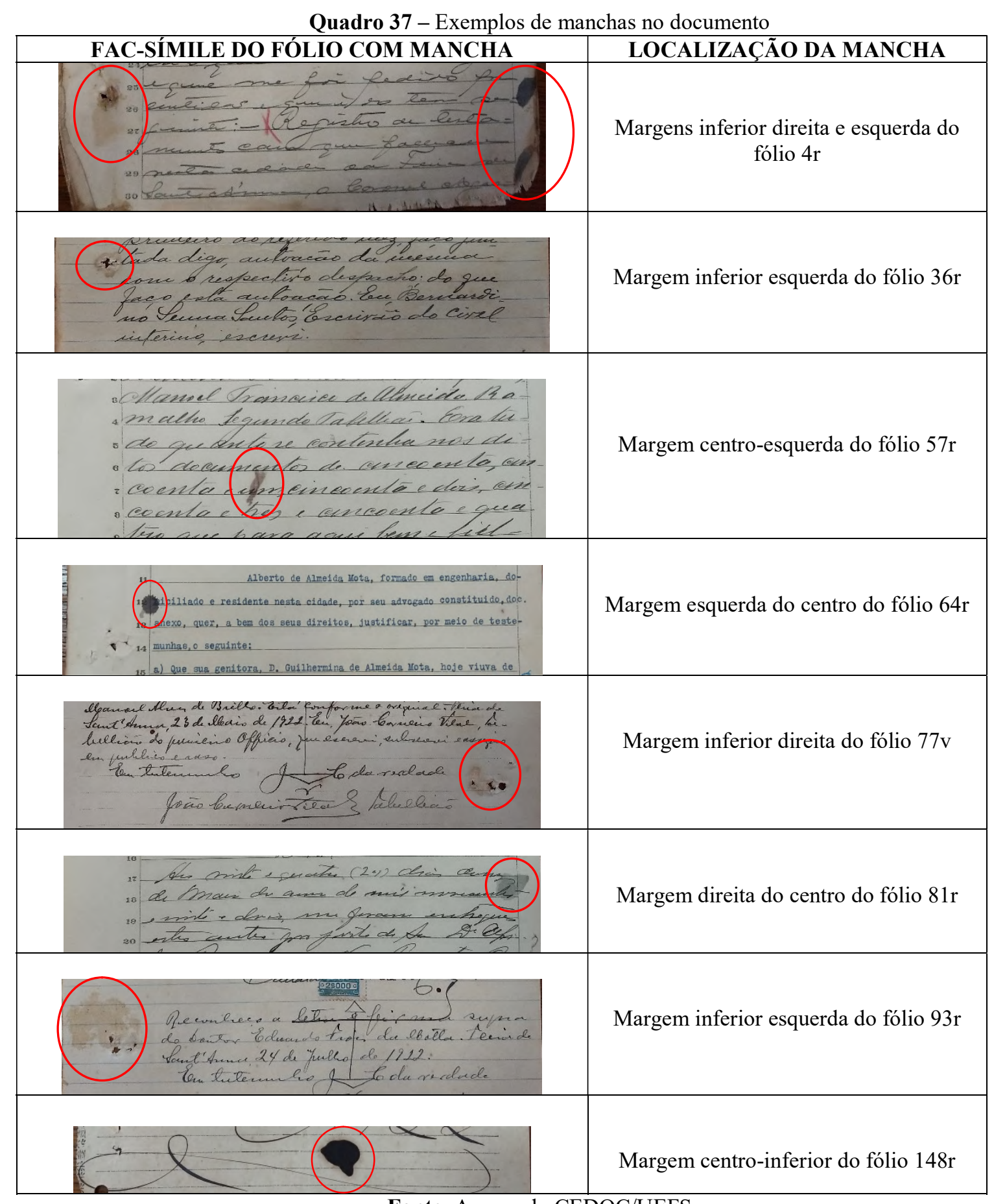

Fonte: Acervo do CEDOC/UEFS

Com exceção dos versos dos formulários constantes no corpo do documento, os únicos fólios que não têm pauta são o recto e o verso do fólio 102, os quais apresentam, inclusive, 
furos no centro e nas laterais do fólio, e uma marca de dobra na vertical da margem central, e a inexistência de numeração progressiva, esta última explicada pelo fato de o escrevente não ter contabilizado o fólio junto com os demais, provavelmente, por estar em branco e porque o referido fólio seria, portanto, a "terceira e quarta capas" do contrato ante-nupcial do segundo matrimônio do inventariado, cuja "folha de rosto" é o fólio enumerado como o 98r. Logo, a falta de numeração nesse fólio gerou sucessivos erros e tentativas de correção, por parte dos escreventes, nos fólios subsequentes, como exemplificado a seguir.

Figura 92 - Detalhes para os furos, a marca de dobra e a inexistência de numeração nos fólios 102

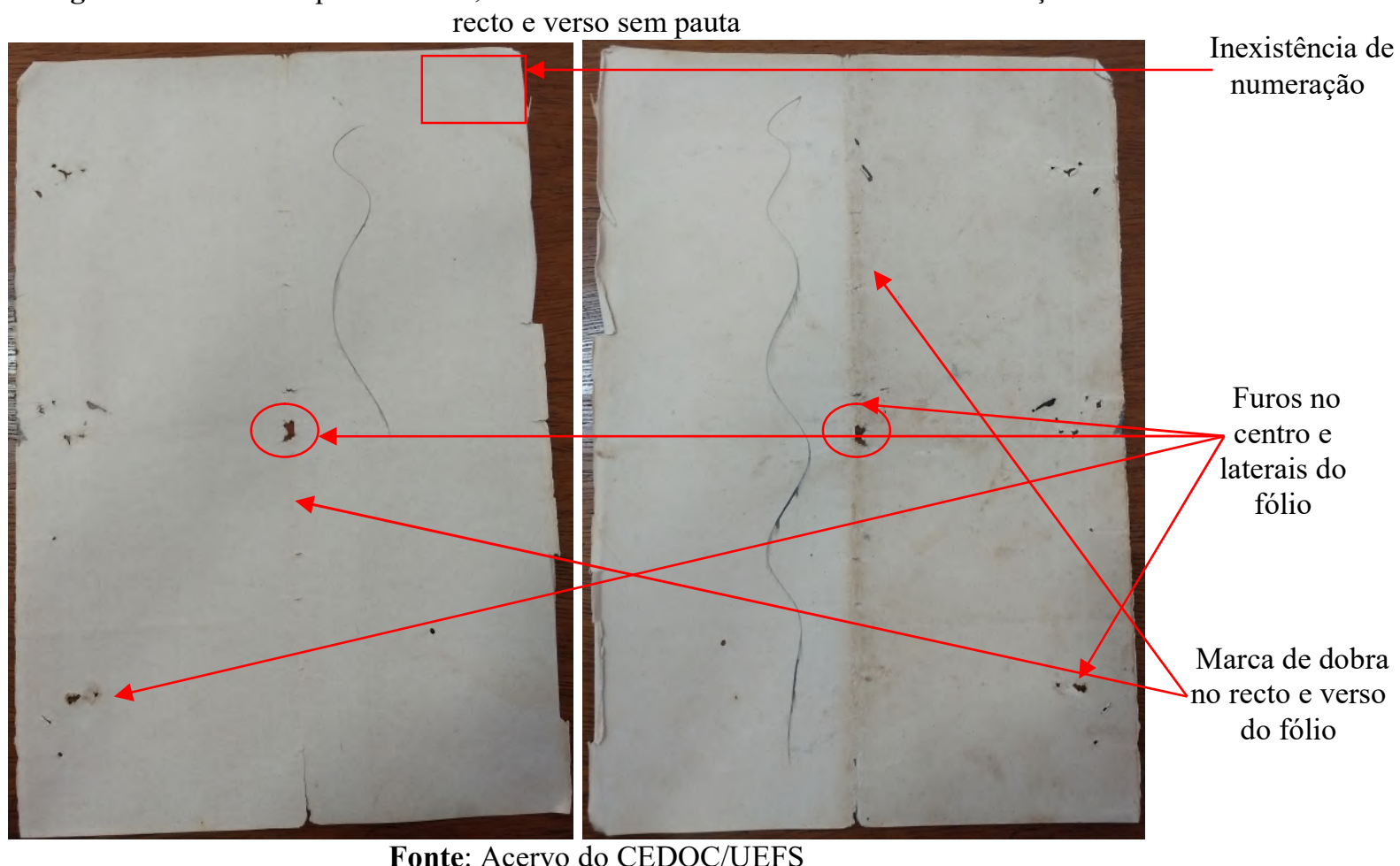

O último aspecto codicológico a ser mencionado é a materialidade dos fólios $150 \mathrm{r} / \mathrm{v}$, 151r/v, 152r/v, 153r/v e 154r/v, que são folhas do livro de caixa da Firma Agostinho Fróes da Motta e Filho, que foram removidas do livro e anexadas e numeradas pelo(s) escrevente(s) do processo. As folhas do livro eram, inicialmente, in-fólios, mas atualmente encontram-se com significativas deteriorações no suporte material, dentre as quais a sua separação pelas respectivas dobras, e o fato de estarem bastante quebradiças nas linhas marginais de alguns pontusais constantes no referido papel, que tem o escudo das Armas Nacionais do Brasil, o mesmo apresentado anteriormente. 
Figura 93 - Exemplo de in-fólio do livro de caixa da firma comercial Agostinho Fróes da Motta e Filho, com perda de suporte material

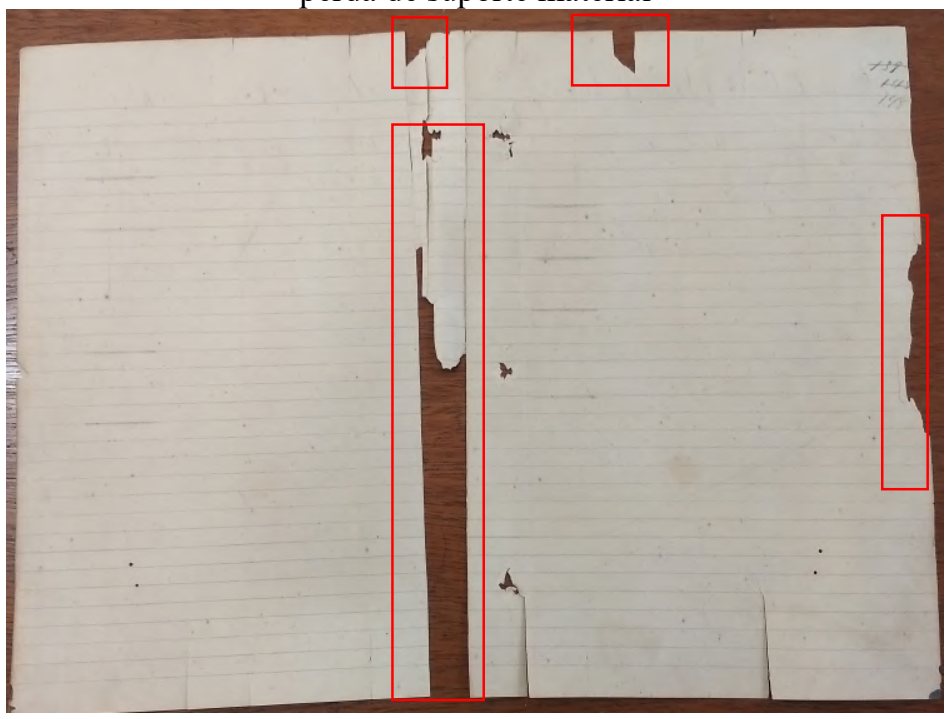

Fonte: Acervo do CEDOC/UEFS

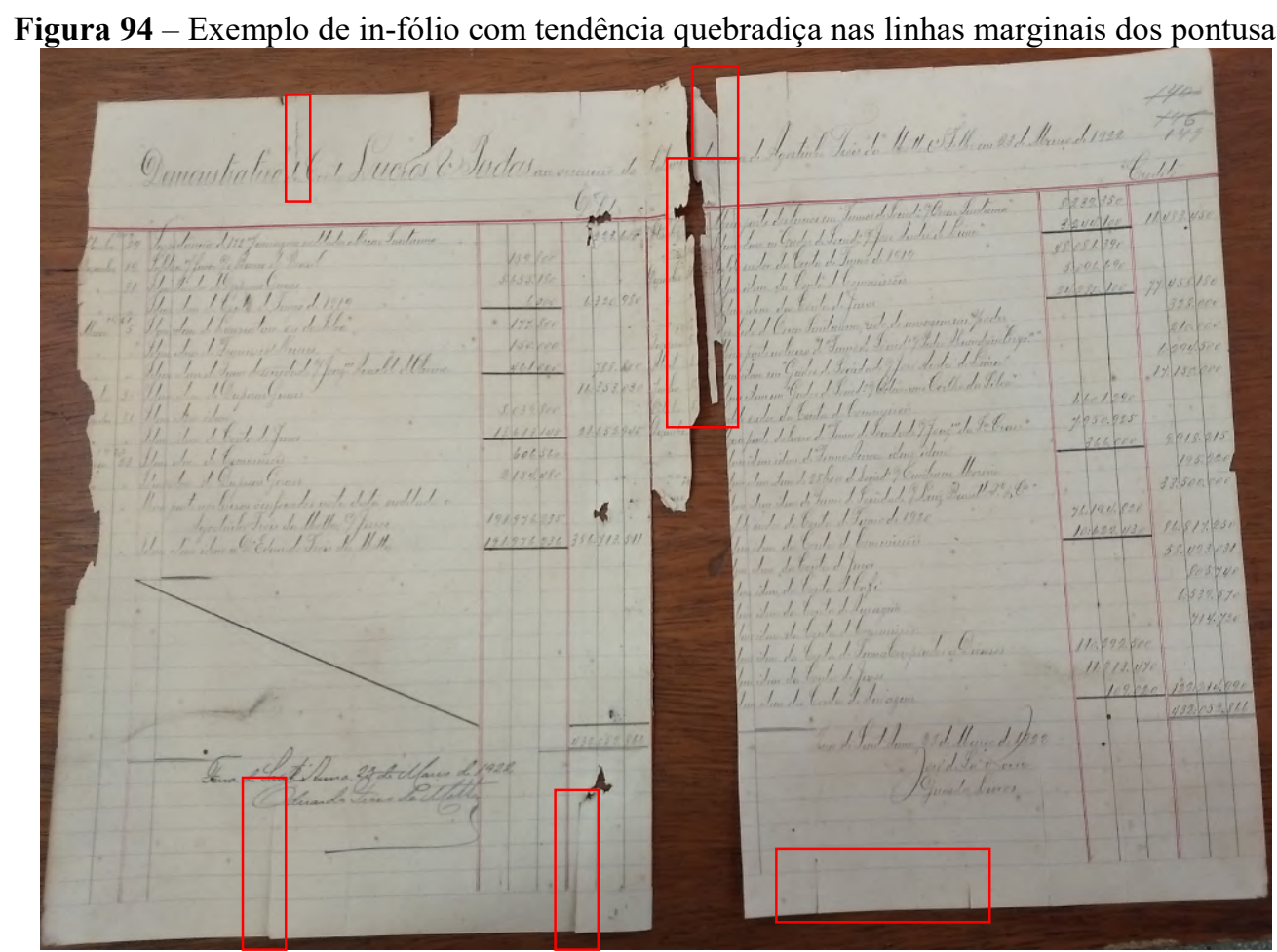

Fonte: Acervo do CEDOC/UEFS

Aos tratarmos dos aspectos paleográficos, primeiro salientamos que o documento também foi escrito em letra cursiva e redigido por muitos punhos que, de forma direta ou indireta, contribuíram para a composição do processo, seja produzindo documentos ou anexando os já existentes ao inventário. Sobre os punhos, listamos os nomes dos escreventes, sejam estes sujeitos da lei, membros ou empregados da família Fróes da Motta, que escreveram o documento. 
Quadro 38 - Escreventes do primeiro volume do inventário de Agostinho Fróes da Motta

\begin{tabular}{|c|c|}
\hline ESCREVENTE & FÓLIOS ESCRITOS \\
\hline Adalberto Alves de Farias & $136 \mathrm{r} / \mathrm{v}$ \\
\hline Affonso Pedreira de Cerqueira & $136 \mathrm{v}$. \\
\hline Agnello Ribeiro de Macêdo & $2 \mathrm{r} / \mathrm{v}, 28 \mathrm{r} / \mathrm{v}, 74 \mathrm{r}$ a $76 \mathrm{r}, 135 \mathrm{r}$, e $138 \mathrm{r}$ a $142 \mathrm{v}$ \\
\hline Agostinho Fróes da Motta & $101 \mathrm{r}$ \\
\hline Albertina Fróes da Motta & $45 \mathrm{r}$ e $118 \mathrm{r}$. \\
\hline Albertino Dantas & $148 \mathrm{r}$ e $149 \mathrm{r}$. \\
\hline Alberto de Almeida Motta & $65 / \mathrm{v}$ \\
\hline Altino Teixeira & $94 \mathrm{r}, 95 \mathrm{r}$ a $97 \mathrm{v}, 122 \mathrm{r} / \mathrm{v}$ a $123 \mathrm{r}, 124 \mathrm{r} / \mathrm{v}$ \\
\hline Aurelio Vasconcellos & 106r a 107r. \\
\hline Bernardino Senna Santos & $36 \mathrm{r}$ e $41 \mathrm{r} / \mathrm{v}, 42 \mathrm{r} / \mathrm{v}$. \\
\hline Cesar Ribeiro de Cerqueira & $32 \mathrm{v}$ e $34 \mathrm{r}$. \\
\hline Diogenes de Sousa Lima & $37 \mathrm{r}$ e $41 \mathrm{v}$ \\
\hline Eduardo Fróes da Motta & $31 \mathrm{r}, 58 \mathrm{r}, 59 \mathrm{r}, 87 \mathrm{r}, 93 \mathrm{r}$. \\
\hline Elpidio Raymundo da Nova & $81 \mathrm{r}$. \\
\hline Jacintho Ferreira da Silva & $\begin{array}{l}2 \mathrm{r}, 28 \mathrm{r}, 30 \mathrm{r}, 35 \mathrm{r}, 42 \mathrm{v}, 44 \mathrm{r}, 47 \mathrm{r}, 51 \mathrm{r}, 64 \mathrm{r}, 74 \mathrm{r}, 79 \mathrm{r}, 80 \mathrm{v}, 81 \mathrm{v}, \\
85 \mathrm{r} / \mathrm{v}, 89 \mathrm{v} \text { a } 90 \mathrm{r}, 117 \mathrm{r} / \mathrm{v}, 118 \mathrm{r}, 122 \mathrm{r}, 123 \mathrm{r}, 124 \mathrm{r}, 135 \mathrm{r}, 138 \mathrm{r}, \\
144 \mathrm{r}, 145 \mathrm{r} .\end{array}$ \\
\hline João Carneiro Vital & $\begin{array}{l}3 \mathrm{r} / \mathrm{v}, 16 \mathrm{r} \text { a } 17 \mathrm{v}, 31 \mathrm{r} / \mathrm{v}, 35 \mathrm{r}, 45 \mathrm{r}, 77 \mathrm{r} / \mathrm{v}, 93 \mathrm{r}, 98 \mathrm{r} \text { a } 100 \mathrm{v}, 101 \mathrm{r} \text {, } \\
136 \mathrm{v} \text {. }\end{array}$ \\
\hline João Marques dos Reys & 108r a 109r. \\
\hline Joaquim Honorio d'Oliveira & $129 \mathrm{v}$ a $133 \mathrm{v}$. \\
\hline Joaquim José Ramos & $37 \mathrm{r} \mathrm{e} 42 \mathrm{r}$. \\
\hline José de Sá Roriz & $150 \mathrm{v}$ a $154 \mathrm{r}$. \\
\hline José Maria Neves & $\begin{array}{l}47 \mathrm{r} \text { a } 50 \mathrm{r}, 51 \mathrm{r}, 58 \mathrm{r}, 59 \mathrm{r}, 64 \mathrm{r} / \mathrm{v}, 79 \mathrm{r} / \mathrm{v}, 80 \mathrm{r}, 110 \mathrm{r}, 111 \mathrm{r} \text { a } 114 \mathrm{r} \text {, } \\
125 \mathrm{r} .\end{array}$ \\
\hline José Telles Barreto & 40r, 83r e 84r. \\
\hline Lyderico dos Santos Cruz & $1 \mathrm{v}$. \\
\hline Manoel Araujo & $82 \mathrm{r}$. \\
\hline Manoel Gomes dos Santos & 121r. \\
\hline Manoel Pimentel & 30r, 44r, 144r, e $145 \mathrm{r}$ a $147 \mathrm{r}$. \\
\hline $\begin{array}{l}\text { Manuel Francisco de Almeida } \\
\text { Ramalho }\end{array}$ & $\begin{array}{l}1 \mathrm{r}, 4 \mathrm{r} \text { a } 15 \mathrm{v}, 18 \mathrm{r} \text { a } 26 \mathrm{v}, 29 \mathrm{r} / \mathrm{v}, 31 \mathrm{v} \text { a } 33 \mathrm{v}, 34 \mathrm{v}, 35 \mathrm{v}, 37 \mathrm{r} \text { a } \\
39 \mathrm{v}, 40 \mathrm{v}, 43 \mathrm{v}, 46 \mathrm{v}, 50 \mathrm{v}, 51 \mathrm{r}, 52 \mathrm{r} \text { a } 57 \mathrm{r}, 58 \mathrm{r}, 59 \mathrm{r}, 60 \mathrm{r} \text { a } 63 \mathrm{v}, \\
65 \mathrm{v}, 66 \mathrm{r}, 67 \mathrm{r} \text { a } 73 \mathrm{v}, 78 \mathrm{v}, 79 \mathrm{v}, 80 \mathrm{r} \text { a } 82 \mathrm{v}, 85 \mathrm{r} \text { a } 86 \mathrm{v}, 88 \mathrm{r} a \\
89 \mathrm{v}, 90 \mathrm{r} \text { a } 92 \mathrm{v}, 94 \mathrm{r}, 103 \mathrm{r} \text { a } 105 \mathrm{v}, 110 \mathrm{r} / \mathrm{v}, 115 \mathrm{r} \text { a } 117 \mathrm{v}, 118 \mathrm{v} \\
\text { a } 120 \mathrm{v}, 121 \mathrm{v}, 123 \mathrm{v}, 125 \mathrm{r}, 126 \mathrm{r} \text { a } 129 \mathrm{v}, 134 \mathrm{v}, 137 \mathrm{v}, 143 \mathrm{v}, \\
155 \mathrm{r} \text { a } 166 \mathrm{v} \text {. }\end{array}$ \\
\hline Petronillo Guaviro de Meirelles & f. $149 \mathrm{v}$ \\
\hline
\end{tabular}

Fonte: Elaborado pela pesquisadora

Especificamente, esses punhos podem ser divididos em dois grupos. O primeiro seria aquele composto pelos "sujeitos" da lei que, em seus devidos cargos e funções, encarregaramse de abrir e conduzir o processo, deixando no documento as marcas das suas scriptae, exemplificadas no quadro seguinte. 
Quadro 39 - Exemplos da scripta dos "sujeitos" da lei que redigiram o primeiro volume do inventário

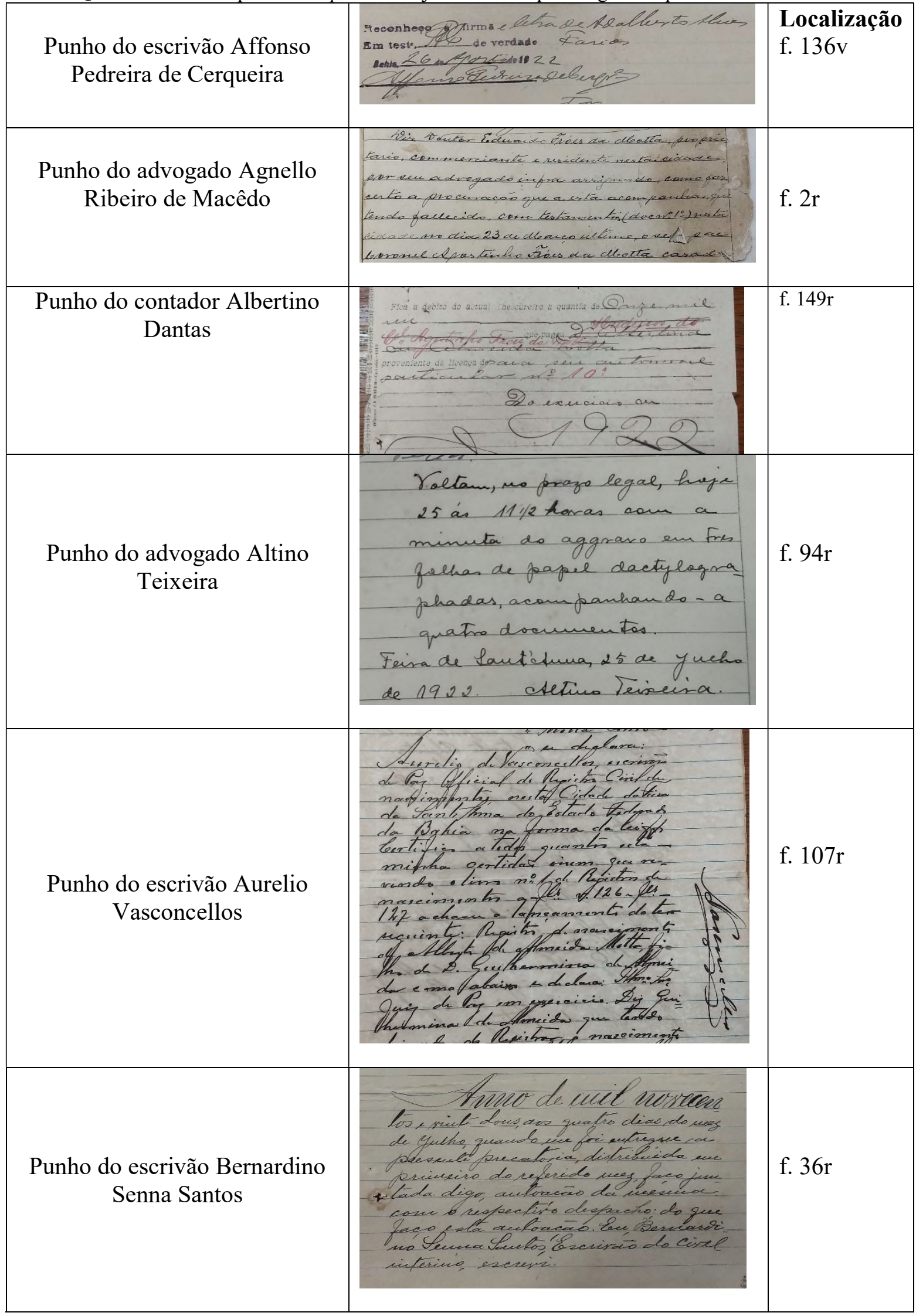




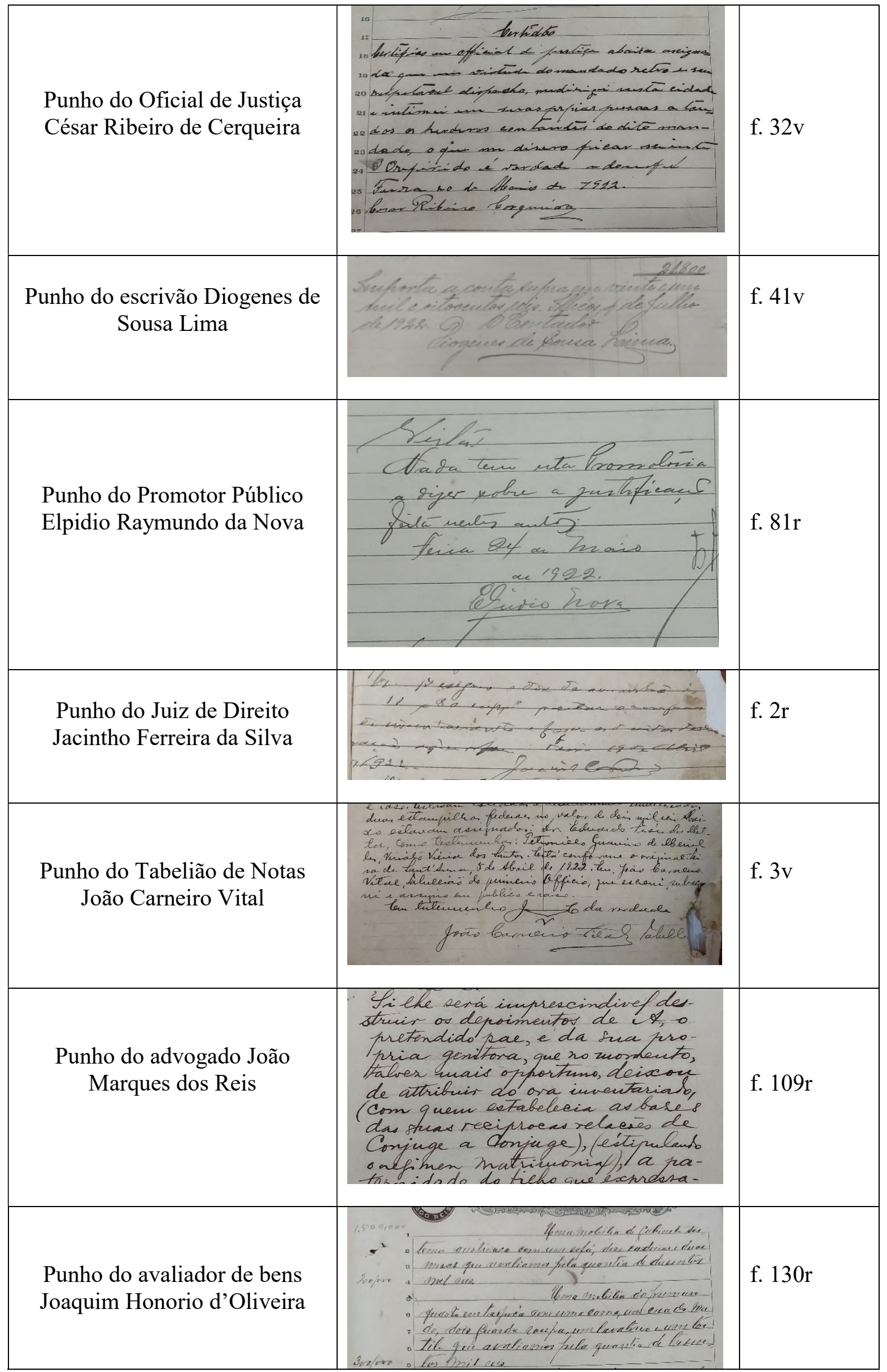




\begin{tabular}{|c|c|c|}
\hline $\begin{array}{l}\text { Punho do Juiz de Direito } \\
\text { Joaquim José Ramos }\end{array}$ & 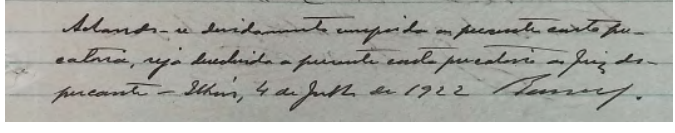 & f. $42 \mathrm{r}$ \\
\hline $\begin{array}{l}\text { Punho do advogado José Maria } \\
\text { Neves }\end{array}$ & 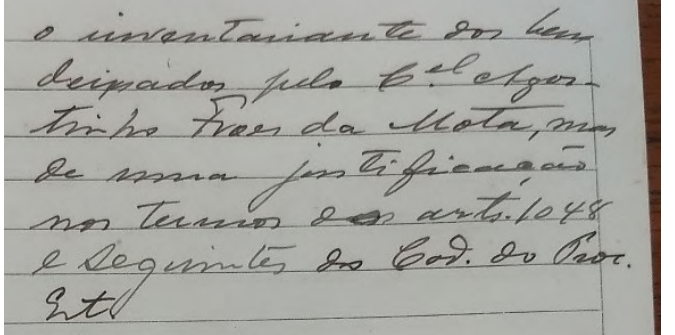 & f. $80 \mathrm{r}$ \\
\hline $\begin{array}{c}\text { Punho do escrivão José Telles } \\
\text { Barreto }\end{array}$ & 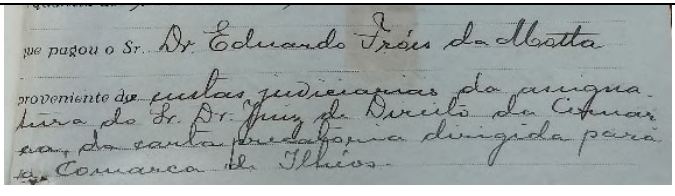 & f. $40 \mathrm{r}$ \\
\hline $\begin{array}{l}\text { Punho do Promotor Público } \\
\text { Lyderico dos Santos Cruz }\end{array}$ & 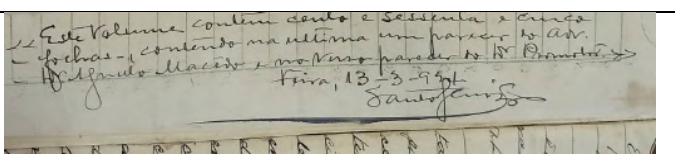 & f. $2 \mathrm{v}$ \\
\hline $\begin{array}{c}\text { Punho do contador Manoel } \\
\text { Araujo }\end{array}$ & 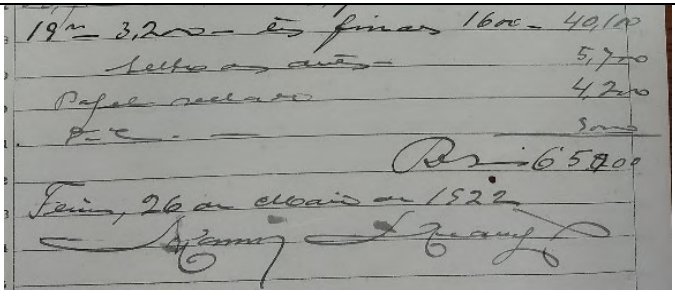 & f. $82 \mathrm{r}$ \\
\hline $\begin{array}{l}\text { Punho do Oficial de Justiça } \\
\text { Manoel Gomes dos Santos }\end{array}$ & 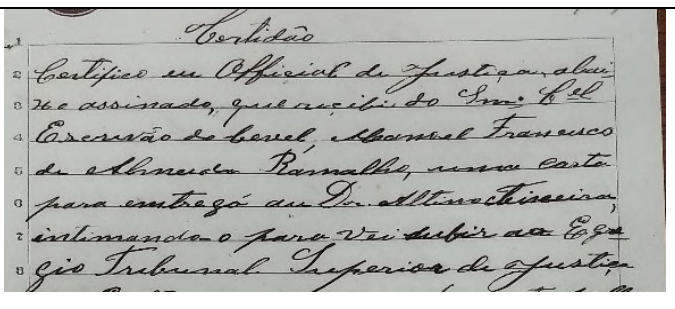 & f. $121 \mathrm{r}$ \\
\hline $\begin{array}{c}\text { Punho do advogado Manoel } \\
\text { Pimentel }\end{array}$ & 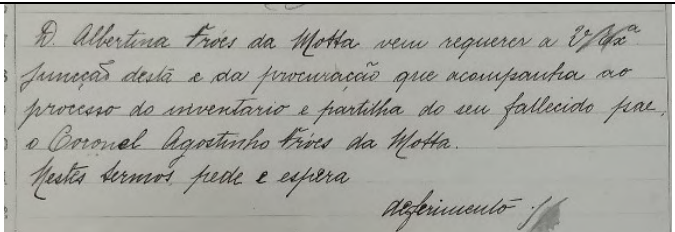 & f. $44 \mathrm{r}$ \\
\hline $\begin{array}{c}\text { Punho do escrivão Manuel } \\
\text { Francisco de Almeida Ramalho }\end{array}$ & 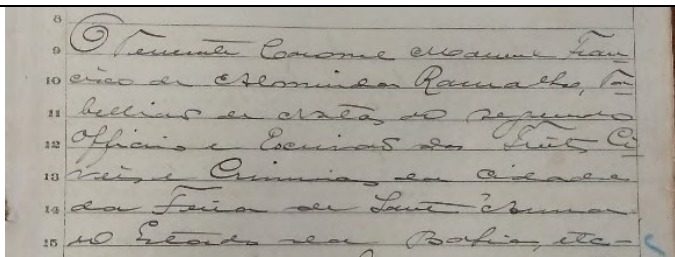 & f. $4 \mathrm{r}$ \\
\hline
\end{tabular}




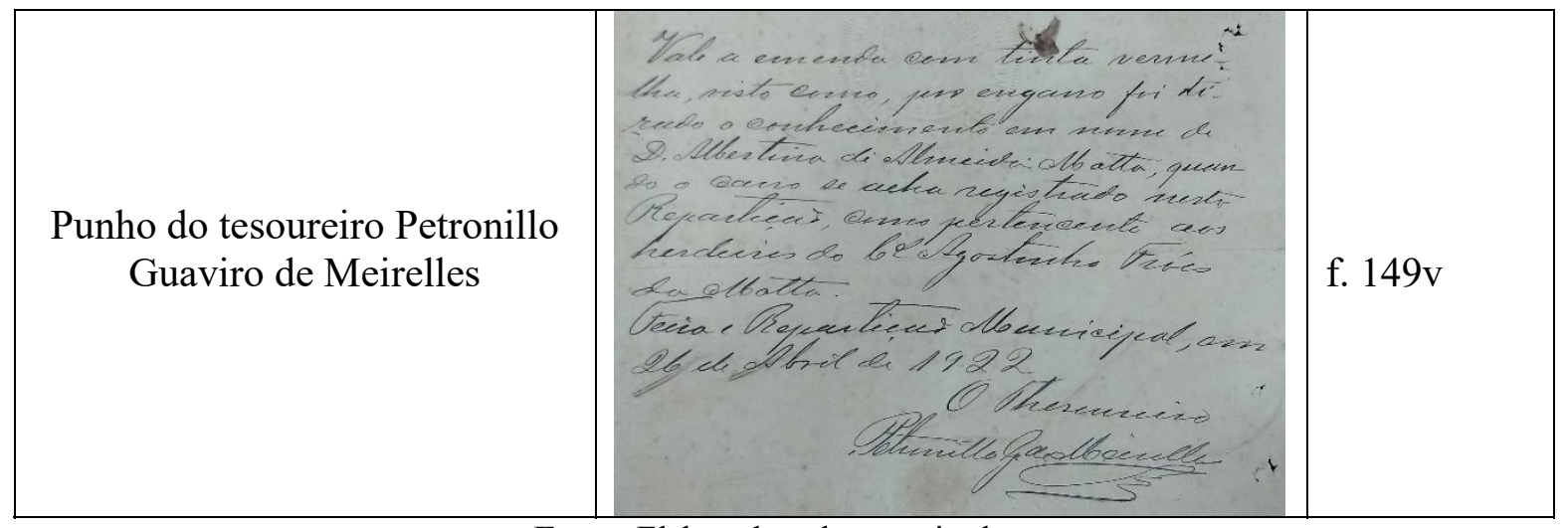

Fonte: Elaborado pela pesquisadora

O segundo seria aquele composto pelos membros ou funcionários da família Fróes da Motta, que contribuíram, por consequência do andamento do processo, para a produção do texto, principalmente porque os ofícios daqueles "sujeitos" não eram, obrigatoriamente, o de escreventes, mas de pessoas interessadas ou beneficiadas no inventário e, por conta disso, tiveram que escrever procurações ou anexar cartões postais e folhas do livro de caixa, produzidos em outros contextos, como provas para esse processo. Nesse sentido, apresentamos alguns exemplos da scripta dos membros da família Fróes da Motta: Adalberto Alves de Farias, Agostinho Fróes da Motta, Albertina Fróes da Motta, Alberto de Almeida Motta, Arthur Fróes da Motta, Eduardo Fróes da Motta, e do Guarda Livros da Firma Agostinho Fróes da Motta e Filho: José de Sá Roriz.

Quadro 40 - Exemplos da scripta dos membros e do funcionário da firma comercial da família Fróes da Motta

\begin{tabular}{|c|c|c|}
\hline $\begin{array}{c}\text { Punho do genro do inventariado, } \\
\text { Adalberto Alves de Farias }\end{array}$ & 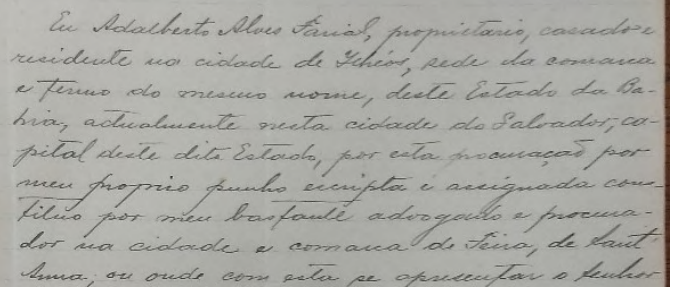 & f. $136 \mathrm{r}$ \\
\hline $\begin{array}{l}\text { Punho do inventariado, } \\
\text { Agostinho Fróes da Motta }\end{array}$ & 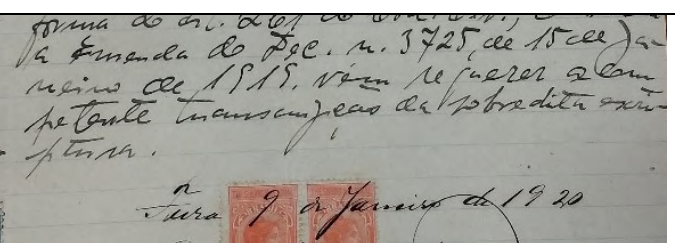 & f. $101 \mathrm{r}$ \\
\hline $\begin{array}{l}\text { Punho da filha do inventariado, } \\
\text { Albertina Fróes da Motta }\end{array}$ & 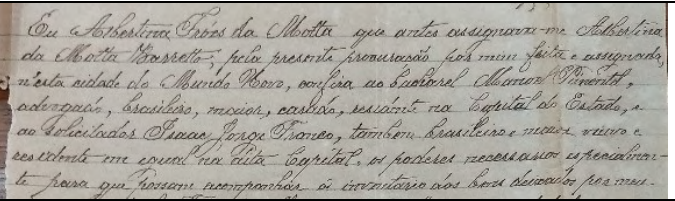 & f. $45 \mathrm{r}$ \\
\hline
\end{tabular}




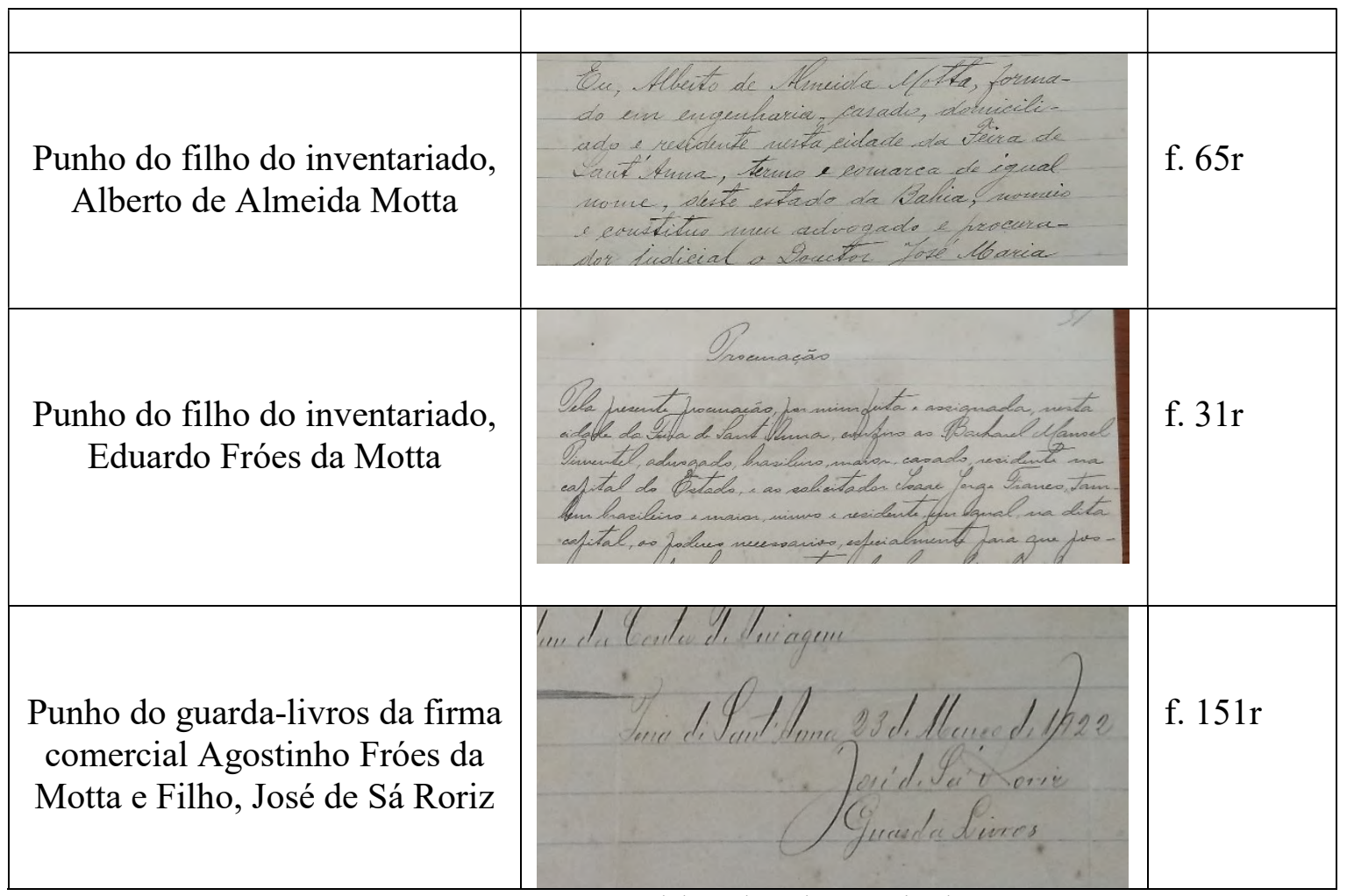

Fonte: Elaborado pela pesquisadora

Os fólios escritos por esses dois grupos também apresentam regularidade de empaginação nas caixas de escrita e muitas linhas, margens e fólios em branco, o que ratifica o nosso argumento inicial de que, no período em que tais documentos foram lavrados, existia uma quantidade substancial de papel circulando nas esferas pública e privada ${ }^{127}$ da cidade, o que implica dizer que o acesso ao papel não era um problema para os escreventes.

Além disso, é possível verificarmos, nos exemplos, um conjunto de escrita bastante regular e, ao mesmo tempo, variável, haja vista ser uma escrita com formato cursivo, mas com particularidades, dentre as quais podemos mencionar o ductus que, junto com o uso da pontuação, acentuação, letras maiúsculas mais trabalhadas, módulos médios ou pequenos, ocupação de toda a caixa de linha e/ou do espaço interlinear (superior ou inferior ou ambos), o ângulo de inclinação inclinado para a direita (o que indica que todos eram destros) define o estilo de cada escrevente; algumas escritas com ritmo mais lento (no caso em que as formas são cuidadosamente traçadas com traços mais grossos ${ }^{128}$ ou nas quais há letras monolíticas), outras com um ritmo mais acelerado, principalmente nos casos em que a escrita apresenta um traçado fino ou bastante fino, e ligaduras em algumas das escritas.

\footnotetext{
${ }^{127}$ Alguns dos advogados do processo também trabalharam para empresas privadas como, por exemplo, firmas comerciais instaladas em Feira de Santana ou na "Baía" (Salvador).

${ }^{128} \mathrm{O}$ escrivão Aurelio Vasconcellos, por exemplo, apresenta um ductus com traços mais grossos e, consequente, uso de mais tinta.
} 
Ademais, nesse documento, também é recorrente a existência de assinaturas pessoais e sinais públicos. Com exceção dos nomes apresentados anteriormente (Agostinho Fróes da Motta, Deoclecio da Silva Daltro, Jacintho Ferreira da Silva, João Carneiro Vital, José Telles Barreto e Manuel Francisco de Almeida Ramalho), e das mesmas características já descritas e que também constam nesse documento, o que sobra são várias assinaturas ou rubricas pessoais, com ganchos ou laçadas, feitas pelos demais escreventes, conforme observado no quadro a seguir.

Quadro 41 - Assinaturas pessoais dos escreventes do primeiro volume do inventário

\begin{tabular}{|c|c|c|}
\hline & $\begin{array}{l}\text { Localização } \\
\text { f. } 136 \mathrm{v}\end{array}$ & $\begin{array}{l}\text { Assinatura pessoal de Adalberto Alves } \\
\text { Farias, com gancho }\end{array}$ \\
\hline & f. $136 \mathrm{v}$ & $\begin{array}{l}\text { Assinatura pessoal de Affonso } \\
\text { Pedreira de Cerqueira, com gancho }\end{array}$ \\
\hline & f. $28 \mathrm{v}$ & $\begin{array}{l}\text { Assinatura pessoal de Agnello Ribeiro } \\
\text { de Macêdo, sem gancho e sem laçada }\end{array}$ \\
\hline & f. $149 \mathrm{r}$ & $\begin{array}{l}\text { Assinatura pessoal de Albertino } \\
\text { Dantas, com laçada }\end{array}$ \\
\hline & f. $45 \mathrm{r}$ & $\begin{array}{l}\text { Assinatura pessoal de Albertina Fróes } \\
\text { da Motta, sem gancho e sem laçada }\end{array}$ \\
\hline & f. $65 \mathrm{v}$ & $\begin{array}{l}\text { Assinatura pessoal de Alberto de } \\
\text { Almeida Motta, com gancho }\end{array}$ \\
\hline ctoltivo & f. $92 v$ & $\begin{array}{l}\text { Assinatura pessoal de Altino Teixeira, } \\
\text { sem gancho e sem laçada }\end{array}$ \\
\hline & f. $108 \mathrm{r}$ & $\begin{array}{l}\text { Assinatura pessoal de Aurelio } \\
\text { Vasconcellos, com laçada }\end{array}$ \\
\hline$\sum^{\prime \prime 2}$ & f. $41 \mathrm{r}$ & $\begin{array}{l}\text { Assinatura pessoal de } \text { Bernardino } \\
\text { Senna Santos, com laçada }\end{array}$ \\
\hline besar Qifirive a Corquu & f. $34 r$ & $\begin{array}{l}\text { Assinatura pessoal de Cesar Ribeiro de } \\
\text { Cerqueira, sem gancho e sem laçada }\end{array}$ \\
\hline ces, de \& Ruina & f. $37 \mathrm{r}$ & $\begin{array}{l}\text { Assinatura pessoal de Diogenes de } \\
\text { Sousa Lima, com laçada }\end{array}$ \\
\hline
\end{tabular}




\begin{tabular}{|c|c|c|}
\hline 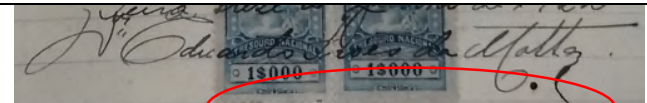 & f. $31 \mathrm{r}$ & $\begin{array}{l}\text { Assinatura pessoal de Eduardo Fróes } \\
\text { da Motta, com laçada }\end{array}$ \\
\hline & f. $81 \mathrm{r}$ & $\begin{array}{l}\text { Assinatura pessoal de Elpidio } \\
\text { Raymundo da Nova, com laçada }\end{array}$ \\
\hline & f. 109r & $\begin{array}{l}\text { Assinatura pessoal de João Marques } \\
\text { Reis, com gancho }\end{array}$ \\
\hline & f. $133 \mathrm{v}$ & $\begin{array}{l}\text { Assinatura pessoal de Joaquim } \\
\text { Honorio d'Oliveira, sem gancho e sem } \\
\text { laçada }\end{array}$ \\
\hline & f. $37 \mathrm{r}$ & $\begin{array}{l}\text { Rubrica de Joaquim José Ramos, com } \\
\text { gancho }\end{array}$ \\
\hline$d^{2}$ & f. $151 \mathrm{r}$ & $\begin{array}{l}\text { Assinatura pessoal de José de Sá } \\
\text { Roriz, sem gancho e sem laçada, mas } \\
\text { com destaque para as maiúsculas } \\
\text { iniciais }<\mathrm{j}>\text {, iniciada na área média- } \\
\text { superior da caixa de linha, onde faz } \\
\text { uma curva à direita e desce } \\
\text { verticalmente até a área superior da } \\
\text { terceira caixa de linha, onde curva } \\
\text { para a esquerda e sobe } \\
\text { perpendicularmente à direita até a área } \\
\text { média-inferior da linha de escrita onde } \\
\text { começou; e para o <r>, iniciado na } \\
\text { área média-inferior da linha de escrita, } \\
\text { onde desce levemente inclinado para a } \\
\text { esquerda, onde curva para a direita e } \\
\text { sobe perpendicularmente até a área } \\
\text { média-superior da terceira caixa de } \\
\text { linha, onde faz uma curva para a } \\
\text { direita e desce inclinando-se para a } \\
\text { esquerda até a caixa de linha onde } \\
\text { começou, local em que curva para a } \\
\text { esquerda e sobe em curva para a } \\
\text { esquerda, até alcançar a área média } \\
\text { superior da caixa de escrita, onde } \\
\text { curva para a direita e desce } \\
\text { perpendicularmente até a linha de } \\
\text { escrita onde começou. }\end{array}$ \\
\hline
\end{tabular}




\begin{tabular}{|c|c|c|}
\hline - BEIS (30, & f. $51 \mathrm{r}$ & $\begin{array}{l}\text { Assinatura pessoal de José Maria } \\
\text { Neves, sem gancho e sem laçada, mas } \\
\text { com destaque para a maiúscula inicial } \\
<\mathrm{j}>\text {, que se inicia na área média- } \\
\text { inferior da caixa de linha, onde curva } \\
\text { para a esquerda, curva novamente e } \\
\text { sobe até a área inferior da caixa de } \\
\text { linha superior, onde curva novamente } \\
\text { para a esquerda e desce } \\
\text { perpendicularmente para a esquerda } \\
\text { até a área média da terceira caixa de } \\
\text { linha inferior, onde curva à esquerda e } \\
\text { sobe perpendicularmente à direita até a } \\
\text { linha de escrita da caixa de linha onde } \\
\text { começou. }\end{array}$ \\
\hline nनfenises & f. $1 \mathrm{v}$ & $\begin{array}{l}\text { Rubrica de Lyderico dos Santos Cruz, } \\
\text { com laçada }\end{array}$ \\
\hline & f. $82 \mathrm{r}$ & $\begin{array}{l}\text { Assinatura pessoal de Manoel Araujo, } \\
\text { com laçadas }\end{array}$ \\
\hline etfarmel games of is Che & f. $121 \mathrm{r}$ & $\begin{array}{l}\text { Assinatura pessoal de Manoel Gomes } \\
\text { dos Santos, com laçada }\end{array}$ \\
\hline & f. 30r & $\begin{array}{l}\text { Assinatura pessoal de } \\
\text { Pimentel, com gancho }\end{array}$ \\
\hline$A P{ }^{\circ}$ & f. $149 \mathrm{v}$ & $\begin{array}{l}\text { Assinatura pessoal de Petronillo } \\
\text { Guaviro de Meirelles, com laçada }\end{array}$ \\
\hline
\end{tabular}

Fonte: Elaborado pela pesquisadora

Outro aspecto interessante é a preocupação e, ao mesmo tempo, a tentativa de correção e recorreção da numeração progressiva dos fólios, feita pelo escrivão Manuel Francisco de Almeida Ramalho, conforme o traçado numérico indica.

Figura 95 - Exemplos de correção da numeração dos fólios

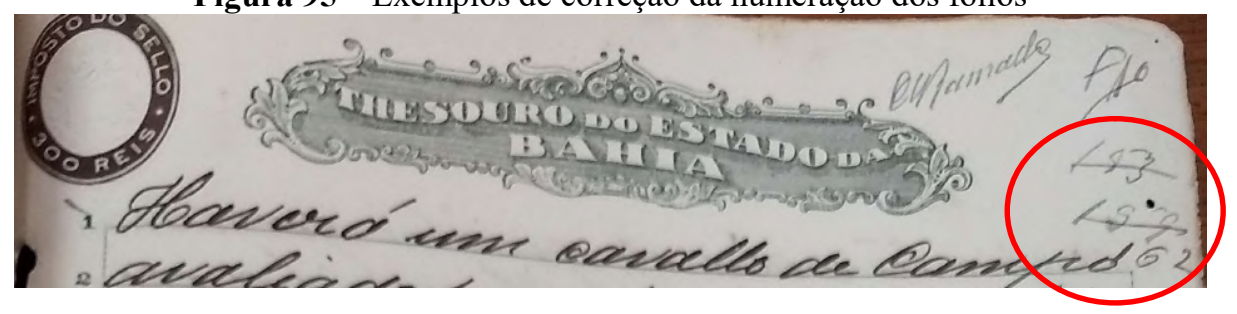




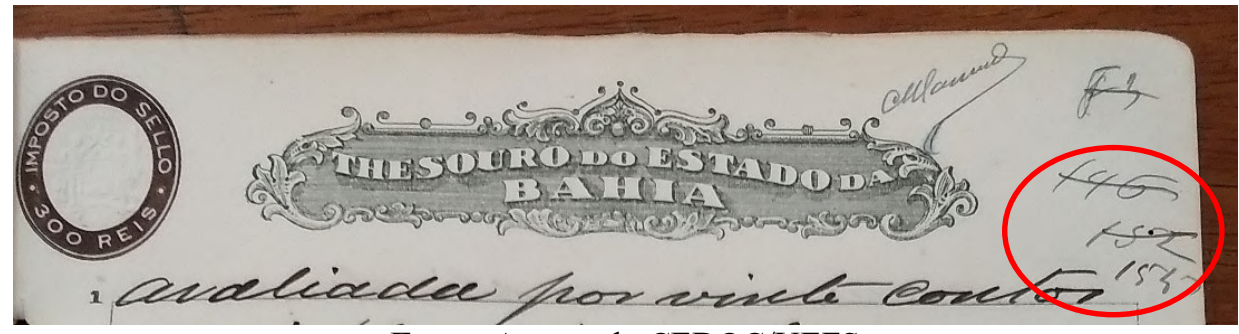

Fonte: Acervo do CEDOC/UEFS

Essas correções indicam que o documento foi contado e recontado, pelo menos, três vezes pelo escrevente e que a recontagem deve ter ocorrido, provavelmente, por conta da inserção de documentos comprobatórios, inseridos em datas diferentes, ao longo do processo, o que gerou, portanto, a alteração na quantidade de fólios e na consequente numeração.

Além disso, outras interferências do escrevente no texto são verificadas nos trechos que foram sublinhados com giz de cera na cor azul ou vermelha, os quais nos permitem depreender que eles foram julgados, por quem os leu, como importantes e, portanto, merecedores de destaques no texto, alguns, inclusive, acompanhados pela anotação "Vide". Mais do que isso, variados trechos com grifos também indicam o "sentido de leitura"129 feito pelo leitor, ou seja, nos casos em que foram inseridas sublinhas e pontuações como exclamações, interrogações ou " $x$ " é possível inferir que se trataram de passagens do texto consideradas, pelo respectivo leitor, obscuras, incompletas ou que deviam ser revisadas, marcadas, portanto, por anotações que constituem as "notas marginais/marginálias"130 do texto.

\footnotetext{
${ }^{129} \mathrm{Na}$ Linguística Textual, o sentido de leitura “[...] é construído na interação texto-sujeitos [...]", na qual a "produção de sentidos [...] se realiza evidentemente com base nos elementos linguísticos presentes na superfície textual e na sua forma de organização, mas requer a mobilização de um vasto conjunto de saberes no interior do evento comunicativo" (KOCK; ELIAS, 2009, p. 11). Logo, ao realizar a leitura de um texto, o leitor realiza a "atividade de reconhecimento, de reprodução" dos códigos linguísticos, podendo, inclusive, inserir códigos gráficos, que permitem identificar a ordem ou a forma como a leitura foi conduzida.

${ }_{130}$ O termo "notas marginais" é usado na Paleografia e "marginálias" na Bibliografia Material, ambos para caracterizar as anotações tardias ou feitas após o material estar pronto ou publicado, e sob a revisão ou simples leitura do próprio autor, de um leitor especializado ou não ou de um dono de uma obra bibliográfica, por exemplo. Esses tipos de anotações são de grande valia para estudar, por exemplo, a gênese, o processo de circulação e recepção dos textos e/ou a proveniência bibliográfica ou do manuscrito estudado.
} 
Figura 96 - Exemplo de trecho sublinhado, com detalhe para a anotação "Vide"

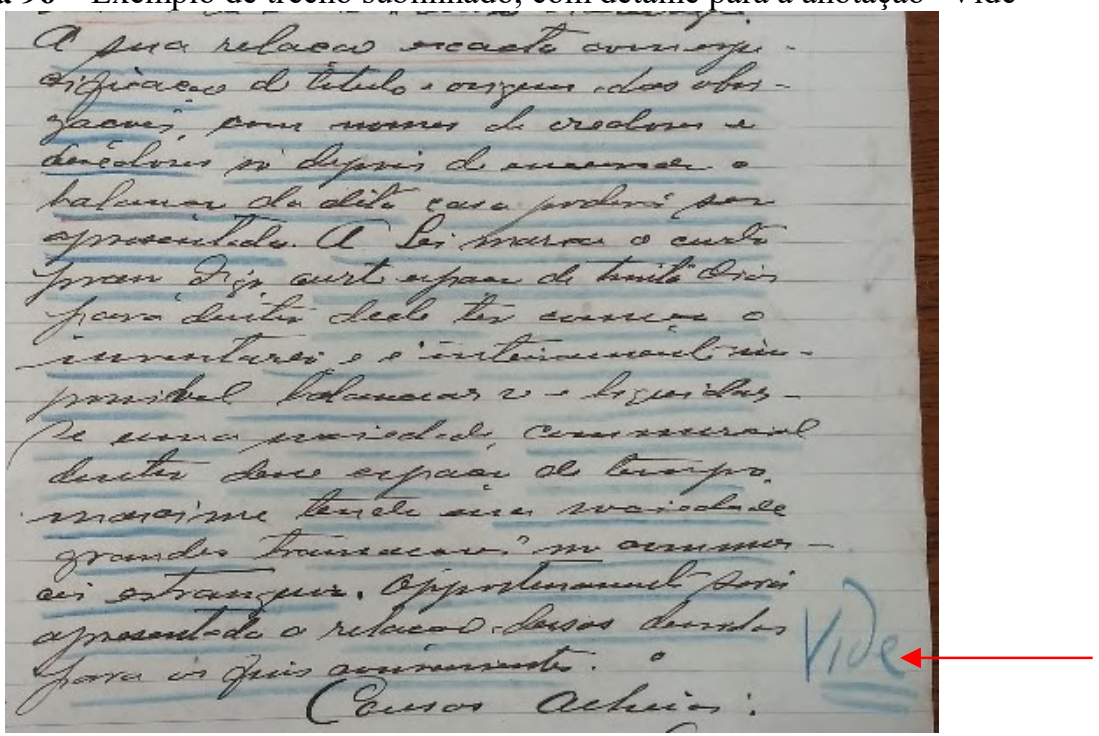

Fonte: Acervo do CEDOC/UEFS

Figura 97 - Exemplos de trechos sublinhados, com detalhes para as inserções de pontuações e de " $\mathrm{x}$ "
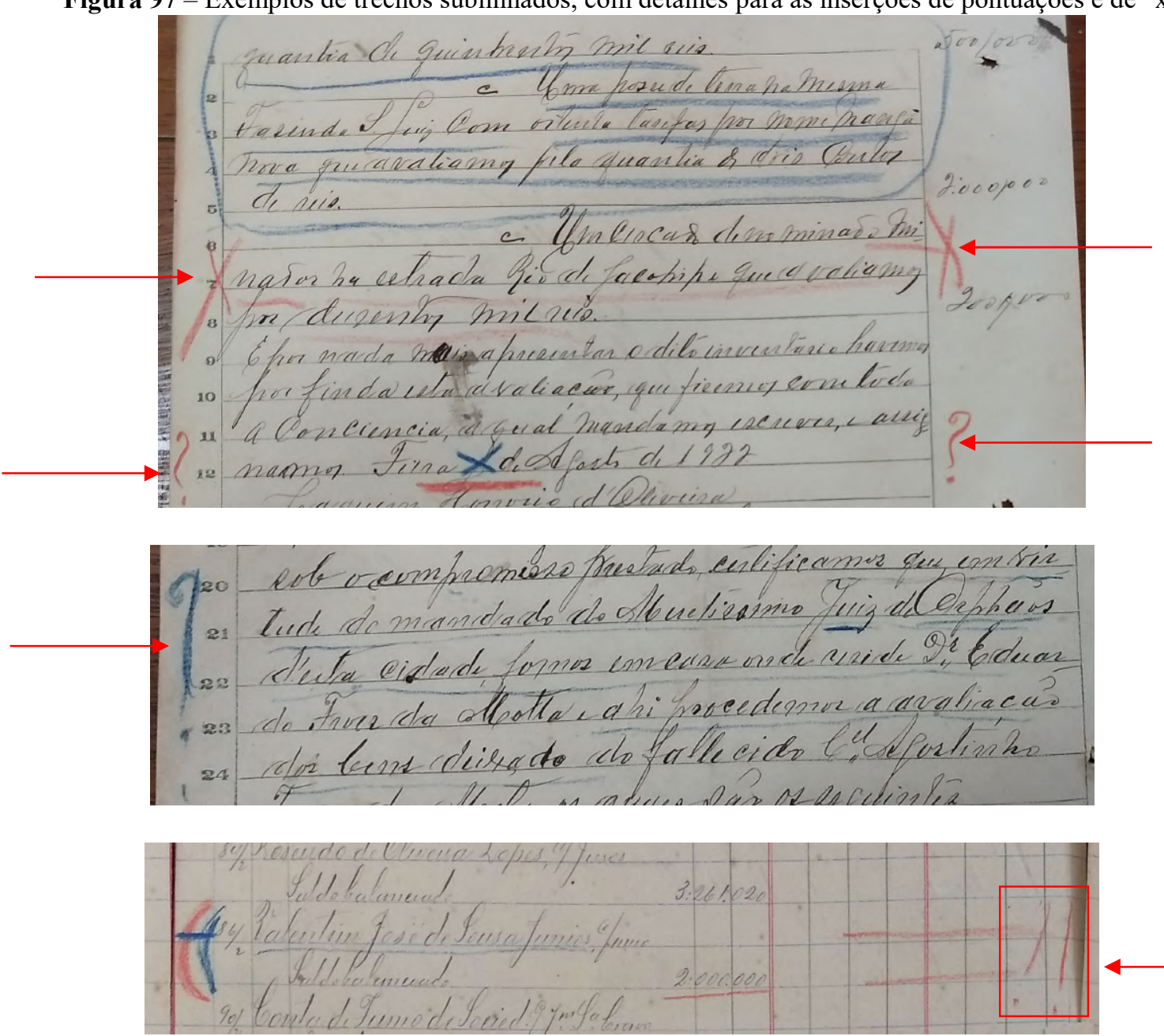

Fonte: Acervo do CEDOC/UEFS 
Figura 98 - Exemplo de trecho datiloscrito com detalhes para as marcações que indicam o sentido de leitura

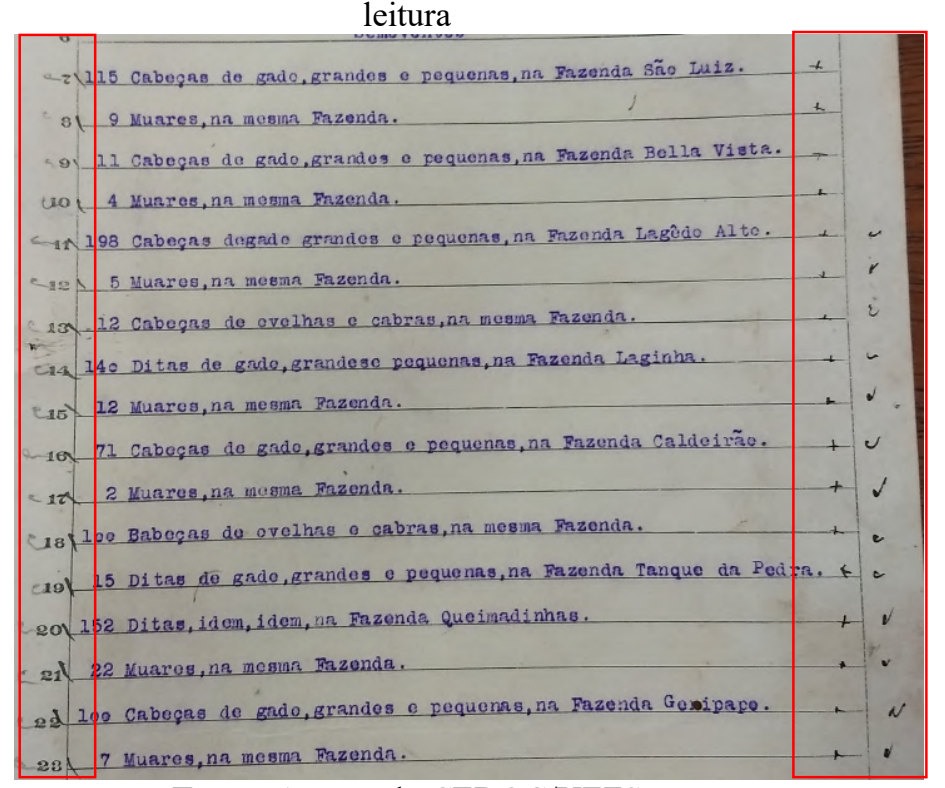

Fonte: Acervo do CEDOC/UEFS

Um dado interessante que indica o cuidado dos escreventes com a redação do texto é o fato de existirem inserções manuscritas, feitas depois que o texto já estava redigido manuscrita ou datilografadamente, pelos escreventes Manoel Pimentel, José Maria Neves e Altino Teixeira, respectivamente, o que indica a existência de um olhar acurado sobre o texto, que seria entregue à Justiça para ser anexado aos autos do processo.

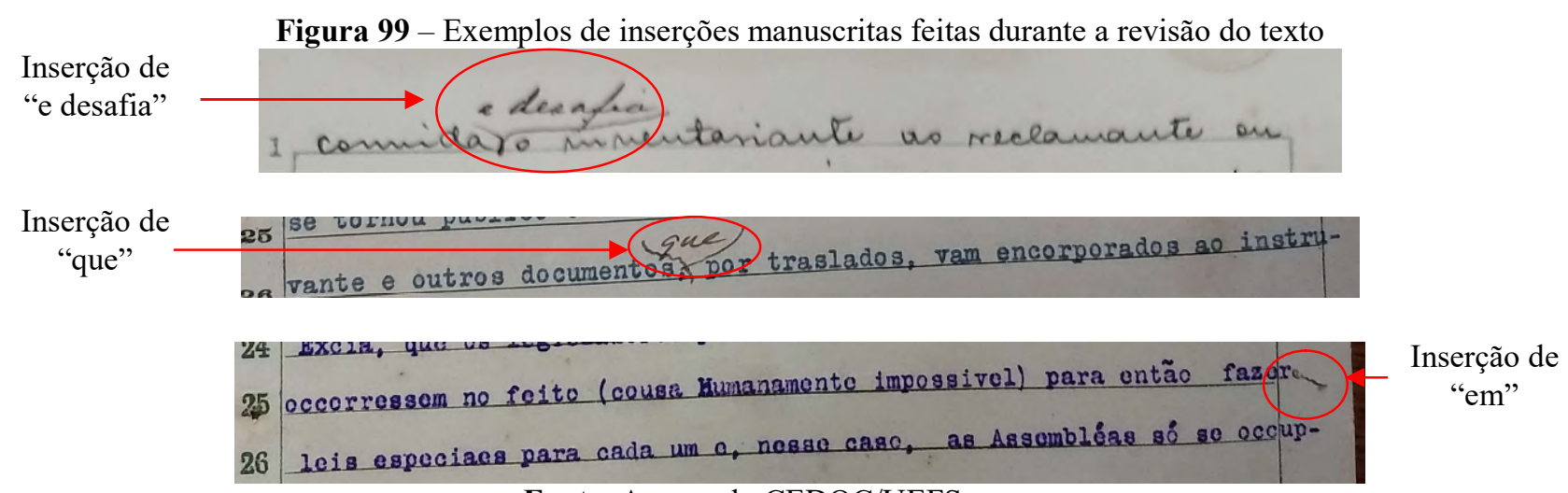

Fonte: Acervo do CEDOC/UEFS

Essa preocupação em apresentar, em Juízo, um documento completo e livre de quaisquer equívocos de interpretação foi a mesma, provavelmente, sentida pelo contador Albertino Dantas e pelo tesoureiro Petronillo Guaviro de Meirelles que fizeram questão de, após anular e inserir uma informação no recto do fólio 149 ("Herdeiros do | Coronel Agostinho Fróes da Motta"), acrescentar uma nova ("Vale a emenda com tinta verme- | lha, visto como, por engano foi ti- | rado o conhecimento em nome de | Dona Albertina de 
Almeida Motta, quan- $\mid$ do o carro se acha registrado nesta | Repartição, como pertencente aos | herdeiros do Coronel Agostinho Fróes | da Motta. | Feira e Repartição Municipal, em | 26 de Abril de 1922 | O Thesoureiro | Petronillo Guaviro de Meirelles") no verso do formulário de pagamento de impostos à Intendência Municipal de Feira de Santana-BA, conforme a figura seguinte.

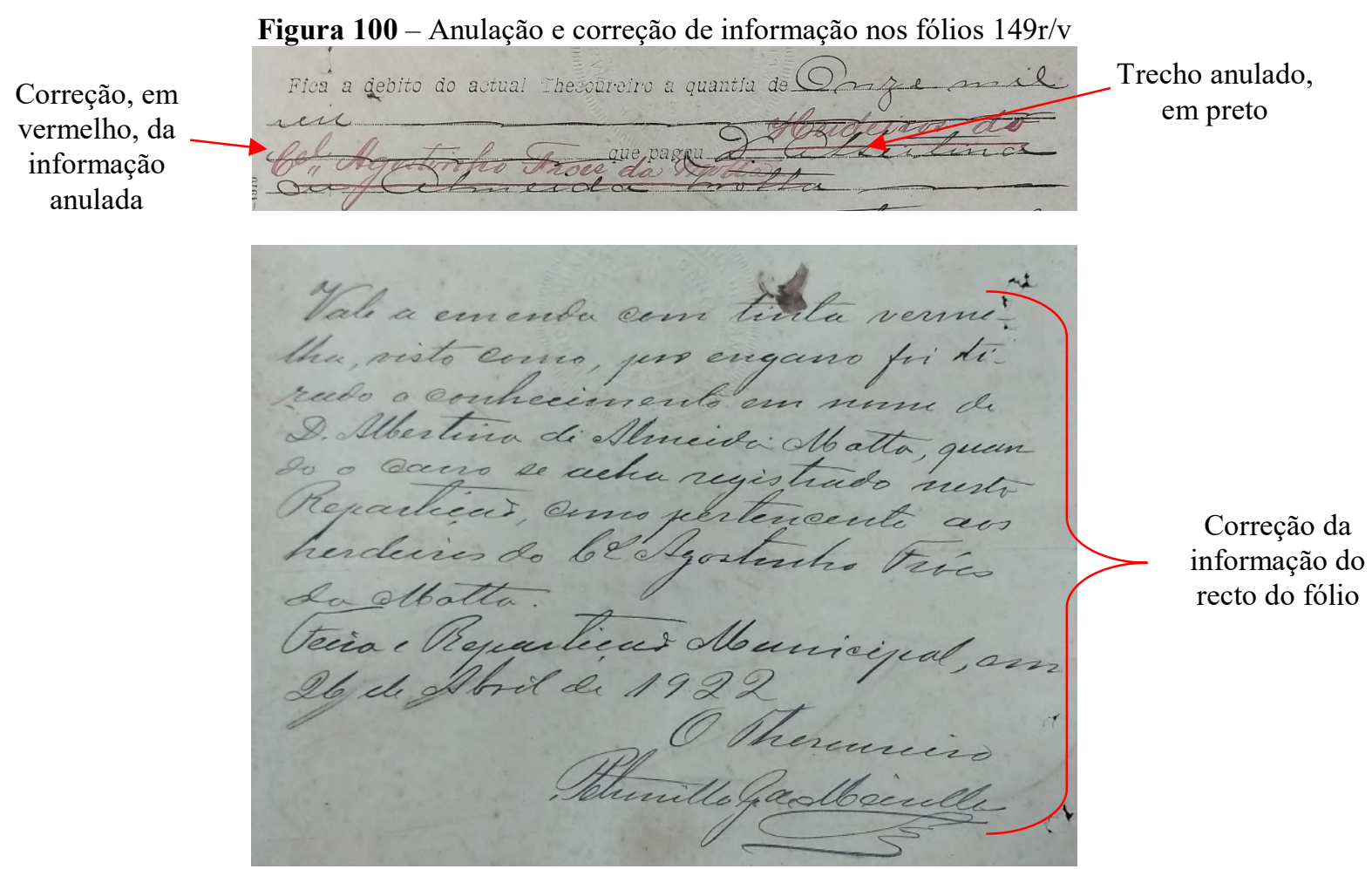

Fonte: Acervo do CEDOC/UEFS

Outro aspecto interessante no documento e, especificamente, nos fólios em branco, cujo escrevente responsável foi Manuel Francisco de Almeida Ramalho é a existência de um longo traço sinuoso, ao centro do fólio, para demarcar o seu não uso e a impossibilidade de ser inserida informação tardia no respectivo fólio, conforme exemplificado na figura 101. 
Figura 101 - Traço longo sinuoso na vertical do centro do fólio $27 \mathrm{r}$

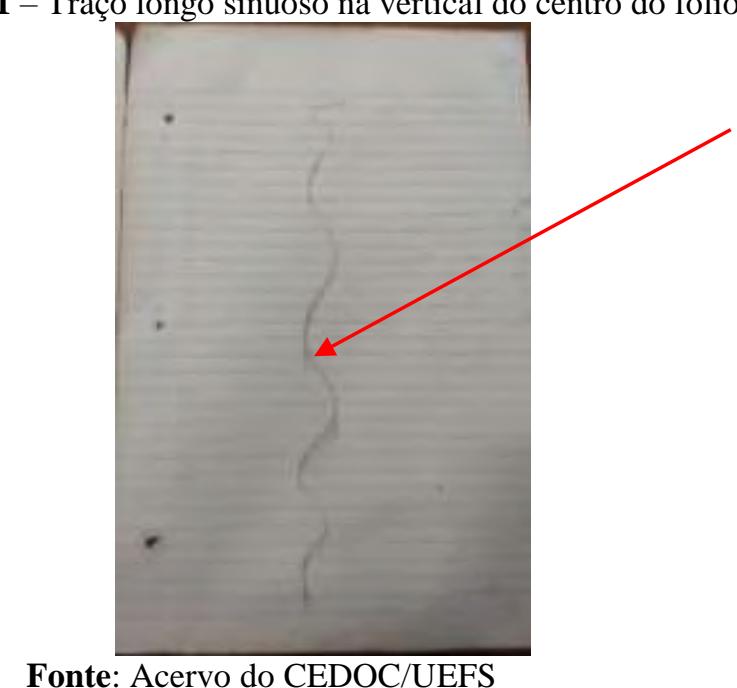

Por fim e não menos importante, selecionamos e listamos amostras de aspectos gráficos e de escrita fonética dos seis escreventes que mais fólios do corpus escreveram: Manuel Francisco de Almeida Ramalho, Jacintho Ferreira da Silva, José Maria Neves, João Carneiro Vital, Agnello Ribeiro de Macêdo e Altino Teixeira, com o objetivo de caracterizar individualmente cada punho.

A escolha de análise da scripta desses indivíduos se deu porque quase todo o corpus fora escrito por eles, o que nos permitiu extrair uma amostragem paleográfica significativa, na qual foi possível coletar, em quase todas scriptae, os dados requeridos. Além disso, decidimos dar visibilidade apenas aos aspectos que se sobressaem no corpus, haja vista os considerarmos representativos da escrita de cada escrevente e, portanto, suficientes para uma amostragem.

Ao apresentarmos os exemplos, contudo, também listamos a sua localização no corpus, para a qual utilizamos as siglas TMAM, para nos referirmos ao testamento de Maximiana de Almeida Motta, TAFM, para o testamento de Agostinho Fróes da Motta, e IAFM, para o primeiro volume do inventário de Agostinho Fróes da Motta, seguidas do número do fólio.

Nos fólios escritos pelo primeiro escrevente é possível notar que a sua scripta apresenta alguns aspectos interessantes, a saber: ausência de cursus e letras monolíticas em alguns trechos dos fólios por ele escritos, separação silábica em conformidade com o acordo ortográfico vigente, aspectos de escrita fonética, uso de grafemas vocálico e consonantal, alternância entre o uso dos grafemas $<0>$ e $\langle u>$ em sílaba final, uso de abreviaturas e de ligaduras e de letra cursiva com ângulo de inclinação para a direita, conforme amostras dispostas nos quadros seguintes. 
Quadro 42 - Exemplos de ausência de cursus do escrevente Manuel Francisco de Almeida Ramalho

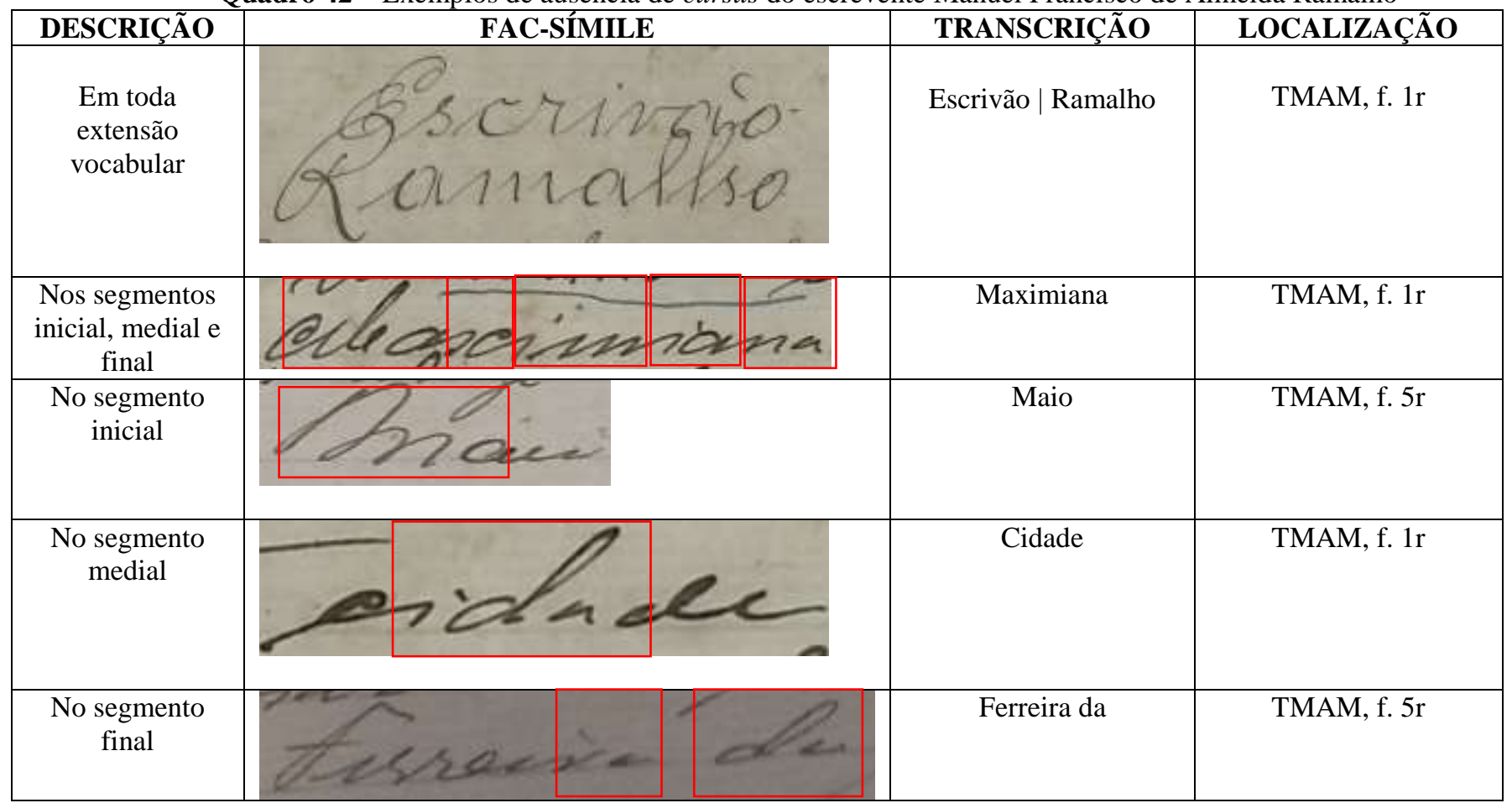

Fonte: Elaborado pela pesquisadora

Quadro 43 - Amostra de aspectos gráficos e de escrita fonética do escrevente Manuel Francisco de

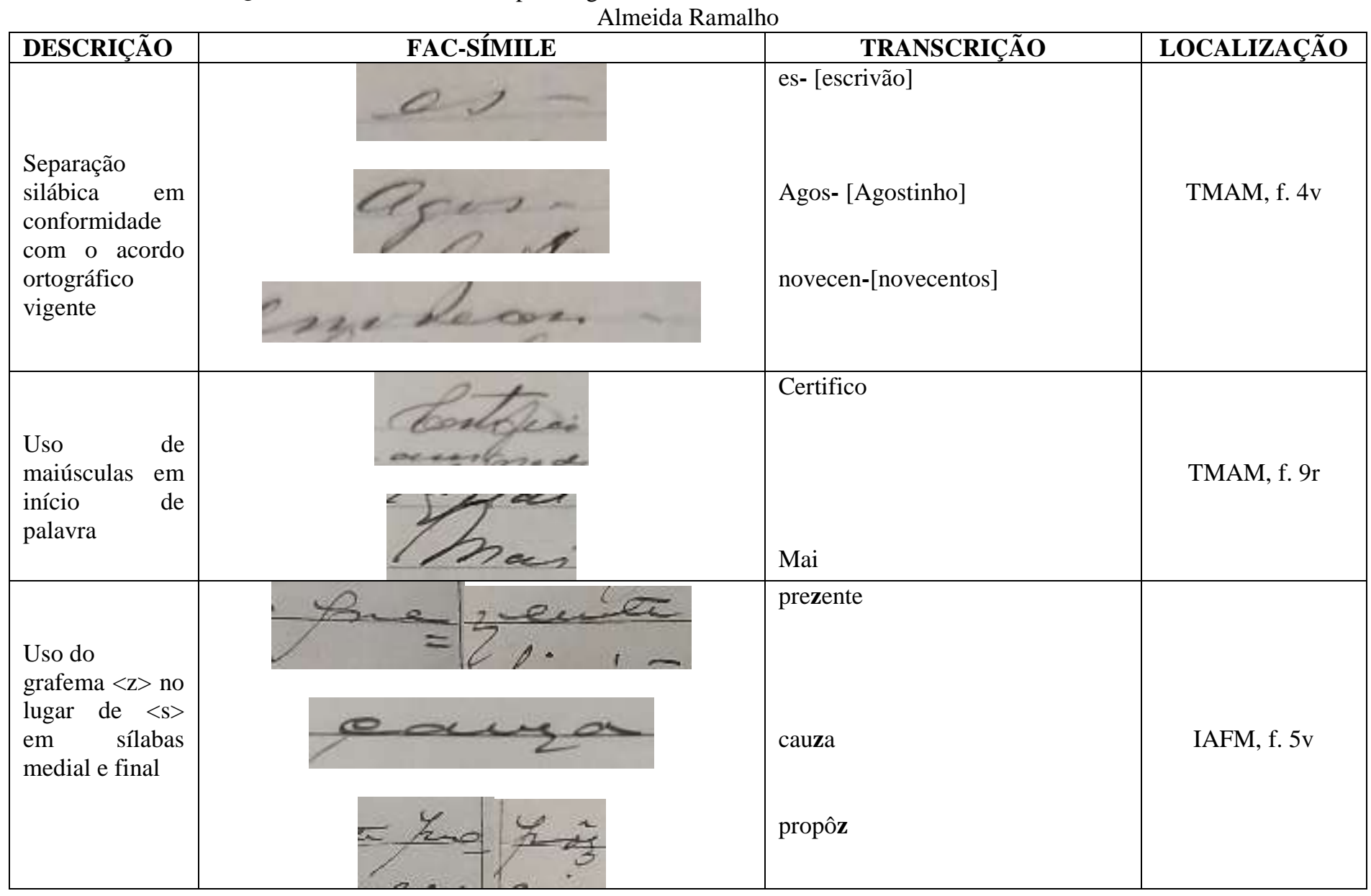




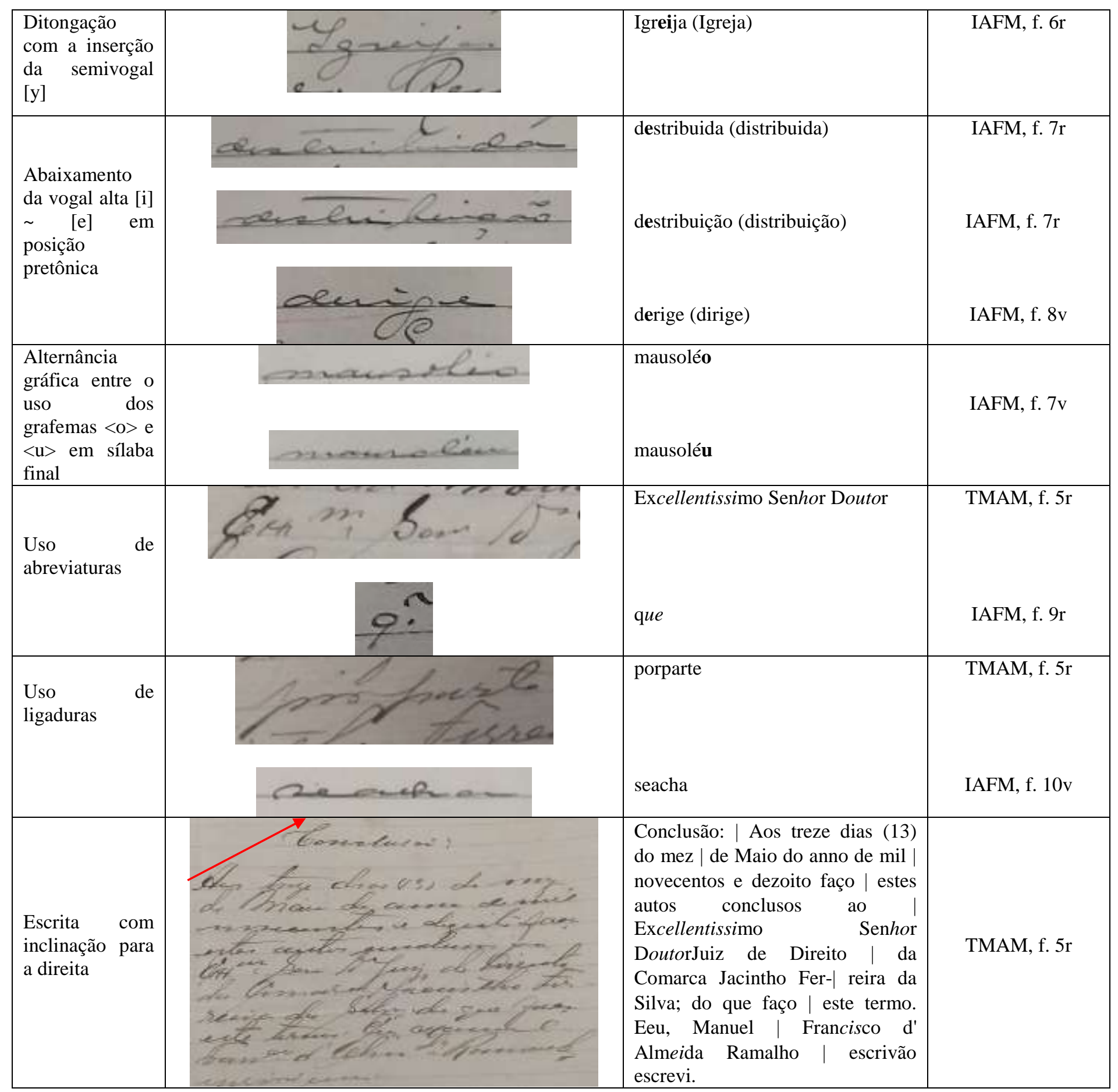

Fonte: Elaborado pela pesquisadora

Já na escrita do segundo escrevente, o Juiz de Direito Jacintho Ferreira da Silva, é possível identificar, além de alguns aspectos paleográficos iguais aos do primeiro escrevente, a ausência de cursus em sílabas inicial, medial e final, uso de escrita fonética e de grafema consonantal, ausência de regramento ideal na linha de escrita, e escrita com ângulo de inclinação muito levemente inclinado para a direita. 
Quadro 44 - Amostra de aspectos gráficos e de escrita fonética do escrevente Jacintho Ferreira da Silva

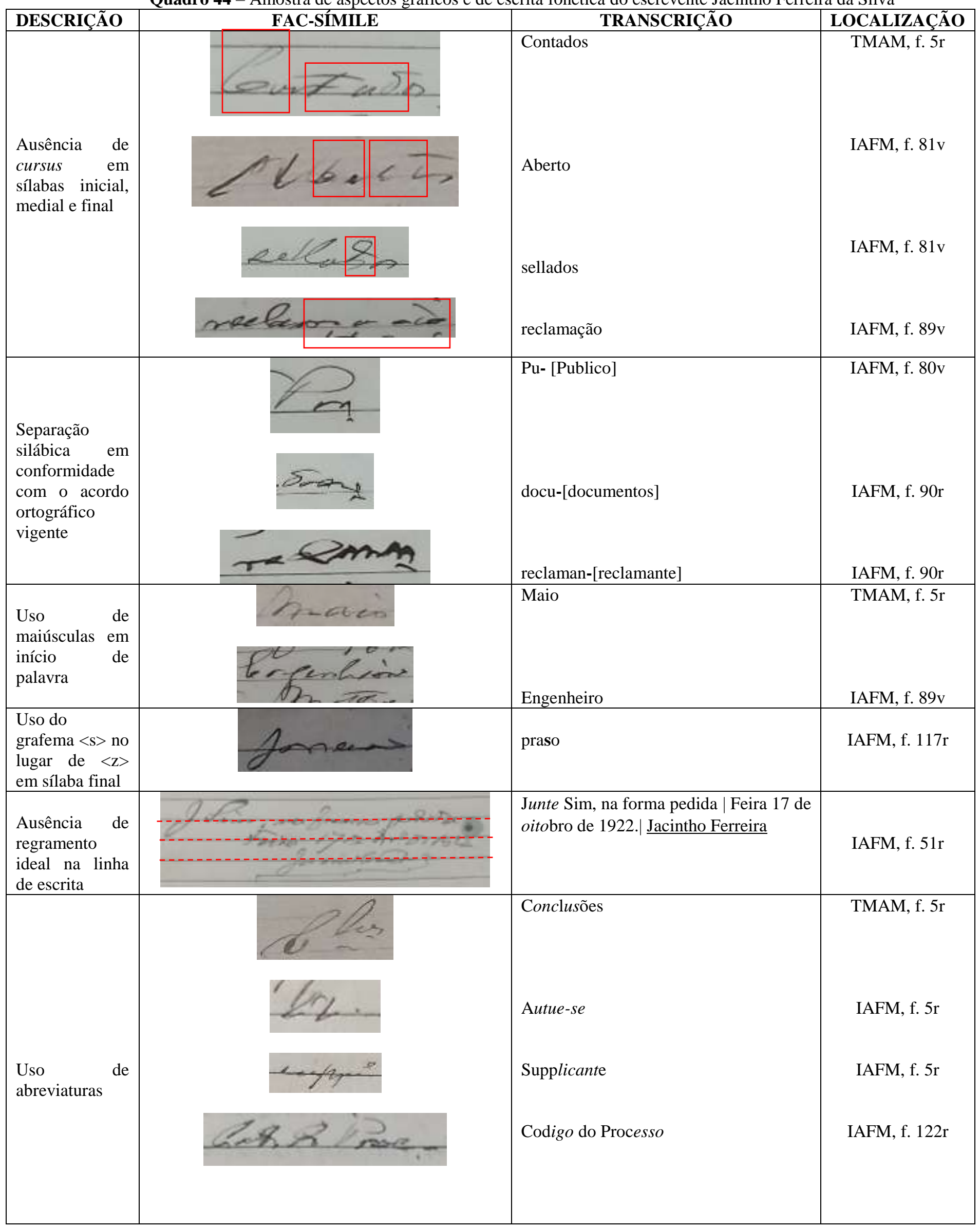




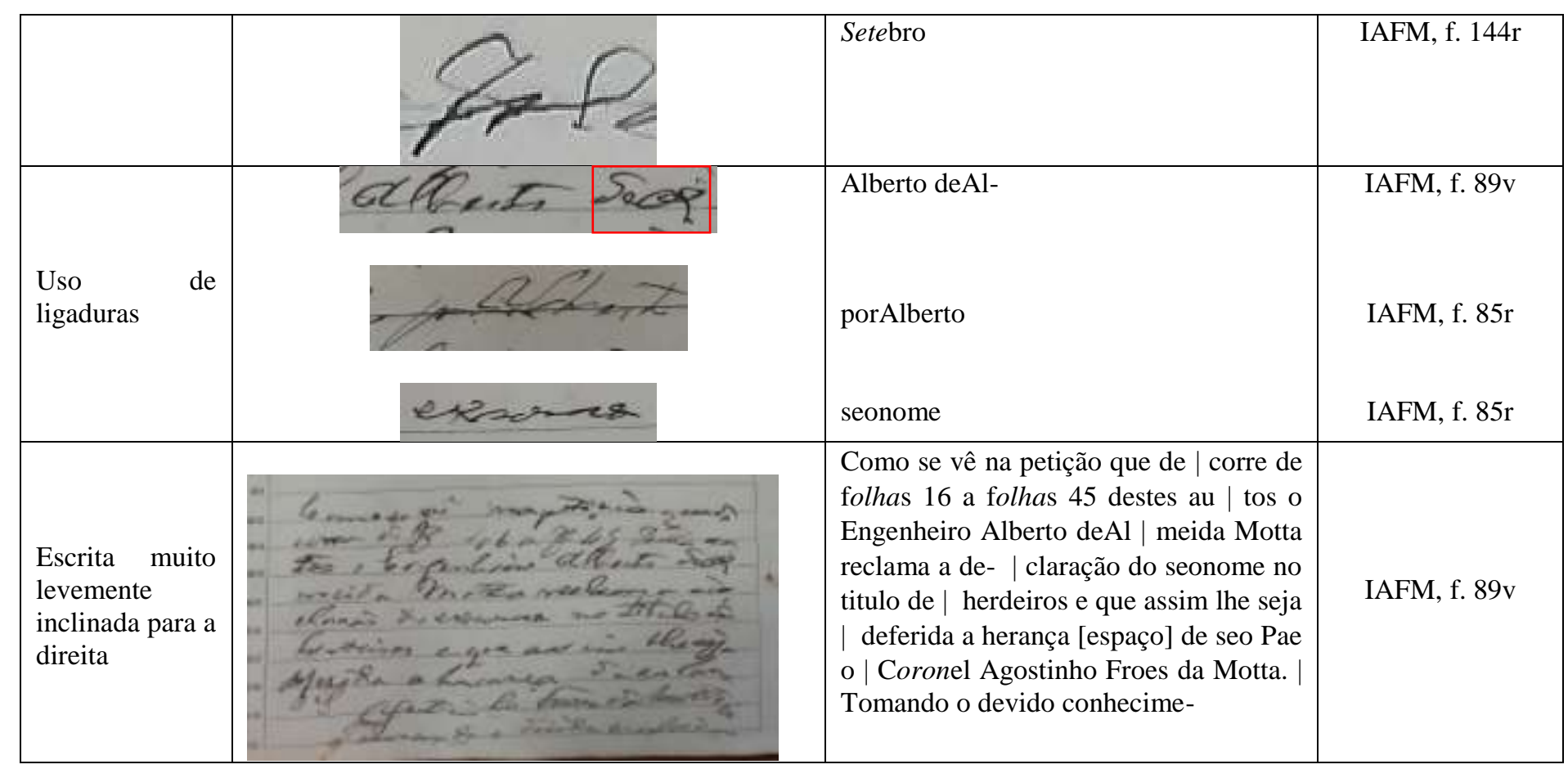

Fonte: Elaborado pela pesquisadora

A scripta do terceiro escrevente, o advogado José Maria Neves, apresenta vários dos aspectos anteriores, mas também outras particularidades, como podemos observar a seguir.

Quadro 45 - Amostra de aspectos gráficos e de escrita fonética do escrevente José Maria Neves

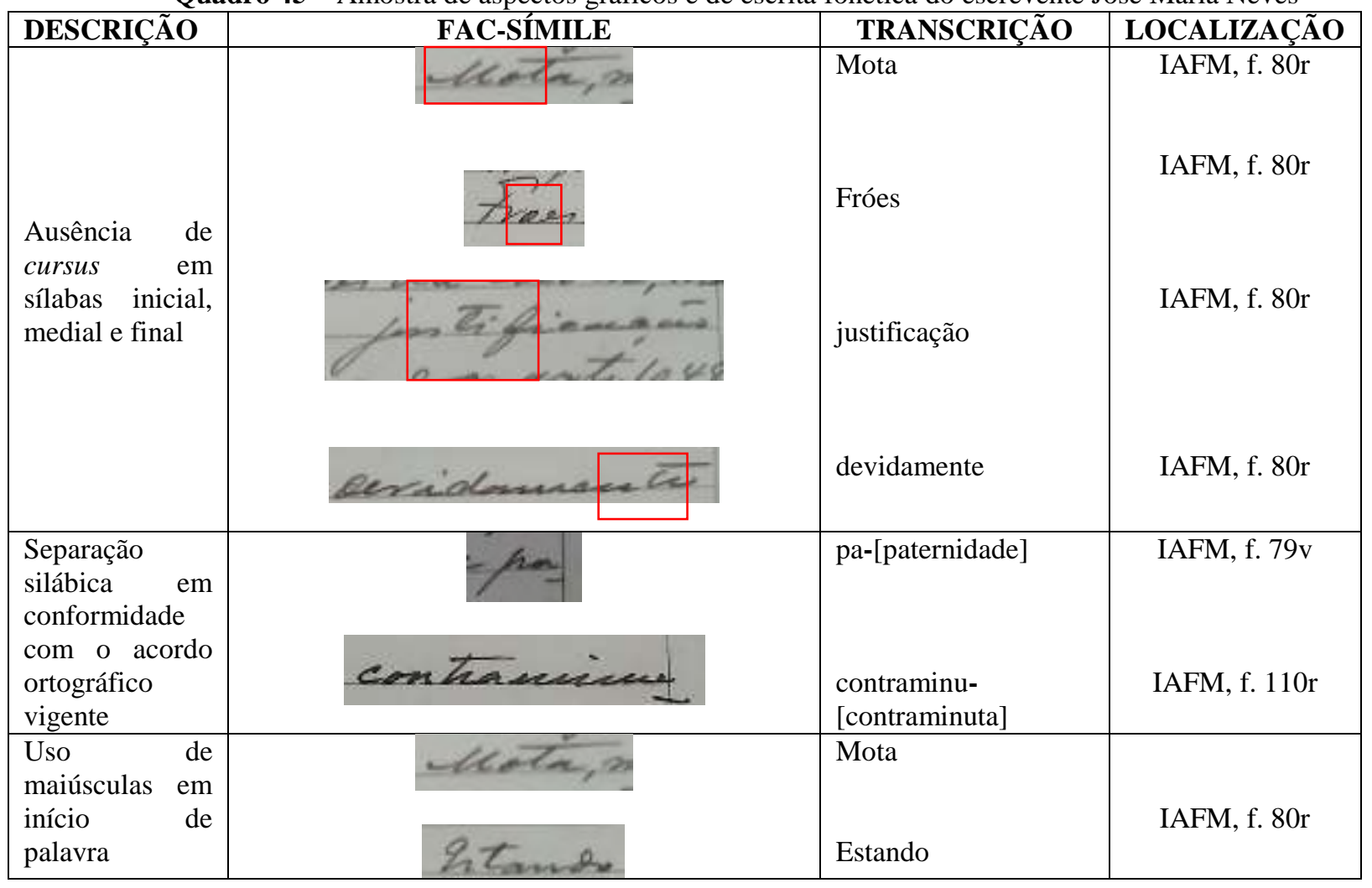




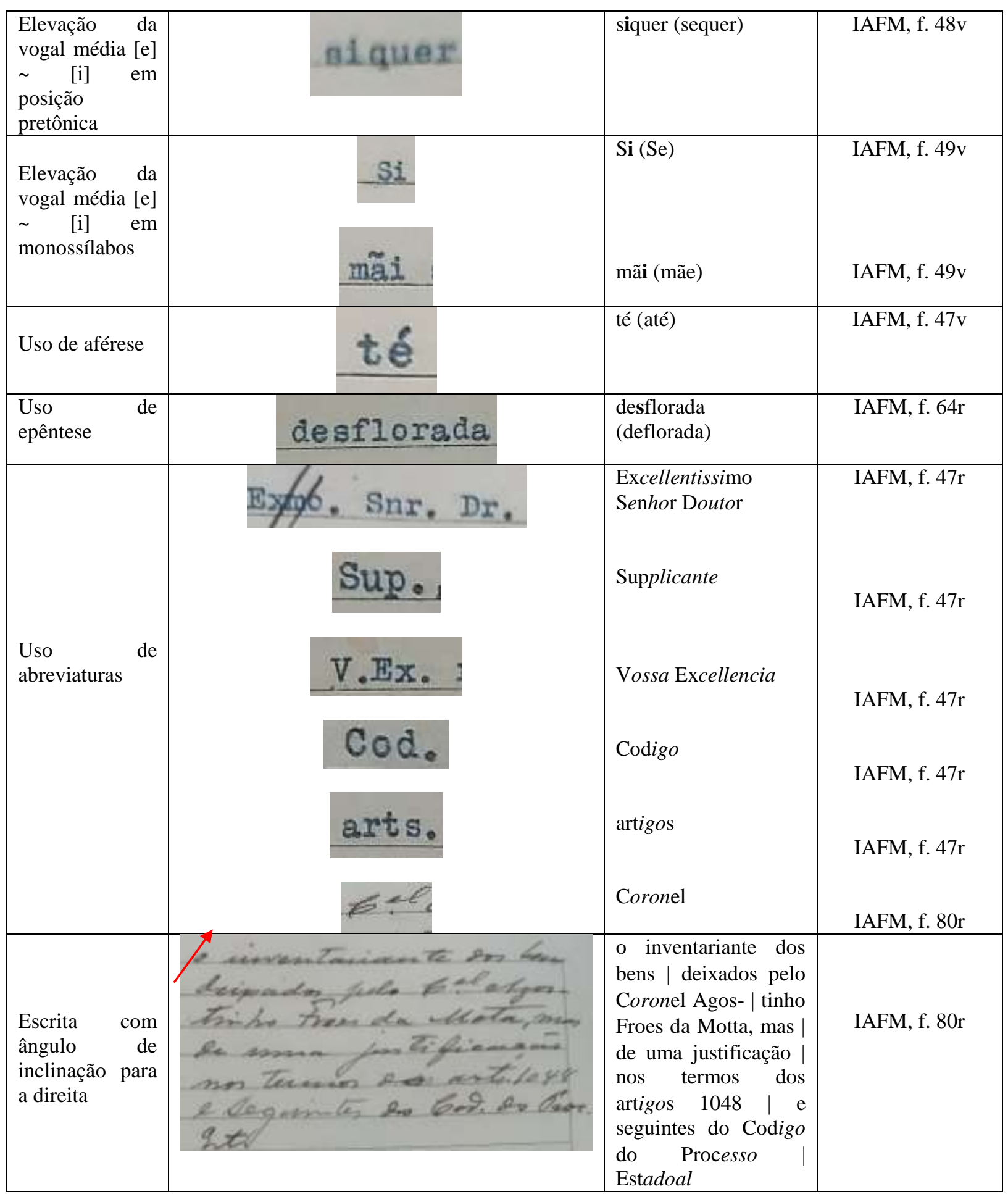

Fonte: Elaborado pela pesquisadora

O escrevente João Carneiro Vital apresentou, nos fólios por ele escritos, separação silábica de acordo com a norma gramatical vigente, uso de maiúsculas apenas em início de substantivos próprios ou depois de pontuação, uso de escrita fonética e de grafemas consonantais, ausência de ligaduras, uso de abreviaturas e escrita levemente inclinada para direita, como pode ser verificado nas amostras seguintes. 
Quadro 46 - Amostra de aspectos gráficos e de escrita fonética do escrevente João Carneiro Vital

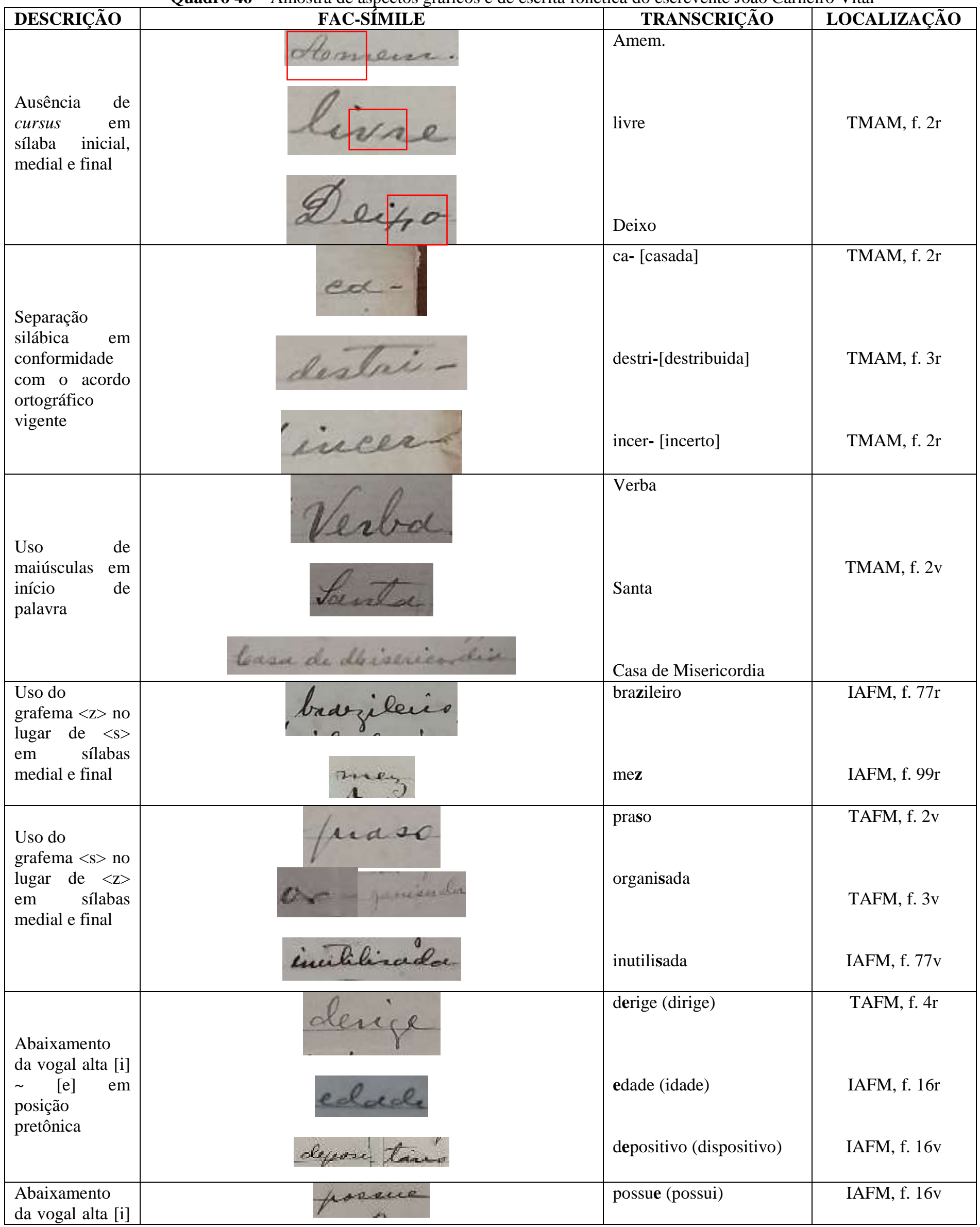




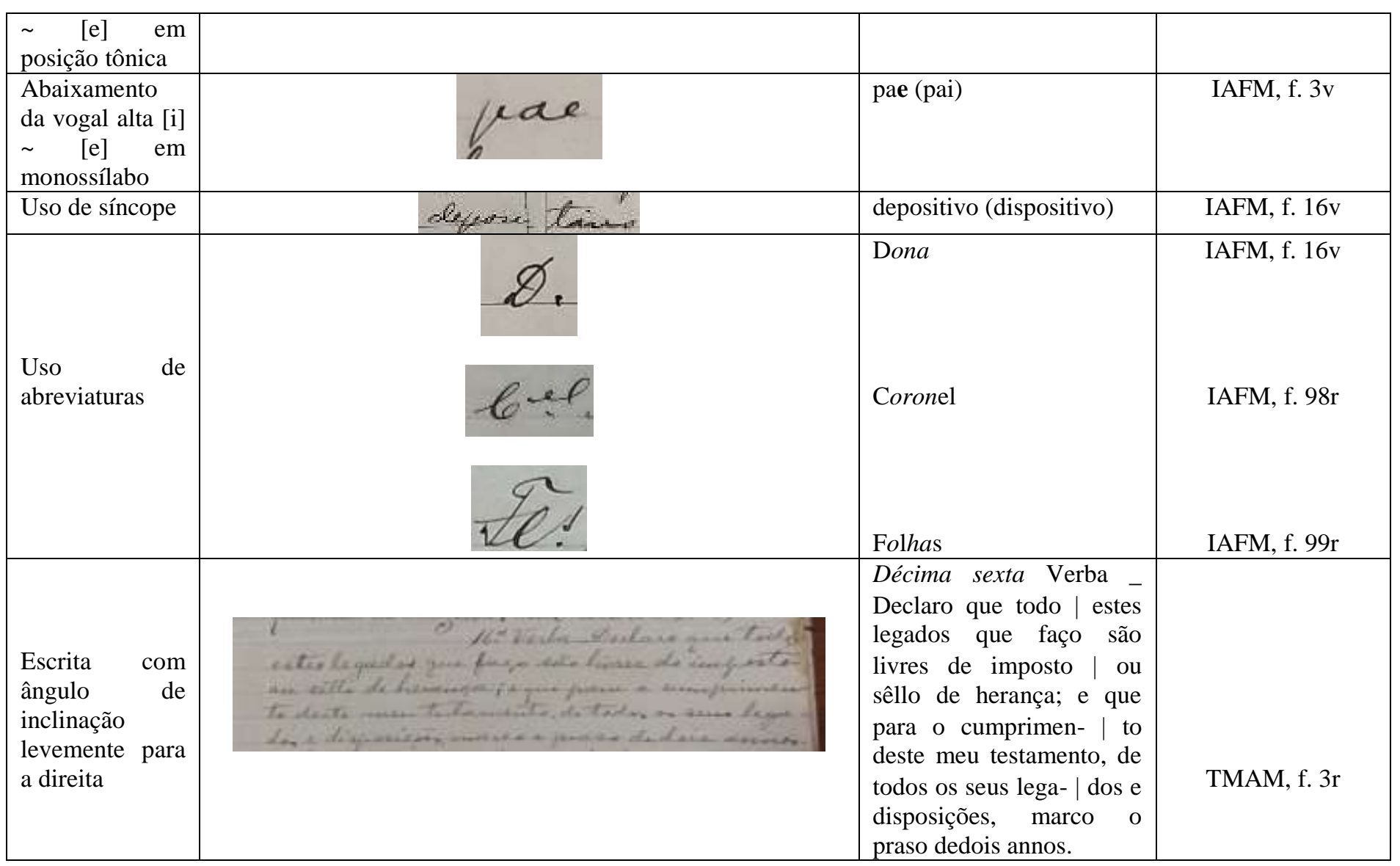

Fonte: Elaborado pela pesquisadora

O penúltimo escrevente, o advogado Agnello Ribeiro de Macêdo, também apresentou em sua escrita vários dos aspectos descritos e outros.

Quadro 47 - Amostra de aspectos gráficos e de escrita fonética do escrevente Agnello Ribeiro de

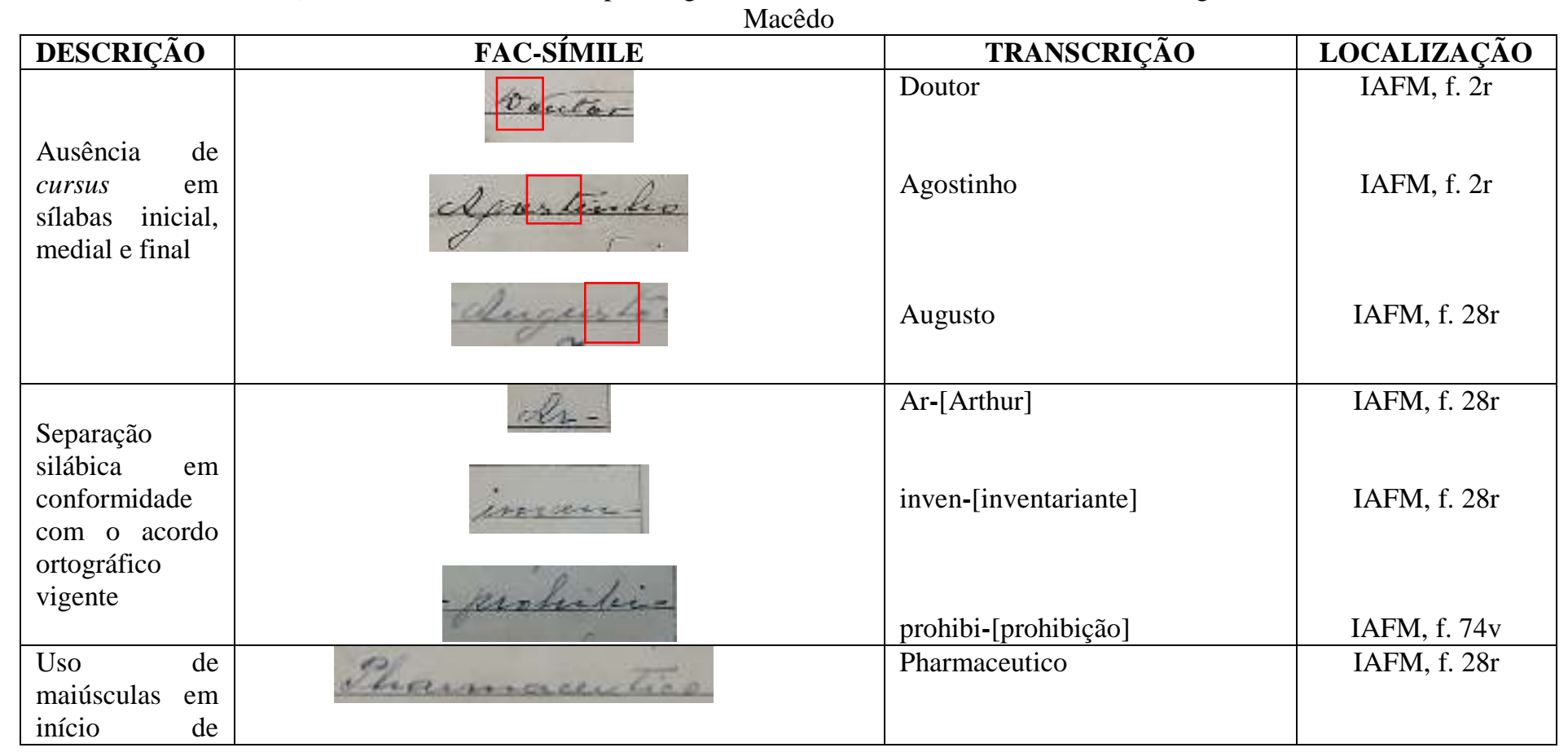




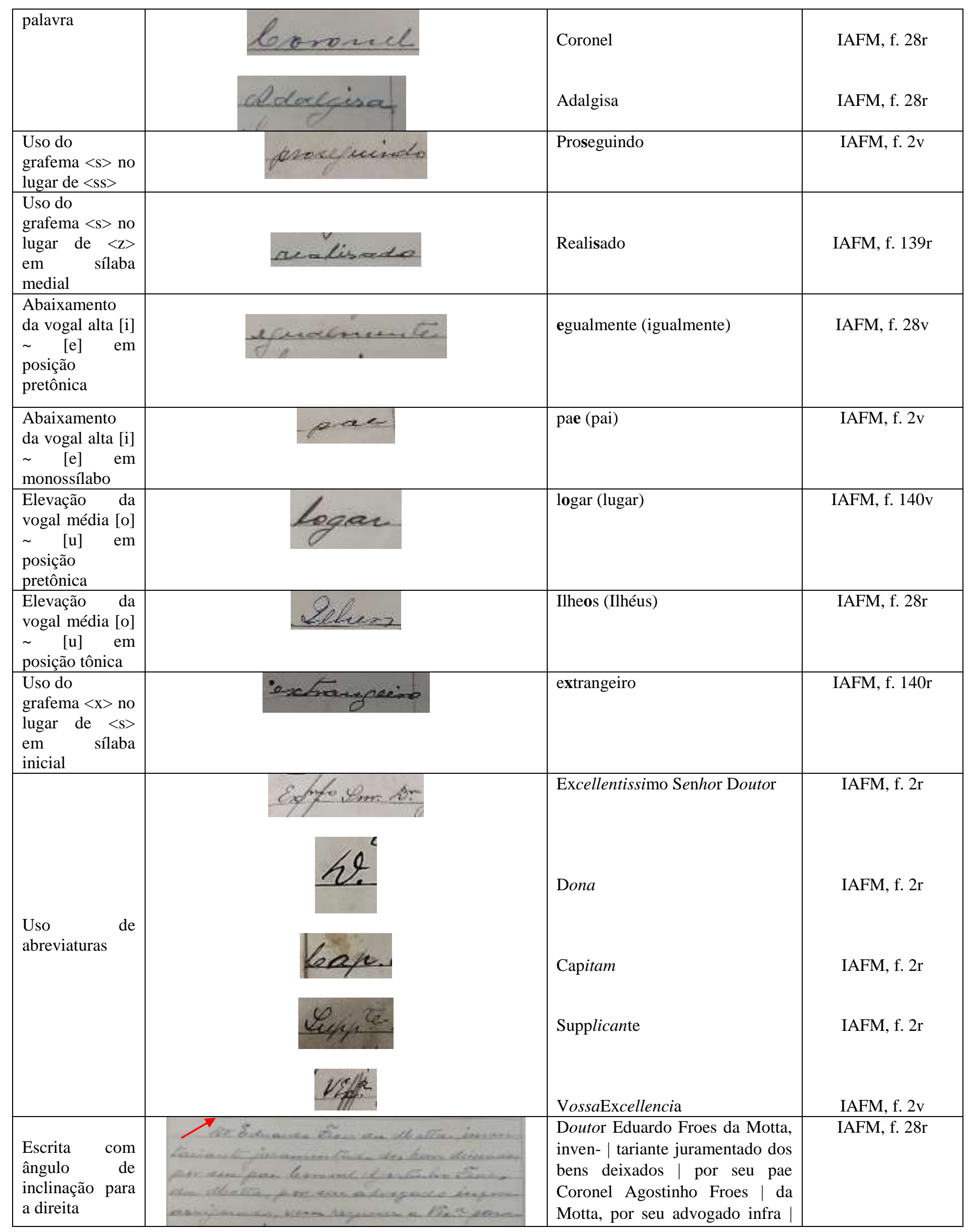


assignado, vem requerer a Vossa

Excellencia para

Fonte: Elaborado pela pesquisadora

Por fim, a scripta do advogado Altino Teixeira também tem, como veremos a seguir, os mesmos aspectos paleográficos dos demais escreventes.

Quadro 48 - Amostra de aspectos gráficos e de escrita fonética do escrevente Altino Teixeira

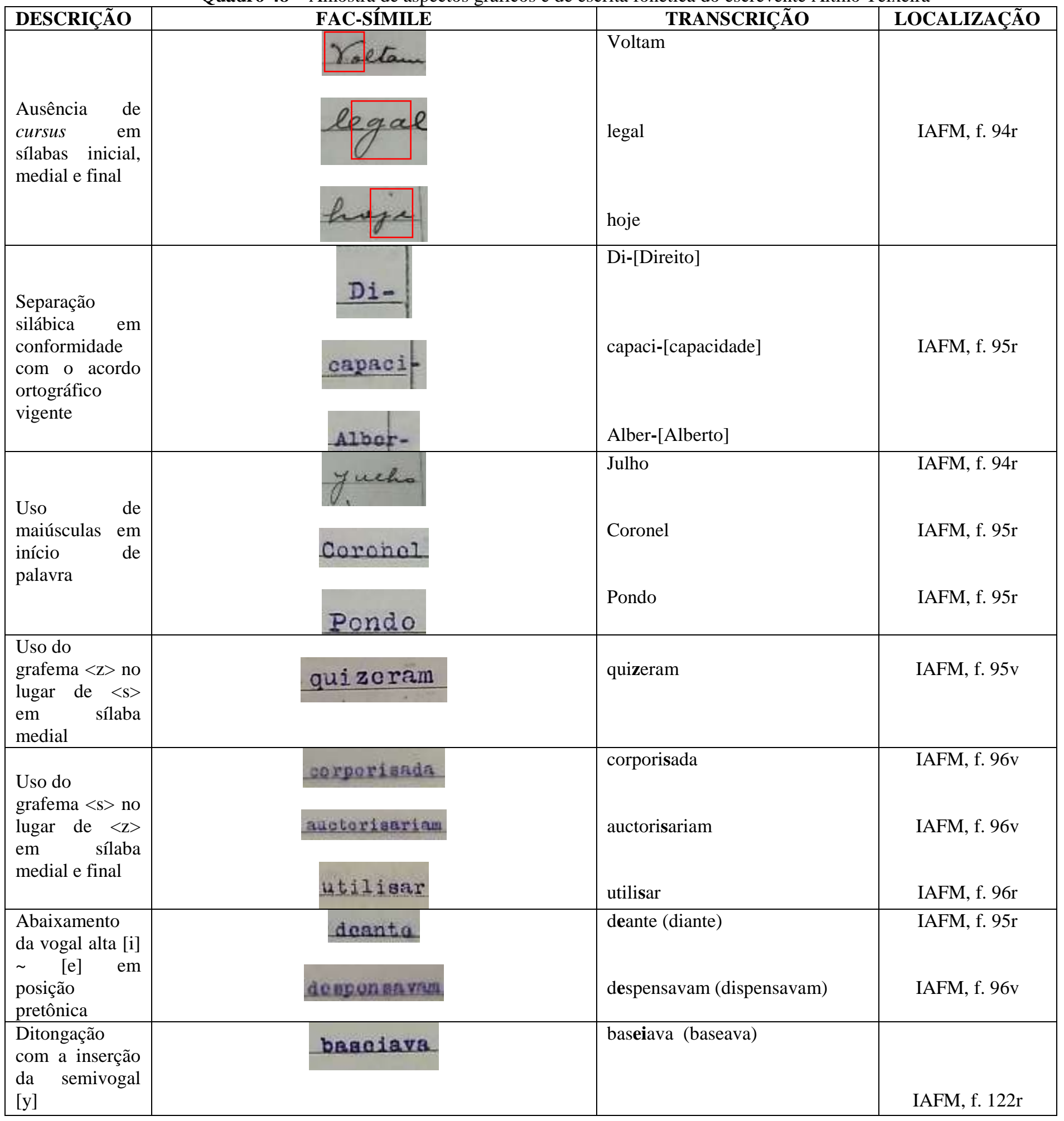




\begin{tabular}{|c|c|c|c|}
\hline & bagciar & baseiar (basear) & \\
\hline \multirow{4}{*}{$\begin{array}{l}\text { Uso } \\
\text { abreviaturas }\end{array}$} & $\sin 6 \sin x \mathrm{Dr}$. & Excellentissimo Senhor Doutor & IAFM, f. 122r \\
\hline & Ced & Coronel & IAFM, f. $122 \mathrm{r}$ \\
\hline & V. Excia & Vossa Excellencia & IAFM, f. $122 \mathrm{r}$ \\
\hline & (atesis). & $($ Advogado) & IAFM, f. $122 \mathrm{v}$ \\
\hline $\begin{array}{l}\text { Escrita } \\
\text { levemente } \\
\text { inclinada para a } \\
\text { direita }\end{array}$ & 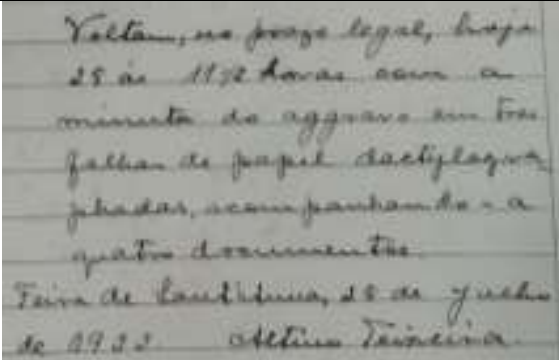 & 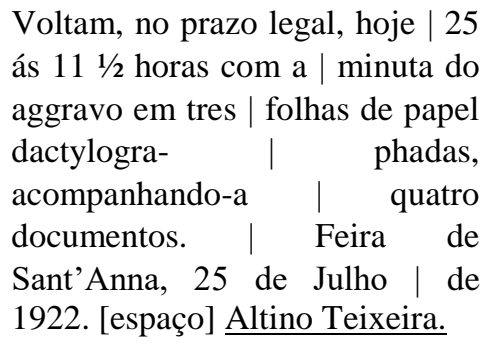 & IAFM, f. 94r \\
\hline
\end{tabular}

Fonte: Elaborado pela pesquisadora

Dessas amostras, constatamos que as escritas dos seis escreventes possuem em comum a ausência de cursus em algumas palavras, separação silábica em conformidade com o acordo ortográfico vigente, uso de maiúsculas em início de palavra, uso de abreviaturas e de letra cursiva com ângulo de inclinação para a direita ou levemente inclinada para a direita. Os demais aspectos, por sua vez, dizem respeito às particularidades paleográficas de cada escrevente, o que nos leva a acreditar que todos os elementos apontados, somados aos cargos e às posições sociais ocupadas pelos escreventes, indicam que, por ofício e/ou formação profissional, eles detinham conhecimento da norma culta do período, já que se trata da produção de textos notariais, que demandam o acesso à uma instrução formal.

Partindo dessa conjectura, realizamos algumas pesquisas e apresentamos, na próxima subseção, uma proposta de categorização do perfil socioeducacional dos escreventes, sobre os quais encontramos informações.

\subsubsection{Descrição das mãos que escrevem: uma proposta de categorização do perfil socioeducacional dos escreventes do corpus}

Como visto, várias foram as mãos que escreveram o corpus desta tese. Com exceção das procurações feitas, a próprio punho, por alguns membros da família Fróes da Motta e dos 
documentos que foram produzidos em outros contextos e anexados ao processo, o que sobra é uma grande maioria de fólios redigida por escrivães, tabeliães, advogados, Juízes de Direito, Oficiais de Justiça, tesoureiros, contadores, coletores estadual e federal, procuradores, promotores de Justiça e lançadores, que se tornaram, por isso, os produtores dos processos jurídicos estudados.

Sobre aqueles "sujeitos", recolhemos informações sobre a sua vida econômica, social e, quando possível, educacional com o intuito de delinearmos os seus perfis sócioeducacionais. Para isso, detivemo-nos a documentos depositados no CEDOC/UEFS, nos arquivos da Intendência Municipal de Feira de Santana-BA, na Faculdade de Direito de Recife, na Faculdade Livre de Direito da Bahia, nas dissertações de mestrado em História, defendidas em programas de pós-graduação brasileiros e em livros, listados nas referências, sobre Feira de Santana-BA, sobre os seus "dirigentes" (CUNHA, 2013) e os "sujeitos" da lei que atuaram na cidade.

Desses documentos, recolhemos dados que indicam que as preocupações com a instrução pública feirense advinham de homens que, diferentes da grande maioria da população local, tiveram uma educação formal, proporcionada, principalmente, pelo poder econômico de suas famílias, que concentravam em suas mãos a política e a economia feirenses, o que lhes possibilitou enviar os seus filhos para fora de Feira de Santana-BA para que estudassem em grandes centros urbanos como, por exemplo, Salvador e Recife, onde o acesso à escolarização era uma prática comum para aqueles estudantes, que se encontravam em idades escolares e condições socioeconômicas consideradas adequadas e favoráveis para a efetivação da escolarização almejada.

Nesse cenário, inseriu-se um seleto grupo constituído por intelectuais e "sujeitos" da lei, que se formaram e/ou ocuparam cargos importantes na administração pública de Feira de Santana-BA. No referido grupo, encontravam-se, entre 1880 e $1925^{131}, 24$ sujeitos - Affonso Pedreira de Cerqueira, Agerico Moreira de Almeida, Agnello Ribeiro de Macêdo, Albertino Pedreira Dantas, Altino Teixeira, Aurelio Vasconcellos, Bernardino Senna Santos, Cesar Ribeiro de Cerqueira, Diogenes de Sousa Lima, Elpidio Raymundo da Nova, Jacintho Ferreira da Silva, João Carneiro Vital, João Marques dos Reis, Joaquim Honorio d'Oliveira, Joaquim José Ramos, José de Sá Roriz, José Maria Neves, José Telles Barreto, Lyderico dos Santos Cruz, Manoel Araujo, Manoel Gomes dos Santos, Manoel Pimentel, Manuel Francisco de Almeida Ramalho e Petronillo Guaviro de Meirelles - que se tornaram funcionários de

\footnotetext{
${ }^{131}$ Selecionamos esse período pelo fato dele compreender a fase de formação acadêmica e o pleno exercício dos cargos públicos, exercidos pelos "sujeitos" que produziram os documentos que trabalhamos nesta tese.
} 
setores públicos ou privados e, no contexto de produção dos processos jurídicos estudados nesta tese, também escreventes.

Desses "sujeitos", aqueles sobre os quais, nos documentos consultados, não há informações adicionais são sobre Affonso Pedreira de Cerqueira, apontado no corpus como Tabelião de Notas da Comarca de Ilhéus; Bernardino Senna Santos, Escrivão Cível da Comarca de Ilhéus; Cesar Ribeiro de Cerqueira, Oficial de Justiça da Comarca de Feira de Santana; Diogenes de Sousa Lima, Contador da Comarca de Ilhéus; João Marques dos Reis, residente em Salvador e "catedrático da cadeira de Direito Civil e jurista dos mais competentes"; Joaquim Honorio d'Oliveira, avaliador dos bens do inventariado; e José de Sá Roriz, Guarda Livros e contador da Firma Comercial Agostinho Fróes da Motta \& Filho, sobre os quais não há menção de que eles tenham desempenhado atividades em Feira de Santana-BA ou nas cidades ou termos circunvizinhos, o que nos leva a conjecturar que, provavelmente, apenas nos acervos de Ilhéus ou em outros documentos de Feira de SantanaBA, ainda desconhecidos, possamos ter mais informações sobre cada um deles.

Sobre os demais, contudo, recolhemos algumas informações, dentre as quais estavam as que diziam respeito a Agerico Moreira de Almeida, que era filho do Coronel Tertuliano José de Almeida com Dona Eliceria Moreira de Almeida, cuja árvore genealógica consta na próxima subseção. De acordo com o inventário ${ }^{132}$ do pai de Agerico Moreira de Almeida, este faleceu em 1939, data em que também nos é relatado que ele já se encontrava desquitado de Dona Ersília Franco de Almeida e que, à época do seu desquite, havia comprado apólices federais com a herança que recebera do inventário do seu pai e que as deixou para as suas filhas com Ersília Franco de Almeida.

Enquanto vivo, Agerico Moreira de Almeida foi escrivão da Comarca de Feira de Santana-BA, provedor da Santa Casa de Misericórdia em 1931 e comerciante, conforme o Folha do Norte (10 mar. 1917, p. 2), que publicou uma nota incentivando a visita dos leitores à Loja Almeida, estabelecimento repleto de "um grande e variado sortimento de fazendas finas e grossas".

Loja Almeida | O sr. Agerico Almeida, acti- | vo negociante nesta cidade, | convidou-nos para, em visita | ao seu estabelecimento, que é | a "Loja Almeida", á rua do | Mercado n. 3, apreciarmos um | grande e variado sortimento de | fazendas finas e grossas, sorti | mento recebido ultimamente da | praça do Rio de Janeiro. Desobrigando-nos do gentil | convite, visitamos, de facto, a | "Loja Almeida", num

\footnotetext{
132 Processo Cível armazendo no CEDOC/UEFS sob a cota: Estante 03, Caixa 79 e Documento 970, lavrado em Feira de Santana-BA entre 1930 a 1940, com 163 fólios e cujas partes interessadas foram Dona Eliceria Moreira de Almeida e o Coronel Tertuliano José de Almeida.
} 
dos ul | timos dias da semana, colhen- $\mid$ do ali excellente impressão, o | que succederá, estamos certos, | a quantos se dirigirem á con- | ceituada casa, cujas vendas são | feitas nas melhores condições.

Logo, identifica-se a presença de Agerico Moreira de Almeida em, pelo menos, três cenários feirenses: ocupando um cargo público, sendo filantropo e comerciante de indiscutível visibilidade social em Feira de Santana-BA.

Sobre Aurelio Vasconcellos, há evidências de que ele foi negociante ${ }^{133}$, escrivão ${ }^{134} \mathrm{da}$ Comarca de Feira de Santana-BA, filho de Antonio Pedro Vasconcellos e Annanias Vasconcellos e casado com Dona Martiniana de Almeida Vasconcellos ${ }^{135}$, com quem teve a filha Antonieta de Almeida Vasconcellos. Quando se tornou funcionário público, Aurelio Vasconcellos assumiu o cargo de escrivão interino do Comissariado de Polícia, em 2 de agosto de 1904, quando o seu pai, que também era escrivão, faleceu e deixou o cargo vago, que foi, portanto, ocupado pelo seu filho Aurelio Vasconcellos, conforme documento avulso transcrito a seguir.

\footnotetext{
Illustrissimo Senhor Coronel Intendente Municipal | [...] Communico-vos para os fins convinientes, que em data de $\mid 1^{\circ}$ do corrente, assumi o lugar de escrivão interino do $\mid$ Commissariado de Policia deste termo para o qual fui $\mid$ nomeado pelo fallecimento de meu Pai, que exercia ef $=\mid$ fectivamente. $\mid$ Assim cumprindo este dever, peço-vos dar as necessa- | rias ordens do Thesouro desta intendencia para que possa $\mid$ o supplicante receber a gratificação a que tem direito em $\mid$ vista do $\S 2^{\circ}$ do Artigo $1^{\circ}$ da Lei Orçamentaria em vigor $\mid$ Aproveito a opportunidade para manifestavos os meus | cinceros respeitos e consideração | Saude e Fraternidade | Feira 2 de Agosto de 1904 | O Escrivão Interino | Aurelio de Vasconcellos (DOCUMENTO AVULSO - LIVRO DE REGISTROS..., 1893-1908).
}

Sobre Albertino Pedreira Dantas, os documentos consultados revelam que ele foi lançador de impostos da Comarca de Feira de Santana-BA, nomeado em 1 de setembro de 1920 pelo Intendente Bernardino da Silva Bahia, dono de animais empregados na vendagem de água, em 1917, e dono de um "modesto Chevrolet", cujo barulho era ouvido por todos (BOAVENTURA, 2006).

\footnotetext{
${ }^{133}$ Informação extraída do inventário de Olydia Vieira Mendes, cujo inventariante foi Aurelio Vasconcellos, localizado no arquivo do CEDOC/UEFS sob a cota: Estante 02, Caixa 53 e Documento 577, lavrado em Feira de Santana - Ba em 1933, com 99 fólios.

${ }^{134}$ Enquanto ocupante deste cargo, Aurelio de Vasconcellos solicitou Licença Prêmio de 6 meses, em 1939, ano em que declarou possuir 34 anos de profissão, conforme consta na Petição de Licença Prêmio armazenada no CEDOC/UEFS, sob a cota: Estante 13, Caixa 360 e Documento 8373.

${ }^{135}$ Informação extraída da partilha amigável de Izídio Manuel de Almeida, sogro de Aurelio Vasconcellos, armazenada no CEDOC/UEFS sob a cota: Estante 11, Caixa 299 e Documento 6710, lavrado em Feira de Santana-BA em 1930, com 17 fólios.
} 
Sobre o advogado Elpidio Raymundo da Nova, Cerqueira e Souza (2009) afirmam que ele foi provedor da Santa Casa de Misericórdia em 1927, 1930 e 1931, nascido em SalvadorBA e casado com Perolina Bahia Nova, com quem teve 11 filhos, dentre os quais estava Raymundo Bahia Nova, que formou-se Bacharel em Ciências Jurídicas, em 1939, pela Faculdade Livre de Direito da Bahia. Elpidio Raymundo da Nova, por sua vez, também se formou em Ciências Jurídicas, em 1912, pela mesma faculdade que o filho e foi o primeiro Promotor Público da Comarca de Feira de Santana-BA, onde assumiu cargos políticos no Poder Executivo, tais como o de Intendente (1928-1931) ${ }^{136}$ e o de primeiro Prefeito (19331935) de Feira de Santana-BA.

Ambas as gestões de Elpidio Raymundo da Nova foram marcadas por acontecimentos significativos para Feira de Santana-BA, tais como a inauguração da rede elétrica na cidade para condução de energia da Usina Hidrelétrica de Bananeiras, a instalação do serviço telefônico e a construção do prédio da Cadeia Pública, onde funciona atualmente a Câmara de Vereadores de Feira de Santana-BA. Na área política, a cidade recebeu a visita do Presidente Getúlio Vargas, e mudou o nome do Distrito de São José das Itapororocas para Maria Quitéria. Na área cultural, durante a sua gestão, foi cantado pela primeira vez o Hino à Feira de Santana, composto por Georgina de Melo Erisman e, na educação, foi inaugurado o Ginásio Santanópolis, construído por iniciativa do odontólogo e professor Áureo de Oliveira Filho (CERQUEIRA; SOUZA, 2009).

Sobre Joaquim José Ramos, no arquivo da Faculdade de Direito de Recife há informações de que ele era filho de Joaquim José Ramos e foi Juiz de Direito da Comarca de Ilhéus, formado em Ciências Jurídicas e Sociais pela mesma faculdade, em 1889 (MARTINS, 1931). Segundo os resultados dos exames anuais feitos por Joaquim José Ramos, este foi "aprovado simplesmente" nos terceiro e quarto anos do curso.

Sobre José Telles Barreto, o periódico Folha do Norte o classificou, em 1923, como um "digno funcionário público", época em que já era secretário da Intendência Municipal, cargo ocupado desde a sua nomeação em 16 de outubro de 1912, durante a gestão de Bernardino da Silva Bahia. Nos anos posteriores, foi escrivão da Comarca de Feira de

\footnotetext{
${ }^{136}$ Informação ratificada na Ação de Embargo, datada de 1933 a 1937, armazenada no CEDOC/UEFS sob a cota: Estante 10, Caixa 255 e Documento 5367, e proposta por Eduardo Fróes da Motta e Maria Lambert de Brito Motta contra Arthur Fróes da Motta e Alberto de Almeida Motta.
} 
Santana-BA, período em que já era casado com Dona Auta Pereira Barreto, com quem não se sabe se teve filhos, conforme inventário ${ }^{137}$ de Idalino Santos.

Sobre Lyderico dos Santos Cruz, nos seus documentos estudantis, constantes no arquivo da Faculdade de Direito da Bahia, consta que ele se formou Bacharel em Ciências Jurídicas, em 1903, pela Faculdade Livre de Direito da Bahia e atuou por um longo tempo como Juiz de Direito na Comarca de Feira de Santana-BA até que, em 1933, assumiu o cargo de Desembargador do Superior Tribunal de Justiça, como consta na ação de embargo (19331937), descrita no quadro 25.

Sobre Manuel Araujo, as fontes nos informam que ele foi Contador, Partidor e Distribuidor do Juízo da Comarca de Feira de Santana-BA, e possuidor da patente de Capitão. Já Manoel Gomes dos Santos, foi, por um longo tempo, Oficial de Justiça da Comarca de Feira de Santana-BA, e membro do Conselho Municipal, em 1902.

Sobre Manoel Pimentel, na sua pasta estudantil, armazenada no arquivo da Faculdade de Direito da Bahia, consta que ele se formou Bacharel em Ciências Jurídicas, em 1894, pela Faculdade Livre de Direito da Bahia e trabalhou como advogado em vários dos processos, cujas partes interessadas foram os membros da Família Fróes da Motta.

Sobre Petronillo Guaviro de Meirelles, nos documentos do Arquivo Público Municipal de Feira de Santana, há informações de que a sua mãe se chamava Carolina Elizia de Meirelles ${ }^{138}$ e de que ele ocupou, pelo menos, três cargos públicos: Secretário da Intendência Municipal, nomeado por Abdon Alves de Abreu, em 30 de abril de 1910; Contador Municipal, nomeado por Bernardino da Silva Bahia, em 16 de outubro de 1912; e Tesoureiro Municipal, nomeado por Agostinho Fróes da Motta, em 30 de dezembro de 1919. Sobre a sua vida particular, nos documentos da Intendência Municipal, no CEDOC/UEFS e no Folha do Norte não constam informações sobre os seus vínculos familiares.

Por fim, sobre os seis escreventes que mais fólios do corpus escreveram, os documentos indicam que Manuel Francisco de Almeida Ramalho ${ }^{139}$ era filho de Antonio de

\footnotetext{
${ }^{137}$ Documento disponível no CEDOC/UEFS sob a cota: Estante 05, Caixa 123 e Documento 1665, lavrado em Feira de Santana-BA em 1924, com 15 fólios e cujas partes interessadas foram Idalino Santos e José Telles Barreto.

${ }^{138}$ Nos livros de alistamento eleitoral da Intendência Municipal de Feira de Santana, o eleitor Petronillo Guaviro de Meirelles inseriu no item "filiação" apenas o nome de sua mãe, enquanto que os demais eleitores anotavam o nome do seu respectivo pai. Assim sendo, a inserção do nome da mãe e não o do pai nos leva a conjecturar que Petronillo Guaviro de Meirelles não soubesse ou não tivesse sido registrado pelo pai, configurando-se filho de mãe solo.

139 Retiramos as informações sobre a sua filiação, o seu casamento e os nomes dos seus filhos de Boaventura (2006) e do Inventário de Dona Maria Emilia de Almeida Ramalho, lavrado em Feira de Santana-BA entre 1946 e 1947, com 57 fólios e cuja inventariante foi Maria José de Almeida Ramalho, irmã da inventariada e de Manuel Francisco de Almeida Ramalho, que foi constituída por aquela como sua herdeira universal. Este
} 
Almeida Ramalho e Bertholina de Almeida Ramalho, e irmão de Maria Emilia de Almeida Ramalho (brasileira, solteira, proprietária e sem herdeiros) e Maria José de Almeida Ramalho (brasileira, maior de 70 anos, solteira, doméstica e sem herdeiros), casado com Maria do Carmo Miranda de Almeida Ramalho (professora do ensino primário do município), com quem teve sete filhos, a saber: Antonio, Regina, Francisco José, João, Ana, José e Maria Emilia de Miranda Ramalho e com os quais morou em uma imponente chácara na Princesa do Sertão.

Organograma 1 - Árvore genealógica de Manuel Francisco de Almeida Ramalho

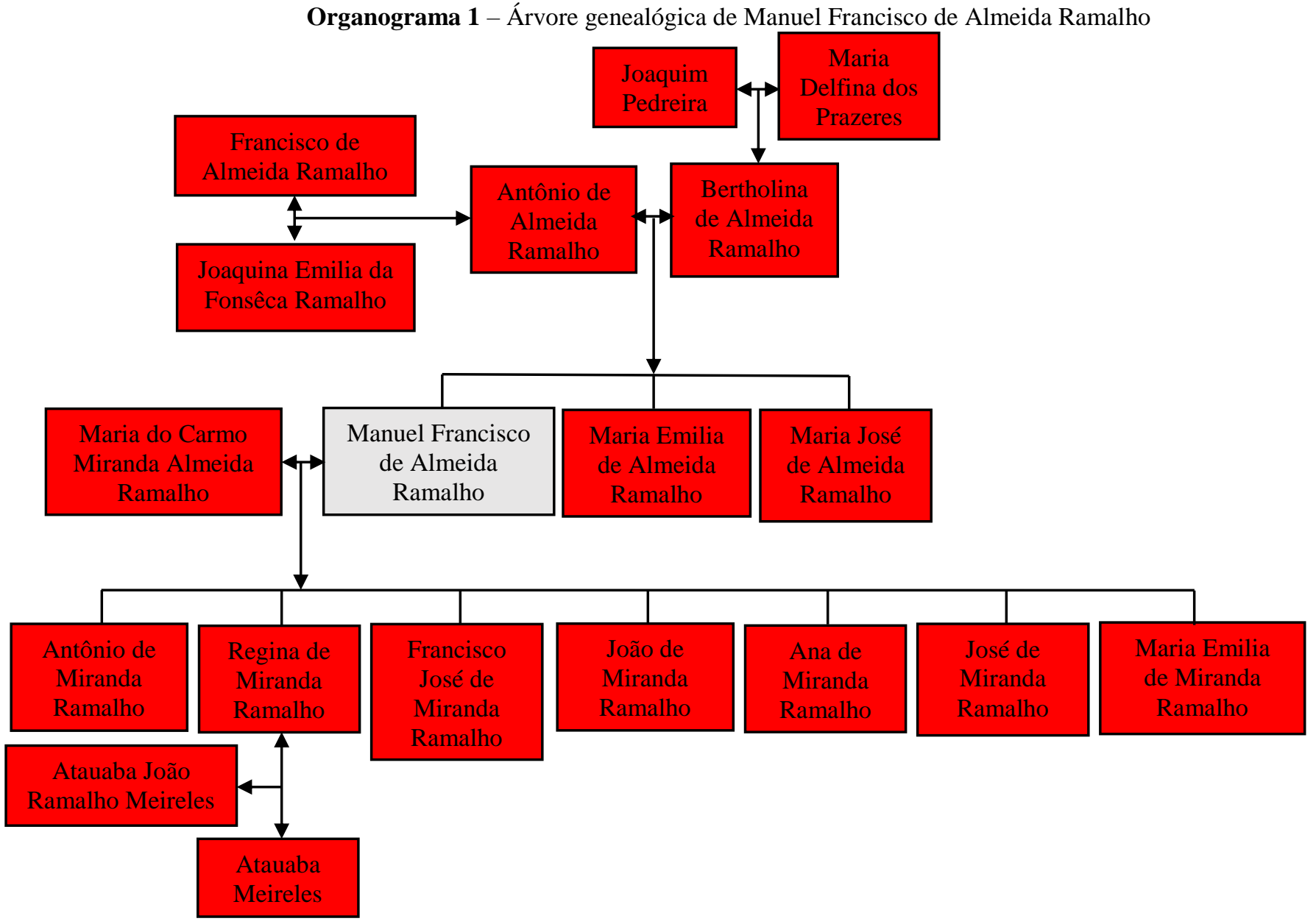

Legenda:

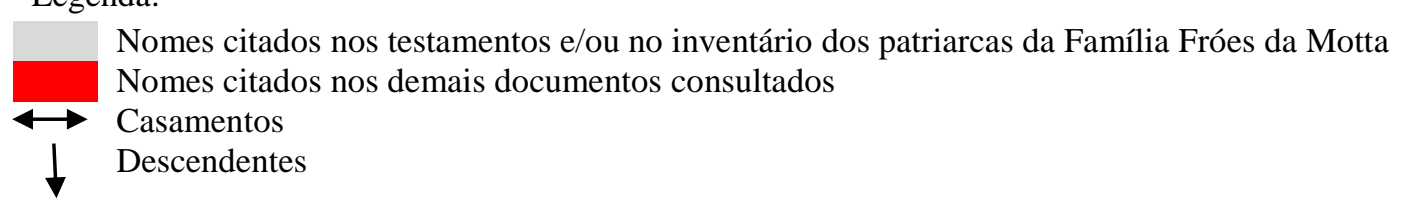

Fonte: Elaborado pela pesquisadora

documento também se encontra armazenado no CEDOC/UEFS sob a cota: Estante 01, Caixa 26 e Documento 279. 
Além de tenente coronel, Manuel Francisco de Almeida Ramalho foi conselheiro municipal, Tabelião de Notas do Segundo Ofício e Escrivão dos Feitos Cíveis e Criminais da Comarca de Feira de Santana-BA, cargo para o qual foi nomeado pelo Intendente vencedor das eleições municipais de 1911, conforme a seguinte nota do Folha do Norte (18 nov. 1911, p. 2): "No (sic) mesma data [13 de novembro de 1911] foi nomeado | Escrivão dos Feitos Civeis e | Criminaes do termo desta ci- | dade o senhor Manuel Francisco | Almeida Ramalho". Contudo, não encontramos fontes que comprovassem o grau de escolaridade do referido tabelião.

Enquanto homem de negócios, entre 1923 e 1924, Manuel Francisco de Almeida Ramalho recebeu uma herança, enquanto inventariante e herdeiro de Sylvestre Alves Barreiros, que foi mencionada em uma ação executiva ${ }^{140}$, cujas partes foram o Coronel Bernardino da Silva Bahia e aquele. Segundo o processo, Manuel Francisco de Almeida Ramalho assinou uma nota promissória no valor de quarenta e um contos, cento e trinta e três mil e quinhentos réis, para a qual foi dada como garantia a herança que ainda seria recebida, apesar de ter apresentado como seu avalista Francisco Amado da Silva Bahia, que intermediou as negociações.

Contudo, pelo fato de não ter recebido o pagamento no prazo estabelecido, Bernardino da Silva Bahia alegou que o executado tinha condições de lhe pagar, pois estava sendo testamenteiro e herdeiro do referido inventariado. Assim, para garantir que receberia a quantia devida, o exequente pediu que fossem penhorados os bens do executado até que a dívida fosse paga. Entretanto, foi através de Arnold Ferreira da Silva que o processo teve um desfecho favorável para o seu sogro, Bernardino da Silva Bahia, pois o familiar deste garantira que a dívida seria paga e, diante do empenho de sua palavra, Bernardino da Silva Bahia anexou ao mesmo processo um termo de desistência da cobrança da referida dívida. Esse documento, portanto, mostra a existência de laços comerciais entre o escrivão, os políticos Bernardino da Silva Bahia e Arnold Ferreira da Silva e Francisco Amado da Silva Bahia, irmão e sócio comercial de Bernardino da Silva Bahia.

Sobre Jacintho Ferreira da Silva, há informações no inventário ${ }^{141}$ de sua esposa de que ele era irmão de Quintino Ferreira da Silva (Juiz de Direito), casado com Dona Maria Amélia Costa Ferreira da Silva, falecida em 9 de dezembro de 1906, em Salvador-BA, com quem teve

\footnotetext{
${ }^{140}$ Processo Cível também localizado no CEDOC/UEFS, sob a cota: Estante 08, Caixa 190 e Documento 3738, lavrado em Feira de Santana-BA entre 1923 e 1924, com 66 fólios e cujas partes interessadas foram Manuel Francisco de Almeida Ramalho e Bernardino da Silva Bahia.

${ }^{141}$ Documento disponível no CEDOC/UEFS, sob a cota: Estante 01, Caixa 25 e Documento 270, lavrado em Feira de Santana-BA entre 1918 e 1924, com 25 fólios e cujas partes interessadas foram Dona Maria Amelia Costa Ferreira da Silva (inventariada) e Jacintho Ferreira da Silva (inventariante).
} 
os seguintes filhos: Manoel Costa Ferreira (casado), Eulina Costa Ferreira (maior e solteira), Carmem Costa Ferreira Teixeira (casada com o Engenheiro João de Oliveira Teixeira), Noemia da Costa Ferreira (maior e solteira) e Osvaldo Costa Ferreira (maior e solteiro).

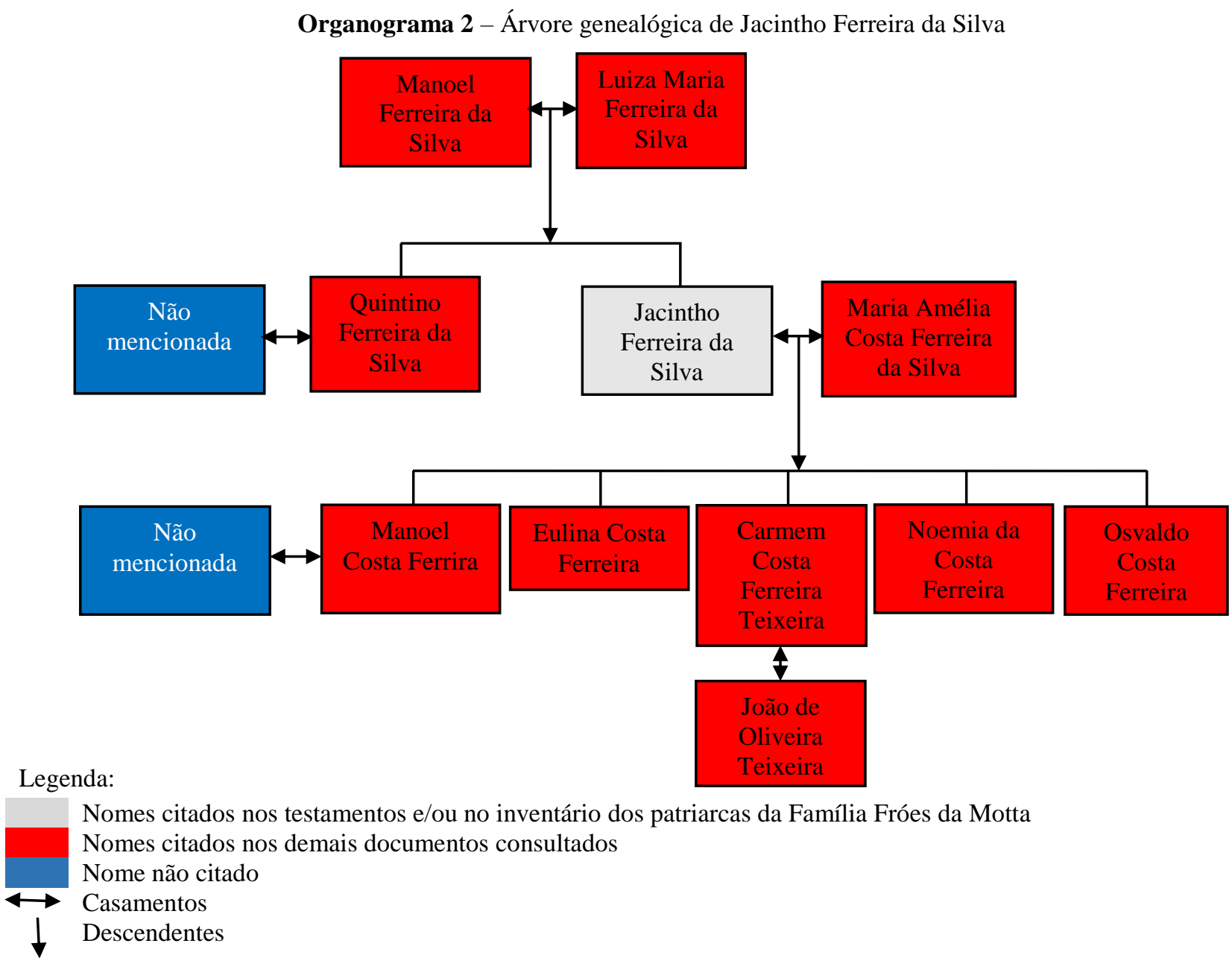

Fonte: Elaborado pela pesquisadora

No mesmo inventário consta a informação de que Jacintho Ferreira da Silva era Bacharel em Ciências Jurídicas e Sociais, informação ratificada na Lista geral dos Bachareis e Doutores que têm obtido o respectivo graú na Faculdade de Direito do Recife desde sua fundação em Olinda, no anno de 1828, até o anno de 1831 (1931), na qual existe a menção de que Jacintho Ferreira da Silva se formou no Curso de Ciências Jurídicas e Sociais pela Faculdade de Direito de Recife e, depois de formado, atuou como Juiz de Direito da Comarca de Feira de Santana-BA.

Sobre a sua vida de estudante, encontramos no Arquivo da Faculdade de Direito de Recife informações de que Jacintho Ferreira da Silva nasceu em 16 de agosto de 1856, era filho de Manoel Ferreira da Silva e Luiza Maria Ferreira da Silva, recebeu o grau de bacharel 
em 12 de novembro de 1880 e foi "aprovado plenamente" em todos os exames anuais que prestou. Depois de formado, tornou-se Juiz de Direito da cidade de Itaberaba-BA, conforme ofício, de 1 de fevereiro de 1904, escrito a próprio punho por aquele.

\begin{abstract}
Juizo de Direito da Comarca de Itaberaba, $\mid$ em $1^{\circ}$ de Fevereiro de 1904. Illustrissimo Senhor Coronel Intendente do Municipio da Fei- | ra de Sant'Anna. | É com a mais alta satisfação que vos communi- $\mid$ co o recebimento do vosso delicado officio de $2 \mid$ de Janeiro ultimo em que vos dignastes commu- $\mid$ nicar-me que em sessão solemne do Conselho | municipal, realisada no dia anterior, prestas- $\mid$ tes juramento e tomastes posse do cargo de Inten- $\mid$ dente desse municipio da Feira de Sant'Anna, | para o qual fostes muito merecidamente eleito nos $\mid$ comicios de 8 de Novembro proximo findo. | Idolatrando minha terra natal, por cujos pro- | gresso e desenvolvimento procurarei fazer quan- | to me permittam as forças, me é agradavel, | vos confesso, ver a frente dos seos destinos mu- | nicipaes os vossos talentos e a vossa auctoridade, | muito justamente apreciada. | Assim confiante, aguardo o praser de ver a | minha terra natal marchar para um fucturo | brilhante, digno della e honroso para vós. | Acceitai-a renovação e as homenagens da mais | elevada estima e o mais serio apreço que vos de- | dico. | Jacintho Ferreira da Silva | Juiz de Direito de Itaberaba (DOCUMENTO AVULSO - LIVRO DE REGISTROS..., 1904).
\end{abstract}

Nesse ofício é possível identificar um Jacintho Ferreira da Silva que amava a sua terra natal, Feira de Santana-BA, e que, ao desejar uma boa administração ao novo Intendente, mantinha os laços políticos e comerciais bem firmes, já que naquele mesmo período ele era locatário de casas que serviam como espaços escolares, alugados à Intendência Municipal. Anos mais tarde, Jacintho Ferreira da Silva se tornou Juiz de Direito de Feira de Santana-BA, onde foi político, comerciante, dono de um sobrado, na Rua Senhor dos Passos, que era a sua residência, filantropo e participante dos eventos sociais da cidade. Sobre a sua aparência, Boaventura (2006, p. 92, grifo do autor) o descreveu como um Juiz de longa data da Comarca de Feira de Santana-BA, "[...] gordo, cheio de afidalgadas banhas forenses, tal e qual amarelecido volume anusto das Institutas em que estudou. [...]".

Sobre José Maria Neves ${ }^{142}$, o inventário de Maria Amélia Costa Ferreira da Silva ${ }^{143}$ declara que ele foi formado em Engenharia e Ciências Jurídicas e Sociais, informação ratificada nos documentos do arquivo da Faculdade de Direito da Bahia, nos quais consta o informe de que ele se formou Bacharel em Ciências Jurídicas e Sociais, em 1905, e no Folha do Norte (10 mar. 1917, p. 1, grifo nosso) ao confirmar a sua chegada à Feira de Santana:

${ }^{142}$ Em 2 de outubro de 1928 foi informado, em uma petição, pelo advogado Agnello Ribeiro de Macêdo, representante legal de João Constantino Faskomy e sua esposa, que o advogado José Maria Neves havia falecido e por isso aquele assumia a representação legal do casal.

${ }^{143}$ Nesse inventário, lavrado entre 1906 e 1924 e cujo inventariante fora Jacintho Ferreira da Silva, o próprio advogado do inventariante e também Tabelião de Notas José Maria Neves se autodeclara formado em Engenharia e Ciências Jurídicas e Sociais, informação reconhecida e autenticada no próprio Cartório em que exercia tais funções. Esse documento se encontra no acervo do CEDOC/UEFS sob a cota: Estante 1, Caixa 25 e Documento 270. 
Doutor José Maria Neves | Temos a satisfação de apre | sentar á sociedade feirense, re | commendando o ao seu justo | acolhimento e ao seu merecido | apreço, o senhor doutor José Maria | Neves, illustre engenheiro e | advogado, que vem trabalhar | nesta cidade. Sua senhoria aqui chegou, | com a sua excellentissima família, no | regular de terça-feira ultima, e | está residindo á rua Senhor $\mid$ dos Passos n. 7. | Causidico intelligente e pre- $\mid$ parado e engenheiro de com- $\mid$ provados meritos, o doutor Neves | exerce com brilhantissimo essas | duas nobilissimas profissões, | sendo, além disso, dedicado | servidor da imprensa. | Apresentamos os nossos cum- | primentos e votos de felicidade | ao senhor doutor José Maria Neves, | certos de que os seus reaes me- | recimentos serão, entre nós, de- | vidamente apreciados.

Além de engenheiro e advogado, a notícia também nos informa que naquele ano José Maria Neves tinha residência na Rua Senhor dos Passos, uma das ruas mais movimentadas da cidade, e que já possuía família, cujos nomes dos membros não apareceram nos materiais que consultamos.

Sobre João Carneiro Vital, constam informações de que ele foi Tabelião de Notas da Comarca de Feira de Santana-BA, redator do Jornal feirense Folha do Norte, vice-presidente da Sociedade Filarmônica Victória, em 1923, e secretário interino do Conselho Municipal durante a licença de 30 dias do secretário titular, conforme ofício da Intendência Municipal, de 10 de junho de 1902: “João Carneiro Vital exerceu o cargo de Secretário interino do Conselho Municipal quando o Secretário Titular, Coronel Tito Ruy Bacellar, esteve de licença por 30 dias por "motivo de moléstia"'.

Mais tarde, em 13 de novembro de 1911, João Carneiro Vital foi nomeado, pela Intendência Municipal, Oficial do registro das hipotecas e já naquele período possuía as patentes de capitão, registrada nos ofícios da Intendência Municipal, e a de major, mencionada nas notas e reportagens do Folha do Norte, nas quais foram parabenizados, por exemplo, três filhos de João Carneiro Vital, a saber: “[...] Luis Welf Ferreira Vital, estudioso acadêmico de medicina, filho do senhor major João Carneiro Vital, honrado notario publico [...] Regina Vital, estudiosa normalista, prendada filha do senhor João Carneiro Vital [...] Fabiola Vital, prendada filha de João Carneiro Vital" (FOLHA DO NORTE, 14 jul. 1923, p. 2).

Ainda sobre João Carneiro Vital, o memorialista Eurico Alves Boaventura (2006, p. 92) o descreveu como um homem "[...] correto, sorrindo com inteligência [...]" e que, entre o cartório em que ele trabalhava e a Coletoria Federal, chefiada pelo Major Leoncio Evangelista dos Santos, sempre havia a reunião de um seleto grupo formado pelo Doutor Macário Gomes 
de Cerqueira $^{144}$, João Carneiro Vital, Jacintho Ferreira da Silva e Gonçalo Alves Boaventura ${ }^{145}$, que se encontravam para conversar durante a "[...] sesta dos que moravam nas imediações da Praça João Pedreira [...]” (BOAVENTURA, 2006, p. 92).

Sobre Agnello Ribeiro de Macêdo, no arquivo da Faculdade de Direito de Recife consta a sua pasta estudantil, na qual há a informação de que ele recebeu o título de Bacharel em Economia e prática forense e em Direito e Processo, em 30 de novembro de 1891, na Faculdade de Direito de Recife, conforme fac-símile do registro da sua carta de bacharel, que nos foi concedido, assim como os dos demais escreventes que estudaram na mesma instituição, pelo arquivo.

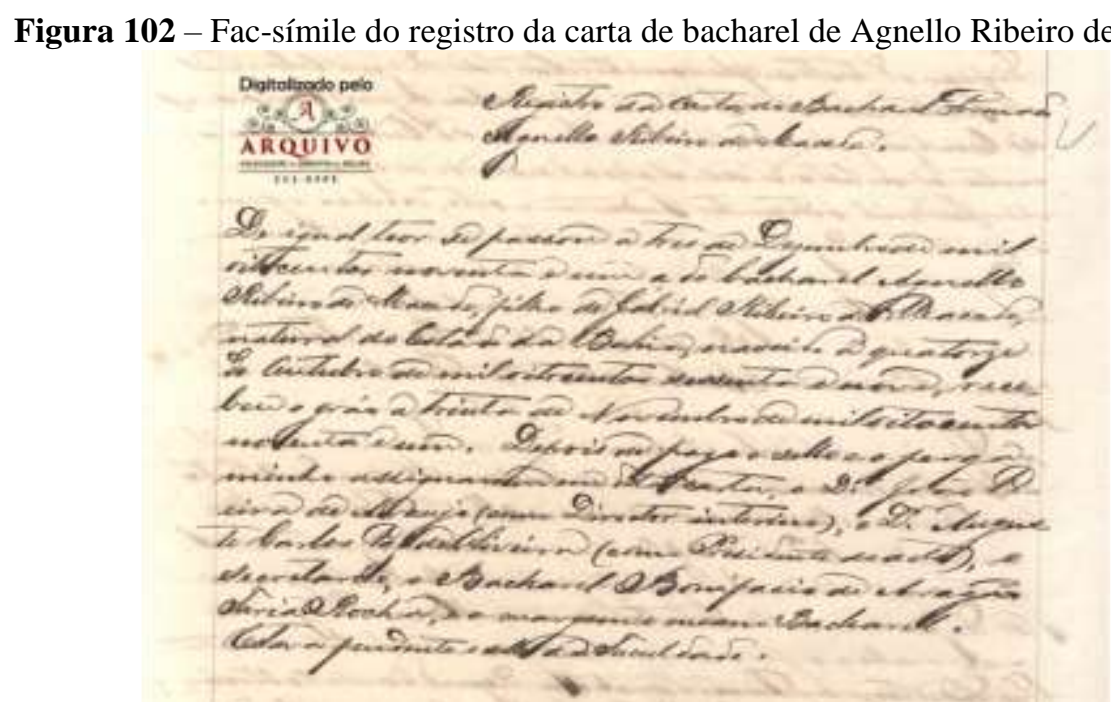

Fonte: Arquivo da Faculdade de Direito de Recife-PE

Desta carta, extraem-se informações de que Agnello Ribeiro de Macêdo era filho de Gabriel Ribeiro de Macedo, natural da Bahia e nascido em 14 de outubro de 1869. Enquanto estudante, os seus exames, realizados em 12 de novembro de 1888, 18 de novembro de 1889, 3 de dezembro de 1890 e 15 de setembro de 1891, revelam que ele era um bom aluno, já que fora aprovado com o conceito "simplesmente approvado". No seu último exame, realizado em 26 de novembro de 1891, ele recebeu, contudo, os conceitos "approvado plenamente em Economia e prática forense" e "approvado simplesmente em Direito e Processo", o que indica o seu provável empenho no curso.

\footnotetext{
144 Importante fazendeiro, casado com Dona Almerinda Pamponet de Macêdo, com quem teve os filhos Antero Pamponet de Macêdo e Lauro Soares de Macêdo, nomes noticiados no periódico Folha do Norte, nos primeiros meses de 1923.

145 Como pontuado na segunda seção desta tese, Gonçalo Alves Boaventura era comerciante de couro, proprietário de terras e Conselheiro Municipal de Feira de Santana (1924-1926), além de pai do memorialista e Bacharel em Ciências Jurídicas, em 1933, pela Faculdade de Direito da Bahia, Eurico Alves Boaventura.
} 
Depois de formado, Agnello Ribeiro de Macêdo trabalhou como advogado e, em seguida, como Juiz de Direito em Cuiabá, época em que já havia constituído família, conforme notícia veiculada no Folha do Norte (19 jan. 1913, p. 1), acerca da sua visita à Feira de Santana-BA.

[...] Como dissemos, chegou a $\mid$ esta cidade em a tarde do dia $\mid 10$ do corrente acompanhado | de sua excellentissima senhora e filhos o | nosso particular amigo digno | filho desta terra doutor Agnello | de Macedo. Sua excellencia que a 7 | annos se achava ausente fa- $\mid$ zendo parte da magistratura $\mid$ do Estado de Mato Grosso, e | ultimamente como juiz de di- $\mid$ reito da comarca da capital, | Cuyabá, está em goso de um $\mid$ anno de licença, devendo de- $\mid$ morar se pouco tempo entre $\mid$ nós, no seio de sua excellentissima fami- | lia e amigos. | excellencia está residindo em a | casa n. 12 a Praça João Pe- | dreira e tem sido muito visi- | tado por amigos e afeiçoados e | sua digna esposa por muitas $\mid$ familias que lhe tem prasentei- | ramente levado os cumprimen- | tos de boas vindas. | Renovamos ao senhor doutor Agnel- | lo as nossas mais amistosas | saudações.

Depois que regressou definitivamente para Feira de Santana-BA, Agnello Ribeiro de Macêdo continuou exercendo os ofícios de advogado, atuando em vários processos jurídicos, dentre os quais no inventário de Agostinho Fróes da Motta, sobre o qual vários desdobramentos se tornaram públicos. Naquele período, o referido advogado começou a escrever uma série de artigos, que começaria com a reportagem intitulada Justiça esfarrapada, dentro da qual foi inserida pelos redatores do Folha do Norte uma carta, escrita por Agnello Ribeiro de Macêdo, em 2 de maio de 1922, esclarecendo os deveres dos funcionários da Justiça.

Justiça es- | farrapada | o dr. Agnello Ma- | cedo vai escapel- | lar as miserias do | nosso "forum" | O provecto advogado e il- | lustre juiz de direito em disponibilidade dr. Agnello Ribei | ro de Macedo inicia hoje, nes- | ta "Folha", a serie brilhantis- | sima de artigos com que vai | demonstrar á saciedade (sic) "o | que foi e o que é a justiça na | Feira". | Da orientação dessa cam- | panha saneadora, de incalcu | lavel effeito moral na alma de | um povo que se não deve a- | bastardar pela indifferença | com que assiste | á trapaça, bar- | ganha, ou feira de ciganos em | que se lhe retalham os direi- | tos mais sagrados, da orienta- | ção dessa campanha saneado- | ra, que tem, decidida e inteira, | a solidariedade da "Folha do | Norte", diz a carta que passa- | mos a estampar: | "Snr. Redactor da 'Folha do | Norte', Affectuosas sauda- | ções. - Tendo lido, na edição | de sabbado ultimo, desse vos- | so conceituado hebdomada- | rio, a noticia que destes so- $\mid$ bre o incidente ocorrido na | occasião em que se proces- | sava, no Paço Municipal e | sala das audiencias do juizo | de direito desta comarca, uma | justificação, por testemunhas, | requerida pelo snr. eng. Al- | berto de Almeida Motta, ani- | nhou-se em mim o desejo de | prestar aos meus conterraneos $\mid$ menos cultos, um serviço, que | penso ser de utilidade, expli- | cando-lhes alguns pontos ou | principios de direito para que | com estes se familiarizem e | assim mais se não deixem | dominar pelo mêdo que ma- | nifestam ter das entidades - | juiz, advogado e escrivão, e $\mid$ melhor saibam defender os $\mid$ seus legitimos interesses, mui- $\mid$ tas vezes explorados por mo- | tivo da ignorancia desses mes- | mos principios. | Conversei comvosco sobre $\mid$ o assumpto e experimentei a | 
grande satisfação de me te- | rem sido franqueadas, imme- | diatamente, com o vosso fran- | co acolhimento, as columnas | desse vosso conceituado he- | bdomadario. | Devo, porem, antes de co- | meçar a dar publicidade aos $\mid$ meus artigos, declarar, com | precisão, que não tenho a | vaidade de suppôr que, com | elles, irei dar liçoes de direito, | escrever monographias juridi- | cas ou, mesmo, divulgar prin- | cipios ou desenvolver theses $\mid$ das quaes possam tirar qual- | quer proveito os meus con- | terraneos em geral. | Não; eu só penso em escre- | ver para os menos cultos, para | os pouco lettrados, para os $\mid$ rusticos, que suppõem errada- $\mid$ mente, que - o juiz é um Pa- | chá, é um Tzar, um Sultão, um | rei, despota ou dictador ab- | soluto; que o advogado é uma | auctoridade - a quem devem | obediencia incondicional - só | porque se encarrega de de- | fender-lhes seus interesses; que | o escrivão - porque lhes guar- $\mid$ da os seus papeis escripturas | e documentos - tem vontade | livre para lhes impor tudo | que quizer, levando-os, mui- | tas vezes, até ao sacrificio. | É esse o serviço que a es- | ses meus conterraneos viso | prestar. | As theses que procurarei | desenvolver serão as seguin- | tes: - O juiz quando é, pro- | priamente, juiz: seus direitos e | deveres. - O juiz quando se | torna réu: seus crimes, seus | vicios e penas a que fica su- $\mid$ jeito. - O advogado, "braço da $\mid$ magistratura”, seus direitos e $\mid$ seus deveres. - O escrivão, ser- | ventuario sublaterno, seus di- | reitos e seus deveres. - A justi- | ça na Feira, o que foi e o que é. | Antes de concluir esta, pa- | rece-me de inteira opportuni- $\mid$ dade divulgar o que disse o $\mid$ exmo. snr. dez. presidente do | egregio Tribunal Superior de | Justiça deste Estado, no dis- | curso que pronunciou na ses- | são inaugural dos trabalhos | do dito Tribunal, em 14 de | Fevereiro deste anno, a res- | peito do mêdo que os jurisdi- | cionados teem dos seus juizes. | Disse elle: "Tem sido uma | de minhas preoccupações, de- | pois que fui investido neste | cargo, fazer desapparecer da $\mid$ parte dos jurisdicionados para $\mid$ com os seus juizes este temor | que os faz muitas vezes aban- | donarem os seus direitos | quando vislumbram da parte | delles qualquer manifestação | em contrario. Tenho animado | as reclamações, que me são di- | rigidas, e, no uso de minhas | attribuições administrativas | vou providenciando para tor- | nar sempre latente a acção | fiscalisadora do Tribunal." | Se, pois, os nosso conterra- | neos tirarem qualquer provei- | to deste meu serviço, que, por | espontaneidade, lhes quero | prestar eu me darei por ple- $\mid$ namente, satisfeito. Junto re- $\mid$ meto-vos o meu primeiro ar- $\mid$ tigo. $\mid$ Do vosso att ${ }^{\circ} . \mathrm{am}^{\mathrm{o}}$. obrm ${ }^{\circ}$ | AGNELLO R. DE MACEDO | Feira, 2 de Maio de 1922 (JUSTIÇA..., FOLHA DO NORTE, 10 jun. 1922, p. 1-2).

Como se pode notar, a carta inserida na referida reportagem nos deixa claro que a intenção do seu escritor, Agnello Ribeiro de Macêdo, não era a de dar lições de Direito aos leitores do periódico, mas a de prestar um serviço de esclarecimento ao público menos letrado sobre as funções inerentes aos cargos de Juiz de Direito, advogado e escrivão. Logo, os artigos que se seguiriam àquele seriam escritos com o intuito de oportunizar aos leitores, em uma linguagem acessível, o conhecimento das doutrinas jurídicas.

No âmbito familiar, Agnello Ribeiro de Macêdo foi membro de uma influente família e se casou com Esther de Freitas Borja (filha de um coronel bastante rico e influente), com quem teve vários filhos, dentre os quais identificamos Eldira de Borja Macêdo, chamada pelo Folha do Norte de "dilecta filha", Anna Benedicta Borja Macêdo, Elmina de Borja Macêdo, Elzira de Borja Macêdo e Elvira de Borja Macêdo, com as quais residiu em uma vistosa chácara denominada "Vallado", localizada em Feira de Santana-BA, a qual estava, segundo Boaventura (2006), à altura da sua posição social. 


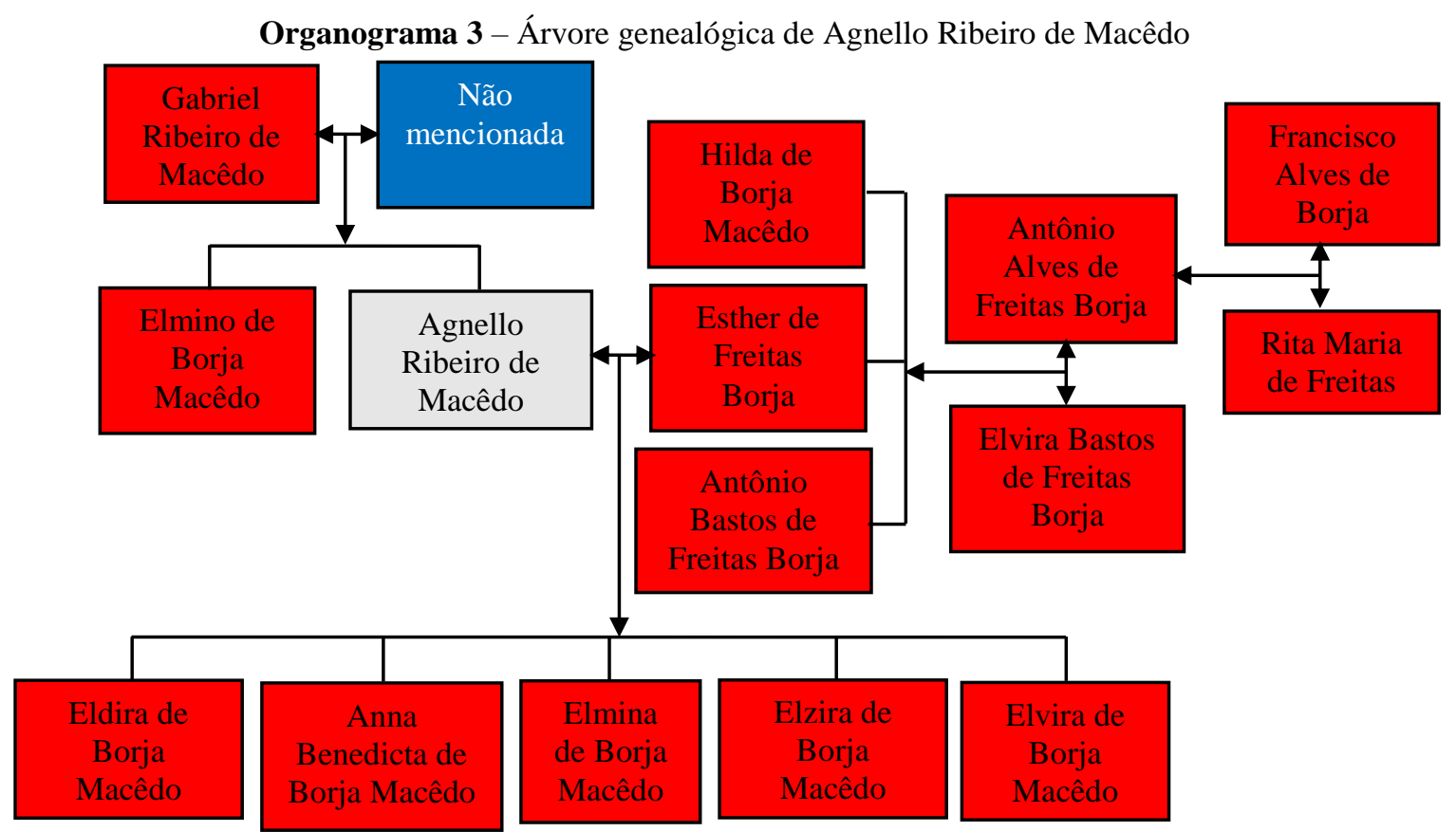

Legenda:

Nomes citados nos testamentos e/ou no inventário dos patriarcas da Família Fróes da Motta

Nome citado nos demais documentos consultados

Nome não citado

$\longmapsto$ Casamentos

$\downarrow$ Descendentes

Fonte: Elaborado pela pesquisadora

Enquanto comerciante, Agnello Ribeiro de Macêdo possuía animais empregados no serviço de vendagem de água, em 1917-1918, e imóveis como, por exemplo, duas casas na Rua Almirante Barroso e uma na Rua do Cruzeiro, ambas localizações valorizadas pelas residências à sua volta.

Sobre o último escrevente Altino Teixeira, este também se formou Bacharel em Ciências Jurídicas, em 1919, pela Faculdade Livre de Direito da Bahia. Depois de formado, atuou como advogado em vários processos cíveis da Comarca de Feira de Santana-BA e, sobre a sua vida particular, nos documentos consultados, não há menção sobre os seus familiares.

A partir desses dados, que ainda nos parecem incompletos devido à falta ou ao desconhecimento de outros documentos que, provavelmente, preencheriam as lacunas existentes, apresentamos, a seguir, o perfil socioeducacional, ainda considerado incompleto, dos escreventes do corpus. 
Tabela 2 - Perfil socioeducacional dos escreventes do corpus

ESCREVENTE PATENTE OCUPAÇÃO GRAU DE

\begin{tabular}{|c|c|c|c|}
\hline & & & ESCOLARIDADE \\
\hline $\begin{array}{l}\text { Affonso Pedreira } \\
\text { de Cerqueira }\end{array}$ & $\begin{array}{l}\text { Não possuía ou } \\
\text { não foi } \\
\text { mencionada }\end{array}$ & $\begin{array}{c}\text { - Tabelião de } \\
\text { Notas da Comarca } \\
\text { de Ilhéus. }\end{array}$ & Não mencionado \\
\hline $\begin{array}{l}\text { Agerico Moreira } \\
\text { de Almeida }\end{array}$ & $\begin{array}{l}\text { Não possuía ou } \\
\text { não foi } \\
\text { mencionada }\end{array}$ & $\begin{array}{l}\text { - Escrivão da } \\
\text { Comarca de Feira } \\
\text { de Santana; } \\
\text { - Provedor da } \\
\text { Santa Casa de } \\
\text { Misericórdia; } \\
\text { - Comerciante. }\end{array}$ & Não mencionado \\
\hline $\begin{array}{l}\text { Agnello Ribeiro } \\
\text { de Macêdo }\end{array}$ & Não possuía & $\begin{array}{l}\text { - Advogado em } \\
\text { Cuiabá e em Feira } \\
\text { de Santana; } \\
\text { - Juiz de Direito } \\
\text { em Cuiabá; } \\
\text { - Articulista do } \\
\text { Folha do Norte; } \\
\text { - Comerciante; } \\
\text { - Proprietário de } \\
\text { imóveis em Feira } \\
\text { de Santana. }\end{array}$ & $\begin{array}{c}\text { Bacharel em } \\
\text { Economia e prática } \\
\text { forense e em Direito } \\
\text { e Processo pela } \\
\text { Faculdade de } \\
\text { Direito de Recife }\end{array}$ \\
\hline Albertino Dantas & $\begin{array}{l}\text { Não possuía ou } \\
\text { não foi } \\
\text { mencionada }\end{array}$ & $\begin{array}{l}\text { - Lançador de } \\
\text { impostos da } \\
\text { Comarca de Feira } \\
\text { de Santana; } \\
\text { - Dono de animais } \\
\text { empregados na } \\
\text { vendagem de } \\
\text { água, em } 1917 .\end{array}$ & Não mencionado \\
\hline Altino Teixeira & Não possuía & - Advogado & $\begin{array}{c}\text { Bacharel em } \\
\text { Ciências Jurídicas } \\
\text { pela Faculdade } \\
\text { Livre de Direito da } \\
\text { Bahia. }\end{array}$ \\
\hline $\begin{array}{c}\text { Aurelio } \\
\text { Vasconcelos }\end{array}$ & $\begin{array}{l}\text { Não possuía ou } \\
\text { não foi } \\
\text { mencionada }\end{array}$ & $\begin{array}{l}\text { - Escrivão; } \\
\text { - Negociante. }\end{array}$ & Não mencionado \\
\hline $\begin{array}{c}\text { Bernardino } \\
\text { Senna Santos }\end{array}$ & $\begin{array}{l}\text { Não possuía ou } \\
\text { não foi } \\
\text { mencionada }\end{array}$ & $\begin{array}{l}\text { - Escrivão Cível } \\
\text { da Comarca de } \\
\text { Ilhéus. }\end{array}$ & Não mencionado \\
\hline $\begin{array}{l}\text { Cesar Ribeiro de } \\
\text { Cerqueira }\end{array}$ & $\begin{array}{l}\text { Não possuía ou } \\
\text { não foi } \\
\text { mencionada }\end{array}$ & $\begin{array}{l}\text { - Oficial de Justiça } \\
\text { da Comarca de } \\
\text { Feira de Santana }\end{array}$ & Não mencionado \\
\hline $\begin{array}{l}\text { Diogenes de } \\
\text { Sousa Lima }\end{array}$ & $\begin{array}{l}\text { Não possuía ou } \\
\text { não foi } \\
\text { mencionada }\end{array}$ & $\begin{array}{l}\text { - Contador da } \\
\text { Comarca de } \\
\text { Ilhéus-BA. }\end{array}$ & Não mencionado \\
\hline $\begin{array}{c}\text { Elpidio } \\
\text { Raymundo da } \\
\text { Nova }\end{array}$ & $\begin{array}{l}\text { Não possuía ou } \\
\text { não foi } \\
\text { mencionada }\end{array}$ & $\begin{array}{l}\text { - Advogado; } \\
\text { - Promotor } \\
\text { Público; } \\
\text { - Provedor da } \\
\text { Santa Casa de } \\
\text { Misericórdia; } \\
\text { - Intendente e } \\
\text { Prefeito de Feira } \\
\text { de Santana. }\end{array}$ & $\begin{array}{c}\text { Bacharel em } \\
\text { Ciências Jurídicas } \\
\text { pela Faculdade } \\
\text { Livre de Direito da } \\
\text { Bahia. }\end{array}$ \\
\hline $\begin{array}{c}\text { Jacintho Ferreira } \\
\text { da Silva }\end{array}$ & Não possuía & $\begin{array}{l}\text { - Juiz de Direito } \\
\text { de Itaberaba; }\end{array}$ & $\begin{array}{c}\text { - Bacharel em } \\
\text { Ciências Jurídicas e }\end{array}$ \\
\hline
\end{tabular}




\begin{tabular}{|c|c|c|c|}
\hline & & $\begin{array}{l}\text { - Juiz de Direito } \\
\text { da Comarca de } \\
\text { Feira de Santana; } \\
\text { - Político; } \\
\text { - Comerciante; } \\
\text { - Filantropo. }\end{array}$ & $\begin{array}{c}\text { Sociais pela } \\
\text { Faculdade de } \\
\text { Direito de Recife. }\end{array}$ \\
\hline $\begin{array}{c}\text { João Carneiro } \\
\text { Vital }\end{array}$ & Capitão e major & $\begin{array}{c}\text { - Tabelião de } \\
\text { Notas da Comarca } \\
\text { de Feira de } \\
\text { Santana; } \\
\text { - Redator do } \\
\text { Folha do Norte; } \\
\text { - Secretário } \\
\text { interino do } \\
\text { Conselho } \\
\text { Municipal; } \\
\text { - Vice-presidente } \\
\text { da Sociedade } \\
\text { Filarmonica } \\
\text { Victoria; } \\
\text { - Oficial do } \\
\text { registro de } \\
\text { hipotecas. }\end{array}$ & Não mencionado \\
\hline $\begin{array}{l}\text { João Marques } \\
\text { dos Reis }\end{array}$ & Não possuía & $\begin{array}{c}\text {-Catedrático da } \\
\text { Cadeira de Direito } \\
\text { Civil; } \\
\text { - Jurista. }\end{array}$ & Não mencionado \\
\hline $\begin{array}{c}\text { Joaquim Honorio } \\
\text { d'Oliveira }\end{array}$ & $\begin{array}{l}\text { Não possuía ou } \\
\text { não foi } \\
\text { mencionada }\end{array}$ & Avaliador de bens & Não mencionado \\
\hline $\begin{array}{c}\text { Joaquim José } \\
\text { Ramos }\end{array}$ & $\begin{array}{c}\text { Não possuía ou } \\
\text { não foi } \\
\text { mencionada }\end{array}$ & $\begin{array}{c}\text { - Juiz de Direito } \\
\text { da Comarca de } \\
\text { Ilhéus-BA. }\end{array}$ & $\begin{array}{c}\text { Bacharel em } \\
\text { Ciências Jurídicas e } \\
\text { Sociais pela } \\
\text { Faculdade de } \\
\text { Direito de Recife. }\end{array}$ \\
\hline $\begin{array}{l}\text { Joaquim Pinto } \\
\text { dos Santos }\end{array}$ & $\begin{array}{c}\text { Não possuía ou } \\
\text { não foi } \\
\text { mencionada }\end{array}$ & $\begin{array}{l}\text { - Escrivão de Paz } \\
\text { e Oficial do } \\
\text { Registro Civil da } \\
\text { Comarca de Feira } \\
\text { de Santana. }\end{array}$ & Não mencionado \\
\hline José de Sá Roriz & $\begin{array}{c}\text { Não possuía ou } \\
\text { não foi } \\
\text { mencionada }\end{array}$ & $\begin{array}{l}\text { - Guarda Livros; } \\
\text { - Contador da } \\
\text { Firma comercial } \\
\text { Agostinho Fróes } \\
\text { da Motta \& Filho. }\end{array}$ & Não mencionado \\
\hline José Maria Neves & Não possuía & $\begin{array}{l}\text { - Engenheiro } \\
\text { - Advogado } \\
\text { - Tabelião de } \\
\text { Notas. }\end{array}$ & $\begin{array}{c}\text { Bacharel em } \\
\text { Engenharia e } \\
\text { Ciências Jurídicas e } \\
\text { Sociais pela } \\
\text { Faculdade Livre de } \\
\text { Direito da Bahia. }\end{array}$ \\
\hline $\begin{array}{c}\text { José Telles } \\
\text { Barreto }\end{array}$ & $\begin{array}{l}\text { Não possuía ou } \\
\text { não foi } \\
\text { mencionada }\end{array}$ & $\begin{array}{l}\text { - Secretário da } \\
\text { Intendência } \\
\text { Municipal; } \\
\text { - Escrivão da } \\
\text { Comarca de Feira } \\
\text { de Santana. }\end{array}$ & Não mencionado \\
\hline $\begin{array}{l}\text { Lyderico dos } \\
\text { Santos Cruz }\end{array}$ & Não possuía & $\begin{array}{l}\text { - Juiz de Direito; } \\
\text { - Desembargador } \\
\text { do Superior }\end{array}$ & $\begin{array}{c}\text { Bacharel em } \\
\text { Ciências Jurídicas } \\
\text { pela Faculdade }\end{array}$ \\
\hline
\end{tabular}




\begin{tabular}{|c|c|c|c|}
\hline & & $\begin{array}{c}\text { Tribunal de } \\
\text { Justiça. }\end{array}$ & $\begin{array}{c}\text { Livre de Direito da } \\
\text { Bahia. }\end{array}$ \\
\hline Manoel Araujo & Capitão & $\begin{array}{c}\text { - Contador, } \\
\text { Partidor e } \\
\text { Distribuidor do } \\
\text { Juízo da Comarca } \\
\text { de Feira de } \\
\text { Santana. }\end{array}$ & Não mencionado \\
\hline $\begin{array}{l}\text { Manoel Gomes } \\
\text { dos Santos }\end{array}$ & $\begin{array}{l}\text { Não possuía ou } \\
\text { não foi } \\
\text { mencionada }\end{array}$ & $\begin{array}{l}\text { - Oficial de } \\
\text { Justiça; } \\
\text { - Membro do } \\
\text { Conselho } \\
\text { Municipal. }\end{array}$ & Não mencionado \\
\hline Manoel Pimentel & Não possuía & $\begin{array}{l}\text { - Advogado; } \\
\text { - Comerciante. }\end{array}$ & $\begin{array}{c}\text { Bacharel em } \\
\text { Ciências Jurídicas } \\
\text { pela Faculdade } \\
\text { Livre de Direito da } \\
\text { Bahia. }\end{array}$ \\
\hline $\begin{array}{c}\text { Manuel } \\
\text { Francisco de } \\
\text { Almeida } \\
\text { Ramalho }\end{array}$ & Tenente coronel & $\begin{array}{l}\text { - Tabelião de } \\
\text { Notas do Segundo } \\
\text { Ofício e Escrivão } \\
\text { dos Feitos Cíveis } \\
\text { e Crimes da } \\
\text { Comarca de Feira } \\
\text { de Santana; } \\
\text { - Conselheiro } \\
\text { Municipal. }\end{array}$ & Não mencionado \\
\hline $\begin{array}{c}\text { Petronillo } \\
\text { Guaviro de } \\
\text { Meirelles }\end{array}$ & $\begin{array}{l}\text { Não possuía ou } \\
\text { não foi } \\
\text { mencionada }\end{array}$ & $\begin{array}{l}\text { - Tesoureiro da } \\
\text { Comarca de Feira } \\
\text { de Santana; } \\
\text { - Secretário da } \\
\text { Intendência } \\
\text { Municipal; } \\
\text { - Contador } \\
\text { Municipal. }\end{array}$ & Não mencionado \\
\hline
\end{tabular}

Fonte: Elaborada pela pesquisadora

A partir desses dados, chegamos a algumas conclusões. Primeiro, nos casos em que os escreventes eram da Comarca de Ilhéus-BA, a escassez de informações sobre a sua formação profissional e a sua vida socioeconômica faz com que algumas lacunas sobre esses aspectos ainda se mantenham em aberto.

Segundo, nos casos em que os escreventes eram da cidade de Feira de Santana-BA, mas os seus nomes não constam nos documentos consultados - os da Intendência Municipal, os processos jurídicos do CEDOC/UEFS, os dos arquivos das Faculdades de Direito de Recife e da Bahia, os livros e dissertações sobre a atuação dos dirigentes políticos na cidade e os exemplares do Folha do Norte publicados naquele período - leva-nos a inferir que se tratavam de pessoas envolvidas exclusivamente com o seu ofício ao ponto de informações sobre a sua vida econômica, social ou pessoal não serem mencionadas em tais documentações ou que precisamos ampliar, a posteriori, a nossa pesquisa sobre esses "sujeitos", na tentativa de sanar tais lacunas. 
Terceiro, a afirmativa de que vários escreventes atuaram em vários cargos públicos na cidade de Feira de Santana-BA se torna inconteste, haja vista os múltiplos ofícios exercidos por vários daqueles que foram, em muitos casos, nomeados pelos Intendentes, mas em cujos termos de nomeação não consta o respectivo grau de escolaridade.

Quarto, nos casos dos seis escreventes que escreveram a maioria dos fólios do corpus, sobre quatro deles (Jacintho Ferreira da Silva, José Maria Neves, Agnello Ribeiro de Macêdo e Altino Teixeira) obtivemos comprovação do seu grau de escolaridade, mas sobre João Carneiro Vital e Manuel Francisco de Almeida Ramalho conseguimos coletar dados sobre a sua vida pessoal e profissional, mas sobre a sua formação escolar/acadêmica ainda não, o que pode ser explicado pelo fato de desconhecermos a existência de documentos que comprovem o grau de instrução daqueles ou porque, simplesmente, não existem.

De qualquer forma, os dados obtidos nos permitem afirmar que os escreventes do corpus foram "sujeitos" que, em sua maioria, pertenciam a famílias influentes e abastadas e à classes sociais semelhantes; que foram "sujeitos" que tinham conhecimento e aplicavam as doutrinas jurídicas; e que apresentavam aspectos similares em sua escrita, haja vista existirem particularidades paleográficas nos fólios por eles escritos, o que nos leva a afirmar que os dois, dos seis escreventes que mais escreveram o corpus e que não tiveram o seu grau de escolaridade comprovado, tinham, por ofício e/ou formação, bastante habilidade na escrita.

Sobre esse aspecto, Marquilhas (2000) defende a ideia de que só se pode falar em inabilidade do escrevente se seis características forem devidamente analisadas, a saber:

A. ausência de cursus, entendida como "[...] o desenho autónomo de cada carácter, ou mesmo de traços de cada carácter, decorrente da falta de agilidade dos músculos da mão [...]” (MARQUILHAS, 2000, p. 239);

B. uso de módulo grande: “[...] dificuldade de integrar as letras num módulo pequeno [...]” (MARQUILHAS, 2000, p. 239);

C. ausência de regramento ideal: “[...] incapacidade de respeitar um pautado mental manifesta-se sobretudo na tendência descendente do alinhamento, à medida que se aproxima a margem direita da folha [...]" (MARQUILHAS, 2000, p. 239);

D. traçado inseguro, aparência desenquadrada das letras, rigidez e falta de leveza do conjunto: "A detecção destas características é naturalmente bastante subjetiva [...]" (MARQUILHAS, 2000, p. 239);

E. irregularidade da empaginação: "falta proporção entre as margens, as quais podem nem sequer estar definidas" (MARQUILHAS, 2000, p. 240); 
F. letras monolíticas: “[...] desconhecimento da alografia combinatória dos sinais em contexto inicial, medial e final" (MARQUILHAS, 2000, p. 240).

Apesar de Marquilhas (2000) ter trabalhado e observado essas características em documentos da esfera privada do século XVII, esses critérios acabam sendo aplicáveis a quaisquer textos manuscritos sobre os quais se investigue a existência ou não de inabilidade na escrita alfabética dos escreventes. Além disso, a própria autora afirma que essas características, que podem aparecer de forma cumulativa e equilibrada ou não, caracterizam a inabilidade na escrita alfabética.

Sobre esse aspecto, casos interessantes aparecem na scripta de dois escreventes que muito pouco escreveram o corpus e, devido a isso, não temos dados que componha uma amostragem, que nos permita afirmar a existência de inabilidade desses redatores. Entretanto, entendemos que se tratam de exemplos, que podem nos direcionar à constatação do nível de escolaridade (ou da sua falta) ou do uso da escrita devido às atividades laborais exercidas pelos dois Oficiais de Justiça que redigiram, ao todo, apenas três fólios do primeiro volume do inventário de Agostinho Fróes da Motta: Cesar Ribeiro de Cerqueira e Manoel Gomes dos Santos, que apresentaram em comum ausência de cursus e presença de letras monolíticas, uso de módulo pequeno (no caso da scripta de Cesar Ribeiro de Cerqueira), regularidade de empaginação na caixa de escrita e regramento ideal na linha de escrita, bem como uso de pontuação e de escrita fonética, traçado grosso e inseguro; e de abreviatura apenas na scripta de Manoel Gomes dos Santos, conforme material amostrado a seguir. 
Figura 103 - Exemplos de aspectos paleográficos na scripta de Cesar Ribeiro de Cerqueira ${ }^{146}$

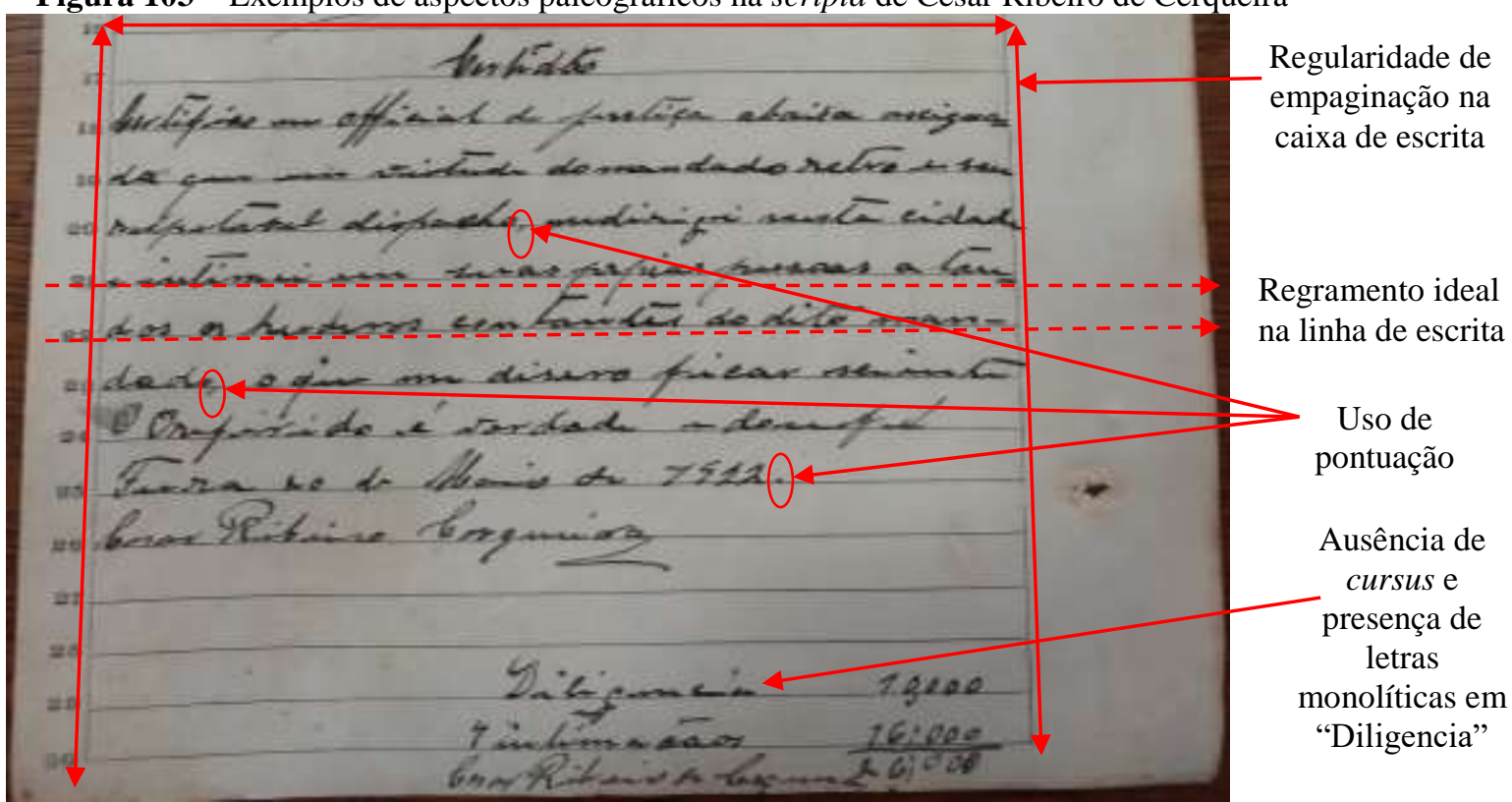

Fonte: Acervo do CEDOC/UEFS

Quanto à escrita fonética, esse fólio e o 34r do IAFM apresentam diversas ocorrências, apresentadas a seguir.

Quadro 49 - Aspectos da escrita fonética de Cesar Ribeiro de Cerqueira

\begin{tabular}{|c|c|c|}
\hline FENÔMENOS FONÉTICOS & PALAVRAS & LOCALIZAÇÃO \\
\hline Síncope & $\begin{array}{l}\text { respetavel (respeitável), } \\
\text { contantes (constantes), prpias } \\
\text { (próprias), Flres (Fróes) }\end{array}$ & $\begin{array}{l}\text { IAFM, f. } 32 \mathrm{v} \quad \mathrm{e} \\
34 \mathrm{r}\end{array}$ \\
\hline $\begin{array}{l}\text { Ditongação com a inserção da } \\
\text { semivogal [w] }\end{array}$ & toudos (todos) & IAFM, f. 32v \\
\hline $\begin{array}{l}\text { Ditongação com a inserção da } \\
\text { semivogal [y] }\end{array}$ & Maciedo (Macedo) & IAFM, f. 34r \\
\hline $\begin{array}{l}\text { Monotongação com supressão } \\
\text { da semivogal [y] }\end{array}$ & $\begin{array}{l}\text { herderos (herdeiros), } \\
\text { distitusão (destituição) }\end{array}$ & $\begin{array}{l}\text { IAFM, f. } 32 \mathrm{v} \text { e } \mathrm{f} . \\
34 \mathrm{r}\end{array}$ \\
\hline Paragoge & fel (fé), onzes (onze) & $\begin{array}{l}\text { IAFM, f. } 32 \mathrm{v} e \\
34 \mathrm{r}\end{array}$ \\
\hline Apócope & bachare (bacharel) & IAFM, f. 34r \\
\hline Nasalização & Justiçã (Justiçam) & IAFM, f. 34r \\
\hline Desnasalização & disero (disseram) & IAFM, f. 32v \\
\hline $\begin{array}{l}\text { Elevação da vogal média [o] } \\
{[\mathrm{u}] \text { em posição pretônica }}\end{array}$ & Agustinho (Agostinho) & IAFM, f. 34r \\
\hline $\begin{array}{l}\text { Elevação da vogal média }[\mathrm{e}] \sim \\
\text { [i] em posição pretônica }\end{array}$ & $\begin{array}{l}\text { dispacho (despacho), falicido } \\
\text { (falecido), recibi (recebi), } \\
\text { distitusão }\end{array}$ & IAFM, f. 34r \\
\hline
\end{tabular}

${ }^{146}$ Neste trecho escrito por Cesar Ribeiro de Cerqueira constam as seguintes informações: “Certidão | Certifico eu official de Justiça abaixa assigna- $\mid$ da que em virtude do mandado retro e seu| respetavel dispacho, medirigi nesta cidade $\mid$ e intimei em suas prpias pessoas a tou- $\mid$ dos os herderos contantes do dito man- $\mid$ dado, o que me disero ficar sciente | Orefirido é verdade e doufel | Feera 20 de Maio de 1922. | Cesar Ribeiro Cerqueira | Diligencia [espaço] 10,000 4 intimaçãos [espaço] 16;000 $\mid<\downarrow$ Cesar Ribeiro de Cerqueira > 26;000”. 


\begin{tabular}{|l|l|l|}
\hline & refirido (referido) & \\
\hline $\begin{array}{l}\text { Abaixamento da vogal alta [i] } \\
\sim \text { [e] em posição tônica }\end{array}$ & Francesco (Francisco) & IAFM, f. 34r \\
\hline
\end{tabular}

Fonte: Elaborado pela pesquisadora

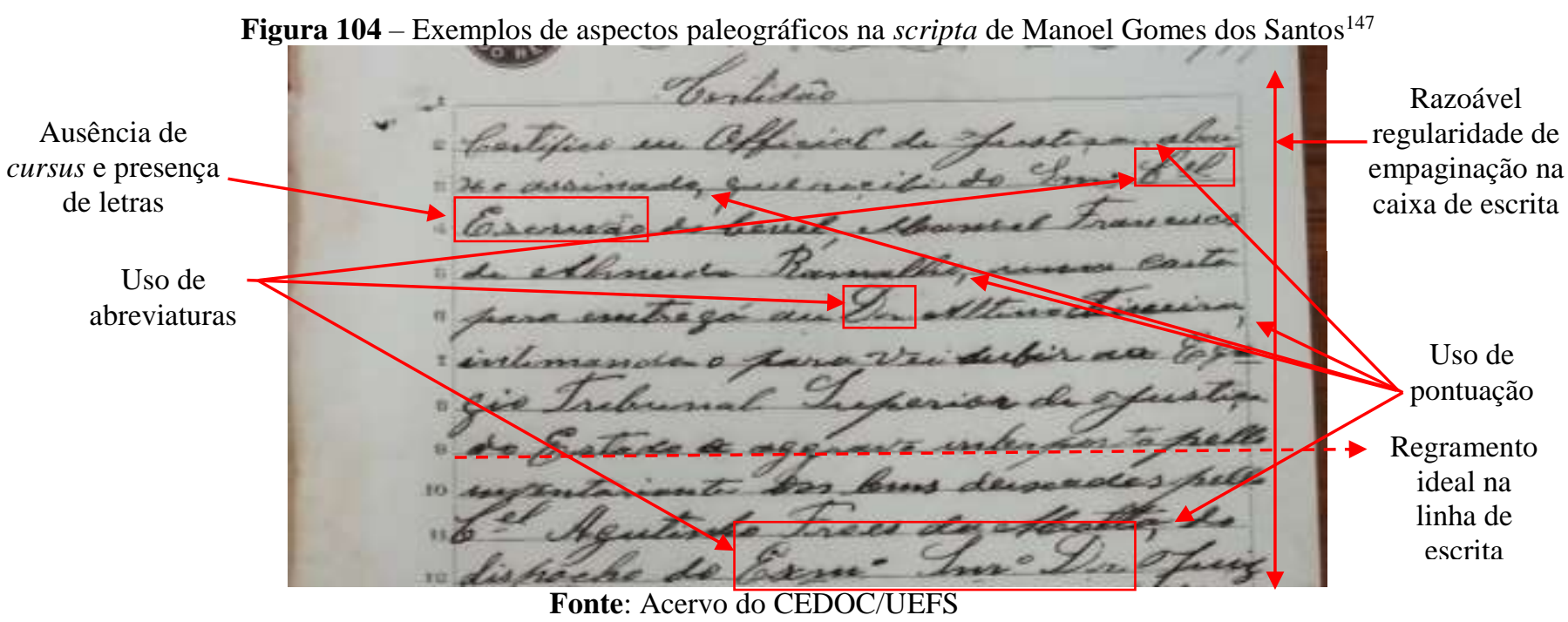

Quadro 50 - Exemplos de aspectos da escrita fonética de Manoel Gomes dos Santos

\begin{tabular}{|c|c|c|}
\hline FENÔMENOS FONÉTICOS & PALAVRAS & LOCALIZAÇÃO \\
\hline Síncope & $\begin{array}{l}\text { Agutinho (Agostinho), } \\
\text { Agotinho (Agostinho) }\end{array}$ & IAFM, f. 121r \\
\hline $\begin{array}{l}\text { Elevação da vogal média }[\mathrm{o}] \text { } \\
{[\mathrm{u}] \text { em monossílabo }}\end{array}$ & $\mathrm{Au}(\mathrm{Ao})$ & IAFM, f. 121r \\
\hline $\begin{array}{l}\text { Elevação da vogal média [o] } \\
\text { [u] em posição pretônica }\end{array}$ & Agutinho (Agostinho) & IAFM, f. 121r \\
\hline $\begin{array}{l}\text { Elevação da vogal média }[\mathrm{e}] \text { } \\
\text { [i] em posição pretônica }\end{array}$ & $\begin{array}{lr}\begin{array}{l}\text { Reçibi (Recebi), } \\
\text { (despacho), } \\
\text { (referido) }\end{array} & \text { refirido } \\
\end{array}$ & IAFM, f. 121r \\
\hline $\begin{array}{l}\text { Abaixamento da vogal alta [i] } \\
\sim \text { [e] em posição pretônica }\end{array}$ & Escrevão (Escrivão) & IAFM, f. 121r \\
\hline $\begin{array}{l}\text { Abaixamento da vogal alta [i] } \\
\sim \text { [e] em posição tônica }\end{array}$ & $\begin{array}{l}\text { Cevel (Cível), Francesco } \\
\text { (Francisco) }\end{array}$ & IAFM, f. 121r \\
\hline
\end{tabular}

Fonte: Elaborado pela pesquisadora

Além dessas características, é possível identificar, no texto escrito por Cesar Ribeiro de Cerqueira, que este escrevente tinha pouca familiaridade com a escrita alfabética em língua

\footnotetext{
${ }^{147}$ Neste trecho escrito por Manoel Gomes dos Santos constam as seguintes informações: "Certidão | Certifico eu Official de Justiça, abai- | xo assinado, que reçibi do Senhor Coronel | Escrevão do Cevel, Manoel Francesco | de Almeida Ramalho, uma carta | para entregá au Doutor Altino Teixeira, | intimando-o para vei subir ao Egre- | gio Trebunal Superior de Justiça | do Estado o aggravo inlerposto pello | inventariante dos bens deixados pello | Coronel Agutinho Froes da Motta, do | dispacho do Excellentissimo Senhor Doutor Juiz [...]”.
} 
portuguesa, o que pode ser constatado, por exemplo, no registro das palavras "Ascignada (Assignado), abaixa (abaixo), Ramalha (Ramalho) e Feera (Feira) (IAFM, f. 32v e 34r)”".

Assim, à exceção da ausência de cursus e da existência de letras monolíticas na scripta dos escreventes e das particularidades de cada um, as demais características apresentadas por Marquilhas (2000) e verificadas nos textos escritos pelos escreventes nos conduzem a afirmar que nenhum deles se enquadram como escreventes "inábeis", mas como "hábeis" ou "pouco hábeis" e, devido a isso, chegamos à conclusão de que, por exemplo, Manuel Francisco de Almeida Ramalho e João Carneiro Vital, apesar de não terem os seus graus de escolaridade comprovados, eram hábeis na escrita alfabética e tinham conhecimento da existência e de como usar, por exemplo, letras maiúsculas apenas em ínicio de substantivos próprios ou depois de pontos, do regramento ideal na linha de escrita, da empaginação na caixa de escrita, das abreviaturas, dos módulos médios (usados também na scripta de Jacintho Ferreira da Silva, José Maria Neves, Agnello Ribeiro de Macêdo, Altino Teixeira e Manoel Gomes dos Santos) e do módulo pequeno (nos casos da scripta de João Carneiro Vital e da de Cesar Ribeiro de Cerqueira), bem como os conectivos no texto (usados por todos) e traçados leves e seguros (usados tanto na scripta de Manuel Francisco de Almeida Ramalho e João Carneiro Vital quanto na de Jacintho Ferreira da Silva, José Maria Neves, Agnello Ribeiro de Macêdo e Altino Teixeira) e grossos e inseguros nas dos escreventes Cesar Ribeiro de Cerqueira e Manoel Gomes dos Santos.

Portanto, todos os escreventes são categorizados como "sujeitos" 1) que tiveram alguma instrução formal, seja no ensino básico ou no nível superior, 2) que tinham pouca (nos casos de Cesar Ribeiro de Cerqueira e Manoel Gomes dos Santos) ou muita habilidade na escrita (no caso dos demais), 3) que eram colegas de profissão não somente neste corpus, mas em outros processos em que eles aparecem como "sujeitos" da lei e 4) que vários deles ocupavam mais de um cargo, além dos do âmbito jurídico.

\subsubsection{Descrição do conteúdo do corpus}

Nesta subseção, elencamos os conteúdos constantes no testamento de Dona Maximiana de Almeida Motta, e no testamento e no primeiro volume do inventário do Coronel Agostinho Fróes da Motta, os quais nos permitirão identificar: a) os seus papéis econômico-sociais no cenário feirense, b) os legados deixados aos herdeiros e c) as relações dos testadores com os seus beneficiados. 
Sobre o primeiro, apresentamos, por ordem alfabética, os "sujeitos" que aparecem no testamento e os papéis por eles ocupados.

Quadro 51- "Sujeitos" processuais do testamento de Dona Maximiana de Almeida Motta

\begin{tabular}{|c|c|}
\hline SUJEITO(A) & OCUPAÇÃ̃O \\
\hline Adalgisa de Almeida Motta & Filha e herdeira da testadora \\
\hline Agerico Moreira Almeida & Escrivão da Comarca de Feira de Santana \\
\hline Agostinho Fróes da Motta & Cônjuge e herdeiro da testadora \\
\hline Alice Fructuoso, casada com João Dantas & Afilhada e herdeira da testadora \\
\hline Amália de Almeida Motta & Filha deserdada da testadora \\
\hline Antônio Alves Barretto & Genro da testadora \\
\hline $\begin{array}{l}\text { Archanja, Maria, Maria José e Chrispina de } \\
\text { Almeida, filhas de Marinho de Almeida }\end{array}$ & Sobrinhas e herdeiras da testadora \\
\hline Argileu, filho de Eufrosina de Almeida & Sobrinho e herdeiro da testadora \\
\hline Arthur Fróes da Motta & Filho e herdeiro da testadora \\
\hline Augusto Fróes da Motta & Filho e herdeiro da testadora \\
\hline Auto Esmeraldo dos Reis & Testemunha no testamento \\
\hline Coronel Bernardino da Silva Bahia & Apresentador do testamento \\
\hline Deoclecio da Silva Daltro & Coletor Estadual da Comarca de Feira de Santana \\
\hline Dona Albertina da Motta Barretto & Filha e herdeira da testadora \\
\hline Dona Maximiana de Almeida Motta & $\begin{array}{l}\text { Testadora } \\
\end{array}$ \\
\hline Eduardo Fróes da Motta & Filho, herdeiro e primeiro testamenteiro da testadora \\
\hline Epiphanio José de Souza & Amigo e Terceiro testamenteiro da testadora \\
\hline Jacintho Ferreira da Silva & Juiz de Direito da Comarca de Feira de Santana \\
\hline João Carneiro Vital & $\begin{array}{c}\text { Tabelião de Notas da Comarca de Feira de Santana e } \\
\text { escrevente do testamento }\end{array}$ \\
\hline José Telles Barreto & Testemunha no testamento \\
\hline Juvencio Erudilho da Silva Lima & Testemunha no testamento \\
\hline Leolindo dos Santos Ramos & Testemunha no testamento \\
\hline $\begin{array}{c}\text { Lydia e Maria José de Almeida, filhas de } \\
\text { Manoel Severiano de Almeida }\end{array}$ & Sobrinhas e herdeiras da testadora \\
\hline Manuel Francisco de Almeida Ramalho & Escrivão da Comarca de Feira de Santana \\
\hline $\begin{array}{l}\text { Maria e Eliza Evangelista de Almeida, } \\
\text { filhas de Maria Mathilde de Almeida }\end{array}$ & Sobrinhas e herdeiras da testadora \\
\hline Pedro Rodrigo do Lago & Testemunha no testamento \\
\hline Pharmaceutico José Alves Boaventura & Testemunha no testamento \\
\hline Quintiliano Martins da Silva & Testemunha no testamento \\
\hline Tertuliano José de Almeida & Primo, Compadre e Segundo testamenteiro da testadora \\
\hline
\end{tabular}

Fonte: Elaborado pela pesquisadora

Sem dúvidas, sem esses "sujeitos" o testamento de Dona Maximiana de Almeida Motta não teria sido produzido nem tampouco conheceríamos os relacionamentos nele mencionados. Sobre estes, narramos, a seguir, as informações que conseguimos extrair acerca de cada um deles, a partir do testamento apresentado.

Logo no termo de abertura do testamento, é-nos dito que Dona Maximiana de Almeida Motta faleceu na cidade de Feira de Santana-BA, no dia 12 de maio de 1918, e que no dia seguinte à sua morte, 13 de maio, o seu testamento foi aberto. Antes desse fato acontecer, contudo, a testadora já temia a sua iminente morte e por isso, no ano de 1915 , foram feitas as considerações pertinentes à sua vontade, as quais foram: a testadora declarou ser da religião 
Católica Apostólica Romana, na qual nasceu e nesta desejava morrer; em seguida, anunciou ser natural da cidade de Feira de Santana-BA, casada pelo regime de comunhão de bens com o Coronel Agostinho Fróes da Motta, de cujo casamento nasceram seus seis filhos: Albertina, Arthur, Augusto, Amália, Eduardo e Adalgisa.

Destes, foi escolhido como o seu testamenteiro o seu filho caçula Eduardo, seguidos do seu compadre e primo o Coronel Tertuliano José de Almeida e do seu amigo Epiphanio José de Souza. Desses três testamenteiros, o que aceitasse o cargo da testamentaria receberia, livre de impostos, um conto de réis. Além disso, a testadora deixou 200 contos de réis, em apólices federais, para os seus filhos, das quais estes e seus netos seriam beneficiários ao longo de 50 anos sem, no entanto, poderem vendê-las ou penhorá-las, passando-as, após aquele período, aos herdeiros de seus filhos.

Após essas considerações, a testadora passou a elencar a herança que deixaria para outros beneficiados, a saber: para as suas quatro sobrinhas não nominadas, filhas de Marinho de Almeida, foi deixado um conto de réis para cada uma; para as suas sobrinhas, Lydia e Maria José, filhas de seu irmão Manoel Severiano de Almeida, foi também deixada a quantia de um conto de réis para cada uma; para as filhas de sua irmã, Mathilde de Almeida, foi deixado um conto de réis para cada uma; para o seu sobrinho, filho de sua falecida irmã Eufrosina de Almeida, e para a sua afilhada, Alice Fructuoso, foi deixado também um conto de réis para cada um(a).

Além dos familiares, a testadora também beneficiou algumas instituições sociais, das quais fazia parte, enquanto católica caridosa: a Santa Casa de Misericórdia e o Asilo Nossa Senhora de Lourdes, ambos de Feira de Santana-BA, e para os quais foi deixada a quantia de um conto de réis para cada um, e para a Sociedade Filarmônica Victória foi deixado o valor de 200 mil réis. Além dessas instituições, a testadora também deixou registrado, em testamento, o valor de um conto de réis, que deveria ser doado às viúvas pobres da cidade, as quais seriam beneficiadas de acordo com a ciência de Eduardo Fróes da Motta, filho escolhido pela testadora para realizar essa atividade.

Em seguida, a testadora deixou claro que estipulava o prazo de dois anos, após a sua morte, para que a sua vontade fosse feita, para a qual foi testemunha e escrivão, o Tabelião de Notas João Carneiro Vital, que se dirigiu à residência da testadora e que, a pedido desta, redigiu, leu e, estando em conformidade com a vontade daquela, datou e assinou junto com Dona Maximiana de Almeida Motta o documento.

Em seguida, foi redigido um auto de aprovação em que foi descrita a data em que o testamento fora escrito, bem como as circunstâncias em que isso ocorreu. Em outras palavras, 
está posto que em 1915 o Tabelião de Notas, João Carneiro Vital, dirigiu-se à casa de Dona Maximiana de Almeida Motta, a seu pedido, para que ele redigisse e lavrasse o referido testamento, haja vista que a testadora o recebeu em casa e lhe entregou um papel em que constava a sua vontade, a qual deveria ser registrada pelo referido tabelião. Após isso, a testadora aprovou o documento redigido e pediu que este fosse costurado e lacrado, sendo aberto apenas depois do seu falecimento, em 1918.

A partir do fólio $4 \mathrm{v}$, foi feito o termo de encerramento do testamento e também foram anexados alguns documentos referentes aos pagamentos feitos ao Coletor Estadual e vinculados ao imposto de custas judiciárias e de emolumentos, arcados por Eduardo Fróes da Motta, que aceitou ser o primeiro testamenteiro de sua mãe, como pode ser verificado nos fólios $9 \mathrm{r}$ e $9 \mathrm{v}$ do referido testamento.

Depois disso o testamento foi encerrado e, a partir das suas informações, conhecemos não apenas os afetos que a testadora tinha, mas as suas ações caridosas para com a sociedade feirense, já que ela apresentou uma preocupação em beneficiar não somente os seus familiares e instituições sociais como também as mulheres pobres e viúvas da cidade, o que nos dá indícios de que esse tipo de atitude poderia não se restringir ao seu testamento, mas à uma postura adotada durante toda a sua vida, o que pôde ser confirmado nos demais processos lidos, no Jornal Folha do Norte e no Memorial histórico da Santa Casa de Misericórdia de Feira de Santana (2009), nos quais a testadora sempre apareceu como uma senhora preocupada com os mais necessitados.

Semelhantemente, no segundo testamento, cujo testador foi o Coronel Agostinho Fróes da Motta, identificamos os seus "sujeitos" processuais, dos quais alguns foram os mesmos que aparecem no testamento anterior.

Quadro 52 - "Sujeitos" processuais do testamento do Coronel Agostinho Fróes da Motta

\begin{tabular}{|c|c|}
\hline SUJEITO(A) & OCUPAÇÃO \\
\hline Adalgisa de Almeida Motta & Filha e herdeira do testador \\
\hline Agnello Cohim Pacheco & Testemunha no testamento \\
\hline Agostinho Fróes da Motta & Testador \\
\hline $\begin{array}{c}\text { Albertino e Elzira, filhos de Manoel } \\
\text { Portugal dos Santos }\end{array}$ & Afilhados e herdeiros do testador \\
\hline Amadeu Saback de Oliveira & Testemunha no testamento \\
\hline Amália de Almeida Motta & Filha deserdada do testador \\
\hline Ambrozio & Esposo de Joanna, sobrinha do testador \\
\hline Antonio Onofre Carneiro & Testemunha no testamento \\
\hline Arthur de Assis & Testemunha no testamento \\
\hline Arthur Fróes da Motta & Filho, herdeiro e terceiro testamenteiro do testador \\
\hline Augusto Fróes da Motta & Filho e herdeiro do testador \\
\hline $\begin{array}{c}\text { Auta e Fortunata Taurinho de Aguiar, filhas } \\
\text { do irmão do testador Floriano Pereira de } \\
\text { Aguiar }\end{array}$ & Sobrinhas e herdeiras do testador \\
\hline
\end{tabular}




\begin{tabular}{|c|c|}
\hline Clodoaldo Severiano de Almeida & Irmão da nora do testador \\
\hline David de Mello Lima ${ }^{148}$ & Empregado e herdeiro do testador \\
\hline Deoclecio da Silva Daltro & Coletor Estadual da Comarca de Feira de Santana \\
\hline Dona Albertina da Motta Barretto & Filha e herdeira do testador \\
\hline $\begin{array}{l}\text { Dona Almerinda Ribeiro Nunes, filha de } \\
\text { Florentino Ribeiro Nunes }\end{array}$ & Herdeira do testador \\
\hline Dona Julia de Sant'Anna & Cunhada e herdeira do testador \\
\hline $\begin{array}{l}\text { Dona Junilha Almeida, casada com } \\
\text { Clodoaldo Severiano de Almeida }\end{array}$ & Herdeira do testador \\
\hline Eduardo Fróes da Motta & Filho, herdeiro e Primeiro testamenteiro do testador \\
\hline Epiphanio José de Souza & $\begin{array}{l}\text { Amigo, Segundo testamenteiro do testador e testemunha } \\
\text { do testamento }\end{array}$ \\
\hline Febronio Joaquim Fructuoso & Cunhado do testador \\
\hline Francisco Almeida & Empregado e herdeiro do testador \\
\hline Guilhermina de Almeida Motta & Segunda cônjuge do testador \\
\hline Hermillo Dias de Carvalho & Testemunha no testamento \\
\hline Jacintho Ferreira da Silva & Juiz de Direito da Comarca de Feira de Santana \\
\hline $\begin{array}{c}\text { Joanna Baptista da Silva }{ }^{149} \text {, esposa de José } \\
\text { do Patrocinio e Silva }\end{array}$ & Prima segunda e herdeira do testador \\
\hline $\begin{array}{c}\text { Joanna, Isaac Sant'Anna Aguiar }{ }^{150} \mathrm{e} \\
\text { Hermenegildo de Sant'Anna Aguiar, filhos } \\
\text { do irmão do testador Jorge Pereira de } \\
\text { Aguiar }\end{array}$ & Sobrinhos e herdeiros do testador \\
\hline $\begin{array}{l}\text { João Grego Faskomy/ João Constantino } \\
\text { Faskomy }\end{array}$ & Genro do testador \\
\hline João Carneiro Vital & Tabelião de Notas da Comarca de Feira de Santana \\
\hline João Simões Ferreira & Testemunha no testamento \\
\hline Joaquim Anacleto de Oliveira & Testemunha no testamento \\
\hline Jorge Pereira de Aguiar & $\begin{array}{l}\text { Irmão falecido do testador e esposo de Dona Julia de } \\
\text { Sant'Anna }\end{array}$ \\
\hline José Borges da Motta & Pai falecido do testador \\
\hline José do Patrocinio e Silva & Compadre do testador \\
\hline José Telles Barreto & Escrivão da Comarca de Feira de Santana \\
\hline Manoel Portugal dos Santos & Compadre e amigo do testador \\
\hline Manuel Araujo & Testemunha no testamento \\
\hline Manuel Francisco de Almeida Ramalho & Escrivão da Comarca de Feira de Santana \\
\hline $\begin{array}{c}\text { Maria de Lourdes, Adalberto Fructuoso e } \\
\text { Octavio Fructuoso, filhos da irmã do } \\
\text { testador Amelia }\end{array}$ & Sobrinhos e herdeiros do testador \\
\hline Maria Valeria de Jesus & Mãe falecida do testador \\
\hline Maria, filha de José do Patrocinio e Silva & Afilhada e herdeira do testador \\
\hline Maximiana de Almeida Motta & Primeira cônjuge do testador \\
\hline Oscar do Espirito Santo & Testemunha no testamento \\
\hline $\begin{array}{l}\text { Ritta, Marinhinha, Almira e Neryna, filhas } \\
\text { de Tertuliano José de Almeida }\end{array}$ & Herdeiras do testador \\
\hline Romana Chagas & Irmã e herdeira do testador \\
\hline Tertuliano José de Almeida & Amigo e Compadre do testador \\
\hline Valentim José de Souza Junior & Testemunha no testamento \\
\hline
\end{tabular}

Fonte: Elaborado pela pesquisadora

148 Dentre as suas funções enquanto empregado do Coronel Agostinho Fróes da Motta estava a de recolher o valor dos aluguéis de cada inquilino e prestar contas no livro do caixa da empresa Agostinho Fróes da Motta e Filho, conforme o terceiro volume do inventário do referido coronel. Além disso, era chamado pelos seus correligionários de major ou de capitão e era pai de duas filhas: Diana Lima e Dinah Azevedo.

${ }^{149}$ Nome completo constante no terceiro volume do inventário do Coronel Agostinho Fróes da Motta.

${ }^{150}$ Segundo o Folha do Norte (3 fev. 1923), Isaac Sant'Anna Aguiar foi aprovado com distinção e louvor no exame anual da Segunda Escola Municipal do sexo masculino, regida pela professora Ubaldina Fortes. 
Nesse quadro podemos identificar vários "sujeitos" processuais, que também se fizeram presentes no testamento de Dona Maximiana de Almeida Motta, o que nos leva a inferir que se tratavam de pessoas, cujos vínculos afetivos se estendiam a ambos os Fróes da Motta, com exceção dos "sujeitos" da lei que estavam apenas cumprindo os seus ofícios em ambos os processos. Para além disso, observamos que o protocolo inicial desse testamento é muito semelhante ao anterior, já que o testador iniciou o texto professando ser da religião Católica Apostólica Romana, declarando-se casado em primeiras núpcias, em regime de comunhão de bens, com Dona Maximiana de Almeida Motta, com quem teve os filhos Albertina, Arthur, Amalia, Augusto, Eduardo e Adalgisa, e casado em segundas núpcias, em regime de separação de bens, com Dona Guilhermina de Almeida, com quem teve o filho Alberto.

No mesmo protocolo, o testador afirmou ser natural de Feira de Santana-BA, filho de pais já falecidos e escolheu como seus testamenteiros, em primeiro lugar, o seu quinto filho Eduardo Fróes da Motta; em segundo lugar, o amigo Coronel Epiphanio José de Souza; e, em terceiro lugar, o seu segundo filho Arthur Fróes da Motta. Ainda sobre os familiares, o testador fez questão de relembrar que a sua filha, Amalia da Motta Faskomy, estava deserdada, como constava no processo de deserdação por ele mencionado.

Além dos familiares que foram mencionados e beneficiados em seu testamento, observamos que, assim como a sua esposa, o coronel Agostinho Fróes da Motta legou a algumas instituições de caridade, das quais participava como sócio, membro ou benfeitor, algumas quantias em dinheiro como, por exemplo, ao Asilo Nossa Senhora de Lourdes de Feira de Santana, para o qual o testador deixou a quantia de dez contos de réis; para a Santa Casa de Misericórdia de Feira de Santana, que também receberia dez contos de réis; para a Sociedade Filarmônica 25 de Março, de Feira de Santana-BA, legou a quantia de quinhentos mil réis, como prova de sua dedicação à instituição; para a Confraria de São Vicente de Paula, localizada em Feira de Santana-BA, ficou a quantia de um conto de réis; para a Sociedade Monte Pio dos Artistas Feirenses, ficou a quantia de um conto de réis; para a Igreja Nossa Senhora dos Remédios, beneficiada com um conto de réis, que seria destinado a reparos, que deveriam ser aprovados pelo seu filho, Eduardo Fróes da Motta, o qual também ficou incumbido de cuidar dos parentes mais pobres, assim como ele próprio havia feito durante toda sua vida, e de administrar a quantia de um conto de réis, que seria distribuída entre as viúvas reconhecidamente pobres. Toda essa preocupação do testador evidencia o quão 
importante para ele era manter as instituições sociais de que participava amparadas, mesmo após a sua morte.

Enquanto patriarca, o testador deixou registrada a destinação de dez contos de réis para a construção de um mausoléu e compra de um terreno perpétuo, na cidade de Feira de Santana-BA, que serviria como descanso eterno para si e para os seus descendentes até a terceira geração. Outras preocupações do testador foram a sua residência - que foi legada ao seu filho Eduardo Fróes da Motta, que receberia o Casarão Fróes da Motta com todos os seus móveis e utensílios - e o amparo à sua segunda esposa, Dona Guilhermina de Almeida, que receberia um seguro no valor de dez contos de réis.

Nesse testamento conseguimos identificar o interesse do testador em manter os seus papéis enquanto pai, esposo, amigo, compadre e filantropo intactos, com exceção de sua filha Amalia da Motta Faskomy, que se manteve deserdada pelo pai. Muitos dos desejos do testador se mantiveram em seu inventário. Contudo, algumas mudanças importantes ocorreram, como veremos a seguir.

No terceiro e último documento editado, o primeiro volume do inventário do Coronel Agostinho Fróes da Motta, identificamos que o seu objetivo inicial consistia no arrolamento e divisão dos bens deixados pelo inventariado. Contudo, com o aparecimento de alguns “sujeitos" processuais inesperados, o processo alavancou questões aparentemente esquecidas, as quais veremos após a listagem dos envolvidos nesse documento.

Quadro 53 - "Sujeitos” processuais do primeiro volume do inventário do Coronel Agostinho Fróes da Motta

\begin{tabular}{|l|l|}
\hline \multicolumn{1}{|c|}{ SUJEITO(A) } & \multicolumn{1}{c|}{ OCUPAÇÃO } \\
\hline Adalberto Alves Farias & Genro do inventariado \\
\hline Adalgisa da Motta Farias & Filha e herdeira do inventariado \\
\hline Afonso Pedreira de Cerqueira & Tabelião de Notas da Comarca de Ilhéus \\
\hline Agnello Cohim Pacheco & Testemunha no testamento \\
\hline Agnello Ribeiro de Macêdo & Advogado \\
\hline Agostinho Fróes da Motta & Inventariado \\
\hline Albertina de Almeida Motta & Filha e herdeira do inventariado \\
\hline $\begin{array}{l}\text { Albertino e Elzira, filhos de Manoel } \\
\text { Portugal dos Santos }\end{array}$ & Afilhados e herdeiros do inventariado \\
\hline Albertino Pedreira Dantas & Lançador da Comarca de Feira de Santana \\
\hline Alberto de Almeida Motta & Filho do inventariado com a sua segunda cônjuge \\
\hline Altino Teixeira & Advogado \\
\hline Amadeu Saback de Oliveira & Testemunha no testamento \\
\hline Amalia da Motta Faskomy & Filha do inventariado \\
\hline Ambrozio & Esposo de Joanna, sobrinha do testador \\
\hline Antonio Onofre Carneiro & Testemunha no testamento \\
\hline Aristophanes Silva & $\begin{array}{l}\text { Testemunha no registro de nascimento de Alberto de } \\
\text { Almeida Motta }\end{array}$ \\
\hline Arthur de Assis & Testemunha no testamento \\
\hline Arthur Fróes da Motta & Filho, herdeiro e terceiro testamenteiro do inventariado \\
\hline Augusto Fróes da Motta & Filho e herdeiro do inventariado \\
\hline
\end{tabular}




\begin{tabular}{|c|c|}
\hline Aurelio Vasconcelos & Escrivão da Comarca de Feira de Santana \\
\hline $\begin{array}{l}\text { Auta e Fortunata Taurinho de Aguiar, filhas } \\
\text { do irmão do testador Floriano Pereira de } \\
\text { Aguiar }\end{array}$ & Sobrinhas e herdeiras do inventariado \\
\hline Bernardino Senna Santos & Escrivão Cível da Comarca de Ilhéus \\
\hline Cesar Ribeiro de Cerqueira & Oficial de Justiça da Comarca de Feira de Santana \\
\hline Clodoaldo Severiano de Almeida & Irmão da nora do inventariado \\
\hline David de Mello Lima & Empregado e herdeiro do inventariado \\
\hline Deoclecio da Silva Daltro & $\begin{array}{l}\text { Coletor Estadual e Juiz de Paz em exercício da Comarca } \\
\text { de Feira de Santana }\end{array}$ \\
\hline Diogenes de Souza Lima & Contador do Juizo da Comarca de Ilhéus \\
\hline $\begin{array}{l}\text { Dona Almerinda Ribeiro Nunes, filha de } \\
\text { Florentino Ribeiro Nunes }\end{array}$ & Herdeira do inventariado \\
\hline Dona Julia de Sant'Anna & Cunhada e herdeira do inventariado \\
\hline $\begin{array}{l}\text { Dona Junilha Almeida, casada com } \\
\text { Clodoaldo Severiano de Almeida }\end{array}$ & Herdeira do inventariado \\
\hline Dona Maria Carlota Falcão de Sousa & Nora do inventariado \\
\hline Eduardo Fróes da Motta & Inventariante, testamenteiro e herdeiro do inventariado \\
\hline Elpidio Raymundo da Nova & Promotor Público da Comarca de Feira de Santana \\
\hline Epiphanio José de Souza & $\begin{array}{l}\text { Amigo, Terceiro testamenteiro do inventariado e } \\
\text { testemunha no testamento e no contrato ante-nupcial do } \\
\text { inventariado com a segunda }\end{array}$ \\
\hline Estanislau Alves Barreto & $\begin{array}{l}\text { Amigo e compadre do inventariado, e testemunha na } \\
\text { solicitação de reconhecimento de paternidade de Alberto } \\
\text { de Almeida Motta, filho do inventariado }\end{array}$ \\
\hline Febronio Joaquim Fructuoso & Cunhado do inventariado \\
\hline Francisco Almeida & Empregado e herdeiro do inventariado \\
\hline Francisco de Assis Garrido & $\begin{array}{l}\text { Testemunha no registro de nascimento de Alberto de } \\
\text { Almeida Motta }\end{array}$ \\
\hline Godofredo Rebello de Figueiredo & Escrivão dos casamentos da Comarca de Feira de Santana \\
\hline Guilhermina de Almeida Motta & Segunda cônjuge e herdeira do inventariado \\
\hline Hermillo Dias de Carvalho & $\begin{array}{l}\text { Testemunha no testamento e Devedor mencionado no } \\
\text { inventário }\end{array}$ \\
\hline Ignacia Falcão de Souza & Mãe da nora do inventariado \\
\hline Isaac Jorge Franco & Solicitador \\
\hline Jacintho Ferreira da Silva & Juiz de Direito da Comarca de Feira de Santana \\
\hline $\begin{array}{l}\text { Joanna Baptista da Silva, esposa de José do } \\
\text { Patrocinio e Silva }\end{array}$ & Prima segunda e herdeira do inventariado \\
\hline $\begin{array}{l}\text { Joanna, Isaac Sant'Anna Aguiar e } \\
\text { Hermenegildo de Sant'Anna Aguiar, filhos } \\
\text { do irmão do testador Jorge Pereira de } \\
\text { Aguiar }\end{array}$ & Sobrinhos e herdeiros do inventariado \\
\hline João Carneiro Vital & Tabelião de Notas da Comarca de Feira de Santana \\
\hline João Grego Faskomy & Genro do inventariado \\
\hline João Simões Ferreira & Testemunha no testamento \\
\hline Joaquim Anacleto de Oliveira & Testemunha no testamento \\
\hline Joaquim Honorio de Oliveira & Avaliador dos bens do inventariado \\
\hline Joaquim José Ramos & Juiz de Direito da Comarca de Ilhéus \\
\hline Joaquim Pinto dos Santos & $\begin{array}{l}\text { Escrivão de Paz e Oficial do Registro Civil da Comarca } \\
\text { de Feira de Santana }\end{array}$ \\
\hline Jorge Pereira de Aguiar & $\begin{array}{l}\text { Irmão falecido do testador e esposo de Dona Julia de } \\
\text { Sant'Anna }\end{array}$ \\
\hline José Borges da Motta & Pai falecido do inventariado \\
\hline José do Patrocinio e Silva & Compadre do inventariado \\
\hline José Maria Neves & Advogado \\
\hline José Pinto dos Santos Junior & Testemunha no inventário \\
\hline José Telles Barreto & Escrivão da Comarca de Feira de Santana \\
\hline Justino de Figueiredo Mascarenhas & $\begin{array}{l}\text { Testemunha na solicitação de reconhecimento de } \\
\text { paternidade de Alberto de Almeida Motta, filho do }\end{array}$ \\
\hline
\end{tabular}




\begin{tabular}{|c|c|}
\hline & inventariado \\
\hline Leoncio Evangelista dos Santos & $\begin{array}{l}\text { Coletor Federal e testemunha na solicitação de } \\
\text { reconhecimento de paternidade de Alberto de Almeida } \\
\text { Motta, filho do inventariado }\end{array}$ \\
\hline Manoel Alves de Britto & $\begin{array}{l}\text { Testemunha na solicitação de reconhecimento de } \\
\text { paternidade de Alberto de Almeida Motta, filho do } \\
\text { inventariado }\end{array}$ \\
\hline Manoel Gomes dos Santos & Oficial de Justiça da Comarca de Feira de Santana \\
\hline Manoel Pimentel & Advogado \\
\hline Manoel Portugal dos Santos & $\begin{array}{l}\text { Compadre, amigo do inventariado e testemunha no } \\
\text { contrato ante-nupcial do inventariado com a segunda } \\
\text { cônjuge }\end{array}$ \\
\hline Manuel Araujo & $\begin{array}{l}\text { Testemunha no testamento e Contador da Comarca de } \\
\text { Feira de Santana }\end{array}$ \\
\hline Manuel Francisco de Almeida Ramalho & $\begin{array}{l}\text { Tabelião de Notas do Segundo Ofício e Escrivão dos } \\
\text { Feitos Cíveis e Crimes da Comarca de Feira de Santana }\end{array}$ \\
\hline $\begin{array}{l}\text { Maria de Lourdes, Adalberto Fructuoso e } \\
\text { Octavio Fructuoso, filhos da irmã do } \\
\text { testador Amelia }\end{array}$ & Sobrinhos e herdeiros do inventariado \\
\hline Maria Valeria de Jesus & Mãe falecida do inventariado \\
\hline Maria, filha de José do Patrocinio e Silva & Afilhada e herdeira do inventariado \\
\hline Mario Pedreira da Silva Dantas & $\begin{array}{l}\text { Testemunha na solicitação de reconhecimento de } \\
\text { paternidade de Alberto de Almeida Motta, filho do } \\
\text { inventariado }\end{array}$ \\
\hline Maximiana de Almeida Motta & Primeira cônjuge do inventariado \\
\hline Oscar do Espirito Santo & Testemunha no testamento \\
\hline Petronillo Guaviro de Meirelles & $\begin{array}{l}\text { Testemunha no inventário e Tesoureiro da Comarca de } \\
\text { Feira de Santana }\end{array}$ \\
\hline $\begin{array}{l}\text { Ritta, Marinhinha, Almira e Neryna, filhas } \\
\text { de Tertuliano José de Almeida }\end{array}$ & Herdeiras do inventariado \\
\hline Romana Chagas & Irmã e herdeira do inventariado \\
\hline Severiano Ferreira de Souza & Pai da nora do inventariado \\
\hline Tertuliano José de Almeida & $\begin{array}{l}\text { Amigo, compadre do inventariado e testemunha no } \\
\text { contrato ante-nupcial do inventariado com a segunda } \\
\text { cônjuge }\end{array}$ \\
\hline Tharcilla Barbosa da Silva & Sogra do inventarido \\
\hline Valentim José de Souza Junior & $\begin{array}{l}\text { Testemunha no testamento e no contrato ante-nupcial do } \\
\text { inventariado com a segunda cônjuge, e avaliador dos } \\
\text { bens do inventariado }\end{array}$ \\
\hline Viriato Vieira dos Santos & Testemunha no inventário \\
\hline
\end{tabular}

Fonte: Elaborado pela pesquisadora

Como se vê, muitos dos sujeitos mencionados nesse documento também constam no testamento do Coronel Agostinho Fróes da Motta, haja vista a trasladação, nesse processo, do próprio testamento do testador, do contrato ante-nupcial do inventariado com a sua segunda cônjuge e da certidão de nascimento de Alberto de Almeida Motta.

De modo geral, o inventário retrata fielmente a vontade deixada, em testamento, pelo Coronel Agostinho Fróes da Motta, que deixou os seus bens para quase todos os seus filhos, com exceção de Amália da Motta Faskomy e de Alberto de Almeida Motta, fruto de seu relacionamento com Dona Guilhermina de Almeida, o qual buscou o seu reconhecimento enquanto filho do inventariado, já que este não o mencionou em seu testamento. 
Além dos cinco $^{151}$ filhos do primeiro casamento, também foram eleitos como herdeiros do coronel os seus amigos, compadres, sobrinhos, afilhados, primas, comadres, as filhas de seus amigos e algumas instituições sociais, mencionadas anteriormente. Ademais, são descritos os imóveis, que seriam herdados por cada um dos seus beneficiados, o que nos dá uma ideia da disposição geográfica da cidade naquela época, já que as casas citadas estavam localizadas nas principais ruas do Centro da cidade, sobre as quais falamos na segunda seção desta tese.

Como se trata de um documento mais extenso do que os dois testamentos, optamos por elencar as suas informações em um quadro, exposto a seguir.

Quadro 54 - Sumarização do conteúdo constante no primeiro volume do inventário do Coronel Agostinho Fróes da Motta

\begin{tabular}{|c|c|}
\hline FÓLIO(S) & CONTEÚDO \\
\hline $1 \mathrm{r}$ & $\begin{array}{l}\text { O Escrivão Manuel Francisco de Almeida Ramalho sumariza as informações gerais } \\
\text { do processo, criando para isso uma espécie de capa, na qual há informações como, } \\
\text { por exemplo, o ano, o nome da Comarca, o número do volume, os nomes do } \\
\text { inventariado e inventariante e o seu nome como Escrivão. }\end{array}$ \\
\hline $1 \mathrm{v}$ & $\begin{array}{l}\text { O Juiz Lyderico Santos Cruz informa o número de "folhas" do volume, incluindo-se } \\
\text { a informação de que consta na última delas um parecer do advogado Agnello Ribeiro } \\
\text { de Macêdo. }\end{array}$ \\
\hline $2 \mathrm{re} 2 \mathrm{v}$ & $\begin{array}{l}\text { O advogado Agnello Ribeiro de Macêdo apresenta as razões para a abertura a feitura } \\
\text { do inventário, destacando para isso os herdeiros do falecido e a firma comercial em } \\
\text { liquidação, cujo um dos sócios era o inventariante Eduardo Fróes da Motta. }\end{array}$ \\
\hline $3 r$ e $3 v$ & $\begin{array}{l}\text { Procuração passada por Eduardo Fróes da Motta ao advogado Agnello Ribeiro de } \\
\text { Macêdo para este ser seu representante legal no inventário do seu pai. }\end{array}$ \\
\hline $4 \mathrm{r}$ a $15 \mathrm{v}$ & $\begin{array}{l}\text { Certidão passada a pedido de Eduardo Fróes da Motta para que fosse trasladado o } \\
\text { testamento do Coronel Agostinho Fróes da Motta, solicitação que foi atendida. }\end{array}$ \\
\hline $16 \mathrm{r}$ ao $20 \mathrm{v}$ & $\begin{array}{l}\text { Certidão passada a pedido de Eduardo Fróes da Motta para que fosse trasladado o } \\
\text { contrato ante-nupcial do seu pai com Dona Guilhermina de Almeida, solicitação } \\
\text { também atendida. }\end{array}$ \\
\hline $21 \mathrm{r}$ & Termo de juramento do inventariante. \\
\hline $21 \mathrm{v}$ ao $26 \mathrm{v}$ & $\begin{array}{l}\text { Declarações e título de herdeiros do inventariado, incluindo nestes fólios os bens que } \\
\text { seriam partilhados entre os herdeiros. }\end{array}$ \\
\hline $27 \mathrm{r}$ & $\begin{array}{l}\text { Fólio em que o Escrivão Manuel Francisco de Almeida Motta afirma que faz juntada } \\
\text { dos autos à petição, que se seguiria. }\end{array}$ \\
\hline $28 \mathrm{r}$ & $\begin{array}{l}\text { Solicitação de Eduardo Fróes da Motta para que os demais herdeiros fossem citados } \\
\text { pelo Juiz para comparecerem à audiência pública em que ocorreria a escolha dos } \\
\text { avaliadores dos bens a serem partilhados. }\end{array}$ \\
\hline $29 \mathrm{r}$ & $\begin{array}{l}\text { Certidão passada pelo Escrivão Manuel Francisco de Almeida Ramalho, na qual este } \\
\text { notifica que expediu carta precatória e mandato para serem entregues ao Oficial de } \\
\text { Justiça Cesar Ribeiro de Cerqueira, que deveria entregá-los ao inventariante. }\end{array}$ \\
\hline $29 \mathrm{v}$ & $\begin{array}{l}\text { Fólio em que o Escrivão Manuel Francisco de Almeida Motta afirma que faz juntada } \\
\text { dos autos à petição, que se seguiria. }\end{array}$ \\
\hline $30 \mathrm{r}$ & $\begin{array}{l}\text { Solicitação de Manoel Pimentel, advogado do inventariante, para que fosse anexada } \\
\text { ao processo a referida solicitação junto com a respectiva procuração que o constituía } \\
\text { representante legal do inventariante. }\end{array}$ \\
\hline $31 \mathrm{r}$ e $31 \mathrm{v}$ & $\begin{array}{l}\text { Procuração passada por Eduardo Fróes da Motta ao advogado Manoel Pimentel e ao } \\
\text { solicitador Isaac Jorge Franco para estes serem seus representantes legais no } \\
\text { inventário do seu pai. }\end{array}$ \\
\hline
\end{tabular}

${ }^{151}$ Albertina, Arthur, Augusto, Eduardo e Adalgisa. 


\begin{tabular}{|c|c|}
\hline $32 \mathrm{r}$ e $32 \mathrm{v}$ & $\begin{array}{l}\text { Requerimento solicitado pelo inventariante para que um avaliador privativo daquele } \\
\text { Juizo, com o consentimento dos demais herdeiros, fizesse as avaliações devidas dos } \\
\text { bens deixados pelo inventariado. }\end{array}$ \\
\hline $33 \mathrm{r}$ & $\begin{array}{l}\text { Certidão passada pelo Escrivão Manuel Francisco de Almeida Ramalho, na qual este } \\
\text { dá ciência da intimação a ser entregue ao advogado Agnello Ribeiro de Macêdo. }\end{array}$ \\
\hline $33 \mathrm{v}$ & $\begin{array}{l}\text { Fólio em que o Escrivão Manuel Francisco de Almeida Motta afirma que faz juntada } \\
\text { dos autos à petição, que se seguiria. }\end{array}$ \\
\hline $34 \mathrm{r}$ & $\begin{array}{l}\text { Certidão passada pelo Oficial de Justiça, Cesar Ribeiro de Cerqueira, acerca da } \\
\text { destituição do advogado Agnello Ribeiro de Macêdo como representante do } \\
\text { inventariante. }\end{array}$ \\
\hline $34 v$ & $\begin{array}{l}\text { Fólio em que o Escrivão Manuel Francisco de Almeida Motta afirma que faz juntada } \\
\text { dos autos à petição, que se seguiria. }\end{array}$ \\
\hline $35 r$ e $35 v$ & $\begin{array}{l}\text { Declaração assinada pelos herdeiros do Coronel Agostinho Fróes da Motta } \\
\text { concordando com as reformas que seriam feitas no Casarão Fróes da Motta, o qual se } \\
\text { encontrava sob a guarda do Dr. Eduardo Fróes da Motta, herdeiro da referida } \\
\text { residência, seguida do respectivo termo de juntada. }\end{array}$ \\
\hline $36 \mathrm{r}$ ao $43 \mathrm{v}$ & $\begin{array}{l}\text { Expedição de uma carta precatória e intimação emitidas da Comarca de Feira de } \\
\text { Santana à de Ilhéus, exigidas pelo Dr. Eduardo Fróes da Motta contra Adalberto } \\
\text { Alves de Farias para que este compareçesse junto com os demais herdeiros à } \\
\text { audiência de nomeação de um avaliador do Juizo para que este realizasse as devidas } \\
\text { avaliações dos bens elencados nos autos do inventário. }\end{array}$ \\
\hline $44 \mathrm{r}$ a $45 \mathrm{v}$ & $\begin{array}{l}\text { Emissão de uma procuração feita por Dona Albertina Fróes da Motta, residente na } \\
\text { cidade de Mundo Novo-BA, designando que o advogado Manoel Pimentel e o } \\
\text { solicitador Isaac Jorge Franco para a representarem no processo de inventário do seu } \\
\text { pai. }\end{array}$ \\
\hline $47 \mathrm{r}$ a $86 \mathrm{v}$ & $\begin{array}{l}\text { Petição solicitada pelo Engenheiro Alberto de Almeida Motta, exigindo a inclusão do } \\
\text { seu nome no título de herdeiros do Coronel Agostinho Fróes da Motta, enquanto filho } \\
\text { deste, apresentando, para isso, provas }{ }^{152} \text { de que sempre foi tratado pelo pai como } \\
\text { filho e que, após o casamento de sua genitora com o seu pai, a lei lhe permitia ser } \\
\text { reconhecido como filho legítimo. Para ganhar a causa, Alberto de Almeida Motta } \\
\text { apresentou testemunhas que confirmaram o seu relacionamento paternal com o } \\
\text { coronel e deste com a sua mãe, apesar das negativas do seu irmão, Eduardo Fróes da } \\
\text { Motta, acerca da veracidade dos fatos apontados pelas provas e pelas testemunhas } \\
\text { inqueridas. }\end{array}$ \\
\hline $87 \mathrm{r}$ & Arrolamento de bens móveis, semoventes e títulos, apresentados pelo inventariante. \\
\hline $88 \mathrm{r}$ ao $91 \mathrm{v}$ & $\begin{array}{l}\text { Termos de audiências, nas quais compareceram os próprios interessados ou os } \\
\text { representantes destes para responderem a petição de Alberto de Almeida Motta. }\end{array}$ \\
\hline $92 \mathrm{r}$ ao $94 \mathrm{v}$ & $\begin{array}{l}\text { Termo de agravo solicitado por Eduardo Fróes da Motta contra a decisão do Juiz de } \\
\text { Direito da Comarca de Feira de Santana de incluir Alberto de Almeida Motta no } \\
\text { título de herdeiros do Coronel Agostinho Fróes da Motta. }\end{array}$ \\
\hline $95 \mathrm{r}$ ao $97 \mathrm{v}$ & $\begin{array}{l}\text { Documento direcionado ao Egrégio Tribunal, no qual o Dr. Alberto Teixeira contesta } \\
\text { a decisão do Juiz de Direito da Comarca de Feira de Santana, alegando, inclusive, } \\
\text { que o próprio sobrenome "Motta", utilizado por Alberto, não seria o sobrenome } \\
\text { pátrio, mas, sim, o "Fróes", que ele não tinha, mas os seus irmãos sim. }\end{array}$ \\
\hline $98 \mathrm{r}$ ao $108 \mathrm{r}$ & $\begin{array}{l}\text { Trasladações da escritura do contrato antenupcial, assinada pelo Coronel Agostinho } \\
\text { Fróes da Motta e Dona Guilhermina de Almeida, e da certidão de registro do } \\
\text { nascimento de Alberto de Almeida Motta, ambas solicitadas por Eduardo Fróes da } \\
\text { Motta para contestar as afirmações daquele e a decisão do Juiz de Direito. Em } \\
\text { contrapartida, o advogado de Alberto de Almeida Motta, Dr. José Maria Neves, pede } \\
\text { vistas do processo. }\end{array}$ \\
\hline $109 \mathrm{r}$ ao $112 \mathrm{r}$ & $\begin{array}{l}\text { Contraminuta apresentada pelo advogado José Maria Neves em que este expõe } \\
\text { argumentos para o fato de o seu cliente não ter sido inserido no testamento do seu } \\
\text { pai, e também a justificativa de que o sobrenome "Motta" seria o sobrenome pátrio }\end{array}$ \\
\hline
\end{tabular}

${ }^{152}$ Como provas de sua relação com o pai e deste com a sua mãe, Alberto de Almeida Motta apresentou cartas, cartões postais, dedicatória no verso de uma fotografia do coronel endereçada por este à sua mãe, dedicatória do seu irmão, Eduardo, enderaçada ao próprio Alberto, e edital de proclamas do seu casamento, publicado no jornal da época, e no qual aparecem como seus genitores o coronel Agostinho Fróes da Motta e Dona Guilhermina de Almeida. 


\begin{tabular}{|c|c|}
\hline & $\begin{array}{l}\text { legítimo, já que as irmãs do seu cliente também o possuíam e não o "Fróes", como } \\
\text { alegado pelo herdeiro Eduardo Fróes da Motta. }\end{array}$ \\
\hline $113 \mathrm{r}$ ao $114 \mathrm{v}$ & $\begin{array}{l}\text { Trasladação do edital de proclamas do casamento de Alberto de Almeida Motta, no } \\
\text { qual aparece o nome do coronel falecido como o seu pai. }\end{array}$ \\
\hline $115 \mathrm{r}$ ao $115 \mathrm{v}$ & Deferimento do pedido do advogado do agravado, Alberto de Almeida Motta. \\
\hline $116 \mathrm{r}$ ao $116 \mathrm{v}$ & $\begin{array}{l}\text { Declaração feita por Dona Albertina Fróes da Motta concordando com as reformas } \\
\text { que seriam feitas pelo seu irmão, Eduardo Fróes da Motta, no Casarão Fróes da } \\
\text { Motta, seguida de um termo de juntada. }\end{array}$ \\
\hline $117 \mathrm{r}$ ao $123 \mathrm{r}$ & $\begin{array}{l}\text { Termo de audiência em que compareceram as partes interessadas e escolheram como } \\
\text { avaliador dos bens do Coronel Agostinho Fróes da Motta, o senhor Valentim José de } \\
\text { Souza Junior. Ainda nesta audiência o advogado de Alberto de Almeida Motta, Dr. } \\
\text { José Maria Neves, contestou a descrição dos bens feita pelo inventariante e } \\
\text { testamenteiro do falecido, alegando, para isso, que as peças de ouro, prata e as pedras } \\
\text { preciosas não haviam sido doadas em vida pelo inventariado, como alegou o } \\
\text { inventariante, pois não havia menção dos nomes dos beneficiados, o que justificava } \\
\text { uma nova inventariação dos bens a serem partilhados, o que fez com que o } \\
\text { inventariante apresentasse uma contestação de tais alegações, o que foi, pelo Juiz, } \\
\text { indeferido. }\end{array}$ \\
\hline $124 \mathrm{r}$ ao $134 \mathrm{v}$ & $\begin{array}{l}\text { Autorização judicial para que os senhores Joaquim Honorio de Oliveira e Valentim } \\
\text { José de Souza Junior realizassem o arrolamento e a avaliação dos bens deixados pelo } \\
\text { inventariado, o que, de fato, ocorreu, seguido do termo de juntada. }\end{array}$ \\
\hline $135 \mathrm{r}$ ao $143 \mathrm{v}$ & $\begin{array}{l}\text { Procuração feita por Adalberto Alves de Farias como representante de sua esposa, } \\
\text { Adalgisa de Almeida Motta Farias, autorizando que o advogado Agnello Ribeiro de } \\
\text { Macêdo os representasse no inventário e partilha dos bens do inventariado, seguida } \\
\text { de uma alegação de que o inventariante, Eduardo Fróes da Motta, havia sonegado a } \\
\text { existência de alguns bens valiosos, os quais são novamente descritos no inventário e } \\
\text { sobre os quais Adalberto Alves de Farias pediu explicações ao inventariante. }\end{array}$ \\
\hline $144 \mathrm{r}$ ao $147 \mathrm{r}$ & $\begin{array}{l}\text { Documento apresentado por Eduardo Fróes da Motta, solicitando que a Justiça } \\
\text { realizasse uma fiscalização nas contas bancárias da firma comercial Motta e Souza, } \\
\text { situadas na Capital (Salvador-Ba), e também autorizasse a transferência dos valores } \\
\text { recebidos pela liquidação daquela firma, na qual o seu pai era sócio, para que ele os } \\
\text { administrasse. Além disso, o advogado do inventariante, Manoel Pimentel, contestou } \\
\text { todas as alegações de sonegação de bens do inventariado, apresentadas por Adalberto } \\
\text { Alves de Farias. }\end{array}$ \\
\hline $\begin{array}{l}148 \mathrm{r}, 149 \mathrm{r} \text { e } \\
149 \mathrm{v}\end{array}$ & $\begin{array}{l}\text { Formulários de pagamentos de impostos referentes a dois automóveis, pertencentes } \\
\text { ao falecido, bem como uma correção, no verso do fólio } 149 \text {, de que o automóvel } \\
\text { pertencia aos herdeiros do Coronel Agostinho Fróes da Motta e não apenas à } \\
\text { Albertina de Almeida Motta, como rasurado pelo lançador de impostos. }\end{array}$ \\
\hline $150 \mathrm{v}$ ao $154 \mathrm{r}$ & $\begin{array}{l}\text { Anexação de folhas do "Livro de Balanço da Casa Comercial de Agostinho Fróes da } \\
\text { Motta e Filho", nas quais estavam descritas as dívidas ativas e passivas dos credores } \\
\text { e devedores da empresa, bem como as entradas e saídas de fardos de fumo, dos juros, } \\
\text { das despesas da empresa, dos empréstimos feitos e dos lucros na venda de gado, entre } \\
\text { outros. }\end{array}$ \\
\hline $155 \mathrm{r}$ ao $164 \mathrm{v}$ & $\begin{array}{l}\text { Trasladação de uma certidão extraída dos fólios } 47 \text { verso ao } 87 \text { verso dos autos do } \\
\text { inventário de Dona Maximiana de Almeida Motta, a pedido do seu filho Eduardo } \\
\text { Fróes da Motta, a fim de comprovar a existência de dinheiro na conta bancária da } \\
\text { firma Motta e Souza, e a existência dos bens do Coronel Agostinho Fróes da Motta à } \\
\text { época do falecimento de sua primeira esposa. }\end{array}$ \\
\hline
\end{tabular}

Fonte: Elaborado pela pesquisadora

Ao termos acesso às informações constantes nos fólios que possuem mancha escrita, constatamos que as relações familiares não eram amistosas, principalmente depois que o Coronel Agostinho Fróes da Motta se casou com Dona Guilhermina de Almeida, acontecimento que, somado ao seu falecimento, desencadeou inúmeras contendas no seio familiar, especialmente porque os filhos do seu primeiro casamento, a saber: Dona Albertina, 
que na época do falecimento do coronel tinha 46 anos de idade, desquitada por sentença judicial e residente em Feira de Santana; o Farmacêutico Arthur, que tinha 42 anos de idade, solteiro e residente na mesma cidade; o Capitão Augusto, que tinha 38 anos de idade, casado e residente na mesma cidade; Dona Amália, que tinha 35 anos de idade, casada com o Coronel João Constantino ${ }^{153}$ Faskomy e residente em Ilhéus-BA; o Doutor Eduardo, que tinha 31 anos de idade, casado e residente em Feira de Santana; e Dona Adalgisa, que tinha 29 anos de idade, casada com o senhor Adalberto Alves de Farias e também residente na cidade de Ilhéus-BA, pareciam não ter uma boa relação com a segunda cônjuge do seu pai, conforme depoimentos de algumas testemunhas arroladas no documento.

Em outros termos, o inventário possui informações que ratificam a vontade do Coronel Agostinho Fróes da Motta, atestada em seu testamento, bem como os conflitos familiares refletidos durante o levantamento e partilha dos bens do inventariado. Sobre esses conflitos, um fato curioso que apareceu no inventário foi a contestação da partilha dos bens por parte de um dos filhos do Coronel Agostinho Fróes da Motta, o qual não foi citado no testamento do seu pai e nem por este registrado. Trata-se de Alberto de Almeida Motta que, no desenrolar do inventário, apresentou documentos pessoais, tais como bilhetes, cartões-postais, fotografias etc. trocados com o seu pai e o seu irmão, Eduardo, durante o período em que aquele morava e estudava na Capital, Salvador-BA, os quais foram anexados ao processo, a fim de comprovar as relações paterno-fraternais existentes entre ele e o seu pai, e entre ele e o seu irmão.

Essa contestação ocorreu com o intuito de provar, na Justiça, que Alberto de Almeida Motta era tão legítimo quanto os seus irmãos, frutos do primeiro casamento do seu pai com Dona Maximiana de Almeida Motta, já falecida. Assim, o desejo de reconhecimento de paternidade fez com que Alberto de Almeida Motta se envolvesse em outros processos contra os seus irmãos, já que os seus direitos, enquanto filho e herdeiro do Coronel Agostinho Fróes da Motta, lhe haviam sido negados.

Devido a isso, encontramos o seu nome em seis processos (duas ações de instrumento de agravo, três ações ordinárias e uma petição) listados no quadro 3. Naqueles documentos, Alberto de Almeida Motta não somente reclama, mas também apresenta provas que o levariam ao reconhecimento de sua paternidade, bem como de sua herança, realizando, para isso, denúncias contra o seu irmão Eduardo Fróes da Motta, justamente porque este contestou

153 É importante mencionar que, no inventário do Coronel Agostinho Fróes da Motta, esse senhor ora é denominado João Grego Faskomy, primeiro sobrenome (Grego) advindo do seu pai, ora João Constantino Faskomy, o que causa, portanto, uma discrepância no uso do seu primeiro sobrenome nos processos. 
as suas alegações, o que fez com que o inventário do patriarca dos Fróes da Motta demorasse de ser finalizado.

Contudo, apesar de apresentar provas e testemunhas a fim de obter o reconhecimento dos seus direitos enquanto filho do inventariado, os seis processos em que foi autor ou coautor se tornaram longos tanto em extensão quanto em cronologia por conta das querelas familiares que emergiram, o que nos permitiu conhecer mais sobre a figura de Alberto de Almeida Motta, que era formado, por interesse do seu pai, em Engenharia, casado com Dona Maria Carlota Falcão de Sousa Motta com quem teve filhos, residente em Feira de SantanaBA e filho de Dona Guilhermina de Almeida Motta com o Coronel Agostinho Fróes da Motta.

Apesar de serem amigos ${ }^{154}$, os irmãos Alberto de Almeida Motta e Eduardo Fróes da Motta "brigaram" judicialmente durante a feitura do referido inventário por interesses relacionados aos bens do seu pai. De um lado, Alberto de Almeida Motta contestou o testamento do pai pelo fato deste não tê-lo citado e nem tê-lo deixado herança e, devido a isso, foi levado a se envolver em alguns processos para provar, legalmente, o seu direito como filho legítimo, já que é mencionado nos documentos consultados como fruto de um relacionamento extra-conjugal à época do seu nascimento, portanto, segundo as leis que vigoravam, os filhos considerados ilegítimos não teriam direito à herança do pai. Devido a isso, Alberto de Almeida Motta buscou provar a relação existente entre ele e o seu pai desde o tempo em que estudava no Colégio das Victórias, em Salvador-BA, até a morte do seu genitor, e atestou que, como na época da produção do inventário a sua mãe e o seu pai já haviam se casado judicialmente, ele teria, portanto, o direito legal de receber o que lhe coubesse como herança.

De outro, Eduardo Fróes da Motta usou argumentos e outras provas para justificar o não recebimento da herança do seu irmão, incluindo-se nestes argumentos o próprio sobrenome Fróes, que Alberto de Almeida Motta não possuía. Apesar das alegações de Eduardo Fróes da Motta, Alberto de Almeida Motta conseguiu provar que era filho do Coronel Agostinho Fróes da Motta, argumentando até mesmo que o dito sobrenome Fróes não era um sobrenome legítimo, haja vista que no próprio nome de batismo do seu pai, este recebera de seu avô José Borges da Motta o sobrenome Motta e não Fróes, atestando que o antropônimo Motta era, de fato, uma herança de família e não o Fróes, como alegado por Eduardo Fróes da Motta.

\footnotetext{
${ }^{154}$ Segundo Alberto de Almeida Motta, a sua relação com Eduardo Fróes da Motta não era apenas de irmãos, mas de amigos, conforme consta nos processos lidos/pesquisados.
} 
Diante dessa informação, emergida da leitura do inventário, decidimos investigar a origem do Fróes no sobrenome do Coronel Agostinho Fróes da Motta e encontramos duas possíveis explicações, a partir de Reis (2012) e Rodrigues (2016), a saber: quando o Coronel Agostinho Fróes da Motta, ainda jovem, foi enviado por seus pais para morar em Feira de Santana, ele foi acolhido por um casal português que tinha uma mercearia. Nesta, o Coronel Agostinho Fróes da Motta começou a trabalhar nas vendas para ajudar os seus benfeitores. Tornou-se bem sucedido enquanto negociante e passou a ser chamado de "Feroz" dada à sua perspicácia nos negócios, mas, por conta do sotaque português do casal, o apelido Feroz passou a ser sonorizado como Fróes, tornando-se, depois disso, uma marca da personalidade do coronel nos negócios. A partir disso, acredita-se que ele tenha passado a adotar em seu nome o sobrenome Fróes, que, a partir de então, tornou-se parte do sobrenome patronímico (Fróes da Motta) conhecido em Feira de Santana-BA, nas regiões vizinhas e nas cidades em que ele passou a ser reconhecido.

Uma segunda explicação seria a de que o Coronel Agostinho Fróes da Motta possuía um passado relacionado à escravidão e que, possivelmente, os seus pais, José Borges da Motta e Maria Valéria de Jesus, teriam sido escravos ou ex-escravos e que, no batismo do filho Agostinho, os pais teriam sentido a necessidade de agradecer ao senhor de escravos por tê-los libertado ou alforriado o seu filho, adotando, como prova de gratidão, o sobrenome Fróes no registro de batismo de Agostinho Fróes da Motta. Entretanto, por falta de dados documentais que atestem a existência de um senhor de escravos com esse sobrenome naquele período ou o registro de batismo do próprio Agostinho Fróes da Motta, não se sabe se uma ou nenhuma das explicações seja verídica.

Ainda sobre os processos em que Alberto de Almeida Motta se envolveu, sabe-se que, mesmo depois de ter provado ser filho do Coronel Agostinho Fróes da Motta, ele, em associação com o seu irmão farmacêutico, Arthur Fróes da Motta, solicitou a instauração de uma ação ordinária contra o seu irmão Eduadro Fróes da Motta, alegando que este havia sonegado impostos, a fim de não prestar as devidas contas das finanças advindas dos bens do seu pai, já falecido. À essa altura, continuavam na Justiça processos contra Eduardo Fróes da Motta por conta dos bens herdados do seu pai e administrados por ele, o que tornou cada vez mais difícil a relação de Alberto de Almeida Motta com Eduardo Fróes da Motta e deste com Arthur Fróes da Motta, por acreditarem que estavam sendo lesados pelo irmão mais novo. Assim, os documentos em que Alberto de Almeida Motta foi parte envolvida nos permitem entender, mais profundamente, a sua relação com os demais membros da Família Fróes da 
Motta, haja vista o conteúdo de cada um deles, descritos nas fichas codicológicas expostas na terceira seção desta tese.

Em síntese, as informações extraídas dos dois testamentos somadas às do inventário nos permitiram identificar as relações familiares constantes no corpus, a partir das quais refletimos sobre a importância daquelas para conhecermos a história da família Fróes da Motta e da cidade de Feira de Santana-BA, bem como a disposição geográfica dos imóveis que, em sua grande maioria, estavam situados nas principais ruas da cidade, o momento histórico vivido por Feira de Santana-BA e pelos Fróes da Motta, as leis vigentes no início do século XX e a língua, atestada nos documentos, que permitem identificarmos diversos aspectos linguísticos, dentre os quais o léxico e, mais especificamente, o vocabulário dos escreventes, a partir do qual pudemos depreender o conteúdo dos documentos, que nos tem oportunizado conhecer aquele momento, aquelas pessoas e aquela Feira de Santana-BA, atualmente distante de nós.

4.3.3.1 Sobre os laços familiares da Família Fróes da Motta: construindo árvores genealógicas

Partindo das informações extraídas dos documentos listados no quadro 3, do livro Árvore genealógica da Família Fróes da Motta (1991) de autoria de Maria Marta Fróes da Motta Oliveira ${ }^{155}$, das obras lidas e listadas na segunda seção e de outros documentos consultados no CEDOC/UEFS ${ }^{156}$, decidimos elaborar duas árvores genealógicas ${ }^{157}$, das quais a segunda está subdividida em mais três partes, haja vista a quantidade de membros existentes na família do Coronel Agostinho Fróes da Motta. Assim sendo, a primeira árvore genealógica foi elaborada com os nomes dos membros da família de Dona Maximiana de Almeida Motta e a segunda, subdividida em mais três partes, com os nomes dos ascendentes e descendentes do

\footnotetext{
${ }^{155}$ Neta de Eduardo Fróes da Motta e, portanto, bisneta de Agostinho Fróes da Motta.

${ }^{156}$ Também extraímos informações da ação de desquite de Igmedio Evangelista de Almeida e de Dona Albertina Motta de Almeida, lavrada em 1940, com 19 fólios e armazenada no arquivo sob a cota: Estante 09, Caixa 237 e Documento 5037; do inventário de Floriano Pereira de Aguiar, lavrado em 1921, com 14 fólios e armazenado sob a cota: Estante 05, Caixa 123 e Documento1657; do inventário de Tertuliano José de Almeida, lavrado entre 1930 e 1940, com 153 fólios e armazenado sob a cota: Estante 03, Caixa 79 e Documento 970; e da ação de lesão corporal de Almerinda de Almeida Motta contra o seu marido, Augusto Fróes da Motta, lavrada em 1922, com 54 fólios e armazendo sob a cota: Estante 05, Caixa 121 e Documento 2431, os quais nos ajudaram a produzir as árvores genealógicas.

${ }^{157}$ Vale destacar que todas as árvores genealógicas, apresentadas nas próximas subseções, foram construídas a partir das informações a que tivemos acesso ao longo da nossa pesquisa, o que quer dizer que há a possibilidade de existirem outros membros que não constam nas referidas árvores pelo fato de não terem sido citados nos materiais consultados.
} 
Coronel Agostinho Fróes da Motta, com o intuito de sistematizar os vínculos familiares identificados durante a leitura dos documentos. 
Organograma 4 - Árvore genealógica de Maximiana de Almeida Motta

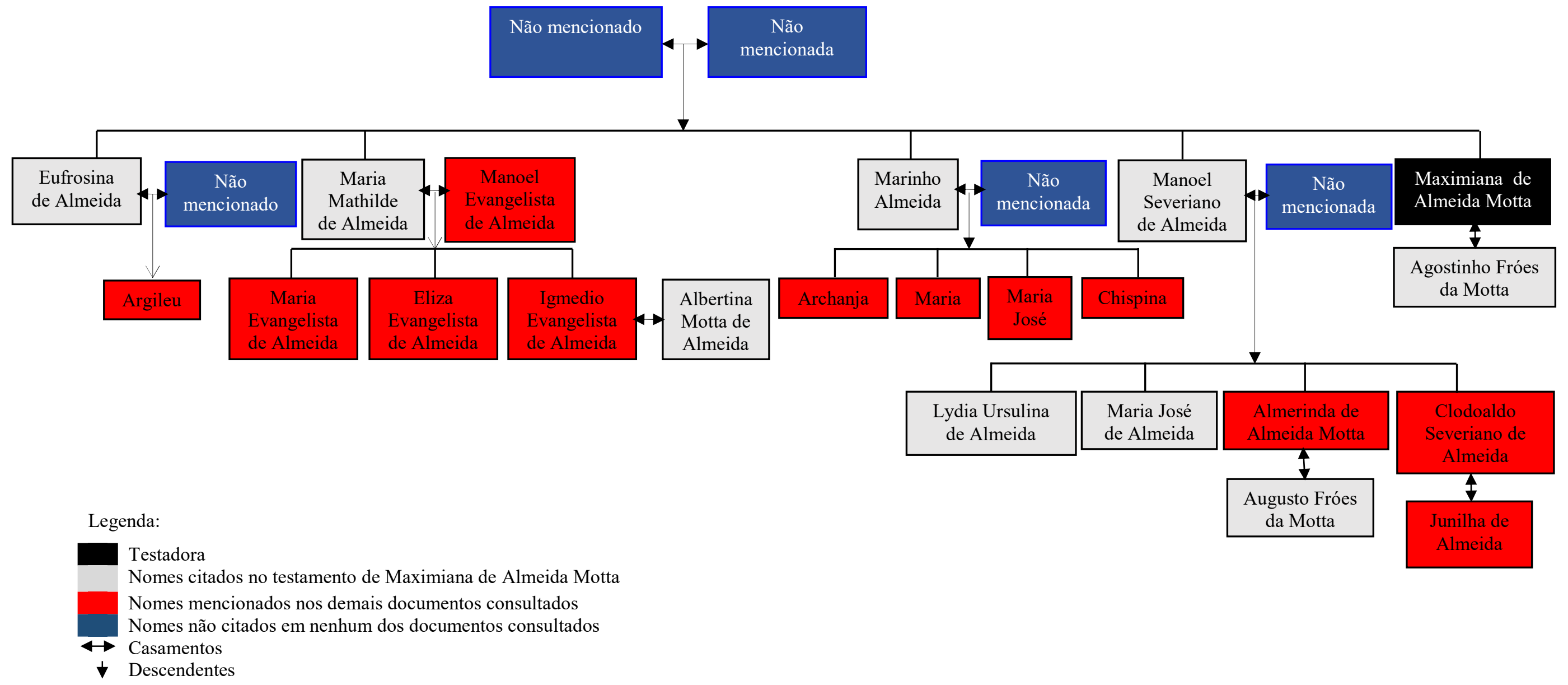


Organograma 6 - Continuação da árvore genealógica de Agostinho Fróes da Motta

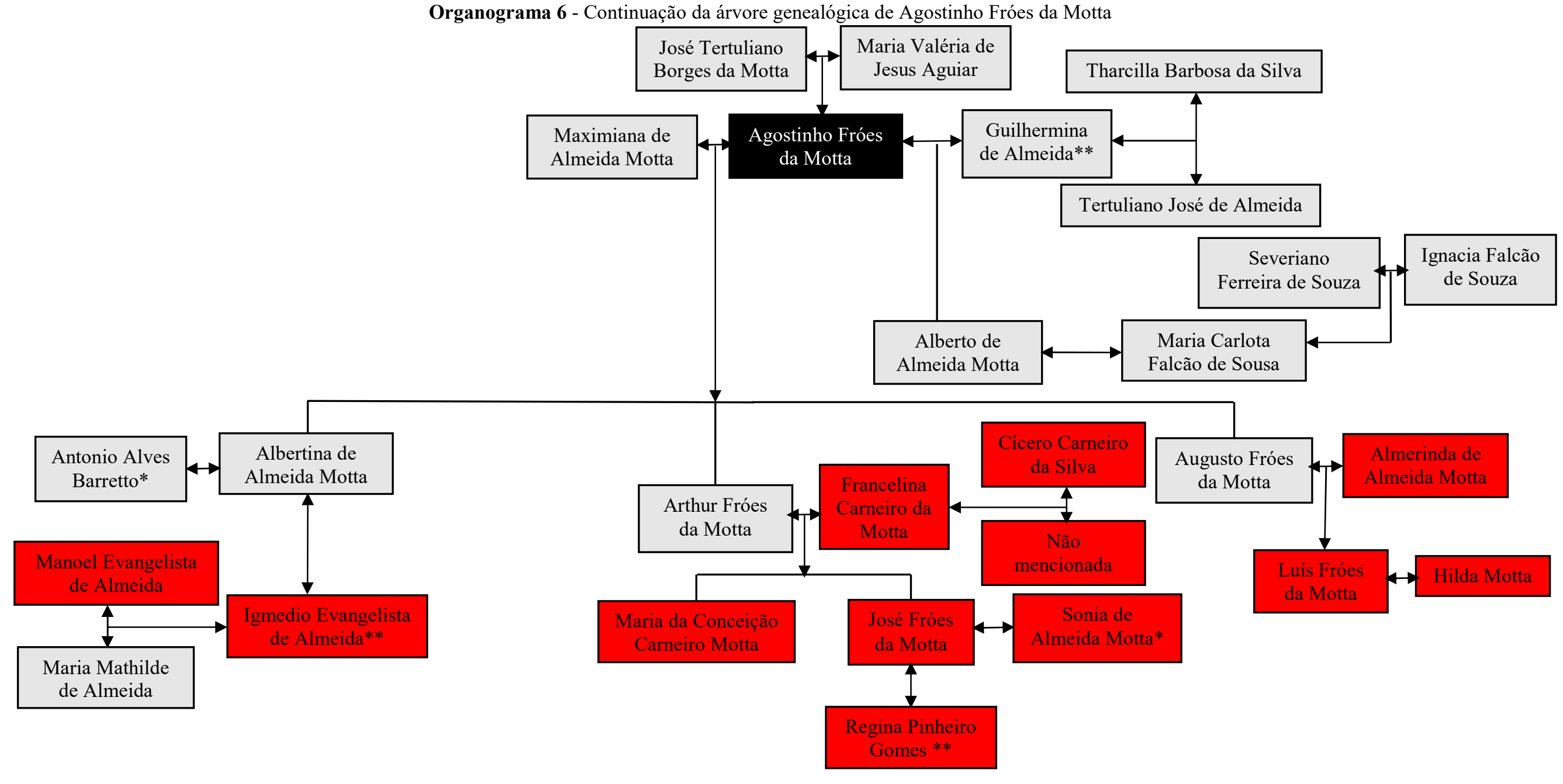


Organograma 7 - Continuação da árvore genealógica de Agostinho Fróes da Motta

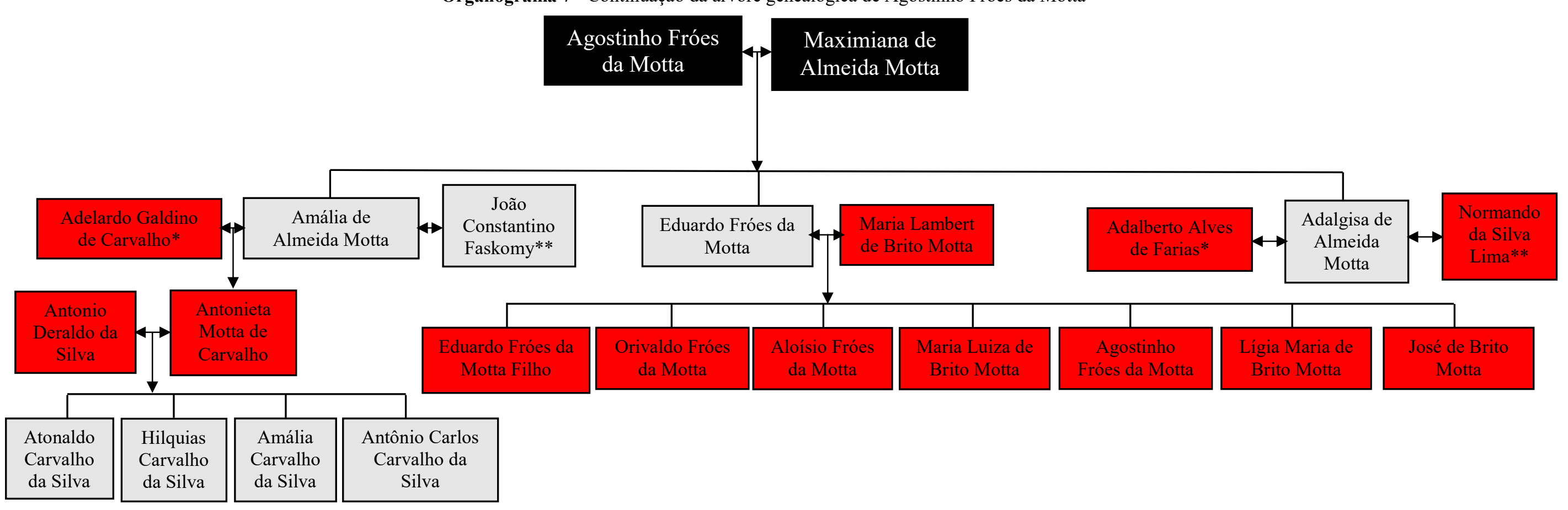


Organograma 8 - Continuação da árvore genealógica de Agostinho Fróes da Motta

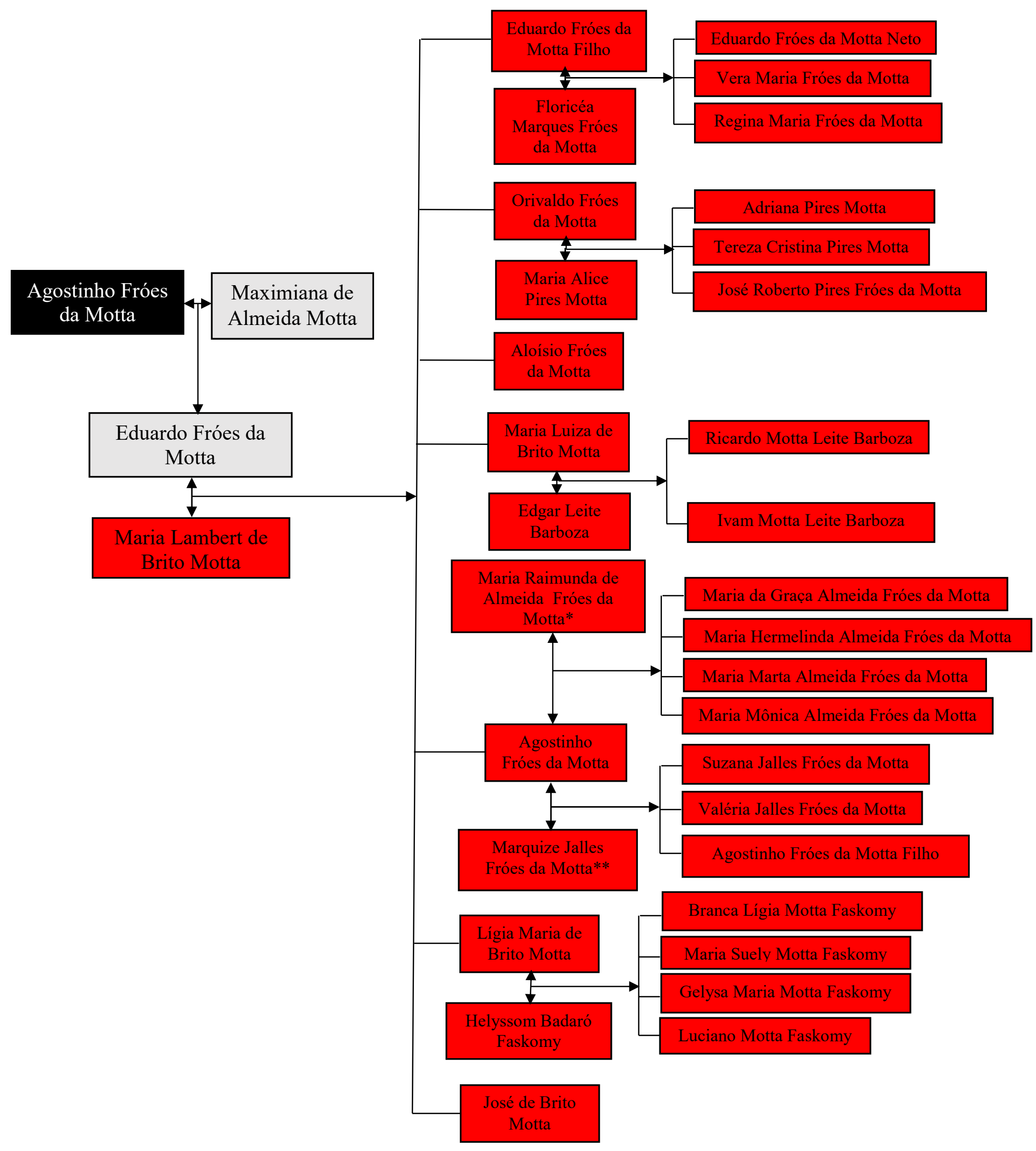


Sobre esses organogramas, destacamos alguns aspectos interessantes, emergidos da leitura dos documentos. No organograma 1 é pertinente ressaltar que no testamento de Dona Maximiana de Almeida Motta foram beneficiadas quatro filhas de Marinho de Almeida, duas filhas de Maria Mathilde de Almeida e o único filho de Eufrosina de Almeida, mas os seus nomes não foram citados, o que só ocorreu nos demais manuscritos lidos. Outro aspecto relevante é que os nomes de alguns membros não apareceram em nenhum dos documentos consultados, como foram os casos dos pais da testadora, do cônjuge de Eufrosina de Almeida e das esposas de Marinho de Almeida e Manoel Severiano de Almeida, sobre os quais o fato mais curioso foi que a testadora não citou os nomes dos seus pais em seu testamento, o que se configura um aspecto, no mínimo, peculiar.

No cronograma 2 boa parte dos nomes dos membros não citados no testamento e nem no inventário do Coronel Agostinho Fróes da Motta foi identificada a partir dos demais documentos consultados, sem os quais não teríamos dados suficientes para construir as árvores genealógicas. Outro ponto importante é que no testamento do Coronel Agostinho Fróes da Motta há a menção dos nomes dos seus pais como José Borges da Motta e Maria Valéria de Jesus, os quais são apontados por Oliveira (1991) como José Tertuliano Borges da Motta e Maria Valéria de Jesus Aguiar, correção que justifica o porquê de os irmãos do falecido coronel terem o sobrenome Aguiar, mas não explica o motivo de o coronel Agostinho Fróes da Motta não tê-lo.

Sobre o filho mais velho dos pais do Coronel Agostinho Fróes da Motta, descobrimos no inventário de Floriano Pereira de Aguiar o nome de sua esposa, Jardelina Tourinho de Aguiar, que declarou ter tido quatro filhos com o falecido, a saber: Auta Tourinho de Aguiar, Theopompo Tourinho de Aguiar, Carlos Tourinho de Aguiar e Theodolina Tourinho de Aguiar, o que nos leva a saber que Fortunata Tourinho de Aguiar era - de acordo com o testador Agostinho Fróes da Motta “[...] minha/ sobrinha Fortunata, filha do mesmo meu/ fallecido irmão Floriano Pereira de Aguiar" (TESTAMENTO DE AGOSTINHO..., 1922, f. 3r, 1. 119-121) - filha de Floriano Pereira de Aguiar, mas conjecturamos que ela fosse filha do referido irmão com outra mulher, cujo nome não foi mencionado. Ainda no testamento do Coronel Agostinho Fróes da Motta há uma quantia destinada à sua irmã, Romana Chagas, a qual é nominada por Oliveira (1991) como Romana Pereira de Aguiar, sobrenome compatível com o dos demais irmãos, o que não explica, contudo, a origem do sobrenome "Chagas", citado no testamento do coronel.

No organograma 3 inserimos o Coronel Tertuliano José de Almeida como o pai de Dona Guilhermina de Almeida por levarmos em conta as afirmações de algumas 
testemunhas ${ }^{158}$ constantes em alguns processos lidos. Contudo, ao consultarmos o inventário de Tertuliano José de Almeida identificamos o nome de sua esposa, Eliceria Moreira de Almeida, que declarou ter tido quatorze filhos, dos quais cinco filhas foram beneficiadas no testamento do Coronel Agostinho Fróes da Motta, a saber: Nerina de Almeida Vital - casada com Pedro Carneiro Vital, irmão do Tabelião João Carneiro Vital - Junilha Moreira de Almeida - casada com Clodoaldo Severiano de Almeida, comerciante e dono de padaria, irmão de Almerinda de Almeida Motta, esposa do terceiro filho do Coronel Agostinho Fróes da Motta, Augusto Fróes da Motta - Almira Moreira de Almeida, Ritta Moreira de Almeida e Maria Moreira de Almeida, denominada pelo Coronel Agostinho Fróes da Motta como Mariinha, em seu testamento.

No organograma 3 também observamos que Albertina de Almeida Motta casou e se desquitou duas vezes: a primeira de Antonio Alves Barretto, que faleceu logo depois do desquite, e a segunda de Igmedio Evangelista de Almeida, sobrinho de Dona Maximiana de Almeida Motta e com os quais não teve filhos. Além desses, Isaura Teixeira da Silva é mencionada, no testamento de Albertina de Almeida Motta, como a companheira desta. Contudo, apenas essa informação não é suficiente para afirmarmos que as duas tiveram um relacionamento homoafetivo ou que dividiram o mesmo teto, cuidando uma da outra, haja vista não termos encontrado, até o momento, nenhum outro documento que comprovasse ou mencionasse o vínculo daquelas e nem o nome da própria Isaura Teixeira da Silva nos catálogos do acervo do CEDOC/UEFS. Logo, a natureza do relacionamento delas se mantém, até este momento, desconhecida, o que impossibilita asseverarmos que a árvore genealógica de Albertina de Almeida Motta esteja, de fato, completa.

No organograma 4 visualizamos a prole de Eduardo Fróes da Motta, bem como o nome da única filha de Amália de Almeida Motta com Adelardo Galdino de Carvalho e os nomes dos cônjuges de Adalgisa de Almeida Motta, que não teve filhos. No organograma 5 demos destaque à genealogia de Eduardo Fróes da Motta, constituída pelos seus filhos, noras, genros e netos, estes últimos também constituíram as suas próprias famílias, conforme Oliveira (1991). Contudo, não as elencamos pelo fato de termos dado destaque apenas às primeiras gerações, que descenderam do Coronel Agostinho Fróes da Motta e de suas esposas.

\footnotetext{
${ }^{158}$ Falaremos sobre as afirmações dessas testemunhas na próxima subseção.
} 


\subsubsection{Descrição do perfil socioprofissional dos sujeitos envolvidos no processo de produção do corpus}

Ao refletirmos sobre os laços familiares, de compadrio e de amizade existentes entre os indivíduos constantes nos documentos a que tivemos acesso, optamos por dedicar esta subseção aos "sujeitos" mencionados como partes interessadas, citadas ou testemunhas nos processos, cujas informações centrais se referem ao clã Fróes da Motta. Em outras palavras, referimo-nos aos antropônimos ${ }^{159}$ que, de forma indireta, contribuíram para a produção do corpus.

Assim, além dos sujeitos considerados protagonistas dos textos (Agostinho Fróes da Motta, Maximiana de Almeida Motta, Albertina de Almeida Motta, Eduardo Fróes da Motta, Adalgisa de Almeida Motta, Amalia da Motta Faskomy, Augusto Fróes da Motta, Arthur Fróes da Motta, Guilhermina de Almeida Motta e Alberto de Almeida Motta) há também aqueles, dentre os quais podemos mencionar os senhores Antonio Alves Barretto, Estanislau Alves Barretto, João Constantino Faskomy, Adalberto Alves de Farias, Tertuliano José de Almeida, Manoel Portugal dos Santos, Amadeu Saback de Oliveira, Agnello Cohim Pacheco, Antonio Onofre Carneiro, Valentim José de Souza Junior, Hermillo Dias de Carvalho, Epiphanio José de Souza, João Simões Ferreira, Arthur de Assis, Oscar do Espirito Santo, Joaquim Anacleto de Oliveira, Juvencio Erudilho da Silva Lima, Quintiliano Martins da Silva, José Alves Boaventura, Leolindo dos Santos Ramos, Pedro Rodrigo do Lago, Coronel Bernardino da Silva Bahia e Auto Esmeraldo dos Reis ${ }^{160}$, que aparecem sequencialmente, e em segundo plano, no conteúdo dos documentos editados.

A partir do levantamento desses antropônimos, elencamos informações, obtidas dos manuscritos, dissertações e livros consultados e listados nas referências desta tese, a fim de conhecermos as relações que ajudaram a construir as narrativas constantes nos processos judiciais, cujos interessados foram os Fróes da Motta, o que pode nos ajudar a compreender, de forma ampla, o processo de produção de tais textos, lavrados no início do século XX, na cidade de Feira de Santana-BA.

\footnotetext{
159 Tomemos nota de que os antropônimos são classificados como os nomes próprios de pessoas, incluindo-se nestes os prenomes e os sobrenomes. Dentro das Ciências do Léxico, mais especificamente dentro da Lexicologia, há uma subárea denominada Onomástica, que se dedica a estudar os nomes próprios de pessoas (antropônimos) e os de lugares (topônimos), buscando-se descrever como se dão esses processos de nomeação e a motivação para a escolha dos nomes. Assim, utilizamos o termo antropônimos para sinalizar que, nesta subseção, focalizamos os nomes próprios das pessoas que aparecem como contribuidores para a produção do corpus da pesquisa.

160 Apresentamos ao longo desta subseção algumas figuras para ilustrar trechos e assinaturas desses antropônimos. Entretanto, listamos apenas uma pequena quantidade para não sobrecarregar o texto.
} 
Logo, ao estabelecermos as relações entre os "sujeitos" processuais, almejamos responder, ao final desta subseção, os seguintes questionamentos: quem foram aquelas pessoas? Qual a sua relação com os Fróes da Motta? E qual a sua contribuição para o processo de produção de tais textos? Para isso, contudo, começamos com o antropônimo Antonio Alves Barretto, sobre o qual levantamos as seguintes informações.

Antonio Alves Barretto foi casado, em primeiras núpcias, com uma das filhas do Coronel Agostinho Fróes da Motta, Albertina da Motta Barretto, com quem viveu durante 13 anos e com quem não teve filhos. Após a "separação de corpos" 161 , Antonio Alves Barretto voltou a morar com o seu pai, Estanislau Alves Barretto, que foi o seu inventariante e herdeiro.

O nome de Antonio Alves Barretto aparece em 4 dos documentos cíveis que selecionamos do acervo do CEDOC/UEFS, a saber: 1) na ação de instumento de agravo interposta por Dona Maximiana de Almeida Motta (na qual ele foi apenas citado como cabeça de sua mulher), 2) na ação de desquite movida por sua esposa, 3) no inventário de seu sogro (no qual foi citado como representante de sua mulher, herdeira do inventariado) e 4) no seu próprio inventário, cujo inventariante foi o seu pai e uma das herdeiras a sua então ex-esposa, Albertina da Motta Barretto. Cabe ressaltar que o Coronel Agostinho Fróes da Motta teve participação direta no processo de desquite de Albertina da Motta Barretto, haja vista que ele alegou cuidar dos direitos de sua filha, pagando, para isso, o advogado Agnello Ribeiro de Macêdo, a fim de agilizar o processo de desquite.

Particularmente, é válido dizer que a participação de Antonio Alves Barretto nesses processos é um indício de sua franca atuação como cabeça do casal e, depois, como ex-marido que buscava se certificar de que o fim do seu casamento não seria financeiramente prejudicial para ele. Evidência disso se encontra no quarto documento em que ele foi a parte principal, mais especificamente, o "sujeito" inventariado de um inventário, cujo maior beneficado foi o seu pai, o Major Estanislau Alves Barretto, no qual há a afirmação de que Antonio Alves Barretto falecera em 10 de maio de 1924, deixando como seu herdeiro e inventariante o referido pai, para quem foram legados vários imóveis adquiridos após o seu desquite judicial com Dona Albertina da Motta Barretto. A partir da ficha de identificação, exposta a seguir, é possível notar que se trata de um inventário, lavrado em 1925, com 11 fólios escritos no recto e verso.

\footnotetext{
${ }^{161}$ Termo utilizado na ação de desquite, descrita na terceira seção desta tese e cujas partes interessadas foram Antonio Alves Barretto e Albertina da Motta Barretto.
} 
Figura 105 - Ficha de identificação do inventário de Antonio Alves Barretto, com detalhe para a sua ficha de identificação
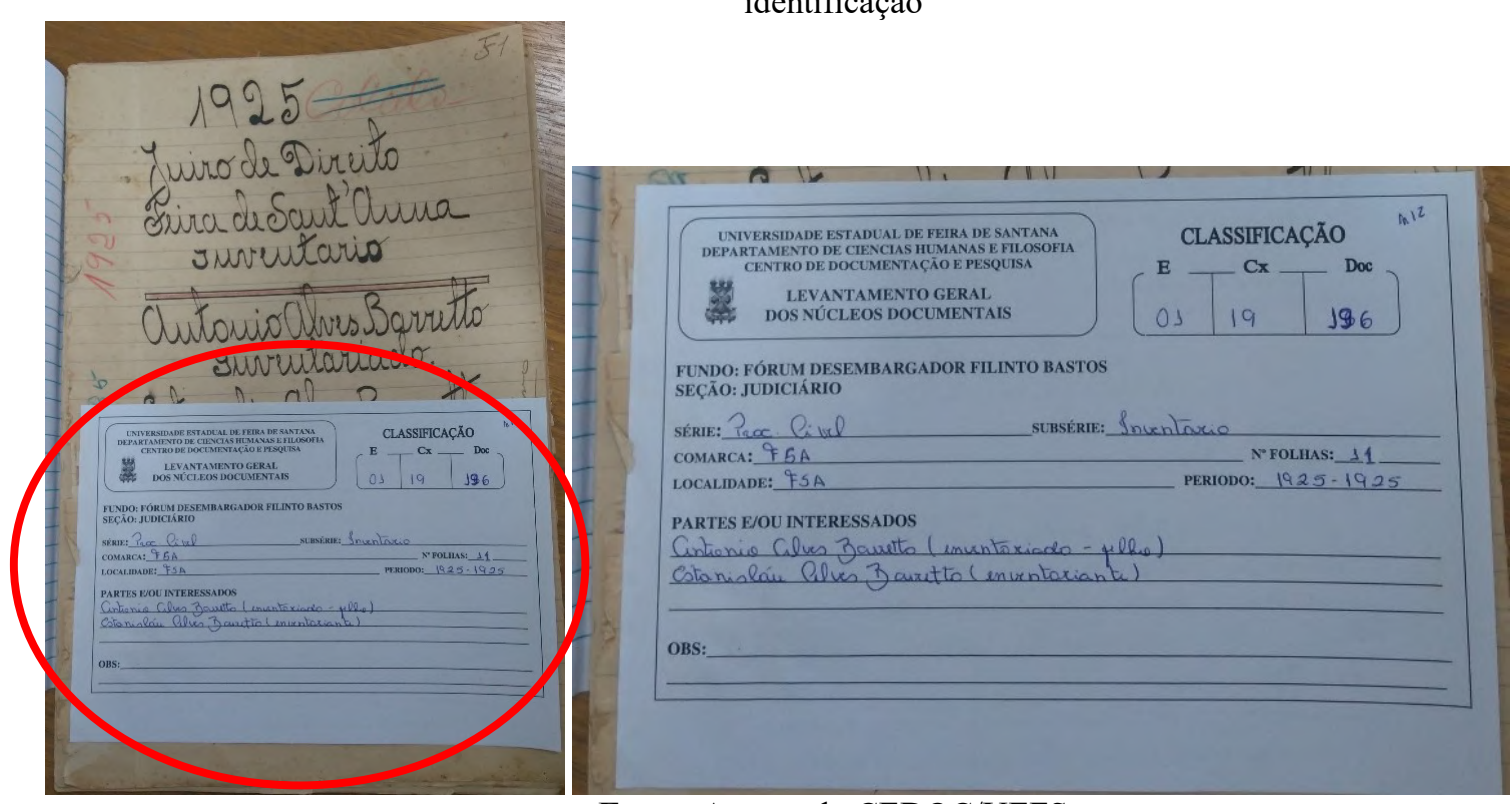

Fonte: Acervo do CEDOC/UEFS

Em outros documentos, constatamos que, do ponto de vista biográfico, Antonio Alves Barretto possuía 45 anos de idade, era comerciante, dono de imóveis no Centro da cidade e residente em Feira de Santana-BA, bem como tinha a patente de Capitão e também possuía instrução escolar dada à sua razoável habilidade na escrita alfabética, cuja letra cursiva é levemente inclinada para a direita, com ausência de cursus e letras monolíticas em alguns trechos, uso de módulo pequeno, respeito de empaginação da caixa de escrita e desvio de regramento ideal na margem direita do fólio por ele escrito (MARQUILHAS, 2000), características verificadas, por exemplo, na procuração ${ }^{162}$ feita para o seu advogado na época em que o seu processo de desquite ocorria, a qual se encontra exposta na figura seguinte.

\footnotetext{
$162 \mathrm{O}$ teor desta procuração é o seguinte: "Procuração | Eu, Antonio Alves Barretto, com- | merciante, casado, domiciliado | e residente n'esta Cidade da Feira $\mid$ de Sant'Anna, termo e comarca $\mid$ de egual nome deste estado da | Bahia, nomeio e constituo meu | advogado e procurador judicial | o Doutor José Maria Neves, advogado, | casado, domiciliado e residente | n'esta Cidade, com escriptorio á | rua Barão de Cotegipe numero 15, espe- | cialmente para me defender na $\mid$ acção de desquite que injusta $\mid$ e illegalmente propoz contra mim $\mid$ minha mulher Albertina da Motta | Barretto, podendo seguil-a em | todos os seus termos até sentença | final, e sua execução uzar dos | recursos legais e acompanhal-os em | qualquer instancia ou Tribunal, | dar de suspeito a quem o fiz, pra- | ticar todos os actos precisos ao bom $\mid$ desempenho. Deste mandato, inclu- $\mid$ sive qualquer procedimento judici- | ario posterior à sentença quando | passada em julgado e obstabelecer | esta em prova lhe convier com reser | va de poderes ou sem ella e revogal-os | querendo. Honerei por valido e firme | quanto fiser meu dito procurador ou | Substabelecido | Feira de Sant'Anna 26 de Fevereiro de 1920. | Antonio Alves Barretto" (AÇÃO DE DESQUITE..., f. 23r).
} 
Figura 106 - Procuração feita por Antonio Alves Barretto para o seu advogado, com detalhe para a sua assinatura com gancho

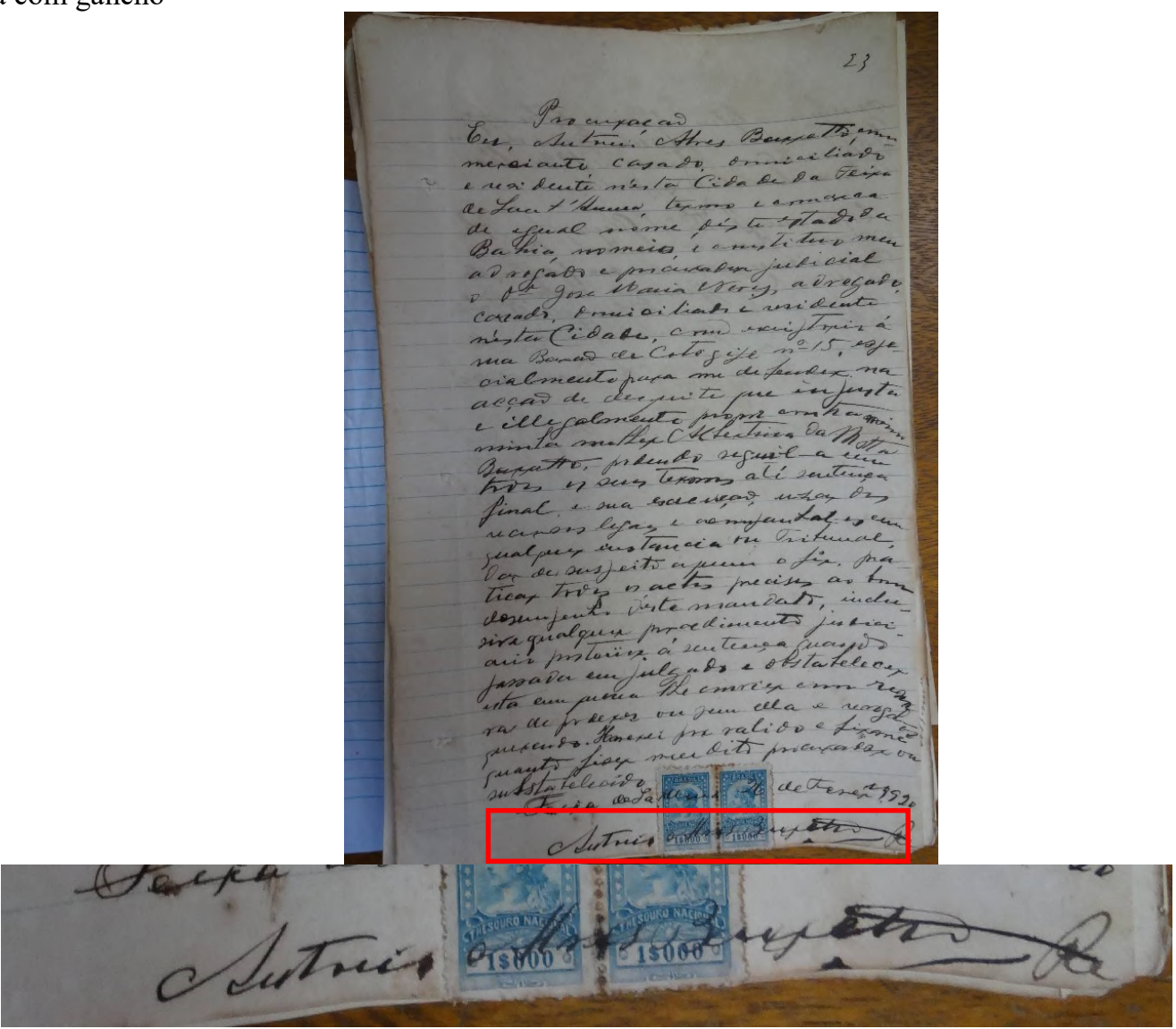

Fonte: Acervo do CEDOC/UEFS

Sobre o pai de Antonio Alves Barretto, é importante começarmos pela sua genealogia para entendermos as relações familiares estabelecidas com o clã Fróes da Motta para, em seguida, conhecermos mais sobre esse "sujeito".

Organograma 9 - Árvore genealógica de Estanislau Alves Barretto

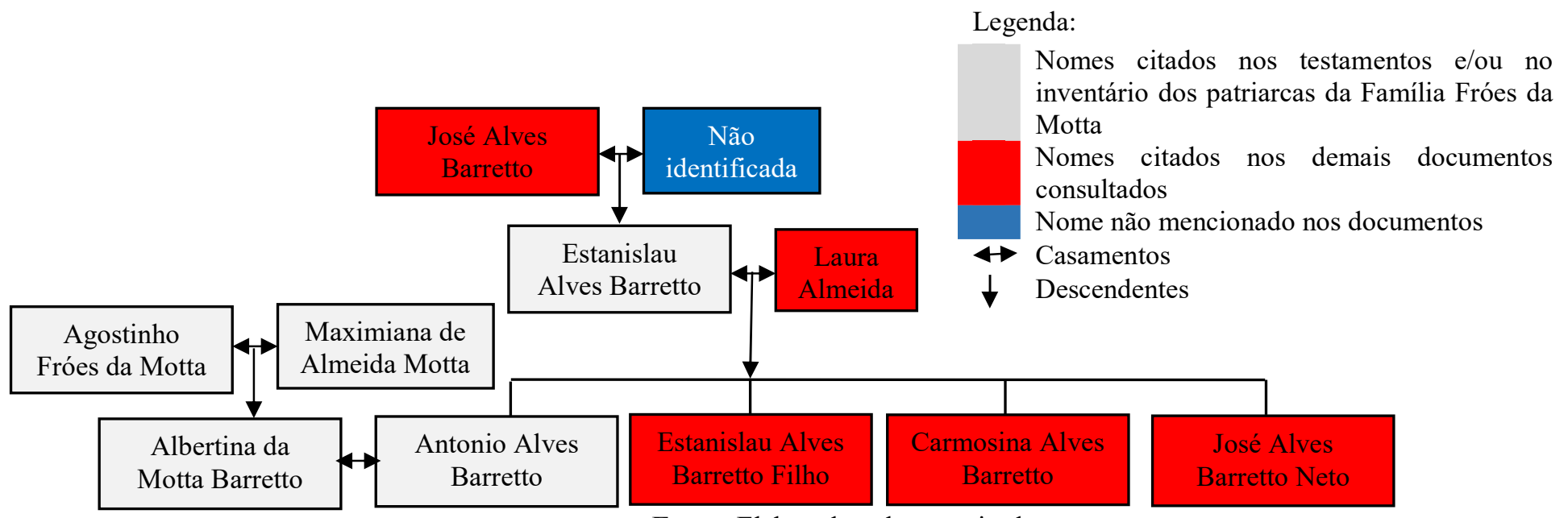

Fonte: Elaborado pela pesquisadora 
Dos quatro filhos, Estanislau Alves Barretto Filho foi o único nomeado Guarda Municipal, em 4 de janeiro de 1916, durante a gestão do Intendente Agostinho Fróes da Motta, com quem o seu pai, Estanislau Alves Barretto, estabeleceu uma relação de amizade, sendo inclusive padrinho de batismo de um dos filhos de Agostinho Fróes da Motta, o engenheiro Alberto de Almeida Motta. Do ponto de vista biográfico, Estanislau Alves Barretto foi major e descrito profissionalmente como negociante e proprietário de açougue, e então viúvo no inventário do seu amigo, Agostinho Fróes da Motta, no qual foi a primeira testemunha convocada para falar sobre o que sabia sobre a paternidade do seu afilhado, haja vista ter sido um amigo confidente do inventariado, como atestado no excerto do seu depoimento ${ }^{163}$, por ele assinado, no referido inventário.

Figura 107 - Trecho do depoimento e assinatura pessoal do Major Estanislau Alves Barretto nos fólios 67v e 69v do primeiro volume do inventário do Coronel Agostinho Fróes da Motta (1922)
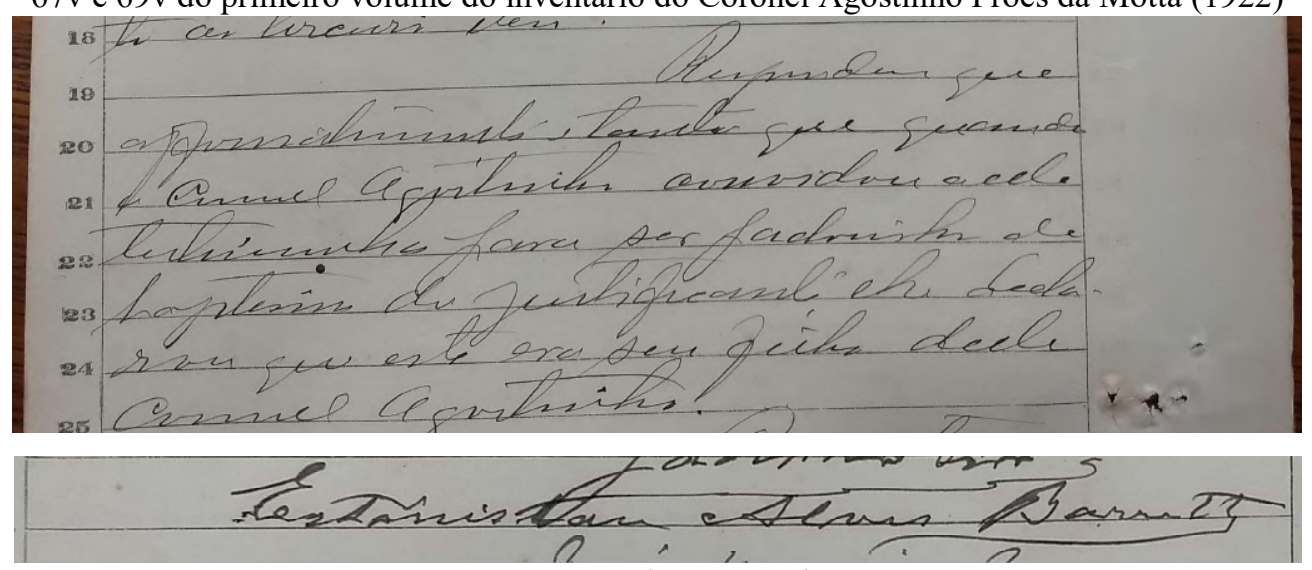

Fonte: Acervo do CEDOC/UEFS

Enquanto amigo do Coronel Agostinho Fróes da Motta, Estanislau Alves Barretto foi apontado por uma das testemunhas, David Sebastião Franco, da ação ordinária de filiação e petição de herança (1922-1927) solicitada por Alberto de Almeida Motta, como autor do rapto de Dona Guilhermina de Almeida, enquanto outras testemunhas do mesmo processo o apontaram apenas como ajudante de Agostinho Fróes da Motta no feito, que tornou a raptada sua "amante, teúda e manteúda" e mãe de Alberto de Almeida Motta, para a qual Estanislau Alves Barretto organizou uma casa onde ela moraria como "amázia" do seu amigo Agostinho Fróes da Motta.

Do ponto de vista político, tanto Estanislau Alves Barretto quanto os seus dois filhos, Antonio Alves Barretto e Estanislau Alves Barretto Filho, aparecem como eleitores em 1911.

\footnotetext{
${ }^{163}$ Neste excerto do depoimento do major Estanislau Alves Barretto, foi afirmado que Alberto de Almeida Motta era filho de Agostinho Fróes da Motta e que a testemunha sabia disso, pois “[...] o Coronel Agostinho convidou a elle | testimunha para ser padrinho de | baptismo do justificante lhe decla- | rou que este era seu filho delle | Coronel Agostinho." (IAFM, 1922, f. 67v, 1. 3231-3235).
} 
E, nas eleições de 13 de novembro de 1927, Estanislau Alves Barretto foi eleito primeiro Juiz de Paz da Cidade de Feira de Santana-BA, cargo assumido em 14 de fevereiro de 1928. Esse dado se torna importante para entendermos que, no período em que os documentos foram produzidos, os Juízes de Paz eram, assim como os intendentes e conselheiros municipais, eleitos pelos eleitores que também ocupavam cargos públicos.

Sobre o terceiro antropônimo, João Constantino Faskomy - também chamado de João Grego Faskomy nos testamentos dos patriarcas da Família Fróes da Motta - foi casado com Dona Amália da Motta Faskomy, com quem propôs uma ação de instrumento de agravo (1918-1919), na qual contestaram a deserdação feita pelos pais daquela. Na referida ação, há a menção de que ele era brasileiro naturalizado, nascido na Síria, funcionário público e residente em Ilhéus-BA, e "cabeça de sua mulher", sendo, portanto, representante legal desta no inventário do seu pai e em outros processos judiciais.

Também é declarado nos documentos que João Constantino Faskomy era coronel, o que nos indica que ele possuía influência política na cidade, além de ter sido declarado como segundo cônjuge de Amália da Motta Faskomy, que se casou, em primeiras núpcias, com o senhor Adelardo Galdino de Carvalho, com quem fugiu de casa e se casou sem a anuência dos pais. Por conta desse fato, a jovem foi deserdada em um processo de deserdação, listado no quadro 3.

Outro aspecto interessante sobre João Constantino Faskomy é que ele foi uma figura importante no contexto de produção dos processos em que o seu nome e/ou o de sua esposa apareceu(ram), já que em todos aqueles ele surge como um marido interessado em defender os interesses legatários de sua esposa, como ocorreu, por exemplo, na ação de instrumento de agravo proposta por ele entre 1918 e 1919, momento em que começava a ocorrer a partilha dos bens de sua falecida sogra, Dona Maximiana de Almeida Motta, e no inventário desta sobre o qual a sua esposa conseguiu receber a sua parte, após várias audiências nos tribunais.

Outros processos em que ele também é mencionado como parte interessada são: na ação ordinária de filiação e petição de herança, requerida por Alberto de Almeida Motta e lavrada entre 1922 a 1927; na petição solicitada por Adalberto Alves de Farias, na qual este exige o devido encerramento da firma comercial Agostinho Fróes da Motta e Filho, lavrada entre 1923 a 1928, cujos interessados foram todos os herdeiros; na ação de espólio dos bens do Coronel Agostinho Fróes da Motta, lavrada entre 1928 e 1929, na qual João Constantino Faskomy alegou que o seu falecido sogro vendeu indevidamente uma casa localizada em Santa Bárbara-BA, que pertencia à sua esposa como parte da herança recebida da partilha do inventário da sua sogra; e na petição solicitada por Adalberto Alves de Farias e Arthur Fróes 
da Motta contra Eduardo Fróes da Motta, lavrada em 1927, na qual os apelantes solicitaram a finalização do inventário do Coronel Agostinho Fróes da Motta, sob pena de o inventariante ser retirado do cargo. Logo, como se tratava de uma das partes interessadas, João Constantino Faskomy nomeou, em um dos processos, o advogado Agnello Ribeiro de Macêdo para defender os seus direitos e os da sua esposa em uma das petições, como pode ser observado na procuração feita a próprio punho por aquele e exposta a seguir.

Figura 108 - Procuração ${ }^{164}$ e assinatura, com laçada, de João Constantino Faskomy, no fólio 514r/v da petição solicitada por Adalberto Alves de Farias e Arthur Fróes da Motta (1927-1930)

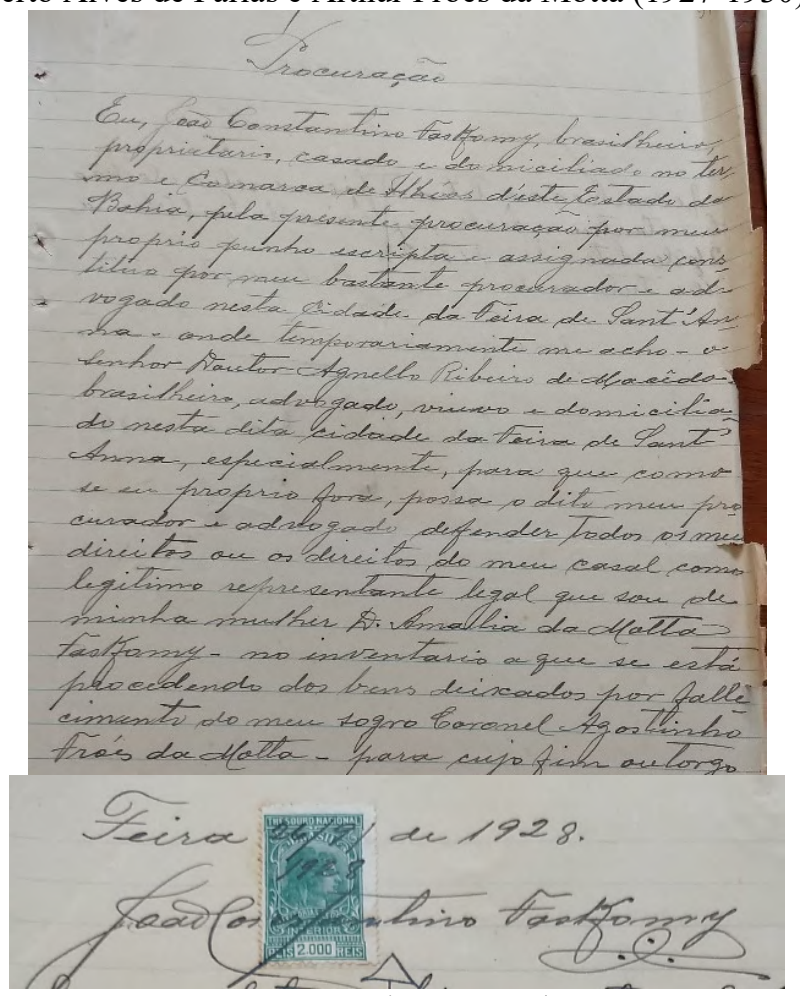

Fonte: Acervo do CEDOC/UEFS

O Coronel João Constantino Faskomy ratifica, na procuração, as afirmações de que era brasileiro, casado com Dona Amália da Motta Faskomy, proprietário ${ }^{165}$ e domiciliado em

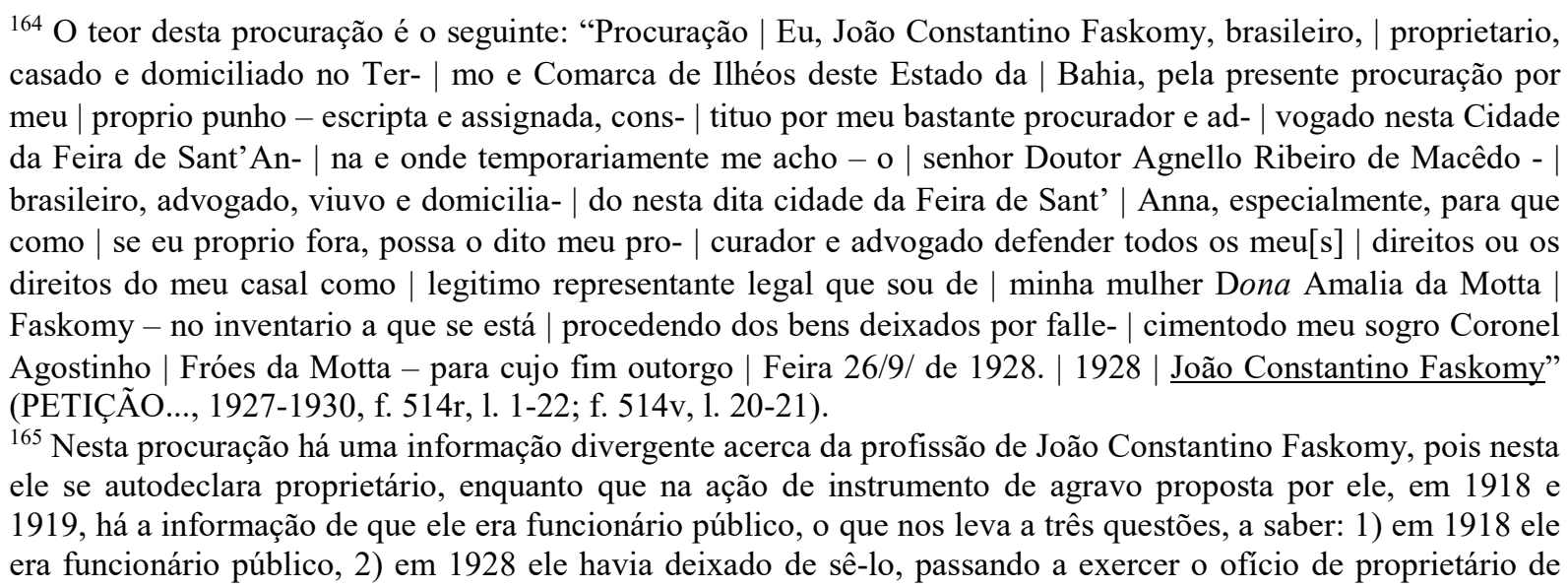


Ilhéus-BA. A partir das informações elencadas, depreendemos que os laços de Amália da Motta Faskomy com os seus cônjuges e os familiares destes se configuravam da forma seguinte.

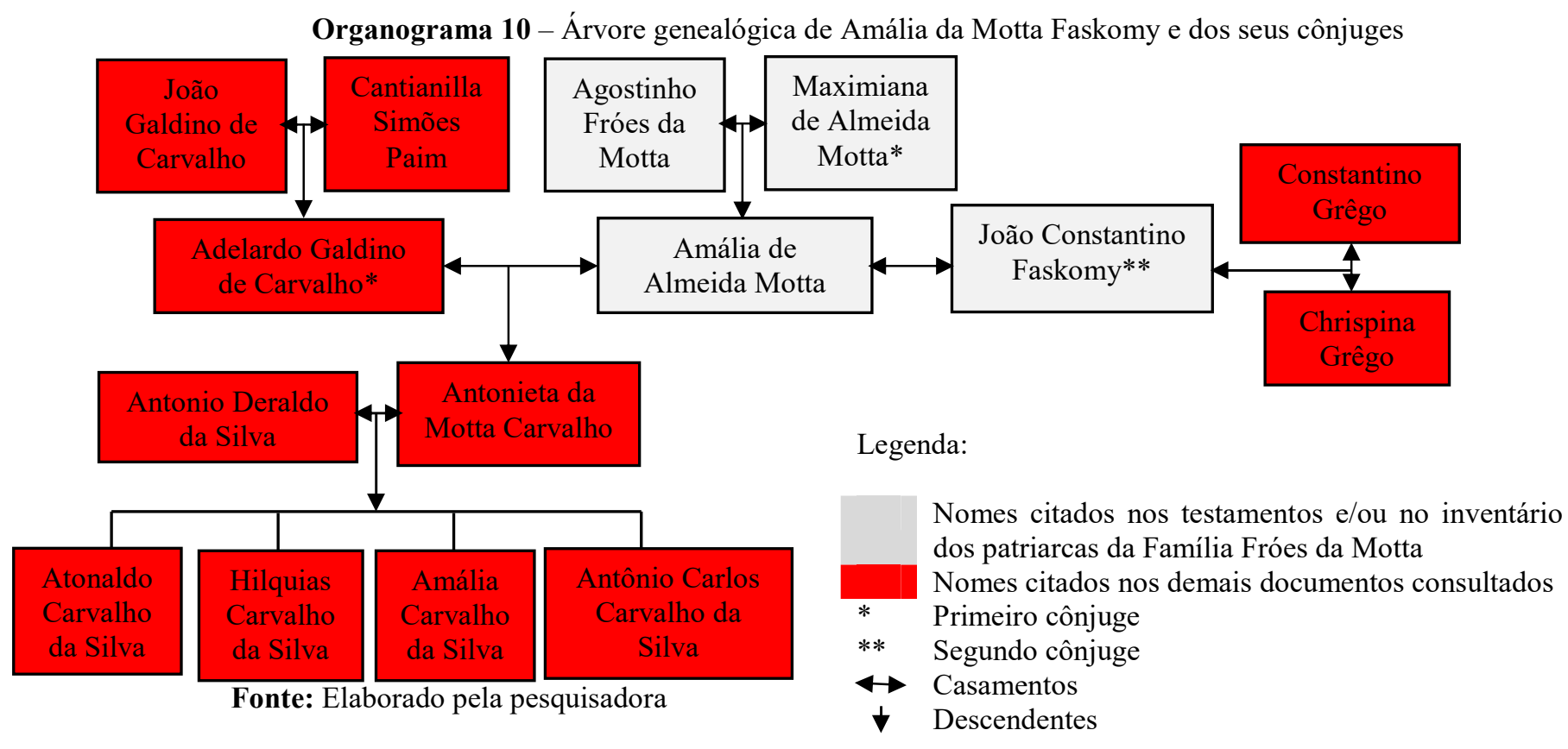

Outro genro de Agostinho Fróes da Motta que aparece de forma constante e incisiva tanto nos manuscritos editados nesta tese quanto nos listados nas fichas codicológicas expostas na terceira seção é Adalberto Alves de Farias, casado, até pouco antes de 15 de dezembro de 1924, com a filha mais nova do Coronel Agostinho Fróes da Motta, Adalgisa de Almeida Motta Farias, data em que esta passou a ser a sua própria representante legal na ação ordinária de filiação e petição de herança (1922-1927), requerida por Alberto de Almeida Motta e nos processos subsequentes àquela data. Antes do desquite, contudo, Adalberto Alves de Farias se apresentou, em 9 de fevereiro de 1923, como representante de sua esposa, como denota a procuração ${ }^{166}$ exposta a seguir.

bens e imóveis, e 3) em 1928 ele exercia as duas ocupações: funcionário público e proprietário. Entretanto, não temos dados suficientes para afirmar qual das hipóteses é a verdadeira, cabendo-nos apenas a certeza de que os documentos consultados atestam que, em 1918, ele tinha a profissão autodeclarada funcionário público e, em 1928, a de proprietário.

${ }^{166}$ O teor desta procuração é o seguinte: "Eu Adalberto Alves Farias, brasileiro, proprie- | tario, casado, residente na cidade de Ilhéos, | actualmente n'esta cidade, pela presente procu- | ração por meu proprio punho escripta e asig- | nada, constituo por meu bastante procurador | e advogado na cidade e comarca da Feira | de Sant'Anna, d'este Estado, ou onde com esta | se apresentar, o Senhor Doutor Agnello Ribeiro de Macê- | do, advogado, viuvo, e residente na dita cida- | de de Feira de Sant'Anna, especialmente para que, | como se eu proprio fôra, possa defender todos | o meu direito e justiça, como cabeça de casal | e representante legal de minha mulher Dona Adal- | gisa de Almeida Motta Farias, n’uma acção ordi- | naria de investigação de paternidade proposta | pelo Engenheiro Alberto de Almeida Motta, contra $\mid$ mim e contra os demaes herdeiros do meu falle- $\mid$ cido sogro 
Figura 109 - Procuração de Adalberto Alves de Farias, no fólio 64r, da ação ordinária de filiação e petição de herança (1922-1927)

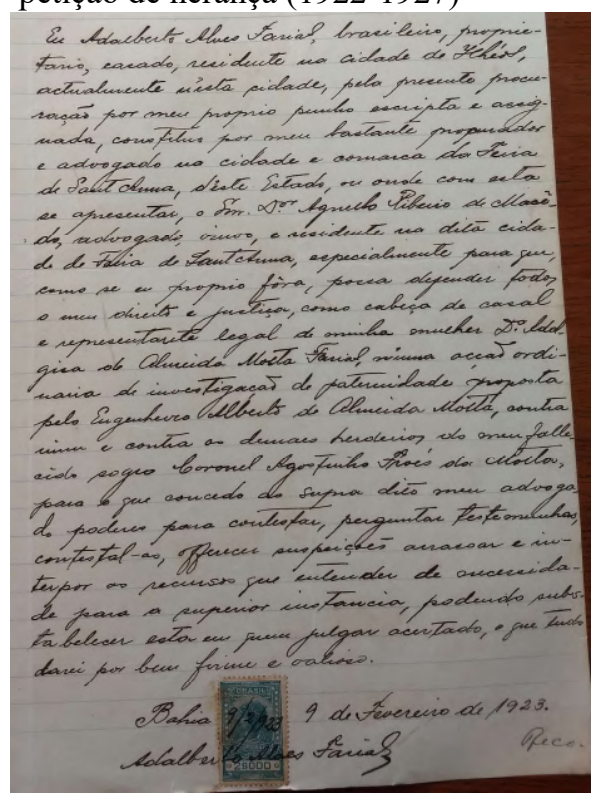

Fonte: Acervo do CEDOC/ UEFS

Como se constata, Adalberto Alves de Farias era brasileiro, proprietário, residente na cidade de Ilhéus-BA e naquele momento se encontrava na Capital do Estado, de onde nomeava como o seu advogado Agnello Ribeiro de Macêdo para o representar e à sua mulher no processo de "investigação de paternidade", proposto por Alberto de Almeida Motta contra Adalberto Alves de Farias e os demais herdeiros do Coronel Agostinho Fróes da Motta.

Além daquele documento, há também uma petição (1923-1928), solicitada pelo próprio Adalberto Alves de Farias, na qual este reclamou o encerramento indevido da firma comercial Agostinho Fróes da Motta e Filho, bem como a negligência do seu cunhado, Eduardo Fróes da Motta, durante o inventário. A abertura desse processo se deu, principalmente, porque tanto Adalberto Alves de Farias quanto os outros herdeiros acusaram o inventariante de sonegação de bens, o que poderia comprometer a equidade na divisão da herança deixada pelo Coronel Agostinho Fróes da Motta aos seus herdeiros.

Já sobre Tertuliano José de Almeida, as fontes confirmam que ele era filho de José Carlos de Almeida e de Alexandrina Maria de Almeida, e casado com Eliceria Moreira de Almeida, com quem teve 14 filhos. Além disso, foi mencionado, no inventário do Coronel Agostinho Fróes da Motta, como a primeira testemunha do seu casamento com Dona

Coronel Agostinho Fróes da Motta, | para o que concedo ao supra dito meu advoga- | do poderes para contestar, perguntar testemunhas, | contestal-as, offerecer suspeições arrasoar e in- | terpor os recursos que entender de necessida- | de para a superior instancia, podendo subs- | tabelecer esta em quem julgar acertado, o que tudo | darei por bem firme e valioso. | Bahia 9/2/923 9 de Fevereiro de 1923. | Adalberto Alves de Farias [espaço] Reco-" (PETIÇÃO..., 1922-1927, f. 64r). 
Guilhermina de Almeida. Entretanto, um fato curioso consta na escritura pública ante-nupcial dos nubentes: ambos declararam que os seus pais eram falecidos, o que significa que o Coronel Tertuliano José de Almeida ou não era o pai de Dona Guilhermina de Almeida ou a sua paternidade era um fato escuso, já que na ação ordinária de filiação e petição de herança (1922-1927), requerida por Alberto de Almeida Motta, é afirmado por uma das testemunhas, Francisco Alves Ferreira Duara, que o pai de Dona Guilhermina de Almeida ainda estava vivo e que era o próprio Coronel Tertuliano José de Almeida e que, à altura do seu rapto para se tornar "amante, teúda e manteúda" do Coronel Agostinho Fróes da Motta, a sua mãe, Tharcilla Barbosa da Silva, já era falecida.

No mesmo inventário, o Coronel Tertuliano José de Almeida aparece como um contraente de dívida passiva no valor de cinquenta e nove contos quinhentos e oitenta e três mil e quinhentos réis (59:583.500), devidos à firma Agostinho Fróes da Motta e Filho. Já no testamento do Coronel Agostinho Fróes da Motta é retratada a amizade deste com aquele quando, por exemplo, são deixadas quantias em dinheiro para as filhas do Coronel Tertuliano José de Almeida: Ritta, Maria (Mariinha), Almira e Neryna, e para Junilha de Almeida, casada com Clodoaldo Severiano de Almeida, que era irmão de Almerinda de Almeida Motta, esposa de Augusto Fróes da Motta, portanto nora de Agostinho Fróes da Motta. Portanto, tratavam-se de pessoas (Ritta, Marinhinha, Almira, Neryna, Clodoaldo, Almerinda, Guilhermina e Tertuliano José de Almeida) que direta ou indiretamente mantiveram laços familiares ou de amizade com o Coronel Agostinho Fróes da Motta.

Semelhantemente, com Dona Maximiana de Almeida Motta o Coronel Tertuliano José de Almeida também mantinha uma relação afetuosa, indicada pela testadora quando esta o elegeu como o seu segundo testamenteiro, além de ter sido declarado como o seu primo, compadre e um dos avaliadores dos bens listados e avaliados no inventário da matriarca, como exemplificado na figura a seguir, que se trata da assinatura do Coronel Tertuliano José de Almeida que aceitou o cargo de avaliador dos bens do inventário de sua prima e comadre, o que revela, mais uma vez, as relações consanguíneas e afetivas do referido coronel com o clã Fróes da Motta.

Figura 110 - Assinatura do Coronel Tertuliano José de Almeida no termo de apresentação para ser avaliador dos bens de Dona Maximiana de Almeida Motta em seu inventário (1918-1919)

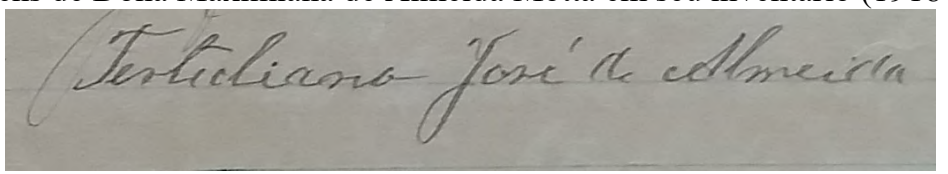

Fonte: Acervo do CEDOC/UEFS 


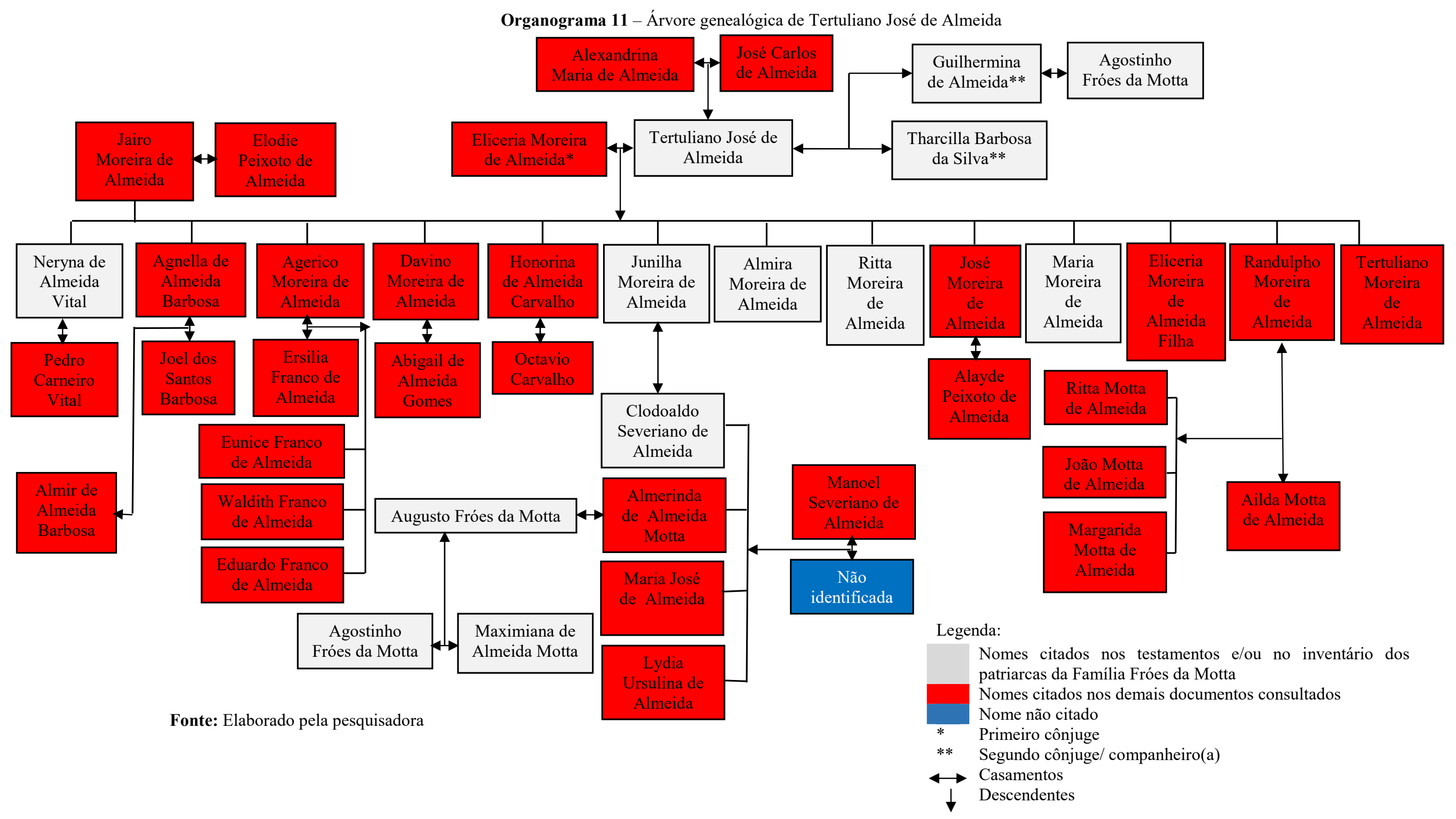


Como se pode notar, Tertuliano José de Almeida foi casado com Dona Eliceria Moreira de Almeida, com quem teve 14 filhos, dos quais 5 foram beneficiados pelo Coronel Agostinho Fróes da Motta, em seu testamento, e a quem é atribuída a paternidade de Dona Guilhermina de Almeida, segunda esposa do referido coronel, portanto Tertuliano José de Almeida era avô de Alberto de Almeida Motta, amigo de Agostinho Fróes da Motta, genro de Clodoaldo Severiano de Almeida, pai de Agerico Moreira de Almeida, escrivão participante da produção do testamento de Dona Maximiana de Almeida Motta e sogro de Pedro Carneiro Vital, irmão do Tabelião de Notas João Carneiro Vital. Logo, as relações familiares entre aqueles "sujeitos" se misturavam e se confundiam, inegavelmente.

Na vida pública, Tertuliano José de Almeida foi um importante fazendeiro, negociante de gado, exportador de fumo, conselheiro municipal durante 11 anos ininterruptos (19151926), Presidente da Filarmônica Victória (1913-1914) e membro das comissões da festa de Nossa Senhora Santana, que era um evento bastante esperado pela cidade. Também possuía uma mansão na cidade denominada "Chácara do Coronel Tertuliano Almeida", que era considerada uma residência majestosa, que perdia em grandiosidade apenas para a do Coronel Agostinho Fróes da Motta (CUNHA, 2013).

Figura 111 - Chácara de Tertuliano Almeida, construída em 1919

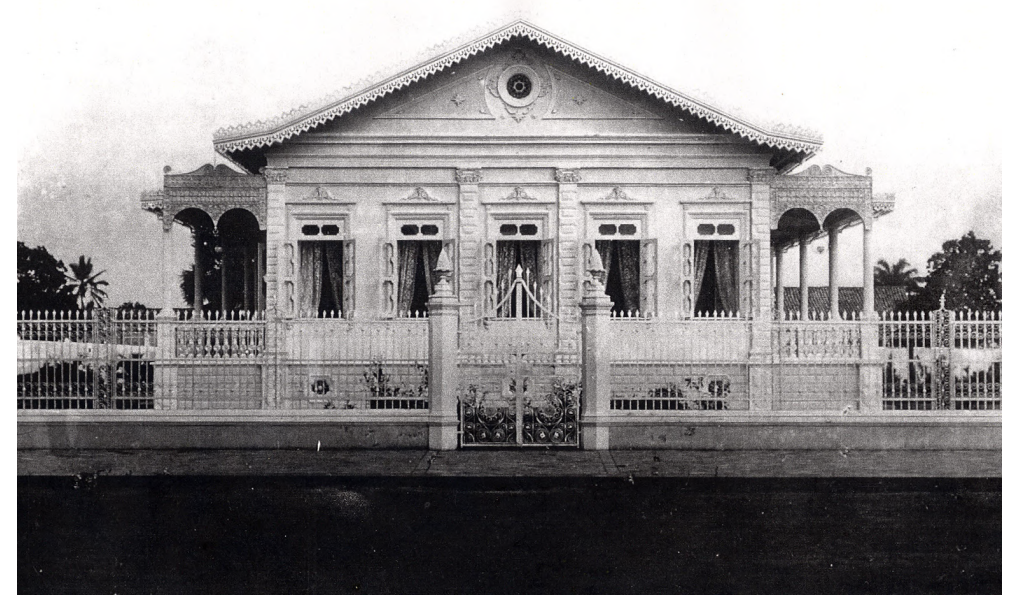

Disponível em: http://www.memorialdafeira.ba.gov.br/conteudo.asp?catimg=7. Acesso em: 17 nov. 2019.

Politicamente, o Coronel Tertuliano José de Almeida fez parte da "Companhia de Melhoramentos da Feira de Sant'Anna" junto com outras figuras importantes como, por exemplo, os Coronéis Bernardino da Silva Bahia e Mario Saback de Oliveira, o Doutor Eduardo Fróes da Motta, os Majores Leolindo dos Santos Ramos e Celso Valverde Martins, 
na qual fizeram grandes coisas por Feira de Santana-BA, tais como: a implantação efetiva do fornecimento de luz elétrica, em 1926, o que gerou na cidade grandes alardes, haja vista o fim do uso de querosene e a animação de empresas para a aquisição do serviço por toda a Feira de Santana-BA (C.f. CUNHA, 2013; FOLHA DO NORTE, 1926).

Sobre Manoel Portugal dos Santos, por sua vez, as fontes o apresentam como major, fazendeiro, dono de armazém e negociante de fumo ${ }^{167}$, filho de José da Cunha Portugal e pai de Salvador Simões Portugal, que era empregado no comércio. Enquanto político, foi Conselheiro Municipal no período de 1908 a 1923 e, portanto, um dos eleitores da cidade. Em 1917 também manteve, junto ao município, animais empregados no serviço de vendagem de água. Enquanto filantropo, foi membro da Sociedade Montepio dos Artistas Feirenses e da Santa Casa de Misericórdia de Feira de Santana-BA.

Enquanto amigo, manteve relação de amizade com o Doutor Agnello Ribeiro de Macêdo, com quem era visto nos eventos religiosos e sociais da cidade como, por exemplo, na noite da festa de procissão à Nossa Senhora Santana, ocasião em que foi visto pelo memorialista Eurico Alves Boaventura (2006, p. 29, grifos nossos) próximo àquele e à sua família: “[...] Junto à bela palmeira, ao lado norte, podia contar-se na certa com a figura de Manuel Portugal, baixote, gordo, a família em volta, quase junto do povo do Dr. Agnelo Macedo. E assim era. As famílias da cidade, ricas ou modestas, todas ali. [...]”. Como se pode notar, além da descrição física de Manoel Portugal dos Santos, o memorialista nos assegura que as festividades religiosas se configuravam como oportunidades de interação social entre as famílias feirenses, abastadas ou não, e como momentos em que as figuras públicas eram vistas junto ao povo.

Além do Doutor Agnello Ribeiro de Macêdo, Manoel Portugal dos Santos também era amigo e compadre do Coronel Agostinho Fróes da Motta, que, em seu próprio testamento, afirmou que os dois filhos daquele eram seus afilhados: Albertino e Elzira, para quem o testador deixou a quantia de dois contos de réis. Outra prova da amizade existente entre ambos é o fato de Manoel Portugal dos Santos ter sido testemunha no casamento do Coronel Agostinho Fróes da Motta com Dona Guilhermina de Almeida, em 5 de Janeiro de 1920, o que evidencia uma amizade solidificada pela política e pelos laços de compadrio, já que a referida testemunha ocupou o cargo de Conselheiro Municipal por 15 anos consecutivos,

\footnotetext{
167 Conforme as memórias de Eurico Alves Boaventura (2006), Manoel Portugal dos Santos era, assim como Agostinho Fróes da Motta, Epiphanio José de Souza e Álvaro Simões, um grande negociante de fumo: “[...] Armazém de fumo era já quase indústria Seu Agostinho, Seu Epifânio Souza, Seu Manuel Portugal, Cel. Álvaro Simões (fícava o coronel revoltado quando se lhe não dava o título dado pelo povo) [...]" (BOAVENTURA, 2006, p. 77).
} 
estando, portanto, presente em quase toda a vida política de Agostinho Fróes da Motta, e porque, nos costumes do Sertão, não se costuma "dar um filho" para qualquer pessoa apadrinhar, mas para alguém que sirva à criança como o seu pai ou alguém que se tenha elevada estima. Por conta desses dois fatos, acreditamos que Manoel Portugal dos Santos e Agostinho Fróes da Motta tivessem uma amizade extremosa, que começou na política e se estendeu à vida particular.

Sobre a testemunha Amadeu Saback de Oliveira, os documentos nos informam que ele era filho de João Lúcio de Oliveira e Emília Saback, negociante e dono de armazém de enfardo de fumo, fabricante de sabão, dono de padaria, capitão, casado com Dona Laura Martins Saback, e possuía quatro irmãos, a saber: o tenente coronel Mario Saback de Oliveira, casado com Rita Bahia Saback de Oliveira; Dona Evangelina Saback, casada com Anésio Marinho Fernandes, Coletor de Baixa Grande-BA; João Saback de Oliveira, grande fazendeiro e casado com Amélia Saback; e Dona Claudionor Saback, casada com Arnaldo Cohim Pacheco, comerciante de fumo, segundo Suplente do Juiz de Direito da Comarca de Feira de Santana-BA na década de 1920 (AS PRIMEIRAS..., 2019) e inquilino, em 1924, de uma das casas de aluguel do Coronel Agostinho Fróes da Motta, situada na Rua Barão de Cotegipe, conforme o terceiro volume do inventário do referido coronel.

Ademais, Amadeu Saback de Oliveira era genro de Quintiliano Martins da Silva, primeira testemunha do testamento de Dona Maximiana de Almeida Motta, cunhado de uma das filhas do Coronel Bernardino da Silva Bahia e de Arnaldo Cohim Pacheco, forte comerciante de Feira de Santana-BA, conforme representado na árvore genealógica seguinte. 
Organograma 12 - Árvore genealógica de Amadeu Saback de Oliveira

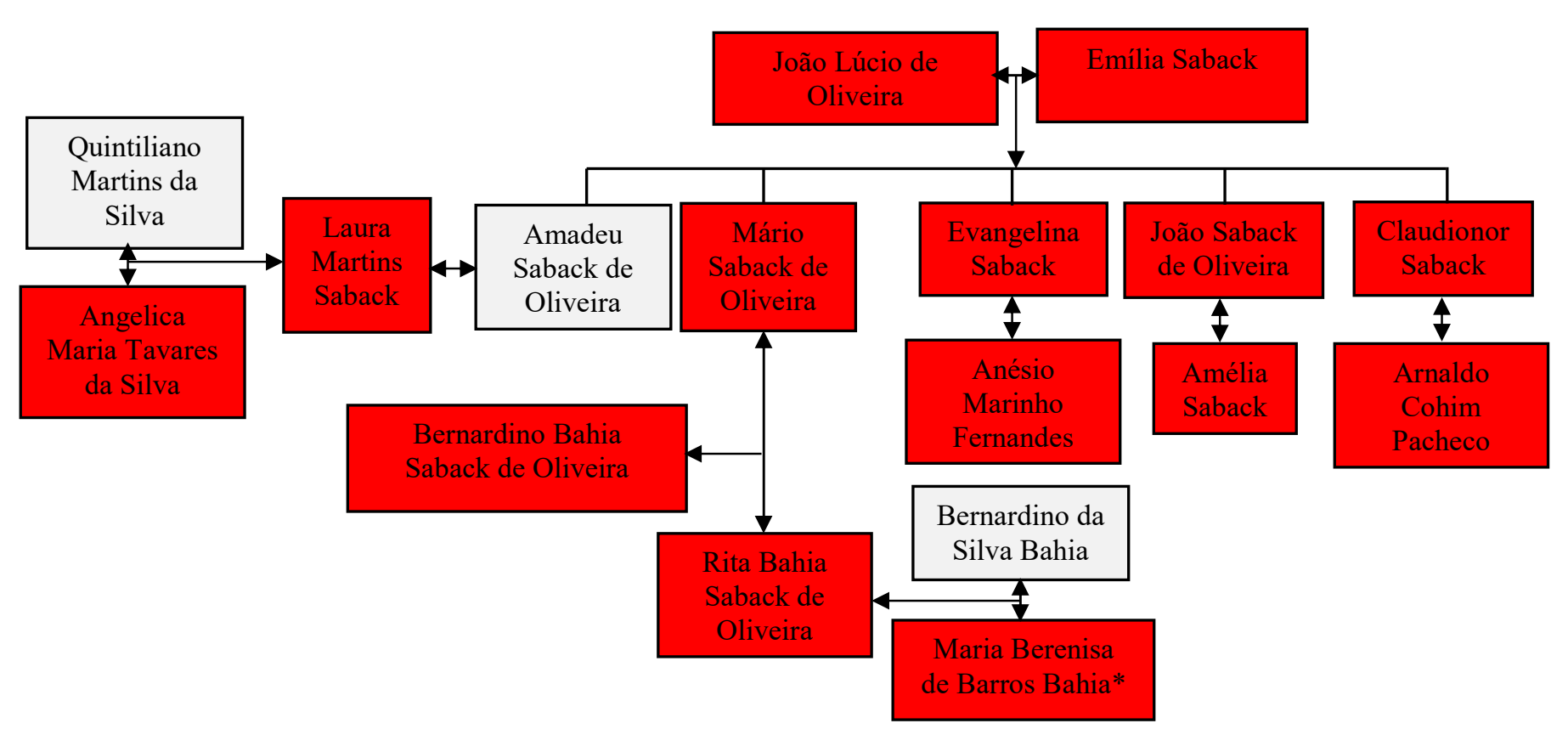

Legenda:

Nomes citados nos testamentos e/ou no inventário dos patriarcas da Família Fróes da Motta

Nomes citados nos demais documentos consultados

Primeira cônjuge

$\longleftrightarrow$ Casamentos

$\downarrow \quad$ Descendentes

Fonte: Elaborado pela pesquisadora 
Amadeu Saback de Oliveira, dono da Padaria da Fé no Centro Comercial de Feira de Santana-BA, foi a primeira testemunha a assinar o testamento, após a sua aprovação por parte do testador Agostinho Fróes da Motta, cuja assinatura junto com a dos demais presentes deu fé ao documento, escrito em 27 de agosto de 1920. Além de Amadeu Saback de Oliveira existia Agnello Cohim Pacheco, que era brasileiro, casado, negociante e residente em Feira de Santana-BA e também foi uma das testemunhas presentes no dia da feitura do testamento do coronel Agostinho Fróes da Motta. Ademais, Agnello Cohim Pacheco fazia parte do seleto grupo de eleitores de Feira de Santana-BA, entre 1910 e 1920, do Conselho Municipal e da Sociedade Monte Pio dos Artistas Feirenses.

Já a terceira testemunha do referido testamento foi Antonio Onofre Carneiro que, além de ser major, negociante, casado, residente em Feira de Santana-BA como o próprio testamento o diz, foi médico, vice-provedor reeleito da Santa Casa de Misericórdia, em 1933, eleitor entre 1905 e 1930 e conselheiro municipal entre 1915 e 1923, período em que o testador também atuou enquanto político até o dia da sua morte.

A quarta testemunha, por sua vez, foi Valentim José de Souza Junior que esteve presente no momento da leitura, assinatura e fechamento do testamento e que foi, além de filho do político e influente fazendeiro Valentim José de Souza, avaliador dos bens do inventariado, capitão, conselheiro municipal entre 1912 a 1915, dono de animais empregados no serviço de vendagem de água, em 1917, e delegado de polícia, nomeado, em 25 de janeiro de 1916, durante a gestão do Intendente Agostinho Fróes da Motta. Enquanto comissário de Polícia, atuou na resolução de vários processos crime ocorridos na cidade como, por exemplo, no auto de defloramento de uma jovem de 18 anos de idade, lavrado em 1904.

Além disso, o Capitão Valentim José de Souza Junior também prestou testemunho em dois processos que envolviam dois filhos de Agostinho Fróes da Motta, a saber: na ação de desquite interposta por Dona Albertina da Motta Barretto contra o seu então marido, Antonio Alves Barretto, em 1920; e em um processo crime contra o Capitão Augusto Fróes da Motta, acusado de tentativa de homicídio contra a sua esposa, Dona Almerinda de Almeida Motta, acusada de adultério.

A quinta e última testemunha presente no momento da aprovação do testamento do testador Agostinho Fróes da Motta foi Hermillo Dias de Carvalho, brasileiro, casado, residente em Feira de Santana-BA, também membro da Sociedade Monte Pio dos Artistas Feirenses e do grupo de eleitores de Feira de Santana-BA na década de 1910. Além disso, foi testemunha, junto com o Capitão Valentim José de Souza Junior, na ação de desquite interposta por Dona Albertina da Motta Barretto contra o seu então marido. Logo, tratam-se 
de cinco testemunhas que participaram não somente do momento em que o Coronel Agostinho Fróes da Motta mandou o Tabelião de Notas, João Carneiro Vital, escrever e lavrar o seu testamento, mas também da vida política e social da seleta classe abastada da cidade.

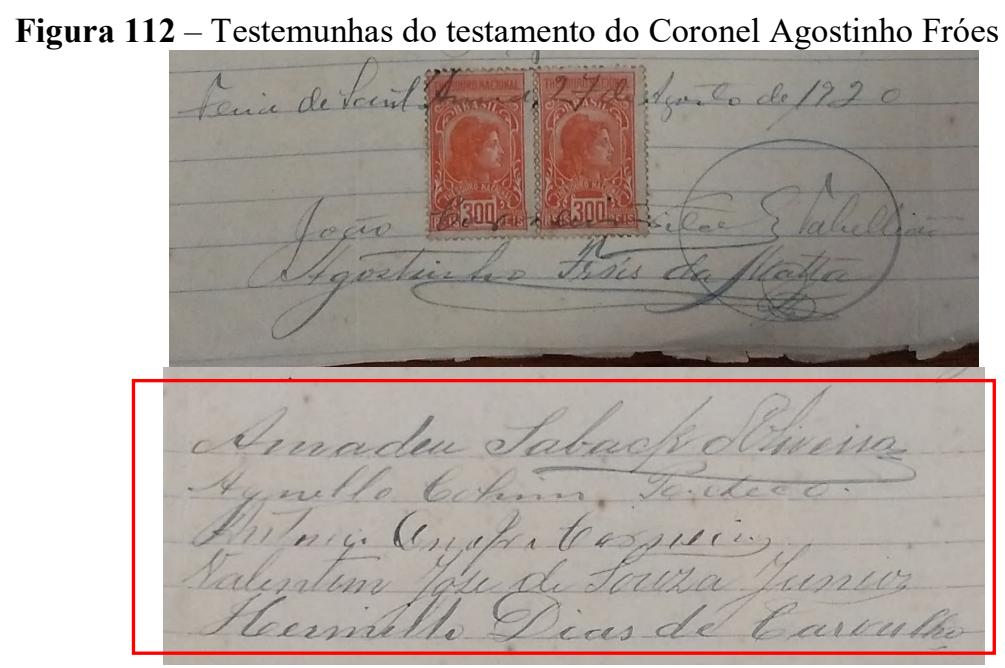

Fonte: Acervo do CEDOC/ UEFS

Depois de selado e guardado o testamento do Coronel Agostinho Fróes da Motta, no dia 17 de fevereiro de 1922 foi trasladado o documento registrado no Livro de Notas do Primeiro Ofício do Tabelião João Carneiro Vital, no qual constavam as presenças do testador, do tabelião, de Valentim José de Souza Junior, de João Simões Ferreira, Arthur de Assis, Oscar do Espirito Santo e Joaquim Anacleto de Oliveira.

Destes, começamos com João Simões Ferreira - visto que já falamos do Coronel Agostinho Fróes da Motta, de Valentim José de Souza Junior e de João Carneiro Vital. João Simões Ferreira foi casado, coronel, negociante, residente e pertencente à classe abastada de Feira de Santana-BA, irmão de Quintiliano Martins da Silva e cultivava uma relação de amizade com o Coronel Agostinho Fróes da Motta, e por isso foi chamado para acompanhar e ser testemunha no seu testamento.

Sobre Arthur de Assis, este foi casado, empregado no comércio, residente e eleitor de Feira de Santana-BA. Ademais, na ação executiva solicitada por Arthur Fróes da Motta contra o seu irmão, Augusto Fróes da Motta, lavrada entre 1922 a 1924, há declarações que nos permitem afirmar que Arthur de Assis possuía uma relação de confiança com Eduardo Fróes da Motta, já que aquele, enquanto empregado desse, aparece como o arrematante dos bens leiloados, pertencentes ao casal Augusto Fróes da Motta e Almerinda de Almeida Motta, a qual rebateu todos os argumentos apresentados pelos advogados dos irmãos Fróes da Motta, 
alegando, dentre outras coisas, que Arthur de Assis, enquanto empregado de Eduardo Fróes da Motta, não tinha condições financeiras para pagar pela arrematação.

Ainda sobre a testemunha, Almerinda de Almeida Motta justifica os seus argumentos dizendo que o arrematante possuía como único bem uma casa simples no Centro da cidade, o que indicava que ele não tinha dinheiro para fazer a arrematação, logo a quantia deveria vir do seu cunhado, empregador do arrematante, que, junto com Arthur Fróes da Motta e Arthur de Assis, era cúmplice de um "golpe" que visava deixá-la sem nada, visto que se tratava de uma "vingança regada com o orgulho ferido" do seu marido, após o ocorrido em 22 de março de 1922, data em que o seu cônjuge disparou um tiro de arma de fogo contra aquela por suspeitas de adultério, e data coincidente com o dia da morte do Coronel Agostinho Fróes da Motta.

Outra informação importante é que Arthur de Assis também foi testemunha em outros dois processos envolvendo Dona Almerinda de Almeida Motta e o Capitão Augusto Fróes da Motta: no processo de lesão corporal, ocorrido em 1922, e na ação de desquite proposta por Dona Almerinda de Almeida Motta contra o seu marido, ambos processos, inclusive, mencionados por ela na ação executiva solicitada por Arthur Fróes da Motta contra o seu irmão, Augusto Fróes da Motta. Essas informações, portanto, permitem-nos afirmar a) que o perfil de Arthur de Assis era o de um homem que pertencia à classe trabalhadora da cidade, portanto assalariado, que tinha apenas um bem imóvel, b) que o seu nome não constava no livo de declarantes de impostos da Intendência Municipal e c) que era um forte aliado pessoal dos irmãos Arthur, Augusto e Eduardo Fróes da Motta, o que justifica a sua presença em tantos processos, cujas partes envolvidas foram os seus patrões.

Um perfil semelhante é o de Oscar do Espirito Santo, penúltima testemunha do testamento de Agostinho Fróes da Motta, que foi casado, filho de Arestides José Alves, negociante, artista, operário, ajudante de arquivista da Sociedade Filarmonica Euterpe Feirense, residente na casa de número 62 da Rua Voluntários da Pátria, em Feira de SantanaBA, listado como eleitor em 1911, e inquilino de Antonio Marques de Almeida, informações mencionadas no testamento de Agostinho Fróes da Motta e trasladadas no seu inventário, e também dispostas nos livros consultados da Intendência Municipal e em uma ação de depósito ${ }^{168}$ proposta pelo próprio Oscar do Espirito Santo.

Um aspecto interessante sobre essa testemunha é que, na ação de depósito supramencionada, ele solicitou que fosse verificada a não existência do seu nome nos livros

${ }^{168}$ No CEDOC/UEFS, há uma ação de depósito solicitada por Oscar do Espirito Santo, armazenada na Estante 13, Caixa 349 e Documento 8001, datada de 1950 e lavrada em Feira de Santana-BA, na qual ele notifica que fez o depósito judicial de 320 cruzeiros, referentes a quatro meses de aluguéis atrasados e cujo locatário se negou a receber. Nesta ação, o Tabelião do Primeiro Ofício foi Almachio Alves Boaventura, já citado nesta tese. 
de pagamento de impostos da Intendência Municipal, a fim de comprovar o seu estado de pobreza, o que nos leva a afirmar que Oscar do Espirito Santo era o menos afortunado dentre os citados nesta subseção, já que foi o único "sujeito" autodeclarado como sem condições financeiras de pagar o valor do aluguel ao seu locatário, justificando-se, para isso, como um artista que não tinha dinheiro.

Distintamente, Joaquim Anacleto de Oliveira, com sessenta e sete anos de idade, em 1922, foi casado, próspero negociante, natural de São Gonçalo dos Campos-BA, residente em Tanquinho-BA e testemunha no testamento do Coronel Agostinho Fróes da Motta e na ação de desquite proposta por Dona Albertina da Motta Barretto contra o seu então marido, na qual depôs em 27 de fevereiro de 1920. Depois de aprovado, o testamento do Coronel Agostinho Fróes da Motta foi apresentado pelo seu filho, Eduardo Fróes da Motta, e aberto em 23 de março de 1922, um dia após a morte do referido coronel, data em que compareceram como outras testemunhas Epiphanio José de Souza e Manoel Araujo.

Epiphanio José de Souza foi casado com Maria Eugenia de Souza, com quem teve os filhos Aloysio Souza e Aurea Souza. Também foi comerciante/negociante ${ }^{169}$ e dono de armazém de fumo, detentor da patente de coronel, nascido na cidade de Cachoeira-BA, onde também possuía residência. Adicionalmente, era amigo íntimo do Coronel Agostinho Fróes da Motta com quem dividiu a sociedade de duas firmas comerciais, das quais a primeira se intitulava "Agostinho Fróes da Motta \& Cia" e a segunda "Motta e Souza". Esta sociedade comercial foi dissolvida em 1919, mas Epiphanio José de Souza continuou como dono da referida empresa e morador no casarão conhecido como Villa Áurea, em Feira de SantanaBA.

Figura 113 - Casarão Villa Áurea de Epiphanio José de Souza

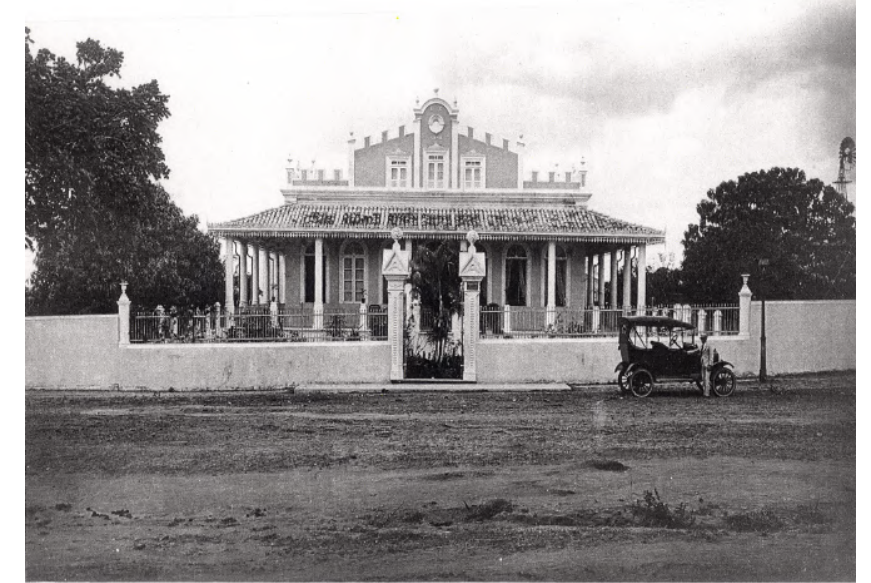

Disponível em: http://www.memorialdafeira.ba.gov.br/conteudo.asp?catimg=7. Acesso em: 17 nov. 2019.

\footnotetext{
${ }^{169}$ Em alguns documentos, Epiphanio José de Souza é descrito como comerciante e em outros como negociante, devido a isso optamos por manter as duas profissões em sua descrição biográfica.
} 
Apesar do fim da sociedade comercial, os coronéis Agostinho Fróes da Motta e Epiphanio José de Souza mantiveram a amizade, inclusive este sendo testemunha no testamento e no contrato ante-nupcial do Coronel Agostinho Fróes da Motta com Dona Guilhermina de Almeida, e sendo terceiro testamenteiro de Dona Maximiana de Almeida Motta e declarado por esta como seu amigo.

Enquanto político, o Coronel Epiphanio José de Souza foi eleito conselheiro municipal, em 1911, bem como tesoureiro da Santa Casa de Misericórdia de Feira de SantanaBA, em 1912, e membro da Guarda Noturna Comercial, quando, inclusive, teve uma de suas casas comerciais roubada. Como símbolo de seu prestígio social e poder econômico, ele viajou para a Europa em 1912, enquanto que Agostinho Fróes da Motta já o tinha feito em 1902 e em 1909 (já que se tem registro de que ele foi, pelo menos, duas vezes para Hamburgo - Alemanha) e Bernardino da Silva Bahia em 1914. Logo, as viagens para a Europa se tornaram parte da vida das figuras políticas e abastadas da cidade, principalmente porque as obras europeias se tornaram essenciais para inspirar a implantação do "progresso" em Feira de Santana-BA, como mencionado na segunda seção.

Outro ponto em comum com o Coronel Agostinho Fróes da Motta é que o Coronel Epiphanio José de Souza também era um “homem de cor" (REIS, 2012), ou seja, ambos, além de terem vindo de famílias humildes, foram negros que conseguiram ascender socialmente em uma sociedade feirense majoritariamente branca. Outra informação relevante é que Epiphanio José de Souza foi inquilino, em 1924, de uma das casas de aluguel do Coronel Agostinho Fróes da Motta, situada na Salgadeira, embora não se saiba qual a finalidade da casa alugada. Além disso, Epiphanio José de Souza se mantinha como um expressivo comerciante de fumo, de couro, de café e de cacau na cidade de Feira de Santana-BA, conforme o terceiro volume do inventário de Agostinho Fróes da Motta.

Em relação ao testamento de Dona Maximiana de Almeida Motta, aberto em 1918, também identificamos testemunhas que mantiveram relações de amizade com a testadora e com os seus familiares, dentre as quais estava Juvencio Erudilho da Silva Lima, que nasceu na Vila do Cumbe-BA, em 20 de agosto de 1850, e migrou para Feira de Santana-BA junto com os seus pais aos 4 anos de idade. Na vida adulta, tornou-se negociante, delegado de polícia, fazendeiro e dono de açougue, além de ter obtido a patente de major e se tornado Conselheiro Municipal nos períodos de 1904 a 1907 e de 1912 a 1915, fazendo, portanto, parte do seleto grupo de eleitores feirenses. 
Enquanto filantropo, foi fundador da Filarmônica 25 de Março, da qual foi Presidente por mais de 20 anos, bem como provedor da Santa Casa de Misericórdia de Feira de SantanaBA, por vários anos, e membro da Sociedade Monte Pio dos Artistas Feirenses. Do ponto de vista dos redatores do Folha do Norte, o major Juvencio Erudilho da Silva Lima, que faleceu de intoxicação urêmica, em março de 1918, foi considerado digno de uma longa reportagem biográfica, segundo a qual era visto, dentre outras coisas, como um homem de "[...] grande evo- | cação. | Alto, moreno, encanecido, | os annos não lhe alteraram a | belleza hellenica dos traços | varonis e a sua figura domi- | nadora, erecta, direita, era bem | a respeitabilidade, o desem- | peno e a nobreza do seu per- | fil moral sem curvaturas [...]" (MAJOR..., FOLHA DO NORTE, 9 mar. 1918, p. 1). Mais do que isso, as condolências recebidas pela família demonstravam o quão significativa era a figura do major Juvencio Erudilho da Silva Lima para os seus correligionários e para Feira de Santana-BA, principalmente porque outros membros da sua família também faziam parte da vida pública. 
Organograma 13 - Árvore genealógica de Juvêncio Erudilho da Silva Lima

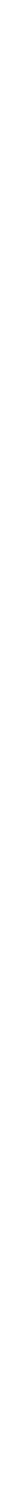


Sobre esses familiares, o pai de Juvencio Erudilho da Silva Lima também foi um major influente na política feirense e teve 7 filhos, dentre os quais figura Dona Vicência de Lima e Silva, casada com Amâncio Ferreira da Silva, com quem teve 4 filhos, dos quais três eram jornalistas, a saber: Raul, Dálvaro e Arnold Ferreira da Silva, os quais fizeram parte da vida pública feirense: dedicaram-se, primeiro, às suas respectivas formações em Jornalismo, seguidas da atividade de redatores do Folha do Norte e, mais tarde, Arnold Ferreira da Silva se tornou Conselheiro e Intendente Municipal, com o apoio do seu sogro Bernardino da Silva Bahia.

O terceiro filho do major Juvêncio Erudilho da Silva Lima, Oscar Erudilho de Cerqueira Lima, foi nomeado Bibliotecário Municipal, em 29 de maio de 1914, pelo Intendente Bernardino da Silva Bahia e, mais tarde, em 19 de agosto de 1935, foi nomeado para ser Secretário Municipal, durante o mandato do Prefeito Heráclito Dias de Carvalho.

A segunda testemunha do testamento de Maximiana de Almeida Motta foi o Coronel Quintiliano Martins da Silva que, além de casado com a “[...] poderosíssima e virtuosa quanto ciumenta [...]” (BOAVENTURA, 2006, p. 181) Dona Guilhermina Adelaide Alves de São Boaventura, era fazendeiro, negociante de gado, dono de imóveis, natural e residente em Feira de Santana-BA, além de um político influente pertencente ao mesmo partido que os Coronéis Agostinho Fróes da Motta, Tertuliano José de Almeida, Bernardino da Silva Bahia e Heráclito Dias de Carvalho, os quais venceram as eleições municipais de 1912. Antes e depois disso, Quintiliano Martins da Silva ocupou o cargo de Conselheiro Municipal nos períodos de 1900 a 1915 e de 1919 a 1923. 


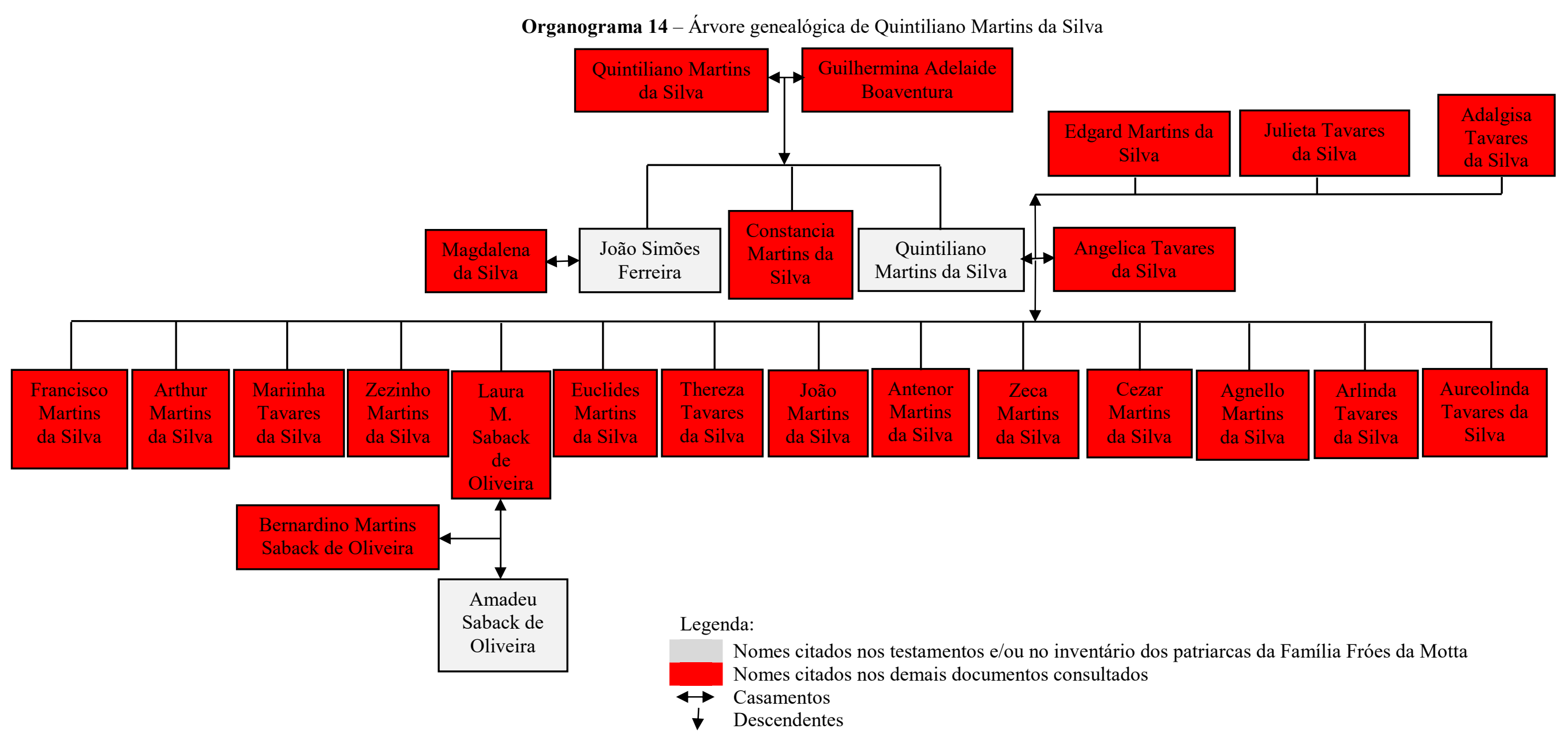

Fonte: Elaborado pela pesquisadora 
Em uma reportagem do Folha do Norte, datada de 21 de maio de 1921, sobre o falecimento do major Quintiliano Martins da Silva não há menção dos nomes de sua mãe, irmão, cunhado e sobrinhos, mas apenas a notícia de que a sua cunhada Magdalena, a sua irmã Constancia e os seus sobrinhos, não nominados, emanavam os pêsames à família pelo falecimento do patriarca, que tinha o mesmo nome do pai, como consta no Livro de indústria e profissões de Feira de Santana (1916).

Ademais, dos membros listados na árvore genealógica, os que aparecem como "sujeitos" processuais dos documentos estudados são, além do major Quintiliano Martins da Silva, o seu irmão João Simões Ferreira e Amadeu Saback de Oliveira, os quais estão ligados por laços de parentesco.

A terceira testemunha do testamento de Dona Maximiana de Almeida Motta foi José Alves Boaventura, que foi farmacêutico, fazendeiro, primeiro Secretário do Conselho Municipal de 1915 a 1919 e Conselheiro Municipal durante 25 anos ininterrruptos (1901 1926) e como tal fazia parte do grupo de eleitores abastados de Feira de Santana-BA. Ainda enquanto político, foi membro da Comissão da Fazenda e Justiça, Instrução Pública e Agricultura, em 1901.

Enquanto comerciante, José Alves Boaventura foi dono da Farmácia Alves, fundada em 1866, e morador de um vistoso sobrado na Rua Senhor dos Passos, que indicava a sua posição econômica e social (BOAVENTURA, 2006). Enquanto filantropo, foi Presidente e Tesoureiro da Filarmônica 25 de março, em 1901 e 1912, e assumiu algumas vezes a direção da Santa Casa de Misericórdia de Feira de Santana-BA.

Enquanto farmacêutico, José Alves Boaventura foi nomeado, pelo menos, duas vezes como perito em processos crimes de defloramento e, como exemplo disso, podemos citar dois autos de defloramento: o primeiro, lavrado em 1904, descreve uma denúncia feita por uma menor de 18 anos de idade, que foi deflorada pelo seu então noivo, e abandonada; e o segundo, lavrado entre 1914 a 1924, igualmente descreve o caso de uma menor de 19 anos de idade, que também foi à Justiça denunciar o seu noivo pelo crime de defloramento; ambos os documentos estão armazenados no CEDOC/UEFS e, nestes, o farmacêutico José Alves Boaventura realizou, junto com um médico, o exame de corpo de delito das duas vítimas para comprovar a existência do crime e o tempo em que este ocorreu, a partir dos indícios físicos apontados na perícia.

Além disso, pelo fato de pertencer à uma família tradicional da qual vários membros atuaram no cenário político e econômico de Feira de Santana-BA, apresentamos, a seguir, a árvore genealógica que conseguimos construir, a partir dos dados constantes nos documentos 
consultados sobre a família Boaventura ${ }^{170}$ com a finalidade de compreendermos as possíveis articulações entre os seus membros.

${ }^{170}$ Dentre os documentos consultados estão o Inventário de Benigno Alves Boaventura, com 263 fólios, escritos no recto e verso, lavrado entre 1896 e 1915 e armazenado no CEDOC/UEFS sob a cota: Estante 1, Caixa 10 e Documento 107; o Inventário de Emilia Simões Ferreira Boaventura, com 17 fólios, escritos no recto e verso, lavrado em 1919 e armazenado no CEDOC/UEFS sob a cota: Estante 4, Caixa 102 e Documento 1303; o Inventário de Elvira Alves Boaventura, com 56 fólios, escritos no recto e verso, lavrado entre 1947 a 1950 e armazenado no CEDOC/UEFS sob a cota: Estante 4, Caixa 109 e Documento 1401; e o Inventário de Guilhermina Adelaide Boaventura, com 110 fólios, escritos no recto e verso, lavrado em 1905 e armazenado no CEDOC/UEFS sob a cota: Estante 4, Caixa 92 e Documento 1172. 
Continuação da árvore genealógica da Família Boaventura
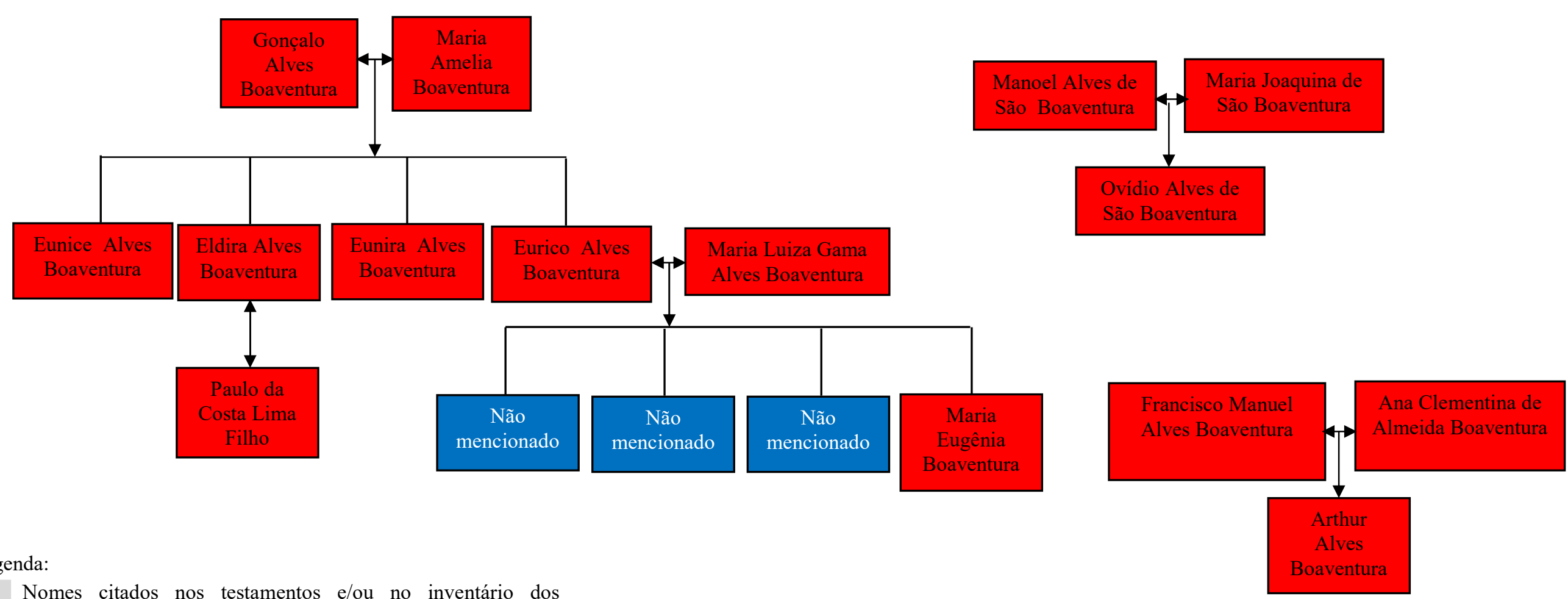

Legenda:

Nomes citados nos testamentos e/ou no inventário dos

patriarcas da Família Fróes da Motta

Nomes citados nos demais documentos consultados

Nomes não citados

* Primeiro cônjuge

** Segundo cônjuge

$\leftrightarrow$ Casamentos

$\downarrow$ Descendentes 
Filho de Constança Januaria de São Boaventura e Pedro Alves Rodrigues, José Francisco Alves Boaventura casou-se com Emília Simões Ferreira Boaventura - que era membro da família de Quintiliano Martins da Silva - e tiveram os filhos José e Joviniano Alves Boaventura. Destes, o primeiro é a testemunha processual sobre a qual falamos e quem deixou uma prole de 3 filhos, cujos descendentes permanceram tendo influência no cenário feirense.

O primo segundo de José Alves Boaventura, Almachio Alves Boaventura, tornou-se Tabelião de Notas, foi vereador e Prefeito de Feira de Santana-BA, casou-se com Zélia Farini Boaventura com quem teve o filho Beraldo Alves Boaventura Neto, que se tornou Deputado Federal entre 1991 e 1995.

Dessa família, até o momento não conseguimos relacionar as genealogias de Gonçalo Alves Boaventura, Manoel Alves de São Boaventura e Francisco Manuel Alves Boaventura com os demais Boaventura e, por isso, mantivemos os respectivos descendentes separados, embora tenhamos encontrado documentos que entrelaçam esses "sujeitos" na mesma família sem, contudo, mencionarem os seus graus de parentesco.

Sobre Arthur Alves Boaventura encontramos informações de que ele nasceu em 15 de março de 1865 e atuou em vários processos jurídicos como bacharel em Direito, título obtido na Faculdade de Direito de Recife, onde se formou em 1885, conforme Registro de carta de bacharel, disponível no Arquivo da Faculdade de Direito de Recife. Durante os anos de sua formação, foram realizados cinco exames nos quais Arthur Alves Boaventura obteve os conceitos "approvado plenamente" (no primeiro, terceiro e quinto anos, cujos exames foram realizados em 11 de novembro de 1881, 12 de novembro de 1883 e 17 de setembro de 1885, respectivamente) e "approvado com distinção" (no segundo e quarto anos, cujos exames foram realizados em 14 de novembro de 1882 e 8 de novembro de 1884 , respectivamente).

Também encontramos informações sobre o primo de José Alves Boaventura, Gonçalo Alves Boaventura que foi, além de fazendeiro e comerciante de couros, Conselheiro Municipal da cidade no período de 1924 a 1926, e sobre o memorialista e poeta Eurico Alves Boaventura ${ }^{171}$, conhecido nacional e internacionalmente, e cujas

\footnotetext{
${ }^{171}$ Para mais informações sobre este Boaventura, sugerimos, por exemplo, a leitura de Para ler Eurico Alves Boaventura (1987), de autoria da pesquisadora Rita Olivieri-Godet.
} 
obras tem sido estudadas por diversos pesquisadores, principalmente os que pesquisam autores baianos.

Outro membro familiar dos Boaventura que teve bastante notoriedade na Feira de Santana-BA do seu tempo foi o Padre Ovídio Alves de São Boaventura, nascido em 1840 e falecido em 1886, que fundou a Ordem Terceira da Penitência de São Francisco, a Escola Sant'Ana, o Orfanato Asilo Nossa Senhora de Lourdes e a Associação das Senhoras da Caridade do Asylo de Lourdes, a Sociedade Montepio dos Artistas Feirenses, a Filarmônica Victória, a Associação de Nossa Senhora das Vitórias, bem como se empenhou na libertação de pessoas escravizadas, na reconstrução da Igreja Matriz e no planejamento da construção de um aprendizado (CUNHA, 2013). Como se pode ver, o Padre Ovídio Alves de São Boaventura foi um visionário que se preocupava, antes de tudo, com a "justiça social”, materializada em suas obras.

De 1900 a 1930, as obras desse pároco serviram de base para o estabelecimento e ascensão social dos comerciantes, fazendeiros, advogados, médicos, farmacêuticos, coronéis, capitães e majores que se lançaram na política feirense, conforme discutimos na segunda seção. Logo, obras como o Orfanato Asilo Nossa Senhora de Lourdes, a Associação das Senhoras da Caridade do Asylo de Lourdes, a Sociedade Montepio dos Artistas Feirenses, a Filarmônica Victória, a Associação de Nossa Senhora das Victórias e a dispensação de quantias significativas para a reforma e manutenção das igrejas da cidade não foram apenas bem vistas, mas foram meios que a elite feirense utilizou para ser bem quista pela população e pelos seus correligionários.

Visibilidade social que não terminou nas obras filantrópicas, mas se estendeu à criação da estrada de rodagem, que ligaria Feira de Santana-BA à capital e ao interior do Estado, cuja influência do Major Leolindo dos Santos Ramos, quarta testemunha do testamento de Dona Maximiana de Almeida Motta, foi, junto com a de outros políticos, imprescindível para a sua inauguração em 1925, principalmente porque aquela obra fazia parte das mudanças que a Companhia de Melhoramentos de Feira de Santana se propunha a fazer, o que contribuiu, sobremaneira, para a consagração da vida política do referido major, que atuou como Conselheiro Municipal de 1915 a 1924, período em que foi segundo Secretário e Presidente do Conselho Municipal, além de Presidente da Guarda Noturna Comercial de Feira de Santana-BA, sócio fundador e fiscal do Banco de Crédito Popular de Feira de Santana-BA e um dos influentes eleitores da cidade.

Enquanto negociante, Leolindo dos Santos Ramos foi sócio do seu irmão Arlindo dos Santos Ramos na "Casa Comercial Ramos e Cia", onde existia um 
armazém de fumo que lhe pertencia e que fazia parte do número de imóveis dos quais ele era proprietário. Outra informação relevante é a de que o seu filho, Leolindo Ramos Filho, foi Presidente da Filarmônica Euterpe Feirense e inquilino, em 1924, de uma das casas do Coronel Agostinho Fróes da Motta, situada na Rua Visconde do Rio Branco, como consta no terceiro volume do inventário do referido coronel.

A quinta testemunha do testamento de Dona Maximiana de Almeida Motta foi Pedro Rodrigo do Lago que possuía prestígio político, já que era do mesmo partido que Agostinho Fróes da Motta, Tertuliano José de Almeida, Bernardino da Silva Bahia e Heráclito Dias de Carvalho, constituindo-se também um dos poucos que compunha o grupo de eleitores da cidade e que teve como auge da sua carreira política a ocupação do cargo de Deputado Federal pelo Partido Republicano, chefiado pelo Dr. Severino Vieira. Além de político, Pedro Rodrigo do Lago foi um próspero negociante e possuía, dentre os seus bens, casas comerciais de torreação de café, fábrica de vinagre e armazém.

Testemunha no testamento de Dona Maximiana de Almeida Motta, Bernardino da Silva Bahia não foi apenas amigo daquela, mas um dos principais parceiros políticos de Agostinho Fróes da Motta, o que nos induz a detalhar a sua relação com Feira de Santana-BA e com o clã Fróes da Motta. Assim sendo, Bernardino Bahia, como ficou política e socialmente conhecido na cidade, era natural de Salvador e filho de Dona Francisca Alves A. Bahia e Bernardino da Silva Bahia, os quais lhe deram o irmão Francisco Amado da Silva Bahia, que mais tarde se tornou o seu sócio na Capital do Estado, onde também morava e comecializava gado. Em Feira de Santana-BA, Bernardino Bahia fixou residência nos anos iniciais do século XX e desde então foi se destacando como um grande comerciante de gado (CUNHA, 2013).

Foi também na Princesa do Sertão que Bernardino Bahia constituiu família, da qual nasceram, do seu primeiro casamento com Maria Berenisa de Barros, quatro filhos, a saber: Amanda de Barros Bahia, Maria Berenisa de Barros Bahia, José Jerônimo de Barros Bahia e Rita Bahia Saback de Oliveira. Esta última foi casada com o tenente coronel Mario Saback de Oliveira, que também era companheiro de política de Eduardo Fróes da Motta, do próprio Bernardino Bahia, de Tertuliano José de Almeida, de Leolindo dos Santos Ramos e de todos os demais que participaram do mesmo partido político que aquele. Depois de viúvo, Bernardino Bahia se casou com Dona Luisa Rubinos Bahia, com quem teve Carlos Arthur Rubinos Bahia, filho caçula e o único que seguiu os passos do pai na carreira política. 
Organograma 16 - Árvore genealógica de Bernardino da Silva Bahia

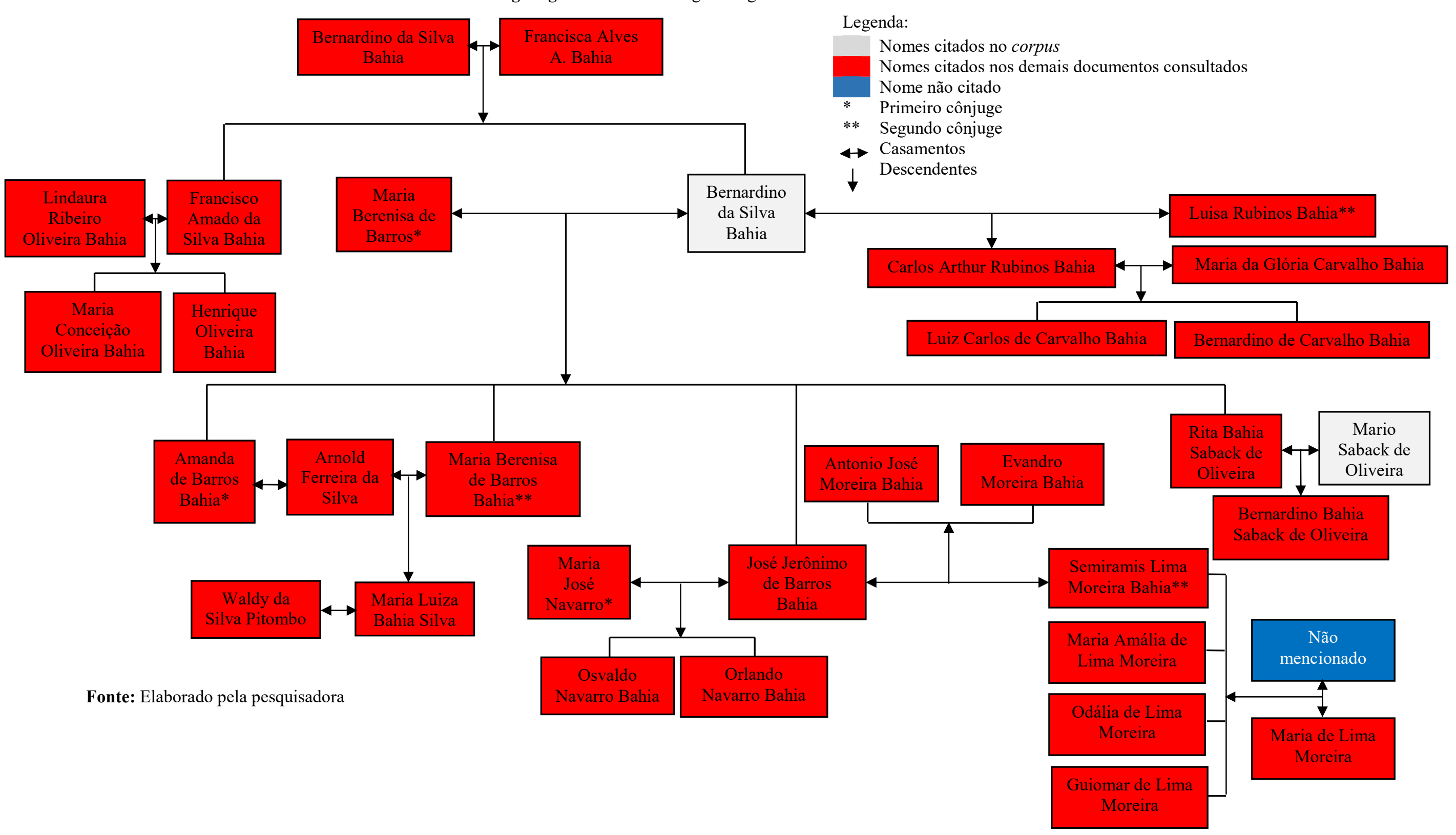


Por conta da amizade e referência política que Agostinho Fróes da Motta representava, Bernardino Bahia viajou para a Europa em 1914, período em que o seu amigo já tinha feito duas viagens à Alemanha, a fim de trazer ideias modernizantes para Feira de Santana-BA. Assim, inspirados em obras europeias, ambos trouxeram para a Princesa do Sertão um plano de modernização de toda a cidade, aplicado, principalmente, com a criação da Companhia de Melhoramentos de Feira de Santana, na qual, junto com os seus companheiros políticos, implementou a modernização das avenidas, ruas, praças, calçadas etc., além de ter atuado como Intendente Municipal durante dois mandatos: 1912 a 1915 e 1920 a 1923, sempre filiado ao Partido Republicano da Bahia, dentro do qual defendeu os seus ideais e os seus apadrinhados, dos quais se destacou o jornalista Arnold Ferreira da Silva, que, junto com os seus dois irmãos mais velhos, tornou-se, em 1922, dono do Jornal Folha do Norte, além de ter sido líder do diretório local do Partido Republicano da Bahia, Intendente Municipal, de 1924 a 1928, e Prefeito de Feira de Santana-BA no mandato de 1959 a 1962.

Contudo, vale destacar que a relação de apadrinhamento estabelecida entre Bernardino Bahia e Arnold Ferreira da Silva se deu, principalmente, porque este se casou com duas das filhas daquele, a saber: em primeiras núpcias com Amanda de Barros Bahia, que faleceu em 1926, e, em segundas núpcias, com Maria Bereniza Barros Bahia da Silva, em 1930, com quem teve a sua filha Maria Luiza (CAMPOS, 2016). Assim como os demais, Arnold Ferreira da Silva fez carreira na política, foi provedor das sociedades de caridade feirenses Monte Pio dos Artistas Feirenses, Filarmônica 25 de Março, Filarmônica Euterpe Feirense, além de ter sido negociante de leite na cidade e parceiro político de Eduardo Fróes da Motta e de outros, que se lançaram na política local, estadual e/ou nacional.

Além de Arnold Ferreira da Silva, Bernardino Bahia também lançou o seu filho caçula na política. Logo, com a criação do Banco Popular de Feira de Santana-BA, Carlos Arthur Rubinos Bahia se tornou secretário daquele banco e trabalhou junto com Eduardo Fróes da Motta e o seu cunhado, Arnold Ferreira da Silva. Entretanto, com o golpe de Getúlio Vargas, Arnold Ferreira da Silva e Eduardo Fróes da Motta se colocaram em lados opostos na política, pois o primeiro se tornou integrante da bancada da Aliança Liberal, e o segundo apoiou Vargas e foi representante do "getulismo" em Feira de Santana-BA (CUNHA, 2013).

Bernardino Bahia, além de ter sido declarado amigo da testadora Maximiana de Almeida Motta e apresentador do seu testamento, também estabeleceu com os Fróes da Motta uma relação de compadrio importante, já que foi padrinho de batismo de Eduardo Fróes da Motta e o auxiliou na política, após a morte do seu compadre e amigo, Agostinho Fróes da Motta. Em outras palavras, ter sido Conselheiro Municipal (1904, 1907 a 1915, 1919 a 1924), 
coronel, comerciante, proprietário, pecuarista, fiscal do banco de crédito agrícola, Intendente Municipal e provedor de sociedades de caridade (CUNHA, 2013) fizeram de Bernardino Bahia não somente um dos homens mais ricos e influentes na Princesa do Sertão nas duas primeiras décadas do século XX, mas um amigo importante para aqueles que desejavam entrar e se manter nas políticas feirense, baiana e nacional, como foram os casos do seu filho, do seu genro e do seu afilhado.

Logo, as histórias de Bernardino Bahia, Agostinho Fróes da Motta, Arnold Ferreira da Silva e Eduardo Fróes da Motta se entrelaçam, pois, além de relações políticas, existiam as de compadrinho e de apadrinhamento, que mantiveram as famílias unidas e o poder centralizado nas mãos de uma elite abastada e sedenta por modernizações, principalmente nos locais em que aquela possuía imóveis, cuja modernização alavancaria os seus valores.

A última testemunha no testamento de Dona Maximiana de Almeida Motta foi Auto Esmeraldo dos Reis que foi Conselheiro Municipal de 1912 a 1919 e, portanto, um dos eleitores da cidade e contribuinte das causas sociais, apoiado, inclusive, pelo Coronel Agostinho Fróes da Motta. Enquanto médico, foi nomeado perito, junto com o farmacêutico José Alves Boaventura, no caso, por exemplo, do auto de defloramento de uma jovem feirense, lavrado entre 1914 a 1924 e mencionado anteriormente. Na seção de propagandas do Folha do Norte, Auto Esmeraldo dos Reis era anunciado como especialista em "partos, moléstias das senhoras e das vias urinárias".

O mesmo periódico também publicou uma nota sobre a nomeação, ocorrida em 5 de novembro de 1911, de Auto Esmeraldo dos Reis para ocupar o cargo de segundo suplente de Juiz de Direito de Feira de Santana-BA: "Judiciarias | Por portaria de 5 do corrente | mez foi nomeado $2^{\circ}$ supplente $\mid$ de Juiz de Direito desta comar- | ca, o doutor Auto Esmeraldo dos | Reis, para servir no biênio de $\mid 18$ de Novembro de 1910 a 18 de | Novembro de 1912, no termo, se- $\mid$ de desta mesma comarca [...]" (JUDICIARIAS, FOLHA DO NORTE, 18 nov. 1911, p. 2).

Anos depois, Auto Esmeraldo dos Reis foi médico particular do Coronel Agostinho Fróes da Motta durante os seus últimos meses de vida, passando, até mesmo, a dormir durante vários dias no Casarão Fróes da Motta, residência do coronel. Nesse contexto médicopaciente durante 24 horas por dia é que surgiu o episódio mencionado por Dona Almerinda de Almeida Motta na ação executiva proposta pelo seu então marido, Capitão Augusto Fróes da Motta, e o seu cunhado, Farmacêutico Arthur Fróes da Motta. Após o disparo do tiro de arma de fogo contra aquela, o Doutor Auto Esmeraldo dos Reis passou a ser execrado publicamente 
junto com aquela, inclusive nos jornais da cidade, justamente por ter sido acusado de atentar contra a honra de Augusto Fróes da Motta e por ter "se aproveitado da amizade" que lhe foi ofertada, mesmo se defendendo das acusações (AÇÃO DE LESÃO..., 1922; CUNHA, 2013; RODRIGUES, 2016).

Após isso, o Doutor Auto Esmeraldo dos Reis mudou-se para a Capital, de onde publicou nos jornais a sua defesa, mas foi novamente rechaçado pela opinião pública, assim como Dona Almerinda de Almeida Motta, que foi morar na casa do seu irmão, Clodoaldo Severiano de Almeida, e ambos "adúlteros" foram "banidos" da sociedade feirense (RODRIGUES, 2016).

Em síntese, como pudemos notar, todos os "sujeitos" descritos tiveram papéis relevantes tanto na produção do corpus quanto na política, economia e sociedade feirenses do início do século XX. Mais do que isso, ao finalizar esta subseção, pudemos compreender as relações dos "sujeitos" elencados com a família Fróes da Motta, em torno da qual aqueles personagens viveram, exercendo cargos internos no Conselho ou na Intendência Municipal ou no seio familiar dos Fróes da Motta, o que os levaram a se relacionar não apenas na política, mas em ações de caridade, em atividades comerciais e em vínculos de casamento ou de compadrio. Logo, sobre alguns indivíduos há muitas informações disponíveis em variados materiais e sobre outros muito poucas, o que se explica, provavelmente, pela importância política, econômica ou social de cada um no cenário feirense.

Diante do exposto, acreditamos que as informações sumarizadas nos permitem responder às seguintes questões: quem foram aquelas pessoas? Qual a sua relação com os Fróes da Motta? E qual a sua contribuição para o processo de produção do corpus?

Sobre a primeira questão, entendemos que se tratavam de homens, cujas relações pessoais, políticas e sociais estavam associadas diretamente com as dos Fróes da Motta, e por isso eles não somente foram testemunhas como também amigos partícipes não somente da celebração da última vontade dos testadores, mas também dos variados momentos da vida pessoal daqueles e dos seus filhos. Logo, a segunda questão complementa a primeira no sentido de que aqueles indivíduos foram pessoas que mantiveram relações de amizade, de compadrio, de apadrinhamento e de laços familiares com os Fróes da Motta, o que explica a presença de cada um deles nos testamentos, e durante a vida política, social e/ou econômica de Dona Maximiana de Almeida Motta e do Coronel Agostinho Fróes da Motta.

Sobre a terceira e última questão, vimos que todos os indivíduos contribuíram para o processo de produção do corpus, justamente por estarem presentes naquele como testemunhas, amigos e/ou compadres, o que indica que não se tratavam de pessoas que 
frequentavam a casa ou que participavam da vida social dos Fróes da Motta esporadicamente, mas de "sujeitos" que mantinham uma íntima relação com a família, e por isso a recorrência dos seus nomes no corpus e nos processos listados no quadro 3 desta tese.

Mais do que isso, portanto, o perfil socioprofissional dos sujeitos apresentados indica que se tratavam de homens, em sua grande maioria, influentes social e politicamente, economicamente favorecidos, casados ou viúvos e com familiares inseridos no comércio, na agricultura, na pecuária e/ou na política feirense, residentes e proprietários de imóveis dentro e fora da cidade e homens de confiança do clã Fróes da Motta.

\subsubsection{Apresentação das edições fac-similar e semidiplomática do corpus}

Nesta subseção, apresentamos as edições fac-similar e semidiplomática do corpus, que são tipos de edição conservadoras, a partir das quais buscamos, conforme assinala Bueno (1967), preservar não somente o conteúdo, mas a língua, a ortografia e as escolhas lexicais dos escreventes, o que coaduna com o nosso objetivo geral de preparar uma edição confiável para fins linguísticos e historiográficos, já que tanto o léxico quanto os aspectos sóciohistóricos são imprescindíveis para o acesso ao texto.

Ademais, por entendermos que os recursos tecnológicos estão à nossa disposição para facilitar a leitura de documentos, utilizamos ferramentas digitais como, por exemplo, o zoom, que nos possibilitou ampliar a imagem de cada caractere do texto; os filtros específicos que realçaram a cor do texto ou focalizaram as características do suporte material; e as ferramentas de ajustes das imagens no que concerniu à cor, ao brilho, ao contraste, à correção de manchas etc., que também auxiliaram na decodificação de passagens de difícil leitura do texto e nas descrições codicológica e paleográfica dos documentos.

À exceção desses contextos, os fac-símiles do corpus foram produzidos, através de fotografias digitais, que respeitaram todos os aspectos gráficos e codicológicos dos documentos. Semelhantemente, a edição semidiplomática também foi realizada com rigor e em ambiente digital, através do uso do processador de texto Microsoft Word, produzido pela Microsoft Office, no qual inserimos tabelas, dentro das quais transcrevemos todos os textos, que obedeceram aos critérios de edição descritos a seguir, e que foram devidamente revisados e tiveram as suas caixas de escrita ocultadas. 


\subsubsection{Descrição dos critérios adotados}

Como sinalizado na subseção 4.2, dentre os tipos de edição existentes, escolhemos aplicar ao corpus desta tese as edições fac-similar e semidiplomática, por acreditarmos que esses dois tipos de edição dão conta de um dos nossos objetivos centrais, que é o de preservar a forma gráfica dos textos e as informações constantes naqueles, interferindo, enquanto editor, somente no sentido de desdobrar as suas abreviaturas, preservando as demais características dos textos, o que confere bastante rigor aos tipos de edições escolhidos.

Partindo desse objetivo e compartilhando das palavras do professor Megale ao dizer, no texto de apresentação da obra Descaminhos e dificuldades: leitura de manuscritos do século XVIII (2008), que todo manuscrito, seja este recente ou não, apresenta alguma dificuldade, seja na decifração de uma letra, sílaba, palavra, frase ou parágrafo, durante a sua leitura, entendemos que se faz necessário um olhar cuidadoso para cada traçado, já que uma das etapas cruciais do nosso trabalho é apresentar uma edição acurada, cuja finalidade é servir como ponto de partida para o estudo do léxico, atestado nos documentos manuscritos ora editados.

Para atingir esse objetivo, contudo, adotamos e, em alguns casos, adaptamos às necessidades dos documentos estudados os critérios de edição elencados nas Normas para transcrição de documentos manuscritos para a história do português do Brasil (NHPB), disponíveis em Megale e Toledo Neto (2005, p. 147-148). Dessas normas, utilizamos para a edição semidiplomática dos documentos os seguintes critérios:

\section{A transcrição será conservadora;}

2. As abreviaturas, alfabéticas ou não, serão desenvolvidas, marcando-se, em itálico, as letras omitidas na abreviatura, respeitando, sempre que possível, a grafia do manuscrito;

3. Não será estabelecida fronteira de palavras que venham escritas juntas, nem se introduzirá hífen ou apóstrofo onde não houver;

4. A pontuação original será rigorosamente mantida. No caso de espaço maior intervalar deixado pelo escrevente será marcado: [espaço];;

5. A acentuação original será rigorosamente mantida, não se permitindo qualquer alteração;

6. Será respeitado o emprego de maiúsculas e minúsculas como se apresentam no original. No caso de alguma variação física dos sinais gráficos resultar de fatores cursivos, não será considerada relevante. Assim, a comparação do traçado da mesma letra deve propiciar a melhor solução; 
7. Eventuais erros ou rasuras do escrevente serão mencionados em nota de rodapé, onde se deixará registrada a lição por sua respectiva correção;

8. Inserções do escrevente na entrelinha ou nas margens superior, laterais ou inferior entrarão na edição entre os sinais: $\langle\uparrow>$ para inserção na margem superior, $<\downarrow>$ para inserção na margem inferior, $<\rightarrow>$ para inserção na margem direita ou $<\leftarrow>$ para inserção na margem esquerda, na localização indicada;

9. Supressões ou correções feitas pelo escrevente no original serão inseridas entre colchetes, tachadas e mencionadas em nota de rodapé;

10. Intervenções do editor hão de ser raríssimas, permitindo-se apenas em caso de extrema necessidade, desde que elucidativas a ponto de não deixarem margem à dúvida. Quando ocorrerem devem vir entre colchetes. Por exemplo: "e que assignaram depois de lhes ser lido po[r]";

11. Letra, palavra ou trecho ilegível por deterioração do suporte material justificarão a intervenção do editor na forma do item anterior, com a indicação entre colchetes [ilegível], [rasgado] ou [manchado];

12. Trecho de maior extensão não legível por deterioração receberá a indicação [corroídas/ rasgadas ou manchadas + ou - " $x$ " linhas]. Se for o caso de trecho riscado ou inteiramente anulado por borrão ou papel colado em cima, será registrada a informação pertinente entre colchetes e sublinhada. Exemplo: [trecho riscado], [trecho anulado por papel colado em cima];

13. A disposição gráfica do texto será preservada, no máximo possível, na edição semidiplomática, o que quer dizer que as linhas e a paragrafação do texto original serão mantidas. A mudança de fólio receberá a marcação com o respectivo número na sequência de duas barras verticais: ||1r. $\|\| ,2 \mathrm{r}$. \|, ||2v. \|, \|3r. \|, indicadas à direita da página e à esquerda do leitor;

14. Na edição semidiplomática, as linhas serão numeradas de cinco em cinco a partir da quinta. Essa numeração será encontrada à margem direita da mancha, à esquerda do leitor. Será feita de maneira contínua por documento e será contada a partir do início da mancha escrita ou de sinais muitos particulares do escrevente até o final da mancha escrita do respectivo fólio;

15. As assinaturas simples ou as abreviadas do punho de quem assina serão sublinhadas. No caso das abreviadas, estas serão desdobradas, marcando-se, em itálico, as letras omitidas na abreviatura, com exceção dos casos em que não for possível o seu desdobramento por conta do seu total desconhecimento ou ilegibilidade. Neste caso, sinalizamos apenas a existência de 
tal assinatura. Exemplos: Assinatura simples: Manuel Francisco de Almeida Ramalho; Assinatura abreviada: JoãoCarneiroVital; Assinatura abreviada não identificada e, portanto, não desdobrada: [Assinatura];

16. As edições fac-similar e semidiplomática serão apresentadas de forma justalinear, estando a fac-similar à esquerda e a semidiplomática à direita do leitor, o que permite que o pesquisador compare o fac-símile com a sua transcrição, de forma que seja possível identificar, entre as duas edições, as intervenções feitas pelo editor na edição semidiplomática em comparação com a edição fac-similar;

17. Na edição fac-similar, apresentada de forma seguida com a semidiplomática, serão inseridos apenas os fólios que possuem mancha escrita. Entretanto, todos os fac-símiles, incluindo-se os fólios em branco, que constituem, junto com os que têm mancha escrita, a totalidade do documento, serão apresentados ao final desta tese, na edição fac-similar completa do corpus disponível no Anexo A;

18. Palavra ou trecho ilegível por conta da caligrafia dos escreventes justificam intervenção do editor, com a indicação de colchetes com reticências para sinalizar leitura não identificada. No caso de trecho com duas ou mais linhas ilegíveis, a indicação disso deve vir entre colchetes com reticências acompanhado da expressão +2 linhas ilegíveis. Exemplo: "Julgo por sentença a justificação constante destes [... +2 linhas ilegíveis $] ”$.

No caso dos fólios manuscritos com cores diferentes de tinta e dos fólios híbridos (compostos por trechos manuscritos e datiloscritos, por trechos datiloscritos com cores diferentes de tinta ou por formulários impressos), propomos os seguintes critérios:

1. Os fólios manuscritos com cores diferentes de tinta serão, na edição semidiplomática, transcritos na cor da tinta próxima, ou correspondente, à que aparece no original com a finalidade de obter uma representação visual semelhante à do original;

2. Os textos dos fólios híbridos serão apresentados, na edição semidiplomática, na cor da tinta próxima, ou correspondente, à que aparece no original, e com destaque em negrito.

Como se pode notar, tanto a edição fac-similar quanto a semidiplomática apresentarão o mínimo de intervenção do editor, por entendermos que, como se tratam de edições feitas para fins linguísticos, não devemos inserir quaisquer alterações nas edições que comprometam os elementos linguísticos, contextuais ou conteudísticos dos documentos.

Por conta disso, critérios como o de número 8 - em que foram acrescidas ao critério reproduzido de Megale e Toledo Neto (2005) as setas, que direcionarão o sentido das 
inserções de textos nas margens feitas pelos escreventes; o de número 13 que - apesar de parecer redundante, já que a nossa proposta é apresentar uma edição seguida e, por isso, de fácil e rápida comparação entre os fac-símiles e a transcrição do texto - é bastante oportuno, haja vista muitos documentos apresentarem erros de numeração, como expusemos nas fichas codicológicas da terceira seção, o que quer dizer que a manutenção desse critério, mesmo quando se apresentam edições seguidas, faz-se pertinente por auxiliar na devida contagem e correção dos fólios que apresentam tal problema; e os de números 1 e 2 para os fólios manuscritos e para os híbridos, ambos redigidos com cores diferentes de tinta - configuram-se uma tentativa de aproximação visual da edição semidiplomática com o texto original, já que buscamos reproduzir a cor da tinta que mais se aproxima daquela encontrada no documento original - o que ratifica a ideia de que todas as informações documentais que interessam à nossa pesquisa estarão preservadas, principalmente porque o nosso objetivo seguinte é estudar o léxico, que acreditamos refletir o vocabulário dos escreventes do corpus. 
4.3.5.2 Edições fac-similar e semidiplomática do testamento de Dona Maximiana de Almeida Motta

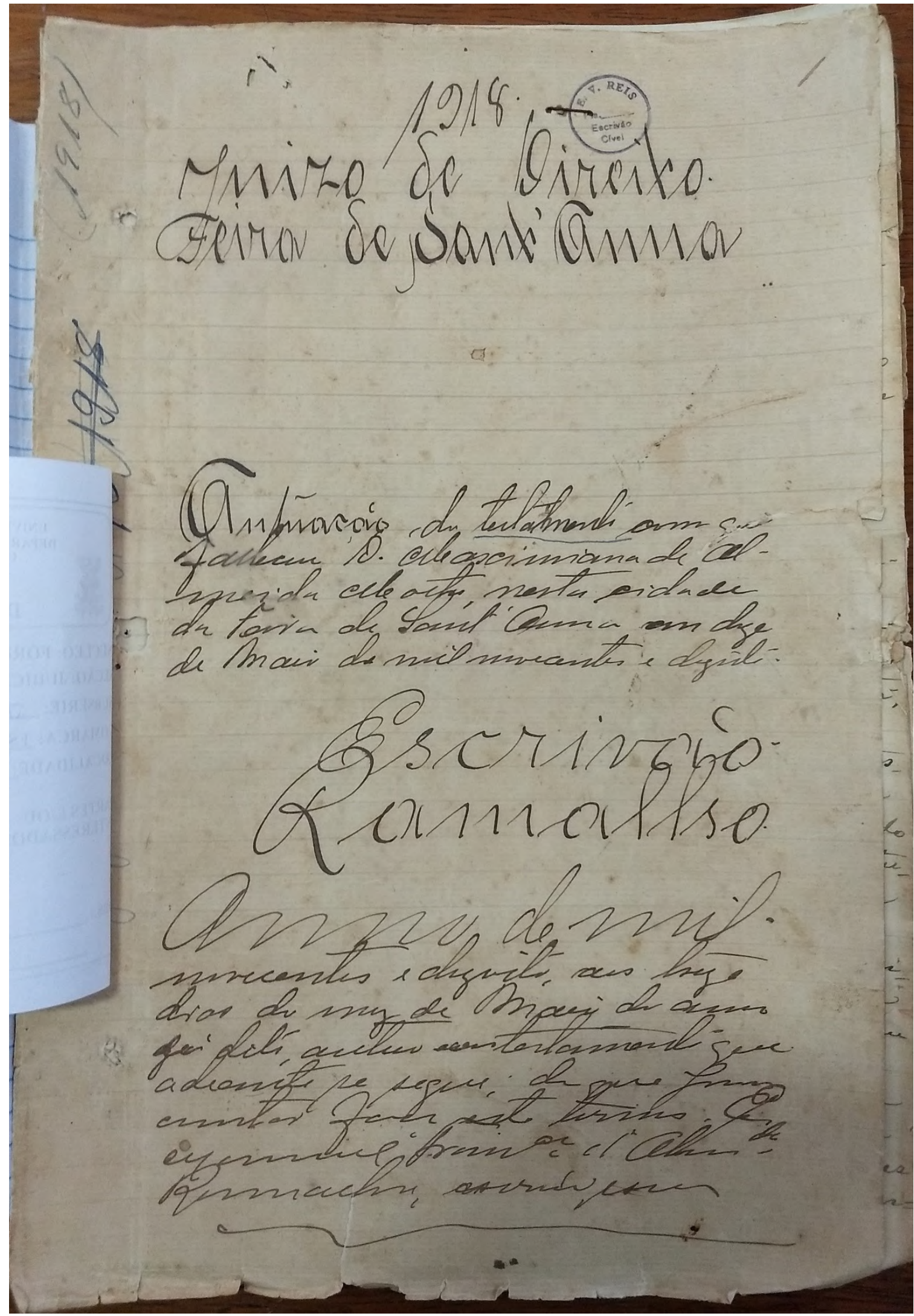




\section{|| 1r. $\|$ \\ $1918^{172}$ \\ Juizo de Direito ${ }^{173}$ \\ Feira de Sant'anna}

10

Autuação du testamento com que ${ }^{174}$

falleceu Dona Maximiana de Al-

meida Motta, nesta cidade

da Feira de Sant'Anna aos doze

15 de Maio de mil novecentos e dezoito.

\section{Escrivão \\ Ramalho.}

$20 \quad$ Anno de mil

novecentos e dezoito, aos treze

dias do mez de Maio do anno

já dito, autuo [esse testamento que

adeante se segue; do que para

25 constar faço este termo. Eu

Manuel Francisco d'Almeida

Ramalho, escrivão, escrevi

172 No manuscrito original, à direita desta datação, há um carimbo molhado de $21 \mathrm{~mm}$ de diâmetro com a inscrição: "E. V. REIS | Fls. | Escrivão Civel".

${ }^{173}$ No manuscrito original, na altura desta linha, há a datação "(1918)" na margem superior esquerda.

174 No manuscrito original, acima desta linha, na margem esquerda, há a datação 24/3/1918 anulada pelo scriptor, e um furo com $8 \mathrm{~mm}$ de diâmetro. 


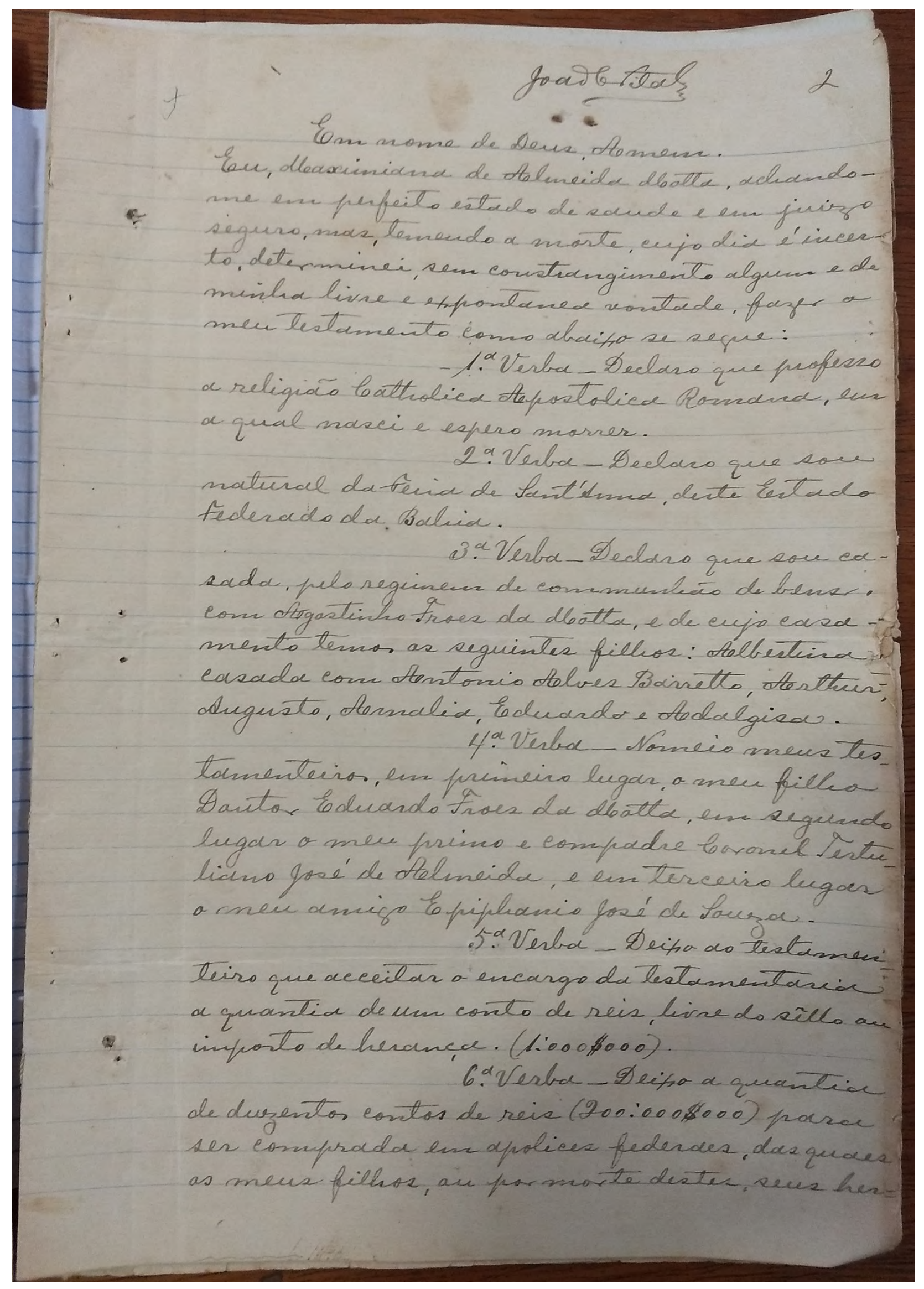


|| 2r. | $<\uparrow \underline{\text { JoãoCarneiroVital }}>$

Em nome de Deus, Amem.

$30 \mathrm{Eu}$, Maximiana de Almeida Motta, achandome em perfeito estado de saude e em juizo seguro, mas, temendo a morte, cujo dia é incerto, determinei, sem constrangimento algum e de minha livre e expontanea vontade, fazer o

35 meu testamento como abaixo se segue: _Primeira Verba_Declaro que professo a religião Catholica Apostolica Romana, em a qual nasci e espero morrer.

Segunda Verba_Declaro que sou

40 natural da Feira de Sant'Anna deste Estado Federado da Bahia.

Terceira Verba_Declaro que sou casada, pelo regimem de communhão de bens, com Agostinho Froes da Motta, e de cujo casa-

45 mento temos os seguintes filhos: Albertina casada com Antonio Alves Barretto, Arthur, Augusto, Amalia, Eduardo e Adalgisa.

Quarta Verba _ Nomeio meus testamenteiros, em primeiro lugar, o meu filho

50 Doutor Eduardo Froes da Motta, em segundo lugar o meu primo e compadre Coronel Tertuliano José de Almeida, e em terceiro lugar o meu amigo Epiphanio José de Souza.

Quinta Verba_Deixo ao testamen-

55 teiro que acceitar o encargo da testamentaria a quantia de um conto de reis, livre do sêllo ou imposto de herança. (1:000\$000).

Sexta Verba_Deixo a quantia de duzentos contos de reis (200:000\$000) para

60 ser comprada em apolices federaes, das quaes os meus filhos, ou por morte destes, seus her $=$ 


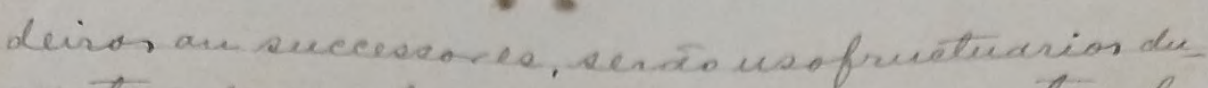

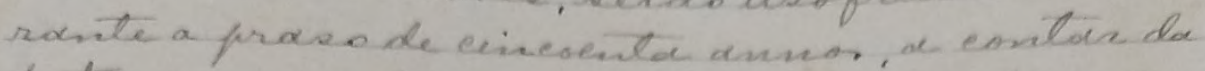

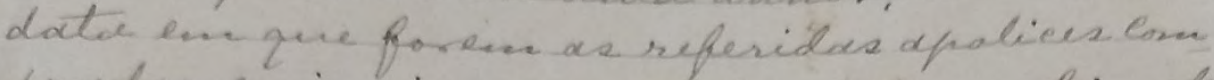

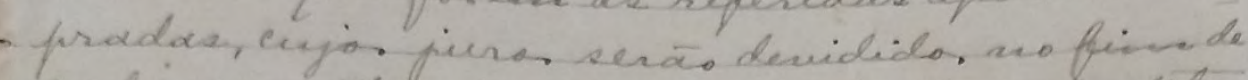

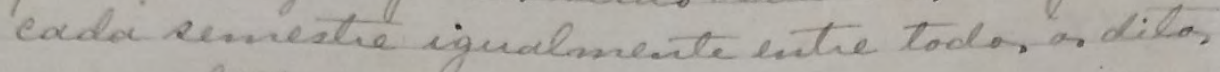

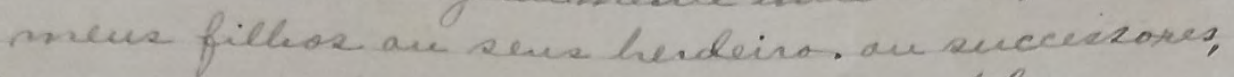

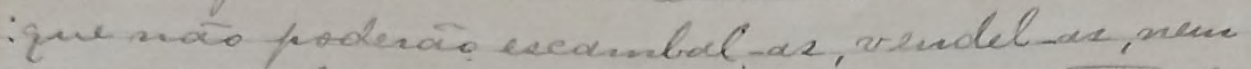

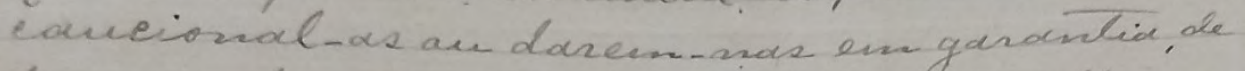

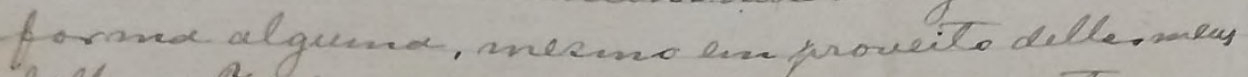
pilhs, tivedo o referido proso de civeventa an-

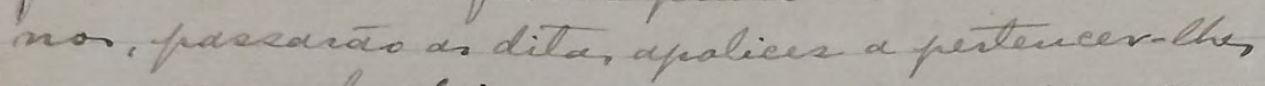

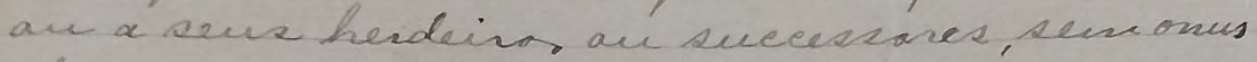
alguser.

\section{7aveiba - Deitro ás minkas} quatro solrinhas, fillude de dledriesleo de tellsmeida, a quantid de une cort to de reis (lioodran) a cada unira.

\section{8: Verba Eeitrodés mischar} sobrishas 'fydid e dlearid fosé, fillnds do men

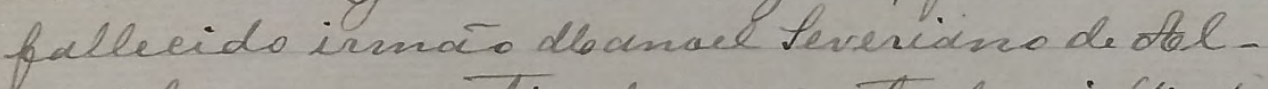

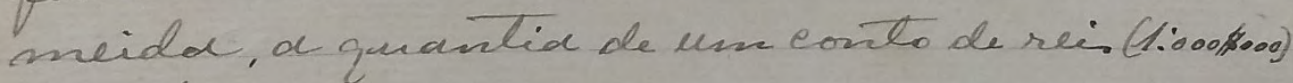
deddal usid.

$$
\text { 9. Verba Deifo des minches }
$$

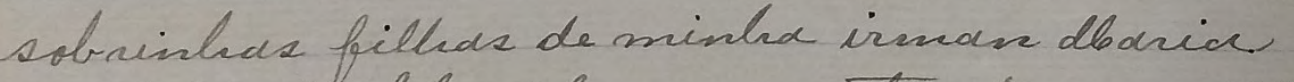
deathilde de toluneida, d quartid de une conto de reis (1.0001000) d edde ipred.

10: Verlid - Deitra di muilea afilludd, fillud de thelice Aruetures, edsada Cover foto Dontas. or quantid de une conto de reis $(10000000)$.

$$
11 \text {. Verba - Deita de Tavald }
$$

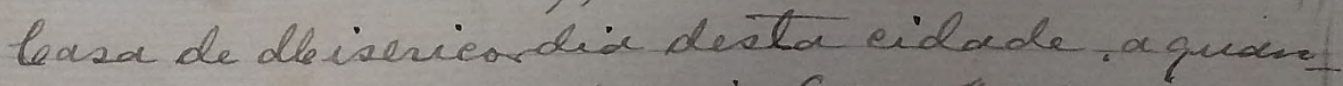
tiar de unes entro de reis $(1.0000000)$. 
|| 2v.|| deiros ou successores, serão usofructuarios durante o praso de cincoenta annos, a contar da data em que forem as referidas apolices com-

65 pradas, cujos juros serão devididos no fim de cada semestre igualmente entre todos os ditos meus filhos ou herdeiros ou successores, que não poderão escambal-as, vendel-as, nem caucional-as ou darem-nas em garantia, de

70 forma alguma, mesmo em proveito delles meus filhos. Findo o referido praso de cincoenta annos, passarão as ditas apolices a pertencer-lhes ou a seus herdeiros ou successores, sem onus algum.

75 Sétima Verba_Deixo ás minhas quatro sobrinhas, filhas de Marinho de Almeida, a quantia de um conto de reis (1:000\$000) a cada uma.

Oitava Verba_Deixo ás minhas

80 sobrinhas Lydia e Maria José, filhas do meu fallecido irmão Manoel Severiano de Almeida, a quantia de um conto de reis (1:000\$000) a cada uma.

Nona Verba _ Deixo ás minhas

85 sobrinhas filhas de minha irman Maria Mathilde de Almeida, a quantia de um conto de reis $(1: 000 \$ 000)$ a cada uma.

Décima Verba_Deixo á minha afilhada, filha de Alice Fructuoso, casada 90 com João Dantas, a quantia de um conto de reis $(1: 000 \$ 000)$.

Décima primeira Verba_Deixo á Santa Casa de Misericordia desta cidade, a quantia de um conto de reis (1:000\$000). 


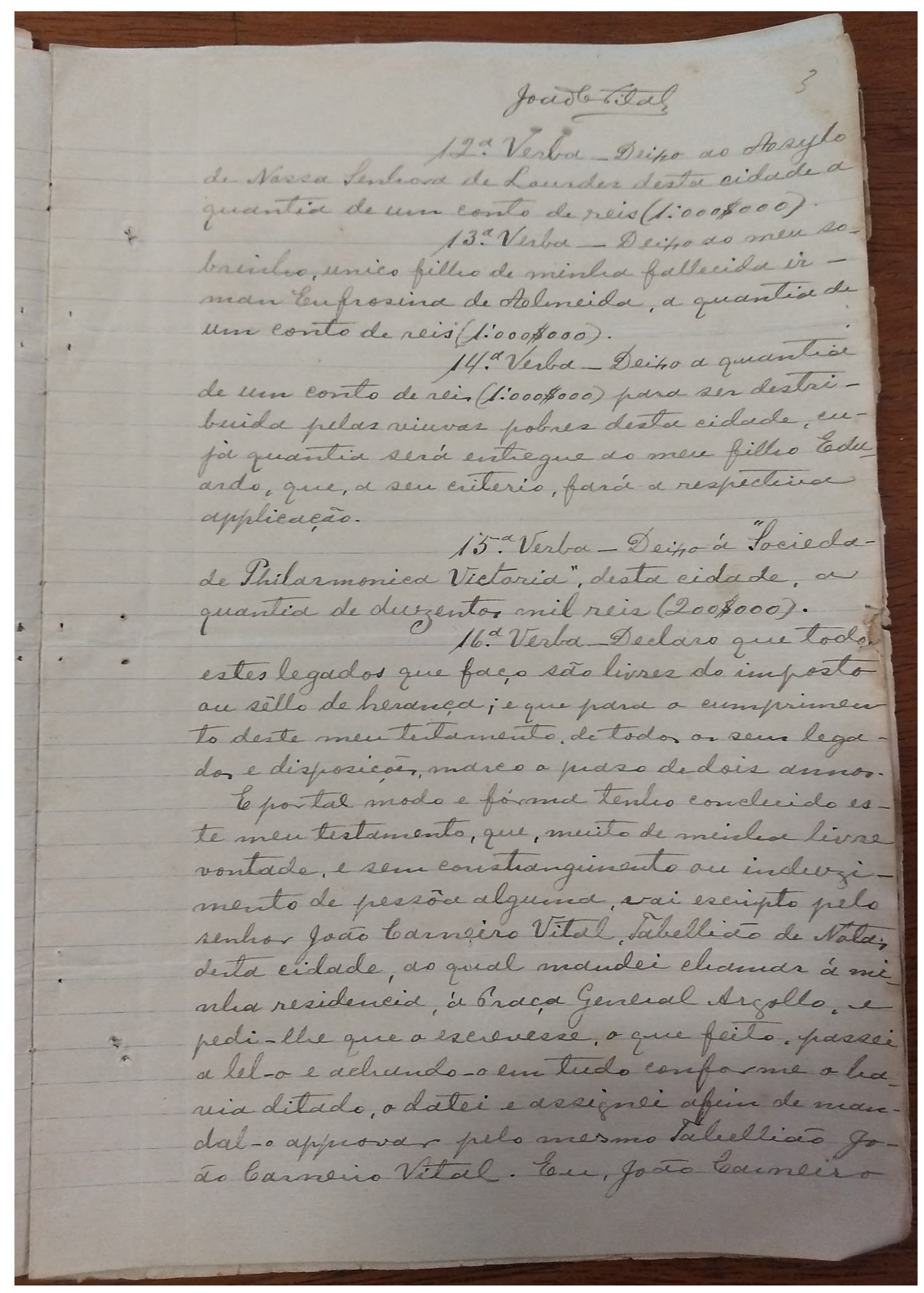


$95 \quad|| 3 r . \|$

$<\uparrow \underline{\text { JoãoCarneiroVital }}>$

Décima segunda Verba_Deixo ao Asylo

de Nossa Senhora de Lourdes desta cidade a quantia de um conto de reis (1:000\$000).

Décima terceira Verba Deixo ao meu so-

100 brinho, unico filho de minha fallecida irman Eufrosina de Almeida, a quantia de um conto de reis (1:000\$000).

Décima quarta Verba_Deixo a quantia de um conto de reis (1:000\$000) para ser destri-

105 buida pelas viuvas pobres desta cidade, cuja quantia será entregue ao meu filho Eduardo, que, a seu criterio, fará a respectiva applicação.

Décima quinta Verba _ Deixo á "Socieda-

110 de Philarmonica Victoria", desta cidade, a quantia de duzentos mil reis (200\$000).

Décima sexta Verba_Declaro que todo[s] estes legados que faço são livres de imposto ou sêllo de herança; e que para o cumprimen-

115 to deste meu testamento, de todos os seus legados e disposições, marco o praso dedois annos.

E por tal modo e fórma tenho concluido este meu testamento, que, muito de minha livre vontade, e sem constrangimento ou induzi-

120 mento de pessôa alguma, vai escripto pelo senhor João Carneiro Vital, Tabellião de Notas desta cidade, ao qual mandei chamar á minha residencia, á Praça General Argollo, e pedi-lhe que o escrevesse, o que feito, passei

125 a lel-o e achando-o em tudo conforme o havia ditado, o datei e assignei afim de mandal-o approvar pelo mesmo Tabellião João Carneiro Vital. Eu, João Carneiro 


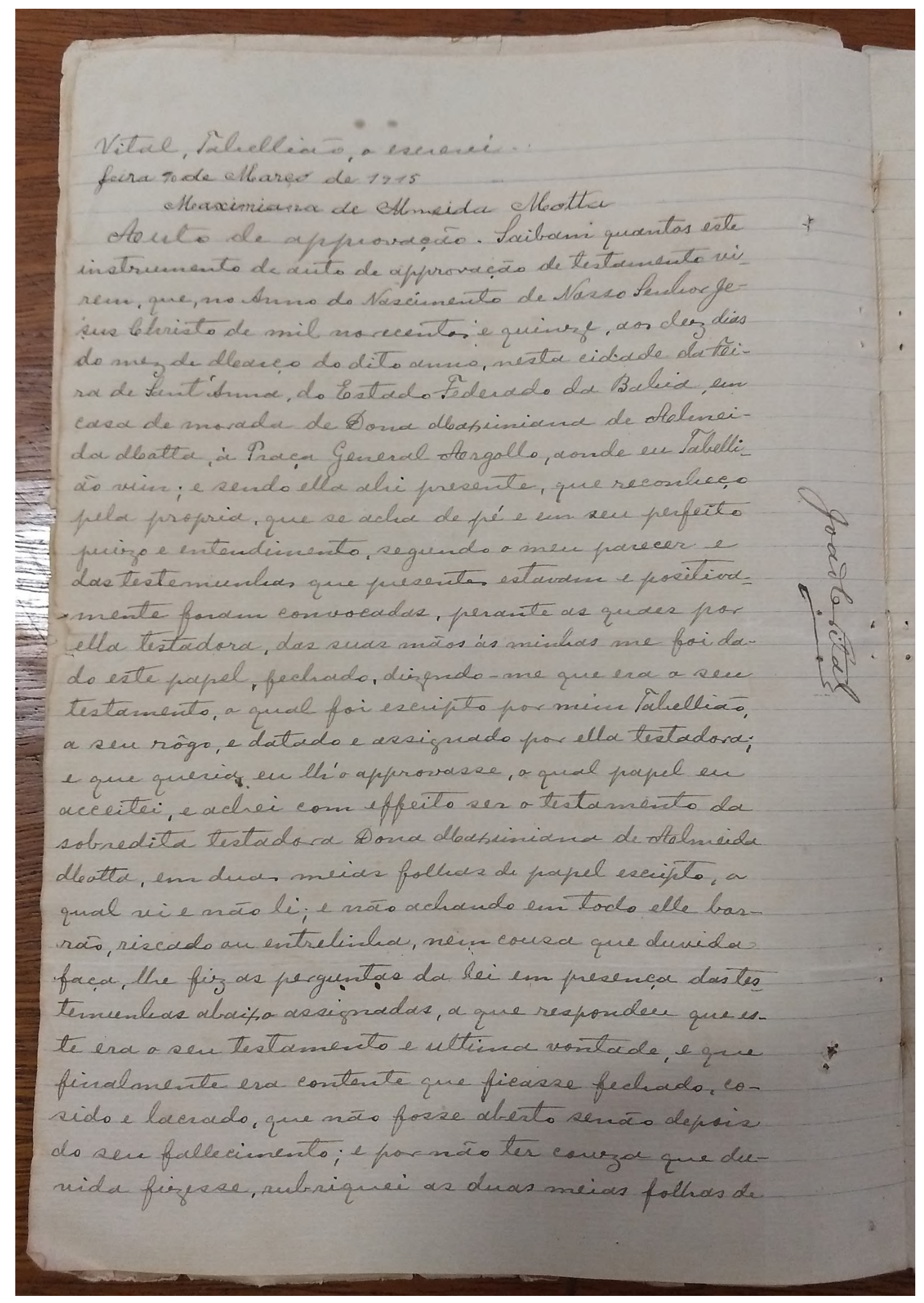


|| 3v.|| Vital, Tabellião, o escrevi.

130 feira 10 de Março de 1915

Maximiana de Almeida Motta

Auto de approvação. Saibam quantos este instrumento de auto de approvação de testamento virem, que, no Anno do Nascimento de Nosso Senhor Je-

135 sus Christo de mil novecentos e quinze, aos dez dias do mez de Março do dito anno, nesta cidade da Feira de Sant'Anna, do Estado Federado da Bahia, em casa de morada de Dona Maximiana de Almeida Motta, á Praça General Argollo, aonde eu Tabelli-

140 ão vim; e sendo ella ahi presente, que reconheço pela propria, que se acha de pé e em seu perfeito juizo e entendimento, segundo o meu parecer e das testemunhas que presentes estavam e positivamente foram convocadas, perante as quaes por

145 ella testadora, das suas mãos às minhas me foi dado este papel, fechado, dizendo-me que era o seu testamento, o qual foi escripto por mim Tabellião, a seu rôgo, e datado e assignado por ella testadora; e que queria eu lh'o approvasse, o qual papel eu

150 acceitei, e achei com effeito ser o testamento da sobredita testadora Dona Maximiana de Almeida Motta, em duas meias folhas de papel escripto, a qual vi e não li; e não achando em todo elle borrão, riscado ou entrelinha, nem cousa que duvida

155 faça, lhe fiz as perguntas da lei em presença das testemunhas abaixo assignadas, a que respondeu que este era o seu testamento e ultima vontade, e que finalmente era contente que ficasse fechado, cosido e lacrado, que não fosse aberto senão depois

160 do seu fallecimento; e por não ter couza que duvida fizesse, rubriquei as duas meias folhas de 


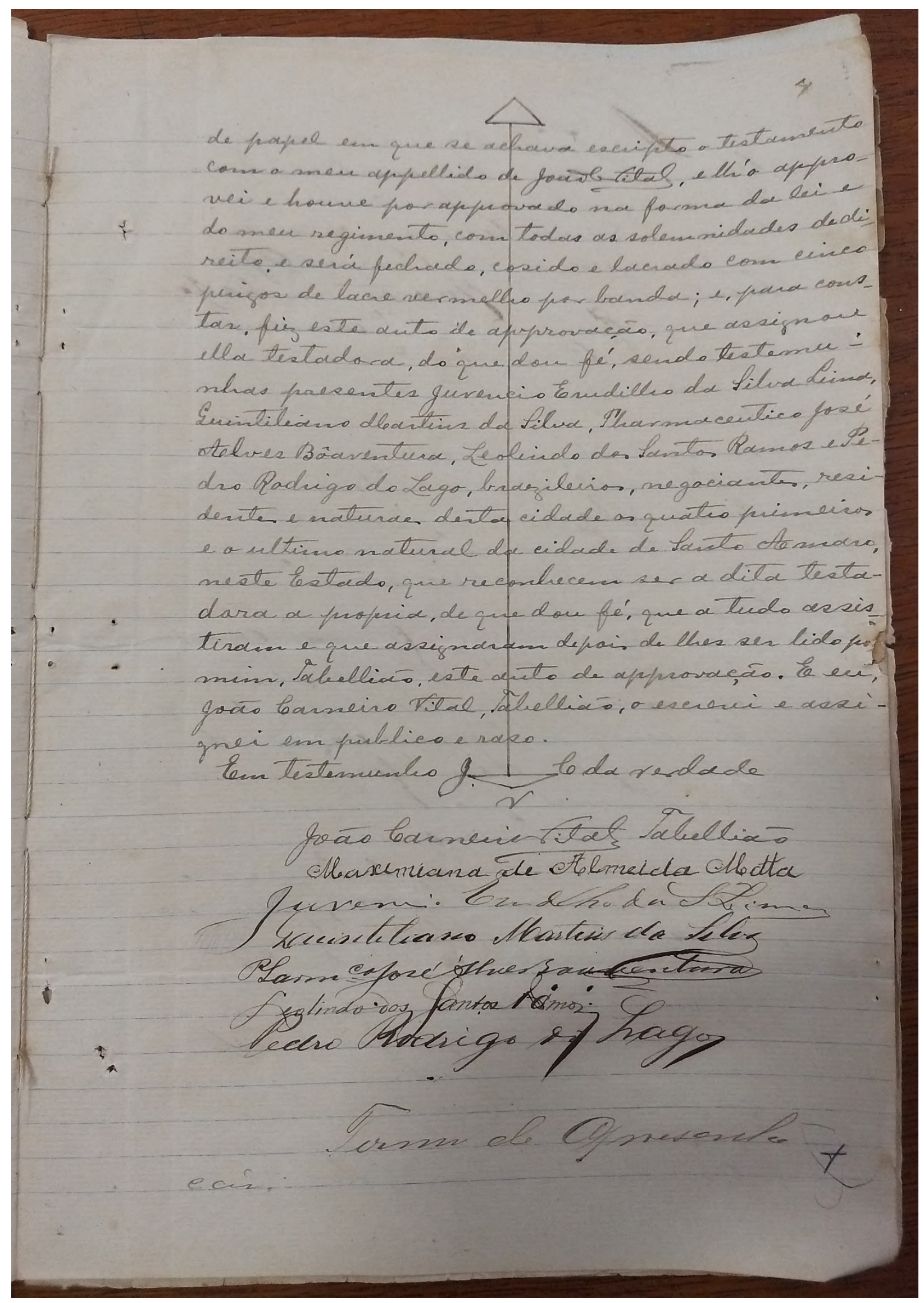


|| 4r. $\|$ de papel em que se achava escripto o testamento com o meu appelido de João Carneiro Vital, e lh'o approvei e houve por approvado na forma da lei e

165 do meu regimento, com todas as solemnidades dedireito, e será fechado, cosido e lacrado com cinco pingos de lacre vermelho por banda; e, para constar, fiz este auto de approvação, que assignou ella testadora, do que dou fé, sendo testemu170 nhas presentes Juvencio Erudilho da Silva Lima, Quintiliano Martins da Silva, Pharmaceutico José Alves Bôaventura, Leolindo dos Santos Ramos e Pedro Rodrigo do Lago, brazileiros, negociantes, residentes e naturaes desta cidade os quatro primeiros

175 e o ultimo natural da cidade de Santo Amaro, neste Estado, que reconhecem ser a dita testadora a propria, de que dou fé, que a tudo assistiram e que assignaram depois de lhes ser lido po[r] mim, Tabellião, este auto de approvação. E eu,

180 João Carneiro Vital, Tabellião, o escrevi e o assignei em publico e raso.

Em testemunho da verdade ${ }^{175}$. João Carneiro Vital Tabellião Maximiana de Almeida Motta $\underline{\text { Juvencio Erudilho da Silva Lima }}$ Quintiliano Martins da Silva Pharmaceutico José Alves Boaventura Leolindo dos Santos Ramos Pedro Rodrigo do Lago

Termo de Apresenta

ção.

\footnotetext{
${ }^{175}$ No manuscrito original, nesta linha, há um sinal público de $188 \mathrm{~mm}$ de altura com as iniciais do Tabelião de
} Notas “J. C. V.”, João Carneiro Vital. 


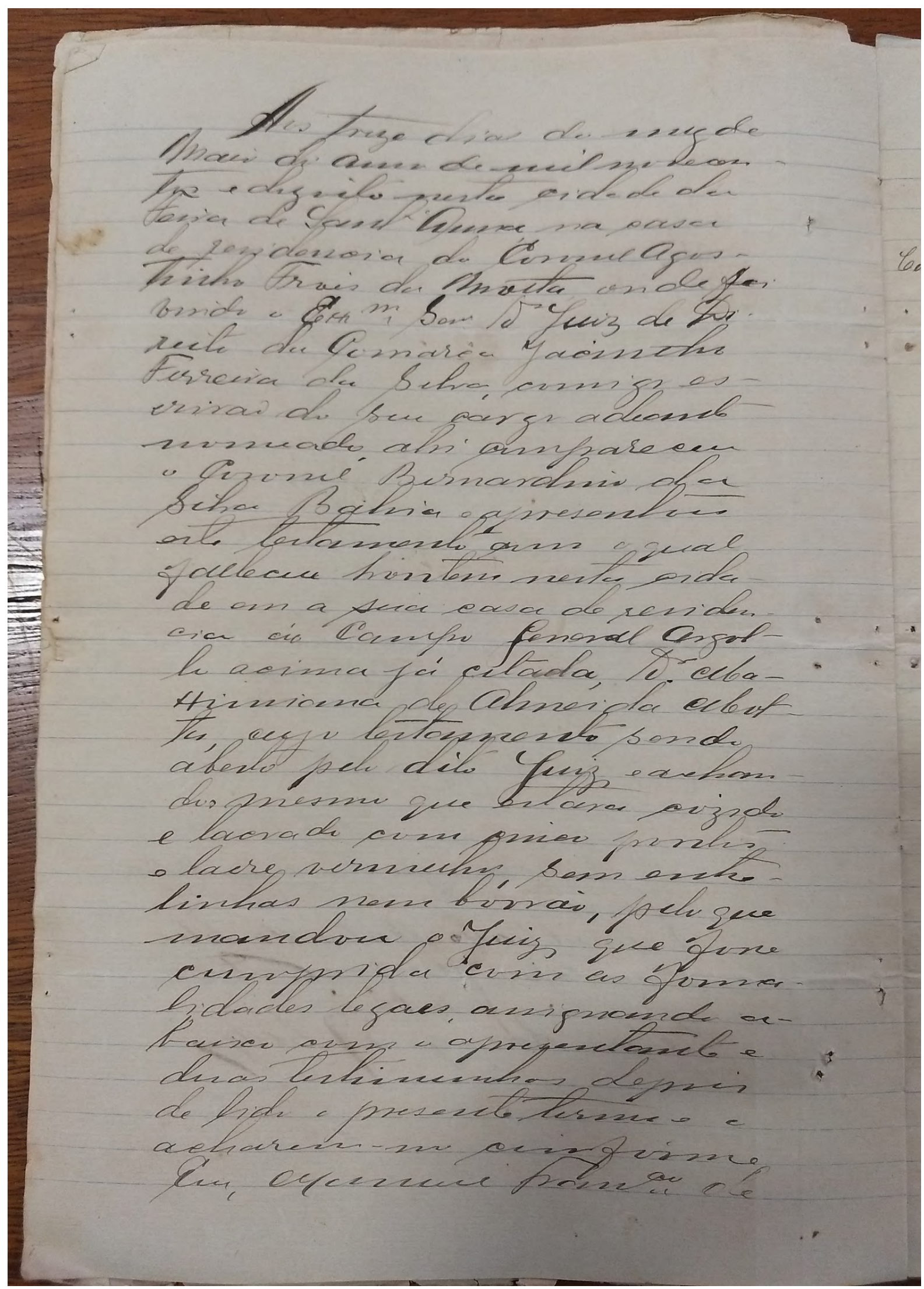


\|4v.\| Aos treze dias do mez de

195 Maio do anno de mil novecentos e dezoito nesta cidade da Feira de Sant'Anna na casa de residencia do Coronel Agostinho Frois da Motta onde foi

200 vindo o Excellentissimo Senhor Doutor Juiz de Direito da Comarca Jacintho Ferreira da Silva, comigo escrivão do seu cargo adeante nomeado, ahi compareceu

205 o Coronel Bernardino da Silva Bahia e apresentou este testamento com o qual falleceu hontem nesta cidade em a sua casa de residen-

210 cia áo Campo General Argollo acima já citada, Dona Maximiana de Almeida Motta, cujo testamento sendo aberto pelo dito Juiz e achan-

215 do o mesmo que estava cosido e lacrado com cinco pontos e lacre vermelho, sem entrelinhas nem borrão, pelo que mandou o Juiz que fosse

220 cumprida com as formalidades legaes, assignando abaixo com o apresentante $\mathrm{e}$ duas testimunhas depois de lido o presente termo e o

225 acharem-no conforme, $\mathrm{Eu}$, Manuel Francisco de 


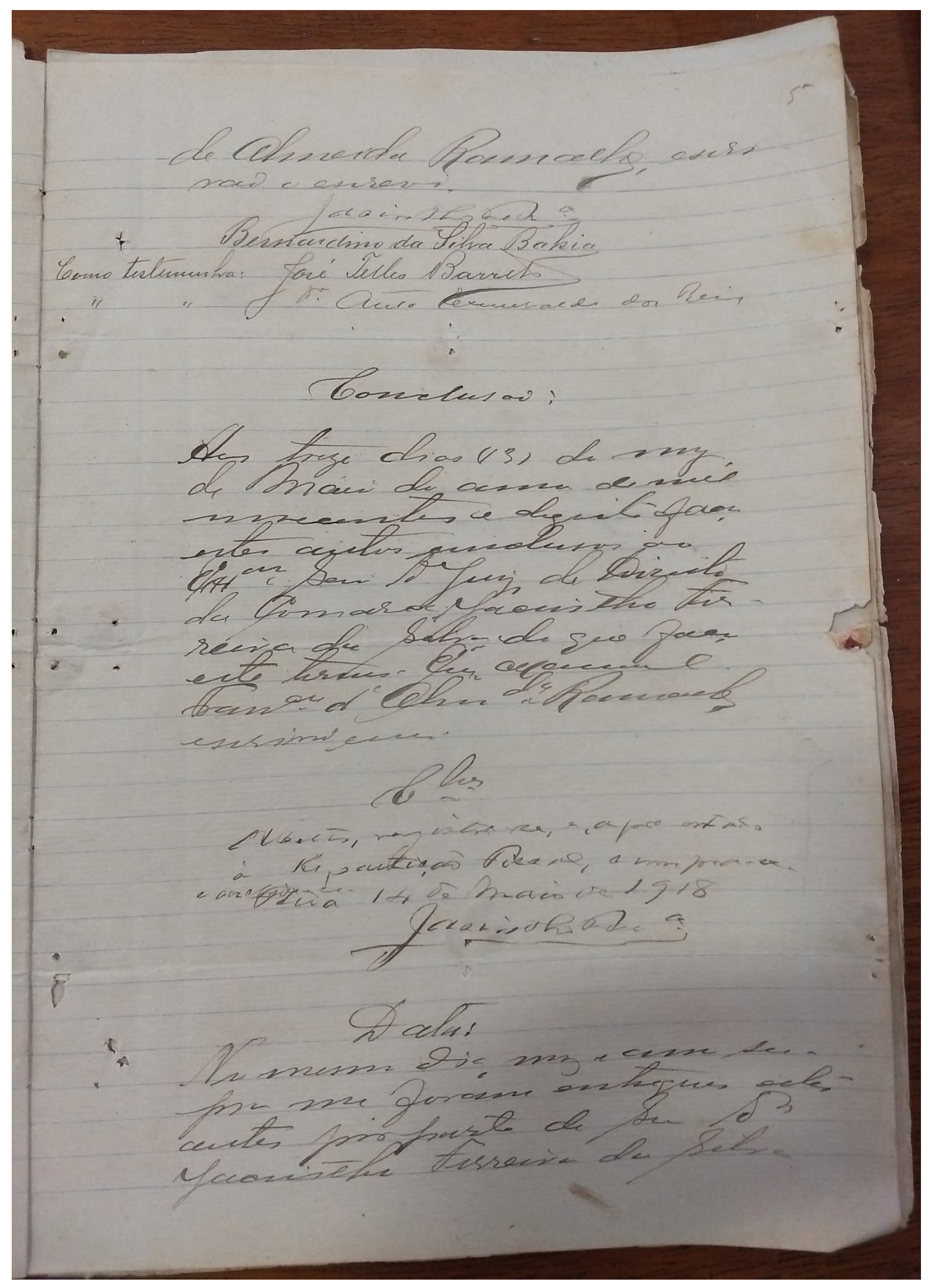


|| 5r.|| de Almeida Ramalho, escri

vão o escrevi.

Jacintho Ferreira

$230 \quad$ Bernardino da Silva Bahia

Como testemunha: José Telles Barreto

" " Doutor Auto Esmeraldo dos Reis

235

Conclusão:

Aos treze dias (13) do mez

de Maio do anno de mil

novecentos e dezoito faço

240 estes autos conclusos ao

Excellentissimo Senhor Doutor Juiz de Direito

da Comarca Jacintho Fer-

reira da Silva; do que faço

este termo. Eu, Manuel

245 Francisco d'Almeida Ramalho

escrivão escrevi.

\section{Conclusoes}

Aberto, registre-se, e, apresentado

250 á Repartição Fiscal, cumpra-se

$<\mathrm{e}$ archive-se $\uparrow>$

Feira 14 de Maio de 1918

$\underline{\text { Jacintho Ferreira }}$

255

Data:

No mesmo dia, mez e anno su-

pra me foram entregues estes

autos por parte do Senhor Doutor

260 Jacintho Ferreira da Silva 


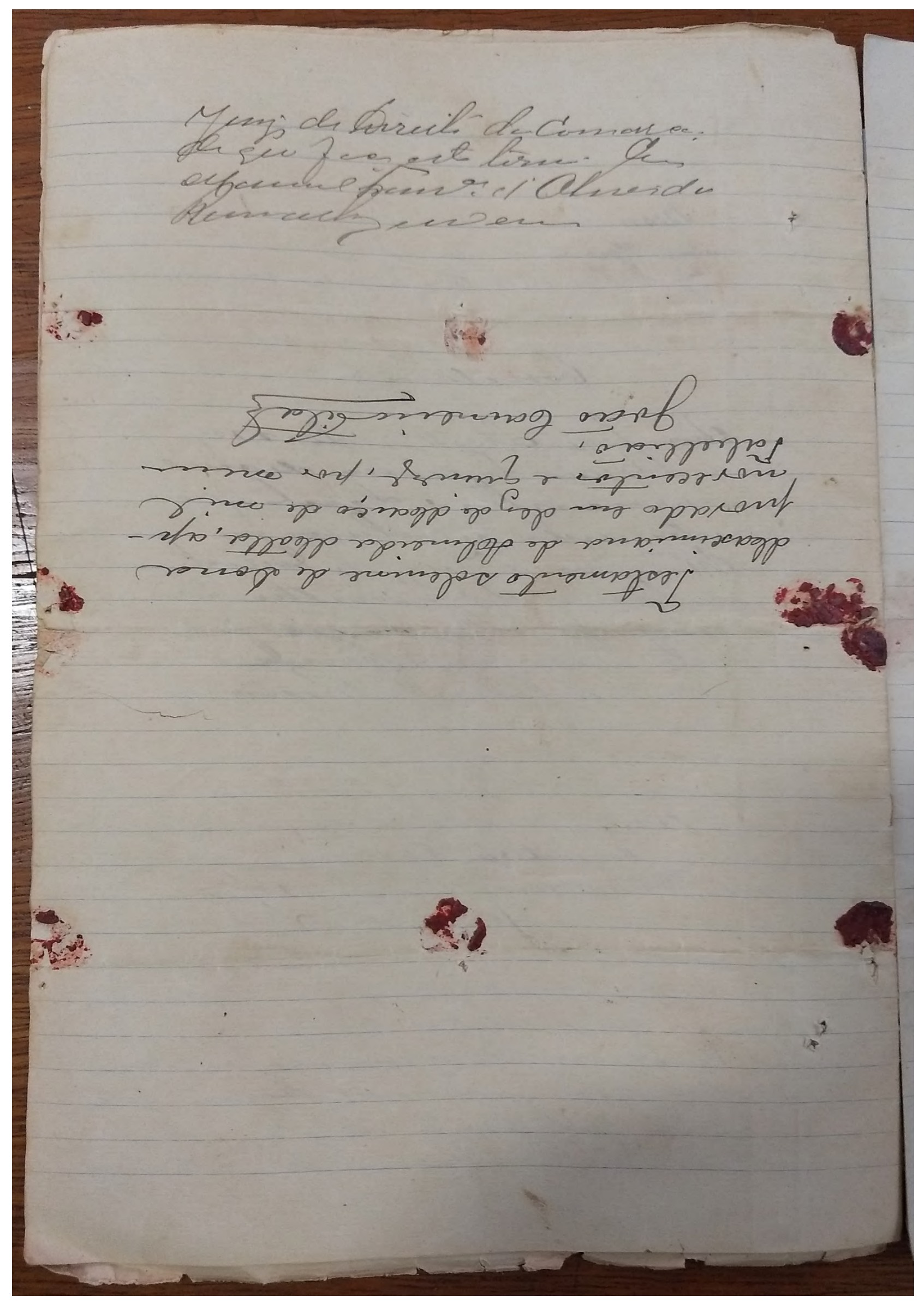


|| 5v.|| Juiz de Direito da Comarca;

do que faço este termo. Eu,

Manuel Francisco d'Almeida

Ramalho [escrivão escrevi]

265

270 Testamento solemne de Dona

Maximiana de Almeida Motta, ap-

provado em dez de Março de mil

novecentos e quinze, por mim

Tabellião.

275

$\underline{\text { João Carneiro Vital }}^{176}$

${ }^{176}$ No manuscrito original, as linhas 270 a 275 foram redigidas na parte externa do sobrescrito, o que se explica pelo fato de o documento ter sido dobrado e selado antes da inserção deste trecho. 


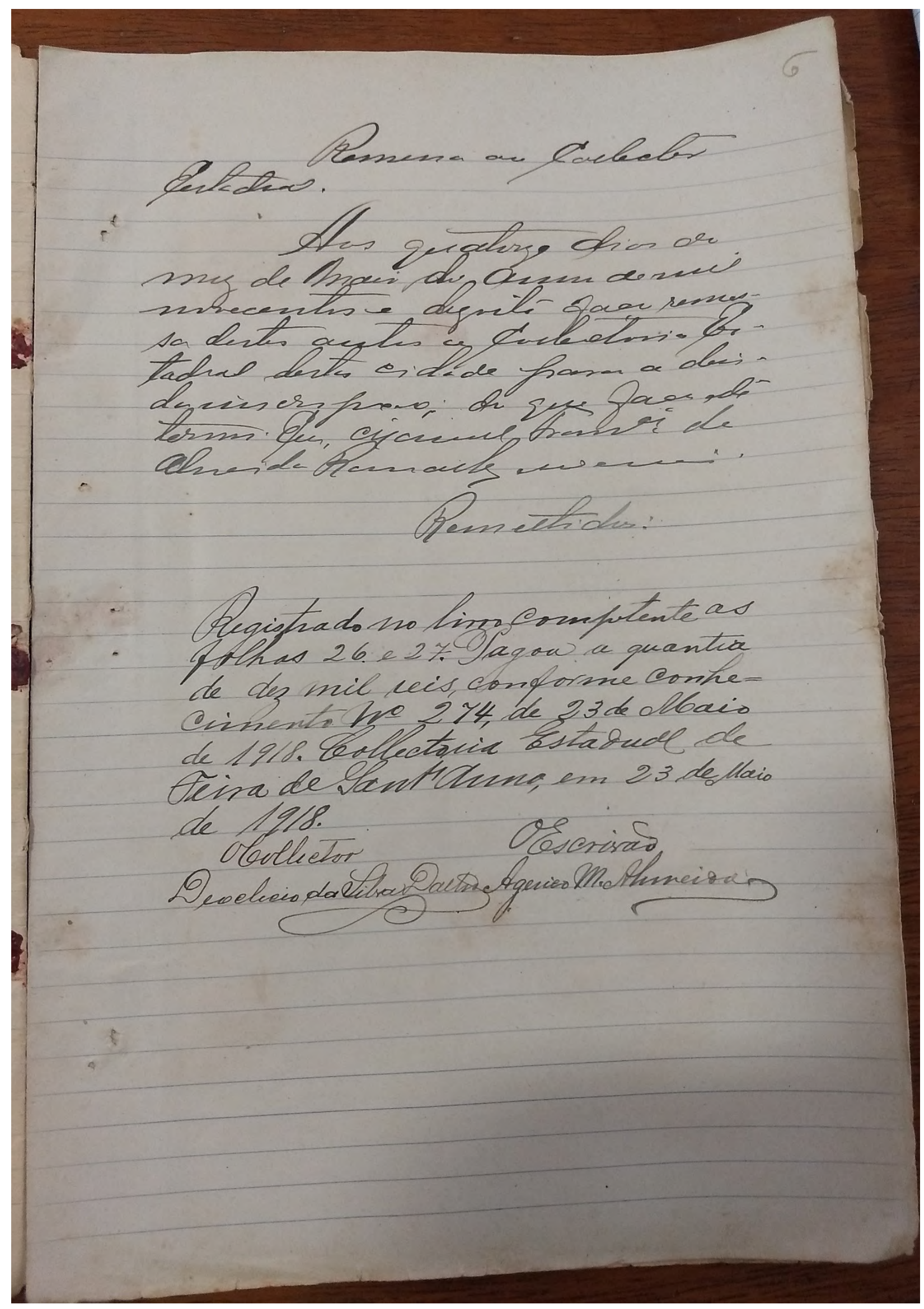


|| 6r. I Remessa ao Collector

Estadual.

Aos quatorze dias do

280 mez de Maio do Anno de mil novecentos e dezoito faço remessa destes autos a Collectoria Estadual desta cidade para a devida inscripção; do que faço este

285 termo. Eu, Manuel Francisco de Almeida Ramalho [escrivão escrevi]

Remettidos:

290

Registrado no livro competente as folhas 26. e 27. Pagou a quantia de dez mil reis, conforme conhecimento numero 274, de 23 de Maio

295 de 1918. Collectoria Estadual de Feira de Sant'Anna, em 23 de Maio de 1918.

OCollector OEscrivão

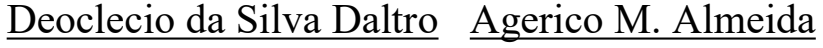




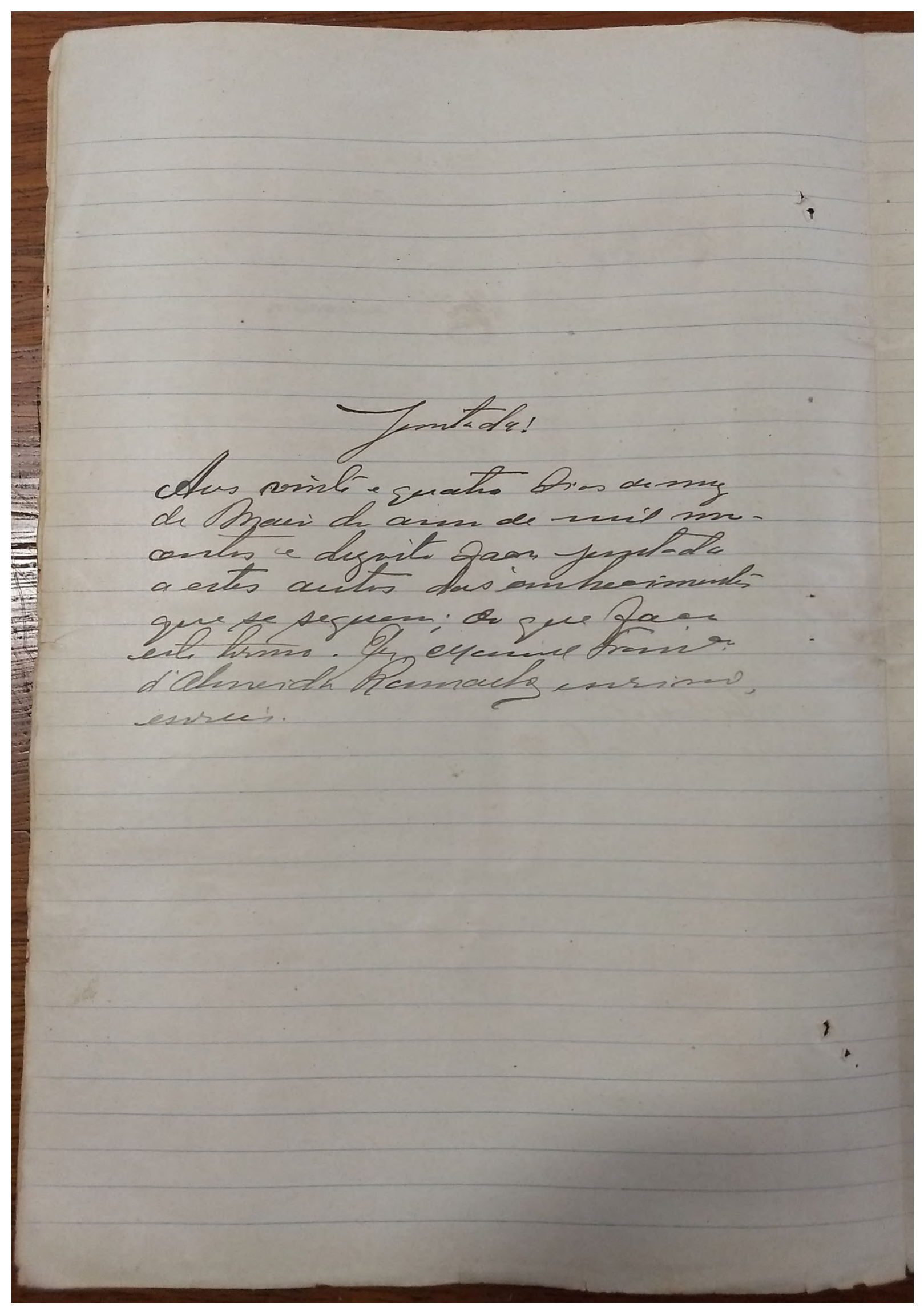


$\|6 \mathrm{v}$.

Juntada:

Aos vinte e quatro dias do mez de Maio do anno de mil novecentos e dezoito faço juntada 305 a estes autos dos conhecimentos que se seguem; do que faço este termo. Eu, Manuel Francisco d'Almeida Ramalho escrivão, escrevi. 


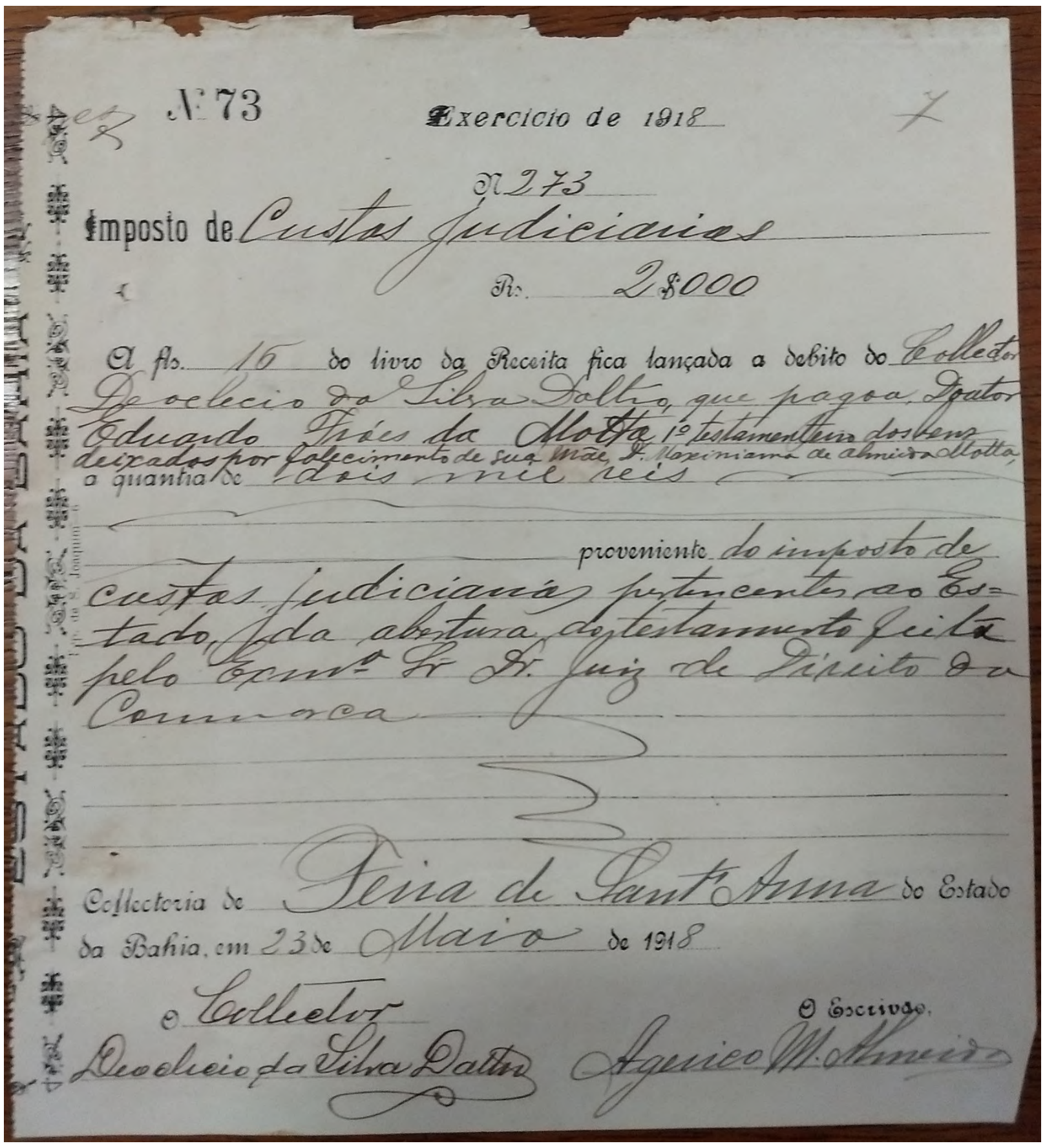


Numero 273

Imposto de Custos Judiciarios

Reis $2 \$ 000$

A folhas 15 do livro da Receita fica lançada a debito do Collector

Deoclecio da Silva Daltro, que pagou, Doutor

Eduardo Fróes da Motta primeiro testamenteiro dos bens

$<\downarrow$ deixados por fallecimento de sua mãe, Dona Maximiana de Almeida Motta, $>$

custos judiciarios pertencentes ao Es-

proveniente do imposto de tado, da abertura do testamento feita

pelo Excellentissimo Senhor Doutor Juiz de Direito da

Comarca

Collectoria de Feira de Sant'Anna do Estado

330 da Bahia, em 23 de Maio de 1918

O Collector

$\underline{\text { Deoclecio da Silva Daltro }}$
O Escrivão

Agerico Moreira de Almeida 
tos 194

xercicio de 1918

imposio de Ginolicuresulat

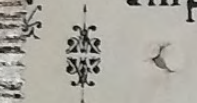

$\mathscr{R}$.

108000

i

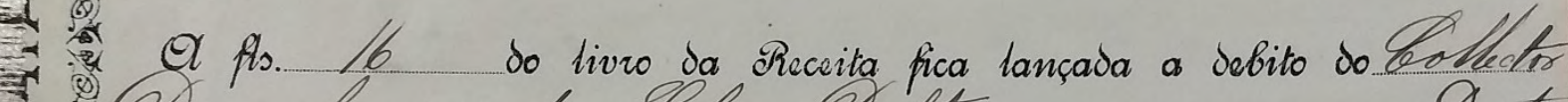

4 a Te aclecí da Lilsa Galtr.

* dupacason

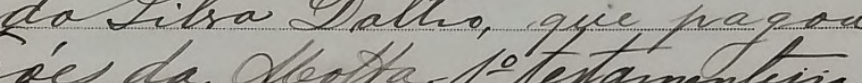
Arutor in

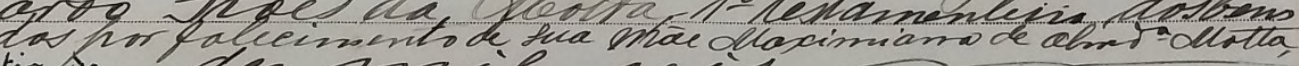
被

1.

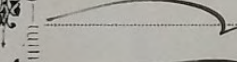

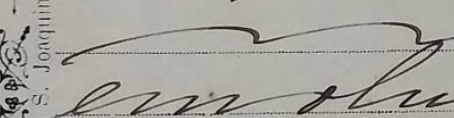

1

cecis 
|| 8r.|| Numero $74 \quad$ Exercicio de 1918

Numero 274

Imposto de Emolumentos

Reis $10 \$ 000$

A folhas 16 do livro da Receita fica lançada a debito do Collector

$340 \quad$ Eduardo Fróes da Motta, primeiro testamenteiro dos bens Deoclecio da Silva Daltro, que pagou Doutor $<\downarrow$ deixados por fallecimento de sua mãe, Dona Maximiana de Almeida Motta, $>$ a quantia de dez mil reis

$$
\text { em }
$$
emolumentos pelo Registro de testamento feito naquella repartição

Collectoria de Feira de Sant'Anna do Estado da Bahia, em 23 de Maio de 1918

O Collector O Escrivão $\underline{\text { Deoclecio da Silva Daltro }}$

Agerico Moreira de Almeida 


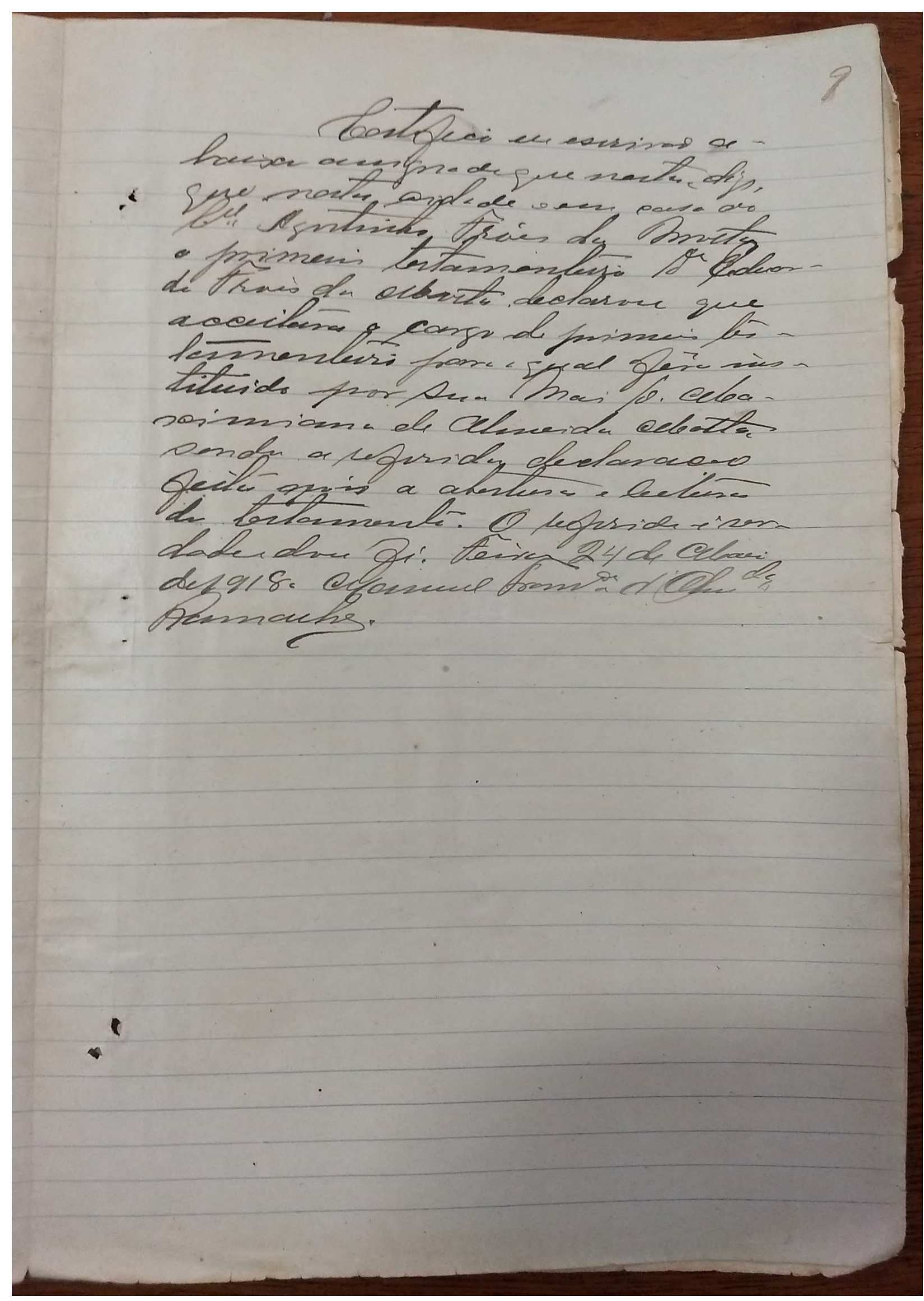


|| 9r.\| Certifico eu escrivão abaixo assignado de que nesta, digo, que nesta cidade e em casa do Coronel Agostinho Fróes da Motta

360 o primeiro testamenteiro Doutor Eduardo Frois da Motta declarou que acceitara o cargo de primeiro testamenteiro para o qual fôra instituido por sua Mai Dona Ma-

365 ximiana de Almeida Motta sendo a referida declaração feita após a abertura e leitura do testamento. O referido é verdade e dou fé. Feira 24 de Maio

370 de 1918. Manuel Francisco d'Almeida Ramalho. 


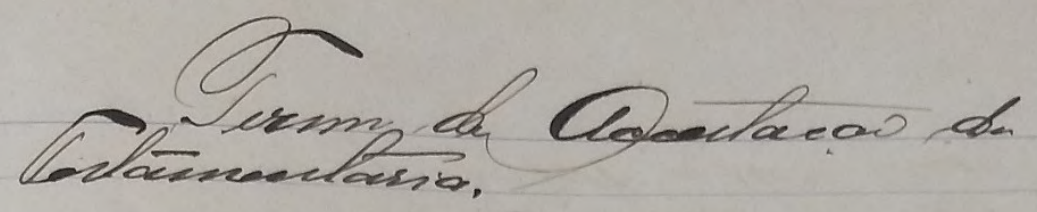

Divosibe quatu (24) osias

$x$

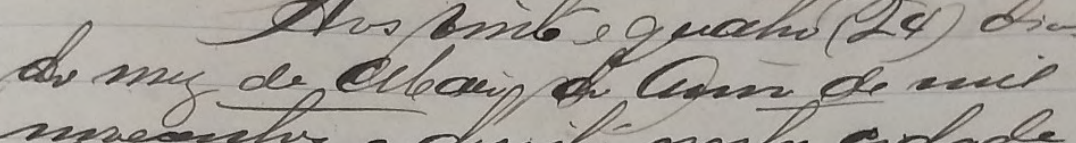

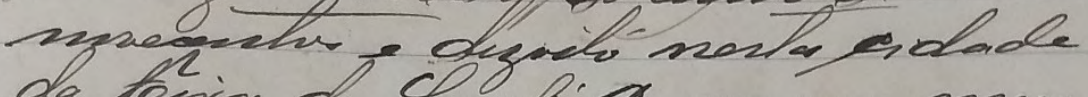

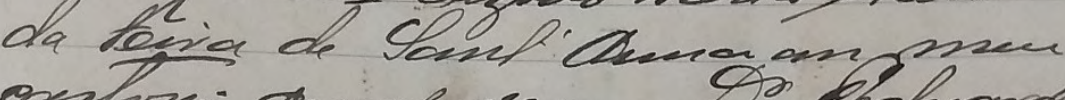

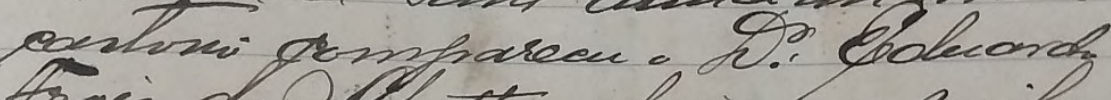

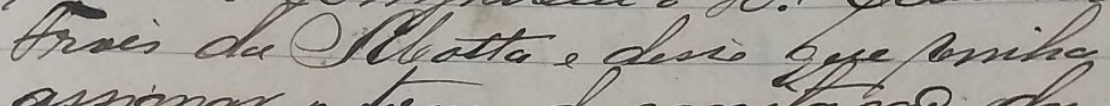

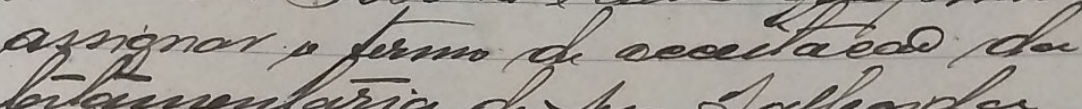

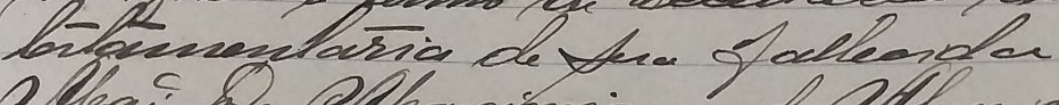

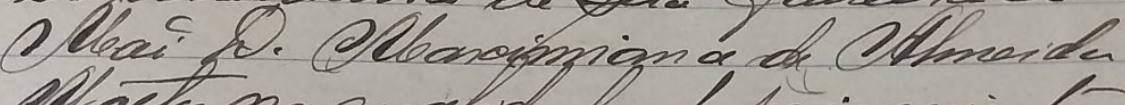

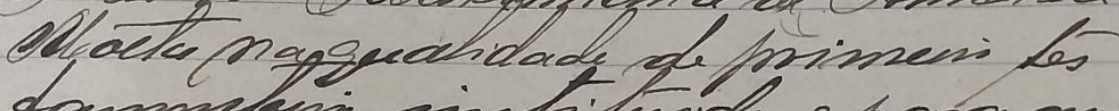

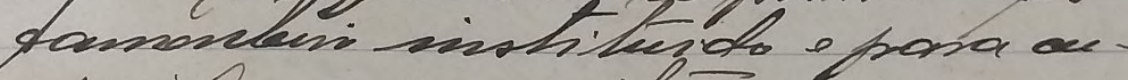

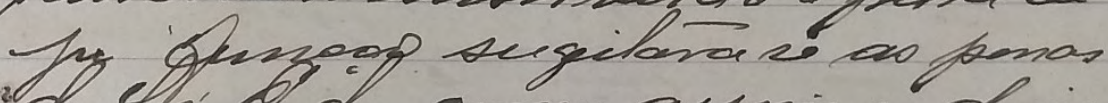

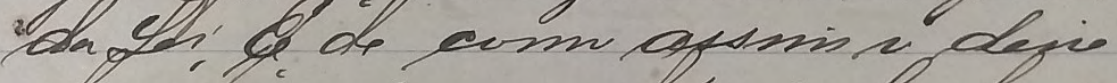

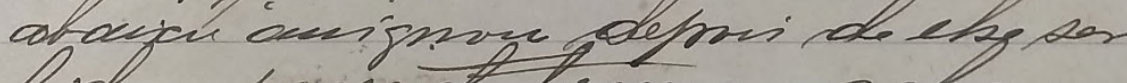

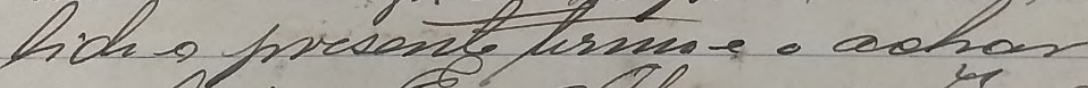

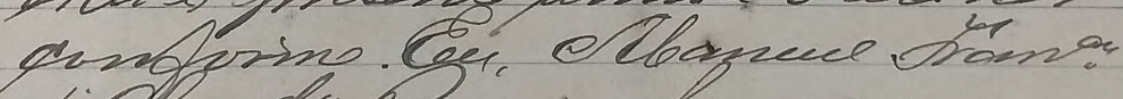

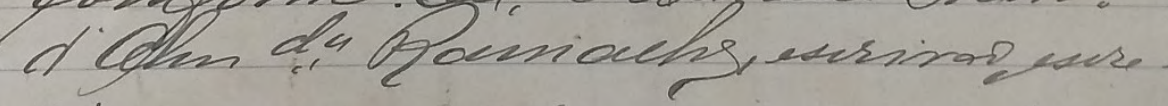

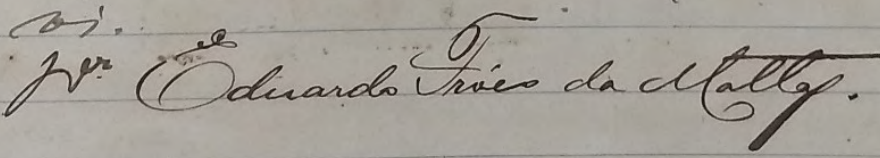


\| 9v.| Termo de Acceitação da

Testamentaria.

375

Aos vinte e quatro (24) dias

do mez de Maio do Anno de mil

novecentos e dezoito nesta cidade da Feira de Sant'Anna em meu

380 cartorio compareceu o Doutor Eduardo

Fróes da Motta e disse que vinha assignar o termo de acceitação da testamentaria de sua fallecida Mãi Dona Maximiana de Almeida

385 Motta na qualidade de primeiro tes tamenteiro instituido e para cuja função sugeitara se as penas da Lei. E de como assim o disse abaixo assignou depois de lhe ser

390 lido o presente termo e o achar conforme. Eu, Manuel Francisco

d'Almeida Ramalho, escrivão escrevi.

Doutor Eduardo Fróes da Motta. 


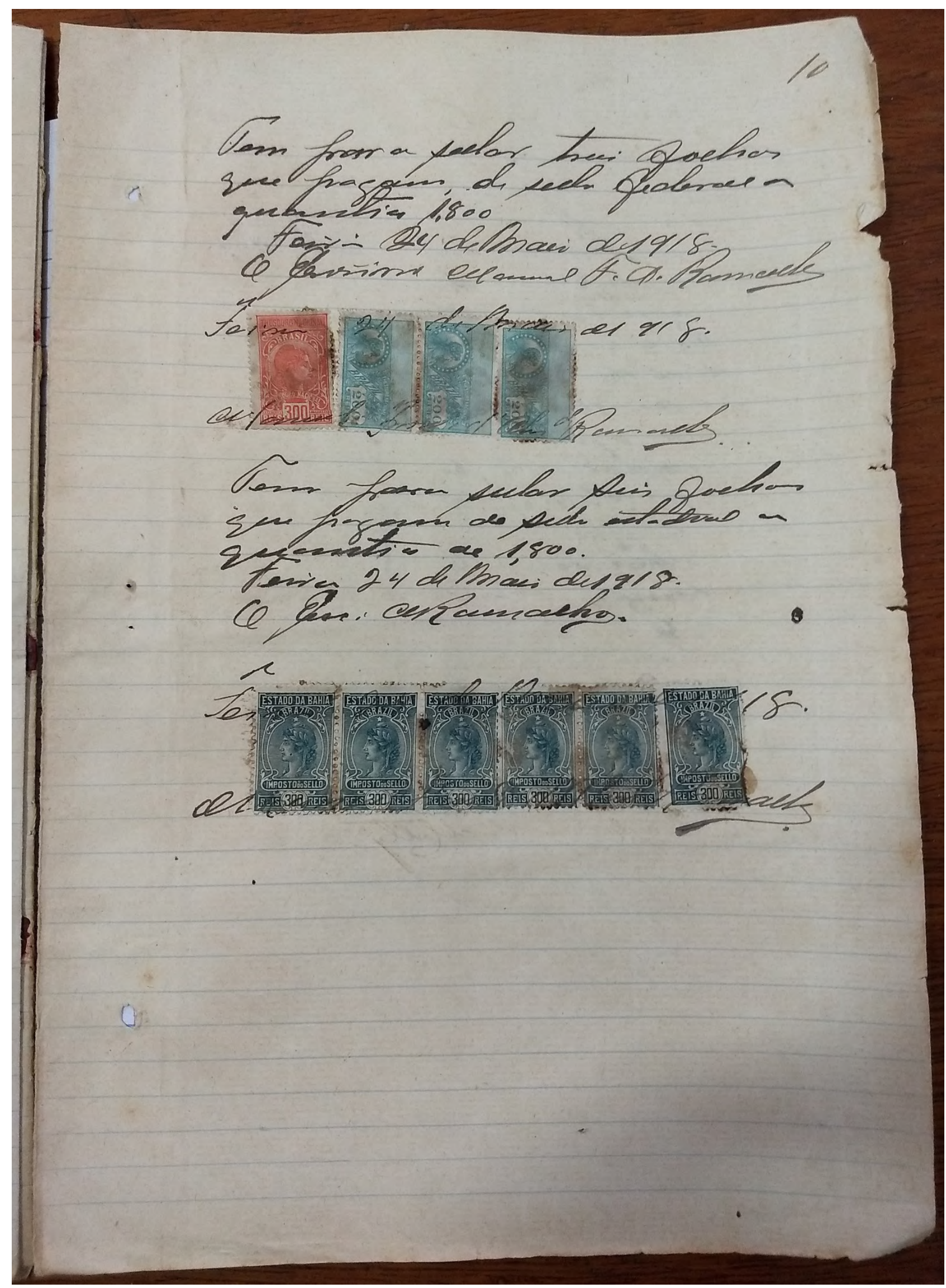


395 || 10r.|| Tem para sellar treis folhas que pagam, de sello federal a quantia 1.800

Feira 24 de Maio de1918.

O Escrivão Manuel Francisco de Almeida Ramalho

400

Feira 24 de Maio de $1918^{177}$.

Manuel Francisco d'Almeida Ramalho.

405

Tem para sellar seis folhas

que pagam de sello estadual a

quantia de 1.800 .

Feira 24 de Maio de1918.

410 O Escrivão: ManuelRamalho

Feira 24 de Maio de $1918^{178}$.

415

Manuel Francisco d'Almeida Ramalho.

${ }^{177}$ No manuscrito original, nesta linha, há um selo de imposto de 300 réis e três de 200 réis cada.

${ }^{178}$ No manuscrito original, nesta linha, há seis selos de imposto no valor de 300 réis cada. 


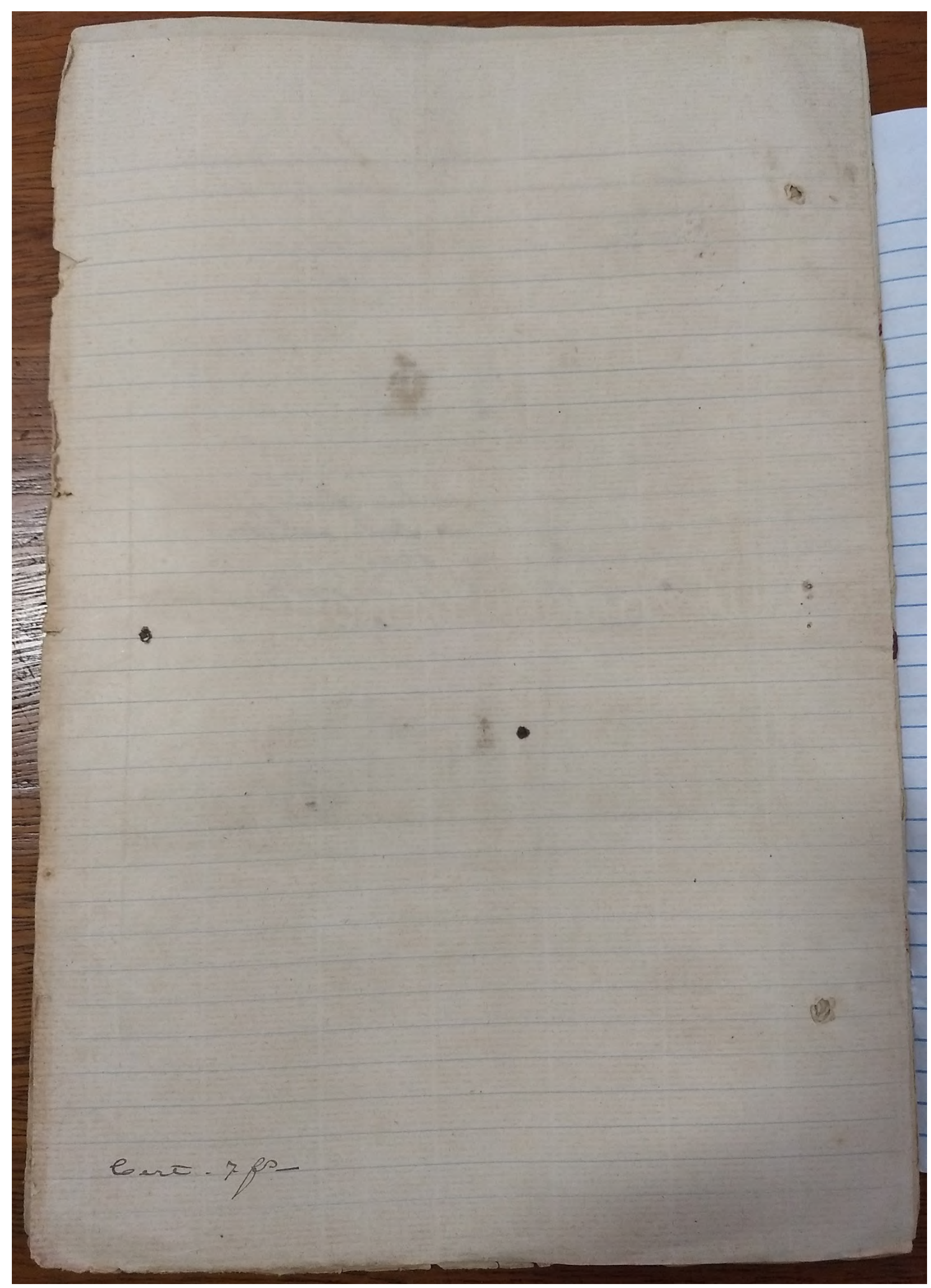


|| 10v.|

Certidão 7 folhas 
4.3.5.3 Edições fac-similar e semidiplomática do testamento do Coronel Agostinho Fróes da Motta

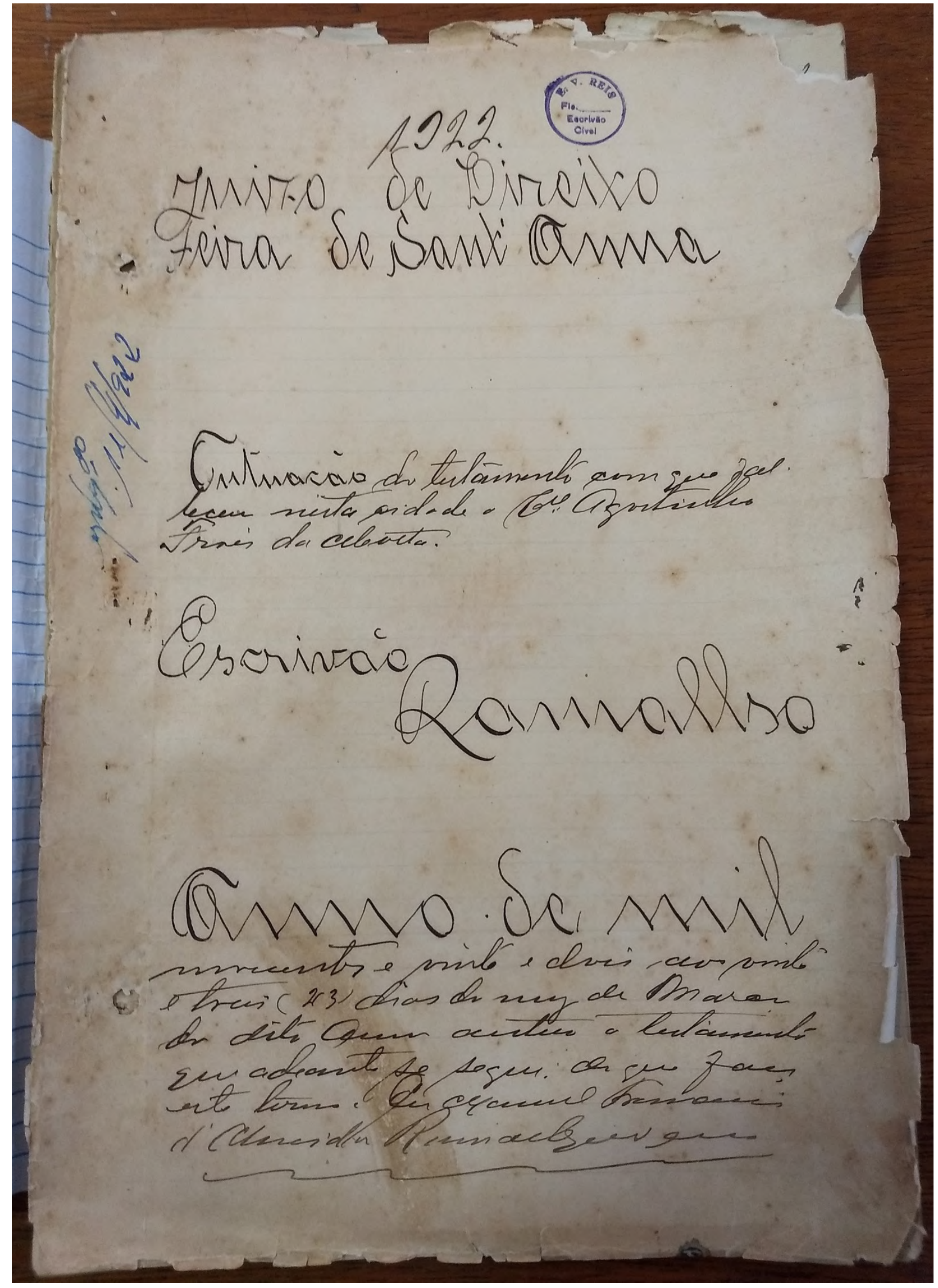


\|1r.\| $1922^{179}$.

Juizo de Direito

Feira de Sant'anna

5

$10 \quad{ }^{180}$ Autuação do testamento com que fal. leceu nesta cidade o Coronel Agostinho Fróes da Motta.

15

Escrivão

\section{Ramalho}

Anno de mil

25 novecentos e vinte e dois aos vinte e treis (23) dias do mez de Março do dito Anno autuo o testamento que adeante se segue: do que faço este termo. Eu Manuel Francisco d'Almeida Ramalho [escrivão escrevi]

179 No manuscrito original, à direita desta datação, há um carimbo molhado de $21 \mathrm{~mm}$ de diâmetro com a inscrição: "E. V. REIS | Fls. | Escrivão Civel".

${ }^{180}$ No manuscrito original, à esquerda desta linha, há a anotação "Julgado 11/4/922" feita com caneta de cor azul, provavelmente tardia. 


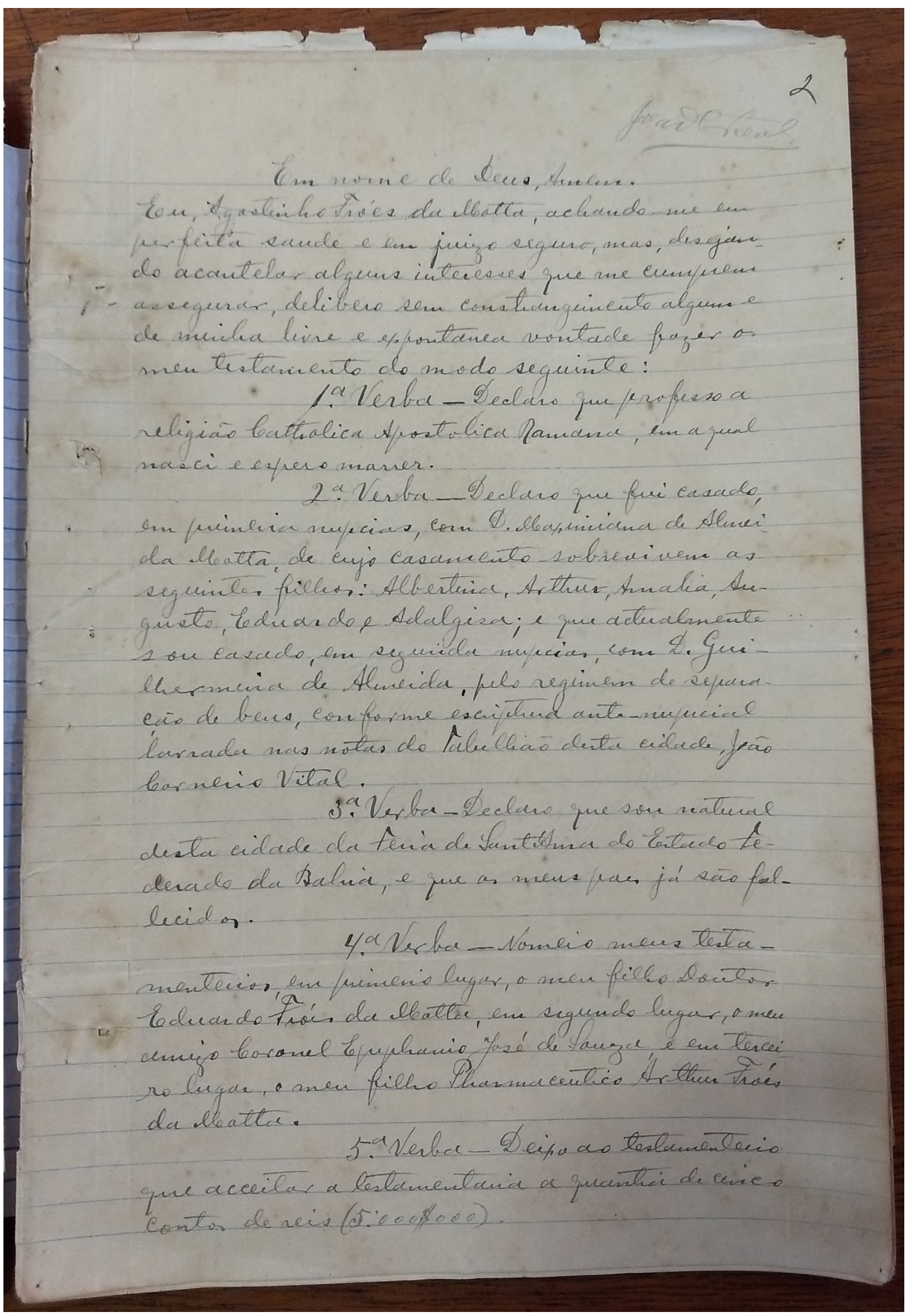


|| 2r. $\| \quad$ Em nome de Deus, Amem. $<\uparrow \underline{\text { JoãoCarneiroVital }>}$

Eu, Agostinho Fróes da Motta, achando-me em perfeita saude e em juizo seguro, mas, desejando acautelar alguns interesses que me cumprem

35 assegurar, delibero sem constrangimento algum e de minha livre e expontanea vontade fazer os meu testamento do modo seguinte:

Primeira Verba _ Declaro que professo a

religião Catholica Apostolica Romana, em a qual

40 nasci e espero morrer.

Segunda Verba _ Declaro que fui casado, em primeira nupcias, com Dona Maximiana de Almeida Motta, de cujo casamento sobrevivem os seguintes filhos: Albertina, Arthur, Amalia, Au-

45 gusto, Eduardo e Adalgisa; e que actualmente sou casado, em segunda nupcias, com Dona Guilhermina de Almeida, pelo regimem de separação de bens, conforme escriptura ante-nupcial lavrada nas notas do Tabelliaõ desta cidade, João

50 Carneiro Vital.

Terceira Verba _ Declaro que sou natural desta cidade da Feira de Sant'Anna do Estado Federado da Bahia, e que os meus paes já são fallecidos.

Quarta Verba _ Nomeio meus testamenteiros, em primeiro lugar, o meu filho Doutor Eduardo Fróes da Motta, em segundo lugar, o meu amigo Coronel Epephanio José de Souza, e em terceiro lugar, o meu filho Pharmaceutico Arthur Fróes 60 da Motta.

Quinta Verba_Deixo ao testamenteiro que acceitar a testamentaria a quantia de cinco contos de reis $(5: 000 \$ 000)$. 


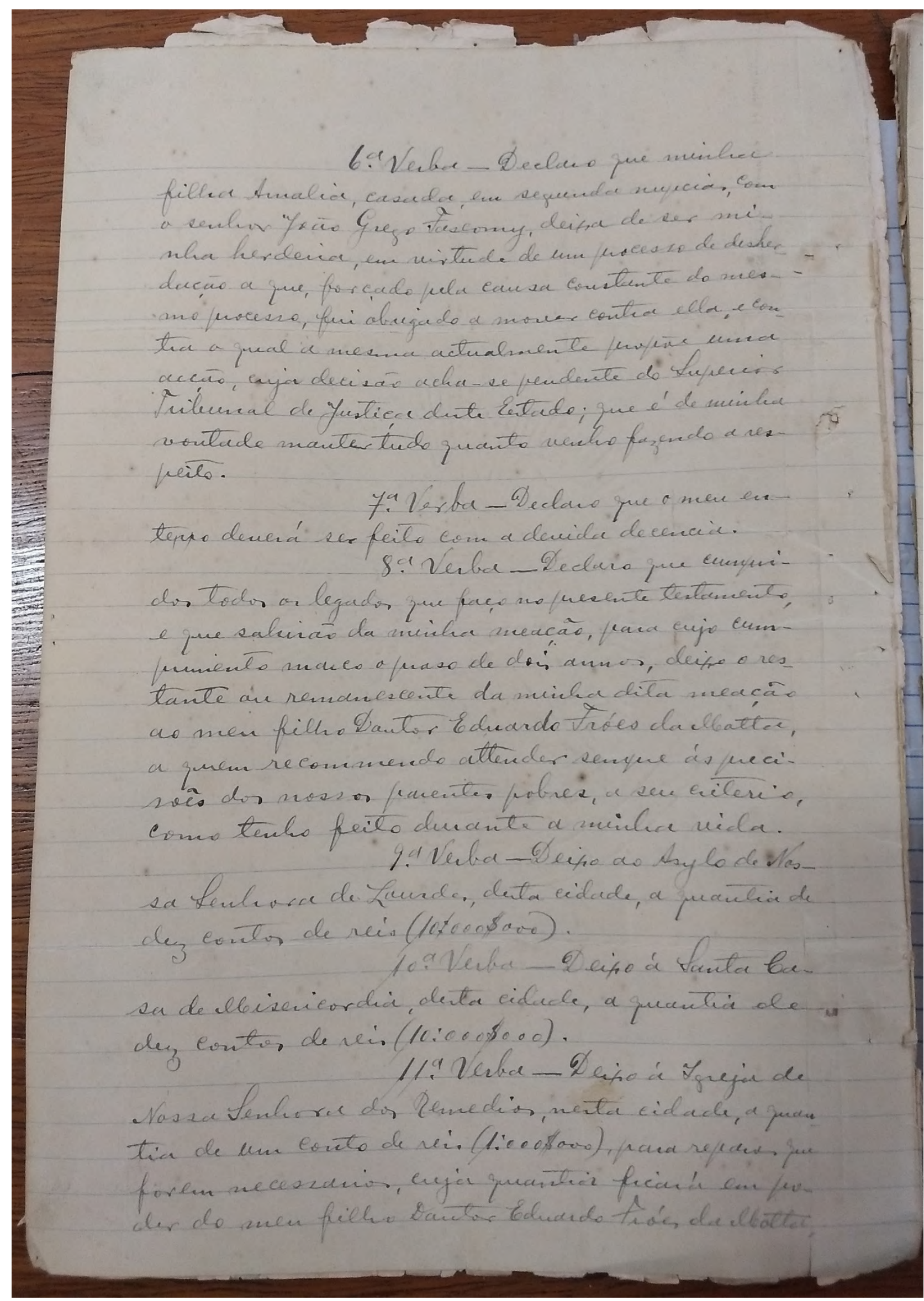


65 filha Amalia, casada, em segunda nupcias, com o senhor João Grego Fascomy, deixa de ser minha herdeira, em virtude de um processo de desherdação a que, forçado pela causa constante do mesmo processo, fui obrigado a mover contra ella, e con-

70 tra a qual a mesma actualmente propõe uma acção, cuja decisão acha-se pendente do Superior Tribunal de Justiça deste Estado; que é de minha vontade manter tudo quanto venho fazendo a respeito.

75 Sétima Verba Declaro que o meu enterro deverá ser feito com a devida decencia.

Oitava Verba _ Declaro que cumpridos todos os legados que faço no presente testamento, e que sahirão da minha meação, para cujo cum-

80 primento marco o praso de dois annos, deixo o restante ou remanescente da minha dita meação ao meu filho Doutor Eduardo Fróes da Motta, a quem recommendo attender sempre ás precisões dos nossos parentes pobres, a seu criterio,

85 como tenho feito durante a minha vida.

Nona Verba _ Deixo ao Asylo de Nossa Senhora de Lourdes, desta cidade, a quantia de dez contos de reis (10:000\$000).

Décima Verba _ Deixo á Santa Ca-

90 sa de Misericordia, desta cidade, a quantia de dez contos de reis (10:000\$000).

Décima primeira Verba _Deixo á Igreja de Nossa Senhora dos Remedios, nesta cidade, a quantia de um conto de reis (1:000\$000), para reparos que

95 forem necessarios, cuja quantia ficará em poder do meu filho Doutor Eduardo Fróes da Motta, 


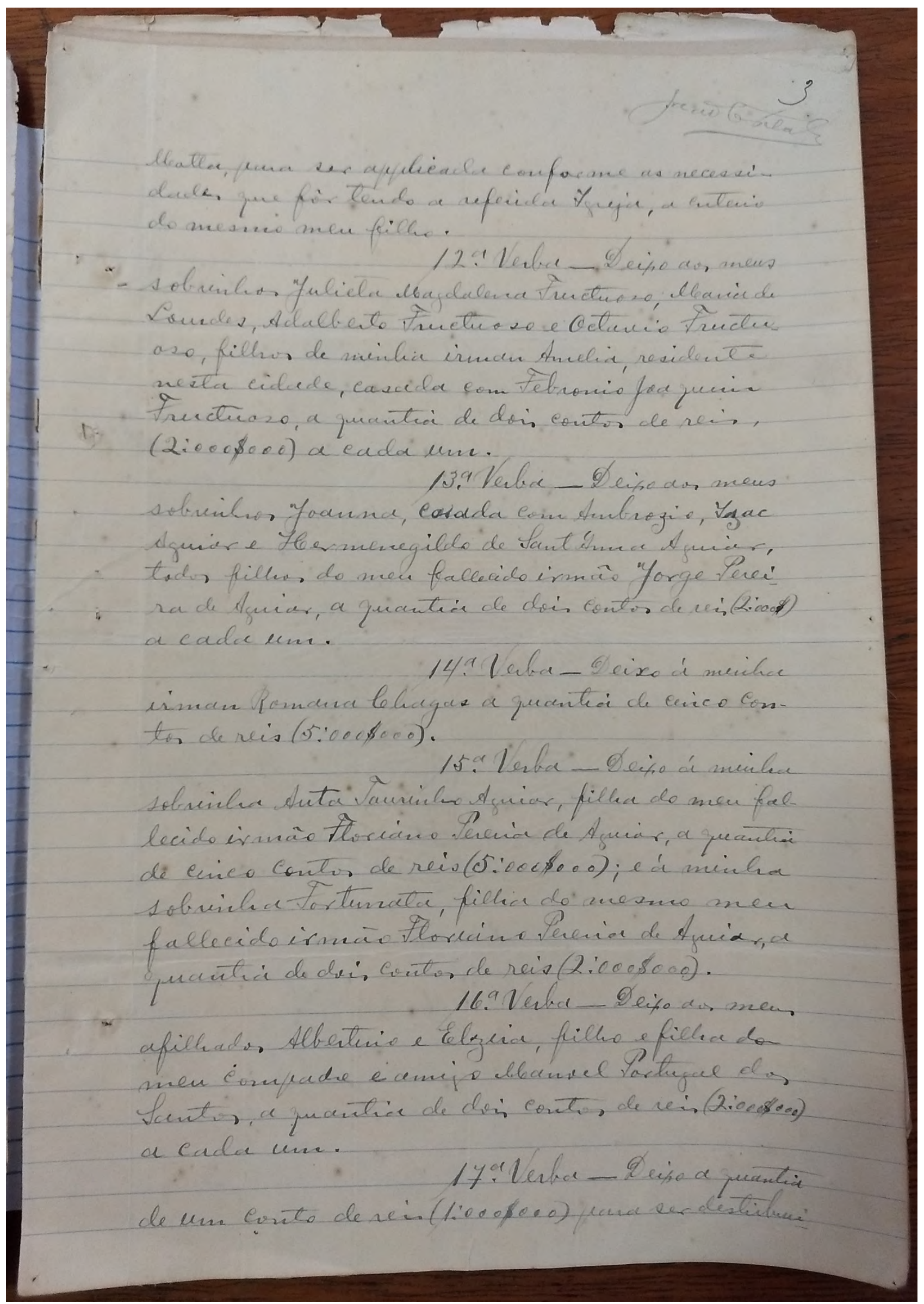


|| 3r.|| Motta, para ser applicada conforme as necessi- $<\uparrow$ JoãoCarneiroVital $>$ dades que fôr tendo a referida Igreja, a criterio do mesmo meu filho.

Décima segunda Verba_Deixo aos meus

sobrinhos Julieta Magdalena Fructuoso, Maria de

Lourdes, Adalberto Fructuoso e Octavio Fructu-

oso, filhos de minha irman Amelia, residente

nesta cidade, casada com Febronio Joaquim

105 Fructuoso, a quantia de dois contos de reis, $(2: 000 \$ 000)$ a cada um.

Décima terceira Verba Deixo aos meus

sobrinhos Joanna, casada com Ambrozio, Izac

Aguiar e Hermenegildo de Sant'Anna Aguiar,

110 todos filhos do meu fallecido irmão Jorge Perei-

ra de Aguiar, a quantia de dois contos de reis (2:000\$)

a cada um.

Décima quarta Verba_Deixo á minha irman Romana Chagas a quantia de cinco con-

115 tos de reis (5:000\$000).

Décima quinta Verba_Deixo á minha

sobrinha Auta Taurinho Aguiar, filha do meu fal-

lecido irmão Floriano Pereira de Aguiar, a quantia

de cinco contos de reis (5:000\$000); e á minha

120 sobrinha Fortunata, filha do mesmo meu

fallecido irmão Floriano Pereira de Aguiar, a

quantia de dois contos de reis (2:000\$000).

Décima sexta Verba_Deixo aos meus

afilhados Albertino e Elzira, filho e filha do

125 meu compadre e amigo Manoel Portugal dos

Santos, a quantia de dois contos de reis $(2: 000 \$ 000)$

a cada um.

Décima sétima Verba Deixo a quantia

de um conto de reis (1:000\$000) para ser distribui- 


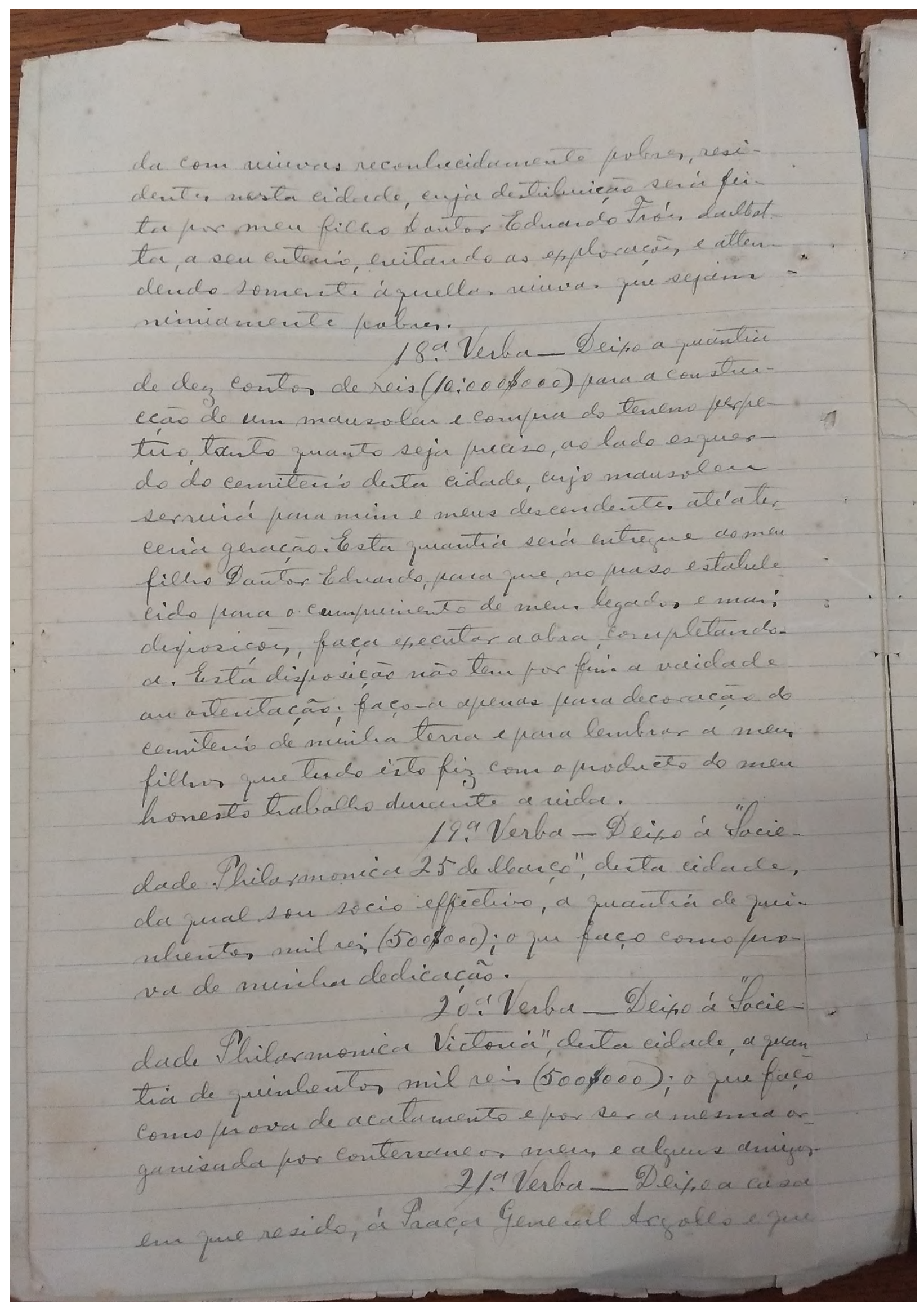


130 || 3v.|| da com viuvas reconhecidamente pobres, residentes nesta cidade, cuja destribuição será feita por meu filho Doutor Eduardo Fróes daMotta, a seu criterio, evitando as explorações e attendendo somente áquellas viuvas que sejam

135 nimiamente pobres.

Décima oitava Verba _ Deixo a quantia de dez contos de reis (10:000\$000) para a construç̧ão de um mausoleu e compra do terreno perpetuo, tanto quanto seja preciso, ao lado esquer-

140 do do cemiterio desta cidade, cujo mausoleu servirá para mim e meus descendentes até a terceira geração. Esta quantia será entregue ao meu filho Doutor Eduardo, para que, no praso estabelecido para o cumprimento de meus legados e mais

145 disposições, faça executar a obra completandoa. Esta disposição não tem por fim a vaidade ou ostentação; faço-a apenas para decoração do cemiterio de minha terra e para lembrar a meus filhos que tudo isto fiz com o producto do meu

150 honesto trabalho durante a vida.

Décima nona Verba __ Deixo á "Sociedade Philarmonica 25 de Março", desta cidade, da qual sou socio effectivo, a quantia de quinhentos mil reis (500\$000); o que faço como pro-

155 va de minha dedicação.

Vigésima Verba _ Deixo á "Sociedade Philarmonica Victoria", desta cidade, a quantia de quinhentos mil reis (500\$000); o que faço como prova de acatamento e por ser a mesma or-

160 ganisada por conterraneos meus e alguns amigos.

Vigésima primeira Verba Deixo a casa em que resido, á Praça General Argollo e que 


$$
\text { [ }
$$


|| 4r.|| que fôra por mim construida, com todos os seus $<\uparrow \underline{\text { JoãoCarneiroVital }>}$ moveis e utensilios, ao meu filho Doutor Eduar-

165 do Fróes da Motta.

Vigésima segunda Verba _ Deixo á minha afilhada Maria, filha legitima de José do Patrocinio e Silva, a quantia de um conto de reis (1:000\$000)

Vigésima terceira Verba __ Deixo á minha

170 prima segunda Joanna, casada com José do Patrocinio e Silva, uma casa das que possuo á rua "24 de Maio", nesta cidade, á escolha dos meus testamenteiros.

Vigésima quarta Verba _ Deixo á Dona Juni-

175 lha Almeida, casada com Clodoaldo Almeida, a quantia de dois contos de reis $(2: 000 \$ 000)$.

Vigésima quinta Verba _ Deixo á Ritta, Marinhinha, Almira e Neryna, filhas legitimas do meu compadre e amigo Tertuliano José

180 de Almeida, a quantia de um conto de reis (1:000\$000) a cada uma.

Vigésima sexta Verba _ Deixo ao senhor David de Mello Lima, como lembrança de seus serviços prestados como empregado, a ca-

185 ca á rua dos Remedios, sob numero cinco (5).

Vigésima sétima Verba _ Deixo ao meu empregado Francisco Almeida, que dirige a minha fazenda "Queimadinhas", no municipio de Mundo Novo, a quantia de cinco contos de reis

190 (5:000\$000).

Vigésima oitava Verba _ Deixo á Confraria de São Vicente de Paula, desta cidade, a quantia de um conto de reis $[(5: 000 \$ 000)]^{181}$, digo, (1:000\$000)

Vigésima nona Verba _ Deixo um se-

195 guro feito na companhia "Caixa Geral das

${ }^{181}$ No manuscrito original, o escrevente anulou o valor da quantia que o testador deixaria para essa instituição. Lição semidiplomática: 1:000\$000. 


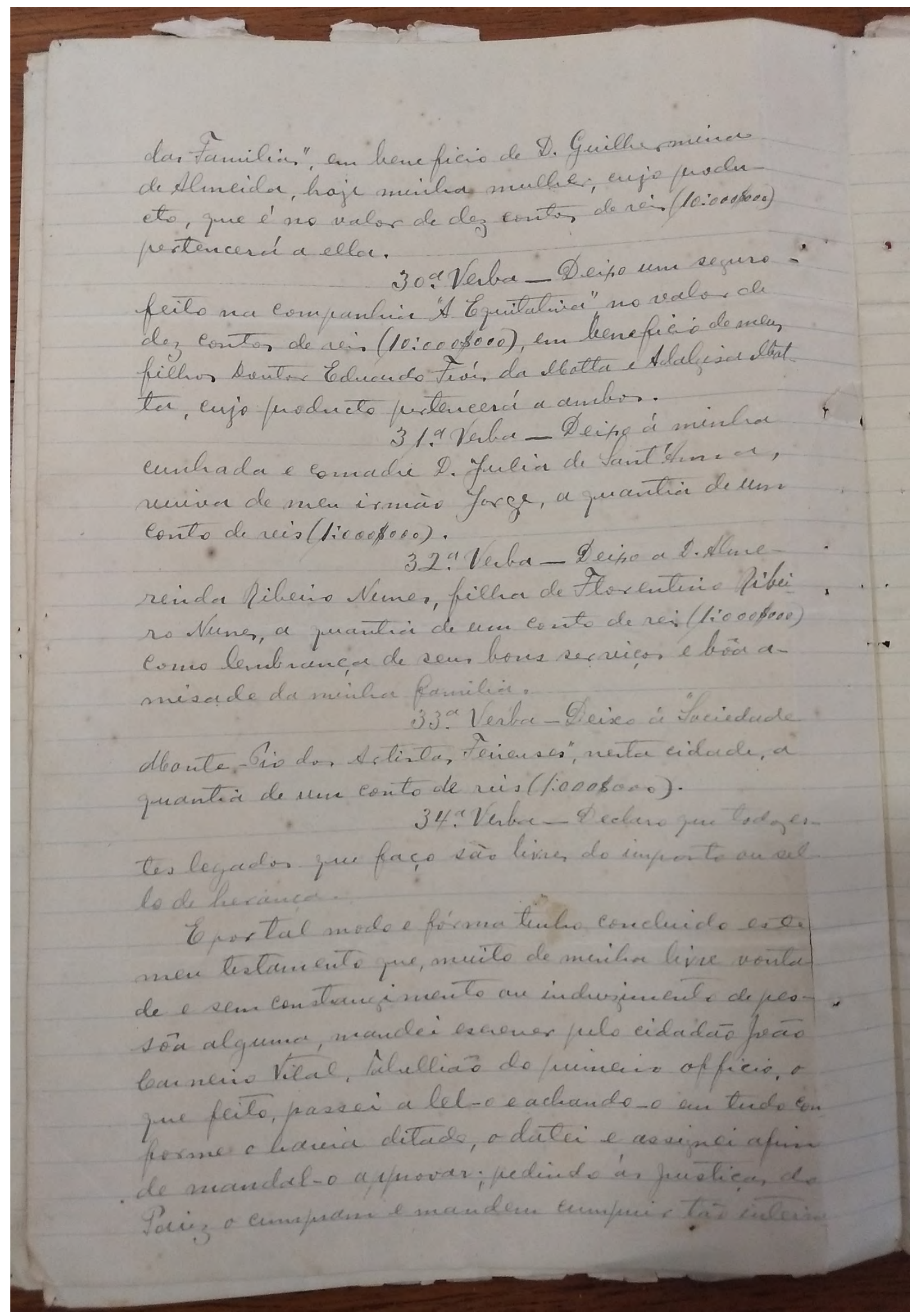


|| 4v.|| das Familias", em beneficio de Dona Guilhermina de Almeida, hoje minha mulher, cujo producto, que é no valor de dez contos de reis (10:000\$000) pertencerá a ella.

Trigésima Verba _ Deixo um seguro feito na companhia "A Equitativa" no valor de dez contos de reis (10:000\$000), em beneficio de meus filhos Doutor Eduardo Fróes da Motta e Adalgisa Motta, cujo producto pertencerá a ambos.

Trigésima primeira Verba Deixo á minha cunhada e comadre Dona Julia de Sant'Anna, viuva de meu irmão Jorge, a quantia de um conto de reis $(1: 000 \$ 000)$.

Trigésima segunda Verba _ Deixo a Dona Alme-

210 rinda Ribeiro Nunes, filha de Florentino Ribeiro Nunes, a quantia de um conto de reis (1:000\$000) como lembrança de seus bons serviços e bôa amisade da minha familia.

Trigésima terceira Verba _ Deixo á "Sociedade

215 Monte-Pio dos Artistas Feirenses", nesta cidade, a quantia de um conto de reis (1:000\$000).

Trigésima quarta Verba Declaro que todos estes legados que faço são livres do imposto ou sello de herança.

220 E por tal modo e fórma tenho concluido este meu testamento que, muito de minha livre vontade e sem constrangimento ou induzimento de pessôa alguma, mandei escrever pelo cidadão João Carneiro Vital, Tabellião do primeiro officio, o

225 que feito, passei a lel-o e achando-o em tudo conforme o havia ditado, o datei e assignei afim de mandal-o approvar; pedindo ás Justiças do Paiz o cumpram e mandem cumprir tão inteira- 


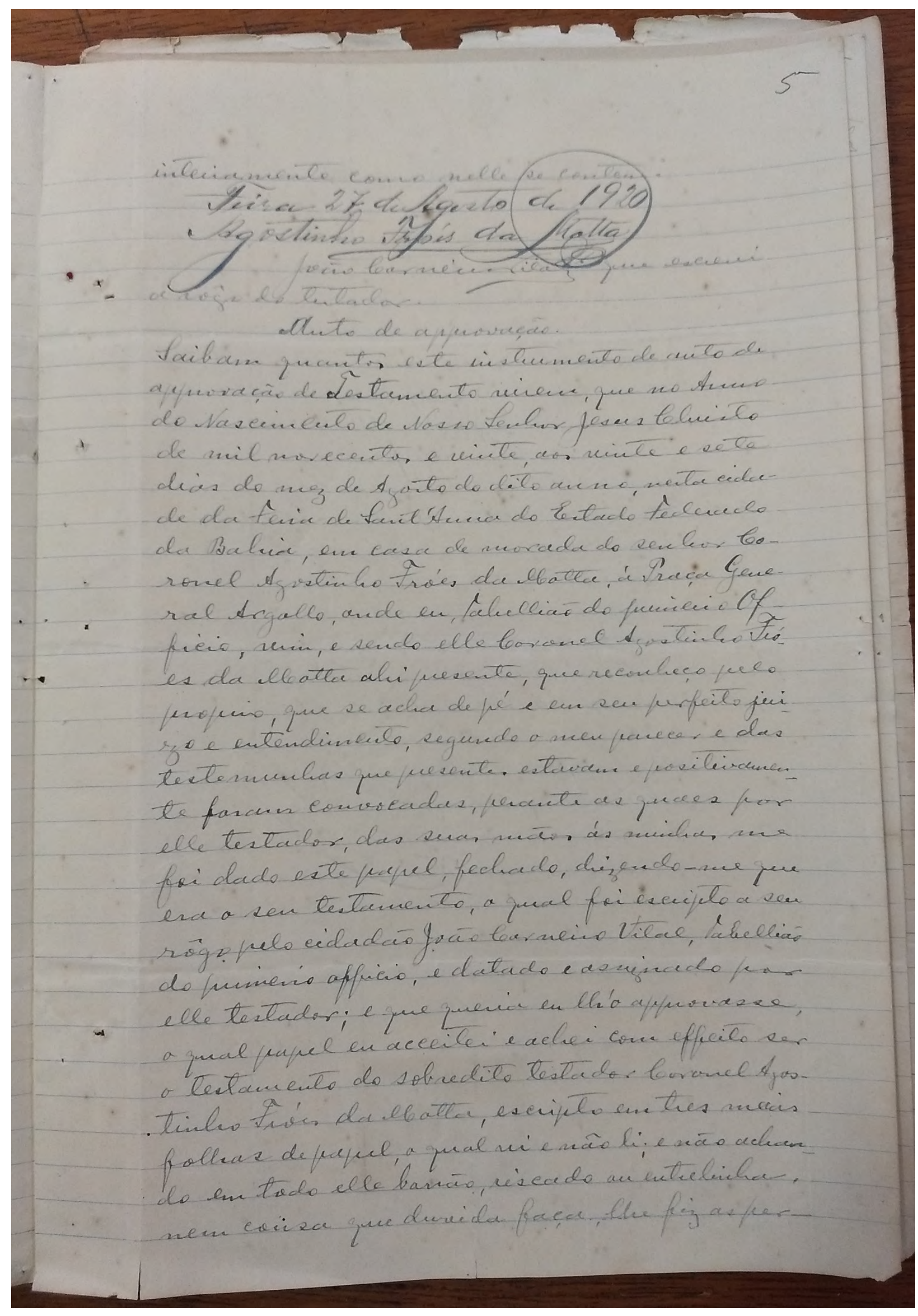


|| 5r.|| inteiramente como nelle se contem:

$230 \quad$ Feira 27 de Agosto de 1920

Agostinho Fróes da Motta ${ }^{182}$

João Carneiro Vital que escrevi

a rôgo do testador.

Auto de approvação.

235 Saibam quantos este instrumento de auto de approvação de Testamento virem, que no Anno do Nascimento de Nosso Senhor Jesus Christo de mil novecentos e vinte, aos vinte e sete dias do mez de Agosto do dito anno, nesta cida-

240 de da Feira de Sant'Anna do Estado Federado da Bahia, em casa de morada do senhor Coronel Agostinho Fróes da Motta, á Praça General Argollo, onde eu, Tabellião do primeiro Officio, vim, e sendo elle Coronel Agostinho Fró-

245 es da Motta ahi presente, que reconheço pelo proprio, que se acha de pé e em seu perfeito juizo e entendimento, segundo o meu parecer e das testemunhas que presentes estavam e positivamente foram convocadas, perante as quaes por

250 elle testador, das suas mãos ás minhas me foi dado este papel, fechado, dizendo-me que era o seu testamento, o qual foi escripto a seu rôgo pelo cidadão João Carneiro Vital, Tabellião do primeiro officio, e datado e assignado por

255 elle testador; e que queria eu lh'o approvasse, o qual papel eu acceitei e achei com effeito ser o testamento do sobredito testador Coronel Agostinho Fróes da Motta, escripto em tres meias folhas de papel, o qual vi e não li; e não achan-

260 do em todo elle borrão, riscado ou entrelinhas, nem cousa que duvida faça, lhe fiz as per-

${ }^{182}$ No manuscrito original, há um círculo de $38 \mathrm{~mm}$ de diâmetro na assinatura do testador Agostinho Fróes da Motta. 


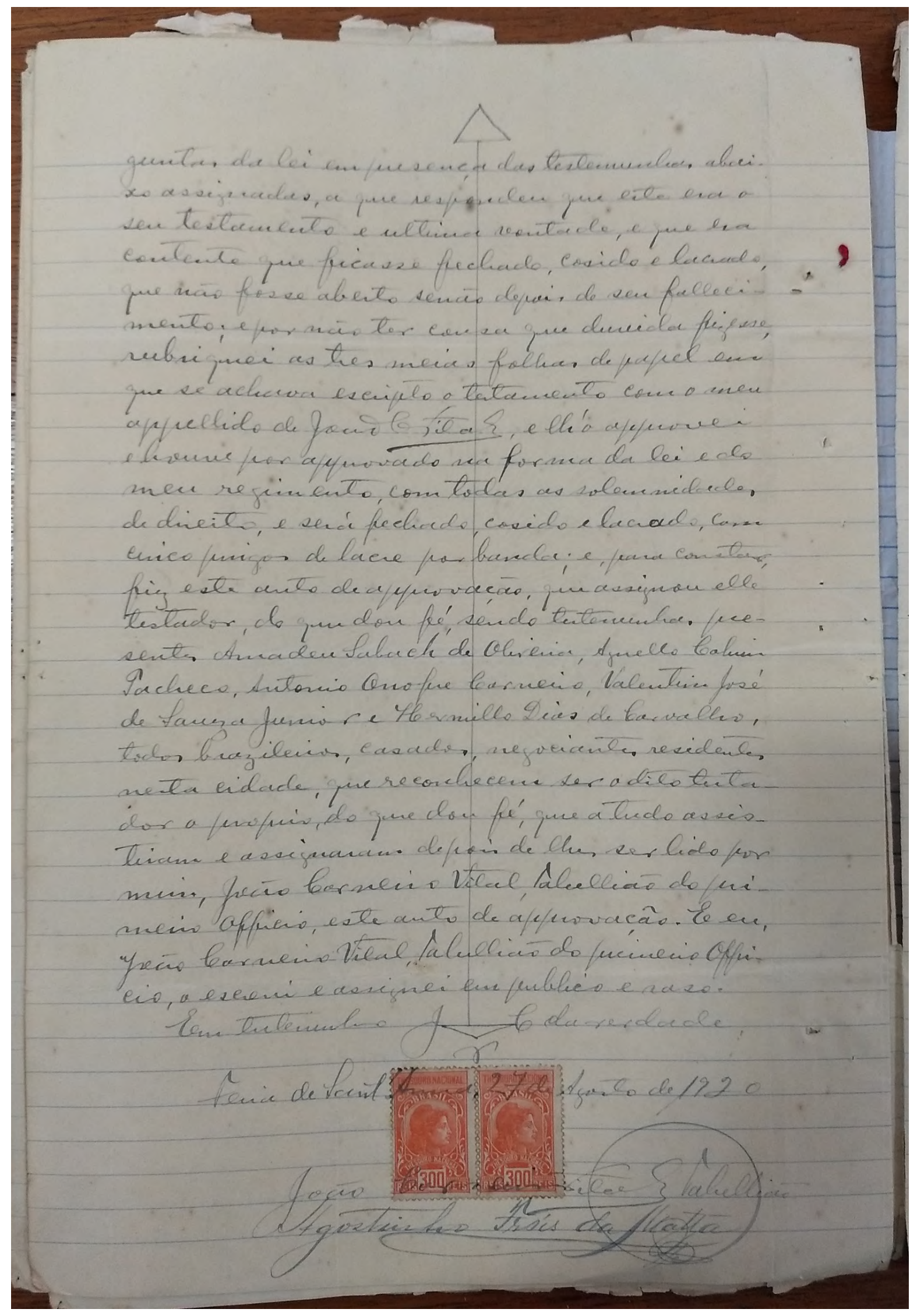


|| 5v.|| guntas da lei em presença das testemunhas abaixo assignadas, a que respondeu que este era o seu testamento e ultima vontade, e que era

265 contente que ficasse fechado, cosido e lacrado, que não fosse aberto senão depois de seu fallecimento; e por não ter cousa que duvida fizesse, rubriquei as tres meias folhas de papel em que se achava escripto o testamento com o meu

270 appellido de João Carneiro Vital, e lh'o approvei e houve por approvado na forma da lei e do meu regimento, com todas as solemnidades de direito, e será fechado, cosido e lacrado, com cinco pingos de lacre por banda; e, para constar,

275 fiz este auto de approvação, que assignou elle testador, do que dou fé, sendo testemunhas presentes Amadeu Saback de Oliveira, Agnello Cohim Pacheco, Antonio Onofre Carneiro, Valentim José de Souza Junior e Hermillo Dias de Carvalho,

280 todos brazileiros, casados, negociantes residentes nesta cidade, que reconhecem ser o dito testador o proprio, do que dou fé, que a tudo assistiram e assignaram depois de lhes ser lido por mim, João Carneiro Vital, Tabellião do pri-

285 meiro officio, este auto de approvação. E eu, João Carneiro Vital, Tabellião do primeiro Officio, o escrevi e assignei em publico e raso.

Em testemunho da verdade ${ }^{183}$

Feira de Sant'Anna, 27 de Agosto de 1920

João Carneiro Vital Tabellião $\underline{\text { Agostinho Fróes da Motta }}{ }^{184}$

${ }^{183}$ No manuscrito original, nesta linha, há um sinal público de $242 \mathrm{~mm}$ de altura com as iniciais do Tabelião de Notas “J. C. V.”, João Carneiro Vital.

${ }^{184}$ No manuscrito original, há um círculo de $43 \mathrm{~mm}$ de diâmetro na assinatura do testador Agostinho Fróes da Motta. 


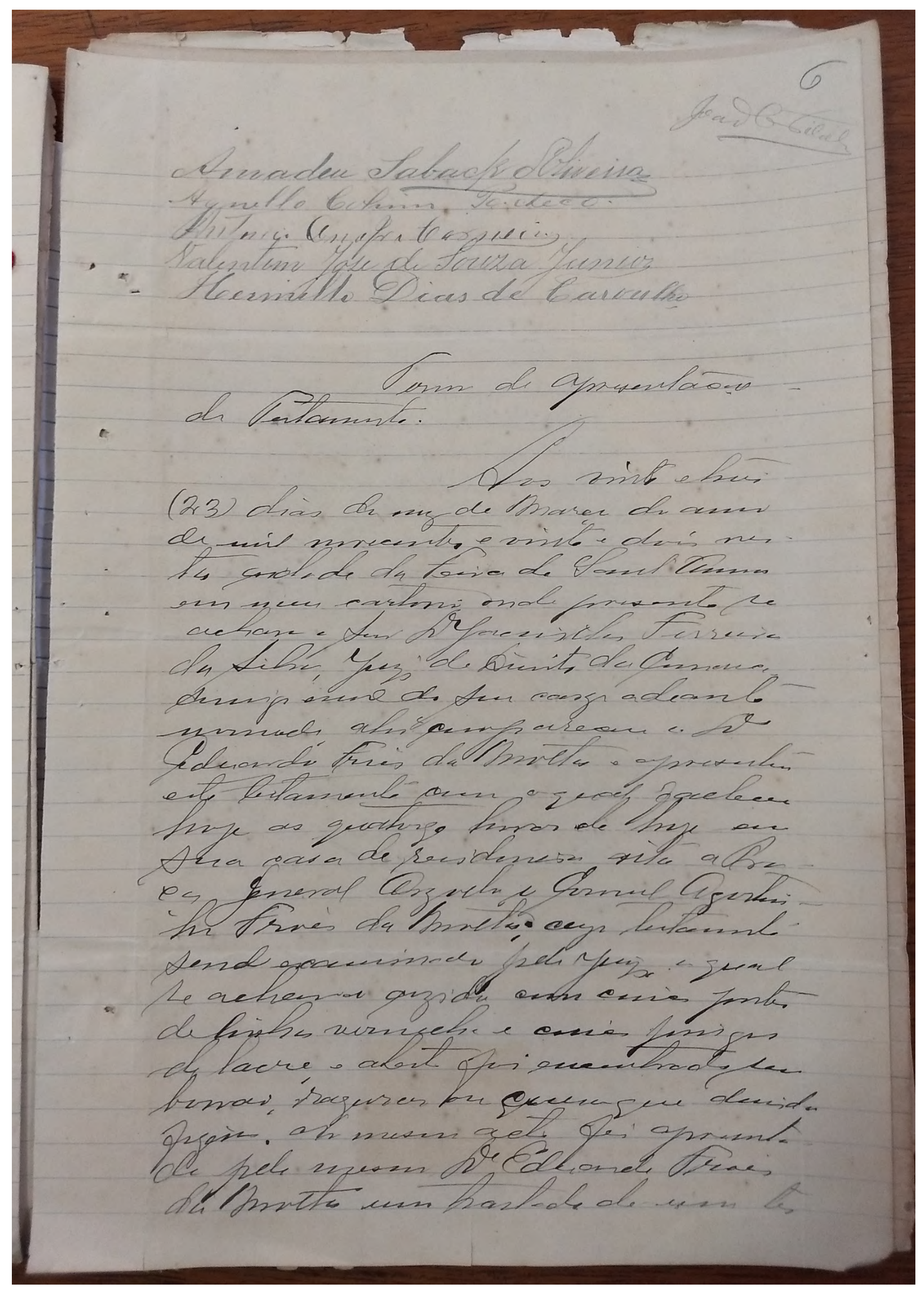


|| 6r.|| Amadeu Saback dOliveira

$<$ 吕ãoCarneiroVital $>$

295 Agnello Cohim Pacheco

Antonio Onofre Carneiro

Valentim Jose de Souza Junior

Hermillo Dias de Carvalho

300

Termo de apresentação

do Testamento.

305 (23) dias do mez de Março do anno

Aos vinte e treis de mil novecentos e vinte e dois nesta cidade da Feira de Sant'Anna em meu cartorio onde presente se achara o Senhor Doutor Jacintho Ferreira

310 da Silva, Juiz de Direito da Comarca comigo escrivão do seu cargo adeante nomeado, ahi compareceu o Doutor Eduardo Fróes da Motta e apresentou este testamento com o qual falleceu

315 hoje as quatorze horas de hoje em sua casa de residencia sita a Praça General Argollo o Coronel Agostinho Fróes da Motta; cujo testamento sendo examinado pelo Juiz o qual

320 se achava cozido com cinco pontos de linha vermelha e cinco pingos de lacre e aberto foi encontrado sem borrao, razuras ou cousa que duvida fizesse. No mesmo acto foi apresenta325 do pelo mesmo Doutor Eduardo Froes da Motta um traslado de um tes 


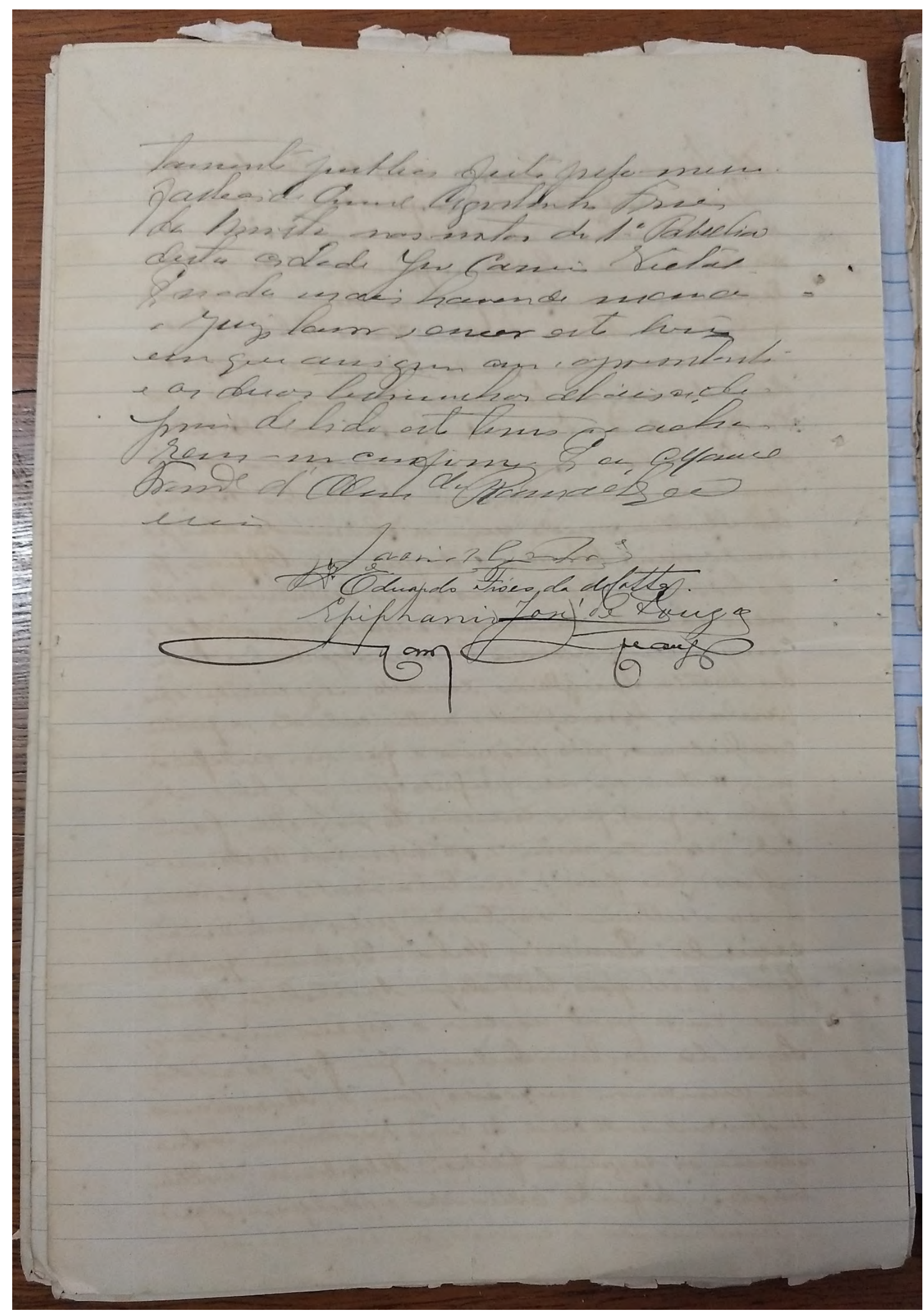


|| 6v.|| tamento publico feito pelo mesmo fallecido Coronel Agostinho Fróes

da Motta nas notas do Primeiro Tabellião

330 desta cidade João Carneiro Vital.

E nada mais havendo mandou

o Juiz lavrar e encer[rar] este termo

em que assignou com o apresentante

e as duas testimunhas abaixo; de-

335 pois de lido este termo e o acha-

rem-no conforme. Eu, Manuel

Francisco d'Almeida Ramalho [escrivão escrevi]

Jacintho Ferreira

340

Eduardo Fróes da Motta

Epiphanio José de Souza

[Manuel Araujo] 


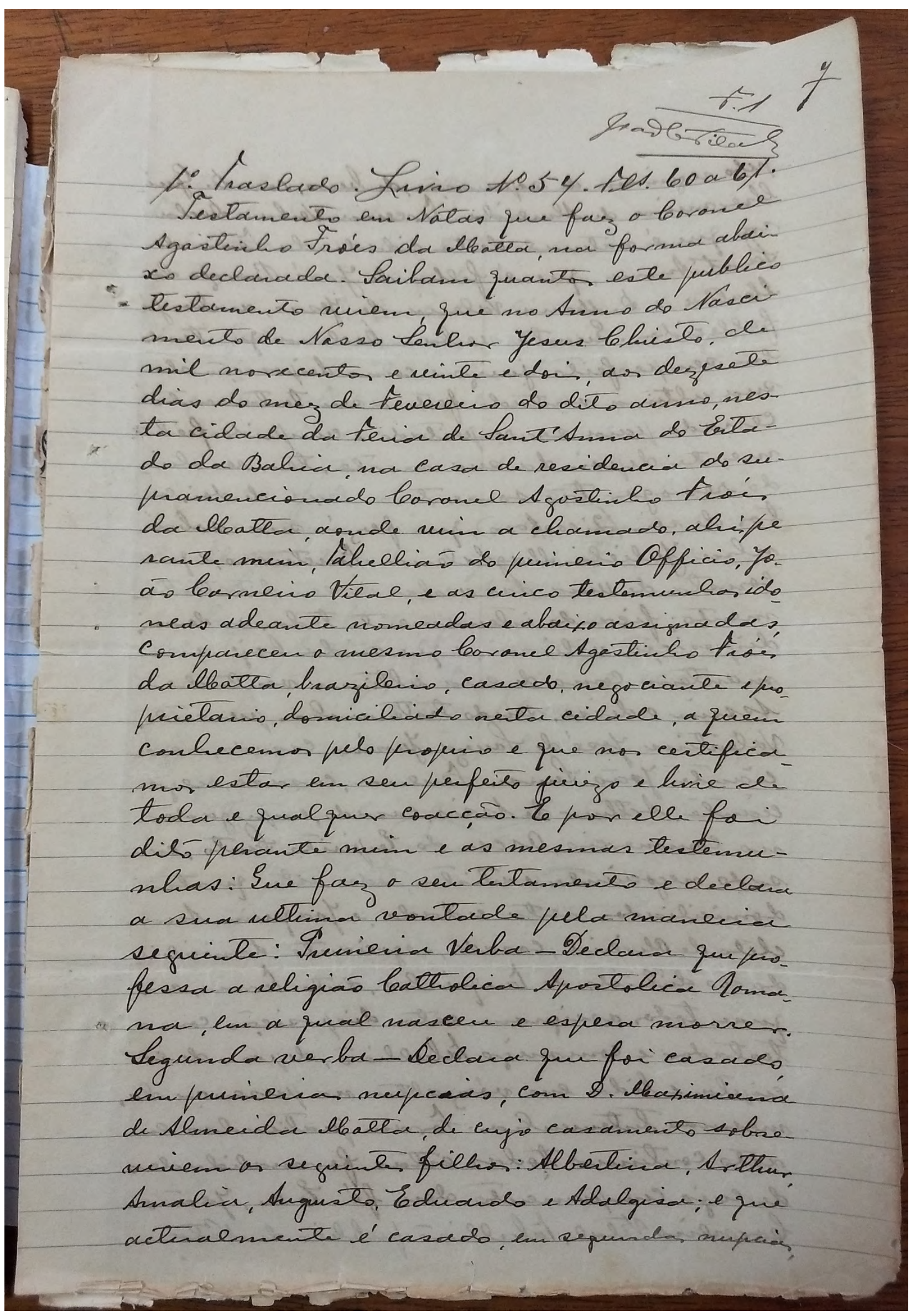


|| 7r.|| Primeiro Traslado. Livro Numero 54. Folhas 60 a 61. $<\uparrow$ JoãoCarneiroVital $>^{185}$

Testamento em Notas que faz o Coronel

345 Agostinho Fróes da Motta, na forma abaixo declarada. Saibam quantos este publico testamento virem, que no Anno do Nascimento de Nosso Senhor Jesus Christo, de mil novecentos e vinte e dois, aos dezesete

350 dias do mez de Fevereiro do dito anno, nesta cidade da Feira de Sant'Anna do Estado da Bahia, na casa de residencia do supramencionado Coronel Agostinho Fróes da Motta, aonde vim a chamado, ahi, pe

355 rante mim, Tabellião do primeiro Officio, João Carneiro Vital, e as cinco testemunhas idoneas adeante nomeadas e abaixo assignadas, compareceu o mesmo Coronel Agostinho Fróes da Motta, brazileiro, casado, negociante e pro-

360 prietario, domiciliado nesta cidade, a quem conhecemos pelo proprio e que nos certificamos estar em seu perfeito juizo e livre de toda e qualquer coacção. E por elle foi dito perante mim e as mesmas testemu-

365 nhas: Que faz o seu testamento e declara a sua ultima vontade pela maneira seguinte: Primeira Verba _ Declara que professa a religião Catholica Apostolica Romana, em a qual nasceu e espera morrer.

370 Segunda verba _declara que foi casado, em primeiras nupcias, com Dona Maximiana de Almeida Motta, de cujo casamento sobrevivem os seguintes filhos: Albertina, Arthur, Amalia, Augusto, Eduardo e Adalgisa; e que

375 actualmente é casado, em segundas nupcias,

${ }^{185}$ No manuscrito original, acima da rubrica do Tabelião de Notas, João Carneiro Vital, há a anotação "F. 1", para indicar que se trata da folha 1 do Primeiro Traslado. 
446

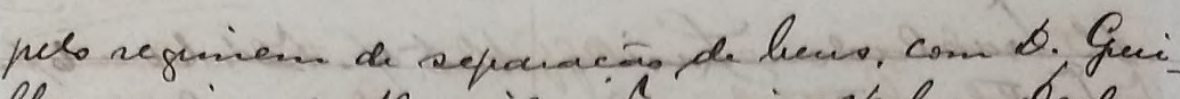
lhermina de theida. Percuier Voba-beda. ra que émature decta cidade da teriaid. Santisma, que e'fillo de fasé Horge da

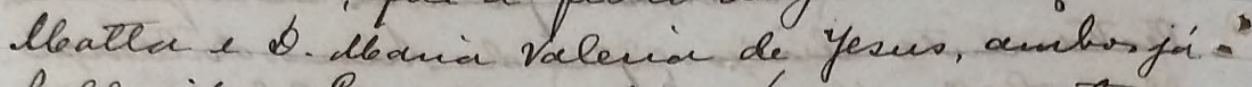
fallecidos. Suata nesba-becland que teudo en sen perfeito juizo e cano dejporicáo de sua ultina vortexde feito a sen testarnento cerrado para ser respeitado e empuido fiel mente defori da sua morte, tew resolui do revogar tá somente a dexid de doricon. tor de vei (2:000,000), que fez à sud sabui.

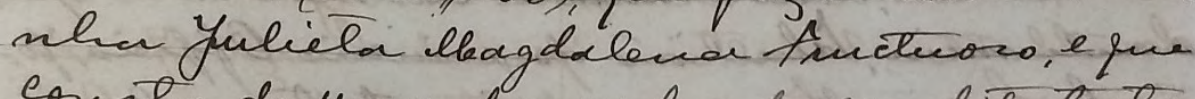
consta de una das nesbar do cen dito léta. mato; fiedndo interiamente todo, as dences. difposicor valiosa, e que ainda hoje as mantan coma de eud ultivar vortade.

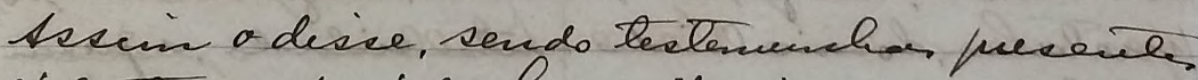
Valentiver yoséde Lauza Juncir, casado, mego

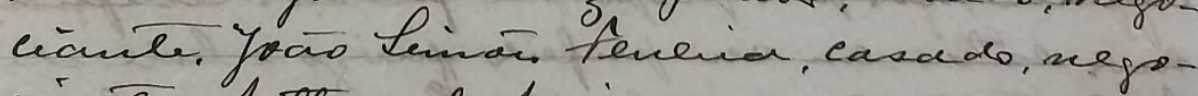
cicinte. Arthur de Assis, easado, enfyegado no Conmereio, Ascas at tesfinito Tasto, ex sado, negaciante entista, toder estes quats. domiciliades neta adade, e Joa puin Ara. cleto de Ohrienar, casado, negocionte doniciliar do no diticto do Lanquinho. dite Fersmo, as juar todor assignan esta dizfosicáa cona a testador e commigo alvelidio, defion de eseiveta lida en vózolta na presenceda,

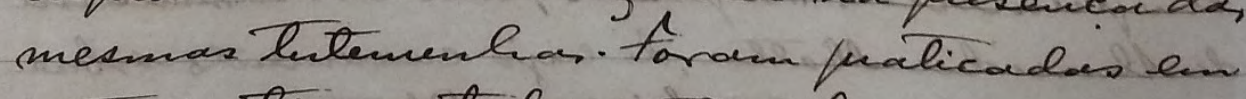
acto continu todas extar forranabidades

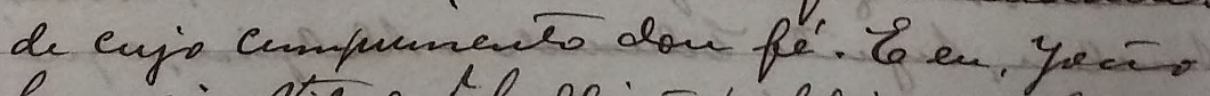
leormeiv Vilal, Achliá fublic de Natex. 
|| 7v.|| pelo regimem de separação de bens, com Dona Guilhermina de Almeida. Terceira Verba _ Declara que é natural desta cidade da Feira de Sant'Anna, que é filho de José Borges da

380 Motta e Dona Maria Valeria de Jesus, ambos já fallecidos. Quarta verba _ Delcara que tendo em seu perfeito juizo e como disposição de sua ultima vontade feito o seu testamento cerrado para ser respeitado e cumprido fiel-

385 mente depois da sua morte, tem resolvido revogar tão somente a deixa de dois contos de reis $(2: 000 \$ 000)$, que fez á sua sobrinha Julieta Magdalena Fructuoso, e que consta de uma das verbas do seu dito testa-

390 mento; ficando inteiramente todas as demais disposições valiosas, e que ainda hoje as mantem como de sua ultima vontade.

Assim o disse, sendo testemunhas presentes Valentim José de Souza Junior, casado, nego-

395 ciante, João Simões Ferreira, casado, negociante, Arthur de Assis, casado, empregado no commercio, Oscar do Espirito Santo, casado, negociante e artista, todos estes quatro domiciliados nesta cidade, e Joaquim Ana-

400 cleto de Oliveira, casado, negociante, domiciliado no districto do Tanquinho, deste Termo, os quaes todos assignam esta disposição com o testador e commigo Tabellião, depois de escripta e lida em vóz alta na presença das

405 mesmas testemunhas. Foram praticadas em acto continuo todas estas formalidades de cujo cumprimento dou fé. E eu, João Carneiro Vital, Tabellião publico de Notas 
448

Natas do funievio Officio, dutu cidade da

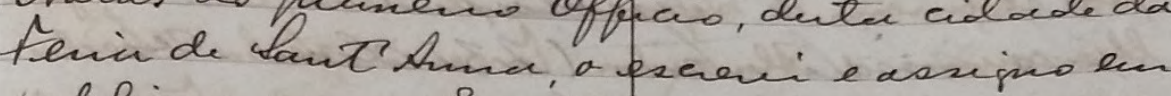

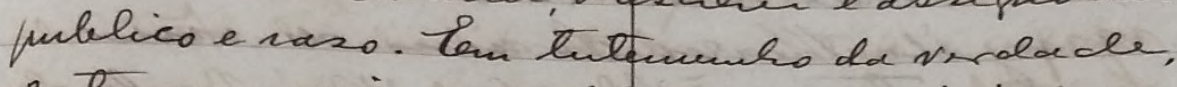
estarea a siral publico eor as inicide.

- y. . . . ahaito colleda duas estampilha federa mo valot de anil e durfars

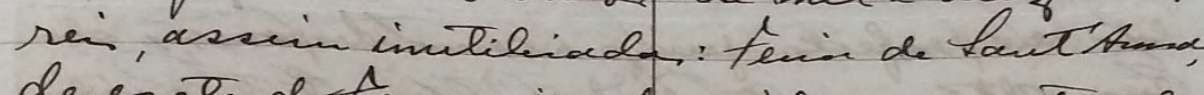
dezeste de teverio de nil norecerbor e winte edoi, e, en cadd und, dezertidoin

* mil morecutor e vinte doi, e sole toda as siziado: Yoino barneivo tilal alubleio. Abaixo estavan assignabos: Agasticho trós da lbatta, Valentin foé de Lauza Yunvir. yoño Linè teuenin, frther de deses, Ascá. do Refinilo Lanto, yooprin Anacleto de Aliriva kesta conforane o origival fen: de Sant tuma, 7 de tererein de/922. Eu, Foño learneino Vilal Aluelia do funerio Officio, que oscri suleseni e ascigios en publieo e vas.

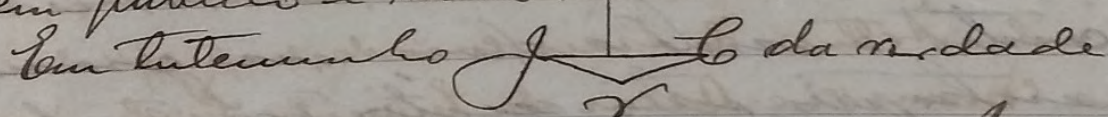

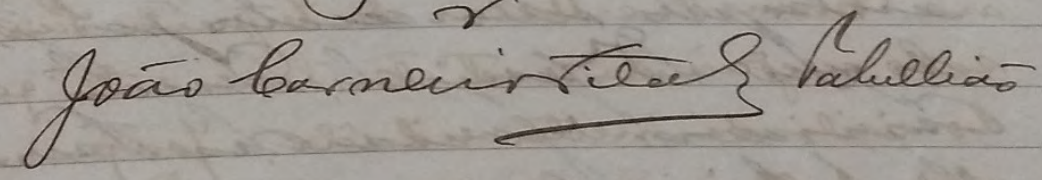


|| 8r.|| Notas do primeiro Officio, desta cidade da $<\uparrow$ JoãoCarneiroVital $>{ }^{186}$

410 Feira de Sant'Anna, o escrevi e assigno em

publico e raso. Em testemunho da verdade, estava o signal publico com as iniciaes

João Carneiro Vital e abaixo colladas duas estampi-

lhas federaes no valor de mil e duzentos

415 reis, assim inutilisadas: Feira de Sant'Anna, dezesete de Fevereiro de mil novecentos e vinte e dois, e, em cada uma, dezesete _doismil novecentos e vinte e dois, e sobre todas assignado: João Carneiro Vital Tabellião.

420 Abaixo estavam assignados: Agostinho Fróes da Motta, Valentim José de Souza Junior, João Simões Ferreira, Arthur de Assis, Oscar do Espirito Santo, Joaquim Anacleto de Oliveira. Está conforme o original. Feira

425 de Sant'Anna, 17 de Fevereiro de 1922. Eu, João Carneiro Vital, Tabellião do primeiro Officio, que o escrevi, subscrevi e assigno em publico e raso.

Em testemunho da verdade ${ }^{187}$

$\underline{\text { João Carneiro Vital Tabellião }}$

${ }^{186}$ No manuscrito original, acima da rubrica do Tabelião de Notas, João Carneiro Vital, há a anotação "F. 2", para indicar que se trata da folha 2 do Primeiro Traslado.

${ }^{187}$ No manuscrito original, nesta linha, há um sinal público de $195 \mathrm{~mm}$ de altura com as iniciais do Tabelião de Notas “J. C. V.”, João Carneiro Vital. 


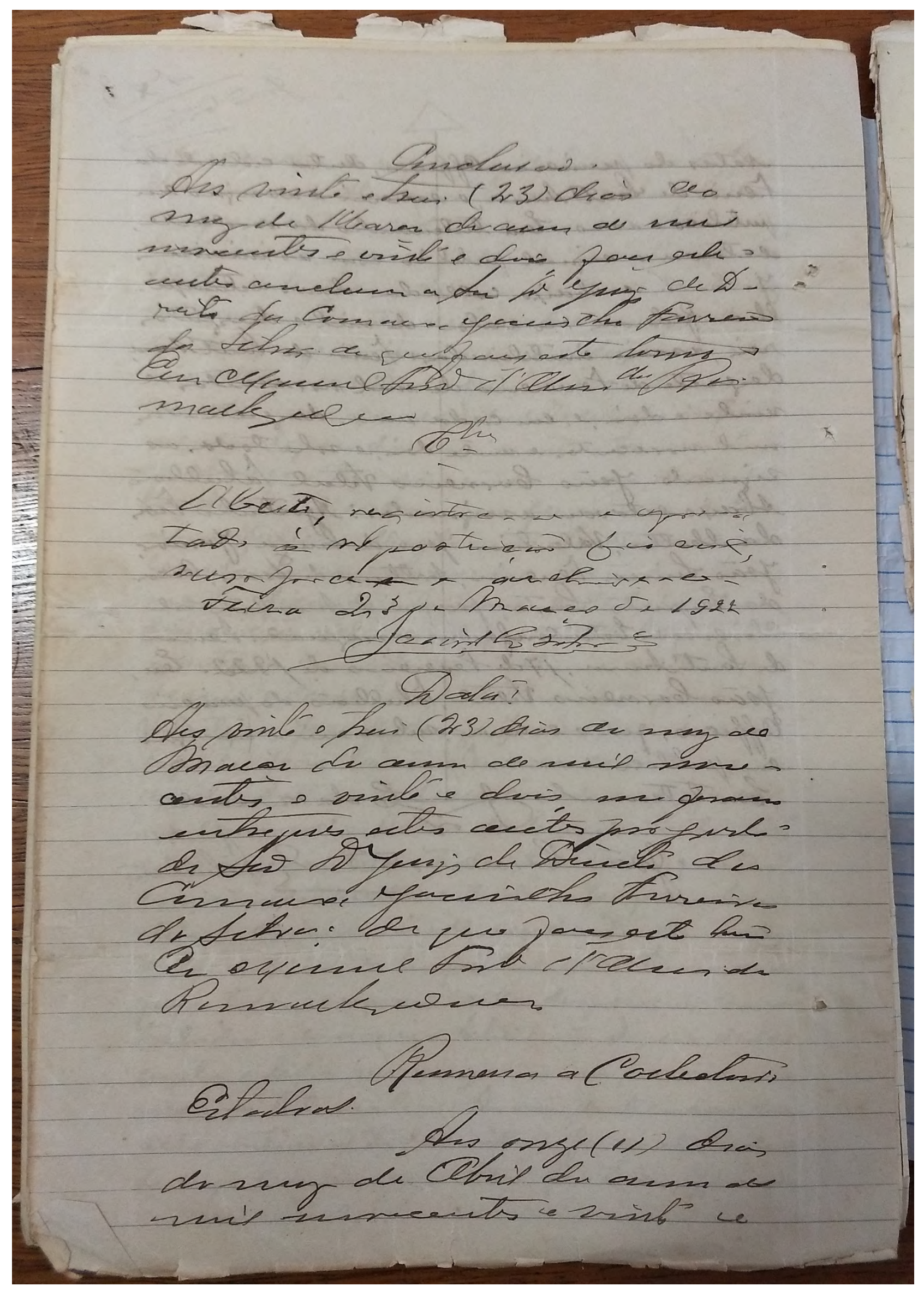


\| 8v. $\quad$ Conclusão

Aos vinte e treis (23) dias do

mez de Março do anno de mil

435 novecentos e vinte e dois faço este

autos conclusos ao Senhor Doutor Juiz de D-

reito da Comarca Jacintho Ferreira

da Silva do que faço este termo.

Eu Manuel Francisco d'Almeida Ra

440 malho [escrivão escrevi]

Conclusoes

Aberto, registre-se e apre-

tado á repartição fiscal,

445 cumpra-se e archivado

Feira 23 de Março de 1922

Jacintho Ferreira

Data:

450 Aos vinte e treis (23) dias do mez de Março do anno de mil novecentos e vinte e dois me foram entregues estes autos por parte do Senhor Doutor Juiz de Direito da

455 Comarca Jacintho Ferreira da Silva; do que faço este termo Eu Manuel Francisco d'Almeida Ramalho [escrivão escrevi]

Estadual.

Aos onze (11) dias

do mez de Abril do anno de

mil novecentos e vinte $\mathrm{e}$ 


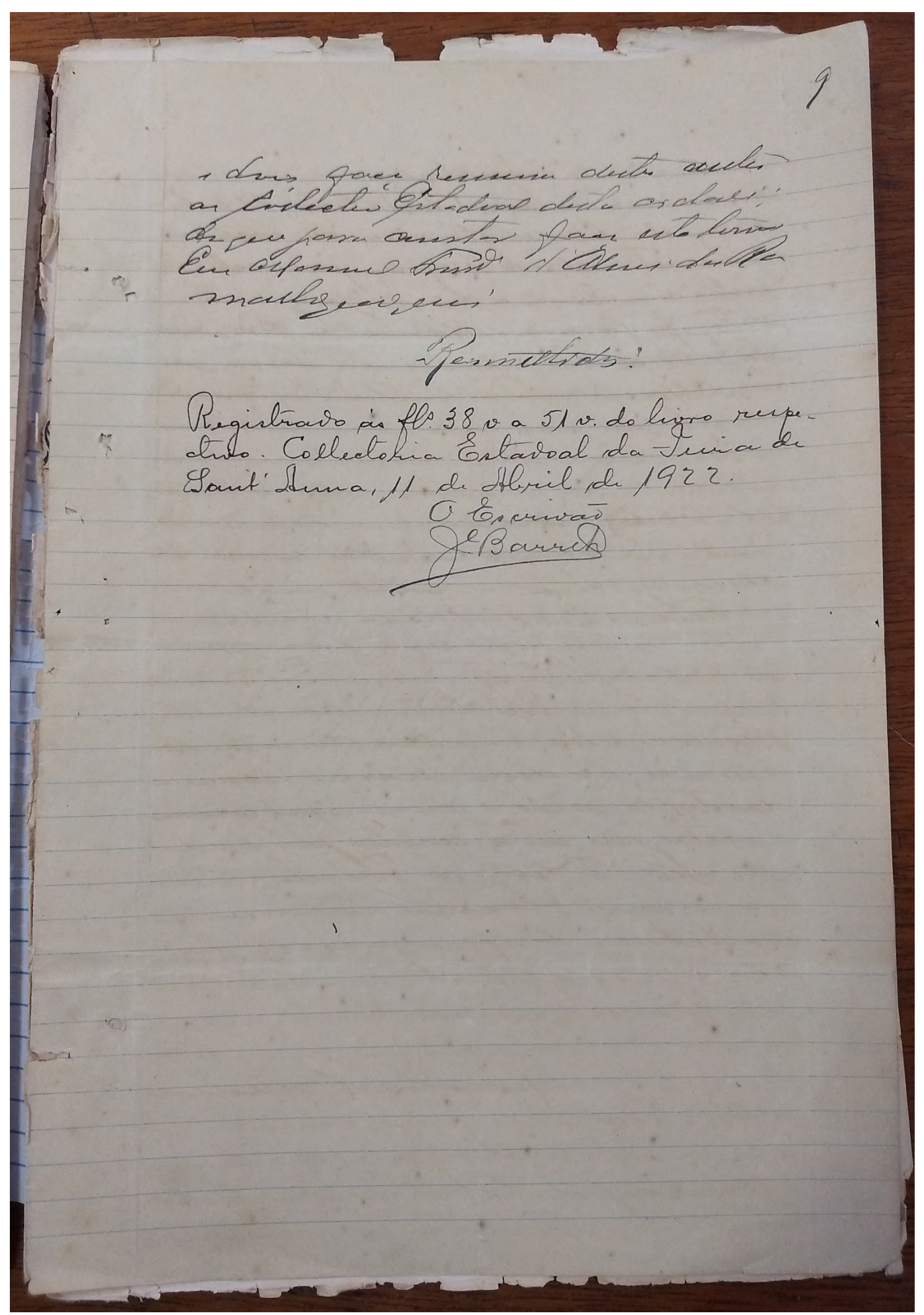


465 || 9r.|| e dois; faço remessa destes autos a Collectoria Estadual desta cidade; do que para constar faço este termo Eu Manuel Francisco d'Almeida Ra malho [escrivão escrevi]

470

Remettidos:

Registrado às folhas 38 verso a 51 verso do livro respectivo. Collectoria Estadoal da Feira de

475 Sant'Anna, 11 de Abril de 1922.

O Escrivão

$\underline{\text { Jose Barreto }}$ 
Exercicio de 1922

Imposto de Enahnuelos

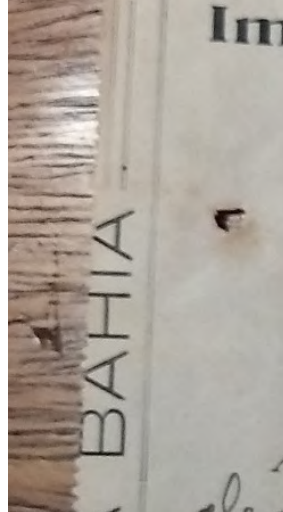

\& clecio da Silva Dallecia a quantia de dez nil reis

O que pasou o sr. Dr. Eduardo Iroies da lbotta

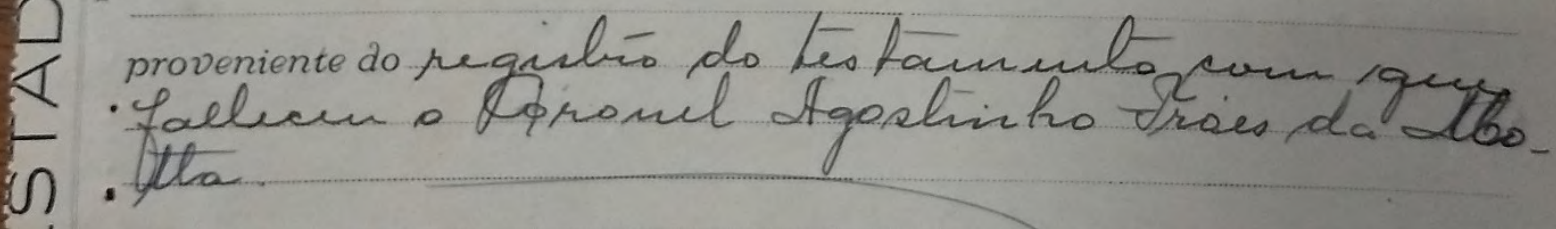

ل

Muita

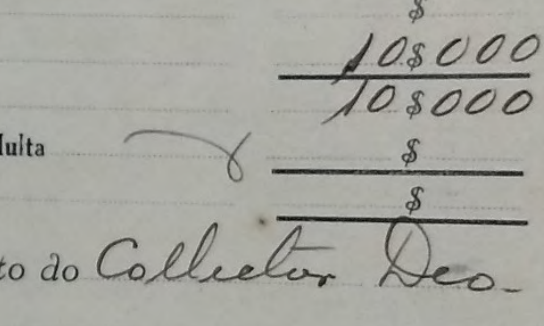

$\frac{10 \$ 000}{10 \$ 000}$

$\frac{s}{\text { Deo. }}$

$\$$ 
|| 10r. || $14 \quad$ Exercicio de 1922

Numero 214

480

Imposto de Emolumentos

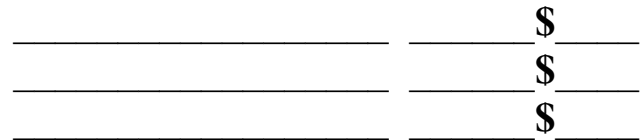

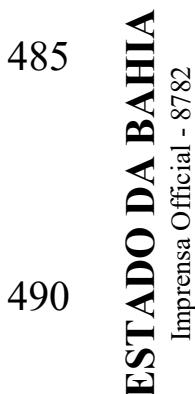

$10 \$ 000$

$10 \$ 000$

Multa

$\$$

A folhas 13 do livro da Receita fica a debito do Collector Deoclecio da Silva Daltro

a quantia de dez mil reis

que pagou o Senhor Doutor Eduardo Fróes da Motta

proveniente do registro do testamento com que

495 falleceu o Coronel Agostinho Fróes da Mo-

tta.

Collectoria da Feira de Sant'Anna do Estado da

Bahia, em 11 de Abril de 1922

O Escrivão

$\underline{\text { José Barreto }}$
O Collector

$\underline{\text { Deoclecio da Silva Daltro }}$ 